The

Thoroughbred

Horse.

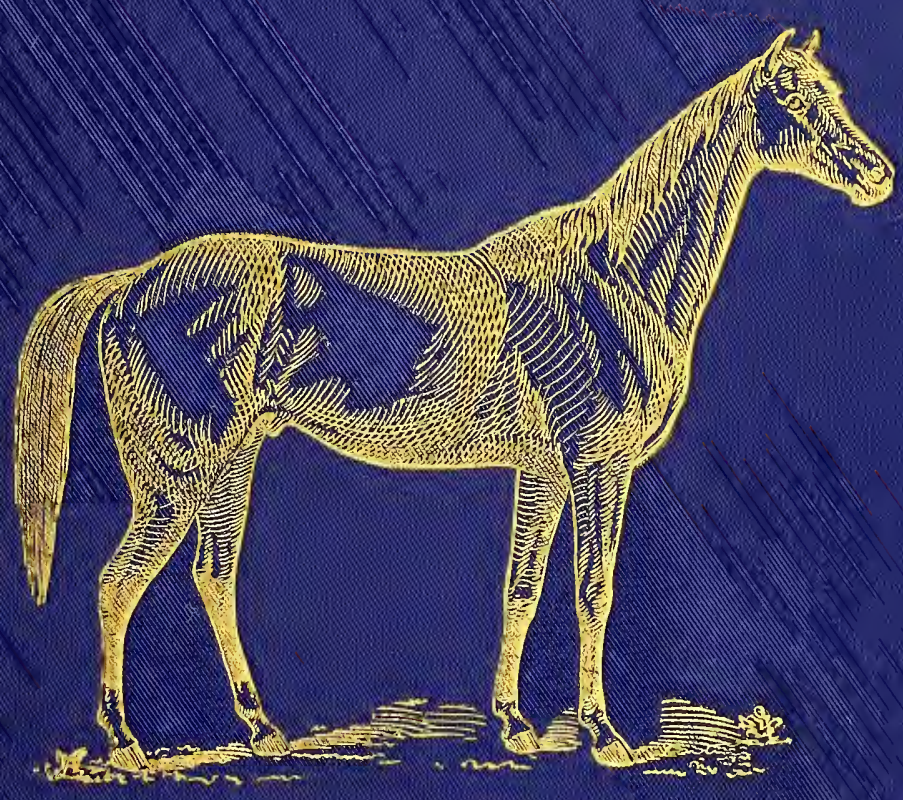

1892.

S. D. BRUCE. 
$e_{-3}$

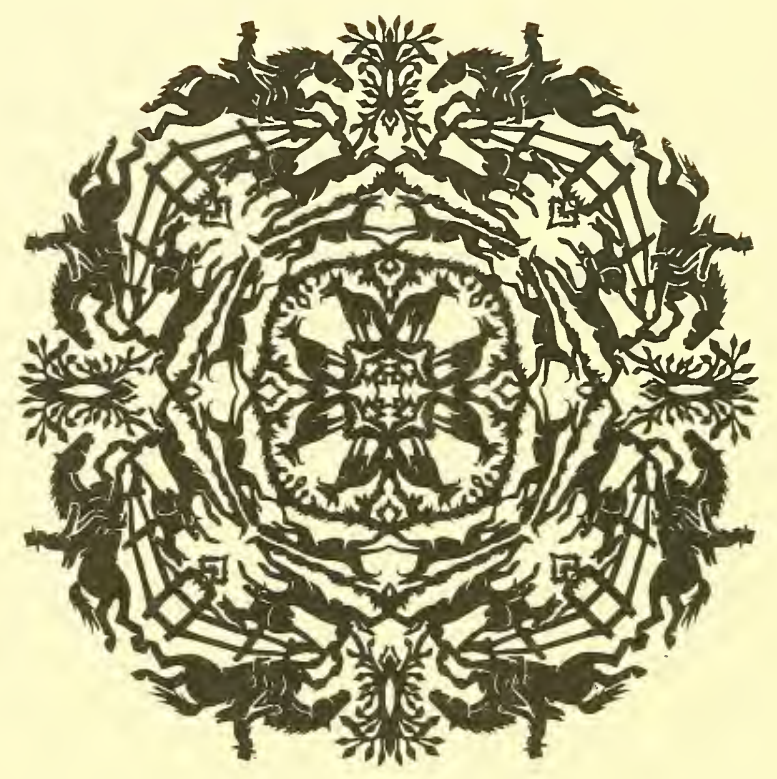

JOHN A.SEAVERNS 


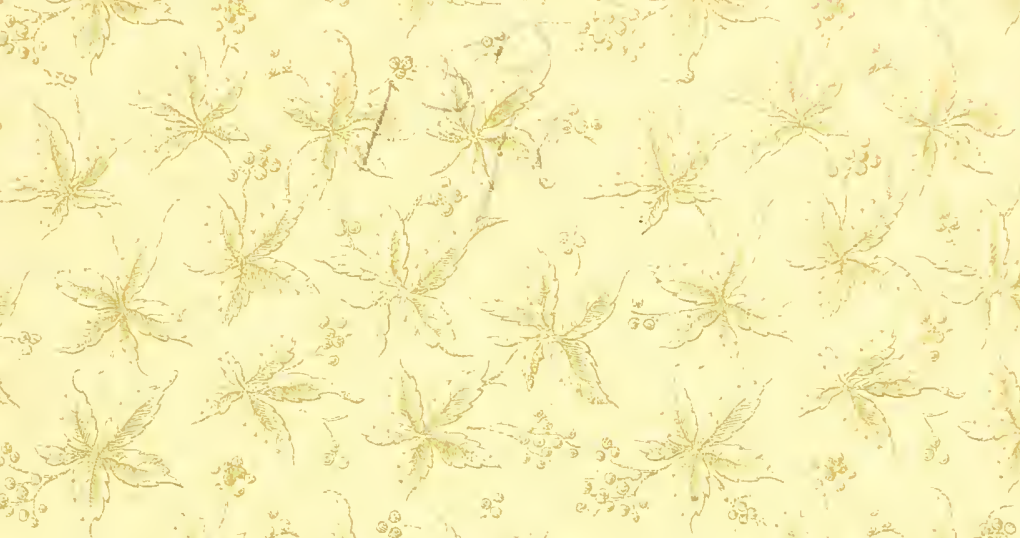

Wobsier Family Lbrany of Veterinary Medicine bumming School of Veterinany Medicine at Tufis University 200 Westboro Road North Grafton, MA 01536 



Digitized by the Internet Archive in 2011 with funding from Boston Library Consortium Member Libraries 



\section{'II I H}

\section{THOROCGIIBRED HORSE}

HIS ORIGIN, HOW TO BREED AND

HOIV SELECT HIM.

WITH TIIE

\section{HORSE BREEDERS' GUIDE.}

EMBRACING ONE HUNDRED TABULATED PEDIGREES OF THE PRINCIPAL SIRES, WITH FULL PERFORMANCES OF EACII AND BEST OF THEIR GET, COVERING THE SEASON OF 1892.

\section{BY S. D. BRUCE,}

Authow of the American Stud Book.

Published AT THE

Office of the TURF, FIELD AND FARM,

Times Bullding, New York.

$$
1892 .
$$


Entered according to the Act of Congress, in the year 1892, Br S. D. Bruce,

in the affice of the Librarian of Congress, Washington, D. C. 


\section{N D E X}

TO 'THE SIRES OF STALLIONS 'TABULA'IED.

PAGE.

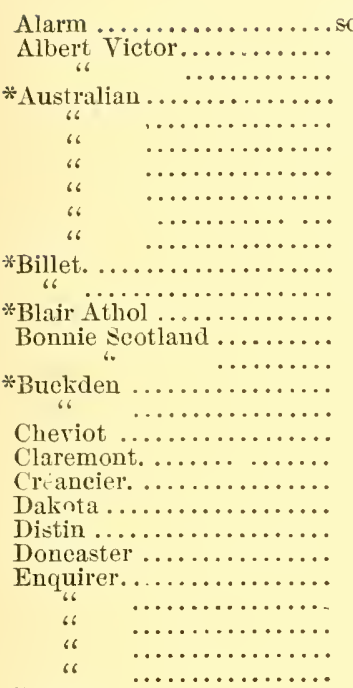

Eolus $\ldots \ldots \ldots \cdots \cdots \cdots \cdots \cdots$

Flageolet.

Galopin

Gilroy

*Glenelg..

*Glengarry

Griustead $\ldots \ldots \ldots .$.

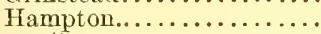

Hermit .....................

Hindoo

* King Ernest ..............

Kingfisher .

King Tom ........

* Leamington

\begin{tabular}{|c|c|}
\hline & $\ldots \ldots \ldots \ldots \ldots$ \\
\hline 66 & $\ldots \ldots \ldots \ldots \ldots$ \\
\hline 66 & $\cdots \ldots \ldots \ldots$ \\
\hline 66 & 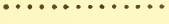 \\
\hline 6 & $\cdots \ldots \ldots$ \\
\hline & $\cdots$ \\
\hline
\end{tabular}

Lexington $\ldots \ldots \ldots \ldots \ldots$

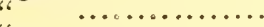

Lisbon $\ldots \ldots \ldots \ldots \cdots \cdots \cdots$

Longfellow.

..............

${ }_{6} 6 \quad \ldots \ldots \ldots \ldots \ldots \ldots$

Lowlander. ................

Macaroni .....................

\begin{tabular}{|c|c|c|c|}
\hline 6 & \multirow{2}{*}{\multicolumn{3}{|c|}{ Marsyas..............*** }} \\
\hline 66 & & & \\
\hline 66 & \multicolumn{3}{|c|}{ West Australian....... } \\
\hline 6 & 66 & 6 & \\
\hline 66 & 66 & 66 & \\
\hline 6 & 66 & 66 & \\
\hline 66 & 66 & 66 & \\
\hline 66 & 66 & 6 & \\
\hline 6 & « & 66 & \\
\hline
\end{tabular}

Himyar

Albert............................ 111

*The Sailor Prinee......................... 111

Fellowelaft.............. 161

Wilful ................ 301

Stockwell............... Stonehenge...............

Iago ................ Bramble................ 119

"6 ........... Luke Blackburn.......... 209

Lord Clifden ........... Bend'or .................... 115

" $\quad \ldots \ldots \ldots \ldots$ Buckmaster.............. 121

Adventurer ...........Paramatta.............. 227

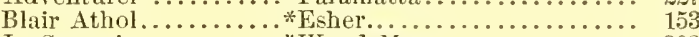

Le Sarrazin...........*Wood Moss.............. 303

*Billet ........... Phil Warren............ 229

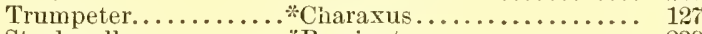

Stockwell............*Rossington ............. 239

*Leamington .......... Ecuador................ 143

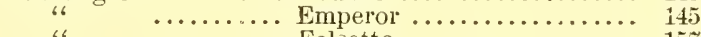

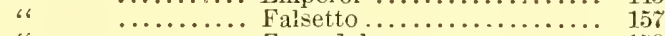

"6 ......... Farandole .............. 159

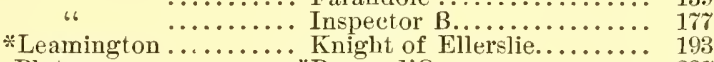

Plutus.............**Rayon-d'Or............. 237

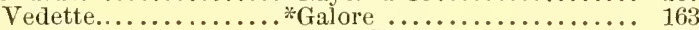

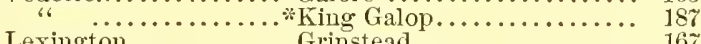

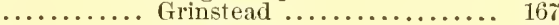

Citadel............. Postguard .............. 233

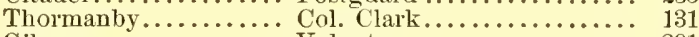

Gilroy............. Volante ............... 291

Lord Clifden.......... Eothen ................ 151

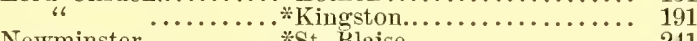

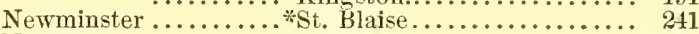

Virgil ............... Hanover.................. 169

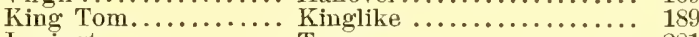

Lexington. ............. Tureo ......................... 281

Harkaway ..........* Great Tom............. 165

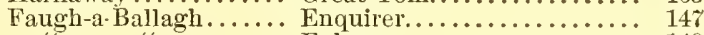

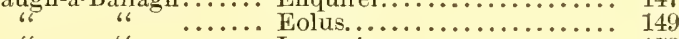

"6 $66 \quad \ldots \ldots \ldots$ Iroquois ................. 179

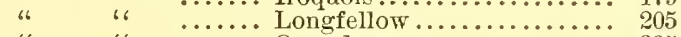

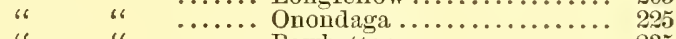

" $"$ " $6 \ldots$. Powhattan .............. 235

$66 \quad 66 \ldots \ldots$ Sensation.............. 245

Boston ............ Stratford................ 265

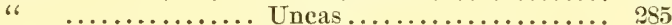

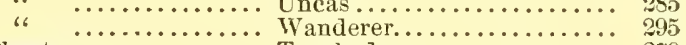

*Phaeton .............. Troubadour................ 279

*Leamington .......... Leonatus.................. 197

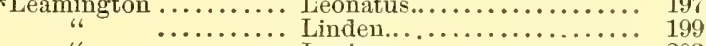

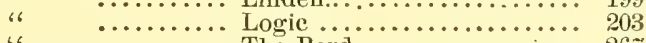

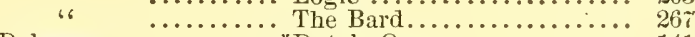

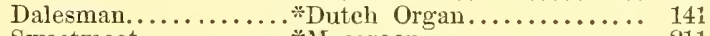

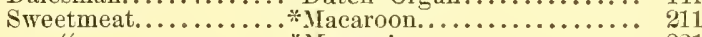

.......... 


\begin{tabular}{|c|c|c|c|}
\hline & & & \\
\hline *Mortemer................ & n of & Compiègne.......... Exile $\ldots \ldots \ldots \ldots \ldots \ldots \ldots \ldots$ & 155 \\
\hline Musket ................... & & Toxophilite........... Maxim ................. & \\
\hline Pero Gomez ............ & " & Beadsman.............*Pontias ... & \\
\hline & & & \\
\hline *Phaeton .. & 66 & 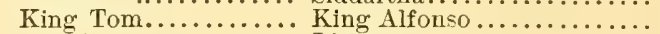 & 185 \\
\hline .............. & "6 & ${ }_{6}^{6} \quad \ldots \ldots \ldots \ldots$ Lisbon. . . . . . . . . . . . . & \\
\hline Planet... & "6 & Revenue............ Whisper............ & \\
\hline * Prince Charlie ............ & $" 6$ & Blair Athol............ Salvator ............ & \\
\hline & "6 & " $\quad$............ The Jacobite ............... & \\
\hline " & "6 & *Wagner ............... & \\
\hline *Rayon-d'Or ................ & "6 & Flageolet............ & \\
\hline Rebel................. & "6 & chaca .............. & \\
\hline Rosicrucian............. & "6 & ck Dean.............. & \\
\hline & "6 & ate...................... & \\
\hline St. Simon................ & "6 & * Masetto .................. & \\
\hline " $\quad \cdots \ldots \ldots \ldots \ldots \ldots$ & & us............... & \\
\hline Scottish Chief............ & 66 & Lord of the Isles .......*DonaId A................ & \\
\hline " $\quad$ (........... & & ka................. & \\
\hline on $\ldots \ldots \ldots \ldots \ldots$ & $" 6$ & ur $\ldots \ldots \ldots \ldots \ldots \ldots$ & \\
\hline$\ldots \ldots \ldots \ldots \ldots \ldots$ & $\because 6$ & *Silvermine............... & \\
\hline Star Davis ................ & "6 & Star.................. & \\
\hline Sterling $\ldots \ldots \ldots \ldots \ldots \ldots$ & 66 & ralist ................. & \\
\hline « $\quad \cdots \ldots \ldots \ldots \ldots \ldots, \ldots$ & 66 & $\ldots \ldots \ldots \ldots \cdots \cdots$ & \\
\hline Peer $\cdots \cdots \cdots \cdots \cdots \cdots$ & "6 & *Ton Gall & \\
\hline .. & 66 & ......... & \\
\hline Traducel" & 66 & *Uhlan. & \\
\hline Traducer .. & 66 & The Libel... & \\
\hline & & *Sir Modred................. & \\
\hline$\cdots$ & $" 6$ & . $\ldots \ldots \ldots \ldots \ldots \ldots$ & \\
\hline ...... & 66 & itor..... & \\
\hline Virgil .................. & $" 6$ & Hindoo.................. & \\
\hline $\cdots \ldots, \ldots, \ldots, \ldots$, & "6 & $\ldots \ldots \ldots+\cdots, \ldots$, & \\
\hline ance & 6 & & \\
\hline $\mathrm{k}, \ldots \ldots \ldots \ldots \ldots \ldots$ & "6 & *Abi & \\
\hline & "6 & *Deceiver. . . . . . . . & \\
\hline
\end{tabular}




\section{N I) F $\mathrm{X}$}

\section{TO THE DAIS OE S'TALLIONS TABULATED.}

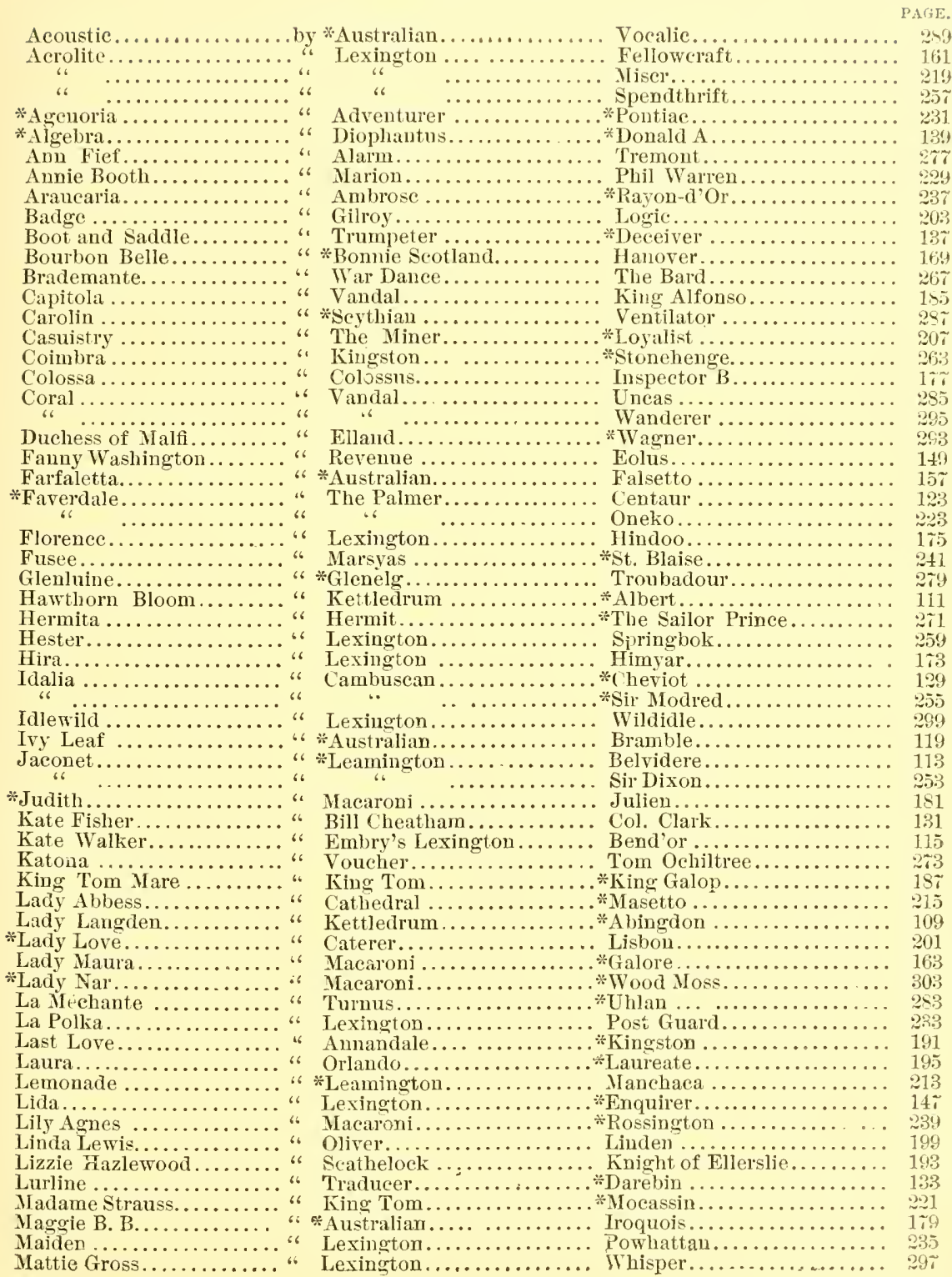




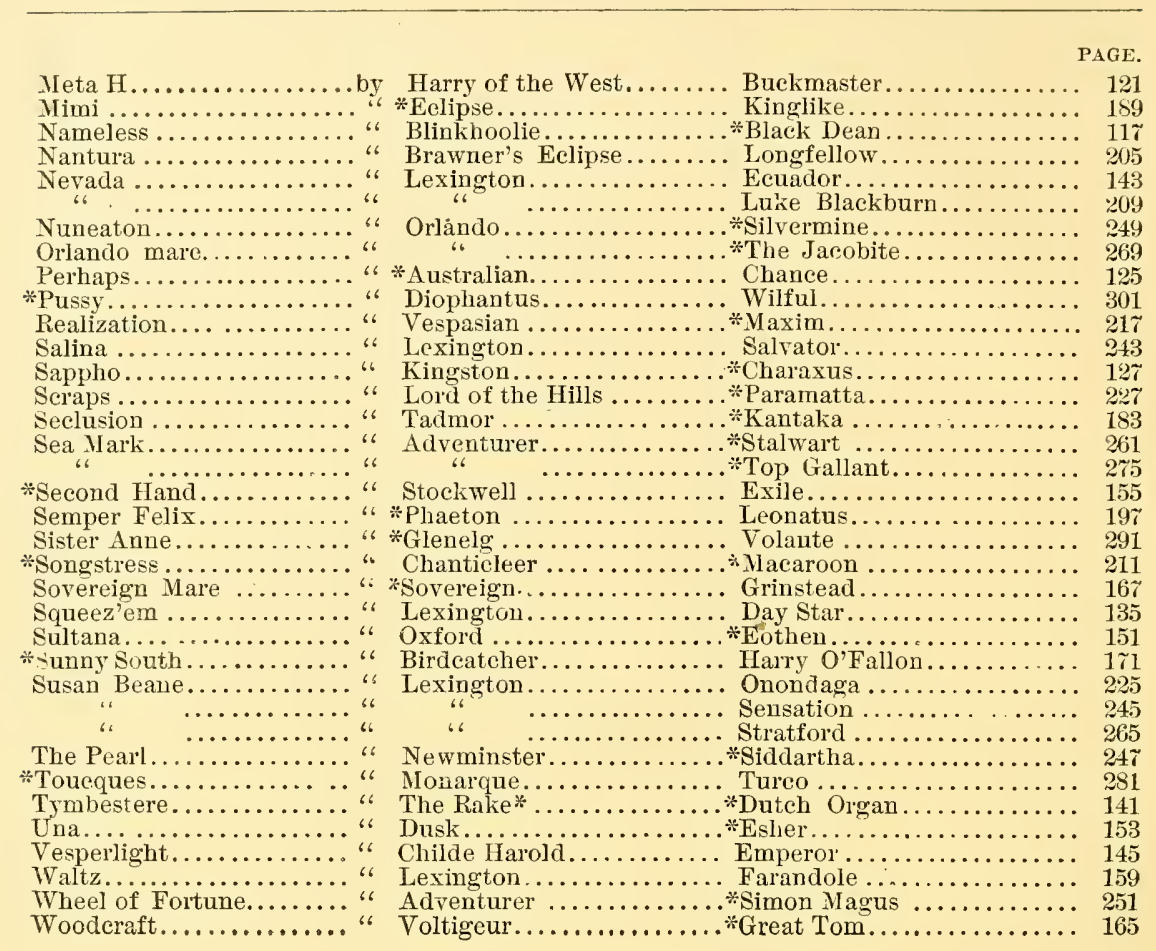




\section{INTRODUCTION.}

Tus anthos in writing this look amb rompiling the talonlated perligrees of the sires to he foumd in it, has been indneed to do so in the lope of their proving usefinl to those engaged in breeding for the turf, or who are seeking to foster this most popnlar national amusement. Very many of on largest breenters igmme the lessons tanght in the "Stmd Book and Rarding Calendar." I earuestly commend to all the necessity of oloserving what somrees and what course of breeding have produced the hest results in England, which may be most properly called the home of the thoroughlued horse. I have given my own riews as to the hest mode to snceessfully breed the race-horse, the best mode to seleet a stallion and brood mare, and the treatment of the same both in the stud and on the farm. I do not expect that all will agree with me. but the ideas expressed and plans snggested will do away with mauy of the chances incident to breeding. There is mueh meertainty, and always will be, attending the best and most careful mode of breeding, and this opinion is strongly exemplified in the frequent ocenrence of one horse being of very ligh form and an excellent race-horse, and a full brother or sister being only ordinary; yet I differ from a great many in the opinion that breeding depends entirely mpon chauce. Aceideuts and other unforeseen eauses, some of them so unimportant and abstruse as to escape our attention or come within onr knowledge, may prevent the best bred and most promising animal from arriving at its natural size and true shape, and a little difference in conformation, symmetry and constitution may make a decided difference in goodness and speed. The foal may be weak and have a delicate constitution, owing to the dam being starved and rxposed to hardships while carrying it, or it may have been inpropery reared. This proves that great care and knowledge are uecessary in rearing horses for the turf, as well as judgment and attention in selecting mares and stallions from which to breed. The chief points are pure blood, conformation, constitution, raing lineage and hereditary somnness. The nearer we get to true shape with the other points combined, the more eertainly we will arrive at excellenee. We often find a large horse of good shape and raeing sfmmetry; but where there is one good large one there are a dozen small or medium sized ones. The greater the size, when combined with the good qualities, the greater the excellence and the powers, for a good little horse camnot cope with a great good one. Hence size with constitution, somndness and symmetry constitute the height of perfection. While I adrocate and comment pure blood, I am convinced that very often pedigree is the only point at which some breeders look, ignoring altogether shape and action; hence failures. The establishment of reputation by a stallion depends on his having good mares 
at first, for if he has only bad and indifferent ones the produce will be in low form and a disappoiutment, and the horse condemned as a failnre. To prove this, it is only necessary to cite the Gorlolphin Arabian and Marske; the former but for the aecident of covermg Roxana and getting Lath wonld hare died mknown, while Marske, who had been standing for half a guinea and was sold for twenty guineas, after siring Eelipse was sold for one thousand guineas and covered at one humlred guineas. Squirt, the sire of Marske, Iad been ordered shot and was saved by the intercession of his groom; he afterwards got Marske, Syphon and the celebrated Squirt mare, the dam of Maislen Purity, Pumpkin and other famons horses. That many good race-horses have proved failures as stallious and many poor race-horses snccessful ones no one can doubt, as instance Lath, who was a famous race-horse but an indifferent stallion, whilst his full brother Cade was an indifferent race-horse but a most excellent stallion. Flying Childers dazzled the world by the splendor of his career on the turf, yet his brother, Bartlett's Childers, proved far the better stallion. Accorling to my notions, no horse can be a good race-horse or a successful stallion that does not possess great symmetry, by which I do not mean beauty, but a show of all those points, such as conformation, length, power and muscle, justly united. Notwithstanding it is often asserted that lorses run in all shapes, it cannot be denied that they rum better and more frequently where they are well and truly shaped and of tried and approved conformation. A horse may appear to the eye of ordiuary judges very plain and ill shaped, and still be in high form, and to the eje of a comnoisseur right in all the material points for racing purposes. The machinery properly put together is the point. Chances and accidents are elosely allied to all pursnits, and more particularly to breeding for the turf, and luck very frequently predominates over skill and judgment; and whilst breeding cannot be made a certainty or rednced to a science, it should not be left to chance. It cannot be too minutely studied, investigated or attended to in all its branches, and the breeder who selects his mares and stallions with eare, attention and judgment as to purity of pedigree, symmetry of form, temper, somnduess and constitution, in fact, those possessing all those essential qualities of speed and stoutness, nust be more successful than one who breeds at haphazard and pays no regarl to these established rules, at the same time crossing and preserving the blood of his mares judieionsly, and aiming to remedy the defeets, deficient properties and inferior qualities of his mares by the stiperior conformation, symmetry, admirable properties and brilliant qualities of the stallion, or vice versa. Those who do this will be more likely to produce a more symmetrical, high-typed and successful race-horse than those who pay no attention to these points. Speculatire experiments may suit those of large fortnnes, but the thinking and judicions breeder, aware of the great expense, constant and unremitting attention necessary for success, will confine himself to the established practice of men whose experience, judgment, attention and success in breerling are worthy of imitation. It is a matter of opinion whether the offspring partake most of the sire or dam. There is no doubt but that they partake of hoth, though very often more of the one than the other. Some of the mares loreed more after themselves, others more after the stallion, then again one foal will partake more after 


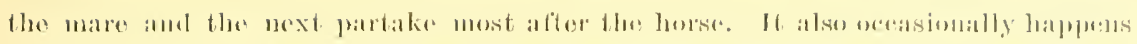

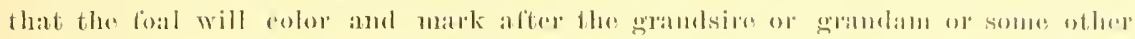

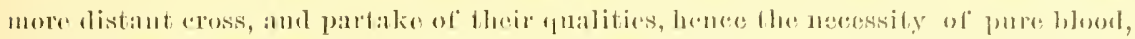

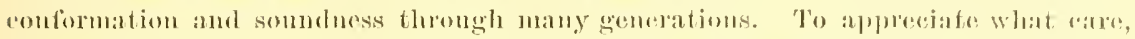

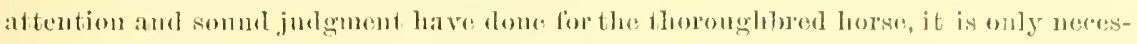
sary for us to look at his origin; muruestionably tho thoroughbred lorse as ho now

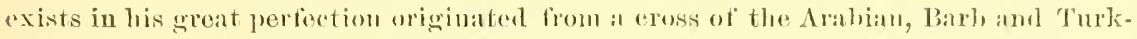
ish horse, the represontative scions heing the Godolphin and barley Lrabians; the former, genorally conceded to he a "liarb," was the sire of Lath, Canlo, Tieguhns, Jiank, Babraham, Bajaket, Ohd Englame, ete. It is said Mr. Coks hronght him from France, and that he bad actually drawn a ealt in the streets of Paris. Mr. Coke gave him to Mr. Williams, keeper of the St. James Coffee House, by whom he was presenter to Lord Godolphin. hence his name. He was teaser to Hologoblin in the years 1730 and 1731, and, on the latter refusing to cover loxana by the liald Galloway, she was bred to the Arabian, and from that cover prodnced Lath, the first colt ever credited to him, which brought him into prominent notice. Ho was represented 15 hands high. The Darley Arabian was the property of Mr. Darley, of Buttercramb, near York. He was the sire of the great Flying Childers, snpposed to be the fastest horse in the world, sire of Second, Snip, Blacklegs, ete., lartlett's Childers and Aluanzor, Bartlett's Childers never raced, but he was famons as a stallion. He was sire of Squirt (the sire of Marske and Syphon) and the Little Hartley mare, the dam of Janns, Blank, Old England, Slonch, ete. 'The Curwen Bay Barb was a present to Lonis XIV. of France from the Emperor of Moroceo, and was brought into England by Mr. Curwen. St, Victor Barb was the sire of the Bald Galloway, and he was the sire of Roxana that brought the Goldophin Arabian into notice. The Comptou Barb was sire of Coqnette and others. Hutton's Bay Barb was sire of Blacklegs. The Byerly Turk was Capt. Byerly's charger in Ireland during King William's wars in 1689. It is from this horse that the Herod blood originated. An examination of the Stud Book and Racing Calendar will show that nearly the entire family of great race-horses, both in England and America, dates back to the sources mentioned, and that it is extreme folly in our day to expect to improve the present magnificent racehorse by an infusion of the blood of the modern Ambian. We commencen npon the Arah, Barb and Turk with a height not exceeding 15 hands, and have, by julicions crossing, generons diet, discreet and eareful handling, built up the most maguificent specinens of the equine race, ranging up to 17 hands in height, with bone, muscle, length, action aus all the other graud qualities in proportion. In the early days of breeding, from necessity, very many of the best horses were very much inbred, and even incestnously so, and the question of inbreeding is one which commends itself strongly to mature consideration and examination. Aceording to the maxim that "like produces like," we ought to follow form, blood, speed and other good qualities, and if these good yualities can be maintained and improver by inbreeding, then it must be desirable to a certain extent. Some of the best English and American horses were very much iubred, and the consangninity of blood did not work deterioration. I am not an adrocate of incestuons breeding, but there is no doubt that manly beanty, gracefnl form and intellectnal vigor have resulted from preservation of these high qualities in the hnman race, where not carried too far; and I can see no reasou why the inbreeding of the truest, best bred and best shaped racers can work au injury 
to the eqnine race. Still, I think, an ont-cross of pure blood, with the essential qualities of a good race-horse, and then back to the superior blood and conformation, is likely to prodnce the best results. I will give a few examples of inbred modern horses in England, and the same in America, and in doing so will select those of high character which distingnished themselres on the turf and in the stud, for instance: The Baron, not only a good race-horse, but sire of Stockwell and Rataplan, was by Birdcatcher by Sir Hercules by Whalebone by Waxy by Pot-8-o-'s by Eclipse. The Baron's danı, Echidua by Economist by Whisker, own brother to Whalebone by Waxy by Pot-8-o-'s by Eclipse; Echidna's dam, Miss Pratt by Blacklock by Whitelock by Hawbletonian by King Fergus by Eclipse. Tonchstone, a fine race-horse and one of the best stallions that ever lived, was by Camel, son of Whalebone by Waxy by Pot-8-o-'s by Eclipse; his dam, Banter by Master Henry, son of Orville by Beningbrough by King Fergus by Eclipse; second dam, Boadicea by Alexander, son of Eclipse. The great Stockwell was much inbred on his dam's side, Pocahontas by Glencoe, dam Marpessa by Muley, son of Orville by Beningbrongh by King Fergns by Eclipse. Muley's dam, Eleanor by Whiskey, son of Saltram by Eclipse. Pocahontas' graurlam was Clare by Marmion, son of Whiskey by Saltram by Eclipse; Clare's dam, Harpalice by Gohanna, son of Mercnry by Eclipse. Queen Mary, the dam of Blink Bonny, Bonnie Scotland, etc., was mnch inbred. Gladiator, her sire, was by Partisan, son of Walton by Sir Peter by Highflyer by Herod; her dam by Plenipotentiary, son of Emilius by Orrille by Beuingbrough by King Fergus by Eclipse; her grandam, Myrrha by Whalebone, son of Waxy by Pot-8 o-'s by Eclipse; her great grandam, Gift by X. Gohanna, son of Gohanna by Mercury by Eclipse, out of a daughter of Sir Peter, son of Highflyer by Herod. Partisan was out of Parasol by Pot-8-o-'s, son of Eclipse. Pocahontas' best son, Stockwell, was by an inbred horse, aud Blink Bonny, Qneen Mary's best danghter, was by Melbourne, a horse inbred to Herod and Eclipse. So, if the preservation of good blool throngh inbreeding in these striking cases has been a success, is it not reasonable to suppose that the same resnlts mnst follow inbreeding to good blood and true shape with other desirable qualities in this country? Boston was inbred to Diomed, as also his best son, Lexington. Wanderer and Lncas are both much inbred on the dam's side, being out of a grandaughter of Glencoe and tracing to an own sister of the old hero. Glenmore, one of the best race-horses recently on the turf, and whose performances are of the best at all distances, is very much iubred. His dam, Lotta, is by Huntor's Glencoe, son of imp. Glencoe and the Blue filly (Fiatt) by imp. Hedgeford, she ont of Lady Thompkins by American Eclipse. Glenmore's grandam, Sally Lewis, is by imp. Glencoe; her dam, Motto by imp. Barefoot, ont of Lady Thompkins by Am. Eclipse. Barefoot was by Tramp and Glencoe's dam by Tramp, so that he is, strictly speaking, incestuonsly bred; ret he was a first class race-horse. Norfolk, a superior race-horse, is inbred to Sir Archy and Diomed. Falsetto is inbred to Lexington, the dam of his sire is by Lexington, and his grandam by Lexington, and he has nine crosses of Diomed. Imp. Eclipse was much inbred; his dam Gaze was by Bay Middleton, son of Snltan and Cobweb by Phantom, son of Walton; Flycateher, his grandam, was by Godolphin, son of Partisan by Walton, and his great grandam was an own sister to Cobweb by Phantom. Then if the Lexington, Leamington and Glencoe blood is to be preserved to the comutry, it can only be done by a judicions course of inbreeding, and so wniting the choice of both as to combine and render permanent the qualities possessed by each. Some regard inbresil. 


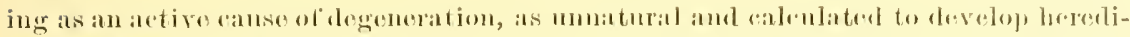

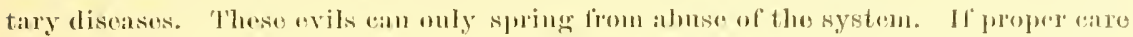

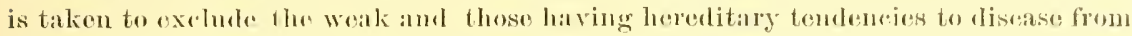

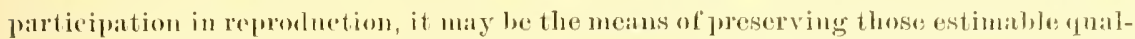

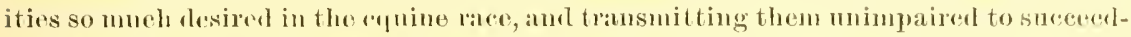
ing generations. 'The greatest suceess has been achieved by breeding form the nearest aflinities of blood, and one should not hesitate to breed a half-hother or sister to. gether where they possess many points of snperiority. ln the selection of a stallion we want first pmo blood, sizo, substance and conformation with symmetry, not a tall, narrow-chested horse, but one inclined to be thick-set; all comseness slomld be avoided, especially in the head, neck, shomlders, ankles and hocks; the aye shonld bo large, clear and bright, with no coarse hair abont it, the absence of which is indicative of high breeding in all animals; the jawbones not too massive or heavy, tapering gratually to the nose, free from beefiness; good space between the jawbones for the windpipe; a elear, full, steady eye denotes good temper and enduring qualities, whilst the one showing too mnel white is generally fond in tlighty, speedy, non-staying horses. The neck of moderate length, deep and not too thick at the crest or cnrve; nostrils large, full and roomy. The ehest moderately wide, the shoulder blade oblique and inclined backward, with snfficient muscle to eover it, with ams long and muscular, cannon bowes short and flat, and the pasterns moderately long, not upright; kuee broad and flat, and rather inclined to areh or bend over than backward or calf-kneed, which causes an extra tension on the back tendons; chest deep, extending down between the elbows, which should be straiglit, inclining neither in nor ont, and toes pointed straight forward; body and barrel round and not too long; mnsenlar arehed loins, with good length from point of the hip to haunch lone, a slight drooping towards the root of the tail, good length from hip to point of stifle and thence to the hock, which should be broad, finely eut and free from beefiness; the cannon bones flat, tendons detached and well defined, feet strong and hoof not too large or too small: back ribs long, round, and slightly detached from the hip joint. There shonld be sufticient general length, not to be determined by the length of the back, hut the ground the horse covers when standing in a natural position. Good blood is essential and necessary, but good form is superiority. In the selection of brood mares, form is as much a desideratum as in the stallion. First select from the most fashionable blood from running families on both sices with conformation, constitution, good temper and speed. Some prefer large mares, others of medium height. Large mares are not preferable because they are large, but if well and trnly shaped, from ruming blood, there is no objection to size. As a rule, the deep-chested, large-bodied, short-legged mares, with large pelvis, with wirle hips and good length, from 15 to $15 \frac{1}{2}$ hands high, have proved the best and most snecessful brood mares. The mare, above all things, showil be good-tempered and free from all hereditary defects and disease. It does not follow that a mare which may be blemished from some unforeseen canse may not be as good a brood mare as one entirely sound. Mares in good health will breed until twenty-five or thirty years old, but they require attention, air and exercise, with proper shelter from storms and bad weather, with suffieient food to keep them alwars in good, strong condition-not beefy fat, as nothing is more fatal to fruitfulness than obesity. Unless kept in good, strong condition, the foals are apt to be weak and weedy at birth. The time to make a race-horse is when the foal is in embyro; in the 
Irish vernacular, to make a race-horse you must do so before he is born. Stallions, to do themselves justice, must have plenty of exereise in the open air. If they eannot be trusted in an open paddock, they shonld be ridden three or four hours each day. Idleness results in indigestion, loss of vigor and flatulence, which often prove fatal. The colts from the day they are foaled shonld be fed, if the dam does not afford sufficient milk to insnre speedy and healthy growth, and broken at weaning time, which should be the last of September or first of October. It is a capital plan to feed the colts in pens for a month or six weeks before weaning them. I am decidedly of the opinion that foals which come the last of March or first of April have full as much arvantage as those foaled earlier before the grasses, necessary to afford an ample supply of milk from the dam, arrive at perfection. Those who believe in having early foals should always sow down in the early fall a patch of good ree for the use of the mares and foals. Stallions, mares and colts all require plenty of fresh air and exercise; air and light is life-darkness, death. Horses, and particularly colts, from their natural actirity, require more exereise than any other animals, and when properly given it is prodnctive of the most salntary effects. It is the more necessary to colts highly and grossly feed than to those stinted or fed moderately. It enables you to preserve them in a perfect state of health. The food is converted into wholesome nonrishment, the cirenlation of the blood promoter, and all the secretions and discharges facilitated. It invigorates the whole system, gives additional flow to the spirits, adds firmness and strength to the muscles, increases the firmness, texture and growth of the bone, promotes insensible perspiration, assists digestion, prevents fiatulence and prepares the sjstem for fresh supplies of aliment. It enables the animal to endure fatigue. In fact, withont constant and habitual exercise no animal can enjoy perfect health. High feeding without proper exercise prodnces many erils, such as indigestion, flatulency, costireness; the circnlation becomes languid, incurable diseases follow, and frequently death terminates the scene. The stallions and mares, treated as I have advised, whose blood is pure and uncontaminated, and whose conformation, strength, actirity aud rigor are conspicuons in every movement, must impart to their offspring not only somnd constitutions, but speed, natire fire and energs, which are necessary to support them under the severest exereise of their powers. With their variety of soil, perennial grasses aud farorable climate, the Americans shonld excel all nations in producing. the most perfect and the grandest of the eqnine race. The greatest danger which threatens onr ultimate success as the grandest breeding and racing nation of the earth is the constant influx of the rejected and trasly animals inporter. What the breeders and racing men of England do not want camnot improve the blood horse of America, but, upon the contrary, work irreparable injurs. 


\title{
THE THOROUGHBRED HORSE;
}

\author{
HIS ORIGIN, HOW TO BREED HIM AND HOW TO \\ SELECT HIM.
}

THe native country of the horse is not certainly known. According to ancient classic nythologr, the beantiful and useful animal originated in the contention of two deities, elunions to confer on the human race the most valuable gift. Minerva, the Goddess of Wistom, War and the Liberal Arts, created the olive tree, when Neptune, the God of the Sea, Rivers and Fountains, to ontrival her, struck the earth with his trident and gave existence to the horse. His noble prowess, bold majestic front, speed of thonght and graceful symmetry have been the admiration of men in erery age and the theme of poets of all lands. Job, Homer, Virgil, Shakespeare and many others have paid willing tribute of their genins to the elegance of his form, the animation of his spirit and conrage. A fiend to man, an ornament to the earth, no other animal has contributed so much to the social advancement of the human race. Speed, endmance, strength, elastieity, elegance and power, qualities so varied and valuable, are so thoronghly combined in this admirable animal as to proclaim him withont a peer in the sphere of animated natnre. In the Bible we are told that as early as 1650 years before the birth of Christ the horse had been domesticated by the Egyptians. When Joseph carried his father's remains from Egypt to Canaan, there went with him both chariots and horsemen. One hundred and fifty years afterwards the horse constitnted the principal strength of the Egyptian army. Pharaoh pursned the Israelites with six hundred chariots, and all the chosen horsenen of Egypt. Fifty years after the expulsion of the Israelites from Ligpt, and 1450 years before the birth of Christ, the horse was so far naturalized and utilized in Greece that the Olympic Games were institnted, including chariot and horse races. This short digression from our subject is justified in order to show that horses were used in races long before the Christian era. Accorling to whyte in his history of the British turf, the earliest mention of race-horses, ealled running horses in those days, was in the ninth century, when Hngh, founder of the royal house of Capet iu France, sent horses as a present to King Athelstane, whose sister, Ethelswitha, he was soliciting in marriage. In the reign of William the Conqueror, the Earl of Shrewsbury imported some stallious from Spain into his estate at Powisland; we find their produce celebrated by Drayton, the poet. This is the first well-authenticated step we can find towards the improvement of the breed of horses. These horses were more than probably of Eastern blood. In the reign of Richard I. matches were run for large sums, and swift-runuing horses were greatly esteemed aud were sold for rery high prices. There is no data in subsequent reigns, but we find Edward III., 1326, purchasing rmning horses, and in the ninth year of his reigu he received as a present two running horses from the king of Navarre, and they were supposed to be valuable as the king made large pecuniary compensation to the person who brought them. In the reign of Heury VII. the custom of gelding horses came into general practice. Henry VIII., 1509, took great paius to improve the breed of horses, especially in the royal stud; Sir Thomas Chalouer, a writer in the commencement of the reign of Queen 
Elizabeth, mentions his having imported horses from Turkey, Naples and Spain. These horses unquestionably were largely bred from Moorish and Barbary bloor. Her successor, James I., in 1602 , placed the turf upon a solir basis and marle it a permanent institution. From the royal patronage accorded it, and rules framed for its regulation, horse racing had a gradual and uninterrupted progress until it reached its zenith. James I. by his public patronage of the race course, and royal support, which was needed to bring it into good form and repute, should be canonized as the patron saint of the turf. But the improvement of the race-horse originated by him was of much and superior importance. The crossing of foreign blood with the English horse was not new at this period, but the eastern blood had never been trier, and to James $I$. is due the credit of first attempting that, which, although considered a failure, has resulted in the excellence of the race-horse of the present day. King James purchased of Mr. Markham an Arabian known as the Markham Arabian. This Arabian was a fillure, and no horses of note or value descended from him. The king subsequently purchased the Turk known as Place's White Turk. Mr. Place Wris subsequently Stud-master to the Protector, Oliver Cromwell. Place's Wlite Turk was the sire of Commoner and Wormwood, and the grandam of Cartouch. GreF Ramsden and Windham. The Brimmer mare, dam by Place's White Turk, grandam by Dodsworth ont of the Layton Barb mare, produced Bay Layton by D'Arey's Connsellor, Brown Farewell and her sister by Makeless. The Place White Turk mare, dam by Dodsworth out of the Layton Barb mare, was the dam of the noted Makeless. Mr. Croft's Brimmer mare, the mare by Hantboy, dam of the Pet mare by Wastell: Turk, Trumpet and Gray Layton, by Counsellor. Bay Layton above was the dam of Old Scar by Makeless, Chesnut Layton by Makeless and scar by Croft's Bay Barb. Brown Farewell was the dam of Gus, Yomng Greyhound and sister to them by Greyhound, and Miss Partner by Croft's Partner. This sister to Guy was the dam of Bay Bloody Buttocks and Grey Bloody Buttocks (Dairy Maid) by Blooly Buttocks, Little Partner (Vane's), Young Partuer, Rerl Rose and sister to them by Croft's Partner. This sister to Vane's Little Partner was the dam of the Starling mare that produced Leedes by Second and his sister that was the dam of Amarantlus. Gift and the mare by $\mathrm{Cub}$ which was foaled in 1762 and imported into America by Gen. Delaney, of New York, prior to the American revolution. Miss PartueI above was the dam of Whimsey and Madame by Bloody Buttocks, Toy by Bartlet's Childers, Drowsy by Fox Cub, Torismond by Old Starling, a filly by Romulhead (dam of Juliet by Bustard in Ireland), Young Cade, Miss Cade, Villager amit Nilksop, all by Cade. A sister to Miss Partner by Croft's Partner was the dam of Sweepstakes and Clio by the Gower stallion, son of the Godolphin Arabian. Clio was the dam of Mr. Wilkinson's Conqueror in Ireland, fonled 17.5t by Bajazet. Another sister to Miss Partuer was the dam of Dormonse, by the Godolphin Arabian, Mercurr, Merryman, and Cadormus by Cade and Bolton, foaled 1752 by Shock, imported into America. Still another sister to Miss Partner was the dam of Miss Romulhead by Roundhead, Changeling and the noted Matchen by Cade, son of the Godolphin Arabian, Young Starling by Starling, etc. Matchem was the best race-horse of his day and famons as a stallion. He got in the twenty-three years he was in the stucl $35 t$ winners of $\$ 755,485.00$. Bay Bloorly Buttocks, mentioned above, was the dam of the famous spinster, better known as Mr. Panton's Widdrington mare by Partner. Spinster was the dam of Spinster and Shepherd's Crab and Fancy by Crab, Mr. Panton's Deputy, afterwards Mr. Vanes Lofty, by Godolphin Arabian, Golden Grove by Blank and others. Spinster by Crab was the dam of a filly by Janus, whose daughter by Skim, son of Traveler, was the dam of Mr. Vernon's Telemachus and Duke of Hamilton's Expectation, both by Herod: Grey Starling by Bolton stirling and others. Fancy by Crib was the tam of Cloudy and Comntess by Blank. Clomdy was the dam of Amaranda by Omninm, son of Snap, foaled in 1771. Amaranda was the dam of Joe Andrews (first called Demis O) by Eelipse, who was the sire of the two good horses Jack Andrews and Dick Audrews, ،lam by Hightlyer. Golden Grore was the dam of Petworth (Gandy) and an own sister by Herod. Petworth was the? dam of Rosina by Woodpecker, she, Rosina, was the dam of Hermes by Moremr, son 


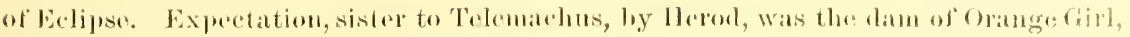

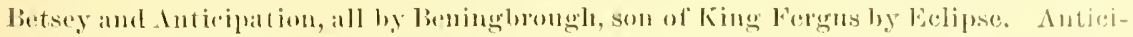

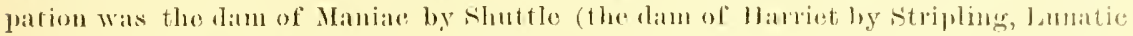

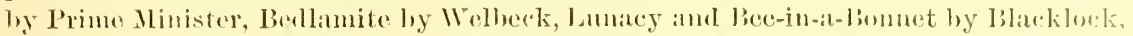

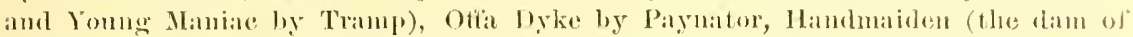
Inheritor by Lottery and Executrix, by Livenool) by Wallon. A filly by Cervantes,

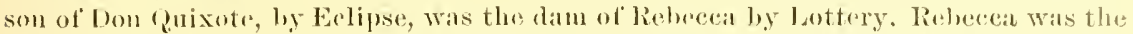
dam of 'The Provost by The Sirldler, Alice Hawthorn by Muley Moluel, Amandale by T'mehstome, Fan Helen by Pantalonom, son of Castrel, that wats the dam of larel of the 1sles liy 'Tomelistone.

Alice Hawthorn was the most famous race-mare of her day, wimner of 16 cups, incluling Doneaster and Goodwood eups, each twice; 18 Queen's plates, and 17 other races, and was the dam of Onlston by Melbourne, a superior racer, 'Thormanhy, wimner of the Derby, 1860, by Melbourne or Windhound, Lady Hawthorn by Mindhound: sweet Hawthorn by Sweetmeat, ete. Lady lfawthorn was the dam of Lidly Alice Hawthorn by Newminster, she the dam of Hawthorn Bloom by Kettledium, she the dam of imported Bread Fruit by Breadalbane, Imported Albert by Albert Victor. Lady Alice Hawthorn was also dan of Hawthorndale by Kettledrum, she the dam of Hauteur, wimner of the 1,000 Guineas, by Rosicrucian. Lady Hawthorn was the dam of Maybloom, by Newminster, she the dam of Corisande, winner of the Cesalewiteh, and her sister, imported Lady Mentmore by King Tom. Lady Hentmore is the dam of Mentmore Lass, winner in England, Rica, a superior race-mare, and Mehallah by Kingfisher, son of Lexington. Another sister to Lady Mentmore and Corisande, Verdure is the dam of imported Judith and Clover by Maearoni, and a sister Vista, she the dam of Bonarista, wimmer of the 2,000 Guineas in 1892, by Bend'or. Sweet Hawthoru was the dam of Lady Nateby by Vau Galen, she the dam of Lady Portland by The Primate, and she the dam of Miss Jummy, winner of the 1,000 Guineas and Oaks, by Petrareh. To Anticipation in the female line trace Inheritor, Berlamite, Common, winner of the 2,000 Guineas, Derby and St. Leger. Maegregor, winner of the 2,000 Guineas, Our Nell, winner of the Oaks, Manganese, winner of the 1,000 Gnimeas, Apology, winner of the 1.000 Guineas, Oaks and St. Leger, Mandralse, The Miner, Wenlock, wimmer of the St. Leger, Kisber, winner of the Grand Prize of Pars and Derby, mported Agenoria and her brother imported Pizarro, sire of Pessara, whose early death was a serious loss to America.

Eugland is entitled to the credit of originating the thoroughbred horse. The breed has spread over the entire mtelligent habitable globe wherever the ralue of beanty in form, ntility, speed combiued with streugth, so mdispensably necessary to labor, pastime, war and the turf is valned. To understand his origin we must begin with the sources from which he has descended and trace him from a combination of the Arab, Barb and Turkish horses. It is mupossible for any man, a stndent of the stud book and conversant with the turf, to look at the present high-bred horse, and those of earlier days, withont being smriprised that the blood which was so highly aud justly esteemed should now be mutashionable and little used, but the judicions crossing and mtermmgling of the blood of Herod, Matchem and Eelipse has built up such a grand and noble specimen of the equine race that the original blood cannot improve it. The three great sources of blood will readily be seen $1 \mathrm{n}$ the following tables:

The Byerly T'nrk was Captain Byerly's charger in Ireland, in King William's wars in 1689, and founded what is styled and known as the Herod Blood. The Byerly 'Turk got Jigg out of a spanker mare. Spanker was by D'Arey's Yellow Turk, who was the sire, also, of Brimmer. Jigg got Partuer out of a sister to Misbury, by the Curwen Bay Barb, who was a present to Lous XIV. from Muley lshmael, King of Moroceo. The Curwen Bay Barl was bonght into England by Mr. Curwen, who procured hm, together with the Thoulouse Barb in France, through Comnt Byram and Count Thoulouse, two natural sous of Lous XIV, the former Master of the Horse, and the latter an Admiral. Thes proved excellent stallions 
Partner got Tartar out of Meliora by Fox, she out of Milkmaid by Sir W، Blacket's Snail. Fox was by Clumsy, son of Wilke's Old Hantboy by the White D'Arey or Sedbury Turk, out of a Royal mare, brought into England by the Master of the Horse to King Charles II. Tartar got King Herod ont of Cypron by Blaze, she out of Selima, a danghter of Bethell's Arabian. Blaze was by Flying Childers, son of the Darley Arabian, dam Betty Leedes by Careless, ont of sister to Leedes by Leede's Arabian. Herod got Highflyer, dam Rachel, by Blank, son of the Godolphin Araljian (Barb), ont of a daughter of Regulus, son, also, of the Godolphin Arabian. Herod, also, got Fortitude, dam by Snap, son of Snip by Flying Childers, out of Milksop by Cade, son of the Godolphin Arabian. Herod also sired Woodpecker, dam Miss Ramsilen by Old Cade, son of the Godolphin Arabian, ont of a daughter of the Lonsdale Bay Arabian, etc. Woodpecker sired 1mp. Buzzarl, out of Misfortune by Dux. Hightlyer got Sir Peter Teazle, commonly called Sir Peter, dam Papillon by Snap, out of Miss Cleveland by Regulus. Among the famons sons of Sir Peter were Sir Solomon, dam Matron, by Florizel, by Herod, out of Maiden, by Matchem; Haphazard, dam Miss Hervey by Eelipse, ont of Clio by Young Carle; Stamford, dam Horatia by Eclipse, out of Conntess, Delpini's dam by Blank; Walton, dam Arethusa by Dungannon (son of Eclipse and Aspasia by Herod), her dam by Prophet, son of Regulus, ont of Virago, Saltram's dam by Snap; Williamson's Ditio, a full brother to Walton; and Sir Oliver, dam Fanny by our imported Diomed, out of Anbrosia by Woodpeeker, ete. This is the first elass or Herod blood.

The Godolphin Arabian, generally believed to have been a Barb, was first the property of Mr. Coke, who presented him to Mr. Williams, the keeper of the St. Janes Coffee House, by whom he was presented to Lord Godolphin. The Godolphin Arabian was teazer to Hobgoblin in the sears 1730 and '1731, and on the latter refusing to cover Roxana, she was put to the Godolphin Arabian, and from that cover she prodnced Lath, a superior race-horse, and in 1734 Cade, by the Godolphin Arabian, who took his name from the faet that Roxana died when he was ten days old, and he was brought up on cow's milk. "To Cade, to breed up in softuess."

Roxana was by the Balı Galloway, son of the St. Vietor Barb, his dam Grey Whynot by Whynot, son of the Fenwiek Barb, his grandam a Royal mare ; Rosana's dam, sister to Chaunter by the Akaster Turk. Carle got Matehem, foaled 1748, dam sister to Miss Partner by Partner, son of Jigg by the Byerley Turk, out of Brown Farewell of Makeless, sou of the Oglethorpe Arabiau; Matchem got Condinetor, dam by Snap, graudam by the Cullen Arabian, out of Grisewool's Lady Thigh by Croft's Partner; Condnetor got Imperator, dam by Herod, grandam Carina by Marske (sire of Eclipse), son of Squirt by Bartlet's Childers; Conductor, also, got Trumpator, dam Brunette by Squirrel, son of Traveler, out of Dove log Matchless, son of the Godolphin Arabıan.

Imperator got Pipator, out of Brunette, the dam of Trumpator, and Pipator got Remembrancer out of Queen Mab, sister to Merenry by Echipse, out of a clanghter of Tartar; Trmmpator got sorcerer, dam Young Giantess, by mporterl Diomed, out of Giantess, by Matchem. This is the second class, or Matchem blood.

The Darley Arabian was the property of Mr. Darley, of Buttererimb, near York. He was thought by some to be a Turk or Syrian horse, but was mquestionably an Arabian of pure blood. He got Bartlet's Childers own brother to Flying Childers, dam Betty Leedes by Careless, son of Spanker, son of the D'Arey Yellow Turk, ont of Sister to Leedes by Leedes Arabian. Bartlet's Childers got Squirt, dim sister to Old Country Wench, by Snake, son of the Lister Turk, ont of Grey Willss by Old Hautboy, son of the White D'Arey or Selbury Turk. Squirt got Marske ont of the Ruby mare by Blacklegs, son of Huttou's Bay Barb, his granlam by Bay Bolton, son of Grey Hantboy. Marske got Eelipse (O'Kelly's) dam Spiletta by Regulus, son of the Godolphin Arabian, grandam, Mother Western by Smith's son of Suake by Mr. Lister's Snake, ont of danghter of the Akaster Turk. Eelipse took his name from the fact that he was foaled during the great eclipse, $1 n$ 1764. Eelipse got King Fergus, dam Tuting's Polly hy Black-and-all-Black (Othello), grandam Fanny by Tartar, Lelipse got Mercury, Yolnnteer and Queen Mab, dam by Tartar, out of a daughter of Mogul by the Go- 
Golphin Arabian. Echipse got Dungannon, dam Aspasia by Heroul, gramelam Doris by Blank, out of Helen by Spectator, son of Crab, by Aleock Arabian. Eolipse got Mefeor, dam daughter of Morlin, by Serond, son of Flying Childers, grandam Mother P'att, by Matesman, son of tho Godolphin Arabian. Eelipse got inporter Saltran,

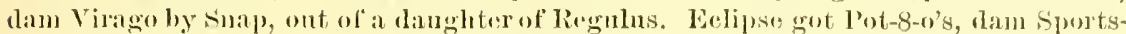
mistress by Wajren's Spertsman, son of Caule, gramblam Golden Loeks by Oroomoko, som of Crab, out of Valiant's dim, by Crab. Volunteer got Wagle and sprear Laglo, ont of a daughter of Highflyer, grandam by lingineer, son of lilaze, ont of a langhter of Regulus. Meroury got Gohamma and Preeipitate, ont of a claughter of Herod, grandam Maiden, sister to Pmmpkin, by Matchem. King Fergus got lieninghrough, out of a danghter of Heror, grandam Pyrha, ly Matehem, ont of Duchess, Jy Whitenose, son of the Godolphin Arabian. King Forgns got Hambletonian, dam loy Iligh. Hyer, out of Monimiat hy Matehem. Saltram got Whiskey, ont of Calash by Herorl, grandam Teresa by Matehem. Pot-8-o's got Waxy and Worthy, ont of Maria lyy Herod, grandam Lisette by Snap, ont of Miss Windsor by the Gorolphin Arabian. 'This constitntes the third class or Eclipse bloor. To these three strains of hlood trace all the horses of this day and all the hest for the last eentury, and the horses now so suecesstinl on the turf in Ameriea and England combine these three strains of blood to a greater or less extent on both the paternal and maternal sirles.

Taking a retrospect of the winners of the two great fixed events of the English turf (there being really no National fixed Event in Ameriea if we except the Futnrity and the Realization stakes), the Derby and St. Leger, we find that in the tail male line 'The Derby, in the 113 years it has been run, has been won by the First line, Herod blood, thirty-five times, commeneing with Diomed in the inauguration Derby, 1780. Diomed was imported in 1798, being then 22 years old. He was solıl for 50 guineas and subseqnently sold to Col. Hoomes, of Virginia, by whom he was imported. He died in Virginia in 1808, being then 31 years old. There is scarcely a really good race-horse of the present day which does not partake of his blood. He was the sire of Sir Arehy, ont of imp. Castianira by Rockingham, justly styled the Godolphin Arabian of Ameriea. Diomed also sired Ball's Florizel, Duroc, the sire of American Eclipse, Potomac, Diomed Eagle, Stump the Dealer, Vingt'un, Hamlintonian Virginius, Peacemaker and a number of superior race-horses and brood mares, thams of winners. Other winners of the Derby imported were Saltram by Eelipse, sire of Whip, also imported, and the Saltram Mare, dam of 'Timoleon, the sire of Boston; John Bull by Fortitude, son of Herod; spread Eagle by Volunteer, son of Eclipse; Sin Harry, son of Sir Peter, by Herod; Arehduke by Sir Peter; Priam by Emilius; St. Giles by Tramp, by Diek Andrews; Blne Gown by Beadsman died on the passage; Kingeraft by King Tom died on the passage, and St. Blaise by Hermit. All these from Priam down trace on the tail male line to Eelipse, whose descendants in a direct male line won the Derby 72 times, including Iroqnois. The rlescendant of Matehem only six times, and one, the horse Aimwell, who won it in 1785, from the Alcock Arabian through Mark Anthony by Spectator by Crab, his dam a sister to Postmaster by Herod. The other great fixed event, the St. Leger, was inangurated in 1776, lnt did not receive its present name until 1778. It was won in 1776 by Allabacniia by Sampson, son of Blaze by Flying Childers, by the Darley Arabian, Sampson's dam by Hip, son of the Curwen Bay Barb, this race has been run one hundred and sixteen years, from 1776 to 1891 inclnsive, and has been won 72 times by the descendants of the Eclipse blood in the tail male line, 28 times by the Herod line and 16 times hy the Matchems, but the wimners were largely inbred to the three great strains of blood. The 2,000 Guineas, another of the important fixed events of the English Turf, was inaugurated in 1809, and has been run annually since that date. It is the important opening three sear old event of the year. It is run over the Rowley Mile, one mile 11 yards. It has been won by the descendants of Eelipse, in the tail wale line, 45 times, by the Herod line, 27 times and by the Matehem line, 12 times. These three erents are open to both eolts and fillies, but few of the latter are entered or start in them, hence the winners have generally been eolts. The Two Thousand Gnineas has been won but four times by fillies, in 1822 by Pastille by Rubens, son of Buzzard; in 1810 
1,5 Crucifix by Priam, son of Emilins, in 1878 by Pilgrimage by The Earl or The Palmer, and in 1882 by shotover by Hermit, son of Newminster. In 1868 Formosa by Buccaneer ran a dead heat and divided the stakes with Moslem. The Derby has been won only three times by fillies, in 1801 by Eleanor by Whisker, in 1857 ly Blink Bonny by Melbourne, and in 1882 by shotover by Hermit. The st. Leger, rm in the fall, has been won more freqnently ly fillies, for the reason that good ones have oftener started for this event. Allabacnlia by Sampson won it in 1776. Hollandaise by Matchem in 1778. Serina by Goldfinder in 1781. Imperatrix ly Alfred in 1782. Omphale by Highflyer in 178t. Cowslip by Hightlyer in 178.5. Yonng Flora by Highflyer in 1788. Pewett hy Tandem in consequence of a foul on the part of Duke of Hamilton's Lanrel colt, in 1789. Panlina hy Sir Peter in 1807. Altisidora ly. Dick Andrens in 1813. Duchess by Cardinal York in 1816. Matilda by Comus in 1827. Queen of Trumps lyy Velocipede in 1835, She also won the Oaks. Blne Bonnet by Touchstone in 1812. Imperieuse by Orlando in 1857. Sunbeam by Chanticleer in 1858. Caller On by Stockwell in 1861. Achievement hy Stockwell in 1867. Formosa he Bnecaneer in 1868, Formosa also ran a dead heat with Moslem for the 2,000 Guineas and won the Oaks the sane year. Hannah by King Tom in 1871. Hannah also won the Oaks. Marie Stuart by Scottish Chief in 1873. Apology by Adventnrer in $187 t$. Narie Stnart and Apology both won the Oaks. Jannette by Lord Clifilen in 187x. Jannette also won the Oaks. Dutch Oven by Dutch Skater in 1882. Seabreeze by Isonomy in 1885. She also won the Oaks. Memoir by St. Simon in 1890. Memoir won the Oalss. The Oaks, the most important fixed event, for fillies only, was estabIished in 1779, the year prior to The Derby. It has been run one hundred and fourteen times, inchnding the rear 1892, and has been won 64 times by the descendants of Eclipse in the tail male line, 37 times by the descendants of Herod and 13 times by the flescendants of Matchem. The length of the Derby course in 1780 and up to 1784 was one mile. From $178+$ up to and including 1871, the distance was one and a half miles. In 1872 and since the start has been from the New High Lerel Starting Post, the distance being one and a half miles and 29 yards. The Oaks is rim over the Derby conrse. The st. Leger course was originally two miles. In 1813 the distance was changed to one mile 6 furlongs and 193 yards. In 1826 the distance was rednced 61 yards and has remained since that date one mile 6 furlongs and 132 yards. It appears firom the statistics above that the tail male line of the Eclipse blood has won a large majority of the fixed events above mentioned, but it must be borne in mind that Matehem tras foaled in 1748, King Herod in 1758 and Eclipse in 1764, so that Eelipse hail the benefit of the danghters of the two other strains of bloor and nearly all of the hest and most famons of his sons and grandsons were from Herod's danghters and granddaughters, fortified by the Alatchem blood. There were but few males from the Hatchen blood compared with the number from the Herorl line, and the same may he said of the number of the Herod's compared with the Eelipse's, and nearly all the descendants of Eelipse which have won the great events in the last quarter of a century, are descended from Whatebone through his sons Canel aud sir Herenles. To the former traces Tonchstone, and to the latter Stockwell, both being inlored to Heroul anil Matchem on both the paternal and maternal sides, and the same is true of every grand race-horse that has appeared in any country on the globe.

It was in the reign of the nn fortunate Charles I. that the introduction of Eastern blood of mnch importance took place, notably the Helmsley Turk, hronght to EnyIand by the Duke of Buckingham, and sold to Mr. Helmsley, hence his name. The Helmsley Turk was the sire of Bastler, whose dam was not known; Hutton's hoyal colt, dam a selbury Royal mare, and Vixen, out of Dodsworth's dam, in Royal mare. Vixen was the dam of the Old Child mare, by the Gresley Bay Arabian (Bay Roan). The Old Child mare was the dam of a tilly, ly the Darley Arabian, which prodnced a filly by Rattle, who was by a son of Sir J. Harpur's Barb, ont of a Rogal mare. This Rattle mare was the dam of silrertail, by Heneage's Whitenose, son of the Hall Arabian; Silvertail was the dam of Whimsey, by Cullen Arabian: Sportsman and Carle, imported into South Carolina in 1762 (both by Cade, son of the Godolphin Arabian): Careless and Fearnonght by Regulus, son of the Godolphin Arabian. 


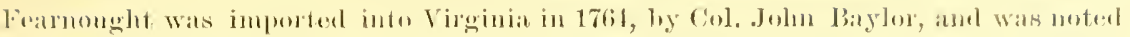

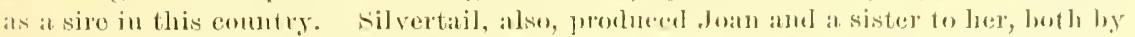

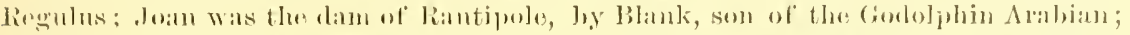

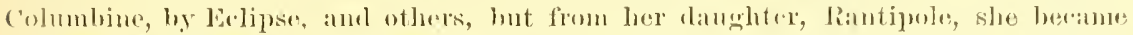
fimoms. Ramtipole was the dam of Nymph, l'nesty and Nimble hy lilorizel. Nimble

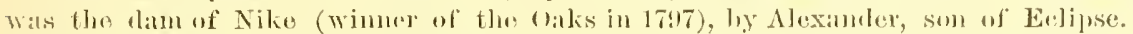
Nutmog loy kir Poter, son of lliglulyer, and Domna Clara, hy Cosario, by Joln linll,

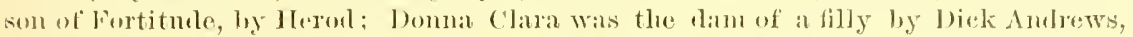
son of Toe Antrews, by Eelipse; Donma Maria, by l'artisan, son of 15 altam, and

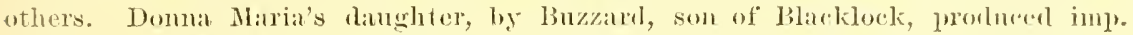
barbarity, hy simoon, son of Camel, by Whalebone, that gave to America the superior mares Ruthless, Relentless and liemorseless, with Yomg Eelipse, liarbarin and lerastation, all by inup. Eelipse, son of Orlando, hy Tomelistone. Nike, thromgh her danghter by Trafilgar, som of Sir Peter by Hightlyer, gave us imp. Alarm by Thumblerolt, son of soreerer, by Trumpator. Alarm was the dam of Zarlora ant Di Vemon, by American Eclipse; Lary Alert (Alert), by Eclipse Lightfout; Clara Howar, lomng Alarm amel Fanny Elssler, by imp. Barefoot. Clara Howarl was a superior mee-nare, and the dam of Eliza Butler and Mary Elliott, ly imp. Leviathan. Mary Taylor, by imp. Sorereign; Angeline, Star-spangled Banner, and Banner, by imp. Albion. Angeline was the dam of Lantana, by Capt. Elgee, and Peytona Barry, be Rogers, son of Lexington. Lantana was the dam of Poca Wiley, hy Mnggins, Larkspar, by Jack Malone, Beersheba, Balance-All, Bran Dance (in England), all by imp. Bonme Scotlaud; the good race-mares Liahtmaln and Panorama, by John Alorgan, and Tantilns, by imp. Great Tom. The reputation of the Helnsley Turk was maiuly established and immortalized as the sire of Bustler, whose dam is not stated in the stud book, or by other authorities, but was undoubtedly ont of one of the Royal mares. He was the sire of Lord D'Arey's Blunderbuss, Old Merlin, the sire of Mr. Betlel's Woodeock aud Castaway, and Mr. Richardson's Merlin. The Boltou Sweepstakes' great graudam was ont of daughter of Bustler. The pedigree of the Ruby mare, by Blacklegs, dam of Marske (sire of Eclipse and imp. Shark), ends in a langhter of Bnstler. The Bolton Sweepstakes was the sire of the dam of Whistle jacket, and the grandam of Mr. O'Felly's fanous Old Tartar mare. The Old Tartar mare was the dam of Merenry, Volnnteer, Qneen Mab, Veuns, Jupiter, Alonis and Lily of the Valley, all by Mr. O'Kelly's noted Eclipse. Bolton Sweepstakes was the sire of Turner's Sweepstakes, ont of a Bay Bolton mare. The mames of Bustler and Hutton's Roral colt are to be found at the eud of the perligrees of many of the most noted horses.

Place's White Turk was imported and owned by Mr. Place, stnd-master to Oliver Cronwell when protector, and was the sire of Mr. Croft's Commoner, Mr. 'Tregonwell's White Turk liare, ont of a natural Barb mare. This White Turk mare was the dam of a mare by the Taffolet Morocco Barb that produced the Byerly Turk mare, wheh was the dam of Grey Ramsden, by Grey Hautboy, son of Hautboy, by the D'Arey White Turk, a filly by Spanker, son of the D'Arey Yellow Turk, one filly each by the Darley Arabian and Newcastle Turk. From the Spanker filly mentioned, descended in Iirect female line, Wooolpecker, Goldfinder, Waxy Pope, Whalebone, Whisker, Partisan, Rockiugham, Glencoe, Bay Midlleton, Lord Lson, Dollar, Trumpeter, Melbourne, Bend'or, Robert the Devil, Uncas, Speculum, Charibert, The Nob, Silvio, B]ne Gown, Pellegrino, Trappist, Craig Millar, Mortemer, King of Trumps (by Lord Clifden), The Lambkin, The Confessor (by The Palmer), Paradox, The Bard (by Petrarch), Minting, and many other noted race-horses and stallions.

The Bserly Turk was one of the valuable importations to England during the reign of William and Mary. He was the charger of Capt. Byerly throughout the war of King William m Ireland in 1689. This Turk became one of the principal founders of the thoroughbred horse. To him traces what is generally styled the First Class, ol Herod Blood. The Byerly Turk was the sire of $\mathrm{Jgg}$, dam by Spanker, son of the D'Axcy Yellow 'Turk. The grandam of Jigg is unknowu. Jig was the sire of Partuer, 1718, ont of sister to Mixbury, by the Curwm Bay Barb, secoml dam by Curwm's Old Spot, 
son of the Selaby Turk, third dam by the white-legged Lowther Barb, out of the Old Vintner mare. He was also the sire of Miss Jigg and her sister, ont of Partuer's dam. Partner got Tartar, 1743, dam Meliora, 1729, by Fox, sou of Clumsy by Hantboy, second dam Witty's Milkmaid, 1720, by Snail, son of Whynot, by St. Victor Barb, third dam by Mr. Curwin's Shields Galloway. Tartar was an excellent racer and superior stallion. He was the sire of King Herod, commonly called Herol. 1758, and his sister Thais, dam Cypron, by Blaze, son of Flying Childers, second dam Selima, by Bethell's Arabian, etc. Tartar was also the sire of Beanfremont, and lír. O'Kelly's mare, dam of Mercury, Volunteer, etc. Herod got Highflyer, 17it, dam Rachel, by Blank, son of the Godolphin Arabian, second dam by Regulus, son of the Godolphin Arabian, out of a daughter of Soreheels, son of Basto, by Byerly Turk, ete. Herod was also the sire of Anvil, Bordeaux, Drone, Florizel (sire of imp. Diomed, winner of the first Derby, 1780), Fortitude, Phenomenon, Postmaster, Telemachus, Woodpecker (sire of Buzzard) and other stallions. He was the sire of many excellent race and successful brood mares, including Calash (dam of Whiskey, br Saltram, and Kite, by Buzzard), Faith (dam of Bobtail), Maid of the Oaks (dam of imp. Druid), Maria (dam of Waxy and Worthy, by Pot-8-o's, Qniz and Wowski by Mentor), Peggy, sister to Postmaster (dam of Peggy, imported to America, and her sisters, Spinnetta and Trumpetta), by Trumpator, son of Conductor, by Matchem, Perdita, Pomona, Sting, sister to Florizel, Tuberose, etc. Herod was a superior race-horse, and as a stallion was inferior to no horse that ever lived. In nineteen years he got 497 winners that won $\$ 1,007,525$. Highflyer got Sir Peter Teazle, 1784 (commonly called sir Peter, winner of the Derby, 1787), dam Papillon, by Snap, son of Snip, by Flying Childers, second dam Miss Cleveland, by Reguhs, out of Midge, br a son of Bay Bolton, tracing to the Byerly Turk mare, dam of the two True Blues, Lady Teazle and Brown Bess, sisters to Sir Peter. Highflyer was the sire of Noble (winner of the Derby in 1786). Skyscraper (wimner of the Derby in 1789). Highflyer was also sire of Omphale and Cowslip, winners of the St. Leger in 1784 and 1735, Spadille aud Yomng Flora, winners of the St. Leger in $\mathbf{1 7 8 7}$ and $\mathbf{1 7 8 8 . ~ H i g h f l y e r ~ n e v e r ~ p a i d ~ a ~ f o r f e i t ~ a n d ~}$ was never beaten. Sir Peter was the best son of Highflyer, and was the best racehorse of his day. He was the sire of imp. Sir Harry, 1795, dam Matron by Alfrel, son of Matchem out of Pilot's dam by Marske. Sir Harry won the Derlyy in 1798, and was imported into Virginia in 1804. He was the sire of Sir Alfred, and Sir Hal, his name is often found in the pedigrees of our best racers. Imp. Robin Redbreast, sire of Sumpter's dam, was by Sir Peter, dam Wren, by Woodpecker. Imp. Archduke, and his brother, Stamford, ont of Horatia, sister to Achilles by Eclipse, second dam Countess, Delpini's dam by Blank. Archduke won the Derby in 1799, and was imported by Col. Hoomes into Virginia in 1803. He is best known in America as the sire of the dam of Countess Plater by Virginian who was the dam of the good race-horse Altorf by imp. Fylde and Janey, dam by imp. Stirling that was the dam of the famous Polly Hopkins and Ivanhoe by Virginian (son of Sir Arehy) and Hyazim by Sir Archy. Sir Peter was the sire of Sir Solomon (first called Tankersler), dam Matron by Florizel, out of Haiden by Matchem. Sir Solomon, 1796, was the sire of Warrior and Mary Ann, the dam of Wiudle by Beningbrongh. Sir Peter also got Haphazard, 1797, and his sister, dam Miss Hervey by Eclipse, out of Clio by Young Cade. Haphazard was a grand race-horse and the sire of Filho-da-Puta, 1812, dam Mrs. Bamet by Waxy, son of Pot-8-o's, ont of daughter of Woodpecker, etc. Filho-rlaPuta won the St. Leger in 1815. Filho-da-Puta was the sire of Birmingham that won the St. Leger in 1830, and Colwick, dam Stella by Sir Oliver, son of Sir Peter. Colwich was the sire of Attila, dam Progress by Langar, son of Selim, that won theDerby in 1842. Haphazard was the sire of Antar and Reginald, that won the 2,000: Guineals in 1819 and 1821 , and Rowena, winner of the 1,000 Guineas in 1820. Imp. Hedgeford, foaled 1825, was by Filho-da-Pnta, dam, Miss Craigie by Orville, son of Beningbrongh, second dan Marchioness by Lurcher, son of Dungaunon by Eclipse, ont of Miss Cogden by Phenomenon, son of Herod, imported into America. Hedgeford was a full brother to Birmingham, and was a good race-horse. He got Duane, a superior race-horse, dam Goodloe Washington by Washıngton, son of Timoleon by Sir 


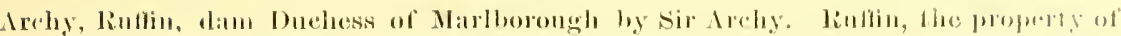
Jos. (a. Loswell, known as tho lueky kontuckian, wont the graat (iokl stakes at lexington, Kontucky, in 18I3, and many other good ranes. Iledgeford was the sileol"

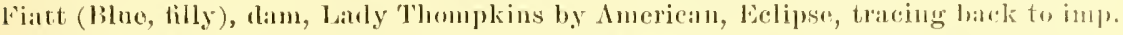
Duchess, that produced Blue Bell hy Chorister, son of imp. Contract by Catton.

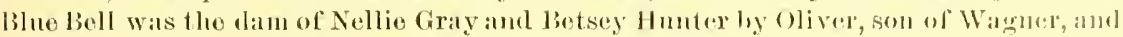
Flight by inp. Loviathan, Julia Mattingly by Joln Morgan, son of imp. Suveleign, Bessio Lee by Hunter's Lexington, and others. Betsey Hunter is the dam of Kate Mattingly (Creosote dam) by John Morgan, Classense, Joe Johnson, Anut, Winnic, Jurlget Wieklitio, ote., nearly all of which racerl well and have prorluceal racr-horses. dilne Filly was also the dam of Kate Hunter, Lizzy Morgan, Hunters' Glentoe, and other's.

Liz̋y Morgan left a distinguished frogeny though her son, Morgan beont hy John Morgan, Ratan, the dam of Wildtire, Girotlé, Girolla, etc. This family has been much inbred, but alwags preserved its individuality. Bhe Bonnet by inp. Hederford, dam Grey lanuy by Bertrand, was one of the best race-mires of her day and it brood-mare that left behind her a history. She was the dam of sueh good ones, as Little Arthur, Nebula (thedam of Asteroid, the mbeaten son of Lexington, Nue Lewis, Luma, Aster and Aneroid, his sisters and brothers, and Asterisk by Ringgold, son of Boston), Alice Jones (Jonesboro's dam), and The Gloamin, all by imp. Glencoe; Lightning, Loadstone, Thunder and Lancaster, a cuartet of superior race-horses, and Bomnet, all by Lexington. Hedgeford was also the sire of the dam of Prunella by imp. Glencoe, she the dam of Sympathy and Lizzie Wr. by imp. Seythian, son of Orlando by Tonchstone, Nellie Grey (the dam of Alroy, Amadis, Aramis, Marie Michon, Bazil, etc.), by Lexington. Other daughters of Hedgeford left good stock, and lis early death was a loss to the country. He combined thcough his sire and dam a large infusion of Herod and Eclipse blood. Maria Black, the daughter of Filho-da-Puta, graudson of Sir Peter, dam loy Smolensko, son of Soreerer by 'Trumpator, out of a laughter of Sir Peter, figured conspicuously on the turf in America in 1838 and 18:39, and won at two, three and four mile heats, in the latter race winning after four heats were run. She was a superior brool-mare, dam of John Black by imp. Trustee, Gertrude by Chorister, son of imp. Contract, Sellie Waters by Gleneoe, Madame Bruce by Bostou, Frank Waters by Wagner, Bay Leaf by imp. Yorkshire and Tripod by imp. Sovereign. But her name and fame is perpetuated throngh her danghter Bay Leat, one of the best brood-mares ever in Awerica. Bay Leaf was the dam of Rubicon, (sent to England), Bay Flower, Beacon, Bayswater, Baywood, Bayonet, Niagara, Bay Rose and Bay Final (a winner in England), all by Lexington, Bingaman and M. A. B. by Asteroid and Bay Bush by Anstralian. Bay Flower was a good race-mare, and lam of several good performers, including Ivy Leaf (the dam of Bazar by Jack Malone), Bramble, Bonnie Leaf, Bye and Bye (Now or Never's dam), Brambaletta (Merry Monarch's dam), all by imp. Bonnie Scotland, Eclat by Enquirer, Thistle by Great Tom, Niagara and Jackson by Luke Blackburm. Eliza by Filho-da-Puta, dam Zephỵrina by Middlethorpe, son of Shuttle by Young Marske, was the dam of the good male Albine by Jeff Daris, son of Hero by Bertrand jr., and she the dam of the good race-horse Gen. Yorke by Planet. Nameless by Filho-da-Puta was a dam of winners, and The Nun's Daughter by Filho-da-Puta, dam The Nun by Blacklock was the dam of the good ruce-horse Consol jr. by imp. Consol and of the Stumps mare, by Stumps, som of Whalebone, that produce Pot-8-o's by Gleneoe, and Blacklock by O'Meara, son of Glencoe. Stamford, the brother to imp. Archduke was a superior race-horse, and his name appears in many excellent pedigrees. Sir Peter got Walton and his brother Williamson's Ditto, ont of Arethusa by Dungannon, son of Eclipse, grandam by Prophet, son of Regulus, out of Virago, Saltram's dam by Snap, grandson of Flying Childers. Walton was a superior race-horse and left a grand reputation as a stallion. He was sire of Phantom, out of Julia (sister to Eleanor) by Whiskey, son of Saltram, grandam Young Grantess, the dam of Sorcerer, by Diomed. Phantom won the Derby in 1811, and Walton's son St. Patrick, dam by Dick Audrews, son of Joe Audrews by Eclipse, won the St. Leger in 1820 and the Gold Cup at York. Phantom got Cedric, out of sister to Repeator by Trumpator, graudam Demirep by Highflyer, who won the 
Derby in 1824, and Middleton, dam Web lsy Waxy, son of Pot-8-o's, ont of Penelope by Trumpator, that won the Derby in 18:5. But Phantom's bestreputation eomes throngh his daughters. He was the sire of Colyreb, ont of Filagree by Soothsayer, son of Sorcerer, grandam Web, sister to Whalebone by Waxy. Colsweb won the Oaks and 1.000 Guineas in 1824, and was the dam of Bay Middleton (son of Sultan, by Selim), that won the 2,000 Gnineas and the Derby in 1836. Bay Middleton was the sire of the Flying Dutehman (dam Barbelle by saudbeck, son of Catton), that won both the Derby and St. Leger in 1819, the Ascot Cup in 1850, and defeated the noted Voltigenr in the Match at York, two miles. Bay Middleton was the sire of Hermit, that won the 2,000 Guineas in 185t, Aphrodite the 1,000 Guineas in 1851, Andorer the Derby in 1854. He was the sire of Ellen Middleton, dam Myrrha by Malek, son of Blacklock, out of Bessy by Young Gouty, grandson of Sir Peter. Ellen Middletom is famons as the dam of Wild Dasrell, that won the Derby in 1855, by Ion, son of Cain, by Panlowitz, bỵ Sir Panl, by Sir Peter, mueh inbred to Sir Peter. Wild Dayrell was the sire of Buecaneer, ont of Cruiser's dam by Little Red Rorer, son of Tramp. Buceaneer was the sire of Kisber, winner of the Derby in 1876, Formosa, wimner of the Oaks and St. Leger in 1868, Cadet, See Saw, Brigantine, winner of the Oaks in 1869, and The Rake, ont of England's Beanty by Bircateher, who was imported atter being a failme in England, but died within a year. Walton was also the sire of Partisan, dan Parasol by Pot-S-o's, son of Eclipse, grandam Prunella bș Highfler, sou of Herod, ont of Promise by Snap. Partisan was the sire of Mameluke, dam Miss Sophia by Stamford, son of Sir Peter, grandam Sophia by Buzzard, son of Woodpeeker. bs Herod. Mameluke won the Derby in 1827, and is known to America as the sire of imp. Mrrtle, the dam of the famous lyood-mare Magnolia by imp. Glencoe, that prodnced snch grand race-horses as Kentucly, second to no son of Lexington over any distance of ground; Madeline, the grandam of Irornois, winner of the Derby, st. Leger and Prince of Wales stakes in 1881. Charley Ball, Prineeton, Charles Morgan, Наnorer by imp. Yorkshire, Simon Kenton. Madonna and Skedaddle by the same sire. and Gilroy, brother to Kentueky and Victory by Uncle Vic, son of Lexington. Partisan was sire of Glancus, dam Namme by Selim, son of Buzzard, and Glanens was the sire of Refraction, that won the Oaks in 1845. and also won the Ascot Gold Cup' from Rockingham. Glaucus was also the sire of The Nob, dam Octave, sister to Oxygen, by Emilins, ont of Whizgig by Rubens. The Nob was the sire of The Nabob, dam Hester by Camel, son of Whalebone, ont of Ionimia by Mnley, ete. The Nabob was the sire of Vermonth, dam Vermeille by The Baron, out of Fair Helen by Priam, and Bois Roussel, dam Agar by Sting, son of Slane; also Nutbourne, out of Pruncess by Merry Monarch. Vermouth got Boiard (wimner of the French Derby and Grand Prix of Paris in 1873), dam La Bossne by De Clare, son of Tonehstone. The Nabob was sire also of Nutbonrne, the sire of imp. Woodlands, dam Whiteface by Turnus. Partisan further handed down the sir Peter lolood through his two sons, Gladiator, dam Panline by Moses (Derby 1822), ont of Quadrille by Selim, and Venison, dam Fawn by Smolensko, son of soreerèr, out of Jerboa by Gohanna, son of Mexeury by Eclipse. Gladiator and Tenison finished second and third to Bay Middleton in the Derby in 1836. Partisan was the sire of Patron, wimner of the 2.000 Gnineas in 1829, Zeal, wimner of the 1,000 Guineas in 1821, and Cyprian, winner of the Oalis 11 1836. Gladiator went to France, where he became famous as a sire. He got Miss Gladiator, dam Taffrail by sheet Anehor, son of Lottery by Tramp. Miss Gladiator was the dam of the famous Gladiateur that won the 2,000 Guineas, Derby, St. Leger and Grand Prix of Paris, and was the only horse which erer accomplislied the teat. Gladiator was sire also of Sweetmeat, dam Lollypop by Stareh or Voltaire, out of Belinda by Blacklock. Gladiator also got Fulvie, the dam of Duteh Sliater by Flying Dutchman. Sreetmeat was the sire of Mincemeat and Mincepie, wimners of the Oalis in 1854 and 1856, and Macaroni, clam Joeose by Pantaloon, son of Castrel, by imp. Buzzard. Macaroni won the 2,000 Gnineas and Derby in 1863 , and was the sire of spinaway, winner of the 1,000 Gnineas and Oalis in 1875. Bomny Jean, winner of the Oaks in 1883, Maegregor, Macheath Courome de Fer, and imp. Macaroon. dam songstress by Chanticleer, son of Birdeatcher. 


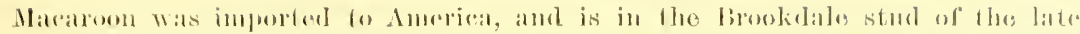

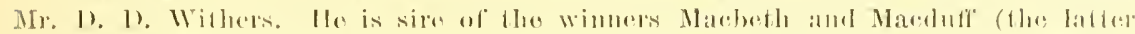

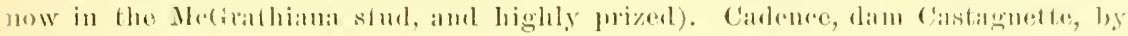

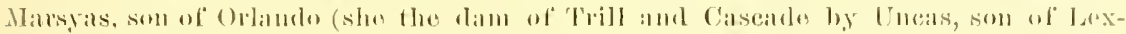

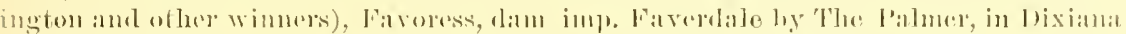

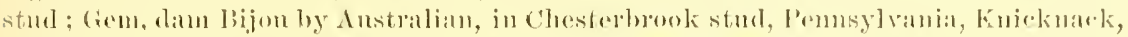

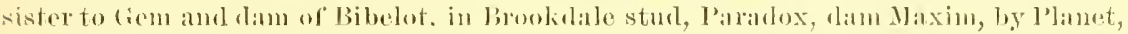

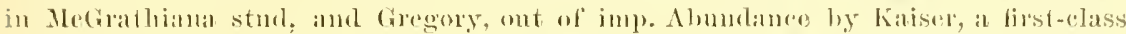
horse. Matearoni also got Boubon (imported liy tho late M. H. Samford), dam bion-

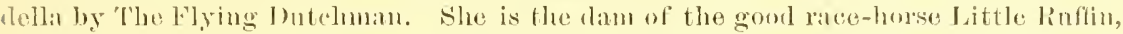
Petershmgh, and their sisters, Carmel amd 'Tulare, all hy Momarehist. Im]. C'loven'

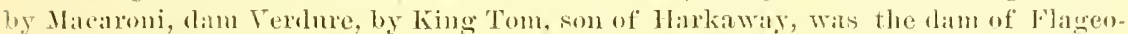
letta and Aftermath by Rayom J'or. Damutless by Matcaroni, dam Artless by Arehy, son of Cance by Whalebone, is the dam of Florimel, Delilah, and Fing Cole by IIl ('sed. and Mr. Jelham and Fearless hy imp. St. Hlaise. Imp. Lady Nax by Macaroni, dam Queen $O$ 'seotts by Hair $\Lambda$ thol, is owned ly Dx. $\Lambda$. W. MeAlester of Missouri. Polenta (in the late Nursery stud) hy Macaroni, dam by Lord of the Isles, son of Touchstome, out of shot by Birleatcher, is the lam of Farina by Kentucky, Tapioea by Kingfisher, Polonius (in Eugland), Polyclora by st. IBlaise, ank Lonise by Ill Lsed. Imp. Invermess by Macaroni, dan Elfida by Faugh-a-lallagh, son of six Hercules by Whalebone, is the dam of Short Line, and Gaxrick by Lexington, Lady Caroline by Australian, Patroness by Pat Malloy, Haidee, Mary K, and Jue Cotton by King Alfonso, the most of which were prominent on the turf, and . Toe Cotton was one of the speediest horses that ever facerl a starter. Iis one mile and three-sixteenths in 2.00 with $109 \frac{1}{2}$ los. up was one of the best races erer rmm, and hils not been exceller, 1 he best being $200 \frac{1}{5}$.

Imp. Judith by Macaroni, dam Terdure, ly King Tom, ont of Nay Bloom, by Newminster, is in the Algeria stud. Imp. Queen Mand, dam Queen of the Vale by Kiug. Tom, out of Agnes by Pantaloon, dam of Queen O' the May, is the dam of Stomey Liontgomery aml Hawkstome.

Moceasiu by Macaroui, dam Madame strauss by King Tom, out of Jetty Treffz by Melbourne, is a large, fine horse, which never racerl. Before going to Canada he got some good horses, such as Vampire, Faith, Amazon, Disclain, etc. He is now in the Eilgewater Stul, Kentucky, and shomld be heard from as a sire. No horse can he better bred.

Macaroni's danghters have been suceesses in the stud in Eugland. Lily Agnes, dam Folly Agnes by The Cure, son of Physician, son of Brutandorf by Blacklock, is the dam of imp. Rossington by Duncaster, son of stockwell, and of the grami race-horse Ormoude by Bend or, son of Inoneasier, by stockwell, and Ronge Rose by Thormanby, the latter and Bend'or Derly wimers, and ormoude, wimner of the 2,000 Gumens, Derby, and St. Leger. Gladiator was also the sire of Fitz Gladiator, dam Zarah by Revellex, son of Comus, by Sorcerer. Fitz Gladiator was the sire of Compiegne, dam Maid of Haxt by The Provost, son of The Saddlex, by Waverly, by Whalebone. Compiègne was the sire of imp. Mortemer, dam Comtesse by The Baron or Nuncio, credited to the latter, who was a son of Plenipotentiary by Emilins. Iortemer was not only a superior. race-horse, but the sire of snch good ones as Chamant, wimner of the 2,000 Gnineas; Ternueil, wiuner of the Grand Prix of Paris, and St. Christophe, wimex of the Gold Fase, Gold Cny and Alesandra Plate at Ascot. His success in America was equal to that in Emope, and whenever lored to mares possessing racing blood the produce was good. He got Exile, dam imp. Second Hand by Stockwell, ont of Gaiety hy. Touchstone, also a superior horse, Adonis, dam Alice Ward by Lexington, Wanda and Winfred, ont of Mimnie Minor by Lexington, Chimera, Cyclops, aud Camhyses out of Lizzie Lneas by Anstralian. Saluda out of Perfection by Leamington, Savanac ont of Sly Boots ly Rivoli, son of Reveme by imp. Trustee; Heimdel and Housatonic ont of Tandalite by Vandal, son. of Glencoe.

Parmesan hy Sweetmeat, dam Gruyere by Terulam, son of Lottery by Tramp, 
grandam Jennala by Touchstone. Parmesan is the sire of Cremorne (winner of the Derby, 1872) dam Rigolboche by Rataplan, son of The Baron, by Birdeatcher, Parmesan is sire of imp. Strachino, out of May Bell, by Hetman Platoff. Faronius by Parmesan dam Zephyr by King Tom, son of Harkaway by Economist, won the Derby in 1871. Favonius was not only a race-horse of merit, bnt is the sire of Sir Berys (winner of the Derby in 1879), dam Lady Langden by Kettledrum (winner of the Derby in 1861), son of Rataplan. Gladiator is immortalized as the sire of Queen Mary, dam by Plenipotentiary, son of Emilins by Orville, grandam Myrrha by Whalebone, son of Waxy by Pot-8-o's, ete. Queen Mary has given ns a grand lot of Stallions an«l Matrons which have made their mark on both sides of the Atlantic. She produced twenty foals, including Haricot by Mango or Lanercost, Braxey by Moss Trooper, son of Liverpool by Tramp, Bab at the Bowster and imp. Balrownie by Annandale, son of Touchstone, Blooming Heather and Blink Bonny by Melbourne, imp. Bonnie Sicotland by Iago, son of Don John by Tramp or Waverly, Bonnyfield, Bonny Breastknot and Bonny Bell by Voltigenr, Broomielaw by Stockwell, Bertie by Newminster, Blinkhoolie by Rataplan, Bertha by Young Melbourue and Bomnie Doon by Rapid Rhone, son of Young Melbonrne. None of her sons or daughters, except Blink Bonny wimner of the Oaks and Derby, 1857, won any of the great fixed events of the Finglish tnrf, Bonuy Doon is the dam of imp. Bella Donna by Hermit, she the dam of the wimner Bel Demonico her first foal. Bonny Bell is the dam of imp. Blythwood and Beanclerc, wimuer of the Middle Park Plate. Haricot produced Caller On by Stockwell, that won the St. Leger in 1861, the Brighton Cup and the Northumberland Plate in 1863 and '64, and was the dam of 'The Pearl by Newminster. Haricot was the dam of Lady Langlen by Kettledrum, that was the dam of Hampton by Lord Clifilen. Hampton was the sire of Merry Hampton (Derby winner in 1887), dam Doll Tearsheet. by Broomielaw, Queen Mary's son, and Ayrshire (Derby winner in 1888) ont of Atalanta by Galopin, son of Vedette. Lady Langden was also the dam of Sir Berys, Derby winner in 1879 Braxey was the dam of Thrift by Stockweil, and she the dam of Tristan by Hermit. Tristan ran second in many of the big events, won the Gold Cup, two Gold Vases and Hardwicke Stakes. Thrift was also dam of Trapeze by Hermit, and Pnrsebearer ly Scottish Chief. Bernice by Stockwell, out of Braxey, was in the Nursery Stud and was the dam of Bertram and Beatrice, the dam of Bellona, she the dam of Belladonna (Arnica's dam), Belinda, etc. Blink Bonny won the Oaks and Derby, 1857, and was the dam of Blair Athol by Stockwell. Blair Athol won the Derby and St. Leger, aud Breadalbane his brother, won the Prince of Wales and Gratwicke Stakes. Blair Athol got Silvio (Derby winner, 1877), out of Silverhair by Kingston, son of Venison. Beanclere by Rosicrucian, dam Bomny Bell, won the Middle Park Plate. Bella Donna by Hermit dam Bonnie Doon by Rapid Rhone, is in the Nursery Stud. Lady Stockwell by Knowsley, son of Stockwell, out of Bab-at-the-Bowster byAnnandale, is in the Walnut Hill Stud in Kentucky, her daughter Salara (imported in utero) by Salvator, is proving a good broodmare, as are also her danghters Sophronia by Ten Broeck and Sungleam by King Alfonso. Venison was the sire of The Ugly Buck, winner of the 2,000 Gnineas in 184t, Miami wimner of the Oaks in 1847 and Clementina who won the 1,000 Guineas in the same year. Venison was also the sire of Alarm, dam Southdown, by Defence son of Whalebone, and of Kingston, dam Queen Ann, by Slane son of Royal Oak by Catton. Kingston was a fine and game horse, he was the sire of Caractacus (winner of the Derby in 1862), Queen Bertha (winner of the Oaks in 1863), Ely, and Silverhair, dam of Silvio (winner of both the Derby and St. Leger), Coimbra, dam of Claremont, imp. Stylites and Imp. Stonehenge in the Brookdale Stnd, and a successful sire. Non Pareille, the sister to Silverhair, was in the late Nursery Stud, and is the dam of Matador by Gladiatem, Perfection by Kingfisher aud Nina, the dam of Punka, by Kentucky. Imp. Babta by Kingston, dam Alice Lowe, by Defence son of Whalebone. is the dam of Glenelg, (imported in utern) by Citadel son of Stockwell, who has es. tablished his reputation as one of the most successful stallions in America. Elthan Lass (imported), by Kingston, dam by Pyrrhus the First, son of Epirus by Langar, out of Palmyra by Sultan, was the dam of Kingfisher, winver of the Belmont, Chanpion and Travers Stakes, and an excellent and snecessful stallion, Sabina (dam of 


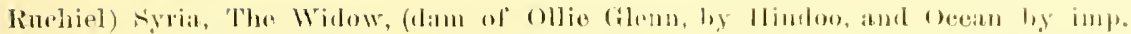

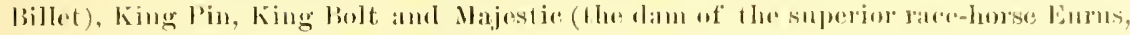

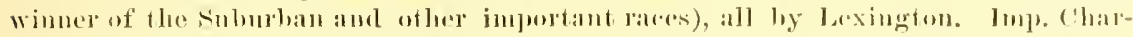

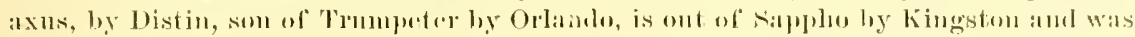
not only a good rate-horse, hut is making himself known as a sulcessinl stallion.

Sir Panl, own brother to l'anlina, winner of the St. Leger in 1807, was hy sir

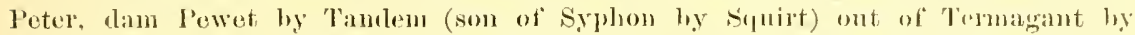
Tantrum, sou of cripple by the Codolphin Arabian. Pewet was the dam also of' Clinkerinal (the dam of Hmmprey ('linker) by ('linker. 'Fermagant was the dam of Evelina by Hughtlyer, the dam of Cervantes, Orville and Panlowitz ly Sir I'anl. 1'anlowity was the sire of Arehilathl (winner of the 2,000 Ginineas), and Cain, dam by Paynator, soll of 'Trmmpator by Conchetor. Cain is famoms as the sire of bou, who ran second in the Derby and St. Leger in 1838 and was the sire of Wridn Dayrell and Tatmor, he the sire of Sechision, Hermit's dam. Wild Dayrell was the sire uf lBucenneer. Wild Oats, imp. The Rake and IInrricane wimner of the 1,000 Guineas, 186.2. Ion was also the sire of Aleline, the granclan of St. Simon by Galopin. St. Simon was disqualitied for the great events, the Derly and St. Leger, hy the reath of Prince Batthyany, but was a smperior race-horse, won a large number of events including the Epsom, Ascot and Goodwood Cnps, and is regarded as one of the best sires in Enyland. The Byerly Turk blow is not less famous through Herod's of her son Woulpecker, foaled in 1773, dam Miss Ramsilen by Cade, son of the Godolphin Arabian, grandam by Lonstale Bay Arabian, third dam sister to Whitefoot, and Bonny Lass, by Bay Bolton, out of a daughter of the Byerly Turk, tracing to a Natural Barb mare. Woodpecker Was a superior race-horse and a grand and successful stalliom. He Was the sire of Bustard, dam Matron by Alfred, imp. Buzzard, dam Misfortune by Dux, imp. Dragon and his danghter are famous in the stud. Ambrosia by Woodpecker, dam Rutl by Blank, was the dam of Fanny (the dam of sir Oliver, Miss Teazle, Poulton, ete.) by Diomerl. Abigail by Woodpecker, dam Firetail by Eclipse was the lam of Zodiac by St. George. Chesmnt and Grey Skim were sisters by Woodpecker, dam silver's lam by Herod. The former, Chesmut Skim, was the clam of Election (winner of the Derhy m 1\&07) by Golnamna; the latter, Grey Skim, was the dam of skim and Castanea, by Gohanna, that figures in many of onr pedigrees. Aetive by Woodpecker, dam Lanra by Whistle-Jacket, son of Mogul, was the dau of 1 mp. Expredition (hy Pegasus son of Eclipse), the sire of Honesty (Monmonth Eelipse's (lam), Katydid, Expedition mare (litm of Aneriean Boy by Sea (inll), Mair of the Oaks (the dam of Medoc, Midas, Gipsy and Cora by Ameriean Eelipse), Katy Amn by Ogle's Oscar. to which the Lewis family trace that has produced so many good ones such as Potomac, Sensation, Stratforl, Onoudaga, Glenmore, Aerobat, John Morgan, Hunter's Lexington, Morgan Scout, Ratan, Giroflé, ete. Matchless, another danghter of Expedition, founded the Morgau family, through her danghter, Laly Morgan hy John Richarl, son of Sir Arehy, another distinguished horse in male line to the Byerly 'Turk. Woodpeeker's danghter Rosina, ont of Petworth by Herod, inbred to the Byerly Turk, was the dam of Hermes, by Merenry, son of Eeipse. Wren by Woodpecker ont of l'apillon (Sir Heter's dam), by Snap, was the dam of Agonistes and imp. Robm Redbreast by sir Peter, the lattor sure of the liobin mare that was the dam of Thoruton's Rattler, Sumpter, Chillers, Elizabeth aur Flirtilla, all b; sir Arehy, a horse in the male line to the Byerly Turk. A danghter of Woodpecker, dam Everlasting by Echipse, was the dam of Fraxinella (grandam of Tramp) by 'T'entham, and Fractuos (the dam of Carthage, Amazon, and Hannibal (this last wimner of the Derby in 1803), all by Driver, son of Trentham by sweepstakes. Woodpecker was the sire of Catharme and Colibri, dam Camilla by Trentham. Catharine was the dam of Golumpus, Hedles, kate and Wanderer by Gohanna, Sprite by Bobtal, and Worthy by Thalebone. Woodpecker got many other good brood-mares. Woodpeeker's son Bnzzard, who was imported into Virgmia in Mareh, 1805, and died in Kentueky in 1808, left his impression deeply on the stock of this country. He got in England, prior to his importation, Horuby Lass, dam Pnzzle by Matehem (she the dam of MoreI. Mango, Trufte, and Emperor by Soreerer), Sophia, dam Huncamunea by High- 
flyer (she the dam of Miss Sophia by Stamford, Miss Sophia was dam of Master Henry and of Mameluke, winner of Derby in 1827), Vanity, dam Dabchick by Pot-8-o's (she the dam of Conceit and Caprice by Walton), and Coquette by Dick Andrews. Buzzard was the sire of the three brothers Castrel, Selim and Rubens, and their sister, Bronze, dam by Alexander, son of Eclipse, and Rosamond, dam Roseherry by Phoenomenon, she the dam of imp. Barefoot by Tramp. Barefoot was the sire of the good race-ntares Motto aud Clara Howard, whose descendants have proven the valne of this blood on the turf.

Castrel was the sire of Bustard, dam Miss Hap by Shuttle, son of Young Marske, Bustarl got Heron, dam by Orville, son of Beningbrough by King Fergus. Herou got the noted race-horse Fisherman, ont of Mainbrace by Sheet Anchor, son of Lottery. Fisherman ran one hundred and nineteen races and won sixty-nine. He was exported to Australia where he made a great reputation as a stallion. Heron was also the sire of Snowdrop, dam Fairy by Filho-da-Pnta, and she the dam of Gemma di Vergs by Sir Hercules, son of Whalebone, who has made a good reputation as a stallion. Castrel was also the sire of Merlin, dam Miss Newton by Delpini, and of Pantaloon, dam Idalia by Peruvian, son of Sir Peter. Pantaloon was the sire of Sleight of Hand, dam Decoy by Filho-da-Puta, and The Libel, dam Pasquinade, sister to Tonchstone by Camel. The Libel is sire of Bribery, dam Splitvote by St. Luke (she the dam of St. Albans, winner of the St. Leger in 1860) ; also sire of Traducer, dam Arethusa by Elis, that is the sire of imp. Sir Modred and Cheriot (see tables). Pantaloon also sired the brothers, Hobbie Noble, Elthiron and Windhound, ont of Phryne by Touchstone. Windhound is admitted to be the sire of Thormanby (winner of the Derloy in 1860) dam Alice Hawthorn by Muly Moloch. Thormanby is the sure of Charibert, Violet (the grandam of Melton, wimner of the Derby in 1885) and Rouge Rose, the dam of Bend'or winner of the Derby in 1880, he the sire of Ormonde. Thormanby was the sire of Thuringian Prince, dam Eastern Princess by Surplice, and he the sire of the superior race-horse Bird of Freedom, winner of the City and Suburban Handicap, Ascot Cup and Gold Vase; also of Plaudit, he the sire of Balfe (a good racehorse and stallion), clam Bohemia by Weatherbit, Thormanby was the sire of imp. Glengarry, out of Carbine by Rifleman. Legerdemain, sister of Drone, sleight of Hand and Van Amburgh by Pantaloon, dam Decoy by Filho-da-Puta, is the dam of Toxophilite by Longbow, son of Ithuriel by Touchstone. Toxophilite is the sire of stray shot, out of Vaga by Stockwell, she the dam of Torpedo, Martini and the noted shotover by Hermit. Toxophilite is sire of Musket, out of daughter of West Anstralian, and he the sire of Petronel, winner of the 2,000 Guneas, 1880. Musket was exported to Australia and has proved highly successful there, as a sire. Pantaloou is the sire of Ghuznee (wimner of the Oaks in 1841), her dam Languish by Cain. Ghuznee was the dam of Storm, Escalade, ete., by T'ouchstone, the latter the dam of Citadel by Stockrell, sire of imp. Glenelg. Pantaloon was the sire of Satirist (winner of the St. Leger in 1841, and the Ascot Gold Vase), ont of Sarcasm by Teniers, son of Rubens. Pantaloon was the sire of the dam of imp. Leamngton, and Jocose the dam of Macaroni. Selim the sire of Langar, dam by Walton, out of Young Giantess by Diomed. Langar was the sire of Stoekport, Elis (winner of the St. Leger in 1836) and Epirus, out of Olympia by Sir Oliver, son of Sir Peter. Epurus was the sire of Pyrrhus I. (winner of the Derby in 1846), dam Fortress by Defence, son of Whalebone. Langar was sire of Vulture, dam Kite by Bustari, son of Castrel, that was the dam of Orlando (winner of the Derby in 1814), by Touchstone, and of Progress, the dam of Atrlla (wimner of the Derby in 1842), her clam by Blacklock. Selim was the sire of sultan, foaled in 1816, dam Bacchante by Willamson's Ditto, out of sister to Calomel by Mercury, son of Eelipse. Sultan was the sire of $1 \mathrm{ml}$. Glencoe, dam Trampoline hy Tramp (see table). Glencoe won the 2,000 Guineas in 1834 , and was imported to America after the season of 1836 . The Glencoe mare, dam Alice by Whalebone, was the dam of Adine by slane, Torment by Alarm and others, but Glencoe's reputation is lastung as the sire of Pocahontas, dam Marpessa by Muley, son of Orville, out of Clare by Marmiou, son of 'Whiskey by Saltram. Pocahontas was the dam of stockwell (winner of the 2,000 Guineas and the st. Leger in 1852), Rataplan (thrrd in the St. Leger in 1s53, Tratio- 


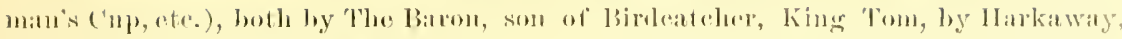

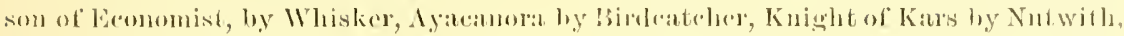

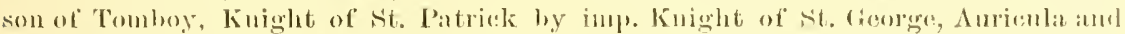

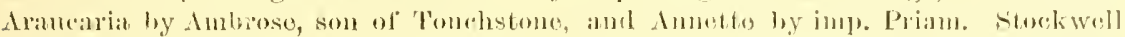

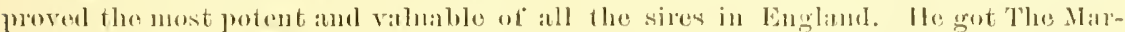
quis, Bothwell and Gang Forwall (wimers of the 2,006 Guineas and The Maryuis also won the st. Leger), Lord Lyon (winner of the 2,000 Guineas, Derby and sl. Leger), blatir Athol, wimmer of tho berby and st. Lexer, Doneaster, wimer of ble

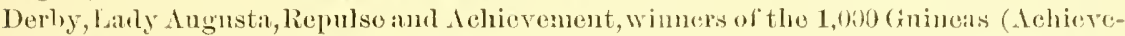
ment also won the St. Leger), Regalia, winner of the Oaks, Savernake and st. Mlbans. the latter winner of the st. Leger, Caller On, the grand mare, winner of St. Leger and a number of Queen's Plates. Blair Athol got Prince Charlie, wimer of the 2,ou() Guineas, Silvio, wmmer of both Derby and St. Leger, ame Critig Millar, winner of the st. Leger. St. Albans got Julins and springtield, the latter the sire of Sainfoin, winner of the Derby in 1890. Doncister got Beml'or, wimer of the Derby, and Bend'or' sired the great Ormonde, winner of the 2,000 Guineas, Derby and St. Leger, Bertram, the graudson of Stockwell, is the sire of Robert the Devil, winner of the St. Leger. Rataplan was the sire of Kettledrum, winner of the Derby, The Miner, lien liattle, Blinkhoolie and Cymbal, good stallions. King Tom got Tomato, winner of the 1,000 Gnineats, Hannah, winner of the 1,000 Gnineas, Oaks and St. Leger, Tormentor and Hippia, Oaks winners, Kingeraft, winner of the Derlyy, Great Tom, King Ernest. King Ban and Piacton, imported into America and successfnl and valuable stallions. Afacanora is the dam of Chattanooga by Orlando, Cachuca by Voltigenr, the latter dam of imp. Castagnette by Marsys and grandam of Quicklime, Chattanooga is the sire of Priutamniere, the dam of Ponlet in France. Arancaria is the dam of Stephanotis ly Macaroni, Wellingtonia by Chattanoogit, and the grand horse Rayon d'Or, now at the head of the Algeria stud (see table). Of all the stallions snbsequent to Diomerl, Glencoe marle the greatest impression on the hlood stock of America. Glencoe got but iew males, and at hisdeath, Vandal and Panic were abont the only sons alive. The latter had no chance in the stnd, and Vaulal little, until purchased by the late Gen. Haxding and put in the Belle Meade stud, when he got Fentilator and Fanguar, out of Carolin by imp. Seythian, son of Orlanulo, Mollie Jacksou, the grand race-mare and great grandam of Foxhall. Ventilator is sire of Mary Anderson, Drizzle, Airtight, Airplant, Airshaft aud others. Fandal also got Vaulalite, the best mare of her day, Vanderbilt (sire of Madstone, ete.), out of Nelrose lyv Childe Harolı, Voltigem (sire of Walter H, Frank Ward, etc.), dam Dnet by Highlander, son of Glencoe, and Coral. dam of Incas and Wanderer. But in Vandal's sou Virgil, we find his greatest excellence. Virgil's dam was Hymenia by imp. Yorkshire. Virgil was the sire of Vayrant, Vigil, Vera Cruz, Vixginius, Fairplay, Virgilian, Santa Anita, Momento, Manuce O, and the grand race-horse and popmlar stallion Hindoo (sire of Hanover, Sallie MeClelland, Buddist, Mabel Glem, etc.), and the unbeaten Tremont, sire of Dagonet, a promising two-year old, 1891. Gleneoe was the sire of a large number of grand brootmares, inchding the sisters Mildred and Lightsome, Charmer the grand race-mare, Sally Lewis, Topaz (dam of Wagram, Waterloo, Loli, Arcola, and Colton), Reel (dam of Lecomte, Prioress, Starke, War Dance, etc.), Iagnolia (lam of Kentucky, Gilroy, Victory, Princeton, Skedadde, Madeline, the grandam of Iroruois, ete.), Norice (dam of Norfolk), Nebula (dam of Asteroid), Kitty Clark (dam of Maiden, La Henderson, etc.), Bonnie Lassie, Blonde, Florine (tam of Illewild, derolite, etc.), Pryor, and his two sisters, one of them the dam of Glycera anil Colossus, by imp. Sovereign, the other the dam of Alumina, Sister of Charity, Lord Jersey, Wheatly, Midsummer, etc. A Glencoe mare was the dam of Optimist. Sultan was the sire of Bar Middleton, dam Cobweb by Phantom, son of Walton by Sir Peter, a splendid race-horse, winner of the 2,000 Gnineas aul Derby, in 1836. He is the sire of Flying Dutchman (winner of the Derby aud St. Leger in 1s19), and his full brother Vanderdecken. Fly. ing Dutchman was sire of Dutch Skater and Dollar. Bay Mildleton was sire also of Audover, dam sister to Aegis, by Defence, winner of the Derby in $1-51$, sire also of Eumni, dam Blue Derils by Velocipede. Ennni was a superior racer and clam of 
Samterer by Birdcatcher, Loiterer by Stockwell and Bravery by Gameboy. Bravery was the dam of Salamauca by Student, and she the dam of Pero Gomez (winner of the St. Leger in 1869) by Beadsman. Bay Middleton was also sire of Cowl, dam Crucifix by Priam. Cowl was the sire of Miss Sellow, the grandam of Hermit, sire of St. Blaise. also Madame Eglantine, the dam of Rosicrucian, and The Palmer, by Beadsman, also of Morgan-la-Faye, dam Miami (Oaks winner, 1847), by Venison, she the dam of Marie Stuart (winner of the Oaks and St. Leger in 1873), by Scottish Chief. But the great reputation of Bay Middleton in the female lime is from Ellen Middleton, the dam of the noted Wild Dayrell. Sultan was the sire of Ibrahim (winner of the 2,000 Guineas, 1835), dam sister to Cobweb by Phantom, Augustus (wimner of the 2,000 Guineas, 1830), dam Augusta by Woful, Achmet (brother to Bay Middleton), winner of the 2,000 Guineas, 1837, Greenmantle (winuer of the Oaks, 1829). dam Dulcinea by Cervantes, son of Don Quixote, and Galata (wimner of the 1,000 Guineas and Oaks, 1832), dam Advance by Pioneer.

Sultan was sire also of Hampton and Adana (the latter imported to America), Łam Rachel by Whalebone; Beiram, dam Miss Cantley hy Stamford; Jereed, dam Iy Lady, by Comus; Ishmael, dam by Phantom, sire of Star of Erin. Selim was the sire of Turcoman, dam Pope Joan by Waxy.

Rubens, the brother to Castrei and Selim, was a good race-horse, and got a large number of racers. He is particularly distinguished for his daughters. Landscape, dam Iris, by Brush, son of Eclipse, won the Oaks in 1816; Pastille, dam Parasol, by Pot-3-0-'s, son of Eclipse, won the 2,030 Guineas and Oaks in 1822, and IVhizgig, dam Penelope, by Trumpator, won the 1,000 Guineas the same year. Whizgig was the dam of Oxygen, winner of the Oaks, and grandam of Trumpeter. Rubens was the sire of the dam of Phosphorns, wimner of the Derby in 1337, and his sister May Day, winner of the 1,090 Guineas in 1831. Rubens was the sire of Defiance, the dam of Dangerons, by Tramp (winner of the Derby in 1833), Defence by Whaleboue, Design by Tramp, and Delight by Reveller, the last two imported into America, and dams of winners. Rubens got Ruby, dam, by Williamson's Ditto, that was the dam of Coronation (Derby wiuner in 1841) by Sir Hercnles. Rnbens was also the sire of Bobadil, dam by Skyscraper, son of Hightlyer. Bobadil was the sire of the grandam of the great brood-mare Magnolia. Rubeus was also the sire of Teniers, dam Snowdrop by Highland Fling, son of Spadille, and Peter Lely, dam Stella by Sir Oliver, winner of the Gold Cups at Worcester, Warwick, and Leicester ; Miniature. the clam of Enamel (winner of the 2,000 Guineas, 1825) by Phantom. Imp. Eliza, dam Little Folly by Highland Fling, was the dam of Emerald (the dam of Topaz), by imp. Leviathan. Rubens sired many other broud-mares that produced winners. The Byorly Turk blood in the male line permeates the pedigrees of all the best race-horses in America, through Diomed, who was sold and imported to Virginia after he was 22 rears old. but such was his natural vigor and stamina that he lived to be 31 years old, having been foaled in 1777, and died in $1808 \mathrm{in} \mathrm{Virginia.} \mathrm{Diomed} \mathrm{was} \mathrm{by} \mathrm{Florizel,} \mathrm{son} \mathrm{of} \mathrm{Herod,} \mathrm{by}$ Tartar, by Partner, by Jigg, by Byerly Tuxk. Diomed's dam was sister to Jumo by spectator, son of Crab by Alcock Arabian, out of Horatia by Blank, son of the Godolphin Arabian. Diomed won the initial Derby in 1780. He also won other races up to fonlmile heats, and got some excellent horses and brood-mares before his importation. such as Glaucus and Lais, dam Grace by Snap, Grey Diomed, Robin Grey, Greyhound, all out of Grey Dorimant by Dorimant; Wrangler, imported into Virginia ; Champion, the Diomed Mare of Lord Fitzwilliam (dam of Wonder and Miracle by Phoenomenon, son of Herod, Caleb Qnotem by Sir Peter, and Cossack by Sir Panl), Diomed Mare (dam of Regulator and Momentilla by Whiskey); Youmg Giantess, dam Giantess by Matchem, the dam of Sorcerer by Trumpator, Eleanor by Whiskey (winner of the Oaks and the first mare to win the Derby, and the dam of Muley, the sire of imp. Leviathan and Margrave), Julia, Lydia and Cressida, all by Whiskey. Julia was dam of Phantom (wimmer of the Derby in 1811) ber IValton, son of Sir Peter. Lydia was the dam of The Corporal by Orville, anil The Drummer by Waxy. Cressida was the dam of imp. Priam by Emilius, Priam got the famous Crucifix (winmer of the 2,000 and 1,000 Gnimeas and Oaks in 1810), the dam 


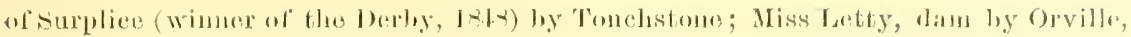

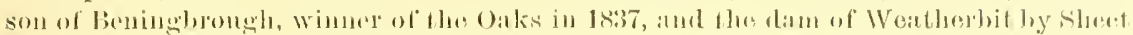

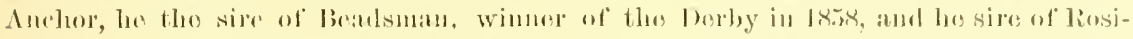

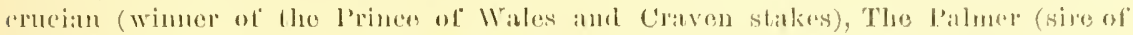

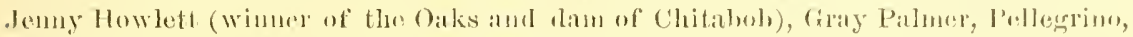

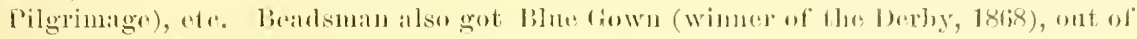

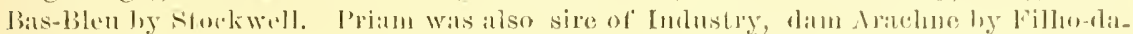

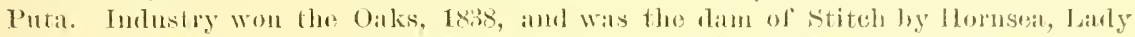

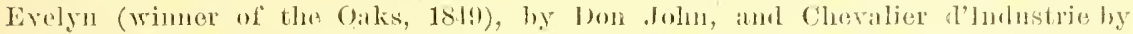
Orlaudo. 1)iomed also got Yommg Noisette, dam Noinetes by Squirrel, she the dan of Clemont, Hymen and Navigator hy Trumpatur, sun of Conductor, amd Mluminu by Whiskey, the latter sire of the grandam of Poealonutas. But it is in Ausrica where Diomed left an imperishable name, Ilo was the sire of Sir Archy, the Godolphin Alabian of America. Sir Arehy was inbred to Byerly Turk through sire and dan. Diomed was a grandson of Herod, and Castimina was by Rockinghan, also grandson of lleroul. Castianira rierd sucessfully in this comutry, as also did her son Sir Archy, who was one of the most successful sires in the world. He was the sire of Bertrand anc Paeitic, out of Eliza by imp. Bedford, son of Dungannon by Eelipse, botl gool and successful stallions. Sir Alchy Montorio (Big Archy) and Sir William of Transport, ont of Transport by Virginius, son of Diomed, Young Lottery, Koscinsko, Saxe-Weimar, Crusader and Phenomenon, ont of Lottery hy imp. Pedford, she out of imp. Anvilina by Anvil, son of Herod, Director and Virginian ont of Mleretrix lyy Magog, Coquette, Arab, Tariff, Brilliant, Eliza and Gen. Brook, ont of Bet Bonnce bs imp. Sir Harry, son of Sir Peter by Highflyer. Coquette, bred to her own sire, Sir Archy, produced Janet (Virginia Lafayette) and Virginia Taylor, Sir Archy got Sir Charles and Janette, flam ly imp. Citizen, son of Paeolet by Blank; Phillis, Gohanna, Brmette, Sally Trent and Charlotte Temple, ont of Merino Ewe by imp. Jack Andrews, son of Joe Andrews by Eclipse; Thornton's Rattler, Childers, Sumpter, Elizabeth and Flirtilla out of the Robn mare by imp. Robin Redbreast, son of sir Peter, she ont of a mare by imp. Obscurity, son of Eclipse. Flirtilla was bred to her own sire and produced Flirtilla, Jr., and Antoinette. Flirtilla, Jr., bred to Boston (inbred to Diomed through Timoleon and Florizel), prodneed Ringgold (a good racehorse and for his chanees a very successful stallion), sire of Onwarl, Delaware, Ringmaster, Tipperary, good race-horses, and Goldring, the dam of Bullion, ete. Ringgold eovered only a few thoroughbred mares. Flirtilla, Jr., also produced Cassandra by imp. Priam, a good raee-mare and the dam of Trojan, Basil and Philo by Mariner, the latter the dam of Lady Blessington by inp. Eclipse, and she the dam of Count D'Orsay, The Comntess and The baroness by Kentueky, Lady Rosebery and Duehess by Kingfisher, and Fairwater by IIl Used. The Baroness is the dam of Barlge, by Ill Used. Lady Rosebery is the dim of Lady Primrose, Lord Dalmeny, ete, and Puchess is the dam of the good race-horse Watterson by Great Tom. Sir Archy was the sure of Vanity and Reality, ont of a dashter of imp. Medley by Gimeraek, both good race-mares, and Reality was the dam of Johnson's Medley by sir Hal, son of imp. Sir Hary, Slender and the noted Bommets o* Blue by Sir Charles. Bounets o' Blue was the dam of Mariner by Shirk, son of Ameriean Lelipse and the noted mare Fashion by imp. Trustee. Fashion beat Boston in the famous match four-mile heats over the Union Course; L. I., Hay 10th, 1812, in 7.321-7.45, the fastest raee ever rum in the world to that date. Fashion starterl in 36 races, 21 of which were four-mile heats, of which she won 21, won eight at three-mile heats, won three at two-mile heats, and lost one, winning 32 out of 36 raees.

Six Arehy got Carolinian, Boxer and Lady Randolpb, out of Poll by imp. Durud, son of Pot-8-o-'s by Eclipse; Wild Bill (Pilot) and Charles Kemble, dam Marra by Gallatin, son of imp. Bedtord and Gabrella, dam Calypso by Bellair, son of imp. Medley. Gabriella, bred to Garrison's Ziuganee (son of Su Archy and Miss Chance by imp. Chance, sou of Lureher by Dungannon), prodnced George Martin and Jiss Martin. George Martin was a super'or raee-horse at all distances and defeated Hannah Harris and the fimous Reel, fom-mule heats, in $7.33,7.43$, in 18t4. He had 
previously won the first heat in $7.36 \frac{1}{2}$, the race being won in $7.39,7.51 \frac{1}{2}$, by the noted little prodigy Miss Foot by imp. Consol, ont of imp. Gabriella by Partisan. Miss Martin was the dam of Tokay by imp. Yorkshire, she the dam of Nannie Butler, King Lear, King Tom, King John and King Henry, gool racers bs Lexington. Nannie Bntler was the dam of Girl of the Period (dam of Gerald, Geraldine and Geranium by imp. Saxon) by Virgil. Namnie Black, sister to Girl of the Period, was the dam of Glene (Jennie June's dam), by Glenelg, Princess Blandina and Brown Princess by Prince Charlie; and Nannie Bay by Glenelg, dam Namnie Butler, is the dam of Temple by Tremont. Gabriella also produced Lize by Anerican Eclipse, son of Duroc by Diomed, that was the grandam of Enquirer, one of the best sons of Leamington, and a very successful stallion. Sir Arehy was sire of Betsey Richards (dam of the good race-horse Gano by American Eclipse); John Richards and Rockingham, dam by Rattle, son of imp. Shark by Marske. He also got Marion and Pandora, dam by imp. Citizen. Marion was the sire of the good race-horse John Blount, that leat Boston and Fashion a first heat of four miles in 7.42, and broke down in the second. Marion was the sire of the good race-mare Maria West, ont of Ella Crump by imp. Citizen, she the dam of the great race-horse Wagner, by Sir Charles, son of Sir Archy, that beat the noted Grey Eagle the two four-mile heat races rm at Louisville, Ky., in 1839, the first one 7.48-7.44, the seeond one in 7.51-7.43. Grey Eagle won the first heat and broke down in the seeond. Maria West was dam of Fanny (dam of Millwood and Lithgow by imp. Nonareh) by American Eclipse, Trinket by Andrew, son of Sir Charles, Margaret Wood br imp. Priam, Chilkle Harold by imp. Sovereign and Nuncio by imp. Herald, son of Plenıpotentiary by Emilius. Millwool was the dam of Mill Creek and Charleston (a superior race-horse taken to England), by imp. Sovereign, Macon, Congaree and Rosa Bonheur, by imp. Glencoe, the latter, Rosa Bonheur, the dam of Plantagenet, a fine race-horse by Planet. Margaret Wood built up a family of her own. She was the dam of Heraldry by imp. Herald, Wade Hampton by Boston, Star Daris hy imp. Glencoe, Maria Wood. Allendale (in Canada), Capt. Travis, Yorktown, Mary TVood and Amua Travis, all by imp. Yorkshire, son of St. Nicholas by Emilius, and Georgia Wood by imp. Kinight of st. George, son of Birdcatcher and Maltese by Hetman Platoff. Heraldry was the dam of Margaret West, Balloon, Parachute, Ascension, Sailor and Godard, all by imp. Yorkshire. Petercumaliuctum and sally of the Valley by Austerlitz, son of imp. Yorkshire and Topaz by Glencoe. Balloon was the dam of Rerolver (a good race-horse and sire)-by Revenue, son of imp. Trustee, The Banshee and True Blue by Lexington, Ballet by Planet, and Buff and Blne by War Dance. The Banshee raced sneeessfully and is the dam of Krupp Gun and others. Ballet is the dam of Balancer, Blne Grass Belle and Modests (good racers) by War Dance, Thundercloud by imp. Thnnderstorm, son of Thunderbolt by Stockwell, Lady Longfellow, and Peg Woffington by Lougfellow, Maj. Richards and Katie H. by 'Ten Broeek. Bnff' and Blue is the dam of Badge (the clam of Logic. Mimnie Elkins and O'lielly), by Gilloy, Banner by Longfellow, Bonnie Blue by imp. Great Tom, Blue Stoeking by Felloweraft, Ban Cloche, Monita Hardy and Sister Geneva by imp. King Ban. Parachnte had no chance in the stud, but was the dam of Parapluie (the dam of Windsail) by Kentucky. Georgia Wood was the dam of Ginger. Ella Wotten, Una and Ginger Pop by War Dance, La Gitana by Lncle Vic, sun of Lexington, and Maggie Woods by Endorser, son of Wagner. La Gitana is the dam of Modjeska and Zingara by Tom Bowling, Guitar by St. Martin, son of imp. Phaeton. and Geneva by War Dance. Genera is the dam of the good race-horse Riley by Longfellow. Sir Archy was the sire of Industry, dam by Ball's Florizel. Industry was the sire of Atalanta, the dam of Boston, Jr. (Cost Johnsou), by Boston, and 2d Priam by imp. Priam, whose names appear in many good pedigrees. Sir Archy got the celebrated Sally Hope, dam an imported mare, by Chance, ont of Jemima by Phoenomenon. Slic was the dam of Alice Riggs by imp. Leviathan. Cicero by Sir Archy, dim by imp. Diomed, was the sire of the dam of the famons Tritle by Sir Charles, and she the dam of Miss Peyton (Allendorf's dam), and Gloriana (the dam of Jack Malone and Pat. Malloy by Lexington, good race-horses and valuable stallions), both by American Eelipse. Stockholder by sir Arehy, dam by imp. Citizen, was the sire of Betsey 


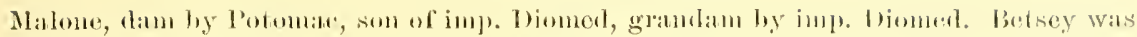

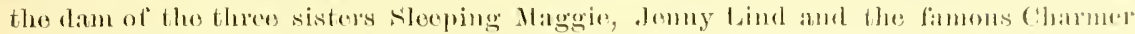

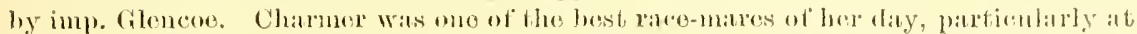

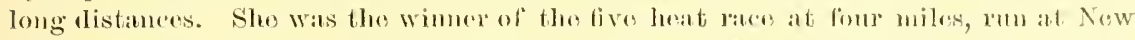

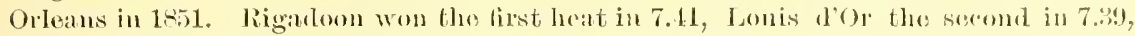

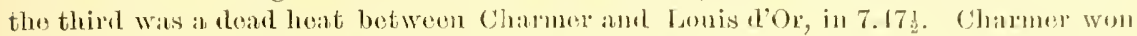
the fourth hoat in $8.05 \frac{1}{2}$, and galloped overe for the lifth heat. Charmer profured, by imp. Torkshire, Maggio Mibehol], whoso danghter Marian (by Malcohm, son of im]. Bombis Seotland and Lady lancastor by imu. Monareh) is the dam of the grand race-horse Emporor of Norlolk and his brothers, all by Norfolk, tho invincible son of Jaxington, and the crack Yo Tambion (winner 1 1-16 miles 1.55 , firstest on recort) by Jor Jooker. Stockholder was also sire of Miss Shepherd (clam Miranda ly Top Gallant, son of Diomel), sho the dam of Miss Russell by Thornton's Rattler, that was the dam of silly Russell by Boston. From sally Russell, through her danghter Miss Russell, cane the famous trotting-mare Maud s., and many others. Sally Kirhy by Stockholiler, dam by Barksstale's Gray Diomed, son of imp. Diomed, was the dam of Princess Ann, Warlock, Black Satin (Ehony) and Sonora Love, all by imp. Leviathan. Princess Ann was the dam of Elizabeth MeNairy and Chaneellor by imp. Ambassador, Cottage Girl and Augusta by imp. Ainderby, son of Velocipede by Blacklock. Cottage Girl, through her ranghters Ninette by imp. Albion, and Arla Cheatham by Lexington, has given us a lot of superior race-horses, sueh as Planetarium and her sons Font and Bob Fisher, by Fonso, Lida Stanhope by Waverls, ete. The name of Stockholder is found in many of the pedigrees of our best race-horses. Lady Burton by sir Archy, dam sultana by the imp. Barb Horse, ont of the imp. Barb Mare, presented to President Jefferson by the Bey of Tunis, was the dam of Conter Snapper by imp. Chance, Sidi Hamet by Yirginian (son of Sir Arehy), and Shyloek by Shyloek, son of imp. Bedford, that was the grandam of the good race-mare Lilac by imp. Leviathan. Sir Arehy was sire of Roanoke, Angelica and Last Chance (ont of imp. Lady Bunbury by Trumpator, son of Conductor by Matchem), also of the noted race-horse Timoleon, dam by imp. Saltram, son of Eclipse, out of a daughter of symme's Wildair, son of imp. Fearnought by Regulus. Timoleon was the sire of the great race-horse Boston, dam sister to 'Tuckahoe by Ball's Florizel, son of imp. Diomed, out of a daughter of imp. Alderman, son of Pot-8-o-'s by Eelipse. Boston has had no superior as a race-horse, and as a stallion was second to none that erer lived for his chances. It must be remembered that when he retired to the stud, racing and breeding had gone down to nothing. Boston ran fortyfive races, won forty, thirty of which were four-mile heats, nine three-mile heats and one two-mile heats. But for an infmity of temper he would have won some races that he lost. Boston was iubred to Diomed, his graudsire sir Archy, and Florizel, the sire of his kikm being both sons of imp. Diomed. Boston had met all the best horses of his day and beaten them all, until conquered by Fashion, first in a race at Camden, N. J., when she won in 7.42, 7.48. John Blount won the first heat and broke down iu the second. This led to the mateh for $\$ 20,000$ a side, run over the Union Conrse, L. I., May 10th, 1812, Fashion winning in 7.32. 7.45 , the fastest race run to that day. Boston was then nine years old and had been in the stud. He was wonderfully successful in the stud, a fact which teuds much to weaken the opinion of Count Lehndorff, who says that no stallion, only two removes from a common ancestry, has ever beeu a suceess in the stud. Boston got Red Eye, a first-class race-horse, dam Lney Long by imp. Priam, and Lexington, the best race-horse at all distances ever bred in America, and the Emperor of stallions. Lexington won all his races but one, and was beaten in that one by Lecompte, son of Boston, by the error of Lexington's jockey in pulling up at the end of the thirl mile in the first heat. The time was 7.26, 7.383. Lexington subsequently won his match against Lecompte's time, 7.26, in 7.19?, and beat Lecompte in $7.23 \frac{3}{4}$, Lecompte being drawn after the first heat, two races unequaled by one and the same horse in the annals of the turf. Lexington's dam, Alice Carneal, was by imp. Sarpedon, son of Emilins, out of Rowena by Sumpter, son of Sir Arehy. Lexington is the sire of the unbeaten Nortolk, dam Novice by Glencoe, Asteroid, dam Nebula by Glencoe, Kentucky (one of the best race-horses ever bred in America), Gilroj 
and Daniel Boome, dam Magnolia hy frleneoe, Lightning, Loarstone, Thmmer ant Lancaster, dam line Bomet by imp. Hedgefort, Beacon, Rulsicon, Bay Flowrr, Baystrater, baytroml, Bayonet. Niagara, Prealiness, bay Rose aud Bay Final, tam Bay Leaf by imp. Jorkshire, son of St. Nicholas by Emilius, Sprightly (the tan wi Tolturno, Elias Lawrence, Aralon anch Aretino), Crueifix (the dam of Fairplay and Semper Felix (the latter the dam of Leonatus), Semper Felix is also dam of Sempu'

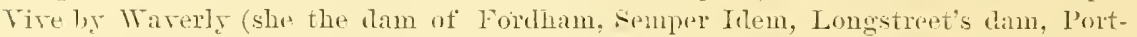
chester, etc.), St. Angnstine aud Latonia (dam of Sena anl Lew Weir), etr.), Lexington also got Salina, flam of Salvator (who has the fastest nile on recort erer $2 u n, 1.3 .5 \frac{1}{2}$ ). Terada (the dam of Luke Blacklon'n, Eenalor, ete.), dam fightsome ly imp. Grencose. Hins, the dau of Mimock, Monitor, Mirth (in Englant and dam of IBouthillier). Lotta C., etc.. dam Milıed, sister to Lightsome hy Glencoe: Stamps, sister to Minx (dam of Katie Pearce), Bertha, Lonisette, Preciosa, etc.: Mairen and her sister La Henderson, dam Kitty Clark hš imp. Glencoe. Maiden was the dam of James $1 .$. Parole, Powhattan (the prouising sire), Perfection, Pappoose, and Parthenia. La Henderson is the ram of Ferila, who has the best four-mile heat. 7.25 , erer rnn by a mare, Aella, Planetia, Tirgilian, etc. Lexington also got Susan Beane, dam Sally Lewis by imp. Glencoe, she the dam of Stratford, Sensation, Onondaga, Susqnehanna. (Potomac's dam), Sonbrette. ete.: Llrica (dam imp. Emilia (Australian's dam) by Fonng Emilins), the dam of Megara (Spinawar's lam), Memento and Ben Ali by Tirgil; Regan (dam Lorette by imp. Sovereign, son of Emilins), the dam of Vigil, Tera Cruz, Jenuie B., Jennie D., Relay, etc.: Florence (dam imp. Weatherwitch hy Weatherbit, son of sheet Anchor by Lottery), the dam of the grand race-horse Hindoo, and his sister Florida, the dim of that most excellent race-mare, Firenzi, whose two races at $1 \frac{1}{2}$ miles in 2.33 and $2.33 \frac{1}{2}$ have nerer been equaler in the worlal;

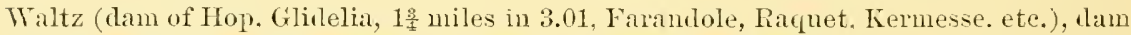
Schottische by imp. Albion, son of Cain or Act:en ; susan Ann (dam of Thora (three miles in 5.25, and the tham of the speerly Iorkville lielle), Henlopen, ete.), dan Roxana by imp. Chesterfield, son of Priam; Finework (dam of Elkhorn Lass, Portland, ete.), dam impl. Filagree hy Stockwell; The Nun (sister to Nortolk and dam of Clara D.), Sister Anne (dam of Volante), dan Torice ly Glencoe; Mattie Gross (dam of Mate, Whisper, Grenala, etc.), ont of Dick Doty's dam by Anerican Eclipse; Arizona (dam of Aranza. Amerirue, Lonise, ete.), out of imp. Zone by The Cure, son of Physician; Hira (dam of the good race-horse and suceessful sire, Hinyar, Hegiaz, Hi Ban, Highflight, etc.), ont of Hegira bs imp. Aubassallor, son of Plenipotentiary ; Lady Motley (dam of Blazes, Lneifer, efc.), her dam, Anna C.. by Glencoe: Echo (dam of Report, Duplex, Echoless and Xaphtha (the grandan of Dewdrop), ete.), ont of Maria Innis Jy imp. Yorkshire; Item (dam of I)an. Sparling. Bob Toolley, Joe Rhorles, ete.), ont of Katona by Toucher, son of Waguer; Woodbine (dam of Bounie Wrod, Belle of the Neade, Boardman, etc.), ont of sister to Compromise by Glencoe; Veritas (dam of Maxim, Lady Prewitt, Tera, ete.), out of Verona by iup. Yorlishire ; Mary Iartin (lam of Santa Anita, Gano s lan), ont of Alice Jones by imp. Glencoe ; July (sister to Susan Aun), Iam of Verdict, Acquittal, ete; Mazmrka, dam of Tallulah (she the dam of Bribery, Miss Ford's dam), Minnie Brown, Zoo Zoo, Grptis, Maze, ete., ont of Jiss Morgan by imp. Yorkshire; Namnie Butler, than of Girl of the Periou, Tannie Black (dam of Brown Princess and Princess Blandina), Nannie bay (Temple's 4lam), Vermont, ete, out of Tokay by imp. Yorkshire; Aerolite, dam of spendthrift.

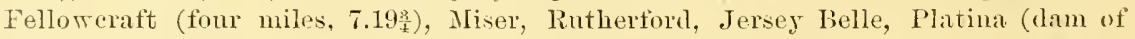
Urake Carter, 3 miles, 5.24, Fellowplay, salile M., Bersan's dam, ete.), ont of Florine by Glencoe, and Aerolite's own sister, Irllewild (4 miles in 7.26 ( 4 miles, 7.25), Fauchon, ete.; Anuie Bush (dam of Bushwhacker, Diana, Virginia Bush, etc), dam Bammer by inp. Albion; The Banshee (dan of Krupp Gum, lirigand Bolle. Emma E., ete.), dam Balloon by imp. Yorkshire; Benlah (dam of Hilarity, Hoder. IIannilual, ete.), dam Enreka by Gleneoe; Blandina, dam of Calisl (Eolian's dam), Christiua, Sea Foam, ete, dam My Laty by Glencoe: Carrie Atherton (dam of Janet Torton, Duke, Nettie Norton, ete.), out of Glyeera by imp. Sorereign ; Connette (daun of Viola, Vivien, Vampire, ete.), out of Susan Harris by Revenne: ('orlelia, clam of 


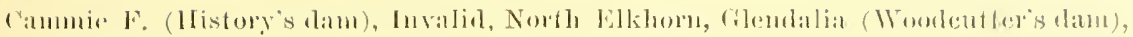

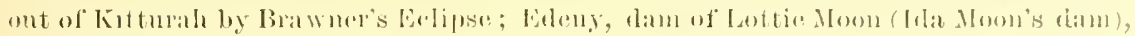

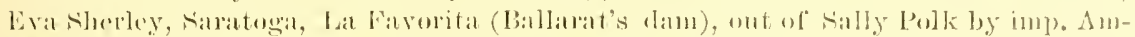

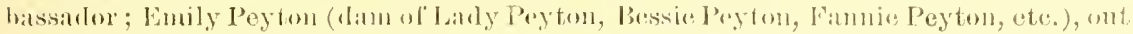

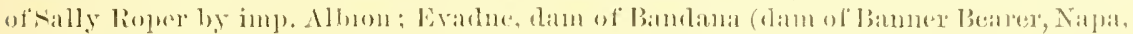

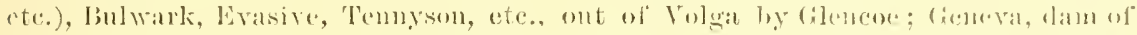

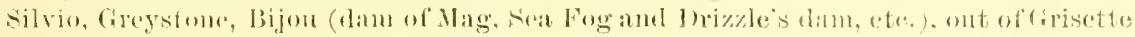

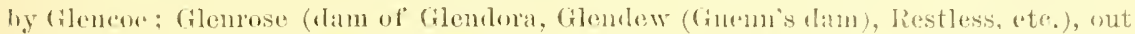

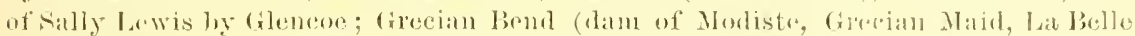

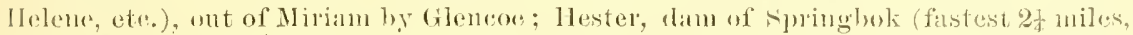

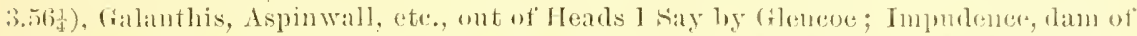

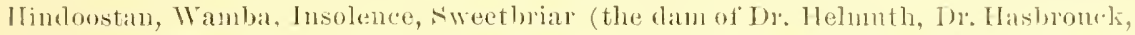
ate.), ont of Magnetta hy Malomet; India (dam of Catleart, Calentta, (xallifet, ete.), lan Miss Morean Wy Yorkslibe; Invernure (dan ot Ganley, Inverwick, ete.), ont wf mup. Invereanld by st. Albans; Lady Wallenstein. dam of Wallenstein (a sucessfinl racer 1 England), Witeh, ete, ont of Lonisa hy Yorlishire ; La Polka (dam of Post Guarl, Strathspey, la Esmeralka, Heel and Toe, los ingeles, ete.), ont of lonce lof Glencoe; Letula (dam of Inrest, L'tility, Cayuga, ete.), ont of C'apitula by Vantal; Lula, dam of Enquirer (one of the best sons of Leamington), Analysis, Oceaniea, The squaw, ete, ont of luze hy Amerimn Exlipse; Lilly Inke (lam of Water Lily, Lizzie l)wyer, Rerl Dress, etc.), ont of Lilla by lorkshire: Marlane 1)ndleg, fam of Juslith, Belinda, Vurgie D. (Hneneme's dam), Vintage, Santa Rita, ete, out of imp. Britannia IV hy The Flymg Dntehman; Majestre, sister to Kingfisher, dam of the superior race-horse Lurus, ont of mp. Elthan Lass ly Kungston, and sabina, full sister to Najestic, and lam of The Widlow, Ucean. Ruchiel, Chief Justice, ete.: Marguerite, sister to Blandina, dan of Prucle, Katie Creel (Kenwool's daur). Azalia. Macola, etc.; Mary Clark, dam of spark, Pure Rze, Grey Dawr, ete., out of Eagless by Glenuoe; Munie Minor, dam of Wrawi k Minority, John Ledforl, Waura, Winfred, etc, ont of Julia by Glencoe ; Miss Bassett, sister to Harry Bassett, daw of Ernest, Masher, Plasir, ete, ont of Canary Bird lyy All,on; Mollue Cad, dam of Maj. Piekett, Molly Cal, Yallisea, etc., ont of imp. Weatherwiteh by Weatherht; Molle Wool, dam of Golden Gate, Altaire, Woollark, Gaseon, ete., out of Hymena by Iorkshire; Mnmlane, dam of Sunheam, Lomger, 'Twnawauda, Blne Wing, The Teal, Blne Garter, ete, out of Sally Bowen ly imp. Hooton : Queen Yictora, suster to Duke of Magenta, lam of Quteu's Orn, Infanta, Jennie Treat, Powhattan Queen, etc; Quickster, sister to Waltz, dam of Falsc-Step, Fenwood, Alitretta, Quekmarch, etc.; Revolt, dam of Regieide, Renegale, Xlismle, etc, ont of sne Washington by Resenne, son of imp. Trustee; Salle (dam of Solicitor, Jathan Oaks, Experience Oaks, Red Coat, Glenclla, ete.), ont of salle by Buforl, son of imp. Touplus by Catton; Sarong (dam of Aristules, Eluza Aranns, Wissahickou, Laisey Hoes, Petershorongh ete.), out of Greek Slare by Gleneve; Springbrook, dam of Sulent Frient, Full Cry (Cherkmate's dam), Verbena (dan of Phil Lee and Mrahael), etc., ont of Eumekfaw, by Alambrino, son of American Erlipse; Sipueeze'em,

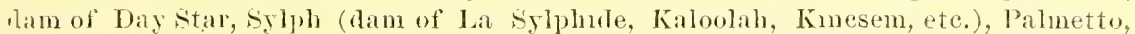
Helena, ete., ont of skedaddle by Yorkshire; sultana (dam of Somlan, she, Padislu, etc.), ont of Milled ly Gleneoe; Ultwma, dam of Aurora Raby (dam of fill Buce and Charley Gorham), Nusance, Sumrise, Sonora, Ultmatmm, etc., ont of Ctilla by imp. Margrare, son of Muley; Zephyr (sister to Arizona), dam of Berliu, Westwind, Typhoon, Zetetie, etc., ont of imp. Zone by The Cure. Amongst the horses of Lexington's get who have done well in the stud and on the turf, we ean mention Nolfolk, never beaten, 3 mles in $5.27 \frac{1}{2}-2.29 \frac{1}{2}$, and a snceesstul stallion; Asteroir, verer beaten, and sile of a number of hood-mares, sncessful podncers, inchuling Mattie WT.

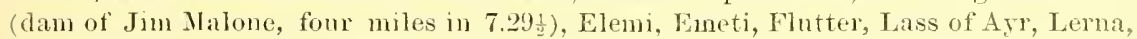
Lma, Modıste, Musan Queen, Waterwiteh, etc.; Kenturky, sire of Bertram, Beatrice Bellona's dam), Woothme (lam of Forester), The Baroness (Iarlge's dam), The, Comntess, Nina, lreehooter; Vanxhall and Foster, hoth good race-horses, the former sue of Viator, Cloverbrook, Oden, ete.; Concorl, sure of Galmay. P'jcolo, ete.: Lever, sure of Leveler, Essillah, La Glorra, Petrel, Mahlstock, Sweetheart ete.; Lncas and 
Wanderer, brothers, both good race-horses and stallions; Jack Malone and Pat Malloj, good race-horses and sires: Lightning (sire of Janet, four miles 7.25), a superior race-horse; Kingfisher, sire of a number of good ones in the Nursery stud, including Fillette (tam of Fides), Magnetism (Iam of Magnetizer), ete.; Harry Bassett, Merrill, Marion, Ansel, Optimist (sire in France of Mars, a popular stallion, and sire of Jongleur); Preakness, a good sire in Eugland; Chesapeake, Colton, sire of Monday, ete., and mans others.

The Herod line is stronger in numbers than the Matchem, but not so numerons as those of the Eclipse line. The best now alive in England are Balfe, a good racehorse by Plaudit, son of Thormanby, dam 13ohemia by Weatherbit, son of Sheet Anelıor by Lottery. Bird of Freedom (winner of the Ascot Gold Vase, Cits and Suburban Handicap and other good races), by Thuringian Prince, son of Thormanbs, dam Vitula by Arthur Wellesley, son of Melbourne. Brnce (winner of the Grand Prize of Paris), by See Saw, son of Buceaneer by Wild Dayrell, dam Carine by Stockwell. Atlantic (wiuner of the 2,000 Guineas), by Thomanby, dam of Hurricane bs Wild Darrell. Charibert (winner of the 2,000 Gnineas), by Thormanby, clam Gertmile by Samnterer, son of Birdeatcher. Macaroon by Macaroni, dam Margery Daw bỵ Brocket, sou of Melhourne. Macheath by Macaroni, dam Heather Bell by Stockwell. Maegregor (wiuner of the 2,000 Gnineas) by Macaroni, dam Necklace by The Fallow Buck. Mask, a great sire, by Carniral, son of Sweetmeat, dam Meteor by Thunderbolt, son of Stockwell. Kisber (wimner of the Derby and Grand Prize of Paris) by Bnceaneer, dam Mineral by Rataplan. Ossian (winner of the St. Leger) by Salvator, dam Musie by Stoekwell. Sir Bergs (winner of the Derby) by Favonius, dam Lady Laugden by Kettiedrum. Salvator (winner of the French Derby and Grand Prize of Paris) by Dollar, son of Flying Dutchman, dam Sauvagine by Ion. Saxifrage by Tertugadin, son of Fitz Gladiator, dam Slapdash by Annindale. Perplexe (winner of the Freneh St. Leger) by Vermonth, son of The Nabob, dam Peripetie by Sting, the last three bred in France. In America re are very strong in the line to Ferod, throngh the sons of Lexington and male descendents of imp. Glencoe. The brothers Uneas and Wanderer. hoth good race-horses by Lexington, dam Coral by Vandal, son of Glencoe. Tom Ochiltree, sire of Major Domo and a superior race-horse by Lexington, clam Katona by Toucher, son of Waguer. Vanxhall, a good race-horse by Lexington, dam Verona by imp. Torkshire. Duke of Magenta, a superior racer, by Lexiugton, dam Magenta by imp. Forkshire. Monday by Colton, son of Lexington, dam Mollie Jaekson by Tanda1, Bishop by Shannon, son of Mínday, dam Bettre Bishop by imp. Buckclen. Argyle by Monday, dam Cuba by imp. Anstralian. Joe Hooker by Monday, dam Mayflower by imp. Eelipse. Day Star by Star Davis, son of imp. Glencoe, dam Sqneez'em by Lexington. Hindoo, a grand race-horse by Virgil, son of Vandal, dam Florence by Lexington. Hanover, a superior race-horse, by Findoo, dan Bourbon Belle br imp. Bounie Scotland. Tocalic by Tirgil, dam Aconstie by imp. Anstralian. Ventilator by Vandal, dam Carolin by imp. Seytlian. Tremont by Virgil, dam Ann Fief by Alarm, was never beaten and is promising well as a sire. Vanderbilt by Vandal, dam Melrose by Childe Harold, son of imp. Sovereign. Vagabond by Vandal, dani Gem by Childe Harold. Vigil by Virgil, dam Regan by Lexington. Portland by Virgil, dam Finework by Lexington. Isaae Murphy by Virgil, dam Mary Howard by imp. Hartington. Imported Mortemer by Compiegne, son of Fitz Gladiator, dam Comtesse by The Baron or Nuncio. Mortemer won the Gold Cup at Ascot, and his sons are Exile, a superior race-horse, dam imp. Second Hand by Stockwell ; Pontico, a good race-horse, dam 1mp. Agenoria by Adventurer; Cholula, a good racer, dam Fanns Lndlow hy imp. Eclipse, son of Orlando; Cyelops, dam Lizzie Lucas by imp. Anstralian: Wilfred, «lam Mimmie Minor by Lexington; Heimdel, dam Vandalite by Vandal. Imp. Macaroon by Macaroni, dam Songstress by Chanticleer, son of Birdeateher. Imp. Moceasin by Macaroni, dam Madame Strauss by King Tom. Imp. Woodlands by Nutbourne, son of The Nabob, dam Whiteface by Turnus. The imported brothers Sir Modred and Cheriot by Tradncer, son of The Libel, dam Iclalia by Cambuscan. Grinstead by Gilros, son of Lexington, dam sister to Ruric by imp. Sorereigu. Gano by Grinstead, dam Santa Anita by Virgil. Flood by Norfolk, dam Hennie Farrow by imp. Shamrock. 
limperor of Norfolk and his brother by Norfolk, dam Maxian hy Maleolun, son of imp. lionnie Soutland.

King Willian, through Mr. Marshall, importer the White Bas, Chillaly, together

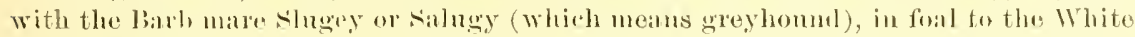

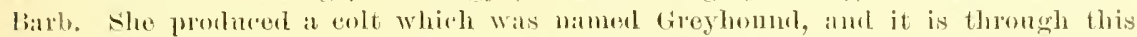

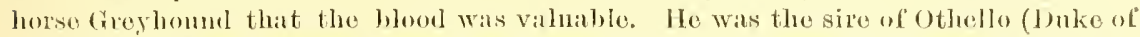
Whaton's), Coliah, Nampson amel his sisters out of a Curwen Ban mare, liake amel his sister out of $\mathrm{Mr}$. Crof't's Pet maro by Wastell's 'T'urk, Desdemona ont of' Chestmut Thomton lig Makeless. The Greghomel mare (sister to Sampson and Goliah) was the dam of Lady Thigh (Grisewool's), Meymell, Craven, Pompey and Jenny spinner by Croft's Paltuer, Cloudy and sally by Forester. Greylound also got Y. Greyhounl, Gny and his sister, ont of Brown Farewell hy Makeless. The sister to Rake was the dam of Barforth and his sister by Croft's Partner. Grisewood's Larty Thigh was the dam of imported Duchess by Cullen Arabian, and Miss Thigh by Rib, she the dan of selim by Bajazet, and the Cullen Arabian nare (sister to imp. Duehess) that was the dam of P'rineipessa by liank, she the dam of Heinel by symirrel. Heinel's daugher by Woodpecker was the dam of Cobbea by Skyseraper [she the grandam of Cadland (Derby wimuer, 1828), by Andrew] and of Mrs. Barnet by Waxy, the tam of Filho-da-Puta, st. Leger winner, 1815. Another full sister to Duchess harl a filly by snap, son of Snip, that was the dam of Conductor, Alfred, Georgiana, Dictator, Scorpion, Eyebright and Laurestiuus, all by Matchem. Georgiana was the dam of Lady Harriet by Mark Anthony, Grouse by Highflyer, Speculator and Mooreock, brother to Gronse. Eyebright was the dam of Jemima hy Pho'nomenon, that was the dam of the Chance mare, imported into Virginia, that was the dam of sally Hope by sir Arehy. The sister to Guy by Greyhonnd was the dam of Bay Bloody Buttocks and Grey Bloody Buttoeks by Bloody Buttocks Arabiau (which was a grey Arabian with a red mark on his hip), Little Partmer (sister to Vaue's Little Partuer, which was the grandam of the imp. Cub mare), Young Partuer and Red Rose by Old Partner. Bay Bioody Buttocks was the dam of spinster (the Widdrington mare) by Old Partner, son of Jigg. Spinster (the Widdrington mare) was the dam of Spinster and Shepherd's Crab by Crab, son of the Aleock Arabian, Lofty by Godolphin Arabian, Golklen frove by Blank, ete. Golden Grove was the dam of Petworth (Gaury) by Herod, and she the dam of Quiz by Tandem, Bounty by Merenry, and Rosina by Woodpecker, the latter the dam of Hermes by Mercury, son of Eclipse. Hermes was the sire of Gibside Fairs, the dam of Emma and Maria by Whisker. Emma was the dam of' imp. 'Trustee and his brother Mumlig (winner of the Derby, 1835), by Catton, The Ladye of Silverkeld Well by Yelocipede, Cotherstone (winner of the Derby, 1813) and Mowerina (West Australian's dam) by Touchstone. Maria was the dam of Euclid, Laura, Equation, Example and Eclipsis by Emilius. Grey Bloody Buttocks ran muder the name of Dairsmail, and was the dam of Parker's Lady Thigh by Hartner, son of Jigg, Coruforth's Forester by Forester, Smallbones and Squirrel by Travelex, son of Partner. Young Greyhound got the dam of Engineer and Miner, out of a daughter of the Curwen Bay Barb. Engineer was the sire of Mambrino, ont of a daughter of Cade by the Godolphin Arabian. Mambrino was the sire of imp. Messenger, out of a daughter of Turf by Matchem, and imp. Mambrina, out of Naylor's Sally by Blank, son of the Godolphin Arabian. Mambrina was the dam of Gallatin, Fairy and Eliza, all by imp. Bedford, and Eliza was the dam of the great race-horse and stallion Bertrand, and Pacific by Sir Arehy by imp. Diomed. A sister to Engineer by Young Greyhound produced a filly by Blaze, son of Flying Childers, that was the dam of Sappho, Semele and Seraphina by Blank. Sappho was the dam of Sophonisba by Squirrel and Nadeap by Eclipse. Madeap's daughter, Caprice, by Anvil, sou of Herod, produced Floranthe by Octavian son of Stripling by Phonomenon by Herod. Floranthe was the dam of Economist by Whisker. Economist was the sire of the wonlerful race-horse Harkarvay, out of Fanny Dawson by Nabocklish. Harkaway got King Tom ont of Pocahontas by imp. Glencoe, and King Tom got imp. King Ernest ont of Ernestine by Touchstone, imp. King Ban out of Atlantis by Thormanby, imp. Phaeton out of Merry Sunshine by Storm, son 
of Totichstone, imp. Great Tom out of Wooderaft by Voltigenr. These horses prover big successes in America, and their daughters are doing equally well in the stud.

The Akaster 'Turk was brought to England about the jear 1700 , by whom the authorities do not state. He was the sire of Chaunter, and a full sister, which was the dam of the famous Roxana (the dam of Lath and Cade), and Silverlocks by The Bald Galloway, Terror and Mr. 'Thwate's Dun Mare (the dam of Mr. Bearer's Drirer). Akaster Turk was also the sire of the dam of William's Fquirrel and his full brother, Smitli's son of Mr Lister's Snake. Silverlocks was omned by Mr. Coke and was the dam of Lord Portmore's Silvertail and Lord Godolphin's Buffcoat by the Godolphin Arahian, who was imported into Virginia, and died there in 17.5. There was also an own sister to Roxana and Silverlocks, which was the dam of Mr. Panton's Cato by Partner, and a sister to Cato was the dam of the Foxhunter mare that produced Molly-long-legs by Babraham. This sister to Cato by Partner was also the dam of imp. Silver (Sylva) by the Belsize Arabian, which was importer into America and was the dam of Sally Painter by Eran's imp. Stirling, also son of the Belsize Arabian, Babriham and a full sister by imp. Fearuought, and Grenadier by True Briton. Sally Painter was the dam of Diana by Clodius, son of imp. Janus. Diana was the dam of Minerva by imp. Obscurity, son of Eclipse. Ninerval was the dam of Camilla by Symme's Wildair, she the dam of Priestly by Chanticleer, son of imp. Wildair. Diana was also the dam of Rosetta by imp. Centinel, son of Blank by the Godolphin Arabian. Rosetta was the dam of Narcissa by imp. Shark, which produced IIerctrix by Magog, son of Chanticleer, which gave us Director and Virginian, brothers by Sir Archy, son of imp. Diomed, good race-horses and stallions. Julietta by imp. Dare Devil, son of Magnet by Herod, out of Rosetta, was the dam of Nell Saunders and sister by Wilke's Wonder, son of imp. Diomed. From Nell Saunders, and her daughter by Pacolet, son of imp. Citizen by Pacolet, son of Blank, bred to Stockholder, son of Sir Archy, dam by imp. Citizen, came the dam of Compromise the great gelding, and Miss Pattie by imp. Glencoe, Martha Dum and Invincible by imp. Sorereign, and Laura (the dan of Harry of the West, Lilly Ward and Fanns Cheatham, all superior racers and by Lexington. Miss Pattie Was the dam of Woodbine by Lexington and Jessamine by Brown Dick (she the dam of Barnton and others), Madeira by John Morgan, Belle of the Meade, Bonnie Wood and Boardman by Bonnie Scotland. Patty Puff by Pacolet, tracing through Rosy Clack (dlam of Tennessee Oscar by Wilke's Wonder), by imp. Saltraw, son of Eelipse, to Diana, was the dam of Tennessee Citizen, Brron, Maria Shelly by Old Stockholder, son of Sir Archy, and the three sisters Angora, Celerity and Velocity, by imp. Leviathan, son of Muley by Orville, good racers, To Celerity trace many good race-horses, such as Ann Percy, the dam of Goldring (Bullion's dam) by linggold, son of Boston. Martha Washington, Bill Deering (Gamble). Martha Dunu by imp. Sovereign son of Emilius by Orville, produced Luln Horton by imp. Albion, son of Cain or Actron, that was the dam of Spartan, Kildare, Pequot, Lute and Killarney by Lexington. Lute was the dam of Virginius by Virgil, a good race-horse, and Glenlnine by imp. Glenelg, the latter the dam of Windrush, a superior race-horse, bs King Alfonso, Patrimony (the dam of the good but unfortunate Lisimons) bs Pat Malloy, Troubadour, the grand race-horse by Lisbon, son of imp. Phaeton by King Tom, that beat The Bard, in the Ocean Stakes, $1 \frac{1}{8}$ miles, 1.56 $\frac{1}{4}$, and Monmonth Cup, $1 \frac{8}{4}$ miles in 3.04, and also won the Suburban Handicap in 1886. Lulu Horton was also the dam of Amy Farley by Planet, she the dam of Titania (dam of Charity by Lever, and Lina by King Alfonso) by Lexington, Mattie Amelia by King Alfonso, Pathfinder, Terese and Blne Grass, a prominent winner in England, by Pat Mallos.

The Selabs Turk (called also the Marshall Turk) was brought to England by Mr. Marshall, brother to the King's Master of the Stud, in King William's reign. He was the sire of Mr. Curwen's Old Spot, sire of the dam of Mixbury and brother to Mixbury (Chedworth's), the latter the sire of Little Bowes (the dam of Mab by Hobgoblin, Regulns Mixbury and Medusa, dam of Weazle by Regulus, Sophia by Blank, anil Young Bowes, the dam of Chedworth's Snap, by Dormouse). The Selaby Turk was 


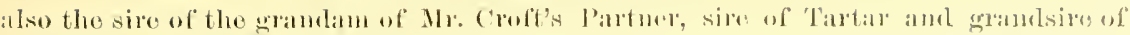

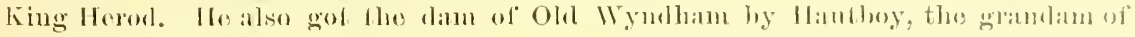

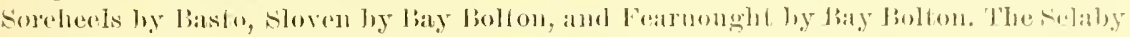

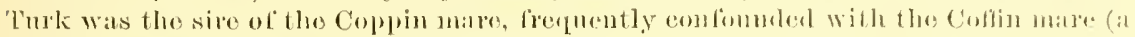

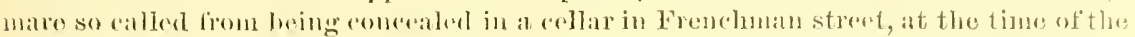

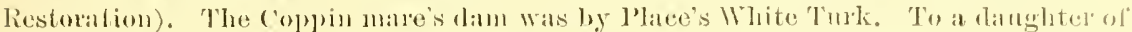
tho Coppin matre hy Commoner, som of l'late's Whito Twli, traces in a direct lemales

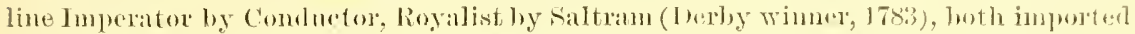
to America, Aetion by Seml, Emilins (I)erby wimer, 1823) by Orville, 1)alesman by King Tom, Barbillon (Fench) by Pretty lioy, son of follo Boy by llakiway, Warminster (importerl) by Newninster, imp. Saxon by bearlsman, inp. Canillat hy King Tom, the dam of Carolin, Vietoria and Medora hy Kentucky, Carina (damot St. Carlo) by Kingtisher, Carita (the dam of King Crab, St. Charles, ete.) ly Yll Lserl, ams her sister Clara, the Iam of Clarenton, Chathan, etc., imp. Qucen Mand Jy Hacaroul, the dam of Qneen of the May, IIawkstone, Stoney Montgomery, etr. 'The Selaby Tnrk Was also sire of tho mare, dam by bustler, gramclam by Place's Trhite Turk, out of a daughter of Dorlsworth, a natural Barb. This mare was the lan of Wincham (Wyurlham) by Hantboy. Tyndham was the sire of Miss Wymllam, ont of a danghter of Belgtade Turk, who was taken at the siege of Belgrade in Turkey from the Basluaw of that place, and sold by the Minister of Prince Lorraine in London to sir. M. Myrill's. He was the sire of Young Belgrarle and of the dam of Miss Wyndham by Wymlham, who prodnced a mare by Brother to Bolton Fearnought, that was the dam of Beanfremont by Tartar, and the Carle mare that was the dam of Lardella by Young Marske, to which traces imp. Frolicksome Fanny (the dam of Tom Corwin by imp. Emancipa. tion, Miss Margrave by imp. Margrave, aud Niua by Boston) by Lottery. Ninat Tas a superior race-mare and a gramd brood-nare, dam of Planet (a superior race-horse), Excheqner, Ninette (dam of Diarolo and Grace Darling by Jonesboro'), Orion by Rerenue, Concluctor by Engiueer, Oriana by Dencalion, son of Revenue, Ripley by Jeff Davis, Eugenia (dam of Enterpe, Enniee and Eusebia by Vauxhall, son of Lexingtou, aud Eula B. by Dickens, ) by Engene, son of Revenne, Eeliptic, the dam of Sunbeam (Constantina and Winston's dam) by imp. Leamington, Bahy aud North Anma. by imp. Strachino, son of Parmesan, Catalpa and Virgo by Abd-el-Kader (son of imp. Australian,) by imp. Eelipse, Algerine, winner of the Belmont stakes, and his sister Algeria by Abrlel-Kader. Algerine is now in the Algeria stud, Erie, Pennsylrania.

The St. Victor Barb was sent to Englawel by Monsieur St. Victor, of France. He was tỉe sire of the celebrated Bald Galloway, his dam Grey Whynot by Old Whynot (son of the Fenwick Barb), graudam a Royal mare. 'The Bald Galloway was sire of Bnckhunter (afterwarts the Carlisle gelding) and Old Lady, a sister to Buekhunter, Lord Portmore's Suake and Daffodil, Grey Robinson, out of sister to Old Country Wench by suake. Grey Robinson was the dam of the famons Regnlus by the Godolphin Arabian. Roxana by The Bald Galloway, dam sister to Cluamter by the Akaster Turk, was the dam of Lath and Cade, by the Godolphin Arabian, and to her the Godolphin owes his snecess in the stud and his immortalit. Roxana was also the dam of Roundhead by Flying Chillers. Silverlocks, sister to Roxana, was the dam of Buffcoat by the Gorlolphin Arabian imported juto Virginia. The sister to Regulus, out of Grey Robinson, was the dam of Polly by Blank, Coquette (the dam of Camilla, Glider, Driver, Darter and Cocker by Trentham) by the Compton Barb, imp. Emilia by Young Emilius (Iam of imp. Australian and Ulrien), ont of Persian by Whisker, imp. Rosalind by Biarnton, dam sister to Bay Rosalind by Orlando, imp. Adriana by Blinkhoolie, dam Essence by St. Albans, imp. Santa Lneia (the dam of Aurelia, Torso, etc.) by Lord Lyon, dant Lady Margaret by Honiton, imp. Star Actress by siclerolite, dam The Tinted Vems by Macaroni, all trace through Connette by The Comptom Barls and sister to Regulus to Grey Robinson. The filly by snap, son of Snip, out of the sister to Regulus, in 1775, prodnced in Ireland, Heroine by Hero, son of Cade. Heroine, in 1781, produced Tom Turf by Lemnox, son of Bustard by Crab, and Young Heroine, the great gramlam of Birdeatcher by Bagot, son of Herod. Another sister to Roxana producel Cato by Partner, and his sister that was the dam of imp. Silver (Sylra) by 
Belsize Arabian. St. Victor Barb was also sire of Cupid, own brother to Bald Galloway, and his sister Points, out of Grey Whynot by Old Whynot, ont of a Royal mare. In 1715 Points foaled the filly Flying Whigg by Williams' Woodstock Arabian. Flying Whigg was the dam of the Large Hartley mare by Mr. Hartley's Blind-Horse, son of the Holderness Turk, Little Hartley mare by Bartlet's Childers, and three fillies by Hip, son of the Curwen Bay Barb. The Large Hartley mare was the dam of imp. Selima by The Godolphin Arabian, and her brothers Babraham, Mogul and Marlborough, sent to Ireland, also a roan filly by Hip. It is to this latter Hip mare that many of our best importations trace their origin, including imp. Maud by Stockwell, the dam of Mandina (the dam of Galway, Piccolo, Elizabeth, Cloverbrook, Oden, Minerva, Empress, Maumee, Marauder, etc.) by imp. Australian, Attraction (the dam of Magnetism, Magnetizer's dam) by imp. Balrownie, Alarm by imp. Eclipse, one of the best and speediest horses of his day and a snecessful stallion. To this Hip mare also traces imp. Jenny Mills by Whisker. She was the dam of Ambassador, imported in utero, by English Plenipotentiary, a good stallion, Liatunah and Sewanee, good racers, by imp. Ainderby, son of Velociperle. To the same identical source traces also imp. Buttereup by The Primate, son of St. Albans by Stockwell, her dam Buttercrambe by Ben Webster, son of Baruton, brother to Voltigeur. She is the dam of a number of winners. The Little Hartley mare was the dam of Jamus, Blank and Old England by the Godolphin Arabian, and Miss Meredith by Cade, son of the Godolphin Arabian. To Miss Meredith trace imp. Boaster, foaled in 1795, by Dungannon, son of Eclipse, imp. Driver, foaled in 1806, by Driver, som of Trentham, and Gabriel, foaled in 1790, by Dorimant, son of Otho by Moses. These horses are found in many of our best racing perligrees.

The Oglethorpe Arabian was the property of Sir 'Thonas Oglethorpe of Scotland. Little is known of his history. He was the sire of Makeless, whose dam was Trumpet's dam by Place's White Turk, second dam by Dodsworth, out of the Laytom Barb Mare. Makeless was not only a distinguished race-horse in his day, but was greatly esteemed as a stallion, being the sire of Sir RaIph Milbank's famons Black mare, the dam of Hartley's Blind Horse by the Holderness Turk, aud Gipsy by King William's Black No-tongued Barb. From the latter in direct female linedescend Sir Arehy (the Godolphin Arabian of America), Highland Mary, Hephestion, Castania, Virgo, Noli-me-Tangere, etc. Makeless was also the sire of Sir M. Pierson's Makeless mare, dam by Brimmer, gran dam by D'Arcy's Diamond (son of the Helmsley Turk), out of an own sister to Old Merlin by Bustler. This Makeless mare was the slam of Bay Bolton (Brown Lusty), and a sister to Bay Bolton bs Grej Hantboy, Bay Lusty and Lamprie by the same stallion, and the Lnggs mare by the Darley Arabian. It is from this sister to Bay Bolton that Dr. Syutax and Little Red Rorer descend in direct female line. The Oglethorpe Arabian was also sire of Bold Frampton. The Blind Horse was bred by Leonard Hartley, Esq., near Richmond, Yorkshire. He was sire of Miss Neasham and the Large Hartley mare, she the dam of Babraham. Mogul, Marlborough and Selima, all by the Godolphin Arabian. Selima was imported into the United States and founded a distinguished family of race-horses. Makeless was the sire of Old Scarborough mare, dam by Brimmer, and she was the ram of Scarborough Colt by Tifter, a filly by Belgracle Turk which was the dam of Miss Wyndham by Wyndham, and a filly by Bay Bolton that was the dam of Young Belgrade by Belgrade Turk. Miss Wrulham was the dam of Beanfremont by Tartar, and IIr. Hutton's mare by Cade, she the dam of Lardella by Young Marske. from whence in direct female line descend Comus by Sorcerer, Slane by Royal Oak, Young Melbonme by Melbourne, North Lincoln by Pylades, son of Surplice, and Sefton by Speculum. Makeless was also the sire of Bay Farewell and Brown Farewell, the latter the dam of GuF, Young Grephound and full sister to these two by Greyhound. This latter mare was the dam of Bay Bloody Buttocks, Grey Blooky Buttocks (Dairymaid) by Bloody Buttocks, Little Partner, Young Partner and Red Rose by Croft's Partuer. Makeless was also sire of Bay aud Chestuut Thoruton, dam Old Thornton by Brimmer, grandam by Dicky Pierson (son of Dodsworth), ont of the Burton Barb mare, a Natural Barb mare of Mr. Burton's. It is from this Burton Barb mare that 


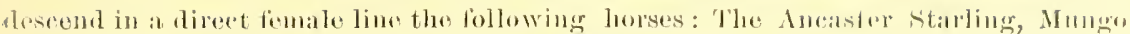

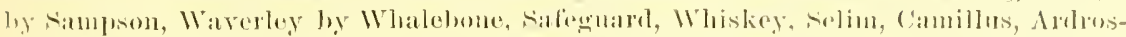

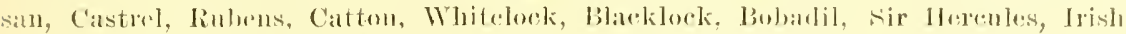

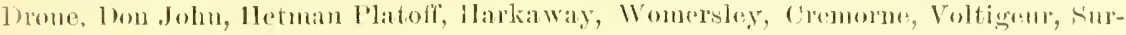

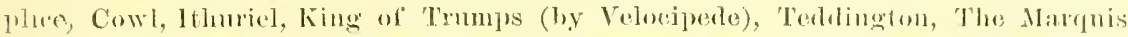
(by stockwell), St. Albans, hord Clifilen, Skirmisher, Laetner, ('amballo, Matryrtom, Mask, Pell Nell, Camelion, 'Thurio, Lmpire (by King Tom), Althotas, Bragg, sheeu, ete.

The following imported borses are also deseendants in the female line from the same mire: Ahjer, Ainderby, Billet, Brilliant, Cllance, Claret, clifilen, Contract, Dou, Eagle, spreal Eagle (wimer of the Derby), Gouty, Granby, Harktorward, Hurrah, Jolly Roger, Langford, Margrave (wimner of St. Leger), Don John (winuer of st. Leger), Merry Tom, Nonplns, North star, l'antaloon (by Herorl), l'hunomenon (winner of st. Leger), Restless, Skylark, St. George, The Tester, Thunderstorm, lorkshire. and Waverly (by imp. Australian), bred in Kentucky.

The Darlę Arăbian was the property of Mr. Darley, of Buttercramb, near York, England, to whom he was presented by his brother, resiling abroad. He was a Bedonim horse of the family ealled Keheilan-Ras-el-Fedawi, imported in the latter end of Queen Anne's reign, about 170?. He was the sire of Almanzor (his tam the dan of Terror by Akaster Turk, and Graham's Champion by Harpur's Arabian, Aleppo, Thitelegs and Smoekface, full brother's to Almanzor), Brisk, ont of Comeyskins' dam bs Jigg, and Cupid, both good horses, Diedains, a Heet lorse, Skipjack, Maniea, imp. Bulle Rock, Dart, Whistlejacket, good plate horses, and Whimsey and Kittỵ Burdett, out of the Ioung Child mare, good plate mares and producers. The great reputation of the Darley Arabian eomes from his son Flying Childers (eommonly ealled Childers), and his full brother, Bartlett's Childers, who was at first ealled Bleeding Childers, from lnis trequently bleeding from the nose. Flying Childers, foaled in 1715, was by the Darley Arabian, dam Betty Leedes hy Old Careless, son of Spanker, and a Barb mare, second dam sister to Leedes by Leede's Arabian, thurd dam by Spanker, fourth dam Old Horoceo mare (Old Peg, Spanker's own dam) by Moroeco Barb, fifth dam, vld Bald Peg by an Arabian ont of a Barb mare. Childers started against the best horses of his time and was never beaten. In the pear 1721 it is sad that Childers ran a trial against Almanzor and Brown Betty, carrying 128 1bs., over the Ronnd Conrse at Newmarket, 3 miles, 6 furlongs and 93 yards, in 6 minutes and 40 secourls. It was also said that he moved 82 feet in a second of time, which is nearly at the rate of a mile in one minute. He ran over the Beacon Course, four miles, one furlong and 138 rards, in 7 minutes and 30 seconds. His stride eovered 25 feet. These performances are not reliable, but he was unquestionably one of the fleetest horses that ever lived. He was not only a superior racer, but a wonderfully valuable stallion. He was the sire of Plaistow, Blacklegs, Second, Snip, Commoner, Blaze, Wiuall, Spankiug Roger, Lord Mamner's Poppet, Fleec'em, Steady, Young Miss Belvoir (the dam of Miss, Redcap and Dnchess by Lath, aud Foxhunter by Blank). He also got two sisters to Young Miss Belvoir, one of whieh was the dam of Allworthy, Cypher and Pytho by Crab, Feather by the Godolphin Arabian, Horatius and Horatia by Blank, and a filly by Pantor's Arabian. 'The other sister was the dam of the Ancaster Blossom and Goidolphin Blossom, both by Crab, the former the dam of Blossom, Jilt and Bragg by the Godolphin Arabıan, Gandy, Gamesome, Grizzle and Chrysolite by Blank. Childers was also the sire of Bay Basto and Brown Basto, sisters to Suip. Bay Basto was the dam of Chance, Crazy and Gipsy by Lath, and Channter by Cade. Bromu Basto was the dam of Hector, Cassandra and Lady by Blank. Sister to Blaze, she the dam of Whitenose by the Godolphn Arabian. Another daughter was the dam of Little Driver by Beaver's Driver. Bartlett's Childers was not raced, but was an excellent stallion, sire of Smales' Childers, Edipus, Grey Childers, squirt (the sire of Iarske and Syphon), Conghing Polly, Little Hartiey mare (the dam of Janus, Blank and Old England by the Godolphin Arabian, Trimmer and Shakespeare by Hobgoblin, Miss Meredith and sloueh by Cade), the dan of Wyrill's Tolunteer, from which mare in direct female hne descend Waxy, Paynator, Thunderbolt (by Sorcerer), 
Smolensko, Colsterlale, Ellington, Ashton, Sonvenir, Ponssin, Bertrin, etc. The mare ont of sister to the Two True Blues, dam of Mirldeton's squirrel, Midge, Thwackum and Camilla by a son of Bay Bolton, Miss Belsea and a sister luy Regulus. son of the Godolphin Arabian. Niss Belsea was the dam of Wildman's Snap, Hyatna, Timility, Rosebud, Harpy, Elfuda and others, all hy Snap, son of Snip, by Flying Childers. Hræena was the dam ot Eagle, Everlasting aud Lavinia by Eelipse, anr Evander by Highflyer. The sister to Miss Belsea by Regulus was the dam of Fribble by Snip, 10 Ireland, the nures Snaprlragon, Curiosity, Angelica and a sister by Snap, and Cypher by finuirel. Cnriosity was the dam of Misfortune by Dux (son of Matchem by Carle), that produeed the great horse Buzzarl, inported into America by Col. Hoones, of Virginia, in 1805. Few horses in his day were snperior to Buzzari, and he left behind hum a distinguished progeny in England, being the sire of the three brothers, Selin, Castrel and Rubens, and their sister, Bronze. Buzzard was also the sire of Rosamond, the dam of inp. Barefoot by Tramp. From Barefoot, throngh his daughter Motto (the dam of Nannie Lewis, Sally Lewis and My Lady, all by imp. Gleneoe) a distinguished fumily of horses lescend. Sally Lew is was the ram of John Morgan by imp. Sovereign. Hunter's Lexington, Glenrose, Susan Beane and Acrobat by Lexington, Linda Lewls by Oliver, son of Wagner, and Lotta by Hnnter's Gleneoe, son of imp. Glencoe, and Fiatt (The Blue Filly) by imp. Hedgeford. John Morgan and Hunter's Lexington were good race-horses and were successtul in the stul. Susan Beane was the dam of Stratford, Sensation, Onondaga, Sionx ant suscuehanna, the last one the lam of the grand race-horse Potomac (winner of the Futurity and Realization Stakes) aud Chesapeake, a good horse. Susan Beane was also the dam of Sontrette and sir Herenles by Alarn.

Glenrose is the dam of Glender, she the dam of the fleet Guenne by imp. Glengarry, and Restless by imp. Mortemer, a real good one. Linda Lowis is the dam of Kisba, Quiver, Withrow (by Longbow, sou of Longfellow) and the superior race-horse and promisng stallion Linden ly Longfellow. Lotta is the rlam of the fine race-horse Glenmore by 1mp. Glen Athol, son of Blair Athol by Stockwell. Glenmore was a good race-horse at all clistances in fast time, his three heats in fonr miles in $7.29 \frac{1}{2}, 7.30 \frac{1}{4}$, 7.31, heing the fastest and best ever run in the world. Buzzard was the sire of Hejhestion, out of imp. Castianira (the dam of Sir Arehy) by Rockingham, son of Hightlyer by Herorl. Hephestion was a good race-horse and quite a suecessful stallon. Buzzarl's daughters were a great sucesss in America. One ont of The Fawn liy Craig's Alfred was the rlam of Oli Court, Lady Alams by Whipster, Huntress by Cherokee, Lady Fortme, the greatglandan of Longfellow, by Brimmer or Blue Beard, and the noted Woorlpecker hy Bertrand. Woolpecker was the sire of Grey Eagle, the competitor of Wagner in the two famons races at Lonisville, Ky., rum in the fall of 1839. Another danghter of Buzzarl, out of Arminda by imp. Merlley, sou of Gimerack by Cripple, son of the Godolphin Arabian, was the dam of Grey Fanny by Bertrand, son of Sir Arehy. Grey Fanny was the dam of Grey Medoc by Medoe, son of Amertean Eelipse, that was the best race-Lorse of his day. He won the great race, fonr-mile heats, at New Orleans, in 1841, the first heat, a dead heat with Aitorf, in 7.35 , second heat won by Altorf in 8.19, and the third and fourth heats won ly Grey Mexloe in 7.t2, 8.17. Grey Fammy also produced Kate Aubrey, a good mare by Ameriean Eelipse, and the noted Blue Bonnet by imp. Herlgeford. Blne Bonnet won a number of good races. and retired in the stud in her ninth year. She was a suecess in the sturl, heng the dam of Little Arthur, Nebula (the dim of the unbeaten Asteroir, sne Lewis, Lmna, and Aneroin by Lexington, and Asterısk by Ringgolel, son of Boston), Alice Jones (the clam of Jonesboro, Mary Martin, Anmette and others by Lexungton), all by 1mp. Glencoe), and the four noted brothers Lightning, Thunder, Loadstone and Lancaster, with their sister Bomnet by Lexmgtou. Nearly all those mentoned raced sucessfully, and those tried in the stnd produced well. Mary Martun was the dim of Finta Anita (Gano's tanu), Tenezuela and Vrulpine by Vrorgil. Lightniug, Loadstone and Lancaster were all superior race-horses, and Lightning for his ehances a sucessfinl stallion. Bomnet is the dam of Steinbol, Chmmessweep, ete. Another daughter of Buzzari was the dam of Nell by Orphan, son of Ball's Florizel by imp. Diomed, that was the 


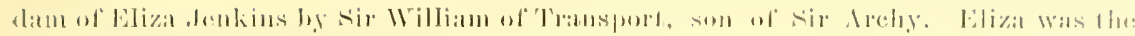

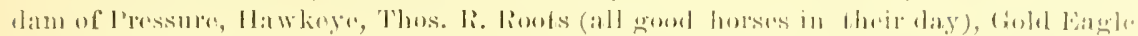

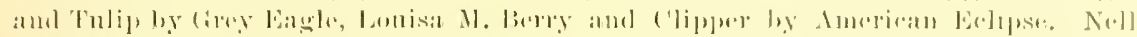

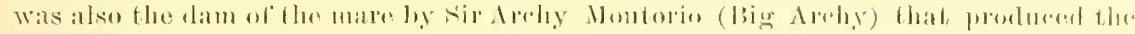

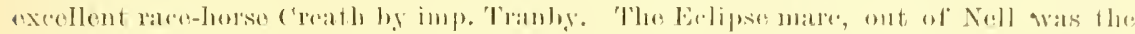

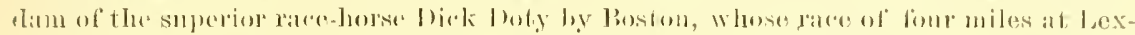

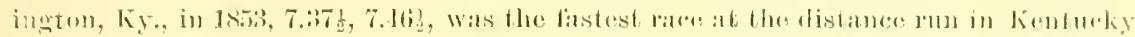

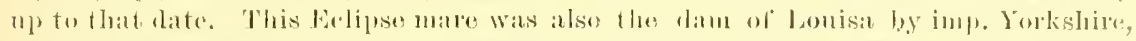

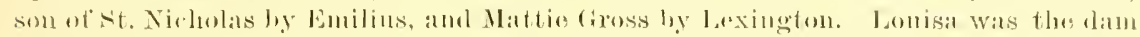

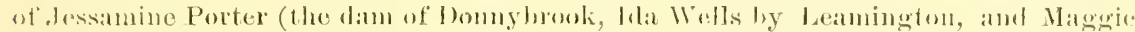

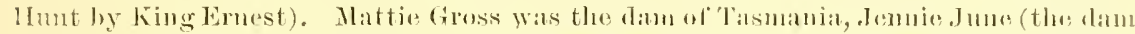
of ban K.), baromet and IIate (asupertor raco-horse), all by imp. Anstralian, Whisper,

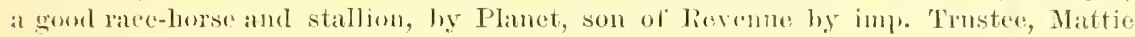
(ilenu (the dinn of Ibonamza) by imp. Glen Athol, and ot lin's.

Darley Arabian got Flying Childers and his hootloer, liartlett's Childers, ont of

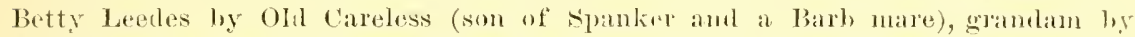
Leedes Arabian, great grandam by spanker (som of the W'Arey Yellow T'urk), ont of

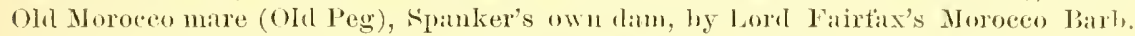

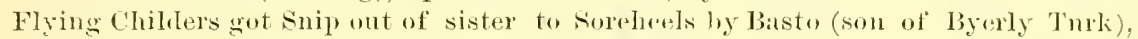
she out of Partuer's dam by the Curwen Bay barly.

The barley Arabian fommled the third arision, or Eclipse line. snip was the sire of Snap, dam sister to Slipby by Fox, wh of lipsy by bay bolton. Smap was the sire of Latham's snap, 1759, dam lormouse's dam by Cade, Cherwortlis Snap, 1760, dan Young Bowes by Dormonse, Snaphlagn, curiosity, and Angelica out of Fribble's dam by Regulns. Snaphlragon was the dam of Paymaster by Ijank, and Rarity by Matehem, she the dam of Math of the Gaks by Herod, and Ratish hy Pot-8-o's, and filly by Gimerack, she the dam of comstable's imported mare by Pot-8-o's, which was the dam of Miller's Damsel by mul. Messenger, she the danl of American Eclipse. Cnrosity was the dam of l'antaluon and Fonng Pantaloom by Matehem, Misfortme (dam or mup. Juzzari by Dux), son of Matchem, Justice aud Faith (dam of Bobtal by Eelipse) by Herod. Angelica was the dam of Flora (Spadille's dam) by squmel, and a filly (dam of sir George) hy Chysolite. Amanda, the dam of imp. Medley, was by snap. Caroline by Snap was the dam of Pomona by Herod. Litis hy Diomed, dam Grace hy Snap, was the dam of spoliator and Thaïs by Trumpator, and Pamela by Whiskey. Jy:pna hy Suap was the dam of Eagle, Ererlasting and Lavinia by Eelipse, and Evander by Hightlyer. Lisette by suap, was the dam of Maria (the dam of Waxy and Worthy by Pot-8-o'-s, Quiz and Wowski by Mentor) by Herod. Middlesex hy Snap was the dam of imp. Seagull by Woudpeckrr. Papillon by Snap, datm Miss Cleveland ly liegnIns, was the dam of the famons Hightlyer, and his sister Lady Teazle by Sir Peter, Wren and Wagtan by Woodpecker. Femultima by Snap was tho dam of imp. Baronet by Vertumuns, sou of Eelipse. Promise by suap was the dam of Peppermint and tie famons Prunella by Highther. From Prunella are descended some of the most famous hurses known to the tuxt, including Penelope (the dam of Wire, Web, Whalehone, Woful. Whislier. etc.) by Trumpator. Virago by snap was the dam of imp. Saltram aud speranza by Eclipse. A clanghter of Snap, dam sister to Regnlus by the Godolphin Araban, was the dam in Ireind of Herome by Hero, son of carle, and Heroine was the dam of Tom Turf, foaled 1781, by Lennox, son of Bustard hy Crab, and of Yomng Heroul b5 Bagot, the gramlam of Irish Birdeatehex. A danghter of Snap, dan sister to inp. Duchess, from which descenderl the Lexington fumily, and the Maid of Oaks famly, out of Lady 'Thigh by Croft's Partuer, was the dan of Conductor, sire of Trumpator, Alfred. Georgiana, ete. all by Matchem. The suap ware out of Warwickshre Wag"s dam by Marlborongh was the dam of imp. Shark by Marske. The Suap mare tam by the Gower stallion was the dam of Postmaster, inxp. Peggy and theix sister, from which have desceuded in the fenale line such good horses as linstard (by Buzzard), Hampton (by Lord Clifilen), Blair Athol and all the Queen Ilary family, Petrarch, Pretender, Nir Berys, Tristan, Beanclere, Rotherhill, ete. From Pegry in 
America, through Peggy her danghter by imp. Bedford, have come a superior lot of race-horses, and there are many now on the turf in direct female line fiom her. A danghter of snap ont of Chalkstone's dam by Shepherd's Crab was the dam of imp. Gabriel by Dorimant. The blood can only be found in the female line, as there is no stallion in the male line from Snap. To Bartlett's Childers, own brother to Flying Chillers, we look for the founder of the Darley Arabian line. He was first distinguished by the name of "Bleeding Childers," from his frequent bleeding from his nose. He was nerer trained for racing but used as stallion. He was the sire of Squirt, foaled in 1732, dam sister to Old Country Wench by Snake, son of the Lister Turk, grandam Grey Wilkes by Hautboy, out of Miss Betty D'Arey Pet mare, daughter of a Sedbury Royal mare. Squirt was a superior race-horse, and when a stallion in Sil Harry Harpur's stud was ordered to be shot, but when Miles Thistlewaite was leading him to the Dog Kennel, he was begged off by sir Harry's groom, after which he became famous as the sire of Marske, foaled in 1750, dam the Rubr mare by Hutton's Blacklegs, grandam by Bay Bolton out of a danghter of Fox Cul, etc, Syphon, dam bs Patriot, son of Bay Bolton, granclam by Crab, ont of sister to Sloven by Bay Bolton, etc, aud Mr. Pratt's famous Squirt mare, her dam Lot's dam by Mogul, ont of Camilla by Bay Bolton. This squilt mare mas the dam of Conundrum, Ranthos, Enigma, Riddle, Miss Timms, Punpkin, Maiden, Rasselas and Purity, all by Matchem, son of Cade. Marske became famous as the sire of Mr. O'Kelly's Eclipse, foaled during the Eclipse in 1764, from which he took his name. Eclipse was nerer beaten and foumded a family of his own. His dam was Spiletta by Regulus, son of the Godolphin Arabrau, grandam Mother Western by Smith's son of Snake, own brother to William's Squirrel by Lister Snake out of a daugliter of Lord D'Arcy's Old Montagil.

Eclipse was the sire of Pot-8-o'-s, foaled 1773, dam Sportsmistress by WTarren's Sportsman, son of Cade by the Godolphin Arabian, grandam Golden Locks by Oroonolio, son of Crab, great grandam by Crab, fourth dam by Croft's Partner, son of Jigg, ont of Thwaite's Dun mare by Akister Turk. Another son of Eclipse was King Fergus, foaled 1775, dam Tutung's Polly bs Black-aud-All-Black, son of Crab, out of Finns by Tartar. tracing through Old Peg by Lord Fairfax's Moroce Barb to a Barb mare. Eclipse also got Joe Andrews, dam Amaranda by Omninm, son of Snap, grandam Clondy br Blank, ete., Merenry, 1778, Volunteer, 1780, Jupiter, Venus and Queen Mab, daun by Tartar (sire of Herod), son of Partner, grandam by Mognl, brother to Babraham, greatgrandaun by Sweepstakes and tracing to the old Vintner mare, Alesander, 1782, Don Quixote, 1784, and Xantippe, dam Grecian Princess by William's Forester, son of Croft's Forester by Hartley's Blind Horse, grandam by Coalition colt, son of the Godolphin Arabian, tracing through Charming Molly bs second to a Royal mare. Eclipse sirer Dungannon, 1780, dam Aspasia by Herod, grandam Doris br Blank, Soldier, 1779, dan Miss Spindleshanks by Omar, son of the Godolphin Arabian, grandam by Old Starling, ete., and imported Saltram, 1780, dam Virago by Snap, out of diughter of Regulus. Eclupse sired three Derby winners, Young Eclipse, 1781, Saltram, 1783, Serjeant, 178t, and one winner of the Oaks, Annette, in 1787. No st. Leger winner is credited to him. Pot-8-0's was a superior race-horse and a raluable and successful stallion. He was the sire of imp. Alderman, dam Lady Bolingbrolie by Squirrel, Waxy, foaled 1790, wimner of the Derby, and Worthy, 1795, dam Maria by Herod, out of Lisette by Suap. Waxp was the sire of Whalebone, Whisker, Woful, Web. Wire and Wilfnl, dam Penelope by Trumpator, son of Conductor by Matchem, ont of Prunella by Hightyer. Whalebone won the Derby in 1810, and Whisker won it in 1815 . Thalebone was the sire of Sir Hercules, dam Peri by Wanderer, son of Gohanna by Mercury by Eclipse, grandam Thalestris bs Alexander, son of Eclipse out of Rival by sir Peter. Whalebone also got Camel, 1822, dam by Seliu, son of Buzzard, ont of Maiclen by Sir Peter, etc., Warerles, 1817, dam Margaretta by Sir Peter, out of sister to Cracker by Highflyer, and Defence, 1824, dam Defiance by Rubens, son of Buzzard out of Little Folly by Highland Fling, son of Spadille. Sir Hereules was the sire of the brothers, Irish Birdeatcher, 1833, and Fangh-a-Ballagh, 1841, dam Giniccioli br Bob Booty, son of Chanticleer by Woodpecker, grandam Flight, by Irish Escape, son 


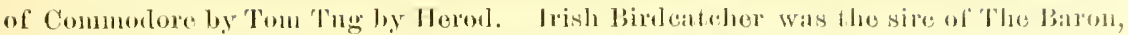

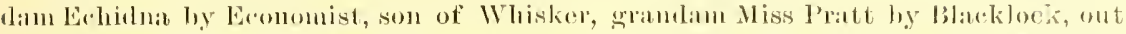

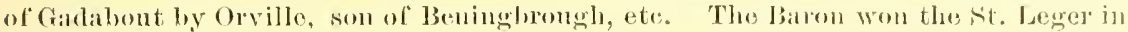

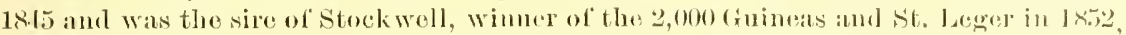
and his brother, Rataplan, dam Poealomtas by (ileneoe, ont of Marjessa by Muley, she ont of Clare hy Marnion, son of Whiskey hy Saltram. Stoekwell was a sujwiol race-horse and as a stallion was the gramdest success ever known, and richly deserver the soluriquet of "Emprerol of stallions." Stockwell was the sireof The Malluis (winner of the 2,000 Guineas and st. Leger in 1862), dam ('inizolli ly Tonchstone, Lord Lyon winner of the 2,000 Gnimens, Derby and St. Leger in 1866i), dam Paraligu Jy Parale grone, son of Tonchstone, Blair $\Lambda$ thol (winner of the Derby and St. Leger in 1861), tam Blink Bomny hy Melbonue, St. Albans (wimner of the St. Leger in 1860), daul lipibery by 'The Libel, son of Pantaloon, Bothwell (wimer of the 2,000 Guineas, 1871), dam Latharine Logie by The Flying Intchman, Achievenent (wimmer of the 1,000) Guineas and St. Leger in 1867), clan Paradign, Caller Ou (wimer of the St. Leger in 1861, the Northumberland Plate twice, Brighton ('np and 34 Queen's l'lates), tham Haricot, by Mango or Lanereost, Gang Forward (wimner of the 2,000 Gnineas in 1873), dam Lady May by Orlando, Doncaster (winner of the Derby in 1873), dam Marigold by 'Teddington. Doncaster got Beul'or (winner of the Derby in 1880), dam Rouge Rose by Thormanhy, and Bend'or got Ormonle (winner of the 2,000 Grineas, Derby and St. Leger in 1886), dam Lily Agnes by Macaroni, and Bonavista (wimner of 2,000 Guineas, 1892), tlan Vista by Maearoni.

Stockwell also sired Larly Angusta (wimuer of the 1,000 Guineas in 1863), dam Meennee by Touclistone, and Repulse (winner of the 1,000 Gnineas in 1866), dam sortie by Melbourne. Rataplan, whilst he did not win any of the great events, was a grand race-horse and a stont one. He was the sire of Kettledrmm (wimuer of the Derby in 1861), dam Hybla by The Provost, and Blinklioolie, dau Queen Mary hy Gladiator. Blinkhoolie was the sire of Wisclom, dam Aline by Stockwell, and Wisclom is the sire of Surefoot (winner of the 2,000 Guiueas in 1890), ont of daughter of Galopin, and sir Hugo (wimner of the Derby in 1892), ont of Mancenre by Lorl Clifilen. Kettledrum was the sire of Lady Langden, out of Harieot by Mango or Lanereost. Lady Laugden is the dam of Hampton by Lord Clifilen, son of Newminster. Hampton is the sire of Merry Hampton (winner of the Derby in 1887), dam Doll Tearsheet by liroomielaw, and Ayrshire (wimer of the 2,000 Guineas and Derby in 1888), dam Atalanta by Galopin. Hampton is also sire of Reve d'or (winner of the 1,000 Gnineas and the Oaks in 1887). Rataplan is the sire of Mantragora, The Miner aut Mineral, tam Manganese (winner of the 1,000 Guineas) by Irish Birdeatcher. Mineral is the dam of Wenlock (wimner of the St. Leger in 1872) by Lord Clifden, and the sister to Wenlock was dam of Geologist by Sterling. Mineral also prodnced Kisber (winner of the Derby in 1876 , and the Grand Pruze of Paris same year,) by Buceaneer. Mandragora by Rataplan is the dam of Mandrake by Weatherbit, Agility and Apology (the latter wimmer of the 1,000 Guimeas, Oaks and St. Leger in 1874), both ly Adventurer, son of Newminster. Honeymoon by Rataplan was the dam of Cradle aud Cylinder by See Saw. The Baron was also sire of Costa out of Catharine Hayes by Lanereost. Costa got some good broad mares. Birdeatcher also got Augur, dam Nickuame by Ishmael, son of snitan; Daniel O'Fonrke (wimner of the Derby in 1852), dam Forget-me-not by Hetman Platoff, son of Brutandorf; Gamekeeper, clam Swallow by Lanereost; Warlock (winner of the St. Leger in 1856), dam Elpline by Emilius. Warlock was the sire of Tynedale. Saunterer by Irish Birleateher, dam Ennni by Bay Middleton, was sire of Gamos (Oalis wimner in 1870), Gertrude, she the dam of Charibert (wimner of the 2,000 Guineas in 1879) by Thormanby, aurl Chileleric by Scottrsh Chief. Kuight of St. George by Irish Burdeatcher, dam Maltese by Hetman Platoff, won the St. Leger in 1854, and was sire of the linight of St. Patrick ont of Poeahontas by Glencoe, Ada B., ete., in England. Kinght of St. George had little or no chance in the stud in America, owing to the Civil War, but he was sire of Bremna (grandam of The Bard, Tibbie Dunbar, etc), Edina (dam of Munnie Me, Elemi, ete.), Eliza Daris (dam of War Song, she the dam of Eole, St. Savionr, Eon, ete.), Fairy (dam of Grey Nun, Artist, ete.), Georgia Wool 
(clam of Ginger. La Gitana, Lna, etc.), Heliotrope (dam of Marchioness, Mariposa. etc.), Jenny H. (dam of .Jentling, Arla S.. Toledo, ete.), Lass of Sidnes (dam of Tulıman, Mary Constant, Phyllis, Mary P., Queechy, ete.), Nishap (dam of Crockfori. Perhaps (the dam of Chinee, Reckon, Doubt, etc.), and Misfortune (dam of Ablotsford. Syntax, ete). Knight of St. George's name appears in many of our best pedigrees. Wormersley by Irish Birdcateher, dam Cinizelli by Tonchstone, was the sire of Collington, Gen. Williams, and Wanona, the grandam of Robert the Devil, out of a daughter of Hampton by sultan. Oxford by Irish Birdcateher, dam Honey Dear lyy Plenipotentiary, is the sire of Sterling, he the sire of Isonomy, the sire of Seabreeze (winner of the Oaks and St. Leger in 1888), and the great Common (winner of the 2,000 Guineas, Derby and st. Leger in 1891). Sterling is the sire also of Paradox, Enterprise and Enthusiast, winners of the 2,000 Guineas, and Harvester, who ran a deal heat in the Derlyy in 1881, and diricled the stakes with St. Gatien. Sterling is also sire of Geologist. Fernandez, Poste Restante, the imp. horses Loyalist, Top Gallant and Stalwart. Birdeateher was sire also of imp. Mickey Free. Faugh-a-Ballagh (winner of the St. Leger in 184t) was the sire of Ethelbert, tam Espoir by Liverpool. [Ethelhert was the sire of Isolina, grantam of Isonomy.] Constance, dam Millmaid by Glanens, and she, Constance, was the dam of Bertram, sire of Robert the Deril. It is to Faugh-a-Ballagh's son Leamington that America is indebted for this blood. Leamington's dam was by Pantaloon, son of Castrel by Buzzard, ont of Daphne by Laurel, son of Blackloek. Leamington made his first season in America in 1866, at the Bosque Bonita stud, and from that season came Enquirer, dam Lida by Lexington, a first. class lace-horse and a successful stallion, Longfellow, the grand race-horse and popular sire. Ilam Nantura by Brawner's Eclipse, son of American Eclipse, Lyttleton, a good race-horse, dam Fanny Holton bx Lexington, and Lynehburg, dam Neutrality by Perenne. These were followed by Eolus, dam Fanny Washington by Revenue, a capital race-horse and one of the most successful stallions in America, and subsequently came Reform, Hyder Ali, James A., Rharlamanthus, the umbeaten Sensation and his brothers Stratford and Onondaga. Parole, Boh Woolley, Aristides, Harold, Ferneliffe, Blazes. the great Iroquois, and a number of most excellent mares, including Susquehanna (dam of Potomae), Franeesea, Katie Pearce (dam of Lizzie S., Ballard, Katrina, etc.), Spinaway, Spark, Jaconet (dam of Sir Dixon, Belvidere, ete.), Mary Buckler, dam of Stonebuck, Perfection (dam of Salucla), Preeiosa, Syria, dam of Dalsyrian, ete., Theodocia, The Sqnaw, Wissahickon, Wrandotte, ete. It will be observed that the best sires of all these both on the turf and in the stud are from those in both male and female line. to the Eclipse and Herod lines of blood. Sir Hereules was also the sire of Coronation (winner of the Derbs in 1841), dam Ruby by Rubens, Gemma di Vergs, sire of Roc. eoco, dam snowdrop hy Heron, son of Bustard by Castrel, Gunboat and Lifeboat, out of Yard Arm by Sheet Anchor, son of Lottery by Tramp, and Robert de Gorham, dam Duveruay by Emilius. Whalebone was the sire of Camel, dam by Selim, son of Buzzard, ont of Maiden by Sir Peter. Camel was the sire of Touchstone, dam Banter by Master Heury, son of Orville by Beningbrough. Camel was one of the most noted of Thalebone's sons, as from his sons Tonchstone, Lanncelot and Simoon, a host of distinguished race-horses and brood mares have deseended. Touchstone won the St. Leger in 1834. He got Blne Bonnet (winner of the St. Leger in 18t5), Orlandlo (winner of the Derhy in 1814.) In this Derby Rumning Reiu, who came in first, was subsequently proven to be a four year old Maccabeus, and he was discualified.

Orlando's dam was Vulture by Langar, son of Selim be Buzzard. Orlando was the sire of Tedlington (wimner of the Derby, 1851), Imperieuse (winner of 1,000 Guineas and the St. Leger, 1557), Fazzoletto, Fitz Rolaud and Diophantus, winners of the 2,000 Guineas, also of Trumpeter, sire of Distin. Sire also of Plutus, the sire of Flayeolet, that got Rayon d'Or, Zut and Beamminet; Marsyas, sire of George Frederick (Derby winner, 1874), dam Lalibran by Whisker. Orlando was also the sire of Little Lady, dam of Camballo, wimuer of the 2,000 Guineas, 1875, Bay Celia, tam of The Dule, Lanra, dam of Petrareh (winner of 2,000 Guineas and St. Leger, 1876), and Doralice the dam of Speculum (winuer of the City and Sulurban, and sire of Sefton. winmer of the Derby, 1878). Terldington was the sire of Marigold, dam of Doncaster, wnner of 


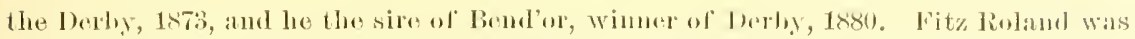

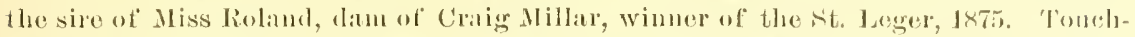
stome was tho most fimoms and valuable of all Camel's soms. Jla was the sine of Cotherstoue, winnex of tho 2,000 Gnineas and Derloy, 18.13, Flateateher and Numykirk, winners of tho 20,000 Guineas in 18.18 and 18.19, Jord of the lskes, winner of the

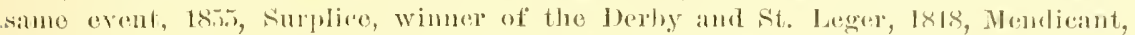

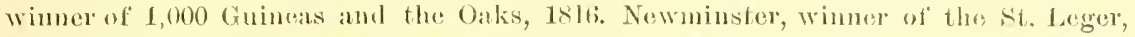
18.1, who was ont of the famous bes's-wing by Dr. Syutax, son of Paynator by 'Trmupator by Conductor by Matrhem, grandam by Ardrossan, som of' Jolum Jiull by Fortitude ly Herod, great-grandam Lady Eliza, by Whitworth, som of Agonistes by Sir Poter, thus tracing to the Matehem and Herod homl. Nowninster got Ailventurer, dam Palma by Emilius. Arventurer won the City and snburban and was tho silo of Pretender, winuer of the 2,000 Guineas and Derby, 1869, Apology, winner of tho 1,000 Guineas, Oalis and St. Leger, 1874, Wheel of Fortune, winner of the 1,000 Guineas and Oaks, 1879, imp. Blythewood, a sire of winners in this country, and Pizzaro, now dead, a horse that promised suceess. Newminster is immortalized as the sile of Hermit, dam Sechsion by Takmor, son of Ion by Cain liy Paulowitz by Sir Panl by Sir Peter, grandam Miss Sellon hy Cowl, sou of Bay Middleton by Sultan by Selim by Buzzard, largely inbrerl to the Herod blood. Hermit won the Derby in 1867 and was one of tho nust snccessful and popular stallions ever in England. Hermit was sire of Trappist, shotover (winner of the Derlyy and 2,000 Guineas, 1882), Trapeze and Tristan, ont of Thrift by Stockwell. Tristan was beaten in the Derby and St. Leger by Iroquois, and in the Grand Prize of Paris by Foxhall, bnt he was a superior race-horse. Hermit also got Torpedo, brother to Shotover, Peter, the grand race-horse, and his brother Timothy, out of Lady Masham, Clairviux, Thebais, and St. Marguerite, ont of Devotion by Stockwell. Thebais won the 1,000 Guineas and Oaks, 1881, and St. Margnerite the 1,000 Guineas in 1832. He was also sire of The Abbot, Charon, Marden and Nantilus out of Barehettina by P'elion, son of Ion. Hermit's son, St. Blaise, winner of the Derby, 1883, dam Fusee by Marsyas, son of Orlando, grandam Vesuvienne by Gladiator, son of Partisan, ont of Tenus by Sir Hereules, has created a sensation. He has been one of the most phenomenal successes in the stud which ever came to this conntry. He is inbred to Tonchstone. Hermit was grandson of Tonchstone and Marsyas, the sire of St. Blaise's dam was also grandson of Tonchstone, and he has a large intusion of Eclipse blood in both sire and dam's side throngh Whalebone and Whiskex. St. Blaise is the sire of La Tosea, St. Florian, Clarendon and many others. Any and all strains of blood suited him. Newminster was sire of Lord Clifien out of The Slave by Melbourne. Lord Clifien won the St. Leger in 1863, and was the sire of Petrarch, winner of the 2,000 Grineas and St. Leger in 1876 (and he the sire of of Busybody and Miss Jummy (winners of 1,000 Gnineas and Oaks in 1884 and 1886), Hawthornden and TVenlock, winners of the St. Leger, 1870 and 1872, Janette, wiuner of the Oaks and St. Leger in 1878. Newminster is also sire of Cambuscan, out of The Alrow by Slane, son of lioyal Oak by Catton. Cambuscan is sire of Camballo, winner of the 2,000 Guineas, 1875. Tonchstone was sire of Lord of the Isles (dam Fair Helen by Pantaloon), he the sire of Scottish Chief, he the sire of Childerie, Violet Melrose (the dam of Melton), Marie Stnart, winner of the Oaks and St. Leger, 1873, King of the Forest, imp. Kantaka (ont of Seclusion, Hermit's dam), and Dundee, ont of Marmalade by Sweetmeat, winner of six ont of seven races at two years old. Touchstone also got Ithuriel, sire of Longhow, he the sire of Toxopholite, the sire of Musket, Maxim's sire, and Bay Areher. Whalebone was also sire of Waverley, out of Margaretta by Sir Peter. Warerley was the sire of Don John (winner of St. Leger, 1838), he the sire of Maid of Masham, the grandam of Peter and Timothy, also of Iago, sire of Bonnie Scotland. The Saddler, by Waverley, out of Castrellina by Castrel, was the sire of Inheritress (dam of the Heiress), and Hybla (the dam of Kettledrum), by The Saddler's son, The Provost, prodnced also Maid of Hart, dam of Compiegne, sire of Mortemer.

Whalebone was the sire of Defence, dam Defiance by Rubens, son of Buzzard. Defence was the sire of Diversion, the grandam of Rosicrucian aud The Palmer, and of 
Protection, the grandam of See Saw. His best son was the Emperor, dam daugluter of Reveller by Comus. He was the sire of Monarque, dam Poetess by Royal Oak, son of Catton. Monarque was the sire of Gladiatenr, dam Miss Gladiator. Gladiatenr was the winner of the 2,000 Guineas, Derby, St. Leger and Grand Prize of Paris in 1865. Giladiateur was the sire of Grand Conp, Highborn, Lord Gongh and Laty Gialys. M[onarque was the sire of La Favorita, the dam of Flageolet, sire of imp. Raron dor. Monarque was sire also of Trocadero, sire of Fra Diavolo, Hospodar and Consul, sire of Archiduc, Farfadet and Nougat in France, and of Reine, winner of the 1,000 Guineas and the Oaks in 1872. Whisker, the brother to Whalebone, was the sire of Economist, dam Floranthe by Octarian, son of Phenomenon by Herod, grandam Caprice by Anril, son of Herod, out of Marleap by Eelipse. He was sire of Harkaway, a grand race-horse up to any weight. Harkaway was the sire of Idle Boy, dam Iole by Sir Hereules; he the sire of Tomboy. Harkaway's great reputation comes through his son King Tom, whose dam was old Pocahontas, dam of Stockwell, Rataplan, ete. Upon him depends almost entirely the transmission of the blood of this wonderfuI horse in the male line. King Tom was the sire of Kingeraft, winner of the Derby in 1870, and his brother, imp. Great Tom, ont of Wooderaft by Voltigeur, King Lud, winner of the Cesarewiteh stakes, out of Qui Vive, sister to Vedette; Skrlark, winner of the Queen's Vase at Ascot; imp. King Ernest, ont of Ernestine by 'Touchstone; imp. King Ban, dam Atlantis by Thormanlos; inp. Phaeton, dam Merre Sunshine by Storm, son of Touchstone. King Tom got a number of choice brood mares. Of these St. Angela, dam Adeline by Ion, was the dam of St. Simon. Enıpress was the dam of Chislehnrst. Premature was dam of Poste Restante. Princess was dam of Royal Hampton, Prince Royal and His Highness. A sister to King Alfred by King Tom was the dam of Euterprise (winner of the 2,000 Guineas in 1887). Zephẹr by King Tom was the dam of Faronins (wimner of the Derby in 1×71). A danghter of King Ton is the dam of the promising young stallion and sire imp. King Galop. Euxine was dam of Town Moor. Whisker was also the sire of Perion, dam Darioletta by Amadis, ont of Selima by Selim. Whisker was also the sire of The Colonel (wimner of the St. Leger in 1828), out of $M_{y}$ Ladry's dam by Delpini, and of Memnon ( $\pi i m n e r$ of the St. Leger in 1825), dam Manuella by Dick Andrews. Whisker's best daughter was Emma, dam of imp. Trustee and of Cotherstone (winner of the 2,000 Guineas aud Derby in 1843), of Mnndig (winner of the Derby in 1835), and of Mowerina, the dam of West Australian. The Colonel was the sire of Chatham, who sired The Gorerness, winner of the 1,000 Gnimeas and Oaks in 1858. Economist was also the sire of Echidna, ont of Miss Pratt by Blacklock, she the dam of The Baron. ete. Kring Fergus was the sire of Young Traveller, wimner of the St. Leger in 1791, Beningbrongh, winner of the St. Leger in 1794, and Hambletonian, winner of the st. Leger in 1795, dam by Highflyer, son of Herod, out of Monimia by Matchem. Hambletonian was the sire of Whitelock, dam Rosalind by Phœnomenon, son of Herod, grandam Atalanta by Matchem, ont of Lass of the Mill by Oroonoko, son of Crab.

Whitelock, 1803, was the sire of Blacklock, 1814, dam by Coriander, sou of Pot8-o'-s, grandam W'ildgoose by Highflyer, out of Coheiress by Pot-8-o-'s. Blacklock was the sire of Brutandorf, 1821, dam Mandine by Pot-8-o-'s, ont of Young Camilla by Toodpecker. Brutandorf was the sire of Physician, dam Primette by Prime Minister, son of Sancho, ont of Miss Paul by Sir Panl. Physieian was the sire of The Cure, dam Morsel by Mnlatto, son of Catton. The Cure was the sire of Polly Agnes and Little Agnes, ont of Hiss Agnes by Birdeatcher. Polly Agnes is the dam of Lily Agnes (the dam of Ormonde and imp. Rossington) by Macaroni. Little Agnes is the dam of Tibthorpe, wimuer of the Steward's Cup, by Voltigenr. Brutandorf was also sire of Hetmau Platoff, who got The Cossack and Neasham. Hetmau Platoff is the sire ef MaItese (dam of imp. Kinight of St. George), Cossack Maid (grandam of Balfe), the grandam of Solon, which mare is great grandam of Barcaldine. Alexina, the dam of Tombos, Muscovite, sire of Vauban (winner of the 2,000 Guineas in 1867), and of Siberia, (1,000 Guineas in 1865), Bunch, Trappist's dam, ete. Blacklock was the sire of imp. Belshazzar, dam Manuella by Dick Andrews (and he, Belshazzar, was the sire of some good ones in America), of imp. Tranby, the sire of Vandal's dam, Young Blackioek 
(Watl's), sire of Maple, out of kithen by sligo, Waxy, and folocipede, dam by Juniper, som of Whiskry, ont of a daughter of sorecere. Velociperle was the side of

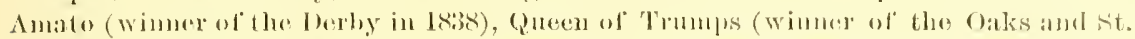

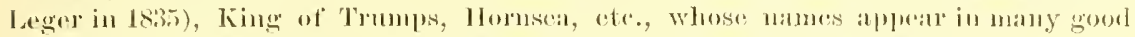

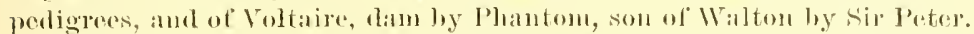

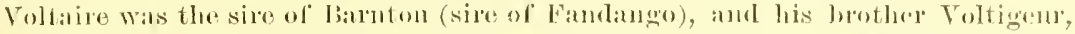

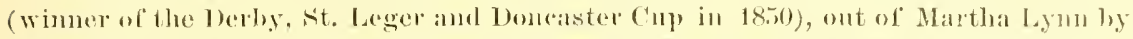

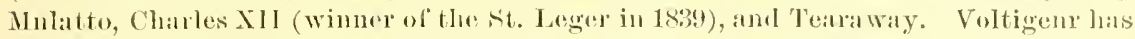

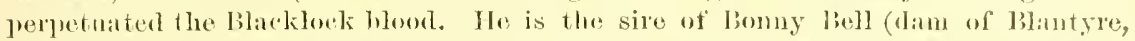
Beamelere, etc.), ont of (qucen Mary, Inleibulla (Iam of Onslow, Ma linlle, rte.), Beatrice, daun of Prestompans, Makeshift (dam of' Poll Mell and Helter skellor lyy Joung Mebonme), Onx Mary Aun (dam of inlp. Doncaster Lass by loncaster), (gui Vive (dam of imp. Felucal), and Vedette, ont of Mrs. Ridgwa ly Birdeatrher. Voltigenr wis also the sire of Skirmisher, The Ranger, inp. Hattington, Tibthorpe, Buckstonc, Cavendish and John Davis. Velette was the hest one of all his get. IIe won the 2,000 Guineas, was not in the Derby or St. Leger, won the Doneaster Cup two consecutive yoars, and many other races. Verlette was the sire of Garlevisure (wimmer of the Cambritgeshire), out of Paradigm hy Paragone, Fpeculum (wimner of the City and Suburban Hamlicap), ont of Doralice by Orlanło, son of Tonehstone, and Galopin (wimner of the Derby in 1875), ont of Flying Duchess bs The Flying lintehman, and it is through these two horses that the Blacklock hlood has become so famous in this day. Spernlum was the sire of Rosebery (wimner of the Cesarewitch and Cambritgeshire Haulicaps), ont of Ladylike by Newminster, Selton (wimner of the Derby in 1878), ont of Lady Sefton Jy WTest Anstralian, son of Melbourue, Flotsan and Jetsan, ont of Flotilla by Kingston, Hagioscope, dam sophia by Macaroni, he the sire of Queen's Buthday, Amphion by Specrlum or Rosebery, ont of Suicide by Hermit, a superior race-horse and a popular stallion, Penton, dam Progress by Thormanb5, he the sire of Penelope, a good mare. Galopin is the sire of Donovan (wimner of the Derlyy and st. Leger in 1889), and Molwena, ont of Mowerina by Scottish Chief, grandam Stockings by Stockwell, Galliard, dam Mavis by Macaroni, ont of Merlette by The Baron, ete. Galliard won the 2,000 Gumeas, Prince of Wales, Ascot, Chesterfield and other stakes. St. Simon is by Galopin, dam St. Angela by King Tom, ont of Arleline by Ion, ete. Donovan and Galliarl are young in the stud bnt must prove suecessful. It is wortly of note that Galopin is moch inbred, being by Vedette, son of Voltigen by Voltaire, his dam Flying Duchess by The Flying Dntchman, whilst his grandam Merope is by Toltaire, son of Blacklock, and his great grandam is Telocipede's dam by Juniper. Galopin's son Donovan won the Derly and St. Leger in 18s9, and scmolina, Innovan's half sister, won the 1,000 Guineas in 1890 , she being by St. Simon, som of Galopin. The Blacklock blood is represented in this conntry throngh descendants of Belshazzar, Tranbr, the sire of Tranbyana, the tam of $13 \mathrm{ig}$ Boston, Belle Lew is by Glencoe, and the Tranby mare, dam of Vandal, Volga and Levity, and their descendants, King Galop by Galopin, dam by King Tom, ont of Sunshine by Thormanby, a verg fine horse and superior breeder. Beningbrough by fing Fergns, tam by Herod, grandam Pyrha by Matchem, ont of Duchess by WThitenose, son of the Godolphin Arabian, is another strong link in the Darley Arabian line. Beninglsrongh got Orville, 1799, dam Evelina by Highflyer, out of Termagant bs Tanirum, son of Cripple by the Godolphin Arabian. Orville won the St. Leger in 1802 and was the sire of Emilins, dam Emily by Stamford, son of Sir Peter, ont of danghter of Whiskey, son of Saltram by Eolipse. Emulius was the sire of Euclid, dam Maria, sister to Emma be Whiskex, he the sire of Bantam, ont of Lady Fanny by Dr. Syntax. Emilins was the sire of Plenipotentiary, winner of the Derby in 1834, ont of Harriet by Pericles, son of Erander by Delpini. Plenipotentiary was the sire of Herald, dam imp. Delphine by Whisker, that won the secoud heat in the great Peyton stake won by Peytona at Nashville, Tenn, October 10, 1843. Herald was the sire of Heraldry, dam of Balloon, Ascension, Parachute, etc. From Balloon a large number of good race-horses have descended. Plenipotentiary was sire of Potentia (winner of the 1,000 Guineas in 1-11) and of Foison (wimner of the Oaks in 1813). Plenipotentiary was a valuable sire in 
the female line in England. He is the sire of the dam of Queen Mary, of Delhi, the great grandam of Bend'or, of Honey Dear, the dam of Oxford, sire of Sterling, ete., of Monstrosity, the dam of The Ugly Buck (wimer of the 2,000 Gnineas in 1814). Priam by Emilius, ham Cressida, sister to Eleanor by Whiskey, son of Saltram by Eelipse, grandam Youm Giantess by Dioned, ont of Giantess by Matchem, won the Derby in 1830 and was imported to America in 1837. Priam was the sire of Crucifix (wimner of the 2,000 Guineas, 1,000 Guineas and Oakis in 1840), ont of Octariana by Getavian, son of Stripling by Phonomenon, Miss Letty (wimner of the Oaks in 1837), out of a daughter of Orville, Industry (winner of the Oaks in 1838) and scamander, her brother, ont of Arachne by Filho-da-Puta. Crueifix's great reputation rests upon being the dam of Cowl by Bay Middleton. Cowl was the sire of Miss Sellon, out of Belle Dame by Belshazzar, and Miss Sellon is the grandam of the great and popular sire Hernit by Newminster. Cowl was also sire of Madane Eglantine, the dam of Rosicucian and The Palmer, out of Dirersion by Defence. Crucifix was also the dam of surplice (winner of the Derby in 1848) by Tonchstone. Surplice was sire of Eastern Princess, the dam of imp. Prince Charlie (wimner of the 2,000 Guineas in 1072), and of Flax, the dam of Queen Bertha (winner of the Oaks in 1863). Miss Letty was the dam of Weatherbit by Sheet Anchor, son of Lottery by Tramp, and Mr Dear by Bay Middleton. Weatherbit was the sire of Beatsman (winner of the Derby in 1853), out of Mendieant by Touchstone. Beadsman was sire of Blue Gown (winner of the Derby in 1>68), and Pero Gomez (wimner of the St. Leger in 1869). Beadsman was also sire of Rosicrucian and The Palmer, the latter sire of Jemny Howlet (winner of the Oaks in 1880), dam of Chitabob, both valuable and successful stallions. Weatherbit is also sire of Brom Bread, out of Brown Agnes by West Australian, he the sire of Toastmaster, a very fine race-horse. Priam got in this coutry Cassandra, out of Flirtilla jr. by Sir Arehy. Cassandra was the dam of Trojan, Basil and Philo by Mariner, son of Shark by American Eclipse. Philo was the dam of Lady Blessington by imp. Eclipse, son of Orlando, she the dam of The Baroness (Badge's dam) by Kentueky, Lals Rosebery and Duchess by Kingfisher, and Fairwater by 111 Used in the Nursery Stud. Priam got a number of other good brood mares in America, such as Cornelia, dam Bay Maria by Eclipse, Creusa, dam of the good race-mare Bostona, dam Miss Valentine by imp. Valentine; Delta, dam of Gazelle by Allion, Talma by Glencoe, Duette by Highlander, son of Gleneoe, out of Gamma by Paeifie; Emily Thomas, dam of Pasta out of Nancy Norman by Tom Tough; Margaret Wood, dam of Star Davis, Capt. Travis, Georgia Wood, etc., out of Maria West by Marion; Eudora, dam of Kate Hays, Martha Worsham, Sally Woodward, ete , ont of Bet Bosley, jr., by imp. Bluster ; Fidelity, dam of Faith, Felieity, etc., out of Maria Lonisa by Monsieur Tonson; Little Rose, tam of Red Rose by Glencoe, ont of Tuberose by Aral, ; Little Trick, dam of Odd Trick by Lexington, ete., out of Bet Bosley, Jr.; Lucy Long, dam of the great racehorse Red Eye by Boston, out of Polly Franklin by Shakespeare, and The Queen, dam of Dencalion, out of imp. Delphine by Whisker. Monareh, own brother to The Queen, was an excellent race horse and left some good brood mares, including Bellamira (dam of Die Clapperton, Embry's Lexington, Concord, etc.), Breeze, dam of the good racemare Albine, Castinet, dam of Highlander by Gleneoe, Young Fashion (dam of surprise, Scotland, Lady Fashion, Columbia, Wananita, Bonnie Kate, etc.), out of the great race-mare Fashion by imp. Trustee, Lady Lancaster (dam of MaIcolm, Ontario, Larly Amanda, etc.), out of Lady Cauton by imp. Trauby, Millwood (dam of Charleston, Rosa Bonheur, Mill Creek, ete.), out of Fanny by American Eclipse. Emilins was also the sire of imp. Sarpedon, dam Learia by The Flyer, son of Vandreke, Jr. by Walton. Sarpedon was the sire of Alice Carneal (Lexington's dam), ont of Rowena hy Sumpter, and Ariel, dam Lancess by Lance. Sarpedon got some good race-horses but left no descendant in the male line. Sorereign br Emilius, dam Flenr-tle-Lis by Bourton, son of Sorcerer by Trumpator, was imported when a yearling and never raced. He was the sire of a large number of good racers, such as Rurie, Charleston (sent to England), Berry, Mogul and Invineible. He got a large number of good brood mares, and his blood is transmitted in the female line to very many of our best horses. Daughters of Sovereign are sister to Ruric (dam of Grimstead), Ann Dumn and Prioress 


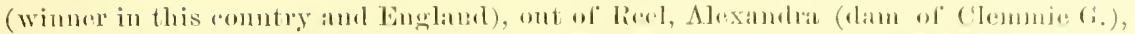

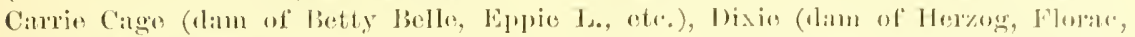

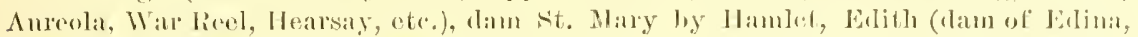

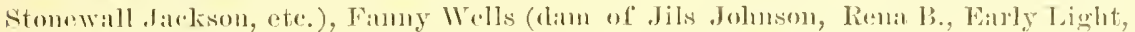

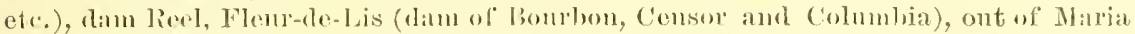
West Jy Marion, Glycera (dam of' Knighthool, Carrie Atherten, Sue Rycher, 'The Glounce, etce), out of sistere to Prior by Glencose, Iorline (ran of Iorline and Iona by lexington, Arniea, Colloulion, ofe.), ont of danghter of Storkholeler, Kate Anderson, out of Chloe Auderson by Rodolph, Lady Barry, Lady sherod, Lorethe (dim of Mishap), Regan, Sophy Barklerly, Lorena, ete.), ont of Mary Ogalen by Thom nhill, som of Glencor, Mamona, dim of good ones, Martha Dunn, dam of Lulu Horton, Miss Carter (dam of Hildegarde, Evelyn Carter, ete.), Miss Odom (dam of Lney Rrooks, Mary Wylie, ete.), Monica, dam of Juanita, Nebraska (dam of Jack the Barber, Syren, ote.), Nora (dam of Bombay, Persia, etc.), Polly (dam of Ooltowah, Mary Wylie, etc.), Princess Royal, Sallie, Rosenary and many others. Dmilins was the sire of St. Nicholas, he the sire of imp. Yorkshire, that marle his impression on the stock of America throngly his sons and daughters, many of the latter being great sncresses in the stud. Orvillo was also sire of Muley, 1810 , dam Eleanor, the first mare that ever won the Derloy and the Oaks, by Whiskey, ont of Young Giantess hy Diomed. Muley was the sire of Muley Moloch, and his sister imp. Britannia, ont of Nancy by Diek Andrews. Muley Moloch was the sire of Alice Hawthom, the famous racer and dam of Onlston, Lady Hawthorn, Sweet Hawthorn, Thormanly, winner of the Derby in 1860, ete., out of Rebecea by Lottery. Britannia left a distinguished progeny throngh her danghters La Victime, Variation and Verona.

Mnley got Morisco, ont of Aquilina by Eagle. Morisco is eredited witl Taurus, ont of Catharine by Soothsayer. Taurus got Turmus, ont of Clarissa by Defence, and Turmus was the sire of Whiteface (the dam of imp. Woodlands, quite snccessful in the stmu); also of Butterfy, wimer of the Oaks, 1860. Muley was also sire of imp. Leviathan, dam by Windle, son of Beninglorongh, grandam by Auvil, son of Herod, and imp. Margrave, dam by Election, son of Golanua by Merenry, ont of Fair Helen by Hambletonian, son of King Fergus. Leviathan was a good race-horse and a valuable stallion, sire of The Poney, Othello, Capt. McHeath, John R. Grymes, etc. His blood is preserved throngh his daughters, of whom Cotillion was the dan of Dance, Schottische, Gallopade, Jr., and O'Meara, all by Glencoe. Dance was the dam of Schottisehe (she the dam of Waltz, Tarantella, Gorlitza, ete.), by imp. Albion, La Polka by Lexington, ete. Crncifix (dam of Gor. Poindexter and Giantess) was by Leviathan, ont of Virginia by Sir Archy. Giantess was the dam of Adnella, the famons Peytona and Union, by imp. Glencoe. Leviathan also got Dolphin, dam by Sir Archy, and Emerald (the clam of Topaz), ont of imp. Eliza by Rubens, son of Buzzard. Topaz was the dam of Lodi, Waterloo, Austerlitz and Wagram by imp. Jorkshire, Colton and Areola by Lexington, and Rivoli by Revenue. Fandango by Leviathan was the dam of Judith (Edith's lam), Rigadoon, Jeanette, Grisette and Hornpipe by imp. Glencoe." Grisette is ram of Geneva, Greyling [Gen. Ewell] by Lexington, aud Quickstep by imp. Anstralian. Flight by Leviathan, ont of Charlotte Hamilton by Sir Charles, was the dam of Oliver by Wagner, Hegira and Mecea by imp. Ambassador, Mahomet and Medina by imp. Sovereign. Betsey Coorly and Sally Jones were sister's to Flight, the latter being the dam of Noty Price by Cust Johnson, Tanered, etc. Gaslight by Leviathan was the dam of Budelight, Beaconlight, etc., out of Pigeon by Pacolet. Jane Mitchell by Leviathan, dam by Stockholder, was the dam of Terrifier and Ella Temple. Other mares by Leviathan were Jeannettean, the dam of Arrow by Boston and grandam of Optimist, who raced suecessfully in England and was valuable as a stallion in France, Laura (dam of Kansas by Sovereigu, Lilly Ward, Harry of the West, Fanny Cheatham and Judge Durrell by Lexington, and Lerna by Asteroid), Martha Malowe (dam of La Bacchante and Julia H. by Glencoe), out of Tachecana by Bertrand, Leviathan mare (dam of satellite by imp. Albion, that was sent to England, and Fanny MeAlister by O'Meara), out of imp. Anna Maria by Truffle, Polly Elliott (dam of Ada Tevis, Pejtona Barry, ete.), nut of 
Caledonia by Jerry, son of Pacolet, Parasina (dam of Mary Hadley, Florence Nightingale and Blazella by O'Meara, Mary Wynne by Jack Malone, and Mattie Seriere by Blacklock), Princess Ann (dam of Elizabeth MeNairy by Ambassador, Cottage Girl and Augusta by imp. Ainderby, son of Velocipede), Waxlight (dam of Torchlight and Scintilla by imp. Gleneoe), out of Pigeon by Pacolet, Beeswing, Sarah Bladen, and many others. Margrave won the St. Leger and was a very snccessful stallion. Nearly all his get were males. He was the sire of Blue Dick, Brown Dick, that ran three miles at New Orleans in 5.30: 5.23, Tom Payne, Alamode, Doubloon, Florin, etc. The few mares that he left have proved the value of the blood in the sturl.

Countess (the dam of Katona by Voucher), was by Margrave, out of a danghter of American Eclipse. Katona was the dam of Bettie West by Colton, Metarie and Joke by Star Davis, Item (Dan Sparling's dam), Kadi, the superior race-horse Tom Ochiltree by Lexington, Goremess by Planet, etc. Crisis, dam of Donerail, was by Margrave, out of Susette by Aratus, Eleanor Margrave and Emma Wright were by Margrare, out of Fanny Wright by Silverheels, son of Oscar by imp. Gabriel. Eleanor Margrave was the dam of Rurica (dam of Harkaway) by Ruric, and Margretta by Lexington. Emma Wright was the dam of Lanra Farris and Miss Doyle by Lexington, Mollie Jackson 1.5 Vandal, the winner of the great three-mile race at Louisville, Ky., in $535 \frac{1}{2}, 5.3+\frac{1}{4}$, $5.28 \frac{3}{2}$, Sherrod wimning the second heat. Mollie Jackson was the clam of Monday by Colton, Long Branch and Famny Ludlow by imp. Eclipse, and Doubt by imp. Eclipse or Cavalier, son of imp. Eclipse. Fanny Ludlow was the dam of Jamaica by Lexington, and she the dam of Foxhall, that won the Grand Prize of Paris, the Cesarewitch and Cambridgeshire Handicaps, ete. Fanny G. by Margrare, ont of Lancess by Lance, was the dam of Endorser by Wagner, Flora G. and Lady Dan Bryant by Lexington, Emma Maratta by Vandal, Estella by imp. Australian, and Fanny B. by Asteroid. Estella is the dam of Alma Mater, that produced the two great trotting stallions Alcantara and Aleyone. Lady Margrave (the dam of Undine by imp. Yorkshire) was by Margrave, ont of Lady Adlams by Whipster. Undine was the dam of Uncle Tie by Lexington, Australia by imp. Australian, Margaret Hunter by Margrave was the lam of Kate Bateman by imp. Yorkshire, Sallie by imp. Sorereign, Greek slave by Glencoe, Stmmps by Lexington, etc. Sallie was the dam of Eagle by Tandal, Long Nine by Lightning, O'Malley by imp. Mickey Free, La Reve (dam of Strychnine), and Lampi by Lightning. Greek Slave was the dam of Black Slave (the dam of Iaratana and Anne Augusta by Leamington, Topsy by Ill Used, Black Gal and Bessie B. by Tom Ochiltree) by imp. Eclipse, son of Orlando, Sarong (the dam of Aristides, Wissahickon, Daisy Hoey, etc.) by Lexington, Petty and Tibitha by Tipperary, son of Ringgold by Boston. Biargrave mare, dam Mistletoe by Cherokee, son of Sir Arehy, was the dam of Mary Chnrehill by Alexander Churehill, son of imp. Zinganee. Capitola (dam of King Alfonso and Belle Barclay by imp. Phaton, Letola by Lexington, Hospodar by Longfellow) by Vandal, La Grande Duchess (dam of Aniella, Talisman, ete.) and Versailles by Vandal. Mary Churchill was the dam of Eva Douglass and Florence Wallace by Vandal, Hamburg by Lexington, Astell (Miss Nailer's dam) by Lexington or Asteroid. A large number of good race-horses trace to this family. Ilargravine, the dam of the superior race-horse Jas. A. Connolls, was br Hargrave, ont of Gabriella by Sir Archy. The Margrave mare, ont of Rosalie Somers by Sir Charles, was the dam of Josephine R. Rowan, and Rebecea T. Price by The Colonel. Rebecea T. Price is the dam of China by Lexington, the superior race-horse Mallstick and Sweetheart by Lever, and Netty Brady by Jack Malone. Utilla by Margrave, dam Too Soon by Sir Leslie, was the dam of Yonng Utilla by Hurricane (Warfield's Florizcl), (she the dam of Tasmania and Teetotal by Melbourne, Jr., son of Knight of St. George, Gaberhunzie by Bonnie Scotland, etc.), Ulverston and Ultima (the dam of Naisance, Sunrise, Sonora, Ultimatum, etc.), by Lexington. Victoire by Margrare, dam Argentile by Bertrand, was the dam of Zaidee by Belshazzar, Vandalia and Bijon by Vandal, Lilla (the dam of Lemonade, Judge Curtis, Chillicothe, and Lilly Duke, the last the dam of Water Lily and Lizzie Dwyer) by Lexington, Vesta by Asteroid, Leonore, ete. There is no horse in the male line from either Leviathan or Margrave. Mruley was sire of Little Wonder (winner of the Derby in 1810) and of Tespa (winner of the Oals in 1833). His daugh- 


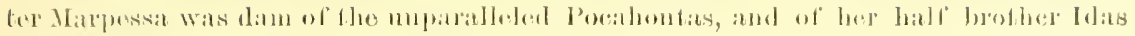

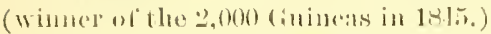

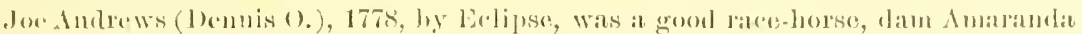

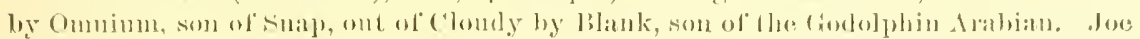

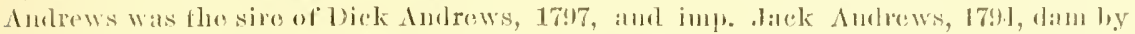

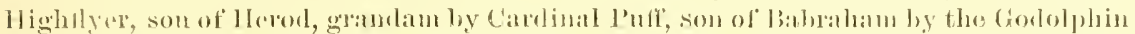

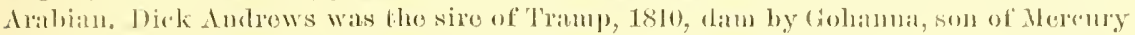

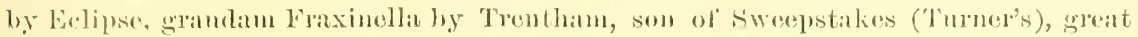

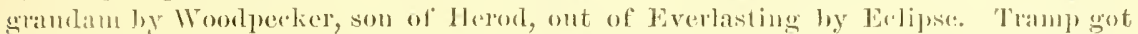

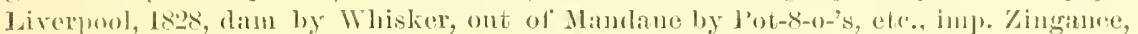

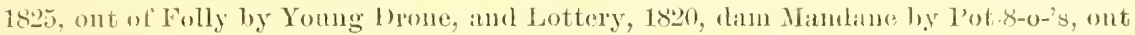

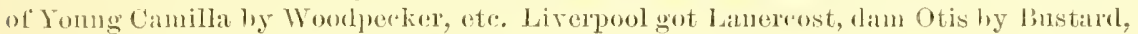
son of Buzzard, ont of Gaylunst's dian hy Election.

Liverpool got Van Tromp and bo Ruyter, dam Barbelle by Sandbek, son of Catton, Lomp-garon, din Moonheam by Tonboy, Colsterdale and Enerchale (Elbington's dam), dam by Tomboy, out of Tesane by Whisker. Tramp got also Little lied liover, lam Miss Syntax, sister to Dr. Syutax by Paynator, lue the sire of the dam of lineeaneer. Lottery was the sire of Inheritor, dam IInd Mailen by Walton, son of Sir Peter, Ternlam, dam Wire by Whisker, and sheet Anchor, dam Morgiaua by Muley. Sheet Anchor got Weatherbit, out of Miss Letty by Priam, and Collingwoorl, out of Kalmia by Magistrate. Weatherbit's blood comes to us through imp. Cicily Jopson (dam of Waverly, Phobe Mayflower, Katrine, Flash of Lightning, etc.), her dam Cestrea by Fangh-a Ballagh; imp. Weatherwiteh (lam of Weatherby, Little Mack, Florence (the last the dam of Hindoo aud graudam of the grand mare Firenzi), Waterwitch, Fonso, the promising sire, Fonwitch, ete. 'Tramp was the sire of 'Trampoline, dim of Glencoe, wimmer of the 2,000 Guineas in 1834, Miss Rose, imp. Yorkshire's lam, out of clanghter of Sancho by Don Quixote, son of Eclipse. Tramp was also sire of Charlotte li est and Tarantula (winners of the 1,000 Gnimeas in 1830 and 1833), Lady Moore Calew, the dan of Mendicant (winner of the 1,000 Gnineas and Oaks in 1816:, and of Furs, dam of Our Nell (winner of the Oaks in 1812). Tramp was also sire of St. Giles (wimner of the Derby in 1832), 1)angerous (winner of the Derby in 1833), and Barefoot (wimner of the St. Leger in 1823), who was imported to America and marle his impression on the stock of this comtry. Mercury, 1778, by Eclipse, dam by Tartar, son of Partner, grandam by Mogul, son of the Godolphin Arabian. Neremy got Gohanna, 1790, dam by Herod, ont of Maiden by Matchew. Gohamna got Wanderer, out of Catherine by Woodpecker. Wanderer was sire of Peri, dim of Sir Hercules. Gohamna also got the dam of Moses (sire of Pauline, dam of Gladiator), Golumpus, out of Catherine by Wroolpecker, sire of the grandim of Melbonrue, imp. Trustee, and Mundig (winner of the Derby in 1835), ont of Emma by Whisker. Trustee was a good and suecessful stallion in America, sire of Rerenue, dam Rosalie Somers by Sir Charles. Revenue got Planet, Exchecquer, Orion and Ninette, out of Nina by Boston. Trustee also got the noted grelding Renbe, out of Minstrel by Medoc, Joln Black, out of imp. Maria Black by Filho-da-Puta, Hidllestone, dam by Bullock's Muckle John. Trustee was the sire of the noted race-mare Fashion, that defeated Boston in the great match. Throngh Fashion's daughter Young. Fashion there are some good ones. Trustee also got Am Sterens (dam of Kate and Frank Boston), out of inp. Caprice by Muley, and the noted Lerity, ont of Vandal's dam by imp. Tranby. Levity was the dam of Ruric by imp. Sovereign, the noterl produciug sisters Lightsome and Mildred by imp. Glencoe, Brenna, the dam of Braslemante (The Bard's dam), Ella Hankins and Athalaric (Tow Martin s dan) by Gilroy, Lever and Legatee by Lexington. Catton was also the sire of imp. Galloparle, ont of Camillina by Camillus, son of Hambletouian by King Fergus. Gallopacle was the dam of Fandango and Cotillion by imp. Leviathan, Cracovienne, Quadrille, Hornpipe and Reel by $1 m p$. Glencoe. Reel is the dam of Prioress, Starke, Lecompte, that defeated Lexington, War Dance, etc. The blood is fonnd in the pedigrees of many of our very best horses.

Catton was the sire of Royal Oak, ont of a daughter of smolensko. Royal Oak got slane out of a daughter of Orville. Slane got Queen Inne, dam of Kingston, out 
of Garcia by Octavian, The Arrow, dam of Cambnscan, out of Sonthdown br Defence, The Merry Nonareh, wimmer of the Derby, 1845, ont of The Nargravine by Little John, son of Octavins, Conyngham (winner of the 2,000 Gnineas, 1817). Catton also got Mulatto, ont of Desdemona by Orville. Mnlatto got Martha Lynu, lam of Toltigeur, ont of Leda liy Filho-da-Puta, Mulatto also got Bloomsbury, wimer of the Derby, 1839, out of Arrot Lass by Ardrossan. Catton got Sandbeck out of Orvillina, sister to Orville, by Beninglorough. Sandbeck got Redshank, sire of Ellen Horne, the grandam of Bend'or, and Barbelle, the dam of The Flying Dutehman, out of Darioletta by Amarlis, son of Don Qnixote by Eelipse. Catton also got imp. Contract ont of Helen by Hambletonian, and imp. Nonplus, ont of Miss Garforth by Walton. Saltram by Eclipse, dam Virago by Snap, won the Derby, 1783, and was importen to America in 1800. He got Whiskey, sire of the dams of imp. Priam, Plantom and Muley, in England. Saltram got the dam of Timoleon (sire of Boston), Jenny Cockracy, and. Betsey Haxall, out of a danghter of Symme's IVildair. A daughter of Saltram dam by imp. Medley, was the dam of Sir Hal by imp. Sir Harry. Saltram got Rosy Clack, out of Camilla by Melzar, son of imp. Medley, she the dam of Tennessee Oscar and Rosetta by Wilke's Wonder, son of imp. Diomed, Patty Puff and her sister, dam of Betsey Saunders by Pacolet. The Darley Arabian male line is represented in England by such good ones as Ayrshire (Derby, 1888) by Hampton, dam Atalanta by Galopin, Bendior (Derby, 1880) by Doncaster (Derby, 1873), dam Rouge Rose by Thormanby, Bendigo by Ben Battle, dam Hasty Girl by Lord Gough, Brag by Strnan, dam Bonnce by Flatterer, Donoran (Derby and St. Leger, 1889) by Galopin (Derby, 1875), dam Mowerina by Scottish Chief, Common (2,000 Guineas, Derby and St. Leger, 1891) by Isonomy, dam Thistle by Scottish Chief, Galliard (2,000 Guineas, 1883) by Galopin, dam Mavis by Macaroni, Galopin (Derby, 1875) by Vedette, dam Flying Duchess by The Flỵing Dutchman, Hagioscope by Speculum, dam sophia by Macaroni, Minting by Lord Lyon, dam Mint Sauce by Young Melbourne, Muncaster by Doncaster, dam Windermere by Macaroni, Lowland Chief by Lowlander, dam Bathilde by Stockwell, Peter by Hermit, dam Lady Masham by Brother to Strafford, Petrarch by Lord Clifden dam Lanra by Orlando. Pero Gomez (St. Leger, 1869) by Beadsman, dam Salamanca by Student, Petronel (2,000 Ġnineas, 1880) by Iusket, dam. Crytheia by Hesperus, Ormonde (2,000 Guineas, Derby and St. Leger, 1886) br Bend'or, dam Lily Agnes by Macaroni, Saraband by Muncaster, dam Highland Fling br Scottish Chief, Silvio (Derby and St. Leger, 1877) by Blair Athol, dam Silverhair by Kingston, Sefton (Derby, 1878) by Speculum, dam Lady Sefton by West Australian, St. Gatien (dead heat with Harvester and walked over for the Derby, 1884) by Rotherhill or The Rover, dam Saint Eılitha by Kingley Vale, Springfield by St. Albans, dam Viridis by Marsyas, Snrefoot (2,000 Guineas, 1890) by Wisdom, dam by Galopin, ont of Miss. Foote by Orlando, The Bard by Petrarch dam Magdalene by Syrian, St. Simon by Galopin, dam St. Angela by King Tom, Timothy by Hermit, dam Lads Masham by Brother to Stafford, Tristan by Hermit, dam Thrift by Stockwell, Wenlock (St. Leger, 1872) by Lord Clifden, dam Mineral by Rataplan, Wisdom by Blinkhoolie, dam Aline by Stockwell, Merry Hampton (Derby, 1887) by Hanpton, dam Doll Tearsheet by Broomielaw, Sainfoin (Derby, 1890) by Springfield, dam Sanda by Wenlock, the two Iast untried in the stud. In America we are full as strong in this blool, not only in imported horses, many of them successes in the stud, but in uative bred horses who. were first-class race-horses and are popular and suceessful stallions. Imported St. Blaise (Derby, 1833) by Hermit, dam Fusee by Marsyas, Rayon d'Or (St. Leger, 1579) by Flageolet, dam Arancaria by Ambrose, Dalnacardoch (deal) by Rataplan, dam Mayonaise by Teddington, Blythewool by Adrenturer, dam Bonny Bell by Voltigeur, The Jacoljite by Prince Charlie, dam sister to Little Lady by Orlando, Lhlan by The Ranger, dam La Meehante by Turnus, Deceiver by Wenlock, dam Boot and Saddle by Trumpeter, Stonehenge by Blair Athol, dam Coimbra by Kingston. Charaxus. by Distin, dam Sappho by Kingston, Maxim ly Musket, dam Realization by Vespasian. Kantaka by Scottish Chief, dan seclusion (Hermit's dam) by Tadmor. Saxon by Beadsman, dam Girasol by Asteroicl. Galore bs Galopin, dam Lady Maura by Macaroni. King Galop by Galopin, dam by king Tom, out of Sunshine by 


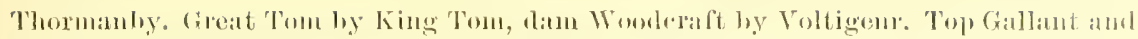

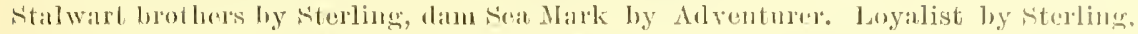

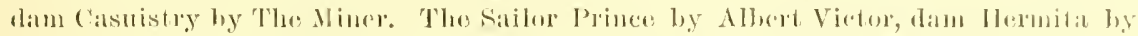

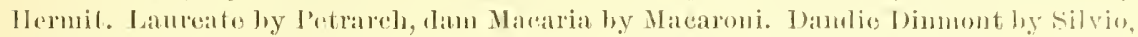

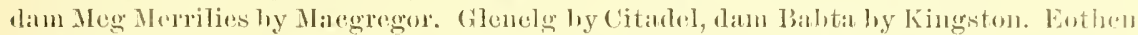

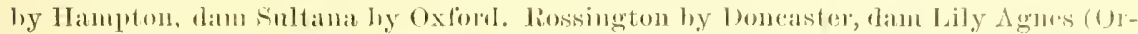

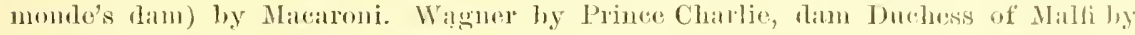

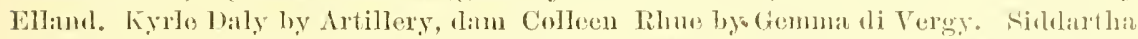
by Pero Gomez, dam The Pearl by Nowminster. Nany of these ane not Jesth or ft. Lecrer winners but very highly lued and successlul stallions. Anongst 1uose: lued in America, and who possess racing qualities sufficient to dass then with the best peloformers in Eirgland, are the following: Salvator by Prince Charlie, dan salina by Lexington (wimner of the fastest mile ever rum in the world, 1.35, and I 1 uniles with 122 1bs. in 2.05), Longtellow, the equal of any sire in the work, lyy imp. Leamington, dan Nantura by Brawner's Eelipse, Leonatus by Longfellow, Jan Senner Felix by imp. Phaeton, winner of ten stakes at 3 jears old, and a successful stallion. Lnke Blackburn by imp. Bonnie Scotand, san Nevala by Lexington, winner of 22 out of 24 races at 3 years old, and a successful stallion. Eolus, a sujerior race-horse and snecessful stallion by imp. Leamington, dam Fanny Washington by Rerenne, Enqurer, a superior race-horse and successfnl stallion by imp. Leanington, dam Lida by Lexington, tho lorothers Onondaga, Stratford and Sensation (umbeaten) by imp. Leamington, dam Susan Beane by Lexington. Inspector B. and Getaway, good racers, by Enquirer, dam Colossa by Colossus, Iroquois (wimner of the Derby and st. Leger in 1851) by imp. Leamington, dam Maggie B. B. by imp. Australian, Lisbon by imp. Phaeton, dam imp. Larly Love by Stockwell or Caterer, Troubarlour by Lisbon, dam Glenhine by imp. Glenelg, Powhattan (hrother to Parole) by imp. Leamington, dam Maiden by Lexington, Alam by inp. Eclipse, dam imp. Mand by stockwell, Panique and Wawekus (brothers) by Alarm, dam Maggie B. B. by imp. Australian, Falsetto by Enquirex, dam Farfaletta by imp. Australian, The Bard, a superior horse, by Longfellow, dam Brarlemaute by War Dance, Blue Eyes by Enquirer, dam Buchu hy Planet, Linden by Longfellow, dam Linda. Lewis by Oliver, Longstreet by Longfellow, dam Semper Idem by imp. Glen Athol, Belvidere and sir Dixon (brothers) hy imp. Billet, dam Jaconet by imp. Leamington, Hingar by Alarm, dam Hira by Lexington, Aramis by inp. Phaeton, dam Nellie Grey by Lexington, Aretino by Aranis, dam sprightly by Lexingtoa, Elias Lawrence by imp. Billet, dam Sprightly by Lexington, Whisper by Planet, dan Mattie Gross by Lexington, Bramble by imp. Bonnie Scotland, dam Ivy Leaf by imp. Anstralian, Fozhall by King Alfonso, dam Jamaica by Lexungton (wimner of the Grand Prize of Paris, etc.), Forester by imp. Ill I'sed, dam Woodbine by Censor or Kentneky, King Alfonso by imp. Phaeton, dam Capitola by Vandal, Pontiac by Pero Gomez, dam imp. Agenoria by Adventurer, Jils Johnson by Longfellow, dam Faniy Wells by imp. Sovereign, His Highness hy inm. 11l Used, dam imp. Princess by ling Tom, a grand good oile, with many others which possess on the temale sirle a large infusion of the coreted Herod blood. In fact, our American horses possess more of the Herod blood through Glencoe, who sired England's most noted matron, Pocahontas, dam of Stock well, Rataplan, King Tom, etc.. than can be found in the world.

The Aleock Arabian was inported into Englaud abont 1720, by whom it is not stated, but from his name by Mr. Aleock. He was noted as the sire of Crab, dam sister to Soreheels by Basto, 2d dam (Partuer's rlaun), sister to Mixbury Gallowas lyy tho Curwen Bay Barb, 3d dam by Curwen's Old Spot, th dam by White-legged Lowther Barb, jth dam the old Vintner mare. This old Vintner mare was the property of Mr. Cnrwen, of Workington, and was said by Mr. Croft to have been the best bred mare and best racer of her day. She was the dam (in addition to the filly above mentioned) of a filly by Pulleine's Chestunt Arabian, which was the dam of the filly by Blossom; son of Curwen's Bay Barb. To the old Vintner mare trace In direct female lne Croft's Partner, Soreheels, Crab, snip, Pacolet, Syphon, Soldier, Mereury, Master Bagot, St. Giles, Bondrow, Dick Andrews, Remembrancer, John. 
o' Gamnt, Ponpey, Muley Moloch, Nutwith, Lambton, The Confessor, Prism, Warlock, Ratan, Springy Jack, Daniel O'Rourke, Wingrave, Outfit, Bendigo, Peter, Peregrine Tertius, etc.

This Arabiau also got Mr. Alcock's Spot, the Duke of Ancaster's Gentleman, and the mare, dam Flash by the Curwen Bay Barb, ont of a natural Barb mare, that was the dam of Dismal by the Godolphin Arabuan, Whitefoot by Bolton Whitefoot, and Trifle by Fox. Crab was a superior race-horse, and as a stalliom in Mr. Panton's stud Was noted as the sire of many good race-horses, stallions and brood mares.

The Godolphin Arabian. This, the most noted of all the Eastern sires, was a dark bay or brown horse, foaled in 1724, and was by many regarded as a Barb. He ras brought from France by Mr. Coke, and it is said that he actually drew a eart in the streets of Paris. Be this true or not, he unquestionably contributed more to the hreed of thoronghbreds than any stallion either before or since his time. Mr. Coke presented him to Mr. Williams, keeper of the St. James Coffee Honse, by whom he was presented to Lord Godolphin, whose property he remained until his death at Gogmagog, in 1753. It is true that every superior race-horse of the present day, either in America, France or England, partakes largely of his blood. The Godolphin was teazer to Hobgoblin, son of Aleppo by the Darley Arabian and Mr. Brewster's ofd Hantboy mare, in 1730 and 1731. On Hobgoblin's refusal to cover Roxana, she was bred to the Godolphin Arabian, and from that cover she prodnced Lath, the first horse the Arabian ever got. Lath, a bay horse foaled in 1732 (named from his flat sides), was a superior race-horse, the best one of his clay. Cade, his own brotler, Was a bay horse, foaled in 173t, and was named Cade from the fact that he was bronght up on cow's milk, his dam dying when he was only ten days old, "To cacle, to bring up in softness." Cade was an indifferent race-horse, bnt a very successful stallion, which suecess is attributed not only to his superior blood, but to his grand symmetry in form. Roxana, the dam of Lath, Cade, and Roundhead by Deronshire Childers, was owned by Lord Godolphin. She was by the Bald Galloway, dam sister to Chaunter by the Akaster Turk, $2 \mathrm{l}$ dam by the Leedes Arabian, $3 d$ dam by Spanker, th dim old Moroce mare (Old Peg, Spanker's dam) be Moroceo Barb, 5th dam Old Bald Peg by an Arabian, ont of a Barb mare. Lath got Hector, Miss (the dam of Fairs) by Shepherd's Crab, Redeap, and Duchess, dam Joung Miss Belvoir by Flying Childers. Duchess, was the dam of Brimstone by Deronshire Chestunt Arabian, and she the dam of Squib by Spectator. A daughter of Lath, out of Brown Basto (sister to Snip), was the dam of Omar by the Godolphin Arabian, Crazy loy Lath, dam Bay Basto (sister to Snip), was the dam of Virago and two sisters by Panton Arabian, and the bay horse Protector, imported into America and here ealled Lath, by Shepherd's Crab. Virago was the dam of Hollanklaise by Matchem (wimner of st. Leger, 1778), and the grey filly Gunilda, imported to Ameriea by Star, son of Regulus Tos the Godolphin Arabian. Gmilka (called also Virago) was the dam of Marske, Mask and Virago by imp. Shark, son of Marske by squirt. From Virago by Shark, mint excellent race-horses hire descended, including Phœnix Belle, Cora Lp̧n, IIiss Carter, Lilae, Joe Daniels, ete. Miss Carter is the dam of Hildegarde, Isse, Poteen, etc. Crazy was also dam of Quill and sister by Feather, son of the Gololphin Arabian. This Feather mare, sister to Quill, was the dam of Anvil by Herod, who was sire of the graudam of imp. Leviathan.

Lath was also the grandsire of Bonnt Lass by Snip. Cade was much more distinguished as a stallion. He got Matchem (1748), chun sister to Miss Partuer by Croft's Partner, 2d dam Brown Farewell by Makeless, 3d dam by Brimmer, 4th dam by Place's White 'Turk, 5th dam by Dodsworth, ont of the Layton Violet Barb mare, Changeling, a brother and a full sister ont of the same mare. Matehem was a superior race-horse, and was a very successful stallion, being the sire of $35 t$ winners in 23 years that won in money $\$ 759,850.00$, in aldition to cnps.

Matehem got Conductor (1767), Alfred, Georgiana, Eyebright, ete., ont of a daughter of Snap by Snip by Flying Childers, 21 dam by the Cullen Arabian, 3d dam Grisewood's Lady 'Thigh by Croft's Partner, 4th dam by Greyhound, tracing thromgh the old Hoztagu uare to a Royal mare. Condnctor got Imperator (1776), dam by Herod, 2d 
dam (arina by Marsko (sire of Eolipse), ont of a damgleter of liank, son ol the

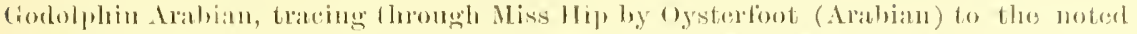
Coppin mase. Combluetor also got Trmmpator (1782), Cat, Cantator, etre, dam linte-

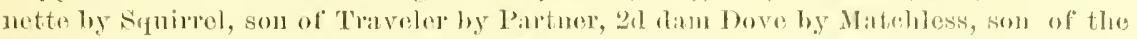

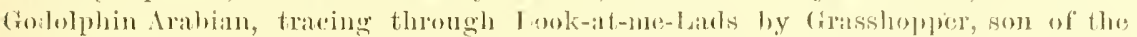

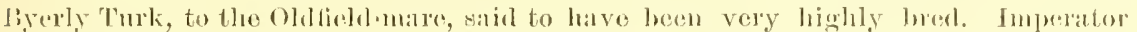

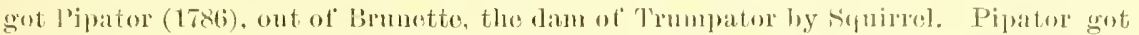
Remembrancer (winner of st. Inger, 180:3) ont of (Qneen Mals, sister fo Mereny by Ealipse. 'Prmmator got Paynator (1791), dam lyy Mark Authomy, son of' Sipectator liy Crab, ol dam Nignora loy Suap, grandson of Flying Clilders, ont of Miss Windsor by the corlolphin Arabian. T'rnmpator also got Sorrerer (1796), dam Yomng Giantess by J)ioned, 2d diun Giantess by Matehem, tracing throngh a sister to Roxana (dan of Lath and Cale), to the old Moroceo mare (Spanker's dam) by Moroceo liarb. Paynator got Dr. Syntax (1811), dam by Beningloongh, son of King Fergus by Eelipse, 2 d dam Jenny Mole by Carbmele, gramulson of the Godolphin Arabian, wut of a danghter of Prince T"Quassaw, grandson of the Darley Aralian. Dr. Sgntax got The Doctor (sire of Malcolm), (lam by Lottery, mut of Elizabeth by Walton, and the noted Bee's-wing, dam of Newminster, ont of a mare by Ardrossan, son of Jolun Bull, ont of Lady Eliza by Whitworth, son of Ayonistes.

Paynator got the dam of Cain by Panlowitz, out of a Delpini mare. Soreerer got Comns, dam Honghton Lass hy Sir Peter, son of Highflyer by Herod, ont of Alexina by king Fergus, son of Eclipse. Comns got Humplney Clinker, out of Clinkerina by Clinker, son of Sir Peter. Humphrey Clinker got Melbourne, ont of danghter of Cerrantes, son of Don Quixote by Eclipse, gramlam hy Golnmpus, son of Gohanna br Merenry. Melboume got West Anstralian (winner of the 2,000 Gnineas, Derby and St. Leger, 1853), dam Mowerina by Tonchstone, ont of Emma hy Whisker, son of Waxy, Blink Bonny (winner of the Oaks and Derby, 1857), dam of Blair Athol (winner of Derlyy and St. Leger, 1864), and Breadalbane, ont of Queen Mary by Gladiator, Canezon (winner of 1,000 Gnineas, 1848), out of Mallame Pelerine by Telocipede, son of Blacklork. Canezon was the dam of Fazzoletto by Orlando, Cape Flyaway by The Flying Dutchman, ete. Melbonrne got Csmba (winner of the Oaks, 1848), ont of Skiff by sheet Anchor, and she was the grandam of Marden, Charon and The Abbot. Marchioness (wimner of the Oaks, 1855) by Melbonlne, unt of Cinizelli by Tonchstone, was sent to Anstralia and was the dam ofAngler hy Fisherman, winner of the Victoria Derby, St. Leger and Ballarat Derby, and sire of Onyx and Robinson Crusoe. Melbourue was also sire of Mentmore Lass (winner of the 1.000 Guineas, 1853), ont of Emerald log Defence. Hentmore Lass was the dam of Hannal (winner of the 1,000 Gnineas, Oaks and St. Leger, 1871). West Australian was the sire of Brown Agnes (dam of Brown Bread), ont of Miss Agues by Birdcatrher, Lady Sefton (dam of Sefton, winner of the Derby, 1878), out of Clarissa by Pantaloon, Solon, sire of Barcaldine, Philammon, etc, out of Darling's dam by Birslcateher, and the dam of Musket by 'Toxopholite. Musket is sire of imp. Maxim, Martiui-Henry and Petronel (winner of the 2,000 Gnineas, six Queen's Plates and the Doncaster Culy). West Australian also got Summersirle (winner of the Oaks, 1859), lam of Printanniere (Ponlet's dam), ont of Ellerdale by Lanercost. WVest Australian also got imp. Anstralian (dam Emilia (imp.) by Young Emilins), who was not only a superior racellorse but one of the best and most popnlar stallions ever in America, sire of Will-

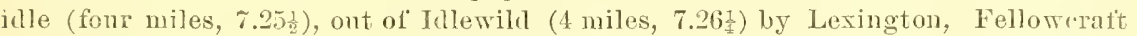
(4 miles, 7.192), Spendthrilt, Miser, Rutherfork, etc, ont of Acrolite by Lexington, Baden Barlen, Helmbold, etc., ont of Lavender by Wagner, Abi-el-Karler, Abl-elKoree, Wilful, Silent Friend, Mate, Atilla, Leinster, Farfaletta (the dam of Falsetto), Magrie B. B., dam of Iroquois (winner of both the Derby and St. Leger), Iry Leaf (dam of Bramble, Brambaletta, ete.), and Lizzie Lucas, dam of Lstton, Cambsses, etc. Melbourne was also sire of Sir Tatton Sykes (wimner of St. Leger, 1846), dam by Margrave (imp.), Prime Minister (dam by Sheet Anchor), who got linight of the Garter (winner of the Tradesman Plate, Chester, 1869), ont of Rosa Bonheur by Touchstone. Kinight of the Garter was the sire of Przedswit, out of The Jewel by 
Stoekwell. Melbourne also got Young Melbonrne, dam Clarissa by Pantaloon, son of Castrel, out of a daughter of Glencoe. Young Melbourue got Gen. Peel and states. man, dam a darghter of Orlando, ont of Brown Bess by Camel. Gen. Peel wou the 2,000 Guineas, 186t, and was second in both the Derby and St. Leger to Blair Athol. Young Melbomme also got New Holland (wimmer of the Goodwood Cup), ont of Bounceaway by Zusder Zee, son of Orlando, Brother to Strafford, out of daughter of Gamelyoy, Rapid Rhone, dam by Lanercost or Retriever, Pell Mell, dam Makeshift by Voltigenr, he the sire of Carlton, out of Bonny Spee by Speeulum. Yonng Melboume showed best through his daughters, Mint Sance, dam of Minting by Lord Lyon (winner of the Grand Prize of Paris), The Lambkin, (wimner of the St. Leger, 1884) by Camballo, and his sister Minthe (winner of the 1,000 Guineas, 1899), ont of Sycee by Marsyas, Adelaide, dam of Peregrine (wimner of the 2,000 Guineas, 1881) by Pero Gomez, dam by Teddington, Faraway, (dam of Rafaello), ont of Maid of Masham by Don John, Patehwork (dam of Quilt, Crosspateh, ete.), ont of Makeshift by Voltigenr; Wheatear (dam of Skylark, winner of the Gold Vase at Ascot, by King Tom, and Harvester, who ran a dead heat and divided the Derby with St. Gatien, 1884), ont of Swallow by Cotherstone. Humphrey Clinker was also sire of Bran, dam Velvet by Oisean, out of Wire, sister to Whalebone by Waxy. Bran was the sire of Onr Nell, wimmer of the Oaks, 1842. Humphrey Clinker was sire of Rockingham (winner of St. Leger, 1833), The Biddy (dam of Priestess by The Doctor) out of Idalia by Peruvian. The Biddy was dam of The Gem by Touchstone, and she the dam of Regalia (winner of the Oaks, 1865) by Stockwell. The Priestess was the dam of Dulcibella by Voltigeur, and she the dam of Idalia by Cambuscan, that produced imp. Sir Modred and inp. Cheviot. Comus Tas sire of Reveller (wimner of St. Leger, 1818), out of Rosette by Beningbrough. Reveller was the sire of imp. Delight, ont of Defiance br Rubens. Delight was the dam of Hagar and Matilda Bynum by imp. Gleneoe, and Shamrock (imported in utero) by St. Patrick, son of Walton by Sir Peter. Shamrock was the sire of Hennie Farrow, out of Irla by imp. Belshazzar. son of Blacklock, she the dam of Mayflower by imp. Eelipse, that produced Joe Hooker, the popular sire, and California by Monday, Warwiek and Annie Lamrie by Hubbard. Mimi, the sister to Mayflower, is dam of Mask, Mikado and Kinglike by King Emest, the latter a very promising stallion. Ballerina by imp. Balrow die, ont of Hemie Farrow, is the dam of Ballinette (dam of Clara W., Alta and Del Norte) by Monday or Young Eelipse, and Countess Zeika (dam of Ed Corrigan, Judge Post, ete. by Norfolk. Reveller was the sire of Zillah, ont of Morisca by Moriseo, son of Muley. Zillah was the dam of Prairie Bird by Tonchstone, and she the dam of England's Beanty by Birdcatcher, she the dam of imp. The Rake (sire of Dundee) by Wild Darrell, Silverhair (the dam of Silvio, silvester and Fetterlock) by Kingston, Rose of Kent (the dam of Sycee by Marsyas) by Kingston. Sycee was the dam of Mint Sance, dam of Minting, winner of the Grand Prize of Paris, and The Lambliu, wimner of the St. Leger, 1864. Prairie Bird was also dam of Vitula by Arthur Wellesley, the lam of Bird of Freedom (wimner of City and Suburban Handicap). Comus was the sire of imp. My Lady ont of The Colonel's dam by Delpini, she the dam of imp. Delphine by Wlisker, that was the dam of imp. Monarch by Priam, The Qneen, full sister to Monarch and imp. Herald hy Plenipotentiary. Sorcerer was the sire of Smolensko (winner of the 2,000 Guineas and Derby, 1813), dam Wowski by Mentor, son of Justice by Herod, ont of Maria, dam of Waxy by Herod. Clari by Smolensko, dam by Precipitate, son of Meremy by Eclipse, was the dam of Chat, Chatterer, Chatterbox and Chitehat by Magpie in Ireland. Smolensko was the sire of Jerry (winner of the St. Leger, 1824), ont of Louisa by Orville. Jerry was the sire of 'Tomboy, ont of Bee's-wing's dam by Ardrossan. Tomboy was the sire of Nutwith, out of daughter of Comus. Nutwith (winner of St. Leger, 1813) was the sire of Knight of Kars, ont of Pocalontas by Glencoe, and of Gameboy, ont of Lady Mloore Carew hy Tramp. Smolenslso was also the sire of The Fawn, ont of Jerboa by Gohanna, and The Fawn was the dam of Yenison by Partisan, son of Walton. Venison was the sire of Kingston, ont of Queen Anne by Slane, son of Royal Oak by Catton, Royal Oak's clam by smolensko. Kingston was the 


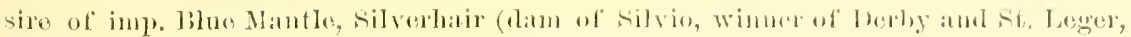

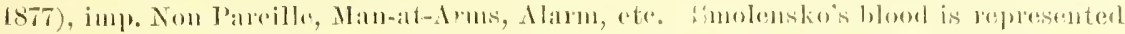

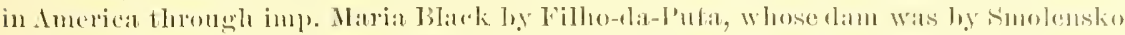

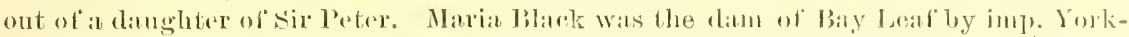

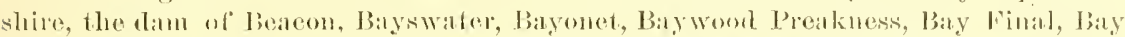
Flower and Niagara by Lexiugton, Bingaman and M. A. B. by Asteroid, and bay Bush by imp. Anstralian. Bay flower is the dam of Try leall, she the dam of

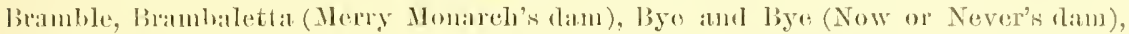

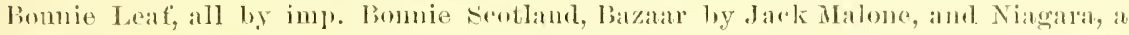
spredy, mood race-horse. hy Luke Blackburn. The gramban of Galloparte, that fommled the great heel and lomee fanilies, is a danghter of Smolensko. Sorcerer is also sire of Soothsayer (winner of the St. Leger, 1811), dam Goldenlocks by Delpini, son of Higliflyer, out of Violet by imp. Shark, son of Marske. Soothsayer was the sire of Filagree, ont of Web, sister to Wire and Whalehone hy Waxy. Filagree was the dam of Cohweb (winuer of the 1.000 Guineas and Oaks) hy l'hantom, sire of Waltom and imp. 1Riddlesworth (winner of the 2,000 Guineas, 1831) by Emilius, and of Charlotte West (winuer of the 1,000 Guineas, I830) by Tramp. Cobweb was the dam of Bay Middleton by sultan, son of Selin by imp. Buzzard. bay Mirdleton was a grand race-horse (winner of the 2,000 Gnineas and Derby, 1836) and successful stallion, being the sire of Cowl, ont of Crueifix by Priam, Hesperus, ont of Plenary by Emilins, Ellen Middleton (dam of Wild Dayrell, winner of Derbs, 18.5), out of Myrrha by Malek, son of Blacklock, Britamia IV., imported (dam of Madame Indley and Browu Priuce, sent to Eugland, by Lexington, Brigand by Planet, Booty by Asteroid, ete). Madame Dudley is the dam of Judith and Belinda by Glenelg, Vintage (the dam of Ruby Royal, Flavilla, ete.) by Virgil. Sauta Rita and Virgie D. (sisters to Vintage), the latter dam of Hueneme by Billet. Booty is the dam of Violator by King Ban, Estelle ly Himyar, exe. Bay Michleton was also sire of Eunice, dam of Sanuterer, ont of Blue Devils ly Velocipede; the dam of King Alfred, aud grandam of Enterpuise, ont of West Country Lass by Venison; Bay Missy, granılam of Scottish Chief, ont of Camilla by Yomug Phantom; The Flyiug Dutchman (winuer of Derby and St. Leger, 1849), sire of Flying Dnehess, Ga]opin's dan, ont of Barbelle by Sandbeck, son of Catton, and of Duteh Slater, out of Fulvie by Gladiator, with other good ones; My Dear (grandan of Oxford by Birdeatcher), out of Miss Letty by Priau; Hesperus the grandam of Petronel, ont of Plenary by Emilius; the sister to Cobweb by Phantom produced Flycateler by Godolphin, son of Partisan, who was the grandam of imp. Eclipse, who got Alarm, Ruthless, Relentless, Remorseless and many other good ones. Soothsayer was sire also of Tiresias (wimner of the Derby, 1819), out of Pledge hy Waxy.

The Gololphin Arabian also got Blossom, Jilt and Bragg, dam Aneaster Blossom by Crab, son of the Aleock Arabian, grandam by Flying Childers, ont of IJiss lbelvoir by Grey Grantham, ete. Jilt was the dam of Arab by Panton Arabian, Jilt, Hornet, Bashful, Caligula aud Bauble, all by 13lank. Cripple was own brotler to Cygnet and Creeper by the Godolphin Arabian, dam 13Iossom, sister to Ancaster Blossom br Crab. Cripple was the sire of the great Gimerack, a superior race-horse amd the sire of imp. Medley, foaled in 1776. Medley was a fine raee-lorse and sire of Grey Diomed (foaled in 1786), dam by Sloe, son of Partner, grandam by imp. Vampire, ont of imps. Calista by Forester; Bellair (Taylor's), foaled 1786, and Calypso, foaler 1793, dam Selima (Yonng) by Yorick, grandam Black selima by imp. Fearnonght, out of imp. Selima by the Godolphin Armbian; Boxer, foaled 1790, dam by iup. Fearnonght; Quicksilver (foaled 1783), dam by Symme's Wildair; Melzar, foaled 1791, dam liy Symme's Wildair, grandan by imp. Tampire, ont of imp. Kitty Fisher by Cade, sou of the Godolphin Arabian; Lamplighter, dam by imp. Lonsdale, by Jolly Roger, son of Gower stallion, out of imp. Kitty Fisher by Cade; Grey Medley (Barry's of Temuessee), dam by True Whig, grandam Circe by Ariel, out of imp. Lady Northumberland; the Medley mare (owned by Marmaduke Johnson of Virginia), dam of Miss Jefferson loy imp. Diomed, Carolina by imp. Saltram, Carolinian by imp. True Blue, and the famous sisters, Tanity and Reality by Sir Archy, the latter dam of Johnson's 
Medley bs Sir Hal, slender and Bonnets o' Blue by Sir Charles, the latter the dam of the noted Fashion (that defeated Boston in the great match, fonl-mile heats, run orer the Tnion Course, L. I., May 10th, 1812, in 7.321, 7.45, the best race run in America to that date), Mariner by Shark, etc. Gimerack was also sire of imp. Clockfast, and of the Iam of Constable's imp. Pot-8-o-'s mare, grandam of American Eclipse. Godolphin Arabian was the sire of Blank, bas horse, foalerl 1710, flam Little Hartley mare by Bartlett's Childers, 2d dam Flying Whigg by William's Woodstock Arabian, 3d dam Points, own sister to the Bald Galloway by the St. Vietor Barb, 4th dam Grey Whynot by Whynot, son of the Fenwick Barb, out of a Royal mare. The Little Hartley mare was also the dam of Janus and Old England, and a filly by the Godolphin Arabian, which filly was the dam of Merlin by Second, Babraham Blank by Babraham, etc. Blank was not successful as a race-horse but was an exceedingly raluable stallion, and sire of Chatsworth ont of Fairy by Shepherd's Crab; Chrysolite, Gaudy and Gamesome, out of Blossom by Panton's Crab; Pacolet ont of Whiteneck bs Panton's Crab, son of Alecek Arabian; Pasmaster out of Snap Dragon by Snap, son of Snip; Tatler out of Spectator's dam by Partuer. Blank was the sire of Countess, ont of a daughter of Rib, son of Crab. Countess was the dam of Horitia and Achilles by Eclipse, DeIpini by Highflyer, ete. Horatia was the dam of Stamford by Sir Peter, and his brothers, the Derby winners, Paris, 1806, and Archduke, 1799, imp. into Tirginia. Blank also got Dizzy (ont of Dizzy by Driver, son of the Wyun Arabian), she the dam of Grey Dorimant by Dorimant, son of Otho; Golden Grove, the dam of Petworth by Herod out of Spinster, the Widdrington mare, by Partner; Helen (the dam of Riot and Brim by Squirrel) out of Mab by Crab; Horatia, dam of Jumo by Spectator, aud her sister (the dam of inp. Diomed), ont of a daughter of Flying Childers; Julia, dam of Promise by Suap, and Prineess by Heror, ont of Spectator's dam by Partuer; Lill, dam of Hippona by Suap, Jocasta and Drone by Herod, ont of Peggr by Cade; Principessa, daw of Heinel by Squirrel, ont of a daughter of the Cullen Arabian.

Little Hartley mare was the dam of Tortoise and his sister by Whitefoot, son of Bay Bolton. This Whitefoot mare was the dam of the Gower stallion by the Godolphin Arabian. The Gower stallion was the sire of Little David, Lord Gower's Sweepstakes (sire of Young Sreepstakes, Trentham, Whitelegs, Corsair, Doctor, etc.), Clio (dam of Conqueror by Bajazet), ete. The Godolphin Arabian got Regulns, and his sister (the dam of Folly by Blank, and Coquette by the Comptom Barb, she the dam of Camilla, Glider, etc., by Trentham), dam Grey Robinson by the Bald Galloway, 2l dam sister to Old Country Weneh by Snake, son of the Lister Turk, 3d dam Grey Wilkes, sister to Clnmsy by Hautboy, th dam Miss Betty D'Arey's Pet mare, dangliter of a Sedbury Royal mare. Regulus was a bay horse foaled in 1739. Under the name of Sweetlips he won a number of races, and at six rears old he won eight Royal Plates and one $£ 50$ Plate. He was never beaten, and was superior to any horse of his day. Regulus was noted as a stallion, and was the sire of Careless, Cato, Morwick Ball, Adolphus, Elephant, South, Turk, Prophet, Vampire (importeri), etc. He was also the sire of A la Grecque, dam of Poutae and sister by Marske, Balloon, Emma and Maria by Telemachus. Regulus also got Spiletta, out of Mother Western by Smitl's son of Snake, ow brother to William's Squirrel by Lister's Snake, ont of an Akaster Turk mase. Spiletta was the dam of O'lielly's Eclipse and his sister Proserpine aud brother Garrick (Hyperion), ete. The Godolphin Arabian was also sire of Babraham, Mlogul, Marlborough, and imported Selima, out of the Large Hartley mare by Mr. Hartley's Bliud Horse, son of the Holderuess Turk. Godolphin Arabian also sirer Bajazet (foaled in 1740), dam by Thitefoot, grandam by Leedes, out of the Moomah Barly mare.

Rachel, rlam of the noted Highflyer by Herod, and Mark Anthony by spectator, was ont of a daughter of Regulus by the Godolphin Arabian ; Rantipole, dam of Nymph and Nimble by Florizel, son of Herod, out of sister to Careless by Regulus : Rutilia. sister to Rachel, dam of Jocasta and Harmony by Herod; Sally, dam of imp. St. George, ont of Poppet by Black Chance, son of Hutton's Bay Barb; Sappho, the dam of Sophonisba by Squirrel, and Madeap by Eclipse, out of a daughter of 


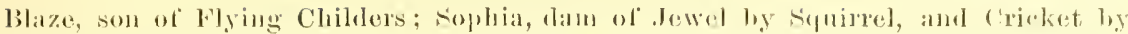

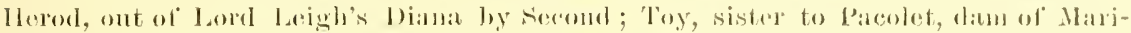

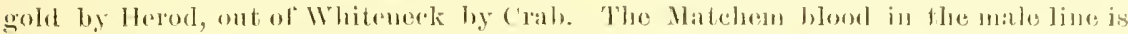
almost extinct in Eugland, and has but dow reputable ropresentatives. Tlag best

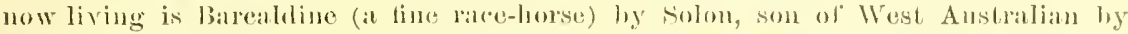

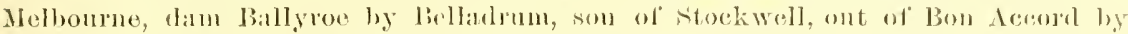

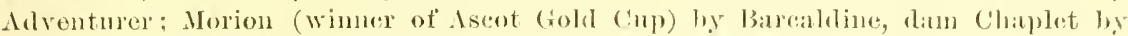
Beadsman, ont of Marane Eglantine hy ('owl; Caulton (wimer of ile l)ouraster

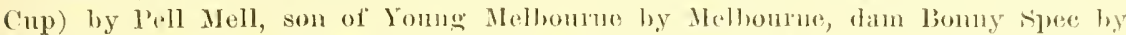
speculum, ont of Bonny May by Newminster; Kilwarlin (won the St. Leger in 1887) by Arlitrator, son of Solon by West Australim, dam Thasty Girl by Lod Gomgl, son of Gladiatem, ont of Irritation by King of 'Trmmps, and Plebeian by Joskin, son of Test Australian, dam Qneen Elizabeth by Mutoerat, son of Pay Mideleton, ont of Bay Rosalind by Orbando. In Ameriea wo are remarkably strong in this hloorl, especally from the Melbonrne line. Inp. Darehin, a superior race-horse, hy The Peer, son of Melbonrne, dam Lurline by Tradncer, son of The Libel by Pantaloon, ont of Mermaid by King Tom; Wiifnl by imp. Anstralian, son of Melbonrne, dam imp. Pussy by Duophantus, son of Orlando, out of Agapemone lyy Bay Midaleton, a gool race-horse and successtinl stallion for his chances; the Anerican-brerl Springhok, winner of the fastest $2 \frac{1}{4}$ miles in the world in $3.56 \frac{1}{4}$, by imp. Anstralian Iam Hester hy Lexington, out of Heals I Say by Glencoe; the brothers Spendthrift, sire of Kingston, Felloweraft, 4 miles in 7.19: and Miser, sire of Yorkville Belle by imp. Anstralian, dan Erolite by Lexington, ont of Florine by Glencoe; Vildidle, 4 miles in $3.25 \frac{1}{2}$, by imp. Australian, dam Idlewild, 4 miles in $7.26 \frac{1}{1}$, by Lexington, ont of Florine by Glencoe; Duke of Montrose, a good race-horse and stallion, by IVaverly, son of imp. Australian, dam Kelpie by imp. Bonnie Scotland, out of Sister to Rurie by imp. Sovereign; Harry O'Fallon, sire of Terra Cotta, etc., by imp. Australian, dam imp. Sunny Sonth by Birdeatcher, out of Equal by The Cure, purely English bres; Strathmore, a fine race-horse, hy Warerly, son of imp. Anstralian, dam Brenna by imp. Knight of St. Ceorge, son of Birdcatcher, out of Lerity by imp. Trustee; Atilla (winner of Travers' stake) by imp. Anstralian, dam Uttima lyy Lexington, ont of Utilla by imp. Margrave.

The Compton Barb (the Sedley Grey Arabian) was brought to England hy Mr. Compton, aud became the property of Sir Charles Sedley, after which he was known as the Serlley Grey Arabian. He was principally noted as the sire of Coquette. ont of sister to Regulus by the Godolphin Arabian. Coquette was the dam of Camilla, Glicler, Driver, Darter, Cocker, and two unnamed fillies hy Trentham, son of Sireepstalies hy the Gower stallion. Camilla was the dam of Colibri, Catherine. Sophia, Crazy, Poetess aud Humming Bird by Woodpecker, son of Herod, Raggerl Jack by Highfler, and Jerboa by Gohann. Catherine was a famous brood mare, dam of Golnmpus, Hedles, Kate, Wanderer and Vagabond by Gohamna, son of Mercury hy Eclipse, Slipper by Preeipitate, Sprite by Bobtail, son of Precipitate, by Mereny, Reetory by Ortarins, and Worthy by Whalebone. Sprite was the dam of Variety by Selm or Soothsajer, Amiahle by Orville, and Spite by Tiresias. Humming Bird was the dam of Mouse (Vittoria's dam), Hanna and Fun, all by Gohanna. Jerboa was a noted snecessful brood mare. She was the dam of Lacerta by Zodiac, that produced The Little Known'by Mules, Little Wonder by the same (winner of the Derby in 1840), Fawn by Smolensko, she the dam of Venison by Partisan. Venison is the sire of Kingston, out of Queen Anne by Slane. Kingston was the sire of Queen Bertha (the grandam of Childerie and Charibert), out of Flax by Surplice, silverhair and imp. Non Pareille, out of England's Beanty by Birdeatcher. Silverhair was the dam of Silvester and of Silvio, that won both the Derby and St. Leger, 1877, the latter by Blair Athol. Kingston also got Han-atArms, ont of Paradigm by Paragone, Alarm ont of Sonthdown by Defence, sire of the grandam of Petrareh, winner of the St. Leger, 1876. The Kingston blood is highly esteemed for stontness.

After the Restoration, and when King Charles II. had been firmly settled on the 
throne, he sent Sir John Fenwick (Master of the Horse aud prominent on the turf) abroad to procure a number of high bred mares and stallions, and the mares so purehased were eallerl Royal mares, one of which was in foal and produced the noted Dodsworth, who was the sire of Dicky Pierson, sometimes called son of Dodsworth. Both of these names are found in may of the old pedigrees. Dodsworth got the grandam of Dyer's Dimple, and the iatter was the sire of SopLonislua, out of sister to Little George by Curwen's Bay Barb. Dodsworth was sire of the grandam of Grasshopper (Ancaster's), and the great grandam of Spicler by the Lonsdale Arabian. Dodsworth also sired the great grandam of Bay Layton lyy D'Arcy's Counsellor, and Brown Farewell by Makeless, the latter the dam of Miss Partner by Partner, the dam of Young Cade by Cade, son of the Godolphin Arabian, and the sister to Miss Partner (who was the dam of the noted Matchem, that founded the Natchem line of blood, and Changeling his brother) by (ade, son of the Godolphin Arabian. Another sister to Miss Partner was the dam of Dormouse by the Godolphin Arabian, and imp. Bolton by Shock. Sir John Fenwick also brought from abroad the Barb horse known as the Fenwick Barb, which was the sire of Whynot, out of a Royal mare, and she was the dam of the Bald Galloway, Cupid, aud Points by the st. Tictor Barb. Points was the dam of Flying Whigg by William's Woodstock Arabian, she the dam of the Large Hartley and Little Hartley mares. The former was the dam of imp. Selima, that founded the Mollie Jackson family, Babraham, Mogul and Marlborough, all by the Godolphin Arabian. The latter was the dam of Janus, Blank and Old Erigland by the Godolphin Arabian, Tortoise by Whitefoot, and Slonch by Cade. Another daughter of Whynot was the dan of Bay Wilkinson and his sister by Snake, and a filly by Hntton's Gres Barb, that was the dam of Grisewood's Partner by Old Partner. Through the descendants of the Bald Galloway, Grisewood's Partner and Selima, the blood of the Fenwiek Barb has been transmitterl to many of the best horses of this day.

After the death of Charles II., the Royal mares were dispersed throughont the Kingtom, and their female descendants were called Royal mares. The Sedbury Royal mare was the dam of Hutton's Royal colt by the Helmsley 'Turk, and great grandam of Old Conntry Wench, aud her sister by Lister's Snake, D'Arey Royal mare, dam of Hantboy by D'Arey White Turk, the Blunderbuss Royal mare, dan of Old Royal by Holderness Turk, and grandam of Hartley's Blind Horse br the same Turk, D'Ares's Royal mare, dam of Brimmer by the D'Arey Yellow Turk, Christopher D'Arey's Royal mare, to which traces the dam of Rachel by Blank, she the dam of Mark Anthony by Spectator, and Highflyer by Herod, the D'Arey Black-legged Royal mare, whose daughter by Lord Oxford's Dun Arabian was the dam of Miss Slamerkin by Yonng True Blue, she the dam of Bustard, Othello (Black-and-allBlack) and Oroonoko, all by Crab, and Duchess by Whitenose. There are other Royal mares, but the larger number of them were in the sedbury stud of the D'Arey family. Lord D'Arey imported the White Turk (called also Sedbury Turk), who was the sire of Old Hantboy (iVilke's). He got Grey Hautboy, the sire of Bay Bolton, ont of daughter of Makeless, Wyndham, the clam of Lister's Snake, the dams of Almanzor aud Aleppo by Darley Arabian, Terror by Akaster Turk, and Champion by Sir J. Harpur's Arabian. D'Arey Yellow Turk got the noterl spanker, out of Old Peg (old Moroce mare) by the Moroeco Barb, out of Old Bald Peg by an Arabian, out of a Barb mare.

The Curwen Bay Barb and Thonlonse Barb were imported in the reign of King Charles II. They were a present from Muley Ishmael, King of Morocco. to Lonis XIV. of France. They were brought from Barbary when Count of Thoulouse was Lord High Admiral of the Fleet and Count Brran was Master of the Horse to tire Monareh. Mr. Curwen, of Workington, got possession of these Barbs aud bronght them to England. The Curwen Bay Barb, from a daughter of Old spot, son of the Selaby Turk, ont of a mare by the White-legged Lowther Barb, ont of the old Vintner mare, got Mixbury, his two sisters and Whiteneck. One of these sisters was the dam of Hiss Jigg and Croft's Partner by Jigg, Soreheels and his sister by Basto, and the other was the dam of Sloven by Bay Bolton. Miss Jigg was the dam of Monkey ly 


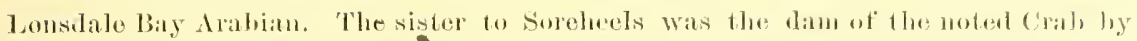

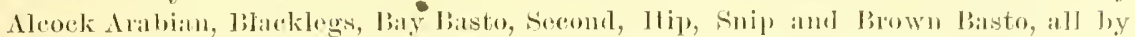

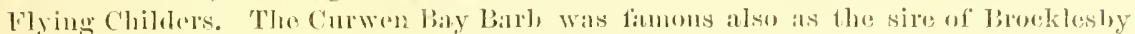

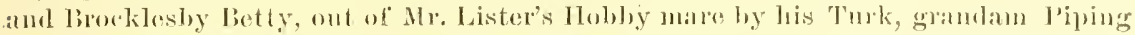
Peg. biockleshy betty was famons on the turf, and was the dam of the gerey mates

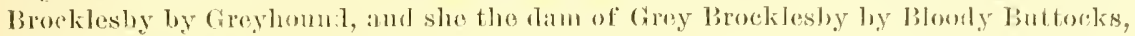

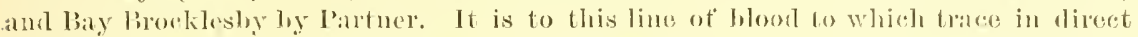

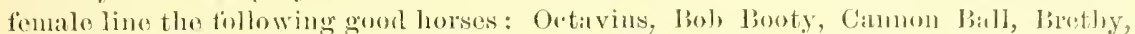
St. Martin, inported Mickey Treo, Chantieleer, Solon, fom King, Xenoplon, Iowland Chiof, Zealut, Hagioseope, laarcaldine, Ossian, Ambergris, Signorina, imus. Filagree aud her daughters, imp. Ga elle and her descendants.

In the reign of James 11, the Stranling, or Lister I'nrk, was Inonglit to England. This Turk was taken in 1686, at the siege of Bnda, by the Duke of berwick, who sold him to Mr. Lister, of Lincolushire, in whose stud he became famons nuller the name of the Lister Turk. He got lirisk and Coneyskins, out of' a danghter of Jigg, son of the Byerly 'Turk, grantam of Bolton Sweepstakes Mr. Lister's Snake (the sire of William's squirrel and his own brother, Smith's son of Suake) ont of a danghter of the Aliaster Turk, the Hobby mare, dam of Brocklesby Betty, and her sister, the dam of Mr. Pelham's Hip by Curwen Bay Barb. Throllgh these, and particularly Coneyskins and Mr. Lister's Snake, the Lister Turk must be legarded as one of the Lastern progenitors of the thoroughbred horse.

Lonsdale Bay Arabian was the property of Lord Lonsdale. He got Lord Lonsdale's Monkey, Spider, Sultan, etc., and Mr. Panton's Veteran. He also got the dam of Miss Ramsrlen by Cade, out of sister to Bonny Lass by Bay Bolton. Miss Riamsden was noted as the dam of Wookpeeker, Quieksand, Wormwood and Whipeorl, all by Herot. Woodpecker was famous as the sire of imp. Buzzard, ont of Misfortme lyy Dux, son of Matehem. Buzzard sired the three brothers, Selim, Castrel and Rubens. Woodpecker also sired a large number of valuable brood mares, including Ambrosia (the dam of Fanny loy Diomed, Cripple by Saltram, etc.), Colibri (lam of Princess by Precipitate, Cardinal Beanfort and Canopus by Gohanua), Rosiua (dam of Hermes by Mereury), Wren (the dam of imp. Robin Relbreast, Agonistes, Tiney and Milo, all by Sir Peter), and the dims of Fractions by Mereny, Fraxinella by Trentham, and Petworth by Precipitate.

The Honeywood Arabian (known by the name of William's Turk) was imported to England by Sir John Williams in the reign of King William. Sir John sold hin to Mr. Honeywood, hence his name. In $1709 \mathrm{Mr}$. Honeywood bred his Byerly Turk mare to this Arabian, and the grey colt, foaled in 1710, was named True Blne, and wou the King's Plate at York in 1718, in which year the Byerly Turk mare produced Young True Blne, his fnll brother, who was the best plate horse of his day. There were two sisters to the two Trne Bhes. It is to these two sisters of the True Blues to which trice, in tireet female line, nearly all the best race-horses and stallions for more than one hundred years, includinw Sir Peter, imp. Buzzard, Skyscraper, Spadille, Champion, Tramp, Master Hems, Bizarre, imp. Chatean Marganx, Rector, Velocipede, The Saddler, Glaucus, Lanercost, Galaor, Sleight of Hand, Flatcateher, Jereny Diddler. Pyrhus the First, Van Tromp, The Flying Dutchman, Stoekwell, Rataplan, King Tom, Hobbie Noble, Galopin, Chattanooga, Windhound, Kettledrum, Knight of the Garter, Mr. Winkle, Statesman, Ivan, Artillery, Plum Pudding, Toxophilite, Knowsley, Tim Whiffler, Lacydes, Musket, Victor by Vindex, Cardinal York, Paul Jones, Victorions, Tomahawk, Gen. Peel, Vermonth, Favonius, Bruce, Vertugadin, Master Kildare, Wellingtonia (in France), Pride of Prussia, Border Minstrel, Quicklime, Highlaud Chief, Maribyrnong (in Australia), imp. Rayon d'Or, imp. Robin Reilbreast, imp. King Ernest, imp. Escape (Horns), imp. Double Duke, imp. Oscar, imp. Eothen, imp. Consternation, imp. Lochiel, imp. Laplog, imp. Mr. Pickwick, imp. Roman, imp. Glengary, imp. Dahnacardoch, imp. King Ban, American Echpse, Viator, Reform, the imp. mares Castagnette, Cyclone, Angela, Periwinkle, Athenais, reardrop and many others of note.

A number of Barb mares were imported to England and were designated by the 
names of their owners. The Burton Barb mare, property of Mr. Burton, sait to have been a natural Barb mare, hat a colt, St. Martin by Spanker, and a filly by Dodsworth. This filly by Dodsworth was the dam of Morgan's Dun by a son of the Helmsley Turk, and an orn sister to him, which produced a filly by Hautboy. The Burton Barb mare had also a filly ly Dicky Pierson, son of Dodsworth. This Dicky Pierson mare was the dam of old Thornton and her sister by Brimmer, son of the D'Arey Yellow Turk. Old Thornton was the dam of Chestunt Thornton by Makeless, she the dam of Lusty Thornton by Croft's Bay Barb, Desdemona by Greyhound, and Woodeock Thornton by Woodeock, son of Bustler by the Helunsly Turk. Lnsty Thornton was the dam of Brown Woolcoek by Woodcock, and Ringbone by Partner. The latter was the dam of Ancaster Starling, Madame Flirt, MIiss Starling and Miss Starling Junior, all by Bolton (Old) Starling, a filly by Bloorly Buttocks (Arabian), a filly by Reguhus, Barforth and a sister by Forester, son of Hartler's Bliucl Horse, Legacy by Cade, and the ehestunt filly Mary Grey, foaled in 1712, and imported to America, by Roundhead, son of Flying Childers. The sister to Old Thornton produced Bay Thornton, who had a filly. by Croft's Bay Barl, and four fillies by Greyhonnd. Brown Woodeock had Emma, Miss Doe and two sisters by Greyhound, Miss Barforth and her sister (dam of Miss Makeless) by Croft's Partneretc. This sister to Miss Barforth was also dam of Roger of the Vale (Jolly Roger), imported to America, by Roundhead, son of Flying Childers, Brown Slipby by Sliply, and Brown Starling by Bolton Starling. It is from this Burton Barb mare that has descended in direct female line Pheuomenon, Mungo, Dick, Warerles, Safegriard, Whiskey, Selim, Castrel, Rubens, Camillus, Ardrossan, Catton, Whitelock, Blacklock, Bobacill, St. Giles, Sir Hereules, Irish Drone, Margrave (imported), Don John, Hetman Platoff, Harkaway, Womersley, Cremorne, Voltigeur, Snrplice, Cowl, Ithuriel, King of Trumps (by Velocipede), Teddington, The Marquis (by Stockwell), St. Albans, Lord Clifden, Mask, Skirmisher, Lecturer, Camballo, Martyrdom, Pell Mell, Cirnelion, Thurio, Umpire (Tom King'), Althotas, Brag, Sheen, Gold, imp. Ainderby, imp. Billet, imp. Chance, imp. Claret, imp. Contract, imp. Eagle, imp. Hurrah, imp. Nonplus, imp. Skylark, imp. Spread Eagle, imp. St. George, imp. Thunderstorm and imp. Yorkshire.

A Royal mare of Capt. Appleyard's, bred to Brimmer (or, as some reports allege, to Son of lsrimmer), produced a filly, which, bred to Bethell's Castawas, son of Merlin, produced a filly, which filly was the dam of a filly by Bethell's Arabian and one by Commoner (Wharton's), the latter was the dam of Grey Childers by Flying Childers. This Castaway mare, above mentioned, was the dam of Bald Charlotte, first called Lady Legs, by Old Royal, son of the Holderness Turk. Bald Charlotte's daughter by the Somerset Arabian was the dam of imp. Kitty Fisher by Cade, she the dam of Wormsly's King Herod, Cripple Fearnought, Young Kitty Fisher, etc., by imp. Fearnonght, son of Regulus by the Godolphin Arabian. It is through Young Kitty Fisher and her daughter by Symme's Wildair that the noted race-horse and stallion Boston traces to this family.

The Dick Buiton Barb mare produced Ruffler aud his sister by a son of Brimmer (and mare by the Chesterfield Arabian). This sister to Rufter was the dam of a filly by Darley Arabian, she the dam of a filly by Fox, son of Clumsey by Hantboy, which produced a filly by Blaze, son of Flying Childers. The Blaze mare was the dam of Riot and Red Rose by Regulus, and Riot was the dam of Flora (the dam of Ruler by Young Marske) hy Lofty. It is to this Dick Burton mare that Ruler, Wanton, Fazzoletto, Cape Flyaway, The Speaker (by Filbert), Wallace and others trace in direct female line.

The natural Barb mare of Mr. Tregonwell, bred to Place's White Turk, produced a fills, which, bred to the Taffolet, or Iforoceo Barh, prodneed also a filly, and this filly, bred to the Byerly Turk, produced a filly which was the dam of Grey Ramsden by Grey Hautbos, a filly by Spanker, one by the Darley Arabian, and one by the Newcastle Turk. The Darley Arabian mare was the dam of Merry Andrew by Fox. Paragon by Suip, a filly by Lonsdale Bay Arabian, and a filly by Partner (Croft's). This Partner mare was the dam of Naylor by Cade, son of the Godolphin Arabian, 
Spectator by Crab, son of the Alcock Arabian, Tatler, Julia and two sisters of Julia hy Blank, son of tho Godolphin Arabian. Naylor was tho dan of contest, imp. Continel (foaled 175\%, and injorted iuto Somth Catolina), Naney and others, all by biamk, Julia was the dam of l'rizo and Promiso by Snap, and Princess by llerod.

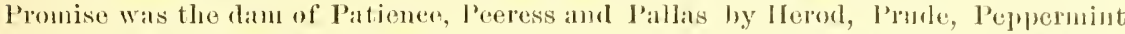
and l'muella by llighilyer, and a filly by Pot-8-o'-s. Prumella was tho daun of Penc-

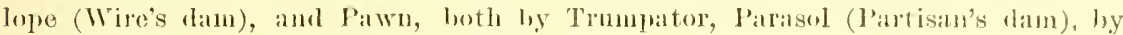
P'ot-8-o's, Pionecr hy Whiskey, Waxy Pope: (lope), wimer of the berhy in 1809, Pledge (Tiresias' dam), Pope Joan and Prndence, all by Waxy, son of Pot 8-o's by Eelipse, and Pignel hy Sorcerer. It is to this Tregonwell Barlo mare that the fibllowing horses trace in direct female line: Woodpecker, Goldtinder, Waxy Pope, Whalelone, Whisker, Partisan, 'Turcoman, Rockingham, Bay Mirlleton, John Divis, Fity Roland, Lorl Lyon, Dollar, Trumpeter, Notbonrue, The Nob, Verulam, 'l'he Cossack, Melbonrne, Bran, Gmubat, Benl'or, Rohert the Devil, Brocket, Uncis, Fetterlock, Silvio, Speculum, Charibert, Childeric, Bhe Gown, Cærnlens, Favo, Pellegrino, Trappist, Craig Millar, Silvester, Orphelin, King of Trumps (by Lord Clifilen), The Lambkin, Glen Arthnr, Controrersy, Town Hoor, Privateer, Victor Chief, The Confessor (by The Palmer), Pararlox, The Bard (by Petrarch), Minting, imp. Glencoe, imp. Eclipse (Morris'), imp. Riddlesworth, 1mp. Athlete, imp. Seythian, imu. Blue Mantle, imp. Glen Lyon, imp. Tubal Cain, Belmont (of California), Uneas, and Wanderer by Lexington, and a number of good prodneing mares.

The mares which have founded families in America are a study to lovers and admirers of racing lineage. One of the most prominent of these, whose descendants bave always been famous on the turf and in the stud, was the Cul, mare. She was a bay mare, foaled in 1762, by Cub, son of Foz by Clumsey by old Hautbor, her dam Amaranthus' dam by Second, sou of Flying Childers, grandam sister to Vane's Little Partner by Partner, son of Jigg by the Byerly 'Turk, mreat grandam sister to Guy by Greyhound (son of King William's White Barb, Chillaby, ont of Slugey, a natural Barb mare), she out of Brown Farewell by Makeless, sou of the Oglethorpe Arabian, tracing to the noted Layton Barb mare. This C'nb mare was imported along with Wildair hy Gen. Jas. DeLancey, of New York, in 1764. Willair was repurehased and sent back to England in 1773. Gen. DeLancey bred several foals by IVildair ont of this Culs mare. Hero, Monlton, Ruth Black Eyes, Bashaw (foaled 1767), and Maria Slanerkin, better known as Old Slamerkin or Miss Slamerkin, and it is from this last mare that so many of the best race-horses in our day derive their origin. Old slamerkin had (in 1788) a filly ly imp. Obseurity, son of Ectipse, Moll by imp. Figure, Fair American by Lloyd's Traveler (this line is nearly extinct), and Dido by $1 m p$. Bay Richmond, son of Feather by the Godolphin Arabian.

The Obsenrity mare of 1788 was the dam of a filly called the Robin mare by imp. Robin Redbreast, who produced Thornton's Rattler, 1816 ; Childers, 1s17; Sumpter, 1818; Elizabeth, 1819, and Flirtilla, 1820-all by sir Alchy. The horses were good stallons, and in the female ine from Flirtilla have come a large nnmber of superior race-horses. Flirtilla produced Tom Kimball, 1832, and Mary Wymn, 1833, by American Echpse, the former sent to Canada; Antoinette, 1829, and Flirtilla, Jr., 1828, by her own sire, Sir Archy; Gaslight by ump. Chatean Marganx. Flirtilla, Jr., producer, 1836, Olympius by American Eclipse ; Ringrold, a superior race-horse and gool stallion, 1842, by Boston, and Cassandra, 1838, by imp. Priam. It is to this last that we look for the descendants of this line. Cassandra produced Trojan, 18t7; Basil, 1848; Philo, 1851, all by Marmer, sop of Shark by American Eclipse; and Prophet, 1856, by imp. Monarch. Philo prodnced Constantine, 1858, by Rerenue, son of imp. Trustee, and Lady Blessington, 1861, by imp. Eclipse, son of Orlando by Touchstone. Lady Blessington produced Count D'Orsay, 1870, a good race-horse, by Kentueky; The Conntess, 1871, by Kentncky; The Baroness, 1874, by Kentucky; Lord Lytton, 1876, by Kentncky or KingGisher, 1878, Lady Roselsery, 1878, Fairwater, 1880, Dnehess, 1881, and Lord Beaconsfield, 1882, all by Kingfisher. The Conntess was the dam of Falco, Le Petit Dne, Contessa, Grand Dnke and Peeress by imp. In Used. These all raced well, and Contessa is the dam of the 
winner Midget by King Alfonso. The Baroness is the dam of Baronella (Music's dani) by imp. Matatlor, son of Gladiateur, Ballerina and Badge (a very superior race-horse and winner in fast time), both by imp. 111 Used; Barcarola and Berceuse, both by Falsetto Lady Rosebery was the dam of Lady Primrose, Lady Margaret, and Lord Dalmeny by imp. Ill Used. These were all good performers on the turf and raluable in the stud. Fairwater is the dam of Gracie by imp. Siudartha, Latie by imp. Hacaroon, and Laughing Water (a good two-year old) by imp. Dalnacardoch. Duchess is the dlam of Watterson, a gool race-horse, by imp. Great Tom.

Old slamerkin prodnced Moll (Young Cub) by imp. Figure. Holl was the dam of Cockfighter and Esopns, good horses, by imp. Grey Highlander; Major Holl and Lady Jane by imp. Obscurity; Jane Hunt, 1796, and her sister by Warle Hampton's Paragon, son of imp. Flimnap, son of South by Regulus. It is from Jane Hunt that this line descends to us. She was the dam, 1802, of Indiana by Butler's Columbus, son of imp. Pantaloou by Herod; Shepherdess, 1803, by imp. Speculator, son of Dragon by Woodpecker by Herod; Sally Sneed, 1807, by imp. Buzzard; Tiger, 1812, and Greeian Princess, 1816, by Cook's or Blackburu's Whip, son of imp. Whip. Indiana was the dam of Hamsah Harris (Paragon), 1807, by imp. Buzzard. Hannah Harris produeed Aurora, 1817, by Aratus, son of Director by Sir Arehy. Aurora prodnced Lancess (Miss Lancess), 1835, by Lance, son of American Eclipse. Lancess raced successfully, and was the dam in 1844 of Ariel by imp. Sarpedon, 1845, Fanny G. by imp. Margrave, sou of Muley, and, 1849, Emma Taylor by imp. Glencoe. Ariel produced Corinne, 1852, by imp. Glencoe, and she in 1861 produced Virginia by Rerente, son of Imp. Trustee. Virginia in 1863 prodnced Jennie C. lyy Norfolk, 1875, Lottery, and, 1879, sister to Lottery by Mouday, son of Colton by Lexington, 1883. Virginius by Longfield, and in 1881 Bagatelle by Jim Brown, son of Foster by Lexington. Jennie C. is the dam of Mark L., 1875, sister to Mark $Z_{\text {.., }} 1879$, and Prudence, 1855, all by Monday, and Jessie C., 1887, by Bishop, son of Shannon by Monday. Sister to Lottery is the dam of Loto, Corona and other tillies by Norfolk, sou of Lexington. Fanny Gr. was a speedy, good race-mare, and the dam of Liz Mardie, 1553, by imp. Glencoe; Endorser, 1856, a tine race horse, by Wagner; Flora G., 1859, Falcon, 1860, Lady Dan Bryant, 1862, all by Lexington; Emma Maratta, 1865, and Viclette, 1867, both by Vandal; Estella, 1865, by imp. Australian. Estella is the dam of Alma Mater, the dam of the trotters Aleantara, record 2.23; Aleyone, 2.27; Alicia, 2.30; Almater, 2.291, and Arbiter, 2.22沜, and Fanny B., 1870, by Asteroid. Liz Mardis was the dam of Leon, 1864, Sir Rnfus, 1868, and in 1873 of a baly filly, all by Lexington; Coquina, 1870, by imp. Australian; Dame Winnie, 1871, by Planet (she the dam of Bridget Ella, 1878, by Wanderer, son of Lexington, and the trotters

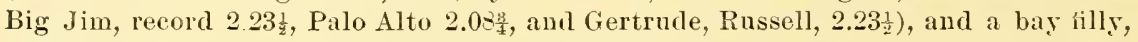
1873, by Asteroid. Leon produced ehestnut filly, 1869, by Colossus, and Galt Reporter, 1870, by same; Lottie, 1874, by King Tom, son of Lexington ; Mecea, 1882, by imp. Billet, and Hindoostane, 188t, by Hindoo. Lottie by king Tom is the dam of Winnamueca, Ballet and Bassanio by imp. Billet, and Houtpelier by Hindoo. Estella is also the dam of bay filly, Timbrel, 1879, by imp. Saxon, Miss Laly, 1882, by Falsetto, Welcome, 1883, and Stella, 1885, both by imp. Mortemer, and Ethelda, 1884, by imp. Moceasin, son of Macaroni; the last named dam or Ethelair by imp. Pizarro. Enmma Taylor produced Eva Bulwer (Miss Bulwer), 1857, by Bulwer, son of Grey Eagle, she the dam of Rutb Ryan and Jewel by Lodi, son of imp. Yorkshire. This stock is owned in California. Emma Taylor is also the dam of Montezmma, 1859, Strideaway, 1853, and Trampolette, 1860, all by Billy Cheatham, son of Craeker by Boston. Trampolette produeed Julia Morgan, 187i, Mercedes (Vivaudière), 1576 , and Gipsy, 1879, all by Lodi. Nereedes is the dam of Manie T. and her sister by Wheatly, sou of War Dance. These are owued in Rancho del Paso stud, California.

Hamnah Harris also produced Jenny slamerkin, 1823, by Tiger, he by Whip, out of Jane Hunt, the grandam of Hannah Harris. Jenuy Slamerkin produced Miss Obstinate, 1829, by Sumpter, and The Mule and her sister by Medoc, son of American Eelipse. Miss Obstinate greatly increased the reputation of this family. She was the dam of Morgiana, 1834, by Thornton's Rattler (brother to Sumpter), Mary 


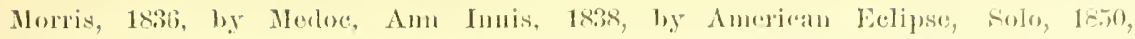

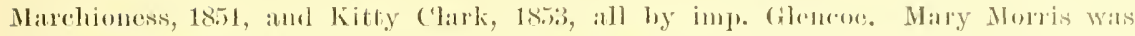

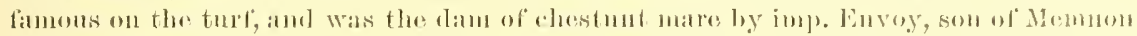

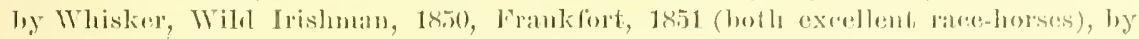

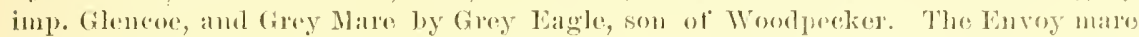

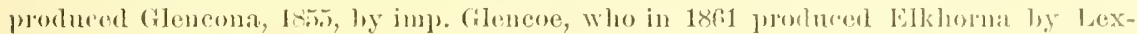

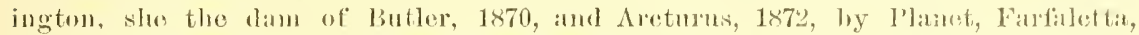

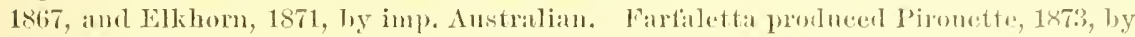
Harvey Villian, son of Astemid, Felicia, 187., ly imp. Placton, Falsotto, 1876 (a grand race-horse and one of the polnlay stallions of tho day), and his sisters, Fortuna, 1875, and Far Simile, 1881, by luquirer, Farfalette, 1886, by imp. Siddanthar. Pironette prodneed llattie Ilarris, 1880, Wool River, 1881, Avondale, 188:2, Grem of the Momntains, 1883, ancl Snsie s., 188t, all by Marmaluke, son of Euquirer. Hattio Harris is the dan of the wimners Spectator by springlok, and Cornie Buckinglatu by Powluttan. The lemainder of this branch of the tamily are in the Fleetwood stucl, Kentueky, and have brod winners.

The Grey Eagle mare prodncer Eagless. 1855, by inp. Glencoe, American (Volscian), 1857, by Vantal, l'riscilla, 1859, by inp. Scytlian, Annette, 1860, by Lexington, Jenny H., 1861, by imp. Knight of St. George, Della, 1866, lyy Ritleman, son of Glencoe, aurl, in 1867, a grey filly by Lodi. Eagless produced Lnua, 1863, and Mat Eagless, 1864, ly Swigert's Lexington, son of Lexington, Nary Clark, 186, and Lexington Belle, 1875, log Lexington, Grey Planet, 1869, Steel Eyes, 1871, and Eaglet, 1876, all by Planet, and, in 1-70, Lizzie Lucas ly imp. Anstralian. They nearly all raced successfully. Luna was the dam of Glenuary, $187+$ (a twin), by inp. Glenelg, Mamie R., 1877, Nimnie D., 1878, both by Longfellow, and Namie R., 1879, by Yirgil. Glenmary is the dam of Glen Ban and Catharine Ban by imp. King Ban, and bay mare Loraine by Lisbon. Namie R. left the filly Cheekie, by Longfollow. Mat Eagless produced Juanita by Wanderer, aud she prodnced Tita, Fanita, Carroll, Blue Vail, Hazel Hurst and others. Mary Clark produced Preciosa, 1876, Spark, 1878 (both winners), by imp. Leamington, Pure Rye, 1883, Grey Dawn, 1885, and oll Rye, 1886, winners, by imp. Billet. Lizzie Lueas probuced Cerise by imp. Noceasin (she the dam of Cherry Stone by King Bolt, and Wild Cherry by Wilful, and the great twoyear old Morello by Eolus, wimmer of 11 ont of 14 races this year), Chimera (daum of Chimere by Irornois), Cyclops, Cambyses, Cleola, Cleofas and Veva by imp. Mortemer, and Leonora by imp. Sir Modred. Eaglet produced Olanthe, Laura Garrison and spring Lagle (Sadie Me) by Springbok. Annette went to California. She was the dam of Oliver Cromwell, Charley Chase and Camilla Vrso by Lusli, Carrie C. (Covey) by Monday, and Jim Farley by Hubbard, and the trotter Ansel, 2.20, in Mr. Rohert Bonner's stud. Camilla Urso was the dam of Raren by Monday, and Armada by Crichton, son of Glencoe (she dam of Meda Howard hy Sarramento, son of Rifleman, and Hazel hy Balboa, som of Norfolk), Miss Camilla (Mozelle) by Monday, and brown mart, 1880, by Shannon. Carrie Covey is the dam of Marin by Thad. Sterens, son of Langforl. Marin is the dam of Reata loy Milner, and Marinette by imp. Partisan, son of Tomahawk, Catalina by Wheatly, Sonoma by Longfield, and Bessie Barnes by imp. Darehiu. Jenuy 1I. protuced Jenuy Plark, 1867, and Jemuy Patterson, 1869, by imp. Australian, Jentling and Saturn hy Planet; Darnley, Ada S. Manette and Toledo by Asteroid, Rosa R. and Useful by l'at Malloy. Jentling is the dam of Vassar by Tirgil (she the dan of Vellum, Mary Porter, Perkins, alias Ben Hur, and Paris by imp. Billet, and a hay filly, 1888, hy the same sire), Grentle by Baywood, and bay filly, 1888, by imp. Rotherhill. Ada s. produced two tillies, Leonat aud Surprise, by Big Fellow, son of War Danee. Manette prolluced Maryetta by Rerl Bluff, son of imp. Australian, Emma Gene and sister by Storey, son of Monarehist. Useful is the dam of Patmos, Laura Forl, ete, by Lougfellow. The Hule prolluced Onr Gal, 1850, Joan D'Are, 1851, and Margaret Morris, 1852, by imp. Glencoe, the last of which was the dam of Harper, Marynis, Marsellaise, Mary Morris and Morris, all by Lexington. Wary Morris was the dam of Lizzie Gant (Bol, Forsyth's ram), Annie Lexington (dam of Brevet by Brigadier, and Bomnie Annie by scot- 
lander), both by Exchecrner, son of Revenue and Bounie Park hy Bonnie Scotland, she the dam of East Lake and Bonnie May by Enquirer, and Bracken by Branble.

Kitty Clark, 1853, by Gleneoe produced Charlotte Buford, 1857, Amn Clark, 1859, Dr. Lindsey, 1e61, Maiden, 1863, La Henderson, 1865, Uncle Nick, 1866, and Utica, 1870, all br Lexington, Rosa Clark, 1864, and Kith, 1873, both by imp. Australian, and Glendolen by imp. Glen Athol. Charlotte Buford was a good mare and the dam of Charade, Culloden and Florence I. by imp. Anstralian, and Ida May by Planet. Florence 1 . is the dam of Florence Payne by Blarneystone, Florence Lamertine by Tom Bowling, Florence Cook by War Danee, Powhattan II. by imp. Glenelg, Florio by Virgil, Florence Fonso by King Alfonso, Florimer by imp. Rayon d'Or, ete. A majority of these were good race-horses, and Florio is the dam of the winner Franeo. Ida May is the dam of Flotsam (Pumice's dam) by Warerly, Jetsam (the dam of Venture) by imp. Strachino, son of Parmesan, and Chissie May, ete., by Clipses. Ann Clark prodnced Aspire, a bay filly by Escape, son of imp. King of Cymry, Mrs Winslow by imp. Australian, and bay filly by Crichton, son of Glencoe. Aspire is dam of Alice Murphy (dam of Donatello and Alice Racine) by Jim Mnrphy, son of West Roxbury, and Josie (dam of Oleander by Aliunde, and Secret by Tennyson) by Ramadan. Mrs. Winslow is the dam of Methilde and Mateal, by Restless, son of Voncher. Maiden was the best filly of her year, and wimner of a number of good stakes, including the Travers at Saratoga. She was the dam of Lady Washington, 1870, by Beacon, son of Lexington, James A., Parole (gelded, and one of the best race-Lorses of his das, wimner in hoth America and in England), Mineola, Perfection, Pawnee (gelded), Paproose, Paw Paw and Powhattan, the successful stallion, all ly imp. Leamington, auk Parthenia by Alarm. Lady Washington is the dam of Combination bs Crockford, son of Lightning, Aileen by Amadis, son of Riroli, Martha Washington by Volturno, son of imp. Billet, ete. Perfection is the dam of Smilax by imp. Saxon, Perception by imp. Mortemer, Saluda by imp. Mortemer, Perfecto hy Duke of Magenta, etc. Pappoose is dam of Parolina bJ Duke of Montrose. Parthenia is dam of mare Rizpaln by imp. Nortemer, and mare Persistence by imp. Sir Modred. La Henderson was the dam of Kitty Claborn by Jerome Edger. Planetia by Planet, Virgilian (a good race-horse), and Vanguard by Virgil, the noted Ferida (four miles $7.23 \frac{1}{\frac{1}{2}}$, fastest ever run by a mare), Aella, a superior race-mare, and Ferona, a winner, all by imp. Glenelg. Planetia is the dam of Placid (Playfellow's dam) by Enquirer, Virginia (Lilly M.) by Yirgil, Fostress (Question's dam), by Foster, Plantress and Ned Cook by Flood, and others. Ferida is the dam of Fay, Medje, Flitaway, Carrie C. and a filly, etc. by Sensation. Aella is dam of Prince George, a winner, Thrill, and three colts by Sensation, the nnbeaten.

Rosa Clark was the dam of Lilly Clark, Lulu Baxter and Judge Spofford by Watson, son of Lexington, Maguolia Clark, Clark and Ophelia Spofiord by imp. Canwell, son of Stockwell, Barclay and Fronie Lonise by imp. Glengarry, son of Thormanby. Lilly Clark is the dam of Goliad, Beulah Clark, Mattie Jackson and Olive Tarcoe by Heretog, son of inp. Anstralian. Magnolia Clark is dam of Pa!metto (Bamboo's (lam) by inp. Glenelg, Emma Mack by Ten Broeck, Ae-le-ta and Iiossuth by Longfellow. Glendolen is the dam of Alsace by Aramis, Atticus by Aristides, and filly by Punster. Kith is the dam of Kinsmatn, a winner, by Houarehist, Tic by Virgil, and Gold Fish by Prince Charlie or Virgil.

Ann Innis by American Eclipse was the dam of Hebron, a good race-horse, Vivandiere and Jim Barton, a good winner, by Grey Eagle, son of Woodpecker, Maria Innis by imp. Yorkshire, and Swigert's Lexington aud La Grande Dnchesse by Lexington. Maria Imis was the dam of Bulletin, Echo and Kathleen by Lexington, Sorereign Eclipse by imp. Sovereign, Australian Chief, Lagonda and Emma by imp. Australian, Select by Swigert's Lexington, and Meteor by Asteroid. Echo was the dam of the geldings Report and Duplex, good race-horses, Nemesis and Naptha by imp. Echipse, Eeboless and Annie IIall by imp. Leamington, Court Hampton by imp. Hampton Court, Eccola (Rose's dam) and her sister by imp. King Ernest. Echoless was the dam of Resomd and Peanuts hy imp. Hampton Court, Glen Echo and Re-Fcho by imp. Glenelg. Nemesis was the dam of Vengeance and sister by 


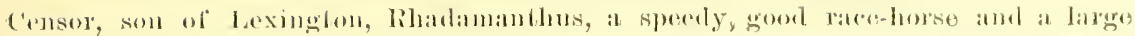

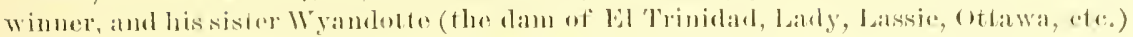

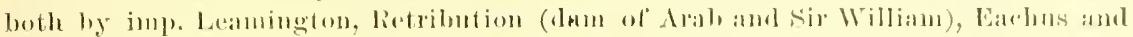

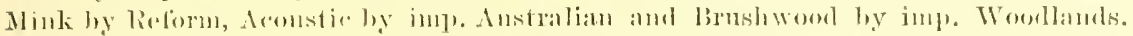

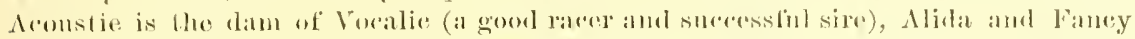
by Virgil, Music, Arasia, ote., loy imp. (Henelg. Naptlat was the dam of Gollen Gate loy imp. Leamington, Explosion and Gleam ly imp. Mampton Come, son of

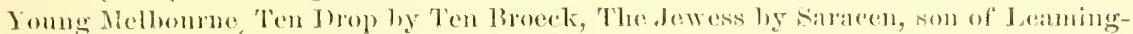
ton, Miss Hattie by Falsetto, ete. Coldon Gate was the diln of Landa Wiustom, Faralone and Oro by Nortalk. Lanra Winston is the dam of Mliss Marker, Snowelpop, Broncluo and suowball by Joe llowker. Explosion is the dam of Jangerons ly Saxon, Disdain (lam of Omesa, Grand Dnke, Arrogance, ete ) by inp. Moceasin,

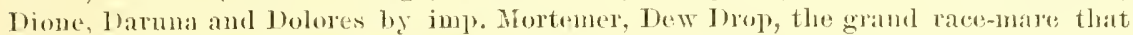

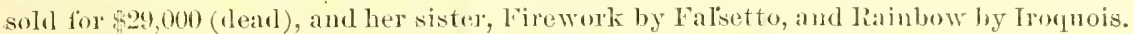
Gleam is the dan of Glitter by imp. Stylites, Firlelia amd Flemington by Falsetto, ete. Kathleen is the dam of Kennesaw, a good horse, Kathairon (dam of Kathleen by Shamon, Keeprake by Flool, and Kenueth by Joe Honker) by Hary of the West, son of Lexingtou, John Happy and the superior race-horse George Kinney by imp. Bonnie Scotland, Hetty, Keunebeck, Khartonm and Pullman by imp. Glengary, kern lyy Teu Broeck, Katuma ly Bramble, etc. Emma by imp. Australian was dau of Julge Huray by Tanxhall, Maggie Duffy loy Charley Howarl, J. O. Nay by Felloweraft, Charity by Sensation, etc. La Gramle Durbesse was the dam of Metella, Aniella and Christine by imp. Anstralian, Elsie by imp. Bonnie Scotland, Mlarmion by Planet, Talisman and Uberto by Virgil. Metella was the dam of Misadie and Miss Ella by Enquirer, the latter dam of Lita, alias Lyda (the dam of Jum Jum, Michael and O. K. by Regent) by imp. Trme Blue, son of Yerlette, Maretzeck and Mariet by King Alfonso, Mendelssoln hy imp. Buckden, Whisperine (clam of Whisban) by Whisper, Miramar (dam of Iola) by Longfellow, Metal by Blue Eyes, amel Maga by imp. Sidclartha. Aniella is tho dam of Allegro (the dam of Aria, Lizzie L. and Conrad O. by Whisper), Anniban by King Ban, Annona and Analem by Blue Eyes. Elsie is the dam of Etma (lam of Ontset, Ontstep, Ontbonnd aud Ontspeed) by King Alfonso, Egeria by Lever, Rumor and Eola by Whisper, Eros II. by Lisbon, ete. Christine is the dam of Gypsy by War Mance, Bonnie Australian, Vice Regent, Montana Regent, Julia L. and Higl Tariff by Longfellow, aus Beth Broek by Ten Broeck. Gypsy is the clam of Pat Regent, Don Regent and King Regent by Regent, and Poet Scont, a superior race-horse, by Longfellow, Gypsy Girl and Lorna Doone by imp. Sir Modred.

Sally Sneed by imp. Buzzard was the dam of Grey Goose by Pacolet. Grey Goose was the dam of John Bascomb, a famons racer, aml his two sisters, Lady Humtsville and Hanmah Harris by Bertrand, son of Sir Archy, Pilot and Glance by Wild Bill, som of Sir Arehy. Lady Huntsville had two fillies by imp. Consol by Lottery. One of these fillies was the dam of Betty Wharton by Othello, son of imp. Leviathan, and she the dam of the good race-horse and stallion, Rebel, and his sister, Miss Socks by Socks, son of imp. Albion, Amna Bishop by Lytle, son of Jim Allen (she the dam of Betty Bedforl by Rupee, aud Ellen Lane by Tar River), West Maria (Anua Hurst's dam) by Gew. Burleson, and Last Clanee by Regent. Glance was the dam of Little Mistress by imp. Shamrock, she the dam of Little Miss by imp. Sovereign, she the dam of Letty by imp. Anstralian, the dam of Grace and Lettina by Harry Bassett, Letretia and her sister by Tom Ochiltree, and Refund by Sensation, Little Miss was also dam of Uga by King Alfonso, and she the clam of Lltimo by Red Bluff, Ianthe by Storey, etc.

Grecian Princess, 1816, sister to Tiger by Blackburn's Whip, was the clam, 1829, of Aun Merry by Sumpter, Titus (Cripple) by Medoe, ete. Ann Merry was the clam of Mirabean and Cub (a superior race-mare) by Medoc, and Barilla by Lient. Bassinger. Cub was the dam of Sportsmistress by American Eclipse, Monte (a good racer) and Martha Buford by Waguer, a filly by imp. Trustee, Famuy Fern and Faun Camplell by imp. Glencoe. Sportsmistress was dam of Aruolı Harris by Whalebone, 
Charles Harris by Wagner, Susan Harris by Revenue, and Alfred Harris by imp. Sovereign. Susan Harris produced Zadoe by Harion, and Coguette by Lexington, the latter the clan of Vivien by imp. Leamington, Viola by inp. Eelipse, Variety, Vixen and Maid of Athens by imp. Saxon, Dolinka by imp. Mortemer, and Cornette by Iroquois. Vivien is the dam of Conanche by Leinster, Yommg Bazar aud Aunt Jane by Bazar, owner in California. Viola is the dam of Mamie M. by imp. Saxon (she the dam of Lille and Lancer by King Alfonso), Blaze Duke by Duke of Magenta, Prosperity by Onondaga, ete. The Trustee mare, out of Cub, produced a filly by $2 d$ Altorf, which was the dam of Lizzie Lewis and Stella Price by Epsilon, son of Pacific. Lizzie Lewis was tlie dam of Varina Bradford by Abu Beelier, som of Mahomet by imp. Sovereign, she the dam of May Curl and Peerless by Bill Bass. Stella Price was dam of Plover Wing by intp. Stone Plover, son of Cotherstone, she the dam of Lady Longstreet by Gen. Longstreet (she the dam of Kate by Frogtown, Bella Golden and Atossa by Bowie, son of Leamiugton), Nancy by St. Valentine, Golden Plover and Minnichee by Chariton, son of Pat Malloy, and Tooan-Tuh by Frogtown.

Martha Buford by Wagner was the dam of Mantua by Lexington, Martha Bnford by Ringgold, son of Boston, and Mand by imp. Australian. The last named produced Bonuie Scotia and Paper Maker by imp. Bonnie Scotland, and Eurydice by imp. Leamington. Eurydice had a filly, Astoria, by imp. Athlete. Fanny Fern was the dam of Engene by Rerenue, Oleata by Lexington, ete. Oleata was the dam of Emily Fuller, Pollywog, Osseo and Oleaster by imp. Eclipse, son of Orlando, Olitipa (one of the speediest mares erer foaled) by imp. Leamington, and Oclessa by imp. Glenlyon, son of Stockwell. Enily Fuller is the dam of Prosper, Pantaloon, Olive and Persuasion by imp. Leamington, Florence E. by Reform, Xallapa and Brussels by imp. Billet, Hammah Moberly by Hindoo, ete. Nearly all these race well. Olitipa. is the dam of Olivia and Orator by imp. Ill Used, Mary C. (Ophelia) by Kingfisher, St. Omer and St. Olga by imp. St. Blaise. Olive is clam of Olivie by Tom Ochiltree, Oliver Twist, All Fours and Oliver by imp. The Jacobite, son of Prince Charlie. Odessa is dam of Udessa by imp. Lhlau. Fanny Camplell produced two fillies, a chestuut filly, 1851, and Gentle Annie by Monte, son of Wagner, that were owned by George Treat, California.

Major Moll by imp. Obscurity was the dam of Patrick Highlander by imp. Brown Highlander, and a filly by Wade Hanpton's Paragon. This Paragon mare was the dam of a filly by imp. Buzzard, and a filly by Copperbottom, son of Brilliant. This Copperbottom mare was the dam of John Henry by Aratus, and Hunter's Duke of Bedford. The Bnzzard mare was the dam, 1826, of Mary Hunter and, 1828, of Kitty Hunter by Marris' Paragon, son of Blackburn's Whip. Kitty Hunter was the dam of a flly by Hephestion, Am Stewart, a good racer, by American Eelipse, and a filly by Goode's Arab, son of Sir Arehy. This blood is only preserved throngh these. two mares. The Goode's Aral mare was the dam of Geneva, a good race mare, by Medoe, she the dam of Madame House by imp. Leviathan. The latter was the dam of Maria and Carrie Cage by imp. Sorereign, Villir Allen (the dam of Pearl by Buekmaster) by Hiawatha, son of imp. Albion, and Epizootic by Rogers, son of Lexington. Maria was the dam of Pennyroyal by imp. Albion, she the dam of Wild Addie and Lnlu L. (Parepa Rosia) by Caledonia, son of Bonnie Scotland. Carrie Cage was the dam of a filly by Jack Malone, Miss Cheatham by Bill Cheatham, son of imp. Albion, a filly by Bulletin, son of Lexington, Betty Bell and Eppie L. by Surprise, son of imp. Bonnie Scotland. Miss Cheatham is the dam of a filly by Prolifie, Cousin Cheatham and Third Cousin by Lncle Vic, and Amelia Johnson by Uncle Tom. Betty Bell is the dam of Bettie L. (Lille MeElwain), Yodena's dam, and Brigade by imp. Brigadier, and Bagatelle by imp. Ill Used. Eppre L. is the dam of Peekskill and a filly, 1888 , by imp. Billet, Lizzie B. and Purity by Hindoo. Epizootic is the dam of Sweetheart by Jack of Diamonds, and she the dam of Va Tout by Faustus, and Omen by Vandal, Jr., son of Vanclal.

Mary Hunter was the dam of Mary Streshley by John Henry, Miss Singleton by Koseinsko, Streshles, Webster, Enerine Price and sister to them by Merloc, and Lady Lovell by Sir Lovell. Mary Streshley produced Neoma Ferguson, John Horace, 


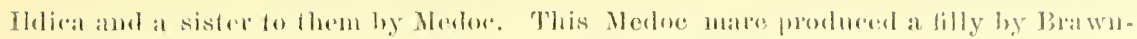

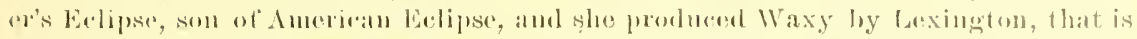

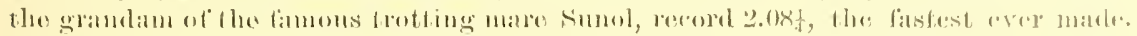

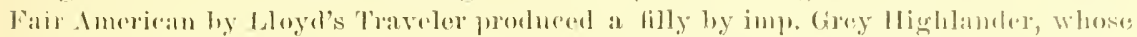

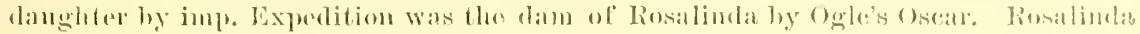

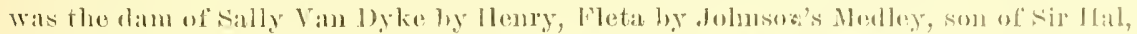

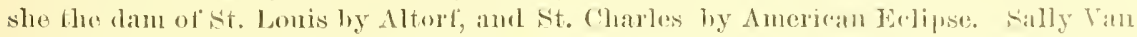
Dylio prodneed a tilly ly Ihugh L. White, son of imp. Leviathan. Oscalomsa is the dam of Olio hy Memmon, son of Epsilon, and she the dam of the Rehe] ruare, fam of Euvenom and Eight to Keven by Enguirer.

Dido by inm, Bay Richmom fomded what is now known as tho Morgan finnily. Dislo produced Prizefighter by imp. Expedition, and Zelipha by imp. Nessenger. Zalipha probluced two bllies, though which the blool is perpetuater, viz., Anrora by imp. Honest John, son of Sir Peter, and Honesty hy imp. Experlinin, som of Pegasus by Eclipse. Amrora produced a tilly by Sir Solomon, son of inup. Tickle Toky ly Alfred by Matchen. This filly was the daun of Matehless by imp. Experlition, she the dam of Lady Morgan by Johu Richards, son of sir Arehy. Larly Morgan was the dan of Sally Morgan by imp. Emaneipation, son of Whisker, and Polly Rowe by Eutaw Shark. Sally Morgan was the dam of Mary Blueskin ly. Grey Eagle, a good race-mare, Miss Morgan and Bondy by imp. Yorkshire, Panic by imp. Glencoe, and Ara C. and Dolly Morgan by Revenne. Miss Morgan was the dam of Mazurka, Mignonette (Mimnie Milton), and India by Lexington, Mattie Morgan and Ave Maria by imp. Anstralian, Addie Hart and Peggy Morgan by Asteroid. Mazmrka was the dam of Mimnie Irown, Gyptis, Zoo Zoo, Tjphoon amd Rebecea, all by imp. Australian, Tallula!, Carlina and Maze by Planet, Zulite (dam of Lela May) by Lisbon, Bull's Head, ete. by King Alfonso. Mimnie Brown was the dam of Medina by Watson, Elissa (dam of Lizzie K. and Lela K.) by Enquirer, Eleanor C. by Powhattan, The Don by Lisbon, ete. Tallulah is the dam of Barbary, bithesome, Bounie Meade and Bribery, all by imp. Bonnie Scotland, Tarantula (Centipede and Tara Blackbum's dam) and Termagant by imp. Great Tom, Tally-Ho and Bettina by Bramble, King Iro by Iroquois, and Talluda by Enquirer. Barbary, a minner, is the dam of Robert Bruce, Tip Top, Rhadamantha (the dam of Little Girl), Miss Mand and Sir Abuer. Blithesome is the dam of Leipsic, Kee-Vee-Na and Irantanga, the tro last by Enquirer. Bonnie Mearle was a winner, and is the dam of Trophy (in Rancho-del Paso stud) by imp. Great Tom, Exile, Eukonia, Nellie B., Kenpton, Reporter and Basil Duke by Enquirer, Dictum and Belle Meade by Iroquois. Briber' is the dam of Lidla C. (Enguerande), Miss Ford, Znieika, Boodler, Blne Dress, Baldwin, Tom Paxton, ete., by Enqurer. Gyptis, a winner, is the dam of Annie C. (Godiva) by imp. Saxon (she the dam of Violet, Vanity, Mamie R. and Ittie Reno by Vanguar(), Golconda by imp. Glenlyon, Moula and Tyrone by imp. Mortemer, Magenta and Fabian by Duke of Magenta. Maze is the dam of Quandar (the dam of Uncertainty by Virgl or Monarchist) and Gleam by imp. Glenelg. Zoo Zoo, a winner, is the dam of Zamora by imp. Saxon, son of Beatsman, Zamor and Zolsel by imp. Mortemer, and Zulu by imp. Pizarro. Zicka is the dam of Leather stocking by imp. Moccasin, Astoria by imp. Kantaka, Zara (Lulu S.) by imp. Mortener, and Pagau by imp. Pizarro.

Mattie Morgan was the dam of Alberta by Watson (she the dam of Mamie K. by Ballukeel, Glen Ellen by imp. Glengary, and Briganzee by imp. Brigadier, son of Monarque), Matagorda, a wmmer, hy imp. Glengarry, she the dam of Enright by Enqurer, Right, Ontright, etc. by Onondaga. Ave Marra was the dam of Martica by Daniel Boone, and a filly by imp. Buckden. Martıca is the dam of Bric-a-Brae (dam of Miss Ryan and Algonquin by imp. Bomie Scotland), Evelyn and sister by Enqurer, Mountain Deer by Iroqnois, ete. India is the dam of Catheart by Lisbon, Calcutta by King Alfonso, and Gallifet by Falsetto. Peggy Morgan is the dam of Austraoid. (the dam of Ubet, Doruix, Mary Tindall, Assiniboine, ete.) by Red Bluff,Petite by Stores, etc. Addre Hart is the dam of Orange Girl, Beck and Bias by Bertram, son of Kentucky, aud Brentano by imp. Great Tom. Dolly Morgan was the dam of Jennie Morgan, 
Ambush and Hayti by imp. Anstralian, Stampede, a fine race horse by War Dance, Aurelins by Asteroid, Pearl Thorn, Bob Miles, Frankfort and a sister by Pat Malloy, aud Despenia by King Alfonso. Jennie Morgan was the dam of Minuie 'T. Morgan (the dam of Gen. Monroe and Fosteral) by Enquirer, Glenival by imp. Glenelg, and Scully by Tom Bowling. Hayti is the dam of Hope, Exeter and Hazel Kirk by Lever, Roger Eastman and Virgilina by Virgil, Haytienne, Genie, Jack Batchelor, My Chick, etc. by imp. Glenelg. Pearl Thorn is the dam of Pearl Set, Pearl Rivers and Pearl Top by Falsetto. Ada C. is the dam of Pill Box, Ballot Box, Abluey, Conner, Treasure Box, Spriug Box, Nareola and Lueky Baldwin by Norfolk, and Surinam by Joe Hooker. Abbey is the dam of La Scala, Porter Ashe, etc., by Joe Hooker, and Osric, a winuer, by imp. Cheviot. Polly Rowe has only one line left, through her danghter Mary Good by Bill Cheatham. She produced Belle of Rockhill by Lynchburgh, son of imp. Leamington, she the dam of Mark Master and Mamie B. by Abdel-Koree, and Daisy by Westminster.

Honesty by imp. Expedition was the dam of Tormentor, Flagellator, Gen. Jackson and Jommouth Eclipse, all good horses and winners. Jonmonth Eclipse was by American Eclipse. He stood in Kentucky and adied there. Honesty also prodnced Heleu Mar by Thornton's Rattler, and Ethelinda by Marshal Bertrand, son of Marshal Duroe by Duroc. Ethelinda produced a filly by imp. Barefoot, which was the dam of Esta by Bolivar, son of Thornton's Rattler. Esta was the dam of Nellie Graves by imp. Eclipse, she the dam of Invergarry and Kate Florence by imp. Leamington, and Kate Florence, the dam of Florrie (Ioue) by Pat Malloy, Gralneca by Kingfisher, and Milesia (the dam of Silvy) by Milesian. It therefore appears that a mare foaled 130 sears ago, throngh one danghter by imp. Wildair, has left scores of descendants who are now racing and wimning. All have speed and stamina, and when any of the mares in the female line to Old slamerkin are bred to horses of pure pedigrees and racing lineage they prodnce race-horses. An examination of the Barb mares will show the distinguished race-horses and stallions tracing to - the Laston Barb mare, to which the DeLancey Cub mare traces.

Duchess (Bland's), called also Diamon l, was foaled about the year 1755 or ' 56 and imported to America by Gen. Alexander Spottswoud. She was by the Cullen Arabian (as also was Jack of Diamonds, imported at the same time), her dam Lady Thigh (Grisewood's) by Croft's Partner, son of Jigg by Byerly Turk, grandam by Greyhound, a natnral Barb, great-grandam Sophonisba's dam by the Curwen Bay Barlb, great-great-grandam by D'Arey's Chestunt Arabian, tracing throngh daughters of Whiteshirt, Lord D'Arey's old Hontugn, Hantboy and Brimmer to a Royal mure. Dnchess was the dam of Apollo and his sister by imp. Traveler, son of Partuer, a filly by Junins, filly by imp. Jack of Diamonds, True Whig by Fitzhngh's Regnlus, son of imp. Fearnought, and a filly by imp. Regulus, son of Regulus by the Godolphin Arabian. This blood is transmitted to us throngh her two danghters, by Jack of Diamonds and imp. Regulus.

The Jack of Diamondis mare, bred to Ariel (son of imp. Traveler by Partner and imp. Selima by the Godolphin Arabian), produced a filly which was bred to imp. Fearnonght and prodnced a filly which was bred to imp. Highflyer, son of Hightyer by Herod. This Highti, fer filly, hred to Melzar, son of imp. Medler, produced Maria, and she produced in 1817 the bas mare Lady Grey by Robin Gres, son of imp. Royalist by Saltram by Eclipse. Lady Grey in 1821 prodnced Lueş by Orphan, son of Ball's Florizel by imp. Diomed, in 1823 bay mare Naria by Davis' Hamiltonian, son of Tayloe's Hamiltouian by imp. Diomed, and in 1826 chestnut mare Rowena by Sumpter, son of Sir Archy. Luey was the dam of Blacknose by Medoc, a tine race-horse, Dick Chinn by sumpter, and Lucilla by Trumpator, son of Sir Solomon. Lucilla was the dam of Carlotta by imp. Trustee, two bay fillies by imp. Tranby, son of Blacklock, and a bay filly by Old Boston. The Tranby mare, foaled in 1s3s, was the dam of Alaric, a fine race-horse by Mirabean, Levity by imp. Trustee, Atala, a superior horse, by Boston, Vandal and Volga by imp. Glencos, and Tistula by imp. Seythian. Tandal was one of the best race-horses of his day (winner of 3-inile heats in $\left.5.36 \frac{1}{2}, 5.33\right)$. 


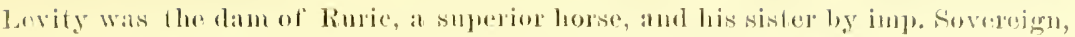

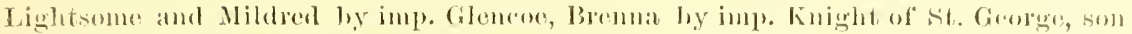
of lindeateher, laver and Legater, a good racer, hy Lexingtom. Lightsome was the

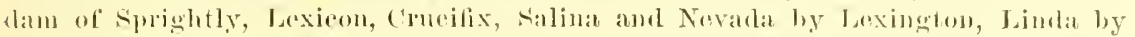
imp. Seythian, son of Orlando, Lively, by limggold, son of lioston, limmet by Isteroid, anch Guharo by imp. Glen Athol. Sprightly was brexl to trotters for yoals,

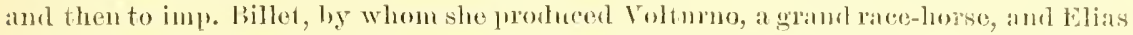
Lawrenee, a good ono and winner at 3 miles at thee gears old in 5.28ta, Lamy Way by imp. Lelipse, Avalon and Aretino (the last a grand race-horse) by dramis, sen of imle. I'lateton. Jaty Way is the dam of Fox Glove by Lever, amd laty Way warl by Virgil. Linda had no chance in the stud, but was the dam of Linda Grenen (Tetere's dam) by imp. Anstralian, and Neptums, a goorl race-loose, by I'lanet. Crucitix was the dam of Fairplay, a good raeer, by Tirgil, Semper felix by imp. Phatou, Cruciform, Crusader and lslanche J. by imp. Australian, Quito (Cuipule), The . Iudge (Cortova), Cortez, St. Angustine, a good lusse, and La Cruz by King Alouso, Maria D. by Lisbon, Cross Fire and St. Albans by Falsetto. Semper Felix is the dam of Semper Vive by Waverly, sum of imp. Australian, Semitone (Kate J.) by imp. Bucklen, Leonatus, a grand race-lorse and successfin stallion, by Longfellow, Latonia (button's dam) by imp. Billet, Felicia aud Senper Paralis by Stratford, ete. Semper Vive is the dam of Semper Idem aud Semper Anum by imp. Glen Athol, Fordham, Folsom and Westehester, all good race-horses, by Falsetto. Semper Irem is the lam of Long Glen, Longstreet (one of the best race-horses in Antriea and winner of 16 ont of 15 races in 1891 , including natel $1 \frac{1}{4}$ miles in $2.07 \frac{1}{2}$, defeating Tenny), Longforl, a good race-horse, Long Beach, etc., by Longfellow. Senitune is dam of Ella Pinkerton by Longfellow, and Semaphore, a wimer, by Onondaga. Blanche $J$. was a good mare and the dam of Blandoua (the dam of Feroua, Donna and Katona) by Longfellow, Sea shell (Long Shore's dam) and Australian Ban by imp. Fing Ban, Blantyre by Lelaps, ete. Maria D. is the dam of Lney B. and Vietorine bỵ Onoudaga, Mark S. (Moxie) and Ed Bell by Duke of Montrose. Salina was the dam of Duchess, Saltpetre and Saltillo by inp. Glenelg, Virlein by Virgil, Prince Clarlie (Priam) and Salvator by imp. Prince Challe. Salvator ran a

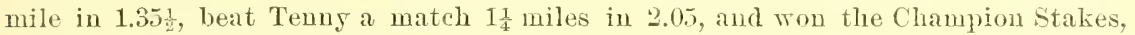

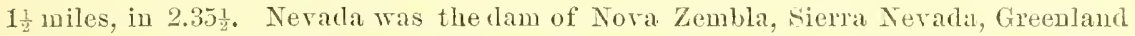
and Greengage by imp. Glengarry, the phenomenal three-year old in his year, Luke Blackbum by imp. Bonnie Scotland, Ecuador, a good horse, by Enquirer, Bradford and Bravo, both winners, by Bramble, and Nera by Longfellow. Nova Zenbla is dam of Nisa and her sister by Shannon, and superba by Flook. Sierra Nerada was the dam of Mountain Range, Monte Rosa's dam, and Wamsutta by Longfellow, Sutro by Enquirer, ete. Guluare is the dam of Costello and the good filly Satisfaction by Sensation, etc.

Nildred was the dam of Zoe and Nittie by imp. Scythian (the latter dam of Fonng Anstralian by imp. Australian, and Gen. Lougstreet by Asteroid II.), Ringlet by Ringgold, she the dam of Reekless and Restless by Toucher, Debby, Jin Lupe. Debbie (Flora) and Epsom by Derby, son of imp. Eciipse, Maximilian, Wandering, J. J. Healy and Waterburs (Rambler) by Wanderer. Mildred prodnced Nora Worth by imp. Eclipse, she the dam of Nero, Rocket, Roxella, North West, startle, Trumps, Darkuess, Renown, Force aud Finality by West Rosbury, and Adrenture 2 rl by Amadis, the majority of which were good racers. Rocket is the dam of liocket II. l,y imp. Intruder (she the dam of Iinnie W. and Lady Summer), Penelope, Nannie S., Leo br Pantaloon, Exicson and Cora A. by inıp. Eric. Roxella was the dam of Molly Malloy (Queen Malloy) by Pat Mallor, Fleet aud Roxella 2 d by imp. Intruder, and Amadias by Amadis. Molly Malloy is the dam of Pequot, Anna s., Birdette and Al by Pantaloon, aud Voltalloy by Voltigeur, Dick Malloy and Sam Murphy by imp. Eric, son of Pretendex. Fleet is dam of Athlete by Amadis, and Lilly and others by Pantaloon. Darkness is the dam of Fleetness and Interloper by inp. Intruder, etc. Fleetness is dam of Alert by Amadis, Dare S., Millic C. aud Sam by Pautaloon. Minx is the dam of Minnock, the great gelding Monitol, Lotta C., Wirth and Romeo, the 
two last in England. Mirth was the dam of Bouthillier, a winner in England last. sear. Minuock is the dam of Salviator, Lady B., Minnarotte, Selma D. by Springhok, and Onondagas by Onoudaga, etc. Lotta C. is the dam of Roulette (Sefton's dam), Illisee aud Lizzie M. by Baden Baden. Stamps was the dam of Katie Pearce by imp. Leamington, she the dam of Lizzie S. (Extra's dam) by Wauderer, Ballard ly imp. Billet, Katrina by Virgil, and Dal by imp. Mortemes. Bertha, Loch Tanna (in England), Lonisette, Preciosa, Billy Piukerton by imp. Glenelg, and Vriieria hy imp. Glenelg or Virgil, munestionably by the latter. Bertha is the dam of Reina Victoria by imp. Saxon, Delphine and Soncy Lass by imp. Mortemer, aud Mohican by Iroquois. Valleria is the dam of Barlight, Laura Stone and Versatile by imp. Rayon d'Or. Snltana is the dam of Sorraua (Inah's dam) and Sultan by imp. Ill Used, Soudan by imp. Matador, Saladin by Nonesuch or imp. 111 Used, she by imp. Glenelg. Padishah, Semiramis and Caliph by imp. St. Blaise.

Brenna was the dam of Tibbie Dunbar by imp. Bonnie Scotlaud, she the dam of Toltigeur, Lena Dunbar (dam of Lena's First), Clifton Bell, Capt. Kidd, Ed smith, Canny Scott, Broadchurch (Bradshaw) and Lads Evangeline by Leinster, and Lizzie Dumbar, the dam of May Dunbar, by Bazar. Lady Erangeline is the dam of Valiant by Monday, Oceaniea, Floodtide, Evelina and a sister by Flood. Brenua was also the dam of Haric by imp. Australian, a good race-horse, Eclair (Factory Girl) by Lightning, Ella Hankins by Gilroy, Britzka by imp Phaeton, Brademante by War Dance, Athalaric by Gilroy, Strathmore, Kinkead and Sir Walter by Warery, Brenda by imp. Thunderstorm, Long Stop by Longfellow, ete. Ella Hankius is the dam of Anadine by Amadis, she the dam of Hilarity by Punster, and Polly S. by imp. Pizarro, and Oriana by Onondaga, bay filly by Pizarro, ete. Athalaric is the dam of 'Tom Martin, a superior holse, by Longfellow, Belle of Brooklyn and Aethel by Stratford. Sister to Ruric by imp. Sovereign was the dam of Kelpie by imp. Bonnie Scotland, Ermengarde, Hilderic (Jim Connor) and Genseric by Lightning, Grinstead, a fine race-horse aul successful stallion, Tilford and Viceros, a good horse, by Gilroy, Pat Farrell and Hypatia by Waverly. Kelpie was the dam of Miss Anstine aud Jauet (wimner at four miles in 7.25) by Lightuing, Maxwell by Gilroy, a filly and Duke of Montrose, a good racer and successfnl stallion, by Warerly, Amnette and Kelp by imp. Straehino, Ovation, Overture and Dalgetty by Onondaga. Miss Austine is the tam of Austina by Waverly. Bridesmaid by imp. Bomnie Scotland, Aconite (Cryolete's dam) by 'Ten Broek, Teuton, a good one, by Ten Broeck, and Faraday, a superior colt, by Himyar. Janet is the dam of Sinaloa, Volnnteer (Dnffer), Sonoris dam by Ten Broeck, Spaldie by imp. Blue Mantle, La Mascotte, Golden Reel ani others by Spendthrift. Annette is the dam of Shoemaker, Ortowin, etc., by Onondaga. Kelp is the dam of Kempie, a winner, by St. Martin, Keepsake, Onaway, Lpward, Ondara, ete. by Onondaga. Ermengarle is the dam of Brocale, Bingen, Baltic and Bedotte by imp. Bonnie Scotland, Belle Walsh (Tusenmbia) by imp. Great Tom, Bellevne (Blackburn and Belvidere) and sister by Bramble. Brocade is the dam of Bertha B. by imp. Buekden, the gelling Bureh, War Dress by War Dance. Long Cloth and Jennie B. by Longfellow, Annie C. by Enquirer, and Dolo by Falsetto. Bertha B. is the Iam of Lizzie Baker by Longfellow, Judge Murray by Ten Broeek, Tom Vaughn (George H.) by King Alfonso, Pat Kelly by Pat Malloy, etc. Beclotte is the dam of still Alarm, Goosennill by Pardee, etc. Hypatia is the dam of Slickaway by St. Martin, Hypocrite by Longtellow, Deceit by Ten Broeck, Escapale by Onondaga, ete. Volga was the dam of Rurica by Rurie, Eminence, Barney Williams, a good horse, Valdine, Invoice and Eratne by Lexington, Jenny IcKinney and Alice Mitchell by Planet, Tecalco ly imp. Glen Athol, ete.

Evadne was the dam of Evasive by imp. Canwell, son of Stockwell, Blink Bonuie, Buckingham, Buwark, and Bandana by imp. Bomnie Scotland, Evasive (Bruce's dam) by John Morgan, Tennyson by imp. Great Tom, Eve Efitingum by Enquirer, Montagne by imp. Mortemer, Eblis, ete., by Iroquois. Blink Bonnie was the dam of saxony by imp. Saxon, and Tnllahoma by Great Tom. Saxony is the dam of Erebus and Once a Week, geldings, Tatian by Great Tom, etc. Tullahoma is the dam of the good mare Tulla Blackburu by Luke Blackbuxu, Tamnany by Iroquois, ete. Bandana is 


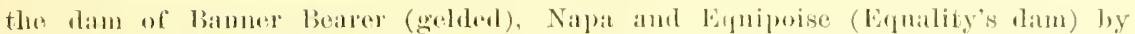

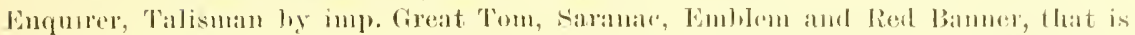

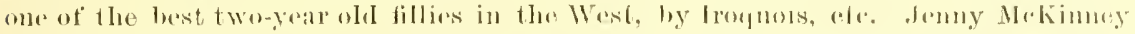

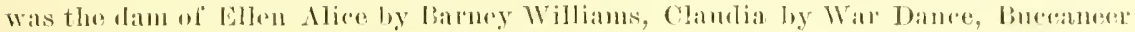

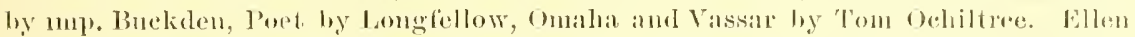
Alco is tho dam of Vigiline and Purly loy Virgil, and Vignline is the dam of Vigilant, Vigilettr by Eolns, while Clandia is the dam of May l). by Voltigenr, som of Vandal, lmpire and lus sister by Fersailles, son of Vambal, Cutalong by imp. liayon d'Or, ete.

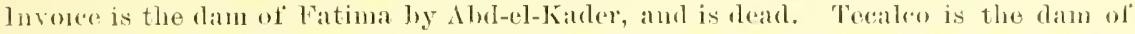
Toln by 'Ten Broeck, Rock-and-Rye Jy Virgilian, Tonigne by Sensation, llot Seoteh by unp). Hopeful, 'The Waulering Jew loy Tom Ochiltree, ete.

Vistula harl no ehance in the stud, but was the dan of Kentucky Belle hy Lexington, she the dam of Pride, Vis-a-Yis and Himalayit, a goor race-horse, by Virgil. Pride is the dam of Ghitter and Pretence by imp. Glenelg. Maria liy Davis Hamiltoman was the dam of Catharine Ogle by 'Trumpator, Tom Benton and Catherine by Bertraud, the latter the Iam of the superior race-horse Alexander Churehill by imp. Zingonee. Rowena by sumptor was the dan of Celestian, a good raeer, and Merry Gold by sir Leslie, Alice Carueal hy imp. Sarpedon, a good race-mare, Saral Moreton by Sidi Hamet, a superior mare, and Boswig by imp. Hedgeford. Merry Gold was the (lan of Hebe and Vulean (Tom Nichols) by lierthune, son of Sidi Hamet, Cyelone and Magelone by Vandal, and Almeria by Jack Lane, son of imp. Yorkshire. There is no report of Hebe since 1875. Cyclone was the dan of Red Wing hy imp. Balrownie, Cyeloid by imp. Lapidist, and a bay filly by kentueky. Magelone was the dam of Lily of the Valley by Lightumg, and Van Billet by imp. Billet. Lily of the Valley was the dam of Kenilworth by Waverly, Frank Martiu by St. Martin, Blue Times by imp. Blue Mantle, and Greynell by imp. Glenelg, the latter the dam of a filly by imp. Deceiver, a colt ly Hindoo, ete.

Alice Carneal tom inted a fumily of her own. She was a gool more at all clistances, was the daw of Miss Trustee by imp. Trustee, Fance and Grey Alice by Chorister, son of imp. Contract by Catton, Lexungton (the renowned racer, wimner of the time mateh, fon miles, 11 7.19: and afterwards defeating Lecompte in 7.233, the fastest two heats of four miles ever run by one horse) by Boston, Didie (Main of Orleans), Release and Reseue by Berthune, Waxy, a fine race-horse, by Buford, Lavender by Wagner, Lmpire by Lecompte, and Annette by imp. Scythian, the last two sent to England. Miss Trustee was the dam of Florizel (Hurieane) ly imp. Belshazzar, Mystery by Ruric, a bay filly by Ringgold, aud Miss Trustee by J. C. Breckenrige, son of Lexington. Mystery was the dam of a bay filly by Revolver, Dil Wiggins, Winchester, and a chestunt filly by imp. Hurral. Fance was the dau of Bazil by imp. Sovereign, Amme Tarlton and Lady Vaudal hy Vandal. Anme Tarlton was the dam of Charity by imp. Hurah, Mnor Jackson ly Dick Jackson, Vietress and Vest. valli by Tietory, son of Unelo Vic. Vietress is the dam of Yangiard, a good racer, Victrix by Longfellow, and a colt by stratford. Vestralli is the cim of Wanda West, Veracity (Festina's laul), Vestella, Vesper bells aud Valedictory by Waulerer. Wanda West is the dam of Speedwest by spendthrif, and Imogene ly Powhattan. Testella is dam of Mahomedan by Hindoo, etc. Grey Alice was the dan of Pickaway by Wagner, and Nelle Gwyun by imp. Bonne Scotland. Nelle Grynu was the dam of Louise Gwym and Faith by mup. Hurrah. Lonise Gwynu is the dam of Grace Lee by imp. Kyrle Daly, and Hector by Grenacla. Release was the dam of Garrie P. by Norbourne, son of Lecompte, Hetty C. ly Uncle Jeff, and Night Rose by inup. Kuight of St. George. Carrie 1'. is the dam of Cape Sterling, Cape Hemy, Cedar Grove and Carrie Race by Cape Race, son of Lexington. Night Rose was the dam of Nightmare by imp. Australian, Voltagne by 1mp. Glen Athol, Fred Fogle by Planet, Haddisco by Pat Malloy, Johmy E. (Pocassett) and tilly by Powhattan. Rescue was the dau of Abu Beeker by Mahomet, Relief'( Maid of the Cave) by Ringgold, Relief'by Star. Davis, Remorse by imp. Eclipse, Abrl-el-Kader, Abd-el-Koree, a good race-horse, and Rigmarole by imp. Australian. Rigmarole was the clam of Regale by Bulletm, Rigmal by Harry of the West. Rigln and Bessie Frankln by 1 mp. Glengary, Carnen (Blne 
Jeans) by Gorlitza, son of Lexington, Merry Dance by War Dance, ete. Riglin is the dam of Rowland, Regina and Royal by Shanuon, Chaucellor by Monday, Gladys by Flood, etc. Bessie Franklin is the dam of Gen. Early and I. O. by Erlanger, son of Enquirer. Carmen is the dam of Blue Streak and Blue Wind by Bingaman, son of Asteroid. Lavender was the dam of Rock by Ruric, Nannie Leteher, Helmbold, a superior race-horse, Bob Shelton, a winner, Lava, Barricade, a wimner, and Baden Baden, a superior horse, by imp. Australian, Lax by imp. Seythian, George Wallace br Asteroid, Buehn by Planet, aud Glen Wood by imported Glen Athol. Nannie Letcher was the dam of Corinne by Planet (she the dam of Rapidity, Sweetheart, America. and Lady Rapture by imp. Rapture), Iignonne (dam of Rapture's Danghter). and Emma G. (dam of Hernit by Hurrah) by imp. Phaeton. Lax was the dam of Sea Brceze by King Lear, she the dam of Slow Breeze by Restless, she the dam of Golden Slipper Jy McCreery, and she the dam of Le Premier by Lucifer, Verge d'Or by Virginius, and Crystallite by Joquita, Bragelone and Neppie Moore by Baywood, the latter the dam of Trosach by Terror; son of Alarm, Virgie by Virgil, she the dam of Ona hy Onondaga, Virgin and Virgin $2 d$ by Milner, son of imp. Leamington, and Release by imp. Strachino.

The Regulus mare out of Duchess prodnced a filly bs True Whig, which produced a filly by Gallant, sou of imp. Fearnought. This filly produced a filly by Rockingham, son of Partner by imp. Traveler, which Rockingham mare was the dam of Annette by imp. Shark, son of Marske, sire of English Eelipse. Annette was the dam of Nanes Air by imp. Bedford by Dungannon by Eelipse, and Maid of the Oaks by imp. Spread Eagle, son of Volunteer by Eclipse. Naney Air was the dam of Transport, Poor Girl and Young Nancy Air by Virginius son of imp. Diomed, and Seagnll by Sir Archy. Transport was the dam of Sir Archy Montorio (Big Archy), and Sir William of Transport, by Sir Archs, Bertrand Jr. and Julia bs Bertrand, son of Sir Arehy, and Clara Fisher by Virginins. The female line from Naney Air bas became extinct.

Maid of the Oaks was the dam of Maid of the Oaks and Lady of the Lake by Hickory, son of imp. Whip, Marshal Duroe and Cinderella bs Duroc, son of imp. Diomed, Forest Maid by Ratray, son of imp. Clifuen, Young Maid of the Oaks by imp. Expedition, sou of Pegasus by Eclipse, Orphan Boy by American Eclipse, and Lionella by imp. Coenr de Lion. Lady of the Lake was the dam of Lady Jackson, Maryland Eelipse, and Misfortune by American Eelipse. The line from here is extinet. Ciuderella was the dam of Hodesty by imp. Expedition (she the dam of Jane Maria and Alpine by Henry (this line is extinct), Betsey Richard (Young) by John Richarls (line extinet), and Lalla Rookh by Ogle's Oscar, son of imp. Gabriel. Lalla Rookh was the dam of Hamilton Moore, Tom Moore and Mark Moore by American Eclipse, Henry Moore, Jim Moore and No Moore br Henry, son of Sir Archy, Cerito by imp. Priam and Hinda by Monmonth Eelipse, the latter the dam of Fanny by Shark, Jr., son of Sliark by American. Eelipse, she the dam of White Oak and Warbeshaw by loung Langford. This female line is extinct. Cinderella also produced Cornelia Conover and Celeste by Henry. Celeste left nothing in the female line. Cornelia Conover was, the dam of Shark, Jr. by Shark, Heiress and Grace Darling by imp. Trustee, and the latter was the dam of Countess by Truxton, son of imp. Barefoot. Countess was the dam of Nettie br lienneth, son of imp. Forkshire, and Xellie by Tonchstone, son of imp. Lapılist. Nettie was the dam of Exotic by Extra, son of Endorser, Fanuy Wizer by Terror, son of Ruric, she the dam of Stilton by imp. Strachino, ete. Nellie is the dam of Una by Gen. Custer, son of Donerail, and Bothwell by Montrose, son of Duke of Montrose. Yonig Mair of the Oaks was the dam of Miss Walton by Mendoza, brother to sir Walter, Katy Ann by Ogle's Oscar, son of imp. Gabriel, Highland Mary, the noted and popular race-horse and stallion Medoc, Cora and Gipsy by American Eclipse, Coronet by Henry, and a mare by Gohama that was dam of Fanny Bonton by imp. Trustee. Miss Walton was the dam of Goliah, Floranthe and Zela br American Echpse, Dosoris by Henry, and Moustache by imp. Trustee. This familr line is extinet. 
Katy Am was the dam of Jady Thompleins by Ameriean lelipse, Madel of Miani by Orphan boy, flem de Lis by imp. Valentine, som of Magistrate, and Routerdy by imp. Skylark. Jably Thompkins was the dam of Tranbyand by imp. Tranby, Motto by imp. Barefoot, sally Am ly imp. Trustee, Fiatt (the l3he filly) lyg imp. Iledgeford, and a tilly by Cadmus. Tranlyyan was the dam of liello lewis, Bay Dick and Maggie Cragg by imp. Glencoe, a tilly by Wagner, Bige IBostom hy Boston, and Altoona by Vineent Nolte, son of American Eelipse. Bello lewis was the dam

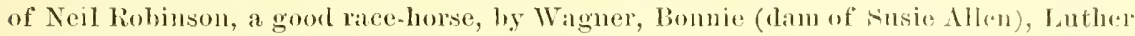
by Lexington, Rurica by Ruric, and several foals by Trotter. 'Thus line las mu out. Maggio Cragg was the dau of Carrie Coshy hy Olıver, son of Waguer, and she the dam of Mily D. (May Beverly), Lady Cripple, locility and Ntella by Hunter's Lexington, Creola by Creermore, son of Asteroid, and Wiekland by Judge Wicklifte. May Bererly was the dam of Maid of Woolland by John Morgan, Proctor Knott by King Pynu and Aetress by Longbow. Maid of Woorlands Wis dam of Burlie Ray by King Pyum, Maid of Richland by Voltigenl, ete. Stellil is the dam of Frank Ward, a good one, Stelletta, Larry Farrell, Sam Ross, Crissie, ete, by Voltigenr, son of Vamdal. Creola is the dam of Cretonia, Trown, etc. by Voltigeur.

Motto was the dam of Red Oak, Namnie Lewis, a real good one (dam of Aldabaran), Sally Lewis, Gov. Wicklifte and My Lady by imp. Gleneoe, Melita Hunter by Lexington, and Raglan by imp. Seythian. Sally Lewis was the dam of John Morgan, a superior race-horse, by mpl. Sorereign, Minnie Lewis bs Revenue, Lotta by Hunter's Gleneoe, Liula Lewis by Oliver, Hunter's Lexington, Glenrose, Snsan Beane and Acrobat, a gool racer, by Lexington, and Planivoo by Planet. Namnie Lewis left notbing in the female line. Minnie Lewis was the dam of Lorentia by imp. Anstralian, Melrose and Alf Riley by Asteroid, Mollie MeGinley by imp. Glen Athol, Pinback by King Pynn, and Zuma by Longbow. Lorentia was the dam of Willie Hinkle by Rogers, son of Lexington, King Cole by King Lear, Anemone by King Pyun, som of imp. Australian, Leesburg by Lever, MeBowling by Tom Bowling, Fonr Tens by Ten Broeck, Lanreate and Unlucky by Leonatus. Willie Hulkle is the dam of Bessie Hunekley by imp. Buekden, Treeks by Ferneliff, Hunley s. and her sister by Erlenheim. Anemone is the dam of Delaware (Dell) by Litule Jim, son of Planet, and she the dam of Bullrusl by Stamperle. Zuma is the dam of Marion C. and her sister hy Harry O'Fallon. Lotta was the dam of Visen by Planet, Glenmore (the superior race-horse, wimner of the great four mile race, three heats, $7.29 \frac{1}{2}$,

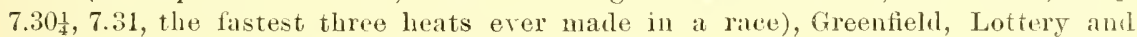
Gladiator by imp. Glen Athol, and a filly by Powhattan, Linda Lewis was the dlam of Nazareth by Asteroul, Kioba and Quiver by Longbow, Linden, a superur racehorse and very promising stalhon, Withrow by Longfellow, and Linnie by Machutf. Glenrose was the dam of Glendora and Glendew by imp. Glengary, Bloxi aud Bnekthorn by imp. Bonnie Scothund, and Restless, a good mare (dau of fiepose), by imp. Nortemer. Glentora is the dau of Emblem (Lam of Lottie S.), Endorat by Enquirer and Beaver by Bramble. Glendew is the dam of Glendar by Nortolk, Guardsman by Homlay, Guenue, Geoffrey and Glenlivet by Flood. Susan Beane was the dam of Strat for (Leamington II.), a superuor race-horse, the unbeaten Sensation, Onondaga, a good racer and sure, Snsquehanna, a good mare, aud sionx, all by imp. Leammgton, Soubrette and su Hereules by Alarm. Susquehamn is tho dam of Sussex by imp. Ill Lsed, Susanna by Kingtisher, Chesapeake, a winner, the great Potomac, am Schuylkill by imj, St. Blaise. Sombrette is the dam of Dirlington by Iroquois, Jobn Lakeland by Rumnymerle, etc.

My Lady was the dam of Ouward, a superior race-horse, by Ringgold, Blandina and Margnerite by Lexington, Maggie Welch by Asteroid, Clifton by Planet, a filly by King Alfouso, and Fungal by Lisbon. Blandina was the dam of Calash by imp. Phaton, Red Blutí by mup. Anstralian, Christina, Bresica (Polna's dam) and Ulsie by King Alfonso, Sea Foam by Lisbon, False Note, Keynote aud Falsita by Falsetto. Calash is the dam of Allemarle and Tar Heel ly Abi-el-Koree, Elite, Etha, Eolan, a very spreedy gool racer, Ethe, Clark, Ethus, Cantey, Cante aud Caleche, all by Eolus. 
Elite is the dam of the winners Capstone, Hetty Carey (Katie C.) and Annie G. by imp. Charasus. Ulsie is the dam of the good fillies Banchsia, Lmma G., etc., by Bend'or, son of imp. Bnekilen. Narguerite was the dam of Fordic Pope by Planet, she the dam of Katura H. by Silent Friend, and she the dam of Meiodiue by Melodist, Prude, Katie Creel (Kenwool's dan), Azalea, Macola and Nettie by King Alfonso, and Lady Athol by imp. Glen Athol. Azalea is the (lam of Gazalea and Pinkie T. by imp. Glengarr. Melita Hunter left nothing in the female line. Sally Ann by imp. Trustee was the dam of Harper by imp. Glencoe, Sandhurst by Lexington, and Kate Quiun by Wagner, she the dam of Herman by Vincente Nolte, Quincy by Ruric, filly by Lexington, one by Ulverston, Wallaby Jack and his sister by imp. Australian, Asteroid II. by Asteroid, colt Anstralian by Yonng Anstralian.

Fiatt (the Blue filly) was the lam of Blue Bell by Chorister, son of imp. Contract by Catton, Kate Hunter, Liz Morgan, Hunter's Glencoe and a sister by $1 m p$. Glencoe. Blue Bell was the dam of Lunette and Cyguet by Big Boston, Grey Don by Hornpipe, son of imp. Glencue, Nellie Grey and Betsey Hunter by Oliver, son of Waguer, Julia Mattingly, Songstress and Songburl by John Morgan, Cruiskeen, Bessie Lee, Specie Payment and Blue Bird (Breastpin's dam) by Hunter's Lexington. Lnnette was dam of Rebel Morgan by John Morgan. There is no female from either her or Crgnet. Nellie Grey was the dam of Sallie Newton and Nannie May (dam of Sue Wilie) by John Morgan, Kate Aclams, Lizzie Hayden and Betty Magrnder by Hunter's Lexington, Lunette by Lougfellow, Malise by Waverly, Lilly Grey by Juclge Wrickliffe, Ellen Terry (Lillie Smith) and a sister by Longhow. Sallie Newton was the dam of Morlesty (Ruth) by Revolver (she the dim of Blush, Laura Keene and Ruth by Ramadan), Eldorado and Little Criss (the dam of Bonnie S. by Planter, Jim Clare by Granger, Ilma B. and her sister by John Harper), both by Revolver, Capt. Flagherty, Lilly B., Autumn Leaf by imp. Hurrah, Sallie Harper and a sister by John Harper, and Frank E. by Probability. Betty Magruder is the dam of Becky B. (Becky Bye) and Maggie P. by Longbow, Lucus by Harry O'Fallon, and st. Bridget by Leonatus. Betsey Hunter was the lam of Kate Mattingly by John Morgan, Chassense, Joe Johnson, Fanny Johnsen, Aunt Tinnie and Jndge Wickliffe by Hunter's Lexington, Inquire by Enqurer, Katbarine M. by imp. Glen Athol, and Miss Hunter (Annex) by Kung Alfonso. Kate Mattingly was the dam of Iybla by Hunter's Lesington (she the lam of King Pippin by King Pynn, Huntress by Bob Woolley, Susie Forbes and a sister by Rebel), Long Girl by Longfellow, Herbert (Tom Plunkett) by imp. Glenelg, Matinee and Miss Mattie by imp. Buckrlen, and The Mand by Erdenhen. Chassense was the dam of Dilsey by Hunter's Lesugton (she the dam of McMurtry by Miser, Mame Cole by Harry O'Fallon, and Miss Gibson by imp. Fing Ban), Little Planet by Planet, Florence D. (Lougchase) by Longfellow (she the dam of Debut by Pit Malloy, and G. W. C. by Little Ruftin). Fanny Johuson is the dam of Sallie Jennings by Ortolan, son of Doweral, Frank B. by Longfellow, Via (Lolion's (Iam), Full Noon, Frago and Nina Damell by Yagahond, son of Yanclal. Salle Jennugs is the dam of Carolma by Harry Lamar, Vagantes by Vagabond, Bonme Blaze by George Iinney, Hattie O'Fallow and Jim Gnest by Harry O'Fallon. Julua Mattungly was the dam of Fanny Mattungly, Belle of Nelson and Belle of Maywood by IInnter's Lexungton, Wanderess by Wanclerer, and Alarmist (Fright's dam) by Alarm. Fanny Mattingly is the dam of Glendale by imp. Glenelg, Equity, a sister, aud Murabean by Enqurer, Turnbull by nup. Great Tom, Mmme L. and other foals by Iroquors. Equity is the dam of Justice by imp. Wootlands, and a filly and colt by imp. Dalnacarloch. Belle of Nelson is dam of Marion by Malise, and Belle Noges ly Grenada. Belle of Magwood is dan of Branch (Stiletto) and Mayrose by Duke of Montrose, the great race-horse Teuny and Maywood by imp. Rayon d'Or, aud Rafter by ump. Kantaka. Songburd is the dam of Boh May aud May Burd by Hunter's Lexungton. Songstress Was the dam of Julia Jackson (Pat Clayton's dam) and Little Jack by Hunter's Lexington. Bessie Lee was the dam of Ornoca ly Ortolan, Procrastunation by Bulwark, Vienuty and Dot by Vigabond. Lzzy Morgan was the dam of Mollie Fisher by 1 p. Finght of St. George, Sally Morgan by Revenue, Morgan scout and Ellen C. 
by John Morgan, Ratan by Jexingtom, Rosy Morgan by Plamet, and Mimuie J). Jye imp. Glen Athol. Mollie Wisher was tho dam of Morgiana hy Joln Margan, Nellio

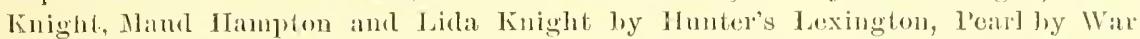
Dance, and lamar by King Pym. Morgiana was the dam of Jewel by War Jance, Panline Lee by Lew Panl, son of Leximgton, Comn hy Danicl Boone, Moriana ley Lomgbow, Harry Fields, Ionnell and a sister hy Ilarry O'fallon. Jowel is the dam of Duette by King Alfonso, Leah Sobel by imp. Buckder, Ban Dance and owel Ban hy imp. King Ban, Jewel H. and Mr. Aplubloy by Himyar, and a chestunt filly by Alarm. Dnette is the dan of Opera anel Oratorio by Harry O'Fallon, Seraploina by imp. Siddartha, and Blno Maid by Blue Eyes. Pearl was the dam of Kossuth by Londonderry, and Banka by imp. King Ban. Mand Hampton is the dam of Creton by Julge Wickliffe, the graml racelorses Ban Fox, King Fox, King Thuma, Lthel and Mabel by imp. King Bau, a colt hy imp. St. Blaise, aml a filly by imp. Sir Montren. Creton is the dam of Jennie S. by Felloweraft, Clean Heels by Duke of Montrose, and Ragnarok by imp. Deceiver.

Sally Morgan was the dam of Maggie Morgan and Charity Morgan (King Cyrus" dam) by Hunter's Lexington, Jack Trigg ly Lightning, Longbow, Sozociont, Longway and Miss Nelson by Longfellow, Vrill by imp. Glen Athol, and Enterpriso by Enquirer. Maggie Morgan was the dam of Janette by Joln Morgan, Tolina by imp. Glen Athol, Orelia by Waverly, Anxiety by Alarm, La Cigale by King Alfonso, and Vender by Virgil. Tolima is the dam of Cuntolima (Kitestring's dam) by Judge C'urtis, Maggie Bruce ly Bill Bruce, Glen Fox by Calignla, Strathlene by imp. Strachino, Countess and Pentolima by imp. Newconrt, and Ogestoh by Lisbon. Orelia is the dam of Ram Lal (Engene Brodie), Mr. Isaacs and Yolande by imp. Glen Athol, and Laura Gie by Falsetto. Anxiety is the dam of Remsen by King Alfonso, and Lizzie Santer by Falsetto. La Cigale is the dam of Maj. Mulford by Longfellow. Vrill was dam of Merter by Rerolver, she the dam of Dew Drop by Chillicothe, son of Lexington, and Cyelon by Chillicothe. Sozodont is the dam of Doolittle by King Alfonso, Ursula by Duke of Montrose, So So by Longfield, and a tilly by imp. Darebin. Ratan was dam of Cuba, Lancewood, Giroflé and Girofla by imp. Leamington, and Wildfire by Wildide (she the dam of Elggewood by Enquirer, Ithaca, and a sister by imp. Saxon). Rosy Morgan was the dam of Maggie D. (the dam of Joe Harris and Twang), and Guadalupe by Pilgrim, Sam Bennett (Rebel Scont) and Nettie (Miss Hankins) by Rebel, and Morgan Scout, Jr., by Silent Friend, son of imp. Anstralian. Nettie is the dam of Rebel Planet by Wake Hampton, son of Rodolph by Gen. Twiggs, Charlcie by Blue Dick, Waneta and Ella Trent by Plusetto.

Flenr de Lis by imp. Valentine was the dan of Buckeye Lass by Armiral, son of imp. Barefoot. Buckeye Lass was the dam of Wooknymph by Wagner, Momareh, Jr., by imp. Monareh, Romance by imp. Seythian, Ella Boston by Lexington, and Waxy (Bertha) by imp. Crniser. Romance was the dam of Prelude by imp. Cruiser, Nellie Boston by Frank Boston, son of Lexington, Roseola by Daniel the Prophet, and Grafton by Virginian, son of Ringgold. Prehde was the dam of Tom Boston by Frank Boston, Lithe and Preface by imp. Hurrah. Lithe is the dam of Lithsome and her sister by Barnton. Nellie Boston is the dam of Fannie Shields, Maggie Shields (Pernma's dam), Woodbine, Valentine and Woodstock, Jr., by Woodstock, Cynthia Rose by Red Eagle, son of Grey Eagle, and Gleu Daly by imp. Kyrle Daly. Fannie Shields was the dam of Sattie Seymour by imp. Hurrab, Good Friday by imp. Kyrle Daly, Belle of Licking and Siddie Mitchell by Grenada. Waxy was the lam of Wexford (Turenne), Dan O'Hara, Bertha May, Mattie G., Harry Wexford and Lady Langtry by Woodstock, son of imp. Australian (the latter the dam of Katie Iac, Benedict and Nivalis by Bertram, son of Kentucky), and Lolah (dam of Susy 'T.) by Northumberland, brother to Norfolk. Cora by American Eclipse was the dam of 2 d Priam aud Lney Toland by imp. Priam, 3d Boston by Cost Johnson, son of Boston, and a chestunt mare by Wagned, she the dam of Ellen Fall and Arele by imp. Albion, Balmoral by Lexington, and Jesse Joiner by Bill Cheatham. Ellen Fall was the dam of Josaphine Sannders by Hiawatha (she the dam of Chili McIntosh, Lawproof and a sister by Victory), and Watsona by Vatson, she the dam of Allman 
and Vina by Colebs, son of Pat Malloy. Adele was the dam of Fanny Moore by imp. Bomie Scotland, Gladys by Ringmaster, son of Riuggold, Ranch-Wai-Me, Rotha, Blisco and Wah-ta-Wah by J. C. Breckenridge, son of Lexington, Wah-ONaisa by Plowman, Fair Count, Wedding Day and Finale by Dulley, son of Planet, and Wahnooka by Bob Woolley. Famie Moore Was the lam of Larly Woodford by Woodford, son of Ringgold, Spiteful by Edgecomb, son of Lexington, Hanony and Nettie Martin by Concord, son of Lexington. Larly Woodford was the dan of Paris Green, Bomie Brnce and Bonnie Lee by scottish Eclipse, son of imp. Bonnie Scotland, Mollie Bawn, Moma Woolford and sallie Hagen by Fanstus, Yolande II. by Aliunde, and Hagen by Pat Farrell. Paris Green was the dam of Fanstina (dam of Spanish Fly and Dick Whittington) by Faustns, and Gretua Green by Moscow, son of War Dance. Bonnie Bruce was the dam of Froila and Bobby Beach by Faustus. Bonnie Lee is the dam of Fansterman, Jack Harding and Bessie Brigus by Faustus. Spiteful is the dam of Leila Belle, Mary Bet. Chaney and Ella S. by Concord, Oli Mike and George Morrow by Duke of Kent. Leila Bell is dam of Ella Rogers hy Duke of Kent, and Mrs. Erans by Ten Stone. Mary Bet. Chaney is dam of Ethaline and West Anma by Duke of Kont. Nettie Nartin is dam of Nettie Kent, Namie P. and Capt. Ruby by Dnke of Kent, and Gracie M. by Ten Stone. Glalys is the dam of Cultivator by Plowman, Miss-Go-Lively (Hatty Cheeney's dam), Oakleaf, Ratou and Telta by Dudley, and Joc. O. Set by Vocalic. Raneh-Wai-Ne is the dam of Zotum, Hatto, Alvela, Zi-Zi, Dover and a sister by Dndley. Wah-ta-Wah is the dam of Eleanore, Toolooah and Comnt Dudley by Dudley. Wah-O-Naisa is the dam of Wan-o-sae-na, Hard to Tell (Duster's dam) and Nekama by Dudles. Balmoral was the dam of Miss Alma by Bill Cheatham, she the dam of Amuie Malloy by Nightshade, Lizzie MeDonald by Escape, and Bitter sweet by Crichton, son of imp. Glencoe, she the dim of Ieewiteh by Ieeberg, Lochiel and Lew Joslyn by imp. Lochiel, son of Sweetweat.

Gipsy, sister to Cora, was the dam of Niagara and his sister by imp. Trustee, Sunbeam by imp. Langford, Young Gipsy hy imp. Nereer, Pryor and his sisters, Nos, 1 and 2, by imp. Glencoe. Pryor was a superior race-horse and died in England. The blood of this branch of the Duchess family is transmitted through the two sisters of Pryor and Iomng Gipsy. The latter was the dam of Bosio by imp. Eclipse, Feathers and Gipsy Lass by Revenue. Bosio was the dam of Rivulet by Rivoli, she the dam of Clematis (Rill) by Creedmore, son of Asteroid, Cornucopia by Virgil, a filly by Flood, and Modesto by Monday. Bosio also produced Heron and Emma Hunter by Lever. Emma Hunter is the dam of Tom Stacey by Lishon, Walter T. (Elk Hunter) by Falsetto, Stranger and A rou Lass by Stratford. Sister to Pryor No. 1 was the dam of Glycera and Colossns, both good racers, by imp. Sorereign, Snsie Spears by imp. Arab Fysanl, Lute, sent to England, and Saratoga by imp. linight of St. George. Glycera was the dam of Knighthood and Suc Ryder by imp. Knight of St. George, Merry Bird by imp. Mickey Free, Carrie Atherton by Lexington, Mary Edith by imp. Fazzoletto, Warpath, The Gleaner and Cordelia by War Dance. Sne Ryder was the dam of Ranee, Bonne Bonche and Remns by Reform, Alistair by Alarm; and Cracksman by imp. Woodlands. Ranee is the dam of Maggie Ahrens, Woodranie, Register and Summer Coon by imp. Woodlands, and Waiting (Miss Doloris) by imp. Dalna. cardoch. Merry Bird was the dam of Annie Richards by imp. Bonnie Scotland, she the dam of Boomerang, Festus, Nodaway Queen, etc, liy Fanstus. Carrie Atherton was the dam of Janet Norton and Duke by imp. Leamington, Nortonian by Panic, Glenroy and Nettie Norton by imp. Glenelg, Buttress by Barricade, Marvine (Canteen's (am) and Mont d'Or by imp. Mortemer. Janet Norton is the dam of Free Love and Keyser by Luke Blackburn. Mary Edith luad a fills by War Dance, and Cordelia was the dam of Mark Daly by imp. Kyrle Daly, and Polaris by imp. Thunderstorm. Susie Spears was dam of Mamie M. Jy War Dance, she the dam of Eastover (Elkrilge's dam) by John Payne, and Sne Casey by Hermut, son of Warwick. Saratoga was the dam of Sweet Sixteen, Monmonth, Simoon, Congressman and Claudina by War Dance. Sweet Sixteen was the dam of Limo by Limestone, son of War Dance, and she the dam of Princess Limo by imp. Prince Charlie, and Limo Brook by Ten Broeck, 


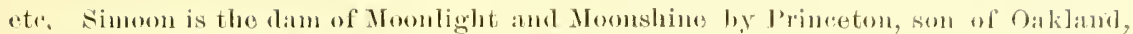

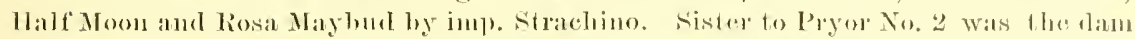
of leporter and Sumuerside by Lexington, loth sent, to lingland, Almuina ly imp.

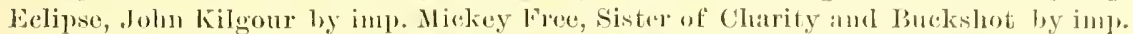

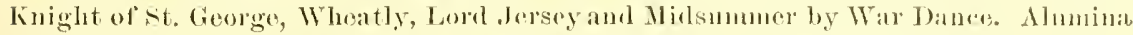

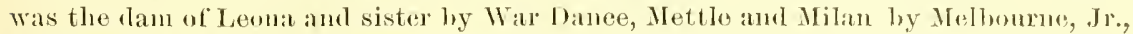
Acluemy, Fairfelel, Analgan, Oxygen and Virginia Keene by Bullion, son af War 1)ance. Leona is the dam of Golden Era by Bullion, Enma Hancoek, Dick Ilancosk amd Stella Walkre ly Outcast, ard Swifter by llycler Ali. Sister of Chauty Was the dam of Pimlico, Warsaw, Sister of Nerey, John R. Swiney and Sisterly by War Dance. sister of Mercy was the dam of Heek hy Leanington or Reform, Bomnie Chiel, I'arke, Compassion and bovotee by Alarm, Inka, Tessa K. and Sister Mario by lieform, Merci and Bashford by imp. Woodlands. Inka is dan of Caress by imp. Woollands, and Alarming by Alarm. Midsmmer was the dam of Billiom by Bullion, Anmmer Storm (Amos A.'s dam) by King Faro or imp. Thunderstorm, Trinkitat (the dam of l)aisy F. and Balgowan by imp. Thunderstorm), Ontlaw aud Eugenia by Outcast, aud a filly by Geo. Kinney. This Duchess family is one of the most tamous racing and producing ones to be foumd in the stud-book.

Peggy, bay mare foaled in 1788, imp. by Col. John Tayloe, Virginia, was by Trumpator, son of Conductor by Matchem, dam Pegry, sister to Postmaster by Helod, grandam by Snap, sou of Snip by Flying Childers, great grandam by Gower Stallion, son of the Gorblphin Arabian, out of a daughter of Childers. Peggy prorlucest Britannia by English Pegasus, Peggry by imp. Belforl, sou of Dungannon by Eclipse, Fairy by Highflyer, and others. A sister to Pegrgy and Aimator was bred to Sir Peter Teazle, son of Highflyer by Herod, then crossed on Young Gohamua, Whalebone and Plenipotentiars, three of the tail-male line to Eclipse, and then to Glarliator, a Herod, and we have thus the great brood mare Qneen Mary, the dam of Ballownie, Bonnie Scotland, Broomielaw, Haricot (the rlan of Cramond and Caller-Ou, wimner of 34 Queen's Plates and the St. Leger, Brighton and Fork Cups), Braxey (tam of imp. Bernice), and Thrift (the dam of Tristan, La Dauphine and Kate Hampton). Blink Bonuy, a winner of the Derby aud Oaks and dam of Borealis, Blair Athol, winner of the Derby and St. Teger, and Brealalbane, winner of the Prince of Wales and Gratwicke stakes. Other famous wimners in the family are Sir Berys (1)erby), Hampton (Epsom Gold Cup, Doncaster and Goodwood Cups and Goodwood stakes), Broomielaw (Dee stakes and Chesterfield stakes), Blinkhoolie (Ascot Gold Vase and Alexandra Plate), Good Hope (Vienna Derby), Beanclere (Midıle Park Plate), and other famous sires and matrons. Peggy by imp. Bedford was the dam of Trumpetta by Hephestion, son of imp. Buzzard and imp. Castianira, the dam of Sir Arehy, by Rockingham. This is the only female credited to her. Trumpetta producel Little Peggy by Gallatin, son of imp. Bedford, imp. Alambrina by Mambrino, and two fillies by Kosciusko, son of Sir Arehy. The two last havo disappeared, leaving nothing behind them. Little Peggy became the property of Dr. Elisha Warfield, of The Meadows, wear Lexington, the breeder of the fumous Lexington. She harl fonl fillies, one hy Sir Arehy Ilontorio (Big Arehy), one, Electra, by Silli Hamet, son of Virginian, one, Too Soon, by sir Leslie, son of Bertrand, and Cherry Bird by Celestion, son of Sir Leslie and Rowena, the dam of Alice Carneal, Lexington's dam. The first two left no female produce. Too Soon prodnced Buford by imp. Nomplus, and Garret Davis by Glencoe, both good race-horses, Primrose by Sisli Hanset, Utilla by imp. Margrare, Peggy by Boston, and Kaloolal by imp. Yorkshire. Primrose left no thoronghbred foals, and the same is true of Kaloolah. Utilla produced Ashland by Mambrino Chief. Wind and Pit-a-Pat by Berthne, a filly by imp. Consternation, Jomng Utilla by Hurricane (Warfield's Florizel), Ulverston and Ultima by Lexington. Funng Ctilla produced several good race-horses, including Monomania (Tasmania), Dr. Butler and Teetotal by Melbonrne, Jr., Gaberlunzie by Bonnie Scotland, Hattie by Australiau, and several foals by Pimlico. Cltima produced Aurora Raby and Attila by inp. Australian, the latter of which wou at a mile, over Jerome Park comrse, in $1.44_{\frac{1}{2}}$, one. mile and a furlong in 1.58, and the Travers stake in 1574, one-aud-three-quarter miles 


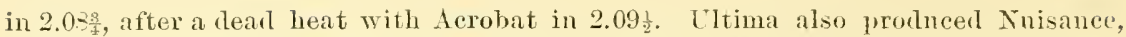
Sunrise and Totilla by Planet, Sonora, Ultinatum and Alma by King Alfonso, Pleasantry and Cleopatra by Falsetto, ete. Aurora Raby was a good race-mare aud the tlam of Bill Bruce, one of the hest sons of Enquirer, Respond by the same sire, anl the noted Jittle gelding Charley (xorham hy Blarneystone. Nuisance prouluced sereral good ones. Sumrise has had no chance in the stud, and the others are virtnally mutried, with the exception of Monomania, who has produced several good ones, such as Monitress, Scissors and Monopoly by War Dance, Mammonist, Monopole, Monogram, Matrimony and Mona, all by imp. Buckilen and good performers, Gilt Edge and Lida Laroy by Gilroy. Pegers by Boston was the dam of Amie Lanrie by Vincente Nolte, son of American Eclipse, Bridget by Padky Bnrns, son of Grey Eagle, Princess Royal by imp. Sovereign, and Mathilde by imp. Scythian. Amuie Lanrie prodnced a number of good ones, such as Kate McDonal, by imp. Mickes Free (the dam of Tronble, the best horse over timber ever in America), and Fest by imp. Pheton (the latter a gool one), Locnst Post, Flying Locust aud others by Melbonrue, Jr., Annie Butler by Uiverston, she the dam of Mary Howard by imp. Hartington, that produced the speedy mare Pearl Jennings, Mary Payne and Ada Rees by Lelaps, son of imp. Leamington, Sally Howard, tam of Mary Ellis, by King Lear, son of Lexington, Isaac Murphy by Virgil, etc. Amuie Lamie is also dam of Experiment by imp. Phaeton, Venturia, and Mamie O. by Virgil, and Locust Bloom by Tom Bowling, the latter the tlam of Chilhowee by King Ban, Elknoe by Longfellow, etc. Ventnria is the dam of some good ones. The family is a racing one, and has produced race-horses uniform!y when properly bred.

Imp. Selima was a bay mare, foaled 1746, bred by Lord Craven, by the Godolphin Arabian, clam Large Hartley mare by Mr. Hartley's Blind Horse, grandam Flying Whigg by William's Woodstock Arabian, great grandam Grey Whynot by Whyuot, son of the Fenwick liarb, ont of a Royal mare. She was own sister to Babraham, Mogul aud Marlborongh. Many of the best horses and suceessful stallions in America and England trace in direct female line to this fanily, such as Blank, Babraham, Gower Stallion, Merlin by Second, Sweetbriar, Hornsea, Amsterlam, Soothsacer, Jerry, Harvester, Skylark, ete. In America imp. Ambassador by Plenipotentiary, imp. Buckrten, imp. Driver, imp. Gabriel, imp. Mendosa, and the following bred in this country, Alarm, Picolo, Oden, Cloverbrook, the famous Grey Eagle, Robm Grey (sire of Lady Grey), Hanover, Foxhall, etc, descent from the same sonrce. Selima was the clam of Partner, Ariel and a sister by imp. 'Traveler, son of Croft's Partner, Stella, selin and Ebony by imp. Othello, Black Selima by imp. Fearnought, etc.

The Traveler mare, sister to Partner and Ariel, was the dam of Peg by imp. Jnniper, she the dam of a filly by imp. Othello, she the dam of the filly ly Leouidas, son of Lloyd's Traveler, and she the dam of filly by Hall's Union, son of imp. Slim, who was the dam of Pandora by Grey Diomed. Pandora was the dam of Daisy Cropper aud silverheels br Ogle's Oscar, Anrora and Pocahontas by Lloyd's Tingt'nu. Anrora was the dam of Fanny Wright by Silverheels, and she the dam of Tiberins by imp. I'riam, Emma Wright and Eleanor Margrave by imp. Margrare. Emma Wright was the dam of Lanra Farris and Miss Doyle by Lexington, Jerseyman aud the noted Nollie Jackson (who won at all distances and won the famons three-mile

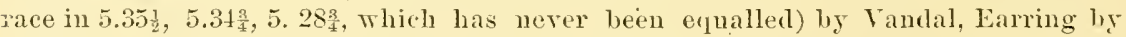
Ringgold, Woodstock by imp. Anstralian, Geo. Wilkes aud Emeti by Astoria. The blood is hest preserved in this line through Mollie Jackson, who was the dam of Monday by Colton, son of Lexington, Famny Ludlow, Temptation and Long Branch by imp. Eclipse, and Doubt by imp. Eclipse or Cavalier, son of imp. Eclipse. Famy Lndlow was the dam of Jamaica by Lexington, Cedrie, Cherokee, Chipola and Choctaw by imp. Saxon, Clare by imp. Glenlyon, Clobnla, Cataline and Comrisamle by imp. Mortemer, and Alexiua by Dnke of Magenta. Jamaica is the elam of the grand race-horse Foxhall, Potosi, American Girl, Alexander and Abaea br King Alfonso, Octopus and Joanna by Falsetto. Donbt is the daun of Mollie Jackson, Ji., by Battle Axe, and Stockton by Spendthrift.

Stella by imp. Othello was the dam of Harmony (dam of Hall's Inion) and a 


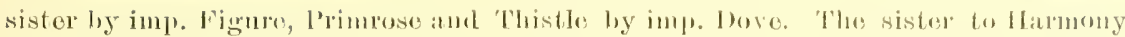

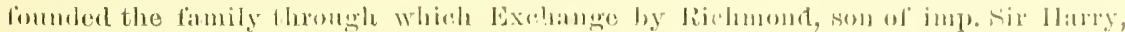

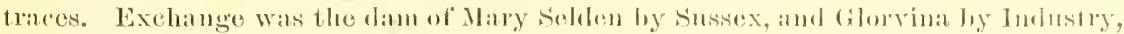

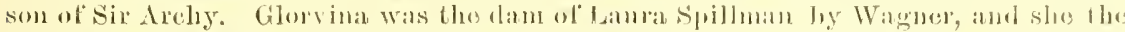

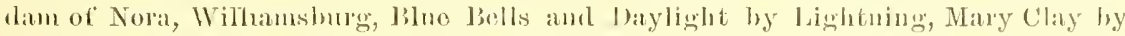

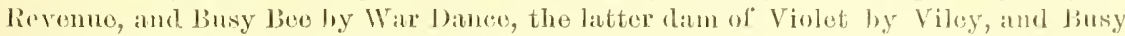

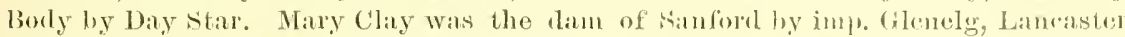

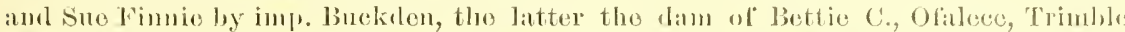

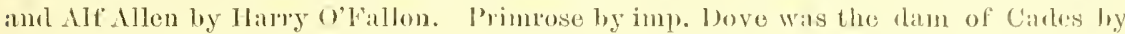
Wormsley's King Herod, she the dam of llornet and sting by imp. loined, and lanly Bolinglooke by imlp. Pantaloon. Lacly Bolinglooke was the dan of Carlia by Symme's Tildair, Destemona and Virginia by imp. Dare Devil, Lavinia, Superior, Primrose, Wrangler and Lady Chesterfield by imm. Diomed. Ludy Chesterfeli was the dam of the mare by sir Archy that was the lam of Ophelia by Wild Medley, and she the dam of the superion race-horse Grey Eagle, and Falcon hy Woodperker, son of Bertrauch by Sir Areliy. Fialcon was the dam of Lilla D. aud lilla D. by Vamclal, Alert by Lexington, and Seythia by imp. Seythian. Ella D. Was the dam of Paris and Paris Belle by Lexington, and Bomrbon Belle (the dam of the grand race-lorse Hanover and Honston by Hindoo) by imp. Bonnie seotland. Alert was the dam of Vandalla (Glencaire's daun) by Vandal, Tolona by imp. Phaeton, Harper by Longfellow, Kenton by imp. Glenely, Richmond, Lookont and Aetive by Virgil. Seythit Was the dam of Ida and Parisa by Paris, son of Lexington, ete. Ida is dam of Virgilia and Idaho by Virgil, Idler by imp. Glenelg, and Irene by Leveller. Parisa is dam of Swamp Fox by Fonso. Cielia by Symme's Wildair was the dam of Fair Forester by imp. Chance, and Rosemary by imp. Diomed. . Fair Forester was the dam of Polly Peacham by John Richaris, son of sir Arehy. She produced a tilly by imp. Monareh which was the dan of Mary O'Neil and Fawn by St. Louis, son of Altorf. Mary O'Neil was the dam of Maggie O'Neil, and she the dam of Tillie W. by Joe Daniels, and Maggie O. by Shannon. Fawn was the dam of Bettie by Gen. Longstreet, she the dam of Mary Sha w hy Gov. Bowie, and Bernice by imp. Intruder. Polly by imp. Sovereign, out of Polly Peachan, was the dam of Susan Gillespie by Engineer, son of Revenue, and Kitty Guild by Hiawatha. Susan Gillespie was the dam of Alice Thompkins by imp. Glengarry, Miss Malloy and Brunette (Omega) by Pat Malloy. There are a few mares from Rosemary: only Eula by Mugrins, Leoua King and Lady Corinne. Virginia by imp. Dare Devil was the dam of Virginia by Sir Archy, she the dam of Caledonia by Jerry, son of Pacelot, Dolphin and the good rice-mare Giantess by imp. Leviathan. Caledonia was the dam of Polly Elliott by imp. Leviathan, she the dam of Peytona Barry bs Rogers, Ada Tevis and Tenth Legion by imp. Albion. Ada 'Tevis was the dam of Blanche Roussean by Commotore, son of Boston, Charlotte Thompson by imp. Nickey Free, and Johnetta by Ansterlitz. Blanche Ronssean is the dam of Luey Wallace and Reel Dance by War Dance, Margaret Haight by Gilrog, La Blanche and Susie L. by Vocalie. Lney Wallace is the clan of Alma by Himyar, Martha and Luminous by imp. Rayon d'Or. Reel Dince is the dam of Cotillion and Minuet by imp. Rayon d'Or, and Fandango bs imp. Kantaka. Charlotte Thompson was the dam of the great gelding Barnum by imp. Bonnie scotland, Sallie Gardner by Vandul, and Miss Mnggins by Muggins. Sallie Gardner is the dam of Gardey and Sallie G. by Flool, and Miss Muggins is the dam of Guitar by Grit, Philopona and Miss Blonde (Peprermint) by Plenipo, son of imp. Bonnie Scotland. Johnetta was the dam of Melita and two sisters by Muggius, son of Jack Malone. Melita is the dam of Von Moltke hy Vermont, son of Vandal, Miss Harding by imp. Great Tom, Egmont by Enquirer, Little Emily (Brillianteen) and Bendigo by Luke Blackburn, and Moi Miloi by Bramble. Dolphin was the dam of Minnow and Whale by Foncher, son of Wagner. Minnow was the dam of a mare by Revenue, she the dam of a filly by Lightning, she the dam of Adlele by imp. Anstralian, she the clam of Banda by Kiug Bau, Adelina by Macduft, and fillies by Linden.

Giantess was the dam of Aduella, Union, Glencoe, Jr., and the grand mare Peytona (winner of the great l'eyton stake at Nashrille, 1843), all by imp. (ilencor. 
Peytona was the dam of two fillies by imp. Ruby, son of Emilins, and Transylrania by imp. Arab Massond. One of the Ruby mares was the tam of Matilda by imp. Sovereigu, she the dam of Miss Tilton bs Daniel Boone, and Satilla by imp. Buckden. Miss 'Tilton is the dam of the gelding G. W. Cook, Miunie by Congressman, Misfit by imp. Siddartha, ete. Transylvania was the clam of PaIm Tree by Lexington, Date Tree by imp. Micky Free, Blanchette and Dewberry by imp. Knight of St. George, Limestone, Lime Tree and Limit by War Dance. Date Tree was the dam of Melodist by Melbourne, Jr, Wah-ta-Wah by War Dance (she the dam of Olemus, Snook and Lass of Tamales), Arabia and Clara L. by imp. Thunderstorm, and Lou Monette by imp. Strachino. Dewberry was the dam of J. H. Haverly by War Dance, Thundercloud by imp. Thunderstorm, aud Mary Berry by Bullion or Outeast. Lime Tree is the dam of Limey by imp. Thonderstorm, Limestreet by Streatlam, Belle of Mediapolis and Limey Long by Lead On, son of imp. Leamington. Limit is the dam of Easter III. by imp. Thunderstorm, and Limitone by Lead On. Some of the best race-horses, brood mares and stallions in England and America trace to this line of blood.

The Popinjay mare was foaled 1808, and imported by Hon. John Randolph, of Virginia. She was by Popinjay, son of imp. Buzzard, dam Bourbon's dam by Precipitate, son of Mercury by Eelipse, grandam Young Tiffany by Highflyer, son of Herod, out of Tiffany by Eclipse, tracing throngh Young Hag by Skim, Hag by Crab, Ebony lyy Flying Childers, and Old Ebony by Basto, to the Massey mare by Mr. Massey's Black Barb, to which trace in direct female line Trentham, Florizel (sire of imp. Diomed), Election, Quiz, Royal Oak, Mulatto, Defence, The Emperor, The Palmer, Rosierueian, Duteh Skater, Doneaster, Gladiatenr, Hermit (sire of imp. St. Blaise, Tristan, Peter, etc.), imp. Flimuap, imp. Barefoot, imp. Shamroek, imp. Speculator, imp. Eliza (the grandam of the great prodncing mare Topaz by Glencoe), imp. Kan taka, imp. Ocean Queen (dam of Tourmaline, Seadrift, Fairy Qneen, etc.). This Popinjay mare was the dam of Parrot, Woodlark and Macaw by Randolph's Roanoke, son ol Sir Archy. Parrot was the dam of Mary Thomas by imp. Consol, and Sally Hnuter by American Eclipse. Mary Thomas was the dam of Odd Stocking, Magnolia and Mary Ogden by Thornhill, son of imp. Glencoe, and Thetis by imp. Sorereign. Odil Stacking's line is extinct. Magnolia was the dam of Kate Jewell by Wagner, several tillies by imp. Sovereign, and Wreath by Brown Dick. Kate Jewell was the dam of Tennessean by Lightning, and a filly by War Dance. Nary Ogilen was the dam of Lorette by imp. Sovereign, and she the dam of Mishap by imp. Knight of st. George, Regan by Lexington, Charette by Lightning, Ada A., Lorena and Namnie B. by Asteroid, Sophy Badder]y by imp. Australian, aud Loriot and Peaceful by Planet. Mishap was the dam of King Benazet and Croekford by Lightning, Misfortune, Mischief and Misdeal by Gilroy, Perhaps by imp. Australian, Marimon by Warerly, Soply and her sister by imp. Strachino, and Misehief by imp. Thunderstorm. Misfortune is the dam of Merrimack and Abbotsford (Mistake) by Warerly, who raced snecessfully in England, Miss Danee (Netroma's dam) by War Dance, Syutax by st. Martin, Hopeful and Glen Fortune by imp. Glenelg, Adversity by Spendthrift, King Fortune by imp. King Ban, and Long Fortune by Longfellow. Perhaps is the dam of Perplex by Gilroy, Warrior and Chance (a good horse) by War Dance, Doubt bs St Martin, Probability and Dilemma by Onondaga, Reckon by imp. Pizarro, and Perblaze by inp. St. Blaise. Sophy is the dam of Repose (Pelhim's dam) by Gilroy, and Morniug Glory by Fonso. Regan, was the dam of Regal, Virgil, Vera Cruz, Virgilette, Relay, Hawley, Vengeance and Printer (Last Chance) by Vigil, Jennie D. and Jennie B. by imp. Glezelg. Jennie D. is the dam of Grismer, Verano, Janova and La Cienega by Grinstead. Jennie B. is the dam of Ganymede, Honduras and a sister by Grinstead. Relay is the dam of Donohne, ete. by Stratford. Ada A, was the dam of Patsey Duffy, Frank Rhoads, Lizzie P., Nubia, Ab. Stemler, Rosa G. (Marc B.), (Tom O'Hara's dam), Ysabel (dam of Warsaw and Florence by Warwiek), Lady Leinster aud Leon, all by Leinster. Lizzie P. is the dam of Idaline Cotton by Jim Brown, Louis P. by Joe Hooker, Varona, ete., by Young Bazar, Sophy Badderly was the dism of Toulie by Gilroy, Olivette by Alarm, Peytona Barry by 1mp. Strachino, 


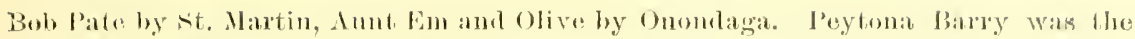
dam of Endie Mills, Salvanos (Boh Thomas), and Sweetheart hy Enduirer. 'Jhetis was the dam of Themis hy Anstorlitz, son of imp. Yorkshire. Themis was the dam of lacota by Lightning, Thesia by Calvan, son of Tipueraly, Chardoth by imp. Prinee Charlic, Tho sheriff hy imp. King Ban, Ben's Pet hy llimyar, and lilly hy imp. Deceiver. 'Thesia was tho dam of blumette by imp. Clanele, and lammona by 'Ten

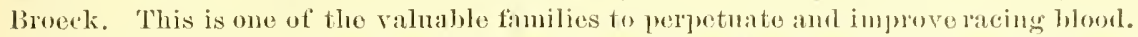
"The l'opinjay mare was not only fashionably breel, but from one ol" the best and most distiugnished somees in the stmd book, and one which has demonstrated its value even to this day.

One of tho latest importatons to which a large number of race-horses owe their origin was Myrtle, imported by Messrs. Kirkman, Nashville, 'Tenn. Myrtle was Jy Manelnke (winner of the Derby in 1827, and second in the st. Leger the same year'), son of Pastisan by Walton and Miss Sophia by Stamford, dam Inharlila (winner of the Gold Cup at Aseot and Drawing-Room Stakes at Goodwood in 1828) by bol,adil, son of Rubeus by imp. Buzzard, graniam Pythoness by Sorcerer, son of Trumpator lyy Conductor, ont of Princess by Sir Peter, tracing throngh the best racing bloor to the Layton Barb mare. Myrtle is eredited with but two foals, Dr. John and Magnolia by imp. Glencoe.

Maguolia became the property of Dr. Mereer, of New Orleans, who presented her to the Hon. Henry Clay, of Kentucky, who gave her to his son, the late John M. Clay, of the Ashlaud stud. She produced a number ot good ones, including Magie, Madonna, Princeton, Charles Morgan, Hanover, Simon Kenton and Skedadılle, all by imp. Yorkshire (son of St. Nicholas by Emilus, and imp. Miss Rose by Tramp), Charley Ball by Wagner, Daniel Boone, a goor race-horse, the noted Cup horse Kentneky and Gilroy ly Lexungton, Victory by Uncle Vie, son of Lexington, and Madeline by Old Boston. Madeline was the dam of Magilalena by Bob Letcher, son of Medoe, Madostone (ran as Kate Dnncan) by imp. Stone Plorer, Income by Revenne, son of imp. Trustee, and Maggic B. B. by imp. Anstralian, and Madelina by Lightning. Magdalena was the dam of Myra by Tite Eye (son of Herr's Boston). Madostone was the dam of Manton by Orion (son of Revenue), Bide-a-Blink and Bee-inthe-Bonnet by imp. Bonnie Scotland. Bee-1n-the-Bonnet was the dam of Mike's Pride (Pike's Pride), Jaubert (Star Ban), Bonnie Bau, French Park, a good race-horse, all by imp. King Ban, Reverta and Craftie by Felloweraft, Pike's Peak (Pixy) br Lelaps, and Senator Hearst by Longfellow. Income was the dam of Goldmine by imp. Anstralian, Compon by Lightning, Incommode, a fine race-horse, by Melbourne, Jr., son of imp. Knight of St. George, Wavelet (dam of Penelope, Tidal Wave and Briar Root) and Clau Alpine by Waverly, Interest (Piclup's dam) by St. Martin, Warda by Long Taw, Rumaway by imp. Highlander, and Onteome by Forester. Golimine was the dam of Pearl (dam of Grayson, and Bijon (the dam of Kilkemny by Geo. Kinney), both by War Path, son of War Dance. Maggie B. B. (winner of the Sequel stakes) was the dam of Lord Clive, Pera (the dam of Petition, Padre's dam, Pericolor, Darya, Gretina), Magnum Bonum, Jaeonet, Harold, Iroqnois, wiuner of the Derby, St. Leger, Prince of Wales, and St. James' Palace stakes, and Francesca, ali by imp. Leamington, Red and Blne (dam of the fine race-mare Sallie McClelland), Panique and Warekns by Alarm, Okemas, Onas, Hntoka and Homeopathy by Reform, Hypatica and Flatlanks by imp. Woodlands. Jaconet is the dam of The Niece (dam of Lydia Belle, Alarm Bell and La Colonia), Mattie T. (dam of Amy Davenport and Ethel S.) by imp. Bullet, Belvidere and Sir Dixon, good race-horses, and Blackloek by smp. Billet, Cambric (Lisric's dam) and Intrepid by Hindoo. Francesea is the dam of Franconia by imp. Billet, Friseo and Halloo by Hindoo. Madelina was the dam, of Ollie C. by Alarm, she the dam of the winner Sir Arthur by Leonatus.

Skedaddle was the dam of Sancebox and Seramble by Star Daris, son of imp. Glencoe, Slyboots by Rivoli, son of Revenue, Sqneez'en by Lexington, Florence B. by Tom Bowling, Joe S. by King Lear, The Slashes by imp. Glenelg. Sancebox was the dam of Sylva springer and Musie Box by imp. Bnckden, and Safety by Buchanan. Sslva Sprunger is the dam of Judith by Ten Broeck. Hot spring by Rebel, Camilla by 
Erdenheim, and Silvaua by imp. Silvermine. Scramble is the dam of Alice J., Ruth Howard, Remember and Maggie J. by Ballinkeel, son of Asteroid, Ontscranble by Outcast, and Sam Morse by Leouatus. Alice J. is the dam of Alice D. (the dam of Pittipat by Pat Molloy), by Arl, son of Revolver. Glenmound, Glemlale and Glencliffe by Glenmore, etc. Remember is the dam of Counterfeit by Glemmore, and Release by Tom Ochiltree or imp. Hopeful. Slyboots is the rlam of the superior race-horse Leveller by Lever, son of Lexington, Sly Dance, Dakota and sachem by War Dance, son of Lexington, Savanae and Volunteer by imp. Mortemer. SI Pavamne by Iroquois, Sumpsicle by imp. Mortemer, Portia by Joe Daniels, son of imp. Anstralian. Squeez'en is the dam of Day Star (mmner of the Blue Ribbon stakes and Kentucky Derby) by Star Daris, Sylph and Tom Naven by imp. Glenelg, Palmetto by Virgil, Recluse, Fardello, aud Helena by imp. Mortemer, Eliza Rooney by Baden Baden, etc. Sglph is the dam of John K. by War Dance, La Sylphide by Felloweraft, Kaloolah, Philip D. and Kinesem by Longfellow, Syiria and sea Mew (Logica's dam) by imp. King Ban. Sylvia is dam of Fauna hy Longfellow. La Sylphicle is the dam of Semper Fidele, a grand race-mare, by Longfellow, Semper Rex by Lelaps, Semper Lex by Falsetto, and Semper Cara by King Alfonso. The fumily is a great racing and producing one. Irognois won the Derby and st. Leger in England, a feat accomplished by few horses, and is now regarded as one of the most valuable and potent sires in the conntry. Kentncky was a first-class race-horse, and was, for his chances, a grand snecess in the stud. The family trace their origin to the Layton Barb mare, to which trace in direct female line Young Greyhound, Cartouch, shepherd's Crab, Matchem, Young Cade, Drowe (by Herod), Blucher, Sir Walter Raleigh, The Ugly Buck, Clairraux, Simoom, Audubon, Philammon, St. Honorat, and many other good ones.

\section{BREEDING.}

In breeding for the Turf purity of blood, racing lineage and true conformation are the desirable and requisite qualities, and a combination of these qualities must improve the mechanical structure which nature conferred upon the horse, designed to gire him strength and fleetness, a combination seldom found in the aninal world, and which greatly enhances his utility to the luman race. These powers, great in an nucultivated state, are susceptible of much increase and improvement by judicious attention to breeding and erossing. It is an axiom in breedng (and this is particularly applicable to the horse) that the eharacter, quality and form of the offspring is governed in a large degree by the qualities we wish to propagate. These should be found in the parents, so that by coupling togetler a male and female entowed with the qualities we wish to be transmitted to the foals, we acquire the power of moulding the prodnce to our ideas. The principle that parents of all breeds and families of whatever species produce foung ones analogous to themselves, has been acted on for ages. The parents should be selected with the greatest discrminatiou, so that by unitiug in their offspring the superiorities possessed by both stallion and nare, the improvement is almost sure to follow. Those who breed for the turf must remember and act upon the value of the precept, and use the utmost cantion and julgment in selecting the sure and dam, so as to combine, improre and render permanent the good qualities possessed by euch. In selecting the parents, independent of conformation, pedigree and racing lineage, it is all important that both be sound, that is, free from any hereditary disease or taint. There are certain diseases which are transmissable from parent to offspring, but they are few. Nearly all the diseases to which the horse is liable, or blemishes, either in certain diseases of the ejes, sparun, ringbones or roaring, are traceable to some cause not lereditary. Nany of our best and most snceessful stallions have been blind, but not from constitutional causes, and the same is true as to roarers, this defect not slowing itself in their oftspring, whilst others, sound in all respects, have bred those with these defects, evidently from some canse unknown. It is a mooted question as to what age brood mares shonld be allowed to commence breeding. If they.have been well rassed, aud are not defieient in energy and museular development, they ean be safely bred to the stallon at three rears old. It is a notable fact that more valuable horses for general nses and more good race- 


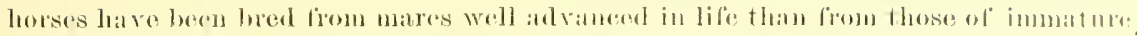

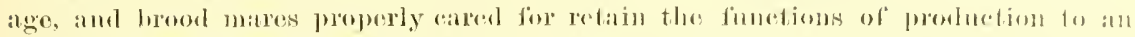

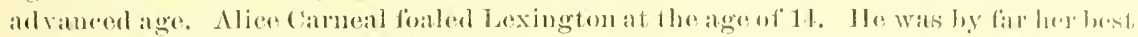

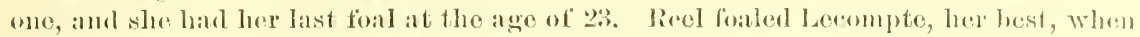

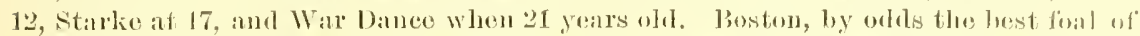

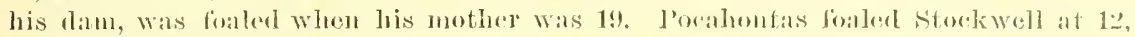

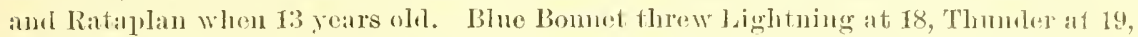

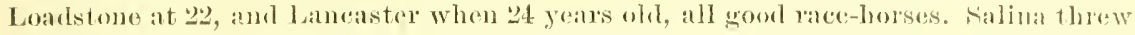

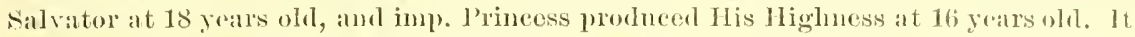
is neassaly in broding race horses that the muscular system of the stallion shomld he tomed mp by ahmolant exercise, and if the stallion will not exorise when turned into his parlock, ho shonld be ridelen. Exercise contributes to his lualth and muscular energy, and if he is deficient in tlese qualities at the time of (opulation. it is lut reasomable to suppose that the forl nust sufler comstitutiomally in a like respert. For a similar reason it is obviously injurions to the stamina of the forl if either $p^{\text {ratent }}$ shall have suffered from insufficient nourishing foor or otlur lebilitating eanses. No animal can be well formed or strong that has been stinterlin the ample supply of groorl nomrishing food necessary to its full development and grow th, from the earliest period of its existence to the complete formation of all its parts. The old sa jing is that the time to commence to breed the race-horse and insme success is to Jegin "betore he is born." The dam is the fonntain, and if she is neglected and starved the prodnce which she is carrying, with the one at her side, will not only show it, but proveit subseruently. Is is but reasonable that such should be the case when the systenl is taxed to contribute to the formation of the elnbryo, as well as to sustain life and supply the foal at her side with nomrishment. Mares should be kept in good, strong condition, not swine fat, but fat enough for health and strength, and to contribute the same to her foals. The foal will be larger, healthier, stronger, and the hair have a glosst and healthy appearance. Many breeders are of the opinion that a mare that has never raced is better to breed from than one that has raced. Statistics do not smpport this position. Some of the most eminent English breerlers, notably Lord Falmouth, bred from no mares that were not tried, and few breeders were inore successful or bred a larger number of wimners of the important racing erents. It is no disadrantage to race mares a reasonahle time, and now that the system of heat racing has been abolished, and horses are not subjected to the long and severc preparation, exhausting the vital powers to a great extent, no reasonable racing or training ean injure mares for breeding purposes. Alice Carneal, the dam of the immortal Lexington, ran two, three and fom mile heats. Reel, the ram of Lecompte, Starke, Prioress, ete, ran four mile heats. Brademante,- dam of The Bard, ran heat races. Idlewild, dam of Wildirle, wou at four miles. Nantura, the dam of Longfellow, raced aud won. Toucques, dam of La Tosea, raced until four years old. Salina, dam of Salvator, raced. Other suecesstul brood mares that raced are Nevada, the diun of Luke Blackburn, Florence, dam of Hindoo and grandam of Firenzi, Aerolite, dam of Spendthrift, Felloweraft, Miser, etc., Ann Fief, dam of the unbeaten Tremont, Maria 13lack, dam of Bay Leaf, the dam of Bayflower, Preakmess, Bayonet, etc., Topaz, dam of IVagram, Lodi, Colton, ete., Fanny IVashington, dam of Eolns, ete., War Song, dam of Eole, St. Savionr, Eom, ete., Nina, dam of Planet, Exchecquer, etc., Arizona, dam of Aranza, Maggie B. B., dam of Iroquois, Panique, etc., Jamaica, dam of Foxhall, Balloon, dam of True Blue, The Banshee, ete., imp. Mand, dam of Alarm, Mandina, dim of Piceolo, Oden, Cloverblook, Marauder, ete., Minx, dam of Monitor, susan Beane, dlam of Sensation, Onondaga, Stratforl, etc., Rescue, dam of Abd-el-Kader, Abd-el-Koree, etc., Sarong, dam of Aristides, Volga, dam of Barney Williams, Levity, dam of Ruric, Legatee, Lever, etc., Iry Leat, dam of Bazar, Bramble, Niagara, Brambaletta, etc., Magnolia, (lam of Princeton, Charley Ball, Magic, ete., Naiden, dam of Parole, James A., Perfection, Powhattan, etc., Magenta, dam of Duke of Magenta, La Henderson, dam of Ferida, Aella, ete., Farfaletta, dam of Falsetto, Felicia, ete., Fanny Holton, dam of Ten Broeck, Ulrica, (lam of Ben Ali, Megara, Memento, etc., Waltz, dam of Gliclelia, 
Farandole, etc., Sultana, dam of She, Padisha, etc., Susquehanna, dam of Potomac, Chesapeake, ete., Belle of Maywood, dam of Tenny. 'There are many others that could be alded to this list, none of which were severely trained and raced at lieats berond their fifth year. It should be an established axiom with breerlers that no thoroughbred animal with hereditary defects should be used in the stud. But the question is, what are hereditary defects? Spindling bone, chronic weakness and infirmities of constitution are the most pronounced hereditary defects. There are defects arising from accidents, such as affections of the wind or respiratory orgaus, in consequence of distemper or severe colds, ringbone or sparins from injury or over strains, which should not be termed or considered hereditary defects, and which are not transmissable from parent to offspring. But to reach the acme in breeding the thoroughbred horse, no constitutionally unsound mares should be used for the stud or breeding purposes. Then how is this fact to be ascertained ? The most practical test of soundness of limbs, digestive organs, constitution. temper and nerrous organization is in training and racing on public tracks. Mares which are trained and raced in their two and three-year old form, when fit, even with moderate suceess, unless some constitutional defect develops, must be regarded as sount; and such mares, if properly mated, should breed sound progeny, and such as shonld race successfully. Accidents or unforeseen canses, of conse, may intervene and prevent success. We have sometimes seen mares, from racing families, which have raced successfully, and retired to all appearances sound and with constitutions unimpaired, that proved failures in the stud. This is doubtless owing to the fact that they were raced too long, and the vital powers exhansted from the effects, and from the long and severe preparation for the class of races which they ran. One or two notable instances can be cited. Fashion a very highly shaped mare, well hred and from a racing famils, was a failure in the stud. It must be remembered that she raced until eleven rears old, ruming 36 races, of which she won 32 . Of these 24 were at four mile heats, of which she won 21, 8 were three mile heats, all won, and 4 two mile heats, of which she lost one. She was bred the first three seasons to her half-brother Mariner by Shark, prodncing two fillies and one colt. Her best produce was Dangerous, her last (foaled when she was 22 years old), by Boniie Scotland. Her daughter Young Fashon by imp. Monarch has done well in the stud, as also her daughters A la mode and Etiquette by Mariner. There are others which were famous on the turf and trained mutil aged that were failures in the stud.

"Breeding In and In." This "expression is used to specify the practice of breeding anmals snccessively from the same race and blood, with similar form and symmetry, and closely allied in blood lines. It has always been regarded as an active cause of degeneracy, as unnatural and calculated to engender and perpetuate hereditary diseases. These evils, in my opinion, can only arise from the abuse of the system. If proper attention and care be taken to exclude the weak and diseased from participating in reprodnction, it will be the means of improving and continuing for an unlimited time those perfections and beanties which are to be highly prized. "Breeding In and In" bestows the power of improving and perpetuating the excellences of any breed of animals and transmitting those excellences numpaired to succeding generations, and for this reason should not be too readily disregarded and condemned. The application of these principles to generation of our useful domestic animals has produced the swift and heautiful rice-horse, the disposition to fitten in cattle, and the fine-roolled brecds of sheep; and that which has been originated and established by art in brecting, can be continned and improved by the same means. By judiciously selecting the parents, both male and female, we can establish new varieties, and by contmung to breed from such improved and perfected stock we will be able to perpetuate the excellent qualities. The evils which often arise in the human race from the mion of those too closely alied in blood may be altogether aroided and obriated in the brute creation, by wholly debarring those tainted with hereditary diseases. or such as are deficient in constitutional stamina, from participation in reproduction. The ligher the intelligence the more marked the deterioration, where there is a tamt of hereditary disease or lack of con- 


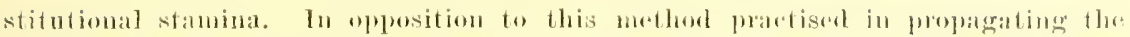

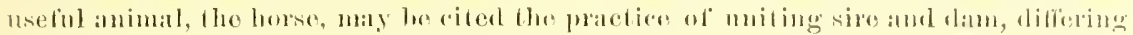

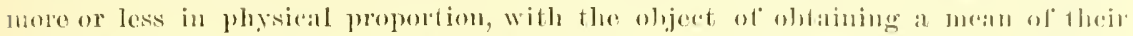

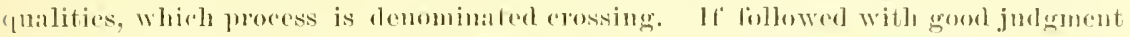

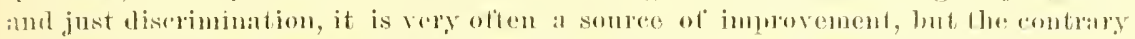

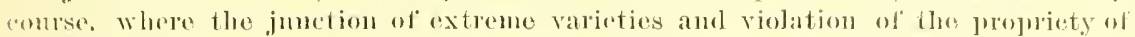
nature has ben permitted, las lect ro the propagation of an animal of inlerior chas-

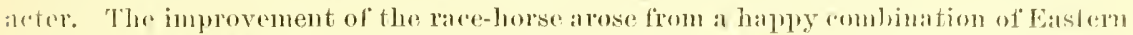

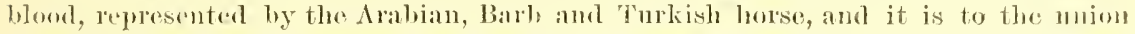
of these bloods that we trace his prevent excellence. The mion of the blowe contferred upon tho possessors womlertul stamina, great speed and the power of resisting and eururing extraordinary leats of muscmlar exertion without fatigne, exceraling all other hreeds in these estimable qualities. In the infaney of racing improvement seemed to mark every tresh infusion of Eastern blool. The Gorlolphin Arabian. Darley Arabian, Curwen Barb, Byerly 'Turk, Lister Turk, Place's White Turk, Compton Barb and the Royal mares originated a progeny celebrated in the anuals of the turf. But the infusion of now Easterm blood is now more likely to degenerate thim to improve the thoroughbred horse. Onr modern race-horse has hecome such a grand and distinct improvement from the sonre that originated him that he excels it in speed, stamina and staying qualities, and that ans further armixture of Eastern blood wonld fail to benelit the horse. It has often been the enstom to cross from one blood into another, and to breed from a stallion or mare of inferior shape, symmetry and gooduess in preference to breed, as it is styled, in and in. Whilst I do not adrocate incestuons breeding, I believe that crossing ont to good blood and form, and them back to the same gool blool and symmetry, if the animals nsed in reproluction are as indicated above, must result in improvement. Onr very best horses from the earliest dates have been bred in and in, often incestuonsly so, without ileterioration, and I an of the opinion that we should keep in good blood, where there is symmetry, constitution and no herelitary disease, even incestnously so, rather than exchunge it for inferior blood and form, under the idea that it is necessary to cross at all events into distinct blood. But as good and bad qualities descend, if we go from superior blood to inferior, and frou high form to bad, the stock must degenerate. I lo not assert that breeding in and in is superior or preferable to any other mode of breeding, but I am confident there are not those physical ohjections to it, which are commonly entertained. An improvement of any race can only be expected from crossing with superior s smmetry of form and better blood, and it is ouly in such cases that we decidedly recommend it. I desire to support my views by facts, and leave the breeder to dram his own conclusious.

I will only cite examples of famons horses. Flying Chilelers was bred in and in. He was the fieetest and most famous horse of his day, by the Darley Arabian, dam Betty Leedes by Old Careless, son of Spauker, by the D'Arcy lellow Turk, grandam sister to Leeles by Leedes Arabian, out of danghter of Spanker, son of D'Arcy Yellow Turk, she ont of old Morocco mare, Spanker's own dam.

Highflyer, the most fimous race-horse of his day, and a grand and successful stallion, was by Herod, dam Rachel by Blauk, grandam b5 Regulus. Blank and Regulus were both sous of the Gololphin Arabian.

Old Fox, an excellent racer and sire of Meliora, the dam of Tartar, the sire of Herod, was by Clumsey, son of Hantbos, dam Bay Peg by Leedes Arabian, ont of Yonng Bald Peg by the same Arabian.

Priestess, the most famous mare of her day, was by Matchless, son of Cade, her dam by the Gower stallion, grandam by Regulus. Cade, Gower stallion and Regulus were all by the Godolphin Arabian.

The celebrated Gimerack, sire of imp. Mielley, was by Cripple, clam by Grisewood's Partner, grandam by Croft's Partner, the sire of Grisewood's Partuer.

Imp. Shark, the most noted race-horse of his lay, and a very successful stallion, was by Marske, son of Squirt by Bartlett's Chillers, his dam by snap, sou of suip by Flying Childers, own brother to Bartlett's Childers. 
The celebrated O'Kelly's Eclipse, who was never beaten or paid a forfeit, was much inbred to Lister Turk and Hautboy, and much of his excellence was attributed to this fact.

Diomed (winner of the first Derby ever rum), imported ts Ameriea when twentrtwo rears old, and the most valuable stallion ever inported, was much inbred. Florizel, his sire, was hy Herod, dam daughter of Cygnet, son of the Gorlolphiu Arahian. His dam sister to Juno was by Spectator, whose dam was bs Partuer, grandsire of Herod. Diomerl's grandam Horatia was by Blank, son of the Godolphin Arabian. Herod, Florizel and Horatia were all inbred to the Darley Arabian through the two Childers.

1mp. Glencoe, whose daughter Poeahontas was the grandest and most suceessful brood mare in England, and whose son Vandal made sneh̀ an impression on the stock of this country throngh his sons, and whose daughters are the dams and grandams of many of the most famons race-horses and stallions in America, was much inbred to Herod, Eclipse and Childers, having no less than eleren rlirect erosses of Herod blood, seren of Eclipse, and the sane to Childers, through Snap.

Imp. Leamington, the grand and sncessful stallion, was much inbred to Heror and Eelipse. He had no less than twenty-five erosses of the former and fourteen of the latter blood.

Imp. Phaeton, a phenomenal snecess in the stnd in Ameriea, is very much inhred to the same blood, Herod and Eelipse, throngh Buzzard's sons, Castrel and Selim, and throngh the best sources, Whalebone, Whisker and Beningbrough.

Imported Priam by Emilins (winner of the Derlss, 1823), and sire of Crueifix (rimner of the 2,000 and 1,000 Guineas aud Oaks, 1840), Miss Letty aud Industry (winners of the Oaks, 1837-1838), was inbred to Whiskey, son of imp. Saltram. He was the highest priced horse imported up to his day, costing, $\$ 17,500$ in England.

Imported Billet, an excellent race-horse and popular stallion, was inbred to Filloda-Puta. Voltigeur, his sire, was by Voltaire, dam Martha Lymu by Mnlatto, ont of Leda by Filho-ra-Puta, Billet's dam Calentta by Flatcateher, whose dam, Decoy, was by Filho-da-Puta, and he has any number of crosses to Eclipse, throngh the best sonrces, Pot-8-o-'s and King Fergus, backed by a large infusion of Herod blood from the best and most potent somrees.

Galopin, the most popular stallion in England (winner of the Derby in 1875), sire of Galliard (winuer of the 2,000 Guineas, 1833), Donovan (winuer of the Derby and St. Leger, 1889), St. Simon (a superior race-horse, sire of Semolina, winner of the 1,000 Guineas, 1890, Memoir, wimner of the Oaks and St Leger in 1890, ete.), is inbred to Voltaire, being by Verlette, son of Voltigenr by Voltaire, dam Flying Duchess by The Flying Dutchman, ont of Merope by Voltaire, who is also inbreil to Blacklock.

Barcaldine, the best living representative of the Melbonrue blood in England, and a very popular stallion, sire of Mimi (winner of the Oaks), is inbred to Birdcateher. He is by Solon, son of West Anstralian by Melbourne, Solon's dam. Darling's dam by Birdeateher. Barealdine's dam Ballyroe by Belladrum, graudam Bon Aceord by Adventurer, ont of Darling's dam by Birdeateher.

Isonomy, the grand race-horse, and who was one of the most popular stallions, sire of Seabreeze, wimner of the Oaks, Common, wimer of the 2,000 Guineas, Derby and St. Leger, is inbred to Birdcatcher, being by Sterling, son of Oxford by Birdcatcher, dam Isola Bella by Stockwell, son of The Baron by Birdeatcher, and traces four times direct to sir Herenles.

Wellingtonia, a superior race-horse and sire of Clover, wimer of the Prix du Jockey Club (French Derby), is inbred to old Pocahontas. He is by Chattanooga, sou of Orlando by 'Tonehstone, Chattanooga's dam Ayacanora by Birleatcher, out of Pocalontas by Glencoe. Wellingtonia's clam Arancaria was by Ambrose, son of Tonchstone, out of Poeahontas by Glencoe.

Merry Hampton, winner of the Derby in 1887 , was inbred to Pocahontis and Qneen Mary on both sides of sire and dam. Hampton, his sire, is by Loril Clifilen, son of Newminster by Touchstone, his dam Lady Langden by liettledrum. son of Rata- 


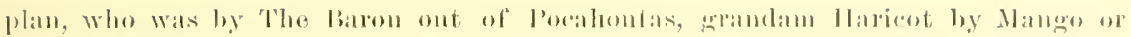

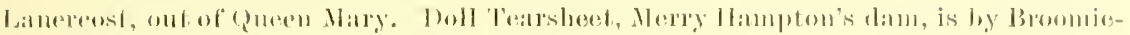

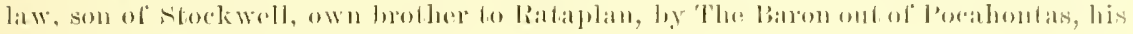
dam Queen Mary lig (iladiator.

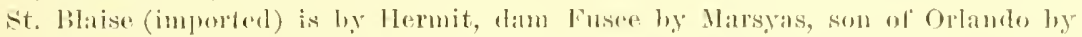

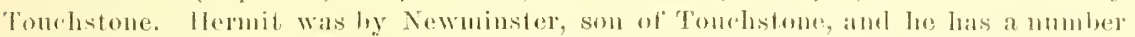

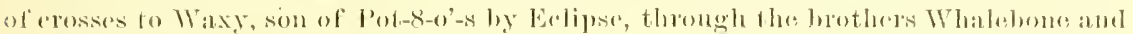

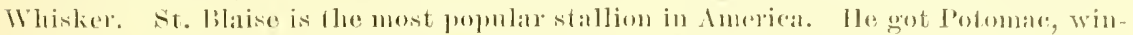

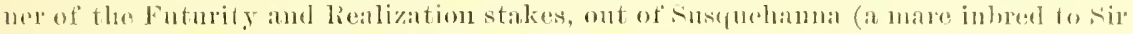
Alely amd liomed), La Tosea. C'hesapeake, ete. Ifo sold at the dissolution of the Nursery stud lor 8100,000 .

Imported 111 Tseet, a superior rare-horse (winner of the Kenner and Serfuel stakes at silutoga, both two miles), sire of Forester, a superior race-horse, liellona, WootHower, Jack of Hearts, Florimel, welilah, Balge and the gramel two-year-old, His llighuess, was inbred to Birleateher. The was by Brealalbane, wother to Blail Athel, son of Stockwell by The Baron by Bireteateher, dam Ellemine by Chanticleer, son of Birdeatcher, and he traces to Waxy many times, through the brothers Whalebone and Whisker.

Imp. Galole is by Galopin, inbred to Voltaire, tam Lady Maura by Macaroni, grantam by StockweII, g'eat grandam by The Flying Intchman. Galopin's dam was be The Flying Dutehman. Gahore was a superior race-horse, but has yet to be trich as stallion.

Imp. Rayon a'Or. the grand race-horse and popular stallion, is inlred to Touchtone, and has almost numberless crosses to Eclipse through the brothers Whalebone and Whisker and throngh Whiskey, also a large number direct to Herocl.

Imp. Deceiver (Pallock), now one of the popular stallious of Ameriea, is inlored to Tonchstone, and has two crosses of Glencoe.

Imp. Mortemer, a superb race-horse and sire of St. Christophe, winner of the Grand Prize of Paris, Verneuil, winuer of the Ascot Gold Vase, Gold Cup and Alexandra Plate, Chamant, wimuer of the 2,000 Guintas, 1877, Exile, Wanla, Pontico and other good ones in America, is inbred to Partisan, son of WaIton by Sir Peter, and has a large infusion of Eelipse blood on both sides from the best sonrees.

Manc of the most famons prodncing mares in England were elosely inbred. Mandragora (dam of Mandrake, Apology aut Agility) and her sister Mineral (dam of Wenlock, St. Leger winner, 1872, schwindler am Kisber, Derby winner, 1876) were inbred to Bircleateher.

Marpessa, the dam of Boarding-Sehool Miss, Pocahontas (the dam of Stock Rataplikn, King Tom, Ayacanora and Arancaria, dam of Rayon l'Or), is inbred to Whiskey. son of imp. Saltram by Eclpse. Her blom is to be fonnd in nearly all the best race-horses of our day.

Sechsion, the dan of the great Hermit, sire of St. 13laise, Marden, Peter, Tristan, ete, is inbred to Sultan, son of Selm by imp. Bnzzari.

Isoline (lam of Isola Bella, Isonomy's dam, and of St. Christophe) was inlreel to Sir Hercules by Whaiebone.

Bay Celia, the fiam of The Earl and The Duke, by Orlando, son of Touchstone by Camel, dam Hersey by Glancus, ont of Hester by Camel, was inbred to Camel.

Howerina, own sister to Cotherstone, was inbred to Waxy and Penelope. Her sire Tonchstone, was a great grandson of Whalebone by Waxy, ont of Penelope. Emma, her dam, and also the dam of imp. Trustee and Mundig, was by Whisker, own brother to Whalebone by Waxy, out of Penelope by Trumpator.

Hauy of our imported matrous were also inbred. Imp. Barbarity by simoom, son of Camel by Whalebone and Sea-Breeze by Panlowitz, son of Sir Panl by Sir Peter, dam by Buzzard, son of Blacklock, out of Donua Maria by Partisan, son of WaIton by sir Peter, was inbred to Sir Peter. Pred to imp. Eelipse. son of Orlando, by Tonehstone by Camel, out of Gaze by Bay Mulcileton, unbred to Phanton (son of Walton hy Sir Peter). Barbarity produced those good race-nares, Relentless, Remorseless and Ruthless, with Barbarian ancl Derastation. Imp. Britannia lyy Muley, son of Orville by 
Beniugbrongh, dam Nancy by Dick Audrews, son of Joe Andrews by Eclipse, out of Spitfire by Beninghrough, son of King Fergus by Eelipse, was inbred to Beningbrongh and Eclipse, and prodnced to imp. Belshazzar (a horse inbred to Eclipse) Verifier, La Verité, Vandyke and La Victime, and by imp. Yorkshire (a horse inbred to Eclipse) Verona, the dam of Vauxhall, Foster, Veritas, etc. A number of superior race-horses are from Verona's daughters. Imp. Princess, dam of Prince Royal and His Highness, is inbred to Snltan. Her sire, King Tom, is a great grandsol of Snltan throngh Glencoe. Her dam is great granddanghter of Sultan throngh Bay Middleton.

Sir Archy, justly styled the Godolphin Arabian of America, was inbred to Herod. He was by Diomed, son of Florizel by Herod, dam imp. Castianira by Rockingham, son of Hightlyer by Herod, and had no less than seven direct crosses of the Godolphin Arabian throngh his dam.

Boston was the best race-horse of his day. He ran 45 races and won 40,30 of which were fonr mile heats, 9 three mile heats, and one two mile heats. He was the best stallion of his day, sire of the immortal Lexington, Lecompte, Red Eye, Tally-Ho. Ringgold, Arrow, Bostona, Nina and many others, and was elosely inbred to imp. Diomed. He was by Timoleon, son of Sir Archy by Diomed, dam sister to Tuckaboe, by Bail's Florizel, son of imp. Diomed. Timoleon's dam was by imp. Saltram, son of Eclipse. Boston's grandam was by imp. Alderman, son of Pot-8-o-'s by Eclipse.

The great Lexington, the only horse that ever ran four miles better than 7.25 on two occasions ( $\left.7.19 \frac{3}{4}, 7.23 \frac{3}{4}\right)$, was inbred. He was by Boston, grandson of sir Arehy by imp. Diomed. Lexington's dam was Alice Carneal by imp. Sarpedon a horse inbred to Eclipse), grindam Rowena by sumpter, son of Sir Arehy, and he had a large infusion of Eelipse blood with the Herod on both sides.

Jack Malone and Pat Malloy, own brothers, both superior race-horses, full of snbstance and quality, were mnch inbred. They were got by Lexington (himself inbred to Sir Arehy by imp. Diomed), dam Gloriana by American Eelipse, son of Duroc by imp. Diomed, grandam Trifle by Sir Charles, son of Sir Arehy by imp. Diomed, she ont of a daughter of Cicero, son of Sir Archy. Both were successful stallions, and many of their danghters are grand good brood mares.

Longfellow, the grand race-horse and stallion, sire of The Bard, Leonatns, Longstreet, ete., is much inbred on his dam's sile. Nantura, his dam, was by Brawner's Eclipse (grandson of Dnroc hy Diomed, his dam by Henrs, son of Sir Archy by Diomed, grandam, Young Romp by Duroc, son of Diomed), Longfellow's grandam, Qniz by Bertrand, son of Sir Archy by Diomed.

The Bard by Longfellow, a very superior race-horse and promising stallion, is inbred to Sir Herenles, having three crosses of that hlood, one throngh Faugh-aBallagh and two throngh Birleateher, the own brother to Fangh-a-Ballagh, and is also inbred to Diomed throngh Lexington, sire of War Dance and Nantmra, dam of Longfellow.

Salvator, the great and popnlar race-horse, whose one and a quarter miles in 2.05. and one mile in $1.35 \frac{1}{3}$, has never been equalled by one horse, is inbred to Glencoe. Stockwell, the grandsire of Prince Charlie (Salrator's sire), was ont of Pocahontas by Glencoe, and Salrator's dam, Salina, is ont of Lightsome by Glencoe.

Enquirer, one of the best sous of Leamington as a race-horse and stallion, is much inbred on his dam's side. Lida, his dam, was by Lexington, son of Boston. by Timoleon by Sir Arehy, his grandam, Lize, by Ameriean Eelipse, grandson of Diomed, his great gramlam, Gabriella, by Sir Archy by Diomer.

Eolus, one of the best and most popnlar and successful stallions in America, is inbred on the dam's side. Revenue, the sire of his dam, was ont of Rosalie somers ly Sir Charles, son of Sir Archy, his graudam Mischief hy Virginian, son of sib Archy, Eolus' grandam Sarah Washington by Garrison's Zingauee, son of Sir Arehy. his great grandam Stella by Contention, he by Sir Archy.

Falsetto, a snperior race-horse, winner of the Plucenix Hotel Stakes, Lexingtois. K5., Clark Stakes, Lonisville, Ky., Travers and Kenuer Stakes at Saratoga, X. Y. , is iu bred to Lexington and Boston on both sire and dam's sides. His sire, Enquirer, wato 
ont of Lida by lexington, and his dam, Farlaleftal, is liy imp. Australian, ont of

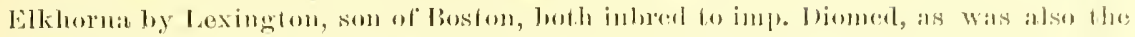

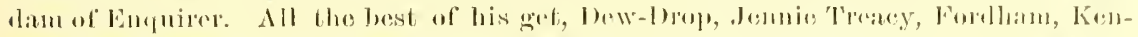

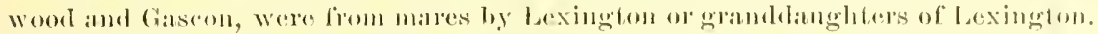

Foxhall, that went to England, and Whom William I) a said was tho best date-

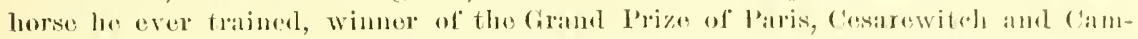

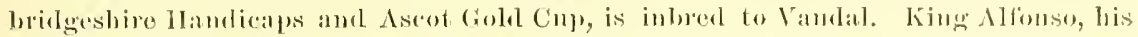
sire, is ont of Capitola ly Vamdal. Jamaica, his dam, out of lanmy Ludlow by imp. Eelipse, sho out of Mollio Jacksom by Vaurlal.

Iranover, the superior race-horse, wimer of all his races at $t$ wo years old, and 20 ont of 27 stakes at threo years old, and now regarter as a promising stallion, is inturer to Vitudal, som of Glencoe, being hy Hindoo, son of Virgil by Vaurlal, dam Bonrbon Belle by imp. Lomie Scotland, ont of Ella D. ly Vaudal.

lishon, a goorl race-horse, sire of Tronbadour, lipple, Grimaldi, ete., is much inlired to Pocahontas. Imp. Phaeton, his sire, was by King Tom, son of Harkaway and Pocahontas by Glencoe, his dam inp. Lady Love by Stockwell or Caterer, son of Stockwell ; Stockwell by The Baron, dam Pocahontas.

Norfolk, one of the best sons of Lexington, both as race-horse and stallion, was closels inbred to Sir Arehy and imp. Diomed. Boston aud Lexington were inbred to Sir Archy and Diomed. Novice, the daw of Norfolk, was by imp. Glencoe, dam Chloe Anderson by Rodolph, son of Sir Archy Montorio, son of sir Archy, grandam Belle Anderson by Sir William of Transport, own brother to Sir Archy Montorio. Norfolk won two of the most remarkable races on record, two-mile heats in $3.37 \frac{1}{2}$, $3.38 \frac{1}{2}$, three-mile heats in $5.27 \frac{1}{2}, 5.29 \frac{1}{2}$.

Many of our best prorlucing native mares are much inbred. Coral, the dam of Uncas a.ui Wanderer, good race-horses and successful stallions, was inbred to Sultan. She was by Vandal, son of Glencoe by Snltan, dam by Cotherstone, grandam by Slane ont of Glencairne, own sister to Glencoe by Snltan.

La Henderson, the dam of Virgilian, Ferida, Aella, Ferona, etc., is inbred to sir Arehy and imp. Diomed. She is by Lexington, dam Kitty Clark by imp. Glencoe, out of Miss Obstinate by Sumpter, son of Sir Archy. Maiden, her sister, is the dam of Parole, James A., Powhattan, Pappoose, Parthenia, ete.

Mattie Gross, the dam of the fine race-horses Mate, Whisper and Grenarla, was inbred to sir Archy and Diomel. She was by Lexington, dam by American Echipse, son of Duroe by Diomed, grandam by Orphan, son of Ball's Florizel by Diomed, Orphan's dam by Diomed.

Fanny Holton, dam of Ten Broeck, whose five races are nnequalled in the worli (mile $1.39 \frac{2}{4}$, two miles $3.27 \frac{1}{2}, 2 \frac{5}{3}$ miles, $4.58 \frac{1}{2}$, three miles $5.26 \frac{1}{2}$, four miles $7.15 \frac{3}{4}$ ), was much inbred to sir Archy and Diomed. She was by Lexington, dam Nantura by Brawner's Eclipse, son of American Eclipse by Duroc by Diomed, Brawner's Eclipse ont of danghter of Henry by sir Archs, grandam sister to American Eclipse's dan by Duroc, son of Diomed, Nantura's dam Quiz by Bertrand, son of Sir Archy.

Aerolite, my beau ideal as a brood mare, and her sister Idlewild, were inbred to Sir Arehy and Diomed. They were by Lexington, clam Florine by inp. Glencoe, ont of Melody by Medoc, son of American Eclipse by Duroc by Diomed. Aerolite, bred to imp. Anstralian (himself inbred to Whisker), prodnced Spendthrift, Felloweraft, Miser, Rutherforl, etc.. all good horses and stallions. Itlewild ran four miles herself in $7.26 \frac{1}{4}$, and her son Wildidle by Australian won at four miles in $7.25 \frac{1}{2}$. Her daughter Fanchon is the dam of winners.

Katona, the dam of the superior racehorse and good stallion Tom Ochiltree, Kadi, Partnership, etc., is inbred to Mnley. She was by Voucher, son of Wagner, out of imp. Britannia by Muley, her dam by imp. Margrave by Muley, son of Orville by Beningbrongh. Her sons by Lexington are inbred to Sir Archy and Diomed.

I have quoted examples enough of both English and American horses to establish my opinion that inbreeding is not injurious, and that, if properly carried ont, it does not lead to degeneracy. Being in possession of good blood, symmetre (by which I mean all the elements of good conformation) and good temper, there can be 
no question that crossing ont and then back to the same good blool, symmetry and temper, the shape and good qualities are preserved and perpotuated, and the produce never degenerates.

\section{CONFORMATION.}

The race-horse, or rather the thoroughbred liorse, from his symmetry, power, graceful action, light, elastic form, speed and stamina, is bejond question the lighest type of the equine family. He prossesses more of the beauties of formation than any animal which approximates to him in size and shape; he excels all others in the in telligent expression of his comntenance and shape of his heal, and in the sinplicity, compactness and completness of his digestive organs, the great leverace of his hocks and hind quarters, and the wonderful mechanism displayed in the construction of his legs and feet.

BOXE.

The bones are the passive agents of locomotion and are the levers npon which the muscles act; they support and sustain the body and act as protectors to the softer and more vital parts. The projections, roughened surfaces of the boues are the points for attachment of the muscles. As these projections act with lever power, they consequently (annot be too long; length of leverage, mechanically speaking, diminishes the intensity of the musenlar action. This is notably applicable to the spinous and transverse processes of the rertebral colmm, the point of the elbow (nlna) and projeeting point of the hocks (os calcis). Largeness of bone is not an invariable evidence of strength, as the density of material and closeness of structure gives greater speeific gravity to the bone of the thoroughbred than is found in common stock. Joints are composed of the articulating surfices of the bones, and are the means of extensive motion. In order that flexure may be as free as possible, and to avoid occurrence of lisease from friction, which sometimes ensues, the bones at the joints shonld have eonsiderable expansion, so as to clivide and distribute the weight as much as possible over an extensive smrface. It is an established law in mechanies that a simple joint loes not possess great strength or armit of much motion. In animals, nature, strength and accelerated motion is aimed at, has made the joint a compound one, or a series of joints. This is the case in the human foot, which is arched, and where strength is insured by the peculiar arrangement of the bones, enabling them to bear the entire reight of the body, while the elasticity is maintained by the play between each separate joint. It is the same, practically speaking, in the knee, hock and foot of the horse, each being composed of a series of joints. In the hock the motion is restricted to two bones, the others being employed in sustaining the weight of the hody and receiving the lever pressure of the point of the hoek, aud imparting a spring to connteract the concussive effects. The motion of each individual joint is in itself insignificint, but the effect of the series combined is sufficient to give strength and protect the parts.

\section{MUSCLE.}

The muscles are the active motive powers of the animal machine, and in most cases give indication of a horse's real energy. They are the true organs of motion and are distinct from the other tissues of the body by their texture and rital contractility. Nuscles are made up of fibres, arranged in bundles, proportioned in quantity to the required action. The effects of their contraction are conreyer to the distant parts by rope-like tendons in which they terminate. The larger museles are provided with correspondingly larger tendons, hence the relative size of the tendons is indicative of musenlar strength. The museles perform varions functions in the animal economy, the most important of which is the result of their contraction on the bones, thus producing locomotion. The effect of the contraction of muscle is the drawing together of the points of attachment, increasing its diameter and lecreasing its length. Hence, in proportion to the length of the muscular fibres, will be their contractile power. In all cases where speed is the desired quality, long muscles are indispensable, providing for the complete flexion and extension of the limbs, thus giving the greatest possible length to the stride. In oriler that this extensive contraction shomld be antinue.l with ease aud withont fatigne, a due proportion of vital tonicity of the muscular fibre 
is indispensable. No animal an bes stome moless tho musces aro bulky and wall

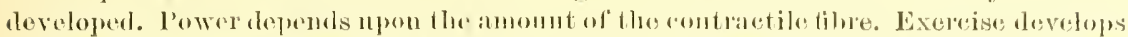

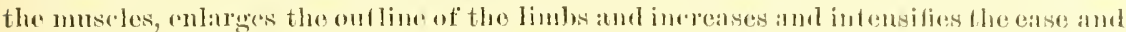
forco of the contraction. Tonicity of the muscular system ronstitutes the loaling (")ment of condition, whinh is jutged ly the firmmess of the museles, alosence of unnecessary comnective fatty tissue between the humbles and betweon the museles and the skin, showing a prominent, distinct, chean and well-defined appearance of eateh muscle beneath the integrments.

THE IIEAD.

No part of the horse more definitely illustrates the smperiority of blood than the bead. A cold, eross ar coarse one is apparent in its eontour. It is a ready eviolence of equine aristocrary and is an numistakable indication of the spirit and temper. The heal should bo oleai and bloodlike, and of a length in proportion to the size of the frame, divested of all mnecessary covering of flesh, anit shomld articnlate with the neck in a free and graceful mamner. The bones of the lower jaw not too hoavy, with snfficient wirth to alnit of flexure towards the throat withont intermption of respiration. The line drawn from the foretop to the mnzzle cannot be too straight. A curvature ontward will indicate sluggishness, and if inwarl is likely to impede respiration. The cranium or sknll should le wide, as containing the sensorium, and the face from the eyes down in due proportion to eonstitute a well-formed head. If narrow between the eyes, the horse is apt to be obstinate and slugrish. The eyes shonld be full, clear and nearly eireular, color rather lark, as those showing too much white are inclined to be flighty and unreliable. If the eyeball is sunk into the orbit or has a eorrugated appearanee of the lids it indieates some latent disease. The ears are the index to the temper of the horse, telegraph his will and give warning of his intentions. I like fair-sized ears, rather long than short, not too wide apart, lively in motion and ereet. They give animation and expression to the head and indieate vigor and endurance. The lips are prehensile. They collect the food and direet its course to the teeth. As an evidence of blood they must be thin, and as an evilence of vigor they must be firm against the teeth and gnms. If relaxed and pendulous it is a sure criterion of the lack of museular energy.

THE NECK AND CREST

A well developed neck, properly shaper, is a sure indieation of strength; a thin, poorly developed one shows weakness and want of constitution. The lower surface, that is, the portion from the point of the shoulder to the larynx or gullet, eannot be too short, while the length from the top of the withers to the poll of the heal should be more than double that of the forner, because there will be less resistance in the air passages and rapid respiration much easier. This formation is affected more or less by the proper eonformation of the other portions of the frame, more particularly of the shoulders. The point of the shomlder being pushed forward and the apex of the shonlder blade being well inelined back into the backbone, lengthens the uper surface of the neek, and the seapula at this point pushed forward shortens the lower surfice to the neek and lessens the space between the breast and the linyx. It is not often that you find a good neek on a barl animal, or a bad shaped neek on a good one. A good neck is strong, deep and brodd, rumning into the shoulders smoothly, and formed as above deseribed. A thin, ewe nerk or a light, tapering, peacocky one is a sure indication of weakness, not only in this part, but of the whole system.

THE SHOULDER.

The shoulder is composed of two bones, the scapula and the humerus, which are enveloperl in strong, powerful museles. A certain proportion of museularity is indispensable to the possession of power and continuance of great exertion. The seapula or shoulder blate shonld be obliquely directed backward, so that the lower end meets the humerns or upper bone of the arm in a slanting direction. This formation not only lessens or obviates coneussion, but increases the performing power of the museles. The shoulder should be well covered with musele, but not bear the appearance of being overloaded. The scapula and humerus being in too straight a line to each 
other act to great disadvantage, and the muscles, in order to overcome the malformation, expend a nseless amount of contractile force. When these bones meet ear.h other in an oblique direction this force is unnecessary, as the parts are already partially flexed and can act with concentrated effect. The linb is more easily elevater and the shoulder action increased. Yonatt says: "The point of the shoulder is projecterl forwarl, and therefore the pillars which support the fore part of the horse are likewise placed proportionately forward, and they have less weight to carry. They are exposed to less concussion, and especially concussion in rapid action. The horse is safer, for having less weight lying before the pillars of support, he is not likely to have the centre of gravity thrown before and beyoud them by an accidental trip, hence he is not likely to fall, and rides more pleasantly as there is less weight in the hand of the rider." A clean, thin, weak and knify shoulder is not desirable, nor is an upright and overloarled one.

THE CHEST.

The chest contains the chief organs of animal life, those of respiration and circnlation. The chest should be of suffieient width to allow free action of the respiratory orgaus. It shonld be not too broad, but round rather than narrow aud deep. It is by the shape of the chest and its capacity that we judge of the constitutional vigor of the animal. The girth of the chest does not give an infallible idea of its internal dimensions. On the principle that a circle contains more than an ellipse, so the broad chest contains a greater internal area than a deep one, but I do not fancy too wirle a chest as you stand before a horse, for in such a formation the frame is not so compact and regular as is required for continued exertion and freedom of action.

THE FORE LEG.

The fore $\operatorname{leg}$ is composed of the cannon bone in the front and two small splint bones behind. The caunon bone sustains the bulk of the weight and communicates it to the pastern. A minor part of the weight is transmitted from the knee to the head of the splint bones, which are attached by centres of ossification to the cannon bone, and when in action descend and break or lessen the conenssive force, and ascend to facilitate the extension of the legs. Thus by playing up and down as the foot is alternately raised and placed noon the ground, they bestow elasticity and prevent concussion. By over exertion or injury this part becomes inflamed and the extremities are mnaturally joined to the cannon bone, which is called splint and prociuces lameness. The camnon and splint bones cannot he too short, relatively speaking, nor the radius or bone of the arm too long. They should be broad and flat as you look at them sideways, the muscles running full in to the knees; the legs should stand perpendicnlar and the elbows as near in a line with the stifle joints as possible, pointing neither in nor out. If inwart, the action is jarring, stiff and weak, owny to the concnssion being more direct. If ontward, the action will incline to be sprawling and ineffective. But if compelled to choose between either, I shonld prefer the in-elbowed horse to the out-elbowed. It is of vital importance that the arm loe muscular, and, as an indication of speed, of good length. The radius or upright bone aud the ulua, which forms the elbow, become consolidated into one when the animal matures. The knee is formed by a treble series of joints, and corresponds to the wrist in a human being. In speedy animals it should be long, broad and flat in front, but not thick when viewer laterally. The six different bones composing it are each covered above and below by a thick coating of cartilage connected together by strong ligaments, separated by flnids and surronuled by membranes. Thus concussion is shared by all of them and by their peculiar connection it is rendered harmless. 'The seventh bone, called the trapezium from its quadrangular shape, is placed behiud the knee, hut bears no portion of weight. Two of the flexor mascles proceed from the bone of the arm and are inserted into it, and being thus thrown off of the limb, act more directly and with considerable power. As the terminous of the muscles descend on the limbs, they are tied down by strong ligamentous bands, particularly in the neighborhood of the joint. The extensor tendons, which lie principally in front of the canuon hone, are prevented from starting, strengthened and assisted in their action, but the flexor tendons which are at the back of the leg wonll be liable to friction 


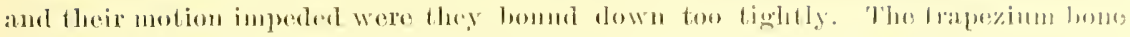

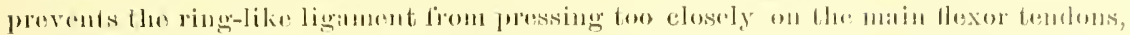

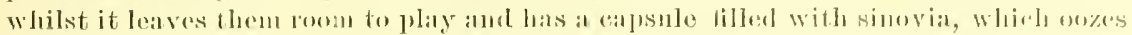

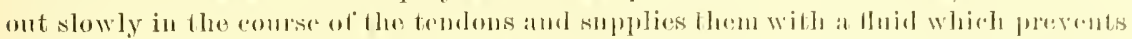

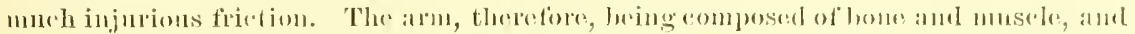

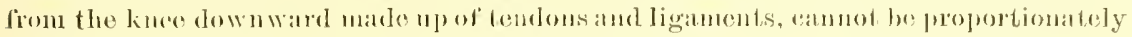
too loug or the space lwt ween the knee and the fet lock joint too short or broal. The

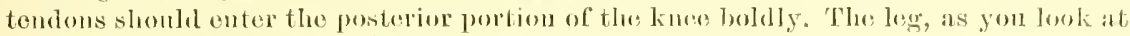
it laterally, as a whole should mot appear to be marle up of a series of joints, Jut slunld present the apperanes of gratually tapering fiom the ellow to the fetlock joint. Looking at the conformation of the whole leg and not at any parts of it, I would arlvise tho discarling of a calf-kneod horse, w what is called hack at the knees. Tlhey are usually speody, but no matter how well shaped the leg in ather respects, thes strain on the legs in such ronformation must be severe and cannot long he endumel withont injury. Lord George Bentinck, who nominally redueod racing to a sicince, tested horses with arched knees and tried them over different courses. His experience was that on level and inclined courses there was little or 110 diflerence, lut orer nphill courses the superiority of the arch-kneel horse was very marked. Of the two formations the arched knee is preferable and will stand longer, that is, if naturally so, not from coutraction eaused by diseass.

THE FETLOCK AND PASTERN.

Four bones compose the fetlock joint: the nper and large pastern, the lower and small pasteru, and two sessamoid bones. From the back part of the cannon or shank bone arises a strong ligament, called hy veteriuarians the suspensury or main ligament, which is of great elasticity, and which passes clown the leg, bifureates and connects with the two sessamoid bones at the back of the pastern joint. This tendon elongates with pressure and contracts when the weight is removed, and thus by its elasticity assists the flexor museles in flexing the pastern joint. When overtaxed this tendon is broken through, and the horse then, in turf parlance, is said to be broken down. When thoroughly so, the point of the fetlock comes to the ground, and the horse is unfit for great exertion or racing afterurarls. The pasterus should not be too upright, nor is an excess of ololinnity desirable, and they shonld be more oblique behind than in front. Nature, having mare snch extensive provision for elasticity in the formation of the front limbs, econonises as much as possible to increase the strength of the parts below. There is, therefore, less necessity for great obliquity of the pasterns in the front legs than in the hiuk ones. Elasticity and strength may be regarded as antagonistic forces. As one predominates the other diminishes; hence, where strength is demanied, a more upright pastern is indicated than where elasticity is refuirel. It may be put down as an axiom, that a horse is unworthy of the name of a race-lorse that does not possess good and properly formed fore-legs, and a material point in such formation is an oblique, large pastern. If the pasterns are too short, or npright and stiff, they indicate a want of speed and tax both foot and leg unduly.

THE FEET.

The true shape of the foot is the segment of a eylinder. The front part of the wall is called the toe, the sistes the quarters, the posterior part the heels. The under surliace of the foot is composed of the frog, bars and sole. It should be high at the Leels, very concave underneath, wideat the bar, with well-dereloped frog, which is both elastic and firm, enabling it to resist the greatest shock without injury to the foot. There shoilil be no enlargenent about the coronet, and the horn should be of healthy color ans of even and regular form. If rings appear of a dirty redish hue, there is some hiclen disease or inflammation.

THE TRUNK OR BODY.

The trunk or horly shonld be of good length, with proportionate depth of girth or true ribs, but more circular than flat and deep. See that the girth is properly formed, with sufficient width throngh the heart, amil that the large muscles, whicl: 
extend forward and outward the ribs that expand the chest, move the shonler blade in action, contract the humerus, liace the muscles of the back and aid the muscles of the haunch in propelling the body. The requisite development of these muscles or thickness between the knees is a great sigu of strength of limb and wind. As a rule, horses of such formation will stay longer aud carry more weight than others. Circularity of carcass with a great development of the lateral muscles interferes the least with movement of the animal, and provides room for healthy digestion. Herring-bellied or light-bodich horses are, as a sule, bad feeders, and a horse which is a bad feeder is seldom or never a reliable race-horse.

BACK AND RIBS.

The false, standing or back ribs will form a gradual decline from the girth, and should not appear to swell ont too far, as viewed from the rear or front. The intercostal muscles between the ribs are connected with the diaphragm internally and externally, and with the muscles of the back. The internal and external muscles of the ribs are beautifully and advantageonsly formed for action, the filres running in adverse direction and crossing each other give arditional strength to nuited action; that is, in contracting and drawing the ribs closer together in connection with the diaphragm, the muscle extending from the thorax or breast to the termination of the loins by distinct fibres by which the viscera is forced backwards and inspiration is perfecterl. The muscles of the abdomen contract and, converging the ribs, push back the diaphragm and expel the air from the lungs. I lo not like a spare-ribbed horse or one deficient in the muscles which act on the respiratory organs, as such horses seldom exhibit ability to perform satisfactorily. The large muscle along the backbone is of vital importance, as it is comnceted with the muscles of the loins, bracing all the muscles of the back and aiding in working the shoulder. Fo horse can ever be a good one, able to carry weight or perform any extraordinary exertion, which is deficient in muscular development of the back. It has been observed that the best backed horses are the best performers. The back should be straight and rather hollow than roached, as in the latter formation the horse is inclined to orer-reach, eary his head low, and possess little or no elasticity of the spine. A little depression just behind the withers and then an almost straight line to the loins is the form most desirable for beauty and strength.

THE LOINS.

The proper formation of the loins is material in all horses, and more especially in the race-horse. They must be broal, well rounded and muscular. The strength of the loin, and more especially of the hind quarter, depends much on this. In formation the bones of the loin are larger than those of the back, and a more dovetailed ninion exists between them than those of the back. Every provision is made for strength. The union of the back and loins shonld be carefully scrutinized, for there is frequently a depression between them at the junction, which shows an imperfection in just formation of the spine, and is an evidence of weakness.

$$
\text { THE CROUP AND TAIL. }
$$

The setting on of the tail is an indication of breeding in the horse, and all those possessing aristocracy of blood, display it in the graceful manner in which the tail is attached to the borly. The croup shonld curve very little and should not be too long. A small, contracted and protruding sphineter of the anus denotes superior muscular energy in the animal, and is an evidence of constitutional vigor.

THE HIND QUARTERS.

The hind quarters differ from the fore ones in the fact that there is less elasticity in their connections. Nature, in order to give greater efficiency to the museles of the hind quarters, has attached the hiud extremities to the frame by direct bony articulations, which is not the case in the thoracic extremities. The functions of the anterior extremities is to support and direct, whilst that of the posterior limbs is to propel the frame.

The hannch is composed of three bones. The ilinm is principally concerned in the formation of the haunch. The ischimm or hip-bore is behind and below the ilium. 


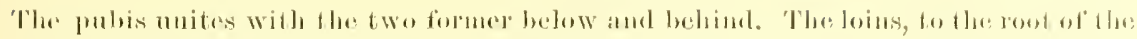

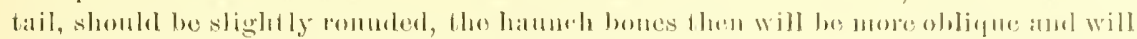

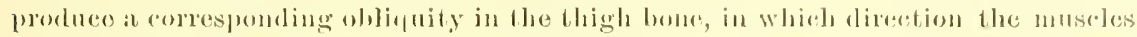

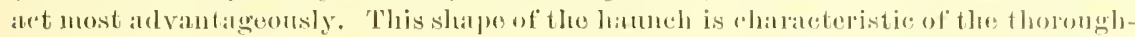

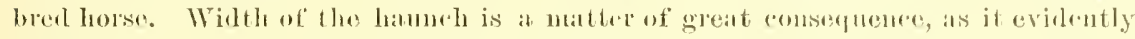

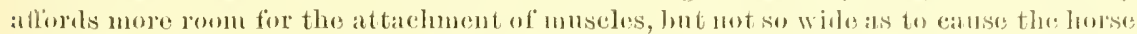

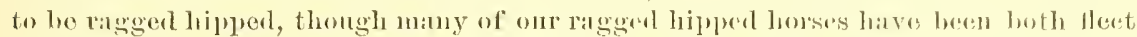
and strong, whilst fow of the narow hipped ones pessess strength. If the ]oins ane

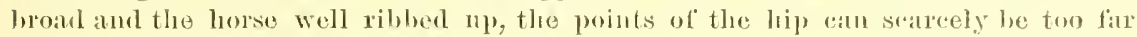
apart. In all quadrupers celobated for speed we fiml the lind legs remarkible for their length, and the museles of the loins and anarters for their great size and power. speed depends almost enticely on the length of the hind extremities and prossession of sufticient power to projel tho careass with viger aul rapidity. If they are refieicut in length of leverige of muscular encrgy, the most perfect formation of the other portion of the boly cammot eorrect the fanlt. The three bones composing the hannch, ilinm, ischinm and probis on each side, form an arch for tle support and protection of the posterior parts of the body and their contents. 'These three bones become partially consolidated, and form at their point of union a cup for the reeption of the hear of the true thigh bone (femur), forming the eavity ot the hip joint, which is a bill-and-socket joint, and known by the name of whirl or romd bone, which is deeply covered with museles. From the hip joint the thigh bone slants forward to meet the lower or second thigh bone (tibia), which, with the patella, a bone corresponding to the knee pan in the hmman race, constitutes the stifle. The lower or second thigh bone is ilirerted backward, forming a consiclerable angle with the true thigh hone, giving the muscles acting on the parts a mechanival advantage which they would not otherwise possess, aud throwing the weight on then in such an oblique direction as to prevent concussion. These two bones, the femur and tibia, should be long, for the reason that it gives them double mechanical power by lengthening the muscular fibre and increasing the leverage at which the muscles act. As the length of the extremities above the knees and hocks is increased, that below these proints is diminished. If the horse has short quarters and shoulders, the columns of support must he elongated somewhere, which is usually below the knee and lock. If he has a deep forehand and long quarters, the cannon bones are diminisher in length, a formation much desired and esteened.

\section{THE HIND LEG, FETLOCKS AND PASTERNS.}

There is little or no difference in the meehanical constrnction of these parts from those of the fore extremities, the anatomy of the parts below the knee and hock. The cannon or shank bone is longer and the splint bone larger in the hind extremities. The pasterns are more oblique aud deservedly so. The elastic play of the nper parts of the fore limbs being much greater, a less obliquity of pastern is requisite. The hind limbs being attached to the frame by bone, it is necessary that the pasterns loe murh more oblique.

\section{THE HOCK.}

The proper eonformation of the hock is of exceeding importance. It is composer of ten bones, between some of which there is extensive motion, while between others the motion is inconsiderable, but there is much strain on all of them during progression. It is scarcely less important than the thigh. If there is malformation or weakness here, the muscles of the thigh wiil be weakened in their force of action or perform their action with feeble results. The os calcis or point of the hock shonlil stand ont boldly from the other bones, as the artion and leverage of the tendons will be in exact proportion to the distance; hence the hock should be broad as you look at it from the sides, and should be free from all beefiness between the os caleis and other bones as well as behind and below the calcis, and taper gradually into the shank without a tied or wasted appearance at the lower extremity, and shonld be straight iu preference to sickled or cow hocked. The os calcis or point of the hock is the most important feature of this joint. It projects ontward and upward from the of her bones and gives attachment, according to its length and direction, to the tenctons of 
the most powerful muscles flexing the limb. The strongest and best wearing hocks are straight. The importance of a proper shaped hock is the more marked from its complicated structmre and great strain in its work, which renders it the seat of lameness. The os calcis too long means an excess of lecerage, hence curlus, an important anatomical feature in the race-horse, who from the natme of his work throws unusual strain on these parts.

\section{BROOD MARES.}

In purchasing mares to breed from it is wise to pay particular attention to the following points :

1. In the management of young mares be careful that they are not overloader with flesh and gross, nor kept too thin, and hence weak. Either extreme is inimical to the production of somid, healthy and strong foals.

2. In selecting a mare for yom stud, examine the stnd-book and see if her dam and grandam have miformly bred winuers, or are descended from a family which is noted as producing race-horses and wimmers. The more superior and somn the racehorses from the immediate and near relatious, the better and wore desirable she must be. If, however, she is the only one of her family from a number of her brothers and sisters tried that has proved a good performer, her acquisition is not so desirable unless she has extraordinary qualities to commend her.

3. Examine carefully in regard to flightiness of temper, nervousness, orgaus of respiration and digestion, shape and somndness of feet, objectionable habits-snch as wind sucking and cribbing. All these must be taken into consideration; also tho strong or weak points whieh are peculiar to her family that may be transmitted.

4. Before buying a mare or mares that have bred foals, in addition to the qualities of her produce, satisfy yourself as to the state of her nterus. Look for ontwarl signs of rupture, and, when trotted or cantered, for a blublering noise, which would indicate rupture extending to its internal parts. Snch an animal is worthless, and if she should chance to have a foal it would be an accident.

5. Examine carefully the bag or udder. See if it is naturally developed aud both sides can be equally used. The condition of the last foal will show whether the mare is a good nurse, and the quality of the monxishment which it received from the dam. The quality and quantity of the mother's milk will solve the question whether the foal will grow into a race-horse or derelop into a miserable weakling:. Snall ancl pruy foals develop with wouderful rapidity at the side of a mare which supplies good, monishing, rich milk. Whilst others, whose foals have size, shape and quality, go baekward and melt a way lilie butter in the sun. It is advisable, with good nares from racing families that produce winners. to take away the foals soon after they drop, and give them to some nuare known to be a good nuxse. Or, if the mother is an indifferent milker, which is readily ascertained by the colt not filling himself, give the best fresh milk, slightly sweetened. He will take it first from the fuger being inserted in the milk, but will soon drink it as a calf. No colt need be despaired of, either from a bad mother or if the mother dies.

Sensitive mares do not easily submit to exchange of foals, but with care and patience yon will have no difficulty. All mares know their own foils hy smell, as one can leadily see by observation, when collected together. Rub into the coats of the foals to be exchanged a little aniseed oil for a few days, until the mares become accustomed to it. This will prepare for the deception. Seprate the mares from the foals and keep them away mutil the pressure of the milk in the bag becomedistressing. The foals being exchanged, the mares are returned and the change will be surcessful.

Aroid purchasing and reject all mares which the stud book reports show have heen repeatedly barren, slipped their foals or prorluced twins.

One of the most important requisites in a brood mare is symmetry of conformation. She should be long, deep in the chest, with large, roomy pelvis, with breadth of hip, in order that the foal have ample room and space for its derelopment. Leggs, light and short-bodied mares camot be expected to produce large foals or gool shaped ones. Other not glaring imperfeetions can be better overlooked than these fanlts in conformation. 
Many good julges do mol like mates with too coatse and luxuriant gionth of

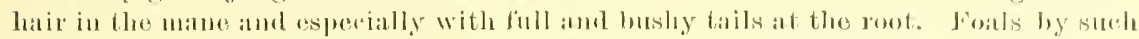

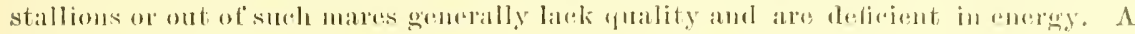

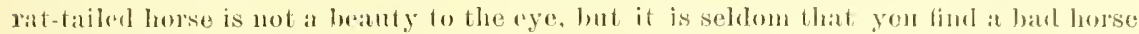
with at rill tail.

With mares possessing the qualitiations mentionol, with narked development of museles and bone, alded to symmetry in conformation, which every animal sluculd possess whin is intended to propagate its speedes, we may hope that the forls will possess simbar gord qualities. I partienlarly hlie horses and mares which possess generue charater, munistakeably expressed, in either sex. I contemn all mares of stuhlish appearance, either in shape or manners, especially when examination is neessary to letermine whether they are mires or gellings. 'The nore quality a mare possesses the move maked will bo the evilence of her sex.

Avoid the system, minously alopted and followed by many, of breeding from mares "I stallions merely beeanse they were gool. Consider the essential fualifications of the race-horse. See that the animal is eminently gifted with certain inestimable rualities, snch as temper, handiness, imnense norvons action and indomitable conrage. These may and often do outweigh great defeets in conformation, but unless sure of such grand qualities and peenliarities heing hamled down to their progeny in equal ratio, do not regarl them beyond their true worth.

It is worse than useless to purchase the stontest, best lred mares from racing fam. ilies, and expect to breed race-horses by fattening them in rich jastures until November, and then starre and halt feed untıl April, unler the filse idea that it mikes the colts hather and tough. It must be remembered that, for every one living through it, two die, and the survivors must have iron constitutions, and with proper food and care monld have proved better, sounder and possess more size and substance. Abundant nourishment tends to the formation of bone and unsele; want of it leads to emaciation, weakness and death.

\section{SUMMING UP (NECESSARILY A REPETITION).}

It is generally claimed and armutted by all writers npon the thoronghbred horse that ho 0 w his origu to three great ancestor's or somrces: The Darley Arabian, Byerly Tulk and the Gololphin Arablan. Although this theory is accepted as true, it is misleading and not sustained by facts. The first class, as arranged in the stud book, is that of the Darley Arabian. If the Arabian alone was entitled to the erent of fombling this line, what becomes of the female line and what credit is due to the mare Betty Leedes that first brought the Darley Arabian into notice? Betty Leedes, the dam of Flymg Chihlers anel Bartlett's Childers, was by old Careless, son of Spanker and a Barl, mare, her dam sister to Leedes (called Cream Cheeks) b. the Leedes Aribian, grandam by Spanker, great grandam old Moroce mare (Old Peg), Spanker's own dam by Lord Fairfax's Moroceo Barb, out of Olel Bald Peg, who was by an Arabian, out of a Barl mare. There were other race-horses in the family pror to the adrent of Flying Childers, but the great excellence of the tamily in the male hue is through the two Chiblers, especially through Bartlett's Childers. Flyiug Childers was said to have been the fleetest horse in the worid. It is said that in the year 1721 he ran a trial against Almanzor and Brown Betty over the Round Conrse at Newnarket, 3 miles 4 furlongs 139 Faxds, carrying 128 los., in 6 minutes and 40 seconds. He ran over the Beacon Course, 4 wiles 1 furlong 173 yards, in 7.30 . It is not beliered that these statements of time are true, as there were no watches in those days by which time conkl be taken. He got Snip, sire of Snap. Bartlett's Childer's founded the Eclipse line. He got Syuirt, daw Shock's dam by Lister's Snake, grandam Grey Wrkes, sister to Clnmsey by Old Hantboy, tracing to a Sedbury Royal mare. So little was squnt esteemed as a stallion that he was ordered to be shot, but was begged off by his groom whlle being led ont to the dog kennel. He afterward got Marslie, Syphon and the noted old Squirt mare, the clam of Pumpkin, Maiden and Purty. Marske got imp. Shark, dam by Suap, son of Snip, a grand race-horse and successful stallion. From the corer of Marske, Spletta produced 
Eclipse and his sister Proserpine. Spiletta was by Regulus, son of the Godolphin Arabiau, out of Mother Westeru by Smith's son of Mr. Lister's snake, omm brother to Willian's Squirrel, out of a daughter of the Akaster Turk. Eclipse got Pot-8-o-'s, King Fergus, Mercury, Alexander, Don Quixote, Saltram, ete. It is to these sons of Eelipse nearly all of the best race-horses of our day in the male line from Eclipse trace their oryin. Pot-8-o-'s, out of a mare by Warren's Sportsman, son of Cade by the Godolphiu Arabian, got Waxy, ont of Penelope by Trumpator, son of Conductor by Matehem.

Waxy got Whalebone, Whisker, Woful and their sisters, Web and Wire, ont of Prunella by Hightlyer, son of Herod. The commingling of this blood with that of the Byerly Turk and Godolphin Arabian is what gave us the grand race-borses in this line. Whalebone got Sir Herenles, out of Pers by Wauderer, son of Gohanna by Mercury, and Sir Hercules got the brothers Irish, Birdcatcher and Fangh-a-Ballagh, out of Guiccioli by Bob Booty, son of Chanticleer by Woodpecker by Herod.

Stockwell by The Baron, sou of Birdcatcher by Sir Hercules by Whalebone by Waxy by Pot-8-o's by Eclppse, dam Pocahontas by Glencoe by Sultan, sou of Selim by Buzzard by Woodpecker by Herod, grandau Marpessa by Muley son of Orville by Beningbrough by King Fergus by Eclipse, ont of Clare by Marmion, son of Whiskey by Saltram by Eclipse. Stockwell got Blair Athol (Derby and St. Leger wimner, 1s61), dam Blink Bonuy (Derby and Oaks winner, 1857) by Melbourne, son of Humphrey Clinker by Comus, out of Queen Mary (dam of Bomnie Scotland, ete.) by Gladiator, son of Partisan.

Blair Athol got Andred, out of Wonderful by Voltigenr ; Clauronald, out of Isilia by Newminster ; Ethus, ont of Theresa by Touchstone; Tanguble, out of 'Touch-meNot by Touchstone; Craig Millar (wimuer of the St. Leger, 1075), out of Miss Rolaud by Fitz Roland, son of Orlando by Touchstone; Prunce Charlie (wimmer of the 2,000 Guineas, 1872, and imported to America), dam Eastern Priucess by Surplice, son of Touchstone, ont of Tomyris by Sesostris, son of Slaue by Rogal Oak. Pruce Charlie got Prestoupans, dam Beatrice by Voltıgeur, out of Bribery by The Libel; Salvator (wimuer of the Suburban Haudicap, $1_{4}^{\frac{1}{4}}$ miles, $2.06 \frac{1}{5}$, and the Mateh $1 \frac{1}{4}$ in 2.05, and the fastest mile ever rum in the world, 1.35 $\frac{1}{2}$ ), dam Salina by Lexungton, ont of Lightsome by imp. Glencoe; Pruce Fonso, out of May Wilsou by King Alfonso; jmp. Wagner, dam Duchess of Malfi by Elland, ont of The Duchess by St. Albans, he the sire of Minnehaha III. ; imp. The Jacobite, dau sister to Little Lady by Orlaudo, out of Volley (own sister to Voltigemr) by Voltaire. Blair Athol also got Silvio (winner of the Derby aud St. Leger, 1879), out of Silverhair by Kingston. Blan Athol got Struan, ont of Terrific by Touchstone, and Struan is sire of Brag, out of Bounce by Flatterer. Silvio is the sire of imp. Silvermine, ont of Numeaton by Orlando, and imp. Dandy Diumont, ont of Meg Merrilies by Macgregor.

Blair Athol got imp. Glen Athol, dam Greta by Voltigenr, ont of Monntain Flower by Ithuriel, son of Touchstoue.

Glen Athol got Glenmore, dam Lotta by Hunter's Glencoe, ont of Sally Lewis by imp. Glencoe. Gleumore was a superior race-horse, winner of the best four-nile.

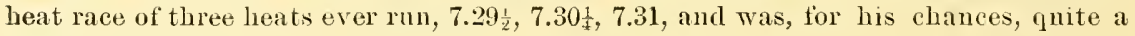
success in the stud.

Blair Athol got imp. Stonehenge (dam Coimbra by Kiugston, ont of Calcavella by Burdcatcher, Son of Sir Hercules) aud his full brother Claremont, the sire of imp. Esher, out of Uua by Dusk.

Blair Athol also got mmp. Child of the Mist, owned by Mr. M. Daly, out of Mal Belle by Lork Ciffien.

Stockwell got Breadabane, own brother to Blair Athoi. Breadalbane got imp. Ill Userl, dam Ellermire by Chanticleer, son of Burlcateher, out of Ellerdale by Laucreost, sou of Liverpool by Tramp. Ill Used was a good racehorse and is sire of Badge, dam The Baroness by lientucky, His Highuess, dam imp. Princess (Royal Hampton's dam) by kung 'Tom, out of Mrs Lincoln by Nortl Lincoln, son of Pylades by Surplice, Forester, dam Woodbue by Censor or lientucks, ont of imp. Fleur-des-Champs by Newminster, Magnetızer, dam Maguetism by Kimgtisher, 


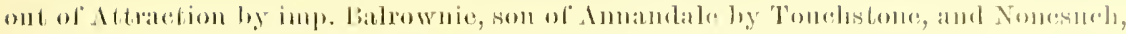

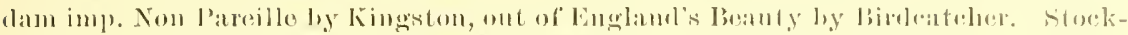

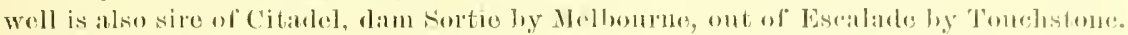

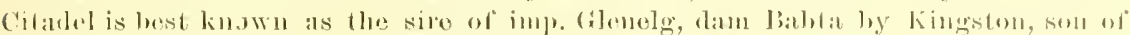

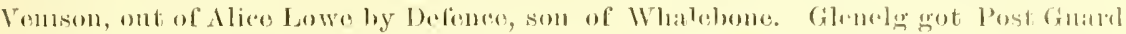

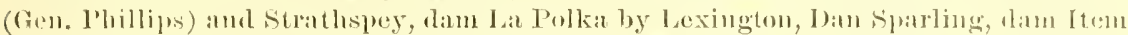

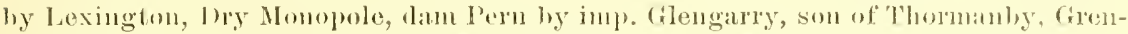

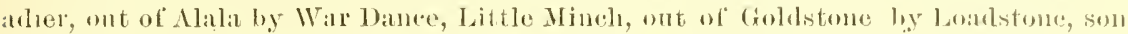

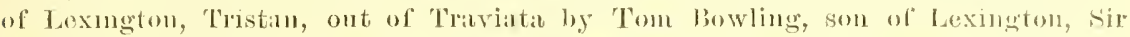

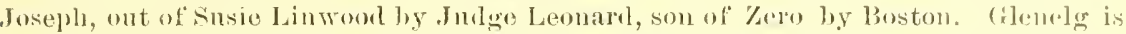

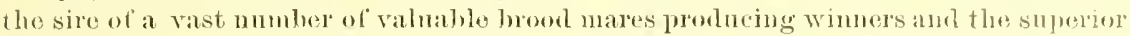
mare Firenzi. Stockwell got Broomielaw, ont of Queen Mary by Glatiator, and Astrernill, ont of Teetotum by Tonchstone. Asteroid got siderolite, ont of Aphrodite hy Bay Mirlleton, Storkwell got The Marpuis (winner of the 2,000 (mineas and st. Leger, 1862), ont of Cinizelli by Touchstone, Rustic, ont of Village Latss by Pyrihus the First, Caterer, tam Selina by Orlando, The Dnke, ont of Bay Celia by Orfanelo. The Duke got Merry Duchess, Blandford, ont of Auricula by Ambrose, and Bertrum, out of Constance by Fauglin-Ballagli, son of Sir Heleules. Bertram got liolert the Derll (winner of the St. Leger, 1880), out of Cast Off ly Promiserl Laul, son of Jericho by Jerry by Smolensko, Lork Lyon (winner of the 2,000 Guineas, Derby and St. Leger, 1866), out of Paraligm by Paragone, son of Tonehstone. Lort Lyon got Mintung, ont of Mint Saluce by Young Melbourne, and Touchet, out of Lady Audley, sister to Buccaneer hy Wild Dayrell. Stockwell also got St. Albans and Savernake, dam Bribery by The Libel, son of Pantaloon by Castrel, ont of splitrote by St. Luke, son of Bellamite by Welbeck by Soothsayer.

St. Albans (winner of the St. Leger, 1860) got Julins, ont of Julie by Orlando; Sprungfield, out of Viridis by Marsyas, son of Orlando. Springfield got sainfoin (winner of the Derby, 1890), ont of Samila by WVenlock.

St. Albans also got Martyrdom, ont of Eulogy by Enclid, son of Enilins; Mr. Winkle, dam Peri by Birdcatcher; Silvester, ont of Silverhair by Kingston, and st. Ronan, out of Elspeth by Birleatcher.

Stockwell got Lord Ronald, out of Edith by Newminster, grandam Deiadawia by Pyrrhus I., son of Epirns by Langar.

Lord Ronald got Master Kildare, ont of Silk by Plum Pudding, son of Sweetmeat.

Master Kildare got Melton (winner of the Derby and St. Leger, 1885), out of Violet Melrose by Scottish Chief.

Stockwell got Thunderbolt, dam Cordelia by Rerl Deer, son of Tenison, ont of Emilia by Toung Enulins. Thunderbolt got Vulcan, ont of Alarum by Alarm; Lemnos, ont of Lanra by Orlando; Reverberation, out of The Golden Horn bs Harkawas, and imp. 'Tlinnderstorm, out of Killarney by Newminster.

Strekwell got Doncaster (wnner of the Derby, 1873), dam Marigold, by 'Telılington, son of Orlande, ont of sister to Smgapore by Ratan, son of Buzzard by Blacklock. Doncaster got Bend'or (wunner of the Derby, 1880, and Epsom Gold Cup), dam Rouge Rose by Thormaby, grandam Ellen Horne by Redshank, son of sand beck by Catton, out of Delhi by Plenipotentiary, son of Emulius, Muncaster, dam Windermere by Macaron, out of Miss Agnes by Burcleateher. Muncaster got Saraband, out of Highland Fling by Seottısh Chief, aud imp. Rossington ont of Lıly Agnes los Hacaron. Bend'or got Ormonde (wuner of the 2,000 Guineas, Derby and St. Leger, 1886), dam Lily Agnes by Macaroni, grandam Polly Agues by The Cure, son of Phrsician by Brutandorf by Blacklock, out of Miss Agnes by Birdeateher, and Orvieto, out of Napoli by Macaroni. Bend'or got Bonavista, wuner of the 2,000 Guineas. 1892. out of Tista by Macaroni, and Kendal, out of Wundermere by Macaroni. Stockwell got Uncas, dam Nightingale by Mountan Deer, son of Touchstone, out of Clarinda ly5 Sir Hercules. Uneas got Prism, dam Rambow by Yorkminster, son of Newminster. out of Blne Bonnet by Yomng Melboume.

Rataplan was own brother to Stockwell by the Baron, dam Pocahontas by 
Glencoe. Rataplan got Blinkhoolie, dam Queen Mary (Blink Bonny and Bonuie Scotland's dam) by Gladiator. Blinkhoolie got Wisclon, dam Aline by Stockwell, grandam Jen d'Esprit by Flateateher, son of Tonchstone, ont of Extempore by Emilius.

Wrisdom sired Surefoot (winner of the 2,000 Guineas and Eelipse stakes, 1891, defeating the great Common), dam by Galopin, grandam Miss Foote by Orlaudo, ont of Gossamer by Birleatcher, and Veracity, ont of Vanish by Honiton. Rataplas got Ben Battle, dam Young Alice by Young Melbourne, ont of Sweet Hawthorn b. Sweetmeat. Ben Battle got Bendigo, ont of Hasty Girl by Lord Gough, son of Glachiateur.

Rataplan got The Miner and Mineral, dam Manganese hy Birleatcher, ont of Moonbeam by Tomboy, son of Jerry by Smoleusko, Kettledrum, dam Hybla by The Prorost, son of The Saddler, out of Otisina by Liverpool, son of Tramp. Kettledrum got Lady Langden, the dam of Hampton and Sir Berys, out of Haricot ly Mango or Lanercost. Rataplan also got imp. Dalnacardech out of Mayonaise by Tedrlington.

Birclcatcher got Oxford, ont of Honey Dear by Plenipotentiary, in the male line to Eclipse. Oxford got Sterling, out of Whisper by Flatcateher, in the male line to Eclipse. Sterliug got Energy, Harvester, Paradox and Isonomy, the latter out of a danghter of Stockwell. Isonomy got Common, the wimner of the triple event in England in 1891, ont of Thistle by Scottish Chief, a horse in the male line to Eelipse. Sterling is also sire of imp. Loyalist, brother to Paradox, Stalwart and imp. Top Gallant, the two last brothers, traciug through Sea Mark, a daughter of Adrenturer, to Pewet, the dam of Sir Paul, Paulina and Clnkeriua, the dam of Humphrey Cliuker, sire of Melbourne, and Pewet was half sister to Evelina, the dam of Orrille, Orvillina, dam of Sanlbeck, Cerrantes, sire of Melbonrne's dam, Panlowitz, sire of Cain, that got Ion, the sire of Wilc Dayrell. Burdeatcher also got imported Knight of St. George, Warlock (sire of Tyndale), Sannterer, imp. Mickey Free and Womersley. Fangh-a-Ballagh got $1 m p$. Leanington, out of a danghter of Pantaloon, a horse in the male line to Hecod. Leamington got Longfellow, out of Nantura by Brawner"s Eclipse, Herod line, sire of The Barl, ont of Brademante by TVar Dance, Herod line. Longford and Longstreet, out of Semper Idem by Glen Athol, son of Blair Athol: Linden, a grand race-horse and promising sire. Enquirer, ont of Lida by Lexington. Heror line, a good race-horse and popular sire. Powhattan, out of Jiaiden by Lexungton. Eolus, out of Fanus Washiugton by Rerenue, son of́Trustee, Eclipse line. Eolus is one of the most popular and successful stallions in America. Hycler Ali, Sensation, Onondaga, Stratford, Aristides, ont of danghters of Lexington, Iroquois, cut of Jiaggie B. B. by Anstralian, Matehem liue. Lelaps, out of imp. Pussy by Diophantus. Then there are Falsetto, Blue Eyes, MeCreery, Fanstus and Inspector B., good stallions nearly all, except Falsetto in the Echpse line. Whalebone got Camel, ont of daughter of Selim, Herod line.

Tonchstone by Camel, son of Whalebone by Waxy by Pot-8-o-'s by Eclipse, lam Banter by Master Henry, son of Orville, by Beningbrough by King Fergus by Eclipse, grandam Boadicea by Alexander, son of Eclipse, out of Brunette by Amaranthus, son of Old England by the Godolphin Arabian.

Touchstone got Artillers, dam Jeanette by Birdcatcher, son of Sir Herenles, grandam Perdita by Langar, son of Selim, ont of Delenda hy Gohanna, son of Mereury by Eelipse.

Artillery was the sire of imp. Kyrle Daly, dam Colleen Rhue by Gemma di Vergy, son of Sir Hercules.

Touchstone sired Claret aud Mountain Deer, dam Mountain Sylph by Belshazzar, son of Blacklock. Claret got Blarney, and Mountain Deer got The Druicl and many good mares.

Touchstone got Assanlts and Storm, ont of Ghuznee by Pantaloon, aud Amnandale, dam Rebeeca by Lottery, out of a daughter of Cervantes son of Don Quixote by Eclipse.

Annandale got imp. Balrownie, ont of Queen Mary by Glaliator. Bahownie got West Rosbury, out of Colnmbia by imp. Glencoe, she out of Fleur de Lis by mup. 


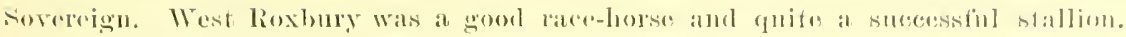

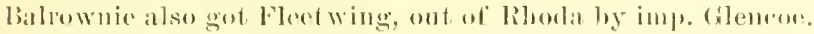

Tonchstome got Cotherstome, dam Emma hy Whisker, son of Waxy. Cotherstome

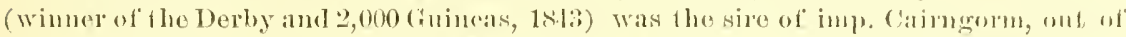

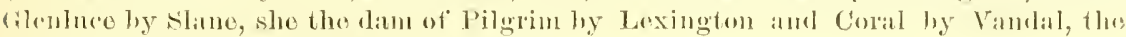
dam of luncas and Wanderer by hexington.

Tomelistono got lthuriel, dam Verlona by Veloriperle, son of liacklock, ont of liosalua ly Milo, son of sir l'eter. Ithuriel got langhow, ont of Miss linwe hy Cintron. Longhow got Toxoplifite, ont of Legerdenain by l'antaloon.

Toxophilito got Musket, ont of a danghter of West Australian ly Mellumrue, and sitray shot (the dam of Shotover and Torpede: by IIormit), ont of Vaga l,y stockwill.

Musket got Petronel (winner of the 2,000 Guineas, 1880), out of Crytheia liy Hesperus, son of bay Middieton, and inp. Maxim (in Raneho del Paso stnd), daun Realization by Vespasian, son of Newminster.

Touchstone got Surplice (wimer of the Derloy, 1848), ont of Crueifix hy imp. Priam, who sired several mares of note, Eastern l'rincess, Flax, ete., also Vindex, Iam Garland by Langar, ont of Cast Steel by Whisker. Vindex got Victor, out of a daughter of Seroggins, son of 'Tramp.

Victor got Valour, ont of daughter of Mount Zion, son of Mountain Deer.

Tonehstone got Lord of the Isles, dam Fair Helen by Pantaloon, out of Relecea by Lottery.

Lord of the Isles got Scottish Chief aud Macdonald, ont of Miss Amn by The Little Known, son of Muley, she out of Bay Missy by Bay Middleton.

Scottish Chief got Childeric, ont of Gertude by Sannterer, Fitz James, out of Hawthoru Bloom by Kettledrum, King of the Forest, ont of Lioness by Fandango, Pursebearer, out of Thrift by Stockwell, imp. Donald A., out of imp. Algebra by Diophantus, imp. Kantaka, ont of Seclusion (Hermit's dam) by Tadmor, and Duulee, out of Marmalade by Sweetmeat.

Touchstone got Newmiuster, dam Beeswing by Dr. Syutax, son of Paynator by Trumpator by Conductor by Matchem, grandam by Ardrossan, son of Johu Bull by Fortitude by Herod, out of Lady Eliza by Whitworth, son of Agonistes by Sir Peter by Hightlyer by Herod.

Newminster got Cambuscan, out of The Arrow by Slane. Cambuscan got Camballo (wimner of the 2,000 Gnineas, 1875), ont of Little Lady by Orlando, son of Touchstone, and Onslow, out of Dnlcibella by Voltigenr.

Newminster got Alventurer (winner of City and Subuxbau), dam Palma by Emilius, out of Francesea by lartisan.

Adrenturer got Ishmael, ont of Lena by Stockwell, Privateer, ont of La Farorita by Thormanby, Glen Arthur, out of Maid of the Glen by Kingston, Pretender, out of Ferina by Venison, and imp. Pizarro, out of Milliner by Rataplan, she ont of Manganese by Birleatcher, auf imp. Blythewood, ont of Bonny Bell by Voltigeur. Pizarro's early death was a serions loss to the country.

Newminster got Catherlial, out of Stolen Moments by Melbourne. Cathedral got Landmark, out of Miss Agnes by Birlcateher.

Nerminster got Hermit (winner of the Derby, 1867), dam Seclusion by Tadmor, son of Ion by Cain, granclam Miss Sellon by Cowl, son of Bay Middleton by Sultan, out of Belle Dame by Belshazzar, sou of Blacklock.

Hermit got The Abbot, Charon and Marden, out of Barchettina by Pelion, son of Ion, Clairranx, Thebais and St. Marguerite, ont of Devotion by Stockwell, Peter and Timothy, out of Lady Masham by Brother to Strafford, son of Young Melbourne, Tristan and Trapeze, ont of Thrift by Stockwell.

Trappist, out of Bunch by Muscovite, sou of Hetman Platoff, Whitefriar, out of Lady Blanche by Thunderbolt, Edward the Confessor, out of Princess of Wales by Stockwell, Retreat, out of Quick March by Rataplan, Zealot, out of Zelle by Stockwell, Sonthampton, ont of Preface by Stockwell. imp. Mr. Pickwick (deacl), out of Tomato by King Tom, sire of Picknicker, Facial I3., Ida Pickwiek, ete., Friar Tuck 
(now in California), out of Romping Girl by Wild Dasrell, and imp. St. Blaise, out of Fusce by Marsyas, son of Orlando, sire of St. Florian, Arluiral, St. Pancras, Clarendon, Padishah, Potomac, Chesapeake, La Tosca, etc.

Newminster got Lord Cliflen, dam The Slave by Melbourne, grandam Tolley (sister to Voltigeur) by Voltaire, out of Martha Lyun by Mulatto, son of Catton.

Lord Cliflen got Petrarch (winuer of the 2,000 Guineas and St. Leger, 1876), and imp. Rotherhill, ont of Laura (the dam of imp. Laureate) by Orlando. Wenlock (winner of St. Leger, 1872) and his sister Siluria (dam of Geologist), out of Mineral by Rataplan, Hampton, and imp. Abingdon and imp. Deceiver, out of Bootanc-Saddle by Trumpeter, son of Orlando, out of Lady Laugden by Kettledrum, Hawthorndeu (sent to New South D'ales), out of Bonny Blink by The Flying Dntchman, and Winslow, out of Creslow by King Tom. Hampton is the sire oi Merry Hampton (winner of the Derby, 1889), out of Doll Tearsheet. by Broomielaw, Ayrshire (wimner of the 2,000 Guincas and Derby in 1888), ont of Atalanta by Galopin, Royal Hampton, ont of imp. Princess (dam of Prince Royal and His Highness) lyy King Tom, Imp. Kingston, out of Last Love by Annandale, and imp. Eothen, ont of sultana by Oxford.

Wenlock got Quicklime, out of Dnvernay by Beadsman. Newminster got Strath conan, out of Sonvenir by Chanticleer, son of Birlcatcher. He was the sire of Scot Guard, Strathavon and Strathern, wiuner of the Royal Hunt Cup, and of Buchanan, out of Flurry by Young Melbourne.

Tonchstone got Orlando, dam Vulture by Langar, son of Selim, ont of Kite by Bustard, son of Castrel.

Orlando got Chattanooga, ont of Ayacanora by Birdcatcher. Chattanooga got Wellingtonia, out of Arancaria by Ambrose, son of Touchstone. Wellingtonia got Clover (wimuer of the French Derby), out of Princess Catherine by Prince Charlie. Orlando got Marsyas (out of Malibran by Whisker), who sired George Frederick (winner of the Derby in.1874) and Albert Victor, out of Princess of Wales by Stockwell. George Frederick was the sire of Bean Brummell. Albert Victor was the sire of Victor Emanuel and imp. Albert, the latter out of Hawthorn Bloom by Kettledrum, and imp. The Sailor Prince, ont of Hermita by Hermit.

Orlando got Orestes (lam by Bay Middleton), he the sire of Orest (out of Lady Louisa by Touchstone), who was the sire of Hollywood, out of Furze Chat by Kiug Tom.

Orlando got Teddington, ont of Miss Twickenham by Rockingham, son of Humphrey Clinker.

Teddington got Moulsey, ont of Sabra by Pantaloon, and Marigold (the dam of Doncaster and imp. Lady Moleswerth), out of Delilah by Thormanby.

Orlando got Trumpeter, ont of Cavatina by Redshank, son of Sandbeck. Trumpeter got Queen's Messenger, out of Queen Bertha by Kingston, and Distin, ont of Miss Bowser by Hesperns. Distin got Aroutes, out of Aroudale by Ratan, and imp. Charasus, ont of Sappho by Kingstou. Charaxus is a very promising sire.

Trumpeter got Plutus, dam by Planet, son of Bay Midlleton, ont of Alice Bray by Venison.

Plutus got Fiageolet, ont of La Favorita by Monarque. Flageolet got imp. Rayon d'Or, ont of Arancaria by Ambrose, son of Touchstone, Zut, out ot Regalia by StockTell, and Beaminet, ont of Beanty by Knowsles.

Orlaudo got imp. Septhian, ont of Seythia by Hetman Platofi, and imp. Eclipse, out of Gaze by Bay Middleton, he sire of Alarm, he sire of Himsar.

Whalebone got Waverles, ont of Margaretta by Sir Peter. Waverley got Don John, out of a Comns mare, and Don Johu got Lago, ont of a selim mure, and he got imp. Bomie Scotland, out of Queen Mary by Gladiator, Herod line. Whalebone also got Defence, ont of Rubens mare, and he got The Emperor, ont of a daughter of Reveller by Comus. Whisker got Economist, out of Floranthe by Oetavian, Herou line. Economist was the sire of Echidna and Harkaway, the latter out of Fanny Dawson by Nabocklish, in the Herod line.

King Tom by Harkaway, son of Economist by Whisker by Waxy by Pot-8-0-'s 
by Eelipse, dam Pocahomtas (dim of Slockwell, Rataplan, ete.) by impe (ilencere,

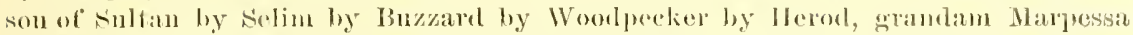

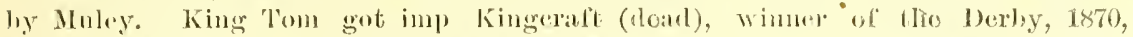
and imp. Great 'on, in the belle Moade stud, Trum., ont of Woodcraft hy Voltiereur, King Lud, ont of Qui Vive (sister to Vedette) ly Vultigenr, skylark, ont of

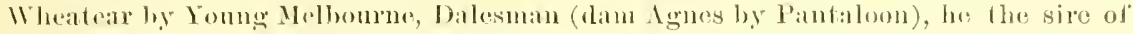
Lowlander, ont of Lufm ly Windlomel, son of Pantaloon, and he the sire of Lowland Chief, out of Bathilde lig sterkwell. King 'om sho got King Alfred, dim by bay Midelleton, Restitntion, dam loy Slane, King o' Scots, ont ol' Katlarine Logie by The lylug Dutchman. Ho got Bruee, ont of Reense hy Neweastle.

ling Tom got imp. King Ban, ont of Atlantis by Thomanby (died in Jixiana Sturl, Ky., Mareh, 1858), inp King Eruest (deat), dam Grnestine by Tourlistonc, in the Brookdale Stud, Mommontlı (o., N. J. Inu. Phacton (died 1874), diun Merry sunshine by Storm.

Pliaeton got 'Ten Broeck (1 mile, $1.39 \frac{3}{4} ; 2$ miles, $3.27 \frac{1}{2} ; 3$ miles, $5.26 \frac{1}{2}$, and 4 miles, 7.15: perfornanees never equalled hy one and the same horse), ont of Fanny Holton by Lexington. King Alfouso, ont of Capitola by Vandal, he the sire of Foxhall (that wou the Grand Prize of Paris, Cesarewitch and Cambricigeshire Handicaps), out of Jamaica by Lexington, aud Lisbon, ont of imp. Lady Love by Stockwell or Caterer.

King Fergus was by Eelipse, dam Creeping Polls by Black-and-All-Black, son of Crab by Aleock Arabian. King Fergus got Hambletonian, out of a danghter of Highflyer by Herod, grandam by Matchem. Hambletonian got Whitelock, ont of Rosalind by Phouomenon, son of Herod. Whitelock got Blacklock, ont of danglter ol Coriander by Pot-8-o-'s. Blacklock got Brutandorf, sire of Physician, sire of The Cure aud Hetman Platoff, imp. Belshazzar, Velocipede, sire of King of 'Trumps, Hornsea, etc.; Voltaire, ont of daughter of Phantom by Walton, Herod line.

Voltigenr by Voltaire, son of Blacklock by Whitelock by Hambletonian by King Fergns by Eelipse. dim Martha Lym by Mnlatto, son of Catton by Golnmpus by Gohanna ly Mercmy by Eelipse, grandam Leda by Filho-da-Puta, son of Haphazard by Sir Peter by Highfyer by Herod, ont of Treasnre by Camrlus, son of Hambletonian by King Fergus,

Voltigenr got Skirmisher and The Ranger, dam hy Gardham, son of Falcon by Bustar by Castrel, ont of daughter of Langar. Skirmisher got Kaiser, dam Regina by King 'Tom.

The Ranger got imp. Uhlan, dam La Mechante by Turums, son of Taurns. Uhlan was a superior race-horse, a successful stallion in France, and is now in Chesterbrook Stud, Pennsylrania. Voltigeur got John Davis, dam Jamaica by Liverpool, son of Tramp. John Davis got John Day, out of Breakwater by Bnceaneer, and Fortissimo, out of Vocalist by Trumpeter. Voltigenr got Tibthorpe, dam Little Agnes by The Cure, son of Physician. Tibthorpe got Thurio (winner of the Grand Prize of Paris), ont of Verona by Orlando.

Voltigenr got Vedette (wimner of the 2,000 Guineas and two Doneaster Cups), dam by Birdcateher, out of Nan Darrell by Inheritor, son of Lottery.

Vedette got Specnlnm (wimner of the City and Suburban), dam Doralice by Alarm or Orlando, ont of Preserve by Emilius.

Speculum got Castlereagh, ont of Lady Trespass by Birdeateher, Sefton (winner of the Derby, 1873), ont of Lady Sefton by West Anstralian, Rosebery (winrer of the Cesarewtch and Cambridgeshire Handicaps), out of Lalylike by Newminster, and Hagioseope, out of Sophia by Macaroui, he the sire of Qneen's Birthday, ont of Matilda by Beamelere.

Vedette got Galopin (winner of the Derby, 1875), dam Flying Duchess by The Flyiug Dutchman, ont of Merope by Voltaire, son of Blacklock.

Galopin got Galliard (winuer of the 2,000 Guineas, 1883), out of Mavis by Macaroni, St. Simon, out of St. Angela by Kung Tom, and Donovan (winner of the Derby aud St. Leger, 1889), ont of Mowerina by Seottish Chief.

Galopin got imp. Galore, a superior race-horse, out of Lady Maura by Macaroni, 
in the Bowling Brook Stud, Ma, and imp. King Galop, dam by King Tom, out of Snushine by Thormanby, now in Iroquois Stud, Lexington, Kentucky.

St. Simon got Memoir (wimner of the Oaks and St. Leger, 1890) and La Flecho (winner of the 1,000 Guineas and Oaks, 1892), out of Quiver by Toxophilite, Semoliua (winner of the 1,000 Guineas, 1890), out of Mowerina, Masetto, ont of Lary Abbess by Cathedral, in Dixiana Stud, Kentucky, and imp. Simon Magus, out of Wheel of Fortune by Adventurer, now in the Rancocas Stud, New Jersey.

Voltigeur got imp. Hartington (winuer of the Cesarewitch), ont of Countess of Burlington by Touchstone, and imp. Billet, dam Calentta by Flateateher, son of Touchstone, out of Miss Martin by St. Martiu, son of Actæon. Billet was the sire of Volturno, Elias Lawrence, Miss Woodford, Barnes, Runnymede, Belvidere and other good ones.

Beniugbrough by King Fergus, dam by King Herod, was the sire of Orville, out of Evelina by Hightlyer by Herod. Orville was the sire of Emilius, out of Emily by Stamford, son of Sir Peter. Emilins was sire of Plenipotentiary, sire of imp. Heralı, imp. Priam, ont of Cressida by Whiskey, son of imp. Saltram, imp. Sorereign, out of Fleur de Lis by Bonrbon (Matehem line), sire of Ruric, ete. Imp. Sarpedon, ont of Icaria by The Flyer, Herod line. Sarpedon was sire of Alice Carneal, dam of Lexington. St. Nicholas, out of Seamew by Send, son of Beninbrough. St. Nicholas was sire of imp. Yorkshire, out of imp. Niss Rose by Tramp, a valuable stallion. Scul by Beningbrough was the sire of Actreon, that got imp. Albion, out of a danghter of Comus or Blacklock. Orville got Muley, out of a daughter of Whiskey. Minley sirecl imp. Margrave and Leviathan, but there are no stallions in the male line from either of these, though the blood is found in many good and successful brook-mares. Muley also got Minley Moloch, the sire of the grand brood-mare imp. Britannia.

Joe Andrews by Eelipse, dam by Omnium, son of snap by Snip, got Dick Andrers, out of Highfyer mare, who got Tramp, out of a mare by Gohanna, son of Mereury. Tramp got imp. Zinganee, Lanereost, ont of Otis by Bustard, son of imp. Buzzard, Lottery, ont of Mandane by Pot-8-o-'s. Tramp got Sheet Anchor, out of a Muley mare.

Weatherbit by Sheet Anchor, son of Lottery by Tramp by Dick Andrews by Joe Andrews by Eelipse, dam Miss Letty by imp. Priam, son of Emilins by Orville by Beninglorongh by King Fergus by Fclipse, grandam by Orville, out of daughter of imp. Buzzard, son of Woodpecker by Herod.

Weatherbit got Brown Bread, out of Brown Agnes by West Australian. Brown Bread got Toastmaster, ont of Mayoress by The Marquis, Hilarions, out of Hygeia by Knight of Kars, and Sweetbread, ont of Peffar by Adrenturer, also the imp. mares Bordelaise, Bread and Honey, Dry Toast, Miss Gwilt and Undererust.

Weatherbit got Maudrake, out of Mandragora by Rataplan, and Beadsman (Derby winner, 1858), dam Mendicant by Tonchstone, ont of Laly Moore Carew by iramp.

Beadsman got Blue Gown (Derby winner, 1868), and Cœrnlens, out of Bas Bleu by Stockwell. Bealsman also got imp. Sason, ont of Girasol by Asteroid, a good sire and winner of the fastest Belmont Stake ever run, The Palmer and Rosicrucian, out of Hadame Eglantine by Cowl. The Palmer got Grey Palmer, ont of Eller by Chanticleer, and Pellegrino, ont of Lady Andley by Macaroni. Rosicrneian got Geheimniss (winner of the Oaks, 1882), Hanteur, (winner of the 1,000 Gnineas, 1383).

Mercury by Eclipse, dam by Tartar, sire of King Herod. Merenry got Gohanna, dam by Herod, grandam Maiclen by Matehem. Gohamna got Elcetion, out of Chestunt Skim by Woodpecker, son of Herod and Golumpus, ont of Catherine by Woodpecker. Golumpus got Catton, out of Lucy Gray by Timothy, son of Delpiur hr Hightyer. Catton got Royal Oak, sire of Slane, out of Orville mare, mpl. Nonplus, out of a Walton mare, imp. Trustee, ont of Emma by Whicker. Trustee sired Rerenue, ont of Rosalie Somers by Sir Charles. Rerenue got Planet and Exclecqnex, out of Nina by Boston aud Rivoli, out of Topaz by Glencoe. Planet got Hubbarl, ont of Mimnie Mansfield by Gleneoe, Dudler, out of Regan by Lexington, and Whisper, out of Mattie Gross by Lexington. Catton also got Mulatto, ont of Desdemona by Orvilie. He was the sire of Bloomsbury and Martha Lymu, the dam of Voltigenr. Catton got Gallopade, dam of Reel. Saltram by Eclipse, dam by Snap, son of Snip by 
Flying Childers, got Whiskey ont of Calash by llorod. Whiskoy was thes sire of.

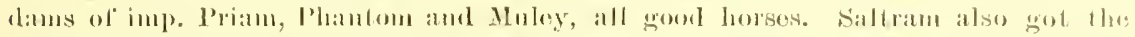

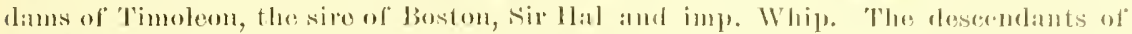

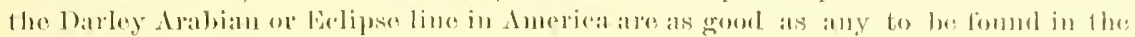

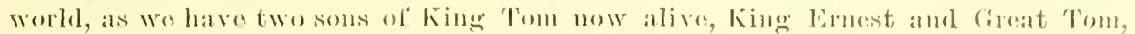

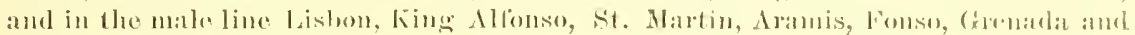
Foxhall. Ill bised and his soms forester, batge and the gramb race-horse His lligh-

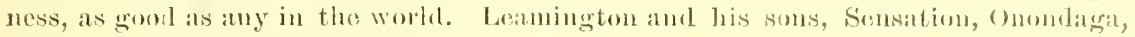

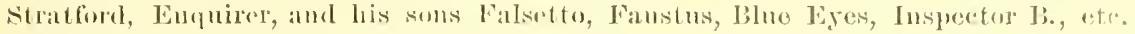
Jonglellow and his sons, The lard, Jils Johnson, Long Jaw, Loonatus, 1, ongstrectand Linden. EoLns and his sons, St. Savionr, Eon, Russell. Aristidos, lioh, Woolley, Hycler Ali, Pantaloon, Lelaps, Outeast, Powhattan, Blazes, Reform, Warwick, ote. Tliere is not any descendant from sir Herenles thromgh Fangh-alsallagh wqual to then. Billot's sons, from the Blacklock line, Barnes, Runnyede, lielvider, lials Law rence, King (ialop, Galore, imp. Simon Magus, Masetto. Touchstone line, imp. St. Blaise, imp. Uhlan, Plevna, Bend'or, Buchanan, imp. Deceiver, imp. Kingston, Rayon l'Or, Blythewool, Alarm, Himyar, Panique, Wawekns, Gabriel, imp. Charaxus, etc. In the Whalebone line tlungh Waverley and Bonnie Scotland's sons, Luke Blacklurn, Bramble, Plenipo, Barnton, Lochiel, Spindrift, etc. Birdcatcher line, Glenelg, I1]Used, Dalnacarloch, Glen Athol, imp. Wagner, The Jacobite, and the great salvator. In the Tramp line, inp. Saxon and imp. Sidkartha, so that the Eclipse line is rery strongly represented by a number of first-class horses descended from racing and producing families.

The Byerly Turk line. The Bycrly Turk was brought into England in the reign of Willian and Jary by Captain Byerly, whose charger he was during the whole of King Villiam's wars in 1689 in Ireland. This noted horse and his owner, Captain Byerly, narrowly escaper eapture on the banks of the Boyne in the last brilliant charge male by the Irish Dragoons, which broke the English lines and retrieved the fortunes of the day for the unfortmate James. The Byerly Turk escaped unscathed, and becane one of the most noted of the founders of the English race-horse. The Byerly Turk got Basto, 1702, dam Bay Peg by Leedes Arabian, grandam Young Bald Peg, also by Leedes Arabian, great grandam old Moroceo mare (Old Peg), Spanker's dam by Lord Farifax's Moтоceo Barb, out of Old Bald Peg lyy an Arabian, out of a Barb mare. Byelly Turk got Jigg, out of a daughter of Spanker by the I'Ares. Yellow Turk. It will he seen that there was good blood to foumd the temale line in this class, as well as in the first class, to the Darley Arabian. Basto got Soreheels and his sister, ont of sister to Mixbury by Curwen's Bay Barb, grandam br Curwen's Ola Spot, son of the Selaby Turk, great grandam by the White-legred Low ther Barb, out of the old Vintuer mare. This sister to Soreheels was the dam of Crab by the Alcock Arabian, Blacklews, Second, Hip, snip, Bay Basto and Brown Basto, all by Flying Childers. Jigs got Partner, 1718, ont of the dam of Soreheels by Basto as above, and with Partner the cross becomes famous in turf history. Partner got Tartar, dam Meliora by Fox, son of Clumsy by Old Hanthoy, grandam Milkmaid by Blackett's Suail, son of Whynot by the Fenwick Barb, ont of a mare by shields falloway, the most famons Galloway of his day. Partner also got Sedbury, out of Old Hontague bs D'Arey's Woodeock aud Olt Traveller, out of sister to Spinuer by Almanzor, son of the Darley Arabian. Partner got imp. Traveler, out of Bay Bloody Buttocks. The great excellence of this blood comes down to us through Tartar's son King Herod, commonly called Herod, daw Cypron by Blaze, son ot Flying Childers, grandam Selina by Bethell's Arabian, great grandan by Graham's Champion, son of Harpur's Arabian, fonrth dam by barley Arabian, ont of a danghter of Old Merlin, son of Bustler. Heror got Florizel, dam by Cygnet, son of the Godolphin Arabian, grandan by Young Cartouch, son of Cartonch, son of the Bald Galloway, tracing through Ebong by Flying Chilters to the Massey mare by Mr. Massey's black Barb. Florizel got imp. Diomed, dam sister to Jumo by spectator, son of Crab, grandam Horatia bs Blank, great grandam hy Flying Chilkers, tracing through Hiss Belvoil by Grej Granthan and Betty Perciral to an imported Barb mare. 
Diomed (wimmer of the Derby, 1780) by Florizel by Herod by Tartar by Partner by Jigg by Byerly Turk, lam sister to Juno by Spectator loy Crab ly Alcock Arabian, out of Horatia by Blank, son of the Godolphin Arabian.

His sons, Sir Archy, dam imp. Castianira by Rockingham by Highflyer by Herod, out of Tabitha bs Trentham.

Ball's Florizel, dam by imp. Shark by Marske, sire of O'Kelly's Eclipse, out of daughter of Harris' imp. Eclipse by Partner.

Duroc, clam Amanda by Gres Diomed by imp. Medley by Gimerack, ont of a daughter of Virginia Cade. Potomac, Hamiltonian, Virginius, Vingt'un, ete.

His danghters in England, Young Giantess, dam Giantess by Mlatchem, the fam of Sorcerer by Trumpator, Eleanor by Whiskey, the first mare that erer won the Oaks aud Derby and the dam of Muley by Orville, Julia by Whiskej, dam of Phantom (winner of the Derby, 1811) by Walton, Cressicla by Whiskey (dam of Antar by Haphazard, winner of the 2,000 Guineas, 1819), and imp. Priam (winner of the Derby, 1830, and two Goodwood Cups) by Emilius, and a Walton mare, dam of Langar and his brother Nicolo (winner of the 2,000 Guineas, 1823) by Selim.

In America the daws of Henry, Cicero, Shylock, Duchess of Marlborough, Lady Chesterfield, Haine's Maria, ete.

Sir Archy got Rattler, Sumpter, Childers and Flirtilla, dam by imp. Robin Redbreast, son of Sir Peter by Highflyer by Herod, ont of daughter of imp. Obscurity, son of Eclipse.

Sir Archy Montorio and Sir Archy of Transport, out of Transport by Virginius, son of imp. Diomed.

Marion, Stockholder and Sir Charles, ont of daughters of inp. Citizen, son of Pacolet by Blank by Godolphin Arabian.

'The brothers Pacific and Bertrand, dam Eliza by imp. Bedford, son of Dungannon by Eelipse, ont. of imp. Mambrina by Mambrino.

Virginian and Director, dam Meretrix by Magog, son of Chanticleer by imp. Wildair.

Sase Weimar, Koscinsko and Crusader, dam Lottery by imp. Bedford, ont of imp. Anvilina by Anvil, son of Herod.

Contention, dam by imp. Dare Devil, son of Magnet by Herod.

Zinganee (Garrison's), dam Miss Chance by imp. Chance, son of Lurcher by Dungannon by Eclipse.

Cicero, dam by imp. Diomed.

Arab, Brilliant, Tariff, Gen. Brooke, the good mares Coquette and Eliza Riley, dam Bet Bounce by imp. Sir Harry, son of Sir Peter.

John Richards; dam by Rattle. son of imp. Shark, Sea Gull, dam Nancy Air by imp. Bedford, Industry, dam by Ball's Florizel.

Timoleon, dam by imp. Saltram, son of Eclipse, out of a daughter of Symmes' Wildair, son of imp. Fearnonght by Regulus by the Godolphin Arabian.

Timoleon got Boston (wimner of 34 four-mile heat and 9 three-mile lieat races), dam sister to Tuckahoe by Ball's Florizel, son of Diomed, grandam by imp. Alderman, son of Pot-8-o-'s by Eclipse, out of daughter of imp. Clockfast.

Boston got Lexington (4 miles, 7.193 and 7.233), dam Alice Carueal by imp. Sarpedon, out of Rowena by Sumpter, Lecompte (4 miles, 7.26, 7.353), dam Reel by imp. Glencoe, out of imp. Gallopade by Catton.

Red Eye, dam Lucy Loug by imp. Priam, Commodore, dam Rosalie Somers by Sir Charles, Cracker, dam by Lance, son of American Eclipse, Riuggold, dam Flirtilla, Jr., by Sir Archy, Tally Ho, dam Nancy Norman by 'Tom Tough. The noted mares Niua (dam of Planet, Exchecquer, etc.), dam imp. Frolicksome Fanny by Lottery, Madeline, grandam of Iroquois, dam Magnolıa by imp. Glencoe, Bostona, dam Creusa by 1 mp. Priam, Goldpin, dam imp. Goldwire by Whalebone.

Lexington got Kentucky ( 4 miles, 7.31 $\frac{1}{2}$ ), Daniel Boone and Gilroy, dam Magnolia by imp. Glencoe, Monarchist (3 miles, 5.34 $\frac{1}{2}$; four miles, $7.33 \frac{1}{2}$, both over Jerome Park old track), dam Mildred by imp. Glencoe, Norfolk (3 mile heats in $5.27 \frac{1}{2}, 5.29 \frac{1}{2}$ ), (lam Novice by imp. Glencoe, Asteroid (never beaten), dam Nebula by 
imp. Glencoe, Tom Ochiltreo, dam Katona by Voucher, son of Wagner, Loudstone,

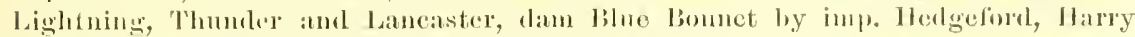
bassett and Charley Llowarl, dam Camary Bird by imp. Albion.

Rubicon, lieanon, Bayswater, Baywood, layomet and Preakness brothers, dam Bay Leat by imp. Forkshire, som of st. Nicholas by limilius.

Coltom, lam 'opay by imp. Glencoe, Jakk Malone and Pat Malloy, dam Gindianat by Amerion Eelipse.

Vauxhall ame Foster, dam Veronat by imp. Yorkshire, out of imp. lsritannia by Muley.

Hunter's Lexington, dam Sally Lewis by imp. Gleneoe.

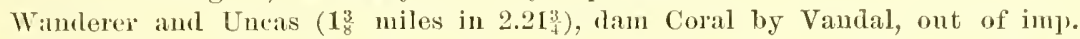
Cairngorm by Cotherstone, War Dance, lam Reel by imp. Glencoe, Kingfisher, daw imp. Elth:m Lass by Kingston.

Merill and Marion, dan Miriam by imp. Glencoe.

Duke of Magenta, dam Magenta by imp. Yorkshire.

Lever and Legatee, ont of Levity by imp. Trustee by Catton, and the following noted mares, Sprightls, dam of Volturno, Snsan Beane, dam of Sensation, Onoudaga, Stratford, Susquchauna (Potomae's daw), Janaica (dam of Foxhall), Nevada (dam of Lnke Blackburu), Erolite, dam of Spendthrift, Miser, Fellowerafts ( 4 miles, $7.19 !$ ),

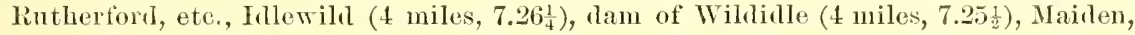

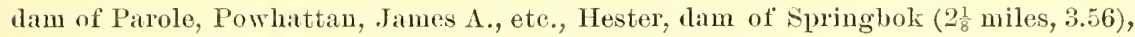
Floreuce, dam of Hiudoo and grandam of Firenzi.

Hira, dam of Himsar, Arizona, dam of Aranza, Regan, dam of Vigil, Vera

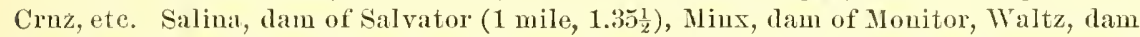
of Glidelia, La Polka, lam of Post Guard (Gen. Philips), Heel and Toe, Strathspey, ete. Kathleen, dam of Geo. Kinmey, Saroug, dam of Aristides, Crueifix, dam of Fair Play, Semper Felix (dam of Leonatus and great grandau of Longstreet), Mattie Gross, dam of Grenada, Mate, ete. Ninnie Holtou, dam of Ten Broeck, Squeer'em, dam of Day Star, Sylph, ete. Stamps, dam of Katie Pearce, Louisette, Preciosa, ete. La

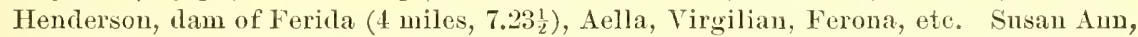
dam of Thora. Lute, dam of Virginius and grandam of Troubadour, Minnie Minor, dam of Warwick, Wancla, John Ledford, etc.

Herod got Woodpecker out of Miss Ramsden by Cade, son of Godolphin Arabian. Woodpecker got imp. Buzzarl, dam Misfortune by Dux, son of Matchem. Buzzard got the three brother's Castrel, Selim and Rubens, dam by Alexander, son of Eelipse, grandam by Highfler, son of Herol. Castrel got Bustard, sire of Heron, ont of Miss Hap by Shuttle, Pantaloon, ont of Idalia by Peruvian, sou of Six Peter by Highflyer. Pantaloon got The Libel, ont of Pasquiuade, sister to Touchstone by Camel, Windhound, Hobbie Noble, The Reiver and Elthiron, ont of Phryne by Tonchstone, Sleight of Hand, out of Decoy by Filho-da-Puta, in Herod line. The Libel got "Traducer out of Arethusa by Elis. Traducer got imp. Sir Hodred and Cheviot, out of Idalia by Cambuscan, son of Newminster. Wiudhound got Thormanby out of Alice Haw thorn by MInley Moloch, Eclipse line. Thormanby got Plaudit out of Plausible by Springy Jack, Charibert, out of Gertrule by Sanuterer, imp. Glengary, out of Carbiue by Rifleman, Rouge Rose, the dam of Bend'or, and Violet, the grantam of Melton. Plaudit, his son, got Balfe out of Bohemia by Weatherbit, Eclipse line. Selim was the sire of Langar, out of a daughter of Walton, son of sir Peter. Langar got Elis and Epirus out of Olympia by Sir Oliver, the latter the sire of Pyrrhus the First, out of Fortress by Defeuce. Langar got Vulture, the dam of Orlaudlo, out of Kite by Bustard, son of Castrel. Selim got Sultan, out of Bacchante by Williamson's Ditto, son of Sir Peter by Highflyer.

Glencoe (wiuner of the 2,000 Guineas, 1834, the Ascot Gold and Goodwood Cups) by Sultau, son of selim by (imp.) Buzzard by Woodpecker by Herod, dam Trampoline by Tramp, son of Dick Audrews by Joe Audrews by Eclipse, graudam Web by Waxy, son of Pot-8-o-s by Eelipse, out of Penelope by Trumpator, son of Conductor by Matehem.

Gleweo got Panic, dam Sally Morgan bs imp. Limaneipation, son of Thhisker by Waxy. 
Star Davis, dam Margaret Wood by imp. Priam. Star Davis got Day Star, dam Squeez'em by Lexington.

Glencoe also got Vandal, dam by imp. Tranby, son of Blacklock bs Whitelock by Hambletonian by King Fergus by Lelipse, grandam Lneilla by Trumpator, out of Lucy by Orphan, son of Ball's Florizel.

Wild Irishman and Frankfort out of Mary Morris by Medoc. Highflyer and Basvecehi, dam Castinet by imp. Monareh, sou of Priam

Glencoe got a number of superior brood mares, such as Magnolia, dam of Kentucky, Daniel Boone, Gilroy and Madeline, the grandam of Iroquois.

Reel, dam of Lecompte, Starke, Prioress, War Dance, Fanny Wells, etc.

Topaz, dam of Austerlitz, Wagram, Waterloo, Lodi, Colton, etc. Novice, dam of Norfolk. Kitty Clark, dam of Maiden (Parole and Powhattan's dam), and La Henderson, Ferida's dam.

Florine, dam of Idlewild (Wildidle's dam) and Erolite, dam of spendthrift, Miser, Felloweraft, etc.

Nebula, dam of Asteroid, Asterisk, etc.

Lightsome, dam of Sprightly, Nevada, Salina and Crucifix.

Mildred, dam of Monarchist, Minx (Monitor's dam), Stamps, Nora Worth, etc.

Sally Lewis, dam of John Morgan, Hunter's Lexington, Snsan Beane (dam of Sensation, Onondaga, Stratford, ete).

Yandal got Virgil, dam Hymenia by imp. Yorkshire. Ventilator, dam Carolin by imp. Scythian. Voltigeur, dam Duet by Highlander. Vanderbilt, dam Melrose by Childe Harold. Vagabond, dam Gem by Childe Harold, son of imp. Sovereign.

Virgil got Hindoo, dam Florence by Lexington, out of imp. Weatherwitch by Weatherbit.

Hindoo got Hanover, dam Bourbon Belle by imp. Bonnie Scotland.

Virgil got Tremont, dam Ann Fief by Alarm. Vocalic, dam Acoustic by imp. Australian. Ben Ali, dam Ulrica by Lexington. Vigil, dam Regan by Lexington. Virgilian, dam La Henderson by Lexington. Portland, dam Finework by Lexington. Isaac Murphey, dam Mary Howard by imp. Hartington.

Vanderbilt got Madstone, dam Nina Turuer by Hiawatha, son of imp. Albion.

Vagabond got Judge Morrow, ont of Moonlight by Joe Johnson, son of Hunter's Lexington.

Rubens was the sire of Bobadil, ont of a daughter of Skyscraper ; Peter Lely, ont of Stella by Sir Oliver; Teniers, ont of Snowdrop by Highland Fling, and Defiance, the dam of Defence, ont of Little Folly by Highland Fling.

Woodpecker got imp. Dragon, out of Juno by Spectator, and Dragon got imp. Speculator, dam by Herod. Woodpecker was also the sire of Chanticleer, out of a daughter of Eclipse, she out of Rosebud by Snap. Chanticleer got Bob Booty, out of Ierne by Bagot, son of Herod. Bob Booty was the sire of Guiccioli, the dam of Birdeateher and Faugh-a-Ballagh. Woodpecker also got Colibri and Catharine, ont of Camilla by Trentham. Catharine was the dam of Wanderer and Golumpus bs Gohanna, son of Mercury by Eclipse. Herod got Hightlyer, dam Rachel by Blank, son of the Godolphin Aribian, ont of a daughter of Regulus by the Godolphin Arabian, tracing to a Royal mare. Hightlyer never paid a forfeit or was beaten. He was the sire of Delpini, ont of Countess by Blank. Delpini was the sire of Timothy, out of Cora by Matchem. Delpini was also the sire of Goldenlocks, the dam of Soothsayer. ont of Violet by Shark, and of Seymour, ont of Bay Javelin by Javeliu, son of Eclipse. Highflyer's most celebrated son was Sir Peter, fouled 1784, dam Papillon by Sual, son of Snip by Flying Childers, grandam Miss Cleveland by Regulus, son of Godolphin Arabian, tracing through the Byerly Turk mare, dam of the two True Blues to the Burton Barb mare, as conjectured. Sir Peter got Walton and Williamson's Ditto, winner of the Derby in 1803, ont of Arethusa by Dungannon, son of Eclipse. Sir Harry (imported), wiuner of the Derby in 1798, ont of Matron by Alfred, son of Matchem. Stamford, imp. Archdnke, wimex of the Derby in 1799, and Paris, winner of the Derby in 1806, out of Horatia, sister to Achilles by Eclipse. Iup. Robin Red. breast, out of Wren by Woodpecker. Walton got Phantom, wimer of the Derby in 
18/1, ont of Julia by Whiskey, and Partisan, ont ol' l'ansol ly Pot-X-o-'s. I'handom

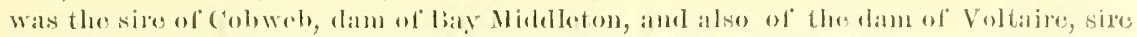
of Toltigent, and his bood is foumd in many of ond best perligres.

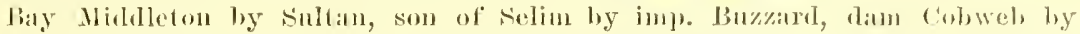

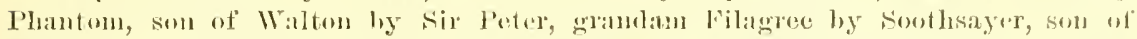
sorecer by Trumpator by Conductor by Matehent, ont wi Web hy Waxy, son of l'otS-o-'s ly Eulipse.

Ilis solls :

Autocrat, dam Empress by Emilius, solz of Orville by Beninglorougl by King Fergus, out of dlangelwurzel by Merliu, son of Castrel by imp. Buzzard.

Cowl, dam Crueitix by Prian (inported), son of Emilins, grandan Oetaviana loy Octavian, son of Stripling by Plichomenon by 11 erou.

Cow is sire of The Conlessor, dan Forest Fly by Mosquito, son of Emilius, out of Walfruma by Velocipede, son of lilacklock. Sire also of Miss Sellon, gramean of Hermit by Newminster, and Kantaka by Scottish Chief (in Algeria stud), out of Belle Dano hy lielshazzar, son of Blacklork.

Cowl is also sire of Madame Eglantine (dam of Rosicrueian and The Palmer hy Beadsnian), ont of Diversion by Defence, son of Whalebone.

The Flying Dutehman (dam Barbelle by Sandbeck, son of Catton by Golumpus, grandam Darioletta by Amadis, son of Don Quixote by Eclipse), was the sire of Amsterlam, dam Urania hy Idle Boy, son of Satan by Lottery by Tramp, grandam Venus by Langar, ont of Testa by Governor, son of Trumpator. He was also sire of Dollar, dam Payment by Slane, sou of Royal Oak by Catton by Golumpus, grandan Receipt by imp. Rowton, son of Oisean by Camillus by Hambletonian.

Dollar is sire of the lrench horse Salvator, dam Sauragine by Ion, son of Cain by Panlowitz, ont of Cuckoo by Elis, son of Laugar, and Fontaiuebleau, dam FinIande by Fon, out of Fraudulent by Venison, son of Partisan ly WaIton.

The Flying Dutchman got also Duteh Sliater, dam FuIvie by Gladiator, son of Partisan, out of Bontique by Giges, sou of imp. Priam; Ellington (winner of the Derly in 1856), dam Ellerdale by Lanereast, son of Liverpool by Tramp, out of a mare by Tom Boy, son of Jerry by Smolensko; Jarnac, dam Joliette by Smplice, son of Tonchstone by Camel, ont of Jessamine by Paragone by Tonehstone; Ignoramus, 1854, dam Ignorance by The Little Known, son of Muley by Orville, ont of Bohemienne by Confederate, son of Comus by Sorcerer; Tom Bowline, 1857, dam Miss Bowe by Catton, son of Golumpus by Gohamna, ont of Tranby's dam by Orville.

Dutch Skater got Insulaire, dam Green Sleeves by Beadsman, son of Weatherbit by Sheet Anchor, out of Mrs. Quickley by Longbow.

Gladiator by Partisan, som of WaIton, dam Panline hy Moses, son of Whalebone or Seymour by Delpini, out of Quadrille by Selim, son of imp. Buzzard. Gladiator got Fitz Gladiator, dam Zarah by Reveller, son of Comus by Soreerer, ont of sister to Wouvermans by Rubens, son of imp. Buzzard.

Fitz Gladiator got Compiène, ont of Maid of Hart by The Provost, son of The Saddler by Waverley, out of Martha Lynn (Voltigeur's dam) by Mulatto. Compiegne was sire of imp. Nortemer, dam Comtesse by The Baron or Nuneio, the latter son of Plenipotentiary by Emilius, out of Eusebia by Emilius.

Mortemer was sire of St. Christophe (wimner of the Grand Prize of Paris), ont of Isoline by Ethelbert; Vernenil (winner of the Gold Vase, Gold Cup and Alexaudr: Plate at Ascot), out of Regalia by Stockwell; Chamant (winner of 2,000 Guineas), out of Araucaria by Ambrose, in France; Exile (a grand race-horse in America), ont of imp. Second Hand by Stockwell; Pontico, out of imp. Agenoria by Adrenturer; Winfred, out of Minnie Minor by Lexington; Cyclops, Cambyses and Cleofas, ont of Lizzie Lneas by imp. Australian; Cholula (Stiegen) and Cataline, out of Fanny Ludlow by imp. Eclipse ; Heimdal, Honsatonic and Iconoelast, ont of Vandalite by Vandal; Savanac, ont of Sly Boots by Rivoli, son of Revenue, with Wanda, Chimera, Restless, Hera, Saluda and Unrest. Fitz Gladiator was also sire of Orphelin, ont of Echelle by Sting. Gladiator sired Ventre-St.-Gris, out of Belle de Tuit by Young Emilius. 
Gladiator also got Sweetmeat, dam Lollypop by Starch or Voltaire, the latter son of Blacklock, out Belinda by Blacklock.

Sweetmeat got Macaroni, dam Jocose by Fantaloon, son of Castrel by imp. Buzzard, out of Lanter (Touchstene's dam) by Master Henry, son of Orville.

. Macaroni got Couronne de Fer, out of Miss Agnes by Birdcatcher; Maximilian, dam Duchess by St. Albans; Macgregor, out of Necklace by The Fallow Buck; imp. Maccaroon, dam Songstress by Chanticleer, son of Birdcatcher, out of Mrs. Carter by Humphrey, son of Sandbeck; imp. Moccasin, dam Madame Strauss by King Tom, he the sire of Vampire, Amazon, Disdain, etc. Maccaroon is the sire of Macduff, out of Jersey Lass by imp. King Ernest, son of King Tom; Macbeth, ont of Jersey Belle (sister to Spendthrift and Felloweraft) by imp. Anstralian; Gregory, dam imp. Abundance by Kaiser, son of Skirmisher by Voltigeur; Masher, dam Miss Bassett (sister to Harry Bassett) by Lexington.

Sweetmeat got Parmesan, dam Grujere by Verulam, son of Lottery by Tramp, out of Jennala by Touchstone.

Parmesan got Faronins (winner of the Derby, 1871), out of Zephyr by King Tom ; Cremorne (winner of the Derby, 1872), ont of Rigolboche by Rataplan ; Hopbloom, ont of Cognisaunce by Stockwell; D'Estommel, out of a daughter of Chanticleer, son of Birdeatcher; Strachino, out of Lady Blanche by Voltigeur; imp. Strachino, ont of May Belle by Hetman Platoff.

Faronius got Sir Bevys (Derby winner, 1879), dam Lady Langden by Kettledrum, son of Rataplan, ont of Haricot by Mango or Lanercost.

Sweetmeat got Carnival, dam Volatile by Buckthorn, son of Venison. Carnival got Mask, ont of Meteor by Thunderbolt, son of Stockwell, and Scobell, ont of Lady Sophie by King Tom.

Sweetmeat got Saccharometer, ont of Defamation by Iago, he the sire of Cnenmber, ont of Aminette by Birdcatcher, and Vanderdecken, ont of Stolen Moments by Melbourne, Lozenge, ont of Down-with-the-Dust ly Star of Erin, son of Ishmael by Sultan.

Partisan was also the sire of Glancus, ont of Nanine by Selim. Glaucus got The Nob and he got The Nabob, and The Nabs's got Vermonth and Bois Roussel. Ternonth got Boiard. The Nabob also got Nutbounse and Nutbonrne got imp. Woodlauds, ont of Whiteface by Turnus. Glaucns was also sire of Milkmaid, the grandam of Bertram, sire of Robert the Devil.

Sir Peter was sire of Sir Panl and Paulina, out of Pewet by Taudem, son of Syphon. Sir Panl was the sire of Panlowitz, ont of Evelina by Highflec. Paulina won the St. Leger in 1807 and was the dam of Galatea by Amadis, the dam of Soldier's Joy, both distinguished brood mares. Paulowitz got Cain, ont of a danghter of Paynator by Trumpator. Cain got Ion, out of Margaret by Edmund, and Ion got Wild Darrell, ont of Elleu Middleton by Bay Middleton.

Wild Dayrell by Ion, son of Cain by Paulowitz by Sir Paul by Sir Peter by Highflyer by Herod, dam Ellen Middleton by Bay Middleton by Sultan by Selim by Buzzard by Woodpecker by Herod, grandam Myrrha by Malek, son of Blackloek by Whitelock by Hambletonian by King Fergus by Eclipse, out of Bessy by Young Gouty, son of Gonty by Sir Peter.

Wild Dayrell got Buccaneer, ont of danghter of Little Red Rover, son of Tramp. Bnccaneer got Kisber (wimner of the Derby in 1876), ont of Mineral by Rataplan. Kisber is the sire of imp. Viola (Victory's dam), ont of Parma by Parmesan. Buccancer got See Saw, ont of Margery Daw by Brocket, son of Melbourue. See Siw got Bruce (wimner of the Grand Prize of Paris), ont of Carine by Stockwell. Buccaneer also got imp. Felneca, ont of Revival by Newminster. Felucea is the dim of Felicia, Feu Follet (dam of St. Florian), etc.

Wild Dayrell got Bold Dayrell, out of Rosina by The Emperor, son of Defence. Bold Dayrell is sire of imp. Lady Darrell and imp. Richmond, ont of Miss Harriot by Kettledrum.

Wild Dayrell also got Wild Moor and Wild Oats, ont of The Golden Horn by IIarkaway, Guy Darrell, ont of Reginella by King Tom, and imp. The Rake, out of 


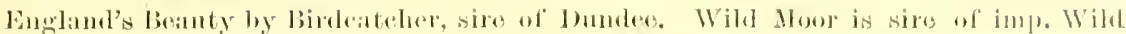
blossom, a grood brool malro.

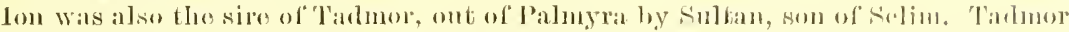

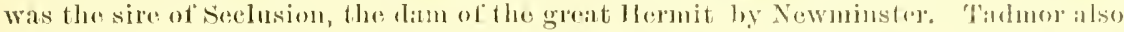

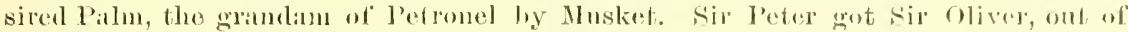

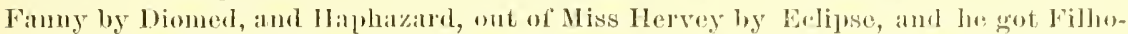
da-Puta, onl of Mrs. Barnet by Waxy. Filho-dal-Puta got (olwick, ont of titella liy

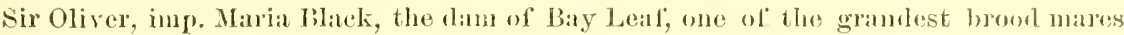

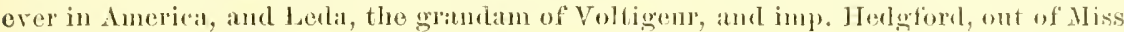
Craigie by Orville. Herlgford was a suecess in this combtry, siro of laufin, Duanc,

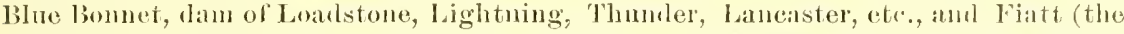
Blue filly), the dam of Hunter's Glencoe, Kite Hunted, Liz Morgan and Blne Bulls, to which Temny traees. Herorl also got Phrenomenon, out of Frenzy by Eelipse, who frot Anvil, that sired tho grandan of Economist and Sitrinling, the sire of Octavian.

Phonomenon was also sire of Rosilind, dam of Whitefock. Ilerod got Drone, out of Lily by IBank, Bagot, ont of Marotte hy Matcliem, and Maria, tha dam of the noted Waxy by Pot-8-0-'s, ont of lisette by Smap. The Byerly Turk class is becoming extinct in Eugland; the best representatives are fomm in America. There is mothing in the male line from Glencoe in Europe, while we have Hincloo, Hanover, Tremont, Vocalic, Ventilator, Vamlerbilt, and his son Malstone, Day Star, Vagaboncl. From Diomed, throngh Boston and his son Lexington, Vauxhall, Uncas, Wanderer, Dnke of Magenta, Monday, Joe Hooker, Grinstead and a few others. It is the interest of Ameriea to preserve this blood. The representatives of it now alive were the equals on the turf of any ever bred in Europe.

The Godolphin Arabian. The Godolphin Arabian was said to have hrawn a cart in the streets of Paris, France. He was purchased and bronght to England by Mr. Coke in 1730, who gave him to Mr. Williams, keeper of the St. James' Coffee Honse, who presented him to Lord Godolphin. Whether he was an Arabian or a Barh is a dispnted point. Hewas a brown bay, abont fifteen hands high, with some white on the off hind licel. It is generally adnitted that he contributed more to improve the thoroughbred horse than any stallion either before or since his tinte. He aecidentally became fumous. He was teaser to Hobgoblin in 1730 and 173I, and npon the latter refusing to cover Roxana, she was bred to the Godolphin Arabian; from that cover Roxana produced in 1732 Lath, the first horse the Arabian ever got. Roxana was by the Bald Galloway, son of St. Victor Barb, dam Grey Whynot by old Whynot, son of Fenwick Barb, out of a Royal mare, Roxana's dam, sister to Chamter by Akaster Turk, gramlam by the Leedes Arabian, great grandam by Spanker, ont of the old Morveco mare, Spanker's own dam by Lord Fairfix's Moroceo Barb, she out of Old Bald Peg by an Arabian, ont of a Barb mare. It will thus be seen that Lath was not a chance horse, his dam being as well bred as any mare of her day, and a racemare of mert, and Lath was a superior lace-horse himself, regarded as seeond only to Flying Childers. In 1734 Roxana prodncerl Cade, the own brother to Lath, and, although he was not celebrated on the turf, it is to him that we are indebted for the Matchem line of blood. Carle lost his dam at foaling, and was brought np by hand. He was a horse of high conformation, and proved one of the best of stallions. Calle got Matchem, 1748, and Changeling out of an own sister to Miss Partner by Croft's Partuer, son of Jigg by Byerly Turk, grandam Brown Farewell by Makeless (son of the Oglethorpe Arabian ), tracing to the Lay ton Barb mare. Matchem was distinguished on the turf and became famous in the stad. He sired in the twenty-three years lie was in the stud 354 winners of $\$ 755,485$, in addition to cups, ete. Matehem got Conductor, 1767, Alfred, 1770, Georgiana, 177I, Eyebright, 1777, and Laurestinus, 1778, all out of a daughter of Snap by Snip, grandan by Cullen Arabian, ont of Grisewood's Lady Thigh by Croft's Partuer, etc. Conductor got Imperator, 1776, out of the dam of imp. Royalist by Ilerod, grandam Carina by Marske, sire of Eclipse. Imperator got Trumpator, 1782, and Pipator, 1786, out of Brumette by Squirrel, son of Traveler by Partner, grandam Dove by Matchless, son of the Godolphin Arabian. Alfred got imp. Tiekle Toby, ont of Cielia by Herod, who got Sir Solomon, ont of Testa by 
Dreadnonght, son of Meade's Celer by imp. Janns, and Sir Solomon got Trumpator, ont of a daughter of Hickors, son of imp. Whip by Saltram. Cade also got imp. Wildair, 1753, ont of a daughter of Steady by Flying Childers. so highly was Wildair valued in England, that he was repurchased and sent back to England, but he left behind him in America Bashaw, Sim's Wildair and Old slamerkin. From the latter very many of the best race-horses of our day and many excellent stallions, including Thornton's Rattler, Sumpter and Childers, have descender.

Trumpator got Soreerer, ont of Young Giantess by Diomed, grandam Giantess by Matehem, and Paynator, dam by Mark Anthony, son of Spectator. Paynator got Dr. Syntax, out of a daughter of Beniugbrough, son of King Fergus by Eclipse. Dr. Syntax was the sire of the noted mare Beeswing, the dam of Newminster by Touehstone. Newminster is sire of Herod (sire of St. Blaise), Lord Clifden and Adrenturer, the sire of Ishmael and imp. Pizarro. Paynator was also the sire of the dam of Cain, sire of Ion, the sire of Tadmor and Wild Dayrell. Tadmor is sire of Seclusion, Hermit's dam. Soreerer was the sire of Comus, ont of Houghton Lass by Sir Peter. Comus got Humplurey Clinker, out of Clinkerina by Clinker, sou of Sir Peter.

Melbourne, 1834, by Humphrey Clinker, sou of Comus by Sorcerer by Trumpator by Conductor by Matehem, dam by Cervantes, son of Don Quixote by Eelipse, grandam by Golumpus, son of Gohanua by Mereury by Eelipse, out of sister to Zodiac by St. George, son of Highflyer by Herod.

Melbourne got Young Melbonrue, dam Clarissa by Pantaloon, son of Castrel, ont of daughter of (imp.) Glencoe. Young Melbonrne got Pell Mell (out of Makeshift by Voltigenr), he the sire of Carlton, out of Bonny Spec by Speenlum ; Strafford and Brother to strafford, ont of danghter of Gameboy, Statesman and Gen. Peel, dam by Orlanclo, Rapid Rhone and Brother, out of mare by Lanereost or Retrierer.

Melbonrne got The Prime Minister (ont of Pantalonade by Pantaloon), he the sire of Knight of the Garter, out of Rosa Bonheur by Touchstone; Arthur Wellesles, out of Lady Barbara by Lancelot: West Australian, dam Mowerina by Tonehstome, ont of Emma (dam of imp. Trustee) by Whisker.

West Anstralian won the 2,000 Gnineas, Derby and St. Leger in 1853. He got The Wizard, dam by The Cure, Ruy Blas (out of Rosati by Gladiator), he the sire of Monrle, Reluisant and Financier; Joskin (out of Peasant Girl by The Major, sou of Sheet Anchor), he the sire of Plebeian, dam Queen Elizabeth by Antoerat; Solon, dam by Birdeateher, grandam by Hetman Platoff, out of Whin by Drone. Solon got Philammon, out of Satanella by Wild Dasrell, and Barealdine, out of Ballyroe by Belladrum. Barcaldine is sire of Morion, out of Chaplet by Beadsman.

West Australian got imp. Anstralian, dam imp. Emilia by Young Emilius, out of Persian by Whisker. Australian got Spendthrift, Felloweraft, Miser and Rutherford. out of Aerolite by Lexington, Helmbold, Baden Baden and Barricade, ont of Lavender by Wagner, Springbok and Aspinwall, ont of Hester by Lexington, Wildidle, ont of Icllewild by Lexington, Wilful, out of imp. Pussy by Diophantus, and Hirry O'Fallon, out of imp. Smuny Sonth by Birdeatcher.

Melbourne is also the sire of The Slave. dam of Lord Clifden, Canezon, Cymba. Marchioness, and of The Peer, ont of Cinizelli by Touchstone. The l'eer is the sire of imp. Darebin, ont of Lurline by Traducer, in the Rancho del Paso Stud of Mr. J. B. Haggin. Humphrey Clinker was the sire of imp. Clink, the dan of Amn Watson, she the dam of Rhynodyne and Watson by Gleneoe. Soreerer got Smolenslio, ont of Wowski by Menter, son of Justice by Herod. Smolensko got Jerry, ont of Lonisa hy" Orville, and Jerry got Tomboy, out of Beeswing's dam by Ardrossan. Tomboy got Gameboy, ont of Lady Moore Carew by Tramp, aud Nutwith, out of a daughter of Comus, and Futwith got Kuight of Kars, ont of Poeahontas by Gleneoe. Sorcerer also got Bourbon, out of a daughter of Precipitate by Mereury, son of Eclipse, and Bourbon was the sire of Flemr de Lis, the dam of imp. Sorereign. Sublensko is the sire of the dam of the great mare imp. Maria Black, dam of Bayleaf by imp. Forkshire, and the grandam of imp. Gallopade, the dam of the noted Reel by Glencoe. From these mares some of our most famous rice-horses, stallions and brood mares owe their origin. Sorcerer also got Soothsayer, ont of Golklen Loeks by Delpini. Sooth- 


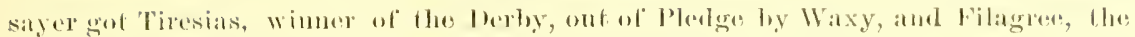
dam of imp. Ridklesworth, and Cobweb, the dan of liay Midellefon.

The Godolphin Arabian also got the Gower Stallion, ont of sister lo Tortoises by

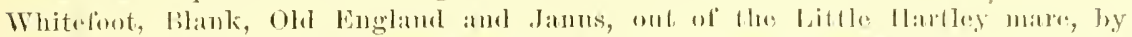

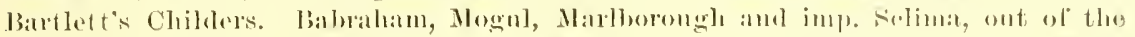

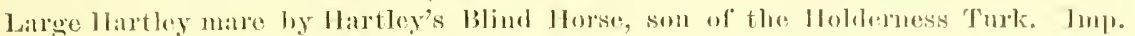
Selima was the dam of Ariel, Pather and their sister, hy Moreton's imp. Tratreler, son of Croftis I'atner; Stella aud Ehony by imp. othello; blarek Solima by imp. Feamonght, son of liegulus. It is firm one of the above fillies, sister to Ariel and Farture, that we are indehted for the limons rase-mare Mollie dackson, whose thee-

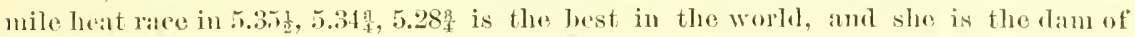
Mombay by Colton, and he the sire of Toe Hooker. Her danghter, Fanny Lublow by inp. Eelipse, is the dam of .Jamaica hy Lexington, and she the dam of the superior race-horse Foxhall, that won the Grand Prize of Paris, the Cesarowiteh and Cambridgeshire llandicaps. Blank got Rachel, the dam of the noted Hightlyer by IIerod, and imp. Centinel, ont of Naylor by Cade, son of tho Godolphin Arabian. Blank got Pacolet, ont of Whiteneck by Crab. Pacolst got imp, Citizen, ont of Princess by 'Tnrk. son of Regulus, le the sire of the dam of Marion. Inp. Citizen got Pacolet, ont of Mary Grey by Tippoo Saib. Pacolet was sire of Monsienr Tonson, Sir Henry Tonson and sir Richarel Tonson, out of Madame Tonson by Top Gallant. Jamus got imp. Janns out of a danghter of Fox, and Janus got Meade's Celer, ont of Brandon by imp. Aristotle, son of the Cnllen Arabian. The name of Celer fignres in many of onr best racing pedigrees. The Godolphin Arabian got Cripple ont of Blossom by Crab, who got Gimcrack, ont of Miss Elliot by Grisewool's Partuer, son of Croft's Partner by Jigg. Gimerack got imp. Medley, ont of Arminda by suap, son of snip, and imp. Clockfast, ont of Miss Ingram by Regulus. Clockfast was the sire of the great grandam of Boston, while Medley was the sire of Gray Diomed, who got Amanda, the dam of Duroe, sire of́ American Felipse, and Melzar, out of Kitty Fisher by symmes' Wildair. Melzar got Maria, ont of a danghter of imp. Hightlyer, son of Highflyer by Herod, and Maria was the dam of Lady Grey by Robin Grey, sqon of imp. Royalist by imp. Saltram by Eelipse. It is to Lady Gray that Lexington, Tandal, and all the Levity family, including Luke Blackburn, Salvator, Leonatus, Longstreet and other noted horses, trace their origin. The Godolphin Arabian got Regnlus, ont of Grey Robinson by the Bald Galloway. Regulus was famons on the turf, and was never beaten. Regulns got Careless aud imp. Fearnonght, ont of Silvertail by Heneage's Whitenose, son of the Hall Arabian, and South, ont of a danghter of Soreheels, son of Jigg. South got imp. Flimmap, out of a daughter of Cygnet, son of the Godolphin Arabian. Regulus got Dragon, ont of Whimsey by Cnllen Arabian, and Dragon got imp. St. George, out of sally by Blank. His name appears in many of onr best perligrees. Regulus got spiletta, the dam of Eclipse, ont of Mother Western by smith's son of Snake, and the mare grandam of Herod's great son Highflyer. Imp. Fearnonght got Symmes' Wildair, ont of a danghter of inp. Jolly Roger. Wildair was the sire of the grandam of Timoleon, Fitzhugh's Regnlus, Gorlolphin and Specimen, ont of imp. Jemny Dismal by Dismal, also son of the Godolphin Arabian, Apollo, Haris' Eclipse, Dandridge's Fearnonght, ete. The Godolphin line is only represented on the other side of the Atlantic by the male descendants of Melbonrue, of which the best representative is Barcaldine, and his son Morion, ont of Chaplet bs Beadsman.

In America we have a number of very highly bred race-horses and successful stallions in the male line to the Godolphin Arabian, throngh the same Melbourue line. Wilful, a good race-horse and sire of wimmers, ont of imp. Pussy by Diophantus, son of Orlaudo. The brothers Spendthrift (sire of Kingston, Lamplighter, ete.), Felloweraft, Rutherford and Miser, the latter sire of Yorkville Belle, Harry O'Fallon, sire of Terra Cotta, and other good ones, ont of imp. Snmny South by Birdeateher; Duke of Montrose, ont of Kelpie by Bonnie Scotland; Strathmore, ont of Brenna by Knight of St. George; Leinster, ont of Luileme by Lexington; Wildidle (4 miles, $\left.7.25 \frac{1}{2}\right)$, ont of Idlewild ( 4 miles, $\left.7.26 \frac{1}{4}\right)$ by Lexington; Algerine, ont of Nina by Boston; Springbok, ont of Hester by Lexington; imp. Darebin, out of Lurline by 
Traducer. There is then no necessity to send abroad for trash to improve this line of blood. In fact, any student of the stud book, or others who have real and digested the book on the thoroughbred horse, must be convinced that, whether we go to the Eclipse, Herod or Matchem lines of blood, we have as good in eaeh and every elass as ean be found in the world. 
T H E

BREEDERS' HAND B00K AND GUIDE. 



\section{ABBREVIA'TIONS.}

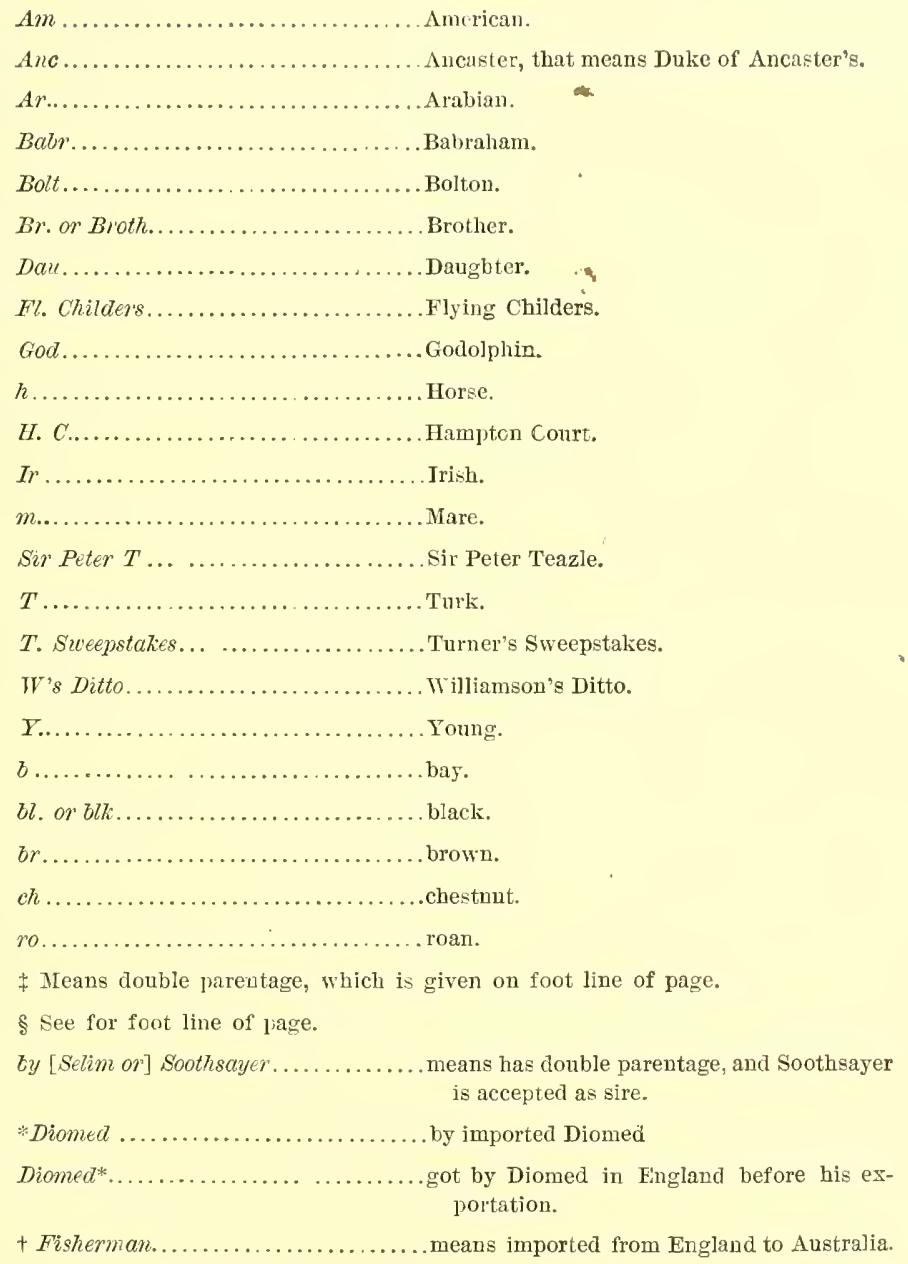

* [The names in the last four instances are only given as example, and the marks hold good for erery other animal.]

The top line on the pages of pedigrees extends the tail male line, which ceases on the ith cross, to the Byerly Turk, Darley Ar. or God. Ar.

The tables give the pedigree full in 5 crosses; after the 5 th cross is given the pedigree of the respective animal in the female line to the 8th cross. 


\section{IMPORTED ABINGDON.}

The property of J. D. Lueas, Goodwood Stud, St. Louis, Mo.

Abixgdox by Wenlock (winner of the St. Leger in 1872), best son of Lord Clifilen, was foaled in 1887, bred by Lord Norreys, dam Lady Langden (dam of Hampton, winner of the Doncaster Cup, Goodwood Cup and Epsom Gold Cups, and Sir Berys, winner of the Derby) by Kettledrum, 2d dam Haricot (dam of Caller Ou, winner of the St. Leger, York and Brighton Cups and 34 Queen's Plates) by Mango or Lanercost, she out of the famous Queen Mary by Gladiator, the dam of Bonnie Scotland, Blink Bonny, that won the Derby and Oaks and was the rlam of Borealis, Blair Athol, winner of the Derby and St..Leger, and Breadalhane, winner of the Prince of Wales and Gratwicke Stakes and sire of imp. III Used. Other famous winners in the family are Sir Berys, wimner of the Derby: Hampton, Epsom Goll Cup, Dóncaster and Goodwood Cups and Goodwood Stakes: Broomielaw, Dee stakes and Chesterfield Stakes; Blinkhoolie, Ascot Gold Vase and Alexandra Plate; Freeman, Great Northern Handicap twice, Goodwood Stakes, Chesterfield Cup and Alexandra Plate; Good Hope, Vienna Derby; Beauclerc, Niddle Park Plate. Thrift, the dam of Tristan, winner of the Ascot Gold Cup and Hardwicke Stakes three times, for which $\$ 40,000$ was refused, is from the same family. The family is potent in great race-horses, prolific brood mares aud successful sires. Abingdon started only once, ran unplaced in the Hastings Plate at Newnarket, won by Heamme. He is a grandly bred horse and from one of the most distinguished racing and producing families in the world. 


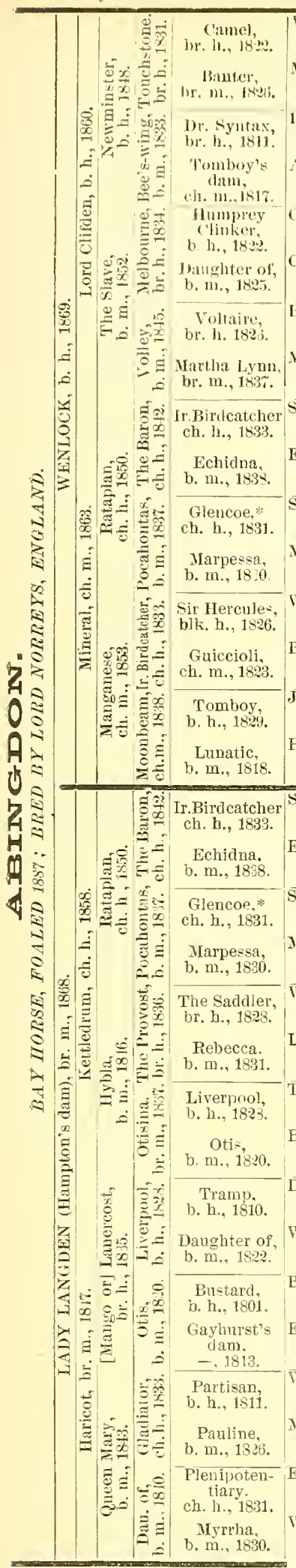

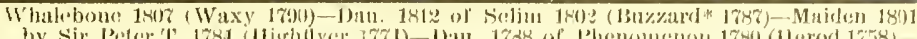

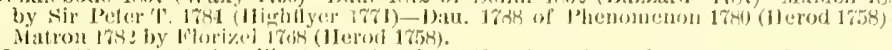

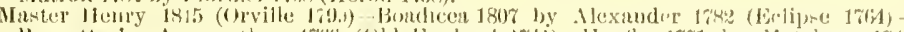

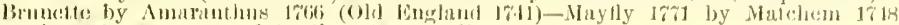

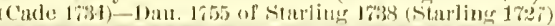

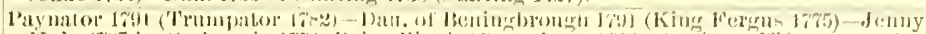

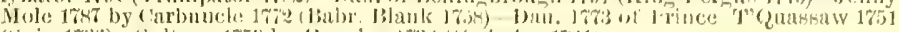

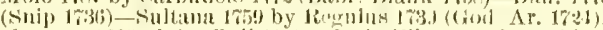

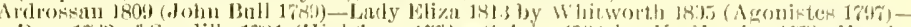
Dau. 1793 of spadille 1981 (1)

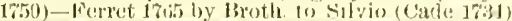

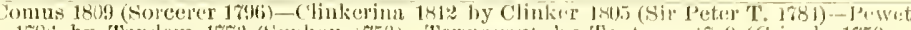

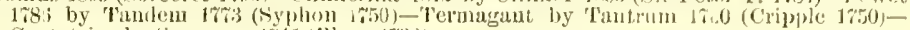
Cantatice by Sampkon litio(13laze 1733).

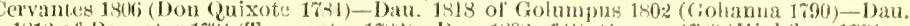

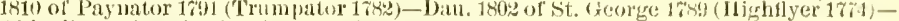
Abigail trise by 11 oodpecher 1773 (1lerod 1758).

Biacklock 1814 (Whilelock 1503) - Dan. 1816 of Phantom 180k (Walton 1796) - 1)au. 1802

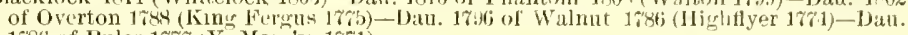
$1 \% 86$ of Ruler $1 \%$ \% ( $\mathrm{Y}$. Maske 17 is)

Mulatto 18:3 (Catton 180.7)-Leda 1821 by wilho da Puta 1812 (1 Iaphazard 1797)-Treasure

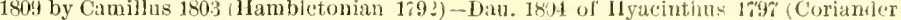
1796)-Flora 1784) by King Fergus 1655 (Eclipse 1\%61).

Sir Hercules 18:6 (Whalebone 180\%)-Guiccioli $18: 3$ by Bob Booty 1804 (Chauticleer 1787) - Flight 1809 by Ir. Escape 1802 (Commodore 1793)-Y. Neroine by Bagot 1780 (Herod 1758)-Ileroine 1775 by Ifero 1753 (Cade 1734).

Economist 18:5 (Wlisker 1812)-Miss Pratt 1825 by Blacklock 181 I (Whitelock 1808)Gadabout 1812 by Orville 1799 (Beningbrough 1791)-Ninstrel 1803 by Sir Peter T. 1781 (Highflyer 17\%4)-Matron 1782 by Florizel 1763 (Herud 1758),

Sultan 1816 (Selim 1802)-Trampoline 1825 by Tramp 1810 (Dick Andrews 1797)-Web 1808 by Waxy 1700 (Pot-8*- 1773)-Penelope 1798 by Trumpator 1782 (Conductor 176\%)-Pimnella 1788 by Highflyer $17 \% 4$ (Herod 1758).

II 1910 (Orville 1799)-Clare 1821 by Marmion 1806 (Whiskey 1689)-Harpalice 1814 by Gohanna 1790 (Mercury 17\%8)-Amazon 1799 by Driver 1783 (Trentham 1766)Fractious 1792 by Mercury $17 \% 8$ (Eclipse 1764).

Whatebone 1807 (Waxy 1790 )-Peri 1822 by Wanderer 1811 (Gohanna 1790)-Thalestris 1809 by Alexander 1782 (Eclipse 1764 )-Rival 180.3 by Sir Peter T. 1784 (IIghflyer 1774) Hornet 170 by Drone $17 \%$ (Herod 1 753 ).

Bob Booty 1804 (Chanticleer 1787) - Flight 1809 by Ir. Escape 1802 (Commodore 1793)-Y. Heroine by Bagot 1789 (Herod 1758)-Heroine 175 by IIero 1653 (Cade 1731)-Dau. 1766 of Snap 1750 (Snip 1736)

Jerry 1821 (Smolensko 1810)-Dan. 1817 of Ardrossan 1809 (John Bull 1789)-Lady Eliza

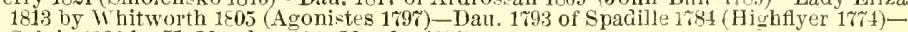
Sylvia 1783 by Y. Marske 1761 (Marske 1750).

Prime Minister 1810 (Sancho 1801)-Maniac 1806 by Shuttle 1793 (Y. Marske 1761)Anticipation 1802 by Beningbrough 1791 (King Fergns 17\%5)-Expectation 1779 by Herod 1753 (Tartar 1743)-Dau. 1758 of Skim 1746 (Starling 1727).

Sir Hercules 1826 (Whalebone $180 \%$ ) -Guiccioli 1823 by Bob Booty 1874 (Chanticleer $178 \%$ ) -Flight 1809 by Ir. Escape 1802 (Commodore 1793)-Y. Heroine by Bagot 1780 (Herod $175 *$ - Heroine 1765 igy Hero 1753 (Cade 1734)

Economist 1825 (Whisker 1812)-Miss Pratt 1825 by Blacklock 1814 (Whitelock 180:) Gadabout 1812 by Orville 1799 (Beningbrough 1791)-Ninstrel 1803 by sir Peter T'1784 Highflyer 17\%4)-Matron $17 \times 2$ by Florizel 1768 (Herod 1\%58).

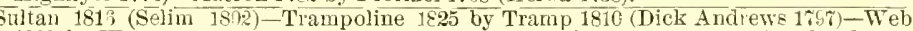
1808 by Waxy 17c0 (Pot-8-o-'s 17\%3)-Penelope 1798 by Trumpator 1r82 (Conductor 176\%)-Prunella 1\%83 by Highflyer 1\%74 (Herod 1\%58)

Mnley 1810) (Orville 1;99)-Clare 1824 by Marmiou 1806 (Whiskey 1989)-Harpalice 1814 by Gohanna 1750 (Mercury 1778)-Amazon 1799 by Driver 1765 (Trentham 1766)-Fractious 1798 by Mercury $1 \% \% 8$ (Eclipse 1\%64).

Waverley $181 \%$ (Whalebone 180\%)-Castrellina 1823 by Castrel 1801 (Buzzard*1787)-Dau. 1815 of Waxy 1790 (Pot-S-o-'s 1773)-Bizarre 1811 by Peruvian 1806 (Sil Peter T. 1784)Violante 1802 by John Bull 1789 (Fortitude 17\%

Lottery 1820 (Tramp 1810)-Dau. 1818 of Cervantes 1896 (Don Quixote 1784)-Anticipation 1802 by Beningbrough $1 \% 91$ (King Fergus 1\%\%) - Expectation 1\%\% by Herod 1 \%58 (Tartar 1743)-Dan. $17: 8$ of Skim 1746 (Starling 172\%)

Tramp 1810 (Dick Andrews 179\%)-Dau. 1822 of IThisker 181.2 (TTary 1890)-Jandane 1800 by Pot-8-0-'s 17\%3 (Eclipse 1761)-_. Camilla 178\% by Woodpecker 1\% (Herod 1758 )-Camilla $17 \% 3$ by Trentham 1766 (T. Sweepstakes 1743 ).

Bustard 1801 (Buzzard $\% 1 \% 8 \%$ )-Dau. 1813 of Election 1804 (Gohanna 1790)-Dau. 1791 of Highflyer $17 \% 1$ (Herod 1753) - Dau. 1773 of Eclipse 1764 (Narske 1750)-Rosebud 1765 by Snap $1650($ Snip $173 j)$

Dick Andrews 179, Joe Andrews 17\%8)-Dau 1803 of Gohanna 1790 (Mercury 1\%a)Fraxinelia $1 \% 98$ by Trentham 1366 (T. Sweepstakes 1T-3)-Dar. $1: 85$ of Toodpecker 1778 (Herod 1753)-Eyerlasting 17\%5 by Eclipse 1761 (Marke 1750).

Whisker 1812 (Waxy 17:0)-Mnndane 1500 by Pot-S-o-'s 17\%9 (Eclipse 1r61)-Y. Camilla $173 \hat{\gamma}$ by Woodpecker $17 \% 3$ (Herod 175S)-Camilla 1768 by Trentham 1766 (T. Sweepstakes 1243)-Coquette 1 - Co5 by Compton Barb.

Buzzard 1787 (Woodvecker 1\%3)-Gipsy 1\%86 by Trumpator 1282 (Conductor li67)Sist. 174 to Postmaster by Herod 1758 (Tartar 1743)-Dau. of Snap 1650 (Snip 1736)Dall. of Gower Stallion 1;40 (God. Ar. 1724)

Election 1804 (Gohanua 1790)-Dan. 1791 of Highflyer 1774 (Herod 1758)-Dan. 17\%8 of Eclipse 1754 (Marske 1759) - Rosebud 1765 by SLap 1750 (Snip 1736) - MLiss Belsea 1753 by Regulus 1739 (God. Ar. 1\%24).

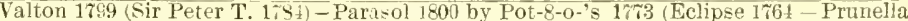
1788 by Highflyer 1774 (Herof 1758) - Promise 1768 by Snap 1750 (Snip 1756)-Julia 1753 by Blank 1740 (God. Al. 172t).

Moses 1819 ([Whalebone or] Sermour 1807)-Quadrille 1815 by Selim 1802 (Buzzard* 178\%)-Canary Bird 1866 by [Whiskey or] Solcerer ] 93 (Trumpator 17-2)-Canary 1797 by Coriander 1786 (Pot-8-0-'s 17\%9)-Mise Green 178 by Highflyer 1 ir ( Herod 1758)

Emilius 1820 (Orvilte 1799)-Harriet 1813 by Pericles 189. (Evander 1801)-Dau. 1812 of Selim 1302 (Buzzard* 1787)-Pipylina 1803 by sir Peter T. $16.5 \pm$ (Highflyer 1774)-Rally 1790 by Trmpator 1782 (Conductor $176 \%$ )

(Waxy 1790)-Gift gr. m. 1815 by Y. Gohanna 1810 (Gohanga 1790)-Sist. b. m. 1802 to Grazier by Sir Peter T. 1784 (Highflyer 17\%4)Sist. b. m, 1788 to Aimator by Trumpator 178 2 (Conductor 1767 ) - Sist. 17\%t to

Gorver Stallion 1740 (God. Ar. 1721)-Dan. of Childers. 


\section{IMPORTED ALBERT.}

\section{WINNER OF THE SEATON DELAVAL STAKES AND SECOND TO SATCHEL IN THE RACING STAKES AT GOODWOOD.}

\section{The property of J. N. Camden, Jr., Hartland Stud, near Versailles, Woodford County, Kentucliy.}

Albert, lay horse, foaled 1882, bred by Mr. R. Jardine, by Albert Victor, own brother to the Derby wimner George Frederick, son of Marsyas by Orlando, dam Hawthorn Bloom, the dam of May Bloom, winner of the May Stakes at.Chester and Tуг Stakes at Liverpool, Fitz James, winner of the Prince of Wales Stakes and an excellent sire in England, Heath Bird, winner of the York Cup and Ayr Gold Cup, Lady Gowrie, winner of the Duke of Westminster's Cup, Whin Blossom, winner of the Findon Stakes, Ebor St. Leger and Brighton Stakes, beating the crack Thebais, wimer of the Oaks; and Hawthorn, full sister to Albert, that won the Prince of Wales Stakes and Osmaston Nursery Hanlicap, in which she beat Reve d'Or, wimner of the Oaks and 1,000 Guineas, by Kettledrum, winner of the Derby and Doneaster Cup, son of Rataplan, own brother to Stockwell. Hawthorn Bloom is full sister to Hawthorndale, daw of Hauteur, winner of the 1,000 Guineas, and daughter of Lady Alice Hawthorn, she being full sister to Maybloom, the great grandam of Bonarista, winner of the 2,000 Guineas in 1892. Ladly Hawthorn, his third dam, is sister to Thormanby (wimner of the Derby and Ascot Gold Cup) and Oulston by Windhound, she out of the noted race-mare Alice Hawthorn, winner of 16 Cups, including two Doncaster and two Goodwood Cups, 18 Queen's Plates and 17 other races, tracing to the Layton Barl, mare. Albert Victor was himself a superior race-horse, he won the Middle Park Plate, beating Hamnah (Oaks and St. Leger winner), Bothwell (2,000 Guineas wimner) and others. At three years old won the Newmarket Biennial Stakes, beating Faronius (winner of the Derby), also ran second to Favonius in the Derby, won Ebor st. Leger, and ran second in the St. Leger. At four years old won the Gold Vase at Aseot, beating Sterling and Dutch Skater, won Brighton Cup, 2 miles, and Great Ebor Handicap. He is sire of Maskel gne, that beat Iroqnois in Hopeful Stakes, Victor Emanuel, winner of the Chesterfield Cup and Great Ebor Handicap, imp. The Sailor Prince, winner of the Cambridgeshire Handicap, beating Carlton, Melton, St. Honorat, etc., Whitelegs, winner of the Royal Hunt Cup at Ascot, and other good race-horses.

Albert is descended in the male line from Eclipse through his son Pot-8-o-'s ancl grandson Waxy, and is full of the blood of that extraordinary progenitor of great race-horses He is descended from Eclipse in the direct male line throngh Pot-8-o-'s, Waxy and Tonchstone, a strain of blood which is in by far the greatest repute in England to-day on account of the fact that the most successful race-horses have been so bred, such as Newminster, Scottish Chief, Adventurer, Hermit, Marsyas, Lord Clifden, Strathconan, Trumpeter, Cathedral, Petrareh, Gladiateur, Melton, Paradox, The Bard, etc. Larly Moore Carew mentioned in the fifth generation was a very celebrated mare, and winner of 18 races.

Albert is $16 \frac{1}{4}$ hands high. He has the best of feet and legs, powerful loin, short, strong back, lut grand length of body, finely sloping shoulders, and clean, intelligent, blood-like head. 


-

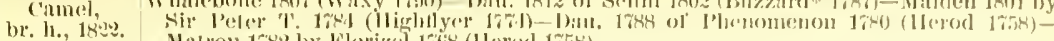

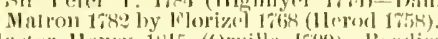

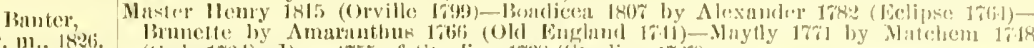
1)r. $111,18: 2,0$

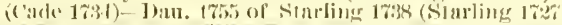

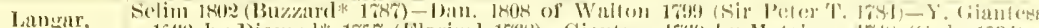

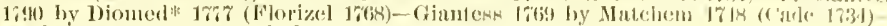

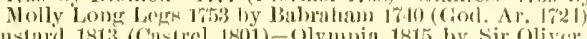

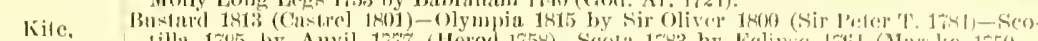

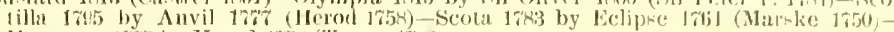

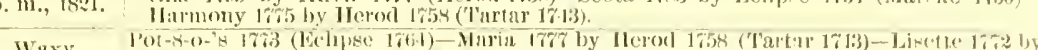

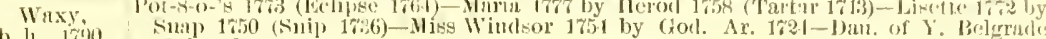
(Feligrale 'Turli).

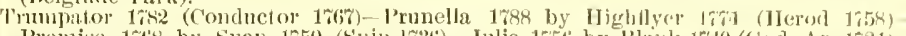

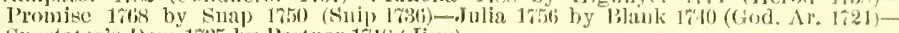
Spechator's Dam 1735 by Pint ner 17 s (Jigg).

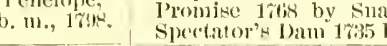

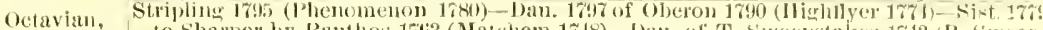

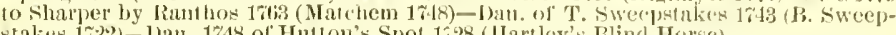

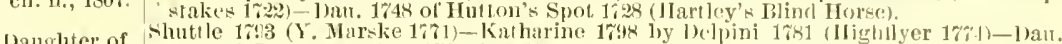

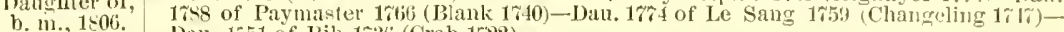
bau. 1751 of líib 1736 (Crab 1722).

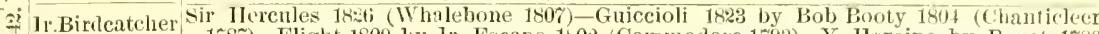

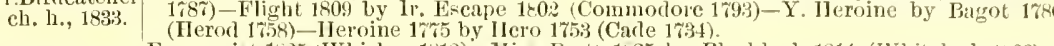

Echidna,

Econonist 1,25 (Whisker 1812)-Miss Pratt 1 105 by Placklock 1814 (Whiteluck 1+08)b. m., 1838 .

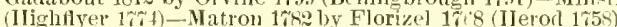

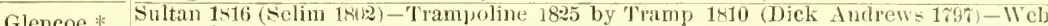

ch.h., 1831. | 1808 by Waxy 1790 (Pot-8-0-'s 1763)-Penelope 1798 by Trumpator 1782 (Conducts) $176 \%$ ) - Prunclla 1788 by Hightlyer $17 \% 4$ (Herod 1758 ).

Iarpessa, Nuley 1810 (Orville 1799)-Clare 1524 by Namion 1806 (Whiskey 1789)-Harpalice 1814 by Gohamna 1790 (Nercury 178) - Amazon 1799 by Driver 1783 Trentham 1761)Fractions 1792 by Mercury 17 (Eclipse 1\%64).

b. $11 ., 18: 30$

Humprey

Comus 1809 (Sorcerer 1756)-Clinkering 1812 by Clinker 1805 (sir Peter T. 1684)-Pewet

b. h., $18 \% 2$.

की 178 by Tandem 1773 (Syplion 1750)-Termagant by Tantrum 1760 (Crip)le 1750 )Cantatrice by Sampson 1745 (Blaze 1793).

Cervantes 1806 (Jon Quixote 1\%84)-Dan. 1818 of Golumpus 1802 (Gohanna 1790)-Dau. 1810 of Paynator 1791 (Trumpator 1782)-Dan. 1892 of St. George 1789 (Hightlyer 1764)-Abigail 1788 by Woodpecker $17 \% 3$ (Herod 1758)

둘

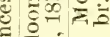

b. $\mathrm{m}$., 182.

Blacklock 1814 (TWhitelock 1805)-Dau 181 of Juniper 1805 (Whiskey 1789)-Dan 1810 ch. h., 18:5.
Dau. 1794 of Pot-8-o-'s 17\%3 (Eclipse 1\%64).

Lady Moore Tramp 1810 (Dick Andrews 179テ)-Kite 1821 by Bustard 1813 (Castrel 1801)-0lvmpia 1815 by Sir Oliver 1800 (Sir Peter T. 1784)-Scotilla 1795 by Anvil 16\% (Herod 1758)Carew, $1830 . \quad$ Scota 1783 by Eclipse 1764 (Narske 1750$)$

Ir.Birdcatcher Sir Hercules 1826 (Whalebone 180\%)-Guiccioli 18:3 by Bob Booty 180: (Chanticleer \begin{tabular}{c|c} 
lr.Birdeatcher & 1787)-Flight 1809 by Jr. Ecape 1802 (Commodore 1703)-Y. Heroine by Bagot 1780 \\
ch. h., 1833. & (Herod 1758)-Heroine 175 by Hero 1753 (Cade 1734).
\end{tabular}

Economist 1825 (Whisker 181:) - Miss Pratt 1825 by Blacklock 1814 (Whitelock 1803)-

Echidua,

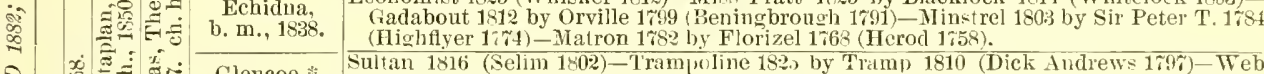

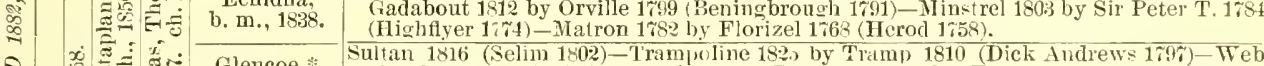

Glencoe,

1808 by Waxy 1790 (Pot-9-o-'s 1 (73) - Penelope 1798 by Trumpator 1782 (Condnctor 1767) - Prumella 1758 by Highflyer 1\% 4 (IJerod 1758).

ch. h., 1831

Marpessa,

Muley 1810 (Orville 1799) —Clare 1-24 by Narmion 1806 (Whiskey 1789)-Harpalice 1814

b. m., 1839 .

Fractious 1792 by Nercury $16 \%$ (Eelipe 1761 )

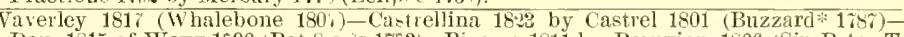
Dau. 1815 of Waxy 1790 (Pot-8-0-'s 17\%3)-Bizarre 1811 by Peluvian 1806 (Sir Peter T 1784)-Violante 182 by John Bull 1789 (Fortitude 17\%)

br. h., 1828

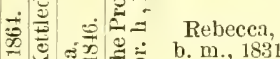

Lottery 18:0 (Tramp 1810)-Dau. 1818 of (errantes 1806 (Don Quixote 1784)-Anticipation 1802 by Beningbrough 1\%91 (King Fergus 17\%5)-Expectation 1779 by Herod 1\%5s

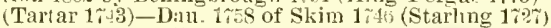

Liverpool,

Tramp 1810 (Dick Andrews 1747)-Dau. 1\%:2 of Whisker 1812 (Waxy 1790)-Mandane 1800 by Pot-8-o-'s 1713 (Echipse 1764)-Y. Camilla 176 by Woodpecker 17\%3 (Herod 1758)-Camilla 1768 by Trentliam $1 \% 66$ ( $\mathrm{T}$. Sweepstakes 1713)

b. h., 1828 .

Bustard 1801 (Buzzard* 1787)-Dau. 1813 of Election 1804 (Gohanna 1790)-Dau. 1791 of

Otis,

$\vdots$ b. m., 1020 .

by Snap 17.50 (Snip 1\%36)

Camel,

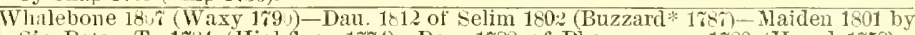
Sir Peter T. 1784 (Highflyer 1774)-Dan. 1788 of Phenomenon 1780 (Herod 1758)Matron $17 \varepsilon 2$ by Florizel 1768 (Herod 1358 )

急 br. h., 182

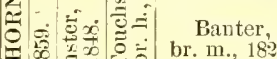

(Orville 1799)-Boadicea 1807 by Alexander 1792 (Eclipse 1 164 ) Brunette by Amaranthus 1\%66 (Ofd England 1741) - Mayfly 1;i1 by Matchem 1\%48

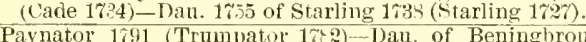

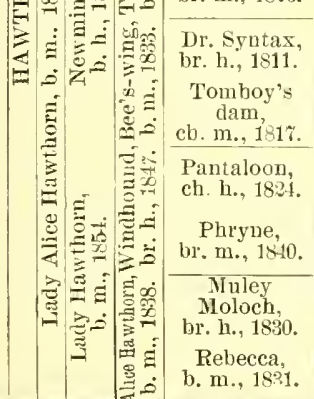

Paynator 1791 (Trumpator 17t2)-Dau. of Beningbrongh 1791 (King Fergus 17\%5) Jenny Hole $138 \%$ br Curbuncle 172 (Babr. Blank 1758)-Dau. 1773 of Prince T'Quas. saw 1731 (Snip 1736) - Sultana 1759 by Regulus 1739 (God. Ar. 1724).

Ardrossan 1809 (John Bull 1789) - Lady Eliza 1813 by Whitworth 1805 (Agonistes 1796)-

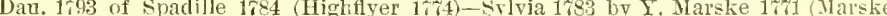
1750) - Ferret 1765 by Broth. to Silvio (Cade 1734).

Castrel 1801 (Buzzard* 17\&7)-Idalia 1815 by Peruvian 1806 (Sir Peter T. 1781)-Musidora 1 fo4 by Neteor 1783 (Eclipse 1764)-Naid-of-all-Work 1786 by Highflyer 17\%4 (Herod 1758 - Dau. $17 \% 1$ of Syphon 1,50 (Squirt 1732)

Touchstone 1831 (Camel 1822)-Decoy 1830 by Filho-da-Puta 1812 (Haphazard 179\%)Finesse 1815 by Peruvian 1806 (Sir Peter T. 1784)-Violante 1802 by John Ball 1is9 (Fortitude 17 (r)-Dau. 1788 of Highflyer 17\%t (Herod 1758).

Mnley 1510 (Orville 1799)-Nancy 1813 by Dick Andrews 1797 (Joe Andrews 17is)Spitfile 1800 by Beninghrough 1\%91 (King Fergus 175)-Dan. of $Y$. Sir Peter 17\% (Doge 1\%6\%)-Dau. of Engineer $1 \% 56$ (Sampson 1745)

Lottery 18:0 (Tramp 1810)-Dan. b. m. 1818 of Celvantes 1806 (Don Qpixote 1 81 -Anticipation ch. m. 1802 by Beningbrough 1791 (King Fergus 1\% 1,79 by Herod 1,58 (Tartar 17+3)-Dan. 178 of Skim 1746 I Starling 172\%)-Dau. 1751 of

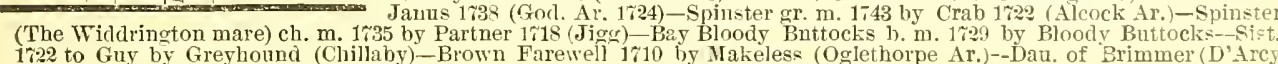
1722 to Guy by Greyhound (Chillaby)-Brown Farewell 1710 by Makeless (Oglethor
Yellow Turk)-Dau. of Place's White Turk-Dau. of Dodsworth-Layton Barb mare. 


\section{BELVIDERE.}

WINNER OF THE RED BANK, REAPER'S, VAN COURTLAND STAKES, WESTCHESTER, LONG BRANCH AND DELAWARE HANDICAPS.

\section{Private stallion in the Preakness Stud of Mr. James Galway, located at the Stonewall Stud of $\mathrm{Mr}$. J. Breckenridge Viley, near Midway, Woodford Co., Ky.}

Belvidere by imp. Billet, son of Voltigeur, foaled 1884, bred in the Rnnnymede Stud, Bourbon Co., Ky., dam Jaconet, own sister to Iroquois (winner of the Derby and St. Leger) by imp. Leamington, son of Fangh-a-Ballagh, out of Maggie B. B. by imp. Australıan, etc. Billet, his sire, was a good race-horse, winner of the Zetland Stakes at York, Egham Stakes at Egham, and other races, by Voltigeur, dam Calcutta by Flatcatcher, son of Touchstone. Billet was one of the best stallions of our moderu importations, sire of Volturno, Miss Woodford, Runnymede, The Pepper, Raceland, Blue Wing and many other winners. Belvidere's dam, Jaconet (Sir Dixon's dam), is full sister to Iroquois, one of the best race-horses, judged by his performances, ever bred in America, and the only horse, except Donovan in 1889 , that ever won the Derby, Prince of Wales Stakes and the Doncaster St. Leger. Iroquois was second to Peregrine in the 2,000 Guineas, and beat him in the Derby. Iroquois also won the Chesterfield Stakes at Newmarket, Lerant Stakes at Goodwood, the Burwell Stakes, Newmarket Derby and other important events. In these races he beat such good ones as Peregrine, Ishmael, Scobel, Geologist, Tristan, Cameliard, Bal Gal, Lucy Glitters and others. Belvidere, therefore, is descended from one of the best bred and most potent racing families in America. His grandam, Maggie B. B., by imp. Australian, was the dam of Pera, Harold, Panique, Red and Blue (Sally HeClelland's dam), etc. Harold had only one coit on the turf, Harefoot, an excellent race-horse, and Harold was own brother to Iroquois, a good index to the poteney of the blood. Madeline, his great grandam, was by the great Boston, sire of Lexington, Lecompte, Bostona, Nina and a host of good ones. Magnolia was the dam of Kentucky, the best son of Lexington. Magnolia was also the dam of Daniel Boone, Magic, Charley Ball, Madonua, Skedaddle, Gilroy, Victory, etc. Skedaddle is the dam of Saucebox, Scramble, Florence B., Siy Boots, Joe S., The Slashes and Squeez'em (the dam of Day Star, winner of the Kentucky Derby, Blue Ribbon Stakes and other fast races) and Sylph (the dam of La Sylphide, $1 \frac{1}{4}$ miles in $2.07 \frac{1}{2}$, and dam of Semper Fidele), Kaloolah, Kincsem, ete. Sly Boots is the dam of Leveller, sly Dance, Sachem and Saranac. Myrtle was by Mameluke (wiuner of the Derby). Bobadilla won the Ascot Gold $\mathrm{Cup}$ and Drawing Room Stakes. Belvidere won the Red Bank Stakes for two-year olds, a Free Handicap Sweepstakes, $1 \frac{1}{8}$ miles, in 1.57궁 won Reaper's Stakes, $1 \frac{3}{6}$ miles, $112 \mathrm{lbs}$, in 2.03; Handicap

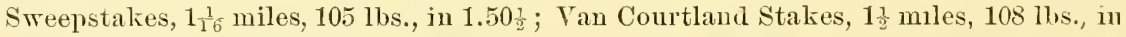

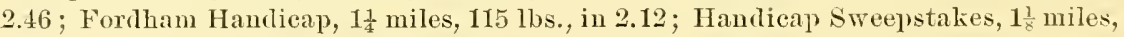

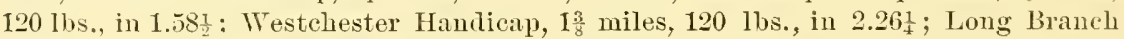

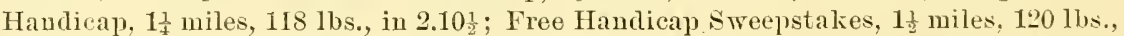
in $2.43 \frac{1}{2}$; Delaware Handicap, $1 \frac{1}{4}$ miles, $120 \mathrm{lbs}$, in 2.09, and was placed secoud aud third in many excellent races in the best of company. He cannot fuil to transmit his great qualities to his progeny. 'The pedigree is pure and unalulterated to the famous Layton Barb mare. 


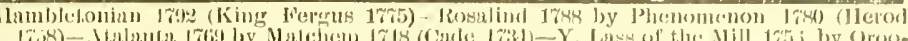

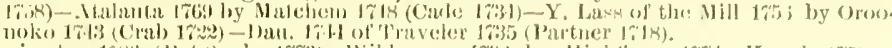

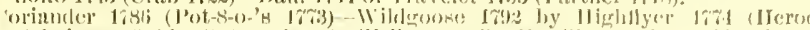

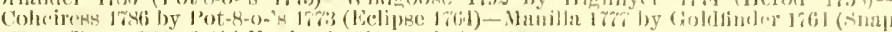

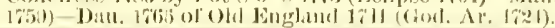

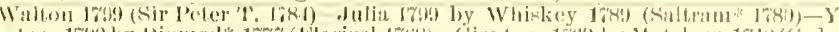

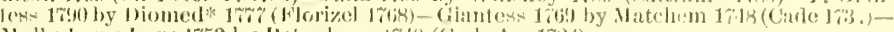

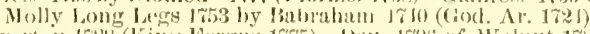

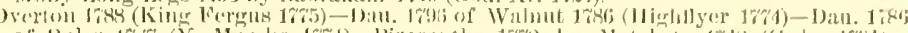

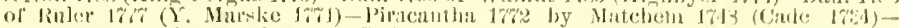

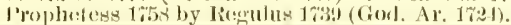

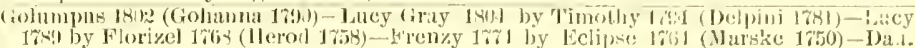
17s! by Florizel 17tis (llerol 1758$)$

of Engineer 1750 (Sampon 17.15).

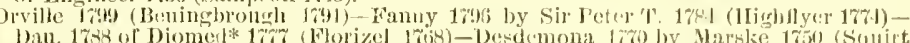

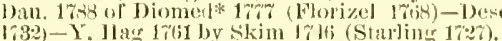

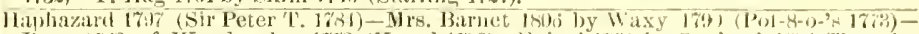
Ditu. 1788 of Woodpecker $17 \% 3$ (IIerod 1778)-lleinel 17\%1 by Squirrel 1751 (T'aveler

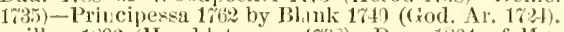

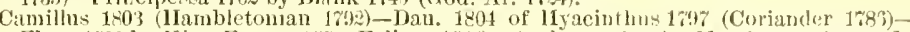
Flora 1789 by King Fergns $17 \% 5$ (Eclipse 17d-1) - Atalanta 176:) by Matehem 174; (Cade 1731) - Y. Lass of the Nit] 175 is by Oroonekn 1745 (Crab 172:

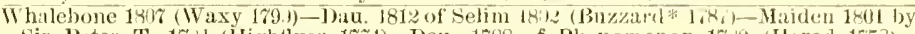
Sir Peter T. 17kt (Highllyer 17\%4)-Dau. 1788 of Phenomenon 1780 (II rod 1753)Mation 172 by Florizel 1768 (1Ierod 1758).

Master II enry 1815 (Orville 19:5)-Boadicen 1807 by Alexinder 178: (Eelipse 17(4)Brumette by Amarantlins 1766 (Old England 1711)-Maytly 1761 by Matchem 1748 (Cade 1731)-Dau. 1755 of Ane. Starling 1738 (Starling $17 \times 7$ ).

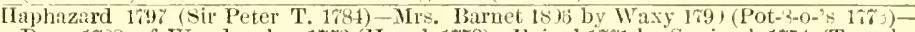
Dau. 1788 of Woodpeeker $17 \% 3$ (IIerod 1758)-Heinel 1\%1 by Squiriel 1754 (Traveler 1735)-Principe-sa 1762 by Blank 1710 (God. Ar. 1\%21).

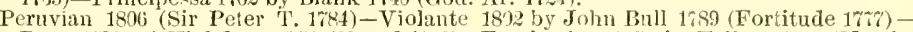
Dau. 1782 of IIgbflyer 178t (Iferod 1758)-Everlasting $17 \% 5$ by Eclipse 1764 (Warske 1\%50)-Hyæna 1\%: 2 by Snap 1750 (Snip 1736).

Send 1804 (Beningbrough 1791)-Diana 1808 by stanferd 1794 (Sir Peter T. 1781)-D.u. 1799 of Whiskey 17et) (Saltram* 1789)-Grey Dorimant 1781 by Dorimant 17\% (Otho 1760)-Dizzy 1757 by Blank 1\%'40 (God. Ar. 1724).

Walton 1799 (Sir Peler T. 1781) - Comedy 1817 by Comns 1'09 (Sorcerer 1796)-Dau. 180: of Star* 1785 (Highflyer 17\%1)-Dan. 1794 of Y. Marske $1 \% \%$ (.Marske 1\%50)-Emma 1781 by Telemachiss 17ro (Herod 17:8).

Traxy 1799 (Pot-8-0-'s 17\%3) - Penelope 1795 by Trumpator 1732 (Conductor 176;) - Prunella 1\%83 by Highflyer 17\% (Herod 1755)-Plomise 1768 by Suap 17:0 (Snip 1736)Julia $175 \mathrm{j}$ by Blank 1740 (God. Ar. 17\%4).

Sorcerer 1796 (Trumpator 1782)-Dau. 180 of Sir Sclomon 1793 (Sir Peter T. 1781)-Dau. 1794 of Y. Marske 17rl (Marske 1750)-Dau. 1788 of Phenomeuon 1780 (Herod 1758)Calliope 1763 by Slouch 1747 (Cade 1734).

Waxy 1790 (Pot-8-o-'s 17\%3)-Penelope 1798 by Trumpator 17S2 (Conductor 1767)-Prunelta 1788 by Highflyer 1774 (IJerod 1759)-Promise 1763 by Snap 1750 (Snip 1\%36)Julia 1756 by Blank 1710 (God. Ar. 1\%21).

Wanderer 1811 (Gohanna 1790)-Thalestris 1809) by Alexander 1782 (Eclipse 1 64) Rival 1000 by Sir Peter T. 1724 (Highflyer 1\% $\%$ )-Hornet 1790 by Drone 1\%r (Herod 1758)-Manilla $17 \%$ by Goldfinder 1\%61 (Šnap 1750).

Chanticleer 1787 (Woodpecker 1743)-Ierne 1790 by Bagot 1780 (Herod 1758-Dau. of Gamahoe (Bustard 1711)-Patty by Tim 1752 (Squirt 1.3?)-Niss Patch 1737 by Justice $17 \% 5$ (H. C. Lit ton Ar.).

Ir. Escape 1802 (Commodore 1793) - Y. Heroine by Bagot 17s0 (Heror 1758)-Heroine $17 \% 5$ by Hero 1753 (Cade 1731)-Dan. 1766 of Suap 1750 (Snip 1736) - Sist. 1743 to Regulua by God. Ar. 1724.

Buzzard 178\% (Woodpecker 1\%3)-Dan of Alexilder 1722 (Eelipse 1\%64)-Dau. of Hightyer 1\%4 (Herod 1758)-Dan. of Alfred 1\% (Matchem 1\%43)-Dan. 1770 of Eng:neer 1756 (Sampson 1745).

Peruvian 1806 (Sir Peter T. 1781)-Musidora 1804 by Meteor 1783 (Eclipse 1i6-1)-Maid of all Work $178 \%$ by Ilighilyer 174 (Herod 1753)-Sist. 17'1 to Tandem by Syphon 1753 (Squirt 1732)-Dau. of Regulus 1739 (God. Ar. 1721)

Blacklock 1814 (Whitelock 1803) - Wagtail 1818 by Prime Minister 1810 (Sancho 1801)Tranby:'s Dam 1812 by Orville 1799 (Beniugbrough 179:-Niss Grimstone 1796 by Weazle 1776 (Herol 1758)-Dan. of Ancaster 1768 (Biank 1710).

Champion 1812 (Selim 1802)-Etiquette $18: 0$ by Orville 1799 (Beningbrough 1991) Boadicea 1807 by Alexander $1 \% 32$ (Eclipse 1'(61)-Brumette by Amaranthus 1766 (Okl England 1711)-Mayfly 1771 by Matehem 1718 (Cade 1734).

Humprey Clinker 1822 (Comms 1809)-Dau. 1825 of Cervantes 1806 (Don Quixote 1684)Dau. 1818 of Golumpus 1802 (Gohama 1790)-Dall. 1810 of Payuatol 1791 (Trumpator 1782)-Cirele 1802 by St. George 1 is 9 (Highflyer 17\%1).

Touchsrone 1831 (Camel 1892)-Emma 18:1 by Whisker 1812 (TVaxy 1790)-Gibside Fairy 1811 by Hermes 1790 (Nercury $17 \%$ ) - Vicissitude 1809 by Pipator 1786 (Impera. tor $1 \% 6$ )-Beatrice $1 \% 91$ by Sir Peter T. 1781 (High flyer 1\%4).

Emilius 1820 (Orville 1799) - Shoveler 1916 by Scurl 1804 (Beuingbrough 1\%91)-Goosander 1805 by Hambletonian 179: (King Fergns 1\%i5) - Rally 1790 by Trumator 1782 (Conductor $176 i$ )-Faney 1780 (Sist. to ${ }^{2}$ Diomed) by Florizel 1768 (Herod 1\%58).

Whisker 1812 (Waxy 1700)-Variety 1816 by [Selim or] Soothsaver 1808 (Sorcerer 1796)Sprile $180 \%$ by Bobtail 179 ) (Preeipitate $17 \%$ ) C Catherine $1 \% 95$ by Woodpecker 1\%:3 (Herod 1758)-Camilla 1 \% $\% 8$ by Trentham $1 \% 66$ (T. Sweepstakes 1743).

Sir Arehy 1805 ("Diomed 1\%\%)-Dan. of Saltram 1780 (Eclipse 1761)-Dau. of Srmme's Wildair 1767 (*Fearnought 1,5)-Dau. of 'Tyler's Driver 1760 (*Othello)-Dau, of * Fallower 1761 (Blank 1740).

Ball's Florizel 1801 (*Diomed 17\%7)-Dan. 1799 of *Alderman 1\%8\% (Pot-8-0-'s17\%3) -Dau of *lockfast 1 rit (Gimcrack 1760)-Dau. of Symme's Wildair 176\% (*Fearnought 1755)-Y. Kitty Fisher $176 \%$ by *Fearnought 1755 (Regulus 1739).

Sultan 1816 (Selim 1802)-Trampoline 1825 by Tramp 1810 (Dick Andrews 17c' - Web 1809 by Waxy 179) (Pot-8-0's 17\%3)-Penelope 1708 by Trumpator 178: (Conductor 1767)-Prunella 1788 by Highflyer 17\%4 (Herod 1758).

Mameluke 1824 (Partisan 1811)-Bohallilla br. m. 1825 by Bobalil 1813 (Rubens 1815)-Prthoness blk. m. 1813 br Sorcerer 1756 (Trumpator 1782) - Princess blk. m. 1796 by Sij. Peter'T.

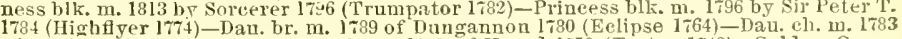
1784 (Highterer 1774)-Dan. br. m. 1789 of Dungannon 1780 (Eelipse 1764)-Dau. ch. M. 1783
of Turf 1760 (Matehem 1748)-Dan. b. m. 1779 of Herod 1758 (Tartar 1743)-Golden Grore

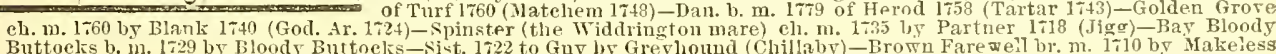

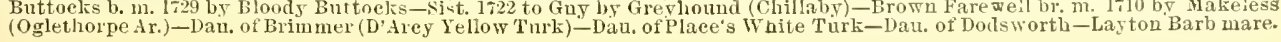




\title{
BEND'OR.
}

\author{
WINNER OF THE COKE STAKES, BOARD OF TRADE HANDICAP AT C'HICAGO, \\ SUMMER HANDICAP WELTER STAKES AT SARATOGA AND OTHER \\ FAST RACES.
}

\section{Property of IIr. John B. Ewing, Willamette Siud, near Nashille, Tenn.}

BexD'or by imp. Buckden, son of Lord Clifden by Newminster, bay horse. foaled 1878, bred by Sidney Taylor, Madison Co., Ky., Aam Kate Walker by Enbry's Lexington, son of Lesington and Bellamira by imp. Monarch, ont of Carrie D. by Don Juan, son of Berthnue by Sidi Hamet by Virginian by Sir Archy. Bendor is half wrother to Ann Fief, the dam of the unbeaten Tremont, by Alarm. Bend'or was a first-class race-horse; at three years old won the Galt House Handicap, $1 \frac{1}{2}$ miles with 951 los., in 2.38 .

Bend'or as a four year old was one of the best race-horses this country has erer produced on the score of speed and weight carrying capacity. He started in twelve races, of which he won nine. At Lonisrille he won a purse, $1 \frac{1}{10}$ miles, 117 lbs., in 1.49, heats of $1 \frac{1}{16}$ miles. 117 los., in $1.49 \frac{3}{9}, 1.49,1.51 \frac{1}{2}$, Bootjack winning the first heat. At Pittsburgh, on a heavy track, he won the Coke Stakes, $1 \frac{1}{2}$ miles, $1171 b s$. in

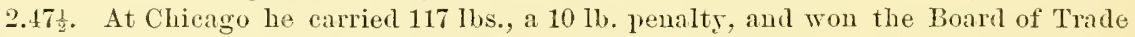
Handicap, $1 \frac{1}{2}$ miles in $2.46 \frac{1}{2}$, track hears. At Saratoga he won the Welter stakes, 1 mile in 1.45 , carrying $149 \mathrm{lbs}$. At same place wón 1 mule and 500 sarls, $115 \mathrm{lbs}$, in $2.10 \frac{1}{2}$, best time on recold to date, beating Ada Glenn; Gen. Monroe, and others, and carrying the top weight; the Summer Haudicap, $1 \frac{1}{2}$ miles, 118 1bs., in $2.35 \frac{1}{2}$, beating the great Thora and other good ones. In the Grand Prize of Saratoga, 1 1 miles, he carried 122 lbs., and was second to Glidelia (5), 116, in 3.01, the fastest race at the listance ever run to that date, At Saratoga he carried 123 los., and won a Handicap Sweepstakes, $1 \frac{1}{2}$ miles in $2.36 \frac{8}{4}$, beating Gen. Monroe (4), 101 lbs., Ada Glen (6), 1031 bs.. and others; a Handicap Sreepstakes, 1 mile and five furlongs, in 2.49, carrsing $1251 \mathrm{bs.}$, and beating Creosote (4), 106 lbs., Lida stanhope (4), 102 1los., and other first-class horses. This race, considering age and weight carried, is the best on record at the distance, and has only been beaten by $\frac{1}{4}$ of a second by Exile (4), $1151 \mathrm{ls}$. Bend'or is a very large, strong horse, and his get all show fine quality. Ann Fief is the dam of the nubeaten Tremont, and two such horses as Bend'or and Tremont from one and the same family is sufficient to establish its prodncing excellence. All of Bend'or's get that have started are winners. Bandusia won the Belles Stakes, $\frac{\Delta}{4}$ of a mile, at Sheeps-

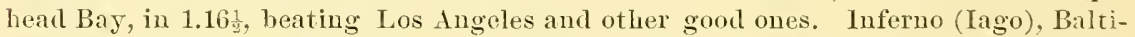
more, A. O. H., Emma J., Goldstep, Goluckr, liheingold, Maid of Alton wood, Exen Weight, Tactician, Billet Doux colt, Strategy colt, Equality, Equity, the latter winner of the Titan and Mermaid Stakes, Mamie B. B., Tea Set, Waltz, etc. There is no stallion now in the stud of greater promise. 


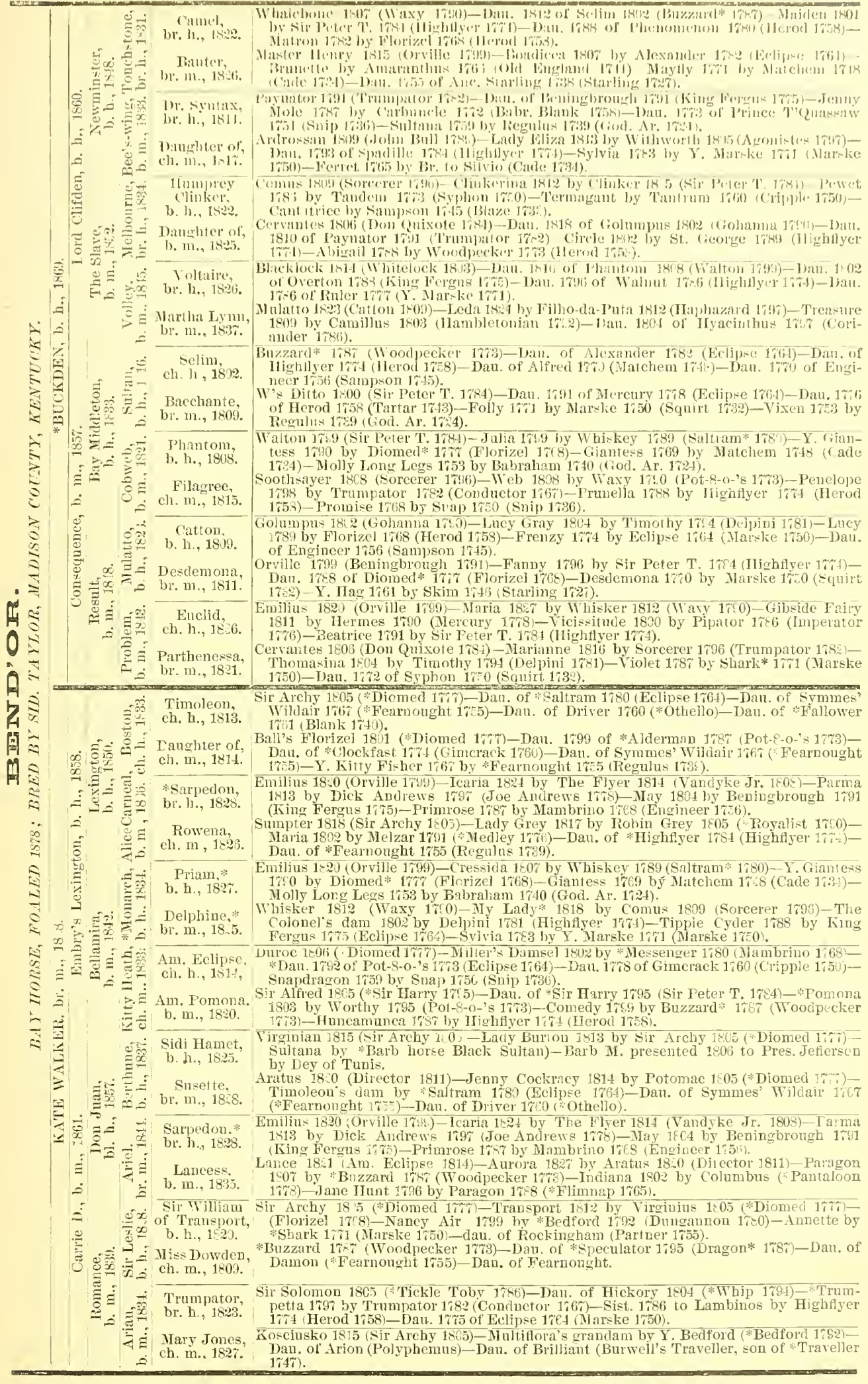




\title{
IMPORTED BLACK DEAN.
}

\author{
Brother to Geheimniss, owned by Eatgene Leigh, La Belle Stud, Yarnalton, Ken- \\ tucky. Stands for public mares.
}

BLACK DEAx, own brother to Geheimniss, winner of the Oaks, brown horse, foaled 1886, bred by Mr. John Watson. By Rosicrucian, son of Beadsman by Weatherbit, dam Nameless, dam of Geheimniss, winner of the Oalks, by Blinkhoolie, son of Rataplan, out of No Name by Tecldington, winner of the Derby, Ascot and Doncaster Cups, son of Orlando by 'Touchstone. Black Dean from an injury never raced but his sister Geheinmiss, one of the best mares of her day. As a two year old she started seven times. On the first occission she ran a dead heat for the Sandown Two Years Old Stakes, which were diviled, and the remaining six races she won, leating some of the best animals in training. As a three year old she won the Oaks; ran second in the Fernhill Stakes at Ascot, beaten a heal; ran sceond in the St. Leger, beating Shotover (winner of the 2,000 Guineas, Derby, ete.) and mauy other high-class animals; and wound up the season by running second at Newmarliet, beating Kermesse, who as a two year old was only beaten once, aud who also won all her three year old engagements with the exception of the race mentioned. As a four year old. Geheimmiss won the Trial Stakes at Ascot, giving 14 lbs. weight to all starter's, won the Bunbury Handicap, one mile; ran second in the Steward's Cup at Goodwool, beaten a head, giving the winner 14 lbs.; ran second for the Portland Plate, carr ring top weight, giving the winner 10 lbs.; won the Kempton Park Cambrilgeshire Trial Handicap, 1 $1 \frac{1}{4}$ miles, carrying $129 \mathrm{lbs}$.; won the Trial Stakes at Newmarket, carrying 140 lbs., and finished the year by giving Brag 21 lbs. aud running second to him for the Brighton Cup. The five year old form of Geheimuiss was brilliant. She earned eight brackets, ran second onee and was placed once. The races she won were the Westminster Cup, $1 \frac{7}{4}$ miles, at Kempton Park, carrying 143 lbs.; the All-aged Stakes at Ascot, carrying $145 \mathrm{lbs}$; the stockbrilge Cup, earryiug $132 \mathrm{lbs}$; a walk over for the July Cup at Newmarket; walk over for the Bunbury Stakes at same meeting; won the Lemnox Stakes at Goodwood, and walked over for the Singleton Stakes at the same place.

Rosicrucian, the sire of Black Dean, is own brother to The Palmer, the sire of Pellegrino and Jenny Howlet, winner of the Oaks, and was a good rice-horse; won the Criterion and 'Troy Stakes, and is the sire of Hantemr, winner of the 1,000 Guineas, and the good stallion Beauclere. Rosicrucian was regarled by Sir Joseuh Hawley as the equal of the Derby wimer Blue Gown, and declared to win the Derby with him. His sire, Beadsman (out of Mendicant, winner of the Oalis), won the Derby (sire of Pero Gomez, wimner of 'st. Leger, and imp. Saxon, winner of the fistest Belmont stake ever run), was a son of Weatherbit (by Sheet Anchor), whose dam. Miss Letty by Priam, won the Oaks. Nameless, Black Dean's lam, produced othrr wimners in Friendless ant Offenheit. Her sire, Blinkhoolie, was by Rataplan (a fill brother to Stockwell), and sire of Kettledrum (winner of the Derby). His clam, Queen Mary, produced imp. Bonnie Scotland and also Blink Bonny, the dam of Blair Athol (winner of the Derby, St. Leger, etc.) ant Brearlalbane, a good race-horse. No Name, Black Dean's second dam, was a winner, aud bred a winner in Bradlangh. Qneen of Beanty, the third dam, prodnced Corlelia, a wimner, and dam of the winners Thunder anil Lady Blanche. Vlie, another of Qneen of Beanty's danghters, produced the winner's First Lord, Black Ailder and Amor. Birthday, the fonrth dam, produced the wimners Filins, Kohinoor, Stockham, Lupellus, Lupns and Vision, while from Hou. oria, the fifth dam, came the winner Broadsword, and Miss Nuttiug (dam of the winner Hawk). Any number of other winners have come from the family, including Mr. Haggin's imported stallion Darebin, in addition to Leamington, Tonchstone, Lameelot and Macaroni, and the American winners Arizona, Aranza, Glenarm, Amerigue. Louise, Palatka, Millie Williams, Zephyr, Cape Race, Armiel, Ella Blackburn. Cyelone, Westwind, Falsehood, etc. Black Dean is a sure and safe foal getter and should suceced in the stud. 


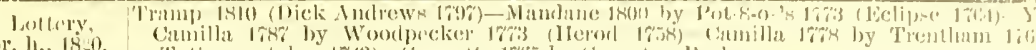

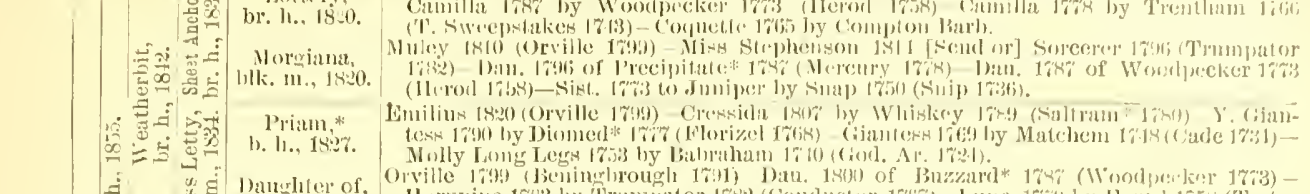

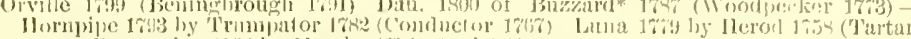

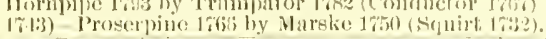

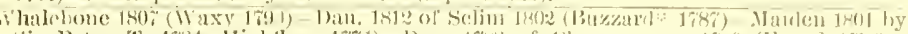

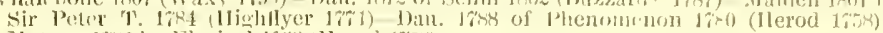

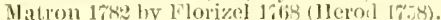

(intmel

lin. I., 182?

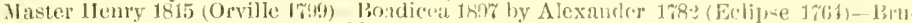

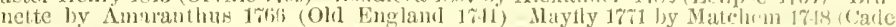

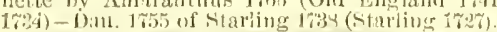

Banter,

Tramp,

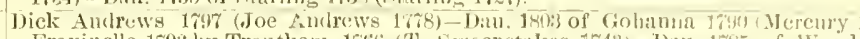

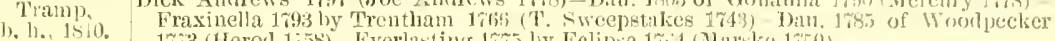

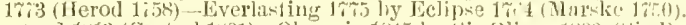

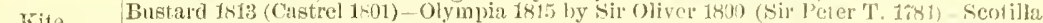

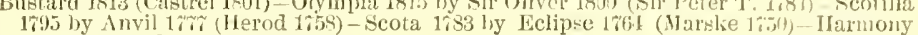
$17 \% 5$ by lleiod 17.58 ('Tartar 174 )

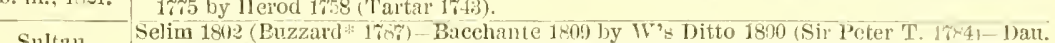

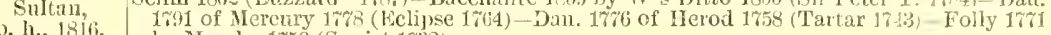
by Marske 1750 (Gquirt 1732)

Phantom 1803 (IV ilton 1699)-Filarree 1815 by Soothsayer 1808 (Sorcerel 1ref) - Web 1808 by Wasy 1790 (Pot-8-0-' 17\%3) - Penelone 1795 by Trumpator 1\%8: (Couductol. 1\%(6i) - Prumella 1 rits by Hightlyer 171 (Herod 1758).

¿ 20.

Priant,

Emilius 1820 (Orville 1799)-Cressida 1847 hy Whiskey 1789 (Saltram*1780j-Y. Gianicss 1790 by Diomed* $17 \% 7$ (Florizel 1768) - Giantess 1769 by Matchem 1718 (Cade 1\% 1 ) Molly Long Legs 1753 by Bibraham 1740 (God. Ar. 17:4).

b. 1., $18 \% 7$.

Dctaviana

b. m., 1815 ,

Octavian 1S\% (Stripling 1795)-Dan. $180 \%$ of Shuttle 1793 (Y. Marske 101)-Zara 1801 by Delpini 1781 (Highfiyer 1\%i4)-Elora $1 \% 89$ by King Fergus 17\%5 (Eelipse 1\%(j)-Atalanta 1769 by Matchem 1748 (Cade 1734)

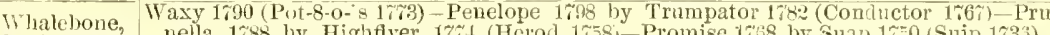

br. h., $180 \%$. nella 1788 by Highfiyer $17 i+$ (Herod 1758;-Promise 1738 by 611 ]) 1750 (Suip 1733) Julia 1756 by Blank $1 \% 40$ (Gorl. Ar. 17.4).

Rubens 1805 (Buzzard: 17\% ) - Little Folly 1806 by Highland Fling 1098 (Spadille 1\%84) -

Defiance, Harriet 1799 by Volunteer 1780 (Eclipse 176.1) Dau. 1785 of Alfred 17\%0 (Matchem

ch. m., 1816. : 1748;-Maguolia 1 \%1 by Marske 1750 (śquirt 1792).

Middleton, Phantom 1803 (Walton 1799) Web 18 s by Waxy 1790 (Pot-8-o-'s 17\%3)-Penelope 179s by 'Trumpator 1782 (Conductor 1767) - Prunella 1788 by Highflyer 1\% (Helod 1758)-

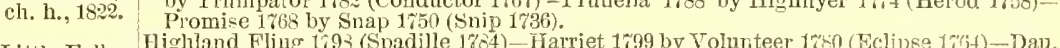

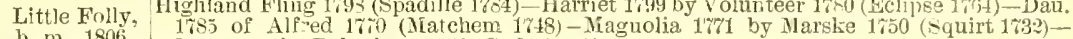

Dau. 175 ; by Babrahani 1,40 (God. Ar. 1721).

Sir Hercules 1826 (Whalebone 1807)-Guiccioli 1823 by Bob Footy 1804 (Chauticleel. ch. h., 1833. 1787)-Flight 1809 by I!. Escape 1802 (Commodore 1793)-Y. Heroine by Bagot 1780 (Herod 1758)-Heroine 1765 by Hero 1753 (Cade 1731).

Echidna, Ecrnomist 1825 (Whisker 1812)-Miss Pratt 1825 by Blacklock 1814 (Whitelock 1803)Gadabont 1812 by Grville 1799 (Beningbrough 1791)-Minstlel 1803 by Sir Peter T. 178t (Highflyer 1774)-Matron 1782 by Florizel 1768 (Herod 1758).

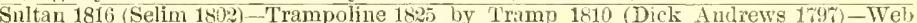

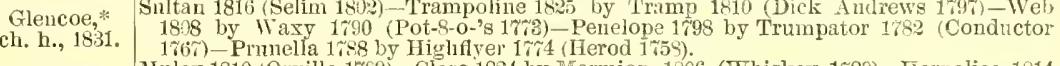

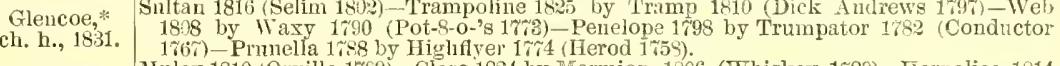

Mulev 1810 (Orville 1\% 16 )-Clare 1824 by límion 1806 (Whiskey 1789)-Harpalice 1814

Marpessa, by Gohamna 1790 (Mercury 1\%78)-Amazon 1799 by Driver 1783 (Trentham 1;66)b. m., 1830. Fractious 1792 by Mercury 17 is (Eclipse 1761).

Partisan Walton 1799 (Sir Peter T. 1784)-Parasol 1s00 by Pot-3-0-'s 17\%3 (Eclipse 176.4... Prunella

b. h., 181. 1788 by Highflyer 17\%4 (Herod 1758)-Promise 1768 by Snap 1750 (Snip 1730)-Julia 1756 by Blank 1740 (God. Ar. 1724).

Panline, Moses 1819 ([Whalebone or] Seymonr 180\%)—Quadrille 1815 by Selim 1802 (Buzzard\% 1787)-Canary Bird 1806 by [WWhiskey or'] sorcerer 1796 (Trumpator 1782)-Canary $1 \% 9 \%$ by Corianter 1780 (Pot-8-0-'s 1763)-Miss Green 178; by Hightyer $17 \% 4$ (Herod 17.8).

Plenipoten- Emilus 18.

ch. h., 1831 1790 by Trumpator 1782 (Conductor 1607 )

Myrrha, Whalebone 1807 (Waxy 1\%90)-Gift 1818 by Y. Golranna 1810 (Gohanna 1\%90) - Dar. 180? of Sir Peter T. 1784 (Highflyer 174)-Dan. 1\%33 of Trumpator 1682 (Conductor 1\%6\%)Sist. $17 \% 4$ to Postmaster by Herod 1758 (Tartar 1r43).

b. $\mathrm{m} ., 1830$. Camel 1822 (Whatebone 1807)-Banter 1826 by Master Henry 1815 (Orville 179n-Loadicea

Touchstone, $180 \%$ by Alexander $1 \% 82$ (Eclipse 1\%64)-Brmette by Amaranthus 1766 (Old England br. b., 1831. 1741,-nayfly $1 \% 71$ by Matchem 1748 (Cade 1;31)

Langar 1817 (Selim 1802 )-Kite 1821 by Bustard 1813 (Castrel 1801) - olympia 1815 by Sir

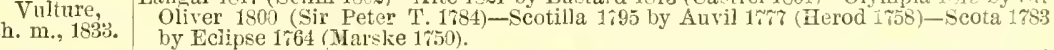

Humprey Clinker 1822 (Comus 1809)-Vledora 1813 by Swordeman 1796 (Frizefighter. 1784)-Ir. Penelope 1797 by Trumpator 1782 (Conductor 1767-Peppermint $178 ;$ by

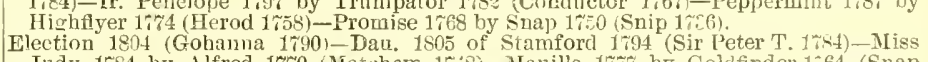
Rockingham

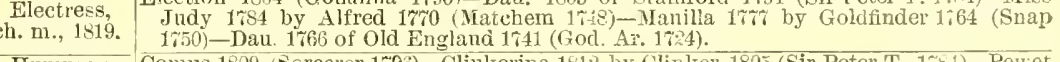

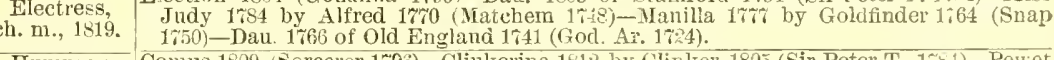
Humprey

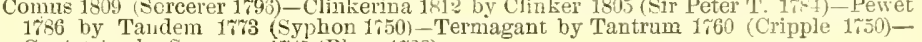
Cantatrice by Sampson 1715 (Blaze 1\%33).

b. h., 18:2.

Cervantes 1866 (Don Quixote 1\%S4) - Dau. 1818 of Golnmpus 1802 (Gohanna 1790)-Dau. 1810 of Paynator 1791 (Trumpato: 1782 ) Circle 1802 by St. George 17S9 (Highflyer 17.4)-Abigail 1788 by IToodpecker $17 \% 3$ (Helod 1758).

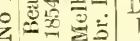

b. $12 ., 1825$.

Castrel 1891 (Buzzard* 178\%)-Idalia 1815 by Peruvian 1806 (Sir Peter T 1 21 )-ylusidor

Pantaloon, 1804 by Meteor 1783 (Eclipse 1761) - Maid-of-all-Work 1786 by Highfyer 1it4 (Herod ch. b., 1824 .

1758)-Dau. 17\%1 of Syphon 1750 (Squirt 1732).

Honoria, Camel is:3 (Thalebone 189\%)-Maid of Honor br. m. 1829 by Champion 181? (Selim 1802) -Etiquette br. m. 1820 by Orvilie 1799 (Benngbrough 1.91)-Boadicea b. m. 1807 hy Alexander 1782 (Eclipse 1764)-Bruuette by Amaranthus 1766 (Old England 1741)Míayfy b. m. $17 \% 1$ by Matebem 1748 (Cade 1\%34)-Dau. blk. m. 1755 of Anc. Starling 1738 (Bolton Starling 1720)-Look-7t-me-Lads ch. m. 1731 by Bristol Grasshopper (Bverly Turk) -Dau. of Sip M. Newton 's Bay Ar.-Lady Mare by Pert (Ely Turk)-Dan. of St. Martin (Spanker)-Dau, of Sir E. Hale's Ar.-Oldie'd IIare. 


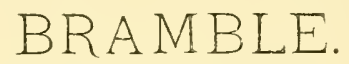

WINYER OF THE YOUNG AMERICA STAKE NO. 2 AND MAXWELL HOLSE STAKES AT NASHVILLE, SARATOGA AND CONGRESS STAKES AT SARATOGA, BALTIMORE CLP, MONHOUTH CLP, WESTCHESTER CLP, SARATOGA CUP, AND OTHER IMPORTANT RACES.

\section{Propeity of Eugene Leigh, La Belle Stud, Yamalton, Ky., and is a public stallion. Terms published annually.}

Bramble by imp. Bomnie Scotland, bred by Gen. IT. G. Harding, Belle Meade Stud, foaled 1875 , dam Ivy Leaf, dam of Bazar, Brambaletta, ete., br imp. Australian, out of Bay Flower, sister to Bayonet, Bayswater, Preakness, ete, by Lexington. Bramble ran seven times as a two-year oll; won the Young America Stakes No. 2 at Nashrille, three-quarters of a mile, in 1.20, track heary, won the Saratoga Stakes, at Saratoga, three-quarters of a mile, in 1.17 . was second in two and thire in two raees. beating Duke of Magenta. Pride of the Village and others. He marle his debut in his three-year old form in the Withers Stake at Jerome Park, one mile, was second to Duke of Magenta in 1.48, each with $1181 \mathrm{ls}$, one of the best races ever mu, the track being muldy and heavy-Danicheff' and Pride of the Village were behind him; beat

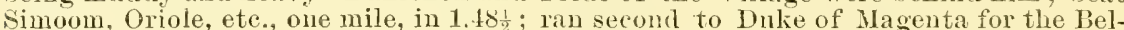

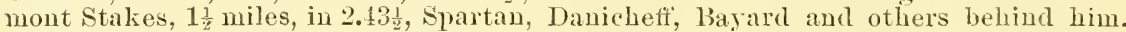
Long Branch, won dash of three-quarters of a mile, beating Idalia. Erypt, ete, in 1.17; same place, was beaten a match, one aul a quarter miles. by Spartan, in 2.16, evidently badly managed or ont of condition. Saratoga, ran second to the Duke of Magenta in Travers Stalies, one and three-quarters miles, in 3.08, a eapital race: won dash of one mile, beating Lou Lanier, Garrick, ete, in 1.45; won dash of one

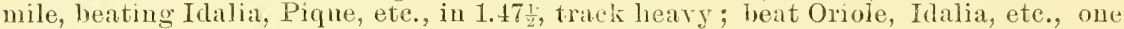
and a quarter miles, in 2.17; walked over for purse, one and a half miles, reeeiver half purse and entrince money; beat Pinne, Pride of the Village, ete., one mile, in 1.47 , carrying $113 \mathrm{lbs}$; ran second to Duke of 1 lagenta for Kenner Stakes, tno miles. in 3.41 $\frac{1}{2}$, with good ones behind him; won raee $1 \frac{1}{8}$ miles, in 1.58, beating Bonmic Wood, Kate Claxton, ete. ; beat Lady d'Arcy. Bomnie Wood, ete. ; three-quarters of a mile, in 1.19 ; beat Putriot, Kate Claxton aul others, one mile, in 1.15). He was sent to Lonisville, where he won the great Anerican Stallion Stakes, $1^{\mathrm{s}}$ miles, in

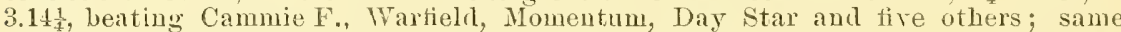
place, was second to Wartield, giving Inim 5 1bs., $1 \frac{1}{8}$ miles, in 1.56 , the fistest race at the distance during the year. Nashville, wou the Maswell Honse Stakes, mile heats, in 1.43, 1.44, beating Warfield and Bergamot. At fonr years old started twenty times, won fifteen raees, was second in two, third in one and mnplaced in two. Brimble at Baltimore won dash of $1 \frac{1}{4}$ miles, defeating Gov. Hampton, Albert and Jndith; time, 2.15 nie 1 Tood, Lon Lanier and Basard, tine, 4.013. Jerome Park, won dash of one mile, defeating Una, Franklin, Bonnie Wood aud three others, time 1.45 $\frac{1}{2}$. Same meeting won the IVestchester Cup, $2 \frac{1}{4}$ miles, defeating his only oplonent, Invermore, time. 4.20 $\frac{1}{2}$. Spring Meetıng, Coney Island Jorkey Club, at Prospect Park, Seaside Handicap, 2 miles, Willtil finished first, Gen. Philips second and Bramble last; time, 3.34 ? Mommonth Park. Won the Oeean Stakes, $1 \frac{1}{s}$ niles, defeating Nonitor, Laneewood, Susquehanna aud Belinda ; time, $1.58 \frac{1}{2}$; won dash $1 \frac{1}{x}$ miles, defeating Una and Tom Scarlet; time, 2.27. Won the Mommonth Cup, 21 niles, defeating Lon Lanier, Gen. Philips and Willtul; Bramble earried 5 los. penalty for wiming the Westehester

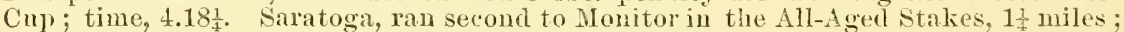

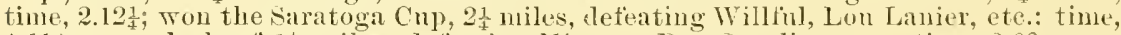
4.11: won dash of $1 \frac{1}{8}$ miles, defeating Mintzer, Dan Sparling, etc.; tinte. 2.00: won dash 1 mile, defeating Bemmett; time, 1.49; won three-(puarters of a mile, deieating Annie Angusta, Bomnie Wood, ete., time, 1.17 $\frac{1}{t}$; won dash of 1 mile. beating Oriole and

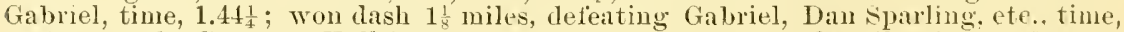
1.58; won the Congress Hall Stakes, heats of thee-quarters of a mile, time, 1.19, 1.18; won the Brighton Cup, $2 \frac{1}{4}$ miles, defeating Franklin by a head, time, $1.16 \%$. At 5 years won the Centemial stakes at Nashville, Tenn., $1 \frac{1}{8}$ miles, in 1.58 , beating beatitude and others; at 6 years, starting only once; ran second to Fericla; at Baltimore, mile heats in $1.44 \frac{1}{2}, 1.4 \frac{1}{2}, 1.48 \frac{3}{4}$, Bramble won the first heat. This was his last race. Iry Leaf, the dam of Bramble, was never trained, Bay Flower, his grandam, was a good race-mare at all distanees, she heat the finnous lihrumlrne three and fonr mile heats at St. Lonis; fom miles, in $7.45 \frac{1}{2}, 7.45$. Bramble is a rich red bay with large star in 


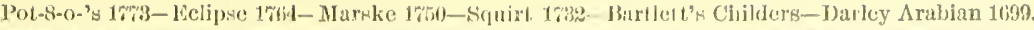

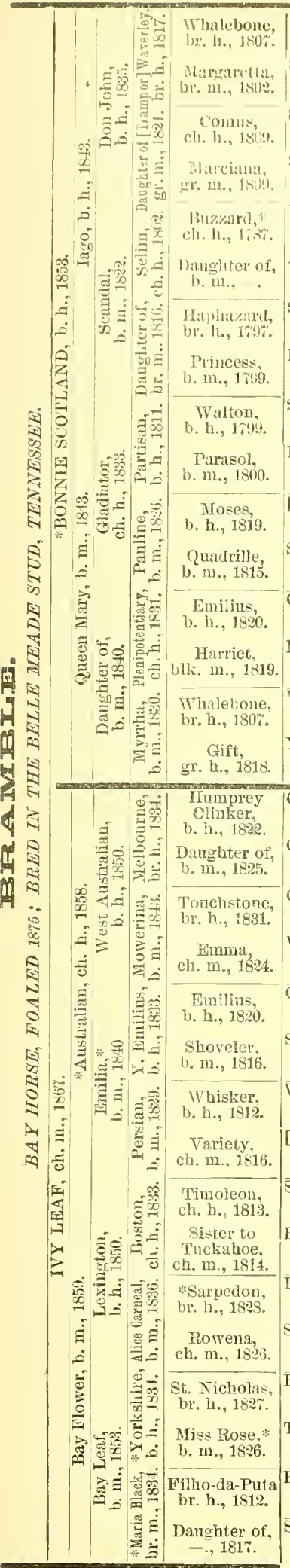

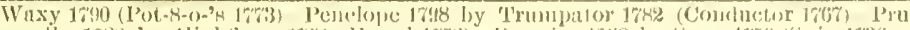

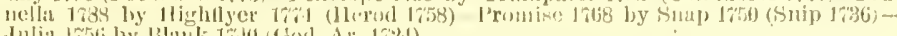

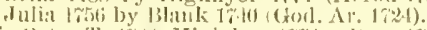

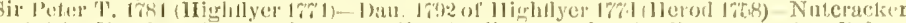

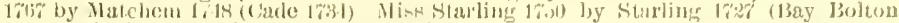

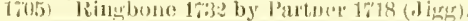

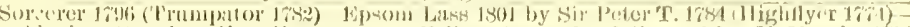

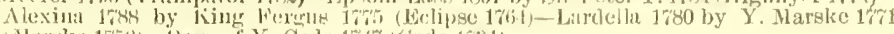

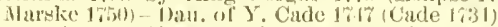

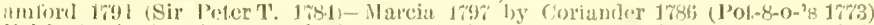

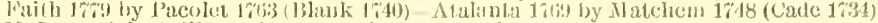

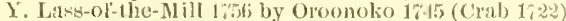

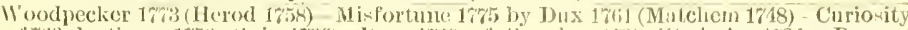

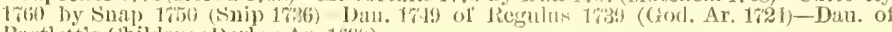
Bartlett's ('hilder's (Darley Ar. 1(its).

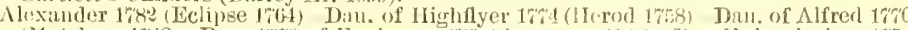

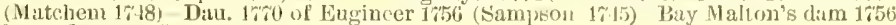
by Cade 1734 (God. Ar. 162 ).

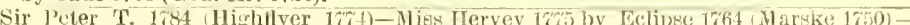

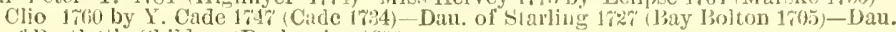
ol' Bartlett's ('hidders (Dacley $\Lambda \mathrm{r}$. 16\%) .

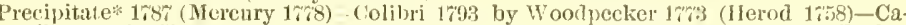
milla $17 \% 8$ by 'Trentham 1766 ('T. Sweepstakes 1\%43)-Coquette 1\%65 by Compton BurbSist. 1493 to Regulne by God. Ar. 1721.

Sir Peter T. 178t (Highilyer 17ft)-Arethusa 1892 by Dungannon 1780 (Eclipse 1rif4)Dim. 17\% of Prophet 1760 (Regulus 1739) - Virago 1764 by Suap 1750 (Suip 1736)-Dau. ol' liegulns $1 \% 39$ (God. Ar. 1721)

Pot-8-0-'s 17\%3 (Eclipse 1764)-Prumella 1788 by llighflyer 1\%74 (FIcrod 1758)-Promine 1768 by Snap 1750 (Snip 1736) - Julia 1750 by Blank 1\%'40 (God. Ar. 17\%4)-Spectator's dam 1735 by Partner 1718 (Jigg).

[Whalebone or] seymour 1807 (Delpini 1781)-Dan. $180 \%$ of Gohanna 1790 (Mereury $17 / 8)$-Grey Skim 1793 by Woodpecker $17 \% 3$ (Herod 1\%58)-Dan. 1\%80 of Herod 1758 (Tartar 1743) - Y. Ilag $1 \% 61$ by Skim 1746 (Starling $17 \%$

Selim 1802 (Buzzard* 1787)-Canary Bird 1806 by [Whiskey or] Sorcerer 1796 (Trumpator 1,82)-Canary 1797 by Coliander 1786 (Pot-8-0-'s 17\%3)-Miss Green $178 \%$ by Highflyer 174 (Herod 1758)-Hariet 1769 by Matchem 1r48 (Cade 1784).

Orvile 1799 (Beningbrough 1791)-Fmily 1810 by Stamford 1\%y4 (sir Peter T. 1784)Datn. 1799 of Whiskey 1789 (Saitram 1780)-Grey Dorimant 1781 by Dorimant 172 (Otho 1\%60)-Dizzy 1757 by Blank 1740 (God. Ar. 17\%4)

Pericles 1809 (Evander 1801)-Dau. 1812 of Selimi 180:2 (Buzzard* 178\%)-Pipvlina 1803 by Sir Peter T. 1784 (Ilighflyer 1rit)-Rally 1 1790 by Trumpator 1782 (Conductor $17\left(; i^{*}\right)$ - Fancy 1780 (Sist. to Diomed*) by Flcrizel 1768 (Herod 1758).

Waxy 1797 (Pot-8-o-'s 17\%3)-Penelnpe 1798 by Trumpitor 178: (Comeluetor 176\%)-Prunella 1783 by Highflyer 17\% (Herod 1758)-Promise 1768 by Snap 1750 (Snip 17:6)Julia 1756 by Blank 1740 (God. Ar. 1\%24)

Y. Gohanna 1810 (Gohanna 17y0)-Dan. 1802 of Sir Peter T. 1\%84 (Highftyer 1761)-Dau. 1788 of Trumpator 1782 (Concluctor 1767)-Sist. 1774 to Postmaster by Herod 1758 (Tartar 1743)-Dan. of Snap 1\%50 (Snip 1736).

Comms 1809 (Sorcerer 1796) -Clinkerina 1812 by Ulinker 1805 (Sir Peter T. 1784)-Pewet 17Só by Tandem 1\%3 (Syphon 1750) - Termagant by Tantrum 1;60 (Cripple 1;:0) Cantatrice by Sampson 1\%45 (Blaze 1733).

Cervantes 1806 (Don Quixote 1784) - Dau. 1818 of Golumpus 1802 (Goharna 1790)-Dau. 1810 of Paynator 1791 (Trumpator 1882 )_Cirele 152 by St. George 1789 (Highifyer 17 (4) - Abigail 1788 by Woodpecker $17 \% 3$ (Gerod 1758

Camel 1822 (Whalebone 180h)-Banter 1826 by Master fienry 1815 (Orville 1799)-Boadicea 1807 by Alexander 1782 (Eclipse 1761)-Brunette by Amaranthus 1\%66 (Old England 1\%41) - Mayfly 1\%1 by Matchem 1\%48 (Cade 1\%34).

Whisker 1812 (Waxy 1090 -Gibside Fairy 1811 by Hermes 1700 (Mercury 17\%8)_Vicis.

situde 1800 by Pipator 1786 (Imperator 1766 )-Beatrice 1792 by Sir Peter T. 1781 (Highfiyer 1\%" - Pyrrha $1 \% 1$ by Naichem 1\%48 (Cade 1\%34)

Orville 1799 (Beningbrough 1791) - Emily 1810 by Stamford 1ro4 (Sir Peter a c784)Dan. 1799 of Whiskey 1789 (Saltram* 1\%80)-Grey Dorimant $1 \% 81$ by Dorimant 1; (Otho 1760)-Dizzy $175 \%$ by Blank $1 \% 40$ (God. Ar. 1\%34)

Seud 1804 (Beninghrough 1\%91)-Goosander 1805 by Hambletonian $1 \% 92$ (King Fergus 1775)-Rally 1790 by Trumpalor 1782 (Conductor $1766^{\prime}$ )-Fancy 1780 (Sist. to Diomed*) by Florizel 1768 (Herod 1758)-Dan. 1763 of Spectator 1749 (Crab 1\%2:).

IVaxy 1790 (Pot-8-0-' 17\% - Penelope 1708 by Trumpator 1782 (Conductor 176\%) - Pruliella 1783 by Highfiyer 1\%4 (Herod 1758)-Promise $1 \% 68$ by Snap 1\%50 (Snip 1736)Jnlia 1756 by Blink 1740 (God. Ar. 1\%:4).

[Selim or] Soothsayer 1808 (Sorcerer 1796)-Sprite 180\% by Bobtail $1 \% 95$ (Precipitate* 1787)-Catherine 1795 by Woodpecker $17 \% 3$ (Herod 1758)-Camilla 17\% by Trentham 1766 (T. Sweepstakes 1,43)-Coquette 1765 by Compton Barb.

Sir Archy 1805 (*Diomed 1\%7)-Dau of *Saltram 1 roo (Eclipse 1764)-Dan of Symmes Wildair 176\% (*Fearnought 1755)-Dau. of Tyler's Driver 1760 (*Othello)-Dau. of * Fallower 1761 (Blank 1740 )

Ball's Florizel 1s01 (*Diomed 17\%7)-Dau. 1799 of "Alderman 1787 (Pot-8-0-'s 17.3)Dau. of *Clockfast $17 \% 4$ (Gimerack 1760)-Dan. of Symmes' Wildair 1767 ("Fearnought 1755)--Y. Kitty Fisher $176 \%$ by *Fearnowght 1755 (Regulus 1759)

Emilius 1820 Orville 1749)-Icaria 1S24 by The Flver 1814 (Vandpke Jr. 1808)-Parma 1813 by Dick Andrews 1797 (Joe Andrews 17r8) - Vay 1804 by Beningbrongh 1791 King Feroms 1755)-Primrose 1787 by Mambriuo 1768 (Engineer 1756).

Sumpter 1818 (Sir Archy 18.5) - Lady Grey 181\% by Robin Giey 1805 (*Royalist 1790)-

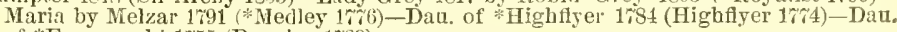
of *Fearnought 1755 (Regulus 1739).

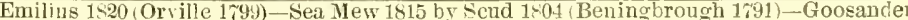
1805 by Hambletonian 1792 (King Fergus 1 25 - Ralle 1790 by Trumpator 1782 (Conductor 1767)-Fancy 1780 by Florizel 1763 (Herod 1758).

Tramp 1810 (Dick Audrews 179:) - Dau. 1810 of Sancho 1801 (Don Quixote 1r84)Blacklock's dam 1799 by Coriauder 1786 (Pot-8-0-'s 17r3) - Wildgoose 1792 by High-

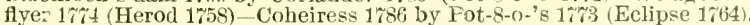

Haphazard 179r (Sir Peter T. 1784)-Mrs. Barnet 1806 by W'axy 1700 (Pot-8-0-'s 17\%9) Dan. 1788 of Woodpecker 1\%3 (Herod 1;58)-Heinel 1\%1 by Squirrel 1754 (Travel\}er 1735) - Principessa 1762 by Blank 1740 (God. Ar. 1721).

Solensko 1810 (Sorcerer 1796)-Dau. br. m. 1803 by SirPeter T. 1784 (Highflyer 1 74 )Dan. gr. m. 1785 by Mambrino 1768 (Engineer $1 \% 56$ )-Marigold $\mathrm{b}$. $\mathrm{m}$. $17 \%$ by Herod 1758 (Tartar 1743)-Toy gr. m. 1761 by Blank $1 \% 40$ (God. Ar. 1\%21)-Whiteneck gr. m. Mixbury by Curwen Bay Barb-Dau. of Curwen Spot (Selaby Turk) -Dau. of White-legged Lowther Barb-Vintner mare. 


\title{
BRAMBLE-Continued.
}

forehead, 15 hands $2 \frac{1}{2}$ inches high, girths 70 inches, leugth of shonlder 28 inches, aromel the arm 20 inches, below the knee $8 \frac{1}{4}$ inches, from hip to point of luock 36 ; inches, around gaskins $16 \frac{1}{2}$ inches, from point of shoulder to point of buttorks 64 inclres. He is full of substance and power, and greatly resembles his sire. He is strongly inbred to Herod and Eelipse through the best sonrees with the Arohy aud Diomed blood throngh Lexington, he was speedy, could stay and earry weight.

Bramble, with a limited chance in the stud, is the sire of the following winners, Biggonet, wimuer of the Withers, etc., Bryson, Brambleton, Borlelaise, Orrlerly, Parl, Bralford, Rambler, Bertha, Amiel, Bravo, Daisy Woodruff, Katunah, Mora, Romp, Wrestler, Barrister, Ben Harrison, Mayor B., Bettina, Blackthorn, Gracie M., Jakie Toms, Manhattan, Perlestrian, Gambler, Wightmau, Ivanhoe II., Nominee, Bellerne, Jack Hurray, Briar, Pixy, Lizzie English, Lady Jane, Thorus, Thornless, Bertha, etc.

\section{BUCKMASTER.}

\author{
(BROTHER TO KIMBALL.)
}

\section{The property of J. D. Lucas, Goodwood Stud, St. Louis, ML. Service by private contract.}

Buchmaster, bay horse, bred by Capt. Wm. Cottrill, Mobile, Ala, own brother to Kimball by imp. Buckden, son of Lord Clifden, dim Meta H. by Harry of the W'est, son of Lexington, ont of Lonisiana B. by Daniel Boone, son of Lexington, thus giving him a double cross of this inestimable blood npon a donble cross of inip. Glencoe through the noted mare Magnolia, grandam of Iroquois, and Fanny King, the dam of the great race-horse Browu Dick, son of imp. Margrave by Mnley.

His own brother Kimball, as a two-year old, won the Young America Stakes, $\frac{5}{3}$ mile, at Nashville, in 1.04量; won the Alexander Stakes, Lonisville, $\frac{1}{2}$ mile, by $1 \frac{1}{2}$ lengths, in 493 seconds, beating Lnke Blackburu, Big Medicine, etc.; ran third to Wallenstein and Fonso for the Tennessee Stakes, Lonisville, beating Luke Blackbnrn Big Medicine, ete., and conceded 5 lbs. to all his opponents; wou the Hotel Stakes, $\frac{8}{4}$ mile, St. Lonis, time, $1.16 \frac{1}{2}$, by 10 lengths, beating Luke Blackibnru, ete.; won the

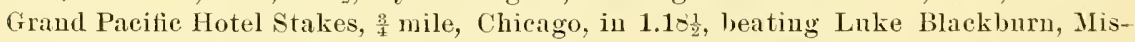
take, Victory, etc., and ran third for the Criterion Stakes, Chicago, beating Luke Blackburn, Wallenstein, Bye-and-Bye, ete. As a three-year old, he won the Cumberland Stakes, mile heats, at Nashville, in two straight heats, 1.49, 1.47 $\frac{3}{2}$; ran second to Fouso for the Kentucky Derby ; second for the Merchant Stalies, St. Louns, and second in the Tidal Stakes, Gravesend, N. Y., to Luke Blackburn. Neta H. prodnced the winners Rnth and Mattie K. Lonisiana 13., the second dam, had only one foal, viz., Meta H., but from the third dam, Maggie G., came Magnolia, Sally Watson. Bonaventmre, Adventure and Buckden Lass. Magnolia produced the wimners The Cripple (Odd Fellow), Mollie Merrill (dam of Ira E. Bride), Aleck Ament, Orange Blossom and Myrtle II. Sally Watson threw Backleo. Peradventure, out of Bonarenture, is the dam of Adventurer, a winner. From Bonaventure came another Adrenturel (by Buckden), in addition to Kitty Wells and Bonny Lass (diln of Enghish Ladty, winner of the Zoo-Zoo Stakes, ete.), and Adventure is the dam of the wimners Lamont and Tedly Venture (a two-year old wimer).

Buckmaster dicl not rum until seven years old. He won $\frac{8}{4}$ of a mile in $1.21_{4}^{\frac{1}{4}}$, with 118 lbs. Won mile heats in $1.47,1.46$. Won at $1 \frac{1}{2}$ miles in 2.44 , and agam in 2.46. Won at a mile in $1.48 \frac{1}{2}$, and half a mile in 0.53 . He was second and third in sereral other races. He is a well-bred horse, tracing to the Barb mire presented to President Jeffersou by the Dey of Trunis. The sous of Bucklen are domg well in the stud. 







\title{
CENTAUR.
}

\author{
(Late THE FAVERDALE COLT.)
}

\section{The property of the Estate of the late D. D. Withers, Broolidale Stud, N. J. Used as private stallion or by contract.}

CExtaur, bay horse, bred in the Brookdale Stud by Mr. D. D. Withers, by the mnheaten Sensation, own brother to Stratford and Onondaga, son of imp. Leahington, dam imp. Faverdale. dam of Frolic, Oneko, Favoress, ete., by The Palmer, own brother to Rosierneian by Beadsman. The Palmer wou the Ascot, Derby, Royal Stakes and Liverpool Antumn Cup, and is the sire of Jenny Howlet, winner of the Oaks, Pellegrino, Pilgrimage (winner of the Dewhurst Plate, the 1,000 and 2,000 Guineas), Grey Palmer, ete. His grandam Georgiana (full sister to Conntess of Burlington, the dam of Carendish and imp. Hartington, winner of the Cesarewitch Handicap) by Tonchstone, winner of the St. Leger and one of the most valuable stallions ever bred in England. Touchstone sired Mowerina, the dam of West Australian, winner of the 2,000 Guineas, the Derby and St. Leger. Mowerina, was ont of Emma, sister to Caroline, the fourth dam of Centanr by Whisker, third dam Lady Emily by Muley Moloch, son of Muley, and sire of the famons Alice Hawthorn, dam of Thomanby, winner of the Derby, tracing throngh Gibside Fairy by Hermes, son of Mercury by Eclipse, to the D'Arcy black-legged Royal mare. Centaur was a first-class race-horse, winner at two years old of the Hopeful Stakes, $\frac{3}{4}$ of a mile, 115 lbs., in 1.16, beating Windfield, Diablo, etc.; was second to French Park in Sequence Stakes, 5 furlongs in 1.04: ran second to Tipstafi in the Sapling Stakes, $\frac{3}{x}$ of a mile in 1.15, conceding lim 10 Jus. ; ran second to Proctor Knott (conceding him 3 lbs.) in Junior Champion Stakes, $\frac{3}{4}$ of a mile in 1.14, with Fresno, Salvator and Diablo behind him; won the Home Bred

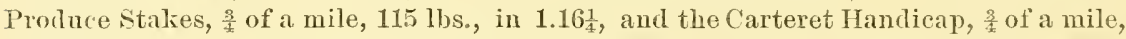
with $121 \mathrm{lbs}$., in 1.16 mile, 115 lbs., in 1.17\%, beating Diablo, Fresno, etc.; won the Algeria Stakes, $\frac{3}{4}$ of a

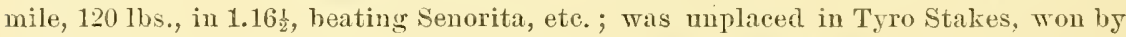
Reporter. At three years old he was unplaced in the Tidal Stakes, won by Salvator; won Handicap Sweepstake, 13 miles, 112 1bs, in 2.23, beating Le Logos, Inverwick ant Reporter; ran third to Salvator and Longstreet in Lorillard Stakes, $1 \frac{1}{2}$ miles in $237 \frac{1}{2}$, and was third to Madstone and Rhono in Newark Stakes, 1 mile in 1.43. He was injured in this race and never ran again. From his grand qualities as a racehorse and high breeding, he shonld be a grand snecess as a stallion. He is descender in direct female line from the Black-legged Royal mare, to which also trace the following excellent race-horses and successful stallions, Oroonoko, Saltram (inported), Beningbrongh, Williamson's Ditto, Cotherstone, West Australian, Walton, Will Dajrell, Parmesan, Diophantus, Caterer, Lord Ronald, Ishmael, Wisclom, 'The Miser, Saxifrage and Harry O'Fallon, in America. 


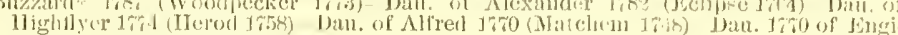

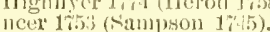

Italia,

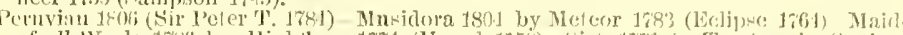
ch. m., 1815

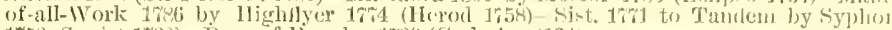

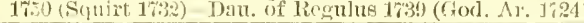

Liturel, br. 1r., 18:1.

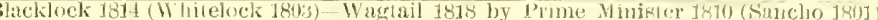

Mrait of

Honlol,

br. m., 1829.

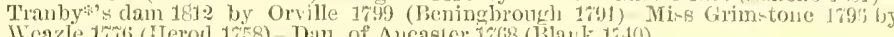
Weazle 17w6 (IIerod 1758) - Duu. of Aucasier Tigr (Blauk 1740)

Timoleon,

Sist, to

Tuckalioe,

ch. $10 ., 1814$

"Sarpedon, br. h., 1828 .

Rowena,

ch. m., 1826 . land $1 \% 11$ ) - Ilaytly $1 \% \gamma^{\prime} 1$ by Matchem 1748 (Cade 1731 )

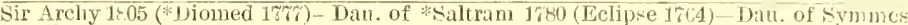
Wildair 1767 ("Fearnought 1'55)-Dau. of Tyler"' Driver 1760 ("Othello) D Dau. * Fallower $1 \% 61$ (Blank 17it)

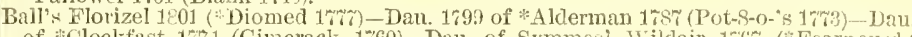

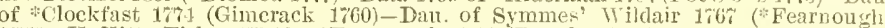
1755)-Y. Kitty Fisher 1\%(i\% by *Fearnonght 1755 (Regulus 1739).

Emilius jo:u (Orville 179.)-leara 16rt by 'The Flyer 1814 (Vandyke Jr. 1808)-Paims 1813 by Dick Andrews 1\% $\sigma^{*}$ (Joe Andrews 1ris)-Nay 1804 by lieningbrough $1 \% 1$ (King Fergus 1775)-Primrose 1287 by Mambrino 17 8 (Engineer 1756)

Sumpter 1818 (Sir Archy 1805)- Lady Grey 1817 by Robin Grey 1805 (TRoyalist 1790)

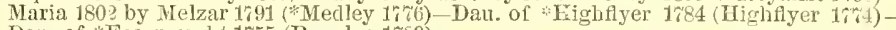
Dan. of *Fearnouglit 1755 (Regulus 17i9).

Sultan,

b. h., 1816 .

elim 1802 (Buzzard" 1'z6) - Bacchante 1809 by W's Dito 1800 (Sir Peter T. 1784) - Dau. 1791 of Mercury $17 \% 8$ (Eclipse 1764)-Dau. 1\%6 of Herod 1758 (Tartar 1748)-Folly 17i by Marske 1750 (Squirt 1732)

Trampoline ch. m., 1825

(Dick Andrens 1796) - - eb 1808 by Waxy 1790 (Pot-8-0-'s 17as)-Penelone 1758)-Promise $1 \%$ - 178 by Snap 1750 (Snip 1796)

Tramp 1810 (Dick Andrews 17\%)-Rosamond

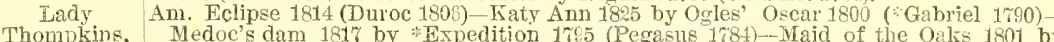
1749 (Cade 1734) - Sist. to Favourite by Regulus 1739 (God. Ar. 1724). ch. m., 1831. *Spread Eagle 1792 (Volunteer 1780)-Annette by *Shark $17 \% 1$ (Marske 1750)

$=0 ;$ Sheet Anchor, Lottery 1820 (Tramp 1810)-Morgiana 1820 by Muley 1810 (Orville 1799)-Miss Stephenbr. h., 1832, Son 1814 by [Bcud or] Sorcerer 1796 (Trumpator 1782)-Dau. 1796 of Precipitate: bi. h., 1e32. $178 \%$ (Mercury 1778)-Dan. $178 \%$ of Woodpeckel 1773 (Herod 1758).

178 . Mercury

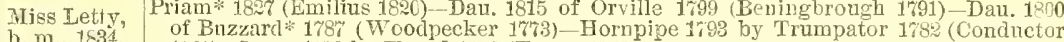

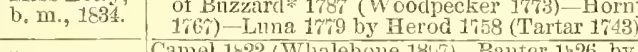

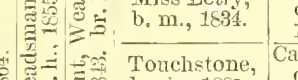

( land $1 \% \pm 1$ - Mayfly $1 \% 1$ by Matchem 1748 (Cade $1 \% 34$ )

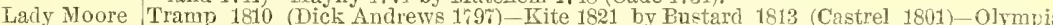
Carew, 1815 by Sir Oliver 1800 (Sir Peter T. 1784)-Scotilla 1795 by Anvil 17\% (Herod 168 ). b. m., 18:0. Scota 1783 by Eelipse 1,64 (Marske 1750).

Bay Middleton, b. h., $18 \div 3$.

Crucifix,

b. $11 ., 1857$.

Defence,

b. h., 1824 .

Folly,

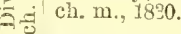

-3) Whalebone

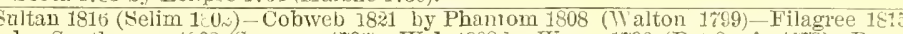
by Soothaayer 1\&03 (Sorcerer 1796)-Web 1808 by Waxy 1790 (Pot-8-o-'s 17\%3)-Penelope 1793 by Trumpator $1 \% 82$ (Conductor 1164 )

Priam* 182\% (Emilins 1820)-Octaviana 1815 by Octavian 1807 (Stripling 1705)-Dan. 18C of Shuttle 1793 (Y. Marske 1r/1)-Zara 1801 by Delpini 1rs1 (Highflyer 17:1)-Flora 1789 by King Fercus 17:5 (Eclipse 1764).

Whalebone 1807 (Waxy lis(l)-Defiance 1816 by Rubens 1805 (Buzzard 1787)-Lit Folly 1806 by Highland Fling 1798 (Spadille 1784)-Harriet 1 ; 99 by Toluuteer 17c0 (Eclipse 176-)-Lady Sarah's dam 1785 by Alfred $17 \% 0$ (Matchem 1\%48).

Middleton 1832 (Phantom 1808)-Little Folly 1806 by Highland Fling 1re8 (Spadille 1784)-Farriet 1799 by Volunteer 1780 (Eclipse 176t) -Dau. 1785 of Allred 1iro (Match em 1749)-Magnolia 1671 by Marske 1750 (Squirt 17.2).

פ: br.h., 180\%. Jula 1788 by Highflyer 17\% (Herod 1758)

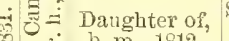

1789 of Phenomenon 1780 (Herod 17:8) - Matron 1782 by Florizel 1668 (Herod 1758) Maiden $17 \% 0$ by Matchem 1748 (Cade 1734).

Master Henry

Orville 17!9 (Beningbrough 1'91)-Miss Sophia 1805 by Stamford 1794 (Sir Petel $\mathrm{T}$

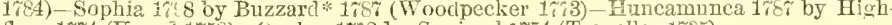
flyce 174 (Ferod 1758)-Cypher $17 \% 2$ by Squirrel $1 \% 54$ (Traveller 1725).

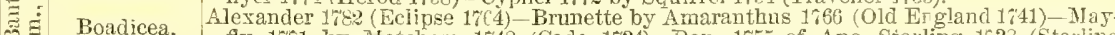

fly $17 \%$ by Matchem $1 \% 43$ (Cade 1\%34)-Dan. 1755 of Anc. Starling 1733 (Starling $172 \%$ )-Look-at-me-Lads 1731 by Grasshopper (Byerly Turk).

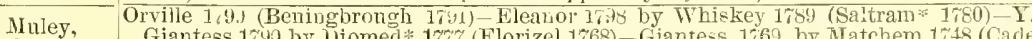

b. h., 1810 . Giantess 1790 by Diomed* 17ir (Florizel 1\%68)-Giantess 1\%69 by Hatchem 1748 (Cade 1734) - Molly Long Legs 1;53 by Baoraham 1\%40 (God. Ax. 1724)

Dick Andrews $179 \%$ (Joe Andrews 17\%)-Spitfire 1800 by Beningbrough 1791 ( $\mathrm{king}$

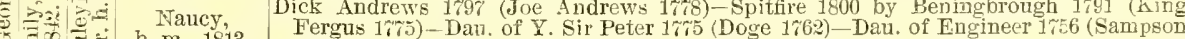

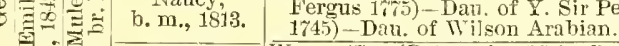
至 Julia 1756 by Blank 1740 (Frod. Ar. 1724).

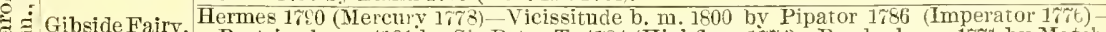

b. m., 1811. Beatrice b. m. 1791 by Sir Peter T. 1784 (Highflyer 174)-Pyrrha b. m. 1771 by Matel em 1748 (Cade 1734)-Duchess b. m. 1748 by Whitenose 1742 (God. Ar. 1724)-Miss
Slamerkin b. m. 1::9 by Y. True Elue 1718 (Honerwood Ar.)-Dau. of Lord

Oxford's Dun Ar.-D'Arcy Blacklegged Royal mare. 


\section{CHANCE.}

The property of $M I r$. James B. Clay, Troquois Stud, Lexington. Stallion advertised for public service each year.

Chaxce, chestunt horse, foaled 1881, bred by the late James A. Grinstead, Walnut Hill Stud, Ky., by War Dance, son of Lexington and the famous Reel; dam of Lecompte (the only horse that ever beat Lexington), Starke, winner of the Goodwood Cup, and Prioress, winner of the Cesarewiteh Handicap, etc., by imp. Glencoe, ont of imp. Gallopade by Catton. Chance was a good race-horse; won two races out of four starts, and was second in one. Won Colt Stake, $\frac{1}{2}$ mile, $1051 \mathrm{lbs}$., in $0.50 \frac{1}{2}$; won purse, 5 furlongs, in 1.0.5 $\frac{1}{2}$. As three-years old won purse, $\frac{3}{4}$ of a mile, 109 lbs., in

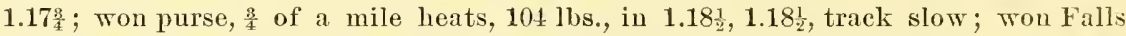
City Stakes, $1 \frac{1}{16}$ miles, $108 \mathrm{lbs}$, in 1.55, beating Highflight, Aretino and others, and was placed in other races. Was placed in several good races at four years old. At five rears old won purse, $1 \frac{1}{x}$ miles, 112 lbs., in 1.57; second to Matinee, $1 \frac{1}{16}$ miles, 108 1bs., in $1.50 \frac{1}{2}$; second to Modesty, $1 \frac{1}{4}$ miles, in 2.11 ; was third in the Tobaceo Stakes and two other races. At six years old won 1 mile 70 yards in $1.51 \frac{1}{4}$; won $\frac{8}{4}$ of a mile in $1.16 \frac{1}{4}$;

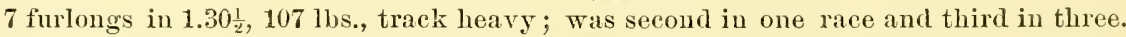
His dam, Perhajs, is the dam of Perplex, Doubt, Dilemma and the speedy, good racemare Reckon by imp. Australian, she out of Mishap by imp. Knight of St. George by Irish Birdcatcher. Mishap, the second dam, produced Crockford, Misfortme (dam of Mistake, a good winner in England, Hopeful, Syntax and Miss Dance, Walcott's. dam), Sophy (dam of Repose, Pelham's dam) aud Mischief (dam of Judge Hughes). Lorette, the third dam, produced Regan, Ada A. (late Ada Allen), Sophy Barlderly and Peaceful. Of these Regan was the dam of Vigil, Vera Cruz, Jennie D. (dam of' Grismer, Verawo and Lijero), Jennie B. (dam of Primero, Ganymede and Honduras), Jolly Sir John, Vengeance and Printer (late Last Chance). Ada A. produced Patsę̧ Duffy, Frank Rhoads, Leon (the two last named each wimners of the California Stakes, ete.), Lizzie P. (dam of Idalene Cotton and Lonis P.) and Rosa G. (dam of Tom O'Hara and Fanny J.). Sophy Badderley prodnced the winners Peytona Barry (dam of Boh Thomas and Worth), Bob Pate and Martindale, while from Peaceful, the last of Lorette's daughters, eame the winners Montezuma and Steve Jerome. It is a noted racing and producing family in both Ameriea and England; from it came Henry Perritt, Mogul, Cazique, Oux Ban, in addition to those above, and in Englanl Florizel, Election, Royal Oak, Mulatto, The :Palmer, Rosierueiam, Duteh Skater, Doneaster, Gladiateur, Hermit (by Newminster), sire of imp. St. Blaise, ete. Chance should be a snceess in the stud; he combines the best racing blood and is from a racing and producing fumily. He is sire of Eagle Bird, a good two year old, and the Narka colt, both winners. He is descented in direct female line from the Massey mare, to which trace Trentham, Florizel, Election, Quiz, Royal Oak, Multo, Defence, The Palner, Rosicrucian, Duteh Skater, Doneaster, Gladiateur, Hermit (by Newminster), The Merry Monareh, Hackthorj and other good ones. 


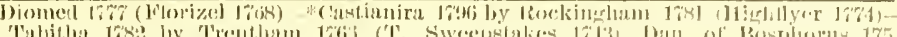

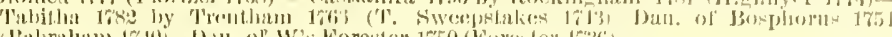

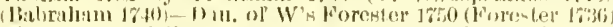

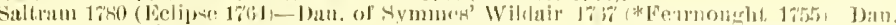

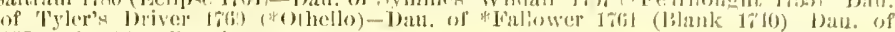

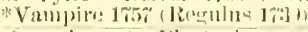

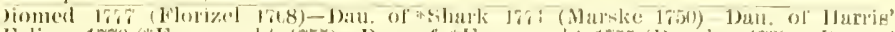

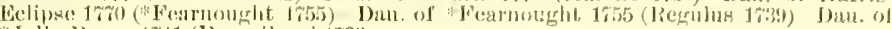

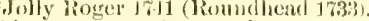

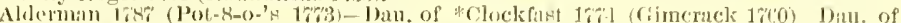

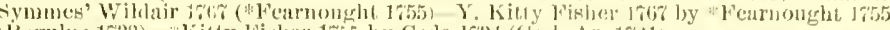

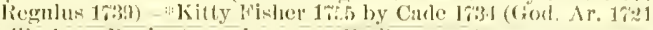

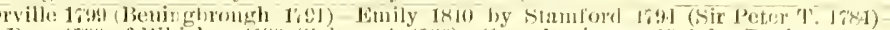

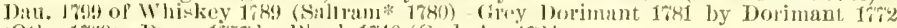

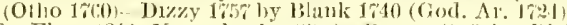

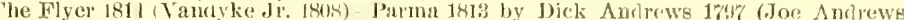

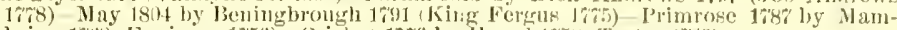

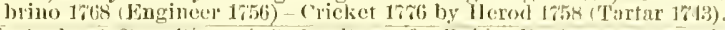

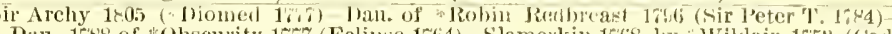
Dau. 1788 of tobscurity 176 (Eclipse 1664) Slamerkiu 1,68 by Wildair 175:3 ('ade 1;34) - Cub nure 1762 by Cub 1739 (Fox 1\%14).

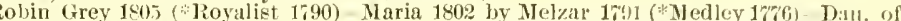

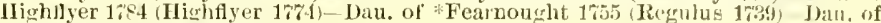

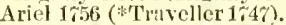

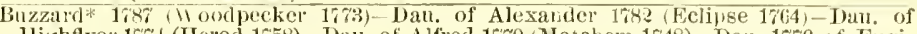
llighflyer 1\%t (Herod 1758)-Dau. of Alfred 17\%0 (Matehem 1748)-Dau. 1760 of Engineer 1756 (Sampson 1745 )

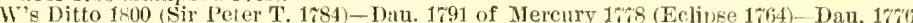
of Herod 1758 (Tartal 17.33)-Folly 1701 by Marske 1750 (Squirt 1732)-Vixen 1753 by Regulus 1739 (God. Ar. 1724)

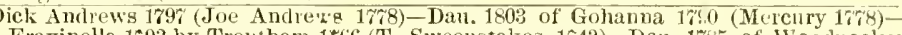
Fraxinella 1793 by Trentham 1:66 (T. Sweepstakes 1743)-Dau. 1785 of Woodpecker 1773 (llerol 1758 )-Everlasting 17\%5 by Eclipse 1701 (Mar-ke 1750).

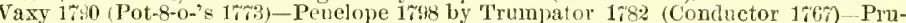
nella 1788 by Hightlyer 1774 (Herod 1758)-Promise 1768 by Snaj) 1750 (Snip 1636) Julia 1,56 by Blank 1 ido (God. Ar. 172t)

Gohanna 1790 (Merculy 1\%78)-Catherine 1795 by Woodpecker 17\%3 (Herod 1758)-Camilla $17 \% 8$ by Trentham 17C6 (T. Sweepstakes 1748)-Coguette $16(5$ by Compton Birb-Sist. 1743 to Regulus by God. Ar. 1724.

Timothy 1794 (Delvini 1781)-Luey 1789 by Florizel 1768 (Herod 1;58)-Frenzy 174 by Eclipse 1761 (Marke 1750)-Dan. of Engineer 1756 (Sampson 1745)-Dan. 1763 of Blank 1710 (God. Ar. 1\%21).

11 ambletonian 1792 (King Fergus 1755) - Faith $177 y$ by Pacolet 1i63 (Blank 1640)-Atalanta 1769 by Matchem 1748 (Cade 1734)-Y. Lass-ol-the-Mill 1756 by Oroonoko 1745 (Crab 1\%:2)-Dau. 1\%44 of Traveller 1\%35 (Partner 1\%18).

molensko 1810 (Sorcerer 1796)-Miss Cannon 1811 by Orville 1799 (Beninglurough 1791)-Dau. 1796 of Weathercock 1785 (IJighflyer 17\%4)-Cora 17\% by Matchem 1\%18 (Cade 17:34)-Dau. of Turk 1763 (Regulns 1739).

Comus 18194 (Sorcerer 1746)-Clinkerina 1-12 by Clinker 1805 (Sir Peter T 1784)-Petwet 1786 by Tandem 1\%73 (Syphon 1750)-Termagant by Tanirum 1\%60 (Cripple 1\%0)Cantatrice by Sampson 1745 (Blaze 1733).

Cervantes 1806 (Don Quixote 1784)-Dau. 1818 of Golumpus 1802 (Gohanna 1790)-Dan. 1810 of Pavnator 1791 (Trumpator 1782)-Circle 1802 by St. George 1\%89 (Highflyer 17\%4)-A bigail 1788 by Highflyer $17 \% 4$ (Herod 1758).

Camel 1822 (Whalebone 180\%) - Banter $1826^{\circ}$ by Master Henj: 1815 (Orville 1ro9)-Boadicea 1807 by Alexander 1782 (Eclipse 1764)-Brunelte by Amaranthus 1766 (Old England 1741)-Mayfly $17 \% 1$ by Matchem 1748 (Cade 1734).

Whisker 1812 (IVaxy 1790)-Gibside Fairy 1811 by Hermes 1790 (Mercury 1768)-Vicissi tude 1800 by Pipator 1 r 86 (Imperator 1\%6)-Beatrice 1791 by Sir Peter T. 164 (Highflyer 17\% j-Pyrrha $1 \% 1$ by Matchem $1 \% 48$ (Cade 1\%34).

Orville 1799 (Beninghrough 1791)-Emily 1810 by Stamford 1794 (Sir Peter T, 1784) Dau. 1799 of Whiskey 1789 (Saltram* 1780)-Grey Dormant 1781 by Dorimant $17 \% 2$ (Otho 1\%60)-Dizzy $175 \%$ by Blank 1740 (God. Ar. 1724).

cud 1804 (Beningbrongh 1\%91)-Goosander 1805 by llambletonian 1792 (King Fergus 1775 -Rally 1793 by Trumpator 178: (Condnelor 1767)-Fancy $17 \varepsilon 0$ by Florizel 1768 (Herod 1755) - Sist. 1763 to Jumo by Spectator 1749 (Crab 1722).

Taxy 1790 (Pot-8-0-'s 17\%3)-Penelove 1798 by Trumpator 1782 (Conductor 1rif)-Plunella $17 \times 8$ by Highflyer 17\% (Herod 1758)-Promise 1768 by Snap 1750 (Suip 1736)Julia 1756 by Plank $1 \% 10$ (God. Ar. 1\%21

[Selim or] S othsayer 1808 (Sorcerer 1;96)-Sprite 180 \% by Bobtail 1795 (Precipitate* 1786)-Catherine 1795 by Woodpeclier 1733 (Herod 1758)-Camilla 17\%8 by Trentham 1766 (T. Sweepstakes 1743)-Coqnette $1 \% 65$ by Compton Barb.

Whalebone 1807 (IIaxy 1790 )-Peri 1822 by Wanderer 1811 Gohanna 1790)-Thalestris 1809 by Alexander 1782 (Eclipac 1764) Rival 1800 by Sil Peter T: 1384 (Wigbrlyer 17\%4)-Ilornet 1790 by Drone $17 \%$ (Herod 1758).

Bob Booty 1804 (Chanticleer 1787)-F'light 1809 by Ir. Escape 1802 (Commodore 17931Y. Heroine by Bagot. 1780 (Herod 1758)-Heroine 17\%5 by Hero 1753 (Cade 1734)-Dau. 1766 of Snap 1750 (Snip 1736).

Brutandorf 1821 (Blacklock 1814)-Dau. 1820 of Comus 1809 (Sorcerer 1796)- Marciana 1809 by Stamford 1794 (Sir Peter T. 1\%84)-Marcia $1697^{\circ}$ by Coriander 1 \%86 (Pot-8-0-'s $17 \%$ - Faitt $1 \% 9$ by Pacolet 1763 (Blank $1 \% 40$ ).

ir Hercules 1826 (Whalebone 180\%) - Mary Anne 1820 by Waxy Pope 1806 (Waxy 1r90)Witch 1811 by Sorcerer 1796 (Trumpator 1782)-Miss Buckle 1801 by Precipitate* 1787 (Vercury 178) - Dan. 1788 of Highflyer 1\%4 (Herod 1758).

Orville 1799 (Beningbrongh 1791)-Emily 1810 by Stamford 1794 (Sir Peter T. 1784) Dau. 1799 of Whiskey 1789 (Saltram* ir80)-Gres Dorimant 1781 by Dorimant $1 \% 2$ (Otho 1760)-Dizzy 1757 by Blank 1740 (God. Ar. 1721)

Bonrbon 1811 (Sorcèrer 1796) - Lady Rachel 1805 by Stamford 1794 (Sir Peter T. 1784) Y. Rachel $1 \%$ ( 99 by Volunteer 1780 (Eclipse 1\%64)-Rachel 1\%90 by Highflyer 1; (Herod 1758)-Dau. 17\%1 of Syphon 1750 (Squirt 1732).

G]encoe 18.31 (Sultan 1816)_*Pickle 1831 by Emilius 1820 (Orville 179y)-MInstard 1821 by Merlin 1815 (Castrel 1801)-Morel 1805 by Sorcerer 1796 (Trumpator 1is2)-Hornty Lass 1796 by Buzzard*178\% (Woodpecker 17\%3).

Consol 1828 (Lottery 1820)-Parrot b. m 1825 by Roanoke 181? (Sir Archy 1805)-Paroquet b. m. 1819 by * Merryfield 1808 (Cockfighter 1796) — * Popinjay mare b. m. 1808 by Popinjay 1797 (Buzzard* 178\%)-Bourbon's dam gr. m. 179\% by Precipitate* 178\% Mercnry 1\%8)-Y. Tiffany gr. m. 1i8i by Highflyer 1774 (Herod 1758)-Tiffany gr. $\mathrm{m}$. 175 by Eclipse 1764 (Marske 1750)-Y. Hag gr. m. 1761 by Skim 1746 (Starling 1\%2\%)-Hag gr. m. 1744 by Crab 1722 (Alcock Ar.) -Ebony b. m. 1728 by Flying Childers 1715 (Darley Ar. 1699)-old Elony blk. m, 1 rit by Basto 1702 (Bjerly T'urk)Duke of Rutland's Massey mare by Hassey's Black Barb. 


\section{IMPORTED CHARAXUS.}

\section{WINNER OF THE LIVERPOOL NURSERY STAKES, WORCESTER CLP, TRADESMAN IELTER CUP, CRATEN STAKES AND OTHER GOOD RACES.}

\section{The property of Capt. R. J. Hancock, Ellerslie Stud, Overton, Da. Yearlings: sold anmully. Service by contract.}

Charaxus, bay horse, foaied 1876 , bred by Mr. J.G. Watkins, by Distin, son of Trumpeter by Orlando by 'ouchstone, dam Sappho by Kingston, son of Venison, ont of Saerifice by Voltaire, son of Blaeklock, etc. Distin, the sire of Charaxus, comes fiom a raeing family. Miss Bowzer, his dam, is the grandam of Craig Millar, winner of the st. Leger and Doneaster Cup, she out of Mangosteen, sister to imp. Mango, winner of the St. Leger, and to Preserve, winuer of the 1,000 Guineas, and grandam of Speculum, winner of the Goodwood Cup. Trumpeter, sire of Distin, is the sire of Plutus, grandsire of Rayon d'Or. Distin is the sire of Avontes, a good raee-horse and wimner of a number of important raecs, and is the sire of Netheravon, a good winner. Kingston, sire of Charaxus' dam, won the Goodwood Cup and was a popular sire in England, and is the sire of Babta, imp. Glenelg's dam, imp. Eltham Lass, dim of Kingfisher, Caractacus, winner of the Derby, imp. Blnemantle, Qneen Bertha, wimer of the Oaks and dam of Spinaway, Wheel of Fortune, both winners of the 1,000 Gnineas and Oaks. Sacrifice, his grandam, is also grandam of Derotion, the dan of Thebais, winner of the 1,000 Gnineas and Oaks, the unbeaten Clairvanx, St. Marguerite, winner of the 1,000 Gnineas and dam of Seabreeze, wimner of the Oaks and St. Leger by Yoltaire, the sire of English Voltigeur, who won the Derby and st. Leger and sired imp. Billet, sire of Barnes, Rnmymede, Miss Woodford, ete., and Vedette, winner of the 2,000 Guineas, he the sire of Galopin, winner of the Derlys. Galopin is the sire of St. Simon, the most popular stallion in Englaud, Galliard, winner of the 2,000 Gnineas, and Donovan, who won both the Derby and St. Leger in 1889, she out of Virginia, the dam of Virago, winner of the 1,000 Guineas, Goodrood and Doncaster Cups, and full sister to Puee, dam of Flea, winner of the 1,000 Guineas and granlam of The Ugly Buck, winner of the 2,000 Guineas, by the St. Leger winner imp. Rowton. Yirginia is out of Pucelle by Mnley, she ont of Medora, wimner of the Oaks, and dam of Gulnare, an Oaks winner, by Selim. The pedigree runs baek through fashionable ehannels to the Layton Barb mare, to which trace Falsetto and Iroquois, and from Golden Grove back the pedigree is identieal with that of Iroquois. To the same fountain liead trace also Powhattan, Parole, Rebel, Virgilian, La Henderson, Ferida, Aella and many others of note on this side and in England. Matchem. Inheritor, Annandale, Ion, Simoom, St. Honorat all descent in direct female liue, anr? are a few of the equine wonders that trace directly to this family. As a race-horse Charaxus was distinguished. At two years old he won the Liverpool Nursery Stakes, in which he beat Strathconan. At three he won the Worcester Welter Cup. 1 mile, $112 \mathrm{lbs}$, the Shobdon Welter Cup, 1 mile, carrying in the latter race 127 1bs., the Alexandra Handicap, 18 miles, 114 lbs. At five he won the Herefordshire Cup, the Birmingham Antumn Handicap and the Worcester Antumn Handicap. At six he won Easter Handicap Plate, $1 \frac{1}{4}$ miles, carrying 136 lbs., at Bath, won the County Members' Plate, 1 mile, carrying 145 lbs, a mile Selling Welter Race. carrying $156 \mathrm{lbs}$. Worcestershire Stakes (Haulicap), $1 \frac{3}{x}$ miles, 124 lbs., Worcester Tradesmen's Welter Cup, 1 mile, with 168 lbs, the Sheprerton llandicap Stakes. $1 \frac{1}{4}$ miles, 132 lbs, and Her Majesty's Plate, at Lichfielil, 2 miles, 137 los. At seren he won the Craven Stakes, $1 \frac{1}{4}$ miles, 115 lbs., at Goodwood. From this it wili be seen that the career of Charaxus on the turf was very highly successful, and his form and royal pedigree should insure his suceess as a sire of race-horses. Tho only ones or his get tried, Capstone, Katie C. (Hetty Cary), Charale, Lester, Annie G., Lallah. Character, Hammie and IIa Belle, are good ones and wimers in first-class compans. 


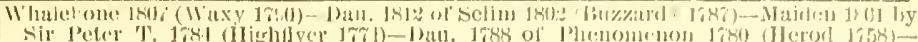

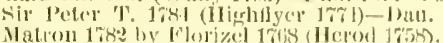

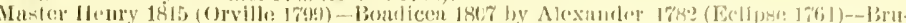

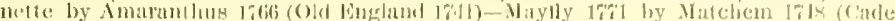

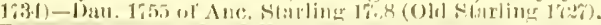

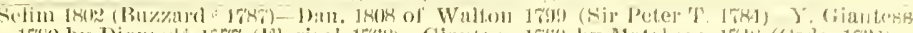

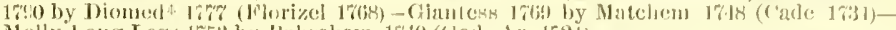

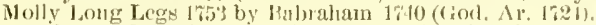

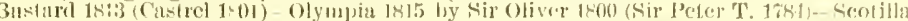

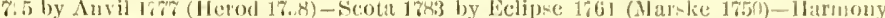

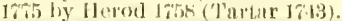

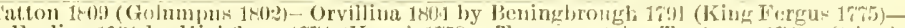

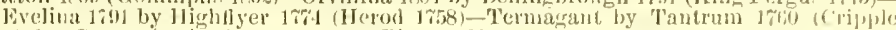

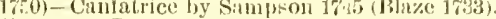

Selim 1802 (Buzmank 178\%)-Dan. of Skyscraper 1786 (1highllyer 1771)-Datt. 1746 of

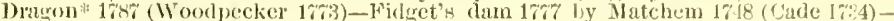

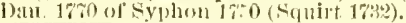

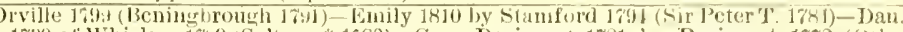

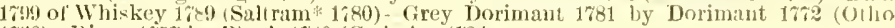

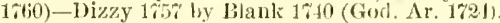

Rubens 1805 (Buzzard: 178\%)-Penelope 1798 by Trumpat or 1782 (Conduclor 17(5)-Prillelia 178 lis llighlyer 17 l (Herod 175s)

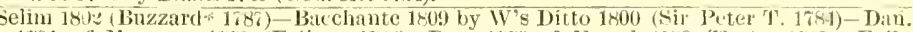
1791 of Mercury $17 \% 8$ (Eclipse 1764)-Dau. 17\%6 of llelod 1558 (1'artar 1743)-Folly 1 1ri by Marke 1750 (Squirt 1620)

Phantom 1008 (Walıon 19!9)-Filagree 1815 by Soothsaver 1808 (Sorcerer 1506)-Wveb 1808 by Waxy 1790 (Pot-9-o-'s 17\%3)-Penelope 17:8 by 'Trumpator 1782 (Conductor

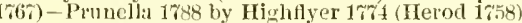

Orville 1749 (Beningbrough 179i)-Emily 1810 by Stamford 1794 (Sir Peter T. 1784)Dan. 179.1 of Whiskey 1689 (Saltram*1780)-Grey Dorimant 1781 by Dorimant $17 \% 2$ (Otho 1\%(0)-Dizzy 1757 by Blank 1740 (God. Ar. 1724)

Pericles 1809 (Evander 1801)-Dan. 1812 of Selim 1802 (Buzzard $\% 178$ )-Pipylina 1802 by Sir Peter T. 184 (Hiobflyer 1774) - Rally 1690 by Trumpator 1782 (Conductor 176 Fancy 1780 (Sist. to Diomed) by Florizel 17C8 (Herod 175\%).

Beningbrough 1791 (King Fergus 1\%ts) - Evelina 1791 by Highflyer 1\% Termagant by Tantrum 1760 (Cripple 1750)-Cantatrice by Sampson 1745 (Blaze 17.85) Dà. 175t of Regulus 1739 (God. Ar. 1724).

Stamford 1794 (Sir Peter T. 1784)-Dall. 1799 of Whiskey 1789 (Saltram*1780)-Grey Dorimant 1781 by Dorimant $17 \% 2$ (Otho 1760)-Dizzy $175 \%$ by Blank 1740 (God. Ar 172!)-Ane. Dizzy 1741 by Driver 1727 (Wynn Ar.).

Castrel 1801 (Bnzzard 1287)-Miss Newton 1804 by Delpini 1781 (Highflyer 17r4)-Tipj]e Cyder 1788 by King Fergus $17 \% 5$ (Eclipe 1761)-Sylvia 1783 by Y. Marske 1\%1 (Marslie 1750)-Ferret 1765 by B:o. to Silvio (Cade 1\%

Solcerer 179: (Trump:tor 1782)-Horuby Lass 1796 by Buzzard* 1787 (Tondpecker $1773)$ - Puzzle 178 by Malchem 1748 (Cade 1731)-Princess 1869 by Herod 1758 (Tartar 1743 ) - Julia 1756 by Blank 1740 (God. Ar. 1\%24)

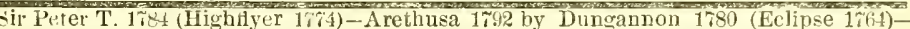
Dan. 17\% of Prophet 1760 (Reguius 1739) - Virago 1764 by Snap 1750 (Snip 1736)-Dau. of Regulus 1739 (God. Ar, 1724)

Pot-8-o-'s 1773 (Eclipse 1764)-Prunella 1788 by Highfiver $17 \% 4$ (Herod 1758)-Promise 1768 by Snap 1750 (Suip 1730)-Julia 1756 by Blank 1r40 (God Ar. 17尺4)-Spectator"s Dam 1735 by Partner 1718 (Jigg).

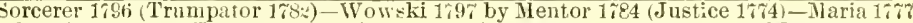
by Herod 1758 (Tartar 1743) - Lisette $17 \% 2$ by Snap 1750 (Snip 1736)-Miss Wiudsor 151 by God. Ar. 1721 .

Gohanna 1790 (Mercury 17\%8) - Camilla 1:r8 by Trentham 1769 (T. Sweepstakes 1743)Coquetie 1764 by Compton Barb_Si-t. 1743 to Rcgulus by God. Ar. 1721-Grey Rolinson $17 \% 2$ by Bald Galloway (St. Victor Barb

Catton 1509 (Golunjpus 18 u')-Dau. 1818 of Smolensko 1810 (Sorcerer 17.6)-Lady Mlary 1800 by Beningbrough 1791 (King Fergus 17ij5)-Dau. of Highflyer 17ití (Herod 1 58 )sist. to Miss Bell by Marske 1.50 (Squirt 173\%)

Orville 1799 (Beningbrough 1\%91)-Eusom Lass 1803 by Sir Peter T 1r8t (Hightyer 174)-Alexina 1785 by King Fergus 1755 (Eclipse 1;64)-Lardella 1780 by Y. Marke $17 \% 1$ (Marske 1750) Dan. of Y. Cade 1747 (Cade 1734).

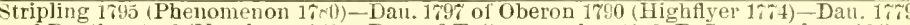
of Ranthos 176:3 (Matchem 1748)-Dat. of T. Sweepstakes 17 13 (B. Sweepstakes 172.) Sist. 1748 to Carcless by Hutton's Spot 1'28 (Hartley's Blind Horse)

Shuttle 1793 (Y. Marske 16\%I)-Katharine 1798 by Delpini 1781 (Highfler 1\%it)-Dau. 1780 of Paymaster 1766 (Blank 1740)-Dau. 174 of Le Sang $1 \% 59$ (Changeling $174 \tilde{\imath})$ Dau. 1751 of Rib 1783 (Crab 1722$)$

Hambletonian 1792 (King Fergns 17i5)-Rosalind 1788 by Phenomenon 1780 (Herod 1758) - Atalanta 1769 by Matchem 1718 (Cade 1734) - Y. Lass of the Milf 1756 by Oroo. noko 1745 (Crab 1722)-Dan. 1744 of Traveller 1735 (Partier 1\%18).

Coriander 1786 (Pot-S-O's 173) - IVildoose 1702 by Hiobfler inf (Herod 1758) Coheiress 1786 by Pot-8-0'-8 $17 \% 3$ (Eclipse 1764)-Manilla 1\% by Goldfinder 1:64 (Snap 1750)-Dau. 176\% of Old Englaud 1741 (God. Ar. 1724)

Walton 1i!9 (Srr Peter T. 1784)-Julia 1794 by Whiskey 1i89 (Saltram* 1:80)-Y Giantess 1;90 by Diomed*1;r (Florizel 1;68)-Giantess 1;69 by Matchem 1;48 (Cade 1724)-Violly Long Legs 1753 by Babraham 1740 (God. Ar. 172!)

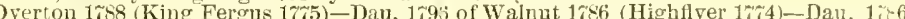
of Ruler 17\% (X. Marske 17\%1)-Pirscantba 1\%2 by Matchem 1748 (Cade 1734)-Prophetess 1758 by Reguins 1739 (God. Ar. 1724)

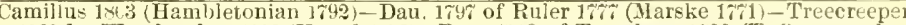
1,89 by Woodpecker 173 (Herod 1758)-Dau. 179 of Trentham 1766 (T. Sweepstakes 1743)-Cunegonde 1,69 by Blank 1740 (God. Ar. 1724)

Woful 1809 (Waxy 1790)-Landscape 1813 by Rubens 1805 (Buzzard*178i)-Iris 1595 by Biush 1785 (Eclipse 1764)-Dau. of Herod 1758 (Tartar 1743)-Doctors sist. 17it by Bush 1785 (Eclipse 1\%64) -
Goldfinder 1764 (Snap 1750).

Orville 1799 (Beningbrough 1\%91) -Eleanor 1698 by Whiskey 1\%89 (Saltram* 17s0)-Y. Giantess 1700 by Diomed*1777 (Florizel 1768)-Giantess 1769 by Matchem 1\%4s (Cade 1734)-Molly Long Legs 1,53 by Babraham 1740 (God. Ar. 1724).

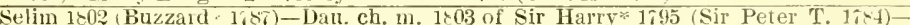
Dau. of ch. m. 1793 by Volunteer 1780 (Eclipse 1764)-Dau. of b. m. 1779 Herod 1758 (Tartar 1743)-Golden Grove ch. m. 1760 by Blank 1710 (God. Ar, 1,24-Spinster (the Widdrington mare) ch. m. 1735 by Partner 1718 (Jigg)-Bay Bloody Buttocks b. m. 1729 by Bloody Buttocks-Sist. 1722 to Guy by Greyhound (Chillaby)-Brown Farewell br. m. 1\%10 by Mlakeless (Oglethorpe Ar.)-Dau. of Brimmer (D`Arcy Yellow Turk)-Dau. of Place's White Turk-Dau. of Dodsworth-Eayton Barb Mire. 


\title{
IMPORTED CHEVIOT.
}

\author{
WINNER OF THE CANTERBURY DERBY, MIDSUMMER HANDICAP AND \\ CRAVEN STAKES, AUSTRALIA.
}

\section{Is in the Fairview Stud of Messrs. Charles Reed \& Sons, Gallatin, Tenn. Yearlings sold annually.}

Cheviot, bay horse, brother to Sir Modresl, foaled 1879, bred in the Middle Park Stud, New Zealand, by Tradncer, dam Idalia by Cambuscan, grandam Duleibella by Voltigeur, ont of Priestess by The Doctor. Imported Sir Morled and Cheviot were both great race-horses in Australia, and both have become decided successes in the stud in America. Cheviot won the Canterbury Derby, Midsummer Handicap, 2 miles, 120 lbs., and Craven Stakes, $1 \frac{1}{4}$ miles, 133 lbs., and only Sir Modred, his brother, conld beat him for the Canterbury Cup. Cheviot is still at the beginning of his stud career. With the same opportunities, he will take equal rank with his oliler brother as a sire. Among his get, very limited in number, are the following: Osric (winner of the Expectation Stakes last year), Gonzales (a winner last season and of four races this year), Dr. Ross, Vernon, Bernardo (who has captured five races this year, 6 furlongs in 1.15, $1.15_{5}^{t}$ and $1.16 \frac{8}{4}$, each time with 119 lbs., 7 furlongs in 1.26 , with $124 \mathrm{lbs}$., and 1 mile 70 yards in 1.48 ), Princess, half a mile in $0.48 \frac{4}{5}$, with 115 lbs.), Castanet (4 furlongs in $0.58 \frac{7}{5}$ ), Mezzotint (a two-year old winner this year at 5 furlongs), Adolph (another two-year old, that defeated a good field this spring at San Francisco), Prize (a two-year old winner at Washington Park, Chicago, this year from a field of fifteen), and Bridal Veil (winner of Ladies' Stakes, St. Paul, Minn., this year). Cheviot's sire, Traducer, was bred in England, by The Libel (son of Pantaloon) and Arethnsa. Tradncer was the best stallion that ever stood in New Zealand. From 1867 to $18: 1$ he got nine winners of the Canterbury Derby, the greatest event in that conntry, viz.: Scandal, Envy, Defamation, Calnmny, Trump, Card, Natator, Sir Modred, The Dauplin and Cheviot. In three of these years his get ran first, second and third, and in two others tirst and second. He also got Vanguard (winner of the New Zealand Cnp), Welcome Jack (winner of the Canterbury Cup), and Lurline, a great mare, ont of inp. Nermaid. Lurline produced Darebin, who won the Victoria Derby of 1881 , and the best horse of his time thronghont Anstralia. Traducer was to New Zealand and Australia what Lexington or Leamington was to ns, or Hermit was to England. Idalia, dam of Cheviot and sir Modred, was the only Cambnsean mare importell to the colonies. She produced Betrayer, Sir Modred, Idalinm, Cheviot, July, all by Traducer, Liverpool by King of Clubs, chestnut filly by Apremont, and a bay filly by Apremont. Betraser won the Canterbnry Champagne stakes, Canterbury Cup, Wanganal Cup and Timarn Cup. Sir Modred won the Dunedin Champagne Stakes, Canterhnry Champagne Stakes, Dunedin Cup, Canterbury Derby, Timaru Cup, Dunetin Birthtay Handicap, Canterbury Cup, Christ Church Plate and the Syrines Great Metropolitan. July ran second for the Dunedin ('ul). Lirerpool won the Welcome Stakes. Cheriot won the Canterbury Derby, Midsummer Handicap and Cravel stakes, and only Sir Modred, his brother, was able to beat him for the Canterbury Cup. Idalia was the Pocahontas of New Zealant, the queen of its stud. In blood she is rare, being a sister to Onslow (who beat Cremorne, in England, in 1871) by Cambuscan, ont of Dulcibella, who won the Cesarewitch in 1860. Thus her grandams are old Bee's-wing (Newminster's dam), Southdown (Alarm's dam), and Martha Lynn (Voltigenr's dam.) Cheriot shonld be a grand stallion. (See Sir Mlodred, page 254.) 


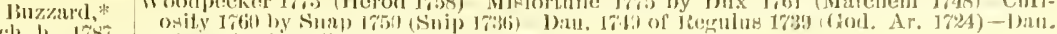

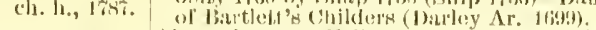

हٔ

बं

尊

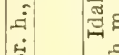

宅

เ⿱丶万仒

\section{Musidora.}

1.. 2m., 18014

Whalebone

Daughter of,

MasterlIenr b. 11., 1815.

Boadicea,
b. $12 ., 180 \%$

Selim,

ch. L., 1802.

Daughter of

ch. $m ., 1808$.

Sir Oliver,

b. h., 1800

Scotilla,

b. m., 1795 .

Paulowitz,

br. L., 1813

Danghter of,

过

สิ

i.

吾

Variety,

m., 1808 .

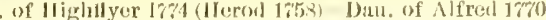

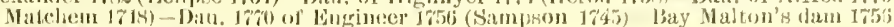

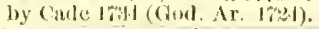

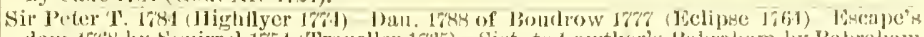

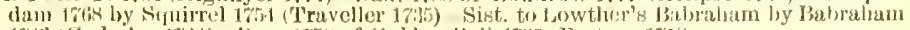

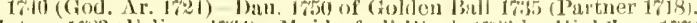

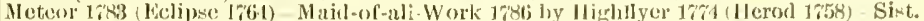

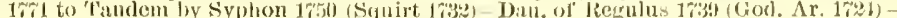

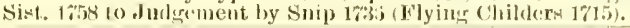

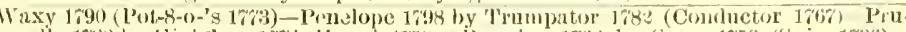

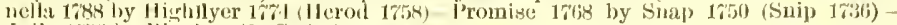
Julia 16,6 loy liank 1\%40 (Gol. Ar. 1\%:2).

Selim 180: (Buzzard* 1787)-Maiden 1801 by Sir Peter T' 1784 (IJiglaflyor 1764)- D:1u. 1788 of Phemmenon 1780 (1lerod 1758) Matron 1783 by Florizel 17(;8(Iierod 1758)-Maiden 1760 by Matchem 1745 (Cade 1731).

Orville 1799 (Buningbrough 1791)-Mliss Sophia 1805 by stamford 179t (Sir l'eter T.

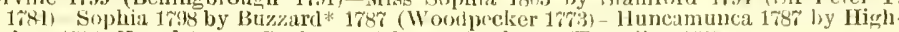

tlyer 17td (Herod 1758)-Cypher 17\%2 ly Squirel 175I (Traveller 1735).

Ilexander 1782 (Eelipse 1764)-Brunette by Amaranthus 17ij; (Old England 1741) - Hav-

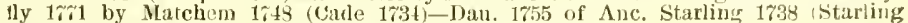
1727) Look-at-me-Lads 1731 by Grasshopper (Byerly 'l'urk)

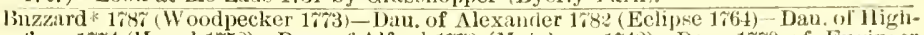
Hyer 17\%4 (IIerod 1758)-Dau. of Alfred 1770 (Matchem 1748)-Dau. $17 \% 0$ of Engincer 1756 (Sampson 1 745 ).

Walton 1799 (Sir Peter T. 1784)-Y. Giantess 1790 by Diomed* 1\%\% (Florizel 1\%(i8)Giantess 1769 by Matchem 1748 (Cade 1731)-Molly Long Legs 1753 by Babraham 1740 God. Ar. 17\%t)-Dan. of Cole's Foxhunter 1727 (Brisk 1711).

Sir Peter T. 1784 (Mightlyer 1774)-Fanny 1790 by Diomed* $17 \%$ (Florizel 1766)-Ambrosia 1783 by Woodpeeker $17 \% 3$ (Herod 1758) - Ruth 1761 by Blank 1740 (God. Ar. 1721) Sist. 1751 to South by Regulus 1739 (God. Ar. 1\%24).

Auvil 17\% (IIerod 1758) - Scota 1783 by Eclipse 1764 (Vlarske 1750)-Harmony 1775 by llerod 1758 (Tartar 1743) Rutilia 1769 by Blank 1740 (God. Ar. 1724)-Sist. 1751 to South by Regulus 1739 (God. Ar. 1721).

Sir Paul 1803 (Sir Peter T. 1784)-Evelina 1791 by Hightlyer 17\%4 (Herod 1758)-Termagant by Tantrum 1760 (Cripple 1750)-Cantatrice by Sampson 1745 (Blaze 1733)-Dau. 1 is $\gamma$ of Regulus 1739 (God. Ar. 1724).

Paynator 1791 (Trumpator 1782)-Dal, 1805 of Delpini 1781 (Highflyer 1774)-Dau. 1795 of Y. Marske 17\%1 (Marske 1750)-Dan. of Dorimond 1758 (Dormouse 1738)-Portia 1758 by Regulus 17.39 (God. Ar. 1724).

Sir Peter T. 1781 (Highflyer $1 \% 74$ )-Fanny 1790 by Diomed $17 \%$ (Florizel 1768)-Ambrosia 1783 by Woodpecker $17 \% 3$ (Herod 1758)-Ruth 1761 by Blank 1740 (God. Ar. 1724)Sist. 1751 to South by Regulus 1739 (God. Ar. 1724).

IIyacinthus 1797 (Coriander 1786 )-Sist 1790 to Swordsman by Weazle 17i6 (Herod 1753) -Dau. of Turk 1763 (Regulus 1739)-Dau. of Locust 1744 (Crab 1722)-Dau. of 1758 Changeling 1747 (Cade 1734).

\section{Camel,}

W' halebone 18)7 (Waxy 1790)-Dall. 1812 of Selim 1802 (Buzzard* 1787)-Maiden 1801 by Sir Peter T. 1784 (Highflyer 1\%4)-Dau. 1788 of Phenomenon 1780 (Herod 1758)Matron 1782 by Florizel 1768 (Herod 1758$)$

공 br. h., 18\%. Matron 1782 by Florizel 1768 (Herod 1758 )

Banter Master Henry 1815 (Orville 1799)..Boadicea 1807 by Alexander 1782 (Eclipse 1764)-Brunette by Amaranthus 1766 (Old England 1741) Mayfly $17 \% 1$ by Matchem 1748 (Cade 1731)-Dau. 1755 of Anc. Starling 1738 (Old Stalling 172\%

मं قُ

Paymator 1791 (Trumpator 1782)-Dau of Beningbrough 1791 (King Fergus 17\%5) -Jenny Ilole 1787 by Carbuncle 17\%2 (Babr. Blauk 1758)-Dalt. 17\%3 of Prince 'T'Quassaw 1751 (Sntp 1736)-Sultana 1759 by Regulus 1739 (God. Ar. 17:4).

Z

E Daughter of

Ardrocsan 1809 (John Bull 1789) - Lady Eliza 1813 by Whitworth 1805 (Agonistes 1797)Dallghter of, A X Y. Z.'s dam 1793 by Spadille 1781 (Highfyer 17\%)-Sylvia 1783 by Y. Marske 1761 (II irske 1750)-Ferret 1735 by Broth. to Silvio (Cade 1734).

atton 1209 (Golumpus 1802)-Dau 1818 of Smolensko 1810 (Sorcerer 1\%96)-Lady Ilary 1800 by Beningbrough 1791 (King Fergus $17 \%$ )-Dau. of Highflyer 1\%4 (Herod 1758)-Sist. to Miss Bell by Marske 1750 (Squirt 1732).

20.1.

Orville 1799 (Beningbrongh 1791)-Epsom Lass 1803 by Sir Peter T. 1784 (Highflyer b. $1 \% 71$ (Marsk 1750 )-Dau. of Y. Cade 1747 (Cade 1731).

过

Whalebone $180 \%$ (Waxy 1790)-Defianee 1816 by Rubens 1805 (Buzzard* 1787)-Little

Defence, Folly 1806 by Highland Fling 1798 (Spadille $17 \times 4$ )-Harriet 1799 by Volunteer 1780 (Eelipse 1\%64)-Dau. 1785 of Alived $17 \% 0$ (Matehem 17-18)

X. Y. Z. 1808 (Haphazard 179\%)-Janetta 1803 by Beningbrough 1791 (King Ferous 1775)-Dau. 1797 of Drone 1777 (Herod 1758). Contessina 1787 by Y. Marske 17\%1 (Marske 1750)-Tuberose 17\%2 by Herod 1754 (Tartar 1743).

घ. Feltonu,

b. m., 1819

Whitelock 1803 (Hambletonian 1792) - Dau 1799 of coriander

Blacklock,

$=$ b. h., 1814 . (Eclipse 1764)-Manilla $17 \% 7$ by Goldfinder 1764 (Snap 1\%50).

$\frac{\widetilde{\sigma}}{6}$ - Daughter of

b. $\mathrm{m}, 1816$

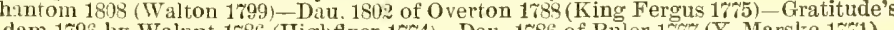
dam 1796 by Walnut 1786 (Highfiyer 1774)-Dau. 1786 of Ruler $17 \%$ (Y. Marske 17t1)Piracantha 1772 by Matchem 1748 (Cade 1734).

Mitulatto,

Catton 1809 (Golnmpns 1802)-Desdemona 1811 by Orville 1799 (Beninobrough 1791)Fanny 1796 by Sir Peter T. 1781 (Highflyer 174)-Dau. 1788 of Diomed $1 \%$ (Florizel 1768)-Desdemona 1770 by Marske 1750 (Squirt 1732).

Filho-da-Puta 1812 (Haphazard 179\%)-Treasure 1899 by Camillus 1803 (Hambletonian 1792)-Dau. 1804 of Hyacinthus 1797 (Corlander 1786 ) - Flora 1789 by King Fergus 1775 (Eelipse 1764) - Atalanta 1769 by Matehem 1\%tS (Cade 1734).

m., 1824

Dr. Syntax, Papnator 1791 (Trumpator 1\%8) - Dau. ot Beningbrough 1791 (King Fer'ous 17\%5)-Jenny

仓․ br. h., 1811 . (Sntp 1736)-Suitana 1759 by Regulus 1739 (God. Ar. 1721)

Lottery 18:0 (Tramp 1810) -Elizabeth 1821 by Walton 1799 (Sir Peter T 1784)-Trulla

它 1815 by Sorcerer 1796 (Trumpator 1782)-Dan. 1796 of Weathercock 1785 (Hightyer 1\%74)-Cora $17 \%$ by Matchem $17 \pm 3$ (Cade 1\%31).

过定 br. m., 182.

Humprey Clinker 1822 (Comns 1809)-Velvet 1823 by Oisear 1809 (Camillus 1803)-

Bran,

IVire 1811 by Waxy 1790 (Pot-8-o-'s 1773) Penelope 1798

ch. h., 1831

ductor 1767)-Prunella 1788 by Highflyer 1774 (Herod 1758)

Idalia,

Peruvian 1803 (Sir Peter T. 1784) - Musidora b. m. 1804 by Meteor 1783 (Eelipse 1764)Maid-of-all-Work b. m. 1786 by Highflyer $177 t$ (Herod 1758)-Sist. b. m. 17\%1 to Tindem by Syphon 1750 (Squirt 1732)-Dau. b. m. of Regulus 1739 (God. Ar. 1724) - Sist. 1758 to Judgement by Snip 1736 (Flying Childers 1715 )-Dau. b. m. 1745 of Cottiugham 1735 (Hartlev's Blnd Horse)--The Warlock Galloway ch. m. 1\%2s by Snake (Lister Turk) - old Lady ch. m. by the Bald Galloway (st. Victor Barb) - The Wharton mare by the Carlisle Turk-Dau. of Byerly Turk. 


\section{COLONEL CLARK.}

Property of Wilson P. Hunt, Glen Echo Stud, Normandy, ML.

Colonel Clark, ehestnut horse, foaled 1882, bred by H. C. Shafer, Tennessee, by imp. Glengarry, son of Thormauby, winner of the Derby, by Windhound, dam Kate Fisher by Bill Cheatham, son of imp. Albion, and Lalla Rookh by imp. Glencoe, out of Lizzie Hoover's dam by imp. Sovereign, etc. Glengarry was imported in December, 1866, and so badly injured that he raced only moderately well. Thormanby, his sire, was by Uelbourne or Windhound, unquestionably by the latter, son of Pantaloon br Castrel. Thormanby defeated, in the Derby, The Wizarl, winner of the 2,000 Gnineas, won the Ascot Gold Cup, and was the sire of Charibert and Atlantis, winners of the 2,000 Guineas, and of Ronge Rose, the dam of the grand race-horse Bent'or, winner of the Derby and sire of the nubeaten Ormonde. Glengarry's dam Carbiue by Rifleman, winner of the Great Yorkshire Stakes, Convivial and Claret. Stakes, and by Touchstone. Colonel Clark's dam, Kate Fisher, is the dam of Kingsland, Joe Mitchell, Lncinda C., Glenfisher, Longfish (winner of the St. Louis Derbs) Kitty Cheatham, etc., and by Bill Cheatham. Henrietta, half sister to Colonel Clark, is the dam of the winners Germania, Sample, Fraud and Harry Glenn. Colonel Clark's grandam the dam of Lizzie Hoover br imp. Sovereign, son of Emilins, and the celebrated Flem de Lis by Bourbon, she ont of Katy Fagan by imp. Leriathan, she the dam of Miss Odom (Bay Odom), the dam of Mary Wylie, Godiva, Shanghai, Savoy, ete., and she ont of Luey Brooks by Old Bertrand, son of Sir Arehy and Eliza by imp. Bedford. The family race and produce race-horses. Colonel Clark was a good race-horse, winner at one inile in 1.45, and again in 1.51 with 149 lbs.. 7 furlongs in $1.28 \frac{1}{2}$, and was placed second in a number of good races with good horses behind him. Colonel Clark has been in the stud only a few seasons, but is the sire of the winners, Lottie Mills, Laura B., Luey Clark, ete. 


\title{
IMPORTED DAREBIN.
}

\author{
The. property of Mr. J. B. Haggin, Rancho-del-Paso Stud, Sacramento, Cal. \\ Used only as private stallion. Iearlings sold ammally.
}

DAREBIN, brown horse, foaled 1878, bred by Mr. S. Gardiner, of Bundoora Park, Anstralia, by The Peer, an English-bred horse, by Melbourne, dam Cinizelli, and full brother to Marchioness, the Oaks wimer, hy Touchstone. Lurline, the dam of Darebin, was one of the best mares that was ever stripped for a race in Australia. She won the Anstralian Cup of 1875, the Christchurch Plate in 1872 and 1873, the Canterbury Cup of 1872 and 1873, and is the dam of Prometheus, Motea Maroondah, etc., the best race-horses of New Zealand. Darebin was one of the greatest, possib]y the greatest, race-horses of the Sonthern Hemisphere. Traducer, the sire of Lurline, was by The Libel, son of Pantaloon and Pasquinade, sister to Tonchstone. Darebin, at two vears old, was so big and raw that he did not do much. He ran third for the Ascot Vale Stakes at the V. R. C. Autumn Meeting of 1881, the race being won by Royal Maid. At the same meeting, with $12 ! 1$ bs., he was second to Coreena, 88 lbs., for the Second Nursery, Tommaline, 106 liss., third, and sixteen others behind them. At Adelaide he was umplaced, with 122 lbs., for the Nursery, won by Henrietta, 1221 bs., and the following rlay won the Two-Year-Old Handicap, 122 lbs., Result, the second horse, having 117 lbs., and Spectre 103 lbs., seven others unplaced. At three years old he began by winning the great Victoria Derby. Santa Claus second, Commotion and several others mplaced. Two days later Darebin essayed a great task. Mr. Dakem, lis owner, started him for the Great Melbourne Cup, two miles (handicap), with 96 lbs., won by Zulu, a four-year old with ouly $80 \mathrm{lbs}$. on his back. At the same meeting he won the Mares' Produce Stakes, 5 lbs. penalty, beating Mommonth, Commotion, Santa Clans, etc. At the V. R. C. Summer Meeting he ran second to Respite for the 'Touraville Stakes, four others starting. He was third in the St. Leger to Commotion and Pell Mell; was second to Bathurst in the Grand Stand Stakes; was unplaced with 122 lbs, to Commotion's 119 lbs., for the Town Plate. At Adelaide he won the St. Leger, beating Dutchman. He also won the Birthclay Cup of $£ 1,000$ with 120 lbs., beating Crystal, 4 years, 107 lbs., Topaz, 3 rears, 100 lbs., and eleven others. At fonr years old Darebin ran unplaced with 135 lbs., to Little Jack. 3 years, 91 1ls., for the Canlfield Cup, twenty-eight starting. At Melbourne he won the Melbourne Stakes, beating Belmont. Larpent and seven others. In the Melhourne Cup he took up 135 Jbs. and ran unplaced to Assyrian, a five-sear old, with 111 lis. At the same meeting won the Royal Park Stakes, beating Lord Burghley, Liberator and three others, and was second to Commotion for the Canterbury Plate, beating smart Wil. liam and two others. Darebin was purchased by Mr. E. C. Cox for stud purposes, aud the great horse crowned a splendid career by landing the Srdney Cup, althongh he had np $134 \mathrm{lbs}$. In this race lue gave $30 \mathrm{lls}$. to Mistaken, who finished second, and 20 1bs. to Willeroo, the third horse, aud conceded 47 lbs. to the rainimum weight, Musjid, an aged gelding.

At the death of Mr. Cox his stud was sold at auction, and Darebin was held in reserve at 1,000 guineas. He was soon after sold privately to $\mathrm{Mr}$. Alexander Gorlon, of the Grange Stud. Ipswich, Queensland, through his agents, Messrs. Rran, Haumond \& Donker. He made the season of 1885 at the Grange Stud. It was at this time that, failing to secure Commotion, Mr. Haggin made an offer of $\$ 15,000$ for Darebin, which was refused, and Mr. Haggin purchased Sir Hodred, the erack racer of New Zealand. His Antipodean purehase pleased him, as the additional purchase of Darebin would indicate.

Darebin is probably nearer to old English Melbourne than any other stallion living, and this alone shonld make his blood eagerly songht after, as the Melbourne blood, as shown through West Australian, Sir Tatton Sykes, Blink Bouny, Mentmore Lass, Barcaldine, imp. Anstralian, ete, etc., has done so exceedingly weli.

Darebin has had no opportmity in the stud in comparison with Sir Modred, hut the number and success of his get which have run demonstate that he needs only time to make as brilliant a reputation as a sire as he earned as a race-horse. Before leaving Anstralia he got many good animals, and here lie is the sire of Ludwig, Kil-

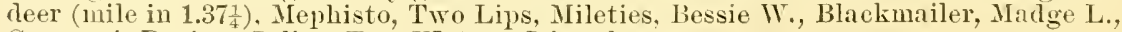
Garwood, Daring, Julien, Tom Watson, Iris colt, etc.

It is to the Oldfield mare to which trace in direct female line Trumpator (by Con(ductor), Touchstome, Buccaneer, imp. Leamingtou, Macaroni, Saccharometer, IVild Oats, Saraband, etc., etc. 


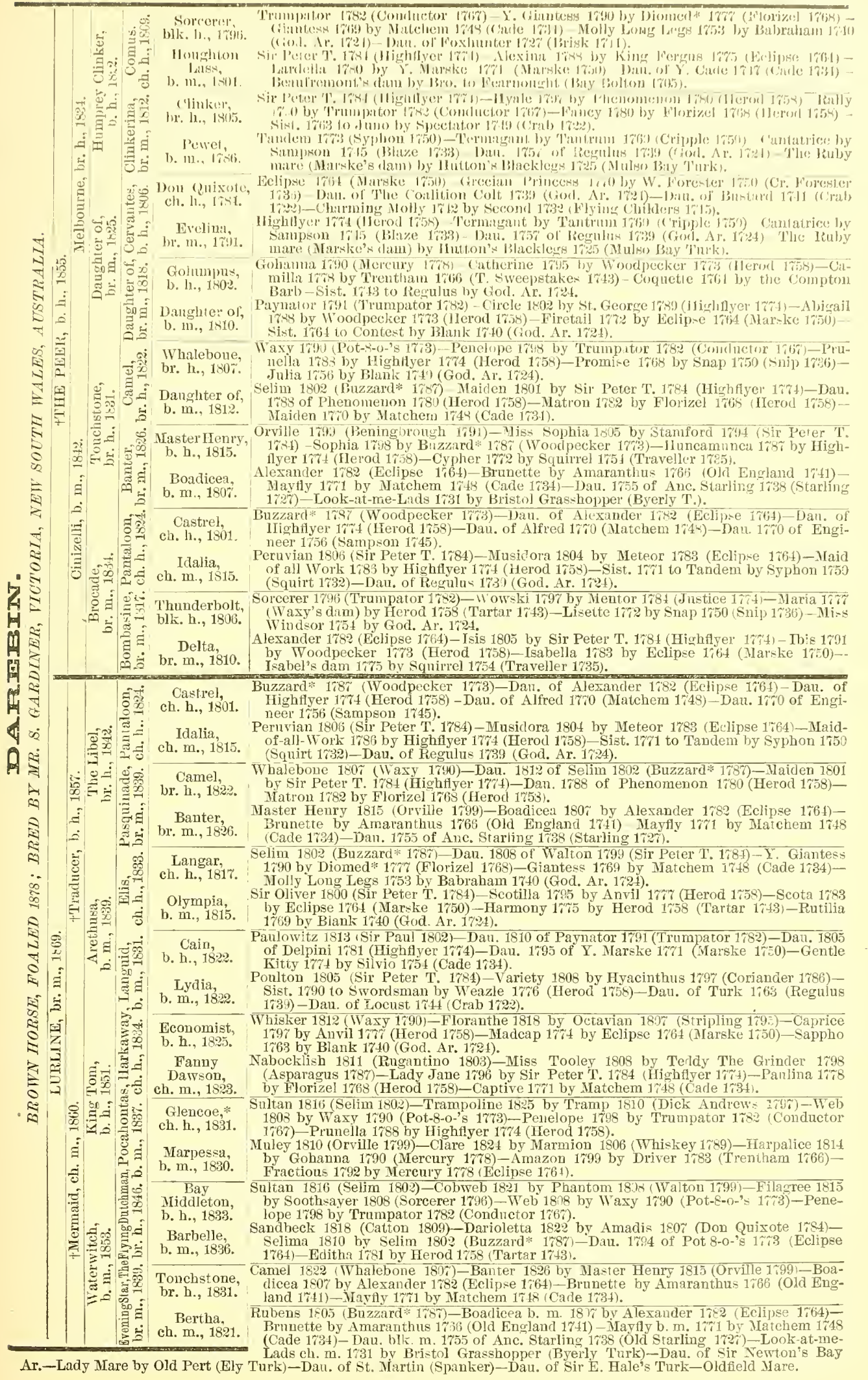




\section{DAY STAR.}

WINNER OF THE BLUE RIBBON STAKES AT LEXIYGTON, AND KENTCCKY DERBY AT LOUISTILLE, KY., IN 1878.

\section{Will stand for mares at the farm of WT. S. Payne, near Lexington, Ky. Terms at opening of season.}

DAY STAR, by Star Davis, son of imp. Gleneoe, bred by John Mi. Clar, Ashland Stud, Kentucky, foaled 1875, dam Squeez'em by Lexington, out of the noted Skedaddle by imp. Yorkshire, son of St. Nicholas by Emilins. Day Star started twice as a two-year old, in 1877, was umplaced in the Colt Stakes, three-quarters of a mile, at Lexington, won by Himyar in 1.16? ran second to Blne Eyes in the Sanford Stake, 1 mile at Lonisville, Ky., in 1.451, beating Himyar. As a three-year oli, won the Blue Ribbon Stake at Lexington, $1 \frac{1}{2}$ miles, in 2.401, defeating Leveler, Solicitor. Blue Eres, Fortuna and six others. Lonisville, kir., Won the Kentucky Derby, $1 \frac{1}{2}$ miles, in 2.37 others; ran dead heat with Solicitor for second place in Clark Stake, 2 miles, won by Leveler in 3.37, beating 3lne Eyes. Nashville, Tenn., ran secoud to Milan, in purse race, 1 mile, $1.45 \frac{1}{4}$, beating Paricles. At four rear's old started eight times, ran a elose, good second to the great mare Janet, 4 miles, in 7.25. he carrying $110 \mathrm{lbs}$. to hel 15, he fonr and she six years old. In this race he beat Charley Bush, Minnoch and two other's. He was then purchased by Charles Reed and put over timber. Baltimore, Md., won steeplechase, full course, earrying 154 lbs., beating Fanstina and Judith. Saratoga, won steeplechase, about $2 \frac{1}{4}$ miles, with 152 1bs. beating Capt. Franklin, Rose and Faustina; ran third in race on tlat, $1 \frac{1}{2}$ miles, won by Tureme, in $2.45 \frac{3}{2}$; was nuplaced in that race, $1 \frac{5}{8}$ miles, won by Oden in $2.5 \frac{1}{4}$; won hurile race, $1 \frac{3}{2}$ niles, over six hurdles, in 2.53ㄹ, beating Frank Short, The Stranger and Rose; ran second to Chimney-sweep, 2 miles, over eight hurdles, in 3.55 , three others behind him, and ran third to Pomeroy and Lizzie D. in steeplechase at Baltimore, in the fall, abont $1 \frac{1}{2}$ miles, in 4.03 ; he was nnplaced in two other races over timber. At six years old started ten tiuses, won tive races, was second in three and third in one. Baltimore, ran dead heat and divided purse in steeplechase with Derbr, beating Joe Hunt and Surprise. Sheepshead Bay, won steeplechase, short course, in 5.15, beating Highland Fling, Capt. Franklin and two others; won steeplechase over fnll conrse, in 5.12, beating Frank Short, Joe Hunt aud two others. Jerome Park, won steeplechase over short course in 3.23, beating Trouble, Bertha and three others; won hurdle race, $1 \frac{3}{4}$ miles, over seven hurdles, in 3.29, carrying $1491 \mathrm{ls}$., beating Ingomar. Frank short, ete. In all the other races he was beaten by the best horses then on the turf, he carrying his full impost of weight. At seven vears old won one race and was third in one. Sheepshead Bay, wou steeplechase, short conrse, in 5.09? beatiug Ohio Boy, Ike Bonbam and four others. Day star is a bright chestnut; with roan flanks, both front ankles white, and one hind foot white halt way to hock, and a narrow white stripe down the face; stanls full 15 . power, is a highly shaped horse and rery evenly balanced all orer, exhibiting speet, strength and enturance in a remarkable degree. He is desceuded from one of the greatest and best racing families in America. On the side ot his sire we have Wagner. Inaria Wool, Heraldry. Wade Hampton, Yorktown, Capt. Travis, Balloon, True Blne anis other famois horses. On the dau's side we have Magie, Marlonna, Princeton. Daniel Boone, Skedadlle, Kentucky, Madeline and Maggie B. B., the dam of Harolil and the great horse Irognois, winner of both the St. Leger and Derby in England. Thus it is fair to presmme that a horse possessing all the qualities of a good racehorse, and descender on both sire and dam's side from one of the best racing timilies in America, and tracing through the eollateral branches to the most famons horses in England, must get race-horses, and we commend Day Star to the breeders of America.

Day Star has covered but few thoronghbred mares, but is sire of the winners Day Dream, Altair, Jack Star, King Star, Celia, winner at 7 furlongs, in 1.28, 1 mile in

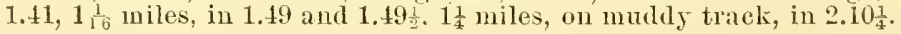




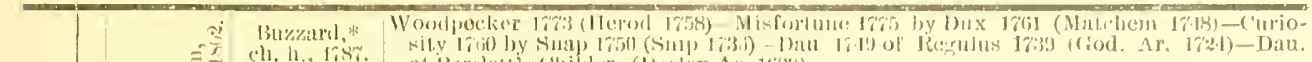

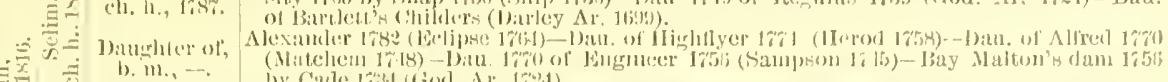

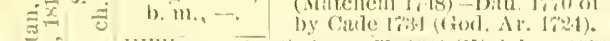

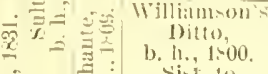

Salomel.

b. 111,16 in

l)icki

Ii]lin:

I?

1):u lora of

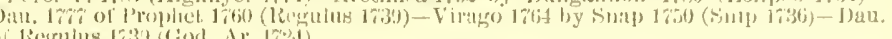

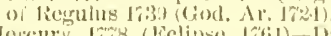

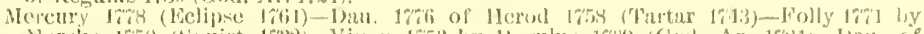

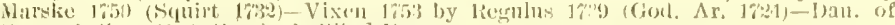

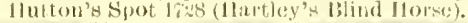

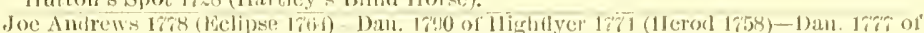

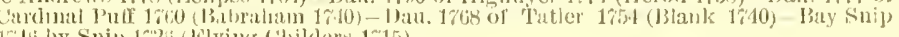

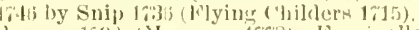

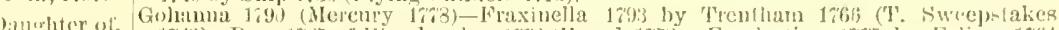

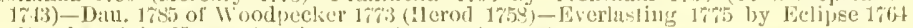
( Marske 1756)-Hyicna 176? by suat) 1750 (Snip) 17i36).

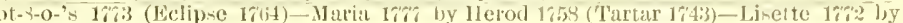

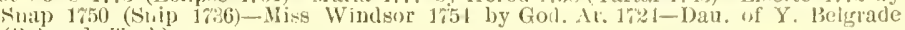
(1'selgride 'l'mrk).

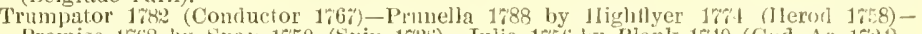
Promise 1768 by Suap 1750 (Snip 179(i) -Julia 175ti by Blank 1740 (Gud. Ar. 1724)Spectator's dan 1355 by Partnel 1718 (Jirg).

b. 1., 179 .

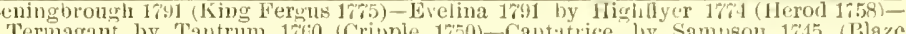
Termagant by Tantrum 1760 (Cripple 1750)-Cantatrice by Sampson 1745 (B]aze 1733)-Dau. 1757 by Regulus 1733) (God. Ar. 1724

Emily Stamford 1794 (Sir Peter T. 1784)-Dau, 179? of Wliskey 178) (Saltram* 1780)-Grey Dorimant $178 \%$ by Dorimant $17 \% 2$ (Utho 1760)-Dizzy 1757 by Blank 1749 (God. Ar. 1721)-Anc. Dizzy $1 \% 41$ by Driver $17 \%$ (Wynn Ar.).

cl. m., 1810

Whiskey,

b. li., 1789

Saltram* 1780 (Eclipse 1764)-Calash $17 \% 5$ by Herod 175 Matehem 1718 (Cade Miss Starling Jr. 1752 by Starling 1\%27 (Bay Bolton 1\%05).

$\equiv$ Y. Giantess, Diomed*17\% (Florizel 1r68)-Giantess 1769 by Matehem 1748 (Cade 1734)-Nolly Long

b. m., 1790. Legs 1753 by Babraham 1740 (God. Ar. 1724)-Dau. of Cole's Foxhunter 1727 (Brikk 1711) - Sist. to Cato by Partner 1718 (Jigg)

Sir Archy,

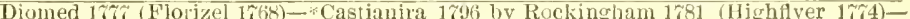

-Tabitha 17S2 by Trentham 1766 (T. Sweepstakes 1743)-Dau. of Bosphorus 1751 (Babrahim 1710)-Dau. of Forester 1750 (Forester 1736).

Citizen 1785 (Pacolet 1763)-Dan. of *Alderman 1787 (Pot-8-0-'s 1763)-Dan, of Ashe's Roebuck ("Sweeper) -Dau. ol' Ilaine's King Herod 1\%70 ("Fearnought 175.5)-Dau. of Partmer 1755 ( $*$ Traveller $1 \% 47$ ).

b. m., -

Pacolet 1itis (Blank 1740)--Princess $17 \% 4$ by Turk 1763 (Regulus 1759)-Fairy Queen 1762

Citizeu, Paco Y. Cade 1747 (Cade 1734)-Black Eyes 1740 by Crab 1722 (Alcock Ar.) - Warlock

b. L., 1.85. Galloway $1 \% 28$ by Snake (Lister Turk).
Huntsman 178. (* Mou-etrap 1\%71)-Dau. of Symmes" Wildair 1\%67 (\%Fearnought 1;55) baughter of, M., 1795. Dau of *Fearnought 1755 (Regulus 1739 )-Dau. of *Janus 1746 (Janus $17399^{\circ}$ ).

\section{Sir Archy,}

Diomed 177 (Florizel 1768)-Castianira 1796 by Rockingham 1781 (Highflyer $17 \%$ )-

b. h., 1805 .

Tabitha 178: by Trentham 1766 (T. Sweepstakes 1743)-Dau. of Bosphorus 1754 (Babraham 1740)-Dan. of Forester 1750 (Forester 1736).

Daugter of Saltram 1780 (Eclipse 1764)-Dan of Symmes' Wildair 1\%67 (*Fearnought 1755) -Dau: of Tyler's Driver 1760 (*othello)-Dau. of *Fallower 161 (Blauk 174)-Dau. of *Vampile $17.5 \%$ (Regulus 1739).

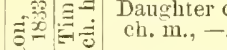

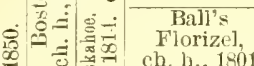

Diomed 17\%7 (Florizel 1768)-Dau. of *Shark 1\%1 (Marske 1750)-Dau. of Harris" Eelipse 1\%70 (*Fearnought 1755)-Dau. of *Fearnought 1\%55 (Regilus 1735)-Dau. of *Jolly Roger 1711 (Rouildhead 193:)-Dan. of Sober John 1748 (Rib 1:6).

Flderman 1787 (Pot-8-0-'s 1773-Dau. of 'Clockfast 17\%4 (Gimcrack 1\%60)-Dau. of b. m., 1799 . Symmes" Wildair $176 \%$ (*Fearnought $1 \% 55$ ) - Y. Kitty Fisher $1 \% 6 \tau$ by Feal'nought 1755 (Regulus 1739) - Kitty Fisher 1755 by Cade 1734 (God. Ar. 1\%24) Emilius, Orville 1799 (Beningbrough 17\%1)-Emily 1510 by Stamford 1794 (Sir Peter T. 1784)-
Dall. 1799 of Whiskey 1789 (SaItram 1780)-Grey Dorimant 1781 by Dorimant $17 \% 2$ (Otho 1760)-Dizzy 175 ; by Blank 1740 (God. Ar. 1724).

b. h., $18: 0$.

The Flyer 1814 (Vandyke Jr. 1808)-Parma 1813 by Dick Andrews 1\%97 (Joe Andrews

Icaria,

1768 - May 1804 by Peningbronoin 1791 (King Ferous 1\%5)-Primrose 1787 by Mambrino 1762 (Engineer $175 \%$ )-Cricket 176 by Herod 1758 (Tariar 1743).

Sumpter. Sir Archy 1805 ( Diomed 1\%7r)-Robin mare by * Robin Redbreast $1 \% 96$ (Sir Peter T. 1784)-Dau. 1788 of *Obscurity 177 (Eclipse 1764)-Slanerkin $1 \% 68$ by *Wildair 1753

ch. h., 1818. (Cade 1734)-C Cub mare 1762 by Cub 1739 (Fox 1714).

Lady Grey, Robin Grey 1805 (Royalist 160)-Maria 18* Fearnought 1755 (Regulus 1r39)-Dau. of Ariel 1.750 ( Traveler 1747 ).

b. m., 1817

Emilius,

Orville 1799 (Beningbrough 1791)-Enily 1810 by stamford 1794 (Sir Peter T. 1784)Dau. 1799 of Whiskey 1789 (Saltram* 1780)-Grey Dorimant 1781 by Dorimant 17\%?

b. h., 182\%. (Otho 1760)-Dizzy 175\% by Blank 1740 (God. Ar. 14\%4).

Sea-mev,

(Beningbrough 1791) - Goosander 1805 by Hambletonian 1792 (King Fergus 175 ) - Rally 1790 by Trumpator 1732 (Conductor 1767 -Fancy 1780 by Florizel 1768 (Herod 1758) - Sist. 1763 to Juno by Spectator 1749 (Crab 1\%22).

Tramp Dick Andrews 1797 (Joe Andrews 17\%)-Dau. 1803 of Gohanna 1790 (Mereury 17\%8)Fraxinella 1793 by Trentham $1766^{\circ}$ (T. Sweepstakes 1\%43)-Dau. 1785 of Woodpecker

1773 (Herod 1758)-Everlasting 17\%5 by Eclipse 1764 (Marske 1750).

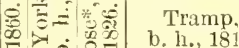

Dingher of, Sancho 1801 (Don Quixoté 1784)-Blacklock's Dam 1799 by Coriander 1'86 (Pot-8.0-'s $17 \% 3$-Wildgrose 1792 by Highflyer 17,4 (Herod 1758)-Coheiress 1786 by Pot-8-0-s 17\%3 (Eclipse 1764)-Maniİla 17\%7 by Goldfinder 1r6t (Snap 1750).

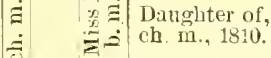

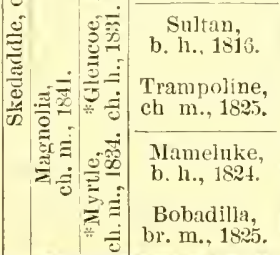

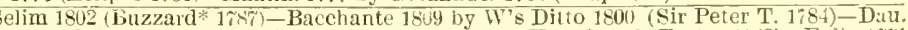

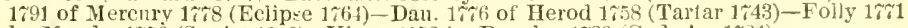
by Mar-ke 1750 (Squirt 1752) - Vixen 1753 by Reguins 1739 (God. Ar. 1721).

Tramp 1810 (Dick Andrews 1707) - Web 1808 by Wary 1700 (Pot-8-0-'s 17r3) Denelope $1 \tau 98$ by Trumpator 1782 (Conductor $176 \%$ )-Prunella 1788 by Highflyer 17i4 (Herod 1758)-Promise 1768 by Snap 1750 (Snip 1736)

Partisan 1811 (Walton 1799)-Miss Sophia 18t5 by Stamlord 1794 (Sir Peter T. 1781) Sophia 1798 by Buzzard* 1rs\% (Woodpecker 1\%:3)-Huncamunca 178\% by Highflyer 1774 (Herod 1758)-Cypher 17\%2 by Squirrel 1\%54 (Traveller 1\%55).

Bobadil 1813 (Rubens 1805)-Pythoness blk. m. 1813 by Sorcerer 1796 (Trumpator 1782) Princess blk. m. 1796 by Sir Peter T. 1784 (Hightyer 17i4)-Dau. br. m. 1784 by Dungannon 1780 (Eclipse 1\%64)-Dau, ch. m. 1783 of Turf 1760 (Matchem 1748)-Dau. b. Ar. 1724)-Spinster ch. m. 1735 by Partner 1718 (Jigg) -Bay Bloody Buttocks b. m. 1729 by Bloody Buttocks-Sist. 1722 to Guy by Greyhound (Chillaby)-Brown Farewell br. m. 1710 by Makeless (Oglethorpe Ar.) - Dau. of Primmer (D'Arcy Yellow Turkj-Dau. of Place's White Turk-Dan. of Dodsworth-Layton Barb Mare. 


\section{IMPORTED DECEIVER.}

WINNER OF THE EPSOM GRAND PRIZE. Property of Messrs. S. C. Lyne \& Co. Stands at Larchmont Stock Farm, Win-
dom, Ky. Service by eontract.

IMPORTED DECEIFEr, bay horse, foaled 1880, bred by Her Majesty Queen Victoria, by Wenlock (winner of the St. Leger), son of Lord Cliften (winner of the St. Leger) by Newminster by Tonchstone. His dam Boot and Saldle by Trumpeter, son of Orlando (winner of the Derby) by Touchstone, out of Rinderpest by Alarm, wimner of the Cambridgeshire Handicap, son of Venison by Partisan. Wenlock is the sire of Sanda, the dam of Sainfoin, winuer of the Derby in 1890. Adine, his (Deceirer's) grandam is by Slane, sire of Conyngham, winner of the 2,000 Gnineas, and Merry Monareh, winner of the Derby, and The Princess, winner of the Oaks, son of Royal Oak by Catton. Alarm is sire of 'Torment, the dam of the Oaks winner Tormentor by King Tom, and dam of Laura, dam of Petrareh, winner of the 2,000 Guineas, St. Leger and Ascot. Gold Cup, imp. Laureate and Rotherhill. Deceiver's great grandam is by imp. Glencoe. Deceiver was a good race-horse at two years old, ran third in the Chesterfield Stakes to Galliard and Export, Malibran, Touch-Me-Not behind him; ran second in Hulnaker Stakes to Beine Blanche, eight others behind him, inclnding Blue Rock, and was unplaced in the Prendergast Stakes. At three years old ran third to Grandmaster and Ossian in the Newmarket Craven Stakes with eight others behind him; mas unplaced

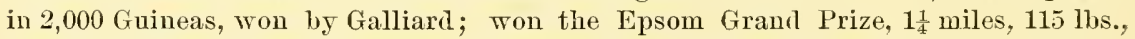
beating Goldfield, Ossian, Energy and four others; was unplaced in the Ascot Derby ; ran second to Galliard in the St. James Palace Stakes, 1 mile, beating Potosi; ran third in the Midsummer Stakes at Newmarket, and was nnplaced in the Stewards" Cup at Goodrood and Chesterfield Cup at Ascot; ran second to Montroyd in Wharneliffe Stakes, 1 mile, at Doncaster, with three others behind him; was third in the Free Welter Handicap Plate at Brighton and third in the Ashcombe Handicap at Lewes. At four years old was unplaced in City and Suburban Handlicap; ran second to Southampton in Princess of Wales Free Handicap at Sandown Park, with nine behind him; was third in the Epsom Town Plate and unplaced in Rosal Stakes at Epsom. Deceiver combines all the best racing blood in his pedigree, and traces to the Childers mare, to which trace in direet female line Bustard (by Buzzard), Hamptou (by Lord Cliften), Blair Athol and all the Queen Mary family, Petrarch, Pretender, Sir Berys, Tristan, Carlton, Beanelerc, Rotherhill and all the Postmaster and Peggy family in America.

Deceiver is a success in the stud. Sire of Brownwood, Ceverton, Cruickshank, Deceit, Doneaster, Ducat, Falstaff, Fay S., Frank Kinny, Florence T., John Berkles, Judge Arkell, Marietta, Mirage, Peddler, Pretender, Puryear D., Orlie, Raguarock, etc. 


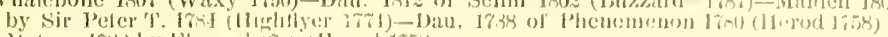

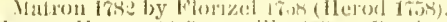

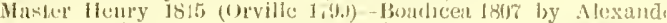

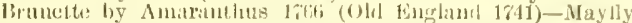

(C'ale lo

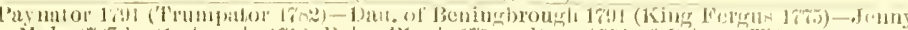

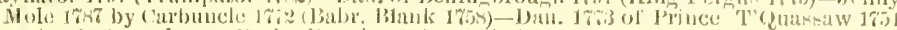

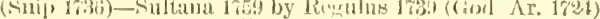

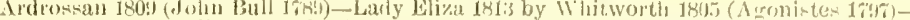

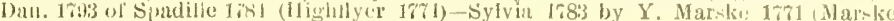

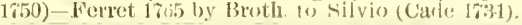

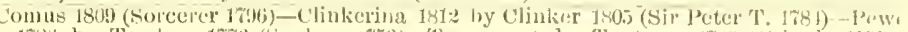

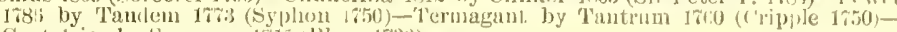

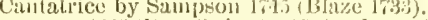

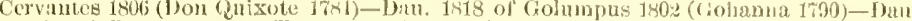

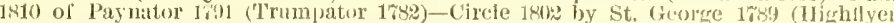
17\%4)-Abigail 1788 by 11 oodpecliex 1703 (Iterod 1758$)$.

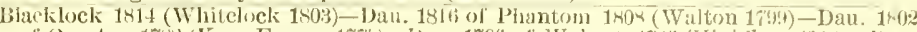

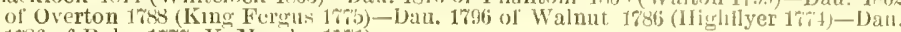
$1 ; 86$ of Ruler $17 \% \%$ (Y. Marske 17\%

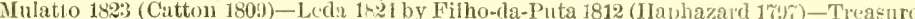

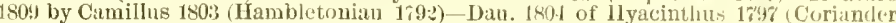
1786)-Flora 1789 by King Ferous $17 \% 5$ (Eclipse 1761).

Sir Hercules 18:6 (Whalebone 180\%)-Guiccioli 18\%3 by Bob Booty 1804 (Chanticleer 17\%7)-Flight 1809 by Ir. E-cape 1802 (Commodore 1793)-Y. Iferoinc by Pasot 1780 (11crod 1758)-IIeroine 1675 by Hcro 1753 (Cade 1734)

Economist 1825 (Whisker 1812) - Miss Pratt 1825 by blacklock 1814 (Whitolock 18(13)Gadabout 1812 by Otville 1799 (Beniugbrough 1791)-Minstrel 1803 by Sir Petcr T. 178 (Highflyer 1\% 1 )-Matron 1722 by Florizel $1 \% 68$ (Herod 1758),

Sultan 1816 (Selim 180:2)-Trampoline 1825 by Tramp 1810 (Dick Andrews 1797)-W Web 1806 by Waxy 1790 (Pot-8-o-'s 1779)-Penelope 1798 by Trmmpator 1782 (Concluctor 1767) - Prunella 1788 by Highflyer $17 \% 4$ (11eror 1758).

Muley 1810 (Orville 1799) - Clare 1821 by Marmion 1806 (IThiskey 1789)-Harpalice 1814 by Gohanna 1790 (Mercury 17\%)-Amazon 1799 by Driver 1783 (Trentham 1\%66)-Fractious 1792 by Mercury $17 \%$ (Eclipse 1\%(6).

Whalebone 1807 (Waxy 1799 )-Peri 1822 by Wanderer 1811 (Gohanna 1890)-Thalestri 1809 by Alexander 1 i 22 (Eclipse 1764)-Rival 1800 by Sir Peter T. 1784 (Highflyer 1774) - Hornet 1750 by Drone $17 \%$ (Herod 1758)

Bob Booty 1804 (Chanticleer 178 ) -Flicht 1809 by Ir. Escape 1802 (Commorore 1793) - Y Heroine by Bagot 1789 (Herod 1758)-Heroine 1775 by Hero 1753 (Cade 1734)-Dan. 1766 of Snap 1750 (Snip 1786)

Jerry 1821 (Smolensko 1810)-Dan. 1817 of Ardrossan 1809 (John Bull 1789)-Lady Eliza 1813 by Whitworth 1805 (Agonistes 1\%97)-Dau. 1793 of Spadille 1784 (Highflyer 1764)Sylvia 1783 by $\mathbf{Y}$. Marske 1\%1 (Marske 1750).

Prime Minister 1810 (Sancho 1801 -Maniac 1806 by Shuttle 1703 (Y Marske 1\%1) Anticipation 180: by Beningbrongh 1791 (King Fergus 1\%i5)-Expectation $1 \%$ by Herod 1758 (Tartar 1743)-Dau. 1758 of Skim 17:6 (Starling 172:

Wha lebone 1807 (Waxy 1690)-Dait. 1812 of Selim 1802 (Bnzzard*1\% $18 \%$ ) Naiden (s01 by Sir Peter T. 1744 (Higbflyer 1\%4)-Dan. 1788 of Phenomenon 1780 (Herod 1758)Matron 1782 by Florizel 1768 (Herod 1758).

Master Henry 1815 (Orville 1699)-Boadicea 1807 by Alexander 1\%82 (Eclipse 164)-Bru nette by Amaranthus 1766 (old England 1741)-Mayfly $17 \% 1$ by Matehem 174s (Cade 1734)-Dan. 1755 of Anc. Starling 17 (5) (Starling 1727).

Selim 1802 (Buzzard $*$ 1787)-Dak. 1808 of Walton 1799 (Sir Peter T. 1784)-Y. Giantes 1790 by Diomed $177 \%$ (Florizel 1\%68)-Giantess 1769 by Matchem 1748 (Cade 1734)Molly Long Lege 1753 by Babraham 1730 (God. Ar. 1724).

Bustard 1813 (Castrel 1801) Olympia 1815 by Sir Oliver 1800 (Sir Peter T. 1784)_Scotilla 1795 by Anvil 17\% (Herod 1758)-scota 1783 by Eclipse $1 \% 64$ (Marske 1\%9)-Harmony 175 by 1 lerod 1758 (Tartar 1743 ).

Gatton 1809 (Golumpus 1802)-Orvillina 1804 by Beningbrough 1691 (King Fergus 1\% Evelina 1791 by Highflyer $1 \% \% 4$ (Herod 175s) - Termagant by Tautrum $1 \% 60$ (Cripple $1750)$-Cantatrice by Sampson 1745 (Blaze 1733).

Selim 1892 (Buzzard* 178\%)-Dau. of Skyscraper 1786 (Highflyer 1\%4)-Dau. 1796 of Dragon* 1\%8. (Woodpecker 1\%3)-Fidget's dam $17 \% 7$ by Iatchem 1748 (Cade 1731)Sist. 1760 to Sweetbriar by Syphon 1750 (Squirt 173:).

Orville 1799 (Beningbrough 1791)-Emily 1810 by Stamford 1694 (Sir Peter T. 104) Dau. 1799 of Whiskey 1789 (SaItram* 1780)-Grey Dorimant 1781 by Dorimant 1772 (Otho 1760)--Dizzy 1757 by Blank 1740 (God. Ar. 17\%4).

Rubens 1805 (Buzzard 178\%)-Penelope 1798 by Trmmpator 1r8: (Conductor 176i)-Prunella 1788 by Highflyer 17i4 (Herod 1758)-Promise 1768 by Snap 1750 (Snip 1\%36)Julia 1756 by Blank 1740 (God. Ar. 1724).

Talton 1799 (Sir Peter T, 1784)-Parasol 1800 by Pot-8-0-'s 173 (Eclipse 1\%64)-Prunella 1788 by 11 ighflyer $17 \%+$ (Herod 1758)-Promise 1768 by Snap 1750 (Snip 1736)-Julia 1756 by Blank 1740 (God. Ar. 1724)

Smolensko 1810 (Sorcerer 1796)-Jerboa 1803 by Gohanna 1790 (Mercury 17\%)-Camilla

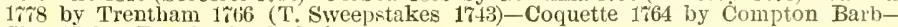
Sist. 1743 to Regulus by God. Ar. 1724

Whalebone $180 \%$ (Waxy 17c0)-Defiance 1916 by Rubens 1805 (Buzzard 1787)-Little Folly 1806 by Highland Fling 1795 (Spadille 1\%84)-Harriet 1\%y9 by Volunteer 1780 Eclipse 1764)-Dain. 1785 of Alfred $17 \% 0$ (Matehem 1748)

X. Y. Z. 1808 (Haphazard 1797) -Janetta 1803 by Beningbrongh 1791 (King Fergus 17\%)-Dau. 1797 of Drone 17\% (Herod 1\%:8)-Contessina 1787 by $\mathrm{Y}$. Narske 17it (Marske 1750)-Tuberose 17\%2 by Herod 1758 (Tartal 1743).

Catton 1809 (Golumpus 1802)-Dan. Ists of Smolensko 1810 (Sorcerer 196) - Lady Mary 1800 by Beningbrough 1\%91 (King Fergus 1\%75)-Dau. of Highflyer 17it (Herod 1758)Dill. of Marske 1750 (Squirt 1732).

Orville $1 \% 99$ (Beningbrongh 1\%91)-Epsom Lass 1803 by Sir Peter T. 1\%83 (Hichflyer 17\%4)-Alexina 1\%85 by King Fergus $1 \%$ (Echipse 1764)-Lardella 1780 by I. Mrarske $17 \% 1$ (Marske 1750)-Dan. of Y. Cade 17ti (Cade 1734).

Sultan 1816 (Selim 1802)-Trampoline 1825 by Tramp 1S10 (Dick Andrews 179\%) - TTeb 188 by Waxy 1790 (Pot-8-0-'s 17\%3)-Penelope 1798 by Trumpator 178: (Conductor $176 \%$ )-Prunella 1788 by Highflyer $17 \% 4$ (Herod 1758).

Whalebone $180 \%$ (Waxy 1700)-Hazardess b. m. 1818 by Haphazard 1797 (Sir Peter T. 1784)-Dan. br. m. 1809 of Orville 1799 (Beningbrough 1791)_Spinetta b. m. 1792 by Trmmpator $178 \%$ (Condnctor 1767)-Pegay b.m. 1778 by Herod 1758 (Tartar 1743)-Dav. of Snap 1750 (Snip 1736)-Dau. of Gower Stallion 1740 (God. Ar. 1724)-Dall. of Childers. 


\section{IMPORTED DONALD A.}

Imported in utero. The Property of J. D. Lneets, Goodwood Stud, St. Lonis, MIo. Service by pricate contract.

Doxald A., chestnut horse, foaled 1881, bred by Com. Kittson in the Erdenheim Stud, Pa., by Scottish Chief, son of Lord of the Isles by Tonchstone and Miss Amn by The Little Known, son of Muley, dam imp. Algebra by Diophantus, son of Orlandlo by Tonehstone, out of. Beatrice by Voltigeur, etc. Scottish CIief, his sire, won the Biennial Stakes at Ascot, and Chesterfield Stakes at two sears old. At three years old ran third to Blair Athol and Gen. Peel in the Derby, won the Bienuial at Ascot and Aseot Gold Cup, beating Lord Clifien, The Ranger and others. Scottish Chief is the sire of Marie Stuart, wimner of the Oaks and St. Leger, Childerie, wiuner of the Chesterfield, Prince of Wales and Prendergast Stakes, third in the Derby to Sefton and Insulaire, and second to Janette 1 the St. Leger, and won the Doncaster Stakes and Ropal Stakes at Nemmarket. Seottish Chief is the sire of the dams of Common, winner of the 2,000 Gnineas, Derby and St. Leger, of Donovan, winner of the Derby and St. Leger, MeIton, winner of the Derby and St. Leger, and Semolina, winner of the 1,000 Gnineas. Algebra, his dam, is by Diophantus, winner of the 2.000 Guineas, grandam Beatrice, dam of Prestonpans, winner, at two years olıl, of the Alexanlra, Prinee of Wales, Nursery, Hopeful and Criterion Stakes. At three years old he beat Philammon aud Petronel (wimner of the 2,000 Guineas) in the Liverpool Antmm Cnp, by Voltigenr, winner of the Derby and St. Leger, and sire of Tedette (wimner of the 2,000 Gumeas). Velette is the sire of Galopin (Derloy winner) and Voltigetr is sire of the dam of Kungeraft (Derby winner) and imp. Great Tom. Bribery, his third dam, is the dam of St. Albans, winner of the St. Leger and half sister to Lady Mary, the dam of Gang Forward, winner of the 2,000 Guineas, by The Libel, ont of Splitrote, half sister to Miss Twickenham, the dam of Teddington, winner of the Derby, Aseot and Doncaster Cups, by St. Lnke. Domald A. had a checquered career on the turf. He started in thirty-four rares and won nine, at $\frac{5}{8}$, $\frac{8}{ \pm}$, 7 furlongs, 1 mile and over hurdles with high weights. Donald A. is a very highIy bred horse and from a distinguished raeing fanily in England, and traces through the hest racing blood to the Burton Barb mare, from which ileseended in direct femalo line Whiskey, Selim, Rubens, Castrel, Catton, Whitelock, Blacklock, Sir Herenles, imp. Margrave, Harkaway, Toltigenr. Surplice, St. Albans, Lord Clifilen, Mask, Pell Mell, Brag, Sheen, Gold, imp. Hurah, imp. Ainderby, imp. Billet, imp. Eagle and Spread Eagle, Waverly (by imp. Australian), ete. 


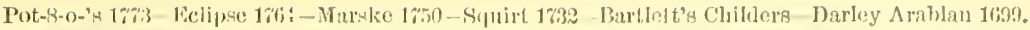

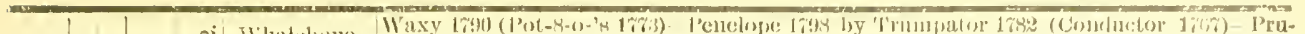

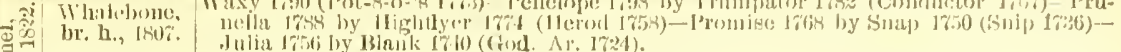

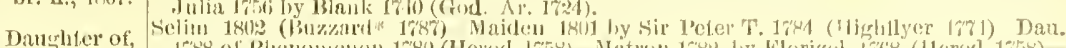

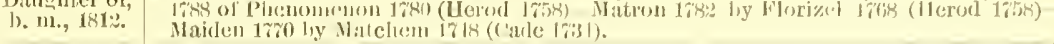

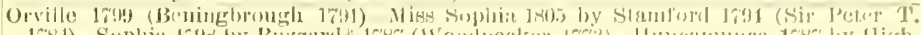

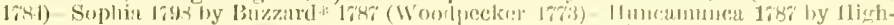

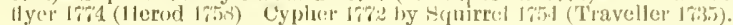

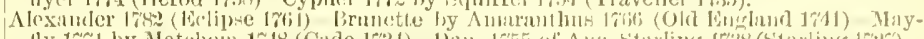

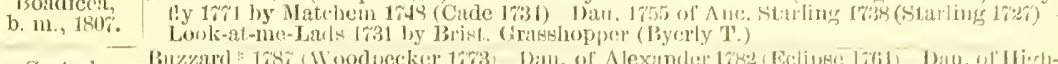

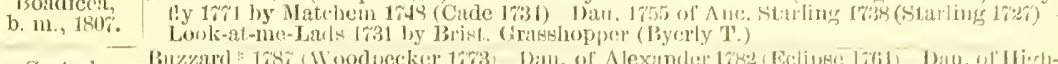

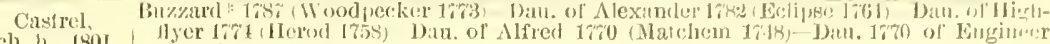
eh. h.. 1801. 17yer (Simpson 1715$)$

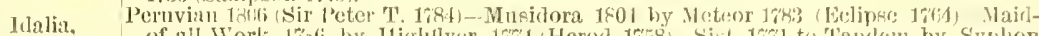

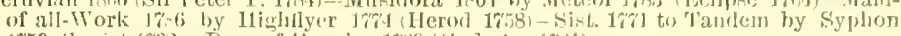

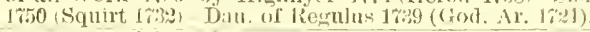

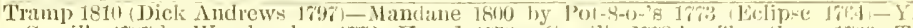
Lottery, br. b., $18: 0$. Sweenstakes 1.13 ) Coquette 1765 by comptom Barb.

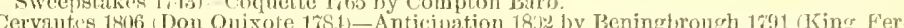

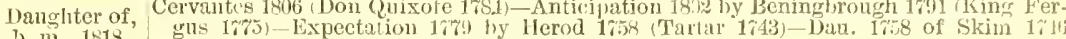

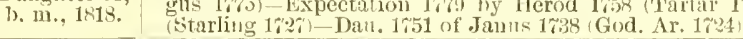

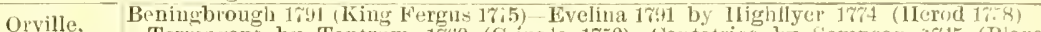
Termagant by Tantrum 17t0 (Cripple 1750)-Cantatrice by Sampson Ift5 (Blaze 1733) Dail. 175; of Regulus 1739 (Goil. Ar. 1724)

Whiskey 1789 (Stltram 170 ) Y. Giantess 1790 by Diomed $17 \%$ (Florizel 176?

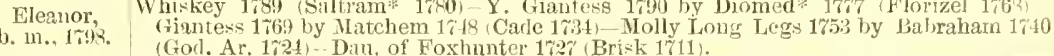

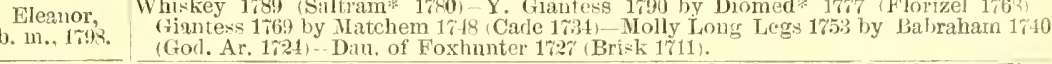

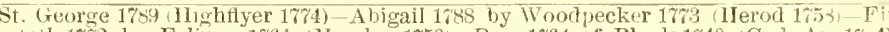

Zodiac, tail 172 by Eclipse 176l (Marske 1750)-Dan, 1;64 of Blank 1740 (God, Ar. 1\%,4) Naylor 174 by Cade 1734 (God. Ar. 1724)

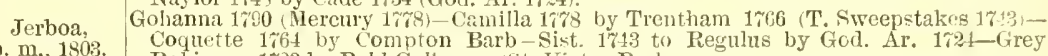

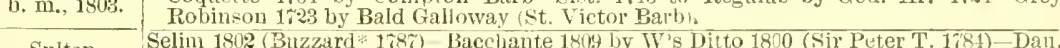
1791 of Mercury $17 \% 8$ (Eelij)se 176:5) Dat. 1776 of IIerod 1758 (Tartar 1743) Folly 17/1 by Marske 1750 (Squirt 173z).

b. h, 1816 .

Cobweb, Phantom 1808 (Walton 1799)--Filagree 1815 by Soothsayer 1808 (Sorcerer 1796/- Weh

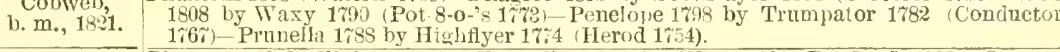

Y. Phantom

Phantom 1808 (Nalton 1799 -Emmeline $181 \%$ by 11 ix

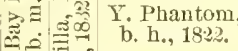

1808 by Sourer 1206 (T) 1774)-Dau. 1 is8 of Woodpecker $17 \% 3$ (Herod 1758).

Sister to Camillus 1803 (Hambletonial 1792)-Dan. 1809 by Sancho 1801 (Don Quixote 1\%s4-

Speaker, Mi-s Hornpipe Teuzle 1802 by Sir Peter T. 1781 (Highflyer 17it)-Hornpipe 1793 by b. m., 1817. Trumpator 1782 (Coudnctor $176 \%$ )-Luna 1789 by Herod 1758 (Tartar 1743).

Camel, Whalebone 1897 (Waxy 1790)-Dan. 1812 of Selim 1892 (Buzzard*178i)-Naiden 1801 by

br. h., 1822. Sir Peter T. 1781 (Highflyer 17\%4)-Dam. 1785 of Phenomenon 1780 (Herod 1753)Iatron 1782 by Florize 1663 (Herod 1758).

Banter, Master INenry 1815 (Otville 1799)-Boadicea $180 \%$ by Alexander 1782 (Eclipse 1764)-Brunette by Amaranthus 1764 (Old Encland 1\%41) - Naytly $17 \% 1$ by Matehem 1 448 (Cade 1734)-Dan. 1755 of Starling 1735 (Starling 1720 )

Langar - Selim 1802 (Buzzard 1\%8\%)-Dan. 1803 or Walton 1\%99 (Sir Peter T. 1781)-Y. Giantess eh. h., $181 \%$.

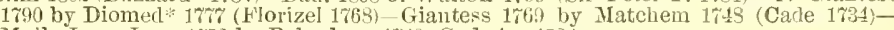
Molly Long Legs 1753 by Babraham 17t0 (God. Ar. 1721

Kite. Bustarl 1813 (Castrel 1801)-Olympia 1815 by Sir Oliver 1800 (Sir Peter T. 1784-Scotilla

Kite. 1795 by Anvil 1777 (Ilerod 1758)-Scota 1783 by Eclipse 1764 (Nareke 1750)-Harmony $17 \% 5$ by Herod 1758 (Tartar 1743)

Orville Beningbrough 1791 (Kiug Fergus 17i5)-Evelina 1791 by Highflsel 17\%4 (Herod 1758\begin{tabular}{l|l} 
b. h., 1\%99. & Termagant by Tantrum 1760 (Cripple 1\%50)-Cantatrice by Sampson 1\%15 (Blazs \\
1733)-Dau. 1757 of Regulus 1739 (God. Ar. 1\%21).
\end{tabular}

Emily, Stamford 1794 (Sir Peter T. 1784)-Dan. 1799 of Whiskey 1789 (Saltram* 1789)-Grey

Emily, ${ }^{2}$ Dorimant 1781 by Dorimant 17\% (Otho 1;60)-Dizzy 1\% 1794)-Dizzy 1741 by Driver 1727 ( TYynn Ar.

Whi-ker, Waxy 1790 (Pot--o-'s 17i3)-Penelope 17:8 by Trumpator 1;82 (Conductor 1i6f)-Pru-

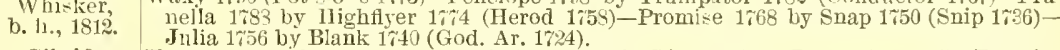

Gibside Hermes 1790 (Mercury 1778)-Vicissitude 1800 by Pipator 1786 (Imperator 1766)-Beatrice

Fairy, 1791 by Sir Peter T. 1784 (Highflyer 1774)-Pyrrha 17\%1 by Matchem 1748 (Cade 1734)Dnchess $1 \% 48$ by Whitunose 1742 (God. Ar. 1\%24). Blacklock. Whitelock 1803 (Hambletonian 1792)-Dau. 1799 of Coriander 1785 (Pot-9-0-'s 1773)-
b. h.,1814. Wildgoose 1792 by Highflyer 17\%4 (Herod 1758)-Coheiress 1786 by Pot-8-0-'s 17\%3 (Eclipse 176t) - Manilla 1\%7 by Golafinder 1\%64 (Snap, 1750).

b. li., 1814.

Phantom 1808 (Walton 1799) -Dau. 1802 of Overton 1788 (King Fergus 17\%5)-Dau, 179 of WaInut 1786 (Highflyer 17\%t)-Dau. 1786 of Ruler 17\% (Y. Harke 1771)-Piracantha $17 \% 2$ by Matchem 17 ts (Cade $173 t$ ).

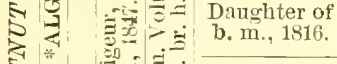

catton 1809 (Golumpus 1802)-Desdemona 1 s11 by Orville 1799 (Beningbrongh 1791)-

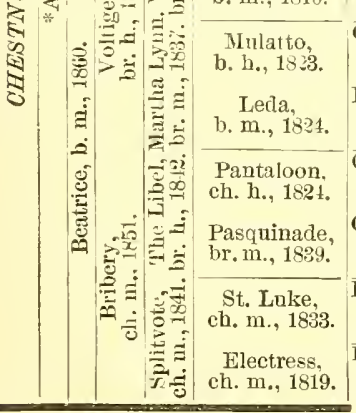
Fanny 176 by sir Peter T. 1781 (Highflyer 174)-Dan. 1783 of Diomed 17 \% (Florizel 1768)- Tesdemona $177_{0}$ by Marske 1750 (Squirt 1732)

Filbo-da-Puta 1812 (Haphazard 1797-Treasure 1809 by Camillus 1803 (Hambletoniaz 1792)-Dall. 1804 of Hyacinthus 1797 (Coriander 1786)-Flora 1789 by King Fergus $17 \%$ (Eclipse 1\%6t)-Atalanta 1769 by Matchem 1748 (Cade 1\%94).

Castrel 1801 (Buzzard $178 \%$-Idalia 1815 by Peruvian 1806 (Sir Peter T. 1FS4)-Mnsidora 1804 by Meteor 1783 (Eclipse 1764)-Maid-of-ail-Work 1786 by Highflyer 17t4 (Herod 1758)-Dau. 17 \%1 of Syphon 1750 (Squirt 1732).

Camel 182: (Whalebone 1807)-Banter 1823 by Master Henry 1815 (Orville 1799)-Boadicea $180 \%$ by Alexander $1 \% 82$ (Eclipse 1\%61) - Brunette by Amaranthus 1766 (Old Ergland 1\%41)-Mayfly 1\%1 by Matchem 1749 (Cade 1\%34)

Bedlamite 1s23 (Welbeck 1815) - Eliza Leeds 1817 by Comus 1809 (Sorcerer 1796)-Helen 1811 by Hambletonian 1792 (King Fergus 17.5)-Susan 1800 by Overton 1788 (King Fergus 17\%5)-Drowsy 1790 by Drone $17 \pi$ (Herod 1758)

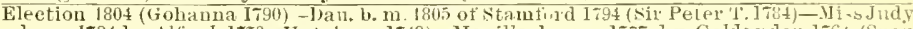

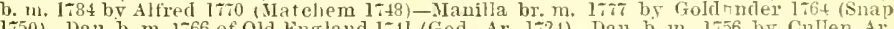
1745- - Miss Cade eh. m. 1750 by Cade 1734 (God. Ar. 172t)-Miss Makeless b. m. 1737 by Y. Greyhound 1723 (Greyhound)-Sist. 1731 to Miss Barfortl br Partuer li18 (Jigg)-Brown

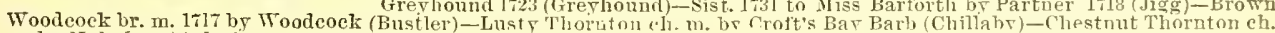
m. by Iakeless (Oglethorpe Ar.)-Old Thornton by Brimmer (W'Arey Yelluw Turk)-Dan. of Diekey Plersou (Dodsworth) Burton Natural Barb mare. 


\section{IMPORTED DUTCH ORGAN.}

Property of Win. Arnette, Sharon Stock Furm, Sharon, Ill. Service fee mulished annually.

Dutci Orgax, bay horse, foaletl 1878, bred by Mr. T. Whiting, by Lowlander, son of Dalesman by King Tom and Lufra by Windhound, son of Pantaloon, dam Tymbestere by The Rake, son of Wild Dayrell by Ion, second dam Timbrel by Rataplan, own brother to Stockwell, out of Belsay by Lanereost, son of Liverpool. Lowlander was a good race-horse, winner of the Great Warwickshire Handicap, Royal Hunt Cup at Ascot, Ascot Plate, Newport Cup twice, Stockbridge Cup, Stewards' Cnp at Chester, Queen's Stand Plate at Ascot, Lenox Stakes at Goodwood, in which he defeated Trappist, ete, and other good races, and is the sire of Lowland Chief, winner of the Stewards' Cnp at Goodrood and Royal Stakes at Epsom. Imp. The Rake, sire of his dam, is sire of the good eolt The Reaper. Rataplan, sire of his grandam, is own brother to Stockwell, a superior race-horse, sire of kettledrum (wimner of the Derby) and of the dams of Apology (winner of the 1,000 Guineas, Oaks and St. Leger), Rigolboehe (dam of Cremorne, winner of the Derby), and Mineral, dam of Wenlock (winner of the St. Leger), and Kisber (winner of the Derby). Belsay, his third dam, is by Lanercost, sire of Catharine Hayes (winner of the Oaks) Van Tromp (winner of the St. Leger) and Ellerdale, the dam of Ellington (winner of the Derby) and Summerside (wimner of the Oaks). Belsay is half sister to the good horse Vindex and Vesta, dam of Sabinus (winner of the Cambridgeshire Handicap aud Ascot Gold Cup). Garland, his fourth dam, is half sister to Gaiety, dam of Gamester (winner of the St. Leger). Duteh Organ ran second to Syringe in the first year of the 24th Zetland Biennial Stakes, 5 furlongs, with three behind him. At three years old ran second to Macadam in Silver Bells Mandicap, 1 mile, at Paisley; second to Master Rat in Maiden Plate, 1 mile, at Ayr; second to Melodious in Plate, $\frac{3}{4}$ of a mile, at Ayr, and was third in Athole Handicap, 5 furlongs. At four years old won the Silver Bells Handicap, 1 mile, 122 lbs., at Paisley; won Glasgow Handicap Plate, 1 mile, 94 lbs., at same place, and same day won the Burgh Hember's Plate, $1 \frac{1}{x}$ miles, 131 lbs., giring 21 lbs. to Astronony, who was second. At five years old ran third in National Hurdle Plate, 2 miles, to Rillotto and Attache. 145 lbs., with seven behind him. At Sandown Park won Claremont Steeplerhase Handicap, 2 miles, $145 \mathrm{lbs}$, in field of nine; won Hampton Hurdle Handicap. 2 miles, at Packington, $151 \mathrm{lbs}$. At Nottingham won Oxton Hurdle Mandicap, 2 miles. 155 lbs., defeating field of eight. Dutch Organ is 16 hands high, weighs 1,265 lbs., good. bone and excellent disposition. 


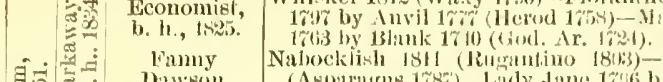

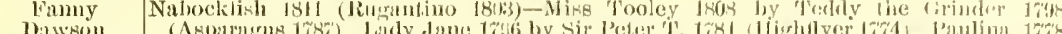

so

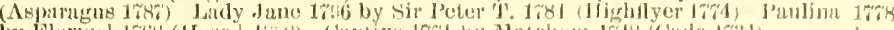

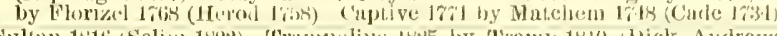

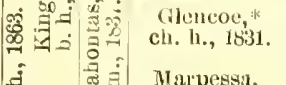

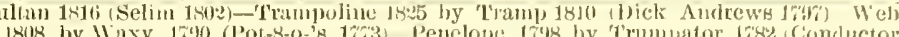

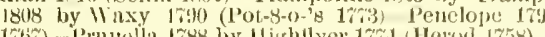

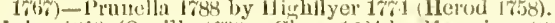

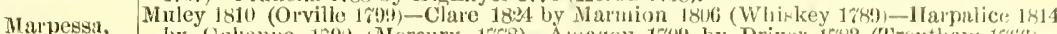

b. m., 1830. Fractions 1792 by Mercury irs (Eclijse 1\%61).

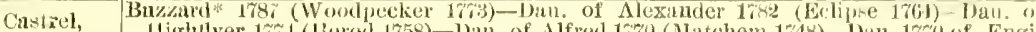
1lighllyer 17 f (lierod 1758)-Dau. of $\mathrm{Alfred} 17 \% 0$ (Matchem 1745)-1)an. 17\%0 of Engincer 1، (Sampson 1745).

ch. h., 1801.

.

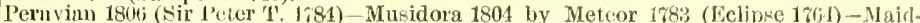
of-all-Work 1;8; by 11ighilyer 1\%4 (Herod 1758)-Dat. 17\%1 of Syphon 1750 (Siquirt 173:) - Dan. of Resulu: 173.t (God. Ar. 1721)

Velosipede,

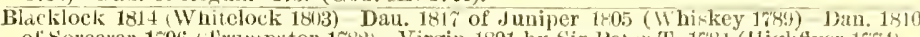

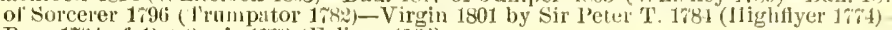

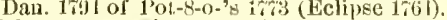

Danghter of

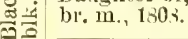

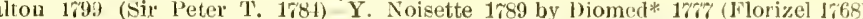

Noisette $17 \% 4$ by Squirel 1754 (Traveller 1735)-Carina 1766 by Marske 1750 (siguirt 1732)-Dan. 175s of Blank 1\%40 (Gol. Ar. 1\%24).

Castrel, Buzzard $178 \%$ (Woodpecker 1773)-Dan. of Alexander 162 Eclipse 1661)-Dau. of Iliti-

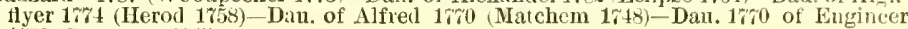
1756. (Sampson 1745).

矛落 ch.h., 1801.

Pernvian 1806 (Sir Peter T. 1784)-Musidora 1804 by Neteor 1783 (Eclipse 1664)_- Vlaid-

Idalia,

of-all-Work 1766 by Highflyer 1\%4 (Herod 17\%8)-Dau. $17 \% 1$ of Syphon 1 r50 (Squirt 1732) Dan. of Regrilus 1799 (God. Ar. 1\%:4).

Camel $182 \%$ (Whalebone 1<0\%)-Banter 1826 by Master Henry 1815 (Orville 1799)-Boalicea $180 \%$ by Alexander 1782 (Eclipse 1\%64) Brunette by Amaranthus 17t66 (Old Englaud 1741) - Mayfly $17 \% 1$ by Matchem 1748 (Cade 1734)

Filho-da-Puta 1812 (Haphazard 179\%)-Fmerse 1815 by Peruvian 1806 (Sir Peter $T$.

Decoy, 1784)-Violante 1802 by John Bull 1789 (Fortitude 17\%)-Dau. 1788 of Highflyel 17, (Herod 1758)-Everlasting $17 \% 5$ by Eclipse 1764 (Marske 1750).

Liverpool 1828 (Tramp 1810) Otis 1820 by Bustard 18U1 (Bnzzard* 18 Election 1804 (Gohanna 1790) -Dau. 1791 of Highfyer 17t+(Herod 1758)-Chanticleer"s dam 1\%:8 by Eclipse 1764 (Marske 1750).

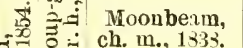

Tomboy 18.9 (Jerry 1801) - Lunatic 1818 by Prime Minister 1810 (Sancho 1801)_Maniac $1800^{\circ}$ by Shuttle 1793 (Y. Marske 17i) Anticipation 1802 by Beningbrough 1791 (King Fergus 1775)-Expectation 17\%9 by Herod 1 \%58 (Tartar 1743).

Blacklock 1814 (Whitelock 1803) Dau. 1817 of Juniper 180.5 (Whiskey 1789) Dau. 1810 of Sorcerer 1796 (Trumpator 1782)-Virgin 1801 by Sir Peter T. 1784 (Highflyer 1;4)Dau. $179+$ of Pot-8-o-'s 17\%3 (Eclipse 1764)

ch. h., 1825 .

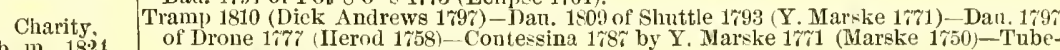

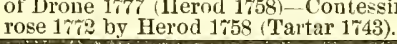

Cain,

Paulowitz 1813 (sir Paul 1802) -Dau. 1810 of Parpator 1641 (Trumpator 1782) Dau. 1805 of Delpini 1781 (1Iighflyer 17\%4)-Dau. 1795 of Y. Marske $17 \% 1$ (Marske 1750)-Gentle

b. h., 1823. $\begin{aligned} & \text { of Delpini 1781 (1lighfyer 174)-Dau. 1795 of Y. Marske } 1771 \text { (Marske 1750)-Gente } \\ & \text { Kitty 17\% by Silvio 1754 (Cade 1734). }\end{aligned}$

Margnet, Sir Harry* 1795 (Sir Peter T. 1784)-Dau. 1793 of Volunteer 1780 (Eclipse 1764)-Dau. br. m., 1831. $17 \% 9$ of Herod 1758 (Tartar 1743).

Sultan 1816 (Selim 1802)-Cobweb 1821 by Phautom 1808 (Walton 1799)-Filagree 1815 Middleton,
b. h., 1833 .

Myrrha,

ch. in., 1831 . by Soothayer 1808 (Sorcerer 1796) - W eb 1808 by Waxy 1790 (Pot-S-o-'s 1773)-Penelope 1798 by Trumpator 1782 (Conductor 176\%)

Malek 1824 (Blicklock 1814)-Bessy 1815 by Y. Gouty 1805 (Gouty 1796)-Graudiflora 1810 by Sir Harry Dimsdale 1800 (Sir Peter T. 1784)-Dau. 1799 of Pipator 1786 (Imperator 176)-Dau. 1796 of Phenomenon 1780 (Herod 1\%58).

Sir Hercules,

Wh halebone 180\% (Waxy 1790)-Peri 18:2 by Wanderer 1811 (Gohanna 1790)-Thalestris 1809 by Alexander 1782 (Eclipse 1;64)-Rival 1800 by Sil Peter T. 1784 (Highflyer 1774 ) - Hornet 1790 by Drone 1777 (Herod 1758).

宽: Bob Booty 1904 (Chanticleer 1787) - Flight 1809 by Ir. Escupe 1802 (Commodore 1793) Y. Heroine by Bagot 1780 (Herod 1758)-Heroine 175 by Hero 1753 (Cade 1734)Dau. 1766 of Snap 1750 (Snip 1736). amel 1822 (Whalebone 180\%)-Banter 1826 by Master Henry 1815 (Orville 1799-B Badicea 187 by Alexander 1782 (Eclipse 1\%64)-Brunette by Amaranthus 1766 (O1d England 17\%1) - Mayfly $17 \% 1$ by Matchem $1 \% 48$ (Cade 1\%34)

Zillah, Reveller 1815 (Comus 1899)-Morisca 18:b by Morisco 1819 (Muley 1810) - Waltz 182: by Election 1804 (Gohanna 1790) - Penelope 1798 by Trumpator 178\% (Conductor 1\%6\%)Prunella 1798 by Highflyer 1\%t (Herod 1\%58. i1 Hercules 182; (Whalebone 1807 -Guiccioli 1823 by Bob Bonty 180-1 (Chantieleer 1787) - Flight 1809 by Ir. Escape 1802 (Commodore 1793)-Y. Heroine by Bagot 1780 (Herod 1753)-Heroine 1775 by Hero 1753 (Cade 1\%34)

궁 $\mathrm{Ir}$.Birdcatcher conomist 1895 (Whisker 1812) - Miss Pratt 1825 by Blacklock 1814 (Whitelock 1803)Gadabont 1812 by Orvile 1799 (Beningbrough 1791) - llinstrel 1803 by Sir Peter $\mathrm{T}$. 1781 (Highflyer 174)-Matron 1782 by Florizel 1 \%68 (Herod $1 \% 58$

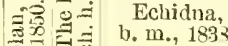
Sultan 1816 (Selim 1802)-Trampoline 18:5 by Tramp 1810 (Dick Andrews 1797)-We! 1803 by Waxy 1790 (Pot-8-0-'s 17\%9)-Penelope 1\%98 by 'Trumpator 1782 (Conductor 17(67)-Prunella 1788 by Highflyer 17\%4 (Herod 1758).

Muley 1810 (Orville 1799)_Clare 1824 by Marmion 1806 (Whiskey 1789)-Harpaijce 1814

Marpessa

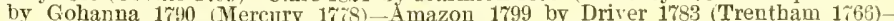
Fractious 1792 by Merculy $1 \%$ (Ecipse 1764 )

Liverpool,

Tramp 1810 (Dick Andrews 179\%)-Dan. 182? of Whisker 181: (Waxy 1790)-Mandane 1800 by Pot-8-0-'s 1773 (Eclipse 1764) - Y. Camilla 178\% by Woodpecker 1773 (Herod 1758)-Camilla 17 is hy Trentham 1766 (T. Sweepstakes 17 13)

b. h.,

Bustard 1801 (Buzzard* 1787)-Dan. 1813 of Election 1801 (Gohanna 1790)-Dan, 1791 of

Otis.

Highflyer 1\% 4 (Herod 1758)-Dan. 1778 of Eclipse 1\%64 (Narske 1750)-Rosebud 1705 by Snap 1750 (Snip 1 736 ).

Selim 1802 (Buzzard*1\%8\%)-Dau. 1805 of Walton $1 \% 99$ (Sir Peter T. 1784)-Y. Giantess

Langar, 1790 by Diomed* $1 \% 7 \%$ (Florizel 1768)-Giantess 1769 by Matchem 1748 (Cade $1734-$ Molly-Long-Legs 1753 by Babraham 1740 (God. Ar. 1724)

Cast-steel, Whisker 18L2 (Waxy 1790)-The Twinkle b. W. 1821 by Waltou 1739 (Nir Peter T. 1784)Dan. gr, m. 1814 of Orville 1799 (Betingbrough 1791)-Lisette gr. m. 1806 by Hambletonian 1792 (King Fergus 175)-Constantia gr. m. 1796 bF Walnut 1786 (Highflyer 1774)-Contes. (Tartar 17+3)-Grey Starling gr. m. 17t5 b. Bolton Starling 172 (Bar Boltou 1705)br. m., 1828.

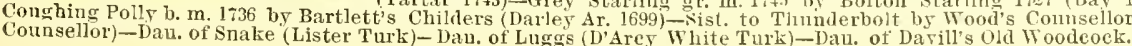




\section{ECUADOR.}

WINNER OF THE LORILLARD STAKE, MONMOUTH PARK, 1884.

Property of Benj. F. Cockrill, Richland Stud, Nashville, Tenn.

ECUADor, ehestnut horse, foaled 1881, bred by Capt. Jas. Franklin, Kennesaw Stud, Temmessee, by Enquirer, som of imp. Leamington and Lida by Lexington, dam Nevada, the dam of the grand race-horse Luke Blackbnrn, winner of 22 ont of 24 races at three years old, Greenland, Nova Zembla, Sierra Nevada, Bravo, ete., by Lexington, grandam Lightsome, dam of Saliua (Salvator's dam), Sprightly (dam of Volturno, Elias Lawrence, Aretino, ete.), Crucifix (dam of Semper Felix, Leonatus' dam), and Semper Vive (dam of Fordham and Semper Idem, Longstreet's dam) by imp. Glencoe, ont of Levity (dam of Lever, Legatee, Ruric, Mildred, dam of Monar'hist), Minx (Monitor's dam), Stamps (dam of Katie Pearce), Sultana (dam of She, Padisha, ete.), Nora Worth (dam of Force, Startle, Renown, ete.), Brenna (dam of Strathmore), Brademante (dam of 'The Bard), Athalaric (dam of Tom Martin), Sister to Ruric (dam of Grinstead), Kelpie (dam of Janet, 4 miles in 7.25), Duke of Montrose, Miss Austine (dam of Teuton, Faraday, ete,), Ermengarde, dam of Brocade (dam of Burch, Jennie B., Bertha B. (dam of Lizzie Baker, Judge Murray, Pat Kelly, etc.). Levity was ont of Vandal's dam by imp. Tranby, that produced Volga (the dam of Barney Williams, Evade, dam of Blink Bonny, the dam of 'lullahoma, she the dam of Tulla Blackburn and the great race-horse Tammans. winner of the Withers, Realization and Lorillard Stakes in 1892). Ecuaclor ran during his turf eareer 109 races, won at 5 furlongs three-quarters of a mile at two rears old, won at mile in $1.45,141$ bs., won the Lorillard Stake, $1 \frac{1}{2}$ miles, 118 lbs., in $2.40 \frac{1}{2}$, won over timber, $1 \frac{1}{2}$ miles, in 2.50: with 138 lbs., won lurdle race, 1 mile, 134 lbs., in 2.00, won hurdle races, $1 \frac{1}{2}$ miles, $160 \mathrm{lbs}$, and 2 miles, $150 \mathrm{lbs}$, and $1 \frac{1}{2}$ miles, $163 \mathrm{lbs}$. He ran in and ont of condition and was both a speedy and game horse. Ecuador is one of the nearest inbred Diomed horses living, his sire being ont of a Lexington ware and his dain by Lexington, tracing back through Eclipse, a grandson of Diomed, and then to a daughter of the great Sir Archy, the Highflyer of America. On his dam's side he belongs to the great Levity family, the ne plus ultra of American pedigrees. This family has produced the greatest stallions of the last half century. Ecuador's dam will ever rank as one of the great matrons of America through her sons, Luke Blackburn, the "nonpareil," Greenland, Nova Zembla, Sierra Nevada, Bravo and others.

Ecuador is roung in the stud, is the sire of the winners Eleanor, Forest Rose, Gov, Brown, Majestic, Salvation, Pete, ete. 


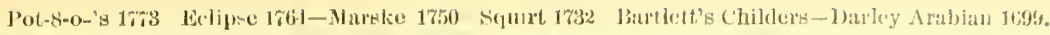

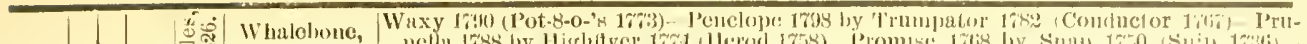

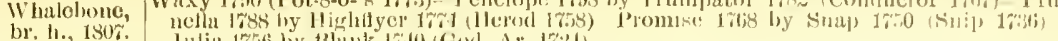

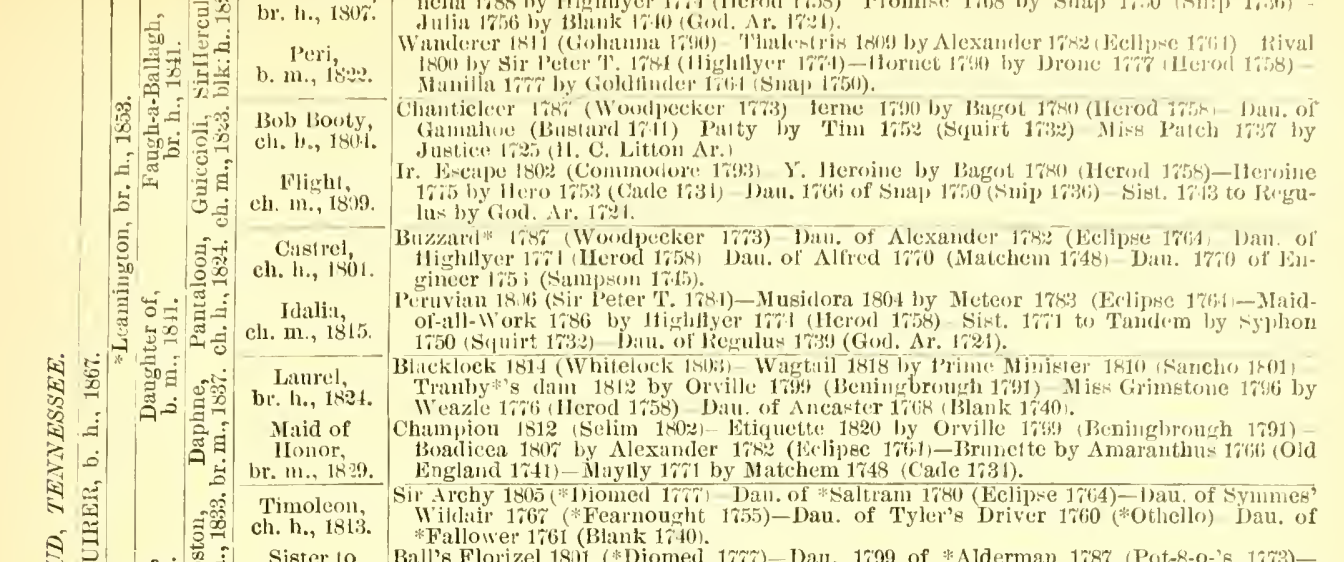

Sister to Ball's Florizel 1801 (*Diomed

Tuekahoe.
ch. m.., 1811 .

Dan. of "Clockiast 17\%t (Gimcrack 1760 --Dau of Symmes' W'ildair $1 \% 6 \%$ (*Fearionght * Sarpedon,

Emilius 1520 (Orvilie 1299)-Icaria 182, by The Flyer 1814 (Vandyke Jr. 1808)-Parma br. h., 18:8. $\quad 1813$ by Dick Andrews 1797 (Joe Andrews 1\%78)-May 1804 by Beningbrough 1791

Rowen?, cl. m., 1826 .

Sumpter 1818 (Sir Archy 1805)-Larly Grey 181\% by Robin Grey 1805 (* Koyalist 1790)— Naria 1802 by Melzar 1791 ("Nedley 1\%76)-Dau. of "Highflyer 1784 (Highflyer 17t4)Dau. of *Fearnonght 1\%5.) (Regulus 1\%3!).

Duroc,

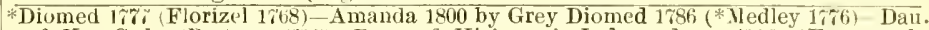
ch. $h, 1805$. of Va. Carle (Partner 1655)-Dau. of Hiekman's Independence 1776 (*Fearnought

(5)-Dan. of Badger (Bosphorus 1;54).

Miller's *Nesseuger 1780 (Nambrino 1768) * Pot-8-o-'s mare 1792 by Pot-8-0-'s $17 \% 3$ (Eclipec Danvel, 1764)-Dan. $17 \% 8$ of Gimerack 1760 (Cripple 1750)-Suapdragon 1759 by Snap 1750 gr. m., 130? (Snip 173; - Dilu. 1749 of Regulus 1739 (God. Ar. 1724).

Sir Archy,

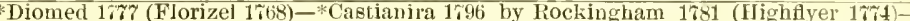

b. h., 1805 .

Tabitha 1782 by Trentham 1766 (T. Sweepstakes 1743)-Dan, of Bosphorus 1754 (Babraham 1740)-Dau. of Forester 1750 (Crott's Forester 1736).

Calypso,
b. m, 1805 . Symmes' Wildair 1767 ("Fearnought 1755) - Picadilla by Y. Fearnought $17 \%$ ' (*Fearnought 1755)-Dan. of Godolphin 17\% (*Fearnought 1755).

\section{Sir Arehy,}

"Diomed 17\%7 (Florizel 1768) - Castianira 1796 by Rockingham 1781 (Highflyer 1\%74)-

b. h., 1805.

Tabitha 1782 by Trentham 1765 (T. Sweepstakes 1743)-Dau. of Bospborus 1\%54 (Babraham 1740)-Dau. of $\mathrm{W}^{\text {'}} \mathrm{s}$ Forester 1750 (Forester 1736). SSaltram 1730 (Eclipse 1764)-Dau. of Symmes' Wildair 176\% (*Fearnought 1755)-Dan.

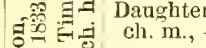

of Tyler"s Driver 1760 (*Othello)-Dau. of *Fallower $1 \% 61$ (Blank 1740)-Dau. of *Vampire 1\%5\% (Regulus 1739).

"Diomed 17\% (Florizel 1768)-1)au. of "Shark 1\%71 (Marske 1\%50)-Dau. of Harris" Eclipse 1\%70 (*Fearnought 1\%55-Dau. of *Fearnought 1\%55 (Regulus 1\%39-Dau, of Jolly Roger 17 s 1 (Rounclhead 1793).

Daughter of *Alderman 1787 (Pot-8-o-'s 17i3) Dau. of *Clockfast 1774 (Gimerack 1760 - T au. of b. m., 1793 .

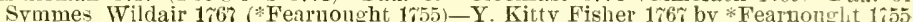
(Regulus 1739) — Kitty Fisher 1\%5) by Cade 1734 (God. Ar, 1\%24).

Otville 1799 (Beningbrough 179t)-Emily 1810 by Stamford 1794 (Sir Peter T. 17it)

Emilius,

Dau. 1799 of Whiskey 1789 (Saltran* 1780)-Grey Dorimant 1781 by Dorimant $17 \%$ (Otho 1760) - Dizzy 1757 by Blank 1747 (God. Ar. 1724).

The Flyer 1814 (Vandyke Jr. 1808)-. Parma 1813 by Dick Andrews 1797 (Joe Andrews

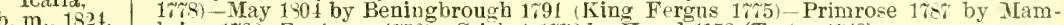
brino $1 \% 63$ (Eng:neer 1755 ) - Cricket $1 \%$ by Herod 1758 (Tartar 1 $\tau+3)$.

Sir Archy 180 j (EDiouned 17\%)-Dat. of *Robin Redbreast 1796 (Sir Peter T. 164) Sumpter, Sir Aar. 1788 of *Obscurity 1\%r7 (Eclipse 1764)-Slamerkin 1768 by *Wildair 1753 ICacle ch. h., 1818. 1734) - *Cub mare 1762 bv Cub 1739 (Fox 1714).

Lady Grey,

Robin Grey 1805 (*Royalist 1790)-Maria 1802 by Melzar 1791 (*Nedley 1\%6)-Dan, of b. m., 1317 .

\begin{tabular}{l|l} 
Selim, \\
ch. h., 1803 .
\end{tabular} *Highflyer 1784 (Highflyer 177t)-Dau, of *Fearnought 1755 (Regulus 1739)-Dau. of Ariel 1\%5 (*Traveller 1747).

Buzzard* 1787 (Woodpecker 1it3)-Dan. of Alexander 1782 (Eclipse 1i64)-Dau. ol HighBacchante, 1,56 (Sampson 1745 )

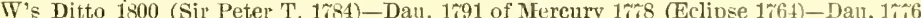
of Herod 1758 (Tartar 1743) -Folly 1771 by Marske 1650 (Squirt 1632)-Vixen 1753 by Regulıs 1739 (God. Ar. 17:4).

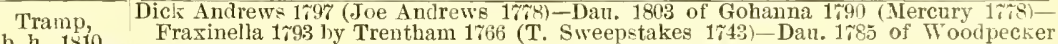
b. h., $1 \times 10$

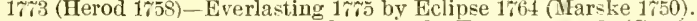

Web Waxy i790 (Pot-8-0-'s 1773) -Penelope 1798 by Trumpator 1782 (Conductor 176\%) - Prunella

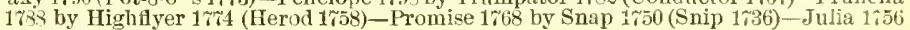

b. m., 1808. $\frac{\text { by Blank 1740 (God Ar. 1721). }}{\text { Golumpas 1802 (Gohanna 1790)-Lucy Gray } 1804 \text { by Timothy } 1794 \text { (Delpini 1781)-Lucy }}$ $1 \% 89$ by Florizel 1768 (Herod 1\%58)-Frenzy $17 \% 4$ by Eclipse 1\%64 (Marske 1;50)-Dau. of Engineer 1756 (Sampson 1 ${ }^{4} 45$ ).

Whisker 1812 (Taxy 1790) (ribside Flairy 1811 by Hermes 1790 (Mercury 1ros)-Vicissitude 1800 by Pipator 1786 (Imperator 1\%66)-Beatrice 1791 by Sir Peter T. 1784 (Highflyer 17:4)-Pyrrha 1771 by Matchem 1748 (Cade 1734).

Blacklock 1814 (Whitelock 1803) - Dau, 1812 of Orville 1799 (Beningbrough 1\%81)-Miss Grimstone 1796 by Weazle 1776 (Herod 1758)-Dau. of Ancaster 1768 (Blank 1740)-

\begin{tabular}{l|l|l} 
To & br. h., 1896. & Grimstone 1796 by Weazle \\
Dan. of Damascus Ar. 1754.
\end{tabular}

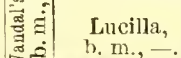

Trumpator 1823 (Sir Solomon 185) - Lucy b. m. 18:1 by Orphan 1810 (Ball's Florizel 1801) Ladv Grey b. m. 1817 by Robin Grey 1805 (*Royalist 1\%90)-Mlaria 1802 by Melzar 1791

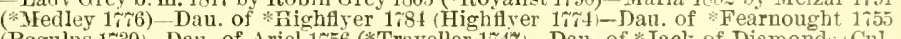
(Regulus 1739)--Dan. of Ariel 1756 (*Traveller 1747)-Dan. of *Jack of Diamonds (Cul-

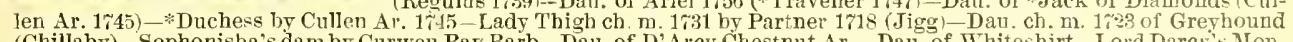
(Chillaby) - Sophonisba's dam by Curweu Bay Barb-Dat. of D'Arcy Chestnut Ar. - Dau. of Whiteshirt-Lord Darcs E Mon, tagu mare by Old Montagu-Dau. of Hautboy (D'Arcy W' hite Turk)-Dau. of Brimmer (D'Arey Yellow Turk) - Poyal mare. 


\section{EMPEROR.}

The property of Pierre Lorillard, Rancocas Stud, Jobstown, N. J., and is a private stallion.

Emperor, bay horse, foaled 1881, bred in the Belle Meade Stud, Tennessee, by Enquirer, son of imp. Leamington and Lida by Lexington; regarded, upon performances and success in the stud, as the best son of Leamington. Emperor's dam Vesperlight, the dam of the superior race-mare Vandalite, that won the Sequel Stakes at Saratoga, 2 miles; the Dixie and Breckenridge Stakes at Baltimore, 2 miles (Dixie in $3.35 \frac{1}{2}$, and Breckenridge, with a penalty of $7 \mathrm{lbs}$., in 3.35 , the fastest ever run to that (ate). Emperor won a Sweepstakes, $1_{8}^{1}$ miles, at Coney Island, in 1.58, his only start. He is exceptionally well bred, tracing to the imported mare Miss Shipton by the famous Waxy. Vesperlight (his dam) is also the dam of Nellie Ransom, and she the dam of Ferncliff, winner of the Withers Stakes. Vesperlight is also dam of Skylight bs Jack Malone, and she the dam of Moonlight, the dam of Judge Morrow. Emperor is virtnally untried in the stud, but his son Vestibule won the Galliard Stakes and showed not only speed but ability to stay. Sirocco is a fast and reliable colt.

Emperor's dam, Vesperlight, is by Childe Harold, son of imp. Sorereign by Emilins and Maria West, dam of Wagner by Marion, son of Sir Archy, grandam Budelight by imp. Glencoe, out of Gaslight by imp. Leviathan, son of Muley by Orville, tracing throngh Miss Shipton by Waxy, son of Pot-8-o-'s by Eclipse, to Maria, the dam of Waxy by Herod, to which trace in direct female line not only Waxy (Derby winner), but Paynator, Thunderbolt (by Soreerer), Smolensko (2,000 Guineas and Derbr), Colsterdale, Ellington (Derbs winner), Ashton, Sourenir, Ponssin, Bertram (sire of Robert the Devil, winner of the St. Leger), etc. The pedigree is strong in the best racing blood,

The following by him are all winners: Belshazzar, Chartrense, Cyrus, Fagot, Happy Dan, Kirseh, 1 mile iṇ 1.38, Padre, Pardon, Uncertainty, Wizard, Stalactite, Wang, Darius, Vestibule, Lorimer, Prince Imperial, Illian, Breeze filiy, etc. 


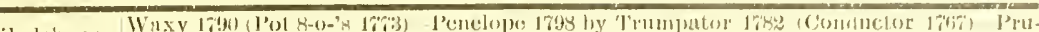

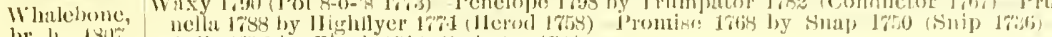

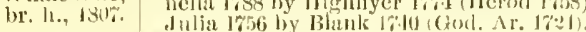

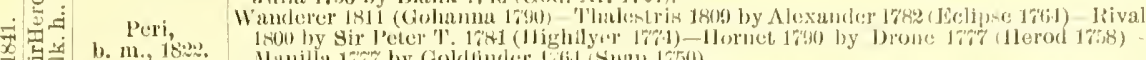

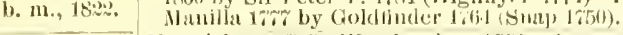

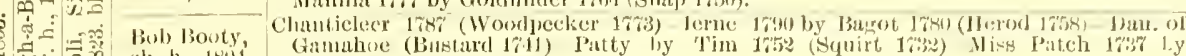
Justice 1,

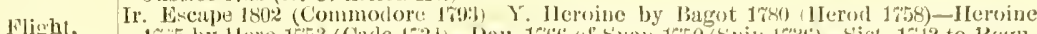
Nlight,
ch. 1n., 1899.
lus by Gol. Ar. 17\%l.

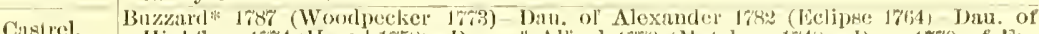

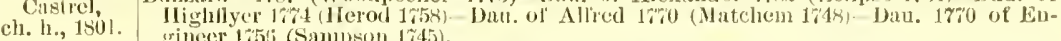
vineer li5! (Sampson 1\%45)

Idalis Peruvian 1806 (Sir Peter T. 1781)-Musidora 1804 by Meteor 1783 (Erlipse 17(64)-Maid-

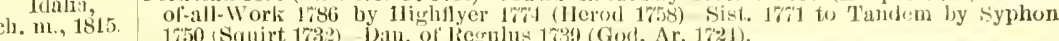
1750 (Squirt 173:) 1)an. of Tecrulus 173!) (Gou. Ar. 17\%1).

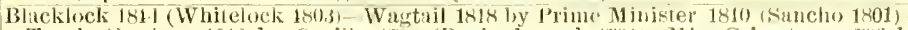

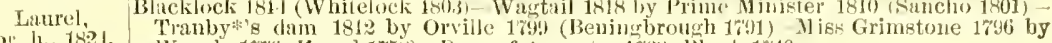

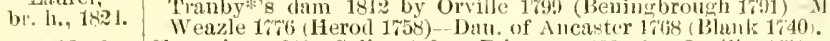

Maid of Champion 1812 (Sclim 180\%)-Etiquette 1820 by Orville 1735 (lingingbrough 1r91)

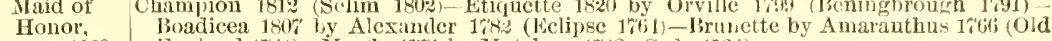

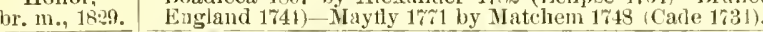

Timoleon, ch. h., 1813.

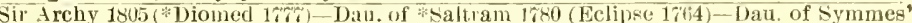
Wildair $176 \%$ (*earnonght 1755)-Dau. of Tyler"s Driver 1760 (*Othello)-Dau. of * Fallower 1761 (Blank 1740 ) ch. m., 1814.

Dau. of Clocklast 17\% (Gimerack 160)- Dau. of Symmes" Wildair $176 \%$ "Fearought 1755)-Y. Kitty Fisher 176, by Fearnought 1755 (Regulus 1739 ).

* Einilius 1820 (Orville 179.t)-Icaria 1821 by The H'lyer 1814 (Vandyke Jr. 1808)-Parm Sarpedon, 1813 by Dick Andrews 17\% (Jue Andrews 17r8)-Way 1804 by Beningbrough 1791 (King Fergus 1\%5)-Primrose 1787 by Mambrino 1768 (Encrineer 1756).

Rowena, Sumpter 1818 (Sir Archy 1805 )-Larly Grey $181 \%$ by Robin Giey 1805 (*Toyalict 1790)Mowena,
ch. m., 18:6.

Dau. of *Fearnonght 1755 (Regulns 1739).

Duroc Diumed $177 \%$ (Florizel 1768)-Amanda 1800 by Grey Diomed 1786 (* Yedley 1766)-Dan

ch. h, 1806. of Va. Cade (Partner 1755)-Dau. of Hickman's Independence 17r6 ( Fearnought Miller's 1755)-Dan. of *Badger (Bosphorus 1754).

Miller's *Messenger 1780 (Mambrino 1768) - Pot-8-o-'s mare 1792 by Pot-8-0-'s 17\% (Eclipse Damsel, 1764). Dau. $1 \% 8$ of Gimerack 1760 (Cripple 1\%50)-.Snapdragon $1 \% 59$ by Snap 1750 gr. m., 1802. (Snip 173j -Dau. 1749 of Regulus 1739 (God. Ar. 1721).

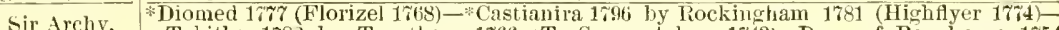

b. h., 1805. Tabitha 1782 by Trentham 1766 (T. Sweepstakes 1743)-Dau. of Bosphorus 1\%54 (Babraham 1'40)-Dan. of Forester 1,50 (Croft's Forester 1736).

Calypso, Bellair 1786 (*Medley 1\%6)-Dau. 1798 of *Dare Devi] 1787 (Magnet 17\%0)-Dau. 1\%92 of Calypso, Symmes' Wildair 1\%67 ("Fearnought 1755)-Picadilla by Y. Fearnought 17r\% ( Fearnouglit 1755) - Dau. of Godolphin 1 r 70 (*Eearnought 17:5).

Orville, Beningbrough 1791 (King Fergus 1775)-Evelina 1791 by Highflyer 17\% (Herod 1758)-

b. h., 1799. Termagant by Tantrum 1760 (Cripple 1750) Cantatrice by Sampson 1745 (Blaze

b. Ł., 1799. 1733) - Dau. 175\% of Regnlus 1739 (God. Ar. 1724)

Emily, Stamford 1794 (Sir Peler T. 1784)-Dau. 1799 of Whiskey 1789 (Sallram* 1780)-Grey Dorimant 1781 by Dorimant 1722 (Otho 1760)-Dizzy 175 by Blank 1710 (God. Ar. 1\%21)-Dizzy 1741 by Driver $1 \% 27$ (Wynn Ar.).

Bourbon.

b. h., 1811 .

Sorcerer 1796 (Trumpator 1782)-Dau. 1797 of Plecipitate* 1767 (Mercury 1778)-Y. Tiffany 1787 by Hightlyer $17 \% 4$ (Herod 1758)-Tiffany $1 \% 75$ by Eclipse $1 \% 6 \pm$ (Marske 1\%50)Y. Hag 1761 by Skim 1716 (Starling $17 \%$ ).

Lady Rachel, Stamford 1794 (Sir Peter T. 1781)-Y. Rachel 1799 by Volunteer 1780 (Eclipse 176-1)Rachel 1790 by Hightlyer 1\%t (llerod 1758)-Dau. $17 \% 1$ ol Syphon 1750 (Squirt 1732)Dan. of Regulus 1729 (God. Ar. 1724)

Sir Archy, "Diomed 1\% (Fiorizel 1768) -Castianira 1796 by Rockingham 1\%81 (Highflyer 17\%4)Tabitha 1782 by Trentham 1;66 (T. Sweepstakes 1743)-Daw. of Bosphorus 1754 (Babraham 1740)-Diu. of Forester 1750 (Forester 1736).

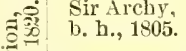

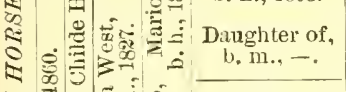
(Pacolet 1765) - Dau. of *Alderman 1786(Pot-8-0-'s 17\%3)-Dau. of Roebuck (Sweeper)-Dau. of Ilaines' King Herod (*Fearnought 1755)-Dau. of Partner 1\%55 (*Traveller $1 \% 17$ )

*Citizen, Pacolet 1763 (Blank 1740)-Princess 174 by Turk 1ff3 (Regulns 1739)-Fairy (2ueen 1762 by Y. Cade 1747 (Cade 1734)-Black Eyes 1\%40 by Crab 1722 (Alcock Ar.)-Warlock Galloway 1728 by Snake (Lister Turk)

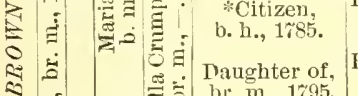

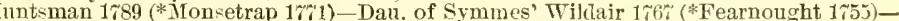
Dau. of Fearnought $1 \% 55$ (Regulus 1739)-Dan. of *Janus $1 \% 46$ (Janus 1739).

Selim,

ch. b., 1802

Bacehante,

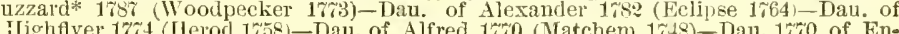
gineer 1\%6 (Sampson 1745 )

V's Ditto 1800 (Sir Petel T. 1784)-Dau. 1791 of Mercury $17 \% 8$ (Eclipse 1664)-Dan, 176 of Herod 1753 (Taxtar 1743)-Folly 1771 by Marske 1750 (Squirt 1732)-Vixen 1753 by Regulus 1739 (God. Ar. 1\%24).

Tramp, Dick Andrews 1797 (Joe Andrews 17\%8)-Dau. 1803 of Gohanna 1790 (Mercury 17r8)b. h., 1810

ITeb,

b. m., 1808

Muley,

b. h., 1810 . Fraxinella 1793 by Trentham 1766 (T. Sweepstakes 1 743 )-Dau. 1785 of Woodpecker 1773 (Herod 1758)-Everlasting 17\% by Eclipee 1764 (Marske 1\%0

Waxy 1790 (Pot-S-o-'s 17\%3)--Penelope 1798 by Trumpator 1782 (Condnctor 1760)-Pronella 1788 by Highflyer $1 \% 4$ (Herod 1758)-Promise 1768 by Snap 1750 (Snip 1736)Julia 1756 by Blank $17 \pm 0$ (God. Ar. 1721).

Daughter of,

Orvile 1799 (Beningbrongh 1791)-Eleanor 1799 by Whiskey 1 r89 (Saltram* 1780) Y Giantess 1\%90 by Diomed*1\% (Florizel 1765)_Giantess 1769 by Matchem 1748 (Cade 1734)-Molly Long Legs 1753 by Babraham 1\%40 (God. Ar. 1724

indle 1804 (Beningbrough 1791)-Dau, 1\%88 of Anvil 1\% (Herod 1758)-Virago 1\%64

Pacolet *itizen 1785 (Pacolet 17(i3)-Mary Grey by Tippoo Saib (Lindsay's A r.) - Dau. of Goode's Brimmer 1\%9 (Harris' Eclipse 1\%60)-Dau. of *Silvereye (Cullen Ar.) - Dau gr. h., 1806. of *Valiant 1756 (Dormouse 1738 )

*Miss

Shipton,

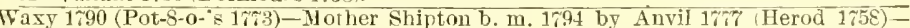
Jemima b. m. 1786 by Satelite $1 \% 74$ (Eclipse 1\%64)-Maria (IVaxy 8 dam b. m. $1 \%$ by Herod 1758 (Tartar 1743) Lisetre b. m. 172 by Snap 1750 (Snip 1736)-Miss ITindsor b. m. 1754 by God. Ar. 1724-Sist. to Volunteer by Y. Belgrade (Belgrarle Turk)Dau. of Bartlett's Chilers (Darley Ar. 1699)-Dau. of Devonshire Grey Turk-Sist. to Westbury by Curwen Bay BarbDau, of Curwen Old Spot (Selaby Turk)--Dau. of Old Toodcock (Bustler). 


\title{
ENQUIRER.
}

WINNER OF THE PHONIX HOTEL AND CITIZEN STAKE' AT LEXINGTON, CONTINENTAL HOTEL AND ROBINS STAKES AT LONG BRANCH. AND THE KENNER STAKES AT SARATOGA, ALL IN 1870.

\author{
Property of Gen. W. H. Jachson, Belle Meade Stud, near Nashrille, Tenn. Ap- \\ plication to Gen. W. H. Jackson, lock box 383, Nashoille, Tenn. Fearling \\ sales annully about MIay 1 st.
}

Exquiper by imp. Leamington, son of Fanglh-a. Ballagh, wed by H. F. Tissman, Louis rille, Ify., dam Lida by Lexiugton, son of Boston, seeond dan Lize by Aneriean Eclipse, ont of Gabriella, dam of George Martin by Garrison's Zinganee, son of sir Archy. As a race-horse Enquirer ranks as the best son of Leamington. hoth as racehorse and sire. He started three times as a two-rear old in 1869; was nuplincen in Sweenstake at Cincinnati ( 1 mile), won by Hambinro in 1.45 ; ran mplaced in Willard Hotel Stakes at Lonisville ( 1 mile) in 1.48 , won by his stable companion, Lruchburg. Won George Elliot Stake for two-year olds at Memphis (1 mile), beating Hambnrg, Lynchburg, Mundane aud Kildare, in 1.48. In 1870, when three rears old, ran six races and wou them all. Lexington, won the Phonix Hotel stakes (mile

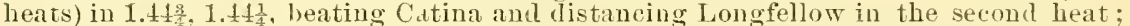
same place won Citizens' Stakes (2-mile heats), in $3.35 \frac{3}{4}, 3.41 \frac{1}{3}$, beating Lyttleton: the first mile in the first heat was run in 1.t31. Cinciunati, won Sweepstakes for threeyear olds (2-mile heats), in 3.50, $3.39 \frac{1}{2}$, beating Conduetor and Restless. Long Branch, won the Continental Hotel Stakes (mile heats), in 1.47, 1.49, 1.51; beating: Lynehburg (who won the first heat and broke his shonlder at the start of the second), Maggie B. B. (dam of Iroqnois), Haric. Snsan Ann, dam of Thora, ete. Same place, won the Robin's Stakes (2-mile heats), beating Kingfisher, who won the first heat, and the Major, in $3.56 \frac{1}{2}, 3.54,4.00$, traek muldy. Saratogi, wou the Kemer Stakes (2 miles), in $3.48 \frac{1}{4}$, beating Hamburg, Telegram and Remorseless, value, 10,250 , the most valuable Kenner ever run. Valne of winnings at three years old, 820,800 . His leg gave way iu his four-yenr old form, and he was put into the stud, but trained again at seven years old, when he started in one race (2 miles) but was mplaced. The family from which he descends is a good raeing oue. His dam, Lida, and grandam, Lize, were not trained. Eclipse, the sire of his grandam, was the race-horse of his day; he heat all the best horses of his time, and won the great sectioual mateh. the North against the Sonth, run over the Union Conrse, L. I., May 27, 1323, for 820,000 a side, Eelipse beating Henrs, who won the first heat, in $7.37 \frac{1}{2}, 7.49 .8 .24$. Gitlrielle, his great grandam, by the renowned sir Archy, was a fine race-mare, and dam of the noted Geo. Martin, which beat Reel and Hamma Harris (t-mile heats), in 7.33, 7 t3. Yet he has always held a high position as a mimning sire. Amongst the

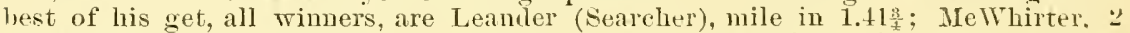
miles, $3.30 \frac{1}{2}$; the fastest race ever run by a three-rear old, Lizzie Whipps (2-mile heats), in $3.36 \frac{1}{2}, 3.39$; Harkaway (mile heats), in $1.13,1.42 \frac{1}{2}$ (2-mile heats), in 3.39 .

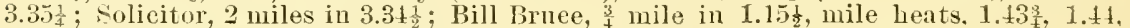
2 miles in 3.36 night. $\frac{7}{8}$ of mile in $1.28 \frac{9}{4}$, mile, $1.12 \frac{1}{2}$, and $1 \frac{1}{8}$ miles, 120 lbs., in $1.55 \frac{1}{2}$ : Getawar, $1 \frac{1}{1}$ miles in 2.07 , fastest on record to that date, 2-uile heats in $3.361,3.35 \frac{1}{3}$; Falsetto. $1 \frac{1}{1}$ miles in $2.08 \% 2$ miles in 3.3.1. with 118 11s.; Pinafore, 1 mile 500 raris, in 2.11: Inspeetor B., Eqmont, Lizzie MeWhirter, Fortuna, Faustus, Reporter, Bamner Bearer. Bella B., Miss Ford, Burch, Basil Duke, Ernest, Telie Doe, Kitty 'T., Marie K., Nellie Van, Boodler, Nelly B., Kee-Vee-Na, Centipede, Arla A., Euterprise, Qneer Tor, Envor, . Emperor, Eloise, Embargo, Mirabean, Executor, Willow, Emigrant. Edisto, Jessica, Entymiou, Equipoise, Napa, Everett. Eemomr. Elitor, Erebus, Clay Pete. Eudurer. Eight-to-Seren, Baldwin, Argenta, Bol, Thomas. Tom Paxton, Lute Fogle, Little Phil, Calignla, Rerenge, Clarissima. Miss Ella, Mamnie Grer, Arleline, Imy Hrale, Lizzie D., Enquiress, Zuleika, Sadie MeNairy, Enigma, Drift, Engarita, Florenee Anderson, Secret, Respond, ete. Enquirer traees throngh severil crosses of sir Arehy to the great imp. Diomed, winner of the first Finglish Derby, and a horse in which the best stork of Amerira can be tracerl throngh nneontaminaterl somrces. There is no better line through whieh to perpetnate and retain this blood, with the Whalebone and Pantaloon blood inlierited through his sire. He is 16 . hands high: wirth, 73 in.: length of shoulder, 29: in.; eiremuference of :rm, 22 in.; aromud the lew below the knee, 9 in ; from point of shomlder to turn of the buttoeks, 69 in.: firm point of lip to point of hock, 38 in.; around the gaskins, 18 11., and weighs 1,200 los. 


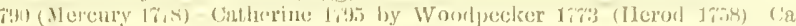
Thialestivis,

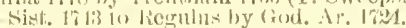

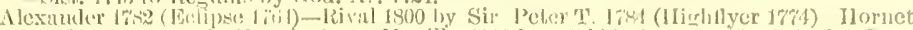

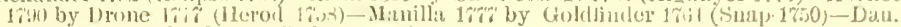
17iti ol Ole binglind 1 i 11 Gad. Ar. 17\%1)

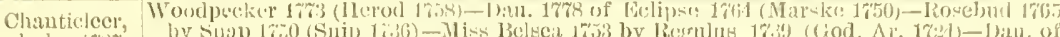
cl. b., 1 risi.

Terne,

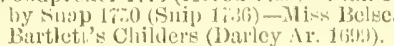

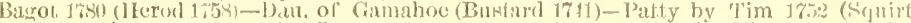
cli. $\mathrm{m} ., 1 \% 90$.

Ir. Escape, Curwen Biy Barb.

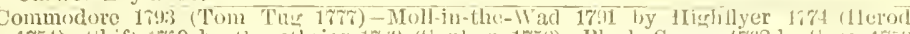

Y. Heroinc, (Snip 1736) Dau. of Cade 1\%3 (Gol. Ar. 1\%:1)

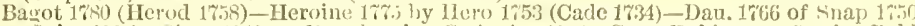
(Snip 173ti) - Sist. 1713 to Rerulus by Gud. Ar. 17:21-Grey Robinson 172', by Buld Galloway (S1. Victor Barb).

Buzzard *

ch. h., $178 \%$

Woodpecker firi3 (1lerod 1758)-Nisfortune 17\% by Dux 1\%61 (Matchem 1748)-Curi-

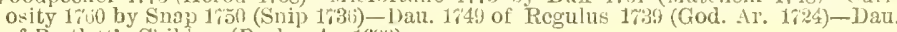
of Bartlett's Childers (Darley Ar, 16.4)

Dangliter of, Alexander 1782 (Eclipsu 17/4)-Dall. ol Highfyer 1774 (Lerod 1758)-Dau. of Alfrer 1770 (Hatchem 1718)-Diau. 17to of Eugineer 175:j (Sampson 1745)-Bay Malton's dam 175t; by Carle $1 \% 34$ ( $($ tod. Ar. 1\%:4).

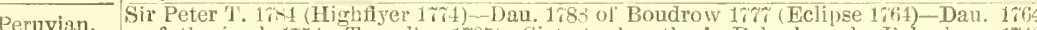
Peruvian, b. h., 1806 .

Nusidora, b. $10 ., 1504$

Blacklock, b. b., 1814.

Wagtail,

b. m., 1818 .

Champion, ch. h., 1812 . Etiquette,
br. m., 1830. of Squirrel 1754 (Traveller 1750)-Sist. to Lowther's Babraham by Babraham 1740 (God. Ar. 1721)-Dilu. 1750 ol Golden Ball 1735 (Partner 1718)

Meteor 1783 (Echpse 1764)-Maid-of-all-Work 17\$f by Highfiyer 1774 (Herod 1758)-Dau. 1771 of syphon 1750 (Squirt 1732)-Dant. of Regulus 1739 (God. Ar. 1724)-Sist. 1758 to Judgement by Snip 1736 (Flying Childers 1715).

Whitelock 1803 (Hambletonian 179:) Dan. 179. ot Coriander 1786 (Pot-8-0-'s 17i3)Wildgoose 1792 by Hightlyer 1744 (Herod 1758)-Coheiress 1786 by Pot-8-0-'s 17\%: (Eclipse 1761)-Manilla 17/7 by Goldfinder 17(6) (Snap 1750).

Prime Minister 1810 (Sancho 1801) - Tranby"s dam 1812 by Orville 1tng (Beninobronoh 1791)-Miss Grimstone 1798 by Weazle 1776 (Herod 1758)-Dan. of Ancaster 1768 (Blank 1740)-Dau. ol Damascus Ar. 1754.

Selim 1802 (Buzzard* 178 )-Podagra 1k0; by Gonty 1695 (Sir Peter T. 1784)-Jet 1785 by Magnet $17 \% 0$ (Herod 1758)-Jewel 17\% by Squimel 1754 (Traveller 1735)-Sophia $1 \% 64$ by Blank $1 \% 40$ (God. Ar. 1\%24)

Orville 1799 (Beningbrongh 1\%91) Boadicea $180 \%$ by Alexander $1 \% 82$ (Eclipse 1764)Brunette by Amarauthus 1736 (Old England 1741)-Nayfly 1\%1 by Matchem $174 \mathrm{~s}$ (Cade 1734)-Dan. 1755 of Starling 1738 (Starling 1725).

Eir Archy,

Daughter of

Diomed 1777 (Florizel 1768) - *Castianira 1796 by Rockingham 1781 (Highflyer 17\%4)-

Tabitha 1782 by Treutham 1766 (T. Sweepstakes 1\%13)-Dau. of Bosphorus 1754 (Babrabam 1740)-Dati. of Forester 1\%00 (Forester 1736).

*Saltram 1780 (Eclipse 1764)-Dan. of Symmes' Wi]clair 1767 (*Fearnought 175a)-Dau. of Tyler's Driver 1\%60 (*Othello)-Dum. of *Fallower 1\%61 (Blank 1740)-Dau. of *Vampire $175 \%$ (Regulu- 1739).

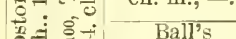

Florizel,

ch. h., 1801.

Diomed 1767 (Florizel 1768)-Dau. of Shark 1\%1 (Marske 1750)-Dan. of Harris" Eclipse 1770 (*Fearnonght 1755) - Dau. of *Fearnought 1\%55 (Regnius 1739)-Dau. of * Jolly Roger 17.1 (Rouid head 1733).

$\odot \equiv$ Dainghter of, b. $11 ., 1 \% 99$.

Alderman 178\% (Pot-8-0-'s 1\%3)-Diu. of *Clockfast 1\%74 (Gimerack 1660)-Dau. of Symmes' Wildair 176; (*Fearnought 1;55)-Y. Kitty Fisher 1\%6\% by *Fearnought 1755 (Regulus 1\%39) - Kitty Fi-ber 1755 by Cade 1\%34 (God. Ar. 1\%34).

Emilius,

Orville 1799 (Beningbrough 1791)-Emily 1810 by Stamford 1794 (Sir Pefer T. 1784)Dan. 1799 of Whiskey if 89 (Saltram 1780)-Grey Dorimant 1781 by Dorimant 17\%: (Otho 1\%ti)-Dizzy 1;5 by Blank 1\%40 (God. Ar. 1724)

Icaria The Flyer 1814 (Vandyke Jr. 1808)-Parma 1813 by Dick Andrews 1797 (Joe Andrews

b. m. 1824. 17r8)-May 1801 by Beningbrcugh 1791 (King Fergus 1\% $1 \%$ )-Primrose 178\% by Mam-

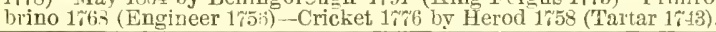

Sumpter Sir Archy 1805 (*Diomed 17\% -Dau. of * Pobin Redbreast 1796 (Sir Peter T, 1r84)Sau. $1 \% 88$ of *Obscurity 17r (Eclipse 1\%(34)-Slamerkin 1768 by *Wildair 1\%53 (Cade 1734 - $\approx \mathrm{Cnb}$ mare 1762 by Cnb 1739 (Fox 1711 ).

Robin Grey 1805 (*Royalist 1290)-Maria 1502 by Melzar $1 \% 91$ (*Medley 1\%6)--Dau. of Highflyer 1784 (Hightlyer 1\%74)-Dau. of *Fearmought 1755 (Regulus 1739)-Dan. of Ariel 1756 (*Traveller $1 \% 4 \%$ ).

i. b. m., $181 \%$.

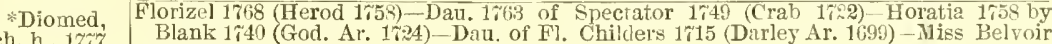
ch. b., $17 \%$.

by Grey Grantham (Brownlow Turk)

Amanda, Grey Diomerl 1\%85 (*Medley 1766)-Dau. of Ta. Cade (Partner 1r55)-Dan. of Hickman's ch. m., 1800

Independence 1176 ("Fearnooght 1755) - Dau. ol *Badger (Bosphorus 1\%54).

Mambrino 1768 (Engineer 1\%6)-Dall. 174 of Turf 1560 (Matchem 1749)-Dau. 1761 of g1. h., 1780, Regulus 1739 (God. Ar. 1724)-Dan. 1753 of Starling 1757 (Bay Bolton 1705)-Snap's dam 1 w39 by Fox 1714 (Clumsey). 1759 by Snap 1750 (Snip 1736) -Dan. 1749 of Regulus 1739 (Godolph. Ar. 1721)-Dau. of Bartlett's Childers (Darley Ar. 1699).

Florizel 1788 (Herod 1758)-Dan. 1763 of Spectatol 1749 (Crab 1722)-Horatia 175s by ch. h.. $17 \%$. Blank 1740 (God. Ar. 1724)-Dan. of Fl. Chilciers 1715 (Darley Ar. 1699)- Miss Belvoir by Grey Grantham (Brownlow Turk)

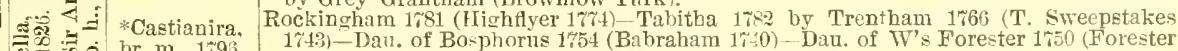

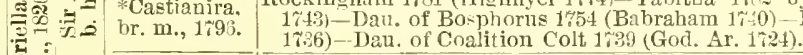

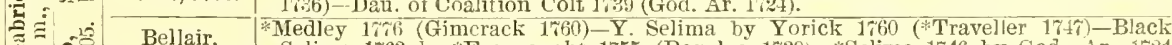

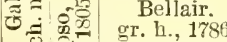

Selima 1763 Gy *Fearnouht 1755 (Reoulus 1739)-*Sim 1746 by God. Ar. 17:4 - Large Hartley mare 1\%29 by Hartley's Blind Horse (Holderness Turk).

Ś. Contention's
dam,
en. m.. 1r98.

Dare Devil 1787 (Magnet 17\%1) - Sallard mare ch. m. 1792 by Symmes Wildair 1\%6\% (*Fearnought 1755)-Picadilla ch. m. by Y. Fearnought 176 (*Fearuought 1755)1747 (Goliah 1730 )-Dau, of *Jolly Roger 1741 (Roundhead 1733)-Dau. of *Taliant 


\section{EOLUS.}

\section{IVINNER OF THE CITY HOTEL STAKES AT BALTIMORE AND OTHER GOOD RACES.}

\section{R. J. Hancock, proprietor, Overton P. O., Va. Tearlings will be sold anmually.}

Eolus by imp. Leamington, son of Fangh-a-Ballagh, bred by Major Thomas WV. Doswell, Bullfield Stud, Hanover Junction, Va., foaled 1-68, dam Fanny Washington, dam of Rappahamock, ete, by Revenue, son of imp. Trustee, ont of Sarah Wash. ington, the dam of Oratrix, Iuspector, ete., by Garrison's Ziuganee, son of Sir Archr. Fanny Washington, his dam, was one of the best mares of her day; was winner at ill distances, 2 mile heats in $3.47 \frac{3}{4}, 3.40 \frac{1}{2}, 3$ mile heats in $5.43,5.44 \frac{1}{2}$, defeating Tar River,

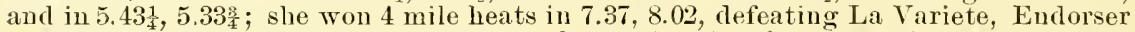
and others, and beat the best ones on all the tracks; her fnll sister, Sue Washington, was also noted as winner at all distances. Revenue, her sire, won at all distances, and was the sire of the great Planet, Exchequer and other good race-horses. Sarah Washington, his grandam, was one of the best mares of her day, winner at all clis-

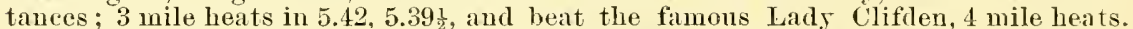
She prodnced Inspector, one of the best race-horses of his day, and Oratrix, that beat the noted Bostona. Eolus did not start as a two-year old, but won three out of the six races in which he started as a three-year old, a club purse, 2 miles, at Saratoga, in $3.388^{3}$;

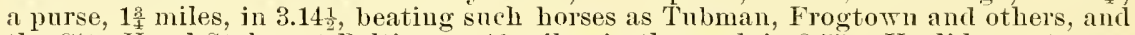

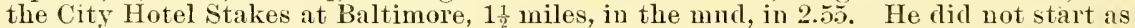
a fonr-year old, and only won three races at five years old; $1 \frac{1}{2}$ miles at Baltimore, in $2.43 \frac{3}{4} ; 1 \frac{8}{4}$ miles at Saratoga, in 3.15 , and one of $1 \frac{1}{8}$ miles, in $2.02 \frac{1}{2}$. He was close up in several races in first-class company. When six years old he ran three races, won two, one of $2 \frac{1}{2}$ miles, at Baltimore, in 4.39 , and one of $2-$ mile heats, in $3.40,3.39 \frac{1}{2}$, 3.36* Mart Jordan winning the second heat. 'This third heat is the fastest and best third heat ever run, and stamped him as a race-horse of the first water, possessing both speed and stamina. He had but one representative on the turf in 1881, Eole, and, although mnch out of condition during the year, he ran creditably in all his races and won some of great merit, notably his $1_{1}^{\frac{3}{2}}$ miles, in $3.07 \frac{1}{2}, 1$ mile and 5 furlongs, in $2.49 \frac{3}{9}, 1$ mile and a furlong, with $1161 \mathrm{ls}$., in $1.58 \frac{8}{4}, 1$ mile and 3 furlougs in $2.24,1 \frac{1}{4}$ miles in 2.11슬 $1 \frac{1}{2}$ miles in 2.391. In 1882 Eole, although saddled with the top weights, won the great Metropolitan Stakes at Jerome Park, 11 miles, in 2.41, deteating General Mouroe, Monitor, Parole, ete., and the Jockey Club Handicap, 2 miles, in 3.38 carryug $123 \mathrm{lbs}$. to Monitor's 122, he being secoud. In the Cones Island Cup he forced Hiuloo to run the first 2 miles in 3.29 , and the $2 \frac{1}{4}$ miles in 3.58 , the fastest race at the distance during the year. Eole won the Monmouth Cup, $2 \frac{1}{4}$ miles, in $4.07 \frac{3}{4}$, beating Girofle and Monitor. He won the Chanpion Stakes, the Morrisser Stakes at Saratoga, and the Autumn Cup at Coney Island, 3 miles, in 5.26 $\frac{1}{2}$, in which he defeated Lida Stauhope, Thora, Glenmore and four others. In this race he carried $120 \mathrm{lbs}$. and conceded all lumps of weight.

Eolus is the sire of the winners Eleve, St. Saviour, Eolist, Eolo, Elkwood, Knight of Ellerslie, Eolian, Calculns. Katlueeu, Notus, Eolic, Starling, Spartan, 'Thorudile, Comut-Me-In, Sonvenir and the grand two-rear old Morello, Diablo, Niuone, Young Grace, Charley Russell, Harry Russell, Eoline, Seedtick. Faustina, Bar Archer, Elkton, John Cavenagh, Albemarle, Amos, Russell, winner at $\frac{1}{2}$ a mile in $46 \frac{1}{2}$ and $49 \frac{3}{4}, \frac{3}{4}$ in 1.10 , $\frac{5}{x}$ in 1.02 , Eurus, one mile in $1.41,1 \frac{1}{8}$ miles in $1.5 .5 \frac{3}{4}, 1 \frac{1}{4}$ miles in 2.08, Ro5al Garter, Sterling, Raymond G., Little Jim and other winners.

Eolus is a dark bay lorse, with star in his forehead and two white hind heels,

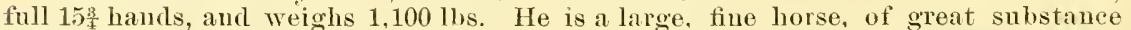
and power, and in addition to his Waxy blood through Whalebone and Whisker, he has four distunct crosses of Sir Archy on his dam's side, and traces to Eelipse and Herod through his collateral branches. The stock all possess symmetry, constitution and staving vowers.

It is to Old Bald Peg in direct female live that the following fanoms horses trace, Lath, Cade, Flying Chililers, imp. Diomed, Sorcerer, imp. Priam, Phantom, Langar, Mule, Plemipotentiary, Grey Medoc, Thunder, Loadstone, Lightuing, Lancaster, aud all the Blue Bomnet family. 


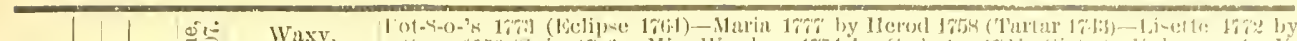

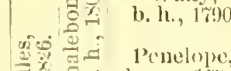

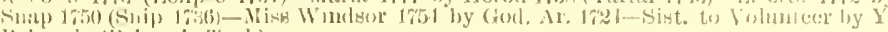
behrate (Belomele Tiurk)

-

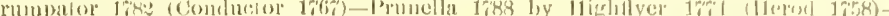

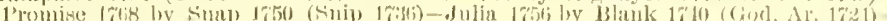

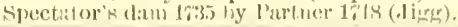

舟

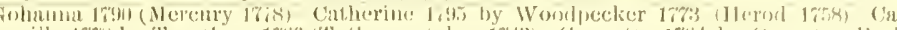

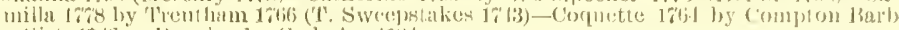

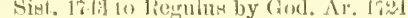

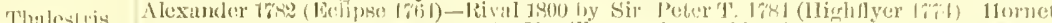

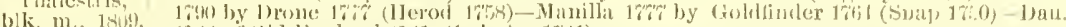

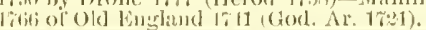

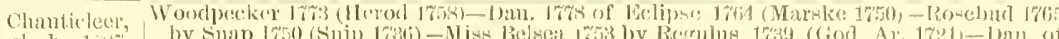

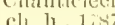

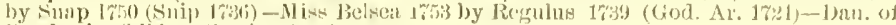

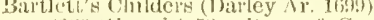

\section{lerter,}

ch. m, 319

3agot

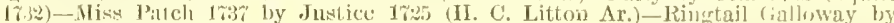
Cumen bity binb.

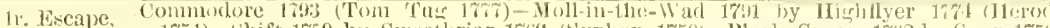

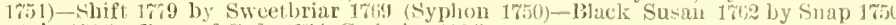
(Nnip 1733(i) Dalt. of Cade 173.t (Gosl. Ar. 1704)

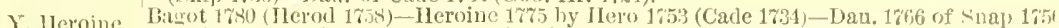
(suip) 1736) - Sist. 17.3 to Rerulus by ( Galloway (Nt. Victol Barb).

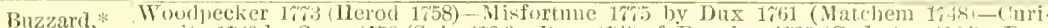
osity 1760 by Snap 1750 (Snip 173j)-1)au. 1649 of Regulus 1739 (God. A1. 1i24)-Dan. of Bartlett's Childers (Darley Al. 16!4!).

ङ. ch. 1., 1\%

Daughter of

\section{Peruvian,}

b. h., $1800^{\circ}$.

Musidora,

b. m., 1804

Blacklock

b. h., 1814 .

184 of by Cade 1734 (God. Ar: 17:4).

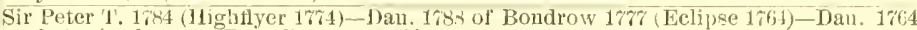
of squirtel 1551 (Traveller 1735)-Sist. to Lowther's Babraham by Babraham 1\%-10 (Crod. Ar. 1724)-Dilu. 1650 ot Golden Ball 7 r35 (Partnel 1718).

Meteor 1789 (Echpse 1761)-Maid-of-all-Work 178 by Highflyer 1764 (Herod 1758)-Dau.

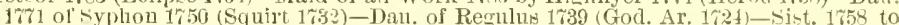
Judgement by Snip 1736 (Flying Childer's 1715).

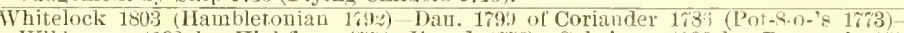

Wagtail (Eclipse 176.1 by Highflyer 174 (Herod 1758)-Colieire

Prina 11 iniser 1810 Sancho 1801 ) Tranby" 1791) Miss Grimstone 1796 by Teazle 176 (Herod 1\%58)-Dan of Ancaster 1 ics (Blank 1740)-Dan. of Damascus Ar. 1754

ch. h., 1812.

Sos (Buzzard*178\%) - Podagra 1805 by Golsty 1796 (Sir Peter T. 1\% - Jet 17 by Magmet $17 \% 0$ (Herod 1758) - Jewel 1775 by Squirrel 1754 (Traveller 17\%5) - Solnia $1 \% 64$ by Blank 1740 (God. Ar. $1 \% 24)$

Etiquette, br. m., $18 \geq 0$

Orville 1799 (Benincbrongh 1 291 )

Brumette by Amaranthis 1406 (Old England (Cade 1731)-Dan. 1755 of Starling 1738 (Starling 172\%).

\section{Golumpus

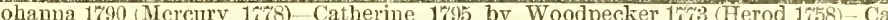

io. h., 1802. milla $17 \% 8$ by Trentham 1766 (T. Sweepstakes 1743)-Coquette 1764 by Compton Barb Sist. 1743 to Regnlus 1739 (God. Ar. $17 \% 1$

\section{Lucy Gray.}

蔗:

Timothy 1794 (Delpini 1781)-Lucy 1789 hy Blank 1740 (God. Ar. 1724).

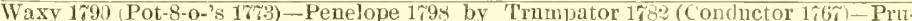
nella 1783 by Hightlyer 174 (Herod 1758). Promise 1768 by Suap 1750 (Snip 1736)Julia 1756 by Blank 1740 (God. Ar. 17\%4).

Hernes 1790 (Mercnry 1778)-Vicissitude 1800 by Pipator 1:86 (Imperator 1\% 6 )-Beatrice 1791 by Sir Peter T. 1784 (Highflyer 1\%t)-Fyrrha $1 \% 1$ by Nlatchem $1 \% 18$. Cade 1.31)-Duchess 1748 by Whitenose $1 \% 12$ (Gor. Ar. 1\%24)

Gibside Fairy b. m., 1811 .

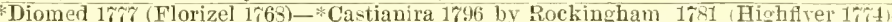

Sir Archy,

Tabitha 1 T2 by Trentham 1766 (T. Sweepstakes $1 \% 43)$-Dau. of Bosphorus 1\%54 (Babraham 1740)-Dau, of Forester 1750 (Folester 1736).

Daughter of, "Citizen 1785 (Pacolet 1763)-Ditu. of Commutation (Symmes' Wildair 1;6\%)-Dau. of *Dare Devil 178\% (Maguet 1\%0)-Sally Shark by *Shark ir/1 (Marske 1:50)-Betsy Pringle by * Eearnought 1755 (Regulus 1739).

Sir Axchy 1805 (*Diomed $1 \% \%$ )-Meretrix by Magog 1799 (Chanticleer)-Narcissa $1 \% 96$ by *Shark $1 \% 1$ (Marske 1750)-Rosetta 1785 by *eutinel 1\%58 (Blank 1710)-Diana by Clorlius $17 \% 8$ ( Janus 1746 )

Virginian,

b. h., 1815 .

Grandam of Tritle,

gr. m.,

Bedford 179: (Dunganuon 1780)-Dat. of Bellair 1786 (\%edley 17\%6)-Dan. of * Shark 1771 (Marske 1750)-Dau. of Symme's Wildair 176\% (*Fearnought 1755)-Dau. of Lex ington 1764 ( Washington).

*Diomed,

ch. h., $177 \%$.

Florizel 1 (⿱一𫝀口68 Belvoir by Grey Grantham (Brownlow Turk).

*astianira,

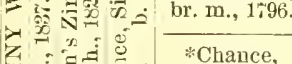

Rockingham 1781 (Highflyer 1\%4)-Tabitha 1782 by Trentham 1\%66 (T. Sweepstakes 1743)-Dau. of Bosphorus 1754 (Babraham 1'10)-Dau. of Forester 1750 (Forester 1736) -Dan. of Coalition Colt 1739 (God. Ar. 1\%:4

Lurcher 1789 (Dungannon 1780)-Recovery 1788 by Hyder Ally 1765 (Blank 1\%40)-P(1b. h., $179 \%$.

Danghter of dita 1769 by Herod 1758 (Tartar 17+3) Fair Fores
Dan. 1746 of Forester 1736 (Hartley's Blind Horse).

Eagle 1796 (Volunteer 1780)-Maria 1805 by Bay Yankee (President 19-8)-Green's Celer mare by Meade's Celer 1\%t Janns 1;46)-Dau. of Partner 1\%5ó (*Traveller 174\%)-Dan. of Apollo 1\%6\% (*Traveller 1\%4\%).

Sir Archy,

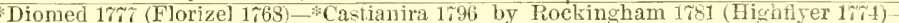
Tabitha 1782 by Trentham 1766 (T. Sweepstakes 1r43)-Dau. of Bosphorus 175: (Babraham 1\%40)-Dau. of Forester 1750 (Forester 1\%36).

b. h., 1805,

Dare Devil $178 \%$ (Magnet $17 \% 0$ ) - Dau. 1792 of Symmes' Wildair 1767 (*Fearnought 1755)

ch. m., 1798 . (*Fearnotight 1755 ) - Dan of *Hob or Nob 1747 (Goliah $1730 \%$

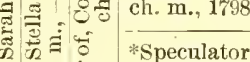
b. h., 1795 .

Dragon* 178\% (Woodpecker 1773)-Dau. 1780 of Herod 1758 (Tartar 1743)-Florizel's dam 1761 by Cyonet 1753 (God. Ar. 1724)-Dau. of Y. Cartouch 1731 (Cartouch 1\%17)Ebony 1288 by Flying Childers 1715 (Darley Ar. 1689)

Pompadour, *Valiant 1756 (Dormouse 173s)-Fenny Cameron by Cuddy 1727 (Fox 1714)-. Miss Belch, m, voir by Grey Grantham (Brownlow Turk)-Dan. of Paget Turk-Betty Percival by
Leedes Ar. Dau. 1690 of Spanker (D'Arcy Yellow Turk)-Oid Aloroceo mare by Ioroceo Barb-old Bald Peg by an Arabian-Barb mare. 


\section{IMPORTED EOTHEN.}

\section{Ouned by Nick Finzer, Esq., Louistille, Ky. Service by contract.}

IMported Eothex, bay horse, foaled 18:3, bred in the Yardles Stud, imported. by the late D. D. Withers as a yearling. by Hampton, son of Lord Clifien, winuer of the Derby, br Newminster, Eothen's dam Sultana by Oxford, son of Birdcatcher by Sir Hercules, out of Besika by Beiram, son of sultau. Hampton, the sire of Eothen, was a superior horse, winner of the Goodwood and. Doncaster Cups, and is half brother to Sir Berys, wimuer of the Derby, both being ont of Lady Langden by Kettledrum, son of Rataplau, owu brother to Stockwell, and out of Haricot by Mango or Lanercost, she ont of Qneen Mary, dam of Blink Bonny (Bair Athol's dam), Bownie Scotland, etc. Hampton is a popular and successful stallion in England, sire of Ayrshire, winner of the 2,000 Guineas and Derby, Reve d'Or, winnex of the 1,000 Guineas and Oaks, imp. Kingston and the great horse Sheen, that won the Cesarewitch Handicap, carrying $128 \mathrm{lbs}$, and the only horse that ever $\pi$ on it with snch an impost. Eothen's dam Sultaua by Oxford, who was the sire of Sterling; who sired the great horse Isonomy. Besika, his grandam, is the dam of Moslem, wnner of the 2.000 Gnineas, and is halt sister to Flying Duchess, the dam of the popular stallion and Derby winner Galopin, she ont of Merope, almost full sister to Velociperle and to Estelle, the dam of Picnic, wiuner of the 1,000 Guineas and the dam of Mayouaise, winner of the 1,000 Gnineas. Sultana, the dam of Eothen, is the dam of the winners Turkish Delight (winner of five races at three years old and two races last sear), Gulbesaz (rimner of fonr races at two years old, including Exuing Plate), Graceful and Ayrshire Lass. Eothen was imported when a jearling by the late D. D. Withers, but was so badly injured in the voyage to America that he was never trained. The oldest of Eothen's get are now yearlings and are good looking colts, of high finish and much promise. From the Byerly Turk mare, dam of the two True Blnes, descend in direct female line the following famous horses, Sir Peter, Buzzard, Tramp. Master Henry, Champion, Galopin, Lanercost, Glaneus, Stockwell, Rataplan, The Flying Dntchman. Fing Tom. Quicklime, Kettledrum, Toxophilite, Faronus, Windhound, imp. Chatean Marganx. imp. Robin Redbreast, imp. Hampton Court, American Eclipse, imp. Rayou d:Or, Reform, imp. King Ernest, imp. King Ban, imp. Ill-Lsed, etc. 


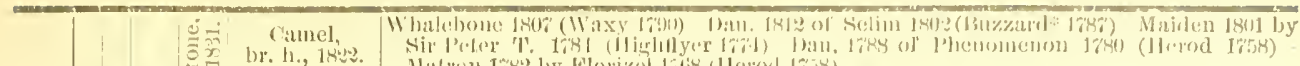

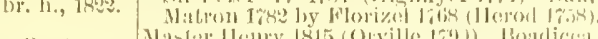

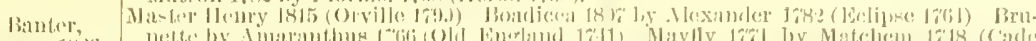

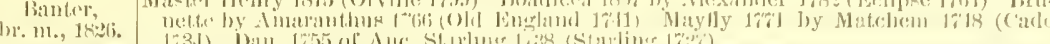

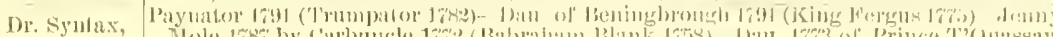

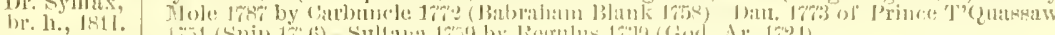

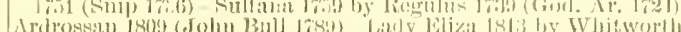

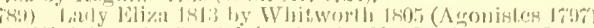

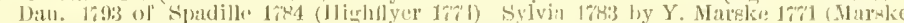

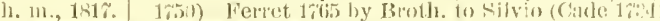

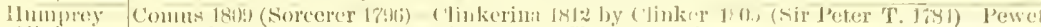
Clinkir,

b. 11., $18 \%$. 1):atuliter of

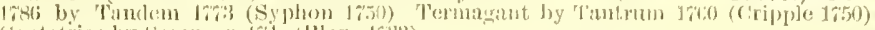

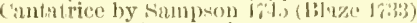

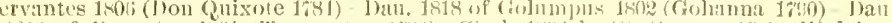

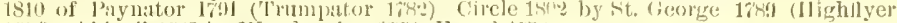

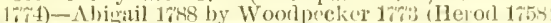

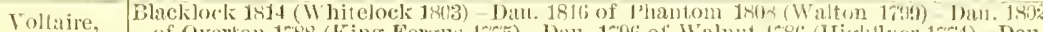

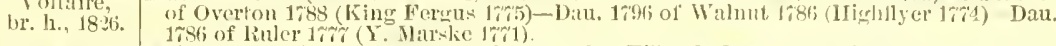

Mulato 1823 (Catton 180.) - Leda 18:- by Filho-da-Puta 1812 (Haplazary 1790)Martha Lynu

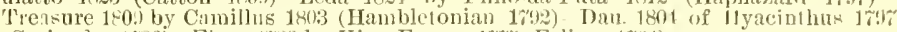

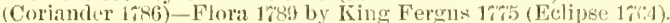

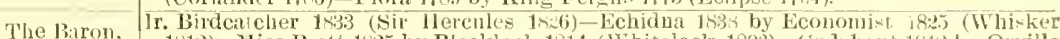
ch. 1., 1812. 1R12) Miss Pratt 1805 by Blacklock 181t (Whitelock 1803) (iadalont 181:2 by Orville

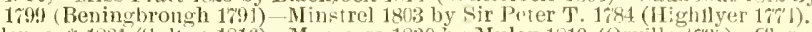

The Prowost, The Saddler 18:8 (IVaverley 181i)-Rebecea 1831 by Lottery 182) (Tramp 1810) Dau br. h., 1836,
(King Fergus 17\%5)-Expectation 17rg by Herod 1i53 (Tartar 1743).

:

Liverpool 1828 (Tramp 1810)-Otis 1820 by Bustard 1801 (Buzzard: 1\%8\%)-Dau. 1813 of

Otisina,

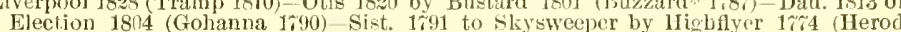
17.58) Dau. 17rs of Eclipse 1764 (Marslie 1750)

Liverpool Tramp 1810 (Dick Andrews 179\%)-Dau. 1822 of Whisker 1812(Waxy 1790) - Mandane Liverpool,
b. h., 18\%8.
1758 by Camilla $17 \% 8$ by Trentham 1766 (T. Sweepstakes 1\% 13).

Otis, Bustard 1801 (Buzzard 178\%)-Dau. 1813 of Election 1804 (Gohanna 1790) Sist. 1\%91 to Skysweeper by Highflyer 17\%4 (Herod 1758)-Dau. 17\%8 of Eclipse 1764 (Marske 1750)-

Rosebud 1765 by Snaj) 1750 (Snip 1736).

b. $m ., 18 \% 0$. Gladiator, Partikan 1811 (Waiton 1;9!h) Panline 18;3 by Moses 1819 ([Whalebone or] Seymour
cl.h., 1833. or] Sorcerer 1796 (Trumpator 1782) - Canary 179\% by Coriander 1780 (Pot-8-0;s 17\%3).

Danghter of Plenipotenliary 1831 (Emilins 18:0)-Myrha 1830 by Whalebone 180\% (Waxy 1790)-

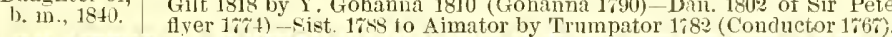

Whalebone, Waxy 1790 (Pot-S-0-'s 17\%3) Penelope 1798 by Trumpator 1782 (Conductor 1767) - Prnbr. h., 1807. $\quad$ Julla 1788 by Highflyer $17 \% 4$ (Herod 1758)

Peri Wanderer 1811 (Golnanna 1790) - Thalestris 1809 by Alexander 1782 (Eclipse 1r64) - Rival

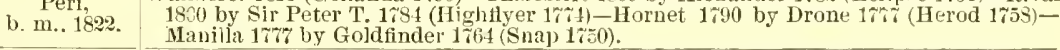

Bol Booty, Chanticleer 1787 (Woodpecker 1773)-Ierne 179 ) by Bacot 1780 (Herod 1758) -Dall. of Bol) Booty, Gamahoe (Bustard 174i)-Patty by Tim 1752 (Squirt 1732) - Miss Patch 1737 by Justice $1 \% 25$ (H. C. Litton Ar.)

Flight Ir. Escape 1802 (Commodore 1793)-Y. Heroine by Bacot 1780 (Herod 1758)-ILeroine

Ir. Escape 1802 (Commodore 1793)-Y. Heroine by Bagot 1780 (Herod 17\%8)-Ileroine $17 \% 5$ by Hero $1753(\mathrm{Ca})$
lus by God. Ar. $1 \% 24$.

ch. m., 1809

Orville 1799 (Beningbrough 1791)-Emily 1819 by Stamford 1794 (Sir Peter T. 1784)-
Dan. 1799 of Whiskey 1789 (Saltram* 1780)-Grey Dorimant 1781 by Dorimant 17\%

Enilins, (Otho 1760)-Dizzy 1757 by Blank 1740 (God. Ar. 1724)

Harriet Pericles 1 409 (Evander 1801) -Dau. 1812 of Selim 1802 (Buzzard* 1787) - Pipylina 1803 by

Sir Peter T. 1784 (Highflyer 17\%4) - Rally 1790 by Trumpator 1782 (Conductor 1767) Fancy 1780 by Florizel 1768 (Herod 1758).

SnItan 1816 (Selim 1802) - Cobweb 1821 by Phantom 1808 (TValton 1799)-Filagree 1815

by Soothsayer 1808 (Sorcerer 1796). IVeb 1808 by Waxy 1790 (Pot-8-o-'s 17i3)-Penelope 1798 by Trumpator 1782 (Conductor $1 \% 6 \%$ ).

Middeton,

b. h., 1833 .

Miss Letty,

Priam* 18\%" (Emilins 1800)-Dau 1815 of Orville $1 \% 99$ (Beningbrough 1\%91)-Dan. 1800 of Buzzari* 1\%87 (Woodpecker 17\%3)-Hormpipe 1793 by Trumpator 1782 (Conductor 176\%) - Luna $17 \% 9$ by Herod 1758 (Tartar 17 13 ).

Suzzard* 1787 (IVoodpecker 1773)-Dau. of Alexander 1782 (Eclipse 1761)-Dau. of Highflyer 17\%4 (Herod 1758)-Dau. of Alfred 1\%0 (Datchem 1748)-Dau. 17\%0 of Engineer 1756 (Sampson 1745).

ch. h., 1802

IV's Ditto isoo (Sir Peter T.

T. 1784)-Dau. 1 r91 of Mercury 1788 (Eclipse 1764)-Dau. 1766

of llerod 1\%59 (Tartar 1\%13)-Folly 1\%71 by Marske 1750 (Squirt 1732)-Vixen 1753 by Regulus 1759 (God. Ar. 1\%21).

涫

Sir Peter T. 1784 (Hightlyer 1774)-Horatia 17\%8 by Eclipse 1764 (Marske 1750)-Countess

$\begin{array}{ll}0 & \text { Stamford, } \\ 0 & 0\end{array}$ 1760 by Blank 1740 (God. Ar. 17:4)-Dau. of Rib 1736 (Crab 1\%22)-Dau. of Tynn Aribian.

Mercury 178 (Eclipse 1764)-Dau. 1\%80 of Herod 1\%5 (Tartar 1743)-Y Hag. 1661 by

ミ Sist. to Silver,

$\frac{2}{2}=\mathrm{gr} . \mathrm{m} ., 1 \gamma 90$.

Skim 1\%4 (Starling 1\%\%)-Hag 1744 by Crab 1722 (Alcock Ar.)--Ebony 1728 by Fi. Childers 1715 (Darley Ar. 16.99).

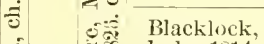

Whitelock 1503 (Hambletonian 1792)-Dau. 1799 of Coriander 1786 (Pot-8-o-'s 17\%3)-

b. h., 1814.

(Eclipse 1764)-Manilla $1 \%$ by Goldfincler 1764 (Snap 1750 ).

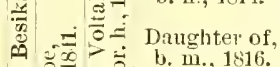

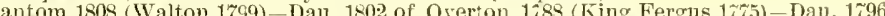

of Walnut 1786 (Highflyer 1\% 1 )-Dau. 1786 of Ruler 1\% (Y. Marske 1\%1) -Piracantha 1772 by Matchem 1718 (Cade $173 !$ ).

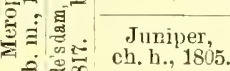

(Saltram* 1;80)-Jenny Spinner 17i) by Dragon* $178 ;$ (Woodpecker $17 \% 3$ ) -Dau. 1775 of Eclip*e 1764 (Marske 1750)-Miss Spiudleshanks $17 \% 0$ by Omar 175. (God. Ar. 17\%')-Dau. 1753 of Starling 172\% (Bay Bolton 1705).

Daughter of, Sorcerer 1796 (Trumpator 7782)-Virgin hr m. 1 01 by Sir Peter T. 1784 (Highflyer 17 44) br. M., 1810 .

-Dau. b. m. 1794 by Pot-8-o-'s 17\% (Eclipse 1764)-Editba b. m. 1781 by Herod 1758 (Tartar 1743) - Elfrida br. m. 1769 by Snap 1750 (Snip 1736)-Uiss Belsea b. m. 1753 by Regulus 1739 (God. Ar. 1724)-Dan. of Bartlett's Childers (Darley Ar. 1699)-Dau. gr. 


\section{IMPORTED ESHER.}

\section{Located in the Hartland Stud, near Versailles, Ky. Services at $\$ 50$ the season, with privilege of return.}

Esher, brown horse, foaled 1883, bred by W. B. Van Haansbergen, owned by J. N. Camden, Jr., Hartland Stud, Versailles, Ky., by Claremont, full brother to Mr. D. D. Withers' imp. Stonehenge, a very richly bred horse, and the sire of many winners in England, namely : Caulahar, Miss Betty, Netherton, Mrs. MaLaprop, Benediet, Verona, Candahar II., Stonefall, Wilkie, Anchencrnive, Humility, Sir David, Hersham, Charlotte, Rereille, etc.

Claremont was a very highly tried horse in his work and was a good race-horse. At two years old Claremont started twice, running second to Camballo for the Hurstbomme Stakes, and third to Balfe for the Chesterfield Stakes. At three rears old he started only twice, ran unplaced to Camballo for the 2,000 Guineas, and ran Galopin to a length for the Derby, beating Balfe, Camballo and others. At four years old he started six times, won twice. The Severn Cup, 1 mile, 151 lbs. up, beating six others, and the Great Antmun Welter Cup, I mile, $151 \mathrm{lbs}$. np, beating five others.

Blair Athol, Claremont's sire, was by Stockwell (winner of the St. Leger), dam Blink Bonny (wiuner of the Oaks and Derby) by Melbonrne. Blair Athol was a firstclass race-horse, winner of the Derby and St. Leger, and a first-class sire in Euglaud.

Ellington, who divides the paternity of Una, Esher's dam, won the Derby, and was by The Flying Dutchman, a famous race-horse, and winner of the Derby, St. Leger and other races, and ont of Ellerdale by Lanercost, who was the grandam of iml. The Ill'Used.

Dust was a son of Wild Dayrell (wimmer of the Derby) and Cireassian Maid by Lanereost.

Esher won three races at two years old. At Nottingham, the Little John Plate of 200 sovereigns, abont 5 fnrlongs, Esher, $12 t$ lbs., won by 2 leugths, Wild Notes, $111 \mathrm{lbs}$, secomd, Joyous, 117 lbs., third, and seren others. At Northampton, for the Anetion Stakes of $£ 245,5$ furlongs, Esher, 114 lbs., won by a length, the Celosia Colt, $11+\mathrm{lbs}$., second, and Glade, $106 \mathrm{lbs}$, third, and fire others. At Stockbridge, for the Stockbridge Foal Stakes of $£ 130$, Bush In, Esher, 126 lbs., won by a head from Morkena, $127 \mathrm{lbs}$., second, Pampas Grass, 121 lbs., third, and three others.

At four years old, Esher won twice. At Newmarket, for the Soham Plate of 200 sovereigns, 5 furlongs, Esherr, 112 llos., won by three parts of a length from invention, 129 lbs., second, Pierrepont, 116 lbs., third, and six others. At Lewes, for the Castle Plate of $£ 195,5$ furlongs, Esher, 126 lbs., won by two lengths from Laceman, 123 lbs., second, Indian star, 123 lbs., third, and four others.

In!p. Esher is a grand looking horse, with plenty of bone, snbstance and every reqnisite for a first-class horse and from his breeding is almost sure to get first-class horses.

Esher combines in his pedigree all the popular wimning strains of the day. Through his sire he has the Blair Athol, Stockwell, Irish Birdeatcher, Melbonrne, Gladiator, Partisan, Venison and Sir Hercules blood, and on his dam's side the Flying Dutchman, Bay Middleton, Sultan, Selim, Lanereost, Irish Birteatcher, Humpllrey Clinker, Comus,Partisan and Whiskey strains. Fsher traces directly through the famons Eleanor, the first nare to win the Derby, to Roxana, that first bronght the Godolphin Arabian into notice. 


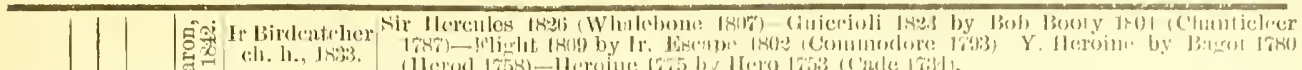

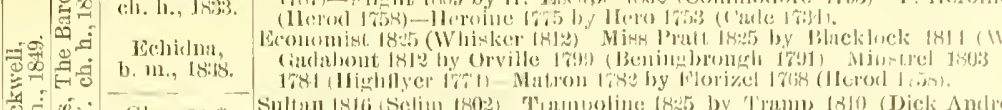

8 过

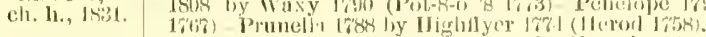

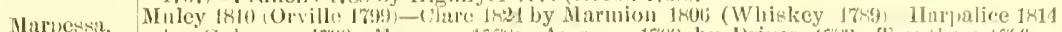

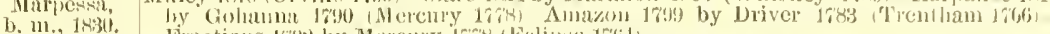

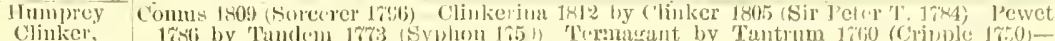

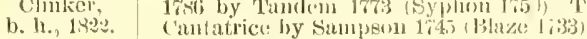

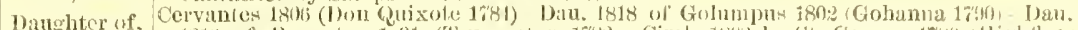

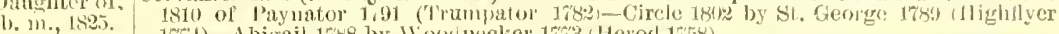

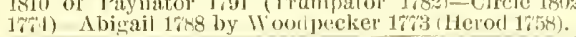

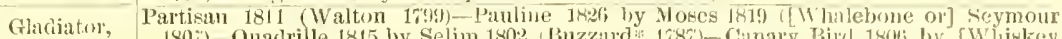

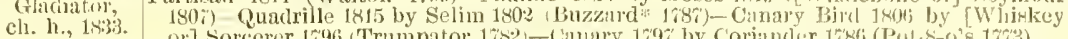

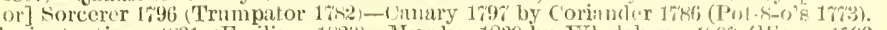

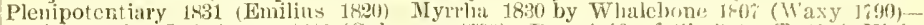

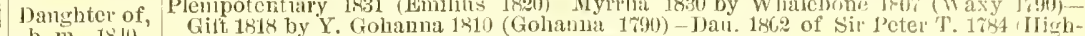
b. m., 18-10. Hyer 17\%4)-Diu. 1788 of Trumpator 1's2 (Conductor 176\%).

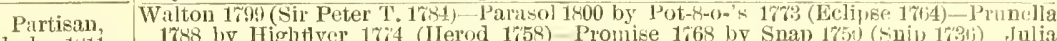
b. b., 1511 1788 by Hightlyer $17 \% 4$ (Ilelod 1;58)-Promise 1768 by Snap 1750 (Silp 173j) ,Julia $1 \% 56$ by Blauk 1740 (God. Ar. 1704).

Smolensko 1810 (Sorcerer 1796)-Jerboa 1803 by Gohanna 1790 (NI (Teny 178)_Camilla

br. m., 1523. $17 \%$ by Trentham 1766 (T. Sweepstakes 1\%43)-Corjuette 1764 by Comjton Larb-Sisl. 1743 to Regulus by God. Ar. 1724.

Slane, Royal Oak $18 \% 3$ (Catton 1809)-Dan. 1819 of Orville 1799 (Beningbroligh 1791)-Elssom Lass 1803 by sir Peter T. 1784 (Highflyer 17,4)-Alexina 1688 by King Fergus $17 \%$ (Eclipse 1704)-Lardella 1780 by $\mathbf{Y}$. Marske $17 \% 1$ (Marske 1750).

b. h., 1833 .

Garcia,

br. m., 1823.

Octavian $180 \%$ (Stripling 1795)-Dau 1806 of Shuttle 1793 (Y. Marske 17\%1)-Katharine 1798 by Delpiui 1781 (Hightlyer 1\%4)-Dan. 1786 of Paymaster 1766 (Blank 1740$)-$ Dau. $177+$ of Le Sang 1759 (Changeling $1747^{\circ}$ ).

Sir Herenles, Whalebone 1807 (Waxy 1790)-Peri 1822 by Wancerer 1811 (Gohanma 1690)-Thalestris blk. h., $18 \% 6$. 1809 by Alexauder 178\% (Eclipse 1664)-Rival 1800 by Sir Peter T. 1784 (Highflyer 17\%4)-Hornet 1790 by Drone $17 \%$ (Herod 1758).

Guiccioli Bob Booby 1804 (Chanticleer 1787)-Flight 1809 by Ir. Escape 180. (Commodore \begin{tabular}{l} 
ch. m.. 1323. \\
1793)-Y. Heroine by Bagot 1780 (Herod 1758)-Heroine 1755 by Hero $1755^{\circ}$ (Cade \\
\hline
\end{tabular}

Ir. Dron Master Robert 1811 (Butfer 1798)-Dan. 1817 of Sir Walter Raleigh 1801 (WaXy 1790)-

gr. h., $18.3 . \quad$ Miss Tooly 1808 by l'eddy the Grinder 1\%98 (Asparagus 178;)-Lady Jame 1796 by The Poten- Dou Juan 1s14 (Orvilie 1799) - Ioll-in-the-Wad 1810 by Hambletonian 1792 (King Ferms

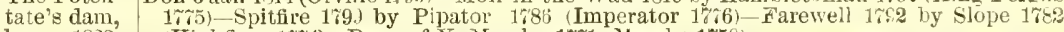
b. m., 1823, (Highflyer 17\%4)-Dau, of $Y$. IIarske 17\%1 (Marske 1750).

Cain,

Paulowitz 1813 (Sir Paul 1802)-Dan. 1810 of Paynator 1791 (Trumpator 178\%)-Dau.

b. h., 1522 . 1805 of Delpini 1781 (Highflyer 174)-Dau. 1295 of Y. Markke 17il (Marske 1\%50)Gentle Kitty $17 \%$ ! by Silvio $17 \% 4$ (Cade 1734).

Margaret,

Edmund 1824 (Orville 1;99)-Medora 1811 by Selim 1802 (Buzzard* 1681)-Dau, 1803 by

| $1 \% 9$ of Herod $1 \% 58$ (Tartar 1743 )

Middleton,

Sultan 1816 (Selim 1802)-Cobweb 1821 by Phantom 1808(Walton 1788)-Filagree 1815 by Soothsayer 1808 ( (corceler 1:96)- Web 1808 by Waxy 1790 (Pot-8-o-'s 17\%3)-Penelope 1798 by Trumpator 1782 (Conductor $176 \%$

Myrrha,

Malek 1824 (Blacklock 1814)-Bessy 1815 by X. Gouty 1805 (Gouty 1796)-Grandiffora 1810 by Sir Harry Dimsdale 1800 (Sir Peter T. 1784)-Dau. 1 \%99 of Pipator 1786 (Imperator 17\%6)-Dau. 1796 of Phenomenon 1780 (Herod 1758).

ch. m., 1831

Tramp 1810 Dick Ancrews 179\%)-Dau. 182. of II hisker 1812 (Waxy 1790)-Miandane

Liverpool,

1800 b Pot-8-o-'s 17\%3 (Eclipse 1\%6') - Y. Camilla 1787 by Woodpecker 1\%i3 (Herod 1758) Camilla $17 \% 8$ by Trentham 1766 (T. Sweepstakes 1743).

Otis, Bustard 1801 (Buzzard $* 1787$ )-Dau. 1813 of Election 1804 (Gohanna 1790)-Dau. 1791 of b. m, 1820. Highflyer 1\%74 (Herod 1758)-Dau. 17\% of Eclipse 1764 (Marske 1750)-Rosebud 1765 by suap 1750 (Snip 1736).

Partisan, Valton 1799 (Sir Peter T, 1\%84)-Parasol 1800 by Pot-8-o-"s 17\%3 (Eclipse 1764)-Prunella 1788 by Highflyer 1774 (Herod 1758)-Promise 1768 by Snap 1750 (Snip 1736)-Julia 1756 by Blank 1740 (God. Ar. 1724).

b. h., 1811.

Sir Peter T. 1784 (Highflyer 174)-Ibis 1791 by Woodpecker $17 \% 3$ (Herod 1758)_Isabella

Isis, 1783 by Eclipse 1764 (Narke 1750) Dau, 175 of Squirrel 1754 (Traveller 1\%35)-Ancaster Nancy 1768 by Blank 1740 (God. Ar. 1724).

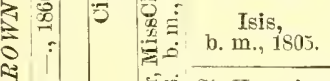

造

जी

Whalebone $180 \%$ (Waxy 1790)-Peri 1822 by Wanderer 1811 (Gohanna 1790)-Thalestri 1803 by Alexander 1782 (Eclipse 1764)-Rival 1800 by Sir Peter T, 1784 (Higbfyer 17\%4) - Hornet 1790 by Drone 1\%\% (Herod 1758).

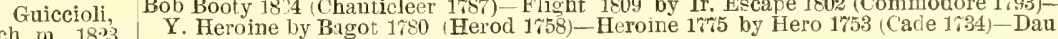
1766 of Snap 175) (Snip 1726).

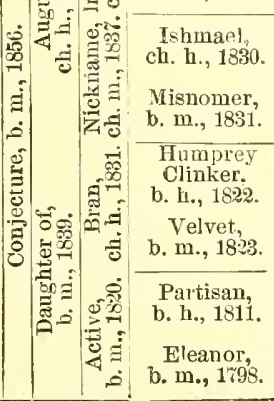

Sultan 1816 (Selim 1802)-Sist. 1820 to Cobweb by Phantom 1808 (Walton 1799)_Filagree 1815 by Soothsayer 1808 (Sorcerer 1796 ) - Web 1808 by Waxy 1790 (Pot-8-o-'s 1763 ) Penelope 1798 by Trumpator 178 ; (Conductor $1 \% 6 \%$ ).

Merlin 1815 (Castrel 1801 )-Dan. of Phantom 1808 (Walton 1799)-Dau. 181\% of Pericles 1809 (Evander 1801)-Mary 1803 by Sir Peter T. 1784 (Higbflyer 17\%4)-Dau. 1788 of

Diomed*1\%7\% (Florizel 1768). 1786 by Tandem 1773 (Syphon 1750)-Termagant by Tantrum 1760 (Cripple 1750)Cantatrice by Sampson 1745 (Blaze 1733).

Oiseau 1803 (Camilns 1803) - Wire 1811 by Waxy 1790 (Pot-8-o-'s 1\%3)-Penelope 1798 by Trimpator 1782 (Conductor $176 \%$ )-Prunella 1788 by Highflyer $1 \%$ i Herod 1\%58) Promise 1768 by Snap 1750 (Snip 1736). Walton 1799 (Nir Peter T. 1784)-Parasol 1800 by Pot-8-0-'s $17 \% 3$ (Eclipse 1764)-Prunella
1788 by Highflyer 1774 (Herod 1758)-Promise 1768 by Snap 1750 suip 1736)-Julia 1756 by Blank 1740 (God. Ar. 1\%24).

Whiskey 1789 (Saltram* 1780)-Y. Giantess b. m. 1790 by Diomed* 17N7 (Florizel 1768)Giantess b. m. 1;69 by Matchem 1748 (Cade 1731)-Molly Long Legs b. m. 1753 by Babraham 1\%40 (God. Ar. 1\%24)-Dau. 1\%4t of Cole's Foshunter 1\%27 (Brisk 1\%11)-

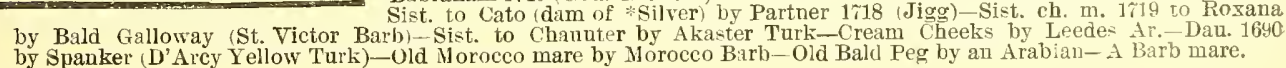




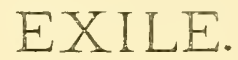

WINNER OF THE BROOKLYN HANDICAP, BROOKLYN CUP, RARITAN STAKES, AND OTHER IMPORTANT RACES.

\section{Property of IIessrs. Charles Reed \& Sons, Fairview Stud, near Gallatin, Tenn. Yearlings sold anmually.}

Exile, bay horse, foaled 1832, bred by Mr. P. Lorillard, Rancocas Stird, N. J., b5 imp. Mortemer, a superior race-horse, wou two races at two years old and was second in three, winning the Omnium, nearly a mile, carrying 123 lbs., a remarkable performance for a two-year old. At three years old he won fonr races out of eight starts, and was second in three and third in oue. At four years old he won nine races, running from $1 \frac{1}{2}$ miles to 2 miles, carrying from 132 to $1.31 \mathrm{bs}$.; was secome in seven, and third in one, being mplaced but once in eighteen races. At tive rears old he won five out of six starts, carrying from 133 to $151 \mathrm{lbs}$, in one of these raees beating Dntch Skater; same vear won the Stockbridge Cum, and the following rear won two ont of four starts, inclnding the Gold Cnp at Ascot, and was pronomeed by Armiral Rons to be by seven pounds the hest horse in England. He was also a successful sire. His son, St. Christophe, won the Gramd Prize of Paris in 1877 and other good races. Vernenil was a wimner on the Continent, and in England won the Gold Tase, Gold Cup and Alexandra Plate at Ascot in 1878. Chamant won the 2,000 Guineas in 1877. In this comutry he sired first-class racers.

Exile's dam inıp. Second Hand, wimner of the Craven Handicap, by Stockwell, winner of the 2,000 Gnineas and St. Leger, grandam Gaiety, the dam of Gamester (St. Leger wiuner), Garuish and Gatabont (the clam of 'Scamauder). Second Hand is full sister to Doncaster, wimner of the Bristol Plate, Chatsworth, Zetland Stakes and Dee stand Colp, etc., great grandam Cast Steel, clam of Galanthns, wimner of the Great Yorkshire Handicap, and Garland (the dam of Vindex), and Vesta (the dam of Vespasian and Sabinus, winner of the Cambridgeshire Handicap and Ascot Gold Cup). To Gossamer, another daughter of Cast Steel, traces Surefoot, wimer of the 2,000 Gnineas. Lisette, the sixth dam, was the dam of Clearwell, winner of the 2.000 Guineas, aud Madame Vestris, to which traces Vedette, Retreat, Sir Hugo and King Lud, ete. Exile was a tirst-class race-horse and is descended from a distinguished racing and prodncing fumily. During his raciug eareer he started 73 times, won 30 races, was second in 17 and third in six. At two years old won a sweepstake, $\frac{3}{4}$ of a mile, 100 lbs., in 1.18, and again $\frac{3}{4}$ of a mile, $11511 \mathrm{~s} .$, in $1.17^{\frac{3}{4}}$ : was secoud to Richmond in the Hopeful Stakes, and second to Brookwood in July Stakes. At three years old wou four out of nine races; purse, $1 \frac{1}{8}$ miles, $103 \mathrm{lbs}$., in 1.57\%; the Raritan stakes, $1 \frac{1}{4}$ miles, 113 lbs., in 2.12⿺ a purse, $1 \frac{1}{8}$ miles, $105 \mathrm{llss}$, in $1.58 \frac{1}{2}$, and pmrse, $1 \frac{1}{4}$ miles, 105 lbs., in 2.11\%. At fom years old won five ont of nine races, was second in three and

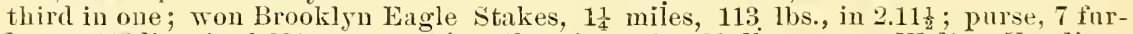

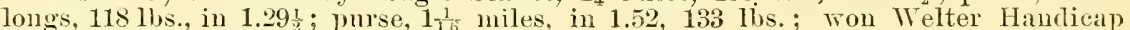
Stakes, $1_{1}^{3}$ miles, 126 los., in 2.03 , the fastest race at the distance to that date, 1886 : won Handicap Sweepstake, $1 \frac{5}{8}$ miles, 116 lbs., in $2.48 \frac{3}{4}$, the fastest race ever run at the clistance with the weight. At five years old.started 14 times, won four races and was second in three; won Bay Ridge Handicap, $1 \frac{1}{3}$ miles, 114 lhs., in 2.36, defeating field of 16: won Sweenstake, $1 \frac{1}{2}$ miles, 121 llos, the top weight, in 2.311; won purse, $1 \frac{1}{4}$

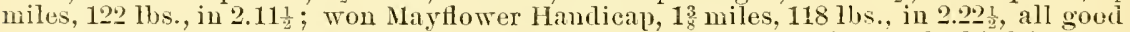
races. At six years old ran 21 races, won 10 , and was second $i n 7$ and third in one;

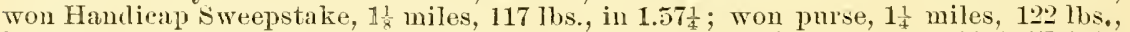
in 2.121; won High Weight Handicap, of a mile, 123lbs., in 1.1s; won High Weight Hauclicap Sweepstake, 2 miles, 140 lbs., in $3.36 \frac{1}{3}$; won purse, $1 \frac{1}{x}$ miles, 1151 lus.. in 2.00 ; won Purse, $1 \frac{1}{x}$ miles, 133 1hs., in 2.033; won purse, 1 mile, $123 \mathrm{lbs}$, in $1.46 \frac{8}{4}$; won Twin City Handicap, $1 \frac{1}{4}$ miles, 117 llss., in 2.08; won Voodlawn Handicap, $1 \frac{3}{16}$ miles, $116 \mathrm{lbs}$, in 2.08?. In these races he beat the best horses of the year. At seren years old won three races ont of six, the Brooklyn Handieal, $1 \frac{1}{4}$ miles. 116 lbs., in 2.07won purse, 1 mile, 124 1ls., in 1.47; won 'Twin City Handicap, $1 \frac{1}{4}$ miles, 125 lls., in $2.09 \frac{4}{3}$. At eight years old won the only two rices in which he started, a sweepstakes.

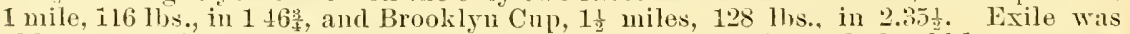
able to go a distance, possessed speed and wis np to weight, and should be a success in the stud, as he is hamtsomety bred. From the old Woodcock mire descend in direct female line the following good horses, skim, Reveller (by Comns), Heron, Alarm, Monarque, Vedette, Cambnscan, Vespasian, Isonony, Fernandez, ling Lud, Lisbon, imp. Woodlands, Pat Malloy, Jack Malone, etc., ete. 


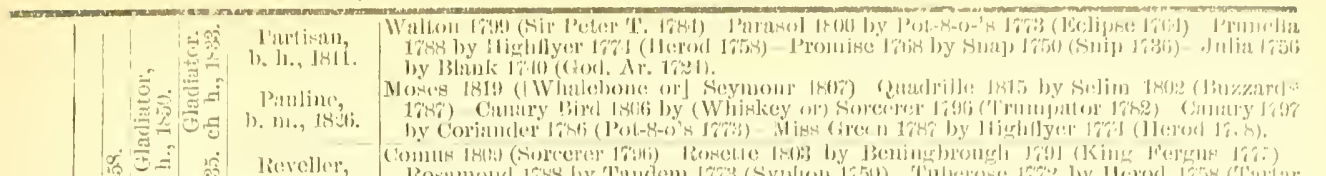

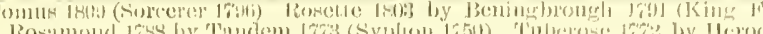

10.

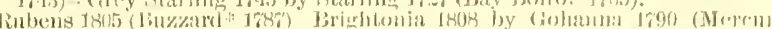

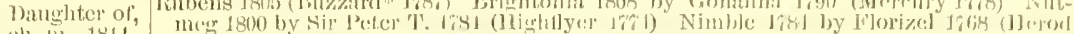

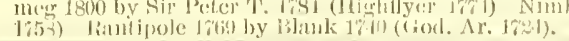

(1). 11., 1814 .

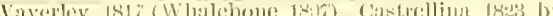

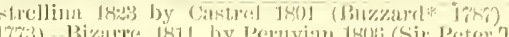

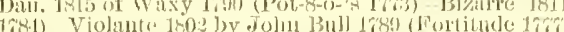

lox. I1., $18 \% 8$.

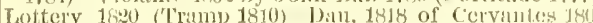

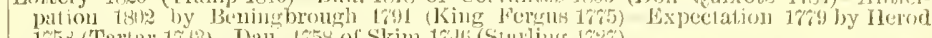

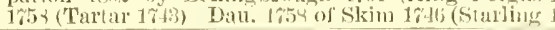

b. $111 ., 183$

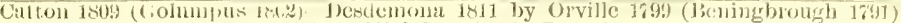

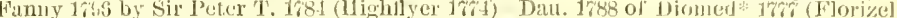

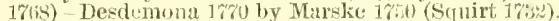

b. 11,1533 .

Leda,

Filho-da-Pula 1812 (1Iapllazard 179\%)-Treasme 1809 by Camillus 180: (I]ambletonian 1792)-Dau. 1804 of Jlyacinthus 1797 (Coriander 1786) Flora 1789 by King Fergn: 1675

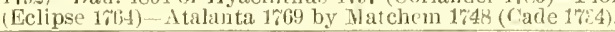

b. m., 18,21

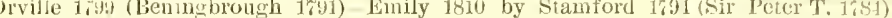

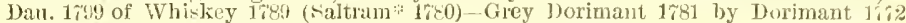
(Otho 1760)-Dizzy $175 \%$ by Blank $1 \% 40$ (God. Ar. 1721).

b. 11., 1820 .

Pericles 1804) (Evander 1801) Dan. 1812 of Selim 1802 (Buzzard* 175\%).Pipylina 1603 I,y

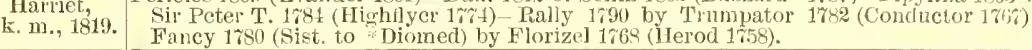

Partican - Waiton 1799 (Sir l'eter T. 1784) - Parasol 1800 by Pot-8-0-'s 1763 (Eclipse 1664) Prunclla

Partisan, 1785 by Hightlyer 1\%44 (Herod 1758)-Promise 1768 by Snap 1750 (Snip 1\%36)-Julia 1756 by Blank 1710 (God. Ar, 1r24)

Waxy 1790 (Pot-8-o's 17\%3) - Scotia 1799 by Delyini 1781 (Higbflyer 1784)-Dau. 1790 of King Fergus 17\%5 (Eclipse 1764)-Celia 1\%5 by Herod 165 (Tartar 1713)-Proserpine 1765 by Marske 1,50 (Squirt. 1732)

gr. m., 1810

Beningbrough $7 \%$ (King Fergus 17\%5) - Evelina 1791 by Highflyer 174 (Herod 178) -

Orville,

b. h., 1799 .

Termagant by Tantum 1660 (Cripule 1750)-Cantatrice by Sampson 17t5 (Blaze 1733) - Dau. 1757 of Regulus 1739 (God. Ar. 1\%24)

ch, m., 1810. Dorimant 1\%81 by Dorimant 17r2 (Otho 1\%6)-Dizzy 1\%5\% by Blank 1\%40 (God. Ar. 1724) - Auc. Dizzy 1711 by Driver $172 \%$ (Wym Ar)

Castrel 1 1 01 (Buzzard $\%$ 1r8\%) - Hiss Newton 1804 by Delpini 1781 (Highflyer 17\% Tipple Cyder 1788 by King Fergus $17 \% 5$ (Eclipse 1764)-Sylvia 1788 by Y, Marske 17\%1 (Marske 1750)-Ferret $1765^{\circ}$ by Broth. to Silvio (Cacle 1734).

Sorcerer 1\%96 (Trumpator 1782)-Hornby Lass 1\%'06 by Buzzard 1\%8\% (Woodpecker 1773)-Puzzle $17 \% 8$ by Matchem 1\%48 (Cade 1\%34)-Princess 1769 by Herod 1758 (Tartar 1743) Julia 1756 by Blank 1740 (God. Ar. 1721).

Whalebone 1807 ( II'axy 1790)-Peri $18: 2$ by Wanderer 1811 (Gohauna 1790)-Thalestris

Sir Hercules, 1809 by Alexander 1782 (Eclipse 1764 ) Rival 1800 by Sir Peter T. 1784 (Highflyer
blk. h., 1826.

blk. h., 1826. 1809 by Alexander 1782 (Eclipse 1764) Rival 1800 by Sir Peter T. 1784 (Highflyer Bob Booty 1804 (Chanticleer 1\% 15 ) -Flight 1809 by Ir. Escape 1802 (Commodore 1793) Y. Heroine by Bagot 1780 (Herod

ch. m., 18 \%.

Whisker 1812 (W:Lxy 17\%(0)-Floranthe 1818 by Octavian 1807 (Stripling 1705) - Caprice 179\% by Anvil 17\% (Herod 168) - Madcap 1\%4 by Eclipse 1\%64 (Marske 1\%0)-Sappho 1763 by Blank $1 \% 40$ (God. Ar. 1\%24).

BlackJock 1814 (Whitelock 1803) - Gadabout 1812 by Orville 1799 (Beningbrongh 1791) -

\begin{tabular}{l|l} 
Miss Pratt, & Minstrel 1803 by Sir Peter T. 1784 (Highflyer 17\%1)-Matron 1782 by Florizel 1768 \\
b. m., 1825. & (Herod 1758)-Mlaiden 170 by Matchem 1\%48 (Cade 1731).
\end{tabular}

\begin{tabular}{l|l} 
Miss Pratt, & Minstrel 1803 by Sir Peter T. 1784 (Highflyer 17\%1)-Matron 1782 by Florizel 1768 \\
b. m., 1825. & (Herod 1758)-Maiden 1\%0 by Matchem 1.18 (Cade 1731).
\end{tabular}

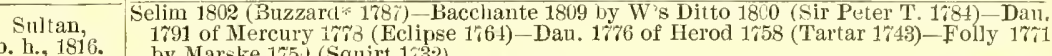
by Marske 1\%5 (Squirt 1632)

b. h., 1816

Tramp 1810 (Dick Andrews 1\%c7) - Web 1808 by Waxy 1790 (Pot-8-o-'s 1723)-Penelope

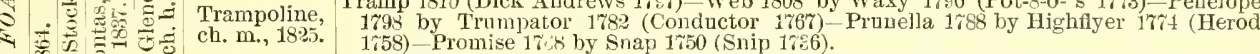

F

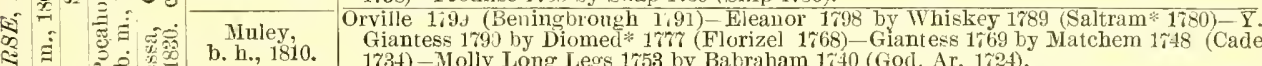

b. h., 1810. 1734)-Mlolly Long Legs 1753 by Babraham 1710 (Gori. Ar. 1721).

Marmion $1805^{\circ}$ (Whiskey 1789)-Harpalice 1814 by Gohanna 1790 (1lercury 17\%8) - Amazon 1799 by Driver 1783 (Trentham 1766) - Fractious 1792 by Mercury 17is (Ecipse 1,64)Dau. 1785 of Woodpecker $17 \% 3$ (Herod 1758). Whalebone, Waxy 1790 (Pot-8-o-'s 177)-Petelope 1798 by Trumpator 1\%82 (Conductor 1767)-Pru-
nclla 1788 by Highfyer 17\%4 (Herod 1758)-Promise 1\%68 by Snap 1750 (Snip 1736)Julia 1736 by Blank 1740 (God. Ar. 1724).

के br. h., $180 \%$.

Seliu 1802 (Buzzard* 178\%)-Maiden 1801 by Sir Peter T. 1784 (Highflyer 1774)-Dan. 1788 of Phenomenon 1780 (Herod 1758)-Matron 1782 by Florizel 1768 (Herod 1758)Maiden $17 \% 0$ by Matchem 1718 (Cade 1\%34).

Z

Orville 1799 (Beningbrough 16y1) - Miss Sophia 1805 by Stamford 1794 (Sir Peter T.

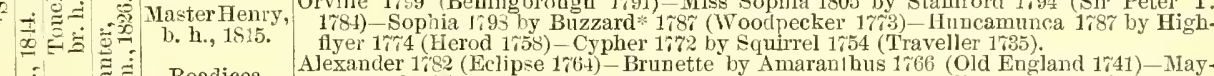

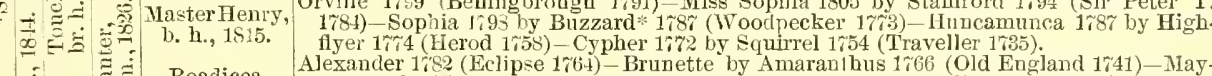

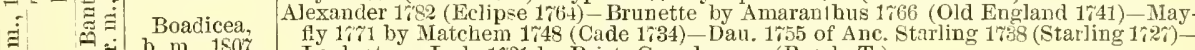
b. m., 150\%. Look-at-me-Lads 1731 by Brist. Grasshopper (Byerly T.)

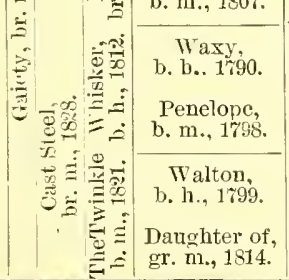

Pot-8-o-'s 17\%3 (Eclipse 1it4)-Naria 1\%7 by Herod 1758 (Tartar 1\%43)-Lisette 17\% by Snap 1750 (Snip 1736)-Miss Windsor 1754 by God. Ar. 1\%21 Sist. to Volunteer by Y. Belgrade (Belgrade Turk)

Trumpator $178: 2$ (Conductor 166\%)-Prunella 1788 by Highflyer 1764 (Herod 1758) Promise 1763 by Snap 1750 (Snip 1786)-J - Jui

Sir Peter 1784 (Hightlyer 1\%4)-Arethusa 1792 by Dungannon 1750 (Eclinse 1764) - Dan

$1 \%$ \% of Prophet 1760 (Regulus 1\%9)-Virago 1764 by Suap 1750 (Snip 1\%36)-Dau. of Regulns $1 \% 39$ (God. A\% 1724).

Orville 1799 (Beningtrolgh 1791)-Lisette gr. m. 1806 by Hambletonian 1792 (King Fergus 17\%)-Constantia gr. m. 1,56 by Walnut 1786 (Highflyer 1\% m. 178; by Y. Narske $17 \% 1$ (Marske 1750)-Tuberose or. m. $17 \% 2$ by Herod 1748 (Tartar 1743)-Grey Starling gr. m. 1745 by Staring $1 \% \%$ (Bay Bolton 1705)-Conghing Polly

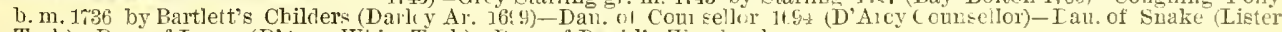
Turk)-Dan. of Liggs (D'Arcy White Tutk)-Dau, of Ditvill's Woodcock. 


\section{FALSETTO.}

WINNER OF THE PHGEXT HOTEL STAKES AT LEXINGTON, CLARK STAKES AT LOUISVILLE, TRAVERS AND KENNER STAKES AT SARATOGA, N. I.. ALL IN 1879.

Located in the Woodbun Stud, A. J. Alexander, proprietor, near Spring Stration, $K y$. Aprlication to L. Brodhead, Spring Station. Ammat sales of yearlings in $T[a y$.

Falsetto by Euqurer, son of imp. Leamington, breil by the late Col. J. IT. Hnut Reynolds, Fleetwool stud, lentucky, foalerl 1876. dam Farfiletta, dam of Felicia, Fortuna, ete, by imp. Australian, out of Ekhorma, dam of Elkhorn, Arcturns. utc., by Lexington. Leamington, Enynirer, Australian aud Lexiugton, alI noted horses, covering the first tonr crosses of the blood of Falsetto, are to be fomucl in this hook. His dam, Farfaletta, has never prodnced anrthing bnt good ones. Felicia and Fortuna were both good race-mares aud ereditable performers. Falsetto marle his maiden effort at Lexington, ky., Nay 10, first clay of the spring meeting, in Phonix Hotel Stakes, $1 \frac{1}{4}$ miles. Ten horses started, Falsetto won, defeating Ada Glem by a neck, scully a good third, balance muplaced; time, 2.08\%. Falsetto's

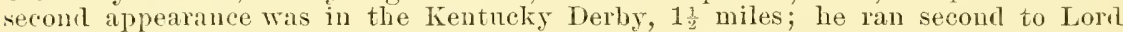
Ilniphy, sutfering his first and only defeat. Strathmore was third, and time 2.37. Same place. May 27 . won the Clark stakes, 2 miles, detenting Bucktie, Trinidad and sis others, time, $3.40 \frac{1}{2}$. Saratoga, Jnly 19 , he met the hitherto invincible Spendthrift. also Harold, Jericho and Dan Sparling, in the Travers Stakes, $1 \frac{3}{4}$ miles. Falsetto won;

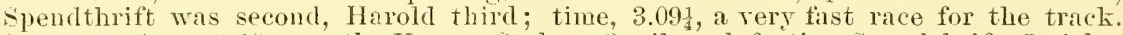
Saratoga, Augnst 12, won the Keuner Stakes, 2 miles, defeating spendthrift, Jericho, Monitor and Harold; time $3.35 \frac{1}{4}$. Total winnings in his three-rear old form, $\$ 18,275$. Falsetto was purchased and sent to England by Mr. P. Lorillard, he paring \$18,000 for him. Giving away in one of his legs in his preparation, he was returned to. America and sold to the Woodburn Stuil. Falsetto is from one of the great racing families of America, his dam, grankam and great grandam were handled but little. but all have proulnced winners; Mary Morris, his fifth dam, was a tine race-mare at all distances, and was the dan of the two fine race-horses, Wild Irishman and Frankfort, the great grantam of Parole, and from the same blool in a direct line sprang Rattler, Chilfers and smmpter, all good race-horses and stallions. Flirtilla by sir Archy was ont of the same fimily, aud from her come Ringgold, the sire of Ourari and Delaware. The imp. Cub mare, from which all this stock emanated, was ont of Amaranthns' dam by second, and they trace throngh a popnlar racing fimily of England to the Layton Barb mare. Falsetto has four of the best racing straius in this comntry to begin with, and his blood is pure throngh a long line of distinguished horses. Falsetto is a suecesstul sire. He is inbred to Lexington, and has the Waxy blood on both sides, from Whalebone, winner of the Derlyy in 1810, to Whisker. winner of the Derly in 1815, and his son Memmon, sire of Envoy, won the st. Leger in 1825. He is also very strongly iuhred to Diomed throngh Lexington, Am. Eclipse and Gabriella. Falsetto is a brom, stands 16 hands $\frac{3}{4}$ of an inch high, with a blaze in his face and snip on the nose, and fonr white ankles.

Falsetto is a grand looker and a horse of tine temper. He has been a grand snecess in the stud. He is the sire of Dewdrop, that sold for $\$ 29,000$, Jemnie T. Rnpert. Ceawood, Emotion, Falsehood, Frontenac, Fernwood, Falcon, Falerua, Folsom, Filmore, Fordham, Foxmede. Ferriere, Forty, Flemington, George C., Gallifet, Gascon. Granite, Glee Boy, Henry Owsley, Kenwood, Keynote, Jume Das, Lizzie scott, Iiracle, Mon Droit, Mnlligan, Patron, Portchester, Pearl Set, Poor Jonathan, Ravenhill, School Girl, Shoshone, Sanford, Tenor. 'Tom Rogers, l'milta, Vulpina, Vandergritt, Willie L., Miss Dixie, Bob L., False B. and many others. To the Layton lBarb mare trace in direct female line Young Greyhound, Matehem, Yomng Cade, Drone (hy Herod), Blucher, Andubon. Kentucky, Daniel Bnone, Gilroy, the great Iroruois. Powhattan, and all the descenclants of the imp. Cub mitre. 


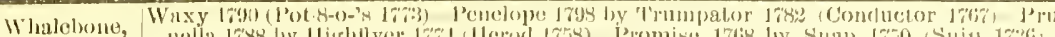

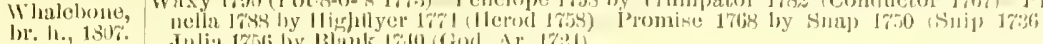

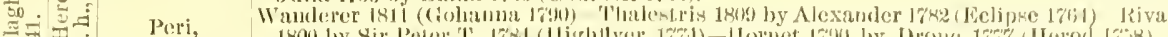

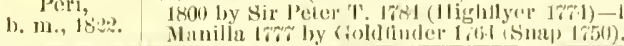

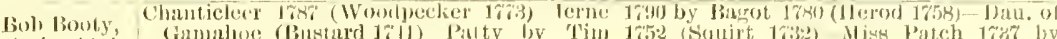

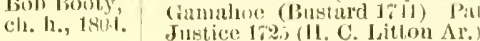

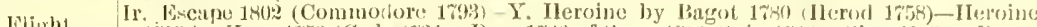

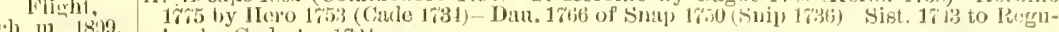

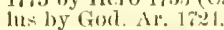

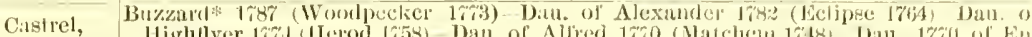

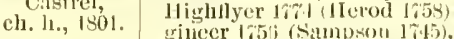

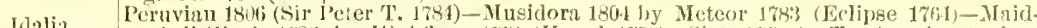

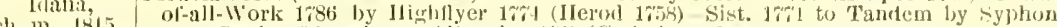

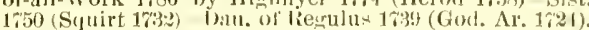

Gumel Blacklock 1811 (Whilelock 180.5) Wagtail 1818 by J'rime Minister 181() (Sancho 1ro1)

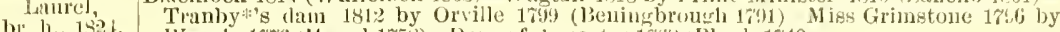

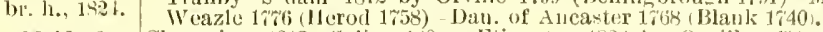

Maid of Champion 1812 (Sulim 180z)-Etiquette 1820 by Orville 17ty (IBeninghrough 1791)

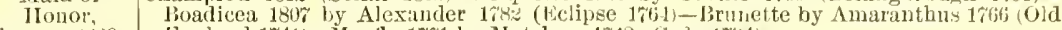

br. I1.., is 9. England 1741)-Maylty $17 \% 1$ by Matchem 1748 (Cade 17si).

Timoleon, Sir Alchy 1805 (*Diomed 17\%)-Dan. of Saliam 1680 (Eclipse 1764)-1)au. of Symmes

Tildair 1767 (*Fearnought 1755)-Dau, of Tyler's Driver 1760 (*Othello) Dau. of *Fallower 1\%61 (Blauk 1740).

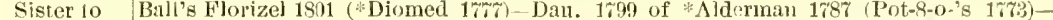

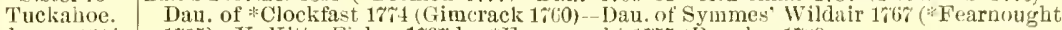

ch. 11, 1,11. 1755)-Y. Kitty Fisher 176* by *Eearnought 1755 (Regulus 17;9).

* Sarpedon, Emilius 1820 (Orville 169.)-Icaria 1824 by The t'lyer 1814 (Vandyke Jr. 1808)-Parma 1813 by Dick Andrews 179\% (Joe Andrews 1\%68)-May 1804 by Reningblough 1791 (King Fergus 17.5)-Primrose 178\% by Mambrino 1768 (Engineer 1756).

Rowen? Sumpter 1818 (Sir Archy 1805) - Larly Grey 181\% by Robin (rey 1805 (* Royalist 1790)-

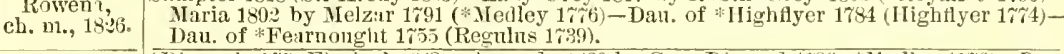

Duroc, Diomed 17fr (Florizel 1768)-Amanda 1800 by Grey Diomed 1786 (* Mledley 1776)-Dan. ch. h, 1506 of Va. Cade (Partner 1755) -Dau. of Hickmul's Indeyendence $176^{\circ}$ (*Fearnought 1755)-Dau. of *Badger (Bosphorus 1\%54).

Miller's * Messenger 1780 (Mambrino 1\%68) — *Pot-8-0.'s mare 1792 by Pot-8-0-'s 1\%;3 (Eclipse

Damsel, 176t)-Dan. 1\%8 of Gimcrack 1760 (Ciipple 1\%50)-Snapdragon 1759 by Snap 1750 gr. M., 1203. (Snip 1736,-Dau, 1749 of Regulus 1739 (God. Ar. 1721).

sir Archy, *Diomed 17\% (Florizel 1\%(6) - Castianira 1796 by liockingham 1781 (Highflyer 1764)b. h., 1805. Tabitha 1782 by Trentham 1766 (T. Sweepstakes 1743)-Dau.

Calypso, Bellair 1786 (* Medley 1776)-Dan. 1\%98 of *Dare Devil 1787 (Magnet 1760)-Dau. 1792 of

Cymmes' Wildair 1767 (*Fearnought 1755)-Picadilla by Y. Fearnought 17\% (*Fearnought 1755 )-Dau. of Godolphin $1 \%$ \% (*Fearnoutolit 1755).

\section{Humprey}

Comus 1509 (Sorcerer 1795)-Clinkerina 1872 by Clinker 1805 (Sir Peter T. 1;84)-Pewet

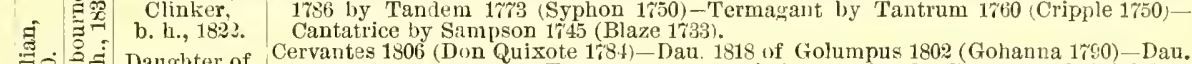
焉

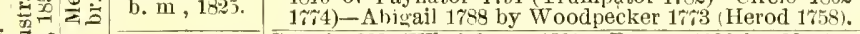

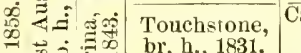

$\Delta$

Emma, Whisker 1812 (Waxy 1690 -Gibside Fairy 1811 by Hermes 1790 (Nercury 17t8)-Vicismel 1822 (Whi\}ebone 180\%)-Banter 1826 by Master IIenry 1815 (Orville 1799)-Boadicea 1807 by Alexander 1782 (Eclipse 1764). Brunette by Amaranthus 1766 (Old England 1741) Mingfly ir\%1 by Matchem 1748 (Cade 1734). 17\%4)-Pyrrha $17 \% 1$ by Matchem 1748 (Cade 1734).

h. m., 1821

Emilins, Orville 1799 (Beningbrough 1791)-Emily 1810 by Stamford 1 01 (Sils Peter T 1784)-

Emilits,
b. h., 1820. Dau. 1799 of Whiskey 1\%89 (Saltram 1\%80)-Grey Dorimant 1\%81 by Dorimant $1 \% 22$
(Ocho 1760)-Dizzy 175\% by Blank 1740 (God. Ar. 17\%4). Scud 1804 (Beningbrongh 1791)-Goosander 1895 by Han b. m., 1816. (Herod 1758)-Dau. 1763 of Spectator 1749 (Crab 1722).

Whisker, Waxy 1790 (Pot-8-o-'s 1778)-Penelope 1798 by Trumpator 178: (Conductor 170

b. b., $1 \times 12$. liella 1 \%88 by Highflyer $1 \% 4$ (Herod 1\%5s)-Promise $1 \% 68$ by Suap 1\%50 (Snip 1\%36)Julia 1 \%5 6 by Blank 1740 (God. Ar. 1721)

Variety,

ch. m., 1816.

1737) Or' Satherine 1795 by (Vol'cerer 1796) - Sprite 1807 by Bobtail 1795 (Precipitate 1736 (T. Sweepstakes 1743)-Coquette 1765 by Compton Barb.

Timoleon, Sir Archy 1805 ("Dinmed 1\%\%)-Dau of saltram 1780 (Eclipse 1661)-Dau of symmes Wildair 176\% ("Fearnought 1755)-Dau. of Tyler"s Driver 1760 (*Othello)-Din. of * Fallower 1761 (Blank 1740).

Sister to

Ball's Florizel 1801 (*Diomed 1\%

Tuckahoe,

ch. m., 1314 1755)-Y. Kitty Fisher 1767 by * * Fearnought 1755 (Regulus 1739 )

Emilius 1820 (Orville 1799)-Icaria 1524 by The Flyer 1814 (Vandyke Jr, 1808)-Parma 1813 by Dick Andrews 1797 (Joe Andrews 1778) May 1804 by Beningbrough 1791 (King Ferwus 17\%5) - Primrose 1787 by Mambrino 1\%68 (Engineer 1756)

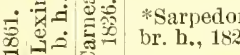

บ. Poweun

Sumpter 1818 (Sir Archy 1805) - Lady Grey $181 \%$ by Robin Grey 1805 (*Royalist 1790) Maria 1802 by Melzar 1791 ( Iedley $1 \% 6)-D a u$. of *IIghflyer 1\%84 (Highflyer 17\%4) Dan. of *Fearnought 1755 (Regnlus 1739).

: ch. m., 18:6

Selim 180? (Buzzard* 178\%)-Bacchante 1809 by W's Ditto 1800 (Sir Peter T. 1784)-Dau,

Sultan,

b. h., 1816.

1791 of Mercury $17 \% 8$ (Eclipse 1\%61)-Dan. 17\%6 of Herod 1758 (Tartar 1743) - Folly 17i1 hy Marske 1750 (Squirt 1\%32).

Trampoline,

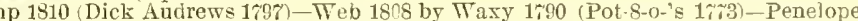
$1 \% 98$ by Trumpator 1782 (Conductor 176i)-Plunella 1788 by Highflyer, 1774 (Herod 1758)-Promise 1768 by Suap 1750 (Snip 1736).

Memnon 1822 (Whisker 1812)-Zarina 18\% by Morisco 1819 (Muley 1810 -Ina 1821 by

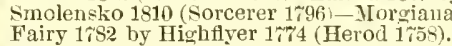




\section{FARANDOLE.}

The Property of Ed. S. Gurdner, Avondale Stud, Saundersville, Temn. Application for service to E. S. Gardner.

Faraxdone, chestnut horse, foaled 1881, bred in the Kennesaw Stud. Tenn., owned by E. S. Gardner, Arondale Stud, Tenu, by Enquirer, son of imp. Leamington, dam Waltz by Lexington, ont of Schottische by imp. Albion. Farandole only ran three races; was second to Joquita in Maxwell House Stake, at Nashville, 1 mile, in 1.18; second to Billy Gilmore in the Kennesaw Stake, $1 \frac{1}{8}$ miles, in 2.098, and seconil

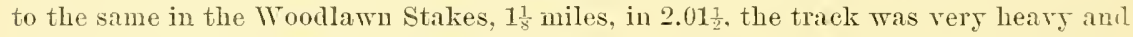
slow in both these races. His sire, Enquirer, is second to no son of Leamington as a race-horse and stallion. Wraltz, his dam was a good race-mare and is from one of the best racing and producing families in the world. She is the dam of Hop (the dam of Kirkman, Carson, Fond-du-Lac, etc.), Glidelia, she haring the fastest race at $1 \frac{8}{4}$ miles ever run up to 1891, Racket, Bolero (a winner in England), Gladiola, Raquet, Kermesse, etc. Schottische is the dam of Ballinkeel, Cachnca, Reveller, Quickstep (the dam of Falsestep, Fernwood, etc.). Dance, his great grandam, was the dam of La Polka, the dam of Post Guard (Gen. Phillips), Strathspej, Heel-and-Toe, Los Angeles, ete. Imp. Gallopade was the dam of the renowned Reel, and she the dam of Lecompte, the only horse that ever beat Lexington, Starke, winner of the Goodwood Cup, Prioress, wimer of the Cesarewitch, War Dance and Fanny Wells. Nellie Grey by Commodore, Jils Johnson and a host of fine race-horses are from this family. which is a famous English one, tracing to Piping Peg, to which trace in direct female line Octavius, Bob Booty. Cannon Ball, St. Martin, Mickey Free, Chanticleer, Solon. Xenophon, Zealot, Barcaldine, Lowlaud Chief, Ossian, Ambergris, Lecompte, Stạlie. War Dance, Jils Johnson, ete. Faraudole combines the best racing blood on both sides, and should be a success in the stud. He is the sire of the wimners Annie Brown, Billy Snith, Donglas, Dixie V., Free Trade, Fringe, Indigo, La Mothe, Melia. P. These are abont all of his get yet trained. 
-

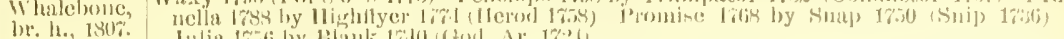

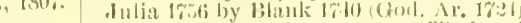

焉

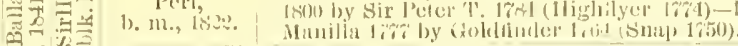

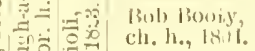

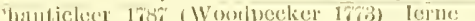

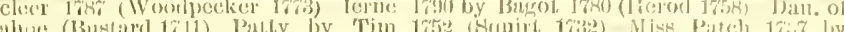

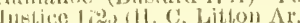

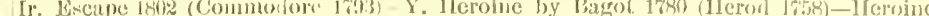

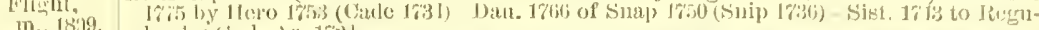
lus by cionl. Ar. 17:

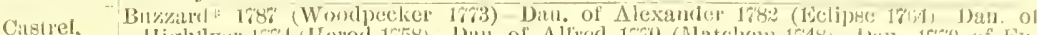
ch. h., 180

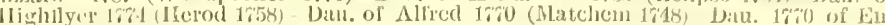
rinecr 155 ; (Sampson 1745).

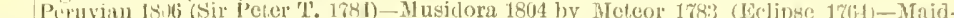

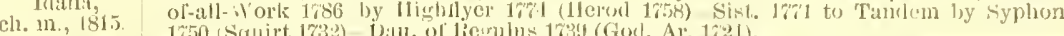

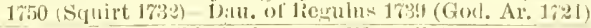

Blicklock 181.1 (Whitelock 1sis) Wartil 1818 by Prime M

tanurel,

br: h., 1821 .

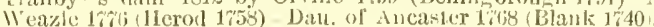

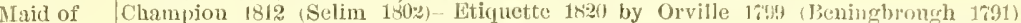
Honor, br. m., 1 in 9

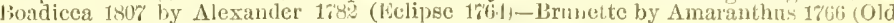
England 1741) - Mayfly $17 \% 1$ by Matchem 1748 (Cade 17\% 1 ).

Tim Arehy 1805 (\$Diomed 17\%) Dan. of Saltram 1780 (Eclip)e 1\%ti4)-Dau. of symmes ch. $\mathrm{h}_{n, 1} 1813$.

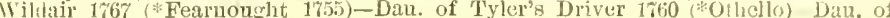
Fallower 1761 (B)ink 1rito)

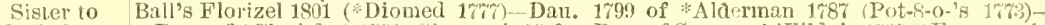
Tuckahoe.
ch. m., 1814.

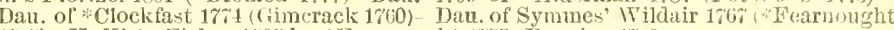
1755) X. Kitty Fisher $1766^{\prime}$ by * *'earnought 1755 (Regulus 17 :

* Emilius 1820 (Orville 179:)-Icaria 1821 by The knlyer 1811 (Vandyke Jr. 1808)-Palma

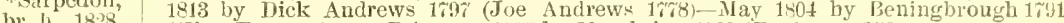
(King Fergus 17\%5)-Primrose 1787 by Nambrino 1768 (Engineer 1756)

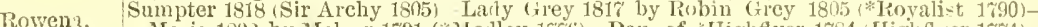
ch. m., 18\%. Maria 180: by Melzar 1791 (H edley 1766)-Dan. of Hightiyer 1784 (Highflyer 17\%1)Dau. of "Fearuonght 1755 (Regulus 1739 ).

D - Diumed 1\%tr (Florizel 1\%68)-Amanda 1800 by Grey Diomed 1786 (*.Nedley 1riff)-Dan.

of Va. Cade (Partner 1755)-Dau. of Hickman's Independence 17\%6 (*Fearnought 1755)-Dall. of "Badger (Bosphorus 1754).

Miller's "Messenger 1780 (Mambrino 1r68) "Pot-8-o-'s mare 1702 by Pot-8-o-'s $17 \%$ (Eciipse Damsel, 1764)-Dan. 1778 of Gimerack 1760 (Cripple 1750)-Snapdragon 1759 by Snap 1750 gr. m, 1203. (Snip 1733)-Dau. 1749 of Regulns 173!) (God. Ar. 1724).

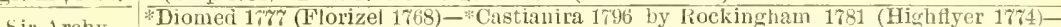
Sir Archy, Tabitha 178, by Trentham 1766 (T. Sweepstakes 1743)-Dan. of Bo:phorus 1951 (Babraham 1740)-Dain. of Forester 17\%0 (Crott's Eorester 1:36).

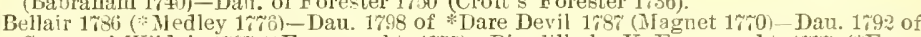
Symmes' Wildair $166 \%$ ("Fearnought 1755)-Picadilla by Y. Fearnonght $17 \%$ ("Fearnoucht 17.55) - Dau. of Godolphin $17 \%$ (* Fearnonght 1755).

Calypso,

Diomel 1777 (Florizel 1768) - *Castianira 1793 by Rockingham 1781 (Highflyer $17 \% 4$ ) -

Sil. Archy, Tabitha 17's by Trentham 1766 (T. Sweepstakes 1713)-Dau. of Bosinoris 1754 (Ba$\begin{array}{ll}\text { b. h., 1805. } & \text { Tabitha 17'3 by Trentham 1766 (T. Sweepstakes 17 13)-Dan } \\ \text { braham } 1740 \text {-Dau, of } 1 \mathrm{~V}^{\prime} \mathrm{s} \text { Forester } 1750 \text { (Forester 1736) }\end{array}$

Danghter of, "Saltram 17S0 (Eclipse 1764) Dau. of Symmes' Wildair 1767 (*Fearnought 1755)-Dau. of Tyler's Driver 1;60 (*othello) -Dan. of *Fallower $1 \% 61$ (Blank 1740)-Dau. of "Vampire 1757 (Regulus 1739).

\section{Ball's}

Florizel,

Diomed 17\%7 (Florizel 1768)-Dan. of *Shark 1\%r1 (Marske 1\%50)-Dau. of Harris Eclipse 17\%0 (*Fearnought 1755)-Dau. of *Fearnought 1755 (Regulus 1739)-Dau. of . Jolly Roger 1711 (Roundhead 1733).

Danghter of

Alderman 1787 (Pot-8-o-'s 1773) D Duu. of *Clockfast 1774 (Gimerack 1760)-Dan. of b. $\mathrm{m} ., 1639$. Symmes' Wildair 1767 (*Fearnought 1755)-Y. Kitty Fisher 176\% by *Fearnonght 1755 (Regulu 1739) -*Kitty Fisher 1755 by Cade 1734 (God. Ar. 1724).

Emilius,

Orville 1799 (Beningbrough 1791) - Emily 1810 by Stamford 1794 (Sir Pater T. 1781) -

b. h., 182$\}$ Dau. 1799 of Whiskey 1789 (Saltram 1780)-Grey Dor
(Otho 1760 -Dizzy 1757 by Blank 1 140 (God. Ar. 1724).

Icaria,

The Flyer 1814 (Vandyke Jr. 18j81-Parma 1813 by Dick Andrews 179\% (Joe Andrews b. $\mathrm{m}, 1824$. 1778)-Nay 1804 by Beningbrough 1791 (King Fergus 17ti5)-Primro:

brino 1768 (Engineer 1756 )-Cricket 1776 by Herod 1758 (Tartar 1713).

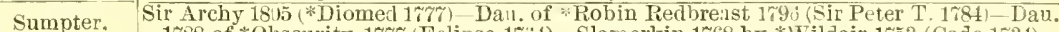
ch. $h, 1818$ 1788 of *Obscurity $17 \%$ (Eclipse 1\% 74 ) - Slamerkin 1768 by *Wildair 1\%53 (Cade 1734) * Cub mare 1762 by Cub 1739 (Fox 17i4).

Robin Grey 1805 (*Royalist 1790) - Naria 1802 by Melzar 1791 (*Medley 1\% 6 )-Dau. of Lady Grey, R*Highflyer 1784 (Highflyer 17\%1) Dau. of *Fearnought 1755 (Regulus 1739) —Dan. of b. m., $131 \%$ Ariel $1 \% 56$ ("Traveller 174\%)

Scud Beningbrongh 1791 (King Fergus 175)-Eliza 1791 by Highflyer $17 \% 4$ (Perod 175s)b. 130 Augusta 1781 by Eclipse 1764 (Marske 1750)-Hardwicke's dam by Ferod 1758 (Tartar 1743) -Nettle 1763 by Bajazet 1710 (God. Ar. 1724).

Stamford 1794 (Sir Peter T. 1784) - Dan. 1799 of th hiskey 1\%89 (Saltram* 1780)-Grey ch. m., 1878. Dorimant 1781 by Dorimant 1\%78 (Otho 1760)-Dizzy $175 \%$ by Blank 1740 (God. Ar. 1724)-Anc. Dizzy 1741 by Driver 1727 (Wynn Ar.).

[Comus or] Whitelock 1803 (Hambletonian 1792)-Dan. 1799 of Coriander 1786 (Po†-8-o-'s 1 1 73 )Blacklock, Wildgoose 1792 by Highflyer $1 \% 74$ (Herod 1758) Coheiress 1786 by Pot-8-0-'s 1763 b. 1., 1814. (Eclipse 1764)-Manilla 1\%个\% by Goldfinder 1\%64 (Snap 1\%50)

Dick Andrews 1797 (Joe Andrews 17\%8)-Mandane 1800 by Pot-8-0-`s 1773 (Eclipse b. 1761)-Y. Camilla 1787 by Woodpecker 17\%3 (Herod 1758)-Camilla 1778 by Trentham 1766 (T. Sweepstakes 1743)-Coquette 1765 by Compton Barb.

b. m., 1809

Selim 1802 (Buzzard* 1\%87)-Bacchante 1809 by W's Ditto 1800 (Sir Peter T. 1784)--

Sultan, Sell 1791 of Nereury $1 \% 78$ (Eelipse 1\%64)-Dau. $17 \% 6$ of Herod 1\%58 (Tartar 1 13) b. h., 1816 Folly 1771 by Marske 1750 (Squirt 1732).

Trampoline

Tramp 1810 (Dick Andrews 179\%) - Web) 1808 by Waxy 1790 (Pot-8-0-'s 1;i3) - Penelope Th. 1798 by Trumpator 1782 (Conductor 1767)-Prunella 1788 by Highflyer 17\%t (Herod 1758)-Promise 1768 by Snap 1750 (Snip 1736).

IIuley 1810 (Orville 1799)-Dan. 1899 of Windle 1804 (Beningbrough 1791) Dan. 1788 of

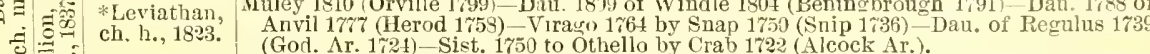

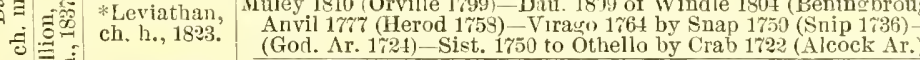

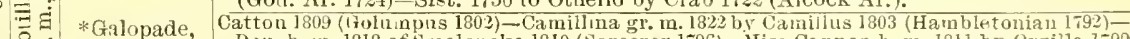
gr. m., 1828 .

Dan. b. Iu. 1818 of Smoleusko 1810 (Soreerer 1796)-Miss Camnon b. m. 1811 by Orrille 1799

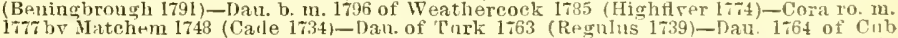

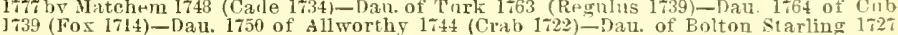
(Bay Bolton 1705)-Dairymajil b. m. 1737 by B1 ody Butocks-Bay Brocklesby b. m. 1731 by Partner 1i18 (Jírg)-Brneklesby

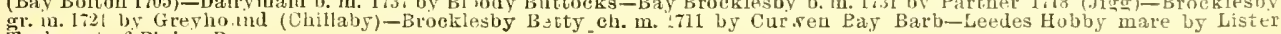
Turk, out of Piping Peg. 


\section{FELLOWCRAFT.}

THE FIRST HORSE TO BEAT LEXINGTON'S FOUR MILE TIME, 7.193, WHICH HE DID AT SARATOGA, AUGUST 20, 1874, RUNNING IN 7.191.

\section{Felloweraft is in the Dixiana Stud. Application to Maj. B. G. Thomas, pro- prietor, Lexington, Ky. Sales ammally.}

Fellowcraft by imp. Anstralian, son of West Australian, bred by A. J. Alexander, Woodburn Stud, Ky., foaled 1870, dam Aerolite, the dam of Mozart, Rutherford, Miser, spendthrift, etc., by Lexington, $2 d$ dam Florine, the dam of Idlewild by imp. Glencoe, out of Melody by Merloe, son of Am. Eclipse. As a two-jear old Fellowcraft started five times and won one race; was unplaced in Hopeful Stakes, one-half mile; mplaced in a dash of three-quarters of a mile; won a dash of three-quarters of a mile in 1.20, beating Marsyas and three others. At Saratoga was unplaced in the Flash Stakes and Saratoga Stakes. As a three-year old he started nine times and won one race. Jerome Park, unplaced in the Belmont Stakes; second to Survivor in a dash of $1 \frac{1}{4}$ miles, run in 2.15; unplaced in the Weatherlyy Stakes, $1 \frac{1}{3}$ miles; was third to Tom Bowling and Springbok in the Jerome Stakes, 2 miles; was third in the Grand Natioual Handicap 23 miles, won by Preakness in 4.08妾, with Harry Basset second. At Saratoga, unplaced in the Travers Stakes, 13 miles, won by Tom Bowling in $3.09 \frac{3}{4}$; second in the Sequel Stakes, won by imp. Ill Used in $3.40 \frac{1}{2}$, and walked orer for a Sweepstakes for three-year olds, 2 miles. When four years old he started twelve times and won three races. Jerome Park, inplaced in the Fordham Handicap, the Jockey Club Handicap, and in a race of mile heats, won by Kitty Pease in 1.43a, 1.44; third in prurse race, 18 miles; third in Handicap Sweepstakes, $2 \frac{1}{2}$ miles, won by Kitty Pease in $4.35 \frac{1}{2}$. At Long Branch, was mplaced in a race of two-mile heats; won purse, $\$ 1,000,4$ miles. in 7.43 ; was second in a race of two-mile heats, won by Tandalite in 3.49, 3.37. At Saratoga, was third in a dash of three miles. won by springbok in 5.423, with Preakness second; won dash of $1_{2}^{2}$ miles in 2.421, beating Katie Pease, The Governess and Wanderer; was second in a dash of $2 \frac{1}{4}$ miles, won by Wanderer in $4.00_{\frac{1}{2}}$; and won dash of 4 miles in $7.19 \frac{1}{2}$, beating Wanderer and hatie Pease. This was the best race, at the distance, ever run up to that date. The first mile was run in $1.47 \frac{1}{4}$, two miles in 3.38 , three mules in $5.29 \frac{1}{2}$, and the four miles in 7.191. This closed the turf career of Fellowcraft. Since his retirement, with a limited advantage, he has sired some fist horses. Knight Templar won three-quarters of a mile in 1.14, three-quarter mile heats in $1.16 \frac{3}{4}, 1.16 \frac{1}{4}$, and 1 mile in 1.42 , all of which are creditable. Blne Lodge won heats of three-quarters of a mile in 1.20, 1.191, beat$i_{n g}$ Brambaletta, Pilgrimage, Maggie C. and others; ran dead heat and divided Citizens' Plate with Long Taw, at St. Lonis, $1 \frac{1}{8}$ miles, in 1.55 . Blne Lodge won some good races in 1882. Felloweraft is a rich chestunt, with star and two white hind feet, is well formed and a fine blood-like specimen of a horse, 16 hands high. He is handsomely bred, was a good race-horse, with great speed and the eapacity to stay over a distance of ground. He is strongly inbred to Diomed and imp. Medley, son of Gimerack by Cripple by the Godolphin Arabian; he possesses the Waxy blood through Whisker and Whalebone, and numerons crosses to Herod and Eclipse, the pedigree terminating in the blood of Nedley by Gimerack.

Felloweraft is the sire of the winners Boaz. Dr. Jekyl, Jin Mmphy, My Feilow, Lady Reel, Harrodsburgh, Wooderaft, Abby Craft, Fellowship, Simrock, Shibboleth. Hansa, Fannie s., Capt. Brown, Hydra, liree Mason, My Craft, Timberland, Tom Tough aud others. 


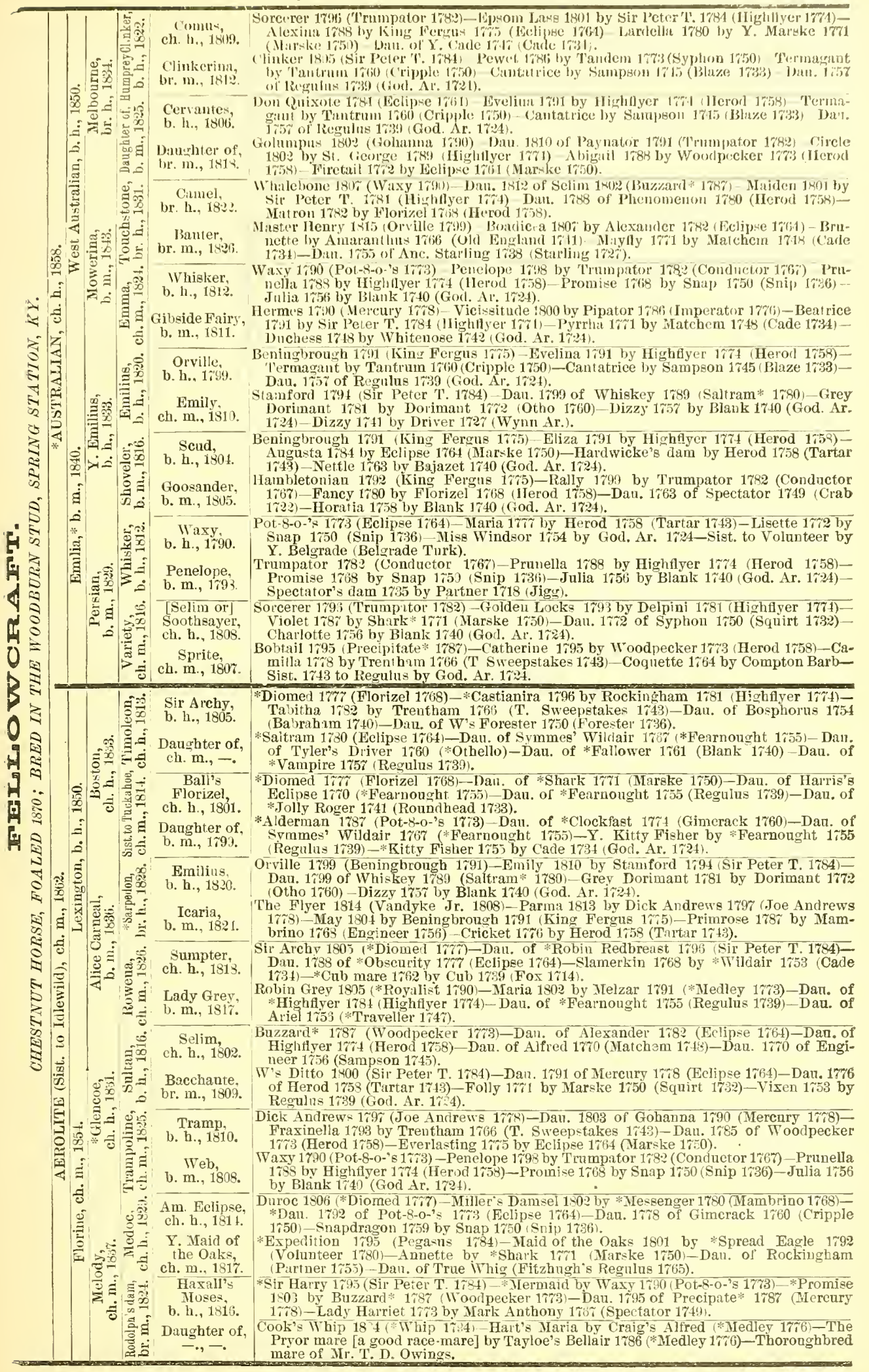




\title{
IMPORTED GALORE.
}

\author{
WINAER OF THE HARRINGTON, HICHALLMAS, PAYNE STAKES, AND MADE \\ A DEAD HEAT FOR THE ST. JAMES' PALACE STAKES.
}

The property of $\mathrm{R}$. W. Walden, Bolingbroke Stud, Middleburg, IId.

Galore, brown horse, foaled 1855, bred by the Duke of Portland, by Galopin, son of Vedette, dam Lady Maura by Macaroni, son of Sweetmeat, out of Koblesse by Stockwell. Galopin, the sire of Galere, won the Derby in 1875, Hzkle Park Plate, New Stakes, Fernhill Stakes and Newmarket Derbs. Galopin is the sire of the unbeaten St. Simon, Galliard (winner of the 2,000 Guineas), Donovan (winner of the Derbs and St. Leger), Atalanta (dam of Ajrshire, winner of the 2,000 Gumeas and Derbr), and of the dam of Surefoot (winner of the 2,000 Guineas), his dam, Lady Manra, like the dam of Galliard, is by Macaroni, sire also of Macgregor (wimer of the 2,000 Gnineas), Spinaway and Camelia (winners of the 1,000 Gnineas and Oaks), Bonny Jean (winuer of the Oaks), Yista, dam of Bonavista (winner of the 2,000 Guineas), and Lily Agnes, dam of Ormoude (winner of the 2,000 Guineas, Derby and St. Leger). Noblesse, his grandam, is by the emperor of stallions, Stockwell, and out of Brown Duchess (winner of the Oaks) by The Flying Dutchman, winner of the Derby and St. Leger.

Galore is an extraordinary fine horse and combines in his pedigree all of the most fashionable strains of linglish blood. He was a superior race-horse, as his performances show.

As a two-year old Galore ranked with the best of his year, nerer did he contend for a prize except with sonngsters of the highest class. He won Harrington stakes at the Derby Spring meeting, Arrandale (a winner) second, and Seabreeze (the winuer of the Oaks and St. Leger the following jear) third, with seven others behind. The Michaelmas Stakes at Sandown Park was also placed to his eredit, snch subsequent winners as St. Symphorien, Blanton, Nunwick, Juggler, Bartizan, etc., being defeated. In the Severals Plate at Newmarket he ran second to Sandal (wimuer of the Halnaker Stakes, Devonshire Nursery), Galore carrying 134 1bs. and the latter 131 los., Hark, Father Confessor and King Galop being in the rear. A rear later Galore proved his two year old form was no fluke by winning the Hastings Plate at Newmarket (distance 1 mile), with such fiyers as Hazleluatch, Sheen, Anareh, Sky Pilot, Caerlaverock and three others, those named being all in the wimning list, and prominent this year (1889). He won the Payne Stakes at Newmarket (one mile and two furlongs), with Patchouli, Scene Shifter and three others behind him. The Derby was the next effort, but he conld get no nearer than fonrth to Arrshire, Crowberry and Van Dieman's Lind; Orbit, Chillington and three others were behind him. In the Frince of Wales' Stakes at Ascot he ran second to Ossory, who accompanied Galore on his ropage across the Atlantic, but died dnring the jonrney; both these colts carried 125 los., giving weight to nearly all their seven opponents. Thes met again in the St. James' Palace Stakes, each carrying 126 1lus., bnt so close did they finish that the judges conld not separate them, a dead heat being the result and stake divided. In the Zetland Plate, Sheen just managed to avenge the defeat which he had previously suffered, but in the Hamilton Park Stakes, over $1 \frac{3}{8}$ miles, eight opponents were easily disposed of.

None of Galore's get have yet raced, hut from his high breeding and excellence as a race-horse he should be a success in the stud.

Galore descends in direct female line from the Royal mare, to which Comcluetor, O'Kelly's Eclipse, Voltaire, Oxforr, Kingston, Scottish Chief, Adventurer, Lexington, Vandal, Leonatus, Longstreet, Salvator anil other good ones trace. 


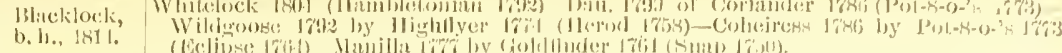

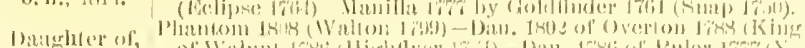

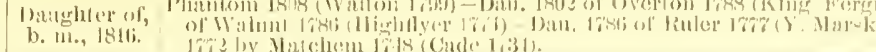

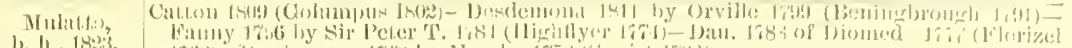

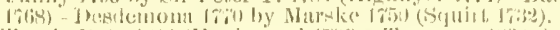

b. 11., 18:2:3.

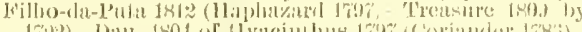

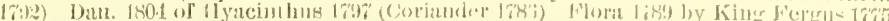

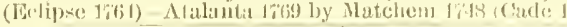

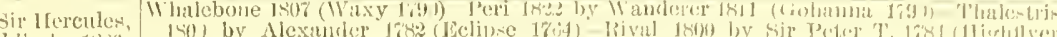

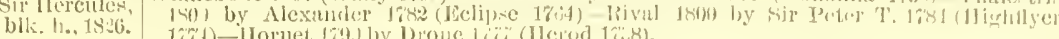
Cruiceioli.

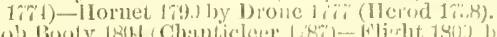

ch. m., 1823.

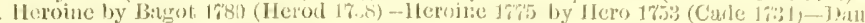

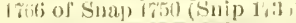

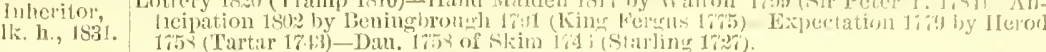

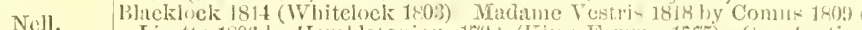

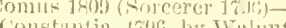

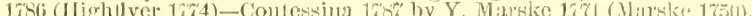

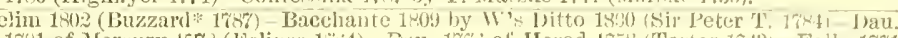

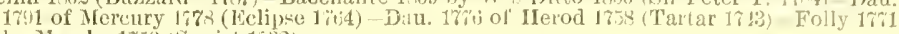
by Marske $1 \% 30$ (Squirt $1 \% 32$ )

Cobweb,
b. 11,1821 .

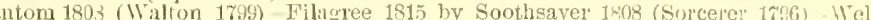

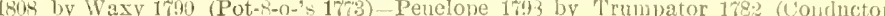
176\%)-Prunella 1788 by Higlifyer 17 is (Herod 1758).

b. h., 1818 .

Darioletta,

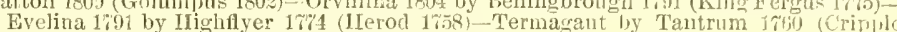
1750)-Cantatriee by Sampson 17.15 (Blaze 17.39 ).

Amadis 180 (Don Quixote 1\%84) - Selima 181) by Selim 180' (B1zzard* 1\% of Pot-8-o-'s 17i3 (Eclipse 1;64)-Editha 1781 by Herod 1753 ('lartal 174?)-Elfrida 1768 by suap 1750 (Snip 1736)

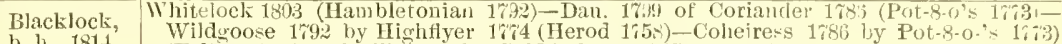

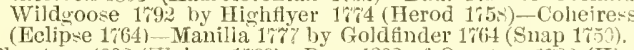

Daughter of,

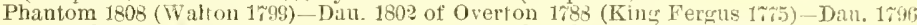
of Waluut 175.3 (Hightlyer 17\%4)-Dau. 1786 of Ruler $17 \%$ (Y. IIarske 1iri)-Pirae intha $17 \tau^{2}$ by Matchem 1748 (Cade 1734).

Whiskey 1789 (Saltram 1760 )-Jenny spinner $179 \%$ by Draqon $178 \%$ (Woodpecker

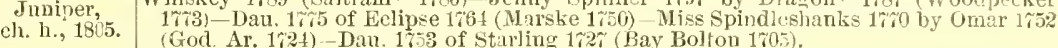

Sorcerer 1796 (Trumpator 1782)-Viroin 1801 by Sir Peter T. 1781 (Highflyer 1674)-Dan.

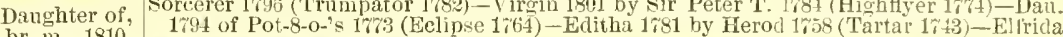
br. m., 1810. 1765 by snap 1750 (Snip 1736).

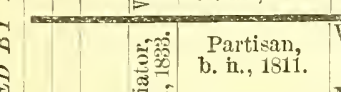

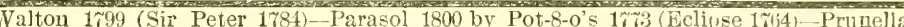

1788 by Highifyer 17\%4 (Herod 1758)-Promise 1\%68 by Snap 1750 (Snip 1736) - Julia 1756 by Hlank 1740 (God. Al: 1724)

\section{¿}

Moses 1819 ([Whalebone or] Sevmo

b. m., 1826 . 1787 ) - Canary Bird 1803 by [Whiskey or] Sorcerer 1706 (Trumpator 1782)-Canary $179 \%$ by Coriander 1786 (Pot-8-o-'s 17i3)-Miss Green $178 \%$ by Hightyer $17 \%$ (fierod 1759).

is [Starch or] Blacklock 1814 (Whitelock 1803)-Dan. 1816 of Phantom 1893 (Walton 17ing-Dan. 180:

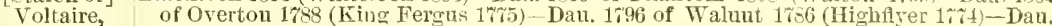
1786 of Ruler $17 \%$ ( $Y$. Marske $17 \% 1$ )

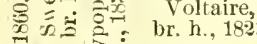

Pelinda

Blackloek 1814 (Whitelock 1803) - W

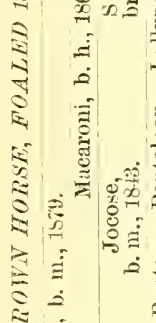

br. $11 ., 18 * 5$

Tranby"s dan 1812 by Orvil:e 1739 (Beningbrough 1791)-Miss Gimstone 1796 by Weazle 17 \% (Herod 1753)--Dau. of Ancaster 1768 (Blank $1 \% 49)$.

Castrel.

eh. h., 1801

Buzzard* 1787 (Woodpecker 17\%3)-Dau. of Alesander 17t2 (Eclinse 176t)-Dzu of Highflyer 17\%t (Herod 1758)-Dau. of Alfred 1770 (Matchem 1748)-Dau. 17\%0 of Engineer 1 to 6 (Sampson $1 \% 45$ ).

Idalia Peruvian 1896 (Sir Peter T 1784)-Musidora 1801 by Meteor 1783 (Eclipse 176-1) - Maidof-all- Th ort 1785 by Highflyer 1774 (Herod 1758)-Dau. 17\% of Syphon 1750 (Squirt 1732)-Dau. of Regilus 1739 (God. Ar. 1721)

ch. M., 181

Orville 17ug (Beningbough 1791)-Viss Sophia 1805 by Stanford 1794 (Sir Peter T.

Nasterflenry, Orre L

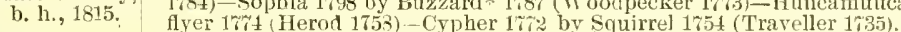

Boadicea Alexancier 1782 (Eclijse 1764)-Brunette by Amaranthus 1766 (Old England 1it1) - May-

b. m., 180\%. fly $17 \% 1$ by Matchem 1\%18 (Cade 1\%34) Dau. 1755 of Anc. Starling 1\%38 (Starling 1\%27)-Look-at-me-Lads 1 \% 1 by Bri-t. Gragshopper (Byerly T.)

É Ir.Birdeateher Sir Herenles 1826 (Whalebone 180\%)-Guiceioli 1828 by Boh) Booty 1804 (Chanticleer

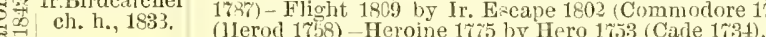

\section{इ \\ 光 \\ Eehidna,

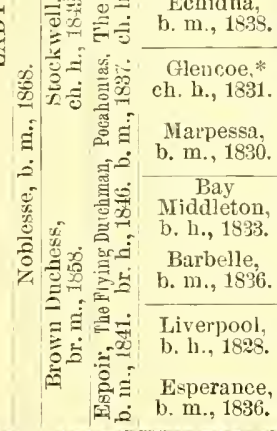

(1lerod 1758)-Heroine 1755 by Hero 1753 (Carle 1\%34)

Gadabout 1812 by Orville 1799 (Beningbrough 1r91)-Minstrel 1803 by Sir Peter T. $1 \% 84$ (Highflyer 1\%4)-JIatron $1 \% 82$ by Florizel 1\%68 (Herod 1\%58).

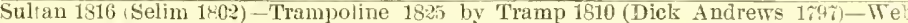
1808 by Waxy 1793 (Por-8-o-'s 1773)-Penelope 1798 by Trumpator 1782 (Conductor 1767 )-Prunella 1788 by Highflyel $17 \%$ (Herod 1758).

Jiley 1810 (Orville 1799)-Clare 1824 by Vlarmion 1806 (Whiskey 1789)-Harpalice 1814 by Gohanna 1790 (Mercury 17\%8)-Amazon 1799 by Driver 1783 (Trentham 1\%(6) Fractions 1792 by Mereury $1 \%$ \% (Eelipse $1 \% 6+$ ).

Sultan 1816 (Selim 18(12)-Cobwe!) 1801 by Pluantom 1868 (Walton 1799)-Filagre( 1815 by

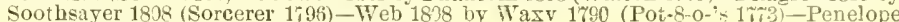
1798 by Trumpator 1782 (Conductor $1 \% 67$ )

Sandbeck 1818 (Catton 1807)-Darioletta 1822 by Amadis 1807 (Don Quixote 1784)-

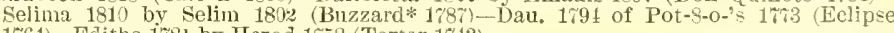
1761)-Editha $178 \mathrm{~s}$ by Herod 1759 (Tartar $1 \% 13$ ).

Trump 1810 (Dick Andrews 1796)-Dau. 1822 of Whisker 1812 (Wasy 1690)-Mandane 1803 bv Pot-4-o 's 1,73 (Eclipse 1,64)-Y. Camilla 1;8\% by Woodpecker 1673 (Herod 17581-Camilla 17\%8 by Trentham 1606 (T. Sweepstakes 17i3).

Lapdon* 1823 (Whalebone 180\%)-Grisette ch, m. 1825 by Nerlin 1815 (Castrel 1s01)-Coquette ch. m. 1814 by Dick Audrews 1797 (Joe Audrews 1778)-Vanity b. m. 1803 by Buzzard* 1787 (Woodpecker 17\%3)-Dabehiek br. m. 1798 by Pot-5-0-s 1; (Eelipse 1764)-Drab b. m. 1791 by Highflyer 17\%4 (Herod 1758)-Hebe b. m. 1774 by Chrysolite 1763 (Blank 17 10)-Proserpine (sist. to Eclipse) b. m. 1763 by IIarske 1750 (Squirt 1732) -Spilett2 b. m. 1719 by Regulis 1735 (God. Ar. 17:4)-Mother Western by Easby Snake (Suake)-Montagn mare by D'Arcy's old Montagu-Da!l. of Kalitboy (D'Arcy White Turk)-Dau, of Brimmer (D'Arey Yellow Turk)-Royal mare. 


\title{
IMPORTED GREAT TOM.
}

\author{
WHNER OF ST. JANES' PALACE STAKES AT ASCOT, AND DONCASTEP \\ STAKES AT DONCASTER, IN 1876.
}

\author{
Property of Gen. TV. H. Juckson, Bell II"le S'l, Wisheille, Tenn. An- \\ mat sale of yourlings ubut MLay 1 st.
}

Great Tox by King Tom, son of Harliaway, bred hy Lord Falmouth, foaled 1873, dam Wooderaft, the dam of Kingeratit, Andred and Anderida by Voltigenr, winner of the Derby, St. Leger and Doncaster Cup, ont of Faleon and Ostreger's dam by Venison. Great Tom starterl once at two years old : at Newmarket lirst Octolier Meeting, for the Boseawen Post Stakes of 10 sovereigns each, for two-rear olds, threequarters of a mile (six suls.) ; won by Twine the Plaiden, 119 lbs., Great Tom, 122 lbs., unplaced. At three rears old started nine times; wou two, was second three times, thirl twice, and mplaced in two. Newmarket Craven Meeting for Post Sweepstakes of 100 sovereigns each, half forfeit, for three year olds, Ditch mile, 7 furlours and 220 rards, Wild Tommy, 122 lbs., was first, Great Tom, 122 lbs., second, Coltuess, 118 llss., third, won by a head, a length and a half between second and third. At Newmarket, for Two Thonsand Grineas Stakes, Rowley mile, 1 mile and 17 yards, won

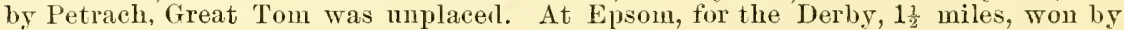
Kisber, Forermuner second, Jnlius Casar third, Great Tom was unplaced, fifteeu starterl. At Ascot, for the Prince of Wales Stakes, 1 mile and 5 furiongs, Petrarch, 127 lbs., first, Great Tom, 115 lbs., secoud, Julins Cæesar, 122 lbs., third, won by it length. St. James' Palace Stakes, old mile (12 subs.), Great Tom, 115 lbs., and Glacis, 115 lbs., ran a dead heat. Great Tom arterwards walked over, and the stakes were dirided. At Doncaster, for the Doncaster Stakes, $1 \frac{1}{2}$ miles (36 subs.), Great Tom, 122 lbs., was first, Coltness, 127 lbs., second, Morning Star, 122 lbs., thirrl, won by two lengths, three lengths between second and third. At Newmarket, for the Triennial Prodnce Stakes, A. F., 1 mile 2 furlongs 73 yards, won by Camembert, 'Twine the Plaiden second, Great Tom third. Beanfort Post Stakes, Rowley mile (5 subs.), won by Twine the Plaiden, Great Tom second, Wild Tommy third, Camembert fonrth. Newmarket Derby, $1 \frac{1}{2}$ miles, Lord Falmouth's Skylight, 123 lbs., first, Moulin, 123 lbs., second, Great Tom, 123 lbs., third, won by a leugth, tiro lengths between second and third.

At form years old he started six times and won once, second once, third twice. and unplaced twice. At New market First October Meeting for the Trienuial Produce Stakes, Ditch In, 2 miles and 105 yards, Angusta was first, Great Tom second, Footstep third. The Cesarewitch Handicap Stakes, $2 \frac{1}{6}$ miles and 28 yards, won by Hilarions, 3 jears, 88 lbs., Great Tom was umplaced. The Champion Stalies, Across the Flat, $1 \frac{1}{4}$ miles and 73 vards, Springfield, 4 years, 130 lbs., first, Silvio, 3 rears, 118 lbs., second, Great Tom, 4 jears, 130 lbs., third. Winding-np Handicap, Rowley mile, 1 mile and 17 rark, Great Tom, 3 vears, 117 los., was first, Angusta, 4 vears, 105 lbs., second, sheldrake, 3 years, 91 lbs., third, won by three lengths, a head between second and third. At Shrewsbury, for the Qneen's Plate, abont 21 miles, sheldrake, 3 years old, 117 lbs., was first, Redonbt, 3 years old, $11 \%$ lbs., second, Great Tom. $t$ jears old, 133 lbs., third. Was mplaced for the Hawkstone Welter Cup, New mile, won by Specnlation, 3 years old, $131 \mathrm{lbs}$.

King Tom, sire of Great Tom, was by Harkaway, the best race-horse of his das. He was not in either the Derby or St. Leger, but won 21 ont of the 28 races in whirh he started "up to the end of his four-year old year, including eight King's Plates, the Goodwood Cnp and the Royal Whip, beating all the best horses on the Irish and English turf, carrying the top weights. He also won the Goodwood Cup when five years old with 130 lbs.

Great Tom is a rich, golden chestnnt, with a white stripe down his face, rumning down between his nostrils, and two white feet behind, half way to the hock. He measures 16 himds 2 inches high; around the girth, 77 inches; length of shoulder, 32 inches; around the arm, 22 inches; below the knee, 9 inches; from point of hip to point of hock, 40 inches ; circumference of gaskin, 19 inches; from point of shoulder to point of bnttocks, 69 inches, and weighs 1,305 los. Among the best of his get are Tyrant (wimner of the Withers and Belmont), General Harding (the best two-year old of 1883, winner of nine ont of ten races), Tennyson, Telie Doe (with the fastest seven furlongs on record, $1.27 \frac{1}{3}$, up to that time), Thackeray, Trombone, 'Treasurer. Tatton, Standiforl Keller. Tabitha, Whizeig. Tartar, Thistle, Belle Pate, Cremorne. Switt, Watterson, Captain Wagener, Caleimm, Dntchman, Hilda, Mayor Nolan. Tarquin, John C., Tally Ho, Millegarde, Brentano, Honeymoon, Great Dixon. Jaces Richelien, Little Billie, Ella, Tullahoma, Tocsin, Tallapoosa (l'roetor hrnott's dam). Tom Boy, Tea liose, Hattie S. Bliss, Trmalnwk. Toribera, Tantrum, Gradnate, Great Gans, Simon Pure, Tangent, Jase Phillips, somano, Gipsy anil many others. 
Wuxy

1), h

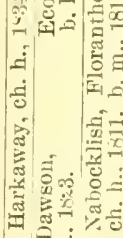

Bacchunte, br. m., $180 \%$

Tramp,

b. h., 1810 .

Teb

Orville, b. 11., 1799 .

Eleanor, b. m., $1 \% 98$.

Marmion,

Harpalice, b. m., 1814

\begin{tabular}{c|c} 
Whitelock, \\
\hdashline$\infty$
\end{tabular}

Dauchter of

Phantom,

b. h., 1808 .

5c Daughter of,

\section{Catton,}

b. h., 1809 .

br. m., 1811 .
br.

Fitho-da-
Puta,

br. h., 1812

Treasure,

\section{Paragol}

b. $12 ., 1800$

Smolensko,

Jerboa,

b. m., 1803

Whalebone, br. h., $180 \%$

Daughter of

b. $\mathrm{m} ., 1812$

Whisker,

Tanmella

b. n., 1869 .
+3: b. m., 1 s08. b. h., 1803

- ch. m., 1809.

ह5: Walton,

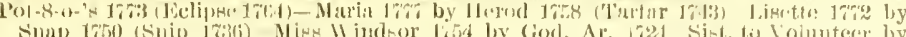

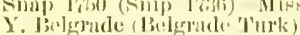

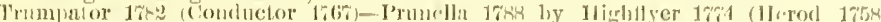

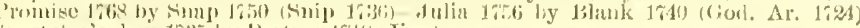

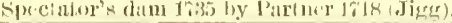

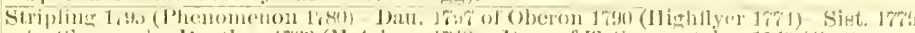

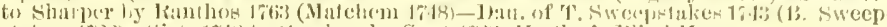

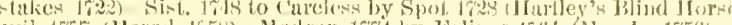

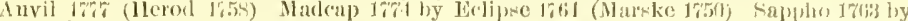

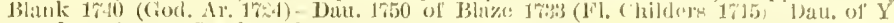
(ireyhomed liz:3 (Greylomal).

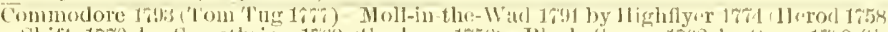

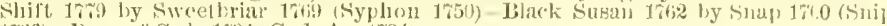

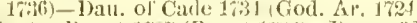

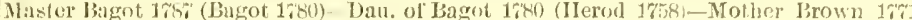

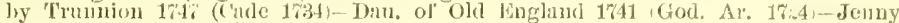
Jessamy 1748 by staring 172r (Bay Bolton $17(5)$ ).

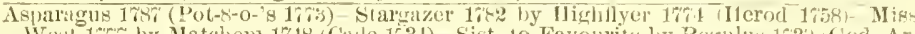

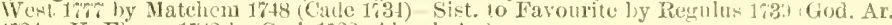

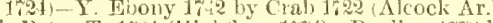

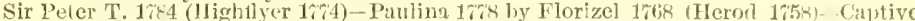

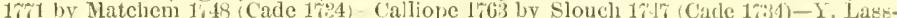
f-the-Mill 1\%56 by Oroonolio $17 \pm 5$ (Cral) 1\%22).

Buzzard $1 \%$ (Woodpecker 163-Dau. ol Alexauder $17 \times 2$ (Eelipse 1\%4) Dall, of Hightlyer 17it (Herod 175s)-Dan. of Alfred 1\%70 (Matehem 174s)-Dan. 170 of Engineer 1756 (Sampson 1745).

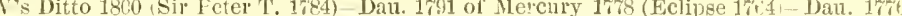
f Herod 1758 (Tartar 1743)-Folly $16 \% 1$ by Marske 160 (Squizt 1632)-Tixun 1rog bJ Regulns 1739 (Gorl. Ar. 7\% 24 ).

Dick Andrews 1997 (Joe Andrews 17\%8)-Dau. 1803 of Gohanna 1790 ( Nerenry 17r8)Fraxinella 1793 by Trentham 1766 (T. Swecpstakes 17.53)-Dau. 1655 of Woodpecker 17.3 (Herod 1755)-Everlasting 175 by Eclipse 1764 (Marske 1750)

Waxy 1790 (Pot-8-()'s 17i3)-Peneloje 1798 by Trumpator 17\&2 (Conductor 176i)-Pru-

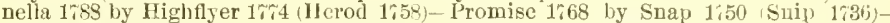
Julia 1756 by Blank 1740 (God. A1. 1724).

Beningbrough 1791 (King Fergns 17\%5) - Evelina 1591 by Highflyer 1\% id (Herod 1758) Termagani by Tantrum 1;60 (Cripple 1750)-Cantatrice by Sampson 1745 (Blaze 1763)Dau. 175 i of Regulus 1739 (God. Ar. 17:4).

Whiskey 1789 (Sultram* 1780)-Y. Giuntess 1700 by Diomed* 1r\% (Florizel 1768) Giantess 1769 by Matchem 1748 (Cade 1734)-Molly Long Legs 1753 by Babraliam 1\%40 (God. Ar. 1724)-Dan. of Cole's Foxhmnter 172i (Brisk 17̄11)

Whiskey 1789 (Saltram* 1780)-Y. Noisette 1698 by Dinmed* 17\% (Klorizel 1768)-Noicet te 1774 by Squirtel 1\%54 (Traveller 1735)-Cariua 1766 by Marske 1\%50 (Squirt 1736)Dau. 1755 of Blank 1\%40 (God. Ar, 1724).

Gohamna 1799 (Mercury 1\%(8)-Amazon 1\%99 by Driver 1783 (Trentham 1766)-Fractious 1732 by Mercury 17\% (Eclipse 1r64)-Dau. 1785 of Woodpecker 1 \% 13 (Herod 175e)Everlasting $17 \% 5$ by Eclipse 1764 (1larske 1750)

Hambletonian 1792 (King Fergus 17\%5)-Rosalind 1788 by Phenomenn $1 \% 00$ (Herod 175s)-Atalanta 1769 by Matchem 1748 (Cade 1724) - Y. Lass-of-the-Mill 1;56 by Oroonoko 1745 (Crab 1722)-Dau. 1744 of Traveller 1735 (Partnel 1718),

Coriander 1786 (Pot-8-0-'s 17\%3) Wildgoose 1792 by Highilyer 1\%, (Herod 1758) Coheiress 1786 by Pot-8-0-'s $17 \% 3$ (Eclipse 17(4)-Camilia 17\% by Goldfinder 1764 (Snap 1750)-Dau. 1766 of Old Erigland 1741 (God. Ar. 17:4).

Walton 1799 (Sir Peter T. 1784)-Julia 1799 by Whiskey 1789 (Saltram*1780)-Y Giantes. 1790 by Diomed*1\%7 (Florizel 1768)-Giantess 1769 by Matchem 1\%18 (Cade 1734)Molly Long Legs 1753 by Babraham 1740 (God. Ar. 1724).

Overton 1788 (King Fergus 17\%)-Dau. 1796 of Walnut 1786 (Highflyer 1\%44-Dau. 1786 of Ruler $17 \%$ (Y. Marske 1;71)-Piracantha 1\%2 by Matchem 1718 (Cade 1734)-Prophetess 1758 by Regulus 1739 (God. Ar. 1720).

Golumpus 1802 (Gohanna 1790)-Incy Gray 1804 by Timothy 1794 (Delpini 1781-Lucy 1789 by Florizel 1\%68 (Herod 1758)-Frenzy 1\%74 by Eclipse $1 \% 61$ (Markke 1;50-Dau. of Engineer 1\%56 (Sampson 1745)

Orville 1799 (Beningbrough 1791) - Fanny 1696 by Sir Peter T. 1 r84 (Highflyer 17r4)Dau. 1788 of Diomed* 17, (Florizel 1768)-Dekdemona 17\%0 by Mlarske 1750 (Squirt $\left.173^{3}\right)$ - Y. Hag 1761 by Skim 1746 (Starling 172\%).

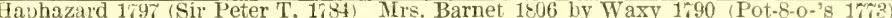
Dall. 178 of $T$ oodpecker $1 \% 3$ (Herod 1\%5)-Heinel 171 by Squirel 1754 (Traveller 1735)-Prineipessa $176 \%$ by Blank 1\%40 (God. Ar. 17\%4).

Camilius 1803 (Hambletonian 1792)-Dau. 1804 of Hsacinthns 1797 (Coriander 1786ீ) Flora 1789 by King Fergus 1\%75 (Eclipse 1;64)-Atalanta $1 \% 69$ by Matchem $1 \% 48$ (Cade 1734) - Y. Lass-of-the Mill 1756 by Oroonoko 1745 (Crab 17:2).

Sir Peter T. 1284 (Highflyer 1rr4)-Arethusa 179: by Dungannon 1780 (Eclipse 1r64) Dau. 1777 of Prophet 1760 (Regulus 1759)-Virago $1 \% 64$ by suap 1750 (Snip 1;36)-Dau. of Regulus $1 \% 39$ God. Ar. 1721).

Pot-8-0-'s 1773 (Eclipse 1764)-Prunella 1788 by Highflyer 1\%/4 (Herod 1:58)-Promise 1768 by Snap 1750 (Snip 1756)-Julia 1756 by Blank 1740 (God. Ar. 1724)-Spectator's dam 1735 by Partner 1718 (Jigg).

Sorcerer 1796 (Trumpator 1782 - Thowski 149- by Nentor 178t (Justice 104)-Maria $1 \%$ (Waxy's dam) by Herod 1758 (Tartar 1743)-Lisette $17 \% 2$ by Snap $1 \% 50$ (Snip $1736)$-Miss Wiudsol 1754 by God. Ar. 1724.

Gohanna 1790 (Mercury 17\%8) - Camilla 1\%8 by Trentham $1 \% 69$ (T. Sweepstakes 1\%3)Coquette 1664 by Comptou Barb-Sist. 1743 to Regulus by God. Al.1221-Grey Robinson 1723 by Bala Galloway (St. Victor Barb).

Waxy 1990 (Pot-8-0's 17\%3) Penelope 1798 by Trumpator 1882 (Condnctor 1\%6\%)-Prunella 1788 by Highflyer 1764 (Herod 1\%8)-Promise 1768 by Sn:1p 1750 (Suip 1736)Julia 1756 by Blank 1\%40 (God. Ar. 1721)

Selim 1802 (Buzzard 1\%87)-Maiden 1801 by Sir Peter T. 1\%84 (Highflyer 17\%4)-Dan. 1788 of Phenomenon 1\%80 (Herod 1758)-Matron 1\%82 by Florizel 1\%68 (Herod $16 \% 8$-Maiden $17 \% 0$ by Matchem 1ris (Cade 1731).

Wasy 1790 (Pot-8-0-'s 17\%3)-Penelope 1798 by Trumpator 178*2 (Conductor 1767) - Pruuella 1788 by Highflyer $17 \% 4$ (Helod 1758)-Promise 1768 by Snap $1 \% 0$ (Snip 1\%36)Julia 1766 by Blank $1 \% 40$ (God. Ar. 1\%21)

Dick Andrews 1797 Joe Andrews 1178) Handane ch. m. 1800 by Pot 8-0-'s 1\%73 (Eclipse 17f4)-Y. Camilla b. m. 178\% by Woodpecker 1;r3 (Herod 1758)-Camilla b. m. 1\%8 by Trentham 1766 (T. Sweepstakes 1743)-Coquette b. m. 17f4 by Comptnn Barb-Sist. b. m, 1,43 to Regulus by God. Ar, 1724-Grey Robinson gr. m. 17\%? by ist. to old Country Wench by Snake (Lister Turk)-Grey Wilkes gr. m. by Hautboy Bald Galloway (St. Victor Barb)-Sist. to Old Country Wench by Snake (Lister
(D'Arcy White Turk) - Miss D'Arey's Pet mare ont of a Sedbury Royal mare. 


\title{
GRINSTEAD.
}

\author{
WINNER OF THE CHAMPAGNE STAKES AT JEROME PARK, MANSION \\ HOUSE STAKES AT LONG BRANCH, ALL-AGED SWEEPSTAKES AYD \\ SLMMER HANDICAP AT SARATOGA.
}

\section{The Property of E. J. Baldwin, Savannah, Los Angelos Co., California.}

Grixstead by Gilroj, son of Lexington, bred by Jas. A. Grinstead, Walnnt Hill Stud, Ky., foaled 1871, dam sister to Ruric by imp. Sovereign, son of Emilins, ont of Levity, dam of Lever, Mildred, Legatee, ete., by imp. Trustee. Grinstead, as a twoyear old, started in two races, of which he won one. At Jerome Park, the Champagne Stakes for two-year olds, 量 of a mile, in 1.173, beating Dublin, Wreathercock and seven others. At Saratoga, was second in the Kentucky Stakes for two-year

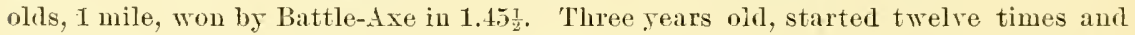
won three races. Jerome Park, won a dash of $1 \frac{1}{2}$ miles in 2.40 beating Kadi and seven others, among which were Harry Bassett, Whisper and Spindrift. Won a dash of $1 \frac{8}{4}$ miles in 3.10, beating shylock, Lyttleton, Wildidle, Kadi and others. Baltimole, Md., won a compensation purse, mile heats, in $1.45 \frac{1}{2}, 1.45 \frac{1}{2}$, beatung six others, among which were Aaron Pennington and Survivor. Jerome Park, was second in

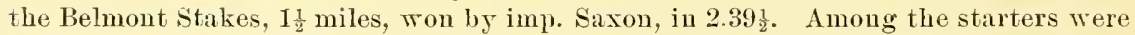
Aaron Pennington, Elkhoru, Rutherford, Brigand and Reform. Saratoga, was second in the Sequel stakes for three-year olds, 2 miles, won by Vandalite, in 3.40. Was third in a dash of 1 mile and a furlong, won by Madge, in 1.57 $\frac{1}{4}$. Was third in a dash of 2 miles, won by Culpepper, in 3.401. Jerome Park, was socond in a handicap, $1 \frac{1}{2}$ miles, won by Skylock, in 2.38. Four years olk, started in eleven races, of which he won seren. Jerome Park, won a race of heats of 1 mile and a furlong, in 1.598, 2.018. beating Rhadamanthus and Fadladeen. Mommouth Park, Won a race of mile heats, in $1.45 \frac{1}{4}, 1.45,1.47$. D'Artagnan won first heat and Grinstead was fifth. Won Mansion House Stakes for four-year olds, $2 \frac{1}{2}$ miles, in $4.40 \frac{1}{2}$, beating Rntherford, Stampede and two others. Saratoga. won Sweepstakes for all ages, $1 \frac{1}{4}$ miles, 2.08 $\frac{a}{4}$, beating Springlok, Olitipa and Mate. Won the Summer Handicap, 2 miles, in 3.37 $\frac{1}{2}$, beating Wildidle and Mattie W. Won a dash of $1 \frac{1}{2}$ miles in 2.40, beating Aaron Pennington, Scratch and two others. Jerome Park, was third in the Jockes Club Handicap, 2 miles, in $3.38 \frac{1}{2}$, won by Wildidle. Was third in the Woodburn Stakes for four-year olds, $2 \frac{1}{2}$ miles, wou by Aaron Pennington, in 4.36 . Saratoga, was third in the Saratoga Cnp, $2 \frac{1}{4}$ miles, Springbok and Preakness running a deal heat for first place, in $3.56 \frac{1}{4}$, which still stants the fastest time on record at the distance. Reno. Tevala, won race, mile heats, three in tive, in $1.47,1.46 \frac{1}{2}, 1.46 \frac{1}{2}$. Bay District Course, Cal, was second in the Wise Plate, a post stake, 4 miles, won by Wildidle, in $7.25 \frac{1}{2}$. As a fire-year old starterl once and was mplaced. Grinstead is a blood bay horse, full 16 hands, of great substance and power, with excellent shoulders. good body and strong, well placed back, hips and loin. He was a good, honest race-horse and comes from a grand racing family, and a host of good ones have descended from it. Grinstead has covered only a few mares. He sired Gano, wi:ner of the Conner stakes, Grismer, Bonita, Goliah, Ed. Ifufinnis, Geraldine, Glen Al:momd, Gamymede, Gladiator, Hoaluras, Cleopatra, Clio, Costa Riea, Hemet, Pnente, Santiago, Sinaloa II., Esperanza, Winona, Salonica, El Rayo, Santa Auna and many other winuers. It is to the Royal mare through old Montagn mare that trace in direct female line Conductor, Eclipse, Sterling, Weatherhit, Oxfor l, Kinrston, Srottish Chief, Adventurer, Lexington, Vandal, Leonatus, Salvator, O.loaligi, Stratforl, Sensation and all the Duchess fimily. 


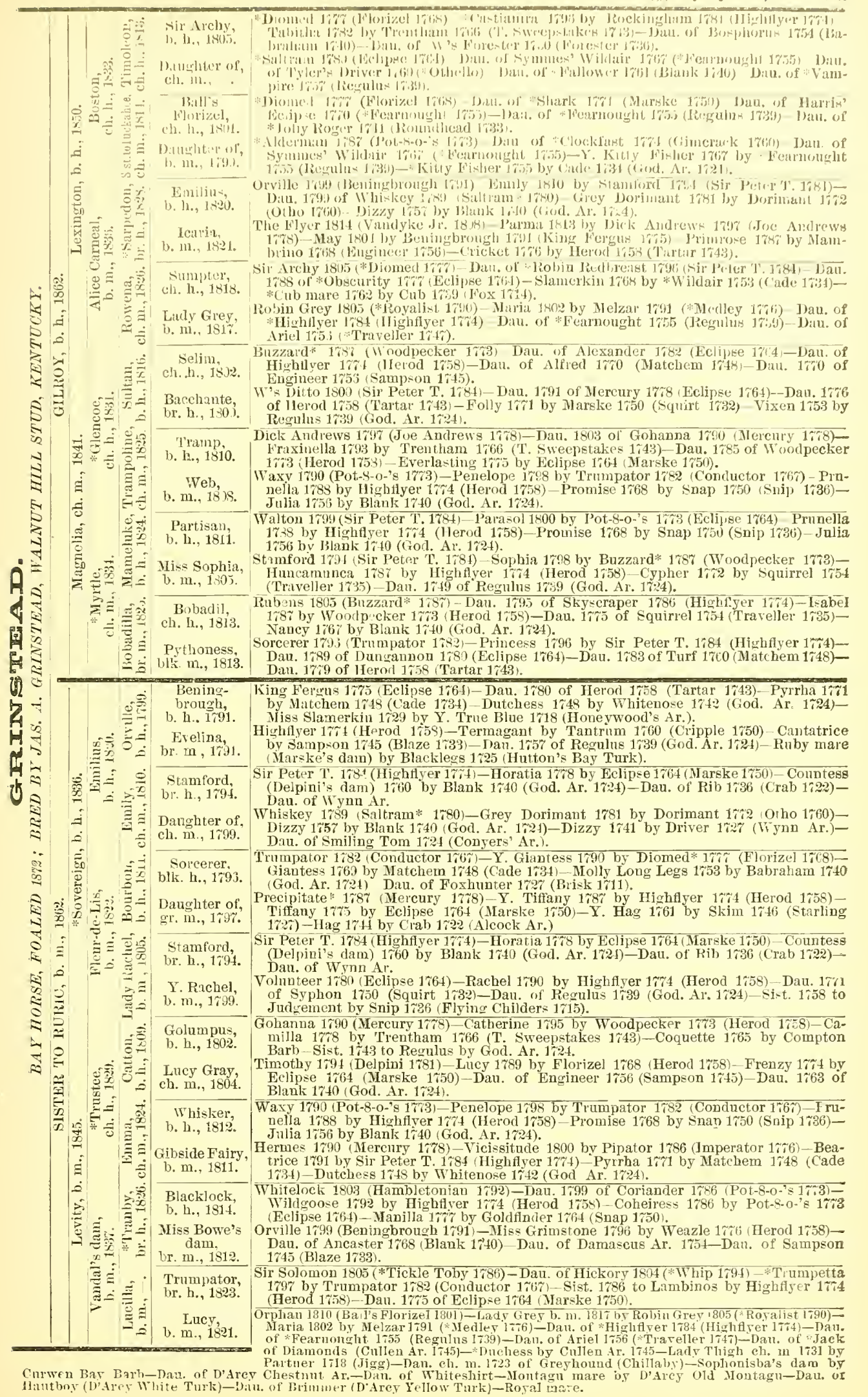

Hiutboy (D' Darh-Dau. of D'Arey Chestunt. Ar.-Dan. of Whiteshirt-Montagu mare oy D'Alcy OId Montagu-Dau, or 


\section{HANOVER.}

WINNER OF THE HOPEFUL, JULY AND SAPLING STAKES AT TWO YEARS OLD, TIVENTY OUT OF TIVENTY-SEVEN RACES AT THREE YEARS OLD, INCLUDING IVITHERS, BELMONT, SWIFT, TIDAL, LORILLARD, STOCKTON, STEVENS, BROOKLYN DERBY, CONEY ISLAND UERBY, EMPORIUM, CHAMPION AND OTHER STAKES.

\section{The property of Milton Young, ILGrathiana Stud, Lexington, Ky.}

HAxover, ehestnut horse, foaled 1884, bred in Runnymede Stul, by Jindoo, son of Virgil, dam Bourbon Belle by imp. Bonnie Scotland, ont of Ella D. by Taulal, son of $1 m p$. Glencoe. Tranover was a grank rice-horse. At two vears old won the Hopeful Stakes, $\frac{3}{4}$ of a mile, 115 lbs., in $1.15 \frac{3}{4}$, beating Fitzroy, Roi d'Or aud three others; won July Stakes, $\frac{3}{4}$ of a mile, 120 lbs., in $1.15 \frac{1}{2}$, defeating Oneko, Roi d'Or, etc.; won Sapling Stakes, $\frac{8}{4}$ of a mile, 1.15, (lefeating Kingston, Austriana and four others. All these races were run at Nonmonth Park. As a three-year old, started 27 times, won 20 races. At Brooklyn won the Carlton Stakes, 1 mile, 118 lbs., in 1.431 ; the Brookdale Handicap, $1 \frac{1}{8}$ miles, $111 \mathrm{lbs}$, in $1.5 \frac{1}{3}$, Dry Monopole, Oriflame and others behind him;

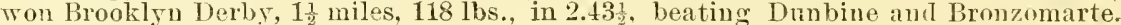
Jerome Park, won Witlers stakes, 1 mile, 118 lhs., in 1.461, Stoekton, Belvidere ete..

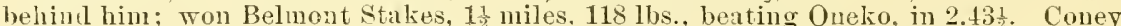
Islanl, won Swift Stakes, 7 furlongs, 118 lbs., beating Kingston and Firenzi, in 1.32, track muddy; won the Titlal Stakes, 1 mile, 118 lbs, beating Kingston and Oneko, in

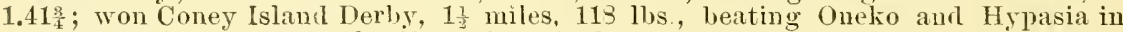
2. $44 \frac{1}{2}$. track heavy; won the Emporinm Stakes, $1 \frac{1}{2}$ miles, 128 1bs., in $2.35 \frac{3}{1}$, beating Dunbine, Oneko and fire others; won the Spindrift Stakes, $1 \frac{1}{3}$ miles, 125 lbs., beating Stockton, $111 \frac{1}{2}$ lbs., and Raveller, 112 lbs., in 2.11. MIonmonth Park, won the Loril-

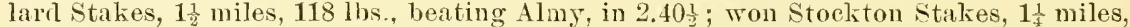

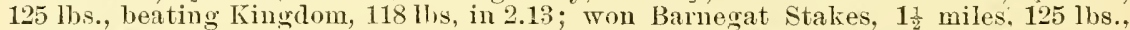

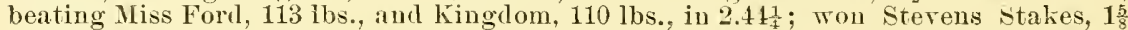
miles, 123 lbs., beating Almy, 114 lbs., in 2.56; ran second to Laggard, 111 lbs., in the Raritan Stakes, Hanorer, 128 lbs., in 2.14, Bralford, 109 lbs., third ; won Champion

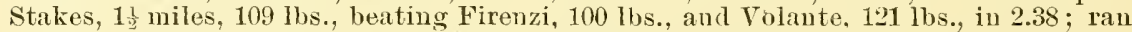
third to Laggard, 118 lbs., and Firenzi, 120 lbs., Hanover, 125 lbs., in the Omnibns Stakes, $1 \frac{1}{3}$ niles, in 2.44, track muldy, Kingston and Esquimau behind him; was beaten by Bauburs, 110 lbs., in Choice Stakes, 11 miles, in 2.45. Hanorer, 118 los. Saratoga, won United States Hotel Stakes, $1 \frac{1}{2}$ miles, 118 lbs., beating Waxy aud others, in $2.3 \frac{1}{2}$. Brooklru Fall Meeting. was unplacerl in first special. $1 \frac{1}{1}$ miles, won by Volaute 112.12 ; second won special, $1 \frac{1}{8}$ miles, $114 \mathrm{lbs}$., in $1.57 \frac{1}{2}$. Faror (5), 123 lbs., Banburg and Grisette behind him. Jerome Park Fall Meeting, beater by Firenzi, 122 lbs., Hanover 125 llos., in Jerome Stakes, $1 \frac{3}{4}$ miles, in 3.09\%. Baitimore, won Breckenritge Stakes, $1 \frac{5}{8}$ miles, 123 lbs., in $2.52 \frac{1}{2}$, bea ting Glemmound, 118 lbs., and Stockton, 11 \&lbs.; won Dixie Stakes, 2 miles, $1231 \mathrm{hs}$., beating Glenmonud, 118 jhs., in 3.51 , track heavy; rau second to Eolian, 11s lbs., 7 furlongs, in 1.28?, two behind him; ran second to Eolian (1), 123 lbs., Hanover (3), 114 los., 1 mile, in 1.13, fonr others behind hin; won purse, 1 mile. 112 los., in 1.41 vears old ran three times, was second to The Barl in Brooklru Handicap, $1 \frac{1}{4}$ miles, each $125 \mathrm{lbs}$, In 2.13, Exile, Volante and seven others behind him ; ran second to Richmond (6), 112 lbs., Hanover (4), 125 Ibs, in Brookdale Handicap. $1 \frac{1}{8}$ miles, in 1.5s, Dry Monopole, Enrus and Fitzroy behind him; ran thind to The Bard (5), 123 lbs.,

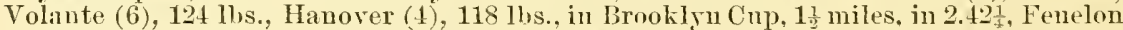
(4), 118 lbs., fourth. At five years old starter 17 times, won 9 races, was second in 6 . third in 1 and mulared in 1. Brooklyn, was muplacer in Brooklyn Handieap, $1 \frac{1}{4}$ niles,

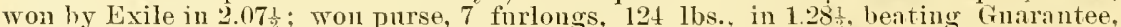
Eolian and Eolo; ran second to Diablo in St. James Hotel Stakes, $1 \frac{1}{4}$ miles, in 2.092, beating Elkwood: was seeond to Marander (4), 122lbs. Hanover (5), 127 los., in Brook-

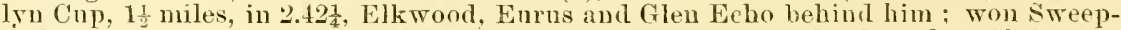
stake, a mile, 125 lbs., in $0.48^{3}$, seven behind him. Coner Istand Joeker Club, won Sweepstake, $1 \frac{1}{8}$ miles, 114 llss., in 1.55. three behind him; won Sweepstake, $5 \frac{1}{3}$ fur-

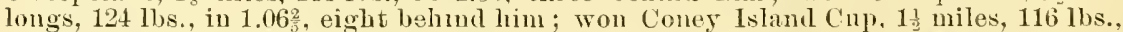
in $2.35 \frac{2}{5}$, beating Firenzi and three others; won Coner Island Stakes, $1 \frac{1}{s}$ miles, 119 lbs.. $11.54 \frac{4}{5}$, Kingston, 12」 $1 \mathrm{bs}$., and three others behind him. Saratoga, won the Calitorma. Stakes, 1 mile, 124 ibs., in 1.431 , three behind him: ran secont to Los Angeles (4), 112 lbs., in Excelsior Stakes, $1 \frac{1}{3}$ miles. Hanover (5), 124 lbs., in 2.13, Montrose third; won Merchants' Stakes, $1 \frac{5}{8}$ miles, 124 lbs., beating Montrose and Elkwood. 


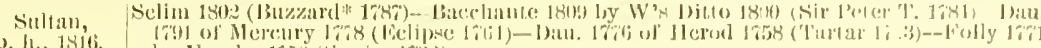

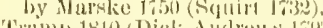

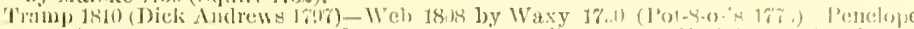

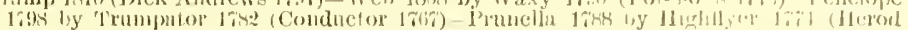

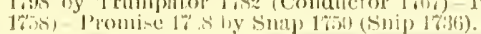

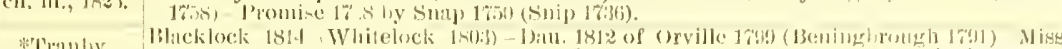

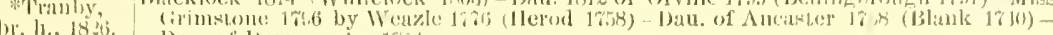

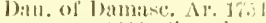

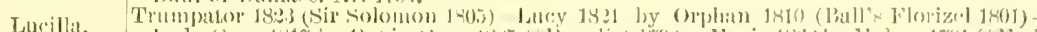

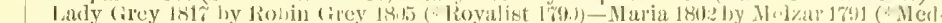

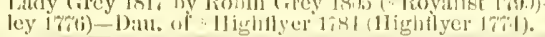

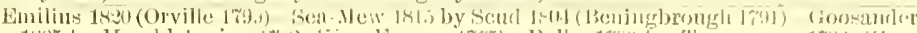

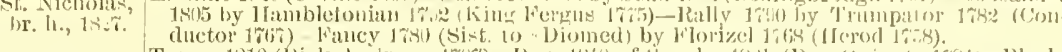

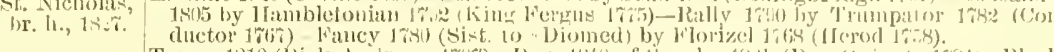

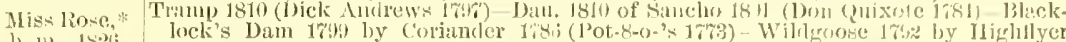

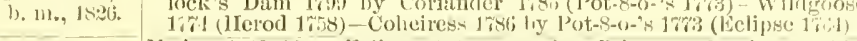

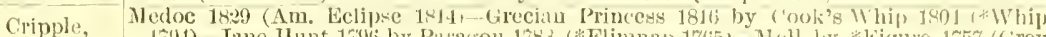

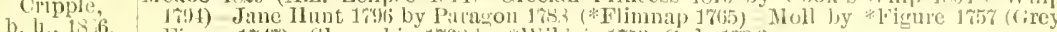

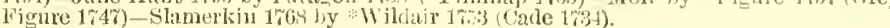

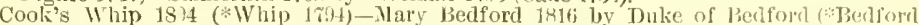

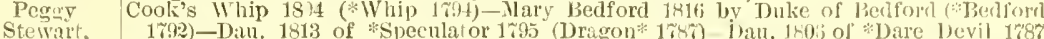

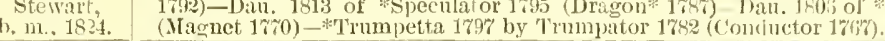

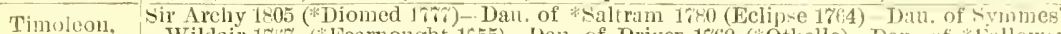

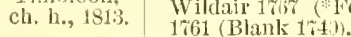

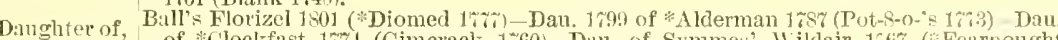

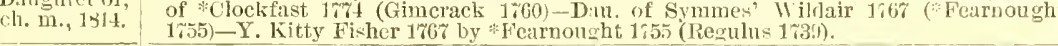

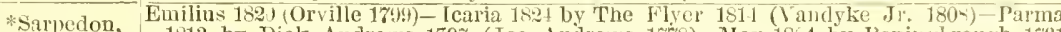

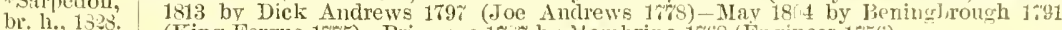
(King Fergus 17\%5) - Primlose $17 \% \%$ by Mambrino 1768 (Engineer 1\%56)

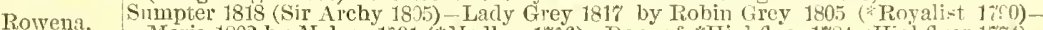
ch. Maria 1802 by Melzar 1:91 (* Medley 1\%6)-Dau. of *Higlufyer 1784 (Highflyer 17\%4). Dau. of Fearnonght 1755 (Regulns 1\%39).

2 Shect Anchor Lottery 1820 (T'ramp 1810)-Morgiana 1820 by Muley 1810 (O:ville 1to9)-Mlis-Steplen Shect Anchor, sou 1814 by [Scud or] Sorcerer 1793 (Trumpator 1782)-Sist. 179; to Peiworth by

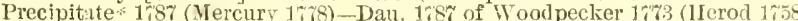

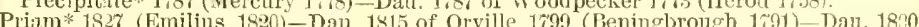

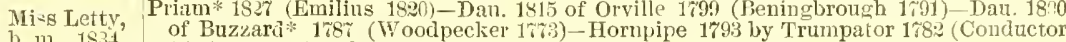
b. m.. 18.34. $176 \%$-Lma $17 \%$ by Herod 1\% (Tartar 1\%.3).

Sir Ilercules 1823 (Whalebone 180\%)-Guiccioli 1823 by Hob Booty 1804 (Chanticleer ch. h., 1833. 1isi)--Flight 1809 by Ir. E-cape 1802 (Commodore 1

Colician 182 ) (Brutandori 1821) Camelina 1823 by Whalebone $180 \%$ (Traxy 1790 -

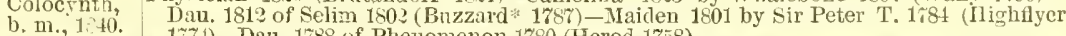
17it) - Dau. 1789 of Phenomenon 1780 (Herod 17\%8)

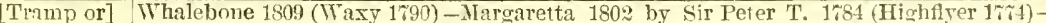

E.: TTrmp or

Dau. 1792 of Highther $17 \% 4$ (Herod 1758)-Nutcracker 1737 by Matchem 1 i 18 (Cade br. b., $181 \%$.

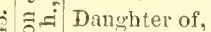
1\%34) - Miss Starling 1750 by St $x^{2}$ ling $172 \gamma^{\circ}$ (Bay Rolton 1\% $0^{-}$). omus 1809 (Sorcerer 1796)-Narc ana 1809 by Stamford 1\%4 (Sir Peler T. 1:81)-Marcia 1797 by Coriander 1766 (Pot-8-0-'s 17\%)-Faith $17 \% 9$ by Pacolet 1\%6: (Blank 1740) Atalanta 1769 by Matchem $1 \% 18$ (Cade 1734 ).

gr. mi., 1821.

Buzzard* 1787 (Woodpeckel 1779)-Daw. of Alexander 1782 (Eclipse 176t)-Dall. of

Selim,

ch. li., 1802 .

Daughter of, Highflyer $17 \%$ (Herod 1758)-Dau. of Alfred 1760 (Matchem 1713)-Dau. $17 \% 0$ of Engineer 1756 (Samoson 1745)

Haphazard $179 \%$ (Sir Peter T. 1784)-Princess 1799 by Precipitate* 178\% (Mercury 1\%8) br. m., 1816. Colibri 1793 by WToodpecker $17 \%$ (Herod 1\%58)-Camilla $1 \% 78$ by Trentbam $1 \% 66$ ( $T$. Sweepstakes 17:3) - Coquette 1765 by C'ompton Barb.

Partisan, Walton 1799 (Sic Peter T. 1784)-Parasol 1800 by Pot-8-o-'s 17\%3 (Eclipse 1764)-Prunella

b. h., 1811. 1788 by Highflyer 1\%" (Herod 1758)-Promise 1768 by Snap 1\%50 (Snip 1\%36)-Julia 1756 by Blank 1740 (God. Ar. 1724).

Pauline. Moses 1819 ([Whalebone or] Seymour 180\%)-Quadrille 1815 by Selim 1802 (Buzzard* 1787)-Canary Bird 1806 by [ II hisliey or] Sorcerer 1796 (Trumpator 1782)-Canary 1797 by Coriander 1786 (Pot-8-o-'s 173) - Miss Green 1787 by liighflyer 1\%44 (Herod 1758).

Fienipoten- Emilins 1820 (Orville 179:)-Hariet 1819 by Pericles 1809 (Evander 1801)-Dan, 181; of

tialy,

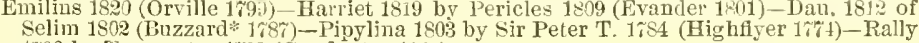
1790 by 1 rumpator 1782 (Conductor $176 \%$ ).

Mrrina,

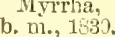

Halebone 1807 (Waxy 1790) - (Xift 1818 by Y. Gohanna 1819 (Gohanna 1\%90) - Dan. 1802 of Sir Peter T. 1781 (Highflyer 177t)-Dau. 1788 of Trumpator 1782 (Conductor 1767)Sist. 1rit to Postmaster by IIerod 1758 (Tartal 1743).

- Selim 1802 (Buzzard*178\%)-Bacchante 1809 by W's Ditto 1800 (Sir Peter T. 1784)-Dau.

b. h., 1816. $1 \% 91$ of Mercury 178 (Eclipse 1704)-Dau. 176 of Herod 1758 (Tartar 17.13)-Folly 17\% by Marske 1750 (Squirt 1732).

Tramp 1810 (Dick Andrews 1390)- Teb 1808 by Waxy 1\%90 (Pot-8-o-'s 1\%3)-Perelope Trampoline, 1793 by Trumpator 1782 (Conductor 1'67)-Prnnella $1 \% 88$ by Highfler $1 \%$ \% (Herod 1758)-Promise 1768 by Snap 1750 (snip 1736).

Black]ock 1814 (Whitelock 1803)-Dau, 1812 of Orville 1799, Beningbrough 1791) - Jiss br. h., 1326. Grimstone 1796 by Weazle 1rr6 (Herod 1758)-Dau. of Ancaster 1768 (Blank 17:0)-

Lncilla Trumpator 1823 (Sir Solomon 1805)-Lucy 1821 by Orphan 1810 (Ball's Florizel 1801)Larly Grey 1817 by Robin Grex 1805 (*Royalist 1790)-Naría 1802 by Nelzar 1791

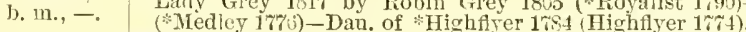

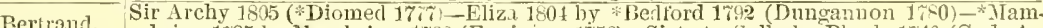
b. b., 1821 .

brina 1785 by Mlambrino $1 \% 68$ (Engineer 1\%56)-Sist. to Sally by Blank 1740 (God, Ar. 1721)-Dan. of Ward $1 \% 31$ (Crab 1722).

*Buzzard 1787 (Woorlpecker 1\%9)-The Faun by Craig's Alfred (*Nedley 1\%6) -

Daughter of Shepherdess by Wormsley's King Herod ("Fearnonght 1750)-Dan, of Traveler 1\%4r

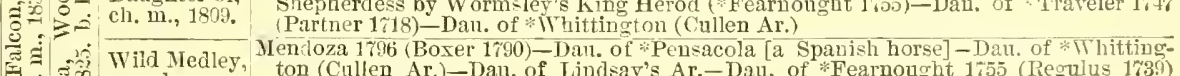
ton (Cullen Ar.)-Dau. of Lindsay's Ar.-Dau, of *Fearnought 1755 (Regulus 1739) -Dan. of Ranger.

gr. li, $\rightarrow$

Daughter of,

Sir Archy 1805 (Diomed 1\%, -Lady Chestertield b. m. 1801 bV *Diomed 1\% (Florizel 1768)-Lady Bolingbroke b. m. by *Pantaloon 1778 (Herod 1758)-Cactes by Wormsley's King Herod (Fearnought 1755 )-Primrose b. m. 1764 by *Dove 1756 (Y. Cade 1747) Traker"s Stella b m. 1758 by *othello (Crab 1702) * Selima b. m, 1716 by God. Ar.

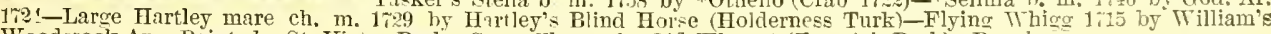
Woodstock Ar.-Points by St. Victor Barb-G:ey Whynot by Old IT hyot (Fenwick Barb)-Royal mare. 


\title{
HANOVER.-Continued.
}

Morris Park, rau second, 119 lbs., to Senorita (3). 106 lbs., in New Rochellê Stakes. $1 \frac{3}{46}$ miles, in 2.03, Taragon and Raceland behind him; ran third to Raceland (4), 120 lbs.,

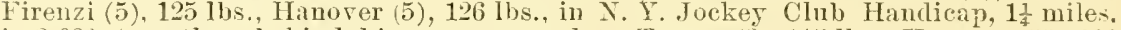
in 2:09: ten others behind him; ran second to Temny (3), 115 lbs., Hanover (5). 122 lis.. in Electric Stakes, 妾 of a mile. in 1.12, seven others behind him; won the Express Stakes, 7 furlongs, 129 lbs., in 1.29, Defaulter (4), $115 \mathrm{ibs}$, and four others behiul him: ran second to Volunteer H., each (5) 122 Ibs., in Sweepstakes, 5o furlongs, in $1.06^{4}$, with five others behind him. This closed his turf career, having won in purses and stakes \$118,000. Hanover traces back to imp. Selima by the Godolphin Arabian, thence to a Royal mare, to which trace in direct female line Blank, Bahraham, Gower Stallion, Merlin (by Second), Hornsea, Rattle, Amsterdam Jerry. Jaeques, Tearaway, Foxhall, Monday, Harvester, etc. He has a donble cross of Glencoe, both from Vandal, and should succeed in the stud.

\section{HARRY O'FALLON.}

\author{
Application to L. B. Fields \& Bro., Fields Place, Lexington, Ky.
}

Harry O'Fallox by imp. Australian, bred by James O'Fallon, St. Louis, Mo., foaled 1869, dam imp. Sunny South, dam of Ozark by Irish Birdeateher, son of sir Hereules, second dam Equal by The Cure, out of Equation, the dam of Diophantus, Archimeles, Artesian, etc. by Emilius. Anstralian is in this volume, Sunny South, Harry's dam, was the dam of the good race-horse Ozark and others, she by the great Birlcatcher, sire of The Baron, who got Stockwell and Rataplan. Birdcatcher sired Ha bena and Manganese, wimners of the 1,000 Guineas, Songstress, winner of the Oaks, Daniel O'Ronrke, winuer of the Derby, The Baron, Knight of St. George and Warlock, winners of the St. Leger, Chanticleer, Early Bird, Sannterer, Exact and other good race-horses. The Cure, sire of his grandam, was a fine race-horse; he won the Champagne Stakes at Doncaster, the Dee stakes at Chester, the Snffolk Stakes at Newmarket, the North Derby Stakes, and was second to Fangh-a-Ballagh in the St. Leger, 1844. He sired Little Agnes, Dictator and others. Harry's great grandam was the dam of Exact, Diophantus, winner of the 2,000 Guineas, and others. Maria, his fourth Ilam, was the dam of Euclid, who was third in the Derby and ran a dead heat with Charles XII. for the St. Leger, Extempore, winner of the 1,000 Gnineas, and other good ones. Harry O'Fallon ran only two races, when out of condition, and was unplaced. There is no more stontly-bred horse in America than Harry O'Fallon. He has double crosses of Whalebone and Whisker, the famons sons of Waxy, and double crosses of the speedy Emilius, and a cross of Touchstone, with any number to Eclipse and Herod througl his collateral branches. Harry has sired a fair number of good horses which have been trained, and they have all run creditably; amongst them, Krupp Gun, Sam Ecker, Expectation, Harry Doswell, Jack of Spades and John Daris, the latter a winner of the Citizens' Plate, $1 \frac{8}{3}$ miles, at St. Lonis, 104 los., in $3.06^{3}, 1 \frac{1}{4}$ miles, in 2.11, the Garden City Cup, at Chicago, $2 \frac{1}{4}$ miles, in $4.30 \frac{1}{2}$, track very muddy, 1 mile and 500 yards, $112 \mathrm{llss.,} \mathrm{in} \mathrm{2.139.} \mathrm{Northwesteru} \mathrm{Stakes,} \mathrm{at} \mathrm{Chicago,} 117$ lbs., in 3.06 , and the Oetober Handicap, 111 lbs., in 2.09, and the wimners Carrie, Harvard, Hiram Wood, Jack Cocks, O'Fellus, Revoke, Chandler, Keystone, Marion C., Miss Flond, Ofalece, Owen Golden, Walker, The Deacon, McDonald, Revival, Heron, Harry Wellon, Carrie A., Callie, Kosciusko K., Santa Lena, Lealville, Tristram, split silk. Alonzo, Bob Toombs, Cnp Bearer, Little Annie, Shiloh, Torrent, Powers, Dud Hughes, Tom Jones, Terra cotta, one of the cracks of his year, with many others. Harry is inbred to Waxy throngh Whalebone and Whisker, both Derby winners, and has many crosses to Eelipse, Herorl and Matehem. Few stallious that ever lived have done as mell with his chances. He traces in direct female line to the same Royal mare to which Oroonolio, imp. Saltram, Benmgbrongh, Williamson's Ditto, Cotherstone, West Anstralian, Walton. Will Dayrell, Parmesan, Diophantus, Orest, Caterer, Lori Ronald, Ishmael, Wistom, The Miser, Sasufrage, ete., trace. 


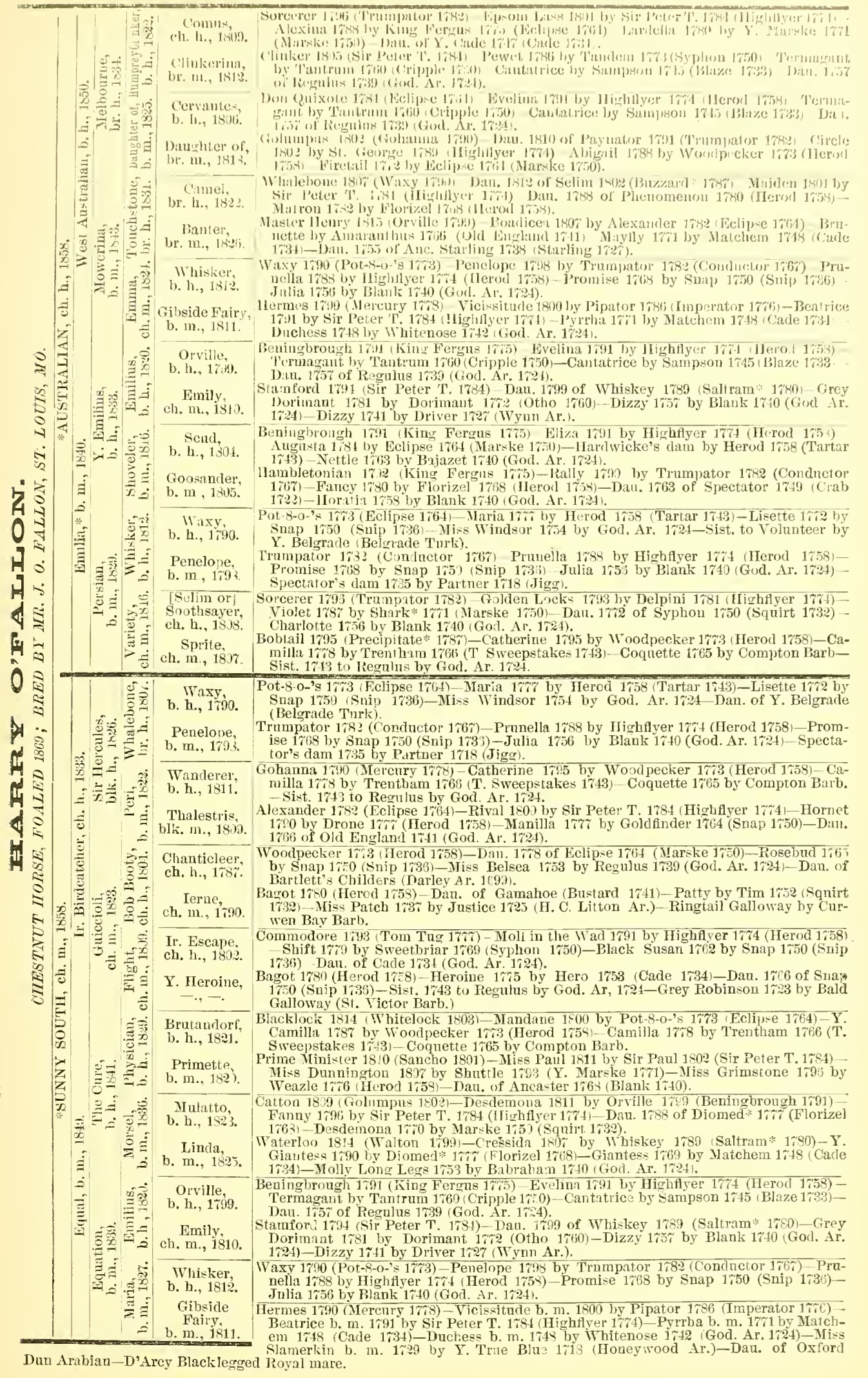




\section{HIMYAR.}

WIXNER OF THE BELLE MEADE STAKES FOR TIVO-YEAR OLDS AT LOUISVILLE, BELLE HEADE STAKLS, No. 1, AT NASHVILLE, PHOENIX HOTEL STAKES AT LEXINGTON, TIE MERCHANTS' ANJ TURF STAKES AT LOUISVILLE, KY., AND JANUARY STAKES AT ST. LOULS.

In the Dixiana Stud, ILaj. B. G. Thomas, proprietor, near Lexington, Try. By private contract. Sales anmually in May.

Hrusar by Alarm. son of imp. Eclipse, bred and owned by Maj. B. G. Thomas, Dixiana stud, Lexington, Ky, foaled 1875 , dam Hira by Lexington, out of Hegira hy imp. Ambassador. Himyar made his debut as a two-year old at Lexington, Ky., in the Colt and Filly Stakes, 5 furlongs, running third to Pomeroy, in $1.04 \frac{1}{4}$. Wou the Colt Stakes, three-quarters of a mile, in 1.163, beating Blne Eyes, Lereler, etc. Fall, won the Colt and Filly Stakes, 1 mile, in $114 \frac{1}{2}$, beating Leveler, Blne Eyes ancl five others. Louisville, won the Belle Meade stakest. hree-quarters of a mile, in 1.16 beating Leveler and fon others. Was third in the Sanford stakes to Blne Eyes and Dar star, 1 mile, in 1.45. Himyar, three years old, started in fire races, won three

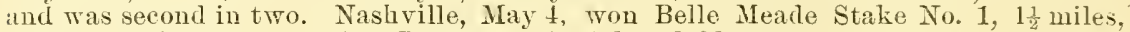
in 2.43, track heavs, beating Bergamot, Artful and Glenmore. Lexington, KF.. Mar 16, won Phøenix Hote] stakes, $1 \frac{3}{1}$ miles, in 3.22 $\frac{1}{2}$, track deep in 1 nnd, benting McHenry, J.R. Swimney and solicitor. Lonisville, $K r$., May 21, ran second to Day star in Ken-

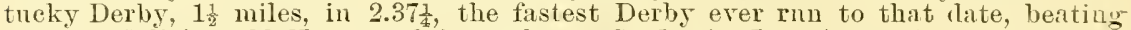
Leveler, solicitor, MeHenry and fonr others. St Lonis, June 4, won January Stakes. mile heats, in $1.42 \frac{1}{2}, 1.43 \frac{1}{2}$, beating Leveler, Kate Claxton and McHenrs. Lexington, Seltemher 13, was second in Elkhorn Stakes, 2 miles, iu 4.041, won by Cammie F., track very muddy. Four years old, started four times, won all of his races. Lexington, won a dash of 1 mile in $1.51 \frac{3}{4}$, track muddy, defeating a field of four; willked over cor Club Purse, 2 miles. Louisville, won a sweepstake for all ages, $1 \frac{1}{8}$ miles, heating Goodnight, Long Tam and fonr others, in 1.56; wo" Club Purse, 2 miles, in 3.35, beating Long Taw and two others. At five vears old started twelve times. Lexington, Ky., was third to Mendelssohn and Verdict in Sweepstake for all ages, $1 \frac{1}{4}$ miles, in 2.08. Won C'lub Purse, mile heats, in 1.421, 1.141, beating Warfield, Vietim. and fonl others. Lonisville, was unplaced in Louisville Cup, $2 \frac{1}{4}$ miles, in $4.20 \frac{2}{2}$, won by Volturno, track very muddy; won the Merchants' Stake, $1 \frac{1}{8}$ miles, in $1.55 \frac{1}{4}$, beating Blue Eyes, One Dime and four others. St. Lou is, was second to L'Argentine,

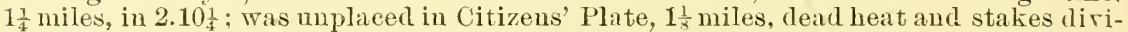
led between Long 'Taw and Blne Lodge, in 1.55 Lexington Fall Meeting, was third to Renown and Montreal, 1 mile, in 1.498, track heavy; was second to Renown in Club Purse, $1 \frac{1}{3}$ miles, no time, five others behind him. Louisville. won Tnrf Stakes, $1 \frac{1}{8}$ miles, in $1.57 \frac{1}{4}$, beating Renown and three others; was second to Bowling Green

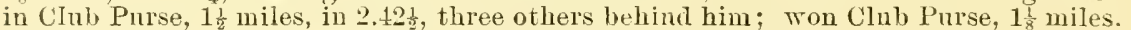
in $154 \frac{3}{4}$, defeating Montreal and Mattie Walker. Nashville, was beaten by Jim

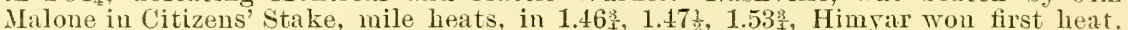
Six years old, Lexington, Ky., was mplaced in Club Pnrse, 1 mile, won by Patti in 1.44. The family is a distingnisher racing one. Hira, his dam, was a fine racemare, Hegira, his grandam, had no equal for speed in her day. She ran 2 miles at New Orleans, in 1850 , in $3.34 \frac{1}{4}$, the fastest time made to that day. Mecea, her finll sister, was also a fine race-mare. Flight, his great grandam, was a superior race-mare and dam of Oliver, a very distingnished race-horse, by Wagnel. winner of three-mile heats in 5.331, 5.39. shylock, Cicero, Pedlar, ote., all distiuguished in their day, descended from the family. Himyar is a light bay with a long star and both hind feet white. He has a neat, bony head, broad between the ejes, good neck, splendid, well-set, oblique shonlders, with ibundance of muscle over the shoulder blade, great depth of girth, good bods, but rather short back ribs. which makes his tlank look light. with broad, strong hips, immense stifle and second thigh, and the muscle ruming tapering to excellent hocks, witl sound feet and legs. Taking him altogether, he is a very tine, well-shaped horse, with most wonderful muscular power behind.

Himyar, as his high racing lineage warranted, is a success in the stud. He is the sire of the speedy Correction, Georgia, Faradir, a prominent stake winner. Other winners (some of them extra gool ones) by Hinyar are Estelle, Lou Dudley, Qnesal (a superior mare), Johnnie Winkle, Greenwieh (an excellent stalie winner), Ḣamilton, Jewel H., Helen, Fannie S, Miss Milliams, Ella T., Lady Mary, Henry Trler, Wih Jim, Mackintosh, Reve d'Or, Mary D., Rosil H., Rorka, Bush Bolt, Himlex, Ben’s Pet, Dago, The Hero, Sir Elwar!, Lord Tom Himyr, The Irommaster, ete.

From the Burton Barb mare descend in direct female line the gool luorses Whiskey, Selim, Castrel, Rubens, Catton, Blacklo:k. Sir Lerenles, Margrave (im. ported), Harkaway. I'oltigenr, snrplice, Cowl, Tedlington, St. Albans, Lord CTitilen, Brag, sheen, Gold, imp. Billet, Major Domo, Defaulter, ete., ete. 


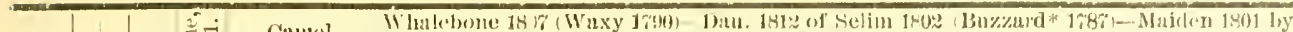

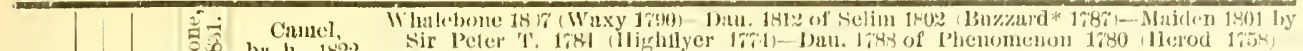

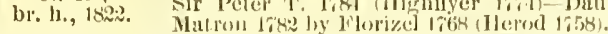

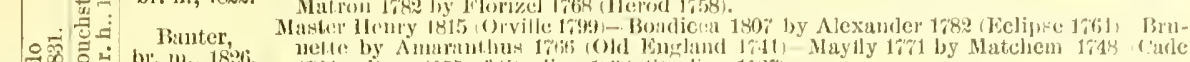

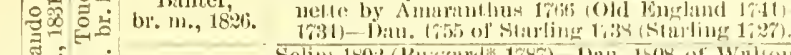

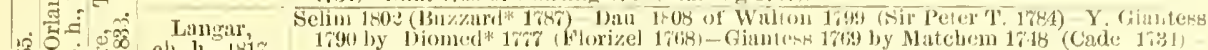

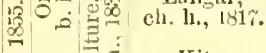
lolly bour lo

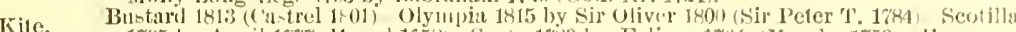

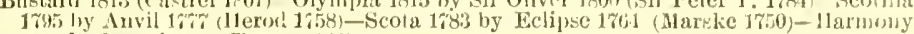

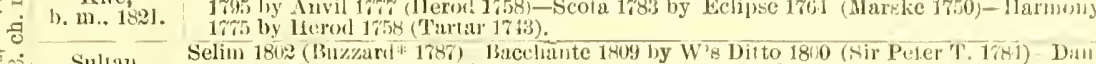

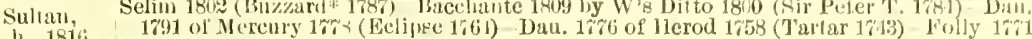

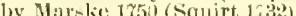

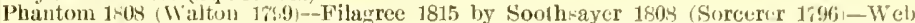

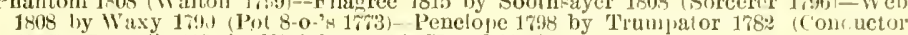
176\%) Plunella 1785 by 11 ierhilyer 1774 (Herod 1758).

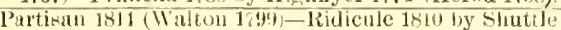

\section{Godolphin, \\ b. h., 1818 .}

of of Mlatehem 1 ris (Cade 1734 ).

है Si-ter to

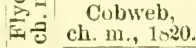

Phaulom 1818 (Walton 1769)-Filarree 1815 by Sonthsayer 1808 (Sorcerer 1996)- Wfel) 1803 by Waxy trio (Pot-8-o-' i 1,is). Penelope 1795 by 'Trumpator 178\% (Conductor 1766)-Prunella 1788 by Hightlyer 17\%4 (Herod 1758

E; Ir.Birdcatcher Sir IIercules 1826 (Whalebone 1807)-Griccioli 1823 by Bob Booty 1801 (Chanticleen

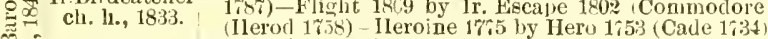

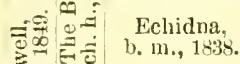

Economist 1825 (Whisker 1812)-Miss Pratt 1-25 ly Blacklock 1814 (Whitelock 1803)

is

Gadabont 1812 by Orville 1799 (Beningbrough 1791)-Minstrel 1803 by Sir Peter T. 1784 (Hightyer 17\%4)-Matron 1742 by Flolizel 176s (Herod 1758).

Glencoe, *

Sultan 1816 (Selin 182)-Trampoline 18\%, by 'Tramp 1810 (Diek Andrews 1797)-Web

ch.h., 1831 1808 by Waxy 1790 (Pot-3.o-'s 17i3)-Penelope 17:8 by Trumpator 1782 (Conductor

176\%)-Prunella $1 \% 88$ by llighflyer $1 \% 4$ (Herod 1\%58).

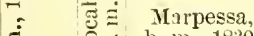

$\therefore$ b. m., 18;0. Fractious 1792 by Nercu:y $17 \% 8$ (Eclipse $1 \% 64$ ).

$\therefore$ L Liverpool

Tramp) 1810 (Dick Andrews 179 )-Dau, 18*2) of 11 hisker 181\% (Waxy 1790)- Mandane 1800 by Pot-8-0-'s 1\%i3 (Eelipse 1;61) - Y. Camilla 1rot by Woodpecker 17\%3 (llerod 1758)-Camilla $17 \% 8$ by Trentham 1766 (T. Sweep-takes 1743).

Bustard 1201 (Buzz:ris 1\%8\%) Dau 1813 of Election 1804 (Gohanna 1\%0)-Dau 1091 of llighflyer $17 \% 4$ (Herod 1758)-Dau. 17r8 of Eclipse 1764 (Marske 1750)-Rosebud 1765 by Snap 1750 (Suip 1736)

焉

$\overline{0} \mathrm{~g}$

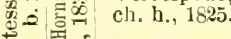

Blacklock 1814 (Whitelock 18.3) Dau. 181 of Junjper 1805 (Whiskey 1789)-Dau. 1810

$\stackrel{\Xi}{\Xi} \stackrel{\mathfrak{\Xi}}{\Xi}$ Daughter of, b. $\mathrm{m}, \mathrm{g}, 1820$.

or sorcerer 1790 (Trumpator 1782 - Vircrin

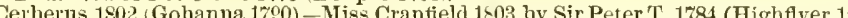

Sir Archy,

Dau. 1790 of Pegasus 1781 (Eelipse 1'64)-Dan. 1783 ol Paymaster 1766 (Plank 1740)Pomona 17r5 hy Herod 1758 (Tartar 1748).

Diomed 17\% (Florizel 1768)-CCastianira 1796 by Rockingham 1781 (Highflyer 1774)

Tabitha 1782 by Trentham 1766 (T. Sweepstakes 1743)-Dau. of Bos Dhorus 1751 Tabitha 1782 by Trentham 1766 ( $\mathrm{T}$. Sweepstakes 17.
(Batraham 1740)-Dau. of Forester 1750 (Forester 1736).

更 Daughter of,

Saltram 1780 (Eclipse 1;64)-Dau, of Symmes' Wildair 176\% (*Fearnought 1755)-Dau. of Tyler's Driver 1760 (*othello)-Dau. of *Fallower 1\%61 (Blank 1\%16)-Dau. of *Vampile 17 i (Regulus 1739).

$\dot{0}$\begin{tabular}{c|c} 
Ball's \\
Florizel
\end{tabular}

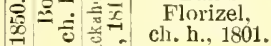

Diomed 1\%7\% (Florizel 1768)-Dau. of *Shark 17 1 (Marske 1750)-Dau. of Harris Eclipse 17\% (Fearuought 1755)-Dau. of *Fearnought 1755 (Regulus 1739)-Dau. of *Jolly Roger $17 \pm 1$ (Rouildhead 1 133 ).

ఏ. Daughter of,

Alderman 1787 (Pot-‘'-o-'s 1773)-Dau, of *Clockfast 1774 (Gimerack 1760)-Dau, of Symues' Wildair $1 ; 67$ (*Fearnought 1755)-Y. Kitty Fisher $176 \%$ by *Fearnought 1755 (Regulus 1734) - Kitty Fivher 1755 by Cade 1734 (Giod. Ar. 17\%!).

3.

Orville 1299 (Beninu, lolluh 1691)-Emily 1810 by Stamiord 1\% (Sir Peter T. 1784)Dau. 1799 of Whiskey 1789 (Saltram* 1789)-Grey Dorimant $1 \% 81$ by Dorimant $17 \%$ (Otho 1\%60)-Dizzy 1\%5\% by Blank $1 \% 40$ (God Ar. 1\%24).

20

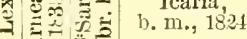

The Flyer 1814 (Vandyke Jr. 1808)-Parma 1813 by Dick Andrews 1797 (Joe Andrew: 17\%(S) - May 1804 by Beningibrolgn 1791 (King Ferous 17n)-Primrose 178\% by Mambrino 1763 (Engineer $1 \% 5$ ) -Cricliet 1766 by Herod 1758 (Tartar 1\%43)

$\dot{\Xi} \therefore$ Sumpter,

Sir Archy 1805 ( $*$ Dioned 1\%r)-Diau of Robin Redbreast 1796 (Sir Peter T. 1784)Dau. 188 of Obscurity $1 \%$ (Eclipse $1 \% 64$ ) Slamerkin 1768 by *Wildair $1 \% 53$ (Cade 1734) - Cub mare 1;62 by Cub 1739 (Fox 1714).

h. h., 1818.

Robin Grey 1805 ( Royalist 1is0)-Marja 1802 by Melzar 1\%91 (*Medley 1\%6)- Dau. of

$\Xi$ Lady.Grey *Highflyer 1\%4 (Hightiyer 17\%4)-Dau of *Fearnought 1755 (Regulus 1\%39)-Dau. of Ariel 175 (:Traveller $174 \%$ ).

Emilius Ori1]le 17:9 (Beningbrougb 1;91)-Emily 1810 by Stamford 1794 (Sir Peter T. 1784)Dau. 1799 of Whiskey 1739 (Saltram* 1780)-Grey Dorimant 1781 by Dorimant 17\% (Otho 1760)-Dizzy $17 \%$ by Blank 1,40 (God. Ar. 17:4).

b. h., 1820

Perieles 189 (Evander 1801) - Dau. 181: of Selim 180\% (Buzzard*1r8\%)-Pipylina 181)3 by

Harriet,

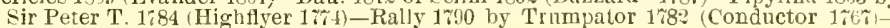
Fancy 1780 by Florizel 1768 (Herod 175

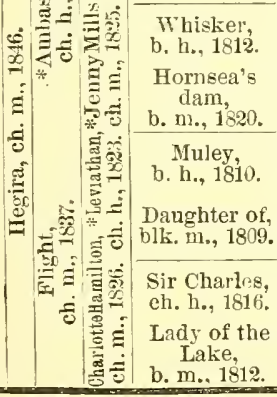

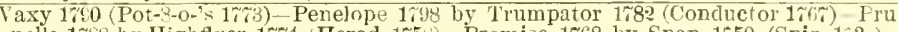
nella 1788 by Hightlyer $17 \% 4$ (Herod 1758)- Promise 1768 by Snap 1750 (Snip 173.) Julia 1756 by Blank $1 \% 40$ (God. Al: 1\%24).

Cerberus 1802 Gohanna 1790)-Niss Cranfield 1803 by Sir Peter T. 1784 (Highfrer 17\%1)-Dal1. 1\%93 of Pegasus 1784 (Eclipse 1\%64)-Dau. 1783 of Paymaster 1766 (Blank

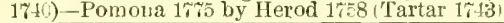

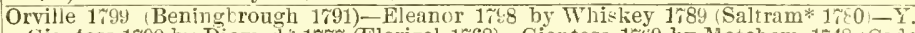
Giantess $1 \% 90$ by Diomed $1 \%$ F (Florizel 1\%68)-Giantess 1769 by Matchem 1748 (Cade 1734) - Mloljy Long Legs 1753 by Babrabam 1740 (God. Al. 1724).

Windle $180+$ (Beningbrough 1791)-Dat. 1788 of Anı il 1\% (Herod 1758)-Virago 1\%64 by Snap 1750 (Snip 173)-Dau. of Regulus $1 \% 39$ (God. Ar. 1\%24)-Sist. 1750 to Otbello by Crab 1722 (Aleock Ar.).

Sir Archy 1805 (*Diomed 17\%7)-Dau. of *Citizen 1785 (Pacolet 1763)-Dau. of Comni tation (Symmes' Wildair 176\%)-Dau. of *Dare Devil 1\%87 (Magnet 1\%70) - Sally Shark by *Shark 1\%71 (Marske 1750).

* Sir Harry 1795 (Sir Peter T. 1784) - Shy"lock's dam by *Diomed 17m (Florizel 1768)Dau. of *St. George 1771 (Dragon 1\%5)-Dau. of *Fearnought 1\%55 (Regulns 1\%39)Dals. of *Jolly Roger 1741 (Roundhead 1733) - *Mary Grey gr. m. 1742 by Roundhead 1733 (F). Childers 1715)-Ringbone 1\%32 by Partner 1718 (Jigg)-Lusty Thornton ch. m. by Croft's Bay Barb (Chillaby) - Chestuut Thornton ch. m. by llakeless (Oglethorpe Ar.) - Old Thornton by Brimmer (D'Arcy Yellow Turk)-Dau. of Dicky Pierson (Dodsworth)-Burton Barb mare. 


\section{HINDOO.}

WINNER OF SEVEN OUT OF NINE STAKES AT TWO YEARS OLD, TWMAER OF THE KENTUCKY DERBY AND CLARK STAKES AT LOUISVTLLE, BLUE RIBBON STAKES AT LEXINGTON, TIDAL STAKES AND CONEY ISLAND DERBY AT SHEEPSHEAD BAY, OCEAN STAKES, JERAEY DERBY AND LORILLARD STAKES AT LONG BRANCH, THE TRAVERE AND KENNER STAKES AT SARATOGA, ALL IN 1881; LOUISTILLE CUP AND TURF STAKES AND CONEY ISLAND CUP, 1882.

\section{Property of the Runnymede Stud, near Paris, Ky. Application to ILessrs. Clay \& Woodford, Paris, Ky. Anmal sales of yearlings in May.}

Hrxpon by Tirgil, son of Vandal, bred by D. Swigert, Elmendorf Stud, Ky., foaled 1878, dim Florence by Lexington, son of Boston, ont of imp. Weatherwitch, dan of Little Mack and Mollie Cad by Weatherbit, son of Sheet Anchor. Hiudoo was the sensation two-year old of his year, started in nine races, won seven, was second in one, third in one. Hindoo, at Lexington, Ky., won the Colt and Filly Stakes for two-year olds, three-quarters of a mile, in 1.17론, beating Alfambra, Brambaletta and seven others. Louisville, KJ., won Alexander Stakes, half a mile, in 50 seconds, beatin Banter, Maretzek and eight others; won the Tennessee Stakes for two-rear olls, three-rquarters of a mile, in 1.16, beating Brambaletta, Ripple, Bontjack and five others. St. Lonis, won the Juvenile Stakes for two-vear olds, three-rnarters of a mile, in $117 \frac{1}{4}$, beating Voltague and six others; won the Jockey Club stakes for twoyear olds, 1 mile, in 1.41, beating Lelex, Voltague and Enniskillen, a fast and gond race. Chicago, won the Criterion stakes for two-rear olds, three-quarters of a mile, in 1.15, beating Ripple, Greenland and three others. This was the fastest three-quarters ever rm by a two-year old to that date. Won the Tremont Hotel Stakes for twoyear olds, I mile, in 1.48, beating Lizzie S., Ripple and Moses. In all these races. except the Tennessee Stakes, he carried $100 \mathrm{lbs}$, in the T'ennessee. $105 \mathrm{lbs}$. Saratoga, ran third to Crickmore and Bonnie Lizzie in the Windsor Hotel Stakes for two-year olels is furlongs, in 1.05, track heavy, beating Thora and four others: ran second to Thora in the Day Boat Line Stakes, three-ruarters of a mile. in $1.17 \frac{1}{4}$, beating Bonnie Lizzie and three others. In these races he carried 110 lbs. He had just changeal hands and did not rum up to his previons form.

Three years old, won eighteen out of twenty races. Lexington, Ky., won Blue Ribbon Stakes, $1 \frac{1}{2}$ miles, in 238 , beating Gretaway, Bend'or, Creosote and four others. Louisville, Ky., won Kentucky Derby, $1 \frac{1}{2}$ miles, in 2.40, beating Lelex, Alfambra and

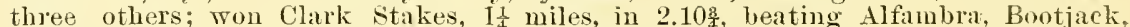
Bend'or and Sligo. Jerome Park, won a rlash of 1 mile and a furlong, in 2.021, beating sir Hngh, Jack of Hoarts and Rob Roy; won a dash of 1 mile and 3 firlongs, in 2.31 , track heavy. Sheepshead Bay, won Tiral Stakes, 1 mile, in 1.43 , beating Crickmore and Samterer; won the Coney Island Derby, 15 miles, in $2.47 \frac{1}{2}$, beating Baltie. Monmouth Park, won Ocean Stakes for all ages, 1 mile and a furlong, in 1.57 , beating Monitor, Glidelia, ete. ; won Lorillari stakes, 1 miles, in 2.39:, beating Criekmore and Saunterer; walked over for a Sweepstakes of $\$ 1,000$ each, with $\$ 2,000$ added. Saratoga, won the Travers stakes, $1 \frac{8}{1}$ miles, in $3.07 \frac{1}{2}$, beating Eole, Getaway and Compensation; won Sernel Stakes, 1miles, in 3.21, track heary. In this race Hincloo earried $123 \mathrm{lbs}$, including a penalty of fire ponnds, and beat Greenland and Talentino: won United States Hotel Stakes, $1 \frac{1}{2}$ miles, in 236 , beating Crickmore, Bonfire and Gladiola; won Kenner Stakes, 2 miles, in 3.32, a fast race. Nonmonth Park. won Champion Stakes for all ages, 11 miles, in 2.39, beating Monitor and Parole ; won Jerser St. Leger.

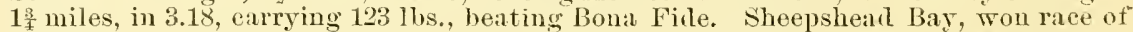

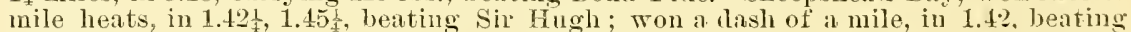
Sir Fngh and Edendary; was second in the Brighton Beach Purse, $1 \frac{1}{2}$ miles, won by Criekmore. in $2.36 \frac{1}{4}$; was third in the September Handicap, 18 miles, won by Crickmore, in 3.03 , Hindoo carrying 123 los.

As a four-year old won tive races out of six. Louisville, Ky., won Louisville Cup, 21 miles, in 3.57 , beating Checkmate, Glidelia, Lida Stanhope and Blazes. Won Merchants' Stakes for all ages, 1 mile and a fullong, in 1.59 , beating Checkmate. Rnnnymede and Creosote; won Turf Stakes, $1 \frac{1}{4}$ miles, in $2.08 \frac{1}{2}$, earring $12.21 \mathrm{bs.}$ beating Checkmate (aged), 123 lbs.. and Creosote (t), 114 lbs. Sheepshead, Wom Coney Island Stakes for three-year olds and upivards, 1 mile and a furlong. in $1.57 \frac{8}{7}$. Barrett the only starter; won Coney lsland Cnp. 2l miles, in 3.58, beating Eole and Parole. This was the best race run at the distance during the rear, and compares favorably with similar races. There is no question but that Himloo was the best 


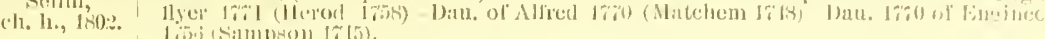

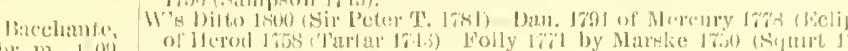

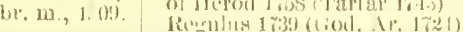

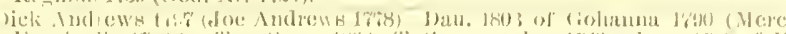

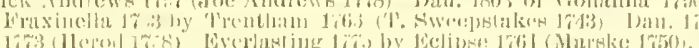

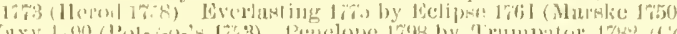

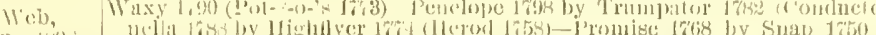

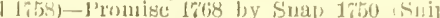

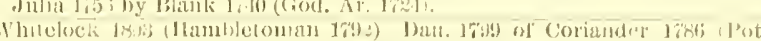

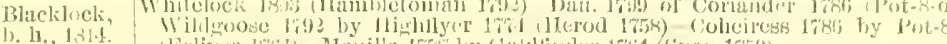

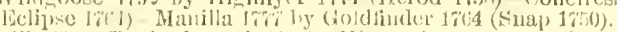

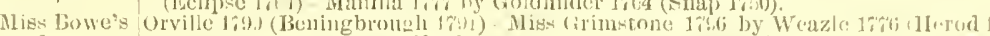

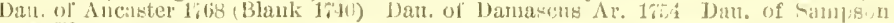
$1 \% 1,(B 1: 1 \% 017: 3)$.

:1. $13 ., 1$, 1 !

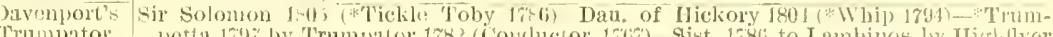

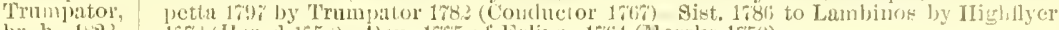

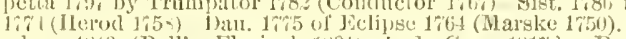

Incy,

b. $111,1,121$.

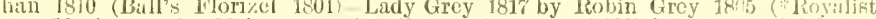

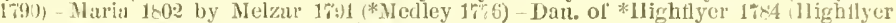
17i4)-Di11. of Fearnonifit 175.5 (Regulus 1786).

Emilius, Orville 1799 (Beningbrough 1791)-Emily 1810 by Stanford 1794 (sir Peter T. 178

b. h., 1820. Dau. 1\%19 of Whiskey 1769 ( Saltram 1780) Grey Dorimant 1781 by Dorimant $17 \%$ Otho 1ito) Dizzy $1 \%$ is by Blank 1740 (God. Ar. 1724).

Sea Mew, Seud 1844 (Beningbrough $1 \% 1$ )-Goorander 1805 by Hambletonian 1792 (King Fergus $1 \% 75$ - Rally 1790 by '1 lumpator 178: (Conductor 176i)-Fancy 1780 by Florizel 1,68 (IIerou 1758) Dau Ires of spectator 174:) (Crab 172:2).

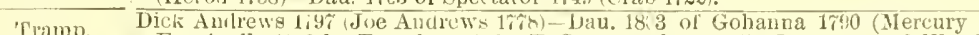

b.h., 1810. Fraxinella 17.3 by Trentham 1766 (T. Sweepstakes 1743) Dau. 1785 of Wondpccker

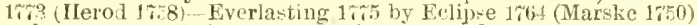

Daughter of, Sancho 18$) 1$ (1)on Quixote 1781/-Blacklock's dam 1699 by Coriander 1686 (Pot-8-0-'s

ch. m., 1810, 17\%3) Wildgoose 1,92 by IIightlyer 17it (Herod 1758)-Coheiress 1786 by Pot-8-0-'s $1 \% 3$ (Eclipse 176 ) - Manilla $17 \% 7$ by Goldfinder 1764 (Snap 1650 \%

Madoc Am. Eclipse 1814 (Duroc 18j6)-Y. Maid of-tle-Oaks 1816 by *Exjedition 17 i5 (Pecnsus

ch. h. 1529. 178\%)-Mlaid-of-the-Oaks 1801 by :Sprorl Eagle 1792 (Volunteer 1780)-Annette by

"Shark 17\%l (Marske 1750)-Dau. of Rockingham (1'artner 1755).

Grecian Cook's Whip 1804 (Whip 1794)-Jane Hunt 1796 by Hampton's Paragon 1788 (:Flim-

Priscess,

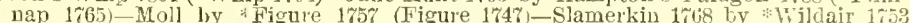
(Cade 1734) - *ab mare 1669 by Cub 1739 (Fox 1711).

b. m., 1816. Whip 1794 (Saltram* 1700)-Speckleback 1790 by Randolph's Celer (Meade's Celer

b. h., 1804. 17\%4)-old Speckleback by Meade's Celer 1\%74 (*Janus 1\%46)-Dau. of *soher John 1748 ( Rib 1\%6)-Thoronghbred mare of Mr. Wade.

1TaryBedford, Duke of Bedford (*Bedford 1\%\%)-Dau. 1813 of *Spcculator 175 (Dragon*178\%-Dau. 1866 of Dare Deril 1787 (Nagnet 17r0) *Trumpetta 1797 by Trumpator 1782 (Conb. m., 1816. ductor 176\%) Sist. 1786 to Lambinos hy 1 ligliflyer $17 \% 4$ (Herod 175*).

Sir Archy, Diomed 1.77 (Florizel 17.8)- Castianira 1796 by Rockingham 1781 (Highflyer 17\%4) -

b.h., 18u5, Tabitha 1782 by Trentham 1.66 (T. Sweepstakes 1743)-Dau. of Bosphorus 1754

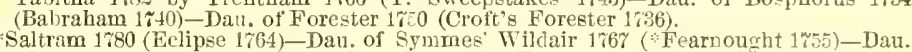

Daughter of, "Sat Tyler's Driver" 1760 (*othello)-Dan. of *Fallower 1761 (Blank 174()-Dau. of of Tyler's Driver 1760 (*Oth
*Vampire $175 \%$ (Regulus 1739 ).

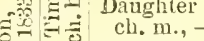

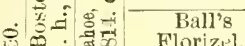

Elorizel,
ch. h., 1801.

*Diomed $17 \% 7$ (Florizel 1768)-Dau of shark $17 \%$ (Marke 1750)-Dau of Harris Eclipse $1 \%$ (* Fearnought 1755)-Dau. of *Fearnought 1755 (Regnlus 1739)-Dan. ol *Jolly Roger 1711 (Rouildiead 1\%33).

Daughter of, *Alderman 1787 (Pot-8-0-'s 1783)-Dau. of t Clockfast 17\%4 (Gimcrack 1760)-Dau. of b. 1700

Symmes" Wildair $176 \%$ ( Fearnought 1755)-Y. Kitty Fi-her $1 \% 67$ by *Feanouglit 1655 (Regulus 1739) - Kitty Fisher 1755 by Cade 1734 (God. Ar. 17\%1).

Emilius, Orville 1799 (Beningbrongh 1791)-Emily 1810 by Stamford 1794 (Sir Peter T. 17 1 ) -

b. h., 1820 . Dau. 1799 of Whiskey 1789 (Saltran* 1780 )-Grey Dori
(Otho 1769)-Dizzy 175 by Blank 1710 (God Ar. 1724).

The Flyer 1814 (Vandyke Jr. 1808)-Parma 1813 by Dick Andrews 1797 (Joe Andrems

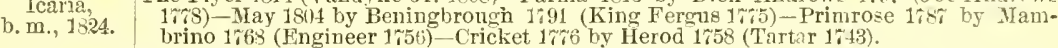

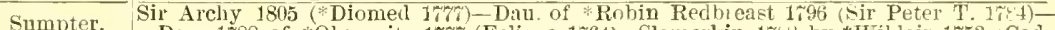
Dau. 1788 of *obscurity $1 \% 7$ (Eclipse 1764)-Slamerkin 1768 by * Tildair 1753 (Cade

1734) $*$ Cub mare 1762 by Cub 1739 (Fox 1714).
Robin Grey 1805 ("Royalist 1790)-Maria 1802 by Melzar 1\%91 (*Medley 1\%6)--Dan. of

Lady Grey, *Highfyer 1784 (Highflyer 1ir4)-Dau of Fearnought 1755 (Regulus 1739)-Dau. of Ariel 1753 (Traveller $\left.1747^{\prime}\right)$.

Lottery, Tramp 1810 (Dick Andrews 1\%97)-Mandane 1800 by Pot-8-9's 17r8 (Eclipse 1764)

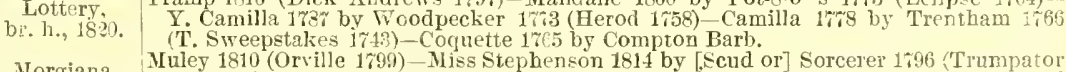

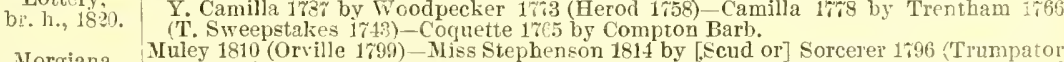
178\%)-Sist. 1796 to Petworth by Precipitate* 178 (1] ercury 17\%8)-Dau. 178, of Woodpecker $17 \% 3$ (Her d 1758)-Dau. 17\%3 of Snap 1750 (Snip 1736)

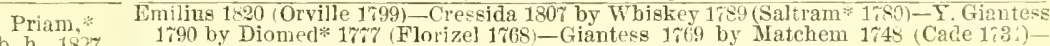
Molly Long Legs 1753 by Babraham 1710 (God. Ar 1724).

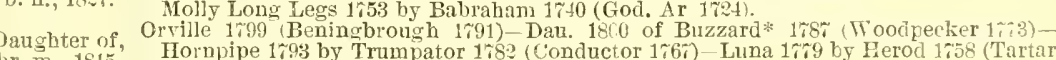

br. m., 1S15. Hornpipe 1793 by Trumpator 1782 (Conductor 176i)

Whalebone 1807 (Waxy 1\%90) - Peri 1822 by Wancerer 1811 (Gohanna 1790)-Thalestris

Sir Hercules, 1809 by Alexander 1789 (Ecliose 1i64-Pival 1800 by Sir Peter T. 1TS4 (Highflyer blk. h., 1826. 1774)-Hornet 1790 by Drone 1767 (Herod 1758)

Bob Booby 1804 (Chanticleer 178\%)-Flight 1809 by Ir. Escape 1802 (Commodore

Guiccioli, 1793$)-Y$. Heroine by Bagot 1780 (Herod 1758)-Heroine 17\%5 by Hero 1753 (Cade

S.

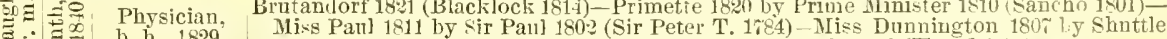

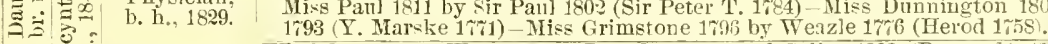

Camelina, Whalebone 180\% (Waxy 1790-Dau. b. m. 1812 of Selim 1802 (Buzzard: 17s, - Maiden b. m. 1801 by Sir Peter T. Ire4 (Highflyer 1, 14)-Dan. ch. m. 1782 of Phenomenon $1 \% 80$ (Herod 1;8)-Matron b. m. 1782 by Flnrizel 1768 (Herod 175s)-Maiden ch. m. 1770 hy Matcbem 1743 (Cade 1724)-Pratt's Old Squirt mare ch. m. 1650 by Squirt 1732

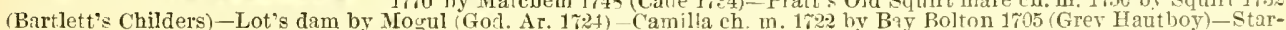
ling's dam by Son of Brownlow Turk-Old Lady by Pulleine's Chestnut Ar.-Dati. of Rockwood-Dau. of Helmsley Tirk. 


\section{HINDOO-Continued.}

race-horse which has appeared in this eountry for more than a decade. It is donbtful if any horse in England conld have beaten him in the great elassie events. Hincloo is a grandly bred loorse, his blood combining all the best strains in Enerlant and Ameriea. His sire is by the best son of Glencoe, and he has a large infusion of Diomed blood through both sides, together with a donble eross of imp. Buzzari, fortitied by the stont crosses Whalebone, Herod and Eelipse on the dam's side. Hindoo is a dark bay, 15 hands $3 \frac{1}{2}$ inches high, with large star in his forehead, right hind foot white to pastern.

Hindoo is a grand suceess in the stud, sire of the great Hanover, Jim Gore, Merry Monareh, one of the best two-year olds of 1891, Hindoocraft, Bnddhist, Honston, Heathen, Chief Jnstiee, Newbirg, Montpelier, Prospeet, Dungarven, War Plot, Woodford, Black Knight, Bowen, Hyaeinth, Headlight, Cortland, Col. Zel, Ward, Hawkstone, Heatherton, Brahmin, Bright Light, Hempstead, O. P. B., Hannibal, Indns, Speth, Kehama, Tar and Tartar, Montpelier, Haleyon and Sir Curtis. Among his danghters are Sallie MeClelland, Catalpa, Mabel Glemn, Hindoo Rose, Hindoo Lass, Hindloogam, Hispania, Iadolin, Nina Areher, Sallie Taylor, IInda, Sunbeam, Lady Hindoo, Lizzie B., Lillian Lindsay, Servia, Franehise, Lizzie C., Miss Thomas, Madnmma, Daplight, Centella, Hannah Moherly, Lizette, Matilda, Natalie, ete.

It is to the Helmsley Turk mare to which trace in direct female line Old Starling, Pumpkin, Gohanna, Camel, The Baron, sire of Stockwell and Rataplan, ete.

\section{INSPECTOR B. (ENVOLEUR).}

\section{WINNER OF THE BELMONT, TIDAL, LORILLARD, TRAVERS, IROQUOIS AND OTHER GREAT STAKES.}

\section{In the Belle Meade Stud, Gen. IV. H. Jackson, proprietor, Nashville, Tenn. Terms published annually.}

Ixspector B., bay horse, foaled 1883. bred in Belle Meade Stud, owned by Gen. W. H. Jackson, by Enquirer, son of imp. Leamington, dam Colossa by Colossus, son of imp. Sovereign, out of Rurica by Rurie, son of imp. Sovereign.

Inspector B. is a very musenlar animal, of the most symmetrical formation, haring great length, good size, grand substanee, and stands on good short legs. His racing lines are as nearly perfeet as possible, and at the stnd he shonld equal his first class performanees on the turf. He eommenced his eareer as a two-rear old at Jerome Park, where he won a mile raee by two lengths, in $0.50 \frac{1}{2}$, beating Dry Monopole. ete. Ran third to Dew Drop and Dry Monopole, in a $\frac{5}{8}$ mile race at sheepshead Bay, beating six others; won a mile race, eoneeding weight to all his opponents, which included The Bard and fire others. At Coney Island, he ran second to Dew Drop, in the Great Eastern Handieap, beating a field of nineteen; ran second to The Bard in the Bonquet Stakes. $\frac{7}{8}$ mile, giving him 4 lbs., behind him were Ban Fox, Blue Wing, Pure Rre and eight others, nearly all in receipt of reight. At Coner Island, won a mile Sweepstakes by a length, in 1.17, beatiug Biggonet, Winfred, Bessie B, and others. At Jerome Park be ran second to Dew Drop in the Champagne Stakes, and wound up his two-year old season by winning a $\frac{3}{4}$ mile sweepstakes at the same place, carrying top weight.

At three he won a sweepstakes, $1 \frac{1}{4}$ miles, with top weight, in 2.11 ; won the Belmont Stakes, $1_{\frac{1}{2}}$ miles, in 2.41, beating The Bard, Linden, Saxony, ete.; won the Tidal Stakes, 1 mile, in 1.46\% beating Biggonet, Quito, Portland, ete ; ran second to

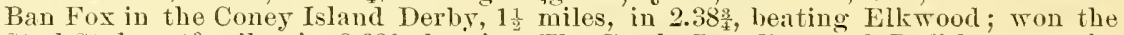
Stnd Stakes, $1 \frac{3}{8}$ miles, in 2.23․ beating The Bard, Ban Fox and Bnffalo: won the

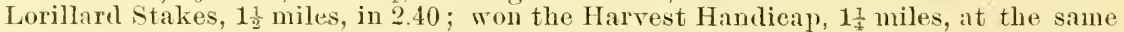
place, earrying top weight; won the Travers Stakes, 13 miles, in 3.10

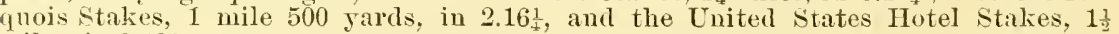
miles, in $2.42 \frac{3}{1}$.

At fire he won at $1 \frac{1}{8}$ miles in 1.55 ; a mile dash on the turf in $1.459 ; 7$ furlongs in 1.29, writh top weight; was seeond to Bradford, 6 furlongs, in 1.14, giving the winner 4 llus.; was second to Swift, $1 \frac{1}{8}$ miles, in $1.5+\frac{1}{3}$, giving the winner 9 lihs.

At six he won the Brookdale Handicap, $1 \frac{1}{8}$ miles, in 1.55, beating Tea Tras, ete.; won a $1 \frac{1}{6}$ miles race; won the Lawnview Handicap, $1 \frac{1}{8}$ miles, in a canter, beating Enxus, ete.; won a $1 \frac{1}{15}$ mile handicap in $1.48 \frac{8}{1}$; walked over for a $1 \frac{1}{8}$ niles race; won a Sweepstakes, $1 \frac{3}{10}$ miles, beating Elkwood, Eurns, ete, in 2.032 , and won the Bay Ridge Handicap, $1 \frac{1}{2}$ miles, with 122 lbs. np, time $2.35 \frac{1}{1}$, beating Tea Tray. Terra Cotta, ete.

Inspector B. deseents in direet female line from the same hosal mare to which Blank, Bal,raham, Gower Stallion, Hornsea, Sontlsayer, Jerry, Ilarrester, Skylark, Foxhall, Mollie Jaelison and all the imp. Selima family trice. 


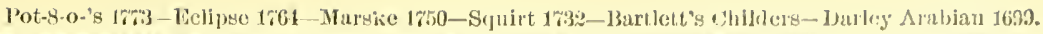

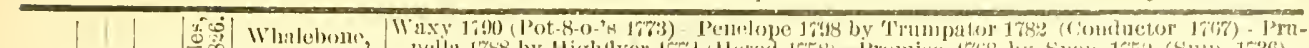

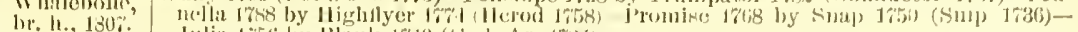

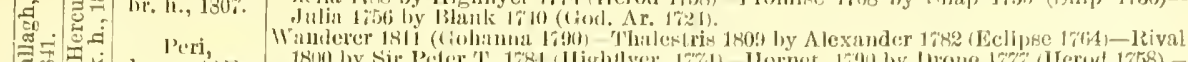

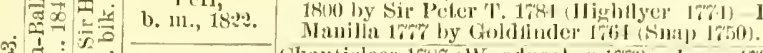

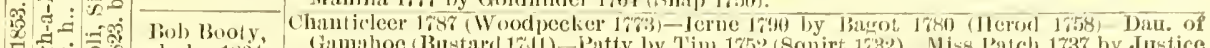

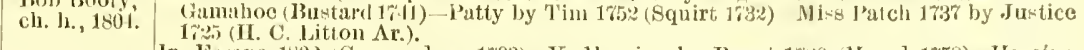
Ir. Hacape 1802 (Commichore 1793) Y. Heroino by Bagot 1780 (Iferod 1758) Heroine

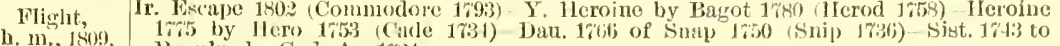
liegulus by God. Ar. $18 \%$ I.

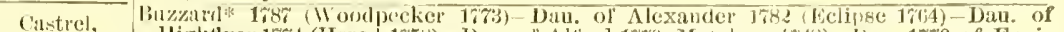

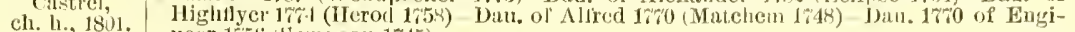
neer 1750 (Simp)son 17.5).

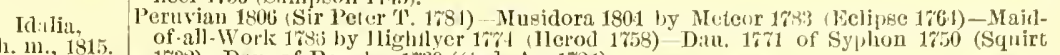
1732)-Dau. of Regulus 1739 (crod. Ar. 1721).

Baurel. Blacklock 1811 (Whitelock 1803 ) Wagtail 1818 by Prine Minister 181t) (\$ancho 1801)

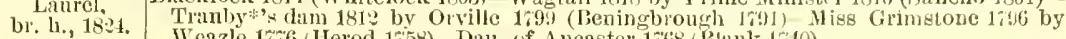

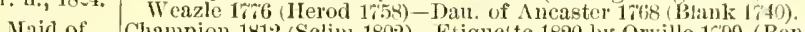

Maid of Champion 1812 (Sclim 1802)-Eiquelte 1820 by Orville 1699 (Beningbrumgh 1791)-Boa-

br. M., 1 29. land 1741) -Mayfly $17 \% 1$ by Matchem 1748 (Cade 1\%31).

Timoleon,

ch. h., 1513 .

(Eclipse 1761)-Dau. of Symmos" * Fallower fr61 (Blank 1740)

Sister to Ball's Florizel 1801 ('Diomed 1777)-Dau. 1699 of *Alderman 178\% (Fot-8-0-'s 1779)-

Tuckahoe, Dan. of *Clockfast 17\%4 (Gimcrack 1760) Dall. of Symmes Willair 1767 (*Fear-

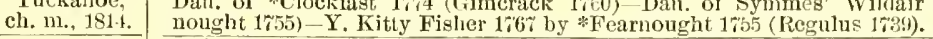

* Sarpedon, Emilin 1820 (Orville 1799)-Iearia 182/ by The Flyer 1814 (Vandyke Jr. 1808)-Parma

br. h., 1828. 1813 by Dick Audrews 1707 (Joe Andrews 17\%8)-May 1804 by Bemingbrough 1791 (King Fergus $17 \% 5$ )-Primrose $1787^{\circ}$ by Nambrimo 1768 (Engineer 1756 ).

Rowena, Sumpter 1818 (Sir Archy 1805)-Lady Grey 1817 by Robin Grey 1805 (*Royalist 1790)-

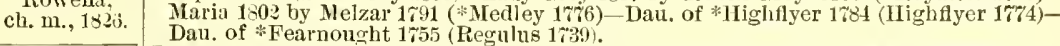

Duroc, *Diomed 17\% (Florizel 1768)_Amanda 1800 by Grey Diomed 1786 (*Medley 1776)-Dan.

ch. h.. 1806. of Va. Cade (Partuer 1755)-Dau. of Hickman's Independence 1\%6 (*Fearnonght viller"s 1755)-Dau, of Badger (Bosphorus 1754).

Mamenger 1780 Mambrino 1768) * Pot-8-o-'s Mare 1792 by Pot-8-o-'s 1773 (Eclipso Damsel, 1764 )-Dau. $17 \% 8$ of Gimerack 1760 (Cripple 1750 ) Snapdragon 1759 by Snap 1750
gr. m., 1803. (Snip 1736)-Dau. 1749 of Regulus 1739 (God. Ar. 1\% 24 ).

Sir Archy, *Diomed 177 (Florizel 1708)-*Castianira 1796 by Rockingham 1781 (Highflyer 1774)b. h., 1805 .

Calypso, Bellair 1786 (*Medley 1776)-Dau. 1798 of Dare Devil 178\% (Magnet 17\%0)-Dan. 1792 of

b. m., 1805. Symmes' Wildair 1767 ("Fearnought 1755)-Picadilla by Y. Fearnought 1777 (*Fearnonght 1755)-Dan. of Fodolphin 1\%70 (Fearnonght 1755)

Orville, Beningbrough 1791 (King Fergus 17i5)-Evelina 1791 by Highflyer 1774 (Herod 1758)-

b. h., 1799 .

'l'ermagant by Tantrum 1760 (Cripple 1750)-Cantatrice by Sampson 1745 (Blaze 1\%33) Dau. 1757 of Regulus 1739 (God. Ar. 1724).

Emily Stamford 1794 (Sir Peter T. 1784)-Dau. 1799 of Whiskey 1789 (Saltram* 1780)-Grey ch. m., 1810. Dorimant 1781 by Dorimant 1\%2 (Otho 1760)-Dizzy 175' by Blank 1740 (God. Ar. 17:4) - Dizzy $17+1$ by Driver 1727 (Wynn Ar.).

Bourbon, Sorcerer 1796 (Trumpator 1782)-Dau. 1797 of Precipitate* 178\% (Mercury 1778)-Y.

Bourbon,
b. h., 1811 . Tiffauy 176\% by Highfyer 17\% (Herod 1758)-Tiffiny $17 \% 5$ by Eclipse 1764 (Marske $1757)$ - Y. Hag 1761 by Skim 1746 (Starling $179 \%$ )

Lady Rachel, Stamford 1794 (Sir Peter T. 1781) Y. Rachel 1799 by Volunteer 1780 (Eclipse 1764)Rachel 1790 by Highflyer $17 \% 4$ (Herod 1758)-Sist. 171 to Tandem by Syphon 1750 (Squirt 1732)-Dan. of Rcgulus 1\%39 (God. Ar. 1724).

Sultan, Selim 1802 (Buzzard* 1787)-Bacchante 1809 by W's Ditto 1800 (Sir Peter T. 1781)-Dan. 1791 of Jercury 17\%8 (Eclipse 1764)-Dau. 1776 of Herod 1758 (Tartar 1743)-Folly 17\%1 by Marske 175 ) (Squirt 1732)

b. $1 ., 1816$

Tramp 1810 (Dick Andrews 179;)-Wel) 1808 by Waxy 1\%90 (Pot-8-o-'s 1763)-Penelope

Trampoline,
ch. m., 1225.
1798 by Trumpator 1782 (Conductor 1767) Promi-e 1768 by Snap 1750 (Snip 1736).

Trampoline,
ch. m., 1205.
1798 by -Promi-e 1768 by Snap 1750 (Snip 1736).

American Duroc 1806 (*Diomed 1\%\%) Miller's Damsel 1802 by * Messenger 1780 (Mambrimo

Eclipse, 1768)- Dau. 1\%92 of Pot-8-0-'s 1\%3 (Eclipse 1764)-Dau. 17\%8 of Gimcrack 1\%60 ch. h., 1814. (Cripple 1750) Snapdragon 1759 by Snap 1750 (Snip 1736).

Y. Maid of *Expedition 1795 (Pegasus 1784)-Maid-of-the-Oaks 1801 by *Spread Eagle 1792 (Tolunteer 1780)-Annette by shark 1\%1 (Narske 1750)-Dau. of Rockingham (Partuer 1755)-Dau. of True Whig (Fitzhugh's Regulus 1765).

Orville 1799 (Beningbrongh 1791)-Emily 1810 by Stamford 1794(Sir Peter T. 1784)-Dan.

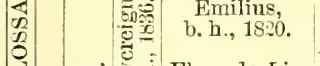

1799 of Wbiskey 1789 (Saltram* 1780)-Grey Dorimant $1 \% 81$ by Dorimant 1\%2 (Otho 1760)-Dizzy 1757 by Blank 1710 (God. Ar. 1724).

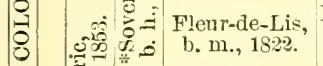

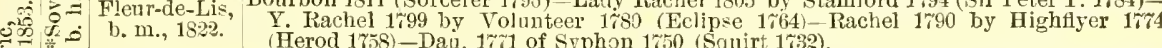

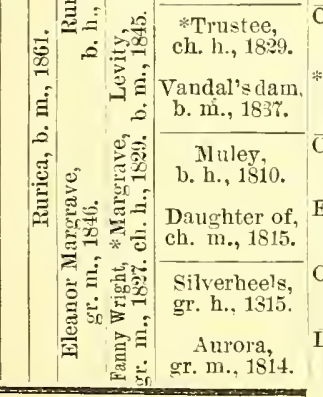

Catton 1809 (Golumpus 1802)-Emma 1824 by Whisker 1812(Waxy 1790)-Gibside Fairy 1811 by Hermes 1700 (Mercury 17r8)-Vicissitude 1800 by Pipator 1786 (Imperator 1776)-Beatrice 1791 by Sir Peter T. 1784 (Uightlyer 174).

*Tranby 18:6 (Blacklock 1814)-Lncilla by Trumpator 1823 (Sir Solomon 1805)-Lucy 1821 by Orphan 1810 (Ball's Florizel 1801)--Lady Grey 1817 by Robin Grey 1805 (*Royalist 1\%90)-Maria 1802 by Melzar 1791 (*Medley 1\%6).

Orville 1799 (Beningbrough 1\%91) - Eleanor 1798 by Whiskey 1789 (Saltram* 1;80) Y. Giantess 1790 by Diomed $17 \%$ (Florizel 1\%68) Giantess 1769 by Matchem 1748 (Cade 1\%31) Molly Long Legs 1753 by Pabraham $1 \% 40$ (God. Ar. 1\%24)

Election 1804 (Gohanna 1\%90) Fair Helen 1808 by Hambletonian 1792 (King Fergns 17\%5) Helen 1801 by Delpini 1781 (Highflyer 1774)-Rosalind 1788 by Phenomenon 1780 (Herod 1758) - Atalanta 1769 by Matchem 1788 (Cade 1\%34).

Ogless Oscar 1800 (*Gabriel 1790)-Pandora by Grey Diomed 1\%86 (*Medley 1766)Floretta's dam by Ilall's Union 1\% ("Slim 1\%68)-Dan. of Leonidas (Lloyd's Traveller) -Dau. of *Othello (Crab 17\%2).

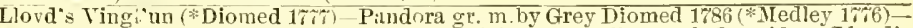
Floretta's dam by Hall's Union $1 \%$ (*) Slim 1768)-Dan. of Leonidas Lloyd's Traveller)-Dau. of *Othello (Crab 1722)-Dan. of *Juniper 1752 (Babraham 1\%40)Large Hartley mare ch. m. 1729 bv Hartley's Blind Horse (Hotrlemess Turk)-Flying Whigg 1715 by Wondstock Ar. Points by St. Victor Bar'-Grey llhynot by Whynot (Fenwick Barb)-Royal mare. 


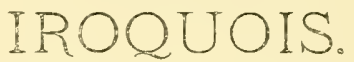

WINNER OF THE CHESTERFIELD STAKES AT NEWMARKET AND LEVANT STAKES AT GOODWOOW, I-80, THE BURWELL. STAKES, DElBY AT EPSOM, PRINCE OF WALES STAKES, DONCASTER ST. LEGER, NEWMARKET DERBY, AND OTHER IMPORTANT EVENTS IN ENGLAND.

\author{
Property of Gen. W. H. Jachson, Belle Meade Stud, near Nashville. Tcm. \\ Application to Gen. W. H. Jrelison, lock box 383, Nashitle, Tern. \\ Yearling sales ammally about June 20th, in New York.
}

IroquoIs by imp. Leamington, son of Fangh-a-Ballagh, bred by Mr. A. Welch, Erdenheim Stud, foaled 1578, dam Laggie B. B., dam of Harold by imp. Anstrilian, second dam Madeline by Old Boston, out of Magnolia, dam of Kentucky by imp. Glencoe. As a two-year-old Iroqnois started 12 times, won 4 races, was second in two and unplaced in six. He made his bow to the prblic by wimning the Newmarket two-rear old Plate, 5 furlongs, defeating Herman, Fuhleborn and three others; his second snecess was winning the two-year old stakes at Epsom, 5 furlongs, beating Eliacin. It the Newmarket July Meeting ran Bal Gal to a head for the July Stakes, a furlougs 136 yards, having Neophite, Thebais and seven others behind him; same meeting won the Chesterfield Stakes, 5 furlongs, beating Panique, Voluptuary and seren others; at Goodwood won the Levant Stakes, 5 furlongs, defeating Isola Madre, Canace and three others; same meeting ran second to Waudering Nun in the Findon Stakes, 多 of a mile, with Albion, Ishmael and Worthing behind him; he was muplaced in his other races. As a three-year old made his first appearance by rnming secoud to Peregrine in the 2,000 Gnineas, having Don Fulano, Camiliard, Scobel and nine others belind him; won the Newmarket Stakes, Ditch mile, beating Lennoxlove; Newmarket Second Spring Meeting, walked over for the Birwell Stakes, Abingdon mile; Epsom Snmmer Meeting, won the 102d renewal of the Derby Stakes, $1 \frac{1}{2}$ miles, defeating Peregrine, Town Moor, Scobel, Geologist, St. Louis, Don Fulano, Tristan and seven others. Ascot won the Prince of Wales Stakes, $1 \frac{5}{8}$ miles, defeating Geologist, Great Carie and four others; same place ron the St. James Palace Stakes, Old mile, beating Leon, Ihis only opponent; Doncaster September Meeting, won the Doncaster St. Leger Stakes, i mile 6 furlongs 132 yarls, defeating Geologist, Lney Glitters, St. Lonis, Falkirk, Bal Gal and nine others; Newmarket Second Oetober Meeting, was third to Bend'or, and Scobel in Champion Stakes, across the flat. 1 mile 2 furlongs and 73 yards, Bnchanan, Falkirk, Muriel and Fidller behind him; won the Newmarket Derby, 1골 miles, beating Ishmael, Lennoxlove and Lord Chelmsford. Thus starting in 9 races, running second for the 2,000 Gnineas, third in the Champion Stakes, and winning the Derby and St. Leger, a feat only accomplisherl ten times in the one hnndred and twelve years they have been rnn: Champion 1 1300, Snrplice in 1818, The Flsing Dntchman in 1849, Voltigenr in 1850, West Australian in 1853, Blair Athol in 1864, Gladiatenr in 1865 , Lord Lyon in 1866, Silvio in $\mathbf{1 8 7 7}$, Iroquois in 1881, Melton in 1885, Ormonde in 1886, Donovan in 1889 and Common in 1891. Not one of all these won so many gool races in the same year. Iroquois is a brown, 16 hands high, with white stripe down the face and white around the coronet of the left fore foot; he has a well placed oblique shouller, good barrel, fime hip and loin and somil, good legs and feet. He is ilescended from the best bred and most snceessful racing finilies in Engiand and America. Maggie B. B. is the dam of Pera (a producing dam), Harold, Paniqne, Jaconet (dam of Sir Dixon and Belvidere), Rerl and Blue (dlam of Sallie MeClelland), and Homeopathy. Madeline, the dam of Maggie B. B., was by the great Boston, sire of Lexington, Lecompte, Bostona, Ninil and a host of good ones. Magnolia prolnced Kentucky, the best son of Lexington, Daniel Boome, Magic, Charley Ball, Madonua, skedaddle, Gilroy, Victory, etc. Skeclarlle is the dan of Saucebox, scramble, 


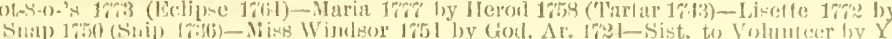

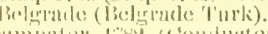

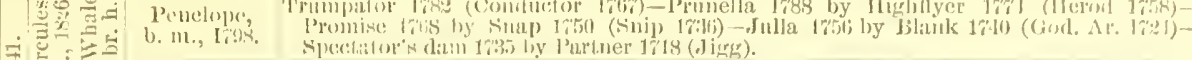

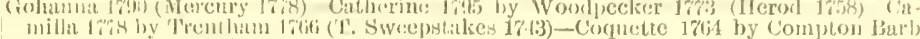

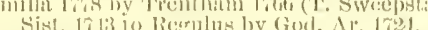

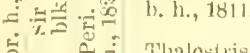
blk. In.

chto Chanticher

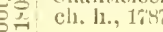

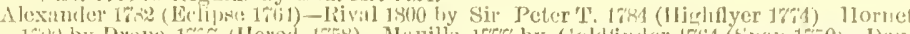

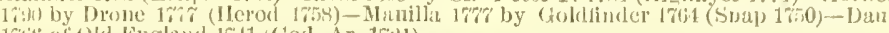

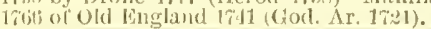

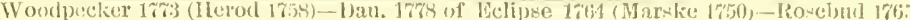

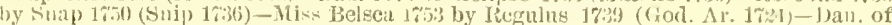
Bartleti's Childer's (Darley Ar. 1(6!)!)

Batot 1750 (IIerod 1758)-Dan. of Gimahoe (Bnstard 17.11)-Patty by Tim 175:2 (Squirt

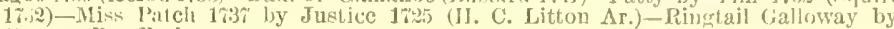
C'urwen biny Burb. 1751) - Shif 1769 by Sweetbriar 17ts:) (Syphon

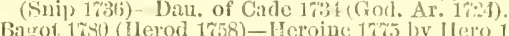

Buzzard, * (Silp 1,36)-Siet. 1;43 to Rerulus by God. Ar. 1721-Grey Robinson 17:3 by bita Galloway (St. Victol liarb)

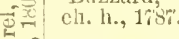

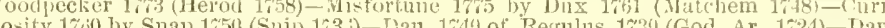

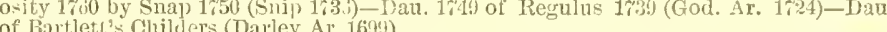
of Bartletr's Childers (Darley Ar. 1699)

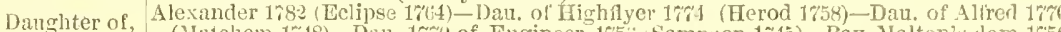
b. m., -. (Hatchem 1r48)-Dan. 1\%0 of

Peruvian, Sir Peter'1'.1764 (Highflyer 17\%4)-Dan. 1785 of' Boudrow 1776 Eclipse 1764) - Dau. 1764 b. h., $1800^{\circ}$. (Cod Arle 1754 (Travellex 1735)-Sist. to Low ther's Babuham by Babraham 1740 (God. Ar. 1721)-Datn. 1750 of Golden Ball 1735 (Partner 1718)

Iusidora, Meteol 1783 (Echuse 1764)-Majd-of-all-Work 1786 by Highfiyer 1774 (Herod 1758)-Dau. 17 \% 1 of Syphon 1750 (Squirt 1732)-Dau. of Regulus 1739 (God. Ar. 1721)-Sist. 1758 to Judgement by Snip 1736 (Flying Childers 1715).

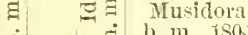

Whitelock 1803 (Kiambletonian 179:) Dau 179: ol Coriander 1734 (Pot-S-0-'s 17t3)

Blacklock, , Wildgoose 1792 by Highfler 17it (Herod 1758)-Coheiress 1786 by Pot-8-0-'s 1779

(Eclipse 1761)-Manila $17 \%$ by Goldtinder 1764 (Snap 1750).

$\stackrel{\oplus \infty}{\infty}$ b. h., 1811

Wagtail Prime Ninister 1810 (Sancho 1801)-Tranby*'s dam 1812 by Orville 1799 (Beninghrough 1791)-Miss Grimstone 1790 by Weazle 1776 (Herod 1758)-Dan. of Ancaster 1768 (Blank 1747) - Dall. of Damascus Ar. 1754.

Champion Selim 180? (Buzzard* 178\%)-Podagra 1803 by Gouty 1796 (Sil. Peter T. 1784)-Jet 1785

ch. h., 1812. by Magnet 17\%0 (Herod 1758)-Jewel 1775 by Squiruel 1754 (Traveller 1735) - Sophia 1 te4 by Blank 1710 (God. Ar. 1724).

혈 Etiquette, Orville 1799 (Beningbrongh 1791)-Boadicea $180 \%$ by Alexander 1782 (Eelipse 1\%64)br.m., 18\%0. Brunette by Amaranthus 1766 (Old England 1741)-Mayfiy 17\%1 by Matchem 1748 (Cade 1734)-Dan. 175 \% of Starling 1733 (Starling 172\%).

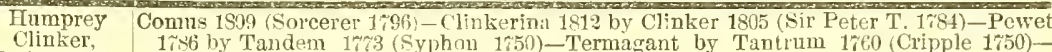

b. b., 182.

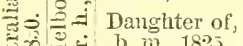

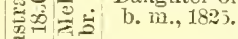

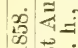

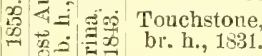

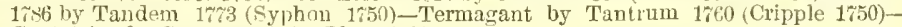
Cautatrice by Sampson 1;45 (P]aze 1;33).

Cervantes 180; (Don Quxote 1581)-Dau. 1818 of Golumpus 1802 (Gohanna 1790) -Dan. 1810 of Paynato: 179] (Trumpator 1\%82)-Circle 1802 by St. George 1789 (Highfiyer 17ri4) - Abigail 1 68 by Woodpecker 173 (Herod 1758).

amel 18:2 (Whalebone 189\%) Bunter 18:6 by Master Ilenry 1815 (Orville 1799)-Boaclicea 1807 by Alexander 1782 (Eclinse 1764)-Brunette by Amarauthus 1766 (Old England 1741)-Mayfly $17 \% 1$ by Matchem $1 \% 48$ (Cade 1734).

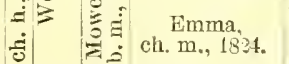

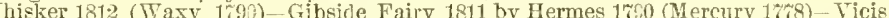
situde 1800 by Pinator 176 (Imperator 1\%6)-Beatrice 1;91 by Sir Peter T. 178

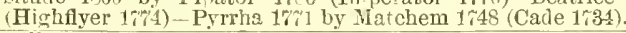

\section{E. Emilius.}

Orville 1799. (Beningbrough 1\%91) - Emily 1810 by Stamford 1694 (Six Peter T. 1784)Dau. 1793 of Whiskey 1783 (Saltram $\% 1780$ ) Grey Dorimant 1781 by Dorimant 17\%? (0 tho 1760)-Dizzy 1,57 by Blank 1;40 (God. Ar. 1724).

(: b. h., 182)

Scud 1801 (Beningbyouch 1591). Goosander 1805 by Hambletonian 1702 (King Ferous

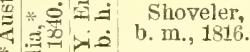

1675) - Rally $17 \% 0$ by Trumpator 1782 (Conductor 1,6\%)-Fancy 1780 by Florizel 1\%68 (Herod 1 $\tau_{53}$ )-Dau. $1 \%$ of Snectator 1749 (Crab 1722)

Whisker,

Waxy 179) (Pot-5-0-'s 17\%3) - Penelope 17.8 by Trumpator 1782 (Condnctor 17(67) - Prunella 1793 by Highflyer 1 wit (Herod ${ }_{x}^{7} 758$ ) - Promise 1768 by Snap 1750 (Snip 1736)Juliz 1756 by Blank 1710 (Godolph. Ar. 1\%24).

b. b., 181?.

[Selim or] Soothsayer 1808 (Sorcerel 1\%96)-Spre

ङई $\dot{\xi} \quad$ Variety

Sir Archy

b. h., 1805 .

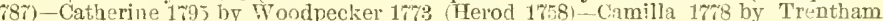
1760 (T. Sweepstakes 1743) - Coquette 17:4 by Compton Barb.

Tabith 17 braham 17t0)-Dau. of 17 .'s Forester 1750 (Forester 1735).

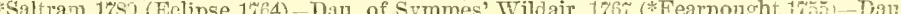
of Tyler"s Driver 1;60 "Othello)-Dan, of Fallower 1661 (Blank 1740)-Dat. of Yampire $1 \%$ r (Regulu= 1739)

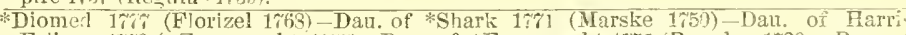
Eelip se 1\%0 (*Fearnought 1755)-Da: of "Fearnought 175j (Regulus 1739)-Dau. of *Jolly Roger $1 \% 11$ (Roundhead 1733).

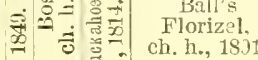

छ. $\quad$ Daughter of

d.

Sீ

Alderman 1787 (Pot-4-0-'s 1,23)-Dau. of *Clockfast 17it Gimerack 1760)-Dau. o Symmes" Wildair $176 \%$ (*Fearnonght 1755)-Y. Kitty Fisher 176\% by Fentnonght 1755 (Regulns 1739) - Kitty Fisher 1755 by Cade 1734 (God. Ar. 1721.

.

Selim $1802($ Buzzard $*$ 1\% $\%$ )-Bacchante 1809 by $11 . ' s$ Ditto 1810 (Sir Peter T. 1\%84) Dan. 1791 of Mercury 1\%78 (Eclipse 1\%(61)-Dau. $17 \% 6$ of Herod 1758 (Tartar 17-43)Folly 1:rit hy Marske 1750 (Squirt 1r:32).

Tramp 1810 (Dick An'rews 1 1798 by Trumpaior 178 ? (Couductor 173\%)-Prunelia 1789 by Highflyel 16it Herod 1i5s) - Promise 1768 by Snan 1750 (Snip 1736).

ธo

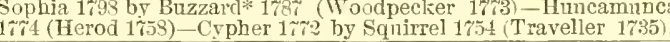

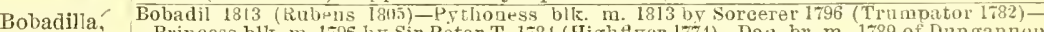
br. m., 1825 . Princess blk. m. 1796 hy Sir Peter T. 1784 (Hightiver 1774)-Dau. br. m. 1789 of Dungannon

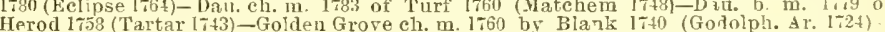

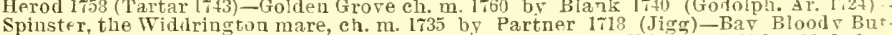
Spinster, the Widirington mare, ch. m. 1735 by Partner 1718 (Jigg)-Bav Bloodr But

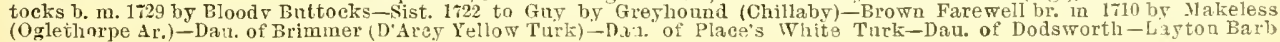
mare. 


\section{IROQUOIS-Continued.}

Florence B., Sly Boots, Joe S., The Slashes and Squeez'em (dam of Day Star, winner of the Kentucky Derby, Blue Ribbon Stakes and other races), Sylph (dam of John K., Kaloolah, Philip D. and Kinesem), and La Sylphirle, $1 \frac{1}{4}$ miles in $2.07 \frac{1}{3}$, she the dam of Semper Fidele. Sly Boots is the dam of Leveler, Sly Danee, Sachem, Savanac and Volunteer II.

Iroquois is a grand suceess in the stur, sire of Tammany, winner of the Great Eclipse Stakes, the Criterion Stakes at Monmonth, the 6 furlongs in both races being

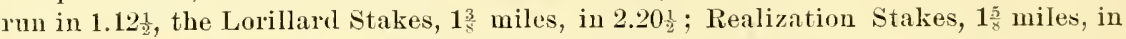
$2.5 \mathrm{I}_{5}^{2}$; Withers Stakes, 1 mile, in 1.40. Adılie was the "crack" filly of the West, winner of eleven races. Other winners by Iroquois are Rancocas, Mohican, White Wings, Mountain Deer, MeKeever, Heylay, Laura Doxey, Guildura, Annie Irwin, Beansey, Darlington, Carteret, Bengal, Algonquin, Eblis, Dictum, Emblem, Irregular, Julins Sax, Kiawah, Pan Handle, Ted Gregg, Malachi, Alice D., Claudine, Nellie Pearl, Minnie L., Iowa, Josie M., Mayflower, Piquante, Rainbow, Starlight, Helen Nichols (unbeaten), Huron, Marguerite, St. Croix, Queen Enid, Interior, Red Banner, Bennett Young, Edith Belmont, Cayuga, a rare good one, Haylee, Nettie B., Princess Loraine, G. W. Johuson, unbeaten and $\$ 22,000$ refused for him. He will stand at the head of the list of winning stallions in 1892.

\section{JULIEN.}

\section{Owned by Messrs. Smith and Hughes.}

Julien, bay horse, foaled 1886, bred by Hon. W. L. Scott, Algeria Stud, Erie, Pa., by imp. Rayon D'or, dam imp. Clover by Macaroni, son of Sweetmeat, grandam Verdure by King Tom, son of Harkaway, etc. Macaroni, the sire of Clover, won the 2,000 Guineas and Derby, and was the sire of the dams of Pilgrimage, winner of the 1,000 and 2,000 Guineas, Ormoncle, winner of the 2,000 Guineas, Derby and St. Leger, Galliard, winuer of the 2,000 Guineas, Busybody, winner of the 1,000 Gnineas and Oaks, and Bonavista, winner of 2,000 Gnineas, and her dam, full sister to Clover, the dam of Julien. Verdure, the grandam of Julien, was a winner in England, and own sister to Corisande, that won the Cesarewitch Handicap in a field of twentyseven at three years old, carrying 110 llos., the Chesterfield, Granby, New, Coronation and Grande Duke Hichael Stakes, by King Tom, sire of imp. Phaeton, imp. King Ban, imp. Great Tom and his brother, Kingeraft, wimer of the Derby, and of the dams of the Derby winner Favouius, and Enterprise, winner of the 2,000 Guineas. Maybloom, Julien's third dam, was full sister to Lady Alice Hawthorn, grandam of Hauteur, winner of the 1,000 Guineas, and out of Lady Hawthorn, fiull sister to Thormanbs, winner of the Derby and Ascot Gold Cnp. Jnlien was a good race-horse, winner at 5 furlongs, and placed second and third in several good and fist races. Rayon d'Or, his sire, is from the Pocahontas family, that produced Stockmell. Rataplan, King Tom and other good ones, and his dam from the great Hawthorn fumly, tracing to the Laytou Barb mare. 


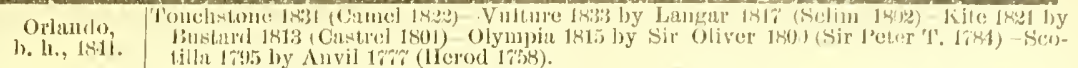

象 Cavalina,

liclibiuli

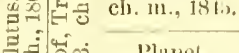

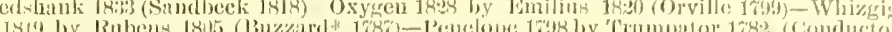

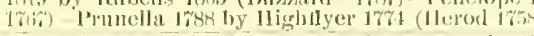

l'linet,
b. h., 1sil.

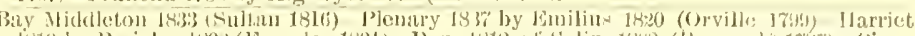

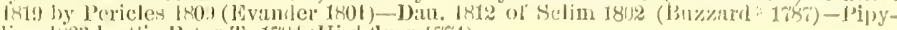

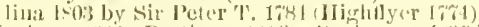

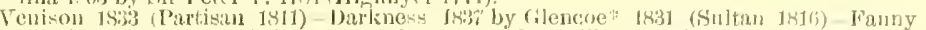

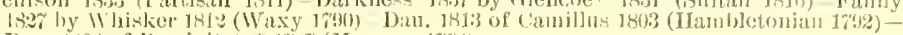

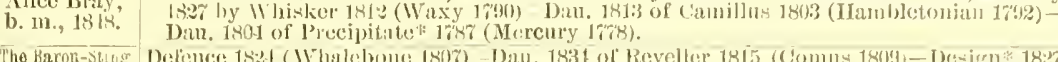

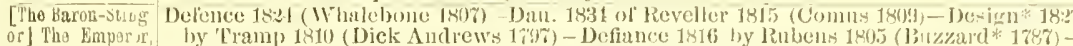

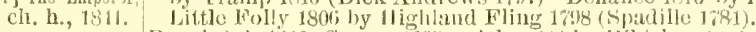

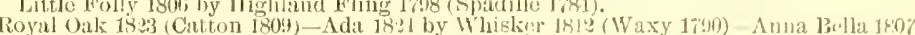

Poeless,

b. $11 ., 1438$.

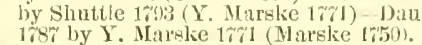

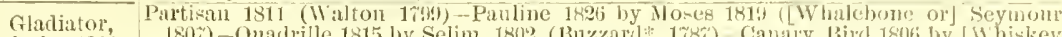

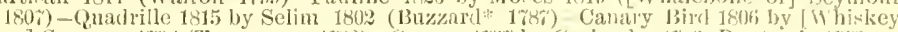

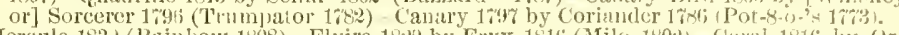

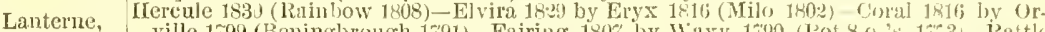

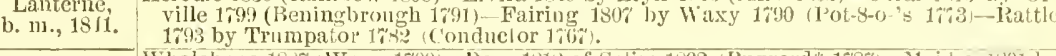

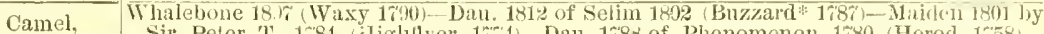
br. h., 1822 . Sir Peter '17. 1781 (ighlilyer 1\%1)-Dau. 1783 of Phenomenon 1780 (Herod 1758)Mation 178\% by Florizel 1768 (1lerod 1758).

Banter,

Master Henry 1315 (Orville 1790)-Baadicen 1807 by Alexander 1782 (Eclipse 1764) Bru

\&.

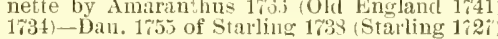

Priam, Emilius 1890 Or

b. h., $182 \%$ (Saltam* 1780-Y. Giantes Iolly Loug Legs 1753 by Babraham $1 \% 40$ (God. Ar. $17 \% 4$.

The Poten- Don Juau 1811 (Orville 1 799 )-Moll-in-the-Wad 1810 by Iambletonian 1792 (Kimo Ferons tate's dam, 175)-Spitfire 1793 by Pipator 178; (Imperalor 17\%6)-Farewell 1792 by Slope 1782 b. m., 1823. (Highflyer 17\%t)-I)au. of Y. Marske 1761 (Marske 1750).

Sultan, Selim 1803 (Buzzard 178\%)-Bacchante 1803 by W's Ditto 1800 (Sir Pel el T. 1C81)-Dau b. h., 1816. 1791 of Mercury $17 \% 8$ (Eclipse 1761)-Dau. 17\% 6 of Herod 1758 (Tartal 1743)--Folly 17'i by Marske 1,50 (Squirt 173:2).

Trampoline, Tramp 1810 (Dick Andrews 17\%) - Web 1808 by Waxy 1790 (Pot-9-o-'s 16i3) - Penelope \begin{tabular}{l} 
ch. m., 18\%5. \\
ch 1798 by Trumpator 1782 (Conductor 176\%)-Prumella 1788 by Highflyer 17it (Herod \\
\hline
\end{tabular}

Muley, Orville 1799 (Beningbrough 179i)-Eleanor 17.8 by Whiskey 1789 (Saltram $* 1780$-Y.

b. h., 1810. Giantess 1790 by Diomed $17 \%$ (Flolizel 1\%(8)-Giantess 1769 by Matchem 1748 (Cade 1734) - Molly Long Legs 1753 by Babraham 1740 (God. Ar. 1724).

Clare, Marmion 1806 (Whiskey 1789)-Harpalice 1814 by Gohanna 1790 (Mercury 17\%)-Amazon 1\%99 by Driver 1783 (Trentiam 1\%66) - Fraclious 179: by Mercury 17\% (Eclipse

b. m., 1821. $\quad 1764$-Dau. 178 ; of Woodpecker $17 \% 3$ (Herod 1758).

Partisan,

1788 by Highflyer $17 \% 4$ (Herod 1758 ) - Promise 1768 by Snap 1750 (Snip 1\%36)-Julia

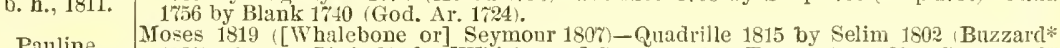

bauline, $178 \%$-Canary Bird 1803 by [Whiskey or] Sorcerer 1795 (Trumpator 1 1782 -Canary $179 \%$

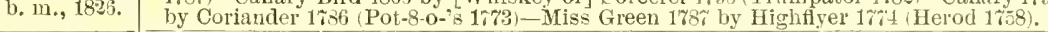

[Starch or]

Blacklock 1814 (Whitelock 1803)-Dan. 1816 of Phantom 1808 (Walton 1799-Dau. 1802

Voltaire,
br. h., 1826.

Belinda, of Overton 1788 ( King Fergus 17\%5)-Dau. 1796 of Walnut 1786 (Hightlyer 17\%4)-Dau.
$1 \% 85$ of Ruler 17\% (Y. Marse 1\%71).

Belinda,

Blacklock 1814 (Whitelock 1803)-Wagtail 1818 by Prime Minister 1810 (Sancho 1801) Tranby*'s dam 1812 by Orville 1793 (Beningbrongh 1791)-Miss Grimstone 1793 by Weazle 1776 (Ferod 17\%8)-Dan. of Ancaster 1763 (Blank 1740).

Castrel.

Buzzard $1 \% 8 \%$ (Woodpecker 17\%3) Dan of Alezander $178 \%$

ch. h., 1801. Highflyer 1\%4 (Herod 1\%58)-Dau. of Alfred $17 \% 0$ (Matchem 1748)-Dan. 1\%:0 of Engineer 1756.(Sampson 1745).

会

Perizvian 1896 (Sir Peter T. 1784)-Musidora 1804 by Meteor 1\%89 (Eclipse 1764)-Maid-

ch. m., 1815. 1732)-Dau. of Regulus 1739 (God. Ar. 1724).

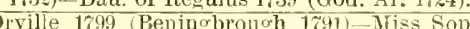

b. h., 1815.

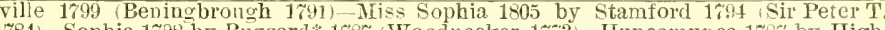
1784)-Sophia 1798 by Buzzard* $1787^{\circ}$ (Woodpecker 17\%3)-Huncamunca 178\% by Highflyer $17 \% 4$ (Herod 1758) - Cypher $17 \% 2$ by Squirlel 1\%5t (Traveller 1735).

Boadicea, Alexander 178\% (Eclipse 1764)-Brunette by Amaranthus 1766 (Old England 1741)-MayLook-at-me-Lads 1731 by Grasshopper (Byerly Turk).

稌 Whisker 1812 (Waxy 1790)-Floranthe 1818 by Octavian 180\% (Stripling 1795)-Caprice 1797 by Anvil 17ry (Herod 1758)_Madcap 1\%4 by Eclipse 1764 (Marske 1\%50)-Sappho 1763 by Blank 1 r40 (God. Ar. 1724).

Fanny Nabocklish 1811 (Rngantino 1803) - Miss Tooly 1808 by Teddy the Grinder 1\%08 (Aspar:Dawson, Florizel 1768 (Herod 1758)-Captive $1 \%$ - C by Matchem 1748 (Cade 1731).

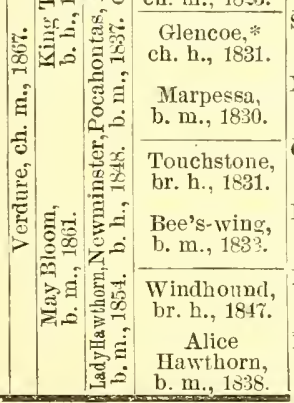
Sultan 1816 Selim 1802 - Trampoline 18.5 by 1808 by Waxy 1790 (Pot-8-0-'s 17\%3)-Penelope 1\%os by Trumpator 1\% $176 \%$ ) - Prunella 1788 by Highilyer rory (Herod 1758

Muley 1810 (Orville 1799)-Clare 1821 by Marmion 1826 (Whiskey 1789)-Harnalice 1314 by Gohanna 1790 (Nercury 17\%8)-Amazon 1799 by Driver 1783 (Trentbam 1766)Fractiotts 1792 by Mercury $17 \% 8$ (Eclipse 1764)

Came] 18 ? (Thalebone 180\%)-Banter 1826 by Master Henry 1815 (Orville 1\%99 Boadicea $180 \%$ by Alexander 1782 (Eclipse 1\%64)-Brumette by Amaranthus 1766 (Old England $17+1$ )-Mayfly $17 \% 1$ by Matchem 1745 (Cade 1734).

Dr. Syntax 1811 (Paynator 1791)-Dau. 1817 by Ardrossan 1809 (John Bull 1789)-Lady Eliza 1813 by Whitworth 1895 (Agonistes 179\%)-Dan. 1793 of Spadille 1784 (Hightlyer 1;it)-Sylvia 1783 by Y. Marske $17 \% 1$ (Marke 1750).

Pantaloon 1834 (Castrel 1801-Phryne 184) by Tonchstone 18.1 (Camel 18.2)-Deeoy 1830 by Filho-da.Puta 181: (Haphazard 1797)-Finesse 1815 by Peruvian 1806 (Sir Petel T. 1784)-Tiolante 1802 by John Bull 1789 (Fortitude 17\%7)

Muley Moloch 1830 (\$n]ey 1810)-Rebeeca b. m. 183L by Lottery 1820 (Tramp) 1810)-Dau. b. m. 1818 of Cervantes 1806 (Don Quirote 1784) -Autieipation e 1 . m. 1902 by Beninghrough 179l (King Ferwus 1755)-Expectation gr. m. 1769 by Herod 1758 (Tartar 1743)-Dau. 1758

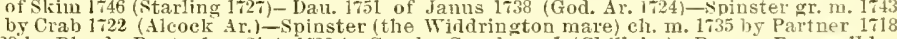
Jigg)-Bay Bloody Buttocks b. m. 1729 by Bloody Bnttocks-Sist. 122 to Guy by Greyhonnd (Chillaby) - Brown Farewell br. m. $170 \mathrm{by}$ 'lakeless (Oglethorpe Ar.)-Dau. of Brimmer (D'Arey Yellow Turk)-Dau. of Place's White Turk-Dan. of Dodsworth-Lay ton Barb mare. 


\title{
IMPORTED KANTAKA.
}

\author{
Owned in the Algeria Stud of the late Hon. W. L. Scott, Erie, Pa.
}

KaxtakA, chestnut horse, $15_{4}^{3}$ hands high, by Scottish Chief, son of Lord of the Isles by Touchstone, was bred by Mr. W. Blenkiron, foaled 1880, dam Seclusion (Hermit's dam) by Tadmor, son of Ion by Cain, grandam Miss Sellon by Cowl, sou of Bay Middleton by Sultan.

Kantaka is of the blood royal, being a half brother of the great horse Hermit, who won the Derby and was one of the best sires that ever lived, as is evidenced by the great performances of Peter, Shotorer, St. Blaise, Tristan, Thebais, Clairvaux, St. Marguerite, Queen Adelaide, ete. Mr. P. Lorillard paid \$ŏ,000 for Kantaka when a yearling, and in his trials he showed great speed and promised well, but he met with an accident and never started in a race. His breeling is of the choicest quality and his sire, Scottish Chief, was himself not only a first-class race-horse, but as a sire of race-horses is one of the most popular stallions of England. He won the Ascot Gold Cup and other good races, and as a sire he has proven his prepotency in having to his credit a good list of winners, among them Marie Stuart, winner of the Oaks and St. Leger, and one of the best mares that ever appeared in England, Thistle, dam of Common, winner of the 2,000 Guineas, Derby and st. Leger, Mowerina, dam of Donovan, winner of the Derby and St. Leger, Senolina, winner of the 1,000 Guineas, Violet Melrose, dam of Melton, winner of the Derby and St. Leger, etc. Lord of the Isles, sire of Scottish Chief, was winner of the 2,000 Guineas, son of the great Touchstone, and on the side of his dam he traces back to stont Herod blood, which is well fortified with the Sultan through Bay Middleton, one of the best racehorses and sires of his das. The remarkable snecess of Hermit as a sire proves the prepotency of the blood of the family to which he belongs. Newminster, the sire of Hermit, was a son of Touchstone, and Scottish Chief, on his sire's side, is also a grandson of Touchstone. CowI, sire of Miss Sellon, the grantam of Kantaka, is a son of Bay Middleton and the famous Crucifix by imp. Priam. The grandam of Scottish Chief is by Bay Middleton, from which it will be seen that Kantaka and Hermit are much more closely allied than simply half brothers, for the same strains of blood are conspicuous on the side of their sires. The capacity, therefore, to transmit racing qualities is abundant in Kantaka, and a horse of his rich breeding must prove himself a successful sire eventually.

Kantaka is still young in the stud, but has to lis eredit Canteen, G. B. Boyden, Dock Wick, Rafter, Irish Dan by Kiantaki or Algerine, 'Tipstaff by Rayon d'Or or Kantaka, Clotho (a very speedy two-year old last season), Flagrant, Guilty, Great Scott, Gold Digger, Knapsack, Ko-Ḱo, Loyalty, Nubian, Chatter, Cascade, Lizzie Gwymne, Picealilli, Queen d’Or, Crocus, Lebanon, Wyoming, Wallace, Village Maid and other good ones.

It is to the Massey mare in direct female line descend and trace their origin the following good horses and stallions: Trentlam, Florizel, Election, Quiz, Roral Oak, Mulatto, Defence, The Palmer, Rosicrucian, Dutch Skater, Doncaster, Gladiateur Hermit by Newminster and many other noted ones. 


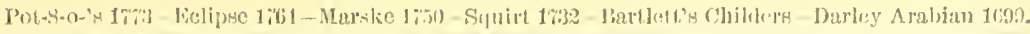

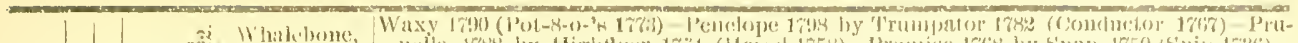

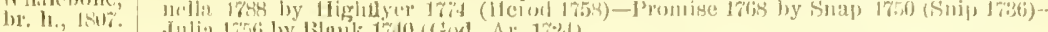

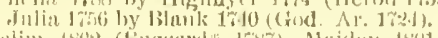

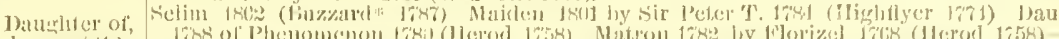

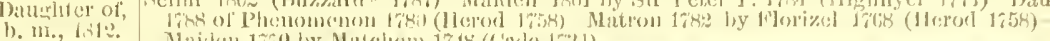

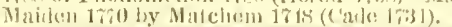

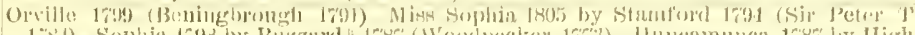

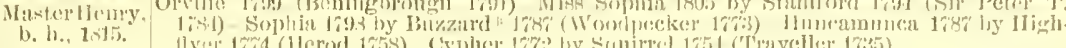

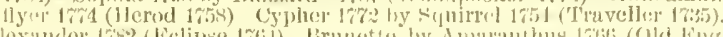

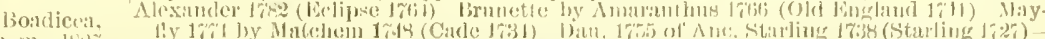

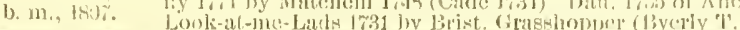

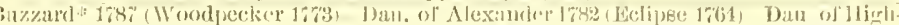

llyer 17\% (J) lint (Simpisun 175)

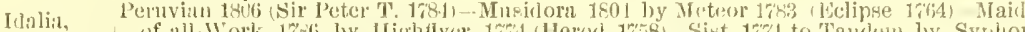

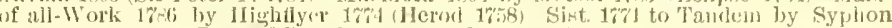

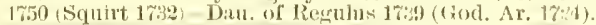

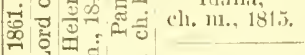

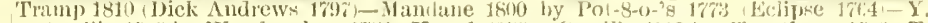

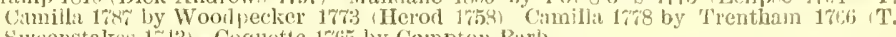

br. h., 1.20. Sweepstakes 1743) Coquette 17(65 by Compton Burb.

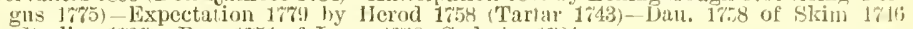

b. 1h., 1818. Starling 17\%')-Dau. 1751 of Janus 1\%38 (God. Ar. 17\%4).

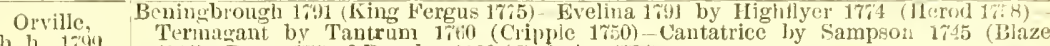
Termacant by Tantrum 1740 (Clipple 1750)-Cantatrice ly Sampson 17.5 (Blaze

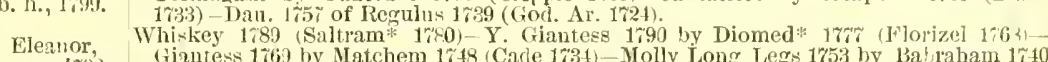
Givntess 1769 by Matchem 1718 (Carle 1731)-Molly Long Legs 175:3 by Bahraham 1710

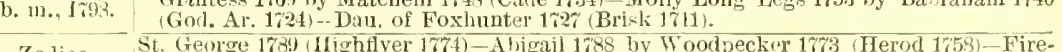

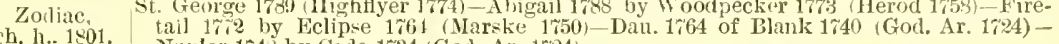
Naylor 1713 by Cade 1734 (God. Ar. 1724 ).

Jerboa, Gohamna 1790 (Mercury 1778)-Camilla 1;68 by Trentham 1766 (T. Sweepstakes 1743)Coquette 1764 by Compton Barb-Sist. 1713 te) Regulus by God. Ar. 1721-Grey

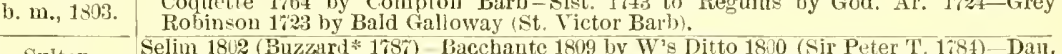

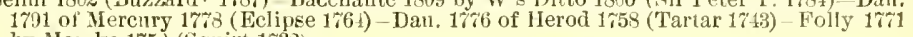

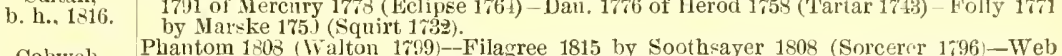

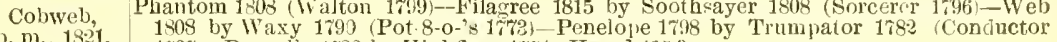
1;6\%-Punelin 1788 by IIighflyer 1\%:4 (Herod 1754).

b. n1, 1821

Phantom $18 \%$ (Waltom 1 \%

1. Phantom, 1808 by Sorcerer 1796 (T'um)ator 1782 ) Cobbë̉ 1802 by Skyscrapel 17.6 (Highflyer 1; 4 )-Dau. 1 - 38 of Woodjecker 1773 (Herod 1758).

Sister to Camillus 1803 (Hawbletonian 1792)-Dau. 1809 by Sancho 1801 (Don Quixote 1rs4)Speaker, Miss IIormpipe Teazle 1802 by Sir Peter T. 1784 (Highflyer 17t4)-Hornjipe 1 it93 by Trumpator 178? (Condnctor 176\%)-Luna $17 \% 9$ by Herod 1758 (Tartar 1743)

Sir Paul 1802 (Sir Peter T. 1784)-Evelina 1791 by Highflyer 174 (Herod 1758)-Terma-

Panlowitz, gant by Tantrum 1760 (Cripple 1750)-Cantatrice by Sampson 1745 (Blaze 1733)-Dau. 17\% of Regulus 1739 (God. Ar. 1724).

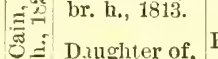

Paynator 17.1 (Trumpator 1789-Dau 1805 of Delpini 1781 (Hiohfiver 1744)-Dan. 179: by Y. Marske 1\%1 (Marske 1750)-Gentle Kitty 1\%74 by Silvio 1754 (Cade 1734)-Duu. of Dorimond 1758 (Dormonse 1738).

然

$=-1$

-1810 .

Orville 1799 (Beningbrough 1791)-Emmeline 1817 by Waxy 1790 (Pot-8-o 's 1773 )-Sol-

cery 1849 by Sorcerer 1796 (Trumpator 1782)-Cobbëa 1802 by Skyscraper 1786 (Highflyer 1774)-Dall. 1788 of Woodpecker 17.3 (Herod 1758). b. h., 1824 .

Selim 180? (Buzzard* 1787)-Dau. 1803 of Sir Harry* 1795 (Sir Peter T. 1784)-Dau. 1793 Medora, of Volunteer 1780 (Eclipse 1764)-Dau. 1779 of Herod 1758 (Tartar 1743)-Goiden Grove 1760 by Blank 1740 (God. Ar. 1\%21).

Selin,

Buzzard* 1787 (Woodpecker 17\%3)-Dan. of Alexander 1\%82 (Eclipse 1761)-Dall. of

ch. h., 1802. giveer 1756 (Sampson 1745 )

Bacchante,

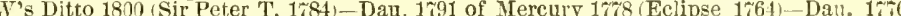
of Herod 1758 (Tartar 1743 )-Folly $1 \% 11$ by Marske 1750 (Squirt 1732)-Vixen 1753 by Regulus 1739 (God. Ar. 1721).

Camel,

Whalebone 1807 (Waxy 1790)-Dau. 1812 of Selim 1802 (Buzzard*1787)-Maiden 1801 by Sil Peter T. 1784 (Highflyer 1\%44)-Dau. 1788 of Phenomenon 1780 (Herod 1758)Matron 1782 by Florizel 1768 ( Herod 1758 ).

br. h., $182:$

Muley 1810 (Orville 1799)-Dau. 1796 of Precipitate* 1787 Nercury 17\%)-Dau. 178\% of

Monimia, Woorpcker 17\%3 (Herod 1758)-Dau. 1\%3 of Snap 1750 (Snip 1736)-Y. Marske's dam 1759 by Blank 1740 (God. Ar. 1724).

Sultan, Selim 1802 (Buzzard*1787)-Bacchante 1809 by W's Ditto 1800 (Sir Peter T. 1781)-Dan. 1791 of Mercury 1778 (Eclipse 1\%64)-Dau. 17\%6 of Herod 1758 (Tartar 1743)-Folly 1771 by Marske 1750 (Squirt 1732)

ai Cobweb,

b. m.. 18:1.

(Walton 1799)-Filagree 1815 by Soothsaver 1808 (Sorcerer 1796) - Web 1803 by Waxy 1790 (Pot-8-0-'s $17 \% 3$-Penelope 1799 by Trumpator 178: (Conductor 1767) - Prunella 1788 by Highflyer $17 \% 1$ (Herod 1\%58).

\section{$\sum^{\infty}$ \\ Pljam,}

Enilins 18:0 (Orville 1799)-Cressida $180 \%$ by Whiskey 1789 (Saltram* 1780)-Y. Giantess

b. h., $102 \%$ Iolly Long Legs 1753 by Babraham 1740 (God. 1769 by

Octavian 1807 (Siripling 1795)-Dan. 1897 of Shnttle 1793 (Y. Marske 17r1)-Zara 1801 by

b. m. 1815 Delpini 1781 (Highflyer 17\%4)-Flora 1789 by King Fergus 1\%75 (Eclipse 1764)-Atalanta 1769 by Matchem 1:48 (Cade 1734).

Blacklock, Thitelock 1803 (Hambletonian 1792)-Datr. 1799 of Coriander 1786 (Pot-8-0-s 173)Eclipse 1\%64)-Nanilla $17 \%$ by Goldifnder $176+$ (suap 1750)

Dick Andrews 1797 (Joe Andlews 17\%8) - Mandane 1800 by Pot-8-0-"s 1rz3 (Eclinse 1764)Y Camilla 1787 by IT A

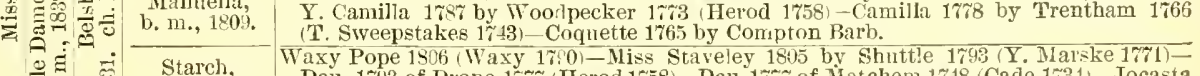

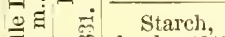

卷

Oiseau 1809 Camillus 1803)-Castanea ch. m. 1803 by Gohanna 1790 (Nercury 1778)-

Cuirass, Grey Skim gr. m. 1793 by IFoodpecker 1\%, (Herod 1758) - Silver's dam gr, m. $1780 \mathrm{ky}$ Herod 1758 (Tartar 1743)-Y. Hag gr. m 1761 by Skim 1716 (Starling $172 \%$ )-Hag gr, m. 1741 by Crab 1722 (Alenck Ar. - Ebony b. m. 1728 hy Flying Childers 1 î15 (Darley Ar. 1699-Ebony blk. m. 1714 by Basto 1 ;02 (Byerly Turk)-Duke of Rutland's Massey mare by Hägsey Bay Barb. 


\section{KING ALFONSO.}

WINNER OF THE KENTUCKY ST. LEGER, TOBACCO STAKES AND GALT HOUSE STAKES AT LOUISVILLE, KY., AND THE LINCK'S HOTEL STAKES AT NASHVILLE, TENN., ALL IN 1875.

\section{In the Woodburn Stud, Spring Station, Ky., A. J. Alexander, proprietor. Applieation to L. Brodhead. Anmual sales of yearlings in May.}

King Alfonso by imp. Phaeton, son of King Tom, bred bs Warren Viley, Esq., Stonewall Stud, near Midway, Ky., foaled 1872, dam Capitola. dam of Belle Barelay and Hospodar by Vandal, son of Glencoe, ont of Margravine, Versaille's dam by imp. Marerave.

King Alfonso's turf eareer was short bnt brilliant. He masle his debut at Lexington, Ky.. September 6, 1 75, in a Sweepstakes for three-yen olds, 1 mile aul 1 fullong, $90 \mathrm{lbs}$. on each, Bob Woolley won in 1.5t, the fastest race ever rmm at the distance to that date, King Alfonso was a close second, with Katie Pearce, Ten Broeck, Elemi and Redman behind him; September 9, was mplaced in Sweepstakes,

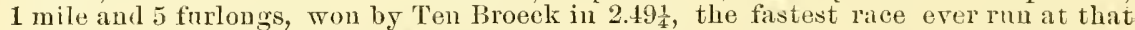
distance to that date, Bob Woolley being second. Lonisville, Ky., September 20, won the Kentncky st. Leger, 2 miles, in 3.34 Verdegris, third, Geo. Graham, Voltigeur and five others; September 2!, won the Tobaceo stakes, mile heats, in $1.14 \frac{1}{2}, 1 . \frac{15}{2} \frac{1}{2}$, beating Gyptis, Misdeal and three others; the next day, September 25, won Galt House Stakes, 2 mile heats, in $3.31,3.40 \frac{1}{2}, 3.49$, beating George Graliam, who won the first heat by a head from King Alfonso, the last quarter of the heat being ron in 24 seconds, Enma C., Add and two others. He closed the season and his turf eareer by winning the Linek's Hotel Stakes, at Nashville, mile heats, in $\mathbf{1 . 4 5}, 1.47 \frac{3}{1}$, beating Misdeal, Asterlite and three others. He was trained the spring of 1876 , when four years old, and showed himself a better horse than ever, but in a very fast trial struek his leg and was thrown out of training, and was sold to A. J. Alexander and placed in the Woodburn Stud.

The fimily has always, as a racing one, ranked one of the best in America. The Albert mare produeed the famous Tiger gelding and Black-eyed Susan, a superior race-mare, dam of Diek Singleton, Plato, Nistletoe, Diek Johnson, Catharine, ete. Dick Singleton defeated the great Collier, four mile heats; Nistletoe wou the match between Kentueky and Tennessee. Mistletoe was the dam of Evergreen by imp. Gleneoe, who produeed Goodwood, Maggiore, Verbena, Glendower and others, aud Margravine, the dam of Mary Churchill, Tourist, Capitola, The Grand Duteh S., Versailles, ete. Mary Churehill was the dam of Hamburg, Wade Hampton, winner of the Sequel Stakes at Long. Braneh and Saratoga in 1872, by Asteroid, and Nettie Viley, she the dam of Conductor, Mirah, ete. The Grand Duteh S. was the dam of Yandell and Lizzie IVhips, both fine race-nags.

King Alfonso is sire of Fonso, winner of the Phcenix Hotel Stakes, $1 \frac{1}{4}$ miles, in

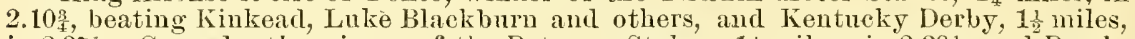
in $2.3 \mathrm{r}_{2}$. Grenada, the winner of the Potomae Stakes, $1 \frac{1}{2}$ miles, in $2.39 \frac{1}{4}$, and Preakness Stakes, both at Baltimore, Belinont, Jerome aud Lorillard Stakes at Jerome Park, Coney Island Derby at Sheepsheal Bay, and Dixie Stikes at Baltimore, ¿ miles, in 3.38, wimning $\$ 32,000$ as three-sear old. At fonr years old, won four out of

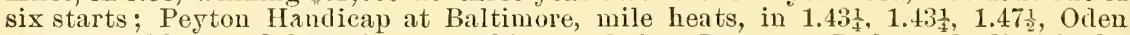
won second heat. Other wimners by him are Quito; Lavacea; Dodette, Ladies' Stake

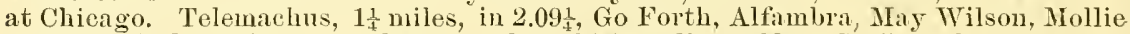
Brown, 5 furlongs in 1.02, Edison, Dnke of Montalban, Mary S., Lost Cause, Windrush, 2 miles in $3.33 \frac{1}{2}$, and again in $3.36 \frac{1}{2}$, Bayadere, Bob Johnson, Infanta, winner of Elizabeth Stakes at Long Branch, Issie, winuer of Ashlaud Oaks, Lexington, Kr.. Katie Creel, winuer of the Kentucky Oaks at Lonisville, $1 \frac{1}{2}$ miles, 2.39, and Illinois Oaks, Chicago. Arno, Lady Prewitt, The Jndge (Cordova), Lorea, Mary S., Olivette, Vera, Don Fulano and Golden Gate, raeed creditably in England, and Foxhall won two out of three stakes in which he started at two years old, beating the best eolts of the year and giving weight. He won the Grand Prize of Paris in 1-81, and is the seeond horse that eved won the Cesalewitch and Cambridge Handicaps in England in one and the same year. 'The first was Rosebery, a fonr-year old, carrying in the Cesarewiteh 103 los., and in Cambriclgeshire 117 lbs. Foxhall, a three-year old, carried in the first 110, and in the latter $126 \mathrm{lbs}$, beating with the top weight Luey. Glitters (3), 91, Tristan (3), 107, Mistike (4), 102, Wallenstein (4), 97, and twentyseven others. He won the Ascot Gold Cup in 1882. Other winners by him are Bessie. June, Joe Cotton, King Lee. 


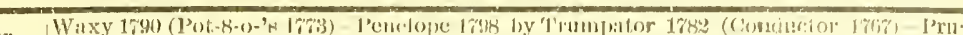

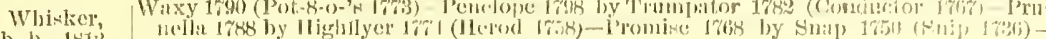

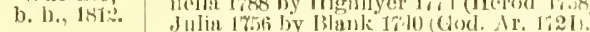

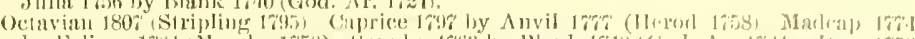

ri:

Florintle,

b. $111 ., 1818$

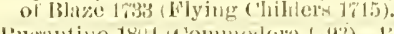

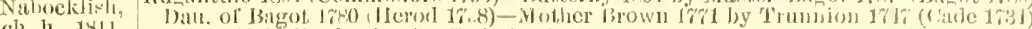

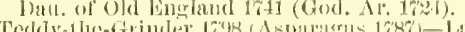

giss Toolcy',
b. 11, , 1nos.

Sultān,

b. 11., 1816.

Trampoline

ch. $111 ., 1825$.

Muley,

b. 1., 1810 .

Clate,

b. m., 1821 .

Camel,

br. h., 18202.

Banter,

br. $m ., 1826$.

Pantaloon,

ch. h., 18:1.

Languish.

b. 11., 1830 .

Touchstone,

br, h., 1831 .

Decoy,

b. m., 1830 .

Emilius,

b. b., 1820 .

Variation,

b. m., $182 \%$.

Selim,

ch. h., 1802.

Bacchante,

br. 1n., 1809.

Tramp,

b. h., 1810

Treb.

b. m., 1808.

Blacklock

b. h., 1814 .

Miss Bowe

dim,

br. m., 1812.

Trumpator,

bu'. h., 182:

Lucy,

b. m., 1821.

Orville,

b. h., 1799

Eleanor,

b. 11., 1798 .

Election,

ch. $h_{\circ}, 180 \frac{1}{x}$.

Fair Felen,

gr. m., 1808.

Sir Archy,

Roxana,

ch. m., -

Tiger,

b. h., 1812 .

Daughter of,

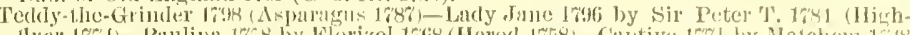

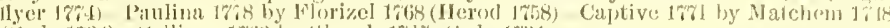

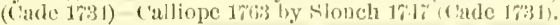

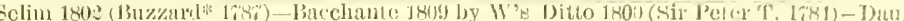

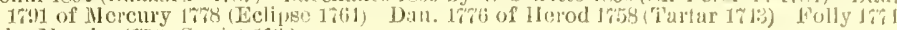
by Marske ron (Squirt 173:2

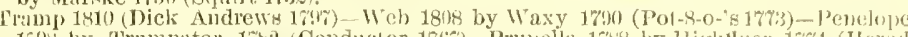

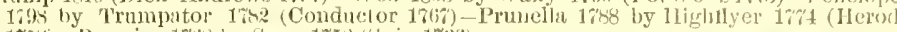
1758)-Plomise 17tis by Silap 1750 (Snij) 17:36)

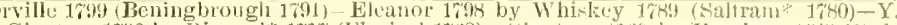

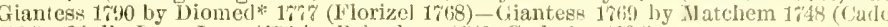
1734) - Molly Long Legs 1753 by Bairaham 1710 (God. A.: 172l)

Marmion 1896 (Wbiskey 1789 - liarpalice 1811 by Gohama $1 \% 30$ (Nerenry 17\%8) Ama-

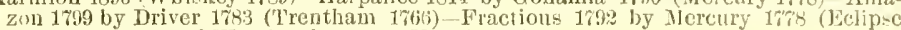
1764)-Dau. 1785 of Woodpecker 17\%3 (flerod 1758).

Thalebone 180\% (Waxy 1790)-Dau. 1812 of Selim 180\% (Buzzard* 178\%) Majem 1801 Sir Peter T. 1784 (Highflyer 1, 14 )-Dan. 1788 of Phenomenon $1 \% 80$ (Herod 17:8)Iation 1782 by Florizel 1\%68 (Herod 1758)

Master Henry 1815 (Orville 1799) - Boadicea 180\% by Alexander 1782 (Eclipse 1761)-Brunettc by Amaranthus 17C6 (Old England 1\%41) - Mayfly 1\%ir by Matcliem 1\%48 (Cade 1734) - Dau. 1755 of Anc. Starling 1738 (Old Starling 172\%).

Castrel 1801 (Bnzzard 16s\%) Idalia 1815 by Peruvian 1806 (Sir Peter T. 1784)-MLusidora 1801 by Meteor 1783 (Eelipse 1;64) Maid-of-all-Work 1786 by Highflyer 17rt (IIerod 1758)-Dan. $17 \% 1$ of Syphon 1750 (Squipt 1\%32)

Cain 1822 (Paulowilz 1813)-Lydia 18\%: by Poulton 1805 (Sir Peter T. 1784)-Variety 1808 by Hyacinthus 1797 (Coriander 1r86)-Sist. $1 \%$ co to Swordsman by Weazle $17 r 6$ Herod 1758)-Dau. of Turk 1763 (Reguhs 1739).

Camel 1822 (Whalebone 18,\%)-Banter 1826 by Master IIenry 1815 (Orville 1799)-Boadicea $180 \%$ by Alexander 1782 (Eclipse 1764) - Bruuette by Amaranthus 1766 (Old Eng land 1741) $\rightarrow$-Mayfly $17 \%$ by Matchem 1748 (Cade 1734)

Filho-da-Puta 1812 (Haphazard $179{ }^{\prime}$ ) - Finesse 1815 by Peruvian 1806 (Sir Peter T. 1784) - Violante 1802 by John Buli 1789 (Fortitude 17\%)-Dau. 1788 of Fighflyer 17\%4 Herod 1758)-Everlasting 17\% by Eclipse 1764 (Marske 1750)

Orville 1799 (Beningbrough 1691)-Emily 1910 by Stamford $1 \% 94$ (Sir Peter T. 1;81)Dat. 1799 of Whiskey 1789 (SaItram* 1780)-Grey Dorimant 1781 by Dorimant $17 \%$ (Otho 1\%60)-Dizzy $1 \% \sigma^{2}$ by Blank 1740 (God. Ar. 1724).

Bustard 1813 (Castrel $180 \mathrm{i}$ )-Johanna Southcothe 1811 by Beningbrough $1 \% 91$ (King Fergus 175)-Lavinia 1802 by Pipator 1786 (Imperator 1766)-Dau. 1790 of Highflyel 1771 (Herod 1758)-Dan. $177 \%$ of Carlinal Puff 1760 (Babraham 1740).

Buzzard* 1787 (Woodpecker 1773)-Dan. of Alexander 1\%82 (Eclipse 1764)-Dau. of Hightlyer 17\%t (Herod 1758) - Dau. of Alfred 17\%0 (Matchem 1748)-Dau. 1770 of Eugineer 1756 (Sampson 1745 )

T's Ditto 1800 (Sir Peter T, 1\%84)-Dau. 1791 of Mercury 1\%8 (Eclipse 1\%64)-Dau, 1; 6 of Herod 1758 (Tartar 1713)-Folly $17 \% 1$ by Marske 1\%50 (Squirt 1\%32)-Vixen 1753 by Regulus 1739 (God. Ar. 1721

Dick Andrews 179; (Joe Andlews 176) - Dan. 1803 of Gohanna 1r90 (Melcury 1778)Fraxinella 1793 by Trentiam 1766 (T. Swe pstakes 1r43)-Dau. 1785 of Woodpecker 1773 (Herod 1755)-Everlasting $17 \% 5$ by Eclipse 1764 (Marske 1750).

Traxy 1790 (Pot-8-o-'s 1\%,3) - Penelope 1598 by Trumpator 1782 (Conductor 176r)-Pmnella 1789 by Highflyer 17t4 (Herod 1;58)-Promise 1768 by Snap 1750 (Snip 1736)Julia 1756 by Blank 1740 (God. Ar. 1724).

Whitelock 1803 (Hambletonian 1792)-Dau. 1799 of Coriander 1786 (Pot-8-0-'s 17\%3)Irildooose 1792 by Highfyer 1764 (Herod 1758)-Colıeiress 1786 by Pot-8-o-'s $17 \% 3$ (Eclipse 1704)-Manilla 1wir by Goldfinder 1764 (Snap 1\%50).

Orville 1799 (Beningbrongh 1791)-Miss Grimstone 1796 by Weazle $17 \% 6$ (Herod 1758)Dan. of Ancaster 1768 (Blank 1740)-Dan. of Damascus Ar. 1751-Dau. of Sampson 1745 (Blize 1733).

Sir Solomon 1805 (*Tickle Toby 1786)-Dau, of Hickory 1801 (*Whip 1794)—Trumpetta 1797 by Trumpator 1782 (Conductor 1767 )-Sist. $1 \% 86$ to Lambinos by Highflyer 1 rra (Herod 1758)-Dau. 1775 of Eclipse 1764 (Marske 1750)

Orphan 1510 (Ball's Florizel 1801)-Lady Grey 181 \% by Robin Grey 1805 (*Royalist 1790)-Maria 1S02 by Mielzar 1791 *Medley 1\%66)-Dau. of *Highflyer 1784 (Highflyer 17\%1) -Dan. of *Fearnought 1755 (Regulus 1\%39

Beningbrough 1791 (King Fergus 17\%5) - Evelina 1791 by Highflyer 1\%4 (Herod 1758)Termagant by Tantrum 1760 (Cripple 1\%50) - Cantatrice by Sampson $1 \% 45$ (Blaze 1\%a3)Dall. 175\% of Regulus 1739 (God. Ar. 1\%24)

Whiskey 1789 (Saltram* 1780)-Y. Giantess $1 \% 90$ by Diomed* 1\% (Florizel 1768) Giantese 1762 by Matchem 1745 (Cade 1734)-Molly Long Legs 1753 by Babraham $1 \% 40$ (God. Ar. 1721)-Dan。 of Coles' Foxhunter 1727 (Brisk 1711).

Gohamna 1790 (Meremry 1778) - Chestnut Skim 1794 by Woodpecker 1\%3 (Herod 1\%8)Silver*'s dam 1780 by Heron 1758 (Tartar 1743)-Y. Hag 1761 by Skim 1716 (Starling

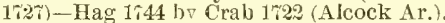

Hambletonian 1\%92 (King Fergus 1\%5)-Helen 1801 by Delpini 1\%81 (Highflyer 1\% Rosalind 1788 by Phenomenon 1780 (Herod 1758)-Atalanta 1769 by Natchem 1748 (Cade 1734) - Y. Lass of -the-Mill 1756 by Oroonoko 1745 (Crab 1722).

Diomel 1\% (Florizel 1\%68) — Fastianira 1\%96 by Rockingham 1\%81 (Highflyer 1\%it)Talitha 1782 by Trentham 1763 (T. Sweepstakes 1743)-Dau. of Bosphorus 1751 Ba raham 17.0)-D $\mathrm{D}$. of Forester 1750 (Forester 1\%36)

Hephestion 1808 (*Buzzard 1\%8\%) - Roxana 1\%98 by *Marplot $1 \% 81$ (Highflyer 1\% ${ }^{2}$ ) Juliet by *Mexican 17\%5 (Suap 1\%50)-Dau. of *Friar 1759 (South 1750),

Cook's Whip 1804 ("Whip 1704) - Jane Hunt 1796 by Hampton's Paragon 1788 (*Flimnap 1765) - Moll by *Figure $175 \%$ (Gley Figure 1\%47) -Slamerkin 1768 by *Wildair 1753 (Cade 1\%31) - *Cub mare 1762 by Cub 1739 (Fox 1714).

Albert 1798 (Americus 1793)-Dau. of Algerine (Dey of Algiers)-Dau. of Grey Alfred 1799 (Lindsay's Ar.) -Dau. of Americus 1793 ("Shark 1\% 1 ) -Dau. of *Medley 17\%6 (Gimcrack 1\%CG)-Dau. of *Shark 1\%1 (Marske 1\%50)-Dau. of *Fearnought $1 \% 5$ (Regulis 1739). 


\section{KINA $A$ IFONSO-COntinued.}

Fing Alfonso is a red bay, 16 hamls, with a star in his forehear, and is one of the truest and best shaped horses in the world. His heal is plitin lout well shaper, and set npon a good, strong misenlar neck, with wide, deep throttle, the shonler's oblicue, broml and well placed, and covered with snitalle musele; the chest is well shaped and full, with great rleyth of girth, the boty full and round, with the finest l,ack, hip and loin ever put on a hoise, being broad, well ronuded and slightly (nurvel. He has great length from the point of the hip to the whirlbone, thence to the point of stifle and hocks, being full of strength and muscle, which run into broad, powerful liocks, the legs and feet being somnd and good. His temper is of the liest. In aldition to his lonble eross of Glencoe, he has the WVaxy bloor throngh Web, Whisker and Whalebone, and is iubred to Sir Archy and imp. Shark, with many crosses of Herod and Eclipse in the collateral branches.

\section{IMPORTED KING GALOP.}

Located in the Iroquois Stud, Jas. B. Clay, proprietor, Lexington, Ky. Terms annually. Yearling sales in May each year.

Krxg Galop, bay horse, foaled 1835, bred by Mr. W. Barrow, imported by S. S. Howland, New York, by Galopin, son of Vedette, dam by King Tom, son of Harka way, out of Sunshine by Thormanby, ete. King Galop's breeding is gilt-edged. His sire Galopin, winner of the Derby in 1875, is the sire of Galliard, St. Simon, Oberou, Donovan, Corrie Roy and Hodwena, a remarkable galas of wimuers for so romg a horse. As a three-year old St. Simon won all of his races, which included the Epsom, Ascot and Newcastle Gold Cups and the Goodwood Cup, and all of his engagements, five in number, at two pears of age. Galliard won the Chesterfield and Prince of 'Tales' Stakes at York, 2,009 Guineas, St. James Palace stakes and Priuce of' Wales' Stakes at Ascot, aud was third for the Derby in 1883. As a two-year old Modwena won nine out of twelve races. Corrie Roy won the Cesarewitch, Goodwood Stakes, Great Ebor Handicap, aud other important races. Oberon won the Select Stakes, was second to Ormonde for the Champion Stakes at Newmarket, and won the Lincolnshire Handicap and other rices. Donovan won both the Derby and st. Leger in 889. These and winners like Fulmen, Sunshine, Little Sister, Arbaces, Galvanic, Gallopin Qneen, etc., have established Galopin, who is by Vedette, out of Flying Duchess by The Flyiug Dutchman, as one of the most successful sires in England. King Galop's dam is by King Tom, who was by Harkaway, ont of Poeahontas (dam of stockwell, "Emperor of Stallions," Rataplan, Knight of Kars and Knight of St. Patrick) by imp. Glencoe. King Tom is the sire of imp. Great Tom (sire of General Harding. Trrant, Telie Doe and of the dam of Proctor Knott), of imp. Phaeton (sire of 'F'en Broeck and King Alfonso), and of imp. King Ban (sire of King Fox and French Park). King Galop's second dant was Sunshine by Thorwanby, winner of the Derby in $1 \geq 67$.

Sunshine was a wonder on the turf: As a two-year old she was only defeated once, and then ran second. She wou the Woodcote Stakes, at Epsom; the July Stakes, at Newmarket; the North of England Biennial Stakes, at York; the Champagne Stakes, at Doncaster; a Sweepstakes, at Newmarket; walked over for the Bretby Stakes, at Newmarket; the Troy Stakes, at Stockbridge, and a Sweepstakes, at Newmarket. The last time she ran as a two-rear old she met her only defeat iu being beaten a head by Frivolity for the Middle Park Plate, at Newmarket, giving the winner 3 lbs., and beating Kingeraft (winner of the Derbs), Hawthorndeu (wimmer of the St. Leger) and thirteen others. As a three-year old Sunshine only started three times; she won the Coronation Stakes at Ascot, ran second to Gamos in the Oaks, and finished second to Normanhy in the Aseot Trieunial stakes. In addition to Sumray and Napoli, Suushine produced at the stud the winners Palermo and Newfielsl.

Smbeam by the noted Chanticleer, King Galop's third dam, was another great rare-mare, and is a two-year old was never nuplaced. She won the Corporation Stakes; the Half Holiday Nursery Handieap, at Manchester ; the Grand Stand Plate, same place; a Plate, at Newnarket, beating a field of nineteen; the Nursery Stakes, at Lirerpool; ran second to Condnctor for a Nursery Plate, at Liverpool; second to 


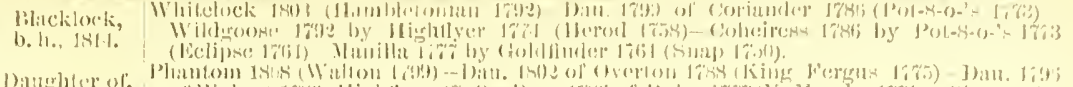

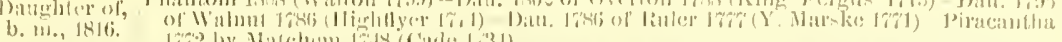

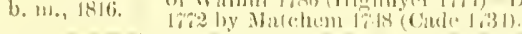

Muli110,

(at1on 1809 ( (

Le'li:1, (1)

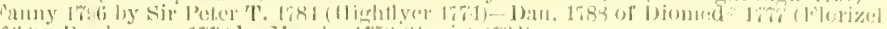

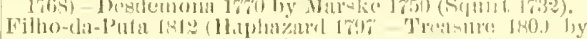

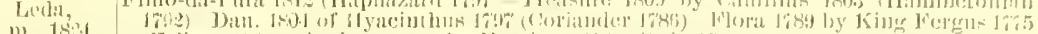

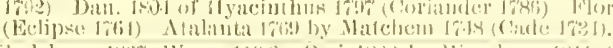

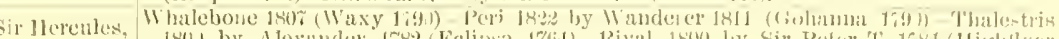

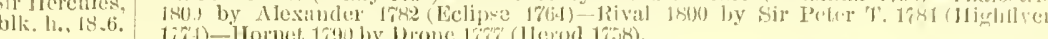

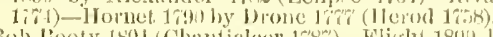

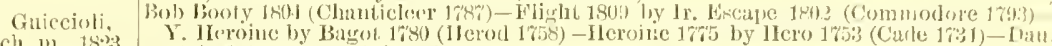

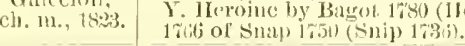

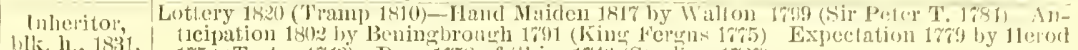

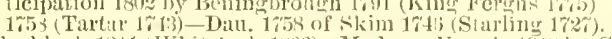

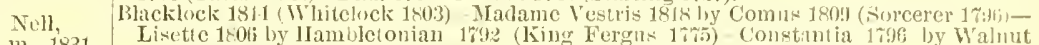

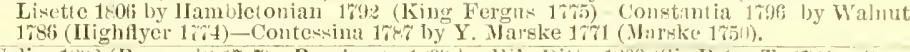

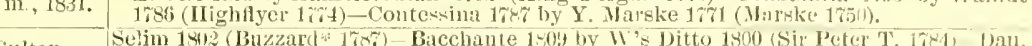
Sultan,

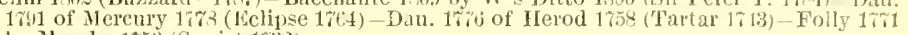
by Harske 1750 (Squirt 1732).

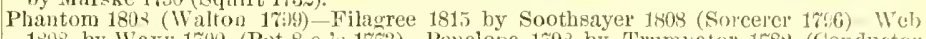
1803 by Waxy 17!n (Pot-8-o-' 17\%3) - Penclope 1792 by T'rumplot 178: (Conductor $\left.170^{\prime}\right)$-Prunella 1788 by ILighflyer $1 \%$. (IIelod 1758).

Cobweb,

Catton 180. (Golumpns 1802)-Orvillina 1804 by Beningbrough 1791 (Kine Fergus $17 \mathrm{n}$ ) Evelina 1791 by Hightlyes 1 rot (Herod 1758)-Termagant by Tantrum 1\%60 (Crijule 1750)-Cantatrice by Sampson 1745 (Plaze 1733).

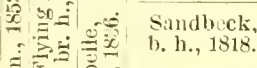

Amadis 180\% (Don Quixote 1\%84). Selima 1810 by Selim 1803 (Buzzard* 1786) - Dau. 1791 of Pot-8-o-'s 17.3 (Eclipse 176-1)-Editha 1781 by Herod 1758 ('1'artar 1748)-Elfida 1768 by Snap 1750 (Snip 1736).

bi. m., 18:3.

Whitelock 1803 (Hambletonian 1692)-Dau. 1709) of Coriander 1786 (Pot-8-0's $1731-$

Blacklock, Whildgoose 1792 by Highfler 17\%4 (Herod 175\%)-Cohciress 1786 by Pot-8-o.'s 17it) (Eclipse 1764)-Manilla 17\% by Goldtinder 1764 (Snap 1750).

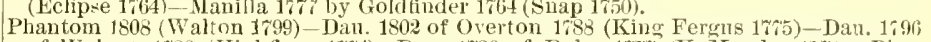
of Walnut 1786 (IIghflyer 17\%4)-Dan. 1786 of Ruler $17 \% 7$ (Y. Marske 17\%1)-Piracintha $17 \% 2$ by Matchem 1748 (Cade 1734).

Daunhter of b. n., 1816

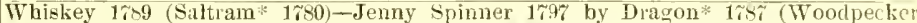

Juniper, 17\%3)-Dan. 17\%5 of Eclipse 1761 (Marske 1750)-Miss Spindleshanks 17i0 by Omar $175:$ ch. b., 18.5. (God Ar. 1721)-Dau. 1753 of Starltug 1\%2\% (Bay Bolton 1705).

Daughter of, Sorcerer 1796 (Trmmpator 1782)-Virgin 1801 by Sir Peter T. 1\%84 (Highflyer 1764)-Dan \begin{tabular}{l|l} 
Danghter of, & 1794 of Pot-S-o-'s 17\%3 (Echipse 1764)-Editha 1781 by Herod 1758 (Tartar 1743)-Ehrida \\
br. m., 1810. & 1763 by Snap 1750 (Snip 1 6 ).
\end{tabular} \begin{tabular}{l|l} 
Whisker, Waxy 1790 (Pot-8-1)'s 1773 )-Penelope 1798 by Trumpator 1782 (Conductor 176\%)-Pru- \\
b. h., 1812.
\end{tabular} b. h., 1812. by Blank 140 (God. Ar. 1\%24)

Octavian $183 \%$ (Slripling 1705)-Caprice 1797 by Anvil 1\% (Helod 1658)-Madcap 17it Floranthe, by Eclipse 1764 (1)arke 1750)-Sappho 1763 by Blank 1r40 (God. Ar. 1704)-Daul. 1750 of Plaze 1733 (Flying Childers 17'15).

b. m., 1818

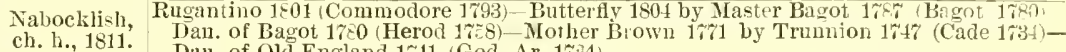
Din. of Old England 1\%t1 (God. Ar. 1\%24)

Iiss Tooly Teddy the Grinder 1798 (Asparagus 1786)-Lady Jane 1796 by Sir Peter T. 1784 (High-

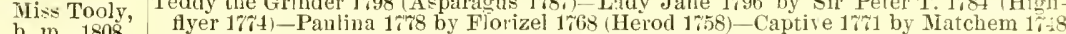

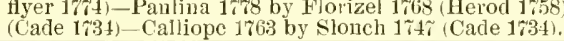

Sultan Selim 1802 (Buzzaid*1787)_Bacchante 1879 by W.'s Ditto 1809 (Sir Peter T. 1784)-Dau.

b. h., 1816. 1791 of Mercury $17 \% 8$ (Eclipse 1;64)-Dau. 1\%6 of IIerod 1758 (Tartar 1743)-Folly $1 \%$, by Marske 1750 (Squirt 1732)-Vixen 1753 by Regulus 1739 (God. Ar. 1\%24).

Trampoline, Tramp 1810 (Dick Andrews 17.7) - Web 1808 by Waxy 17.0 (Pot-8-o-'s 173)-Penelole Trampoline, 1\%95 by Trumpator 1792 (Conductor :767)-Prumella 1788 by Highflyer 1rit (Herod 1759)-Promise 176t by Snap 1750 (Snip 1766 ).

Nuley, Orville 1793 (Beningbrongb 1791) Eleanor 1798 by Whiskey 1789 (Saltram\% 1780) - I.

b. h., 15io. Giantess 179. by Diomed 17i (Florizel 1768)-Giantess 1769 by Matchem 17ts (Cade 1731) - Molly Long Legs 1753 by Batrabam 1710 (God. Ar. 1721).

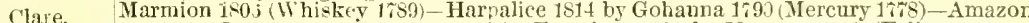

b. m., 1824. I 1799 by Drivel 1783 (Trentham 1766) - F'actions 179:2 by IIcrcury 17\%8 (Eclipse 1\%64)Dain. 1,85 of W wodpecker $1 \% \% 3$ (Herod 1\%58).

Pantaloon, Castrel 1801 (Buzzard 178\%)-Idalia 1815 by Peruvian 1866 (Sir Peter T. 1784)-Musidor

ch. h., 1621. 1804 by Meteor 1783 (Eclipse 1764)-Naid-of-all-Work 1786 by Hightlyer 1ri4 (Herod

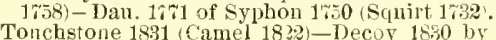

Pliryne,

by Filbo-da-Pita 1812 (Haphazard 169\%)-

br: m., 1840.

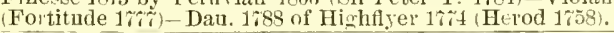
Nu'er Molnch Muley 1810 Orville 1799 -Nancy 1813 by Dick Andrews $179 \%$ (Joe Andrews $178 \%$ )

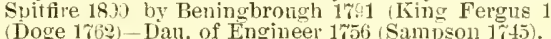

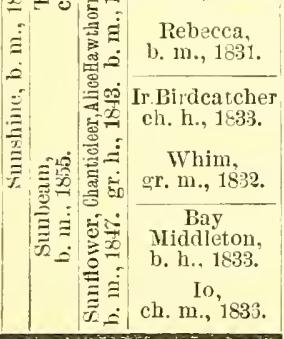

Lottery 18.0 (Tramu 1810-Dan. 1815 of Cervantes 1806 (Don Quisole 1784)-Anticipation 1802 by Beningbrough 1791 (King Fergu- 17\%)-Expectation $17 \% 9$ by Herod 1759 (Tartar 1\%43)-Dan. 1758 of Skim 174 i (Starling 1\%\%

Sil Hercules 182; (II hale one 180\%) Gaiccioli 1823 hy Bob Booty 1804 (Chanticleer 173\%) Flight 1809 by Ir. Ezcape 1802 (Commodore 1\%93) - Y. Heroine by Bagot 1780 (Herod 1758) Heroine 1\% 15 by Hero 1753 (Cade 1 234 ).

Ir. Drone 1823 (Master Rokert 1811) - Kiss 182\% by Wasy Pope 1806 (Taxy 1790)-Dau. 1810 of Champion $17 \%$ (Pot- -0 -'s 17\%3) - Brown Fanny 1\%:9 by Maximin 1785 (Ever-

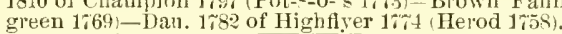

sultan 181ti (Selim 1832)-Cobweb 1831 by Phantom 1803 (Walton 1799)-Filagree 1815 by

Soothsayer 1808 (Sorcerer 1795)-Web 1878 by Waxy 1790 (Pot-S-0-'s 17\%3)-Penelope $1 \% 93$ by Trumpator 1782 (Conductor $1 \% 6 \%$ ).

Tanrus 1826 ([Phantom or] Mrrisco 1819)-Problem ch. m. 18:3 by Merlin 1815 (Castre] 1801)-Pawn b. m. 1803 by Trumpator $178 \%$ (Conductor $176 \%$ - Prunella b. m. 1788 by Highflyer 1\%4 (Herod 1758 )-Promise br. m. $1 \% 68$ by suap 1250 (Snip 1726)-Julia $1 \% 18$ (Jigg)-Bonny Lass b. m. 1723 by Bay Boltro 17 (G) (Grey Hantboy)-Dau. of Darley Ar. 1699-Dan. of Bjerly Turl -Dau. of Tafolet Burb-Dau. of Place's White Turk-Natual Barbinare of Mr. Tregonwci:" 


\title{
IMPORTED KING GALOP-Continued.
}

Perfection for the Findon Stakes, at Goodwool ; second to Gildermire for the Rawcliffe Prodnce Stakes, at York, and ran third in another race. As a three-year old she won the Palatine Stakes, at Chester; the Biennial stakes, at Bath; the Coronation Stakes, at Ascot: a Sweepstakes, at Goodwood: the Chesterfiel Cup, the same place; the St. Leger, at Doncaster; walked orer for the Don Stakes and the Select Stakes, and ran second to stapleton for a Handicap Plate. As a four-year old Sunheam won a Sweepstakes at Goodwooi, over the Cup course, and ran second to Znyder Zee for the Chesterfield Cup, beating twenty-one opponents. In arkition to Sinshine (King Galop's (lam). Sunbeam produced anougst others Merry Sunshine (winner of the Zetland Stakes), and the grand race-horse Phohus, who, as at three-jear oll. also captured the Zetland Stakes, in adilition to the Colnmn Produce Stakes, at Newmarket, the Benuington Stakes, the Beanfort Prorlnce Stakes, ete.

King Galop promises well in the stnd. He traces in the female line to the Rosal mare, from which descent in direct line Woodpecker, W'halebone, Whisker, Partisan, imp. Glencoe, Melbonrne. Bend" or, Robert the Devil, Bay Middleton, imp. Mortemer and all the Prunella family.

\section{KINGLIKE.}

WINNER OF THE YURSERY STAKES AND HARVEST HANDICAP.

\author{
Is a private stallion in the Brookdale Stud of the estate of D. D. Withers. \\ Tearlings sold anmully.
}

Kixglike, bay horse, foaled 1880, bred in the Brookdale Stud, by imp. Fing Eruest, son of King Tom and Emestine by Touchstone, dam Mimi by imp. Eclipse. son of Orlando, grandam Hennie Farrow by imp. Shamrock, ete. Kinglike was an excellent race-horse, won the Nursery stakes at Jerome Park at two jears old, in a good field of twelve colts. At three years old won purse at Monmouth Park, $1 \frac{1}{\ddagger}$ miles, in 2.12, defeating Parole, Fair Count and Heel-and-Toe; won Handicap Streepstakes,

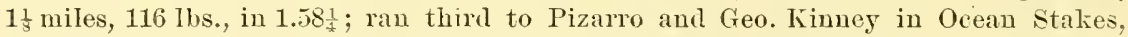
$1 \frac{1}{\frac{1}{8}}$ miles, in 1.56 $\frac{1}{2}$; was third to Renegade and Gonfalon, in Barnegat Stakes, $1 \frac{1}{3}$ miles, in 2.39⿱艹 5 lbs., with five others behind him; ran third to Breeze and Rica, 1 mile, in 1.43, with five others behind hin; second to Pizarro, 1 mile, in $1.433^{3}$, with four other's behind him. At four years old ran second to Miss Woodford in Coney Island Stakes,

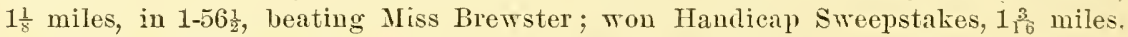

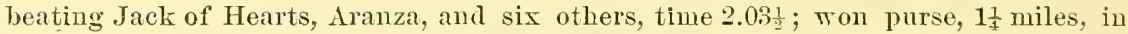

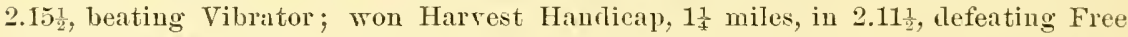
Gold, Rica, Monitor, Barnes and five others : ran third to Drake, Carter and Heel-andToe, in Monmouth Handicap, $1 \frac{1}{2}$ miles, in 2.37 $\frac{1}{2}$, Lonisette, Monitor and Barnes behiuct him; won Handicap Sweepstakes, $1_{4}^{\frac{1}{4}}$ miles, in 2.11 him; was third to Tom Martin and Ferg Kyle in Twin City Handicap, 1ج miles, in $2.10 \frac{1}{4}$, fifteen others behind him. He is descended from a grand racing family. From it came Electra, dam of Rebeca, Marian, Winifred, Elizabeth (dam of Eminence), Hidalgo, El Dorado, Yolande (dam of Beverwyck) and Fitz James, also Hennie Farrow, Ida, Madam Bosley. Hennie Farrow being the dam of Privateer, Ballerina (dam of Ballet Girl, Balinette, Countess Zicka and Lou Spencer), Maytlower (dam of Joe Hooker, Wild Rose, Warwick and Amnie Laurie). Mimi (dam of Mark. Mikado, Viceroy and Stately), the successful sire Shannon, the good race-horse and sire Flood, and the great race-mąre Mollie MeCarty, dam of Fallen Leaf and Mollie McCartş's Last.

Kinglike has only covered a few mares, but is the sire of those good horses Charley Post, Text and the Lanra Gonli colt, a wimer. 


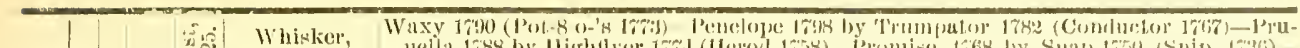

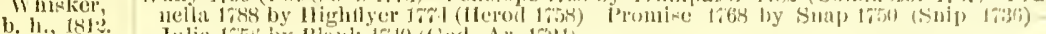

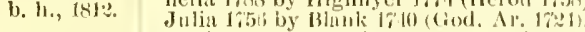

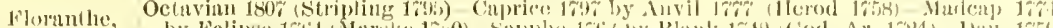

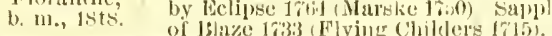

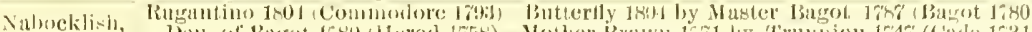

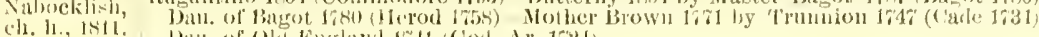

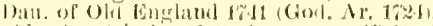

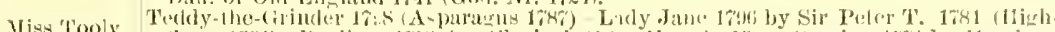

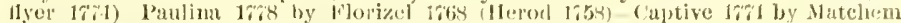

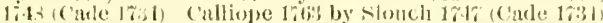

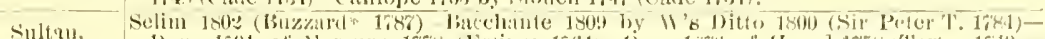

b. 11., 1516 .

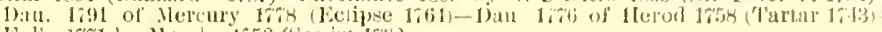
Folly lort by Matske 1650 (Squixt 1732).

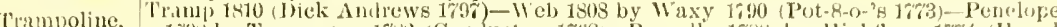

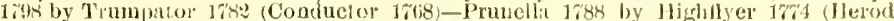
1753)- P'omise 1;63 by Snap 1750 (sni\}) 1736).

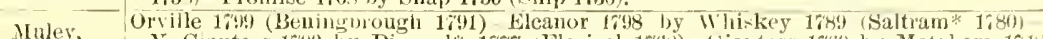

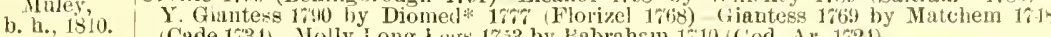
(Cade 1734) - Molly Long ixys 1753 by Habrabaw 1710 (God. A1. 1721).

Clare Marmion 1806 (Whiskey 169)-Harpalice 1814 by Gohama 160 (Nereury 1 78 )-Ama-

b. 11., 18:4 Zou 17\%9 by Driver 1783 (Trenthau 1766)-Fructious 179: by Mrreury 1678 (Eclipse

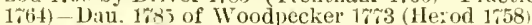

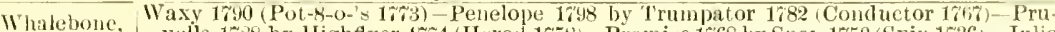

br, b. $180^{\circ}$ nella 1788 by IJighflyer 1764 (H (rod 1658)-Promise 1768 by Snap 1750 (Snip) 1736)-Julia 1756 by Blank $17 t 0$ (Goll. Ar. 1724).

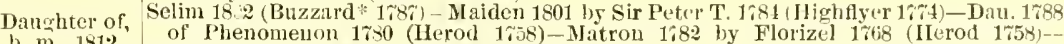

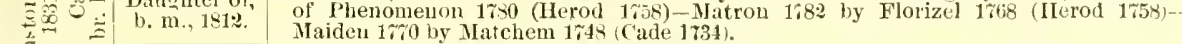
Orville 1799 (Beningbrough 1791) - Miss Sophí 1805 by Stamford 1704 (Sir Peler T.

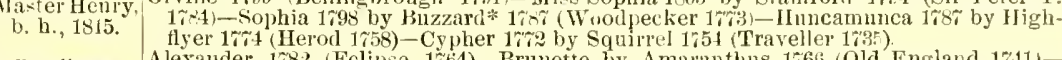

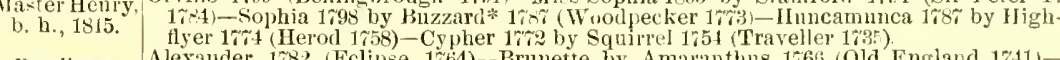

Boadicea, Alexander 176 by Watehem 1748 (Cade 1734)-Dan. 1755 of Anc. Starling 1738 (Starling b. m, 180\%. 172\%)-Look-at-me-Lads 1731 by Grasshopper (Byerly Turk).

Whisker Waxy 1790 (Pot-8-o-'s 17T3)-Penelope 1798 by Trumpalor 1782 (Conductor 1667)-Pril-

b. h. nella 1785 by Highflyer 1744 (Herod 1758)-Promise 1768 by Snap 17.0 (Suip 1736)Julia 1756 by Blank 1740 (God. Ar. 1\%:4).

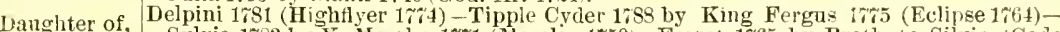

b. $180^{\circ}$, Sylvia 1783 by $\mathbf{Y}$. Marske $1 \% 71$ (Narske 1700 - Ferret 1665 by Broth. to Silvio (Cade 1734)-Dat. of Reguius 173) (God. Ar. 1724).

Tiresias 1816 (Soothsayer 1808)-Rivulet 1813 by Rubens 1805 (Buzzard* 168\%)-Dau.

b. h., 1825 . $1 \% 93$ of Pot-8-o-'s 1\% $\% 3$ (Eclipse 1\%64)-Huneamunca 1\%8\% by Highflyer 1\% 4 (Herod 1758)-Cypher 17\%2 by Squirrel 1754 (Traveller 1735 ).

Otis,

Bustard 1801 (Buzzard* 1787) -Dau. 1813 of Electiou 1804 (Gohinna 1790)-Dau. 1791 of

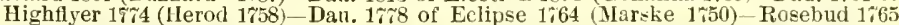
by Snap 1750 (Nnip 1\%26).

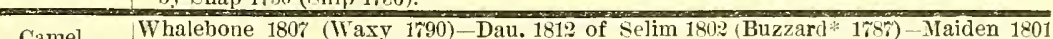
br. h., 1832 .

by Sir Peter T. 1781 (Hiwhflyer 1774)-Dau. 1788 of Phenomenon 1780 (Herod 1758)viatron $178 \%$ by Florizel $1 \% 68$ (Herod 1758).

Banter, Master Henry 1815 (Orville 1799)-Boadicea 180; by Alexander 1782 (Eclipse 1764)-

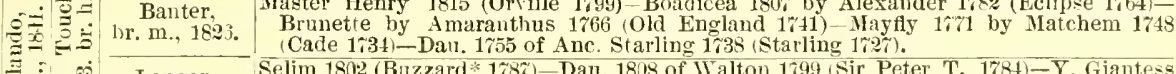

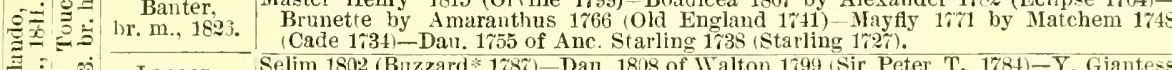

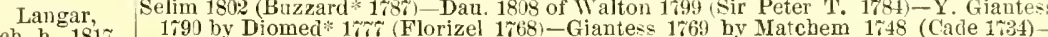
Molly Long Legs 173 by Babraham 1740 (God. Ar. 1,24).

Kite, Bustard 1813 (Castrel 1801) - Olympia 1815 by Sir Oliver.1800 (Sir Peter T. 1784) - Sco-

b. m., 1821. tilla 1795 by Auvil $17 \% 7$ (Herod 1758)-Scota 1783 by Eclipse 17et (Míarse 1750)Harmony $17 \% 5$ by Herod 1758 (Tartar 1713 ).

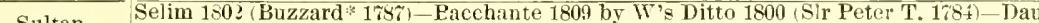

bultan, 1791 of Nercury 178 (Eelipse 1764)-Dan. 1\%6 of Herod 1758 (Tirtar 1\%43)-Folly 1\%1 by Marske 1750 (Squirt 1732).

by Marske 1750 (Squirt 1732).
Phantom 1808 (Walton $1 \% 99$ )-Filagree 1815 by Soothsayer 1808 (Sorcerer 1\%96)- $\pi \mathrm{eb}$ 1803 by Waxy 1790 (Pot-8 o-'s 17\%3)-Penelope $179 \mathrm{~s}$ by Trumpator 1782 (Conductor 1;60)-Prunella 1788 by Highflyer 1\%t4 (Herod 1758).

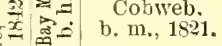

Partisan 1811 (Walton 1799-Ridicule 1810 by Shutle $1 \% 93$ (Y. Marske 1\%al)-Dau. 1792

Godolphin,

b. h., 1818 . of Dungannon 1780 (Eclipse 1761) -Letitia 1783 by Highflyer 17\% (Herod 1758)-Dau. of Matehem 1718 (Cade 1731)

Sister to Phantom 1808 (Walton 1799)-Filagree 1815 by Sooth-ayer 1808 (Sorcerer 1\%96) - Web Cobweb,

ch. m., $18: 0$. 1803 by Waxy 1793 (Pot-8-o-'s 1778)-Penelope 1793 by Trumpator 1782 (Conductor 176\%)-Prunella 1788 by Highflyer 17\% (Herod 1758).

Sir Peter T. 1\%84 (Highflyer 174)-Arethusa 1792 by Dungannon 1780 (Eclipse 1764)-

b. h., 1789 . Dau. $17 \%$ of Prophet $1 \% 60$ (Regulus 1739)-Virago $1 \% 61$ by Snap 1750 (Snip 1\%36)-Dau. of Regulus 1739 (God. Ar. 1724).

Daughter of, Dick Audrews 1797 (Joe Andrews 1\%78)-Dau. 1800 of Trumpator 1789 (Conductor 176\%)-

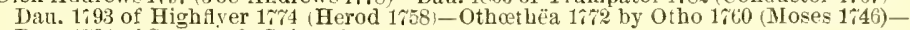
Dau. 1764 of Snap 1750 (Snip 1736 ).

b.

Comus 1809 (Sorcerer 1796)-Rosette 1803 by Beninghrongh 1\%91 (King Fergus 17\%) Rosamond 1788 b7 Tandem ifis (Syphon 1750)-Tuberose 17\%2 by Herod 1758 (Tartar 1743)-Grey Starling 1745 by Starling 1\%27 (Bay Bolton 1\%05).

Rereller,

Defiance, Rubens $1805^{\circ}$ (Buzzari 178\%)-Little Folly 1806 by Highland Fling 1798 (Spadille 1\%s1)

(h. 1\%48)-Magnolia $1 \% 71$ by Marske 1750 (Squirt 1732).

Dhitelock 1803 (Hambletonian 1692)-Dau. 1699 of Coriander 1786 (Pot-8-0-'s 1) 1 3 )

b. h., 1814

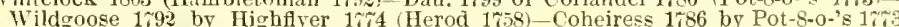
(Eelipse 1\%64)-Nanilla $1 \% \%$ by Goldtinder $1 \% 64$ (Snap 1\%50).

Ianuella, Dick Andrews 1797 (Joe Andrews 17\%)-Mandane 1800 by Pot-8-0-'s 17i3 (Echpse b. 1761)-Y. Camilla 1787 by Woodpecker $17 \% 3$ (Herod 1758)-Camilla 1\%rs by Trentham 1766 (T. Sweepstakes $1 \% 43$ )-Coquette $1 \% 65$ by Compton Bal'b.

Facolet 1806 (:Citizen 1785)-Nadam Tonson 1814 by Top Gallant (Gallatin 1799)Dan. of Barry's Grey Medley (*Medley 1; 76 )-Dau. of *Oscar $(Y$. Snip 1750Dau. of * Fearnought 1755 (Regulns $1 \% 39$ ).

Sir

Nancy Nichol

Eagle 1796 (Volunteer 1780)-Bet Bosley ch. m. 1815 by Wilkes ${ }^{*}$ onder 1800 (*Diomed 17\%)-Simmes' br. m. by Chanticleer (Symmes' Wildair 1\%6\%)-Dan. of *Stirling 1is (Volunteer 17S0)-Dau. of Clodius 17\% (*Janus 1\%16)-Dan. of *Silvereye (Cuilet)

Dau. of * Monkey 1725 (Lonsdale B Ay Ar.) - Imported mare from the Stud of Mr. Harrison of Brandon. 


\section{IMPORTED KINGSTON.}

Owned by Messis. S. Sanford \& Son, Hurricane Stud, Amsterdam, 1. I. Yearlings sold anmally.

Tingston, chestnut horse, foaled 1882, bred by Mr. S. Mason, imported 1887, br Hampton, son of Lord Cliflen (winner of the St. Leger) and Lady Langden, dam of Sir Berys by Kettledrum (wimner of the Derby), son of Rataplan, own lirother to Stockwell, ont of Haricot (dam of that marvellous mare Caller Ou), which was out of the famous Qneen Mary (dam of imp. Bonnie Scotland, Blink Bonny, winner of the Derlyy and Oaks, and dam of Blair Athol, winner of the Derby, St. Leger, etc.). Hampton was a first-class race-horse, winner of the Goodwood and Doncaster Cnps, in ardition to the Northumberland Plate, and also the Goodwood and Metropolitan Stakes, etc. At the stud his services hare always been in the greatest demand, and he has stood at the head of the wimning stallions in England, where his book was full three years in advance. He has sired Merry Hampton (winner of the Derby), Ayrshire (winner of the 2,000 Guineas, Derby, etc.), Reve d'Or (wimner of the Oaks, ete.), Royal Hampton (winner of the City and Suburban, ete.), Gay Hampton (a good stake winner) and hosts of other good ones. Last Love, Kingston's dam, prodnced the winners Courtier by King of 'Trumps, Hymen and Bonaparte by Voltigeur, and Mandeville by Mandrake. Her sire, Annandale, a son of Tonchstone, ran second in the Derby to Merry Monarch, beating. Weatherbit, Idas, Mentor, John Davis and twenty-five others. He also ran second to Weatherbit in a Sweepstakes of 300 sorereigns each, $3 \frac{5}{8}$ miles, at Goodrood ; ran second to Queen Mab in the Aseot Stakes, beating twelve other cracks; won Her Majesty's Plate at Chester, about $2 \frac{1}{6}$ miles; won the Queen's Plate, 3 miles, at Shrewslunry; won the Caledonian Handicap, 2 miles, carrying top weight, in addition to other good performances. He was a hali brother to one of the greatest of all race mares, viz., Alice Hawthorn (dam of Thormanby, winner of the Derby, and also of those grand performers Onlston, Findon, Lady Hawthom, Conwold and Sweet Hawthorn, whose danghter, Rebecea, was a star of the first magnitude, and another of her daughters, Fleur d'Oranger, also proved a winner, and produced the winner Grallab). Fair Helen, another of Annandale's half sisters, prodneed Lord of the Isles, who won the 2,000 Guinoas and sired the great Seottish Chief, ete.

Executrix, the grandam of Kingston, was by Liverpool (sire of Lanereost), and a half sister to the great race-horse Inheritor, winner of many gold cups, King's and Qneen's Plates. Kingston only started in one race at Kempton Park, when he ran into a fence and was permanentiy injured in his shonlders. He is a horse of fine size and great substance, handsomely bred from a great racing family.

From the Layton Barl mare have descended in direct female line Young Greyhound, Cartonch, Natehem, Young Cade, Drone by Herod, Andubon, Philammos, St. Honorat, Kentueky, Dauiel Boone, Gilroy, Iroquois and all the Maguolia family. 


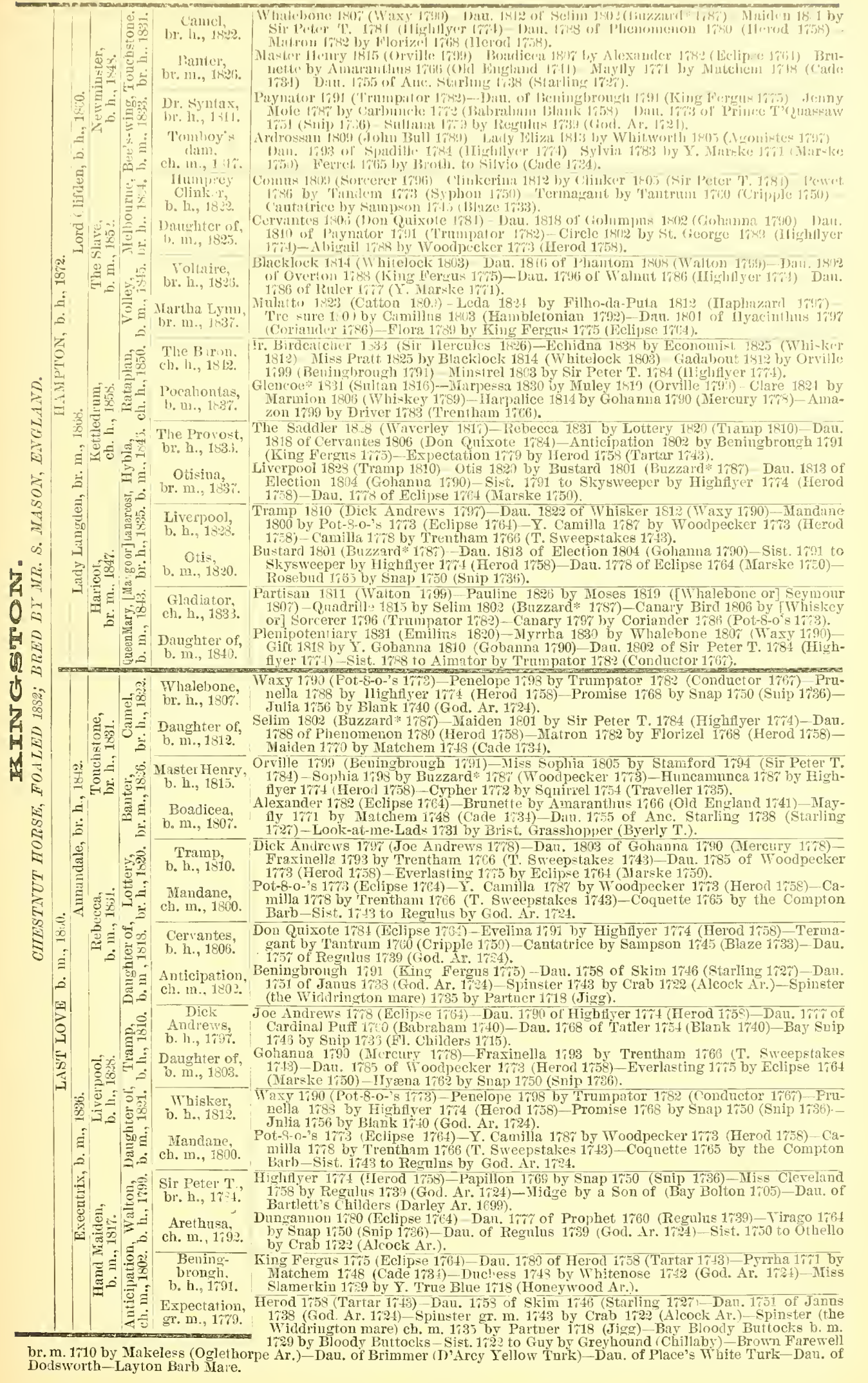




\section{KNIGHT OF ELLERSLIE.}

The property of L. O. Appleby, Monmouth County, N. J.

Knight of Ellerslie, bay horse, foaled 1881, bred by Capt. R. J. Hancock, Ellerslie Stud, Va., by Eolus, son of imp. Leamington and Fanny Washington by Revenne, son of imp. Trustee, dam Lizzie Hazlewood by Scathelock, son of imp. Eclipse, grandam War Song, the dam of Eole, St. Saviour, Eon, etc., by the great War Dance, tracing through Eliza Davis, dam of War Cry, to the noted imp. Melrose by Melbourne, she the dam of Target (the dam of Creedmoor, Britomarte, Rifle, etc.), Moss Rose (the dam of Hard Wood, Ben Wade, etc.), Melbonrne Jr., John Porter, ete. Lizzie Hazlewood's eolts all race, she being the dam of Knight of Ellerslie, Thomasia, Charlie Dreux, winner of the Van Courtland Stakes, Westchester Handicap, defeating the noted Firenzi, Charley Arnold, etc.

Knight of Ellerslie was a superior race-horse. When three years old won a purse, 1 mile, with 95 lbs., in 1.491 ; won Army and Nary Stakes, $1 \frac{1}{8}$ miles, 118 lbs., on

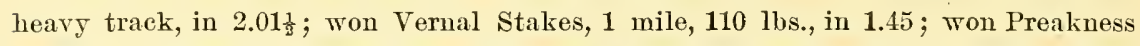
Stakes, $1 \frac{1}{2}$ miles, in $2.39 \frac{1}{2}, 110 \mathrm{lbs}$, and was second to Panique in the Belmont Stakes, $1 \frac{1}{2}$ miles, in 2.42, with Himalaja and Vocalie behind him. He was unplaced in the Emporinm, in which race he was injured and did not start again.

Knight of Ellerslie descends in direct female line from a sister to Old Merlin by Bustler, to which trace Dr. Syntax, the sire of the noted Bee's-wing, Little Red Rover, sire of the dam of Buccaneer. 


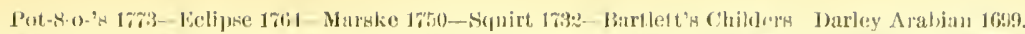

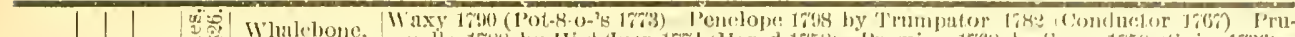

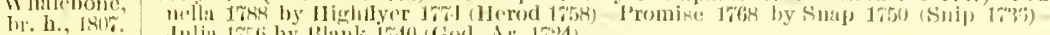

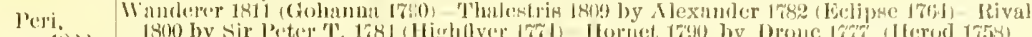

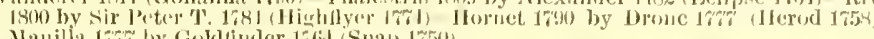

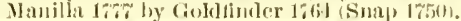

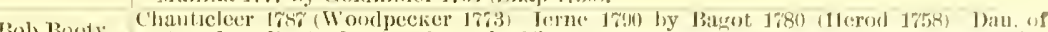

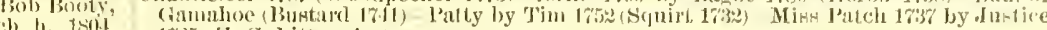

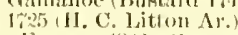

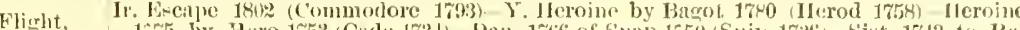

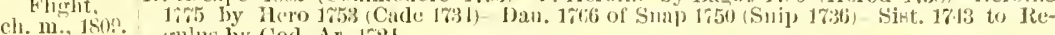
inulus by God Ar. Irat.

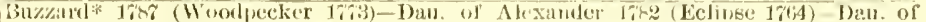

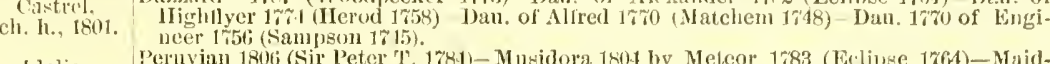

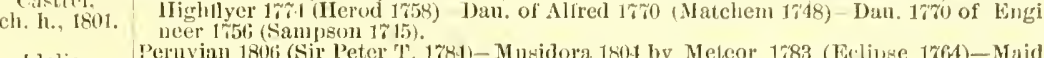

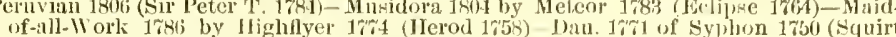
173:) - Dam. of Rerutus 173!) (God. Ar. 17:4).

Talia,

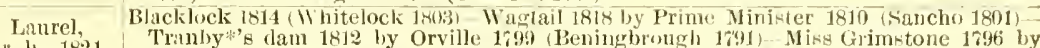

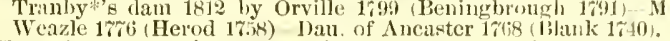

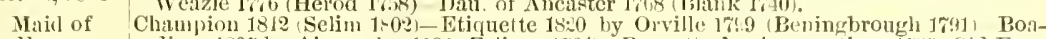

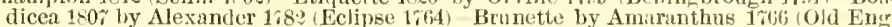
land 1745$)$ - Mayfly $17 \% 1$ by Matchem 1748 (Cade 1734).

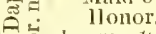

1)

Golumpus 1802 (frohanna 1790) Lucy Gray 1804 hy Timothy 1794 (Delpini 1781)- Lncy

Catton, 178!) by Florizel 1\%68 (Herod 1\%58)-Frenzy 17\%1 by Eclipse 1\%61 (Mar-ke 1750)-Dau of Encineer 1756 (Sampson 1745).

Emma.

Whisker 1812 (Waxy 1690)-Gibside Fairy 1811 by Ilermes 1790 (Mercury 178)-Vicisgitule 1800 by Pipator 1786 (Imperator 176 ) - B trice 1791 by Sir Peter T. 1784 (Highflyer 174.-Pyrha 17i'1 by Matchem 1748 (Cade 1734).

ch. in., $18:$

Sir Archy 1805 (*Diomed 1\% D) Dau of Citizen 1785 (Picolet 1763)-Dau, of Commu tation (Symmes' Wildair 1767)-Dan. of 'Dare Devil 178\% (Magnet 17\%0)-Sally Shark by Shark 1\%' (Marske 1750).

Sir Charles

Virginian 1815 (Sir Archy 1805)-Dau, of *Bedford 1792 (Dungannon 1780)-Dau. of Bellair 1:8\% (* Medley 1\%6)-Dau. of "Shark 1\%1 (Marske 1; Willair 1706 (*Fearnought 1755).

क्. Mischief,

b. b. m., 1820

Sir Arehy,

b. l1., 18 i)

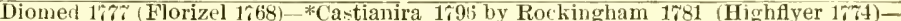
Tabitha 1 r82 by Trenlham 1766 ( $T$. Sweepsiakes 1743)-Dau. of Bosphorus 1751 (Babraliam 1740)-Dan. ol Forester 1750 (Forester 1736).

Chance 1797 (Lurcher 1789)-Dau, of *Eagle 1796 (Volunteer 1780)-Maria 1805 by Bay Tankee (President 1788)-Green's Celer mare by Meade's Celer 1674 (*Janus 1746)Dau. of Partner 1755 (*Traveller 174\%).

Contention, Sir Archy 1805 (*Diomed 17\%)-Dau. 1768 of *Dare Devil 1787 (Magnet 17\%0)-Dau. 1692

ch. h., 1815. of Symmes Wildair 1\%6r (*Fearnonght 1755)-Piccadilly by Y. Fearnought $1 \% 7 \%$ (*Fearuought 1755)-Dan. of Godolphin 17\%0 (*Fearnought 1755) Daughter of, *Speculator 1795 (Dragon 1\%s\%)-Pompadour by "Valiant 1756 (Dormouse 1738)low Turk)-Dau. of Paget Turk.

Camel 1822 (Whalebone 180\%)-Banter 1826 by Master Henry 1815 (Orville 1799)-Boa-

dicea 1-07 by Alexander 1782 (Eclipse 1764)-Brunetle by Amaranthus 1766 (Old Eng land 1\%11) - Jayfly $1 \%$ w by Matchem 1748 (Carle 1\%34).

Vulture, ch. m., 1833.

Lanorar 181 (Selim 1802)-Kite 1521 by Bustard 1813 (Castrel 1801)-Olympia 1815 by Sir Oliver 1800 (Sir Peter T. 1784) - Scotilla 1755 by Anvil 1\%, (Herod 1758)-Scota $178 ?$ by Eclipse $1 r^{\circ} t$ (Marske 1750 )

Bay

b. b., 1833 .

Sultan 1816 (Selim 180:) - Cobweb 18:1 by Phantom 1898 (Walton 1799)-Filagree 1815 by Soothsayer 1808 (Sorcerer 1796) - Web 18 by Waxy 1790 (Pota8-0-'s 17/3)-Penelope 1798 by Trumpator 1782 (Condnctor 1767 )

E. Flycatcher

Godolphin 181s (Partican 1811) - Sist 18:0 to (Cobweb br Phantom 1808 (Talton 1799) Filagree 1815 by Soothsayer 1808 (Sorcerer 1796) - Web 1808 by Waxy 1790 (Pot-8-0-' 1; 73 ) Penelope 1795 by 'Trumpator $178 *$ (Condnetor 176\%)

*Trustee, Catton 1809 , Golımpu-1802) Emma 1824 by Whisker 1812 (Waxy 1790)-Gibside Fairy 1811 by Hermes 1790 (Mercury 1778)-Vicissitude 1800 by Pipator 1786 (Imperator

ch. h., 1829. 17\%6-Beatrice 1791 by Sir Peter T. Iis4 (Higlifyer 174).

Rosalie

Somers,

b. $11 ., 18$ is

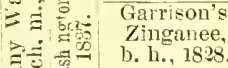

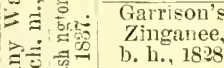
Dau. of Bedford 1792 (Dungamon 1\%80)-Dau, of Bellair 1786 (*Medley 17\%6)-Dan. of Shark $1 ; 71$ Marke 1\%0).

Stella,

* Archy 1805 (*iomed 17\%) - Niss Chance by *Chance 179\% (Lurcher 1789)-Dau. o celer mare by Jeade's Celer 1 wis

Contention 1815 (Sir Archy 1805 - Dau of * Speculator 1795 (Dragon* 1787)-Pompadour by Valiant 1756 (Dormouse 1738)-*Jenny Cameron by Cuddy 1727 (Fox 1714)-Miss Belvoir by Grey Grautham (Brownlow Turk

Pimoleon 1813 (Sir Archy 1805)-Dau, 1814 of Ball's Florizel 1801 (*Diomed 1\%r )-Dan. 1799 of Alderman 178 (Pot-8-0-'s 17\%3)-Dau, of *Clockfast 1774 (Gimcrack 1760)Dau. of Symmes' Wildair 1767 (*Fearnought 1755)

हैं $\mathrm{ch}$. h., 1833 .

Sarpedon 1898 (Emilins 1820)-Rowena 1826 by Sumpter 1818 (Sir Archy 1805)-Lady Grey 1817 by Robin Grey 1805 (*Royalist 1790 -Nlaria 1802 by Melzar 1791 ( Medley $17 \% 6)$-Dan. of $*$ Highflyer 1784 (Highflyer 1\%4).

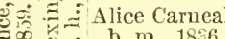
b. m., $18: 6$.

* Glencoe,

Snltan 1816 (Selim 1802)-Trampoline 1 - 525 by Tramp 1810 (Dick Andrews 179\%)-Web 1808 by Waxy 1790 (Pot-8-0-'s 1773)-Penelcpe 1798 by Trumpator 1782 (Condmetor $\left.1766^{*}\right)$ - Prunella 1788 by Highflyer 17 , 4 (Herod 1758).

*Galopade, Catton 1809 (Golumpus 1802 )-Camillina 1822 by Camillus 1803 (Hamlletonian 1\%92)-

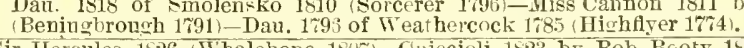

is $\mathrm{gl}, \mathrm{m}, 1828$

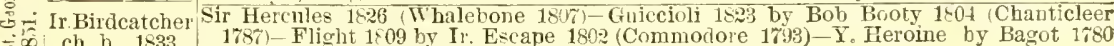

$+\infty$ ch h, 1830 (Herod $1758,-$ Heroine 1775 by Hero 1753 (Cade 1734)

Wi Maltese.

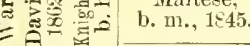

Hetman Platoff 1630 (Bintandorf 1801) - Taterwiteh 1833 by Sir Hercules 1826 (TVhalebone 180 ) - Maly Anne 1860 1)y Waxy Pope 1803 ( Waxy 1790) Witch 1811 by Sorcerer 1793 (Trumpator 1782)-Miss Buckle 1804 by Precipitate*178\% (Mercuty 1\%:8).

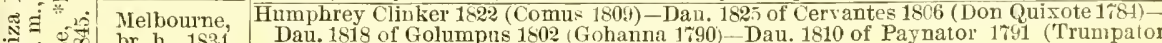
Dau. 1818 of Golumpus 1802 (Gohanna 1790)-Dau. 1810

Buley Moloch 18.50 (\$uley 1810) - xist, ch, m. 1832 to Righton by Palnerin 1816 (Amadis

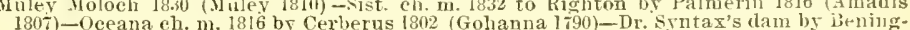
brougl 1791 (King Fergus i7t5)-Jemn Mole b. m. I787 by Carbmele litz Balraliam brougl 1791 (King Fergus 175)-Jenny Mole b. m. 787 by Carbuncte 172 (Batraliam Blank 1739 (God. Ar. 1724)-Dau. of Partner 1718 (Jigo)-Dau, of Gallant's smiling Tom Ii24 Ius 1739 God. Al. 724)-Dau. of Partner 1 8 (Jigg)-Dan. of Gallants smith (Conrer Ar.)-Traveller"s dam b. m. by Almanzor Tor (D'A Tarley Ar. 1699)-Sist. to Bar bollow Turk)-Dau. of D'Arcy Diamoud (Helmsley Turk)-Sist. to

Herlin by Bustler (Helmsley Turk). 


\section{IMPORTED LAUREATE.}

Imported and owned by Messrs. Stephen Sanford \& Sons, Hurricane Stud, Ansterdam, N. Y. Yearlings sold anmully.

Laureate, brown horse, foaled 1879, bred by Mr. Gosden, by Rosicrucian, son of Beadsman and Madame Eglentine by Cowl, son of Bay Middleton, dam Laura, the dam of Petrarch, winner of the 2,000 Guineas, St. Leger and Ascot Gold Cup, Protomartyr, Fraulein (winner of the Doncaster Cup), Lemnos, imp. Rotherhill, etc, by Oriando, son of Tonchstone, second dam Torment, the dam of Nana Sahib, Arlrasta, Tormentor (Oaks winner), ete, by Alarm, son of Venison; third dam by imp. Glencoe, etc.

Rosicrucian, the sire of Lanreate, won the Criterion and Troy Stakes, and is the sire of Hautem, winner of the 1,000 Guineas, Geheimniss, winner of the Oaks, imp. Black Dean and Beauclerc, and is full brother to The Palmer. Orlando, the sire of Laura, won the Derby aud was the sire of Little Lady (dam of Camballo), Lady Mary (dam of Gang Forward), and of the dam of Gen. Peel, all winners of the 2,000 Grimeas, also of Doralice (dam of Speculum, winner of the Goodwood Cup).

Laureate was a high class race-horse. He won the Craven Stakes, 1 mile, 117 1bs.,

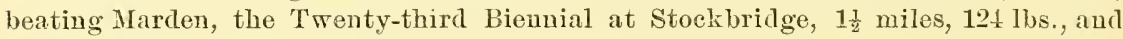
the Singleton Stakes at Goodwood, 1 mile, $117 \mathrm{lbs}$., and was seconel in the Chesterfield Cup, 11 miles, won by Vibration, second in the Scarborough Stakes, 1 mile, won by Alban, giving him 12 lbs. He is the sire of the winners Poet Laureate, Lnllabs, Qneen Lanra, Stokesley, Frank Patros, Lagunos and Guinevere. Bonnie Scotland was a success in America, and the descendants of imp. Peggy from the same family are noted in this conntry and in England. Lanreate traces iu direct female line to the Childers mare, to which traces Bustard (by Buzzard), Hampton (by Lord Clifiten), Blair Athol and all the Qneen Mary family, Pretender, Sir Berys, Tristan, Carlton, Craftom, Bonnie Scotland, Bernice and Bella Domna in the Nursery Stud, and all the Peggy family in America. 


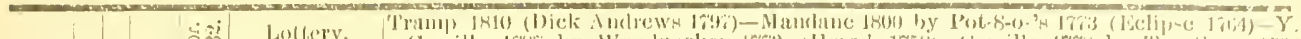

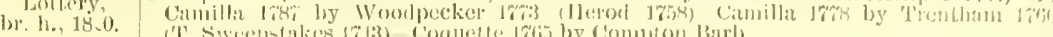

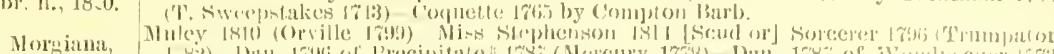

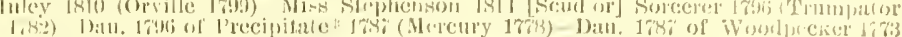

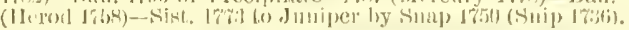

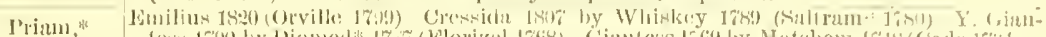

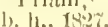

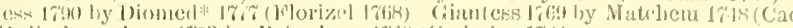

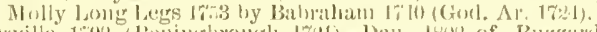

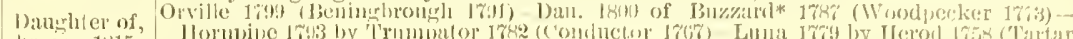

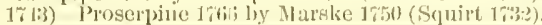

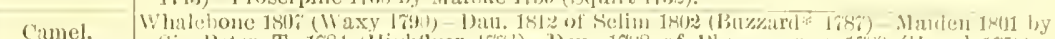

br: 11., 182?

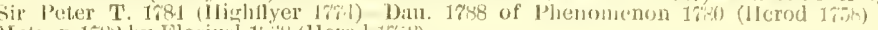

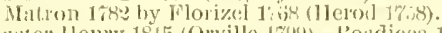

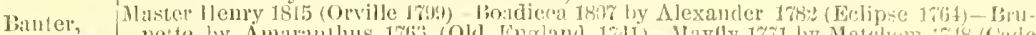

Bittrer,

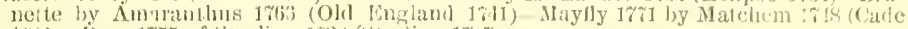

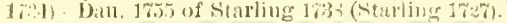

Tramp,

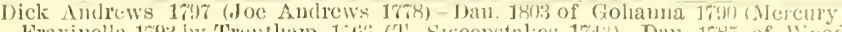

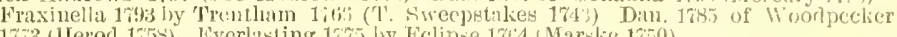

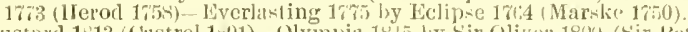

Fite, Bustard 1s13 (Castrel 1-01) Olympia 18ls by Sir Olivel 18!) (Sir Peter T'. 1ixl) Sccilla

b. K. 1 17 i. by Herod 17.58 (Tartar 17.13).

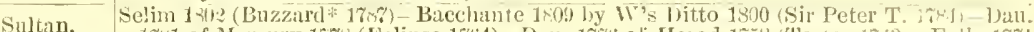

). 1., 1816 .

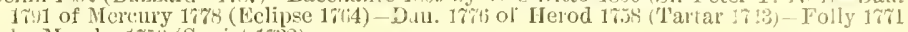
by Harske $1 \% 50$ (Squirt 1739).

Phantom $180 ;$ (Walton 17.99)-Filagree 1815 by Soothsayer $180 \mathrm{~s}$ (Sorcerer 17.65) Wel)

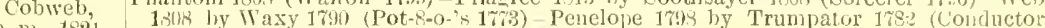
17 (bi) - Prunella 1788 by Highlyer 17 i (Ilerod 1758).

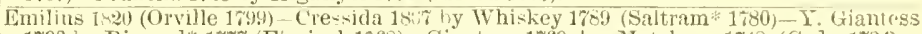
$1 \% 90$ by Diomed $177 \%$ (Fiorizel 1768). Giantess 1769 by Matchem 1718 (Cade 1734)Arolly Long Leus 1753 by Babraham 1710 (God. Ar. 1904)

Priam,*

b. $11 ., 18: 27$

Octavi'un $18 \%$ (Stripling 179.)-Dau. 180 \% of Shutt le $1 \% 93$ (Y. Nar-ke 17\%1)-Zara 1801 by Delpini 1781 (Hightlyer 1774)-Flora 1789 by King Fergus 17\%5 (Eclijse 1761)-Atalanta 1769 by Itathem 1748 (Cade 1734).

b. 1 in., 1815

Whalebone,

br. h., $180 \%$.

Taxy 1790 (Pot-8-0-s $\overline{173}$ )-Penelope 1798 by Trumpator 1782 (Condictol 176\%)-Prunella 1788 by Hightlyer $17 \% 1$ (Heror 1758)-Promise 1768 by Snap 1750 (Snil 173 $j$ ) Julia 1756 by Blank 171 ) (God. Ar. 1724).

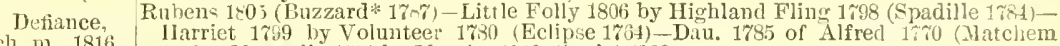
ch. $11,, 1816$. 17:8) - Magnolia 17it by Marslie 1750 (Squirt 1732).

Middleton, Phantom 180 i (Walcon 1799) - Treb 1808 by Waxy 1790 (Pot-8-o-'s 17i3)-Penelope 17:8 ch. h., 1822 . by Trumpator 1782 (Conductor 17u7) - Prunella 1788 by Highfyer 17\% (Herod 17j8)Promite 1768 by Snap 1 ron (Snip 1756)

Little Folly, Highland Fling 179 ; (Spadille 17-4)-Harret 1799 by Volunteer 1700 (Eclipse 1r6t)-Dau.

Little Folly, 178.5 of Alfred $17 \% 0$ (Malchem 1718)-Magnolia 1771 by Narslse 1750 (Squirt 1732)Dall. 1759 by Babrahaur 1740 (God. Ar. 1721).

Whalebone, Waxy 1790 (Pot-8-o-'s 1773)-Penelope 1793 by Trumpator 1782 (Conductor 1767) - Prunella 1788 by Highfyer 1774 (Herod 175S)-Promise 1768 by Snap 1759 (Snip 1736)-Julia 1756 by Blank $1 \% 40$ (God. Ar. 1\%24).

Selim 1802 (Buzzard* 1787)-Mairlen 180 ! by Sil Peter T. 1781 (Highflver 17\%4)-Dan. 1789 of Phenomenon 1780 (Herod 175\%)-Matron 1782 by Florizel ir. 8 (Herod 1\%53)Maiden $17 \% 0$ by Natchem 1748 (Cade 1\%34)

Daughter of,

b. m., 1812 .

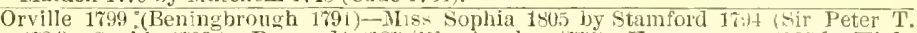

Master Henry, 1784)-Sophia 1798 by Buzzard $1: 8 \%$ (Woodpecker 17\%3)-Huncanunca 178 by High flyer 1744 (Herod 1758 ) - Cypher 17\% by Squirrel 1754 (Traveller 1735).

Boadicea Alexander 1792 (Eclipse 1764)-Brunette by Amaranthus 1766 (Old England 1741)- HIay-

b. m., $180 \%$ fly $17 \% 1$ by Matchem $1 \% 48$ (Cade 1\%4)-Dau. 1755 of Anc. Starling 1128 (Starling 172\%)-Look-at-me-Lads 1731 by Bri-t. Grasshopper (Byerly T.).

Sulim, Buzzard $185 \%$ (Wootpecker 1773)-Dall. of Alexander 1,8\% (Eclipse 176t)-Dau. of Highflyer 17\%4 (Herod 1758) -Dau. of Alfred 17\%0 (Hatchem 1718)-Dau. $17 \% 0$ of Engineer 1756 (Sampson 1\%45).

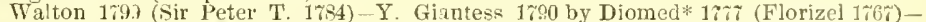
Giantess 176 . by Matchem 174, (Cade 173:) Molly Long Legs 1753 by Babraliam 17 10 (God. Ar. 1721)-Dau. of Cole's Foshunter 1727 (Brisk 1'i11).

Castrel 1 001 (Buzzard 1787)-Miss Hap 150ti by Shuttle 1,93 (Y. Marske I,i])-Dan. $17 n 8$ ol Sir Peter T. 1781 (Highflyer 17\%1) - Miss Hervey 1\%75 by Eclipse 1if4 (Narske 1750 ) - Clio 1760 by Y. Cade 1717 (Cade 1734).

Sir Oliver 1.500 (Sir Peter m. 1784) - Scotilla 1795 by Anvil 1rir (Herod 1758) - Seota 1783 by Eclipse 17i:4 (Marske 1750)-Harmony 1\% 1769 by Blank 1740 (God. Ar. 1721).

Olympia, b. M., 1815.

Partisan.

Walton 1r9t (Sir Peter 1784)-Paraso! 1400 by Pot-8-os 1773 (Ecliuse 1764)-Yrunella 1728 by Hightlyer 1734 (Herod 1758)-Promise 1768 by Snap 1750 (Snip 17Bli)-Julia 1756 by Blank 1740 (God. Ar. 1724).

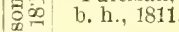

ai $\ddot{\Xi} \dot{\mathrm{J}}$ Fawn,

br. m., 1823.

Smolensko 1810 (Sorcerer 1796)-_Jerboa 1803 by Gohanna 1:90 (Mercury 17ro)-Camilla $17 \% 8$ by Trentham 1766 ( $T$. Sweepstakes 1\%43)-Coquette 1764 by Compton Barb-Sist. 1743 to Regulus by God. Ar. 1721.

Defence, Whalebone $180 \%$ (Waxy li9h-Defiance 1-16 by Rubens 1805 (Buzzard 178\%)-Littla Folly 1806 by Highland Fling 1798 (Spadille 1784)- Harriet 1799 by Tolunieer 1780 (Eclipse 1;6-1) Dau. 1785 of Alfred 1ivo (Matchem 17+8)

X. Y.Z. 1808 (Haphazard 1\%9\%)-Janetta 180:3 by Beningbiough 1791 (King Fergus

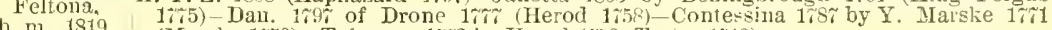
(Marske 1750) Tuberose 17\%2 by Herod 1758 (Tartar 17t3).

Sultan, Selim 1s02 (Buzzard 1\%8i) - Bacchante l y0y by W's Ditto 1800 (Sir Peter T. 1;84) - Dan. 1791 of Mercury 1\%8 (Eelipse 1;64)-Dau. 1\%6 of Herod 1758 (Tartar 1;43)-Foliy 17\%1 by Marske 1750 (Squirt 17\%2)

Tramp 1010 (Dick Andrews 179\%) - 11 eb 1809 by Wary 1090 (Pot-8-o-"s 173)-Penelope

\begin{tabular}{l} 
Trampoline, 179 by Trumpator 1782 (Conductor $176 \%$ )-Prnnella 1788 by Highflyer $1 \% 7+$ (Herod \\
ch. m., 18\%5. \\
\hline
\end{tabular}

ch. m., 18\%5.
1798)-Plomice 1768 by Snap 1750 (Snip 1796).

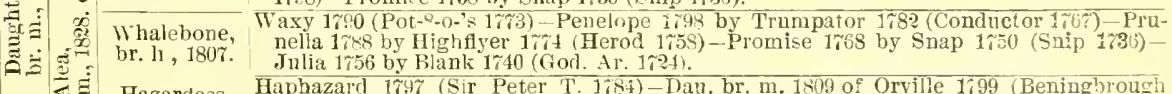

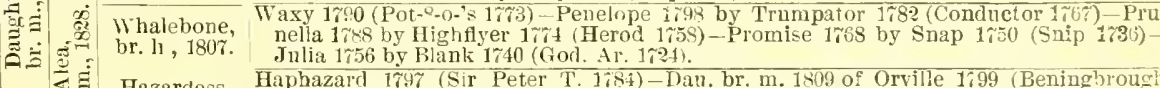

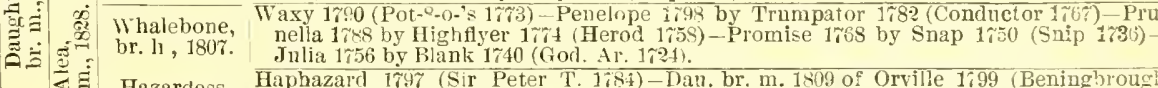

Hazardess, Haphazard 1797 (Sir Peter T. 1int)-Dan. br. m. 1809 of Orvile 1799 (Bening?rough Herod 1758 (Tartar 1\%:3) - Dan. of Snap 1750 (Snip 1736)-Dau. of Gower Staition 12 10 (God. Ar. 1,2!)-Dau. of Childers. 


\section{LEONATUS.}

\section{In the Rammymede Stud, MLessrs. Clay \& Woodford, proprietors, Paris, Ky. Yearlings sold anmually in May.}

Leonatus, bas horse, foaled 1880, bred by J. Henry Miller, Lexington, Ky., by Longfellow, son of imp. Leamington, dam Semper Felix by imp. Phaeton, son of King Tom by Harkaway, grandam Crucitix by Lexington, ont of Lightsome by imp. Glencoe. Leonatns is descended from the most celebrated racing and produeing families in the Stud Book. Semper Felix, his dam, is the dam of the winners Warder, Leopold and Felicia II. and of Semper Vive and Latonia, the last named the dam of Sena and Lew Weir, while Semper Vive is the dam of Fordham, Folsom, Portehester and Semper Idem, the latter the dam of the great Longstreet and Longford. Crucifix, the second dam of Leonatus, is one of Lexington's best danghters. Besides Semper Felix she produced the winners Fairplay (a very good horse), St. Albans, the stake winners Quito and St. Augustine, and Blanche J., a producer as well as winner, being the dam of Sea Shell and Blantyre, the former the dam of Long Shore and Toss Up. Maria D., another daughter of Crncifix, is the dam of Mark S. and Ed. Bell. Without going back to Lightsome and Levity, it will be seen that it is a family of the grandest excellence.

Leonatns was a superior race-horse, started only once as two-year old; ran second in Maiden Stakes, $\frac{8}{4}$ of a mile, $105 \mathrm{lbs}$. , in 1.22 ; at three years old won ail his stakes, defeating the best three-year olds of his year, including Drake Carter; won the Blue Ribbon, $1 \frac{1}{2}$ miles, $105 \mathrm{lbs}$. in $2.38 \frac{1}{2}$; won the Kentucky Derby, $1 \frac{1}{2}$ miles, 105 lbs., in

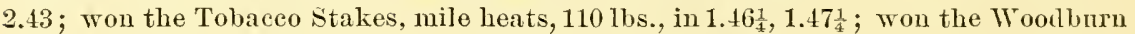
Stakes, $1 \frac{1}{8}$ miles, $110 \mathrm{lbs}$, in $2.00 \frac{1}{\frac{1}{4}}$; won the Hindoo Stakes, $1 \frac{1}{2}$ miles, $110 \mathrm{lbs}$., in $2.40 \frac{1}{\frac{1}{4}}$; won the Ripple Stakes, $1 \frac{1}{\ddagger}$ miles, muddy track, 110 lbs., in 2.301 ; won the Himyar Stakes, $1 \frac{3}{8}$ miles, 115 lbs., in $2.27 \frac{8}{4} ;$ won the Dearborn Stakes, 1星 miles, 115 1bs., in $3.12 \frac{1}{4}$; won the Green Stakes, $1 \frac{1}{8}$ miles, $115 \mathrm{lbs}$, in 1.58; won the Illinois Derby, $1 \frac{1}{3}$ miles, 115 lbs., in 2.51.

Leonatus is a success in the stud npon all classes of mares. He is the sire, among others, of Lord Peytort, a winner of seven races as a two-year old, National, Lemoine H., Birthday, Lake Breeze, Dore, Ed. Eshelby, Ed. Leonard, Judge Hughes, Leontine, Boyle Rhodes, Go-as-Yon-Please, Miracle, Lagadere, LEona wrlu, Florence Slaughter, Leader II., Leo, Leo En, Lemmbria, Perlid, Ned. Pendleton, Red Light, Rex, Sam Morse, Unlneky, Davidson, Labrador, Later On, Little Prince, Serenader, Vexation, Ja Ja, Leta B., Ollie Glenn, Ethel S., Etruria, Jennerette, Nerina, Sir Arthur, Leonata. Warsaw, etc. He is descended in direct female line through old Montagn mare from the Royal mare to which traces Condnetor, O'Kelly's Eclipse, Filho-da-Puta, Voltaire, Sterling, Oxford, Springfield, Marsyas, Adventurer, Prince Charlie, Lexington, Vanılal, Monarchist, Volturno, Luke Blackburn, Salvator, The Bard, Strathmore, Tom Mlartii, Grinstead, Duke of Montrose and other noted horses. 


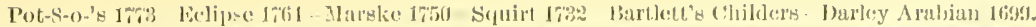

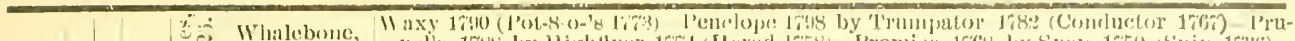

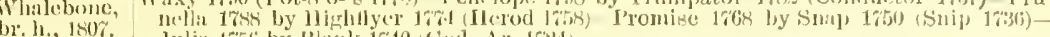

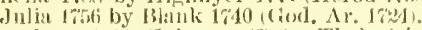

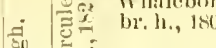

1). 121., 1si2.

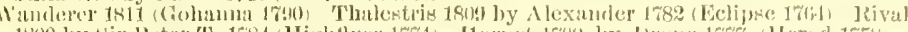

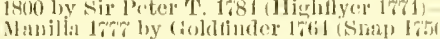

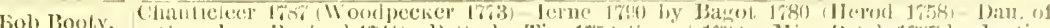

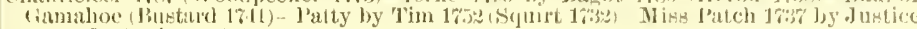
17:*5) (11. C. Lillion $\mathrm{Al}$.

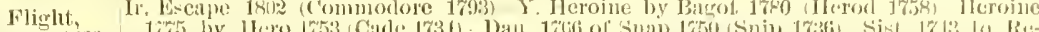

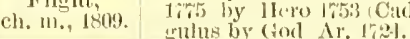

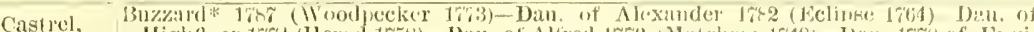

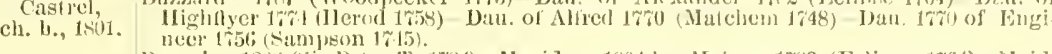

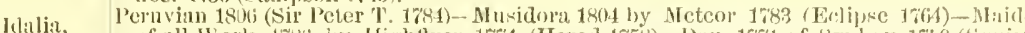

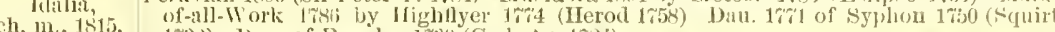

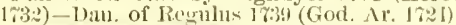

Lanrel, Blackbuck 1814 (11 hitelock 18(13)- Wagtail 1818 by Prine Minister 1810 isuncho 1801

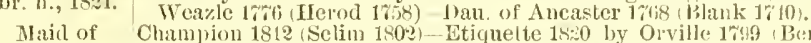

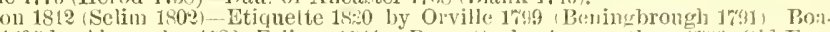
dicea $180 \%$ by Alexander 1782 (Eclipse 17fid-- Bunette by Amaranthus 176to (old Eng-

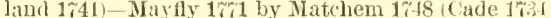

\& br.m., 18:

Dutoc,

ch. 1., 1806

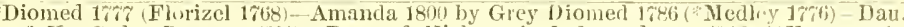
of Ta. Cade (Partner 1755)-Dan, of Hickman's Independence 17i6 ("Furuought 1755)-Dau. of "Badger (Bo-phorus 1754).

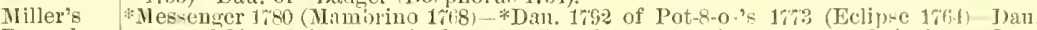
Damsel, gr. m., 180\%. 1749 of Regulus 1739 (God. Al. 1\%24)

\section{Ilenry,}

ch. h., 1819

Archy 1805 biomed 1\% 5 ) Dan. of Diomed 17\% (Florizel 17is)-Bellona by Bellair 1786 (*) Medley 17\%6)-Indian Queen by Pilgrim 17\%4 (*Fearnought 1\%55)-Dau. of *Valiant $1 \% 56$, (Dormouse 1738 )

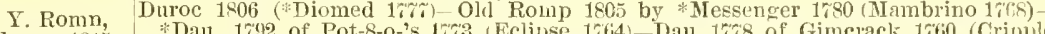

ch. m., 1815 .

(Eclipse 1 (764)- Dau

Sir Archy, Diomed 17\% (Florizel 1,68) *Castianima 1796 by Rockingham 1781 (Highfyer 1774,

b. h., 1805. Tabitha 1\%82 by Trentham 1766 (T. Sweepstakes 1\%43)-Dau. of Bosphorus 175 (Babraham 1740 - Sist. to Grecian Princess by Forester 1\%0 (For 'ster 1736)

Eliza, Bedtord 1792 (Dungamnon 1780) - Mambrina 1785 by Mambrino $1 \%(88$ ( Ingineer 1756)-

Eliza,

Sist. to Sally by Blank 1740 (God. Ar. 1724)-Dan. of Thard 1731 (Crab 1\%22)-Dau. of Merlin (Bustler).

[Brimmer or]

Stirling

$\dot{0}=$ ch. h. $180^{\circ}$

ch. h., 180:

dam,

of Brilliant 1650 (Crab 172:)-Dau, of Tartar 1743 (Partner 1718)-Dau. of Son of Flying Childers 1715.

der's (Blaze 1\%33).

Economist, Whisker 1812 (Taxy 170)-Floranthe 1818 by Octavian 186 (Stripling 1795)-Caprice

b. h., 1825 . 1763 by Blank 1740) (God. Ar. 1724).

a

हิ-

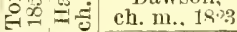

Tabocklish 1811 Rugantimo 1803) Miss Tooley 1808 by Teddy-the-Grinder 1698 (Asparagus 1787)-Lady Jane $\mathbf{1 7 9 6}$ by Sir Peter T. 174 (Highfiyer 1764)-Patiua 1768 by E]orizel 1768 (Herod 1\%58) Captive $1 \% 1$ by Matehem $1 \% 18$ iCarle 1\%34)

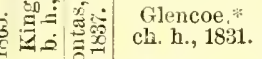

1816 (Seliu 1802)-Trampoline 1825 by Tramp 1810 (Dick Andrews 179t)-

1808 by Waxy $1 \% 90$ (Pot-8-o's 1773)-Penelope 1798 by Trumpator 1\%82 Conduelor 1767)-Prunella 178s by llimhfiver $1 \% 4$ (Herod 1\%58).

Marpessa, Muley 1810 (Orville 1799)-Clare 18:4 by Marmion 1-06 (Whiskey 1789)-Harpalice 1814

b. m., 1830. by Gohanna 1790 (Mereury 1778)-Amazon 1699 by Driver 1783 (Trentham 1766)Fractions 1792 by Mercury $17 \% 8$ (Eelipse $17(64)$.

Tounstone, Camel 1822 (Whalebone 180\%) - Bunter 18\%6 by Naster Henry 1815 (Orville 1\%9) - Boa-

br. h., 1831. dicea 1807 by Alexander 178\% (Eclipse 1\%64)-Bruuette by

Pantaloon 1821 (Castrel 1801) - Lanowic 1830 by Cain 1822 (Panlowitz 1813) - Lydia 18?2

Ghuznee, $\quad$ by Ponlton 1805 (Sir Peter T. 1\%84)-Variety 1808 by Hyacinthus 1797 (Coriander 1786)-Dau. 1790 of Weazle 1766 (Herod 1758).

Fal-tafi, Touchstone 1831 (Camel 1822)-Decoy 1830 by Filho-da-Puta 1812 (Haphazard 1\%96)

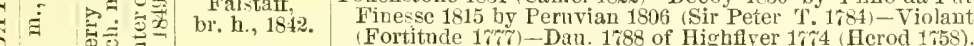

$\therefore \quad$ Sister to Emilins 1820 (Orville 1w9) Tariation

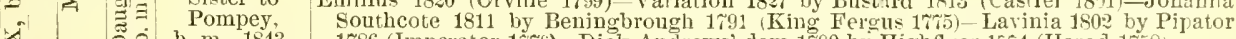

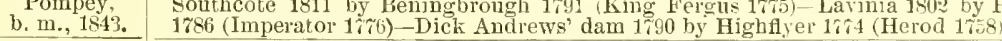

Timoleon Sir Archy 1805 (*Diomed 17rĩ)-Dan. of *Saltram 1780 (Eclipse 1764)-Dan. of srmmes" ch, h., 1813. Fallower $1 \% 61$ (Blank 1740$)$

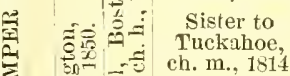

Bill's Florizel 1801 (*Diomed

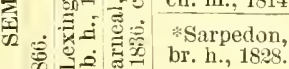

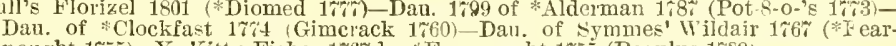
nought 1755)-Y. Kitty Fisher $176 \%$ by Fearnought 1755 (Regulus 17.59)

Emilius 1820 (Orville 1799) - Icaria 1824 by The Flyel' 1814 (Vandyke Jl. 1808)-Parma $1813 \cdot$ by Dick Andrews 1697 (Joe Andrews 1768)-Nay 1801 by Beringbrough 1791 (Eing Fergus $17 \% 5$-Primrose 1787 by Mambrino 1668 (Engineer 1756 )

:

Sumpter 1818 (Sir Areby 1805)-Lary Grey $181 \%$ by Robin Grey 1805 (*Royalist 1790) -

Maria 1802 by Melzar 1791 (* Nedley 1\%\%6)-Dau. of *Highflyer 1784 (Highflyer 1744)Dau. of *Fearnought 1755 (Regulus $1 \% 9$ ).

$\stackrel{\Delta}{\Delta} \quad$ Sultan,

Selim 1842 (Buzzard* 178\%)-Bacchante $1 \times 69$ by W's Ditto 1800 (Sir Peter T, 1784)-Dau.

1791 of Mercury $17 \% 8$ (Eclipse 1764)-Dan. $17 \% 6$ of Herod 1758 (Tartar 1743)-Folly 1771 by Narske 1750 (Squirt 1732)

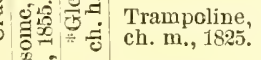

Tramp 1810 (Dick Andrews 179\%) - Web 1808 by Waxy 1790 (Pot-8-o-'s 17\%3)-Penelope 1798 by Trumpator 1\%82 (Conductor 1,6\%)- Prunella 1788 by Highflyer 1ir4 (Herod 1758)-Promise 1768 by Snap 1750 (Snip 1\%36).

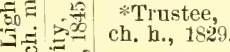

Catton 1809 (Golumpus 1802) - Emma $18 \% 4$ by Whisker 1812 (ITaxy 1790)-Gibside Fail' 1811 by Hermes 1790 (Nercury 1\%r8)-Vicissitnde 1600 by Pipator 1 866 (Imperator 1\%(6)-Beatrice 1791 by Sic Peter T. 1784 (Highflyer 1\%1).

¿ Vandal's dam

Tranbe 1826 (Blacklock 1814)-Lucilla b. 3a. by Trumpator 1823 (Sir Solomon 1815)-Lucy b. m. 1821 by Orphan 1810 (Ball's Florizel 1801 )-Ladj Grey b. m. 181 T bF Robin Grex 1805 (Royalist 1790)-Maria $1802 \mathrm{by}$ Melzar 1791 ("Medles 17:6)-Dan. of Highflyer 178t (High-

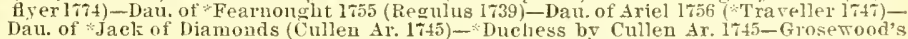
b. m., 1837 .

Dau. of Jaek of biamonds (Cullen Ar, 1745)- Duehess bv Cullen Ar. 1745-Grosemood's Lady Thigh ch. m. 1731 by Partner 1718 (Jigg)-Sist. el. m. 1723 to Sampson by Grephound (Chillabs)-Soplyonisba's dam by Curweu Bay Barb-Dan, of D'Arey Chestuut Ar.-Dau. of Whiteshirt-Old Montagu
Hautboy (D'Arcy White Turk) - Dau. of Brimmer (D'A rey Yellow Turk)-Royal mare. 


\section{LINDEN.}

WINNER OF THE NEWARK AND CITIZENS' STAKES, SHREWSBLRY AND GRAND NATIONAL HANDICAPS.

\section{The property of James Galuony, Preakness Stud, located in the Stonewall Stud, Breckenridge Vitey, Hidway, Ky. Terms anmally.}

Lindex, bay horse, foaled 1883, bred by S. P. Laneaster, Ky., by Longfellow, son of imp. Leaniugton, diun Liuda Lewis by Oliver, sou of Wagner, grandam Sally Lewis, dam of John Norgan, Hunter's Lexington, Lotta (Glemmore's dam), Susan Beane (dam of Sensation, Stratford, Onondaga and Susquehanna, dam of Potomac) by imp. Gleneoe. Mr Lady, the fnll sister to Sally Lewis, was the dam of Blandina by Lexington, she the dam of Calash, which produced Elite, Eoilan and Ulsie, dam of Bandusia.

Linden did not race at two years old. At three years old ran second to Bandala in a Free Handieap, $1 \frac{1}{16}$ miles, in 1.55; ran third to Inspector B. and The Bard, in the

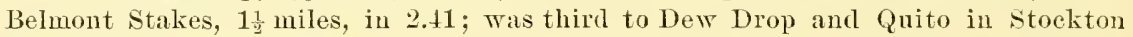

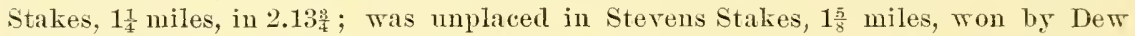
Drop in 2.5 $4_{4}^{1}$; was third to Charity and The Barl in the Raritan Stakes $1 \frac{1}{4}$ miles, in 2.14, Pontico and Winifred behind him; won the Newark Stakes, 1 mile, 105 1bs., in $1.44 \frac{1}{2}$, with nine others behind him; was umplaced in the Omnibus Stakes, $1 \frac{1}{2}$ miles won by The Bard in 2.39; ran second to Elkwood in Kenner Stakes, 2 miles, in 3.34 three others behind him; was third to The Bard and Ferona in September Stakes.

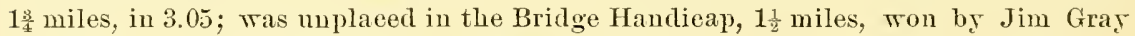
in 2.391 ; and in Sheepshead Bay Stakes, $1 \frac{1}{4}$ miles, won by Blue Wing in 2.08. At four years old won Free Handicap Sweepstakes, $1 \frac{3}{16}$ miles, 110 lbs., in $2.13 \frac{1}{2}$, beating Phil Lee and Enigma ; was unplaced in the Suburban, Bay Ridge, Fonrth of July

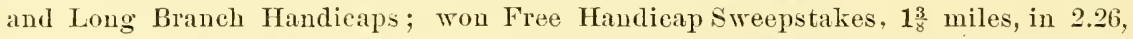

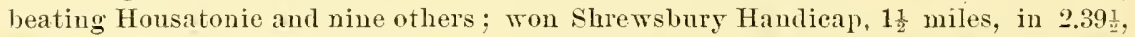
beating Grimaldi and seven others: was nuplaeed in the Hidsummer Handicap, won

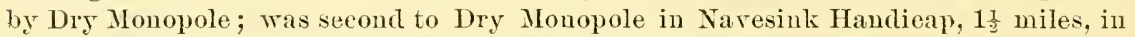

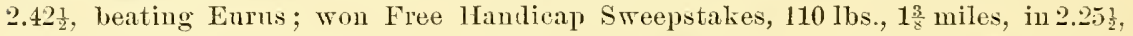
with four others behind him ; won Handicap Sweepstakes, $1 \frac{1}{2}$ miles, in 2.44. 110 lbs., and another, $1 \frac{3}{8}$ miles, $115 \mathrm{lbs}$, in 2.2613 ; wou Grand National Handicap, $1 \frac{1}{2}$ miles, 117

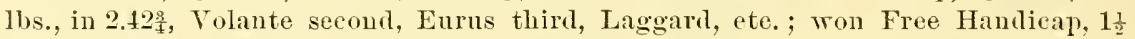

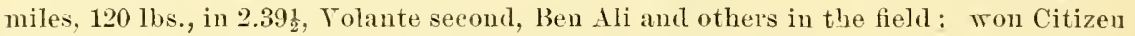
Stakes in a canter, 110 lbs., $1 \frac{1}{2}$ miles, in $2.40 \frac{1}{2}$. Firenzi, Dunbine and six others behind him. At five years old won Handieap, $1 \frac{1}{8}$ miles, 122 1ls., in $1.56 \frac{1}{4}$, six hehind him : was unplaced in City Handicap; was secoml to his stable eompanion Belvidere in Fordham Handieap, $1 \frac{1}{4}$ miles, $128 \mathrm{lbs}$. in $2.11 \frac{1}{\frac{1}{4}}$, five behind him; was mplaced in Suburban, won by Elkwood; and ran third to Terra Cotta and Fireuzi in Sheepshead Bay Handieap, $1 \frac{1}{8}$ miles, in 1.53, fire behind him.

Linden is from a grand raeing and prodneing fimily, one that has made its mark mpon the turf in England and America. He is young in the stud, but is the sire of the winner Lnstre and other promising two-year olds. He is descended in female line from the same Royal mare to which traees Eelipse, Voltaire, Sterling: Oxford, Kingston. Seottish Chief, Lexington, Tandal, The Bard, Leonatns, Sensation, Salvator, Longstreet, Potomac and all the Duchess family. 


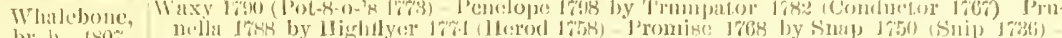
br. $11, \sin \%$

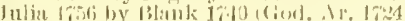

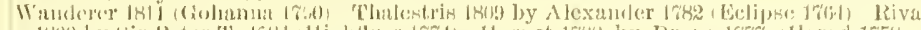

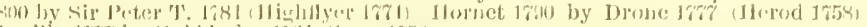

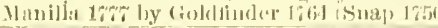

5. $13,132$.

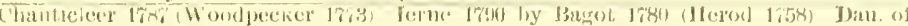

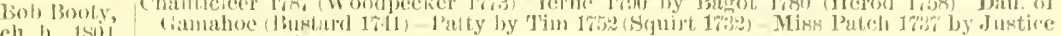
cls, h., 1 sili,

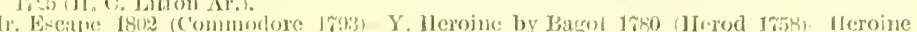

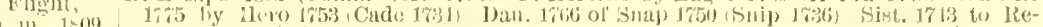
malus by (iod Ax. 170.

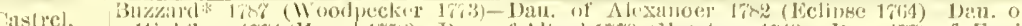

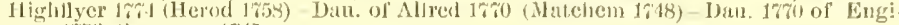

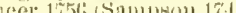

cl. 11., $1(30)$

Jilili:1,

ch. $111,1815$.

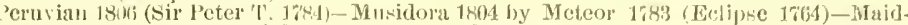

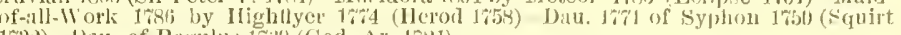
1732)-1)an, of Regulu- 17:3!) (God. A1. 17\%1).

L:tural,

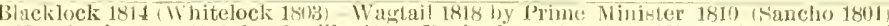

bl. H., I.K.…

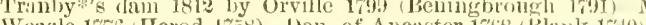

Homor

IIonor,

\section{Duroc,}

ch. h., 1803

Miller's

Damsel,

gr. m., 18:2.

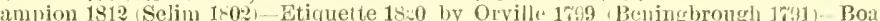

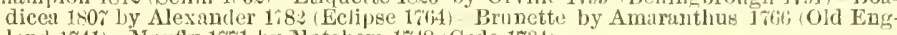
land 1741)-ILayfly $17 \% 1$ by Matchem 1718 (Cade 1791

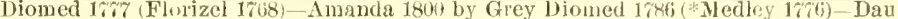
ol Ta. Cade (Partner 1755)-Dan. of Hickman's Independence 17i6 (Eearnought 1755) - Dau, of Badger (Bosphortss 1754).

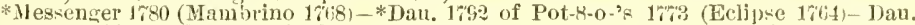
17 s of Gimcrack 1760 (Cripple 1750) - Snapdragon 1759 by Snap 1756) (Suip 1736)-Dau. 1749 of Regulus 1639 (God. Ar. 1724)

Henry, ch. h., 1819

I. Romn, ch. $12 ., 1815$

Sir Archy b. 11., 1505 .

Eliza, ch. $\mathrm{m}, 1804$.

列 Bellair 1786 (* Medley 17\%6)-Indian Queen by Pilgxim 17\%4 (*'earnought 1755)-Dau. of "Valiant 17iffi (Dotmouse 17/38).

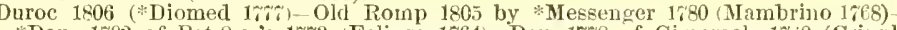
Dan. 1792 of Pot-8-o-'s 1\%?3 (Eclipse 1764)-Dau. $17 \% 8$ of Gimerack 17'00 (Cripple 1750)-Snapdragon 1659 by Snap 1750 (Snip 1736)

Diomed 1\% (Florizel 1:68) - *Castianira 1796 by Rockingham 1\%81 (Ilighflyer 1\% Tabitha 1782 by Trentham 1766 (T. Sweepstakes 1743)-Dan. of Bosphorus 1754 (Baioraham 1740) - Si-t. to Grecian Princess by Forester 1\%0 (Forester 1756.

Bediord 1792 (Dungamon 1\%80) - Mambrina 1785 by Mambrino 1768 (Engineer 1\%56)Sist. to Sally by Blank 1\%40 (God. Ar. 1\%24)-Dau. of WVard 1\%31 (Crab 1\%22)-Dan. of Merlin (Bustler).

[Brimmer or] *Stirling 1291 (Volunteer 1680)-Brilliant 1729 by *Natchem (Bosphcrus 1751) - *Dau Blue Beard, of Brilliant 1750 (Crab 172\%) Dau. of Tartar 1743 (Partner 1718)-Dau. of Son of ch. h., 1802. Flying Childers $1 \% 15$.

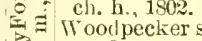

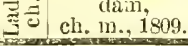

Flying Childers 1:15. of *Traveller 1747 (Partner 1718)-Dau. of *Whittington (Cullen Ar.)-Dau. of *Chil-

b. h., $1800^{\circ}$.

Diomed 17\% (Florizel 1766) - Castianira 1796 by Rockingham 1781 (Highflyer 174) -Tabitha 1782 by Trentham 1766 (T. Sweepstakes 1743)-Dau. of Bosphorus 1754 (Babraham 1740)-Dau. of W's Forester 1750 (Croft's Forester 1736).

Daughter of, (Pacolet 1763)-Dau. of Commutation (Symmes Wildair 176\%)-Dau. o Dare Devil 1787 (Maguet 1770)-Sally Shas

\section{Marion,}

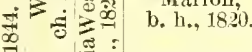
Sir Archy 1805 (*Diomed 17\%) - Dau. of Citizen 1785 (Pacolet 1763)-Dau. of *Aldermin 178 (Pot-8-o's 1\%3)-Dau. of Ashe's Roebuck (*Sweeper)-Dau. of Hayne's King Herod (*Fearnought 1755).

Citizen 1785 (Pacolet 1763)--Dau. 1795 of Huntsman 1789 (*Mousetrap 1761)-Dan. of Symmes' Wildair 17f7 (*Fearnought 1755)-Dan. of *Fearnought 1755 (Regulus 1739) -Dan. of *Janus 1746 (Janus 1739)

: br. m., -

II

Orville 1789 (Beningbrough 1791)-Eleanor 1798 by Whiskey 1rs9 (Saltram* 1790) - Y.

b. h., 1810 Gi:intess 1790 by Diomed* 1767 (Florizel 1768)-Giantess 1769 by Matchen 1748 (Cade 1784)-Moly Long Legs 1753 by Bahraham 1740 (God. Ar. 1724).

$\div$ Daughter of, indle 1804 (Beningbrough 1\%91)-Dau. 1788 of Anvil 17\% (Herod 1758)-Tirago 1764 by Snap 1750 (Snip 1726)-Dau. of Regulus 1759 (God. Ar. 1724)-Sist. 1750 to Othello by Crab 1722 (Aleock Ar.)

Sir charles,

Sir Archy 1895 (*Diomed 17\%)-Dau. of *Citizen 1785 (Pacolet 1763)-Dau. of Commntati m (Symmes' Wildair 1 $\sigma_{6 \%}$ )-Dau. of *Dare Devil 1\%8\% (Magnet 1\%0)-Sally shark by * Shark 1\%r1 (Marske 1\%50).

灵- ch. h., 1810 . ch.

Lady of the *Sir Harry 1795 (Sir Peter T. 1784)-Shylock's dam by *Diomed 17\%7 (Florizel 1;68)Dau. of *St. George 17\%1 (Dragon 1757)-Dan. of *Fearnought 1755 (Regulus 1739) Dau. of *Jolly Roger 1741 (Roundhead 1733).

b. m., 1812 .

Selim,

Buzzard* $178 \%$ (Woodpecker 173)-Dau of Alexander 1782 (Eclipse 1764)-Dan. of
Highflyer $17 \%$ (Herod 1758 )-Dau, of Alfred $17 \% 0$ (Natchem 1748)-Dau. $17 \%$ of Engineer 1 i56 (Sampson 1745).

Bacchante,

W's Ditto 1800 (Sir Peter T. 1784)-Dau. 1791 of Mlercnry $17 \% 8$ (Eclipse 1\%64)-Dau. 1776 of Herod 1758 (Tartar 1743)-Folly $17 \% 1$ by Narske 1750 (squirt 1732)-Tixen 1753 by Regulus 1739 (God. Ar. 1724).

Tramp,

Dick Andrews 1797 (Joe Andrews 1778) - Dau. 1803 of Gohanna 1790 (Mercury 17\%8)Fraxinella 1793 by Trentham 1765 (T. Sweepstakes 1743)-Dau. 1785 of Woodpecker $1 \% \% 3$ (Herod 1\%58)-Everlasting $17 \% 5$ by Eclipse $1 \% 64$ (Marske 1\%50).

Web Waxy 1790 (Pot-8-o-'s 1773)-Penelope 1798 by Trumpator 1782 (Conductor 1767)-Prunella 1789 by Highflyer 1774 (Herod 1758)-Promise 1768 by Snap 1750 (Snip 1786)Julia 1756 by Blank 1740 (God. Ar. 1724)

b. m., 1808 .

Dick Audrews 1757 (Joe Andrew's 1\%8)-Dau. 1803 of Gohanna 1790 (Mercury 1\%*8)-

Tramp, Fraxinella 1:93 by Trentham 1;66 (T. Sweepstakes 1743-Dau. 1785 of Woodpecker 1763 (Herod 1758)-Everlasting $17 \% 5$ by Eclipse 1764 (Malske 1750).

Buzzard* 178\% (Woodpecker 17\%3)-Roseberry 1792 by Phenomenon 1780 (Herod 1758)Miss West $17 \%$ by Matchem 1748 (Cade 1\%34-Dan. of Reoulus 1739 (God. Ar. 1724)-

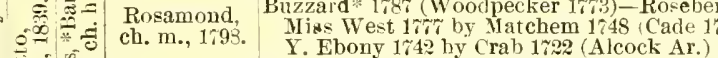

Am. Eclipse,

ch. $\mathrm{h}, 1814$.

Duroc 1806 (*Diomed 17\%)-Milker's Damsel 1802 by * Messenger 1780 (Mambrino 1768) - Pot-8-o-'s Mare 1792 by Pot-8-o-'s 1773 (Eclipse 1764)-Dau. 1778 of Gimcrack 1760 (Cripple 1750)-Snap Dragon 1759 by Snap 1\%0 (Snip 1736).

Katy Ann, Ogle's Osear 1800 (:Gabriel 1790)-Y. Maid of the Oaks ch. m. 1817 by Expeditiou 1795 ch. m, 1825 .

(Pegasus 1784)-Nlaid of the Oaks ch. m. 1801 by - Spread Eagle 1792 (Volunteer 1780)Annette by 'Shark 1771 (Marske 1750)-liau. of Roekingliam (Partuer 1755)-Dau. of True Whig (Fitzhngh's Regulns 1765)-Dau. of Baylor's Gallant 1770 (*Fearnought 1755)-Dau. cf Burwell's Regulus 1747 (Regulns 1739)-*Dnehess by Cullen Arabian 1745-Tady Thigh

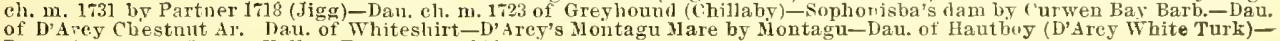
Dau. of Brimmer (D'Arcy Yellow Turk)-Roval lare. 


\section{LISBON.}

WINNER OF THE ALEXANDER STAKES A'T LOUISVILLE, KENTUCKY, 1876.

\section{In the Woodburn Stud, Spring Station, Ky. Application to L. Brodhead, Spring Station, $K y$. Ammal sales of yearlings in May.}

Lissox by imp. Phaeton, son of King Tom, bred by Richard Ten Broeck, foaled 187t, dam imp. Lady Love by Stockwell or Caterer, son of Stockwell, second dam Chere Auie by Sweetmeat, out of Blame by Tonchstone. His dąm, Lady Love, was a winner in England at two years old, and won the Stewards' Cup at Chester at fonr years old. Chere Amie, his gran lim, was also a race-mare and winner. Caterer, the reputed sire of Laty Love, was a good race-horse. He won the Findon Stakes at Goodwood when two years old, defeating Wingrare, Alvediston, Kaiser and others, and was second to the Marquis in the 2,000 Gnineas with Alvediston, Wingrave and thirteen others behind him. Sweetmeat, the sire of his grandam, was a superior racelorse, won the Qneen's Vase at Ascot, and the Doncaster Cup in 1845. He was the sire of Mincepie and Mincemeat, both Oaks winners, and Macaroni, winner of the Derby and 2,000 Guineas, and second in the list of winning sires in 1882. Tonchstone, the sire of his great grandam Blame, won the St. Leger, the Ascot Gold Cup in 1836-37, and the Doncaster Cup in 1835-36, and was second to no sire of his day. Lisbon started three times as a two-year old and won one race. At Lonisville, Ky., won the Alexander Stakes, half-mile, in $0.49 \frac{3}{4}$, beating $1 \mathrm{I}$ CWhirter and seren others. Was third in the Colt Stakes at Lexington, Ky., three-quarters of a mile, King Faro and Mc Whirter ruming dead heat for first place, in 1.18?. In this race Lisbon beat Allen Pinkerton, Headlight, Planetarian and Edinburg. Was third in the Belle Meade Stakes at Louisville, three-qnarters of a mile, in 1.17, won by McWhirter, BadenBaden second. As a three-year old he starter only twice, and was unplaced in both of his races. Lisbon is the sire of Ripple, who won the Long Branch Handicap, $1 \frac{1}{4}$ miles, in 2.101, beating Checkmate, Parole and Sir Hngh; also the the Shremshury

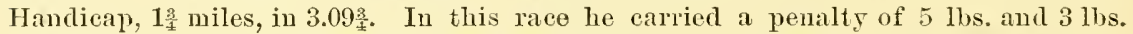
overweight. He unfortunately died that winter. Troubalonr (that defeated The Bard), Fagan, Pat Sheedy, Catheart, Grimaldi, an extra good one, Quincey, Clatter, Leland, Sea Foam, Artless, Lislind, Lisimony, Lizzie Glenn, Amos A., Indiana, Jack Rose, Steve Jerome, Sly Lisbon, Portuguese, Farine, Glenoid, Troratore, Lisbon Mraid, Glenoid, Liselg, Leoculus, Mamie B., all winuers. Lisbon is a refl hay, full $15 \frac{1}{2}$ hands high, with a blaze face and four white ankles. He is a horse of immense substance and power, and in conformation second to none, is very muscnlar, like all of Phieton's sons, and great constitution. In addition to his donble cross of Glencoe through King Tom and Stockwell, he has a donble cross of Touchstone on each side, eight erosses of Waxy throngh Economist and Emma by Whisker and Camel and Sir Hercules by Whalebone, fortified by the blood of Herod throngh the famous Highflyer, and Eclipse throngh Pot-8-o-'s and King Fergns. The blood is worth preserving through the granddaughters of Phaeton and daughters of Great Tom, King Ban and. King Ernest.

Lisbon descends in direct female line from the Woudcock mare, to which trace Reveller (by Comns), Heron, Alarm, Monarque, Verlette, Cambusean, Tespasian, Isonomy, Ising Lud, Exile and other good ones. 


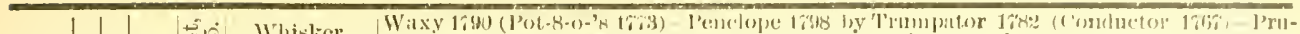

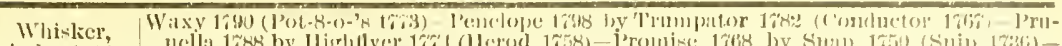

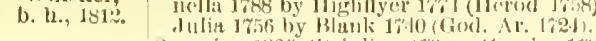

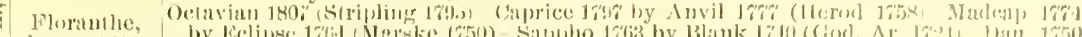

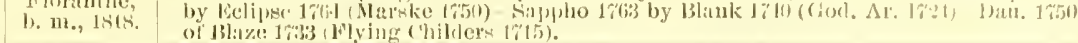

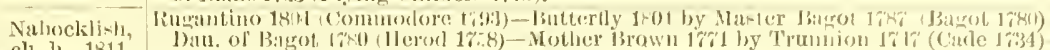

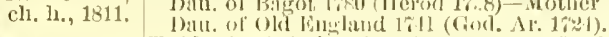

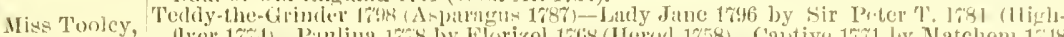

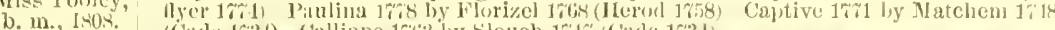

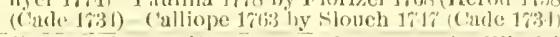

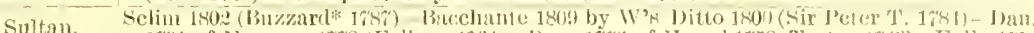

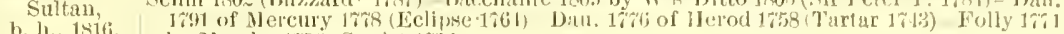

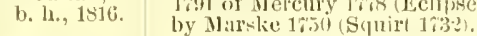

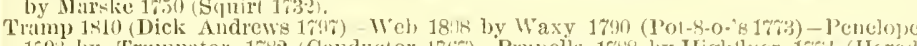

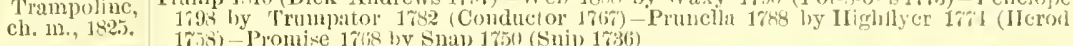

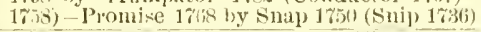

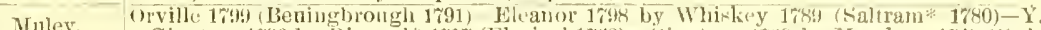

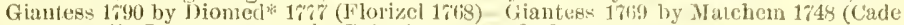

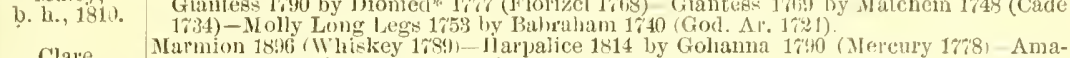

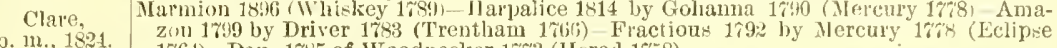

b. 11., 1821. $\quad$ Z 611 -Dau. 1785 of Woodpecker $17 \% 3$ (IIerod 1758).

Camel Whalebone 1807 (Waxy 1790)-Dau. 181\% of Selim 1802 (Buzard 178\%) Itaiden 1801

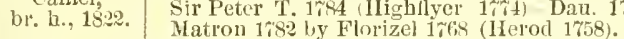

Banter Master Henry 1815 (Orville 1799)-Boadicea 1807 by Alexander 1782 (Eclipse 176-1) BiuBanter,
br. m., 1836.
nette by Amaranthus 1766 Old England 17+1) Mayfly 17r1 by Matchem $174 s$ (Cade
1731)-Dan. 1755 of Anc. Starling 173k (Old Starling 1727).

Panteon Castret 1801 (Buzzal 'd* 178\%)-Idalia 1815 by Peruvian 1806 (Sir Peter T. 178t) Musidora ch. h., 1834 1804 by Meteor 1753 (Eclipse 1;64)-Naid-of-all-Work 1786 by Highfiyer 1;64 (IIerod 1758 ) Dau. $17 \% 1$ of Syphon 1750 (Souirt 17\%2)

Languish, Cain 18:2 (Panlowitz 181:3)-Lydia 1822 by Poulton 1805 (Sir Peter T. 1684)-Variety

b. m., 1830. 1808 by Hyacmthus $1 \% 9 \%$ (Coriander 1786) Sint. 1790 to Swordman by Weazle $1 \% 6$ (Herod 1758)-Dau. of Turk 1763 (Regulus 1739).

Tamel 1822 (Whalebone 18(\%) - Banter 1 26 by Master Henly 1815 (Orville 1799) - Boa-

Ticea 1807 by Alexander 1782 (Eclipse 1764)-Brunette by Amalanthus 1766 (Old England $1 \% 41$ )-Mayfly $17 \% 1$ by Matchem 1748 (Cade 1734).

Decoy Filho-da-Puta 1S12 (Haphazard 179')-Finesse 1815 by Peruvian 1806 (Sir Peter T.

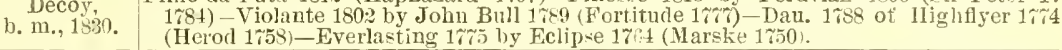

Emilins, Orville 1799 (Beningbrolygh 1791)-Emily 1910 by Stamford 1794 (Sir Peter T, 1784)-

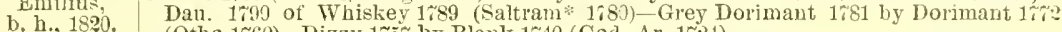
(Otho 1\%60)-Dizzy 1\%5i by Blank $1 \% 40$ (God. Ar. 1\%24).

Tariation, Bustard 1813 (Castrel 1801)-Johunna Southcothe 1811 by Beningorough 1791 (King

b. m., 182\%. Fergus 1\%7\%)-Lavinia 1 to2 by Pipatol 1786 (Imperator 1\%6)-Dau. $1 \%$ of of Highflyer $17 \tau 1$ (Herod 1758)-Dau. 1767 of Cardmal Puff 1760 (Babraham 1710).

Sir Hercules 1826 (Whalebone 1807)-Guiccioli 1823 by Bob Booty 1804 (Chanticleer 178\%)-Flight 1809 by Ir. Escape 1802 (Commodore 1793) - Y. Heroine by Bagot 1780 (Herod 1758 ) - Heroine $17 \% 5$ by Hero 1753 (Cade 1734).

Economist $18 \% 5$ (Whisker 1812)-Miss Pratt 1825 by Blacklock 1814 (Thitelock 1803) Gadabout 1812 by Orville 1799 (Beningbrongh 1\%91) - Min-trel 1803 by Sir Peter T 1784 (Highflyer 1774) - Matron 1782 by Florizel 1768 (Herod 1758).

Sultan 1816 (Selim 1802)-Trampoline 1825 by Tramp 1810 (Dick Andrews 1797)-Teb 1898 by Waxy 1790 (Pot-8-o-'s 1773) - Penelope 1798 by Trumpator 178: Concluctor 1707 -Prunella 1788 by Highflyer $17 \% 4$ (Herod 1758 ).

Mnley 1810 (Orville 1799)-Clare 1824 Jy Marmion 1806 (Thiskey 1689)-Harpalice 1814 by Gohanna 1790 (Mercury $17 \%$ )-Amazon
Eractious 1792 by Mercury $17 \% 8$ (Eclipse 1704 ). Camel 1822 (T'haleoone 1 107 ) - Banter 18\% by Master Henry 1815 (Orville 1799)-Boadicea $180 \%$ by Alexander $1 \% 82$ (Eclipse $1 \% 61$ )- Brunette

Langar 1817 (Selim 1802)-Kite 1821 by Bustard 1813 (Castrel 1801)-Olympia 1815 by Sir Oliver 1800 (Sir Peter T. 1784)-Scotilla 1\%5 by Anvil 1\% (Herod 1758)-Scota 1703 by Eclipse 1764 (Marske 1750 ).

Blacklock 1814(Whitelock 1803)-Dau. 181\% of Juniper 1805 (Whiskey 1789 -Dau. 1810 of Sorcerel 1793 (Trumpator 1782)- Virgin 1801 by Sir Peter T. 1784 (Highflyel 174)Datı. 1794 of Pot-8-o-'s 17\%3 (Eclip:e 1764).

Whisker 1812 (Waxy 1790)-Gibside Fairy 1811 by Hermes 1790 (Blercury 178)-Vicissitude 1803 by Pipator 1786 (Imperator 1\%(6)-Beatrice $1 \% 91$ by Sir Peter T. 1i81 (Highflyer 17\%t)-Pyrrha $1 \% 1$ by Natchem 17.8 (Cade 1734)

Walton 1\%99(Sir Peter T. 1784)-Parasol 1800 by Pot-8-o-'s 1\%3 (Eclijse 1764)_Prunella $17 \times 8$ by Highflyer 1\%74 (Herod 1758)-Promise 1768 by Snap 1750 (Snip 1736)-Julia 1756 by Blank 1;10 (God. Ar. 1721).

Moses 1819 ([Thalebone or] Seymour 180\%)_Quadrille 1815 by Selim 180? Buzzard\% 178\%)-Canary Bird 1806 by (T'hiskey or) Sorcerer 1\%96 (Trumpator 1\%8\%)-Cauart 1797 by Coriander 1786 (Pot-8-o-'s 1\%3)-Miss Green 1787 by Highfifer 174 (Herod 1758).

Blacklock 1814 (Whitelock 1803)-Dau. 1816 of Phantom 1808 (Walton 1799)-Dau. 1802 of Overton 1788 (King Fergas 1\%(5)-Dau. 1796 of Walnut 1786 (Highflyer 17\%4)-Dau. 1\% \&f of Ruler 17rin (Y. Marske 1ini).

Blacklock 1814 (Whitelock 1803) - Wagtail 1818 by Prime Minister 1810 (Sancho 1801)Tranby*'s dam 1812 by orville $1 \% 99$ (Beningbrough 1791)-Miss Grimstone $1 \% 96$ by Weazle $17 \% 5$ (Herod 1758)-Dau of Ancaster 1768 (Blank 1710 ).

Whalebone 180\% (Waxy 1790)-Dan. 1812 of Selim 1802 (Buzzard* 1687)-Haiden 1801 by Sir Peter T. 1781 (Highflyer 1\%1) -Dan. 1788 of Phenomenon 1780 (Herod 1758)Viatron $1 \% 82$ by Florizel $1 \% 6 \mathrm{~S}$ (Herod 1753 )

Master Heury 1815 (Orville 1799)-Boadicea 180\% by Alexander 1782 (Eclipse 1761)Brunette by Amaranthus 1\%65 (Old Fngland 17t1)-Mayfly 1\% by Matchem 1748 (Cade 17:4)-Dnu. 175. of Anc. Starling 1738 (Starling 1\%2\%)

Jerry 1821 (Smolensko 1810)-Diu. 1817 of Ardrossan 1809 (John Bull 1789)-Ladj Eliza 1813 by Whitwo th 1805 (Agonistes 1797) - Dau. 1793 of Spadille 1781 (Highflyer 1, w)Sylvia $1 \% 83$ by $\mathbf{Y}$. Marske 1771 (Marske $1 \% 50$ ).

Bustald 1813 (Castrel 1801)-Dau. b. m. 1830 hy 11 ule 1810 (Orrille 1799)-Rosanue b. m. 1811 by Dick Ar.drews 1797 (Joe Andrews 1778)-Rosette br. m. 1803 by Beuingbrough l791 (King Fergus 1775) - Rosamond b. m. 1788 by Tandem 1773 (S sphon 1750)-Tuberose gr. m. 172 of Herod 1758 (Tartar 1743)-Grey Starling gr. m. 7745 by Bolton Starling 1727 (Bay sellor mare by Wond's Connsellor 1691 (D'Arey Counsellor)-D tu. of Snake (Lister Turk)-Dan. of Luggs (i) Aice White Turk) -Datl. of Davill's Old Woodcock. 


\section{LOGIC.}

The property of MIS. J. M. Clay, Ashland Stud, Lexington, Ky. Service by contract. Yearlings sold anmully.

Logic, bay horse, foaled 1886, bred by J. M. Clay, by Longfellow, son of imp. Leamington, dam Badge by Gilroy, son of Lexington, ont of Buff and Blne by War Dance, son of Lexington and Reel by imp. Glencoe. Logie is a fine large horse over 17 hands in height and was a horse of great promise, but badly handled and injured early by an accident. He started only a few times, ran second to Robin

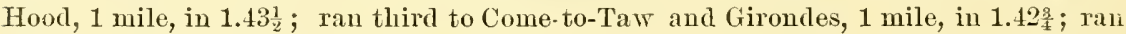
third in Twin City Derby, $1 \frac{1}{4}$ miles, in 2.10. His sire is the most popular stallion in America, and no son of Longfellow is from a family more noted as a racing and prodneing one. Buff and Blue was the dam of Badge (Logic and Minnie Elkins' dam), Ban Cloche, Blue Stocking (Barefoot's dam), Monita Hardy, Sister Geneva, ete. La Gitana, from the family, is the dam of Genera (Riley's dam) by War Dance, Glitter, Daisy, Guilford, Pommery Sec, Appomatox, ete., Revolver, a good race-Lorse ancl stallion. The Banshee, from this family, won the Travers Stakes, Westchester Cnp, ete., and was the dam of Krupp Gun, Brigand Belle, etc. Heraldry, the fourth dam, was a good race-mare, dam of Parachute, Ascension, Sally of the Valley (Essillah's (lam), etc., by imp. Herall, winner of the second heat in the great Peyton Stakes run at Nashville, 1843, he by English Plenipotentiars, son of Emilins by Orville; fifth dam Margaret Woods, winner of the Trial Stakes at Nashville, 1843, dam of Wade Hampton, Star Daris, Maria Wood, Capt. Travis, La Gitana, ete., she by imp. Priam (winner of the Derby), son of Emilius and Cressida by Whiskey ; sixth dam Maria West by Marion, son of Sir Archy. Maria West was a good race-mare and dam of the noted Waguer, who defeated Gray Eagle in the two fanous four-mile heat races run at Lonisville, Ky., in 1839.

Logie has a donble cross each of Lexington and Glencoe blood and three crosses of the famous Emilius blood, one through Yorkshire, son of St. Nicholas by Emilius, one through Priam, winner of the Derby, and one throngh imp. Heralt, son of Plenipotentiary (Lion of Doncaster) by Emilins.

Logic's oldest foals, now sncklings, are rare good ones and will race successfully. 


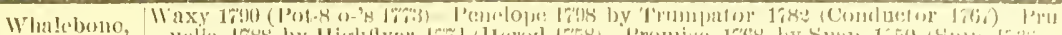

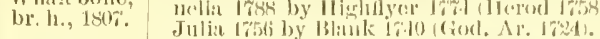

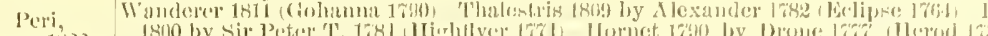

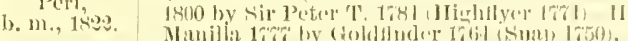

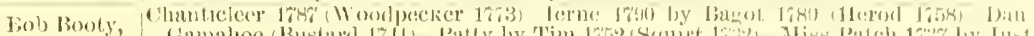

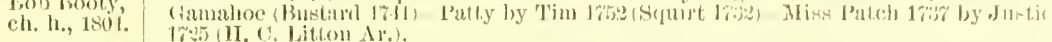

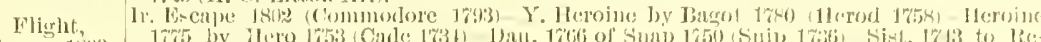
(1). $111 ., 1809$

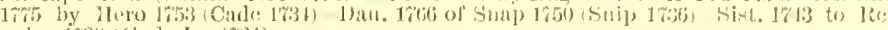

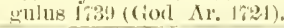

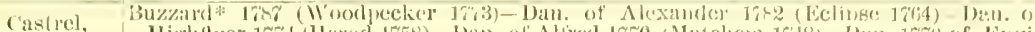

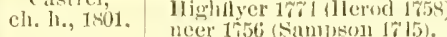

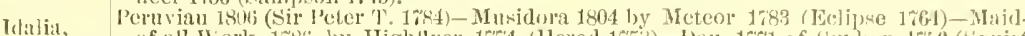

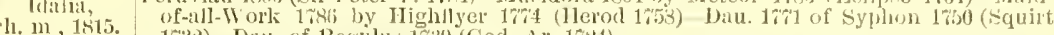
173:2)-Dau. of Regiilus 173: (God, $\wedge \mathrm{r}$. 1724).

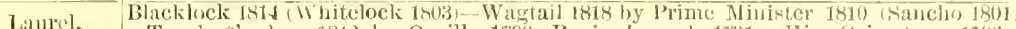

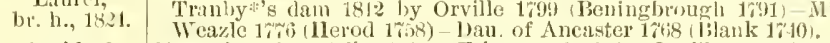

Mail of Champion 1812 (Selim 1502)-Etiquette 18.0 by Orville 17!9 (Beningblough 1761)- Bon-

Honor,

br. 11 ., 1829. dicea 180; by Alexander 1783 (Echipse 17(64) Brunette by Amaranthus 1766 Old Eng land 1741)-Mayfly $17 \% 1$ by Matchem $1 \% 18$ (Cade 1734)

Duroc,

Miller's

Damse!,

gr. m., 1812.

Ilenry,

ch. h., 1819

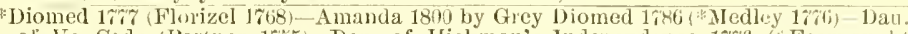

ol Ya. Cade (Partner 1,b5)-Dal. of Ilickman's Independence 17r6 ("Fearnought $1755)$ - Dau of "Badger (Bosphorus 1754).

* Aiessenger 1780 (Nambrino 1768)-*Dau. 1792 of Pot-8-o-'s $17 \% 3$ (Eclipse 1\%64)-Dau. $17 \% 8$ of Gimerack 1760 (Cripple 1750) - Snapdragon 1759 by Snap 1750 (Sni] 1736)-Dan. 1749 of Regulus 1739 (God. Ar. 1724). Y. Romn, Duroc 1806 ("Diomed 1\% Old Romp 180.5 by Messenger $1 \% 30$ (Mambrino $1 \%(1)$

ch. $11 ., 1815$

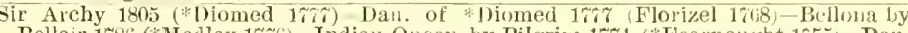

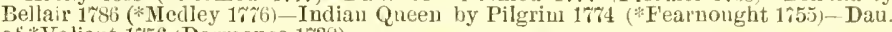

*Dau. 1\%t2 of Pot-8-o-'s 1\%33 (Eclipse 1764)-Dau. 1\%:8 of Gimerack 1760 (Criplele 1750) - Snapdragon 1759 by Snap 1750 (Snip 1736)

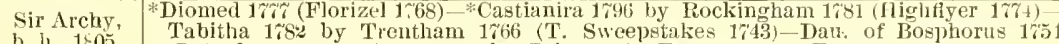

b. h., 1805 .

Eliza,

ch. $\mathrm{m}, 1804$.

(Babraham 1;40)-Sict. to Greciau Princess by Forester 1\%50 (Forester 1736 .

Bediord 1702 (Dungannon 1780) - * Mambrina 1\%85 by Mambrino 1768 (Engineer 1756) Sist. to Sally by Blank 1; 40 (God. Ar. 17\%4)-Dau, of WTard 1731 (Crab 1722)-Dall. of Merlin (Bustler).

Brinmer or I3lue Bentrd,

Merlin of Brilliant 1750 (Crab 1722)-Dau. of Taltar 1743 (Partner 1718)-Dau. of Son of Flying Childers 1715 .

dam,

of *Traveller 1\%t7 (Partner 1718)-Dau. of *ll hittington (Cullen Ar.) - Dau of *Chil ders (Blaze 1\%3')

'Timoleon, Sir Archy 1805 (*Diomed 1\% -Dan. of :Saltram 1780 (Eclipse 1\%64)-Dan. of Symmes ch. h., 1813. *Fallower $1 \% 61$ (Blank 1740 )

Sister to
Suckahoe,

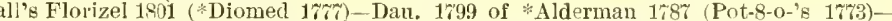

Dau. of * Clockfast 17\%4 (Gimerack 1\%60)-Dau. of Symmes" Wildair 1;6\% "Fearnought

1755) - Y. Kitty Fisher 1767 by *Fearnought 1755 (Regulus 1739

* Sarpedon, Lmilius 18\%0 (Orvilie 179;)-Icaria 1824 by The Flyer 1814 (Vandyke Jr. 1898)-Parma

1813 by Dick Andrews 179\% (Joe Andrews 1\% 78 )-May 1804 by Beningbrough 1\%91

(King Fergus 17.5)-Prim rose 1787 by Mambrino 1768 (Engineel 1756)

Rowena, Sumpter 1818 (Sir Archy 1805)-Lady Gley 1817 by Robin Grey 1895 (* Loyalist 1790) -

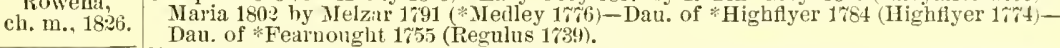

Sultan,

b. h., 1816

Selim 18 2 (Bnzzand 1787)-Bacchante 1802 by W's Ditto 1800 (Sin Peter T. 1784)-Dan. 1791 of Mercury $17 \% 8$ (Ecipse 17(4)-Dau. 1776 of Hered 1758 (Tartar 1743)-Folly 17\%1 by Marske 1750 (Squirt 1\%\%2)

Trampoline, Tranp 1810 (Dick Andrews 1797)-Web 1808 by Waxy 1790 (Pot-8-o-'s 17r3)-Penelope \begin{tabular}{l|l} 
ch. m., 1825. & 1798 by T'rumpator 1782 (Conductor 1767)-Prunella 1788 by Hightlyer 1774 (Herod \\
\hline
\end{tabular}

Mameluke, Partican 1811 (Walton 1749)-Miss Sophia 1805 by Stamford 1694 (Sir Peter T. 1784)Sophia 1793 by Buzzard* 1787 (Woodpeckes 17\%3)-Huncamunca $1 \% 87$ by Highflyer

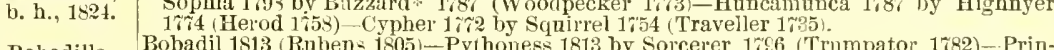

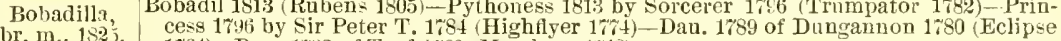
1764)-Dau. 1783 of Turf 1760 (Natchem 1748 ).

Boston, Timoleon 1813 (Sir Archy 1805)-Dal. 1814 of Ball's Florizel 1801 (*Diomed 1rif)-Dau.

Boston, 1799 of *Alderman 1787 (Pot-8-o-'s 1\%73)-Dau. of *Clockfast 174 (Gimcrack 1760) Dau. of Symmes' Wildail 1767 ( Fearnought 1755).

Sarpedon 18:8 (Emilius 182) -Rowena 1826 by Sumpter 1818 (Sir Archy 1805)-Lady Grey 1817 by Robin Grey 1805 ("Royalist 1790) - Maria 186\% by Melzar 1\%91 (* Medley 1766 -Dau. of *Hightiyer 1;81 (Iightlyer 1\%1).

送

b. m., 1836 .

:Glencoe,

Sultan 1816 (Selim 1802)-Trampoline 1825 by Tramp 1810 (Dick Andrews 179\%)-Web 1808 by IVaxy 1\%.0 (Pot-8-0's 1\%氵3)--Penclope 1798 by Trumpator 1782 (Conductor $176 i$ )-Prunella 1788 by Hightlyer $1 \%$ (Herod 1758 ).

*Galopade Cation 1899 (Golumpis i892)-Camillina 182? by Camillus 1s03 (Hambletonian 179?) -

gr. m., 1828. Dau. 1818 of Smolensko 1810 (Sorcerer 1696)-Miss Cannon 1811 by Orville 1 \%99

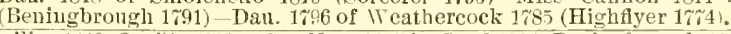

- St Nicholas Emilius 1820 Orville 1799)-Sea Mew 1815 by Scud 1804 (Beningbrough 1791) - (roosander

Or. li., 18:\%.

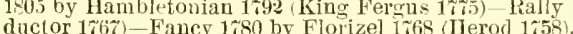

芒芒 Miss Rose, * b. m., 1826 . ductor 1767 -Fancy 1780 by Florizel 1768 (11erod 1758

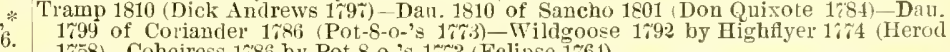
1758)-Coheiress 1785 by Pot-9-0-'s 17\%3 (Eclipse 1764).

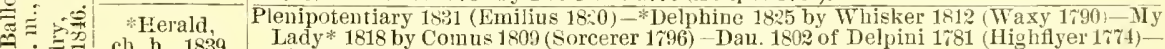
ch. b., 1839. Lady* 1818 by Com as 1809 (Sorcerer 1796)-Dau. 1802 of

Margaret Ella Crump br. m. by *itizen 1785 (Pacolet 1763) Dau. br. m. 1795 of Huntsman $1 \% 89$ (*Mousetrap 1 171)-Dau. of Symmes" Wildair $176 \%$ (*Fearnought 1755)-Dan. of * Fearnonght 1;5.) (Regulns 1;39)-Dat. of Janus 1\%16 (Janus 1\%9). 


\section{LONGFELLOW.}

WINNER OF THE PRODUCE STAKES AT LEXINGTON, KY., OHIO STAKES

AT CINCINNATI, AND CITIZENS' STAKES AT NASHTILLE, 1870, M10NMOUTH CUP AT LONG BRANCH, 1871 AND 1872, SARATOGA CUP IA 1871.

\section{Owned by F. B. Harper, Nantura Stud, near IFidway, Woodford Co., Fy. Seasons full at $\$ 1,000$.}

LoxgFellow by imp. Leamington, son of Faugh-a-Ballagh, bred by John Harper, foaled 1867, dam Nantura, dam of Extra, Fanuy Holton, ete , by Branner's Eelipse, son of Am. Eelipse, ont of Quiz, sister to Qneen Mary, by Bertrand, son of Sir Archy. Longfellow was a fast, good race-horse, made his debut at Lexington. Ky., May 16, 1870, in Phœnix Stakes, mile heats, for three-year olds, won by Enquirer in 1. $14 \frac{3}{4}, 1.44 \frac{1}{2}$, Catina seeond and Longfellow third and distanced. Same

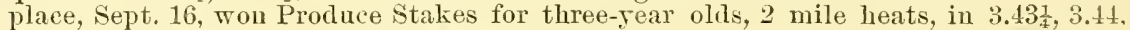
beating Trinkle, ete. Cincinnati, Ohio, Sept. 30, won Ohio Stakes for three-year olds, 2 inile heats, in $3.37 \frac{1}{2}, 3.55 \frac{1}{3}$, beating Pilgrim. Memphis, Tem., Oct. 25, won

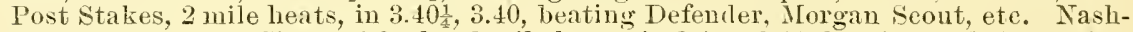
ville, Oct. 12, won Citizens' Stake, 2 mile heats, in $3.41 \frac{2}{4}, 3.41$, beating and distancing Morgan Seont, ete. Lexington, Ky., May 24, 1871, walked over for purse $\$ 400,2$ mile

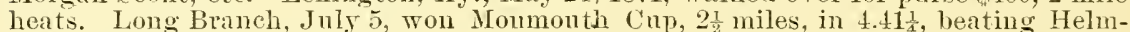
bold, Regarils and Preakness. Saratoga, Juls 14, won Saratoga Cnp, $2 \frac{1}{4}$ miles, in 4.023, beating Kingtisher, the first mile was rim in $1.40 ;$ Ang. 19, walked over for puxse of $8800,2 \frac{8}{4}$ miles; Ang. 23, was beaten by Helmbold, 4 miles, in $7.49 \frac{1}{4}$. Lex-

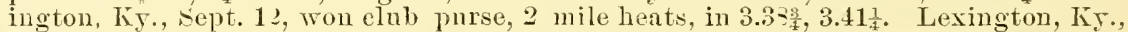

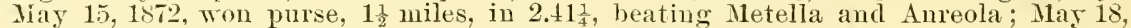
won Woolley stake, 3 miles, in 6.1003, beating Metella, Talaria, ete. Long Branch, July 2, won Monnouth Cup, 21 miles, in 4.34; July 4, won purse, mile heats, three best in five, in 1.561, 1.54, 1.43, beating Susan Ann, Metella and Arizona. Saratoga, July 16, was beaten by Harry Bassett for the Cup, $2 \frac{1}{3}$ miles, in 3.59, the fastest race to that date. The first mile was run in 1.44, the first two miles in 3.30. Longfellow pullerl np lame, and with this race closed his tun $\mathrm{f}^{\circ}$ eareer, starting in sixteen races, won fourteen, lost two, and wou $\$ 15,000$ in money. Nantma, his dam, was a rery superior mare and good winner, Brawner's Eelipse, her sire, was a fine race-horse, and much inbred to imp. Diomed, Quiz, his grandam, was a fine race-mare, Bert. rand, her sire, son of sir Arehy, was one of the best race-horses and stallions of his day.

Longfellow stands nearly 17 hands high, with white stripe down his face, with left hind foot white above the aukle, and a little white ou the coronet of thr xight hind foot. He has a neat ear, broad forehead, with Roman nose, long, well-shaped neck, xumning into strong, well-shaped shonlders, preat depth of girth, rather light tlank, good strong hips, with good length of whirlbone and stifle, and thence to the hoek; good legs and teet. The following are the hest of his get: Thora, a tirst-class mare, her 3 miles at Snratoga when three years old, with 99 1hs., in $5.25 \frac{1}{4}$, was a remarkable race; also her Pimlico Stake, $2 \frac{1}{x}$ miles, in $3.47 \frac{1}{4}$. Other good ones are Edinburg, Irish King, Jils Johnson, Leonard, Lilly R., Long Taw (Dave Mloore). Mollie Merrill, Gen. Pike, John Harper, Georgia A., Odı Fellow, Toun Montane, Beli Boy, Cornena (Miss Nailer), Longitude, Long Girl, Wildmoor, Wildtellow, Freeland, Hospoctar, Fellowplay, Minuie D., Lucy Long, Mary Corbett, King Dutehman, Loug Girl, Annie G., Hypoerite, Clay Storkton, Faloolah, Longstreet, Riley, Poet scout, Barefoot, Rainbow, Lew Weir, Lannes, Semper Fidele, Peg Woffington, Irish Chiet, Cassins and many others. In addition to his leing a son of Leanington, he is much inbrerl on the dam's sirle to Sir Archy and Diomed, well fortified with the blood of Herod and Eclipse, upon that of Partuer and Regulus, son of the Godolphin Arabian. Longfellow traces in direet female line to the Nerlin mare, to which traces Herod (King Herod), Coronation, knight of St. George, Promised Laud, Carlton, imp. Glenelg, etc. 
Waxy,

b. h. 1 (1, Dielgrale (lielgriade 'l'urk).

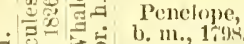

車

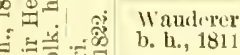

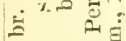

\section{b. h., 1811 .}

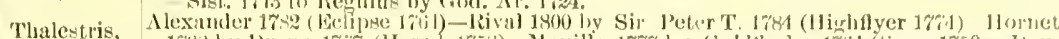

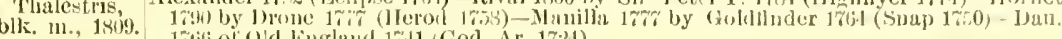

Chanticleer.

ch. h., 1\%:

l'rine,

ch. m., 1790.

1r. Escape,

(h. h., 18u2

I. lleroine

Buzzard,

ch. 1., 1\%8\%

Daughter of,

b. m.,

Peruvian,

b. b., 1806 .

Mnsidora,

b. m., 1804

Blacklock

b. h., 1811 .

Wagtail,

b. m., 1818

Champion,

ch. h., 1.12

Etiquette,

br. m., 1820 .

Tititi of Old lingland 1\%11 (God. Ar, 17:1).

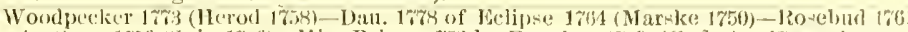

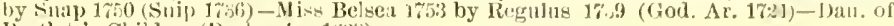
Bartletio Childers (1)arley Ar. 169\%).

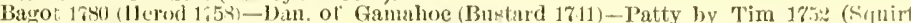

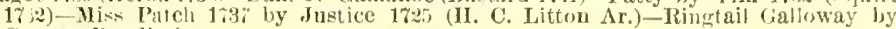
Curwen B:y li:atb.

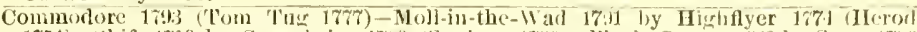
175t)-Shift 179 by Sweetbriar 1769 (Sy\}hon 1750)-Black Surau 1762 by Snap 1750 (Sinip 1\%36) - Dan, of Cinde 1731 (God, Ar. 17\%4)

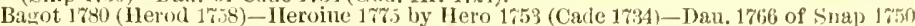
(Snip 1735)-Sist. 1743 to Regulus by God. Ar. 17\% - Grey Robinson 1\%(2) by Bald Galloway (St. Viclor Barb).

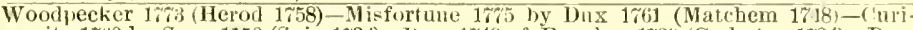
osity 1760 by Snaj) 1750 (Snip 1735)-Dau. 1749 of Regulus 1739 (God. Ar. 1724)-Dan. of Barlett's Chidders (Darley Ar. 1609)

Alexander 1782 (Eclips 1764)-Dau, of Highflyer 1\%4 (Herod 1758)-Dau, of Alfrerl 17w0 (Hatchem 1788)-Diku. 1\%0 of Engineer 1756 (Samj)en 1745)-Day Malton's dam 175t by Carle $1 \%: 3$ (God. Ar. 1\%:4).

Sir Peter '1'. 17' (Highflyer 1\%4)-Dau. 1786 of Boudrow $177 \%$ (Eclipse 1761)-Dan. 1764 of Squirrel 1754 (Traveller 1735)-Sist. to Lowther's Babrahaus by Babraham 1740 (God. Ar. 1724)-Dau. 1750 of Golden Ball 1735 (Partner 1718).

Veteor 1783 (Eclıpse 1761)-Maid-of-all-Work 1781; by IIighflyer 1774 (Herod 1758)-Dan. 1771 of Syphon 1750 (Squirt 1732)-Dau, of Regulus 1739 (God. Ar. 1721)-Sist. 1758 to Judgement by Snip 1736 (Elying Childers 1715).

Whitelock 1803 (IIambletonian 179:)-Dau. 179!) of Coriander 1786 (Pot-8.o-'s 1773) Wildgoose 1792 by Highflyer 1774 (IIerod 1758)-Coheiress 1786 by Pot-8-0-'s 1779 (Eelipse 1764)-Manilla $17 \% 7$ by Gollfinder 1\%64 (Snaj) 1\%0)

Prime Mlinister 1810 (Sancho 1801)-Tranby*'s dam 1812 by Orville 1799 (Beninghrongh 1791)-Miss Grimstone 1796 by Weazle 1776 (Herod 1758)-Dau. of Ancaster 1768 (Blank 1740) - Dall. of Damascus Ar. 1754.

Selim 1802 (Buzzard* 178\%)-Podagra 1805 by Gouty 1796 (Sir Peter T. 1784)-Jet 1785 by Magnet 1760 (Hero 1758 ) - Jewel 1775 by Squirıel 1754 (Traveller 1795)-Sophia 1764 by Blank 1710 (God. Ar. 17\%4)

Orville 1799 (Beningbrough 1791) - Boadicea $180 \%$ by Alexander 1782 (Eclipse 1764)Brurette by Amaranthus 1766 (Odd England 1741)-Nayfly 1771 by Matchem 1748 (Cade 1\%34)-Dau. 1\%55 of Starling 1738 (Stalling 172\%)

*Diomed Florizel 1768 (Herod 1758)-Dau. 1763 of Spectator 1749 (Crab 1722)-Horatia 1758 by ch. h., 1\%:\% Blank 1710 (God. Ar. 1724)-Dan. of F

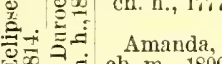
ch. m., 1800 gr. h., 1780 . -

b. h., 1805

Mambrino 1768 (Engineer 1756)-Dau. 1\%4 of Turf 1760 (Matchem 17 48 )-Dat1. 1\%61 Regulus 1739 (God. Ar. 17:4-Dau. 1753 of Srarling 1;2\% (Bay Bolton 1705)-Snau's dam 1739 by Fox 1714 (Clumsy).

Pot-8-o-'s 17\%3 (Eclipse 1764)-Dan. 17\%8 of Gimcrack 1760 (Cripple 1750) - Snap Dragon 1759 by Snap 1750 (Snip 1736)-Dau. 1749 of Resulus 1739 (God. Ar. 1724)-Dau. of Bartlett's Childers (Darley Ar. 1699)

*Diomed 1, Forizel 1;68) - Castianira 17:6 by Rockingham 1781 (Highflyer 1\%4)Tabitha 1782 by Trentham 1766 (T. Sweepstakes 1;43)-Dau. of Bosphorms 17:4 (Babraham 1740) Dau. of Forester 1659 (Forester 1;36).

Daughter of,

- Indian Queen by Pijgrim 17\%4 (*Fearnonght 1755)-Dau. of *Valiant 1756 (Dormouse 1738)-Dau. of Janus 1746 (Janus 1788).

Duroc,

ch. h., 1906 .

Diomed 17\% (Florizel 1768)-Amanda 1800 by Grey Diomed 1:86 (* Medley 1\%76)-Dau. of Va. Cade (Partner 1755)-Dau. of Independence 1\%t6 (*Fearnought 1755)-Dau. of *Badger (Bosphorus 1754).

Old Romp.

$>$ - ch. m., 1805

* Diomed.

ch. h., 1irit. (Eclipse 1\%64)-Dau. Dau. 1749 of Reculis 1739 (God Ar 1724 )

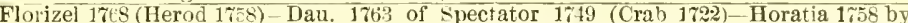
Blank 1710 (Grd. Ar. 1724)-Dau. of Fl. Childers 1715 (Darley Ar. 1699)-Migs Belvoir by Grey Grantham (Brownlow Turk)

*Cagtianira Rockingham 1781 (Highflyer 17\%1)-Tahitha 1782 by Trenthan 1766 (T. Sweepstake 1743)-Dan. of Bosphorus 1754 (Babraham 1740) - Dau. of W's Forester 1750 (Forester 17.6)--Dau. of Coalition Colt 1739 (God. Ar. 1724)

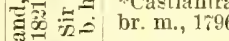

Dungannon 1780 (Eelinse 1\%64)-Fairy 178 by Hiohtlyer 17\% (Herod 1758 -Faily

*Bedford,

b. $\mathrm{b}, 1792$

Mambrina Queen 1.62 by Y. Cade 1747 (Cade 1734)-Routh's Black Eyes 1741 by Crab 1722 (Alcock Ar.) - Warjock Galloway 1728 by Snake (Li-ter Turk).

Mambrino 1768 (Engineer 1756)-Sist. to Sally by B]ank 1740 (God. Ar. 1724)-Dau. Ward 1731 (Crab 1722)-Dau. of Merlin (Bustler)-Lady Mare by Duke of Ancaster"s Pert (Ely Turk).

Tolunteer 1780 (Eclipse 1761)-Harriet 1753 by Ilighflyer 17\%4 (Herod 1758)-Dau. 176\% of $\mathbf{Y}$. Cade $174 \%$ (Carle 1734)-Chikerkin 1749 by Second $173 \%$ (Flying Childers 1715)Suan's dam 1739 by Fox 1714 (Clumsey)

b. b., 1791 .

Matchem (Bosphorns 1754) - Dau. of Brilliant 1750 (Crab 1722)-Dau. of Tartar

Brilliant,

1743 (Partner 1;1S)-Dau. of a Son of Flying Childers 1715-Bushy Molly 1;1 $\tilde{\gamma}$ by H. C. Litton Ar.

Woodpecker 173 (Herod 1758)-Misfortune 17\%5 by Dax 1761 (Matebem 1748)-Curiosit

*Buzzard

ch. h., $178 \%$

1760 by Snap 1750 (Snip 1736)-Dau. 1749 of Regulus 1739 (God. Ar. 1721)-Dall。 of Bartleft's Childers (Darley Ar, 1699).

The Fawn

Craig's Alfred (*Medley 17\%6)-Shepherdess by Wormsley's King Herod (*Fearnough 1755)-Dau. of Moreton's *Traveller 1747 (Partuer 1718)-Dau, of Whittington (Cullen Ar.) - Dau, of *Childers (Blaze 1733) -*Dau. 1758 of Babraham 1 740 (God. Ar. 1721)-Dan blk. m. 1752 of Starling 1\%2\% (Bay Bolton 1\%05)-Salome blk. m. 1733 by Bethell's Arabian-Dau. of Graham's Champion 1707 (Harpur's Ar.)-Dall. of Darley Ar. 1699-Dan. of Merlin (Bustler). ‡ Lady Fortune is by Brimmer or Blue Beard. Blue Beard's pedigree is accepted upon Mr. J. W. Fenwick's statement. 


\section{IMPORTED LOYALIST.}

Owned in Belle Meade Stud, Gen. IV. H. Jachson, proprietor, Nashville, Tenn. Icarling sales anmutly in May.

LorALIST is a bay horse, foaled 1885 , bred in the Yardley Stud. Loyalist is a rerv highly bred horse, full brother to Paradox, being by sterling, ont of Casuistry by The Miner, Blair Athol's conqueror out of Lady Caroline by Grlando. Loyalist never started, but his brother Paradox was a first-class race-horse. As a two-year old he made his mailen essay in the Middle Park Plate, for which he ran a dead heat with Royal Hampton for third place, behisd Melton (the Derby winuer) and Iaintiailles, nine others tinishiug in the rear. The only other race in which he started as a twoJear old was the Dewhurst Plate, which he won by three lengths, turning the tables on Xaiutrailles and also beating Lonely (wimer of the Oaks), Farewell (winner of the 1,000 Grineas) and six others. As a three-vear old Paradox began by winning the 2,000 Guineas; he ran second to Melton in the Derby, beaten a head only. After that he never knew defeat. He was then shipped to Frince, where he captured the Grand Prize of Paris with the greatest ease. Having returned to England, he won the Sussex Stakes at Goodwood, wiving Royal Hampton, who was second, 9 lbs., and eonceding more weight to the other four runners. At Newmarket he won the Champion stakes from foul ethers with 100 to 12 laid on him. His racing eareer closed with his victory in a handicap across the flat at Newmarket, in which he gare from 14 to 34 lbs. to his antagonists. Sterling, his sire, was a great race-horse, and sired many cracks, including Isonomy, Enterprise, winner of the 2,000 Gnineas, and Enthnsiast (winner of the 2,000 Guineas, etc.), Harvester (who ran a dead heat in the Derby with St. Gatien), and many other good ones. Casuistry, Loyalist's dam, only started as a twojear old, when she won a Maiden Plate at Epsom, beating Isolina, Beddington, Broat Arrow, Fanfare, Mexico and seven others. She is a full sister to that good race-horse, Coutroversy, who won hosts of races, including the Lincoln Handicap, the LiverpooI Cup, carrying 124 lbs., the Edinburgh Gold Cup, carrying 130 lbs. and beating CraigMillar (winner of the St. Leger, etc.) and Thunder, winner of the City and Suburban; ete. and he also beat the speedy Lowlander in a match. Casuistry is a danghter of The Miner, wimer of the Great Yorkshire Stakes, where he beat Blair Athol. He is full brother to Mineral (that raced nnder Mr. Ten Broeck's colors), the dam of Kisber (wimner of the Derby and Grand Prize of Paris), and of Wenlock (wimier of the st. Leger). Her dam, Lady Caroline, is by Orlando (wimer of the Derby, and sire of Teddington, the winner of the Derbr, the 2.000 Gnineas winners, Fazzoletto, Diophantus and Fitz Roland, and of Imperiense, the wimuer of the 1,000 Guineas and st. L.eger). Out of daughters of Orlando came Camballo, Gang Forward, General Peel, winners of the 2,000 Guineas, Petrarch, winner of the 2,000 Guineas and St. Leger. Not to forget that imp: Eelinse, a highly valued eross for speed, is son of Orlando. Lady Caroline threw other winners besides Casuistry and Controversy, her list inclucling the stake winners Childe Harold, Lady Stately and Conrert, and is out of a Stockwell mare, Lady Blanche, a combination of blood that prodnced Gang Forward (winner of the 2,000 Guineas), and she is a danghter of Clementine, winner of the 1.000 Guineas, and half sister to Bay Midilleton (winner of the 2,000 Guineas and Derby), and Achmet (winner of the 2,000 Gnineas) by Venison. Clementine's dam was that famous mare Cobreb (winner of the 1,000 Guineas and Oaks) by Phantom. All the sons of Sterling are getting racers abroad. Isonomy is the sire of Common, winner last year of the 2,000 Gnimeas, Derby and St. Leger, Seabreeze, ete. There is no better bred son of Sterling than Loyalist, not even Isonomy himself, Enterprise, Enthusiast, Doubloon or Fernaudez.

Loyalist descends in direct line from the same Royal mare to which traces Woodpecker, Waxy Pope, Whalebone, Whisker, Partisan, Bay Midlleton, imp. Glencoe, Melbourne, Robert the Devil, Bendor, imp. Eclipse (Morris), Uncas, Wanderer and all the Prunella family. 


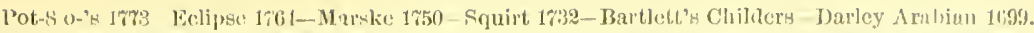

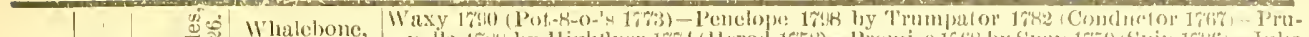

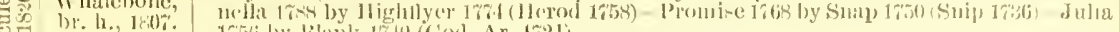

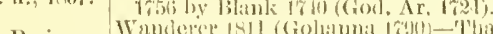

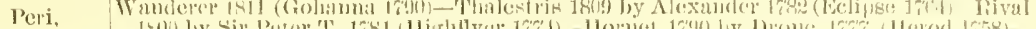

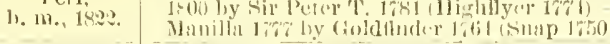

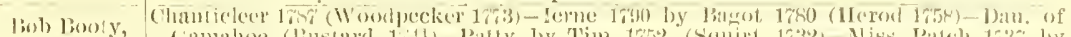

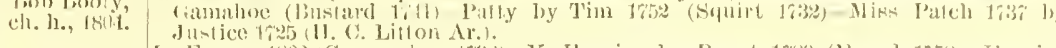

में

Flight,

Ir. Necupe 150: (Commorlore 1at liegulis by (iorl. Ar, liod.

हैं Emilius,

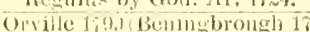

1). h., $152 \%$,

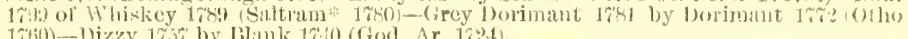

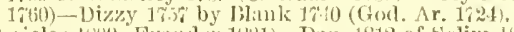

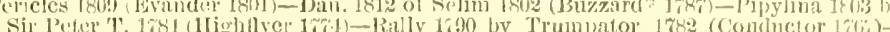

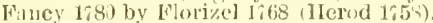

Bily

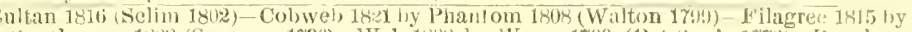

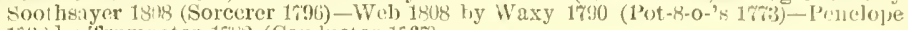
$15: 2$ by 'Trumpator 178: (Conduct or 1767)

Midlletom,

Aiss Letty,

b. $13 . .1831$.

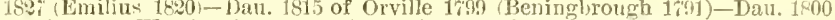
of Buzzare : 1787 (Woodpecker 17\%3)- Hornpipe 1793 by Trumpator 178: (Conduetor

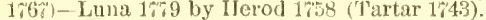

कृ. Camel,

Whalebone $180 \%$ (Waxy 1590) Dall. 1812 of Selim 18(2 (Buzzard" 1787)-Maiden 1801

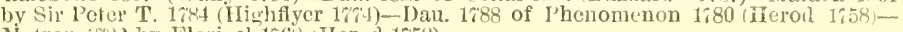
diatron $198^{2}$ by Florizel 1603 (IIerod 1758).

Banter,

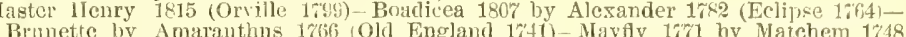
Cade 1731)-Dan. 1755 of Ane. Starling 1738 (Starling 172i).

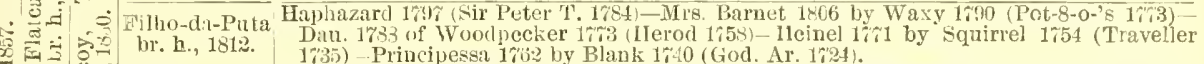

Peruvian 1803 (Sir Peter T. 1784) - Violante 1802 by John

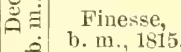
1789 Fortiturle 1 in 1750) - Hyæena $17 \% 3$ by Snap 1750 (Snip 1736 )

Himprey

b. b, $18 \%$ ?

Comns 1899 (Sorcer(r 1796)-Clinkeritia 1812 by Clinker 1805 (Sir Peter T. 1rist)-Pewet 1786 by Tandem 1773 (Sypbon 1\%50)-Termagant by Tantrum 1760 (Cripple 1;50)Cantairice by Sampson 1745 (Blaze 1783).

Danghter of

Cervantes 1893 (Don Quixote 1i84)-Dau. 1818 of Golumpas 1802 (Gohanna 1;90)-Dan. 1810 of Paynator 1791 (Trumpator 1;E2)-Circle 1802 by St. George 1789/Highflyer 17i4) - Ahigail 1789 by Woodpecker $17 \% 3$ (Herod 1758),

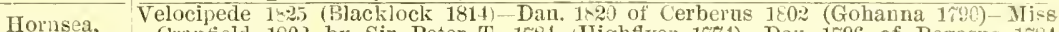
Hornsea,
ch. h., 1833. Crantield 1803 by Sir Peter T. 1784 (Highflyer 1r74)-Dau. 1796 of Pegasus 1784
(Ecipse 1\%

Solace Longwiast 1821 (Whalebone 180\%)-Dulcamara 1818 by Waxy 1790 (Pot-8-0-'s 1\%i3)b. m., 1830.

Witch 1814 by Sorcerer 1:96 (Trumpator 1782)-Cobbëa 1802 by Sky\&craper 1786 (Hightyer 17\%4) Dan. 1788 of Woodpecker $17 \% 3$ (Herod 1758).

Ir. Burdcatcher

ir Hercnles 1826 (Whalebone 180\%)-Guiccioli 1823 by Bob Booty 1804 (Chanticleer 178\%)-Flight 1809 by Ir. Escape 1802 (Commodore 1r93)-Y. Heroine by Bagot $1 \mathrm{r}^{2} 0$ (Herod 175)-Heroine 1 rito by Hero 1753 (Cade 1734)

Echidna Economist 1305 (Whisker 1812) - Mise Pratt 1825 by Blacklock 1814 (Whitelock 1803)

Gadabont 181 ? by Orville 1799 (Beningbrough 1791)-Ninstrel 1803 by sir Peter T. 1 r84 (Hightlyer 17t4)-Matron 1782 hy Floilizel 1768 (Herod 1558

b. m., 1833

Glencoe,

Sultan 1816 (Selim 1802) - Trampoline 18:5 by Tramp 1810 (Dick Andrews 169r)- 1 Teb 1808 by Wary 1790 (Pot-8-0-'s 17is)-Penelope 1798 by 'Trumpator 1782 (Conductor

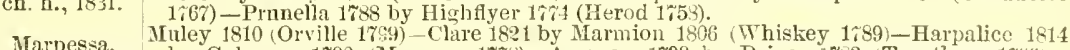

by Gohanna 1790 (Mercury 1778) - Amazon 1799 by Diver 1783 (Trentham 1766)Fractions 1793 by Mercury $17 \% 8$ (Eclipse 17e4)。

b. m., 183

Whalebone 1807 (Waxy 179.1)-Peri 1822 by Wanderer 1811 (Gohanna 1790)-Thalestris

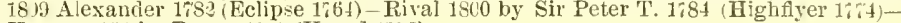

Hornet $19 \%$ by Droue $17 \% 7$ (Herod 1758 ).

blk. h., 1826

1809 by Ir Fscape 1802 (Commodore 1595 $\mathrm{Y}$. Heroine by Bagot 1780 (Herod 1758)-Heroine 17\%5 by llero 1753 (Cade 1734)-Dan. 1766 of Snap 1750 (Snip 1736).

Jelry 1821 (Smolensko 1810)-Dau. 1817 of Ardrossan 1809 (John Bull 1789) - La dy Eliza

Tomboy, 1813 by whitworth 1805 (Agonistes 1797) -Dau. 1793 of Spadille 1784 (Hichflyer 1 $\pi 4$ ) - Sylvia 1783 by Y. Marske $17 \% 1$ (Marske 1i50).

Prime Minister 1810 (Sancho 1801)-Maniac 1803 by Shuttle 1793 (Y. Narske 1riv)-

Anticipation 1802 by Beningbrough 1791 (King Fergus 17\%5)-Expectation $17 \% 9$ by IIerod 1753 (Tartar 1743) - Dau. 1755 of Skin 1746 (Starling 1727).

Whalebone 180\% (Waxy 1;90)-Dau. 181: of Selim 1802 (Bnzzard* 178\%)-Nlaiden 1801 by

Camel,

演. br. h, 1822. Sir Peter T. 1784 (Hightyer 1774)-Dan.

Banter,

Master Henry 1815 (Orville 1r99)-Boadicea 1807 by Alexander 1782 (Ecljpse 1661)Brunette by Amaranthus 1766 (Old England 1741)-Mayly 1771 by Matchem 1748 (Cade 1734)- Dan. 1\%55 of Anc. Starling 1738 (Starling 172\%).

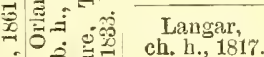

Selim 1802 (Buzzard 1 1 8 - Dan 1808 of if alton 1799 (Sir Peter T. 1r81) Y Giantess 1790 by Diomed* 1777 (Florizel 1788)-Giantess 1769 by Matchem 1748 (Cade 1734)ILolly Long Legs 1753 by Babraham 1740 (God. Ar. 1724).

Bnstard 1813 (C. istrel 1801)-Olympia 1815 by Sir Oliver 1800 (Sir Peter T 1781) ScoBnstard 1813 (Cistrel 1801-Olympia 1815 by Sir oiver 1800 (Sir Peter T. 1781)-Scomony $17 \% 5$ by Herod 1758 (Tartar 1 $\tau_{43}$ )

$\therefore$ b. m., 1821 .

r. Birdcatcher 1:333 (Sir Hercules 18:6)-Echidna 1835 by Economist 1825 (Whisker

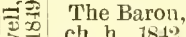
1812) - Niss Pratt 1525 by Blacklock 1814 (W hitelock 1803 ) _ Gadabout 1812 by Orville 1799 (Beningbrough 1791) - Minstrel 1803 by Sir Peter $T$, 1784 (Highflyer 1774).

S. ch. h., 18t

Pocahontas, Glencou sosi (Sultan 1810 - Mar Marmion 1806 (Whiskey 1759) - Harpalice 1814 by Gohanna 1790 (Mercury 1\%78)-Amazon 1799 by Driver 1783 (Trentham 1766).

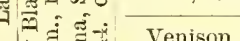

br, b., 1833.

Tartisan 1811 (Walton 1799)-Fawn 18*3 by Smolensko 1810 (Sorcerer 1796)-Jerboa 1803 by Gohanna 179 (Mercury 1\%5)-Camilla 1 \%8 by Trenthan 1766 (T.Sweepstakes 1\%t3)Coquet:e 1764 by Compton Barb.

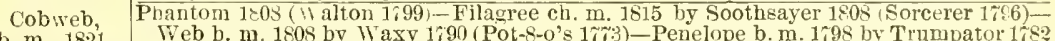

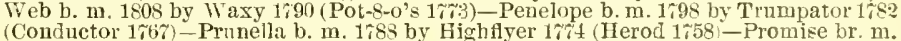
$1 \% 68$ by Snap 1750 (Snip 1736)-Julia h. m. 1756 by Blank $1 \%+0$ (God. Ar. 1\%21) - Spectator's dam b. m. 1735 by Partner 1718 (Ji gro - Bonny Lass b. m. 1723 by Bay Bolton 1705 (Grev Hautboy) -Dau. of Darley Ar. 1699-Dau. of Byerly Turk-Dan. of Taffolet Barb- nan. of Place's White Turk-Natural Barb mare of MIr. Tregonwell's. 


\section{LUKE BLACKBURN.}

WINNER OF THE TIDAL, LONG ISLAND S'T. LEGER AND GREAT CHALLENGE STAKES AT SHEEPSHEAD BAY, OCEAN AND CHAMPION S'TAKES AT LONG BRANCH, UNITED STATES HOTEL STAKES AND GRAND UNION PRIZE AT SARATOGA, KENTUCKY ST. LEGER AND GREAT AMERICAN STALLION STAKES AT LOUISVILLE, KY.

\section{In the Belle ILeade Stud. Application to Gen. W. H. Jackson, proprietor, lock box 383, Nashville. Tenn. Anmual sale of yearlings about May 1st.}

Luke Blackburn by imp. Bonnie Scotland, bred by Messrs. J. \& A. C. Franklin, Summer Co. Teun., foaled 1877, dam Nevada by Lexington, out of Lightsome, dam of Salina, Sprightly and Crucifix by imp. Glencoe. In 1879, as a two-rear olı, Blackburn ran with indifferent sncess. He started thirteen times, won two races, was second in six, third in one and unplaced in four. Lexington, May 12, ran second in the Colt Stakes, $\frac{1}{2}$ mile, time, 0.50. Louisville, Ky., May 21, ran second to Kimball in the Alexander Stakes, $\frac{1}{2}$ mile, time, 0.493, eight started. St. Louis, Mo., June 13, again finished second to Kimball in the Hotel Stakes, $\frac{3}{2}$ of a mile, time, $1.16 \%$ Chicago, Iill., June 23, ran second to Kimball (third time) in Grand Pacitic Hotel Stakes, $\frac{3}{4}$ of a mile, time 1.181, Wargentine finished third. Saratoga, Aug. 2, ran second to Lucy George, $\frac{5}{8}$ of a mile, time, 1.048; Giroflé and Cassatt behind him; same place, Ang. 12, ran second to Grenarla in the Wimlsor Hotel Stakes, $\frac{5}{x}$ of a mile, time, 1.031, seven started. Antumn Meeting, Coney Island Jockey Clnh, Prospect Park, Sept. 6, won his nuaiden race, the Breeze Purse, 辛 of a mile, defeating Giroflé, Queen's Own and four others, time, 1.17\%. Brighton Beach Fair Gronnds, X. Y., Sept. 18, won the Ocen Stakes, $\frac{3}{4}$ of a mile, defeating Elias Larrence (Late Bilsteiu), Qnito and three others, time, 1.18. After this race Lnke Blackburn was retired, and became the property of Dwser Bros., who gave $\$ 2,500$ for him.

in the year 1880 Luke Blackburn started in twenty-four races, lost two and won twenty-two. His first race was at Lexington, Ky., when he ran third to Fonso and Kinkead in the Phrenix Hotel Stakes, $1 \frac{1}{4}$ miles, won by Fonso in 2.08s, Blackburn sick and was mufit to run. Won a dash of af a mile at Jerome Park in 1.18, defeating Checkmate and three others; won a dash of $1 \frac{1}{8}$ miles in 1.58 , beating Scotilla, Checkmate and two others; won a race of 1 mile and 3 furlongs, in $2.28 \frac{1}{4}$, beating Scotilla and two others; defeated Monitor, $1 \frac{1}{2}$ miles, in $2.39 \frac{1}{2}$, and won the Handicap Sweepstakes, $1 \frac{1}{4}$ miles, in 2.13.

All these races were rmm at Jerome Park during the Spring meeting. Sheepshead Bay, June 19, won the Tilal Stake, 1 mile, in 1.45, defeating Kimball, Kitty J. and Grenada; June 22, won the Coney Island Handicap, 1 mile and 3 furlongs, in 2.24. beating Duke of Iontrose and Vagrant; Jume 26, was beaten in purse race, $1 \frac{1}{4}$ miles, in 2.12, by Duke of Montrose, Blackhurn fell in the first quarter and unseated his jockey. Long Branch, $j u l y 3$, won the Ocean Stakes, 1 mile and a furlong, in 2.03 $\frac{1}{2}$,

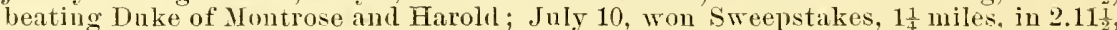
beating, with 110 lbs. up, Duke of Montrose, 105 lbs., and Grenada, 110 lbs. Sara. toga, July 16, won the All-agerl Sweepstakes, $1 \frac{1}{4}$ miles, in 2.11 and Folturno; July 24, won mile and a ftarlong, in 1.58, beating Gabriel and Giroflé; Jnly 27, won dash of a mile, in 1.43t, beating Turfman: Jnly 31 , won Smmmer Handicap, $1 \frac{1}{2}$ miles, in 2.39, carrying 110 lbs., concelling Juanitil 20, Gen. P'hrlips 2:3 ant Aila Glenn 17los. Saratoga, Aug. 5, won United States Hotel Stakes for three-year

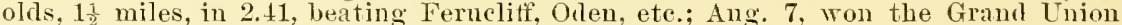
Hotel Prize, handicap, 116 libs. 11p, 1: miles, in 3.07, beating One Dime, 110 los., Glenmore, $118 \mathrm{lbs}$., and three others. In this race he conceded all from 20 to $361 \mathrm{los}$ : Aug. 12, won the Kenner Stakes, 2 miles, in 3.35 , beating Glidelia and Oden. Long Branch, Ang. 17, won the Champion Stakes, 1 miles, in 2.34, beating Monitor, Uneas, Grenada and Report, in the fistest and best race ever l'm at the listance to that date. Sheepslieal Bar, Sept. 4, won the Great Challenge Stakes for all ares, $1 \frac{1}{3}$ miles. in 2.38, beating Monitor, Uncas and One Dime: Sept.9, won the Long lsland St. Leger, 18 miles, in $4.07 \frac{1}{1}$; sept. 14 , won a mateh race for 85,000 , beating Uncas, each carryisg 108 lhs. $1 \frac{1}{3}$ miles, in $2.42 \frac{1}{2}$. Lonisville. Kr.. Sept. 27. Won the hentncky st. Leger, 2 miles, in 3.42, heating Finkead; Sept. 30 , won the Great Ameriean Stallion Stakes, 18 miles, in 3.04, beating Kimball and Big Metlicine. In this race he ingured the ynarter of one of his fore feet bally.

At fonc years old started in two ratces. Jerome Park, won elub purse, 1 mile, in 


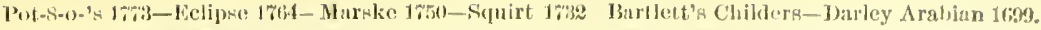

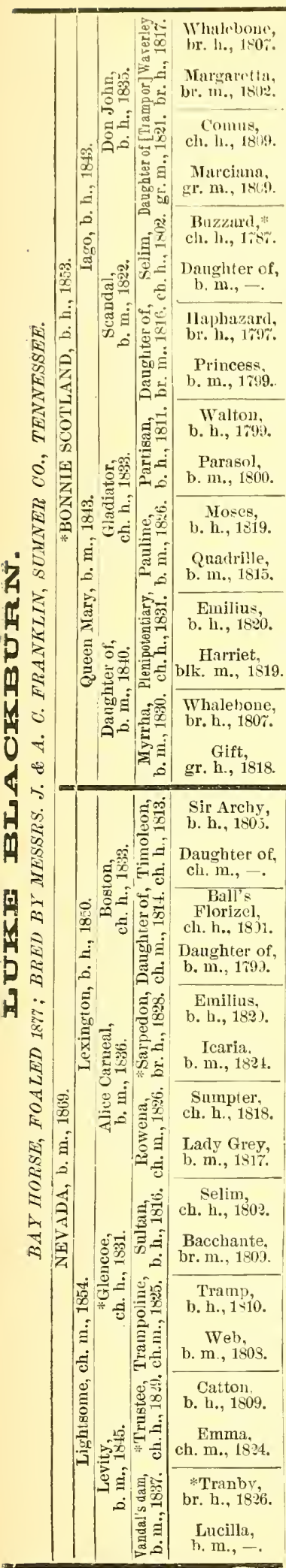

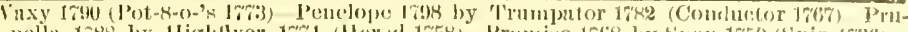

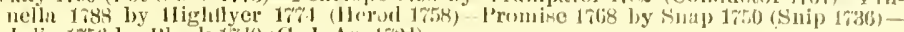
Julia rotot by Blauk $1 \% 10$ (God. Ar. 170.1)

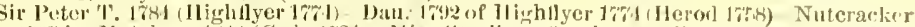

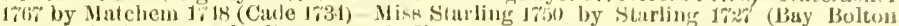

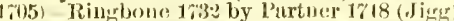

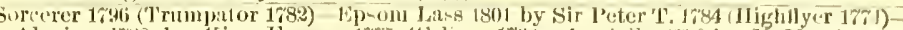

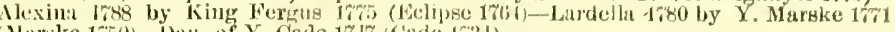
Marske 1750)-1 Mall. of $\mathrm{X}$. Cade $17 \mathrm{r}$ (Cade 1731)

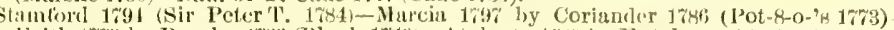

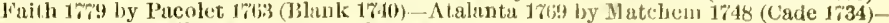
Y. Lltsa-of-the-Mill 1,5t; by Oroonoko 1;15 (Crab 1;22).

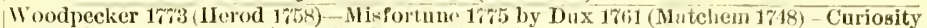
1760) by Snap 1750 (Snip 1\%36) Dan. 1\%49 of Regulus 1739 (1 iod. Ar. 1721)-Dun. of Bartlett's Childers (Darley Ar. 1696).

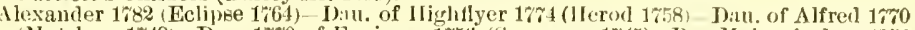
(Natchem 1\%48)-Dau, $17 \% 0$ of Engineer 1756 (Sampsou 17\%5)-Bay Malton's dam 1756 by Cade 1734 (God. Ar. 1724).

Sir Peter T. 1784 llighlyer 174)-Miso Hervey $17 \% 5$ by Eclipse 1764 Marske 1750$)$ Clio $1 \% 60$ by Y.Cade 1747 (Cale 17:4)-Dau. of Starling $1 \% 2 \%$ (Jay IBolton 1705)-Dau. of Bartlett's Childer's (Darley Ar. 16:99).

Precipitate ${ }^{k} 1787$ (Mercury 1\%7)-Colibri 1793 by Woodpecker 1773 (IIerod 1758)-Camilla 1768 by Trentham 1766(T. Sweepstakes 1\%43)-Coquette 1765 by Compton BarbSist. 1743 to Rerulus by God. Ar. 1721.

Sir Peter T. 1784 (Hightlyer 17\%4)-Arethusa 1792 by Dungannon 1780 (Eclipse 1764)Duu. 17\% of Prophet 1760 (Regulus 1739)-Virago 1764 ly Suip 1750 (Snip 1736)-Dau. of Reguluts 1\%39 (God. Ar. 1724).

Pot-8-o-'s 1\%3 (Eclipse 1764)-Prunella 1788 by lligliflyer 1\%4 (Herod 1758)-Promine 1768 by Snap 1750 (Snip 1736)-Julia 1756 by Blank 1740 (God. Ar. 1724)-Spectator's dam 1735 by Partner 1 r 18 (Jigg).

Whalebone or) seymour 1807 (Detpiui 1781)-Dau. $180 \%$ of Gohanna 1790 (Mercury 1778) - Grey Skim 1793 by Woodpecker 1\%3 (Herod 1758) Dau. 1780 of Herod 1758 (Tartar 1743)-Y. llag $1 \% 61$ by Skim 1746 (Starling 172\%).

Selim 1802 (Buzzard*178\%)-Canary Bird 1806 by [Whiskey or] Sorcerer 1796 (Trumpator 1782)-Canary 1797 by Coriander 1786 (Pot-8-0-'s 1773)-Miss Green 1787 by Ilighflyer 1744 (Herod 1758)-Harriet $1 \% 69$ by Matchem $1 \% 48$ (Cade 1\%24).

Orville 1799 (Beningbrough 1791)-Emily 1810 by Stamford 1794 (Sir Peter T. 1784) Dall. 1799 of Whiskey 1789 (Saltram* 1780 -Grey Dorimant 1781 by Dorimant 17\%2 (Otho 1760)-Dizzy 1757 by Blank 1740 (God. Ar. 17\%4)

Pericles 1809 (Evander 1801)-Dau. 1812 of Selim 1802 (Buzzard* 178\%)-Pipylina 1803 by Sir Peter 'T. 1784 (Ilighflyer 17\%4)-Rally 1790 by Trumpator 1782 (Conductor 1761)-Fancy 1780 (Sist. to Diomed*) by Flerizel 1768 (Herod 1758).

Waxy 1790 (Pot-K-o-'B 17\%3)-Penelope 17\% by Trumpator 1\%82 (Conductor 1767)-Prunella 1788 by Highflyer 1\%4 (Herod 1758)-Promise 1768 by Snap 1750 (Snip 1736)Julia 1756 by Blank 1740 (God. Ar. 1724).

Y. Gohanna 1810 (Gohanua 17:0)-Dau. 1802 of Sir Peter T. 1784 (Highflyer 1774)-Dau. 1788 of 'Trumpator $178 \%$ (Conduetor $\left.176^{\prime}\right)$-Sist. $17 \% 4$ to Postmaster by Helod 1758 (Tartar 1743)-Dau. of Snap 1\%50 (Snip 1736)

Diomed 1\%7 (Florizel 1768)- Castianira 1796 by Rockingham 1781 (Highfiyer 17\%4)Tabitha 1782 by Trentham 1766 (T. Sweepstakes 1743)-Dau. of Bosphorus 1754 (Babraham 1740)-Dau. of IV's Forester 1750 (Forester 1736).

Saltrau 1780 (Eclipse 1764)-Dau. of Symmes' Wildair 1767 ("Fearnought 1755)-Dan. of Tyler's Driver 1760 (*Othello)-Dau. of *Fallower 1;61 (Blank 1740)-Dau. of * Vampire 1,57 (Regulus 1739).

Diomed 17\%7 (Florizel 1\%(68)-Dau. of *Shark 1\%1 (Marske 1\%50)-Dau. of Ilarris" Eclipse 1770 (*Fearnought 1755)-Dau. of *Fearnought 1755 (Regulus 1739)-Dau. of *Jolly Roger 1741 (Roundhead 1733).

*Alderman 1787 (Pot-8-0-'s 17:3)-Dau. of *Clockfast 17\%4 (Gimerack 1760)-Dau. of Symmes Wildair 1767 ( Fearnought 1\%55)-Y. Kitty Fisher 1767 by *Fearnought 1755 (Regulus 1739) — * Kitty Fisher 1755 by Cade 1734 (God. Ar. 1\%24).

Orville 1799 (Beningbrough 1791)-Emily 1810 by Stauford 1794 (Sir Peter T. 1784)Dau. 1799 of Whiskey 1789 (Saltram* 1780)-Grey Dorimant 1781 by Dorimant 177\% (Otho 1760) - Dizzy 1757 by Blank 1749 (God. Ar. 1\%24)

The Flyer 1814 (Vandyke Jr, 1808)-Parma 1813 by Dick Andrews $179 \%$ (Joe Andrews 1778)-May $180+$ by Beniugbrough 1\%91 (King Fergus 1\%5)-Primrose 1787 by Mambivo 1763 (Engineer 1759 ) - Cricket 1766 by Herod 1759 (Tirtar 1743).

Sil Archy 1805 (*Diome'l 17\%)-Dall. of *Robin Redbreast 1796 (Sir Peter T. 1784)Dau. 1798 of *Obscurity 1\%\% (Eclipse 1764)-Slamerkiu 1768 by *Wildair 1753 (Cade 17:34) — * Cub mare 1762 by Cub 1739 (Fox 1714)。

Robin Grey 1805 (*Royalist $1 \% 90$-Maria 1802 by Melzar $1 \% 91$ (* Medley 17\%)-Dau, of *Highflyer 1784 (Highflyer 1774)-Dau. of *Fearnought 1\%55 (Regulus 1\%39)-Dau. of Ariel 1\%56 (*Traveller 1\%4\%)

Buzzard 1\%8\% (Woodpecker 1\%\%3)-Dau. of Alesander 1782 (Eclipse 1764)-Dan. of Highflyer 17\%t (Herod 1758)-Dau, of Alf red $17 \% 0$ (Yatchem 1\%18)-Dau. 17\%0 of Engineer 1756 (Sampson 1745)

V" D Ditto 1800 (Sir Peter T. 1784)-Dau, 1\%91 of Wercury 1\%8 (Eclipse 1761)-Dau, 1\%6 of Herod 1758 (Tartar 1743)-Folly 1\%71 by Marske 1750 (Squirt 1732)-Visen 1753 by Regulus 1\%39 (God. Ar. 1724).

Dick Andrews 1697 (Joe Andrews 17\%8)-Dan. 1803 of Gohanna 1790 (Mercary 17\%8)Fraxinella 1703 by Trentham 1766 (T. Sweepstakes 1\%43)-Dau. 1785 of Woodpecker $17 \% 3$ (Herod 1758)-Everlasting 17\%5 by Kclipse 1764 (Marske 1750).

IV asy 1730 (Pot-8-o-'s 1773) - Penelope 1792 by Trumpator 1\%82 (Conductor 1767)_.Prunella $1 \% 58$ by Highflyer $17 \% 4$ (Herod $1 \% 58$ )-Promise 1768 by Snap 1750 (Snip 1736)-Julia 1756 by Blank $1 \% 49$ (God Ar. 1\%24)

Golumpus 1802 (Gohanna 1790) - Lucy Grav 1804 by Timothy 1794 (DeIpini 1781) - Lucy $1 ; 89$ by Florizel 1768 (Herod 1758)-Frenzy 17\%4 by Eclipse 1764 (Marske 1750)-Dau. of Engineer 1756 (Sampson 1715$)$

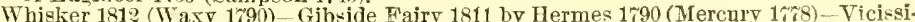
tude 1800 by Pipator 1786 (Imperator 176 )-Beatrice 1791 by Sir Peter T. 1781 (Highflyer 1\%4)-Pyrrha $1 \%$ by Matchem 1748 (Cade 1734).

Blacklock 1814 (Whitelock 1803)-Dau. 1812 of Orville 1799 (Beningbrough 1701) _Mis Grimstone 1796 by Weazle $1 \% 6$ (Herod 1\%8)-Dau. of Ancaster 1\%68 (Blank 1740)Dall. of Damascus Ar. 1754

Trumpator 1828 (Sir Solomon 185) - Lncy b. m. 1821 by Orphan 1810 (Ball's Florizel 1801) Lady Grey b. m. $181^{\prime 7}$ by Robin Grey 1805 (*Royalist 1790)-Maria 1802 by Melzar 1791

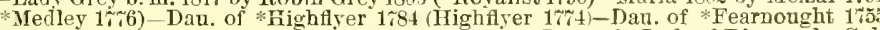
Regulıs 1\%39--Dan. of Ariel 1756 (*Traveller 1\%47)-Dau. of *Jack of Diamonds (Cullen Ar. 1745) _*Duchess by Cullen Ar. 1745 - Lady Thigh ch. m. 1731 by Partner 1718 (Jigg)-Dan. ch. m. 1723 of Greyboura (Chillaby) Sophonisba's damby Curwen Bay Barb-Dan of D'Arcy Chestnut Ar. - Dan. of Whiteshirt-Lord Darcy's Montagu mare by Old Montagu-Dan. of Hautboy (D'Arey White Turk)-Dan. of Brimmer. D'A 'cy Yellow Turk) - Royal mare. 


\section{IUKE BIACKBURI.-Continued.}

1.45, beating Topsy and Potomac. Was mplaced in Coney Island Cup, Ton by Glenmore in 3.58: This closed his racing career.

Luke Blackburn is a light bay, with large star and two white ankles behiud: he stands, fairly measured, 15 hands and $2 \frac{1}{2}$ inches high. Blackburu is a horse of rare s.mmetry; measures $69 \frac{1}{2} \mathrm{in}$. around the girth; Iength of shoulder, $27 \frac{1}{3}$ in.; around the arm, $19 \mathrm{in.}$; below the knee, $s$ in.; from point of shonlder to point of buttocks, 61 i11.; from hip to point of hock, 38 in.; around gaskins, 17 inches.

His pedigree is a happy combination of speedy and stout erosses. being much inbred to Diomed through his best son sir Archy, and from the family which prodnced Lexington and Vandal. If high form and racing abilitr, with fanltless action compler with high breeding and racing descent are tokens of excellence, Luke Blackburn is the peer of any horse living and must prove an invaluahle stanlion.

He is the sire of the following wimners: American Lads, Proctor Knott (winner of the Futurity Stakes), Niagara. Bendigo, Lithbert. Rebellion. Minnie Palmer. Nina W.. Tariston, Lemon, Lemon Blossom, Lakewool, Tom Elliott, Cerberus, La Grippe, Trula Blackburn, Chicora, Luke Alexander, Uncle Bob, Wurth, Thad Rowe. Belle Blackburn, Fort Worth and many other winners.

\section{IMPORTED MACCAROON.}

\section{Maccaroon is a private stallion in the Brookdale Stud, Estate of D. D. Withers, proprictor, IIonmouth County, near Holmdel, X.J.}

MaCCaroox by Macaroni, son of Swcetmeat, bred by Mr. T. T. Parker, foaled 1871, dam Songstress by Chanticleer, son of Irish Birdcatcher, ont of Mrs. Carter by Humphres, son of Sandbeck by Catton. Haccaroon made his first appearance as a two-year old in the Nursery Stakes, 1 mile, won by Rutherford in 1.47? and was nnplaced; same meeting, ran second to Asteroid, Sne Washington Colt, three-quarters

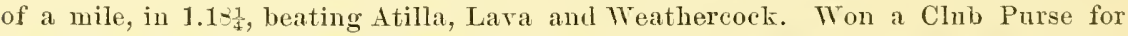
maiden two-year olds, three-quarters of a wile, in 1.17 $\frac{1}{4}$, beating Weathercock, Mattie W., Mary Buckley and Juliana. As a three-year old started four times; was unplaced in Withers Stakes, 1 mile, won by Dublin in 1.50, track hears; was unplaced in

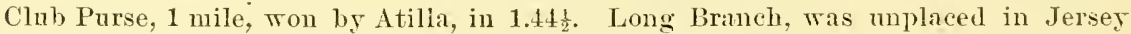
Derby, $1 \frac{1}{2}$ miles, won by Brigaul in 2.44: was third in Robins Stake, 2 miles. won hy Acrobat, in 3.42, beating Bamerette. Macaroni, his sire, won the 2,000 Guineas and the Derby, and is the sire of Spinaway, the wimmer of 1,000 Guineas and Oaks. Camelia, wimner of the 1,000 Guineas, sire also of Lamphrey, Ramsbmry, Termicelli, Gloucester, Bonny Jean and Macheath, the best two-year old in England in 188.2, wimner of eight out of eleren prominent erents in which he started. Macaroni was seconil to Hermit on the list of winning sires in 1882. Chanticleer, the sire of his dam, was son of Birlcatcher, own brother to Faugh-a-Ballagh, and sired Habena and Manganese, winner of the 1,000 Guineas, Songstress, wimner of the Oaks, Daniel O'Rourke, wimner of the Derby, Knight of St. George, Warlock and The Baron, all St. Leger winners. The Baron was sire of the great Stockwell and Ratiplan. Maccaroou has not sired many colts which have been trained. Nancy, at two years old. Won Homebred Stakes at Jerome Park, three-quarters of a mile, in 1.19, beating Oden, Juanita and others. She also won Monmonth Oaks, beating Glidenia, Bỵe-and-Bye amd others. Macbeth and Macduff, both wimers at two years old. Machuff won Champagne Stakes at Jerome Park, and in 1882 won a Handicap Purse at Jerome. 1 $\frac{1}{8}$ miles, in 1.59. defeating a field of eight, and the Free Handicap, $1 \frac{1}{2}$ miles, in 2.41, 107 Ihs., beating Gen. Monroe (4), 105 1bs., and four others. Barbara, Maroon, Electricity, Frank Mullins, Gregors, a superior eolt, Manda, Rival, Masher, Helen Block, Cactus, Roonette and some other good ones.

Maccaroon is a red chestunt, 16 hands and $\frac{\pi}{4}$ of an inch high, has a small star and snip, and weighs $1.180 \mathrm{lhs}$. He is a fine formed horse. of goor temper, and oniy needed a chance to distinguish himselt in the stud. His daughters should be invaluable in the sturl, and his son, Machnft, is a suecess as a stallion. 


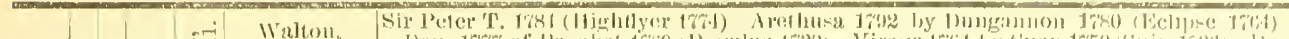

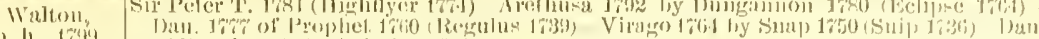
of lierulus lisis) (

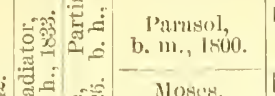

i

-

ड्

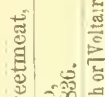

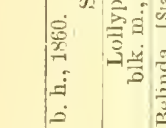

sis.

政

से

的

Flight,

ch. m., 1809.

Raster

gr. h., 1811

Duughter of

É $\dot{E} \dot{\dot{b}}$ br. m., $181 \%$.

莬

Waxy Pope,

b. h., 1806

Daughter of,

o br. m., 1810.

수요 Catton

b. h., 1809 .

我 Orvilina,

\&

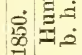

. 1004

Cerberus,

Dr. Syntax's

dam,

总

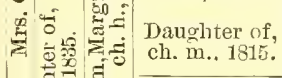

Thunderbolt blk. b., 1806.

Daughter of b. m., 1810 .

(3)

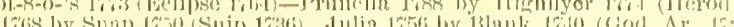

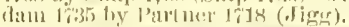

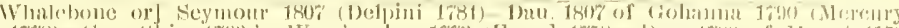

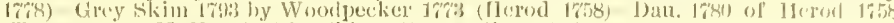

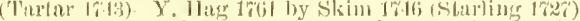

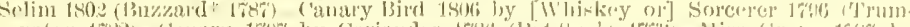

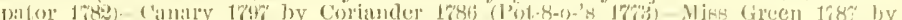

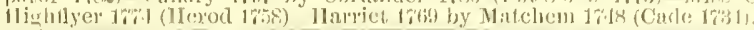

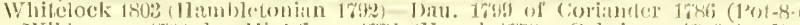

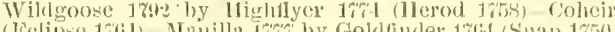

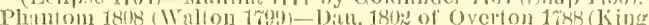

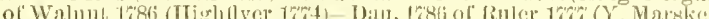
1; 2 by Mateliem 1748 (Cacle 1731 ).

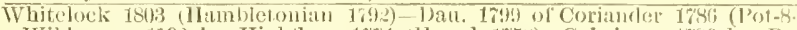

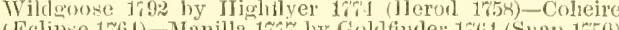

Prime Urininter 1810 (Staucho 1801) - Tranby

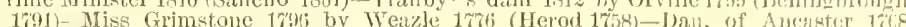
(Blank 1\%40)-Dan. of" Dimascus Ar. 175.

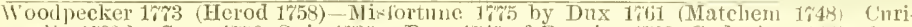
osity 1,60 by Suap 1750 (Snip 1736)... Dau. 174) of Regulus 1739 (God. Ar, 17\%1)-batu. of Bartlett's Childer's (Darley Ar. 1694t)

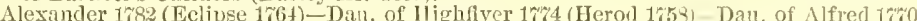

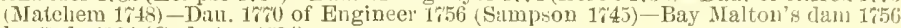
by Cade 1\%34 (God. Ar. 1\%21).

Sil Peter 'L. 1784 (Highflyer 1\%4)-Dau. 1788 of Boudrow 17ir (Eclipse 1764)-1)au. 1769 of Squirrel 1754 (Traveller 1785) - Sist. to Lowther's Babraham by Babraham 1740 (God. Ar. 1724) - Dau. 1,50 of Golden Pall 1'35 (Partner 1\%18).

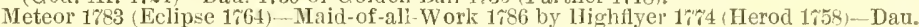
1\%'1 of Syphon 1750. (Squint 1\%32)-Dau. of Regulus 1r39 (God. Ar. 1721)-Sist. 1758 to Judgement by Snip $1 \% 35$ (Flying Clnilder 1\%15).

Beuingbrough 1791 (King Fergus 1\%75) - Evelina 1\%91 by 10ighflyer 1774 (Herod 1\%58)Termagant by Tantrum 1760 (Cripple 1750)-Cantatrice by Sampsou 17it5 (Blaze ['133)-Dati. 175i of Regnlus 1739 (God. Ar. 1724).

Stamford 1794 (Sir Peter T. 1784)-Sophia 1798 by Buzzard*1\%87 (Woodpecker 17\%3) -

Hnucamunca $178 \%$ by Higluflyer $17 \% 4$ (1Ierod 1758)-Cyphel $17 \%$ by Squirel 1754 (Traveller 1735) - Fribble's dam 1r49 by Regulus 1739 (God. Ar. 1\%24)

Eelipse 1,6t (Marske 1750)-Grecian Princess 17r0 by W's Forester 1750 (Fol"ester 1735) - Dau. of Coalition Colt 1789 (God. Ar. 1724-Dan. of Bustard 1711 (Crab 1622) Charming Molly 174: by Second 1732 (Flying Cliilders 1715).

Amaranthus 1766 (Old Eugland 1741)-Mayfly 1\%ri by Matchem 1748 (Cade 1734)—Dau 1755 of Anc. Starling 1733 (Starling 1\%2\%)-Look-at-me-Lads 1731 by Grasshopper (Byerly Turk)-Dau. of Sir Newton's Bity Ar

Wraxy 1790 (Pot-8-0-'s 17\%3)-Penelope 1798 by Trumpator 1782 (Conductor 1767)-Prunella 1788 by Highflyer 1774 (Herod 1758)-Promise 1768 by Snap 1750 (Suip 1736)Julia 1756 by Blank 1740 (God. Ar. 17\%4).

Wanderer 1811 (Gohanna 1790)-Thalestris 1809 by Alexander 1782 (Eclipse 1;64)-Riva

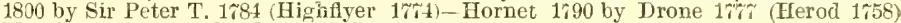
Manilia 1 \% 7 by Goldfinder 1764 (Snap 17\%0).

Chanticleer 1\%87 (Woodpecker 1\%\%)-Ierne 1190 by Bagot 1780 (Herod 1758)-Dau, of Gamahoe (Bustard 1711) - Patty by Tim 1752 (Squirt 1732)-Miss Patch 1737 by Justice 1725 (H. C. Litton Ar.).

Ir. Escape 1802 (Commodore 1793)-Y. Heroine by Bagot 1780 (Herod 1758)-Heroine $1 \% 15$ by Hero 1753 (Cade 1734)-Dau. 1766 of Snap 1750 (Snip 1736) - Sist. 1743 to Regulus $1 \% 39$ (God. Ar. 1\%24).

Buffer 1798 (Prizefighter 1,84)-Spinster 1805 by shuttle 1593 (Y. Marske 1\% 1)-Dau. $179{ }^{\prime}$ of Sir Peter T. 1\%84 (Highflyer 1\%4)-Bab 1\% 87 by Bourdeanx 1\%4 (Herod 1758)Speranza 1778 by Eclipse-1764 (Marske 1750).

Sir Walter Raleigh 1801 (Waxy 1790)-Miss Tooly 1808 by Teddy-the-Grinder 1798 (Asparagus 1787) -Lady Jane 1796 by Sir Peter T. 178.4 (Higkflyer 17.44)-Paulina 1ris by Florizel 1768 (Hetod 1758)-Captive $17 \% 1$ by Matehem 1748 (Cade 1734).

Waxy 1790 (Pot-8-o-'s 17r3)-Prunella 1788 by Highflyer 17\%4 (Herod 1758)-Promise 1 r68 by Snap 1750 (Snip 1736)-Julia 1756 by Blank 1710 (God. Ar. 1724)-Spectator's dam 1735 by Partner 1718 (Jigg).

Champion 1797 (Pot-8-o-'s 17r3)-Brown Fanny 1799 by Maximin 1785 (Evergreen 1769)-Dau. 1782 of Highflyer 1764 (Herod 1758) - Trinket 1767 by Matchem 1748 iCade 1734) - Mliss Elliot ly Grisewood's Partner 1;30 (Partner 17'18).

Golumpus 1802 (Gohanna 1200)-Lucy Gray 1804 by Timothy 1794 (Deipini 1781)-Lucy 1789 by Florizel 1768 (Herod 1758)-Frenzy $17 \% 4$ by Eclipse 1764 (Marske 1750)-Dait. of Enginear 1756 (Sampson 1745)

Beningbrough 1791 (King Fergus 17\%5)-Evelina 1791 by Highflyer 17r4 (Herod 1758)Termagant by Tantrum 1760 (Cripple 1750) - Cantatrice by Sampson 1745 (Blaze 1728) Dau. 1757 of Regulns 1739 (God. Ar. 1724)

rohanna 1790 (Mereury 1778)-Dau. 1780 of Herod 1758 (Tartar 1743)-Desdemona 17\%0 by Marske 1750 (Squirt 1\%32)-Y. Hag 1761 by Skim 1\%16 (Starling 172\%)-Hag 1714 by Crab 1722 (A]cock Ar.).

Beningbrongh 1791 (King Fergus 17\%5) _ Jenny Mole 178; by Carbuncle 17\%2 (Babl. Blank 1\%8) - Dau 1, 63 of Prince T'Quassary 1751 (Snip 1726) - Sultana 1759 by Regulus 1759 (God. Ar. 1724)-Dau, of Partner 1718 (Jigu).

Orville 1799 (Beningbrough 1791)-Eleanor 1798 by Whiskey 1789 (Saltram* 1\%80-Y. Giantess 1790 by Diomed* 17\%7 (Florizel 1768)-Giantess 1\%69 by Matchem 1\%18 (Cade 1734) - Molly Long Legs 1753 by Babraham 1740 (God. Ar. 1724).

Election 1804 (Gohanna 1790)-Fair Helen 1808 by Hambletonian 1fge (King Fergus 1\%75) Helen 1801 by Delpini 1781 (Highflyer 1\%4)-Rosalind 1788 by Phenomenon 1780 (Herod 1758)-A talanta 1769 by Matchem 1748 (Cade 1734).

Sorcerer $179 ;$ (Trumpator 1782)-TV owski 1797 by Mentor 1784 (Justice 1\%74)-Maria 17\% by Herod 1758 (Tartar 1743)-Lisette 1\%\%2 by Snap 1\%50 (Snip 1\%36)-Miss TWindsor $175+$ by God. Ar. 1724

Sancho 1801 (Don Quixote 1784) - Niss Teazle h. m. 1799 by Sir Peter T. 1784 (Highffer 17\%1)-Fanny ch. m. 1790 by Diomed* 1777 (Florizel 1768)-Ambrosia b. m. 1783 b Woodpecker $17 \% 3$ (Herod 1758)-Ruth 1761 by Blank 1740 (God. Ar. 1724)-Sist. 1i51 to South by Regulus 1739 (God. Ar. 1721)-Dan. of Sorebeels (Basto 1702 )-Dau. blk. 1 .
hristopher D'Arcy Royal mare by Blunderbuss (Bustler)-Old Grey Royal by D'Arcy of Makeless (Oglethorpe Ar.) Christopher D'Arey Roya
White Turk-Dau. of D'Arcy Yellow Turk-Royal mare. 


\section{MANCHACA.}

The property of Leonidas Cartwright, Fairview Stud, San Augustine, Texas.

MANCHACA, black horse, foaled 1881, bred by R. N. Weisiger, by Rebel, son of Socks by imp. Albion, dam Lemonade by imp. Leamington, grandam Cricket by Daniel Boone, ont of the famons race-mare Lilly Ward by Lexington.

Manchaca never raced but is from a racing and producing family, is $16 \frac{1}{4}$ hands high, off hind pastern white, beantiful head and neck, with the best of feet and legs, is symmetrically formed and of high finish. Rebel, his sire, was a good race-horse and successful stallion. Lemonade, his dam, is a danghter of imp. Leamington, whose sons and danghters have been very successful in the stud. From his daughters have come Potomac, Sir Dixon, Belvidere, Chesapeake, Strideaway, Carley B., Solid Silver, Britannic, Lizzie S., Redstone, Katrina, Buckstone, Ovid, Tecumseh, Hinda, Spinalong, Dalsyrian and numerous other high class winners. Lemonade also produced Springlight (dam of Charlie Ford) and Incoleame, who was a winner both at two and three years old. Cricket, the second dam, is the dam of Krick and Critic, the former one of the best $t$ wo-year olds of her year and the dam of the winners Krikina and Koran. Lily Ward, the third dam, was a first-class race mare and prodnced Ascension, Mary Faris, Hattie Huger, Buckette and Emily Coster. Ascension produced the Kentucky Derby winner Ascender. Buckette produced the winner Jim Bennan, and Emily Coster gave us the two-year old winner Clementine. Lanra, the fourth dam, produced the superior race-horses Harry of the West and Judge Durell and the producing mares Fanny Cheatham and Lerna. Fanny Cheatham is the dam of Fanuy Brown, Belle Palmer and Memento. Lerna produced Nellie Booker (dam of Ten Booker, Oarsman, Bootmaker and The Sheriff), and the winners Ida K. (dam of Ida Pickwick), Sister, John Y., Newcastle, Frontenac, Falerna and Elsie S. The Stockholder mare, the fifth dam, was a success in the stud, prodncing Compromise, Martha Dunn (dam of Lulu Horton), Invincible and Iodine. It is a grand fanily, from which have come Glenluine, Troubadonr, Lizzie Krepps, Virginins, Kildare, Amy Farley, Mattie Amelia, Blue Grass (a great horse in England), Ballarat, Windrush, Puzzle, Punster, Sue Wynne, Billy Gilmore, and any number of other good animals.

Manchaca is descended in direct female line through old Bald Peg and the Barb mare, to which trace Lath, Cade, Flying Childers, Diomed (imp.), Sorcerer, Priam (imp.), Phantom, Langar, Muley, Plenipotentiary, Tronbadonr, Harry of the West and other good ones. 


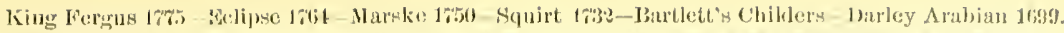

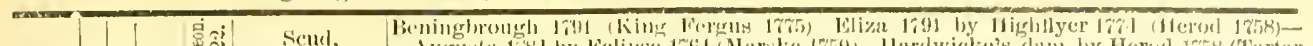

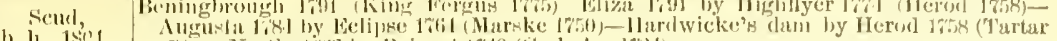

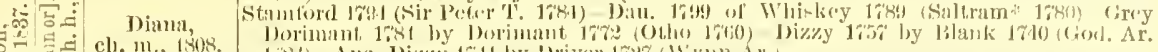
1., III, Ros. 1,

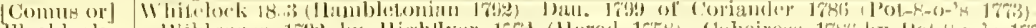

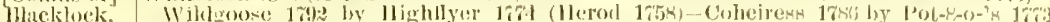

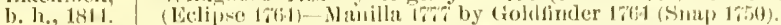

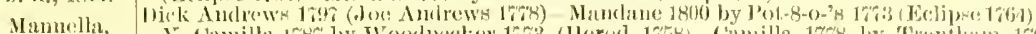

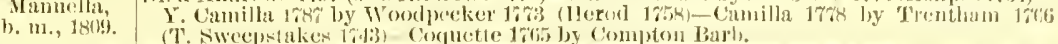

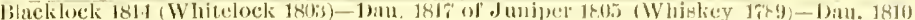

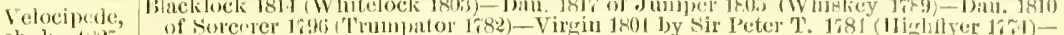

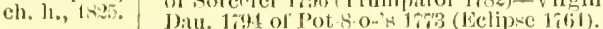

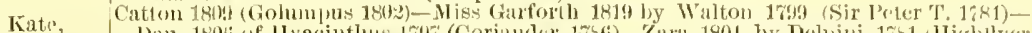

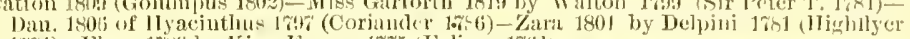

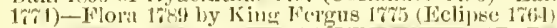

(3. $\mathrm{m} ., 152 \mathrm{~s}$

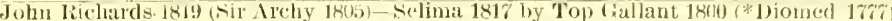

Corsica,

b. h., 183:

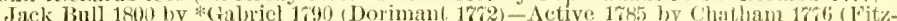

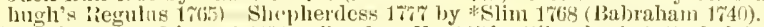

Lady Alehiana, Equa 1315 by Chance 1796 (Lurelier 1789)-Jan. of Republican President 17 es ("IIighflyer 1781)-T)an. of *Ranger (liegulus 173!i).

Muley,

골

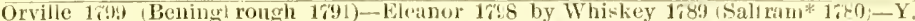

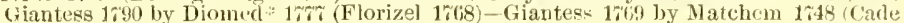
1731)-Molly Long Legs 17.3 by Babraham 1760 (God. Ar. 1724).

Windle 180 I (Beningrbrough 1791) Dau. 1784 of Anvil 17\% (1lerod 1758)-Virago 17fi by Snap 1750 (Sui] 173.) - Dau, of Regulus 1739 (God. Ar. 1724)-Sist. 1750 to Othello loy Crab $1 \% 22$ (Alcock Ar.)

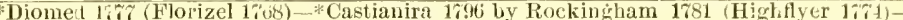

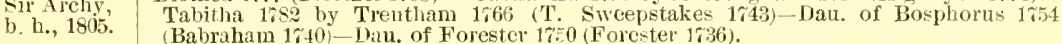

b. h., 1805. Tabitha 16s2 by Trentham 1766 (T. Swcepstakes 1743)-Dau. of Bosphorus 1754
(Babraham 17.40)-Diu. of Forester 17:0 (Forester 1736). Junius (*Bazard 178\%)-Dau. of *Citizen 1785 (Pacolet 1\%68)-*Barb mare presented 1806 to President Jeflerson by the Dey of Tunis.

aulohter of

Tramp 1810 (Dick Andrews 179\%)-Nandane 1800 by Pot-8-0-'s 17\%3 (Eclipse 1664)-Y.

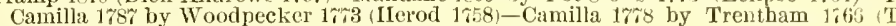
Sweepstakes 1 743 )-Coquette 1765 by Compton Barb.

br. 1., 1830

Cerberus 18: (Gohanna 1790)-Miss Newton 1804 by Delpini 1781 (IIghflyer 17itTipple Cyder 1788 by King Fergus $17 \% 5$ (Eclipse 1764 -Sylvia 1\%:3 by Y. Marske 1\%i1 (Marske 1750)-Ferret 1765 by Broth. to Silvio (Cade 1734).

Dattghter of

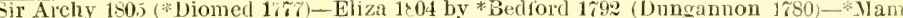
brina 1785 by Mambrino 1765 (Engineer 1756)-Sist. to Sally by Blank 1740 (God. Ar. 1724)-Dau. of TVard 1731 (Crab 1,22)

, h., 18:1

Pacolet 1896 * Citizen 1785)-Sally Sneed 1807 by *Buzzard 1\%8\% (Woodpecker 1\%3)Jane Hunt 1796 by IIampton's Paragon 1788 (*Flimnap 1765)-Moll by *Figure $175 \%$ (Figure 1\%47)-Slamerkin 1768 by *Wildair 1753 (Cade 1734).

gr. m., 181

Whalebone,

Taxy 1790 (Pot-8-o-'s 1773) - Penelope 1798 by Trumpator 1762 (Conductor 1767) Prunella 1788 by Highflyer $17 \%$ (Ilerod 1758) Promise 1,68 by Snap 1750 (Snip 1\%36)Julia 1756 by Blank 1740 (God. Ar. 1724).

Peri,

b. m., 1822

Wanderer 1811 (Gohanna $3 \% 90$ )-Thalestris 1809 by Alexander 1782 (Eclipse 1\%64)-RivaI 1800 by Sir Peter T. 1784 (Hightlyer 17\%1)-Hornet 1790 by Drone $17 \% 7$ (Herod 1758)Maniilla $17 \% 7$ by Goldfinder 1764 (Snap 1\%50).

Bob Booly, Chanticleer 1787 (11 oodpecker 17\%3)-Ierne 179) by Bagot 1780 (Iterod 1758)-Dau. of Gamahoe (Bustard 1741)-Patty by Tim 1750 (Squirt 1732)-Miss Pateh 173 by Justice 1725 (H. C. Litton Al')

Ir. Escape 1802 (Commodore 1793) - Y Heroine by Barot 1780 (Herod 1758)-Heroine 1775 by Hero 1753 (Cade 1734) - Dau. 1766 of Snay 1750 (Snip 17:6)-Sist. 1743 to Fegulus by God. Ar. 1724.

ch. m., 1809

Castrel,

ch. h., 1801

Buzzard 1787 (Woodpecker 1773)-Dau. of Alexander 17s2 (Eclipse 1764)-Dau. of Highflyer $17 \% 4$ (Herod 1758)-Dau. of Alfred 1770 (Matchem 1748)-Dau. 1770 of Engi. neer 1 i 56 ( $\mathrm{sampson} 1745$ ).

Idalia,

Peruvian 1806 (Sir Peier 'T' 1784)_Musidora 1804 by Neteor 1'i83 (Eclipse 1764)-Maidof-all-Work 1783 by Highflyer $17 \% 4$ (Herod 1\%58)-Dan, 17\%1 of Syphon 1750 (Squirt 1732)-Dau. of Regulus 1739 (God. Ar. 1721).

ch. m., 1815.

Laurel,

Blacklock 1814 (Whitelock 1803) - IT agtail 1818 by Prime Minister 1810 (Sancho 1801) Tranby*'s dam 1812 by Orville 17'9 (Beningbrough 1;91) - Miss Grimstune 17:6 by Weazle $17 \% 6$ (Herod 1758)-Dau. of Ancaster 1768 (Blank 1740).

Iaid of Champion 1812 (Selim 1802) - Etiqnette 1820 by Orville 1r99 (Beningbrongh 1691) - Boa-

Honor

br. m., 1829.

Boston.

ch. b., 1833.

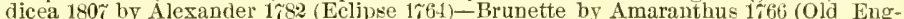
land 1\%41)-Mayfly 1\%1 by Matchem $1 \% 48$ (Cade 1\%24).

Timoleon 1813 (Sir Archy 1805)--Sist. 1814 to Tuckahoe by Ball's Florizel 1801 (*Diomed 17\%7)-Dau. 1799 of *Alderman 1787 (Pot-8-o-'s 17i3)-Dau. of *Clockfast 17\%4(Gim. crack 1 160 )-Dau. of Symmes' Wildair 1667 ('Fearnought 1755).

Sarpedou 1828 (Emilius 1820)-Rowena 1826 by Sumpter 1818 (Sir Archy 1805)_Lady Grey $181 \%$ by Robin Grey 1805 (*Royalist 1790 )-Maria 1802 by Melzar 1791 (*Medley 1\%6) - Dan. of *Highflyer 1784 (Highflyer 1\%4).

b. m., 1836 .

* Glencoe,

Sultan 1816 (Selim 1<02) - Trampoline 18\%5 by Tramp 1810 (Dick Andrews 179n)-Web 1808 by Waxy 1790 (Pot-8-o-'s 1773)-Penelope 1798 by Trumpator 178: (Conductor $1 \% 60$ ) - Prunella 1788 by Highflyer $17 \% 4$ (Herod 1758).

Mameluke 1824 (Partisan 1811)-Bobadilla 1825 by Bobadil 1813 (Rubens 18c5)-Pytho-

* Myrtle, ness 1813 by Sorcerer 1796 (Trumpator 128\%)-Princess 1796 by Sir Peter T. 1784 (Bighfyer 1744)-Dau. 1789 of Dungannon 1780 (Eclipse 1\%4).

Timoleon 1813 (Sir Archy 1805) - Sist. 1814 to Tuckahoc by Ball's Florizel 1801 (\% Diomed 17\% -Dau. 1799 of *Alderman 17si (Pot-8-0*'s 17\%3)-Dau. of *Clockfast 17\%t (Gimcrack 1760)-Ddu. of Symmes' Wildair 1767 ("Fearnought 1755).

Boston,

cb. h., 1833.

Sarpedon 1895 (Emilius 1820)-Rowena 1820 by Sumpter 1818 (Sir Archy 1805) -Lady

Alice Carneal, Grey 1817 by Robin Grey 1305 (*Rovalist 1i90)-Maria 1802 by Melzar 1791 (* Medley

b. m., 1836. 176)-Dat. of Highflyer 1781 (High̆flyer 1\% 14 ).

Nuley 1810 (Orville 1799)-Dan. 1809 of Windle 1804 (Beningbrough 1791)-Dau. 1788 of Anvil 177\% (Herod 1758)-Virago 1764 by Snap 1750 (Snip 1736)-Dau. of Regulus 1739 (God. Ar. 1724).

Stuckhuleter (S1r Areh, 1805)-Dau. eh. m. 1822 of Pacolet 1806 ("Citizen 1785)-Nell Saunders eh. m. 1815 by Wilkes' Wonler 1800 ('Dioned 1777)-Julietta by Dare Deril 1787

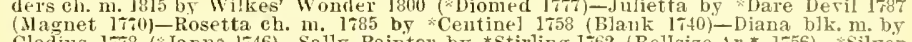
Clodius 178 (Janus 1746)-Sally Painter by *Stirling 1762 (Bellsize Ar. * 1756)-*Silver (ab. 1762) by Bellsize Ar.* 756-Sist. to Cato by Partner 1718 (Jigg)-Sist. eh. M. 1719 to Daughter of

Roxana by Bald Galloway (St. Vietor Barb)-Sist. to Channter by Akaster Turk-Cream Cheeks by Leedes Ar.-Dau, 1690 of 


\section{IMPORTED MASETTO.}

\section{Owned by J. C. Smith. In the Dixiana Stud, MLajor B. G. Thomas, proprietor, Lexington. Terns advertised ammally. Sales of yearlings anmully.}

MaSETto, bay horse, foaled 1888, bred by Mr. C. D. Rose, by St. Simon, the mnbeaten, dam Lady Abbess by Cathedral, grandam Latly Sophie by King Tom, out of Bridle by The Saddler, ete. St. Simon did not start in the Derby and St. Leger, in consequence of the death of his breeder and nominator Prince Batthyant, but he was never beaten during his turf eareer; won the Aseot Gold Cup, Goodwood Cup and Epsom Gold Cup. St. Simon is the sire of Memoir, winner of the Oaks and St. Leger, Semolina, winner of the 1,000 Guineas, La Flèche, winner of the 1,000 Gnimeas and Oaks and second in the Derby. His dam, Lady Abbess, is the dam of Bel Demonio. winner of the Gerard Plate, The Rous Plate, Great Eastern Railway Handicap, Empress Prize and Wellington Plate, and by Cathedral, winner of the Manchester Tradesman Cup, son of Newminster, winner of the St. Leger, Lady Abbess is full sister to Exeter, Ninner of the Hardwicke Stakes, ont of Lady Sophie by King Tom, sire of imp. King Ban, Imp. Great Tom, imp. Phaeton and Kingeraft, winner of the Derby, also of Hannah, winner of the 1,000 Gnineas, Oaks and St. Leger, Hippia and Tormentor, winners of the Oaks, sire of the dam of Enterprise (winner of the 2,000 Gnineas) and Zephyr, dam of Favonius (winner of the Derbr). Bridle was the dam of Habella (winner of the 1,000 Guineas), her sire, The Sacldler, is the sire of Sorello (winner of the 1,000 Guineas). Masetto as a two-year old ran unplaced in the stud Produce Stakes at Newmarket; received forfeit from Simon Magus in Produce Match at Newmarket; was third to Keronal and Barbatello in Bradford Plate at Leicester, and mplaced in Maiden Plate at Newmarket. Masetto is a finely bred horse, has a donble cross of King Tom and is from a good racing and prodncing family. He is descended in direct female line from the old Vintner mare, to which trace Partner (Croft's), Soreheels, Crab, Snip, Pacolet, Mercury, Dick Andrews, Muley Holoch, Daniel O'Rourke, Bendigo, Peter, Peregrine, etc., in England; Bramble, Preakness, Barswater, Bayonet, Vauxhall, Muggins, Bishop and all the Allegrante, Bay Leaf and Virago family. 


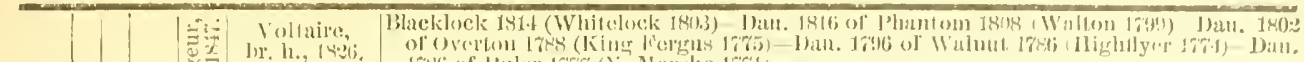
lir. li., 14:

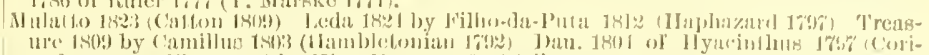

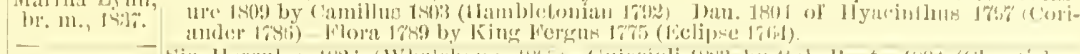

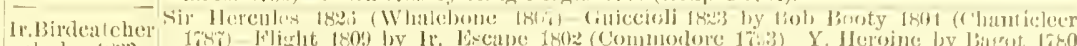

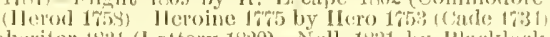

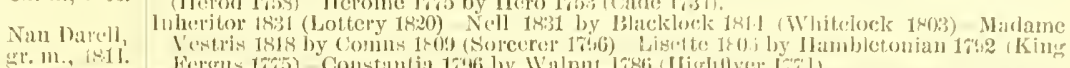

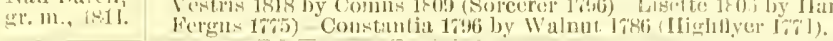

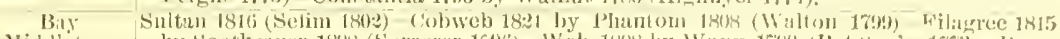

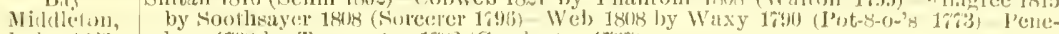

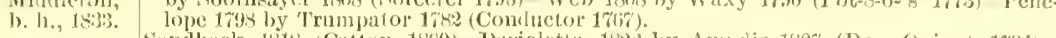
bitrlielle. b. $\mathrm{m}, 1 \times 3)$.

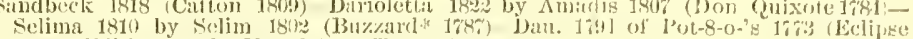

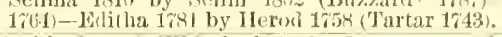

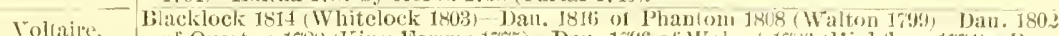

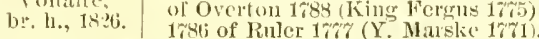

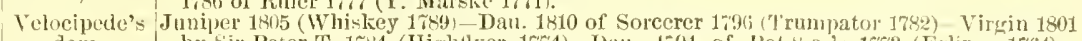

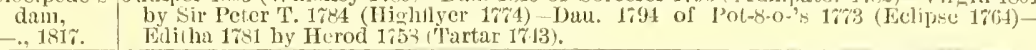

Economist, Whisker 1812 (Waxy 1\%:0)-Floranthe 1818 by Octavian $180 \pi$ (Stripling 17t5) - Caprice

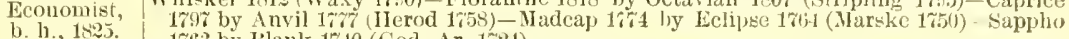
Fanny 1703 by Blank 1740 (God. Ar. 172).

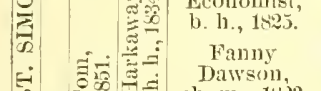

至

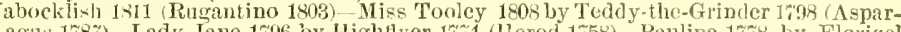

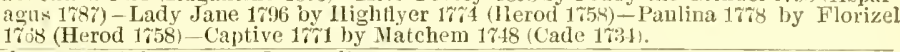

Glercoe,
ch. h., 1331.

ntan 1-15 (Selim 1502)-Trampoline 1825 by Tramp 1810 (Dick Andrews 1790)-Wel) 1808 by Waxy 1790 (Pot-8-0-'s 17\%3)-Penelope $1 \% 98$ by Trumpator 1782 (Conductor

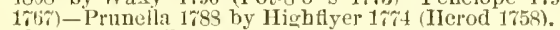

Marpessa, Muley 1810 (Orville 1799)-Clare 1824 by Marmion 1806 (Whiskey 1\%89)-Ilarpalice 1814 b. m. 183 . by Gohanna 179) (Mercury 17\%8) - Amazon 1799 by Driver 1783 (Trentliam 1766)Fractious 1792 by Mercury 1778 (Eclipse 1764).

Cain, Paulowitz 1813 (Sil Paul 1802)-Dan. 1810 of Paynator 1791 (Trumpator 178\%) - Dau b. h., $13: 3$. 1805 of Delpini 1781 (Highflyel 1\%4)-Dau. 1795 of Y. Jiarske 17\%1 (Marske 1750)Gentle Kitty 1774 by Silvio 1754 (Cade 1734).

Nargaret, Edmund 182 (Orville 1799)-Medora 1811 by Selim 1802 (Buzzard 1:87)-Dau, 1803 of

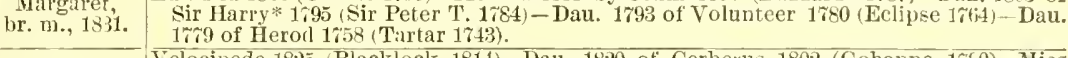

Telocipede 18:5 (Blacklock 1814)-Dan. 18:00 of Cerberns 1802 (Gohanna 150)-Miss Hornsea, Cranfield 1803 by Sir Peter T. 1784 (Highflyer 1774)-Dau, 1796 of 1'egasus 1784

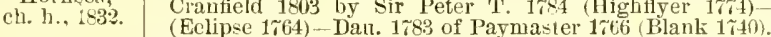

Laceria, Zodiac 1801 (St. George 1789)-Jerboa 1803 by Gohamna 1790 (Mercury 1768)-Camilla

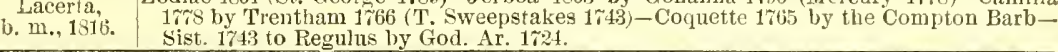

Camel. Thalebone $180 \%$ (Waxy 1790)--Dau. 1812 of Selim 1802 (Buzzard $178 \%$ - Maiden 1801 by \begin{tabular}{c|c} 
Camel, & Sir Peter T. 1784 (Highflyer 1774)-Dan. 1788 of Phenomenon 1780 (Herod 1758)-11a- \\
tron 1782 by Florizel 1768 (Herod 1758)
\end{tabular}

Master Henry 1815 (Orville 1r99)-Boadicea $180 \%$ by Alexander 1782 (Fclipse 1\%64) -

Banter,

Bimnette by Amaranthus 1766 (Old England 1\%41)- Mayfly $17 \% 1$ by Matchem $1 \% 48$ (Carle 1734)-Dau. 1755 of Anc. Starling 17E8 (Old Starling 17\%r). Dr. Syutax, Paynator 1791 (Trumpator 178\%)-Dau, of Beningbrough 1791 (King Fel'ous 1775)-Jenny
Mole 1787 by Carbuncle 17\%2 (Babraham Blank 1755)-Dau. 1773 of Pricce T'Quassaw 1751 (Snip 1736)-Sultana 1\%59 by Regulus 1799 (God. Ar. 1724).

br. h., 1811 .

Ardrossan 1809 (Johı Bull 1789)-Lady Eliza 1813 by Whitworth 1805 (Agonistes 1797)-

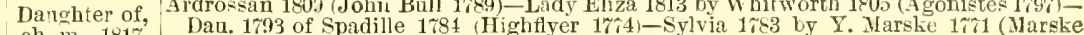
1750) - Ferret 1765 by Broth. to Silvin (Cade 1734).

Humprey Comus 1809(Sorcerer 1796)-Clinkerina 1812 by Clivker 1805 (Sir Peter T. 1784)-Pewet

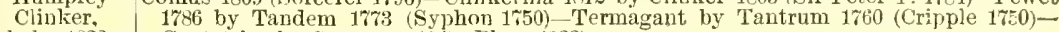

b. h., 1823. Cantatrice by Sampeon 1745 (Blaze 1733).

Daughter of Cervantes 1806 (Don Quixote 1784)-Dau. 1818 of Golumpus 1802 (Gohanna 1790)-Dau. 1810 of Paynator 1701 (Trumpator 1682 ) Circle $180 \%$ by St. George 1789 (Hightlyer 17\%4) - Abigail 1788 by Woodpecker $17 \% 3$ (Herod 1758).

Sleight-of- Pantaloon 1824 (Castrel 1801)-Decoy 1830 by Filho-da-Puta 1812 (Iaphazard 179\%) Hand, Finesse 1815 by Peruvian 1806 (Sir Peter T. 1i84)-Violante 1802 by John Bull 1is9 br. h., 1836. (Fortitude 17\% )-Dau. $1 \% 88$ of Highflyer 17\%4 (Herod 1758).

Dam of Sir Marorave* 1829 Muley 1810)-Patty Primrose 1830 by Confederate 1821 (Comus

Tatton Sykes. $\quad 1809$-Sybil 1822 by Interpreter 1815 (Sonthsayer 1808)-Galatea 1816 by Amadis 1807 ch. m., 1836. (Don Quixote 1784)-Paulina 1804 by Sir Peter T. 1784 (Highflyer 1774).

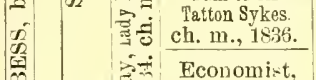

b. h., 1825 .

Thisker 1812 (Waxy 1700 ) - Floranthe 1818 by Octavian $180 \%$ (Stripling 1797 by Anvil 1777 (Herod 1758)-Nadcap 1774 by Eclipse 1764 (Marske 1750)-Sappho 1763 by Blank 1740 (God, Ar. 1724).

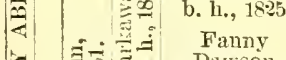

(1)

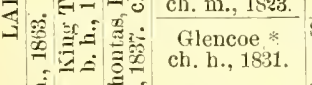
agu 178\%)-Lady Jane 1796 by Sir Peter T. 1;84 (Highfler 1ri4)-Panlina 1\% Florizel 1768 (Herod 1758) - Captive $17 \% 1$ by Matchem 1748 (Cade 1724).

Sultan 1816 (Selim 1802 - Trampoline 1825 by Tramp 1810 (Dick Andrews 1797)-Web 1808 by Waxy 1790 (Pot-8-0-'s 17\%3)-Penelope 1798 by Trumpator 1782 (Conductor' 1767)-Prunella 1788 by Highflyer $17 \% 4$ (Herod 1758

Muley 1810 (Orville 1709 -Clare 1894 by VIarmion 1806 (Whiskey 1789)-Harpalice 1814 Miarpessa, My Gohanna 1790 (Nercury 178)-Amazon 1799 by Driver 1 is 83 (Trentham 1766)Fractions 1792 by Mercu:y $1 \%$ (Eclipse 1764).

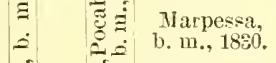

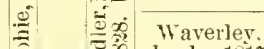

के

Whalebone 1807 (Waxy 1790)-Margaretia 1802 by Sir Peter T. 1784 (Highflyer 1\%4) Dau. 1792 of Highflyer 1774 (Herod 1758)-Nutcracker 176\% by Matchem 1748 (Cade 1734) - Miss Starling 1750 by Boit. -tarling 172\% (Bay Bolton 1705)

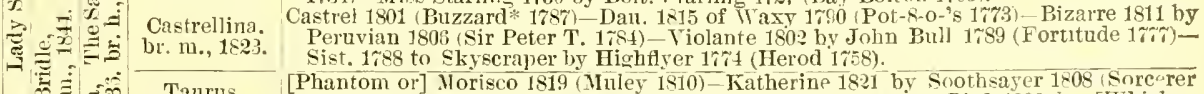

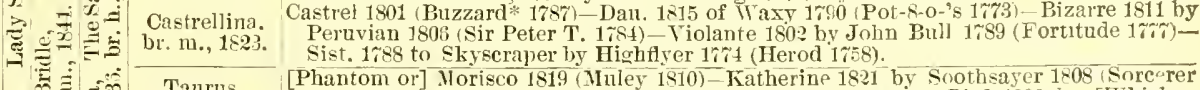

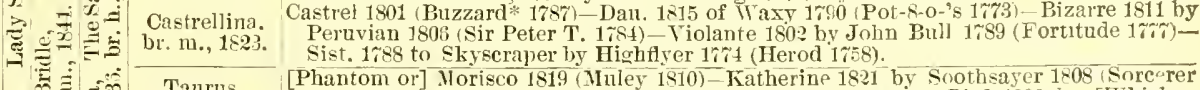

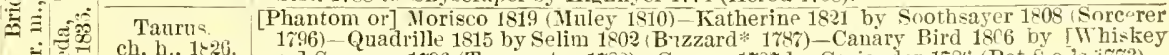

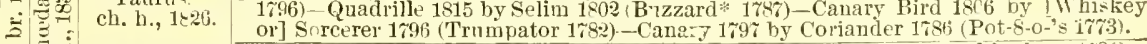

Mona. Partisan 1,11(Walton 1799)-Hiltonia h. m. 1804 by Patriot 1790 (Rockingham 1781)II Is Juston b. m. 1790 by King Fergus 1775 , Eclipse 1761)-Colmmbine 1781 by

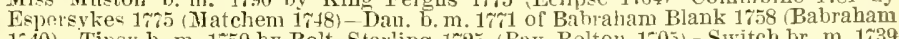
1740) - Tipsy b. m. 160 by Bolt. Starling 172.5 (Bay Bolton 1705)-Switch br. m. 1739 b. m:, 1819 


\title{
IMPORTED MAXIM.
}

\author{
The property of J. B. Haggin, Rancho-del-Paso Stud, Sucramento, Cal. Year- \\ lings sold annually.
}

MAxim, brown horse, foaled 1884, by Musket, son of Toxophilite, dam Realization by Vespasian, son of Newminster; second daul Hopeful Duehess by Flying Dutehman; third dam Espoir by Liverpool, out of Esperance by Lapdog.

Maxim is regarded as the most valuable horse ever bred in New Zealand, and is the first son of Musket importer to Ameriea. Musket (winner of Ascot Stakes and Alexandra Plate) is the sire of Petronel, wimner of the 2,000 Guineas and Doncaster Cup, Martini-Henry, wimuer of the Vietoria Derby and Melbonrne Cup, Carbine, the winner of the Jielbourue Cnp in 1890, Nordenfeldt, winner of the Victoria Derby, and other good ones. Vespasian, the sire of Realization, Maxim's dam, was one of the best horses of his day, winner of Weston, Raweliff Stakes and C'imbolton Cnp; was full brother to Sabinus, wimner of the Cambridgeshire Handicap and Aseot Gold Cup, and hy Newminster. Hopeful Duchess, his grandam, is full sister to Brown Duchess, winner of the Oaks, by The Flying Dutehman, winner of the Derby and St. Leger, sire of Flying Duchess, dam of Galopin, winner of the Derby, Bonny Blink, dam of Hawthornden (winner of the St. Leger), Katherine Logie, dam of Bothwell (winner of the 2,000 Guineas).

Maxim's turf career was a glorious one. The first day he was stripped in public was Dec. 27, 1886, when he started for the Middlepark Stakes, and won by a length from Gipsy King, Fair Nell and thee others being behind the pair mentioned. The next dlay he gave weight and a beating to Gipsy King, Kimberley and two others in the Nursery Handieap, foing the five furlongs in 1.04, winning very easily. He mas theu shipped to Melbonrne, where, thongh riding under the disadvantages entailed by a lengthy trip and late arrival, he foreed the celebrated Abercorn to extend himself in the Produce Stakes, and was beaten by ouls a short head. Going baek to his native land for the Canterbury Autumn Meeting, Maxim started a red hot favorite for the Champagne-Stakes and won by a length, doing the six furlongs in the good time of 1.15, and pntting down such notable ones as Sextant, Gipsy King, Sultan and Cruehfield. Of these four, three subsequently. hecame record holders, and the fourth (Sultan) captured the Dnuedin Cup and other leading events. On the second day of the C. J. C. referred to, the eourse was fetloek-deep in muri, aud Sextant, having 5 lbs. the best of the weights and an advantage at the start, beit him onls a length. As a three-year old Maxim won all his races. These were the Hawke's Bay Guineas, in whieh he beat Lady Florin, Bangle, Waterfall and The Orator ; the Flying Handicap, in which he was left at the post aud had apparently no charee at all till neariug the straight; the Spring Handicap at the same meeting, heating Rivnlet, Pearl and five others; and then coming baek to Canterbury he made an exhibition of Gipsy King, Sextant and Cruchfieid in the Derbs, one and a half miles, rmn in 2.40, and distanced Nelson in the Canterbury Cup, doing the two miles and a quarter in $4.01 \frac{1}{\frac{1}{2}}$. It will be seen that Maxim started in ten races, of which he won eimht and was second in two. This is really first-class, and when it is remembered that there are undeniable reasons for each of his defeats, and that he never met any but the rery best horses, it will be realized that the bare figures do not do the horse justice. All who saw him racespeak of his wonterful power and his far-reaebing stride, and those who have seen him since agree that he is the most magnificent looking stallion ever bred in New Zealand. The Australians say that it is athousand pities that sueh a. splendid horse shonld leave Neт Zealand.

Maxim is ilescented in direct female line throngh the old Montagu mare to the Royal mare, to which traees Conduetor, Eelipse (O'Felly's), Voltaire, Sterling, Weatherbit, Springfield, Seottish Chief, Adventurer, Prince Charlie, in England ; Lexington, Vandal, The Bard, Leonatus, Salvator, Longstreet, Sensation, Onondaga, Stratford, Tenny, Luke Blackburn, and all the Duchess family iu America. 


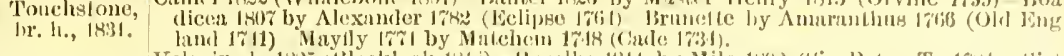

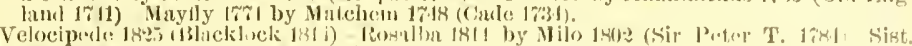

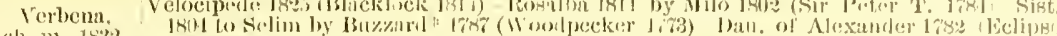

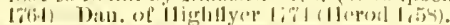

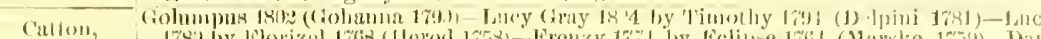

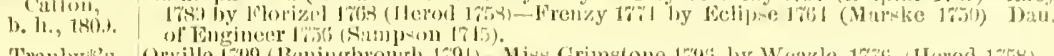

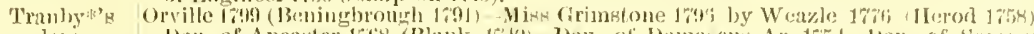

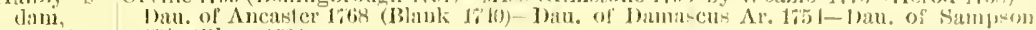
$1 \% 13(1: 19 \%: 17333)$

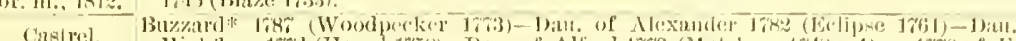

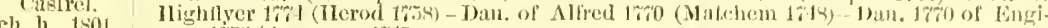
neev 1 the (simpion 1215$)$.

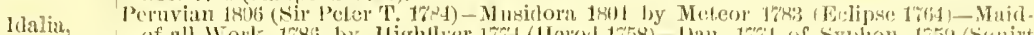

ldalia,

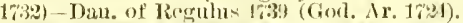

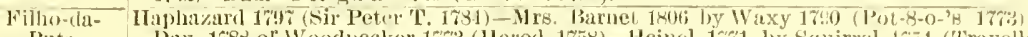

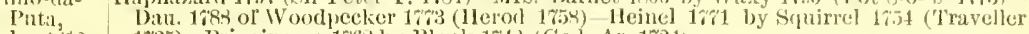

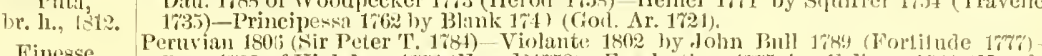

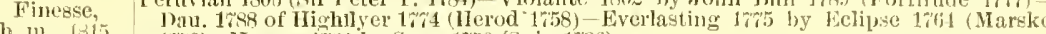
1750)-1Iyana 1762 by Snap 1750 (Snip 1736).

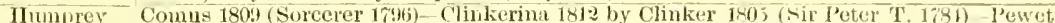

Clintrer.

b. h., 18:2.

1786 by Tandem $17 \% 3$ (Syphon 1750)-Termagant by Tantrum 17it) (cripple 1750)Cantatrice by Sampson 1745 (B)aze 1733$)$

Cervantes 1806 (Don Quixote 1\%81)-Dau. 1818 of Golanpus 1 - (S02 (Gohanna 1790) I)au. 1810 of Paynator 1791 (Trumpator 1789)-Cirele 1802 by fit. George 17 si) (llighllyer 17,4)-Abigail 1788 by Woodpecker $17 \% 3$ (IITerod 16iss).

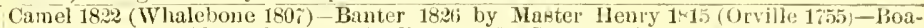

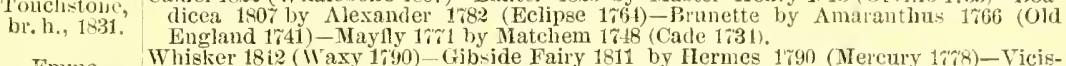

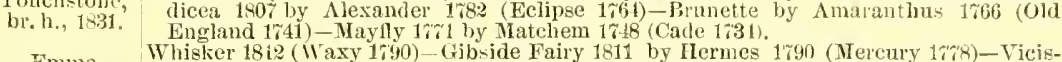

Emma, situde 1800 by Pipator 1786 (Imperator 1766)-Beatrice 1691 by sir Peter T. 1781 (Hightlyer 17\%t) - Pyrrha 17\%1 by Natchem 1\%48 (Cade 1724).

Whalebone, Waxy 1790 (Pot-8-o-'s 17i'3) - Penclope 1798 by Trumpator 17 83 (Conductor) 176\%-Pru-

br. h., $160 \%$ nella 1788 by llighfiyer $17 \% 4$ (Ierod 1758)-Promise 1768 by Snap 1750 (Snip 1736)Julia 1756 by Blank 1740 (God. Ar, 1724).

Danghter of, Selim 1802 (Buzzard* 178i) Maiden 1801 by Sir Peter T. 1784 (1Iighflyer 174)-Dau. 1788 of Phenomenon 1780 (IJerod 1758) - Matron 1782 by Florizel 1765 (Herod 1758)Maiden $17 \% 0$ by Matchem 1718 (Cade 1734).

Brutandorf Blacklock 1814 (Whitelock 1803)-Vandane 1800 by Pot-8-o's 17\%3 (Eclipse 1764)-Y.

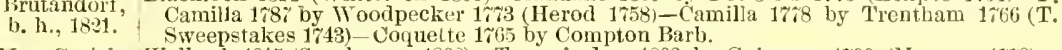

Mrs. Cruick- Welbeck 1815 (Soothsayer 1808) -Tramp's dam 1803 by Gobanna 1790 (Nercury 1ri8)-_

shanks, Fraxinella 1793 by Trentham 1766 (T. Sweepstakes 1743)-Da11. 1785 of Woodpecker $17 \% 3$ (Herod 1758) - Everla*ting $17 \% 5$ by Echipse 1764 ( Marske 1\%50)

Camel Whalebone 1807 (IVaxy 1790)-Dau. 181\% of Selim 1802 (Buzzald*1787)-Maiden 180

b1. 182. by Sir Peter T. 1781 (Highflyer 17i)-Dan. 1788 of Phenomenon 1780 (INerod 1758)-

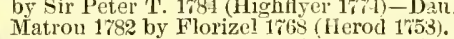

Master Henry 1815 (Orville 1799)-Boadice: 180\% by Alexander 17s9 (Eclipse 1661)Brunette by Amaranthus 1763 (Old England 1711) - Mayfly $1 \% 1$ by Matchem 1718 (Cade 1734)-Dau. 1755 of Anc. Starling 1738 (Starling 172\%).

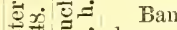

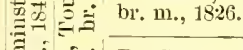
فํ.

br. h., 1811. 1751 (Snip 1736) Sultara 1759 by Regulus 1739 (God. Ar. 1721).
Tomboy's Ardrossan 1809 (John Bull 1784)-Larly Eliza 1813 by Whitworth 1803 (Agonistes 1\%9\%)

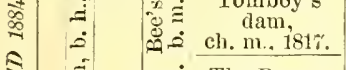

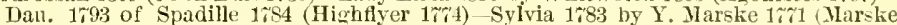
1750) - Ferlet 1765 hy Broth. to Silvio (Cade 1724). r. Birdcatcher 1833 (Sir Hercules 1826)-Echidna 1838 by Economist 18:5 (WThisker 1812) - Miss Pratt 1825 by Blacklock 181: (Whitelock 1803) - Gadabont 1812 by Orville 1799 (Beningbrongh 1\%91) - Minstrel 1803 by Sir Peter T. $1 \% 81$ (Highflyer 1\%个4).

ch. h., 1842.

Pocahontas,

Glencoe* 1831 (Sultan 1816) - Jarpessa 1832 by IIuley 1819 (Orville 1\%9) Clare 1824 by Narmion 1806 (Whiskey 1789)-Halpalice 1814 by Gohanna 1790 (Mercury 17\%)-Amazon 1799 by Driver 1783 (Trentham 1766 ).

$>$ s.

‡ Langar.

Selim 1802 (Buzzard* 1787)-Dau. 1808 of Walton 1799 (Sir Peter T. 1784)-Y. Giantess 1790 by Diomed*1\%\% (Florizel 1708)-Giantess $1 \% 69$ by Matchem 1748 (Cade 1734)Nolly Long Legs 1753 by Babraham 1710 (God. Ar. 1724).

ธ่

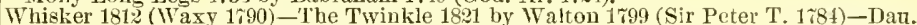

$\therefore$ br. m., 1828 .

1814 of Orville 1799 (Beningbrough 1791) - Lisette 1803 by Hambletoniau 1792 (King Fergus 1775)-Constantia 1.95 by Wainut 1786 (Highflyer 1784)

\section{Sultan,}

Selim 1802 (Buzzard 178\%) - Bacchante 1809 by W's Ditto 1800 (Sir Peter T. 1781)-Dau. $1 \% 91$ of Mercury 178 (Eclipse 1\%64)-Dau. 1\%6 of Herod 1\%58 (Tartar 1\%43)-Folly 1\%1 by Marske 1750 (Squirt 17.32).

Cobweb, Phantom 1803 (Walton 1799)-Filagree 1815 by Soothsayer 1803 (Sorcerer 1796) - Web

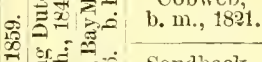

1803 by Waxy $17: 00$ (Pot-8-o's 17\%3) - Penelope 1793 by Trumpator 1782 (Conductor 176i')-Prunella 1788 by Highflyer $17 \% 4$ (Herod 1758).

Catton 1809 (Golumplns 1802) Orvillina 1804 by Beningbrough 1\%91 (Kiug Ferous 1\%75)Evelina 1791 by Highfiyer 1644 (Herod 1758)-Termagant by Tantrum 1760 (Cripple 1\%50)-('antatrice by Sampson 1745 (Blaze 1733).

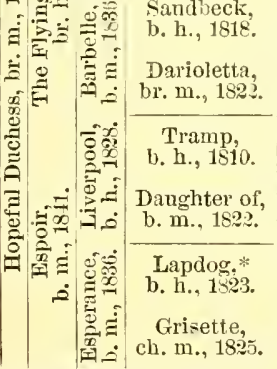

Amadis 1807 (Don Quixote 161)-Selima 1810 by Selim 1802 (Buzzard*178\%)-Dau. 1791 of Pot-8-o's 1\%73 (Eclipse 1\%61) - Editha 1781 by Herod 1758 (Tartar 1613)-Elfrida 1\%68 by Suap 1750 (Snip 1733 ).

Dick Andrews 1797 (Joe Andrews 1\%78)-Dan. 1803 of Gohanna 1790 (Mercury 17\%8)Fraxinella 1793 by Trentham 1766 (T. Sweepstakes 1743)-Dau. 1685 of Woodpecker 1733 (Herod 1758)-Everlasting $17 \% 5$ by Eclipse 1764 (Marske 1750).

Whisker 1812 (Waxy 1790) - Mandane 1800 by Pot-8-o-'s 17\%3 (Eclipse 1761) $\mathrm{T}$. Camilia 1787 by Woodpecker 173 (Herod 1 758 ) Camilla 1\%8 by Trentham 1\%66 ( $\mathrm{T}$, Sweepstakes (743)-Coquette $1 \% 65$ by Compton Barb.

Whalebone 1807 (Waxy 1790)-Dau. 1812 of Canopus 1803 (Gohanna 1\%90)-Dan. 1804 of Y.Woodpecker $17 \% 4$ (Woodpecker 17\%3)-Fractious 1792 by Mercury 1\% (Eclipse 1764) Dau. 1785 of Woodpecker $17 \% 3$ (Herod 1758).

Merlin 1815 (Castrel 1801)-Coquette ch.m. 1814 by Dick Andrews 1796 (Joe Andrews 1778) - Vanity b m. 1803 by Buzzard*178\% (Woodpecker 1\%'3)-Dabchick bu. m. 1798 by Pet-8-o-'s 1773 (Eclipse 176t)-Drab b. m. 1791 by Hightlyer 17\% (Herod 1758)Hebe b. m. 1774 by Chrysolite 1\%63 (Blank 1740)-Proserpine b. m. 1766 by Marske 1750 (Squirt 1732)-Spiletta b. m. $1 \% 49$ by Regulis 1739 (God. Ar. 1724)-Mother Western by Easby snake (Snake)-Montagu
mare by D'Arcy's Old YIontagu-Dan. of Hantboy (D'Arcy White Turk)-Dau. of Brimmer (D'Arcy Yellow Turk) Royal mare. 


\section{MISER.}

BROTHER TO SPENDTHRIFT.

The property of Chas. Reed \& Sons, Fairview Stud, Gallatin, Tenn. Tearlings sold anmully.

Mrser, chestnut horse, foaled 1877, bred in the Woodburn Stud, by imp. Australian, son of West Anstralian by Melbourne, dam Aerolite, sister to Idlewild by Lexington, ont of Floriue by imp. Gleneoe.

Miser is a full brother to Spendthrift, Felloweraft (4 miles, in 7.1912) and Rutherford, all of which were first-class race-horses. Since placed in the stud they have become famous as sires of race-horses. Rutherford sired Lucky B., Molly MeCarthy's Last, Estrella and Harry Rose, while Spendthrift's great doings at the stud is shown by

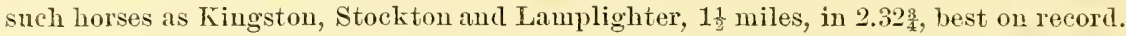
The dam of Miser, Aerolite, is one of the most successful in turf annals, for her raciug excellence and for the uniform and almost invariable transmission to her descendants of first-class racing qualities. She produced Mozart, Spendthrift, Felloweraft, Jersey Belle, Platina, Trafalgar and Rutherfort. Florine, the second dam, was the dam of Idlewild, the best race-mare of her day ( 4 miles, in $7.26 \frac{1}{4}$ ) and of Legal Tender. Idlewild was the dam of Wild Idle, a great horse ( 4 miles, in 7.25 $\frac{1}{2}$ ), and now a distingnished sire. Miser is one of the most promising young sires in this comntry.

In 1889 only two of Miser's get started, and each of them were winners, viz.: English Lady and Cadaverous. English Lady was a very high class filly, winner of the Zoo Zoo Stakes, s. of a mile, at Latonia, by three lengths, in 1.17, beating Dilemma, Sis O., Lee, Ballyhoo, Kitty Cheatham and Heartsease, all of which were wimmers. Three other good races also fell to her share during the season. In 1890 she proved herself the champion three-sear old filly of the West, by winning the Stranss Handicap, 1 mile, at Lexington, by three lengths, in 1.42; a Handicap, $1 \frac{1}{8}$ miles, at Lonis-

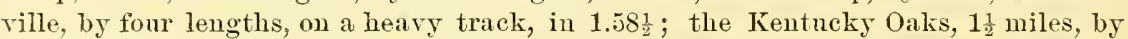
three lengths, in $2.42 \frac{1}{2}$, and the Latonia Oaks, $1 \frac{1}{\frac{1}{4}}$ miles, by three lengths, in $2.08 \frac{8}{4}$; a mile race at Saratoga, in 1.42; the Kenner Stakes, $1 \frac{8}{t}$ miles, beating Sir John, etc., in

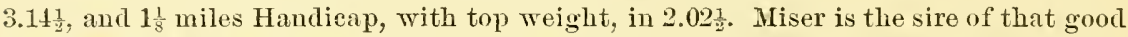
performer Lady Washington, wimner of the Senorita Stakes, $\frac{1}{2}$ mile, in 0.52, at Memphis, beating Honte Rosa, Amnie Brown and seven others; the Nantura Stakes, $\frac{5}{8}$ of a mile, Lexington, in a field of nine, in $1.05 \frac{1}{2}$, the Breeders' Stakes, $\frac{5}{8}$ of a mile, in $1.04 \frac{8}{4}$, and the Hurstbonrue Stakes, $\frac{5}{8}$ of a mile, Lonisville, in $1.05 \frac{1}{4}$. Adventurer was another two-rear old son of Miser that wou races, and was a winner last year. Buckhonnd, Markstone, Milo, MeNurtry, Rongh Diamond, Mendicant, Poverty, Mark S., Jennie Cottrill and Penurious are also among his wimners, and it is safe to say that everything by him wins, for his representatives are noted for quality rather than quantity, his opportmities having been very limited to within the past year or two.

His best representative, however, is the fleet and game filly Yorkville Belle, win. ner last year of the Hollywood Handicap, the Autumn Stakes, the prospect Stakes, the Willow Stakes, the Fashion Stakes and the Nursery Stakes, and second in the Expectation, fourth in the Junior Champion and second in the Futurity, proving herself the best of her age and sex. This year she has won the Gazelle, Ladies", Mermaid, West End Hotel and Onnibus Stakes. It is a grand racing tamily, having both speed aud stamina; Drake Carter, Rutherfort, Con Cregan, Sallie M., Bersan, Mozart, Trafalgar, Kingeraft, Macbeth, Macduff, Favor, Legal Tender, Melody, Rodolph and a host of others come from it. 


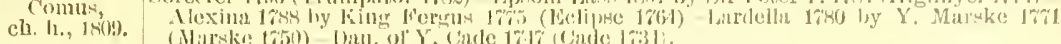

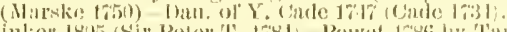

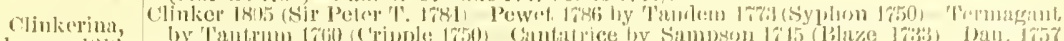

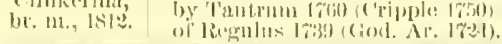

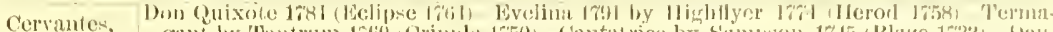

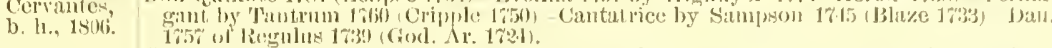

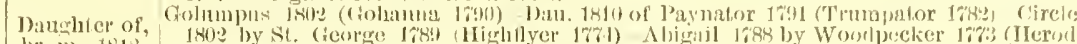

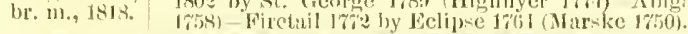

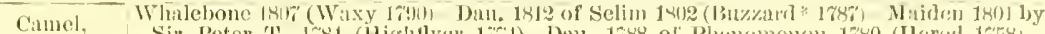

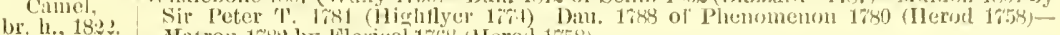

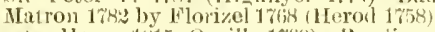

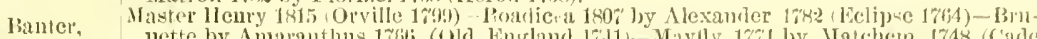

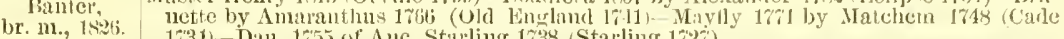
1731)-Dan. 1755 of Anc, Stalling 1738 (Starling 17\%7).

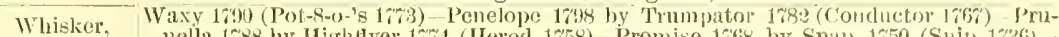

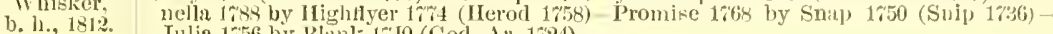
Julia 1 rist by Blank 170 (God. Ar. 1724).

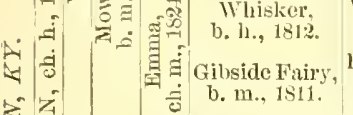

lermes 1 \% 10 (Nereury 17\%8)-Vicissitule 1800 by Pipalor 1\%86 (Imperator 17\%6)-Beatrice

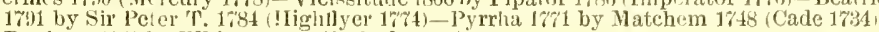
Duchess 1748 by Whitenose 1742 (God. Ar. 17\%).

Orville, Beningbrough 17n (Kins Fergus 175)-Evelina 1791 by Highflyer 17it (Herod 175s)

b. h., 1799. Termagant by Tantrum 1760 (Cripple 1750)-Cantatrice by Sampson 1745 (13laze 1730)Dau. $175 \%$ of Regulus 1739 (God. Ar. 17:-1).

Emily, Stamford 179f (Sir Peter T. 1784) Dan. 1799 of Whiskey 1789 (Saltram* 1780)-Grey

ch. m., 1810. Dorimant $1 \% 81$ by Dorimant 1\% (Otho 1\%60)-Dizzy 1757 by Blank 1710 (God. Ar 17:24-Dizzy $1 \% 41$ by Driver 1727 (Wynn Ar.).

Scud Beningbrongh 1791 (King Fergus 17\%5)-Eliza 1791 by Highflyer 1774 (Ilcrod 175s)

b. h., 1804. Augusta 1784 by Eclipse 1764 (Mar-ke 1750)-Hardwicke's dam by Herod 1758 (Tartar 1743 ) - Nettle 1763 by Bajazet 1740 (God. Ar. 1\%24).

Goosander, Hambletonian 1792 (King Fergus 17/5)-Rally 1790 by Trumpator 1782 (Condnctor

b. m. 1805, 1\%67)-Fancy 1780 by Florizel 1768 (Ilerod 1758)-Da11. 1763 of Spectator 1749 (Crab 1722)-Horatia 1758 by Blank 1740 (God. Al. 1724).

Waxy Pot-8-o-'s 1773 (Eelipse 1764)-Maria 17in by Herod 1758 (Tartar 1743)-Lisette 17\%2 by \begin{tabular}{l|l} 
b. h., 1790. Snap 1750 (Snip 1736)-Miss Windsor 1754 by God. Ar. 1704-Sist. to Volunteer by \\
Y. Belgrade (Belgrade Turk).
\end{tabular}

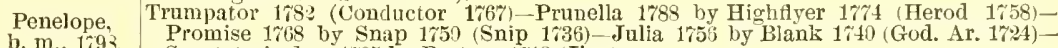
b. m., 1793. Spectator's dam 1735 by Partner 1718 (Jigg).

[Selim or] Sorcerer 1693 (Trumpator 1782) Golden Locks 1793 by Delpini 1781 (Hionflyer 1774)-

Soothsayer, Violet 1787 by Shark 17\%1 (Marske 1750)-Dau. 17\%2 of Syphou 1750 (Squirt 1732)ch. h., 1808. Charlotte $1 \% 56$ by Blank 1\%40 (God. Ar. 17\%4).

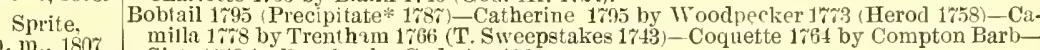
ch. m., 180\%. Sist. 1713 to Reguhis by God. Ar. 17\%1

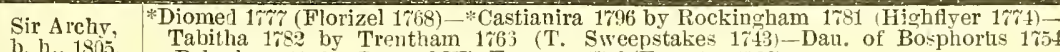
b. h., 1805 . (Babraham 17 \pm 0 )-Dau. of W's Forester 1750 (Forester 1736).

Daughter of, *Saltram 1780 (Eclipse 1;64)-Dau. of Symmes' Wildair 1767 (*Fearnought 1755)-Dan. of Tyler's Driver $1 \% 60$ (* Othello)-Dau. of *Fallower 1\%61 (Blank 1\%40)-Dau. of *Vampire 175\% (Regulus 1\%39).

Ei ch. m., -

Ball's

Diomed $17 \% 7$ (Florizel 1768)-Dau. of *Shark 17\%1 (Marske 1750)-Dau. of Harris's ch. h., 1801

Daughter of, Ecipse 170 ( Fearnought 1755)-D

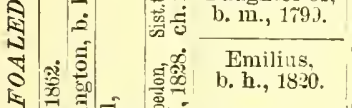

Alderman 178\% (Pot-8-0-'s 17\%3)-Dan. of *Clockfast 17\%t (Gimcrack 1760)-Dan. of Symmes' Wildair 1767 ("Fearnought 1755)-Y. Kitty Fisher by *Fearnought 1755 (Regulus 1739) - KIit Iy Fisher 1755 by Cade 1734 (God. Ar. 1724). Dau. 1799 of Whiskep 1789 (Saltram* 1780)-Grey Dorimant 1781 by Dorimant 17\%: (Otho 1760) Dizzy 17.57 by Blank 1749 (God. Ar. 1724).

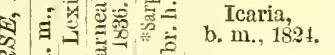

(Vandyke Jr. 1808) Parma 1813 by Dick Andrews 1797 (Joe Andrews 17\%8)-May 1 1804 by Beningbrough 1791 (King Fergus 1\%i5)-Primrose 1787 by MIambrino 1763 (Eng:neer 1\%56)-Cricket 1766 by Herod 1758 (Tartar 1743).

Sumpter, Sir Archy 1805 (*Diomed 17\%)-Dau. of *Robin Redbreast 1796 (Sir Peter T. 1784)ch. h., 1818. Dau. 1789 of *Obscurity $17 \% 7$ (Eclipse 1764)-Slamerkin 1768 by *Wildair 1\%3 (Cade ch. h., 1818. 1731) - * Cub mare 1762 by Cub 1739 (Fox 1714)

Lady Grey, Robin Grey 1805 (*Royalist 1\%90)-Maria 1802 by Melzar 1791 (*Medley 17\%3) -Dat. of b. m., 181; *Highflyer 1784 (Highflyer 1\%74)-Dau, of *Fearnought 1755 (Regulus 1\%39) -Dau. of Ariel 1753 (*Travelier 1747 ).

Selim, Buzzard* 1787 (Woodpecker 17\%3)-Dan. of Alexander 1782 (Eclipse 1\%61)-Dau. of ch. h., 1802. Hightlyer 17\%! (Herod 1758)-Dau. of Alfied 1770 (Matchem 1748)-Dau. 1770 of Engich. h., 1802. neer 1\%56 (Sampson 1745).

T's Ditto 1800 (Sir Peter T. 1\%4)-Dan. $1 \% 91$ of Mercury 1\%8 (Eclipse 1\%64)-Dair. 1\% br. m., 1809 . of Herod 1758 (Tartar 174) - Folly 17\%1 by Narske 1750 (Squirt 1732)-Visen 1753 by Regulus 1739 (God. Ar. 17:4).

b. Tramp, 1810 .

Dick Andrews 179; (Joe Andrews 17\%8)-Dau. 1803 of Gohanna 1790 (Mercury 17\%s)-

Web,

b. in., 1808 .

Am. Eclipse,

ch. h., 1814 1\%3 (Herod 1758)-Everlasting $1 \% 5$ bv Eclipse $1 \% 64$ (Marske 1\%50).

Waxy 1790 (Pot-8-o-'s 1773) - Penelope 1793 by Trumpator 1782 (Conductor 1767) - Prunella 1788 by Highflyer 1774 (Herod 1758)-Promise 1768 by Snap 1750 (Snip 1736)-Julia 1756 by Blank 1740 (God Ar. 1\%21)

Y. h., 1814 . the Oaks,

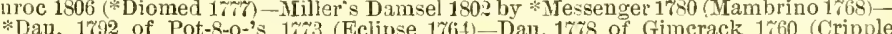
1750 ) - Snapdragon 1759 by Snap 1750 (Snip 1736 )

Expedition 179 (Pegasn 1784 - Maid of the Oaks 1801 by $\%$ Spread Eagle 1792 (Volunteer 1780)-Annette by kshark 17\%1 (Marske 1750)-Dau, of Rockiugham (Partner 1755) -Dan. of True iVhig (Fitzhugh's Regulus 1765).

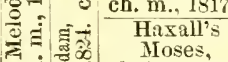

b. 13., 1816.

호욜 Danghter of

* Sir Harry 179.j (Sir Peter T. 1781) - *Nermaid by Waxy 1790 (Pot-8-0-'s 17\%3) - *Promise 1803 by Buzzard* 1787 (Woodpecker 1773)-Dan. 1795 of Precipate* 1787 (Mercury 17\%8)-Lady Harriet $1 \% ; 3$ by Mark Anthony 176\% (Spectator 1\%19).

Cook's Whip 184 (*Whip 1794)-Har't's Maria by Craig's Alfred (*Vedley 17\%6)-The

Pryor mare [a good race-mare] by Tayloe's Bellair 1786 (*Medley 1\%6)-Thoroughbred mare of $\mathrm{Mr}$. T. D. Owings. 


\title{
IMPORTED MOCCASIN.
}

\author{
Owned in the Edgewater Stud, F. S. Ashbrook, secretary, Cynthiana, Ky.
}

Moccasix by Macaroni, son of Sweetmeat by Glacliater, bred isy Mr. H. W. Deacon, foaled 1874 and imported by Mr. P. Lorillard when a yearling, dam Madame. Strausz, clam of Raweliff aud Ormelie by King Tom, son of Harkaway, ont of Jetty Treffz by Melbonrne, son of Hnmphrey Clinker by Comns. Macaroni, the sire of Moccasin, won the 2,000 Gnineas and the Derby in 1863, and is the sire of Spinaway, winner of the 1,000 Guineas and Oaks, Camelia, winner of the 1,000 Gnineas, and of Macheath, the best two-year old in England in 1882, and favorite for the Derbr, Lilly Agnes, dim of Ormonde. Sweetmeat, Macaroni's sire, was by Gladiator, second to Bay Midrleton in the Derby. Sweetmeat was a noted race-horse. ran twenty-four times as a two and three-cear old and met but one defeat. He won the Doncaster Cup and other important events. Moceasin has a donble eross of that popular blood Pantaloon, which is famous for speed and staying qualities, and is a true racing strain. Pantaloon's son, Van Amburgh, was second to Coronation in the Derby, and Satirist, another son, won the St. Leger, beating Coronation; he is sire of Ghuznee, winner of the Oaks, and of Cardinal Puff, Elthiron, Hobbie Noble, The Reirer, second to West Anstralian in the St. Leger, Hernandez, winner of the 2.000 Guineas, and of Windhomnl, the sire of Tho!manhy. Leamington was ont of a diangliter of Pantaloon. King 'Tom, the sire of his dam, is too well known to need comment, sufficient to say he was by Harkaway, ont of Pochahontas, the dam of Stockwell and Rataplan by Gleneoe. His grandam is by Melbourne, sire of West Anstralian, winner of the double events, Derby and St. Leger, Blink Bonny, wiuner of the Oaks and Derloy, and the dam of Blair Athol, wimer of the Derby and St. Leger, Sir Tatton Sykes. winner of the St. Leger, Cymba and Marchioness, winner of the Oaks. The Melbournes are remarkable for size, snbstance and sonulness, large bone and racing shape. Moccisin never raced, but his first colts, all out of mares the refuse of his owner, were very reputable performers. Vampire and Faith won six races out of twenty-fonr starts in 1851. Vampire three, carried $140 \mathrm{lbs}$, and ran a mile in 1.46. The two-year old P. Lorillard won four races out of seven starts in 1882. Amazon and Distain are both creditable performers, Distain won Optional stakes. Other winners by him are Leather Stocking, Mayona, Mohawk, Mokana, Mamood, ete. He is the sire of Cerise, which is the dam of Morello, one of the best two-year olds erer seen, winner of the Futurity, 1892, in 1.12t, as a sick horse. The Macaroni blood is most popular in England, and he is the only Macaroni horse accessible to the breeding public in America. He is a dark bay or brown, with great substance and power, fine temper and full 16 hands high. He should be invalnable to perpetuate the King Tom strain of blood throngh the descendents of Phaeton, King Ban and Great Tom. He is descended in direct female Iine from the Royal mare, to which traces Hightlyer, Don Qnixote, Alexander. Stnmps, Colwick, Orlando, Bearlsman, Albert Victor, George Fredlerick, Galliard, in Eugland; Martini-Heury, Nordenfeldt, in Anstralia ; Macaroon (imp.), ete. 


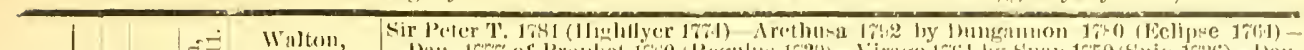

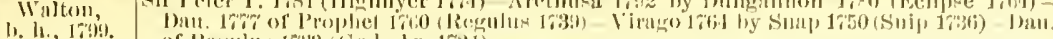

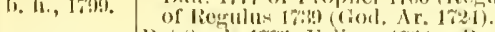

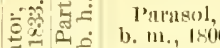

จำ

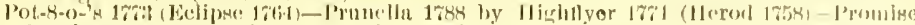

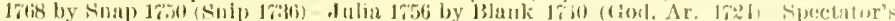

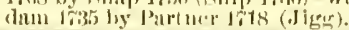

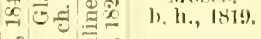

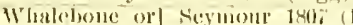

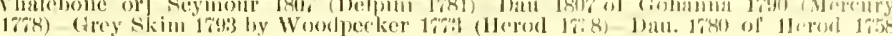

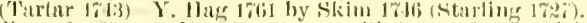

Quadrille,
1). $11 ., 1$ 1

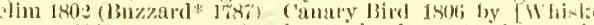

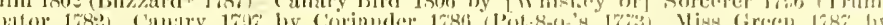

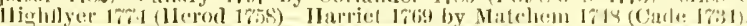

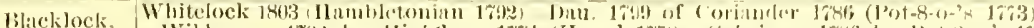

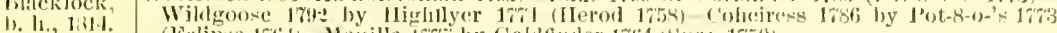

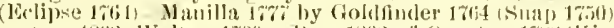

Dinghter of

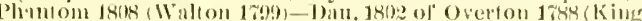

\section{b. $111 ., 1316$.

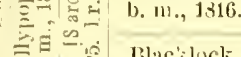

b. 11. 1811

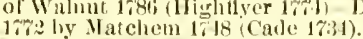

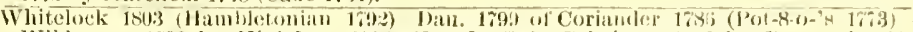

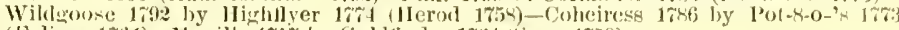

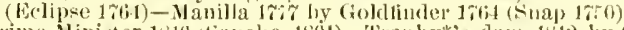

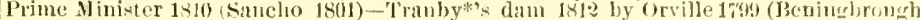

Wartail,
b. In., 1 isis. 191) Jiss Grimstone 17,94 by Weazle

$\overline{3}$ Buzzard, * (Blank 1741) - Dau. ol Damaccus Ar. 175. osity 1760 by Suap 1750 (Snip 1736)-Dim. 171, of Regulus 1739 (God. Ar. 1724)-1)atu. of Bartlett's Childers (Darley Ar. 1tom)

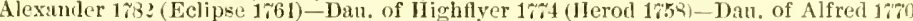
Mateliem 1746)-Dan. 17\%0 of Engineer 1756 (Sampson 1745)-Bay Malton's dam 175; by Cade 1\%34 (God. Ar. 1\%?4).

\section{है. \\ b. 11., 1806 .}

Sir Peter I. 1784 (Highter 174)-Dan. 178 of Boudrow 17\% (Eclipse 1764)-Dan. 17ti of Squirrel 1;54 (Traveller 1735) - Sist. to Lowther's Babraham by Babraliam 1; 40 (God. Ar. 1721)-Dau. 1750 of Golden Ball 173j (Paltner 1718)

Musidora, Meteor 1783 (Eelipse 1764)-Maid-of-all-Work 1786 by Highflyer 17rt (Herod 1758)-Dau. b. m.. 1804. to Judgement by Snip 1736 (Flying Chi]ders 1715).

Orville, Beningbrough 1791 (Kung Fergus 17\%5)-Evelina 1791 by Highflyer 1774 (Iherod 1758)-

Orville, 1733) - Dan. 1757 of Regulus 1739 (God. Ar. 1724).

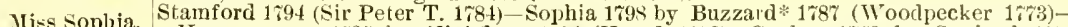

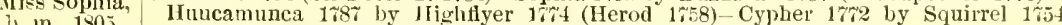

(Traveller 1735) Fribble's dam 1749 by Regulus 1739 (God. Ar. 1\%24).

$=5$. $10 ., 180$.

Alexander,

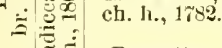

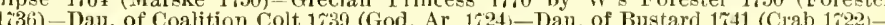
Charming Molly $1 \% 42$ by Seeond 1732 (Flying Childers 1715).

Brunette, Amaranthus 1766 (Old England 1\%41)-Mavfly 17\%1 by Natchem 1\%48 (Cade 1734)-Dan. 1755 of Anc. Starling 1733 (Starling 172\%)-Look-at-me-Lads 1731 by Grasshopper (Byerly Turk) - Dan, of Sir Newton's Bay Ar.

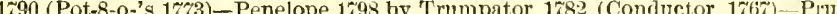
nella 1789 by Highflyer 1774 (IIerod 1758)-Promise 1768 by Snap 1750 (Snip 1736) Julia $1 \% 56$ by Blank 1\%40 (God. Ar. 17:4)

Oclavian 1807 (Stripling 1795)-Caprice 1797 by Anvil 17\% (Herod 1758)-Mladcap 17\% by Eclipse 1764 (Marske 1750)-Sappho 1\%63 by Blank 1740 (God. Ar. 1724)-Dau. 1750 of Blaze 1733 (Flyjng Childers 1;15).

Rilgantino 1894 (Commodore 1793) - Butterfly 1804 by Master Bagot 178\% (Bagot 1780)Dau. of Bagot 1730 (Herod 1758)-. Mother Brown 17i1 by Trunnion 1747 (Cade 1734)Dau. of Old England 1741 (God. Ar. 1721).

Teddy-the-Grinder 1793 (A sparagus 178\%)-Lady Jane 1796 by Sir Peter T. 1\%84 (High-

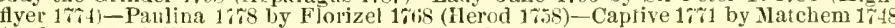
(Cade 1731)-Calliope 1763 by Slouch 1747 (Cade 1724).

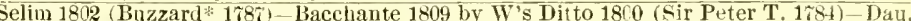
1791 of Mercury 17ro (Eclipse 1764)-Dau. 17 t6 of Herod 1758 (Tartar 1743)-Folly $17 \% 1$ by Marske 1750 (Squirt 1732 )

Tramp 1810 (Dick Andrews 1\%9\%) W W eb 1808 by Waxy $1 \% 90$ (Pot-8 o-'s 1\% 1798 by Trumpator 1782 (Conductor 1i6\%)-Prunella 1 i 88 by Highfyer 1754 (1Ierod 1.55)-Promise 1768 by Snap 1750 (Snip 1736 )

Orville 1793 (Beningbrongh 1791)-Eleanor 1798 by Whiskey 1789 (Saltram* 1780)-Y Giantess 170 by Diomed* 1\% (Florizel 1\%68)_Giautess $1 \% 69$ by IIatchem $1 \% 48$ (Cade 1734)-Molly Long Legs 175:3 by Babraham 1740 (God. Ar. 1724)

Marmion $180 ;$ (Whiskey 1789 ) - Harpalice 1814 by Gohanna $17 \% 0$ (Netcury 17r8)-Amazon $1 \hat{\imath} 99$ by Driver 1783 (Trenthum 1763)-Fractious 1792 by Mercury 178 (Eclipse 17(54) - Dau. 178 s of 1 oodiecker $17 \% 3$ (IIerod 1755).

Sorcerer 1796 (Trumpator 1\% $8 \%$ ) - Houghton Lass 1801 by Sir Peter T. 1i 81 (Hightlyer

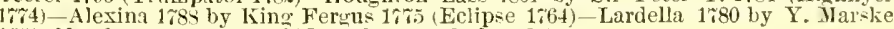
$1 \%$ (Narske 1750) Dau. of Y. Cade 174r (Cade 1734)

Clinker 1805 (Sir Peter T. 1781)-Pewet 1786 by Tandem $17 \% 3$ (Ssphon 1750)-Termagant

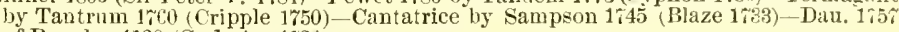
of Regulus 1739 (God. Ar. 1724).

Don Quixote 1784 (Eclipse 1764)-Evelina 1791 by Highflyel $17 \% 4$ (Herod 1758)-Termagant by Tantrum 1700 (Cripple 1750) - Cantatrice by Sampson 1645 (Blaze 1733)-Dau. $175 \%$ of Regulus 1739 (God. Ar. 1724).

Golnmpus 1802 (Gohanna 1700)-Dau. 1810 of Paynator 1791 (Trumpator 1783)_Circle 1802 by St. George 1789 (Highflyer 17\%4)-Abigail 1783 by Woodpecker $17 \%$ (Herod 1758)-Firetail $17 \% 2$ by Ecipse 1764 (Marske 17.0.

Casirel 1801 (Buzzard\% 1 R T)-Idalia 1815 by Peruvian 1806 (Sir Peter T 1 184 ) Musidora 1804 by Meteor 1\%83 (Eelipse 1\%64)-Maid-of-all-Work 1785 by Highflyer 17t4 (Herod 1758 )-Dan. 1771 of Syphon 1750 (Squirt 1722)

Filho-da-Puta 1812 (Haphazard 1790)-Hybla 1821 by Rubens 1805 (Buzzard* 178\% Larissa 1813 by Trafalgar 180\% (Sir Peter T. 1\%84)-Meteora 1802 by Meteor 1:83 (Eclipse 1764)-1laid-of-all-Work 1786 by Highflyer 17t4 (Herod 1758).

Blacklock 1814 (Whitelock 1803)-Dau. 1816 of Phantom 1808 (Walton 1799)-Dan. 180? of Overton 1788 (King Fergus 175)-Dau. 1796 of T1alnut 1786 (Highfyer 17\%4)-Dan. 1786 of Ruler 17 ir (Y. Marske 1771) Olympia b. m. 1815 by Sir Oliver 1800 (Sir Peter T. 1784)-Scotilla b. m. 1795 by Anvil $177 \%$ (Herod 1758)-Scota b. m. 1783 by Eclipse 1764 (Narske 1750)-Harmony 175 by Herod 1758 (Tartar 1\%43)-Rutilia b m. 1\%69 by Blank 1\%40 (God. Ar. 1724)-Sist. 1751 io South by Regulus 1739 (God, Ar. 1724) - Dau. of Soreheels (Basto 1702)-Dau. blk. m. by Makeless (Oglethorpe Ar.) Christopher D'Arcy's Royal mare by Blunderbuss (Bustler)—old Grey Royal by D'Arcy White Turk-Dau. of D'Arcy Yellow Turk-Royal mare. 


\section{ONEKO.}

The property of W. S. Bumes, Melboune Stud, Lexington, Ky. Sales anmually.

OxEкo, brown horse, foaled 1884, bred in the Brookdale Stud, by Lncas, son of Lexiugton and Coral by Vandal, dam imp. Faverdale, dam of Centanr (Faverdale colt) by The Palmer, own brother to Rosicrucian by Beadsman. The Palmer wou the Ascet Derby, Royal Stakes and Liverpool Antumn Cup, and is the sire of Jenny Howlei, winner of the Oaks, Pellegrino, Pilgrimage (winner of the Dewhrst Plate, the 1,000 and 2,000 Guineas), Grey Palmer, etc. His grandam Georgiana is (full sister to Comntess of Burlington, the dam of Cavendish and imp. Hartington, winuer of the Cesarewitch Handicap) by Tonchstone, winner of the St. Leger and one of the most valnable stallions ever bred in England. Tonchstone sired Mowerina, the dam of West Australian, winner of the 2,000 Guineas, the Derby and St. Leger. Mowerina was ont of Emma, sister to Caroline, the fourth dam of Centaur by Whisker, third dam Lady Emily by Muley Moloch, son of Muley and sire of the famons Alice Hawthorn, dam of Thormanby, winner of the Derlys, tracing throngh Gibside Fairy by Hermes, son of Merenry by Eelipse, to the D'Arey Blacklegged Royal mare.

Oneko commenced his turf career at two sears old by running third to Tremont an. Queen of Elizalseth for the Foam Stakes, fire-eighths of a mile, at sheepshead Bay, beating Roi d'Or, Nat Goodwin, Alaric and four others. At Monmonth Park, in the July Stakes, three-quarters of a mile, ran second to the mighty Hauorer, beaten by the shortest of heads, beating Roi d'Or, Fitzroy and Reveller, time, $1.15 \frac{1}{2}$; at Monmonth, in the Criterion Stakes, three-quarters of a mile, he finished fourth to Nilton, Firenzi and Fitzroy, beating Strideawas, Flageoletta, Cambyses, Racquet, Puzzle and fonr others. Oneko began his three-sear old career by rmning third to Tarbouche in a $1 \frac{1}{\ddagger}$ mile race at Jerome Park, beating Strideaway and Lizzie Baker.

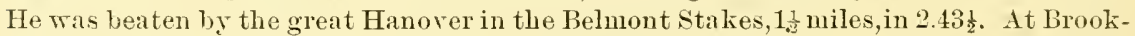
lyn ran third in a mile race to Fitzroy and Stuyvesant, in 1.43, beating Dunbine, Young Luke, Alaric and Valentine; was third in the Tidal Stakes, at Sheephead Bay, 1 mile, in 1.41온, to Hanover and Kingston. For the Coney Island Derby; $1 \frac{1}{2}$ miles, in 2.44 $\frac{1}{2}$, Oneko again finished second to Hanorer, Hypasia third; and ran second to. Dunbine, beaten a neck, in the Beacon Stakes, $1 \frac{3}{16}$ miles, 2.03, defeating Connemara, Fitzroy, Bradford, Reveller, Prodigul, etc. Oneko elosed his three-year old rear by running third in the Emporinm to Hanover and Dunbine, $1 \frac{1}{2}$ miles, in 2.35 , the defeated ones being Stockton, Wilfred, Brynwood, Banbridge and Shasta.

With Hanorer out of the way Oneko wonld hare been a first-class stake trinner, and he must be placed in that class. The breeding of Oneko is excellent. His sire, Uncas, was a grand race-horse and a sncessful sire. Faverdale, Oneko's dam, prodnced the winners Frolic and Centaur (Faverdale colt), the latter one of the best horses of his das. Myopia, a danghter of Faverdale, produced the winner Melinda and Briganza, dam of the two-year old winner J. L. Knight. His grandam, Georgiana by Touchstone, was a successful stnd matron, throwing a number of winners in Measure for Measure, Farnsfield, Sunset, Irommaster, Split the Difference and Cœur de Lion. His fifth dam, Gibside Fairy, was the grandam of imp. Trnstee (Levity's sire). Cotherstone (winner of the 2,000 Guineas, Derls, ete.), Mundig (wimner of the Derbr, ete.), and West Anstralian (winner of the 2,000 Gnineas, Derby, St. Leger, etc.). and the great grandam of Parmesan, sire of the Derbs wimners Cremorne and Faronius.

He is descented in direct female line from the Blacklegged Royal mare, to which traces the following excellent race-horses and successful stallions: Oromoko. Saltram (imp.), Beningbrongh, Williamson's Ditto, Cotherstone, West Australian, Walton, Wild Darrell, Parmesan, Diophantns, Caterer, Lord Ronald, Ishmalel, Wisdom, The Miser, Saxifrage and Harry O'Fallon, in Ameriea. 


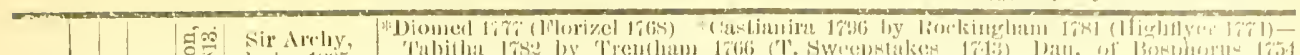
1) aumhtikit uf, ('l1. 111.

liall':

l'lorizel.

cl. h., Isil

1)anghter of

b. 11., $17 ! n$ ?

Emilins.

b. I1., I.:2)

Ictria,

b) $311 ., 1$ in:4.

siampler,

cir. 11., 1818.

Larly Grey,

b. $11 ., 181 \%$.

Sultan,

b. h., 1516 .

Trampoline,

ch. m., 1825.

:Tranby,

br. h., $18 \% 6$.

Iucilla,

b. m.,

Touchstone,

br. h., 1831.

Emma,

cb. m., 1 s.t.

Slane,

b. h., 1833.

Glencairne, b. m., 1838 .

$\pm \frac{a j}{*}$ Sheet Anchor, br, h., 1832 .

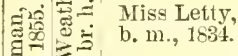

胥雚 $=$

A

Toulebstone

br. h., 1831.

Lady Noore Carew, Bay

Midaleton,

Crucifix,

b. m., 18,

Defence,

b. h., 1824

Folly,

ch. m., 1830.

"Thalebone,

Ф્- lor. h., $180 \%$

Dangbter of,

Mister Henr

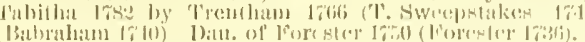

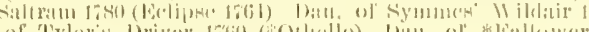

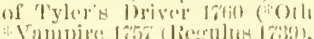

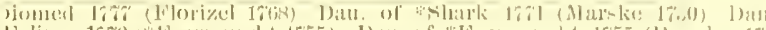

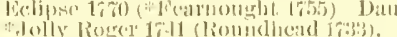

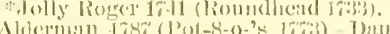

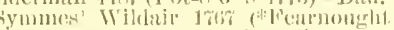

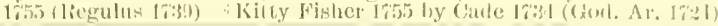

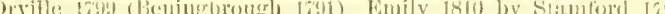

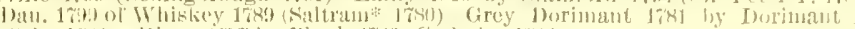

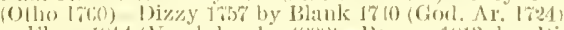

The lyer 1814 (Vandyke of 1808 ) - Parma 1813 by bick

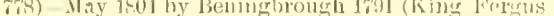

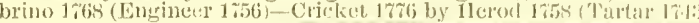

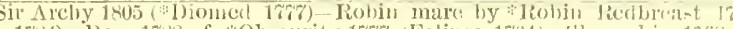

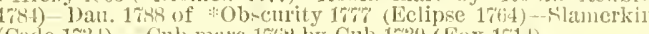

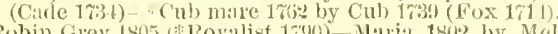

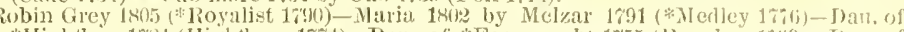

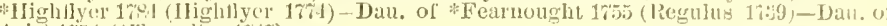

Ariel 175: ("Travelier $174 \%$ ).

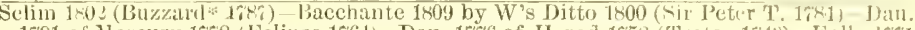
1791 of Mereury $17 \% 8$ (Eelipse 176-1)-Dan. 1\%6 of Herod 1i58 (1'urtar 1743) Folly lifi by Marske 1750 (Squint 173:3)

Tramp 1810 (Dick Andrews 17\%) - Web 1808 by Waxy 1;90 (Pot.8.o-'s 17is)-Penelope 179. by T'rumpator $178 \%$ (Conductor 1767)-Prunella 1788 by 11ighflyer 177t (Ilerod 17:8)-Promise 1763 by Snap 1750 (Snip 17:36)

Blacklock 1814 (Whitelock 14.08)-Dan, 1812 of Orville 1709 (Beningbrough 17sl) Mirs Grimstone 1795 by Weazle $17 \% 6$ (IIerod 1758)-Datu. of Ancaster 1768 (Blank 1r40)Dau. of Damascus Ar. 1754.

Trumpator 1623 (Sir Solomon 1805) - Lucy 1821 by Orphan 1810 (Ball's Florizel 1r01) Lady Grey 181; by Robin Grey 1805 (*Royalist 1790)-Maria 1802 by Melzar 1791 (*) Hedley $1 \%(6)$-Dan, of * Highflyer $178+$ (Highflyer $1 \% 4$ ).

Camel 1822 (Whalebone 180\%)-Banter 1826 by Haster Henxy 1815 (Orville 1796)-Boadicea $180 \%$ by Alexander 1782 (Eclipse 1761)-Brunette by Amaranthus 1766 (Old England 1741)-Maylly 17\%1 by Matehem 17.8 (Carle 1i31).

Whisker 1812 (Waxy 1;90)-Gibside Fairy 1811 by Hermes $1 \% 90$ (Mercury 178)-Ticissitude 1800 by Pipator 1786 (Imperator 17\%6)-Beatrice 1701 by Sir Peter T. 1784 (Highllyer 17\%4) - Pyirha 17\%1 by Matchem 1748 (Cade 1734).

Royal Oak 1823 (Catton 1809) Dan. 1819 of Orville 1799 (Beningbrongh 1791)-Epsom Lass 1803 by Sir Peter T. 1781 (11ightlyer 1\%4)-Alexina 17es by King Fergus 1\%i5 (Eclipse 1764)-Lardella 1780 by Y. Marske 17r1 (Marske 1750).

Sultan 1816 (Selim 1802)-Trumpoline 1825 by Tramp 1810 (Dick Andrews 169\%)-Web 1808 by ITaxy 1790 (Pot-8-o-'s 1773) - Penelope 1798 by Trumpator 1782 (Concluctor 176\%)-Prunella 1788 hy Highfiyer 1 irt (Herod 1758).

Lotter'y 1N20 (Tramp 1810)-Morgiana 1850 by Muley 1810 (Orville 1799)-Mist Stephenson 1814 by [Scud or] Sorcerer 1796 (Trimpator 1782)-Dau. 1796 of Precipitate* 1787 (Mercury 178)-Dau. 1787 of Woodpecker 17\%3 (Herod 1758)

Priam; 1827 (Emilius 1820)-Dan. 1815 of Orville 1799 (Beningbrough 1791) Dau, 1800 of Buzzard* $178 \%$ (Woodpecker 17\%3)-Hornpipe 1793 by Trumpator 1782 (Conductor $176 \%$ ) Luna 1769 by Herod 1758 (Tartar 1743 .

Came 18:2 (Whalebone 18i7) Banter 1826 by Master Henry 1815 (Orville 1799)-Boadicea 1507 by Alexander 1782 (Eclipse 1764)-Brunette by Amaranthus 1766 (Old England 1741)-Mayfly $17 \% 1$ by Matchem 1748 (Cade 1734).

Tramp 1810 (Dick Andrews 179\%) - Kite 18:21 by Bustard 1813 (Castrel 1801)-Olymuia 1815 by Sir Oliver 1800 (Sir Peter T. 1784)-Scotilla 1795 by Anvil 1\%7 (Herod 1758)Scota 1 i 3 by Eclipse 1764 (Marske 1750).

Sultan 1816 (Selim 180:) Cobweb 1821 by Phantom 1808 (Walton 1F99)-Filagree 1815 by Soothsayer 1808 (Sorcerer 1796) - Web 1808 by Waxy 1790 (Pot-8-o-'s 1773)-Penelope 1993 by Trumpator 1782 (Conductor $176 \%$ )

Priam*1827 (Emilius 1820)-Octaviana 1815 by Octavian 1807 (Stripling 1605)-Dan. $18 c \%$ of Shuttle 1793 (Y. Marke 1\%'1) Zara 1801 by Delpini 1\%81 (Highflyer 1\%4)-Flora 1789 by King Ferous $17 \% 5$ (Eclipse 1764)

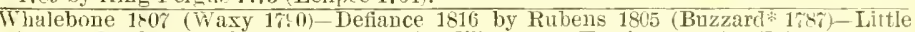
Folly 1806 by Jighland Fling 1798 (Spadille 1781)-Harriet 1799 by Folunteer 1780 (Eclipse 1\%64) Lady Sarah"s dam 1785 by Alfred 1\% 70 (Matehem 1748)

Viddleton 182: (Phantom 1808)-Little Folly 1806 by Highland Fling 1798 (Spadile 1784) Harriet 1799 by Volunteer 1780 (Eclipse 1764)-Dau. 1785 of Alred 17 \%0 (Matchem 174S)-Magnolia 17r1 by Marske 1750 (Squirt 1\%3\%).

Waxy 1790 (Pot-8-o-'s 1\%3)-Penelope 1798 by Trumpator 1782 (Conductor 1667)-Prunella 1788 by Highfyer 174 (Herod 1758)-Promise 1768 by Snap 1700 (Snip 17:36)Julia 1756 by Blark 1\%t0 (God. Ar. 1724).

Selim 1802 (Buzzard 1\%8)-Maiden 1801 by Sir Peter T. 1\%8f (Highflver 17it)-Dau. 1788 of Phenomenon 1780 (Herod 1\%8) - Matron 1782 by Florizel 1768 (Herod 1\%8)Maiden 1770 by Matchem 1748 (Cade 1734 ).

Orville 1799 (Beningbrough 1791)-Miss Sophia 1805 by Stamtord 1794 (Sir Peter T

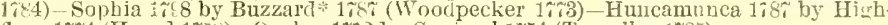
flyer 1\%4 (Herod 1\%8) - Cyplier 1\%: by Squirrel 1\%4 (Traveller 1\%55).

Alexander 1782 (Eclipse 1704 ) - Brunette by Amaranthus 1766 (Old En gland 1;41)-Mir. fly 1701 by Natehem 1748 (Cade 1734)-Dau. 1755 of Anc. Starling 1738 (Starling 1 $2 \%$-Look-at me-Larls 1231 by Grasshopper (Byerly Turk).

ฐं Boadicea, b. m., $180 \%$.

Muley,

Urvil]e 1,9.3 (Beningbrough 1791)-Eleanor 1738 by Whiskey 1709 (Saltram 1780 ) $Y$. Giantess 1740 by Diomed* $17 \%$ (Florizel 1768) Giantess 1769 by Matchem 1748 (Cade 1734) - Molly Long Legs 1753 by Babraham 1740 (God. Ar. 1724).

Dick Andrews 1797 (Joe Andrews 178) Spitfire 1800 by Beningbrough 1791 (King Fergus 17\%)-Dau. of Y. Sir Peter 1\%75 (Doge 1762)-Dau. of Engineer 1756 (Sampsou

1745) - Dau. of Wilson Arabian.

b. m, 1813 .

11axy 1790 (Pot-8-o-'s 1773)-Penelope 1798 by Trumpator 1782 (Conductor 176i)-Pru-

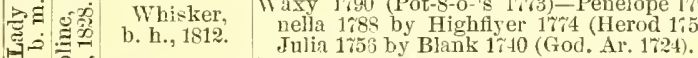

ఏ Gibside Fairy,

Hermes 1790 (Hercury 1788)-Fieissitude b. m. 1800 by Pipator 1786 (Imperator 176) Beatrice b. m. 1791 by Sir Peter T. 1784 (Highflyer 1\%4)-Pyrrha b. m. $1 \% 71$ by Matchem 1718 (Cade 1734)-Duchess b. m. 17t8 by Whitenose 1742 (God. Ar. 1724)-Miss Slamerkin b. m. 1729 by $\mathrm{I}$. True Blue $1 \% 18$ (Honeywood Ar.)-Dan. of Lord

Oxford's Dun Ar.-D'Arcy Blacklegged Royal mare. 


\section{ONONDAGA.}

WINNER OF THE JUVENILE STAKES AT JEROME PARK, JULY STAKES AT LONG BRANCH, AND KENTUCKY STAKES A'T SARATOGA, 1881.

Will be used as private stallion in the McGrathiana Stud, near Lexington, Fayette County, Ky., Milton Young, proprietor. Annual sales of yearlings in May.

ONondafi by imp. Leamington, son of Fangh-a-Ballagh, bred by Mr. A. Welsh, Erdenheim Stud, Penusylvania, foaled 1879, dam Susan Beane, dam of Stratford, Sensation, ete., by Lexington out of Sally Lewis, dam of John Morgan, Hunter's Lexington, Acrobat, ete., by imp. Glencoe. Onondaga as a two-year old started in nine races, of which he won four. Jerome Park, won the Juveuile Stakes, half a mile, in $0.50 \frac{1}{2}$, beating Gerald, Memento and twelve others. Sheepshear Bay, won match, three-quarters of a mile, in $1.15 \frac{1}{2}$, beating Sachem. Monmouth Park, wou the

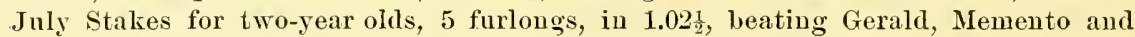
three others. Saratoga, won the Kentncky Stakes for two-year olds, three-quarters of a mile, in 1.16, beating Nighteap and Glenarm. Sheepshead Bay, was second in the Surf Stakes for two-year olds, 5 furlongs, won by Marsh Redon (StonehengeJulietta Colt) in 1.031. At Monuouth Park, was third in the August Stakes for twoyear olds, three-quarters of a mile, won by Marsh Redon in 1.16, and was unplaced in his other races. Onondaga, complaining in his legs, was retired. He is from one of the great racing families of America, is own brother to Sensation, the invincible horse of his year, his cham is own sister to Acrobat and Hunter's Lexington, and half-sister to John Norgan; all were good race-horses, and, for their chances, snccessful sires. The peligree is well fortified with Arehy and Diomed blood, "pon the Eclipse and Herod, and traces throngh the dam of Medoc to the family which gave Lexington and

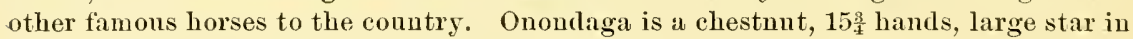
his forehead and snip on the nose, with white hairs in his flanks, left hind foot white above the ankle; he is a good-shaped horse, and was speedy; the family is a racing one, and he is a sucess in the stud, sire of the following winners: Bixby, Blithesome, Loug Branch, Ovation, St. Clair, The Crow, Tocor, Black Pausy, Bootmaker, Blessed, Blessing, Buttou, Goolloe, Ocean Wave, Once Again, Oregon, Hopeful, Onaway, Ontright, Nilton, Delemma, Ambulance, The Sheriff, Chimes, Orsman, Unadaga, Hub S., Cnrt Gunn (Locohatchee), Yale '91, Julio, Portlaw, Busteed, Narina, Derfagilla, Yazoo, Content and many others.

Onondaga traces in direct female line throngh the old Montagu mare to the Royal mare, to which traces Conductor, O'Kelly's Eelipse, Sterling, Weatherbit, Oxford, Kingston, Scottish Chief, Adventurer, Lexington, Vandal, Leonatus, Duke of Montrose, Grinstead, The Bard, Strathmore, Luke Blacklurn, Salvator, Voltumo, etc. 


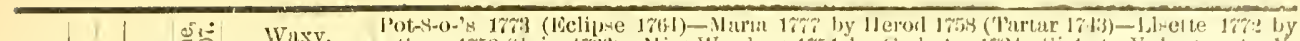

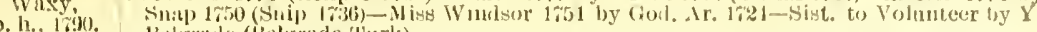

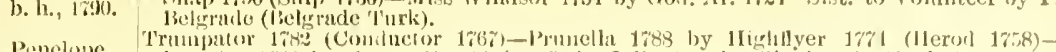

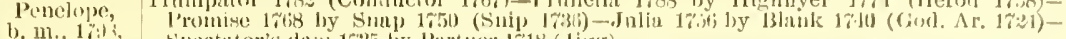

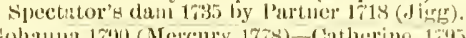

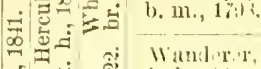

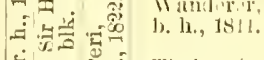

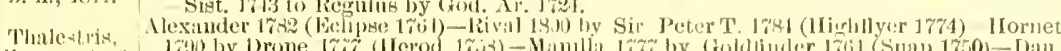

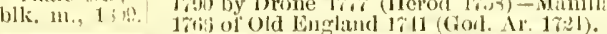

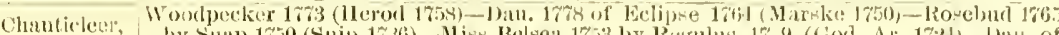

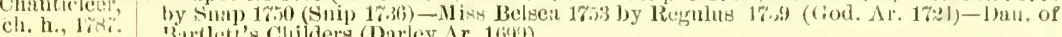
Jurtlet,'s Childers (Darley Ar. 165, ).

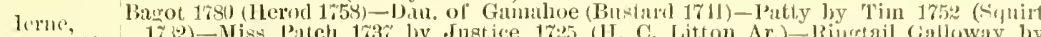

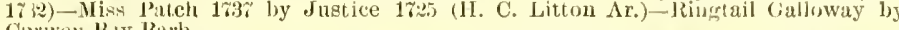
Curwen B.1y Barb.

ch. 111., li, 1).

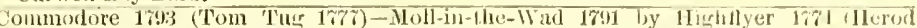

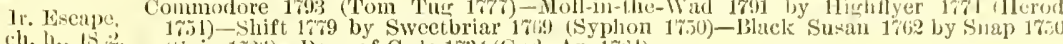
(Sinib 173i) Dau. of Cadle 173! (God. Ar. 17:t).

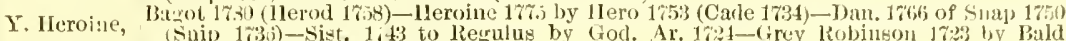
Galloway (St. Viclor Larb).

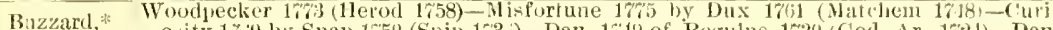
o-ity 170 by Snap 1750 (Snip 1735)-Dan. 1649 of Regulns 1\%3! (God. Ar, 1724)-Dau.

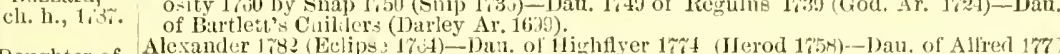

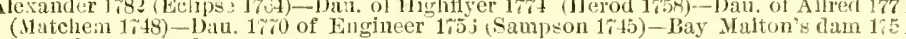

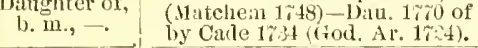

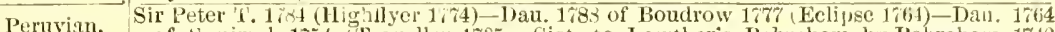

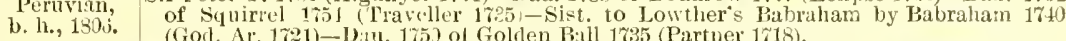
(God. Ar. 1721)-Ditu. 1753 ol Golden Ball 1735 (Partuer 1718).

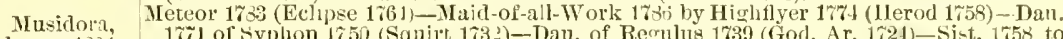
b. m., 1301. Jndgement by Snip 1\%3j(Flying Childers 1715).

Blacklock Whitelock 1803 (Hambletonian 179:-Dau. 1799 of Coriander 173j (Pot-8-0-'g 1763)-

b. h., 181t. Wildgoose 1792 by Highflyer $17 \%$ (IIerod 1758)-Coheiress 1786 by Pot-8-0-'s 17\%3 (Eclipse 1\%61)-Manilla 17\% by Goldfinder $1 \% 64$ (Snap 1\%:0).

Wagtail Prime Minister 1810 (Sancho 1801)-Tranby"s dam 1812 by Orville 1799 (Beningbrongh

Wagtail, 1791)-Miss Grimstone 1796 by Weazle 1766 (Herod 1758)-Dall. of Aneaster 1768 (Blank 1\%47) -Dall. of Damascus Ar. $1 \% 54$.

Champion Selim 1802 (Buzzard*178\%)-Podagra 130 j by Gouty 1793 (Sir Peter T. 1784)-Jet 1785

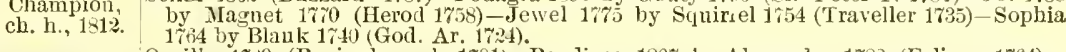

Etiquette, Orville 1799 (Beningbrough 1791)-Boadicea $187 \%$ by Alexander 1782 (Eclipse 1764)-

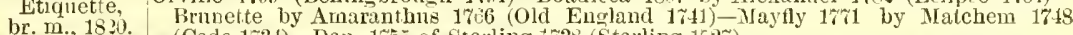
(Cade 1731)-Da:1. 175 \% of Starling 1739 (Starling 172\%)

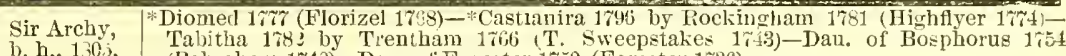

Sir Archy,
b. h., $130 ;.$ (Babraham 1740)-Dau. ol' Forester 1750 (Forester 1736).

Daugliter of, *Saltram 1783 (Eclipse 1764)-Dau, of Symmes' Wildair 1767 ("Fearnought 1755)-Dau. of Tyler's Driver 1760 (*Othello)-Dan, of *Fallower 1r61 (Blank 1740)-Dau. of *Vampire 1757 (Regulus 1739\%.

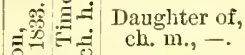

Ball's

cb. h., 1801.

Danghter of,

b. $\mathrm{m} ., 1799$.

Jolly Roger $17+1$ (Rouidhead 173. )

Alderman 1787 (Pot-S-O-'s 1\%3)-Dan of klockfast 17\%4 (Gimerack 1260)-Dan. symmes' Wildair $176 \%$ ( Fearnought 1655$)-$ K. Kitty Fisher $176 \%$ by *Fearnought 1750 (Regulus 1739) - Kitty Fisher 1\%55 by Cade 1734 (God. Ar. 1724).

Emilius, Orville 1799 (Beningbrough 1791)-Emily 1810 by Stamford 1794 (Sir Peter T. 1784)\begin{tabular}{l|l} 
b. h., 1830. & Dau. 1799 of Whiskey 1789 (Saltram th 1789)-Grey Dor \\
(Otho 1760)-Dizzy 175\% by Blank 1740 (God. Ar. 1724)
\end{tabular}

The Flyer 1814 (Vandyke Jr. 1808)-Parma 1813 by Dick Andrews 1\%9\% (Joe Andrews 17\%8)-May 18l4 by Beningbrongh 1791 (King Fergus 1\%5)-Primrose 178\% by Mambrino 1763 (Engineer 1756)-Cricket $17 \% 6$ by Herod 1758 (Tartar 1743).

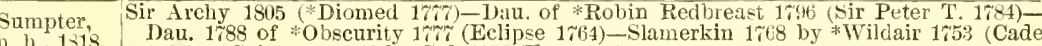
1734) - * Cub mare 1\%62 by Cub 1\%39(Fox 1\%1\%)

Lady Grey, Robin Grey 180.5 (*Royalist 1790)-Maria 1802 by Melzar 1791 (*Medley 17\%6)--Dan. of

b. m., 181\% *Hightlyer 17S4 (Hightlyer 1\%74)-Dau. of Fearnought 1755 (Regulus 1739)-Dau. of Ariel 1756 (*Traveller $1 \% 4 \%$ ).

Selim Buzzard* $178 \%$ (Woodpecker 17\%3)-Dan. of Alexander 1783 (Eclipse 1\%64)-Dau. of

ch. h., 1802.

Highflyer $17 \% 4$ (Herod 1758)-Dau. of Alfred $17 \%$ (Malchem 1748)-Dau. 17to of Engineer 1756 (Sampson 1745 ).

W's Ditto 1800 (Sir Peter 'T 1784)-Dan, 1791 of Mercury 1\%8 (Eclipse 1764) -Dan, 17ra

of Herod 175s (Tartar 17.13)-Folly $17 \% 1$ by Marske 1750 (Squirt 1\%2)-Vixen 1753 by Regulus $1 \% 39$ (God. Ar. 1\% $1 \%$ ).

Tramp, Dick Andrews 1797 (Joe Andrews 1778)-Dau. 1803 of Gohanna 1790 (Mercury 178)-

Tramp,

Fraxinella 1793 by Trentham 1766 (T. Sweepstakes 1743)-Dan. 1785 of Woodpecker $1 \% 73$ (Helod 1\%55) - Everlasting 17\%5 by Eclipse 1\%64 (Marske 1750).

Waxy 1790 (Pot-8-o-'s 1773-Penelope 1793 by Trumpitor 178? (Conductor 176;)-Prunella 1785 by Hightyer $1 \%$ (Herod 1758)-Promise 1768 by Snap $1 \% 50$ (Snip 1\%36)-Julia 1756 by Blank 1740 (God Ar. 1724).

b. mi., 1808 .

Tramp,

b. b., 1810 .

焉

Dick Audrews 1797 (Joe Andrews 17\%8)-Dau. 1803 of Gobama 1790 (Mercury 17is)$17 \% 3$ (Herod 1\%58) - Everlasting $17 \%$ by Eelipse 17t*4 (Marske 1\%50).

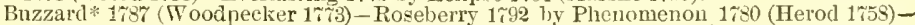
Miss West 1777 by Matchem 1748 (Cade 1734)-Sist. to Favourite by Regulus 1739 (God. An. 1724)-Y. Ebony 1742 by Crab 1722 (Alcock Ar.).

Am. Eclipse,

Duroc 1806 (*Diomed 177\%)-Miller's Damiel 1802 by *Messenger 1780 MIambrino 1768) - Male 1792 by Pot-8-0-'s 17\% (Eclipse 1764)-Dan. 17\% of Gimerack 1760 (Cripple 1750)-Snapdragon 1759 by Snap 1759 (Snip 1 736$)$.

Katy Ann, Ogle's Oscar 1800 ( Gabriel 1790)-Y. Maid-of-the-Oaks cli. m. 1817 by *Expedition 1795 ch. 1m., 1625. Pegasus 1\%4)-Maid-of-the-Oaks ch. m. 1801 by $*$ Spread Eagle 1792 (Volnnteer 1:8j)Anuette by *Shark 1\%1 (Marske 1759)-Dau. of Rockingliam (Partuer 1755)-Dau of
True Whig (Fitzhagh's Regulus 17(5)-Dau. of Gallant 17\%0 (*Fearnonght 1\%55)-Dau.

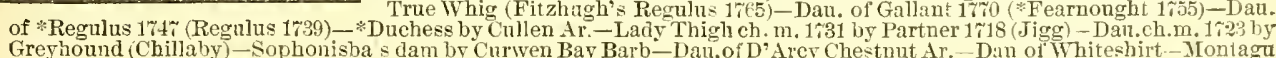
mare by D'Arey's old Montagu-Dau. of Hautboy(D'Arey White Turk)-Dall.of'Brimmer(D'Arey Yellow Turk)-Royal mare. 


\section{IMPORTED PARAMATTA.}

In the Dixiana Stud, ILijor B. G. Thomas, Proprictor, Lexington, Ky. Tearlings sold annually.

Paranitta, bay horse, foaled 1886, bred by Mr. A. Totrn, Australia, imported March, 1888, by Cheviot, son of Adventurer and Grey Stocking by Stockwell, dam Seraps by Lord of the Hills, son of Tonchstone, ont of Ragpicker by Fisherman, etc. Paramatta has a treble cross of Tonchstone throngh his sire and dam, and this npon the Stockwell is a choice combination. His dam, Scraps, is the dam of the rimers Morcean and Gen. Gordon; her sire, Lord of the Hills, is own brother to Lord of the Isles, winner of the 2,000 Guineas, out of Ragpicker by (Engl.) Fisherman, one of the stontest and gamest horses that ever ran in England. He started one hundred and twenty times, won seventy races; amongst them were twenty-six Qneen's Plates, the Queen's Tase at Ascot and Gold Cup twice, the Cumberland Plate, etc. Fisherman is sire of Angler, Maribyrnong, ete.

Ragpicker, his grandam, is full sister to Sylvia, winner of V. R. C. Oaks, and dam of Goldsborongh, winner of the A. J. C. St. Leger; of Robin Hood, winner of the V. R. C. Derby and A. J. C. St. Leger ; of Martini-Henry, winner of T. R. C. Derly, $1 \frac{1}{2}$ miles, in 2.39, Melbourne Cup, 2 miles, in 3.30, the fastest times on record, carrsing 7 st. 6 lbs., the heaviest weight ever carried by a three-year old to rictory in the latter race, and of the V. R. C. St. Leger, $1 \frac{8}{4}$ miles, in $3.24 \frac{1}{2}$.

Chrysolite, half sister to Sylvia, was the dam of Lapidist, winner of the T. R. C. Derby, 1873, and of Vanclnse, winner of the T. R. C. Oaks, 1832, and the dam of Onyx, which prodncel that great race-horse Nordenfeldt, winner of the Victoria Derby in 1885. Sylvia was out of Juliet, great grandam of Paramatta, and dam of Charou, winner of the Victoria Derby, 1869, is regarded as the Levity of Australia. Juliet is closely bred in blood to Orlando, winner of the Derby. Paramatta was a good race-horse, but had little chance on the turf; did not race nntil his fourth year; was winner at 1 mile, 112 lbs., in $1.48 \frac{1}{4}$; won purse, $6 \frac{1}{2}$ fnrlongs, $115 \mathrm{lbs}$., in $1.28 \frac{1}{2}$, defeating seven good ones, track muddy; ran second to Michael in Handicap, 1 nile, in 1.41, three behiud him; won three good races of $1 \frac{1}{s}$ miles each, in good company, and was placed in several good races in good company.

Paramatta is a symmetrically shaped horse and excellent temper, combines in his pedigree the best racing blood in the world and is from a distinguished racing family. He descends in direct female line from the same Royal mare to which trace Sonth, Highflyer, Dou Quixote, Alexander, Peter Lely, Elis, Stumps, Colwick, Orlaudo, Beadsman, Albert Victor, Geo. Frederick, Galliard, in England ; Martini-HemrGoldsborough, Nordenfeidt, etc., in Australia. 


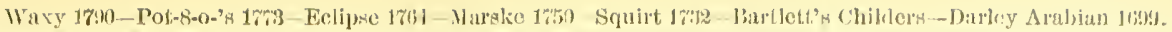

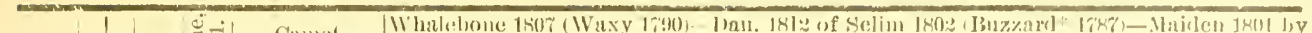

b) 1 . h., $18: 2$.

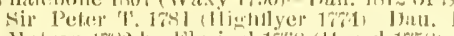

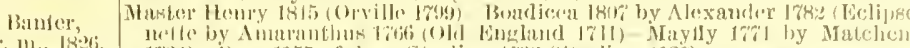

(1)

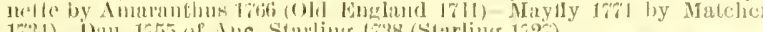

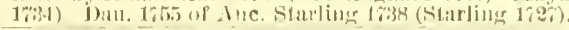

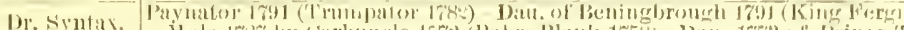

bi. li., list

Tomloov's

litul,

(.). $111,, 1817$.

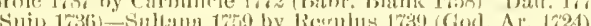

(N)

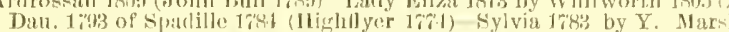

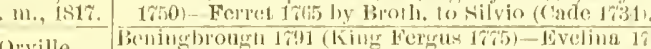

b. 1., 17.99

Einily,

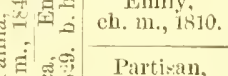

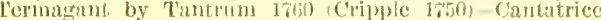

1733) Dan. 175\% ol Regulus 1739) (God. Ar. 17\%1)

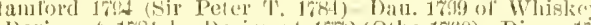

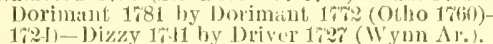

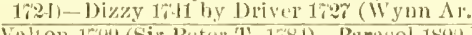

b. h., 1811 .

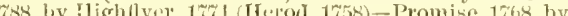
1756 by Plank $1 \% 10$ (God. Ar. 19-31)

] Daughter of,

İ br. m., 1815 .

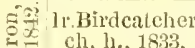
110

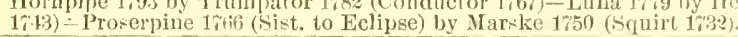

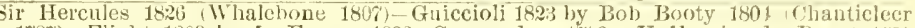
187 )-Fliglit 1809 by Ir. Escape 1802 (Conmodore 1\%(3)-Y. Heroins by Bayot 1780

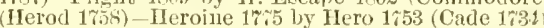

¿ E Echidua.

Ecomomist 1825 (Heroile 175 by Hero 1753 Cade 131 .

o. $\mathrm{m} ., 18 ; 8$. Gadaboat 1812 by Orville 1799 (Beningbrough 1391)-Minstrel 1808 by Sir T'eter T.

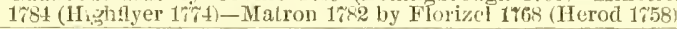

Flencoe, *ै

ch. h., 1831 .

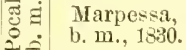

utan 1816 (Selim 180? - Trampoline 1825 by Tramp 1810 (Dick Andrewe 176) - ITel) 1808 by Waxy 1790 (Pot-8-0-'s 1773)-Penlope 1798 by Trumpator 178: (Couductor 176i )--Prumella 1788 by Hiohflyer $17 \% 4$ (Herod 1758 .

Betimin

b. h. 1839

Wasp,

ch. m., 1839

Jereed.

b. h., 1834 .

Sister to

* Ainderby,

Iuley 1810 (Orville 1799)-Clare 1824 by Marmion 1806 (Whiskey 1789) - Harpalice 1814 by Golianna 1790 (Mercury 1\%8)-Amazon 1799 by Driver F83 (Trentham 1766)Fractious 1792 by Mercury $17 \% 8$ (Eclipse 1\%64).

Brutandorf 1821 (Blacklock 1814)-Dau. 1820 ol Comus 1809 (Sorecrer 179ij)-Marciana 1809 by Stamford 1794 (Sir Peter T. 1784)-Marcia 1797 by Coliander 1786 (Pot-8-o-'s

17\%3) - Faith $17 \% 9$ by Pacolet 1763 (Blank 1'40)

Muley Noloeh 1830 (IIuley 1810-Dau, 1836 of Emilius 1820 (Orville 1799)-Bee-in-a Bonnet 1825 by Blacklock 1814 (Whitelock 1803) Maniac 1806 by Shuttle 1i 93 (Y. Marske 17\%1)-Anticipation 1siz by Beningbrongh 1791 (King Fergus 17ro)

Sultan 1816 (Selim 1802) - My Lady" 1818 by Comus 1809 (Sol'Celer 1796)-Dau. 1802 of Delpiui 1781 (Highflyer 1\%ir) - Tipple Cyder 1788 by King Fergus 1\%75 (Eelipse 1;64)Sylvia 1783 by Y Marke $17 \% 1$ (Narske 1750 )

Velocipede 1825 (Blacklock 1814) - Kate 1823 by Catton 1809 (Golumpus 1802)-Miss Garforth 1819 by Walton 1799 (Sir Peter T. 1784)-Dan. 1806 of Hyaciuthu: 1797 (Coriander 1785)-Zara 1801 by Delpini 1781 (Highflyer 1\%i4).

Thalebone,

Waxy 1790 (Pot-8-0-'s 17\%3)-Penelope 1796 by Trumpator $178^{\circ}$ (Conductor 1767)-Prunella 1788 by Hightlyer $17 \% 4$ (Herod 1758)-Promise 1768 by Snip 1750 (Suip 1736)Julia 1756 by Blank $1 \% 40$ (God. Ar. 1724

Dif. h., 180 . br.

Selim 1802. (Buzzard* 1787)-Maiden 1801 by Sir Peter T. 1784 (Highflyer 1774)-Dau. 1785 of Phenomenon 1700 (Herod 1758)-Matron 1782 by Florizel 1768 (Herod 1758) Majden $17 \% 0$ by Natehem 1748 (Cade 1734).

is $\Xi_{3}$ Orville 1799 (Beuingbrough 1791) - visi Soj

ㄹ. Master Henry, 1799 (Beuingbrough 1791) - Miss Sophia 1805 by Stamford 179t (Sir Peter T. 1784)-Sophia 1738 by Buzzard*178\% (Woodpecker 17\%8)-Huncamunca 1 $18 \tilde{i}$ by Highflyer $1 \% 4$ (Herod 1\%58)-Cypher 1\%72 by Squrrel 1754 (Traveller 1735).

b. h., 1815.

Alexandel 1782 (Eclipse 1861)-Brunette by Amaranthus 1786 (Old Fuoland 1741) - May-

Boadicea, fly 1771 by Matchem 1743 (Cade 1734)-Dall. 1755 of Ane. Starling 1738 (Starliug 172\%) Look-at-me-Lads 1731 by Bristo] Grasshopper (Byerly Turk).

Buzzar * 1\%8 (Woodpeeker 17\%3)-Dau. of Alexander 178\% (Eclipse 1\%61)-Dau. of Highflyer $17 \% 4$ (Herod 1753)-Dan. of Alned 1\%0 (Hatchem 1\%48)-Dau. 1\% 0 of Engineer 1753 (Sampson 1745 )

Peruvian 1806 (Sir Peter T. 1781)-Musidora 1804 by Meteor 1783 (Eclipse 1664)-Maid-

Idalia, ol-all-Work 1786 by Highfler 17\%t (Herod 1758)-Sist. 17r1 to Tandem by syphon

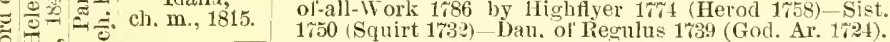

8. Camilla $178 \%$ by Woodpecker 17\%3 (Herod 1753)-Camilla 17\%s by Trentham 1766 (T. Siveepstakes 1\%43)-Coquette 1765 by Compton Barb.

br, h., $18 \geq 0$

Daughter of, Cervantes 1806 (Don Quixote 1784)-Anticipation 1802 by Beninglongh 1791 (King b. m., 1818. (Starling 1\%2\%)-Dau, 1751 of Jauus 1238 (God. Ar. 1\%21)

Bustard, Casirel 1801 (Bnzzard 178\%) Miss Hap 1806 by Shuttle 1793 (Y. Marske 1\%,1) - Dau. 1:9

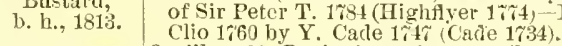

Danshter of, Orville 1793 (Beniugbrough 1791)-Rosanne 1811 by Dick Andrews 1796 (Joe Andrews

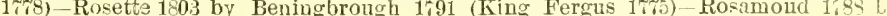

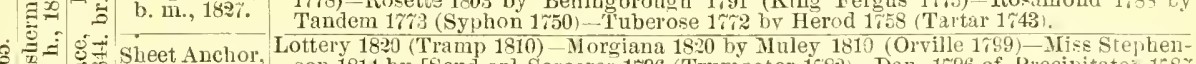
son 1814 by [Scud or] Sorcerer $1 \% 96$ (Trumpator 1782 -Dau. $1 \% 96$ of Precipitate $1 \% 8 \%$ (Mereury 17\%)-Dall. $178 \%$ of Woodpecker $1 \%+3$ (Herod 1758).

Bay Middleton 183:3 (Sultan 1816) -Nitoeris 1829 by Whisker 1812 (Tasy 1600)-Mann-

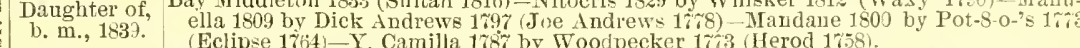

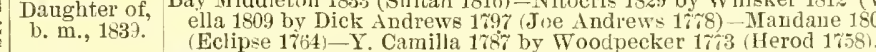

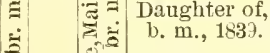

Whalebore $180 \%$ (Waxy 1790)-Dau. 1812 of Selim 1802 (Buzzard $\%$ 178\%)-Maiden 1801 by

Camel,

Sir Peter T. 1781 (Highflyer 1774)-Dan. 1788 of Phenomenon $1 \% 80$ (Herod 175s)Natron 1782 by Florizel 1768 (Herod 1758$)$.

br. $\mathrm{h}, 18,2$

Master Henry 1815 (Orville 1799)-Boadicea $180 \%$ by Alexander 1782 (Eclipse 1764) - Bru-

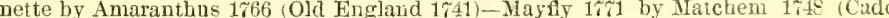

1734) - Dall, 1755 of Ane. Starling 1798 (Starling 1\%2\%)

br. m., 1836 .

Tombor, Jery

b. h., 1829. 1813 by Whitworth 1805 (Agonistes 179\%)-Dau. 1793 of Spadille 178t (Highflyer 17\%4)-Sylvia 1783 by Y. Marske 17\%1 (Marske 1750).

Kite,

Bustard 1813 (Castrel 1801)-Olympia b. m. 1815 by sir Oliver 1800 (Sir Peter T. 1\%81) Scotilla b. m. 1795 by Anvil 17\% (Herod 1758) - Scota b. m. 1783 by Eclipse 17te (Narske 1 150 -Harmony 1775 by Herod 1758 (Tartar 1743)-Rutilia b. m. 1769 by Blank 1740 (God. Ar. 1724) - Sist 1751 to South by Regulus 1739 (Godl. Ar. 1721) Dau. of Soreheels (Basto 1602)-Dau. blk. m. of Makeless (Oglethorpe Ar.) Christ. D'Arcy's Royal mare by Blunderbuss (Bustler) Old Grey Royal by D'Arey White Turk-Daul. of D'Aley Yellow Turk-Royal mare. 


\title{
PHIL WARREN.
}

\author{
The property of Leonidas Cartwright, San Augustine, Texas. Terms of serice. \\ advertised annually.
}

Phil WArrex, ehestnut horse, foaled 1836, bred by Philip Warren, Illinois, by Dakota, son of imp. Billet and Experience Oaks by imp. Bonnie Scotland, dam Annie Booth by Marion, son of Lexington and Miriam by imp. Glencoe, grandam Lady Vic by Unele Vic, son of Lexington, great grandam Bonnie Jean by Bonnie Ladıle, etc., thus giving him three crosses of Lexington and two of imp. Glencoe blood from most excellent sources. Dakota, from an injury, nerer raced. His dam, Experience Oalis, was a good and successful race-mare and dam of Voleano and Bonvie Oaks; his gran. dam, Sallie, was the dam of the good race-horses Nathan Oaks, Solicitor and John Mullins, Isola was a great race-mare, prodnced Olio, the dam of Biddy IIalone and Dufiy. Susette was another famous race-mare and dam of Berthune by sidi Hanet, of Crisis, that produced Donerail. Jenny Cockracy was the best mare of her day and dam of Maid of Lodi, Creeping Kate and Betsey Harrison, the dam of that good horse Denmark by imp. Hedgeford. War Over, Ium Yum, Mollie Saffle, Connemara, Tarragon, Owen Bowling, War Dnke, Warfellow, Impromptu and Palisade are from the same good family, which traces to the imp. Saltram mare, dam of the good race-horse Timoleon, sire of the immortal Boston, that sired Lexington, Lecompte, Salina, Salvator's dam, ete.

On the dam's side Phil Warren traces to the same family that prodnced Bonnie Lassie, Belle Anderson (dam of Zenith and Ripple), Chloe Anderson, dam of Norice (she the daw of the mubeaten Norfolk, sire of El Rio Rey, Emperor of Norfolk, ete.). It is a racing and producing family, as evidenced by the form of snch horses as Asteroid (never beaten), Freeland, Long Knight, Clara D., Sister Anne, Maria Stuart, Yolante, Bombay, Sovereign Pat, Grimaldi and a host of others which have descended from it.

Phil Warren is a bright chestnut horse with both hind feet and off front ankles white, a snip on nose and stripe down his face. Is $15 \frac{3}{t}$ hands high, with good, fine head and neek and great museuiar development. His pedigree is a rare combination of good raeing blood. 


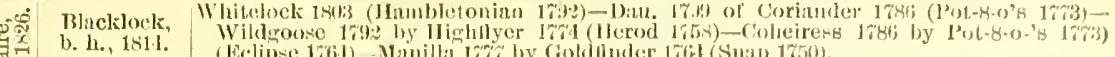

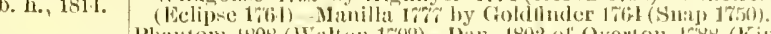

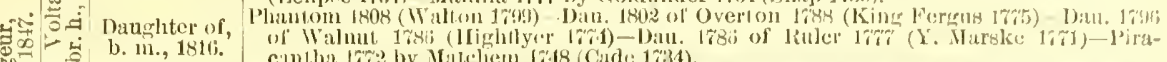

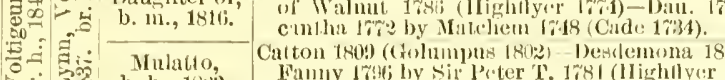

b. h., $18: 3$.

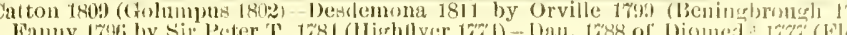

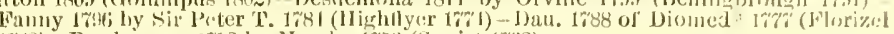

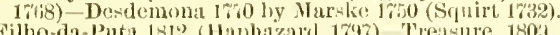

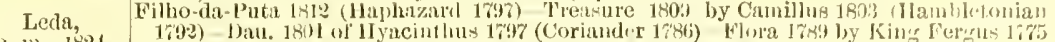

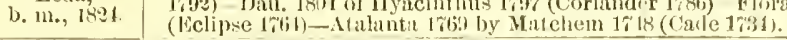

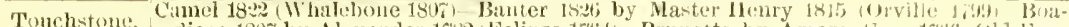

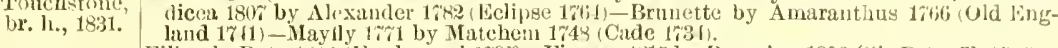

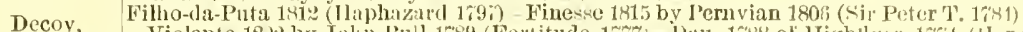

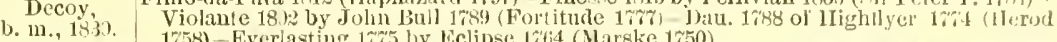
1758)-Everlasting $17 \% 5$ by weljpse 1;itid (Harske 1750).

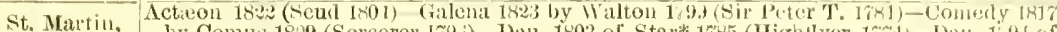

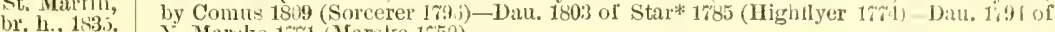
I. Marske 17i (Marske 1,50).

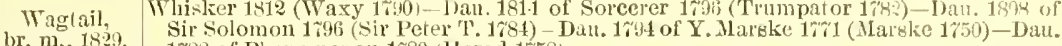
1788 of Phenomenon $1780(11 \mathrm{erod} 1758)$.

Don Jolan,

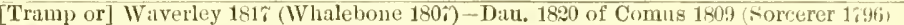

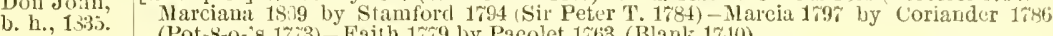
(Pot-5-o-'s 17\%3) - Failh $17 \% 9$ by Pacolet $1 \% 63$ (Blank 1740).

Scandal,

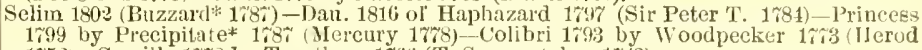
1758)--Camilla 17 is by Trentham 1 \%66 (T. Swecpstakes 1\% i3)

家

Partisau 1811 (IValton 1799)-Pauline 1826 by Moses 1819 ([Whalebone or] Seymour

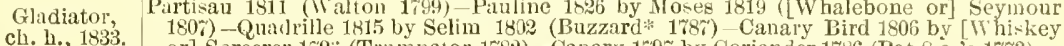

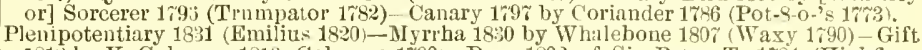
Daughter of, $181 \mathrm{~s}$ by Y. Gohauna 1810 (Gohanma 1\%90)-Dau. 1802 of Sir Peter T. 1r84 (Hightlyer 1774)-Dau. 1788 of Trumpator 1782 (Colductor $1766^{\prime}$ ).

Timoleon 1813 (Sir Arehy 1805)-Sist. 1814 to Tuckahoe by Ball's Florizel 1801 ("Diomed

Boston, 17\%) -Dall. 1799 of *Alderinan 1787 (Pot-8-0-'s 17\%3)-Dau. of *Clockfast 1771 (Gimcrack 1760)-Dau. of Symmes' Yrildair 176\% (*Fearnonght 175.5).

\section{ch. h., 1833 .}

* Sarpedon 1838 (Emilius 1820)-Rowena 1826 by Sumpter 1818 (Sir Archy 180.5:-Laiy Grey $181 \%$ by Robin Grey 1805 (*Royalist 1790)-Maria 1802 by Melzar 1\%91 (*ILedley $17 \% 6)$-Dan. of *llighfyer 1784 (Highflyer $17 \% 4)$.

(1)

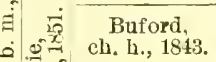

*Nonplits 1824 (Catton 1849) - Too Soon 1835 by Sir Leslie 1828 (Sir William 182) -

Little Peggy 1821 by Gallatin 1\%99 (*Bedford 1792)-Trumpetta 1816 by Hephestion 1807 ("Buzzard 178\%)-Peggy 1803 by *Bedford 1792 (Dungannon 1780).

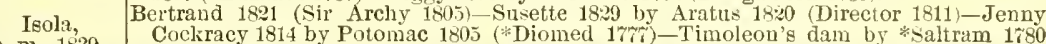
Cockracy 1814 by Potomac 1805 (*Diomed 17\%)-Timoleon's dam by wsaltram 1780 (Echipse 1764)-Dau. of Symmes' Wildair 1767 (*Fearnought 1755).

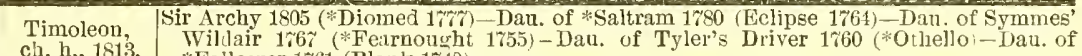

Timoleon, ch. h., 1813. *Fallower $1 \% 61$ (Blank 1710).

ter to

Balt's Florizel 1 s01 (*Diomed 1\%r)-Dau. $1 \% 99$ of *Alderman 1787 (Pot-8-0-'s 17,3) Tuckahoe, Dau of Clockfast 1 * Gimerack ch. m., 1814. 1755)-Y. Kitty Fisher $1 \% 6 \%$ by *Fearnonght 1755 (Regulus 1\%39).

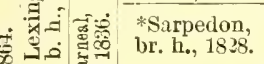

Emilins 1820 (Orville 1693)-Iearia 1824 by The Flyer 1814 (Vandyke Jr. 1808)-Parma 1813 by Dick Andrews 179; (Joe Andrews 17i8)-May 1804 by Beningbrough 1\%91 (King Fergus 17\%5) - Primlose 178; by Mambrino 1768 (Engineer 1756).

Rowena Sumpter 1818 (Sir Arehy 1805)-Lady Grey 181\% by Robiu Grey 1805 (*Royalist 1\%90)ch. m., $18 \%$.

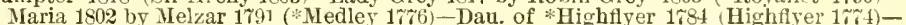
Dau. of * Fearnonght 1755 (Regulus 1739 ).

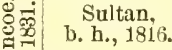

Delim 1802 (Buzzard*1\%8\%) Bacchante 1809 by W's Ditto 1800) (Sir Peter T. 178t)-Dau. 1791 of Mercury $17 \% 8$ (Eclipse 1764)-Dau. $17 \% 6$ of Herod 1758 (Tartar 1743)-Folly 1\%71 by Marske 1750 (Squirt 1732).

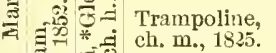

Tump 1810 (Dick Audrews 179\%) - Web 1808 by Waxy 1790 (Pot-8-o-'s 17\%3)-Penelope 1798 by Trumpator 1782 (Condnetor 176\%)-Plunella 1788 by Highflyer 1744 (Herod. 1758)-Promise 1733 by Snap 1750 (Snip 1736).

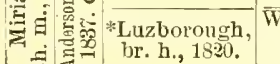
W's Ditto 1800 (Sir Peter T. 1781)-Picton's tlam 1814 by Diek Andrews 1\%97 Joe Andrews 17\%) Eleanor 1798 by Whiskey 1789 (Saltram* 1780)-.Y. Giantess 1\%90 by Diomed* 1\% (Florizel 1768)_Giantess 1;69 by Matchem 1748 (Cade 1\%31).

Daughter of,

ir Charles 1816 (Sir Alchy 1805) - Famons quarter mar. by Bess Brimmer (Blue Beard $1802)$ - [Miriam is grandam of Duke of Magenta].

Boston,

ch. h., 1833.

Timoleon 1813 (Sir Archy 1805)--Sist. 1814 to Tuekahoe by Ball's Florizel 1801 ( Diomed

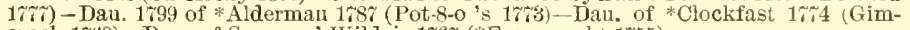
crack 1660)-Dau. of Syumes' Wildair 166\% (*Fearnought 1755).

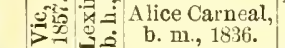

Sarpedon 1823 (Emilins 1820)-Rowena 1826 by Sumpter 1818 (Sir Archy 1805)-Lady

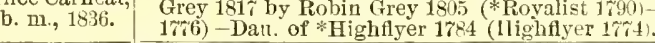

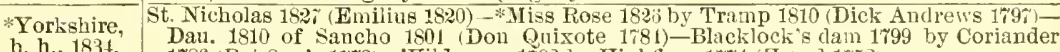
1786 (Pot-8-0-'s 17,3) - Wildgoose 1792 by Highflyer $1 \% 4$ (Hecod 1758)

Lady *Margrave 1829 (Muley 1810 -Lady Adams 1425 by Whipster Cook's Thip 1801)

Margrave,

ch. m., $184 \%$.

Woodpecker's dam $180 \%$ by *Buzzard 1787 (Woodpecker 1;i3)-The Faun by Craig's Alfred (*Medley $1 \%(6)$-Shepherdess by IV's King Herod (*Fearnonght 1\%5).

*Glencoe,

Sultan 1816 (Selim 1802)-Trampoline 18:5 by Tramp 1810 (Dick Andrews 1 1.: - Web ch. h. 1831 . 1809 by Waxy 1790 (Pot-8-o-'s 1773)-Penelope 1798 by Trumpator 173: (Conduetor 1767)-Prunella 1\%8s by Highflyer 174 (Herod 1758).

Magdalen Medoc 1829 (Am. Eclipse 1814)-Keph"s dam 1825 by Sumpter 1818 (Sir Archr 1805)Mau. 1811 of Lewis's Eclipse (*Diomed 1\%*)-Hart's Mariaby Craig's Alfred (*Medley

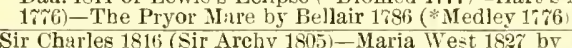

Wagner,

Sir Charles 1816 (Sir Arehy 1805)-Maria West 1827 by Marion 18:0 (Sir Archy 1905Ella Crump by *Citizen 1785 (Pacolet 1763)-Dau. 1795 of Huntsman 1789 (\%)lousetrap 17\%1)-Dau. of Symmes' Wildair 1767 (*Fearnought 1755).

Butterfy, Sumpter 1818 (Sir Archy 1805)-Dau. of *Buzzard 1787 (Woodpecker 17\%3)-Dau. of डे ch. m., 1825. Dandridge's Fearnought (Fearnought $1 \% 55$ ) -Dau. of *ann 1716 (Janus
[The Dandridge Fearnought mare was a good race-mare about the year 1790$]$. 


\section{IMPORTED PONTIAC.}

The property of J. O. Donner, Ramapo Stud, New Jersey.

Pontrac, black horse, imported in utero by Mr. P. Lorillard, foaler 1881, is by Pero Gomez, winuer of the St. Leger, son of Beadsuran and Salamanca by student, son of Cluatham. Agenoria, his dam, is own sister in hlood to Agility and Apology. The latter wou the 1,000 Gnineas, Oalis, St. Leger and Ascot Gold Cup. Milliner, his grandam, is on sister to Maudragora, the dam of Mandralie (wiuner of the Doncaster Cup), Agility and Apologs, and to Mineral, the dam of Wenlock (winner of the st. Leger), Sehwindler and Kisber (winner of the Derby and Graud Prize of Paris). Milliner is also dam of imp. Pizarro, a superior race-horse. Moonbeam by Tomboy was the dam of Lompgaron, Moonshine, ete. The family is one of the best racing ones in England. Pontiac won the Suburbau Handicap, $1 \frac{1}{4}$ miles, 102 lbs., in $2.09 \frac{1}{2}$; the Cousolation Sweepstakes, the same distance, $1091 \mathrm{los}$. , in 2.12; the Free Handicap, 1 mile, at Ionmonth, with 120 lbs., in $1.43 \frac{3}{ \pm} ; 1 \frac{1}{8}$ miles, 111 lbs., in 1.57 ; the Passaic Stakes,

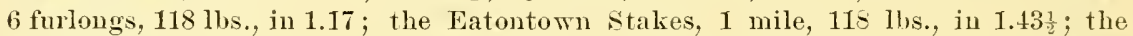
Manhattan Handicap, $1 \frac{1}{4}$ miles, 121 lbs., in 2.14, and the Fres Handicap Sweepstakes, $1_{\frac{5}{16}}$ miles, in $2.26 \frac{1}{2}$, with 123 lbs. At five years old won the Coney Island Stakes, $I_{\frac{1}{x}}$

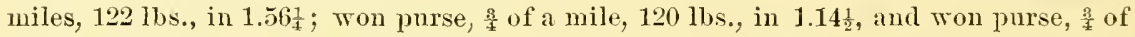

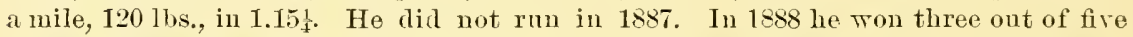

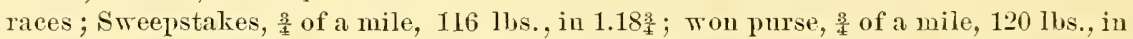

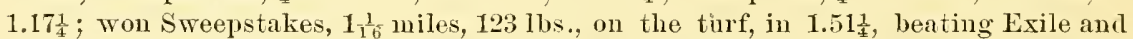
three others. He was placerl second or third in a large majority of the races in which he was beaten, and met and defeated the best and speediest horses on the turf dnring: his career. Adventurer, the sire of his dam Agenoria, won the City and Suburban Handicap and was the sire of Pretender, winner of the 2,000 Guineas and Derby, Apology, winner of the 1,000 Gnineas, Oaks and St. Leger, Wheel of Fortune, winner of the 1,000 Guineas and Oaks. Rataplan, the sire of his grandam, was own brother to Stockwell and a superior race-horse, winner of 42 ont of the 71 races in which he started, including Tradesman's Cup, at Manchester, and was the sire of Kettledrum, winner of the Derby. Manganese, his third dam, won the 1,000 Guineas, and was hy the great Birdeateher, sire of The Baron (St. Leger winner), imp. Knight of St. George (St. Leger wiuner), Daniel O'Ronrke (Derby winuer), aud Mrs. Ridgeway, his daughter, was the dam of Tellette (wimner of the 2,000 Guineas) and sire of the popnlar Galopin (wimner of the Derby).

Pontiae is a fine, symmetrically formed horse and from a very distinguished racing and prodncing family. He should be a success in the stud. He is tescended in direct female line from the Layton Barb mare, to which traces Ioung Greyhonuch, Matehem, imp. Drone (by Herod), Jomng Carle, lsheher, Philammon, simoon, imp. Comus, Kentucky, Gilroy. Daniel Boone, the great Iroquois, Parole, Powluattan and all the descendants of the imp. Cab mare and Magnolia family. 


\section{POST GUARD (GEN. PHILLIPS).}

The property of MLssrs. Stephen Sanford and Sons, Hurricane Stud, Amsterdam, N. Y. Yearlings sold ammally.

Post Guard (first called and raced under the name of Geu. Phillips), chestunt horse, foaled 187t, bred in the Preakness Stud, by Mr. M. H. Sanford, by imp. Glenelg, son of Citadel by Stockwell, dlam La Polki, Cam of Strathspey, Heel-and-Toe, Los Angeles, etc., by Lexington, grandam Dance, dam of Schottische, Redora, etc., by imp. Glencoe, great granrlam Cotillion, dam of Gallopade, Jr., O'Meara, etc., bs imp. Leviathan, out of imp. Gallopade, dam of Reel (the dam of War Dance, Lecompte, Starke, Prioress, Fanny Wells, ete.), by Catton, son of Golumpus by Gohanna. Under the name of Gen. Phillips, at three sears old, started in nine races, won eight; mile heats in $1.48,1.45 \frac{1}{2} ; 1 \frac{1}{\frac{1}{4}}$ miles, in $2.12 ; 1 \frac{1}{2}$ miles, in 2.42 , and $1 \frac{3}{4}$ miles, in $3.15 \frac{1}{2}$. At four years old started fifteen times, won six races, was second in one and third in four; won at mile heits, $1 \frac{1}{\frac{1}{4}}$ miles, $1 \frac{1}{2}$ miles, $1 \frac{3}{4}$ miles, and the Westchester Cap, $2 \frac{1}{4}$ miles, $118 \mathrm{lbs}$, beating Parole and St. James, and was placed in sereral fast races. At five years old started eighteen times, won three races, was second in three and third in four; won Handicap Sreepstake, 2 miles, 115 lbs., in $239 \frac{1}{4}$; $\pi$ on purse, $1 \frac{8}{x}$ miles,

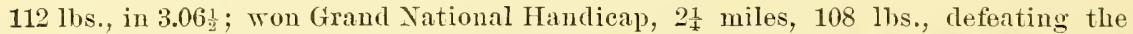
noted Ferida, in $4.07 \frac{1}{2}$. At six years old started twenty times, won three races, was second in four and third in six ; won purse, $1 \frac{1}{8}$ miles, $108 \mathrm{lbs}$., in $1.56 \frac{1}{2}$; won purse, $1 \frac{1}{2}$

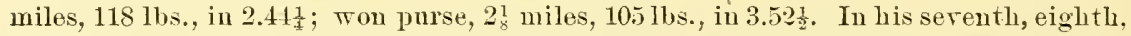
ninth and tenth years he started in trenty-four races, principally hurdle and steepleehases, of which he won twelve, carrying from 136 to $168 \mathrm{lbs}$. He was a horse of fine speed and a game one, capable of ruming four-mile heats.

Post Guard is fashionably bred and from one of the best racing and producing families in the world. Lon Lanier, from it, was one of the best race-mares of her day at all distances. Lady Hardaway by Commodore, son of Boston, from it, is the dam of Miss Hardaway and Mercedes, the latter the dam of Barnes, Runnrmede, Lydia, ete. Gallopade, Jr., own sister to Dance, was the dam of Schottische (she the dam of Waltz, Ballinkeel and Reveller). Waltz is the dam of Glidelia, she having the fistest record uutil 1e91 at $1 \frac{3}{4}$ milès, 3.01, and of Hop, the dam of Carson, Fond du Lac, Kirkman, ete. Imp. Gallopade was the dam of the renowned Reel, and she the dam of Lecompte, the only horse that ever beat Lexingtou ; Starke, winner of the Goodwood Cup; Prioress, Tinner of the Cesarewiteln: Wrar Dance and Fanny Wells. Nellie Grey, by Commodore, Jils Johnson, and a host of fine race-horses. are from this family.

Post Guard is almost untried in the stud, but is the sire of the winners, Guard, Rear Guard, Guardiana, Our Jaggie, Post Master, Some More, Miss Aggie, Zam Post, etc. He is descended in direct female line from Old Piping Peg, to which traces Bob Booty, Mickey Free, Chanticleer, Solon, Xenophon, Barcaldine, Lowland Chief, War Dance, Lecompte and all the Reel family. 


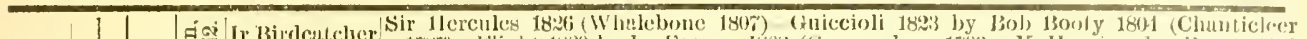

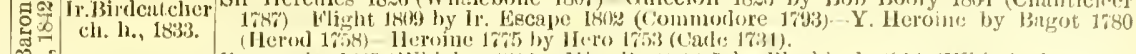

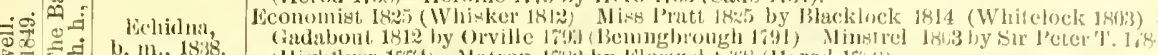

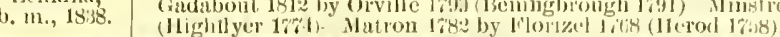

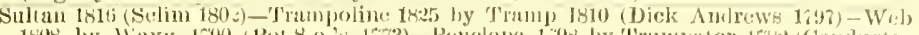

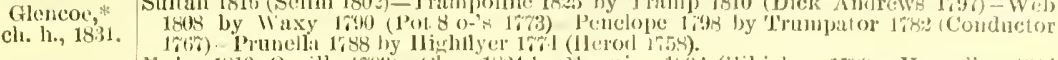

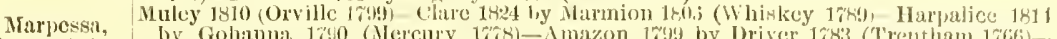

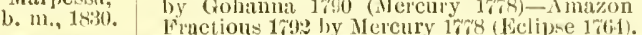

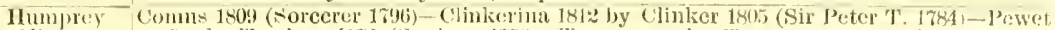

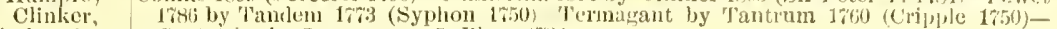

b. li., 18:2. Cantatrice by Sampson lit5 (Blaze 173:3).

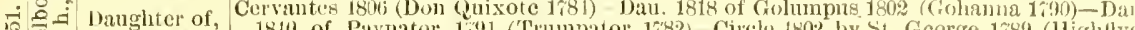

b. m., 18:5, 1810 of Paymator 1791 (Trumpitor 1782) Circle ino: by St. Gcorge 1789) (11ighllyer 17\%4) - Abjgail 1788 by Woolpecker 1733 (Jlerod 1758 .

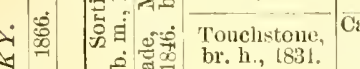

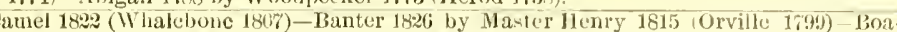
dicea 1807 by Alexander 1782 (Eclipse 17(61)-Brunote by Amaranthus 1766 (Old Eng

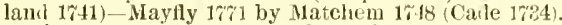

Ghunee Pantaloon 18:4 (Castrel 1801)-Languish 1830 by Cain 1822 (Panlowitz 1813)-Jydia 18\%2

b. m.,1838. by Poulton 1805 (Sir Peter' T. 1784)-Variety 1808 by Hyaciutlus 1797 (coriander $1786)$ - Dall. 1790 of IVeazle $1 \% 6$ (Herod 1758).

Partisan, Walten 1799 (Sir Peter T. 1781)-Parasol 1800 by Pot $8-0{ }^{-7} 81773$ (Eclipse 1764) Prunelli Partisan,
b. h., 1311.
1756 by blank 1740 (God. Ar. 1724).

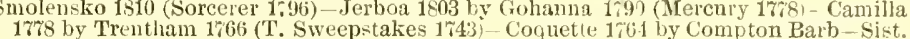
$1 \% 13$ to Regulus by God. Ar. 1 r.24.

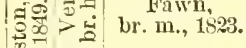

Royal Oak 1823 (Catton 180J)-Dau. 1819 of Orville 1799 (Beningbroush 1791)-Ep $50 \mathrm{~m}$ b. b., $18: 33$. Lass 1803 by Sir Peter T. 1784 (Highflyer 1\%'4)-Alexina 1/88 by King Fergus 1\%i5 (Eclipse 1764)-Lardelka 1780 by Y. Harske 1 ric (Marke 1750).

Garcia, Octavian 1807 (Stripling 1795)-Dan. 1806 of Shuttle 1793 (Y. Marske 1; 11 -Katharine br. m., $18: 3$. 1798 by Delpiui 1781 (Highflyer $1 \% 4$ ) -D D
1774 of Le Sang 1759 (Changeling 1717 ).

Whalebone, Waxy 1790 (Pot-8-o-'s 17\%3)-Penelope 1798 by Trumpator 1782 (Conductor 17fir)-PruWr. nella 1788 by Hightlyer 17 i 4 (Herod 1758)-Promise 1768 by Snap 1750 (Snip 1736)Julia 1756 by Blank 1\%10 (God. Ar. 1724).

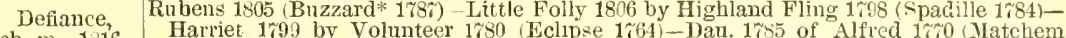
1748)-Nagnolia $17 \% 1$ by Marske 1750 (Squirt 1732).

Rubens 1805 (Buzzard * 1787) Tiney 1801 by Sir Peter T. 1784 (Higbflyer 1774)-Wren

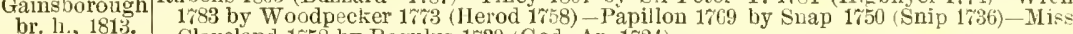
Cleveland 1759 by Regulus 1739 (God. Ar. 1721)

Danghter of

Topsy 'Turvey 1805 (St. George 1;89)-Agnes 1805 by Shuttle 1793 (Y. Marske 1;1) Dau. 1738 of Highflyer 1774 (Herod 1758)-1)au. 17\%9 of Goldfinder 1764 (Snap 1750) Lady Bolingbroke 1763 by Squirrel 1754 (Traveller 1735).

Sir Archy

*Diomed 17\% (Florizel 1768) - *Castianira 1796 by Rockingham 1\%81 (Hiobflyer 1\%/4)

b. h., 1805 .

Tabitha 1782 by Trentham 1re6 (T Sweepstakes 1r43)-Dau. of Bosphorns $1 \% 4$ (Babrabam 1740)-Dat. of Forester 1750 (Forester 1736).

Saltram 1780 (Eclipse 1764)_Dau. of Symmes? Wildair $176 \%$ ("Fearnought 1755)-Dau. of Tyler"s Driver 1760 (*Othello)-Dau. of *Wallower 1r61 (Blank 1\%40)-Dau. of Vampire $175 \%$ (Regulus 1739).

Daughter of

Diomed 1777 (Florizel 1768)-Dau. of *Shark 17\%1 (Marsle 1750)-Dall. of Hartis" Eclipse 1770 (*Eearnought 1755)-Dan. of *Fearnought 1755 (Regulus 1739)-Dan. of * Jolly Roger 1711 (Romndhead 1739).

Alderman 1787 (Pot-8-0-'s 17r3)-Dan. of *Clockfast 17\%4 (Gimcrack 1r60)-Dau. of Symmes' Willair 1767 ("Fearnought 1755 ) - F. Kitty Fisher 1767 by *Fearjought 1755 (Regulus 1739) - Kitty Fisher 1755 by Cade 1734 (God. Ar. 1724).

ch. h., 1801 .

Daughter of

b. m., 1799.

Orville 1799 (Beningbrough 1701) - Emily 1810 by Stamford 1794 (Sir Peter T. 1\%84)

Emilius,
b. h., 1820 .

Dau, 1799 of Thiskey 1789 (Saltram $* 1780$ ) - Grey Dorimant 1781 by Dorimant $1{ }^{2} \% 2$ (Otho 1760$)$-Dizzy $175 \%$ by Blank 1740 (God. Ar. 1724).

Tcaria The Flyer 1814 (Vandyke Jr. 1808)-Parma 1813 by Dick Andrews 179r (Joe Andrews 17r8)-May 1894 by Beningbrough 1791 (King Fergus $17 \% 5$-Primrose $178 \%$ by Mambrino 1768 (Engineer 1756)-Cricket 176 by Herod 175s (Tartar 174:3)

b. m., 1824

Sir Archy 1805 (*Diomed 1\% $1 \%$-Dan of *Robin Redbreast 1696 (Sir Peter T 1\%84) -

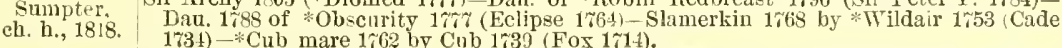

\begin{tabular}{c|c} 
Sumpter. \\
ch. h., 18i8.
\end{tabular}

Robin Grey 1805 ( $*$ Royalist 1790)-Maria 1802 by Melzar 1791 (*Medley 1\%6)-Dau. of

Lady Grey, *Highflyer 1784 (Highflyer 1\%:4)-Dan. of *Fearnought 1755 (Regulns 1\%39)-Dau. of Ariel 1756 (*Traveller $1 \% 4 \%$ )

Selim.

Buzzard* 1737 (Woodpecker 17\%3)-Dau of Alexander 1782 (Eclipse 1764)-Dan. of Highflyer 1774 (Herod 1758)-Dau. of Alfred 1770 (Natchem 1748)-Dau, 17\%0 of Engineer 175: (Sampson 1745).

胥赵 ch. h., 1802

Bacchante W's Ditto 1800 (Sir Peter T. 1784)-Dan. 1791 of Me!cury 17\%8 (Eclipse 1764)-Dau. 17\%6 of Herod 1758 (Tartar 1743)-Folly $17 \% 1$ by Marske 1750 (Squirt 1732) - Vixen 1753 by Regulus 173) (God. Ar. 1724).

Dick Andrews 169\% (Joe Audrews 1\%78) - Dan, 1803 of Gohanna 1790 (Nelcury 1\%

Tramp,

Fraxinella 1793 hy Trentham 1766 (T Swe pstakes 1743 )-Dan. 1785 of Woodpecker $1 \%$ (1leror 175s)-Everlasting $17 \% 5$ by Eelipse 1764 (Marske 1750).

Web Waxy 1790 (Pot-8-1)-'s 17r3)-Penelope 1798 by Trumpator 1782 (Conductor 1\%6\%)-Prnnella 1789 by Highflyer $17 \% 4$ (Herod 1758)-Promise 1768 by Snap 1750 (Snip 1 136 )Julia 1756 by Blank 1740 (God. Ar. 1724)

b. m., 1808

Orville 179) (Beningbrough 1791)-Eleanol 1798 by Whiskey 1789 (Saltram 1780 ) -Y.

Muley,

Giantess 1793 by Diomed* $17 \%$ (Florizel 1762)-Giantess 1769 by Matchem 1748 (Cade 1734)-Molly Long Legs 1753 by Babraham 1740 (God. Ar. 1224).

Windle 1804 (Beningbrough 1791)-Dau. 1\%88 of Anvil 1\%, (Herod 1\%58)-Virago 1\%64

Daughter of, Windle 1804 (Beningbrough 1791)-Dau. 1688 of Anvil 17\% (Herod 175s) by Snap 1750 (Snip 1736)-Dau. of Regulus 1739 (God. Ar. 1724)-Sist. 1750 to Othello
by Crab 1722 (Alcock Al.).

Daughter of, Wind by Snap 1750 (Snip 1736)-Dau. of Regulus 1739 (God. Ar. 1724)-Sist. 1750 to Othello
by Crab 1722 (Alcock Al.).

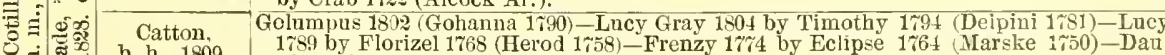
b. h., 1809. of Engineer 1756 (Sampson 1745).

Camillina, Camillus 1903 (Hambletouian 1792)-Dau. b. m. 1818 by smolenst5o 1810 (Sorcerer 1796)-Miss camillina. Cannon b. m. 1811 by Orville 1799 (Beningbrough $1 \% 91$ )-Dau. b. m. 1796 of Weathercock (Regulus 1739)-Dau. 1764 of Cub 1739 (Fox 1714)-Dau. 1750 of Allworthr 174t (Crab. 1722)-Dau. of Starling $172 \%$ (Bay Bolton 1705)-Dairymaid b. m. 1737 by Bloody Buttocks-Bay Brocklesby b. m. 1731 by Partuer 1718 (Jigg)-Brocklesby gr. 117. 1721 by Grejhound (Cliliabj)-Brocklesby Betty ch. m. 1711 by Curwea Bay Barb- Hobby mare by Lister Tark ont of Piping Pıg. 


\section{POWHATTAN.}

\section{OWN BROTHER TO PAROLE.}

In the Woodbum Stud, A. J. Alexander, proprietor, near Spring Station, Woodford Co., Ky. Application to L. Brodhead, Spring Station, Ky. Ammal. sules of yearlings in May.

Powhattax by imp. Leamington, son of Faugh-a-Ballagh, bred by Mr. A. Welch, Erdenheim Stud, Pa., foaled 1879, dam Maiden, dam of Parole by Lexington, son of Beston, ont of Kitty Clark by imp. Glencoe. Powlattan started in only one public race, that at Long Branch; meeting with an accident, he was unplacer. He was considered quite promisiug, and ran a very fast trial at Jerome Park in the spring. Parole, his own brother, has been one of the noted popular favorites of the turf. After racing in his three, four and five-year old form in this comntry, he was sent to England, and won the Newmarket Handicap, last $1 \frac{1}{2}$ miles of the Beacon Conrse, beating the great Isonomy, Lina and three others. He won the City and Sulurban Handicap, $1 \frac{1}{4}$ miles, 119 lbs., beating Ridotto, Cradle and fifteen others, and the great Metropolitan Stakes (handicap), $2 \frac{1}{4}$ miles, 124 lbs., beating Castlereagh; the Great Cheshire Handicap Stakes, $1 \frac{1}{4}$ miles, carrying 134 lbs., defeating Reefer, sir Joseph, Ridotto and four others, and also won the Epsom Gold Cup, 1즐 miles, 125 llos, beating Alchemist and Primrose. The fumily has always been a successtul racing one. Maiden, his dam, won the Travers Stakes at Saratoga, the grandam and great grandam were all winners, and from the stock have come such horses as Mary Morris, Wild Irishman, Frankfort, Falsetto, Felicia, Fortuna, Sumpter, Childers, Rattier, Ringgold, Flirtilla, Mary Wymm, Tom Kimball, Cassandra, The Countess, Turco, John Bascomb, Helen Mar, Anr Merry, Tiger, Ann Imnis, Hebron, Neteor, George Kinney, Perfection, Salurla, Perception, Peregal, Oolah and, in the early days of racing, old slamerkin. Then, on the score of blood and raciug lineage, Powhattan should commend himself to the public. Powhattan is a solid bas, with large star, left fore and right hind ankles white, his head is bony and expressire, with large, full eyes, high at the withers like his noted brother, good barrel, great depth of girth, with good loin and fine coupling, and has the Lexington hind leg; he is $16 \frac{1}{3}$ haurls high. Whilst he has not the racing record of his great brother, he is a Leamington from a racing family on both sides, and as nearly all the Leamingtons are suecesses in the stud, he shonld be. Flying Childers electrified the world by his brilliant raciug eareer, but his brother, Bartlett's Chillers, excelled him in the stıd, as also did Cade excei his famons racing brother Lath. Powhattan is much inbred to Sir Archy and Diomed, and traces liack withont a flaw through Amaran. thus, dam to the Layton Barb mare.

Powhattan is the sire of the winners Duhme, Poteen, Pocassett, Cherry Blossom, Burlington, an extra good one, E. D., Ela, Flossie, Indiạ Princess, Palisade, Pem P., Pilgrim, Capt. Jack, Imogene, Palestine, Melanie, Mary Comroy, Pennyroyal, The Pooky, Elsie S., Old Pepper, Cornie Buckingham, The Distiller, Pow Wow, Conrt Lore, Banjo, Mamhassett, Llewellyn, Padlock, etc.

Powhattan descends in direct female line from the Layton Barb mare, to r: hich trace Joung Greyhonul, Matchem, Young Cade, Drone (by Herod), Blncher, simoom, Audubon, Philammon, St. Honorat; ete. 


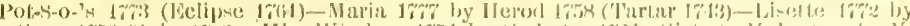

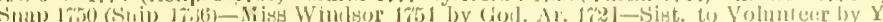

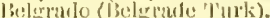

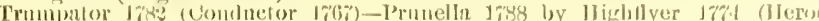

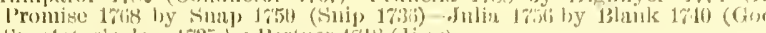

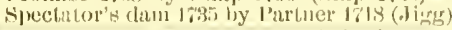

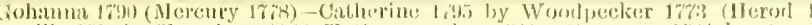

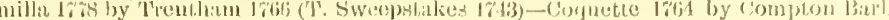

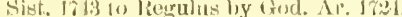

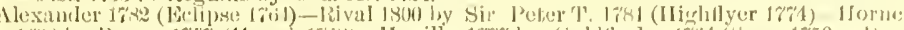

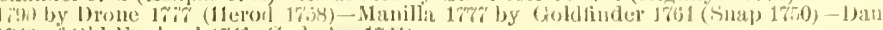
litit; of (old Bugland 17:11 (God. Ar. 17:1)

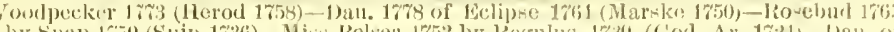

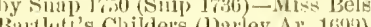

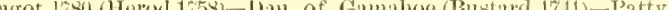

17. Curwen baty Barb.

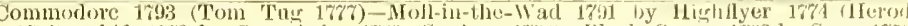
175-) - Shift 1769 by Sweetbriar 1769 (Syplon 17.00)-Blatek Susan 1762 by Snal) 1\%to (Snip) 173(i) - Dau. of Cude 173+ (God. Ar. 1\% 4 )

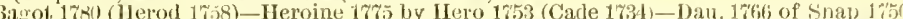

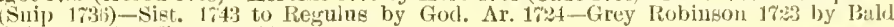
Galloway (St. Viclor liarb)

Woodpecker 17\%3 (Ierod 1758)-Nisfortme 1765 by Dux 1761 (Matchen 1748)-Curiosity 1760 by Snap 1750 (Snip 1736)-Dau. 1749 ol Regulus 1739) (God. Ar. 1724)-Dau. of Bartlett's Childer's (Darley Ar. 1699)

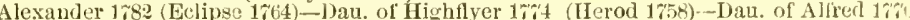

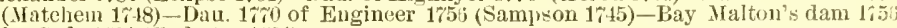
by Carle 1734 (God, Ar. 1724).

Sir Peter '1'. 17it (IIghflyer 17\%4)-Dau. 1785 of Boudrow 1777 (Eclipse 1764)-Dan. 1764 of squirel 1751 (Traveller 1735)-Sist. to Lowther's Babraham by Babraliam 174) (God. Ar. 1724)-Dan. 1750 of Golden Ball 1735 (Partner 1718)

Veteor 1783 (Eclupse 1\%61)-Maid-of-all-Work 1786 by Highflyer $17 \% 4$ (Herod 1758)-Dau

17\% of syphon 1750 (Squirt 1732)-Dau, of Regulus 1739 (God. Ar. 1724)-Sist. 1758 to Judgement by Snip 1735 (Flying Childers 1715)

Whitelock 1803 (Hambletonian 1792)-Dau. 1799 of Coriander 1786 (Pot-8-0-'s 17i3) -

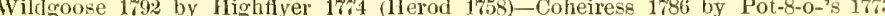
Eelipse 1\%64) - Manilla $17 \%$ by Goldfinder 1764 (Snap 1\%50)

Prime Uinister 1810 (Saneho 1801) - Tranby*'s dam 1812 by Orville 1799 (Beninghrough 1791)-Miss Grimstone 1796 by Weazle 1766 (1Ierod 1758)-Dau. of Ancaster 1768 (Blank 1740)-Dau. of Damascus Ar. 1754.

Selim 1802 (Buzzard* 1787) - Podagra 1803 by Gouty 1796 (Sir Peter T. 1781) Jet 178 by Maguet $17 \% 0$ (Herod 1758)-Jewel 1775 by Squirrel 1754 (Traveller 1735)-Sophia $1 \% 64$ by Blank 140 (God. Ar. 17:16).

Orville 1799 (Beningbrongh 1791)-Boadicea 1807 by Alexander 1782 (Eclipse 1704)Bruvette by Amaranthus 1766 (Old England 1741)-Mayfly 1 \% 11 by Matchem 1 \% 4.9 (Cade 1\%31)-Daı. 1755 of Starling 1733 (Starling 1\%2\%)

*Diomed 177 (Florizel 1768) - *Castianira $1 \% 96$ by Rockingham 1781 (Highflyer 1744)-

Tabitha 1782 by Trentham 1766 (T. Sweepstakes 1743)-Dan. of Bosphorus 175t (Babraham 1740)-Dan. of Forester 1750 (Forester 1736).

Saltram 1780 (Eclipse 1764)-Dau. of Symmes' Wildair 176\% (*Fearnought 1755)-Dau. of Tyler's Drivel 1760 (\%Othello)-Dan. of *Fallower $1 \% 61$ (Blank 1740)-Dau. of *Vampire $175 \%$ (Regulus 1739).

Diomed $17 \% 7$ (Florizel 1768)-Dau. of *Shark 17\%1 (Marske 1750)-Dan. of Harris Eclipse $17 \% 0$ (*Fearnonght 1755)-Dau. of *Fearnought 1\%55 (Regulus 1739)-Dau. ol *Jolly Roger $17+1$ (Roundhead 1 233 ).

Alderman 1787 (Pot-8-o-'s 1\%73)-Din. of *Clockfast $17 \% 4$ (Gimeraek 1760)-Dau. of Symmes" Wildain $176 \%$ (*Fearnought 1755)-Y. Kitty Fisher 1767 by *Fearnonght 1755 (Regulus 1739) —*kitty Fisher 1755 by Cade 1734 (God. Ar. 17\%1).

Orville 1799 (Beningbroush 1791)-Emily 1810 by Stamford 1794 (Sir Peter T. 1784)Dau. 1799 of Whiskey 1789 (Saltran* 1780)-Grey Dorimant 1781 by Dorimant $17 \%$. (Otho 1760)-Dizzy $175 \%$ by Blank 1740 (God. Ar. 1724).

The Flyer 1814 (Vandyke Jr. 1808)-Parma 1813 by Dick Andrews 1697 (Joe Andrews 17r8)- May 1814 by Beningbrougn 1\%91 (King Fergus 1\%w5)-Primrose 1787 by Mambrino 1768 (Engineer 1750)-Cricket $17 \% 6$ by Herod 1758 (Taitar 1743).

Sir Archy 1805 ( Diomed 1\% ${ }^{\mathrm{m}}$ )-Dinu of *Robin Redbreast 1796 (Sir Peter T. 1784)Dau. 1788 of Obscurity $1 \%$ (Eclipse 1\%64)-Slamerkin $1 \% 68$ by *IVildair 1753 (Cade 1734) - Cub male $1 \% 62$ by Cub 1739 (Fox 1\%14)

Robin Grey 1805 (*Royalist 1790)-Maria 1802 by Melzar 1791 (*Medley 17\%6)--Dau. of Hightlyer 1784 (Hightlyer 1\%4)-Dau. of *Fearnought 1755 (Regulus 1739)-Dau. of Ariel 1753 ( $*$ Traveller 1747 ).

Buzzard* 1787 (Woodpecker 1773)-Dan. of Alexander 1782 (Eclipse 1764)-Dau. of

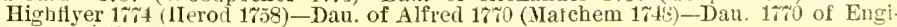
neer 17506 (Sampson 1745)

W's Ditto $1 \times 00$ (Sir Peter T. 1784)-Dau. 1691 of Mercnry 178 (Eclipse 1764)-Dau. 1\% of Herod 1753 (Tartar 1\%43) - Folly 1\%71 by Marske 1750 (Squirt 1\%32)-Tixen 1753 by Regulus 1739 (God. Ar. 1\%24).

Dick Andrews 1797 (Joe Andrews 17r8)-Dau. 1803 of Gohanna 1799 (Aercury 1\%78)Fraxinella 1793 by Trentham 1766 (T. Sweepstakes 1743)-Dat. 1785 of Woodpecker $17 \%$ (Herod 1758) - Everlasting $17 \% 5$ by Eclipse 1;6 (Marske 1750).

Waxy 17:10 (Pot-8-0-'s 1773-Penelope 1793 by Trumpator 1782 (Conductor 176i)-Prunella 1758 by Hightlyer $177^{2}$ (Herod 1\%58)-Promise 1768 by Snap 1750 (Snip 1736)-Julia 1756 by Blank 1740 (God Ar. 1721).

-Diomed 177 (Florizel 1 668 ) - *astianira 1796 by Rockingham 1781 (Highflyer 17r4)Tabitha 1782 by Trentham 1766 (T. Sweepstakes 1745)-Dan. of Bosphorus 1751 (Babraham 1740)-Dau. of Forester 1750 (Forester 1736)

Robin Redbreast 1\%6 (Sir Peter T. 1784) -Dau. 1\%88 of *Obscurity 17\% (Eclipse 1761) Slamerk in 1768 by * $\pi$ ildair 1753 (Carle 1734) - * Cub mare 1762 by Cub 1759 (Fox 1714) Dau. 1755 of Seeond 1732 (Flying Childers 1715)

Cook's Whip 1804 (*W bip 1794) - Jane Hunt 1795 by Paragon 1785 (*Flimnap 1705) Moll by Figure $175 \%$ (Grey Figure 1\% $\%$ )-Slamerkin 1 $\% 68$ by * Wildail 1\%53 (Cade 1734) * Cub mare 1'62 by Cub 1739 (Fox 1\%14).

Buzzard 1787 (Woudpecker 1773)-Indana b. 1u, 1802 by Columbus ( Pantaloon 1758)-Jane Hunt b. w. 1796 by Hamptou's Paragon 1788 ("Flimnap 1765)-Holl b. m. by inop. Figure 1757 (Grey Figure 1747)-Slamerkin b. m. 1768 by Wildair 1753 (Cade 1734) -Cub inare b. m. 1762 by Cub 1739 (Fox 1714 ) - Amaranthus' dam b. m. 1755 hy second 1732 (Flying to Vane's Little Partner by Partner 1718 (Jigg)-Sist. 1722 to Guy by Greylumul (Clillabr) - Brown Farewell br. m. 1710 by Makeless (Oghetuorpe Ar.) - Dau. of Brimmer (D'Arey Yellow Turk)-Dau, of Place's White Turk-Dau, of Dodsworth-Laston Barb unare 


\section{IMPORTED RAYON-D'OR.}

WINYER OF 'THE CLEARTELI AND LEVANT STAKES IN 1878, ST. JAMES' PALACE STAKES, THE GREAT CHALLENGE STAKES, CHAMPION STAKES AND DONCASTER ST. LEGER IN 1879.

In the Algeria Stud, Erie, Pa., the property of the Estate of Mr. Wr. L. Scott, as private stallion.

RAYON-D'OR (Ray of Gold) by Flageolet, son of Plutus, bred in Dangu Stul, France, foaled 1876, dam Arancaria, dam of Chamant, Camelia, etc., Jy Amlirose, son of 'Touchstone, ont of Pocahontas, dam of Stockwell, Rataplan, King Tom. ete.. ly. imp. Glencoe. Rayourl' Or as a two-year old won the Levant stakes, half a mile. at Goodwood, carrsing 122 lbs., beating Flavius, Galantha and two others. At Doncaster won a Sweepstakes, at three-quarters of a mile, with 129 lbs., beating Charibert and Reconciliation. At the Newmarket Second October Meeting won the Clearwell Stakes, carrying 131 lbs., Ringleader and Bay Archer, 122 1bs. each, second and thirh, and three others; won the Glasgow Stakes at the Newmarket Honghton Meeting, three-quarters of a mile, beating Ringleader and Glencairn. Rayon-d'Or' was wuch fancied, both for the 2,000 Guineas and Derly, but his rmming was a disappointment. He was third to Charibert and Cadogan for the 2,000 Gnineas, and was mplaced for the Derly, won by Sir Berys. At Ascot was third for the Prince of Wales stakes to Wheel of Fortme and Adventure; on the third clay he won the St. Jimes' Palace Stakes, with 122 lbs., over the severe "Old mile," beating Charibert, Ruperra and seven others. At Goodwoul Rayon dOr won the Susser stakes. 1 mile, beating Ruperra, Leap Year and Exeter, and the great Doncaster st. Leger, Ruperra second aud Exeter third, and fourteen others mplaced, includiug the winner of the Derbr. sir Berss. Rason-d'Or "walled over" for the Zetland stakes, Mr. Crawfurl's Pell Mell colt saving his stake. At the Termarket First October Meetin won the great Foal Stakes, with 131 lbs., beating Discord, Palmbearer and three others, but at the same meeting was beaten by Bas Archer for the Newmarket st. Leger, lie yielding 7 lbs., after which Rayon-d'Or won the Select Stakes, Rowley mile, beating Discord and three others; the Champion Stakes, across the flat, 1 mile 2 furlongs and 73 yards, beating Placida, the Oaks winner, Exeter and five others, and the Great Challenge Stakes, Bretby Comrse, 6 furlongs, heating Lollypop, Placida, Parole and others. He closed his three-year-old career bs muning thirr. for "handicap "Across the Flat" to Out of Bounds. who earried 110 ibs. to Rayou-d'Or's $126 \mathrm{ll}$ s. His earnings for the year amounted to 587,735 . As a four-rear old Raronl'Or won the Prix dn Cadran, 2 miles and 5 furlongs, beating Znt, Salteador and others, and the Prix Rainbow, 3 miles and a furlong, beating Zut and Clocher. He was sent to England, where, on the 16 th of April, at Newmarket, he "walked over" for the Post Stalies (the two middle miles:. At the Newmarket First Spring Meeting he walked over tor the Prince of Wales Stakes (the Cesarewitch Course). At Ascot won the Rons Memorial Stake over the New mile, carring 132 lbs., but in running for the Hardwicke stakes, at the same meeting, orer the swinler Course (1+ miles) he was beaten a hear by Exeter, to whom he was giving 10 lbs.. This race closed his tint career.

Flageolet, his sire, was a superior race-horse. Won the Hopeful, Rutland. Forlorn, Rowley Mile, Burwell, 5 furlongs, aud Criteron Stakes. As three-rear old won the Goodwood Cup, in which he beat both Favonims and Cremorne, the Derby wimners of 1871 and 1-7: ; won the Grand Dnke Nichael Stakes, at Newmarket First October Meeting; won a free Handicap sweepstakes across the flat, and the Jockey Chn Cup at the Newmarket Houghton Meeting. At fom sears old won the Claret Stakes at Newmarket, England.

An analysis of his tabulated pedigree will show that he is richly and fashionably bred. He has a double cross of Glencoe, a triple cross of Diomed, a double cross of Tonchstone, fortified by the blood of IVhalebone, dombled in upon the Herod and Eclipse blood on both sides to the Byerly mire, dam of the two True Blnes. In color he is a rich true chestmut, with a large, rather faint star in his forehead, standing 16 hands $3 \frac{1}{2}$ inches in height, and a horse of trne symmetry.

Rayon- $\mathrm{a}^{\prime} \mathrm{Or}$ is the sire of the winners Roi d'Or. Daphne, Defense. Bronzominte, Quotation, Ransom, Laura Stone, Belle d'Or. Tndor. Te: Tray, Somerset. Temny, Flageoletta. Arundel, Laly Hemphill, Sparling. Pat Oakley, Quibihler. Julien. Louis d'Or, Alchemist, Harbor Lights, Bellair, Chaos, Chatean d'(or. Coldstream. Cotillion, Gendarme, Gipsy Queen, Gipsy King. Jake Miller, Leighton, Marander, Ossil, Centalur, Toid, Craw fish, Amulet, Torrhfight, Gnito, Banquet, Bolero. Franeo, Miss Ransom, John Atwoor, Minnet. Aftermath, Sterling. Miss Olive. The Doctor: Florimor, Exclusion, Iartha, Cntalone, Pararlox, Canteen, lona, Kingstord. Ayala, Alealle, Versatile, Coxswain, Monopolist, Lutre, Lonise dor and Marwook. (see? imp. Eothen, page 150.) 


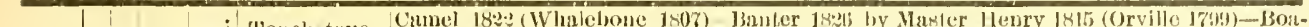

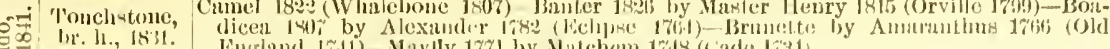

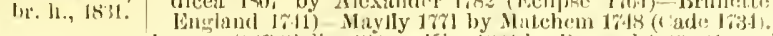

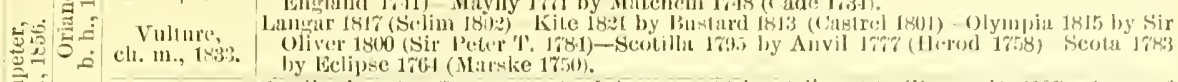

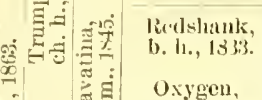

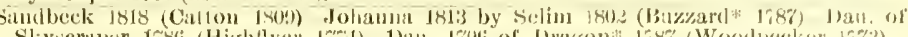

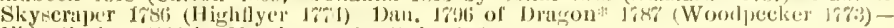

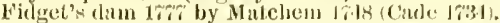

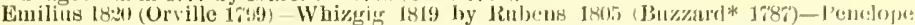

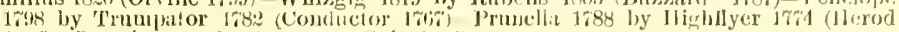
17,5)-Promise 16tio by smap 175.) (Snip 1736)

- 13 ay -

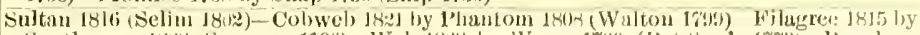

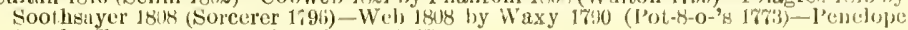

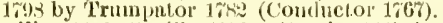

Midillotou,

Emilius 18:0 (Urville 1799)-Ilarriet 1819) by P'ricles 1809 (Evander 1801)-Dan. 18120f

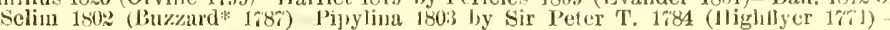

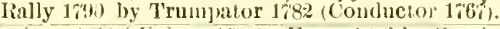

$\sum_{0}^{\infty} \quad \underbrace{\infty}_{0}$

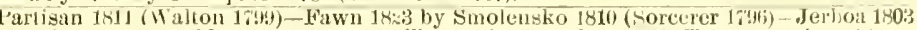

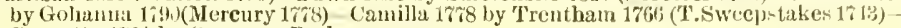
Coquette 1764 by Compton Barb.

Sเ

Glencoek 1831 (Sultan 1816)-Fanuy 1827 by Whisker 1812 (Waxy 1790)-Dau. 1813 of

Darliness, Glencoesus 1803 (Hambletonian 1792)-Dau 1844 of Precipitate*1787 (Mercury 1768)Mendeza*'s dam 1783 by Paymaeter 1666 (Blank 1640).

*. ch. m., $183 \%$.

כิ Defence,

Whalebone $180^{\circ}$ (Waxy 1790)-Defiance 1616; by liubeng 1805 (Buzzard* 188\%)-Litte Folly $180 ;$ by Highland Fling 1798 (Spadille 1681). Harriet 1799 by Volmuteer 178!) (Eclipse 1614) -Dau. 1785 of Alfred $17 \% 0$ (Matclem 16.48).

政 Daughter of, Rer

Reveller 1815 (Conus 1809)-Design 1827 by'Tramp 1810 (Dick Andrews 1797)-Defiance

(Buzzard' 1787)-Litl]e Folly 1806 by Highland Fling 17'98 (Spadille 1784)-Harriet 1799 by Volunteer 1780 (Eclipse 1761).

Royal Oak, Catton 180. (Golumpus 1802)-Dan. 1818 of Smolensko 1810 (Solcerer 1796)-Lady Mary 1800 by Beningbiongh 1791 (King Fergus 17r5)-Dau. of IIighflyer 17\%1 (Herod 1758)Sist. to Miss Bell by Marske 17:0 (Squirt 1732)

Whisker 1812 (Waxy 1690)-Anna Bella 180\% by Shuttle 1793 (Y. Marske 1r71)-Dau.

Ada,

b. m., 1834 . 1797 of Drone 17\%7 (Herod 1758)-Contessina 1787 by Y. Marske 17\%1 (Marske 1750)Tuberose 1\%72 by llerod 1;58 (Tartar 1743).

Partisan, Waltou 1799 (Sir Peter T. 1781)-Parisol 1800 by Pot-8-o-'s 1763 (Eclipse 1764)-Prune]la 1788 by Highflyer 1761 (Herod 1758)-Promise 1768 by Snap 1750 (Snip 1736) -Julia

b. h., 1811. $\begin{aligned} & 1786 \text { by Blank 1740 (God. Ar. 1724). } \\ & \text { Moses 1819[Whalebone or]Seymonr 180\%(Delpini 1781) - Onadrille } 1815 \text { by Selim 1802(Buz- }\end{aligned}$

Pauline,
zard $178 \%$-Canary Bird 1806 by [W hiskey or] Sorcerer 1796 (Trumpator 178\%)-Canary zard 1787)-Canary Bird 1806 by [Whiskey or] Sorcerer 1795 (Trumpator 1782) -Canary
1797 by Coriander 1786 (Pot-8-0-'s 173)-Miss Green 1787 by High flyer $17 \% 4$ (Herod 1758).

Rainbow 1808 (Walton 1799)-Aimable $18: 2$ by Election 1801 (Golıannit 1790)-Dau. 1808

Hercule, Rat of $Y$. Whiskey 1801 (Whiskey 1789)-Dau. 1800 of Walnut 1786 (Highflyer 17\% - Bay Javelin 179.3 by Javelin $17 \%$ (Eclipse 1\% 64 ).

Elvira, Eryx 1816 (Milo 1802) - Coral 1816 by Orville 1799 (Beningbrough 1791) - Fairing $1 \times 07$ by

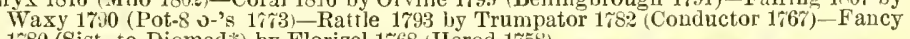

b. m., 1839. 1780 (Sist. to Diomed ${ }^{*}$ ) by Florizel 1768 (Herod 1758).

Whalebone, Waxy 1790 (Pot-8-0-' 1773)-Penelope 1798 by Trumpator 1782 (Conductor 1767)-Julia

$1 \% 56$ by Blank $1 \% 10$ (God. Ar. 1724).
Selim 1802 (Buzzard $1 \% 8 \%$ - Maiden 1801 by Sir Peter T. 1781 (High flyer 1774)-Dau. 1\%88

Danghter of, of Phenomenon 1780 (Herod 1758)-Matron 1782 by Florizel 1768 (Herod 1758)-Maiden $17 \% 0$ by Natchem 1748 (Cade 1734).

Orville 1799 (Beningbrough 1791)-Miss Sophia 1805 by Stam ford 1794 (Sir Peter T. 1784)

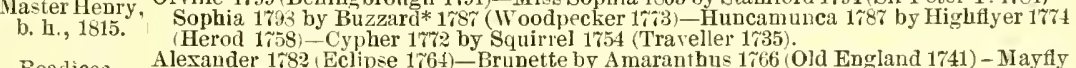

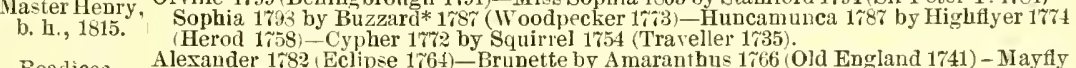

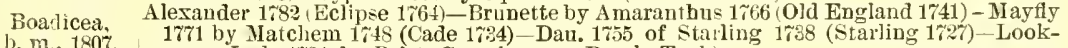
at-me-Lads 1731 by Brist. Grasshopper (Byerly Turk).

Emilius, Orville 1799 (Beningbrough 1791)-Emily 1810 by Stamford 1r94 (Sir Peter T. 1781)-Dau.

b. h., 1820 . 1799 of Wbiskey 1789 (Saltram* 1780 )-Grey Dorimant 1781 by Dorimant $17 \%$ (O) 1760)-Dizzy $175 \%$ by Blank 1740 (God. Ar. 1;24).

Cressida, Whiskey 1789 (Salt ram* 1780)-Y.Giantess 1790 by *Diomed 177 (Florizel 1r68)-Giantess 1769 by Matchem 1748 (Cade 1784)-Molly Long Legs 1753 by Babraham 1740 (God. Ar.

b. m., 180\%. $\frac{1724 \text { )-Dau. of Foxhunter } 172 \% \text { (Brisk 1711). }}{\text { Don Juan, }}$ Orville 1799 (Beningbrough 1791)-Peterea 1804 by Sir Peter T. 1781(Highflyer 1771)

b. h., 1814. Mary Grey 1784 by Friar 1768 (Hero 1753)-Timante by Tim 175: (Squilt 1732)Noblessa 1769 by Gamahoe (Buslard 1741). Moll-in-the- Hambietonian 1792 (King Fergus 17\%)-Spitfire 1799 by Pipator 1:86 (Imperator 1766)-
Wad. Farewell 1792 by Slope 1782 (Highflyer 1774)-Dau. of Y. Marske 17\%1 (Marske 1750)Dat. of Broth, to Silvio (Carle 1734).

Selim. Buzzard* $173 \%$ (Woodpecker 17\%3)-Dall. of Alexander 1\%82 Eclipse 1\%64)-Dau. of

ch. h., 1802. Highflyer 1\%74 Herod 1758)-Dau. of Alfred $17 \% 0$ (Matchem 1\%48)-Dau. 1770 of Engineer 1755 (Sampson 1745)

Bacchante, W's Ditto 1800 (Sir Peter T. 1784)-Dau. 1791 of Mercury 17\%8 (Eclipse 1;64)-Dall. 1\%76

Bacchante, $\quad$ of Herod 1758 (Tartar $1 \% 43$ )-Folly $1 \%$ 1 by Marse $1 \% 50$ (Squirt 1732) Vixen 1753 by Regulus 1739 (God. Ar. 1724).

Tramp, Dick Andrews 1797 (Joe Andrews 17\%8)-Dall. 1803 of Gohanna 1790 (Merenry 1\%73)-

b. h., 1810. Fraxinella 1793 by Trentham 1766 (T. Sweepstakes 1\%13)-Dau. 1785 of Woodpecker Fraxinella 1793 by Trentham 1766 (T. Sweepstakes 1743 ) - Dinu. 178 -Everlasting 1775 by Eclipse 1764 (Marske 1750 ).

WTeb, Waxy 1790 (Pot-8-o-'s 17\%3)-Penelope 1798 by Trumpator 1782 (Conductor 1767)-Prunella 178s by Highfiyer 17\%4 (Herod 1758)-Promise 1768 by Snap 1750 (Snip 1736)-Julia 1756 by Blank 1710 (God. A1. 17\%1).

Orville, Beningbrough 1\%91 (King Fergus 17\%5)-Eveiina 1791 by Highflyer 1it4 (Herod 1i58)b. h., 1799 .

Termagant by Tantrum 1760 (Cripple 1750)-Cantatrice by Sampson 1745 (Blaze 1733)Dau. 175\% of Regulus 1739 (God. Ar. 1721).

Whiskey 1789 (Saltram* 1\% 60 ) -Y. Giantess 1790 by Diomed* 1\% $\%$ (Florizel 1\%68)-Giantess 1\%69 by Matchem $1 \% 48$ (Cade 1\%34)-Molly Long Legs 1;53 by Babraham 1\%t0 (God. Ar. 1724)-Dau. of Cole's Foxhunter 1727 (Brisk 1\%11)

b. m., 1798 .

Whiskey 1789 (Saltram 1780$)$-Y. Noisette 1798 by Diomed*17\% (Florizel 1768)-Noisette 1774 by Squirrel 1754 (Traveller 1735 ) C Carina 1766 by Narske 1750 (Squirt 1732)Thunder's rlam 1755 by Blank 1740 (God. Ar. 1724).

b. h., 180 :

Gohanna 1790 (Mercury 17\%8)-Amazon b. m. 1799 by Driver 1783 (Trentham 1766)-

Harpalice Fractious b. m. 1792 by Mercury 1\%/8 (Eclipse 1761)-Dan. b. m. 1785 of Toodpecker $17 \% 3$ (Herod 1758) -Everlasting b. m. 1775 by Eclipse 1 64 (Narske 1750)-Hyæna br. m. Dan. of Bartiett's Childers (Darley Ar. 1699)-Dan. gr. m. by Honeywood's Ar.-Dam of the two True Blues by Byerly Turk.

1 Honarque is by The Baron, Sting or The Emperor. Emperor's pedigree is accepted. 


\title{
IMPORTED ROSSINGTON.
}

\author{
The property of MIr. F. B. Harper, Nantura Stud, Mridway. Terms of sericic \\ advertised ammally.
}

Rossingtox, chestunt horse, foaled 1831, bred by Duke of Westminster, br Doncaster (son of Stoekwell), dam of Lily Agnes (dam of Ormonde, Farewell alik Ossory) by Macaroni; grandam Polly Agnes (dam Jessie Agnes) by The Cure:"great grandam Miss Agnes (dlam of Muncaster and Kendal) by Birdeatcher, out of Agnes by Clarion.

Rossington started in three races. At two years old ran third to Katerfeltn and Timhel in Two-Iear Old Plate at Liehfield, with seven others behind him : ran third in the Rutland Stakes to Raffaello and Sinbad, with Pantaloon behind him: was unplaced in the Studley Castle Handicap Nursery Plate, 1. mile, won by Scottish EarI. Rossington is nearly full brother to the mnbeaten Ormonde, the latter being by Bend'or, son of Doncaster by Stockwell, whilst Rossington is by Doneaster, who won the Derby and ran second for the St. Leger in 1873, and sired Bend'or, the Derby winner of 1880 , his first year in the stud.

The most important fuct in connection with Rossington is that he is one of the great "Agnes family" the most snecessful English racing family of the present generation. His grandam, Polly Agnes by The Cure, was a erack performer, and in the stud protuced Rural Dean by Cathedral, Lily Agnes by Macaroni, Flenr-te-Lis by Mandrake, Tiger Lily by Macaroni, Jessie Agnes by Macaroni, Bay Agnes by Speculnm. Lily Agnes was a mare of inmense speed, winning, among her many races, the Doneaster Cup, Great Ebor Handicap, with 120 1bs, and the Northumberland Plate of 1874 as a three-year old. As a brood-mare Lily Agnes proved a great treasure; she produced Nareissus by Speculum, Eastern Lily by Speculum, Rossington by Doncaster, Farewell (winner of the 1,000 Guineas of 1885) by Doncaster, Ormonde (wimmer of the Criterion Stakes and Dewhurst Plate of 1855, and the 2,000 Guineas, Derby and St. Leger of 1886, etc.) by Bend'or, and Ossory (winner of the Criterion, 1887) by Bend'or.

On the sire's side of the pedigree Rossington's graudsire, Macaroni, won the 2.000 Guineas and Derby of 1863 . His sire, Sweetmeat, has shown his prepoteney remarkably in the Derby. He begot Maearoni (Derby winner), Parmesau, sire of two Derby winners, Cremorne and Favonins. The last-named got another Derby winner in Sir Berys. Macaroni got three Oaks winners in Spinawas, Camelia and Bonnie Jean ; a 2,000 Guineas wimner in Macgregor, who got one in Scot-Free. Tedington, maternal grandsire of Doncaster, won the Derby in 1851, and was one of the gamest horses which ever ran, as his memorable race with Kingston, Stockwell and others for the Emperor's Plate showed.

Rossington is 16 hands high and a good-shaped horse. In the stud he has not yet had a fair trial, but is the sire of the wimners Emma Primrose, Ida Rossington, Rally, Freu Lee (dam Mamie O.), Unadilla, Belfast, Coquette, Lollie, Emin Ber. Sabine, Frank Eiseman, Sarah Remey, ete. $\mathrm{H}_{\theta}$ is deseended in direct female lini from sister to Stripling by Hutton's Spot. to which trace Burgundy, Glemmasson. Ambrose, Dundee, Brown Bread, Vau Amburgh, Muncaster, Kendal, Ormonde, imp. Stonehenge and all the Agnes family. 


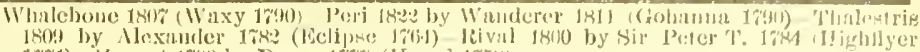

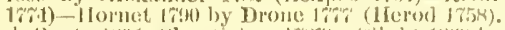

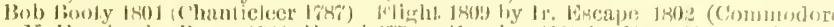

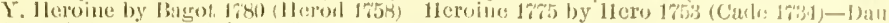

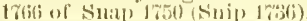

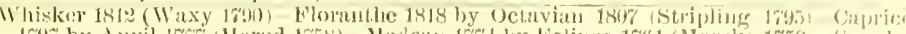

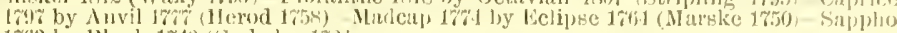

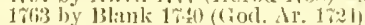

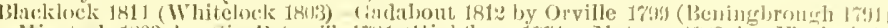

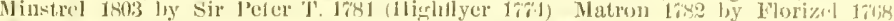

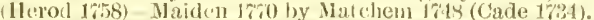

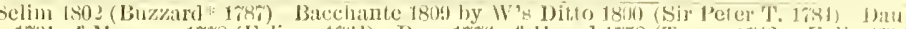

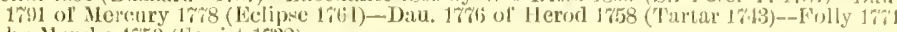

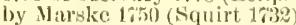

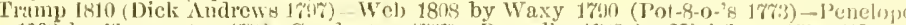

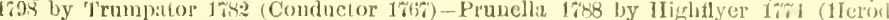

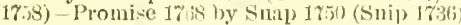

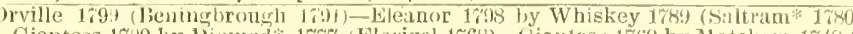

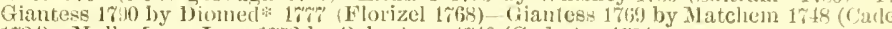

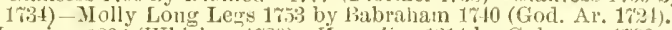

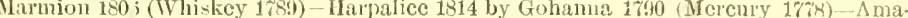
1799 by Driver $17 \times 3$ (Trenthim 1765) Fractions $179: 3$ by Mercury 1rik (Eclipse 1764)-Dau. 1785 of Woodpecker $17 \% 3$ (Herod 1758).

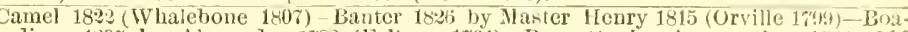
dicea 1907 by Alexander 178? (Lclipse 1764)-Brunette by Amaranthus 17tit; (OId England 1\%+1) - Mayfly $1 \%$ it by Matchem 1\%48 (Cade 1\%34).

Langar 181í (Selim 180:2) - Kite 18\%1 by Bustard 1813 (Castrel 1801) - Olympia 1815 by Sir ( by Eclipse 1764 (Marske 1750).

Humprey Clinker 18:2 (Comus 1809)-Medora 1813 by Swordsman 1796 (Prizefightel

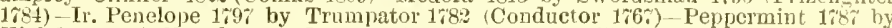
Hightlyer $17 i^{4}$ (Herod 1758)-Promise 1768 by Snap 1750 (Snip 173

Election 1804 (Gohamna 1790)-Dan. 180, of Stamford 1704 (Sir Peter T. 178t)-Yise

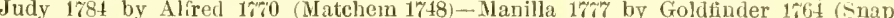
1750)-Dan, 1736 of Old England 1741 (God. Ar, 1724)

Blacklock $181+$ (Whitelock 1803 )-Nliss Newton 1804 by Delpini 1781 (Highflyer 1ro4) Tipple Cyder 1788 by King Fergus 1 \% Marske 1750)-Ferret 1765 by Broth. to Silvio (Cade 1734).

Picton 1819 (Smolensko 1810-Dan, 1824 of Selim 180: (Buzzard* 179\%)-Dau. 1804 of Pipator 1786 (Imperator 176) Queen Mab 1785 by Eclipse 1764 (Marske 1750)-Mercury's dam by 'Tartar 1743 (Partner 1718).

Humprey Clinker 18:3 (Comns 1809)-Dan. 1825 of Celvantes 1805 (Don Quixole 1781)-Dau. 1818 of Golumpus 1802 (Gohanna 1790)-Dau. 1810 of Paynator 1791 (Trumpator 1782) C Circle 1802 by St. George 1789 (Highflyer 1774)

Phantom 1808 (II alton 1799)-Elizaheth 1823 by Rainbow 1808 (Walton 17991-Belvoirina 1813 by Stamford 1794 (Sir Peter T. 1784) - Sist. 1790 to Silver by Mercury 16ts (Eclipse 1764)-Dau. 1780 of H Lerod 1758 (Tartar 1743)。

Walton 1799 (Sir Peter T. 1781)-Parasol 1800 by Pot-8-0-'s 17io (Eclipse 1764)-Prunella 1788 by Ifightyer $1 \%$ it (Herod 1758 )-Promise 1768 by Snap 1750 (Snip 1\%36)-Julia 1756 by Blank 1740 (God. Ar. 1796).

Moses 1819 ([Whalebone or] Seymour 1807) _Quadrille 1815 by Selim 1802 (Buzzard*1\%87) - Canary Bird 1806 by [Whiskey or] Sorcerer 1696 (Trumpator 1782)-Canary 1797 by Coriander 1786 (Pot-8-0-'s 1; 73 )-Miss Green $178 \%$ by Highflyer $17 \% 4$ (Herod i 158 ).

Blacklock 1814 (Whitelock 1803)-Dau. 1816 of Fhantom 1808 (Walton 1799)-Dau. 1802 of Overton 1788 (Kiug Fergus 1\%5)-Dau. 1\%90 of Walnut 1\%86 (Highflyer 1\% 1786 of Ruler $1 \tau \tau 7$ (Y. Marske $1 \%$ ( 1 1).

Blacklock 1814 (Whitelock 1803) - Wagtail 1818 by Prime Minister 1810 (Sancho 1801

Tranby*'s dam 1812 by Orville 1\%93 (Beningbrongh 1\%91)-Miss Grimstone $1 \% 96$ by Weazle $17 \% 6$ (Herod 1\%58)-Dan, of Ancaster 1;68 (Blank 1740).

Buzzard* 1787 (iVoodpecker 17\%3)-Dau, of Alexander 1782 (Eclinse 1764)-Dan, of

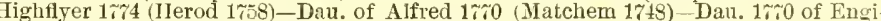
neer $1 ; 56$ (Sampson $1 \tilde{1}+5)$.

Peruvian 1806 (Sir Peter T. 1784)-Musidora 1804 by Meteor 1783 (Eclipse 1\%64)-Maidof-all- IT ork 1786 by Highflyer 17\%4 (Herod 1758) - Sist. to Tandem 17it by Syphon 1750 (Squirt 1792)-Datt. of Regnlue 1 (r39 (God. Ar. 1724).

Orville 1799 (Beningbrough 1791)-Miss Sophia 1805 by Stamford 1791 (Sir Peter T. 1784) Sophia 1798 by Buzzard*178\% (W oodpecker 1\%73)-Huncamunca 1787 by Highflyer $17 \tau^{4}$ Herod 1758)-Cypher 1\%2 by Squlrel 1754 (Traveller 1735).

Alexander 1\%82 (Eclipse 1\%64)-Brinette by Amaranthus 1\%66 (Old England 1741)-Mayfly 1771 by Matchem 1748 (Cade 1734)-Dau. 1\%55 of Allc. Starling 1\%'s (Starling 1\%2\%)Look-at-me-Lads 1 \%al by Brist. Grasshopper (Byerly Turk).

Blackloci 1814 (1Thitelock 1803)-Wandane 1800 by Pot-8-0's $17 \% 3$ (E.clipse 176t)-Y. Camilla $178 \%$ by 1 oodpecker $17 \% 3$ (Herod 1758 -Camilla 17\%8 by Trentham 1766 (T. Sweepstakes 1\%(3) - Coquette 1765 by Cempton Barb.

Prime Minister 1810 (Sancho 1801) - Niss Paul 1811 by Sir Paul 1802 (Sir Peter T. 1\%\&4) Miss Dunnington 1807 by Shuttle 1793 (Y. Marske 1771)-Miss Grimstone 1795 by

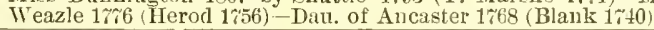

Calton 1809 (Golumpus 18?2)-Desiemona 1811 by Orvilie 1799 (Beninobrough 1991)

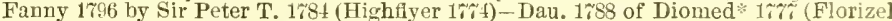
1768)-Desdemona 1730 by Marske 1750 (Squirt 1732).

Waterloo 1814 (Walton 1799) - Cressida 180\% by Whiskey 1789 (Saltram*1;89)-Y. Giantess 1790 by Diomed* 1777 (Florizel 1768-Giantess 1769 by Matchem 1748 (Cade 1\%34)-Nolly Long Legs 1 \%53 by B:brabam 1740 (God. Ar. 1724).

Thalebone $1800^{*}$ (Waxy 1790)-Perí 1822 by Wanderer 1811 (Gohanna 1\%90)-Thalestri1809 by Alexander 1782 (Eclipse 1764)-Rival 1800 by Sir Peter T. 1784 (Highflyer 17\% 7 )-Hornet 1;90 by Drone $17 \% 7$ (Herod 1758).

Bob Booty $180 \div$ (Chauticleer 1:87) - Flight 1809 by Ir. Escape 1802 (Commodore 1793)Y. Heroine by Bagot 1\% 80 (Herod 1758) - Heroine 17\% by Hero 1758 (Cade 1 734 )-Dau. $1 \tilde{r} 66$ of Snap 1750 ( Snip 1736)

Sulian 1816 (Selim 180:)-Clara 1829 by Filho-da-Puta 1812 (Haphazard 1\%9r)-Clar 1894 br Smolensho 1810 (Sorcerer 1796)-Dau. 180 of Precipitate* 178\% (Jlercury 1778 )-Y. Juno 1788 by Highflyer $17 \% 4$ (Herod 1758).

Priam* 1827 (Emilius 1820)-The Potentate's dam b. m. 18:3 by Don Juan 1814 (Orville

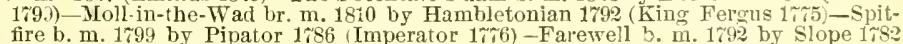
Highflyer 1\%1-Dan. of Y, Marske 1\%1 (Mareke 1\%0)-Dau. of Broth. to Silvio (Cade 1734) -Sist. to Stripling by Hutton's Spot 1728 (Hartley's Bliid Hor'se). 


\section{IMPORTED ST. BLAISE.}

WINNER OF THE TROY STAKES, 1882, AND THE DERBY, 1883.

\section{The property of Messrs. Chas. Tieed \& Sons, Faiview Stud, Gallatin, Ienn. Yearling sales anmully.}

ST. BlaISE, chestnut horse, bred by Lorl Alington, foaled 1830, imported by the late Hon. A. Belmont, by Hermit, son of Newminster loy Tonchstone, dam Fusee by Marsyas, son of Orłando by Touchstoue, grandam Vesurienne by Gladiator, son of Partisan and sire of sweetmeat, ont of Venus by Sir Hercules, son of Whalebone. A glance at his tabulated pedigree will show that St. Blaise is a highly and tashionably bred horse. Hermit, his sire, won the Derby and was the most popular stallion in England. Amongst the wany race-horses he sired may be meutioned 1'ristau, Shotover (wimner of the 2,000 Guineas and the Derby), Peter, Thebais(winuer of the 1,000 Guineas and Oaks), St. Marguerite, St. Lonis, st. Medard, Lonely (winner of the Oaks), ete. Marsyas sired George Frederick, the Derby winner of 1874 , who was a success at the stud, among his get being Frontin (winner of the Grand Prize of Paris), Beau Brummel, etc. St. Blaise is inbred to Touchstone, and in his pedigree will be found the blood of Blacklock, Sultan, Gladiator and Sir Herenles.

St. Blaise was himself a good race-horse. As a two-rear old started six times, won four races, incluting a walk-over and a dead heat. He made his debut in and won the Stockbridge Biennial, 6 furlongs, at the Bibury Club meetiug, beating four others. In the Troy Stakes he had a waik-over; won the Hurstbourue Stakes, abont 5 furlougs, both these events being at Stockbridge; he was lefeated by Macheath, but was seconl, beating Mr. Honldsworth's Adriana, conceding her weight. In the Holecomb Stakes, at Goodwood, 6 furlongs, ran a dead heat with Elzevir; and iu the Dewhnrst Plate at Newmarket, 7 furlongs, he was not placed. Won the Newmarket Troy Stakes, 5 furlongs 140 yarls, giving weight to everything that started. At three veits old, in the 2,000 Guineas, won by Galliard, he run unplaced. He turned the tables by winning the Derby from Highland Chief, second, Galliard third. St. Blaise's performance was very meritorions showing the greatest pluek and stamina. In the Grand Prize of Paris he vindicaterl his rictory by runuing second to Froutin, who was thought the best three-year old of that year, ouly heaten a head; the good colt Farfadet was a poor third, three lengths away. In the Ascot Derby lie conceded 10 lbs. to the winner, Ladislas, and 17 lis. to Ossian, who rin second and afterward won the St. Leger. He closed his turf ant three-year old career by walking over for the Stockbridge Biennial for three-year olds and the Winchester Biemnial stakes.

St. Blaise was a good class race-horse and has shown himself a phenomenally snceessful stallion. His sire, Hermit (winner of the Derby, ete.), was one of the best stallions England has ever known. Fusee (St. Blaise's dam) won as a two-year old the Chelmsfork Nursery Handicap, beating a field of eight, and the stratton "Nursery Haurlicap, earrying top weight, defeating seven others. She was second in the Nursery Plate at Croydon and third in the Ramsay Abbey Nursery Handicap. At three rears old she started eleren times and won nine races, including the Nursers Cup, 1 mile, at Chester; the Little John Stakes, 1 mile, at Nottingham; a Welter Cup Handicap, 1 mile, at Kingsbury, carrying top weight; the Kingsburr Handicap, $1 \frac{1}{4}$ miles, again carrying top weight; the Qneen's Plate, 2 miles, at Nottingham; the Queen's Plate, upwarls of $3 \frac{1}{2}$ miles, at Newmarket; the Queen's Plate, 2 miles, at IVinchester; the Qneen's Plate, 3 niles, at Salisbury, and the Qneen's Plate, 2. miles, at Chelusford. Thus proving a speedy and game animal and possessed of the highest stamina. In the stmd Fusee has proved suceessful. She produced, to the cover of Blair Athol, Go Baug (winuer of the Winchester Biennial Stakes at two rears old), Friar Rush (a tull brotber to St. Blaise), a good and frequent winner. Next eame st. Blisise, and, after missing one year, she prodnced Mateh Girl by Plebeian, who was is stake wimner at two years old. Fusee produced auother full brother to St. Blaise in Candlemas, a good performer, winner of the Epsom Grand Prize, the Zetland liennial and the Chesterfield Cup. Fusee also produced Fuse (by Bend'or), that won the Kempton Park 'Two-Year Old Stakes.

St. Blaise is the sire of the winners Lady Agnes, Mamie B., Mr. Pelham, Patishah, St. Carlo, St. James, Arlair, Almiral, Beanty, Belisarius, Chatham, Chesapeake, Clarendon, Coriolanus, Enily Carter, Fanstina, Fearless, Flavia, Fritz, Her Highness. La Tosca (oue of the best fillies ever foaled), Lizzie, My Queen, Polydora, Potomac (winner of the Fnturity aud Realization Stakes), st. Charles, St. Onier. st. Patrick, St. Denis, st. Mark, St. Carolus, St. Florian (a grand one), Schuylkill, Flattery, Chatham and other's.

He is descended in direct female line from the Belgrade Turk mare, to whith traces Taurus, Gladiator, Sting, Bellidrum, New Holland, Boulevari, Lelaps, ITilful, ete. 


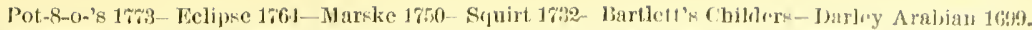

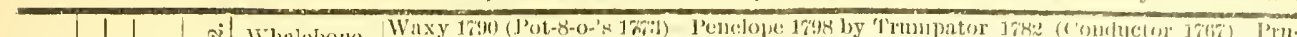

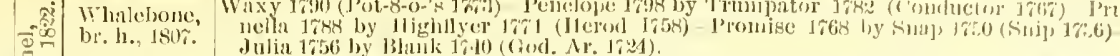

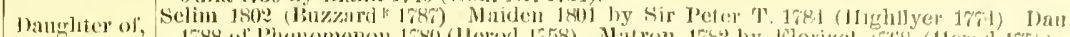

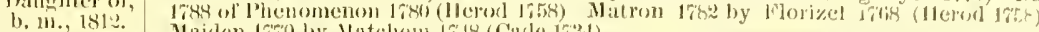

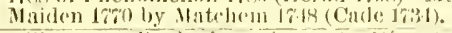

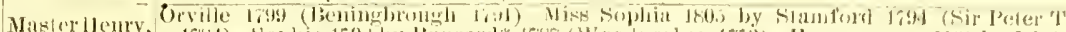

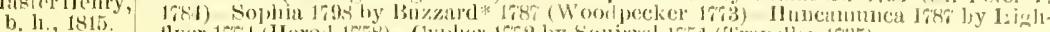

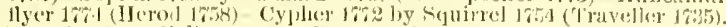

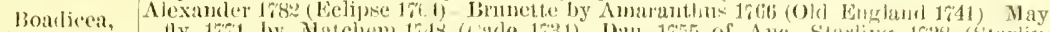

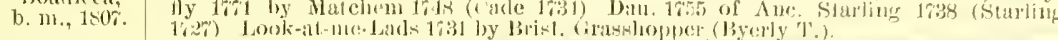

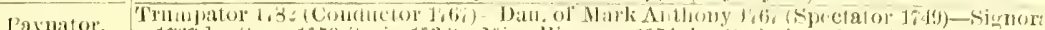

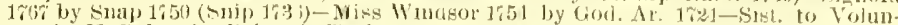

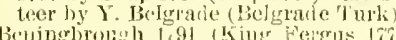

$\stackrel{\vec{D}}{=}$ br. h., $17 ! \mathrm{i}$

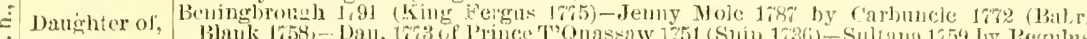

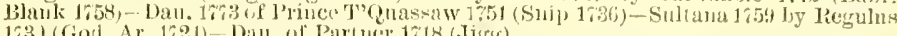
173.) (Goti. Ar. 1721)-Dall. ol Partuer 1718 (Jiges)

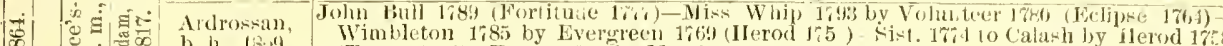

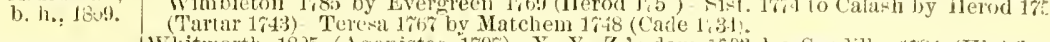

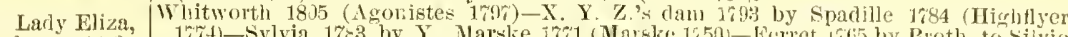
b. m., 1513.
(Cade 1734)-Dau. of Regulus 1639 (God. A\%. 1624).

Cain,

b. h., 1822 .

Paulowitz 1813 (Sir Paul 189\%)-Dau. 1810 ol Paynator 1791 (Trumpator 178\%) - Jau. 18:5 of Delpini 1681 (IIjgliflyer 17\%1)-Dau. $17: 5$ of X. Marske $17 \% 1$ (Narske $17 \% 0$-Gentle Kitty 1 rit by Silvio 1754 (Cade 17?4).

Margaret,

br. m., 1831 .

Edmund 18\%4 (Orville 1799)-Nedora 1811 by Selim 1802 (Buzzard* Jren)-Dau. 1803 o

Sir Harry* 1795 (Sir Peter T. 1784)-Dau. 1793 ol Volunteer 1780 (Eclipse 1764)-Dau. 1759 of Herod 1758 (Tartar 1743).

Sultan,

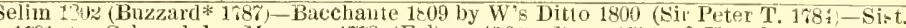
1791 to Calomel by Mercnry $17 \% 8$ (Eclipse 1764)-Dau. 1\%6 of Herod 17\%8 (Tartar 1743)-Folly $17 \% 1$ by Narske 1750 (Squirt 173:)

Fester, Camel 1822 (Whalehone 18\%)-Moninia 1821 by Juley 1810 (Orville 1709) - Sist. 1\%(6 to

br. m., 1832. Petworth by Precipitate*1787 (Mercury 17t8)-Dan, 1787 of Woodpecker 17i3 (II rod 1758)-Sist. 1773 to Jnmiper by Snap 1750 (Snip 1736).

Bay Sultan 1816 (Selin 18(2)-Cobweb 18\%1 by Phantom 1808 (II alton 1799)-Filacree 1815

Niddleton, by Sootheayer 1808 (Sorcerer 1796) - Web 1808 by Waxy 1790 (Pot-8-0-'s 1\%73) - Penelope

b. h., 1833. 1798 by Trumpator 1 i 22 (Conductor $176 \%$ )

Crucifix, Prian* 1827 (Emilus 1820) - Octaviana 1815 by Octavian 180\% (Stripling 17\%5)-Dan. 180\%

b. m., 183\%. of Shuttle 1793 (Y. Marske 1\%71)-Zara 1801 by Delpini 1781 (Highflyer 17r4)-Fiora $1 \% 69$ by King Fergus $17 \% 5$ (Eclipse 1764)

Belshazar * Blacklock 1814 (Whitelock 1803)-Mannella 1809 by Dick Andrews 179 (Joe Andrews

1768)-Nandane 1800 by Pot-8-0-'s 17,3 (Eelipse 16(4)-Y. Camil]a 1iE7 by Woodpecker $17 \% 3$ (Herod 1758)-Camilla $17 \% 8$ by Trentlam 1766 (T. Sweepstakes 174 .

Ellen, Starch 1819 (Waxy Pope 1806)-Cnirass 1823 by Oiseau 1809 (Camillns 1803)-Castanea

b. m.,1831. 18$) 6$ by Gohanna 1799 (Mercury 17\%8)-Grey Skim 1703 by Woodpecker 1773 (Herod 1758)-Dan. 1780 of Herod 1758 (Tartar 1743).

Camel, Whalebone $180 \%$ (Waxy 179u)-Dau. 1812 of Selim 1802 (Buzzard* 178i) - Maiden 1801 by bamel,
bi., 1822. Sir Peter T. 1784 (Highflyer 1771)-Dau. 1788 of Phenomenon 1780 (Herod 1758)-
Matron 1782 by Elorizel 1768 (Herod 1758).

Banter, Master Henry 1815 (Orville 1799)-Boadıcea 18c7 by Alexander 1782 (Eclipse 1764)--Bru-

茟 nette by Amaranihus 1766 (Old Engiand 1741)-Mayfly $17 \% 1$ by Natelem 1748 (Cade 1784)-Dau. 1755 of Ane. Starling 17.88 (Starling 172 $\%$ ).

Langar Selim 1802 (Buzzard*1787)-Dan. 1808 ol Walton 1799 (Sir Peter T. 1784)-Y. Giantess

ch.h., $181 \%$.

1700 by Diomed* 1777 (Florizel 1\%68)-Giantess 1769 by Matchem 1748 (Cade 1734)Molly Long Legs 1753 by Pabraham 1740 (God. Ar: 1721).

Kite, Bustard 1813 (Castrel 1801) _Olympia 1815 by Sir Oliver 1800 (Sir Peter T. 1781)_Scotilla

b. m., 1821.

17.5 by Anvil 1777 (Herod 17:8) - Scota 1783 by Eclipse 176-1 (Marske 1750)-Harmony 175 by Herod 1758 (Tartar 1743).

Waxy, Pot-8-0-'s 17 3 (Eclipse 1764)-Maria 1776 by Herod 1758 (Tartar 1743)-Lisette 172 by

b. h., 1790

Snap 1750 (Snip 1\%36)-Miss Windsor 1754 by God. Ar. 1724-Sist. to Volunteer by Y. Belgrade (Belgrade T.)

Penelope, Trumpator 1782(Conduetor 1767)-Prnnella 1788 by Highfly er 1\%4 (Herod 1\%58)-Promise 1768 by Snap 1750 (Snip) 1726)-Julia 1756 by Blank 1\%40 (God. Ar. 1721)-Spectitor's dam 1735 by Partner 1718 (Jigg)

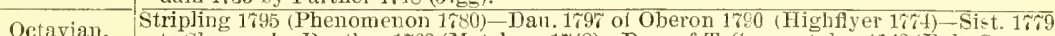
ch. h., 1807.
stakes 1722) Sist. 1748 to Care]ess by Spot 1728 (Hartley's Blind Ilorse).

Shuttle 1793 (Y. Marske 17\%1) - Katharine 1798 by Delpini 1781 (Hiuhflyer 1r.4)-Dau. 1786 of Paymaster 1766 (Blank 1740)-Dau. $17 \% 4$ of Le Sang 1 \%59 (Changeling 1747)Dau. 1751 of Rib 1730 (Crab 1722)

Daughter of b. m., 1806.

$\therefore$ Walton,

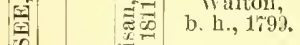

Peter T. 1784 (Highfiyer 1\%r4)-Arethusa 1792 l)y Dungannon 1780 (Eclipse 1r64)Dau. $17 \% 7$ of Prophet 1760 (Regulus 173\%) - Virago 1764 by Snap 1750 (Snip 1736)-Dau. of Regulus 1739 (God. Ar. 1724 ).

Parasol, Pot-8-o-'s 1773 (Eclipse 1;64)-Prunella 1788 by Highflyer 16i4 (Herod 1758)-Promise 1768 by Snap 1750 (Suip 1736)-Julia 1756 by Blank 1740 (God. Ar, 1724)-Spectator's dam 1735 by Partner 1718 (Jigg).

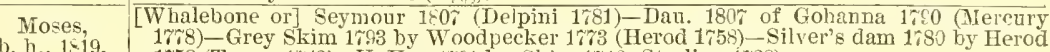

b. h., 1819 . 1758 (Tartir 1743) - Y. Hag 1761 by Skim 1746 (Starling 1728)

Quadrille, Selim 1802 (Buzzard* 178j)-Canary Bird 1806 by [Whiskey or] Sorcerer 1\%s6 (Trum-

1815 pator 1782)-Canary 1797 by Coriander 1786 (Pot-8-o-'s 17i3)-Miss Green 17s7 by Highflyer $1 \% \div 4$ (Herod 1758 )-Harriet 1769 hy Natchem 1748 (Cade 1734 ).

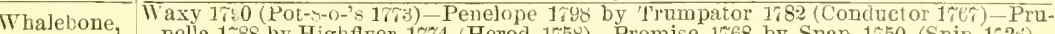

br, h., $180 \%$, nella 178s by Highflyer 1774 (Herod 1758) - Promise 1768 by Snap 1750 (Snip 1730)Julia 1756 by Blank 1740 (God. Ar. 1721).

(-)

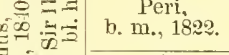

$>$ च $\quad$ Emilius,

1800 ber 1811 (Gohanna 1,90)-Thalestris 1809 by Alexander 1\%82 (Eclipse 1\%C4)-Rival

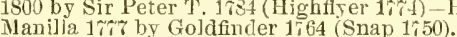

Orville 1799 (Bening crough 1791)-Emily 1810 by Stamford 1794 (Sir Peter T. 178i)-Dau.

1799 of Whiskey 1789 (Saltram*1780)-Grey Dorimant 1781 by Dorimant 1 \% (Otho 1760)-Dizzy 1757 by Blank $17 \div 0$ (God. Ar. 1724)

J Danghter of, [Scud or] Pioneer 1804 (T) Tiskey 1789)-Canary Bird br. m. 1806 by [Whiskey or] Sor'cerer

- b. m., 1820. 1796-Canary b. m. 1797 by Coriander 1786 (Pot-8-o-'s 1773) - Miss Green b. m. 178\% by Highflyer 17\%4 (Herod 1758)-Harriet b. m. 1 r69 by Matchem 1748 (Cade 1734)-Flora. b. m. 1749 by Reguliz 1739 (God. Ar. 1724)-Dat. of Bartletr's Childers (Darley Ar.

1699)-Dau. of Bay Bolton 1705 (Grey Hautboy)-Dau. of Belgrade Turk. 


\section{SALVATOR.}

WINNER OF THE TITAN, MAPLE, REALIZATION, LORILLARD, CHAMPION AND TIDAL STAKES, THE SUBURBAN HANDICAP, ANU OTHER PROMINENT EVENTS.

\section{Property of J. B. Haggin, Rancho-del-Paso Stud, Sacramento, Cal. Yearlings sold annually.}

Salyator, chestumt horse, fonled 1886, bred in the Elmendor î Stud, Ky., brimp. Prince Charlie, son of Blair Athol by Stockwell, dam Salina, dam of Danicheff, Duchess, etc., br Lexington, ont of Lightsome, dam of Nevada (Lnke Blackburn's (lam), Crucifix (Semper Felix's dam), Sprightly. (Volturno's dam), etc., by imp. Glencoe, tracing througl Levity by imp. Trnstee to Vandal's dam by imp. Tranby. Salvator is descended from one of the grandest racing and best prodncing families in the world. From it hare come the grand race-horses and stallions Lexington (four miles in 7.19: and 7.23:), Vandal, the best son of imp. Glencoe, Alaric, Ruric, Lever, Monitor, Volturno, Longstreet, The Bard, Monarchist, Aretino, Lnke Blackburn, Tom Martin, Strathmore, Duke of Montrose, etc.

Salvator was a first-class race-horse. At two years old he won forr rhees ont of six in which he started, ran second to Proctor Knott in the Futurity Stakes, three-

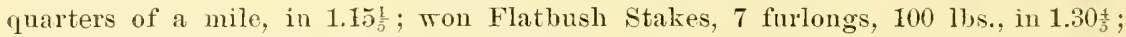
Maple Stakes, three-quarters of a mile, 120 lbs., in 1.17妾; Tuckahoe Stakes, Jerome Park, 1,400 yards, $120 \mathrm{lbs}$, in 1.24; Titan Stakes, 1,400 sards, $117 \mathrm{lbs}$, in 1.223. At three years old won seven out of eight races in which he started. Won the Tidal

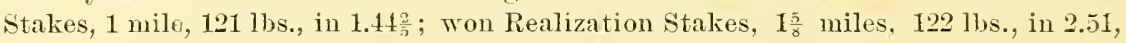
Tenny, Long Dance, Longstreet and five others behind him; won Lorillard Stakes, $1 \frac{1}{2}$ miles, 118 lbs., in 2.37 $\frac{1}{2}$, Longstreet, Centanr (Farerdale colt) and five others bebind him; was third to Longstreet $118 \mathrm{lbs}$., and Proctor Knott, $120 \mathrm{lbs}$, in the

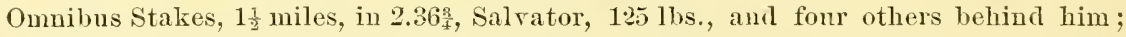
won the Jersey. Handicap, $1 \frac{1}{\frac{1}{4}}$ miles, 124 lbs., in $2.10 \frac{3}{1}$, nine others behind him; won September Stakes, $1 \frac{33}{4}$ miles, $129 \mathrm{lbs}$, in $3.05_{5}^{2}$, beating J. A. B. and Sorrento: won Sweepstakes, $1 \frac{1}{16}$ miles. 127 lhs., in $1.59 \%$; won purse, $1 \frac{1}{16}$ miles, 113 llss., in 22.01. At four years old won all his races. Won the Suburban Handicap, $1 \frac{1}{ \pm}$ miles, 127 lbs., in $2.06_{5}^{4}$, Cassins, 107 lbs., second, Tenn5, 126 lbs., third, Reclare, Prince Royal, Longstreet, Firenzi, Raceland and others behind him; won the match against Tenny, each carrying 122 lbs., $1 \frac{1}{4}$ miles, in 2.05 ; walked over for Monmouth Cup, $1 \frac{8}{4}$ miles; won the Champion Stakes, $1 \frac{1}{2}$ miles, beating Tenns, each $122 \mathrm{lbs}$., in $2.35 \frac{1}{2}$; won the purse of $\$ 2,500$ to beat the best time on record, $1.39 \frac{1}{4}$, earrying $110 \mathrm{lbs}$; he ran the clistance in $1.35 \frac{1}{2}$, the fastest and best mile ever $\mathrm{rm}$ in the world. He retired from the turf solind.

Salina, the dam of Salvator, was a good race mare. Won the Monmouth Oalks, Continental Hotel Stakes, and the Robins Stakes, 2 mile heats, Bugaman Stakes, and other good races. Prince Charle his sire, was the Prince of the two-rear old course, and combines in his perdigree all the most desmable strains of blood, Stockwell, Touchstone, Molbonrne, and Priam through Crneifix. He must be a snecess in the stud.

He is decended in direct female line through old Montagu mare from the Royal mare, to which traces Contuctor, O'Kelly's Echpse. Filho-da-Pnta, Veltaire, Sterling, Oxford, Springfield, Marsyas, Adventurer. Prince Charlio, Lexington, Vandal, Monarehist, Tolturuo, Luke Blacklunrn, Salvator, The Bard, Strathmore, Tom Martin, Grinstead, Duke of Montrose, Potomac, Tenny, and other noted horses from the Duchess family. 


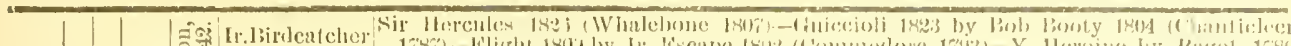

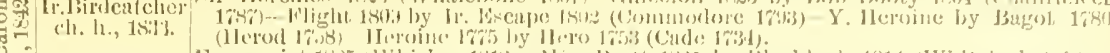

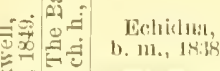

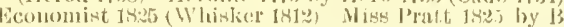

b.

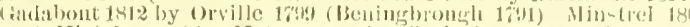

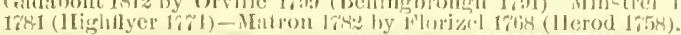

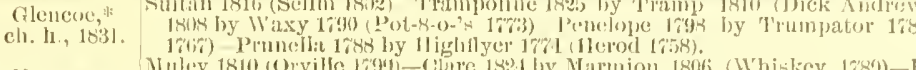

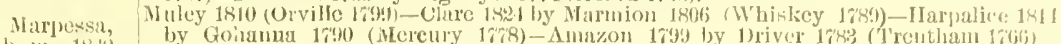

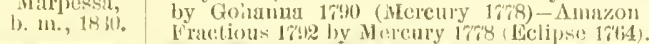

llumprey Comus 180! (Sorcerer 17!6)-Clinkerima 181:3 by (linker 1805 (Sir l'eter T' 1288)-1'ew

b. 11., 1 , $4: 2$ :

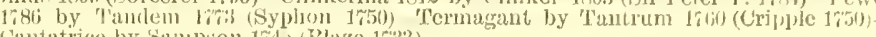

Cantatice by Sampson 174.) (Blaze 17\%3).

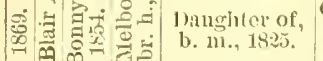

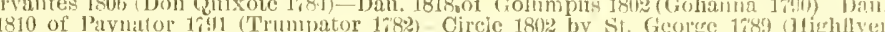
17i1) Abigail 16R8 by 11 oodpecker 1763 (Herod 1758).

Cradiator,

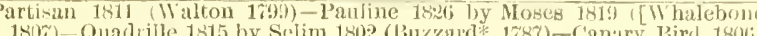

Daughter of,

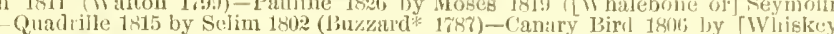

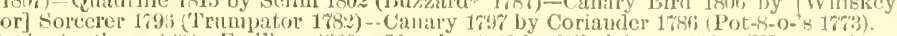

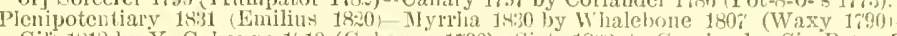

b. w., 1840 . Gilt 1818 by Y. Gohamlia 1s]0 (Gohanua 1790) Sist. 1802 to Grazier by Sir Peter T.

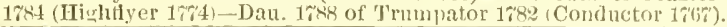

Camel, Whalebone 1807 (Waxy 1\%y0-Dan. 1812 of Sclim 1802 (Buzzard 1787) Haiden 1x01 hy b1: h., 18:2.

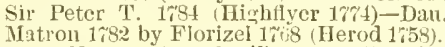

Banter, Master 1Ienty 1815 (Orville 1795)-Boadicea 180\% by Alcxander 1\%89 (Eclipsc 1764)-

br. m., 1825. Brunctic by Amaranthus 1766 (Oir England 1\%41)-Maylly $17 \% 1$ by Matchem 1748 (Cade 1734)-Dau. 1755 of Anc. Starling 1738 (Starling 179\%).

Priam, Em Emilius 18:30 (Orville 1793)-Cressida 1807 by Whiskey 1789 (Saltram 1780)-Y. Giantess

b. h., 182\%. 1790 by Diomed* $17 \% 7$ (Florizel 1768)-Gianles: 1769 loy Matchem 17ts (Cade 1734)Molly Long Legs 1753 by Babraham 1740 (God. Ar. 1r24).

Octaviana, Octavian 1807 (Stripling 1795)-Dau. 1807 of Shuttle 1793 (Y. Marske 17r1)-Zara 1801 by Delpini 17s1 (Highflyer 17\%1)-Flora 1789 by King Fergus 17\% (Eclipse 1764)-Atalanta 1769 by Ilatchem $1 \% 49$ (Cade 1734 ).

Slane, Royal Oak 1823 (Catton 1809)-Dau. 1819) of Orville 1799 (Beningbrongh 1791)-Epsom

h., 1833. Lass 1803 by Sir Peter T. 1784 (Highllyer 17\%4)-Alesina 1788 by King Fergus $17 \%$ (Eclipse 176t) -Lardella 1789 by Y. Marske 17\%1 (Marske 1750).

Palmyra, Sultan 1816 (Selim 1802)_Hester 1832 by Camel 1822 (Whalebone 1807)-11onimia 1821 br. nl., 1838. by Muley 1810 (Orville 179) - Sist. 1796 to Petworth by Precipitate* 178\% (Mercury 17781-Dan. 178\% of Woodpeckel 17rm (1lerod 1758).

Glaueus, Partisan 1811 (Walton 1799)-Nanine 1823 by Selim 1802 (Buzzard\% 1787)-Bizarre 1811 $\begin{array}{ll}\text { b. h., 1830. } & \text { by Peruvian } 1806 \text { (Sir Peter T. 1784)-Violante } 1802 \text { by Johu Bull } 1789 \text { (Fortitude } \\ \text { 17\% -Dan. } 1789 \text { of Highflyer 1\%t (Herod 1758). }\end{array}$

Io, Taurus 1823 ([Phantom or] Morisco 1819)-Arethissa 1824 by Qniz 1798 (Buzzard*

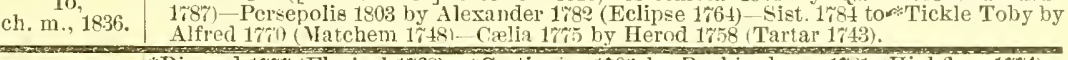

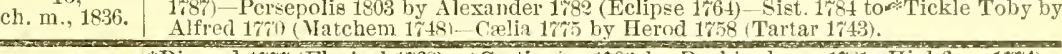

åci Sil Archy

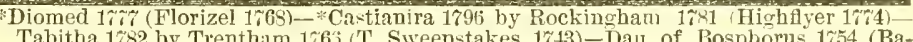

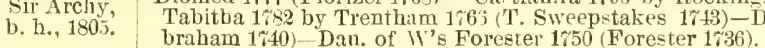

braham 140)-Dan. of h's Folester 1750 (Forester 1736).

Daughter of,

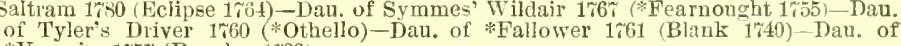
*Vampire 175\% (Regulus 1,39).

5ำ Diomed 1\% (Florizel 1\%68)-1)au. of *Shark 1\%il (Marslie 1750)-Dau. of Harris Eclipse 1770 (*Fearnought 1755)-Dau. o1 *Fearnought 1755 (Regulus 1739)-Dau, of *Jolly Roger 1741 (Rommithead 1783).

(1) 1801

Daughter of

* Aiderman 1787 (Pot-8-0-'s 17:3)-Dai

Syman 1787 (Pot-8-0-'s 17,3)-Dau. of *Clockfast $17 \% 4$ (Gimerack 1760)-Dau. of Symmes' Wildair 1767 ( Fenrnol1ght 1755)-Y. Kitty Fishel 1767 by *Fearnought 1755 (Regulus 1739) - Kitty Fisher 1755 by Cade 1794 (God. Ar. 1724).

-

Orville 1799 (Beningbrough 1791)-Emily 1810 by Stamford 1r91 (Sir Peter T. 17S4)

Emilius,
b. L., 182).

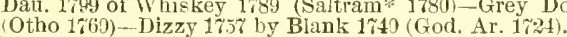

The Flyer 1814 (Vandyke Jr. 1808)-Parma 1813 by Dick Andrews $179 \%$ (Toe Andrews

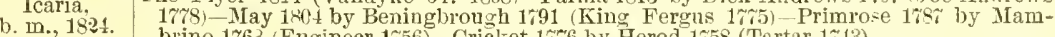
blino 1763 (Engineer 1756)-Cricket 1766 by Herod 1758 (T) rtar 1743 ).

Sumpter Sir Archy 1805 (*Diomel 1\%\%)-Dan. of *Robin Redbreast $1 \% 96$ (sir Peter T. 1784)-

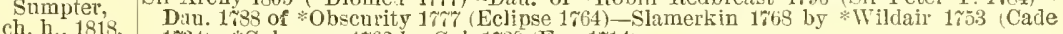
1734 - $* \mathrm{Cub}$ mare $1762 \mathrm{br}$ Cub 1739 (Fox 1714 ).

Lady Grey, Robin Grey 1805 (*Royalist 1790-Maria 1802 by Melzar 1791 (*Iedley 1 1\%6) - Dan. of

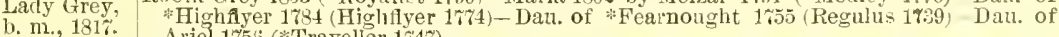
Ariel 175 ; (

Selim, Buzzard 1787 (W oodpecker 1\%3)-Dau. of Alexander 1782 (Eclipse 1664) Daul of Hichflyer 1\%4 (Herod 1\%5)-Dau, of Alfred 1\%\%0 (yatchem 1\%18)-Dau. 1\%60 of Engineer 1756 (Sampson 1745 ).

ch. h., 1802 .

Bacchante, W's Ditto 1800 (Sir Peter T. 1\%84)-Dau. 1791 of Mercury $1 \%$ (Eclipse 1;6t) -Dau. 1;i6 br. m., 180. .

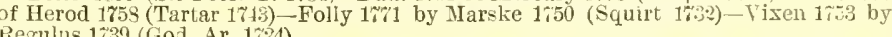
Regulus 1739 (God. Ar. 1724).

Dick Andrew 1797 (Joe Andrews 17\%8)-Dau. 1803 of Gohanna 179) (Mercury 1768) -

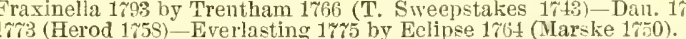

b. h., 1810 .

Vaxy 1730 (Pot-8-0-8 $17 \% 3$ ) - Penelope 1rigzby Trumpator 1783 (Confilcto

Web,

175 bighflyer 174 (Herod 1758)-Promise 1708 by Snap 1750 (Snip 1736)-Julia 1756 by Blank 174) (God Ar. 172 ).

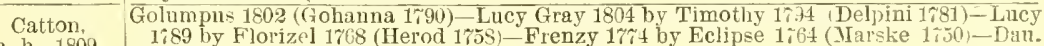
1;89 by Florizel 1768 (Herod 1753)-Frenzy $17 \% 4$ by Eclipse 1;64 (Marske 1\%50)-Dau.

of Engineer 1756 (Sampson 1745 ).

Emma,

( flyer 1800 by Pipator 1786 (Imperator $176^{6}$ )-Beatrice

ch. m., 1824 .

Blacklock 1814 (Whitelock 1803)-Dnu. 1 -D12 of Orville 1799 (Beninghrough 1;e1) _ Jiss

Tranby, Grimstone 160 by Weazle 17\%6 (Herod 1758)-Dau. of Ancaster 1768 (Blank 1110)Dall. of Damascus Ar. 164 .

Lucilla, Trumpator 1823 (Sir Solomon 185)-Lucy b. m. 1820 by Orphan 1810 (Ball's Florizel 1801) Trumpator 1823 (Sir Solom on 185 ) - Lucy b. m. 1820 by Orphan 1810 (Buil's Florizel 1801)
- Lady Grey b. m. 1817 by Robin Grey 1805 (*Royalist 1790)-JIaria 1802 by Melzar 1791 - Lady Grey b. m. 1817 by Robin Grey 1805 (*Royalist 1790)-Jiaria 1802 by Melzar 1791 (Regulus 1739 )-Dau. of Ariel 1756 (*Truveller 1\% 1 \%)-Dan. of Jack of Diamonds (Cu]-

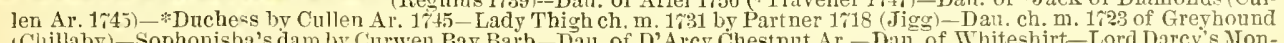
(Chillaby) -Sophonisba's dam by Curwen Bay Barb-Daw, of D'Arcy Chestnut Ar.-Dan. of II hiteshirt-Lord Darcy's Montagu mare by Old Montagu-Dau, of Hautboy (D'Arcy White Turk)-Dau. of Brimmer (D'Arcy Iellow Turk)-Royal mare. 


\section{SENSATION.}

WINNER OF THE JUVENILE AND NURSERT STAKES AT JEROME PARK, JULY, CRITERION AND ACGUST STAKLS AT MONMOUTH PALK, SARATOGA AND FLASII STAKES AT SARATOGA, AND CENTRAL STAKES AT BALTLIORE, 1879.

\section{Sensation is private stallion in the Rancocas Stud, Mr. P. Lorillard, proprietor, Jobstown, N. J.}

SExsatrox by imp. Leamington, son of Faugh-a-Ballagh, bred by Mr. A. Weleh, Erdenheim Stud, Pa., foalea 1877, dam Snsan Beane, dam of Stratford, Susquehanua, Onondaga, ete., by Lexington, son of Boston, ont of Sally Lemis, dam of John Morgan, Hunter's Lexington, Aerobat, ete, by imp. Glencoe. Sensation was truly the sensation of his.two-year old rear. Started eight times and won all of his races. Jerome Park, May 31, won the Juveuile Stakes, half-mile, defeating Ethel and nine others, time, 0.50. Monmouth Park, July 8, non the July Stakes, 5 furlongs, defeating his stable companions, Grenada and Rosalie, who finished respeetively seeond and third, and ten others, time, 1.07. Saratoga, July 22, won the Flash Stakes, half-mile, Grenada and Rosilie again finishing second and thixd, five others behind them, time, 0.498; same meeting, July 29, won the Saratoga Stakes, three-quarters of a mile, defeating Grenada, who finished seeond, Beata, Glidelia, Giroflé and 13̧̌-and-By, time, 1.18. Mommonth Park, Aug. 23, won the Angnst Stakes, three-quarters of a mile, defeating Grenada, who ran seeond, azd seven others, time, $1.18 \frac{1}{2}$; sane meeting, Aug. 26, won the Criterion Stakes, three-quarters of a mile, earrying 5 lbs. penalty, and defeated Grenada, second, and fire others, time, 1.22, track slow and heary. Jerome Park, Oct. 2, wou the Nursery Stakes, three-quarters of a mile, defeating Ferneliff, Grenada and four others, time, 1.1\%. Baltimore, Oct. 23, won the Central Stakes, 1 mile, defentiug Grenada and Oden, time, 1.50 $\frac{1}{4}$. Total wimnings for the year, 320,250 . He met aurl defeated all the best two-year olds of his year, wimning from a half to one mile. He bursted his foot in the spring of 1880 , which eompelled his retirement. He is from one of the great racing families of the comntry. Acrobat and Hunter's Lexington, full brothers to his dam, were fine race-horses and conld stay a distance. John Morgan, a half brother, was also a snperior race-horse, and. for his ehanees, a rery suceesstul stallion. Hotto, Namuie Lewis, Alchebaran were all grood ones. Glenmore is also firom the same family, and his dam traces baek to the dam of the great race-horse Medoc, who was the most suecessful sire in any day on all sorts of mares. Sensation is a brown, full 16 hands high, with a white stripe down his fice and a little white on the pastern of his left fore leg. He has a fine, wellplaced shoulder and is symmetrieally formed all over, with faultess action and gool temper. Being a son of Leamington and tracing to a raeing famils, and an uncommon fine race-horse, he is a suceess in the stud. He has the Dautaloon and Whalebone erosses on the sire's side, and the Gleneoe on the dam's, with the blood of sir. Archy and Diomed throngh its best somees.

Sensation has been user very little in the stnd. bnt is the sire of the following wimners: Banker, Carrie C., Lord Fanntleroy, Loantaka (wimer of the Suburban Handicap), Centaur (Faverdale colt), Iy Own, Guaruntee, Queen Elizabeth, Specialty, Raymond, Salviui, Chemise, Flitaway, Satisfaction, Prince George, samnterer, Comnt, Sentiment, Tenletta and others.

Sensation traees to the sane Royal mare thromgh oll Montagn mare to which trace in lirect female line Condiuctor, Eclipse, Sterling, Weather-hit, Oxforl, Fingston, Seottisl Chief, Alrenturer, Lexington, Vandal, Leonatus, Salvator, Onondaga. Stratford and all the Duchess family. 


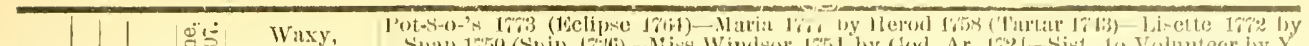

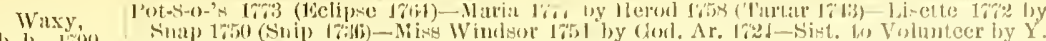

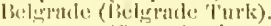

-

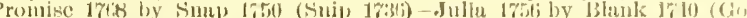

$(1,0,1)$

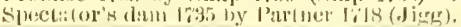

II anderer.

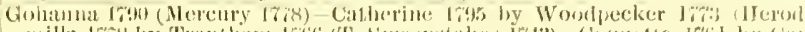

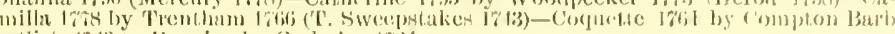

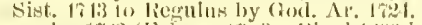

a

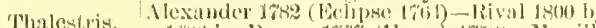

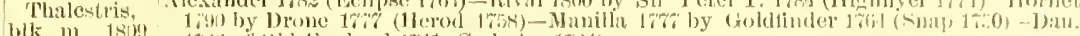

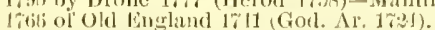

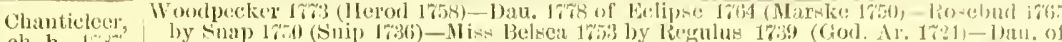
ch. h. bartleti's Childers (Warley Ar. 16iYs)

Ferne,

ch. m.. lian.

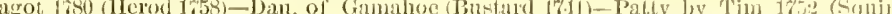

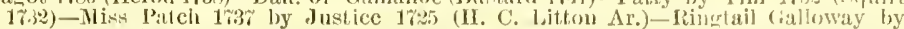
Cuiveu B:1y Batb.

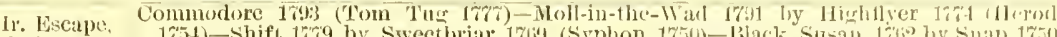

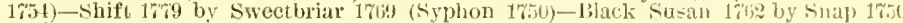

ch. h., 18 de. (Suij) 1736) Dau. of Cade 1731 (Cod. Ar. 1\%2.1).

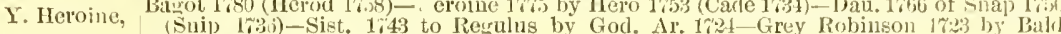
Galloway (St. Viclor Barb).

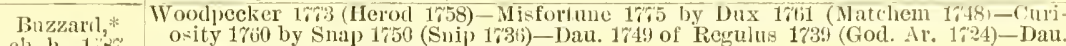
of Bartlett's Chihters (Darley Ar. 16\%)

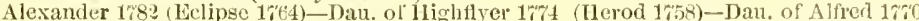

Daughter of, (Natchen 1748)-Dau. 17\%0 of Engineer 1756 (Sampson 1745)-Bay Malton's daw 175f;
b. m., -.

b. m., -. (Matchem 1748)-Dau. 1770 of Engincer 1750 (Sampson 1745)-Bay Malton's dam 175f)

Peruvian,

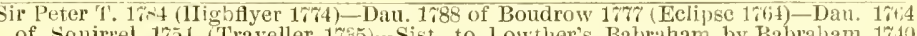
of squirrel 151 (Traveller 1755)-Sist. to Lowther's Babraham by Babraham 1710 (God. Ar. 1721)-Dizu. 1750 of Golden Ball 1785 (Partner 1718)

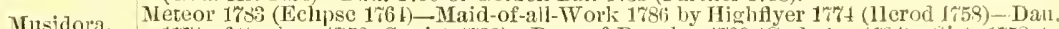

1r\%1 of Syphon 1750 (Squirt 1732)-Dau. of Regulus 1739 (God. Ar. 1726) - Sist. 1758 to Jurlgement by Snip 1730 (Flying Childers 1;15).

Blacklock, Whitelock 1803 (Hambletoniau 1792) Dau. 1799 ol Coriander 1736 (Pot-8-0*'s 1783)

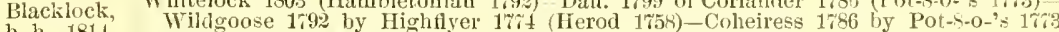
(Eclipse 1764)-Manilla 17\% by Goldfinder 1\%64 (Suap 17\%0)

Wartail Prime Minister 1810 (Sancho 18001)-Tranby"'s dam 1812 by Orville 1 cog (Beninghrough

b. m., 1818 .

Champion, Selim 1802 (Buzzard* 1787) Podagra 1605 by Gouty 179, (Sir Peter T. 1784) -Jet Ir8

ch. h., 1812 .

Etiquette, Orville 1799 (Beningbrough 1791)-Boadicea $180 \%$ by Alexander 1\%82 (Eclip) 1\%C4)-

Brunette by Amaranthms 1766 (Odd England 17t1)-Mayfly 1761 by Matchem $17 \pm$ (Cade 1731)-Da:1. 1\%55 of Starling 1 \%38 (Starling 172\%).

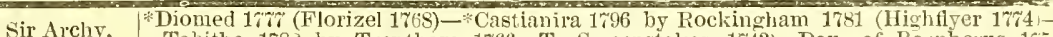

b. h., 1805. Tabitha 1783 by Trentham 1766 ('T. Sweepstakes 1743)-Dau, of Bosphor'us 175t (Babraham 1749)-Dau. of Forester 1750 (Forester 17:36).

Daughater of, "Saltram 1780 (Eclipse 1764)-Dan. of Symmes Wildair 1767 (*Feamought 1755)-Dan. *Vampire 175r (Regulus 1739).

1.

ch. m., -

ch. h., 1801.

Diomed $17 \% 7$ (Florizel 1\%68)-Dau. of *Shark 1771 (Marske 1750)-Dau. of Halris"

Eclipse $17 \%$ ("Fearnought 1755)-Dau. of Fearnought 1755 (Regulus 1739)-Dau. of *Jolly Roger 17+1 (Romidhead 1738).

Daughter of, "Alderman 1787 (Pot-8-0-'s 1r/3)-Dau. of *Clockfast 17\%4 (6imcrack 1760)-Dau. of

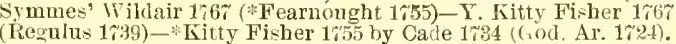

b. m., 1799.

Emilius,

b. h., $18: 0$.

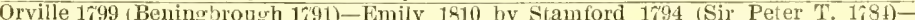
Dat. 1799 of Whiskey 1789 (Saltram* 1783) - Grey Dorimaut 1781 by Dorimaut $17 \%$ (Otho 1\%60)-Dizzy 1\%5 by Blank $1 \% 40$ (God. Ar. 1\%2t).

Tcaria The Flyer 1814 (Vandyke Jr. 1808)-Parma 1813 by Dick Andrews $179 \%$ (Joe Andrews 1778)-Nay 181$) 4$ by Beningbrongh $1 \% 91$ (King Ferous 1\%5)-Primrose 176 by Mambrino 1764 (Engineer 1751) - Cricket 1\%i 6 by Herod 1758 (Tartar 1743).

b. m., 1824.

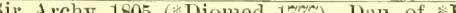

(Sir Peter. T, 1 104 )

ch. b., 1518. Tau. 185 of \%obeurity 17\% (Ecipse 1764)-Slamerkin 1768 by *Wilclair 1759 (Cade 1734) *Cub mare 1762 by Cub 1739 (Fox 1711).

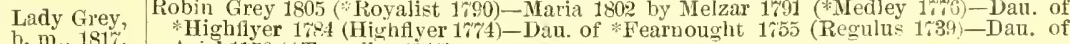

b. m., 181\%. Ariel 1756 (*Traveller 1\% $1 \%$ ).

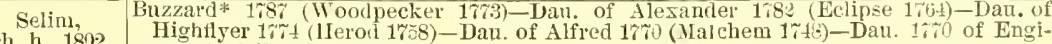

ch. h., 1892.
neer 1756 (Sampson 1745).
W's Ditto 1800 (Sir Peter T. 1784)-Dan. 1791 of Mercury 1\%8 (Eclipse 1\%64)-Dan. 1\%6

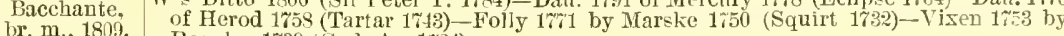
Regulus $1 \% 39$ (God. Ar. 1\%24).

Tramp, Dick Andrews 17\% (Joe Andrews 1778)-Dau. 1803 of Gohanna 1790 (Mercury 1\%s)-

b. h., 1810

Frasinella 1793 by Treutham 1766 (T. Sweepstakes 1742$)$-Dat. 1785 of Woodpecker $17 \% 3$ (Herod 1758) - Everlasting 1\%\%5 by Eclipse 1764 (Marske 1750).

Web, Wary 1790 (Pot-8-0-'s 17\% - Penelope $1 \% 93$ by Trumpator 1782 (Condnctor 1\%6\%)-Prunella

b. m. 1808. 1 288 by Hightlyer $17 \% 4$ (Herod 1758)-Promise 1768 by Snap 1750 (Snip 1736)-Jnlia 1756 by Blank $17^{4} 0$ (God Ar. 1\%21).

Tramp,

Dick Andrcws 1797 (Joe Andrew

b. h., 1810 .

Firins 17\%8)-Dau. 1803 of Gohanna 1790 (Mercury 17,8)17:3 (Herod 1758)-Everlasting 175 by Eclipse 1764 (Marske 1750).

Buzzard $178 \%$ (Woodpecker $17 \%$ ) - Roseberry 1792 by Phenomenon 1780 (Herod 1\%58)Miss West $17 \% 7$ by Matchem 1748 (Cade 17?4) - Sist. to Favourite by Regulus 1739 (God. Ar. 1724-Y. Ebony 1742 by Crab 1722 (Alcock Ar.)

Duroc 1806 (*Diomed 1\% - Miller's Damsel 1802 by * Jessenger 1180 Mambrino $1^{\prime \prime}(68)$ - Mare 1792 by Pot-8-o-'s $17 \% 3$ (Eclinse 1764)-Dau. 17\% of Gimeruck 1760 (Cripple 1750) - Snapiragon 1759 hy Snap 1750 (Snip 1736).

ch. h., 1814

Ogle's Oscar 1800 ( Gabriel 1740)-Y. Maid-of-the-Oaks ch. m. 1817 by sExpedition 1795 (Pegasus 1784)-Maid-of-the-Oaks ch. m. 1801 by *Spread Eagle 1792 (Volunteer 1780)-

Tive Whig (Fitzhagh's Regnlns 16(5)-Dau. of Gallant 17\%0 (*Fearnought 1755)-Dau.

Katy Ann,
ch. m., 1825 . of *Regulus $171 \%$ (Regulns 1739)_*Duchess by Cullen Ar-Lady Thigh ch. m. 1731 by Partner 1718 (Jigg)-Dan.ch.m. 1723 by mare by D'Arcy's old MIontagu-Dau.of Hautboy(D'Arcy White Turk)-Dau.of Brimmer(D'Arcy Yellow Tulk)-Royal mare. 


\section{IMPORTED SIDDARTHA.}

The property of Dr. A. W. MLAlester, Columbia, MIo. Terms anmally. Yearlings sold anmually.

Siddintha, bay horse, foaled 1880, bred by Mr. W. I'Anson, by Pero Gomez, son of Beadsman, sire of Blue Gown and other good ones. Pero Gomez was beaten a head in the Derby by Pretender, and beat him in the St. Leger, whieh he won. Pero Gomez is the sire of Pontiac, Merrythonght, Gil Blas, Harbinger, Hidalgo, Espada, Titania, ete. Siddartha is out of The Pearl, the dam of Selby, winner of the Great Yorkshire Handieap, 1=86, by Newninster, sire of the noted Hermit. He is from the grandest raeing family in England. Caller Or, his grandam, won 31 Queen's Plates, the Doncaster St. Leger and the Brighton and York Cups. Blink Bonns, ont of Qneen Marf, won the Derby and Oaks and was the dam of Borealis, Blair Athol (winner of the Derby and St. Leger), and Breadalbane (wimner of the Prince of Wales and Gratwicke Stakes). Other famous winners in the family are Sir Berys (winner of the Derby), Hampton (winner of the Epsom Gold Cup, Doneaster and Goodwood Cups and Goodwood Stakes), Broomielaw (winner of the Dee Stakes and Chesterfield Stakes), Blinkhoolie (winner of the Ascot Gold Vase and Alexandra Plate), Freeman (winner of the Great Northern Handieap twice, Goodwood Stakes, Chesterfield Cnp and Alexandra Plate), Good Hope (winner of the Viennia Derby), Beanclere (winner of the Middle Park Plate). Thrift, the dim of Tristan, for which $\$ 50,000$ was refused, is from the same fimily. The family is potent in great race-horses, prolifie brood mares and suecessful sires. The colts by Siddartha are said to be the liest their dams ever produced. Siddartha never raced, but Mr. Jacob Pinens, who trained him. says he was a very speedy, good race-horse.

Siddartha is the sire of the winners Crispin, Joe Walton, Sid, Gracie, Edl. Dougherty, Chauntress, Millie R., ete. He has had little or no chance in the stud, but is a symmetrieally formed horse and descended from one of the grandest and best raeing and producing families in the world, and must sneceed in the stud.

He traces in direct female line to the Childers mare, to which trices Postmaster (by Herod), Bustard (by Buzzarl), Aimator, imp. Balrownie, imp. Bonnie Scotland, Hampton (by Lord Clifilen), Blair Athol, Breadalbane, Pretender, Sir Berss, Tristan, Carlton, Crafton, imp. Bernice and Belladonna, and all the Queen Mary fimily in England; Aurora Raby, Bill Bruce, Atilla, and all the imported Peggy family in America. 


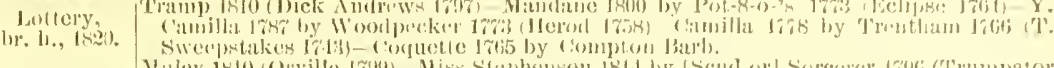

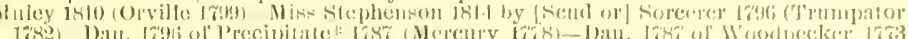

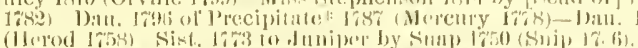

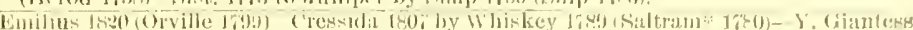

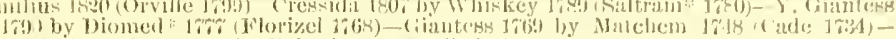

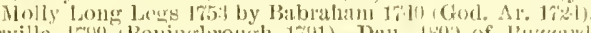

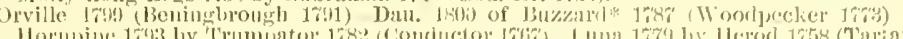

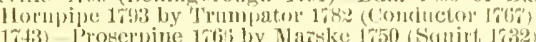

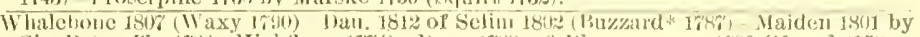

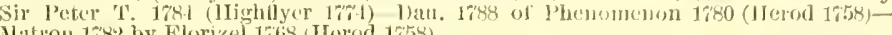
Matron 1782 by Florizel 1768 (Iferod $175 \mathrm{~S}$ ).

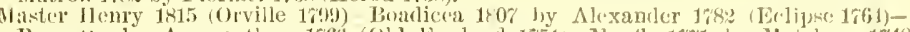

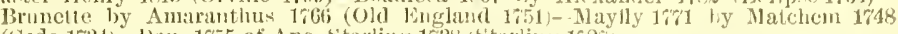
(cade 1754)- I)an. 1755 of Anc. Starline 1734 (Starline 172

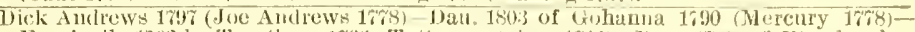
Fraxinella 1793 by 'Trentham 1766 (T. Nweepstakes 17t3) bau. 175is of lloodjecker $17 \% 3$ (Herod 1758 - Everlasting $17 \% 5$ by Eclipic 1764 (Mareks 1750$)$.

Bustard 1813 (Castrel 1801)-Oiympia 1815 by Sir Oliver 1400) (Sir jeter 'T? 1784)-Sco-

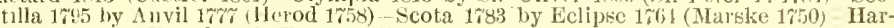
mony $17 \%$ hy Herod $1 \% 58$ (Tartar 1\%43).

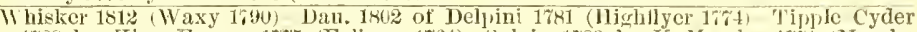
1788 by King Fergus 17r5 (Eclipse 1764)-Sylvia 1783 by Y. Marske 1771 (Marske 1750)-Ferret 1 \%65 by Broth. to Silvio (Cade 1731).

\& Camel 1822 (Whalebone 180\%)-Monimia 1821 by Muley 1810 (Orville 1799)-Dan. 1796 of Precipitate\$ 1787 (Mercury 1\%78)-Dan. 1787 ol Woodpecker 1\%'3 (Herod 1758)-Sist. 17 ro to Juniper by Snap 1750 (Snip 1736).

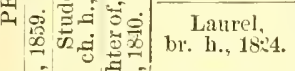

Blacklock 1814 (Whitelock 1803) - IVagtail 1818 by Prime Minister 1810 (Sancho 1801) Tranby*'s dam 1812 by Orville 1799 (Beningbrough 1791)-Miss Grimstone 1796 by Weazle 1\%to (Herod 1758)-Dau. of Ancaster 1768 (B]ank 1\%40).

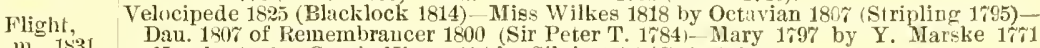
(Hal'ke 1\%59)-Gentle Kitty $17 \% 4$ by Silvio 1754 (Carle 173i).

Tomboy, Jerry 1821 (Numolenstio 1810)-Dau. 1817 of Ardrossan 1809 (John Bull 1784) Lady Eliza

b. h., 18\%;. 1813 by Whitworth 1805 (Agonistes 1797)-Dan. 1793 of Spadille 1784 (Hightlyer 1764)-Sylvia 1753 by Y. Markke 1 rin (Marske 1ri50).

Lady Moore Tramp 1810 (Dick Andrews 1797). Kite 1821 by Bustard 1813 (Casirel 1801)-Olympia 1815 by Sir Oliver 1800 (Sir Peter T. 1784) - Scotilla 1795 by Anvil 17\% (Herod ir58)Carew,

b. m., 18:0. Scota 1783 by Eclipse 176! (Narske 1750)

Sultau 1816 (Selim 1802)-Cobweb 1821 by Phantom 1808 (Walton 1799)-Filagree 1815 by Soothsayer 1808 (Sorcerer 1796)-Web 1808 by Waxy 1790 (Pot-8-o-'s 17i3)-Penelope 1798 by Trumpator 1782 (Conductor $1 \% 6 \%$ ).

Blne Devi]s, Velocipede 1825 (Blacklock 181 ) C Care 1825 by Woful 1809 (Waxy 1790)-Dau, 1819 of Rubens 1805 (Buzzard* 1787) - Tippitywitehet 1808 by Waxy 1790 (Pot-8-0-"s 17\%3)Hare 1794 by sweethriar 1769 (Syphon 1750 ). Whalebone, Waxy 1790 (Pot-8-o-'s 1773)-Penelope 1798 by Trumpator 1782 (Conductor 1766)-Pru-
mella 1788 by Highflyer 1744 (Herod 1758)-Promise 1768 by Snap 1750 (Snip 1736)Julia 1756 by Blank 1740 (God. Ar. 1724)

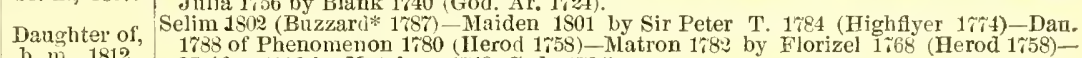
Haiden $17 \% 0$ by Matchem 1748 (Cade 1731).

Orville 1799 (Beningbrough 1791) - Miss Sophia 1805 by Stamford 1791 (Sir Peter T. 1784) Sophia 1798 by Buzzard* 1787 (Woodpecker 17\%3)-IJuncamunca $178 \%$ by Highflyer 1 tit (Herod 1758)-Cypher 17\%2 by Squirrel 1654 (Traveller 1,35)

Alexander 178: (Eclipse 1\%64)-Brunette by Amaranthus 1766 (Old England 1741) -

Boadicea,
b. m., 180\%.
Mayfly $17 \% 1$ by Matchem 1748 (Cade 1734)-Dau. 1755 of Starling 1788 (Starling
172\%)-Look at-me-Lads 1731 by Grasshopper (Byerly Turk).

Moadicea, m., 180\%.
172\%)-Look at-me-Lads 1\%31 by Grasshopper (Byerly Turk). Paynator, Trumparor by Snap 1750 (Snip 1'736)-Miss Windsor 1754 by God. Ar. 1624 - Sist. to Tolunteer by Y. Belgrade (Belgrade Turk).

Beningbrough 1791 (King Ferous 1\%5)-Jenny Mole 1\%si by Carlonncle 1\%2 (Babr. Blank 1755) Dau. 1773 of Frince T'Quassaw 1751 (Snip 1736)-Sultana 1759 by Regulus 1739 (God. Ar. 1724)-Dau. of Partner 1718 (Jigg). Timbleton 1785 by Everoreen 1769 (Herod 1758)- Volunteer 1780 (Eclipse 1764) 1743)-Teresa 1767 by Matchem 1748 (Cade 1734 ).

Tady Eliza, Whitworth 1805 (Agonistes 1\%9\%)-Dau. 1293 of Spadille 1784 (Highflyer 1\%4) - Sylvia Lady Eliza, 1783 by Y. Marske $17 \% 1$ (Marske 1750)-Ferret 1765 by Broth. to Silvio (Cade 1734)-
b. m., 1813. Dau. of Regulus 1739 (God. Ar. 1721).

Ẽ Ir Birdcatcher Sir Hercules 18:36 (Whalebone 180\%)-Guiccioli 1823 by Bob Booly 1801 (Chanticleer

传 178') -Flight 1809 by Ir. Escape 180:2 (Commodore 1793)-Y. Heroine by Bagot 1780 (Herod 1\%58)-Heroine $17 \% 5$ by Hero 1753 (Cade 1734) Economito -Heroine 175 by Hero 1733 (Cade 17s4). Gildabout 1812 by Orille 1799 (Beningbrough 1791)-Min=trel 1803 by Sir Peter T. 1784 (Highflyer 17\%1)-Hatron 1782 by Florizel 1768 (Herod 1'5s).

Sultan 1816 (Selim 180z)-Trampoline 18:5 by Tramp 1810 (Dick Andrews 1\%97)-Web 1808 by Waxy 1790 (Pot-8-0-'s 1763)-Penelope 1798 by Trumpator 1782 (Conductor $1767)$ - Prunella 1788 by Highflyer $17 \% 4$ (Herod 1758).

Inley 1810 (Orville 17.9) Clare 1824 by Marmion 1806 (Whiskey 1;89)-Harpalice 1814 by Gohanna 1790 (Nercury 1778)-Amazon 1799 by Driver 1783 (Trentham 1766)Fracticus 1792 by Mercury $17 \% 8$ (Eclipse 1764).

Tramp 1810 (Dick Andrews 1\%9\%)-Dau. 1s22 of Whisker 1812 (Waxy 1\%90)_Mandane 1800 by Pot-S-o-'s 17r3 (Eclipse 1764) - Y. Camilla 1787 by Woodpecker 17t3 (Herod 175)-Camilla $17 \% 8$ by Trentham 1766 (T. Sweepstakes 17 \%3).

Bustard 1801 (Buzzard 178\%)-Dau. 1813 of Election 1804 (Gobanna 1790)-Dau. 1791 of Highflyer 17\% (Herod 1758)-Dau. $17 \% 8$ of Eclipse 1764 (Narske 1750)-Rosebnd 1765 by Snap 1750 (Snip 1736).

Partisan 1811 (Walton 1799)-Pauline $18: 6$ by Moses 1 s19 ([Whalebone or] Seymour 1807) - Quadrille 1815 by Selim 1802 (Buzzard* 1\%8j)-Canary Bird 1806 by [Thiskey or] Sorcerer 1796 (Trumpator 1782)-Canary 1797 by Coriander 1786 (Pot-8-o-'s 17\%3).

Plenipotentiary 1831 (Emilius 1820)-Myrrha b. m. 1830 by Whalebone 180\% (Waxy 1790)-Gift gr. n. 1818 by Y. Gohanna 1810 (Gohanna 1790)-Sist. to Grazier b. m. 1802 by Sir Peter T. 17St (Highflyer 174)-Sist. to Aimator b. m. 1788 by Trumpator 1782 (Conductor 1667)-Sist. b. m. 17\%4 to Postmaster by Felod 1758 (Tartar 1713)-Dau. of 


\section{IMPORTED SILVERMINE.}

The property of $R$. E. Roberts, Georgetown, $K y$.

Silvermixe, brown horse, foaled 1881, bred ly Mr. WT. Smith, by Silvio (winner of the Derby and St. Leger, Ascot Derby and other goorl races), son of Blair Athol by Stockwell. Blair Athol also won the Derby aud St. Leger, and was the sire of imp. Prince Charlie (winner of the 2,000 Guineas) and other good horses. Silrermine's dam, Nnneaton by Orlando (winner of the Derby), son of Tonchstone, and the sire of the dams of Camballo (winner of the 2,000 Guineas), Petrarch (wimner of the 2,000 Guineas and St. Leger), Gang Forward (winner of the 2,000 Gnineas), Gen. PeeI (winner of the 2,000 Guineas), ete., grandam, Nun Appleton by Bay Middleton (winner of the 2,000 Guineas and Derby), son of Sultan, sire of imp. Glencoe. Bay Micldleton is the sire of The Flying Dutchman (winner of both the Derlsy - and St. Leger in 1849), sire also of the dam of Wild Darrell (winner of the Derby) and of the dam of Sunleam (winner of the St. Leger). His dam, Nnneaton, is own sister to Julia, dam of Julius by St. Albans, son of Stockwell. Silvermine is almost brother in blood to Julius, who won the Cesarewiteh Handicap, Newmarket Biemuial Stakes, Beaufert Cup, and defeated Hermit in a match. Julius was an excellent stallion, sire of many good winners, and full brother to Julius Cresar (winner of the Westminster Stakes, second to Petrareh in the 2,000 Guineas, third to Kisber in the Derby, and third to Petrarch in the St. Leger, beating Kisber, won the City and Suburban Handicap and Royal Hunt Cnp, and was a snecessful stalliou). Silvermine, therefore, is not only a well-bred horse, but is from a racing and producing famils of great merit.

Silvermine was regarded as a good race-horse. Started in three races at three sears old, but won none. With a very limited chance in the stud, he is the sire of the wimners Silver Charm, Silver Lake, Sunshine Whiskey, Mine Heart, Silvermint, ete.

He traces in direct female line to Daffodil, to which traces Vanxhall snap, Mambrino (sire of imp. Messenger), Otterington, Grog, Lambinos, Ansel, Virgil and all the descendants of imp. Trumpetta in America. 


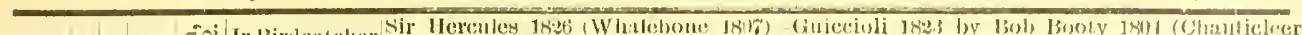

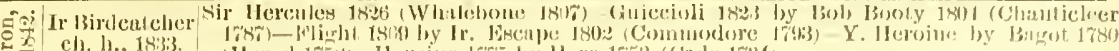

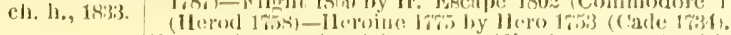

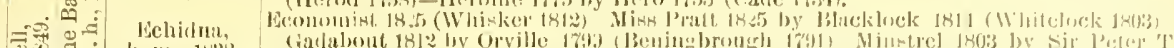

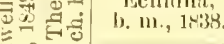

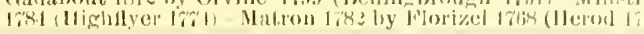

alencoe,

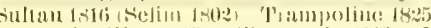

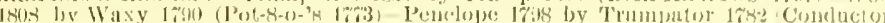

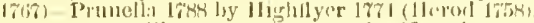

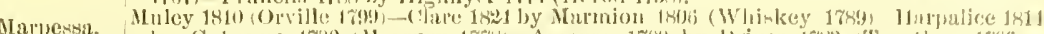

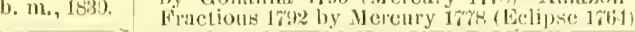

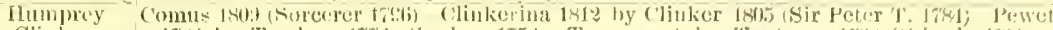

Clinker,

b. 11., 18:2,

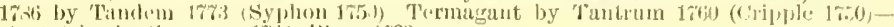

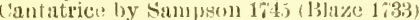

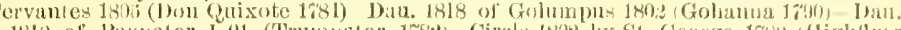

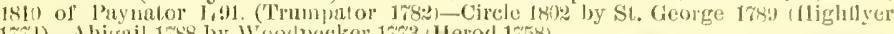
17\%1) Abicail 1788 by Woodpecker 1783 (Herod 175M)

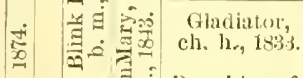

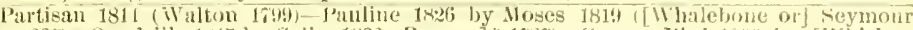

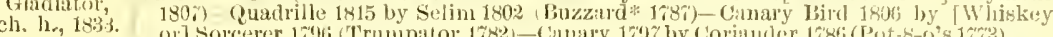

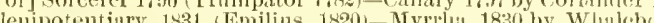

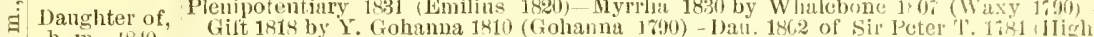

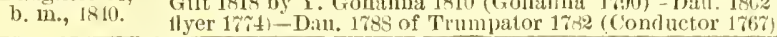

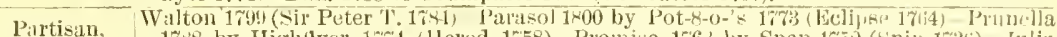

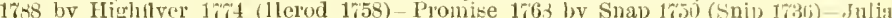
1756 by Jiank 1740 ( (xod. Ar. 1\%21).

b. 11., 1811 .

Fawil.

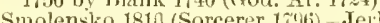
$7 \%$ by Trentham 17bli (T. Swe(pstakes 1\%43) -Coquette $1 \%(1$ by Comjuton Barb-Sist. $17+3$ to Regulus by God. Ar. $1 \% 24$.

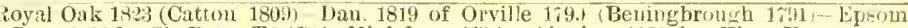
Lass 1803 by Sir Peter T: 1784 (lIighfyer 17\%4)-Alexina 1788 by King Fergu- 17\%. (Eclipse 17tit)-Lardella 1780 by Y. Markke 17\%1 (Mal'ke 1750).

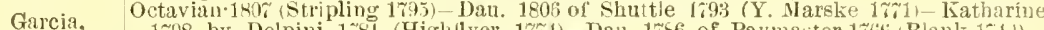

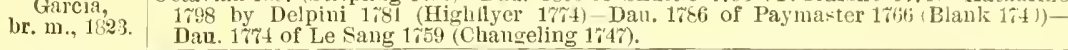

Sir Herenles, Whalebone 18,7 (Waxy 1790)-Peri 1822 by Wanderer 1811 (Gohanna 17u(1) - Thalestris

blk, 180 by Alexander 1782 (Eclipse 1764-Rival 1800 hy Sir Peter T. 17x4 (Hightyel 1\%i4)-Hornet $1 \% 90$ by Drone 1 i $\%$ (Herod 1758)

Guiccioli, Bob Booby 1804 (Chanticleer 1\%8\%)-Flight 1809 by Ir. E-cope 1802 (Commoriore 1793)-Y. Heroine by Bagot 1780 (Herod 1758)-Heroine 17i5 by Hero 1753 (Cade 1731)-Dau. 1766 of Snap 1750 (Snip 173 i). dicen $180 \%$ by Alexander 1782 (Eclipse 1\%(64)-Brumette by Amaranthus 1\%66।0]d England 17t1) - Hayfly 1;"'1 by Matehem 1748 (Cade 1734).

Zillah, Reveller 1815 (Comns 1899 - Morisea 1826 by Morisco 1819 (MIuley 1810 - Taltz 182. by

ch. m., 1835. Election 1804 (Gohama 1\%90)-Penelope 1798 by Trumpator 1782 (Conductor 1767)Prunella 1788 by Highflyer 1 rit (Helod 1r58)

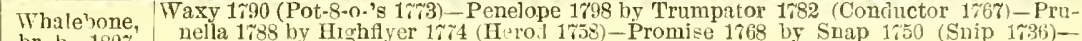

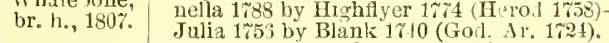

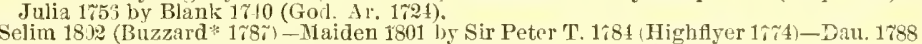

Daughter of, Selim of Phenomenon 1730 (Helod 1758)-Matrou 1782 by Florizel 1768 (Herod $17581-$ Maiden $17 \% 0$ by Matchem 1748 (Cade 1734).

b. m., 1812. Orville 1709 (Beningrough 1791 - Jiss Sophis

\section{b. h., 1815.}

Boadicea, b. m., $180 \%$. 1784). Sophia 1703 by Pir Peter T. 1784) Sophia 1793 by Buzzard* 1787 (1 oodpecker 17\%3)-Huncamunca 1r8\% by Highflyer $17 \% 4$ (Herod 17\%) - Cypher 17\%2 by Squirrel 1754 (Traveller 1735).

Alexander 1722 (Eclipse 1764)-Brunette by Amaranthus 1766 (Old England 1741) - IIay. fly $17 \% 1$ by kiatchem 1\%48 (Cade 1734) - Datl. 1755 of Ane. Starling 1738 (Starling 1727)-

Look-at-ine-Lads 1731 by Bristol Grasshopper (Byerly Turk).

Selim,

ch. h., 1802 . tyer 1774 (Herod 1758) 1756 (Sampson 1745).

范

Walton 1\%99 (Sir Peter T. 1781) - Y. Giantess 1790 by Dlomed $17 \%$ (Florizel 1768)Giantess 1763 by Matchem 1718 (Cade 1731)-Molly Long Legs 1753 by Babrabam 1740 (God. Ar. 1721)-Dan, of Cole's Foxhmuter 1\%2\% (Brisk 1711).

Castrel 1801 (Buzzard 1787)-Mi.ss Hap 1806 by Shuttle 1793 (Y. Marske 17i I) - Dau. 1798

Bustard,

of Sir Peter T. 1781 (Highflyer 1774)-Miss Hervey $17 \% 5$ by Eclipse 1764 (Marske 1'50)Clio 176 ) by $\mathrm{Y}$. Cade $17 \%$ (Cade 1734 )

Olympia, Sir Oliver 1800 (Sir Peter T. 1784)-Scotilla 1795 by Anvil 17\% (Herod 1758) Scota 1783 by Eclipse 1761 (.Iarske 1750)-Harmony $17 \% 5$ by Herod 1758 (Tartar 17.13)-Rutili 1769 by Blank 1740 (God. Ar. 1724).

b. m., 1815

Buzzand 1 to

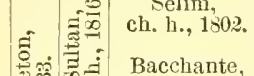
Dat of Alexander 178 ? (Eclipse 1661)-Dau. of Highflyer $17 \%$ (Herod 1\%5)-Dau. of Alfred 1\%0 (Matchem 1\%t8)-Dau. 17\%0 of Enginecr

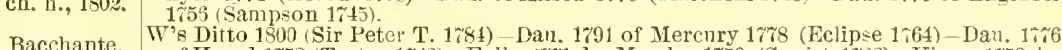
Bacchante, of Herod 1758 (Tartar 1743) - Folly $17 \% 1$ by Marske 1750 (Squirt 1732) -Vixen 1\%53 by Regulns 1739 (God. Ar. 1\%24). Giantess 1790 by Dioned $17 \%$ (Florizel 1768)-Giantess 1769 by Matchem 1748 (Cade
1734 ) - Molly Long Legs 1753 by Babraham 1740 (God. Al. 1724). 1734) - Molly Long Legs 1753 by Babraham 1740 (God. Al. 1724).

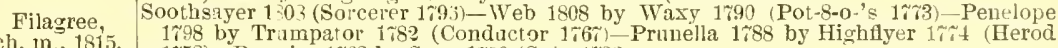
1758)-Promise 1768 by Snap 1750 (Snip 1796

Ch.

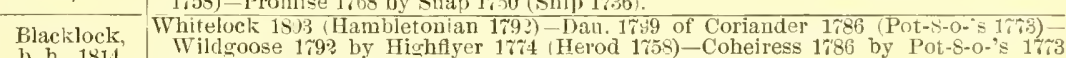
b. h., 1814 . (Eclipse 1 $\% 64$ )-Manilla $17 \%$ by Goldfinder 1764 (Snap 1750).

Velocipede's Janiper 1805 (Whiskey 1\%83)-Dan. 18I0 of Sorcerer 1796 (Trumpator 178:2)-Virgin 1801 by Sir Peter T. 1781 (Highflyer 17\%4)-Dau. 179t of Pot-8-o-'s 173 (Eclipse 1764)Editha 1781 by Herod 1758 (Tartar 1\%43).

Waxy 1790 (Pot-8-0-'s 17\%3) - Penelope 1795 by Trumpator 1782 (Conductor 176\%)-Prunella 1788 by Highflyer $17 \% 4$ (Herod 1758 ) - Promise 1768 by Snap 1750 (Snip 1\%36) Julia 1756 by Blank $1 \% 40$ (God. Ar. 1721).

b. n., 1812,

Orville 1799 (Beningbrongh 1791) - Otterington's dam b. m. 1805 by Expectation 1796

b. m., 1812. (Sir Peter T. 1\%84)-Calabria b. m. 1\%95 by Spadille 1\%84 (Highflyer 17\%t)-Grog"8 dam 1781 by Allired trwo (Natchem 1748)-Dau. of Locust. 1744 Crab 1\%:2)-Dau. b. m. 1781 by AlTred 170 (Matchem 1748)-Dan. of Loctst. 1744 Crab 1722)-Dau. o. m. 1\%24)-Dan. of Bolton Little John 1731 (Partner 1718)-Durham's Favourite gr. m. 17æ8 by Son of Bald Galloway-Daffodil's dam by Sir T. Gascoigne's Foreign Horse. 


\title{
IMPORTED SIMON MAGUS.
}

\author{
Is private stallion in the Rancocas Stud, property of $I[)$. P. Lorillard, \\ Jobstown, N.J.
}

Sruox Magus, brown luorse, foaled 1888, bred by the Duke of Portland, hy St. Simon, son of Galopin ly Vedtette, lam Wheel of Fortume, dam of Oberon, Dorlona, etc. by Adventurer, son of Newminster by Touchstone, grandam Queen Bertha, dam of Qneen's Messenger, Spinaway, ete., by Kingston, son of Venison, out of Flax by Surplice, son of Tonchstone, etc. St. Simou did not start in the Derby and st. Leger, in consequence of the death of his breeder and nominator, Prince Batthrany, but was never beaten during his turf eareer. Won the Epsom Gold Cup, Ascot Cup, Gold Cup at Nerreastle, Goodwood Cup, and other good races. St. Simon is the sire of Semolina (winner of the 1,000 Guineas), Memoir (winner of the Oaks, St. Leger and Nermarket Stakes), Signorina (winner of the Select Stakes), St. Serf (winner of the Epsom Grand Prize, Rons Memorial Stakes. Snssex Stakes and other good races), La Flèche (winner of the 1,000 Guineas, Oaks, St. Leger and second in the Derby in 1892).

Simon Magus is brother to Oberon (wimner of the Lincoln Haudicap, etc.), and half brother to Dolona, a stake winner. These were the only living produce of Wheel of Fortune up to 1889. Wheel of Fortune was a good mare. At two rears old won the Richmond Stakes at Goodwood, the Prince of Wales Stakes at York, walked orer for the Wentworth Stakes at Doncaster, wou the Buckenham Stakes at Newmarket, won the Triennal Proluce Stakes, Newmarket, and the Middle Park Plate. At three Jears old Wheel of Fortune won the 1,000 Gnineas, the Oaks, the Prince of Wales Stakes at Ascot and the Yorkshire Oaks. Queen Bertha, Simon Magus's graurlam, was a first-class race-mare. At two years old she beat Blne Mantle and Falcon and was never nnplaced. At three rears old won the Oaks, ran second in the Ascot Derby stakes, won the Ascot Triennial St:kes, ran second to Lord Clifulen in the St. Leger, and second to Macaroni for the Doneaster Cup. In the stud Queen Bertha did well. She produced Gertude, a good performer and wimmer of races, including the Yorkshire Oaks. She prodnced Charibert (winner of the 2,000 Guineas), Childeric (a good race-horse, second in the St. Leger, etc.), and the wimner King Clovis. Her full sister, Blanchfleur, prodnced the two good winners Srringe and Chonfleur. Spinaway, daughter of Qneen Bertha, won the 1,000 Gnineas, Oaks, ete., produced Busplody (wimner of the 1,000 Gumeas, the Oaks, etc.), Spinning Jemny (dam of Spinaway Top), and the winners Merry-go-round, Darnaway and Arcadian. Queen Bertha produced the race-horse Qneen's Messenger and the winners Paladin and Great Carle. Flax, the great grandam (by Surplice, winner of the Derby, St. Leger, etc.), portuced the wimmers Reginella, Hollyfox, Honiton (a good sire), Conrtmantle, Linsey Woolsey, Traveller's Joy and Folengo. Of these Regunella produced Guy Dayrell and Cobham, and the winuer Queen Gladys. Her diughter Zingarella prodnced the winners Simon and Donald Caird.

Sinon Magus ram in three races and paid forfeit in a mateh to Imp. Masetto. He won no race.

He is ilescended in direct female line from the Tregonweil Natural Barb mare, to which traces Woodpecker. Whalebone, Whisker, Partisan, Rockingham, imp. Glencoe, Bay Middleton, Trumpeter, Melbonrne, Bran, Bend'or, Robert the Devil, Speculum, Charibert, Silvio, imp. Mortemer, The Lamblin, Paralox, The Bard (by Petrarch), imp. Eelipse, in England : Uneas, Wanderer, and all the descendants of old Prunella. 


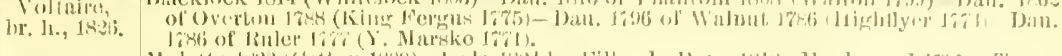

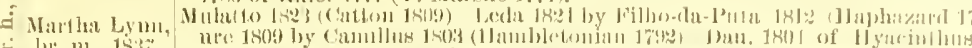

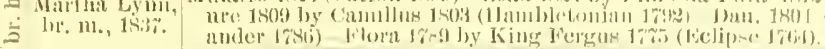

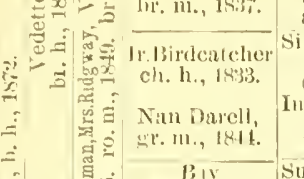

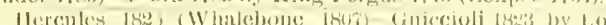

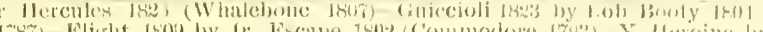

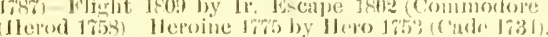

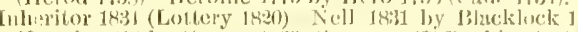

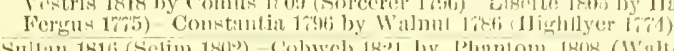

b. h., 1s:3is.

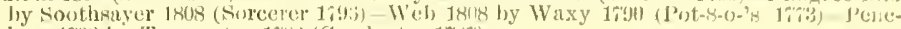

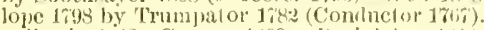

13:trleelle.

b. $111 ., 18336$.

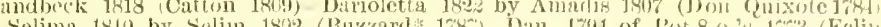

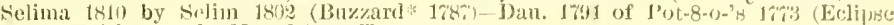

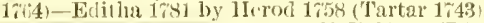

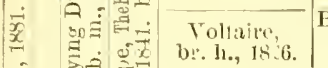

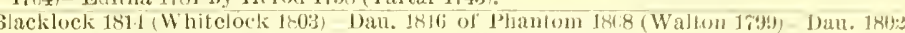

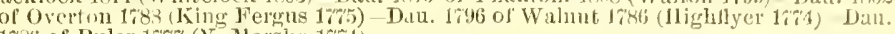

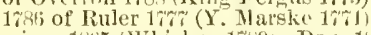

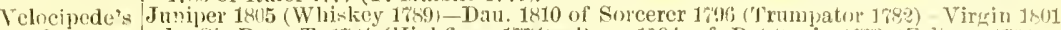
dialit, Elitha 1 wisl by Helod 1953 (Tartar 17.13 ).

Whi-ker 18I2 (Waxy 1700)-Floranthe 1818 by Octavian 1808 (Stripling 1795)-Caprice

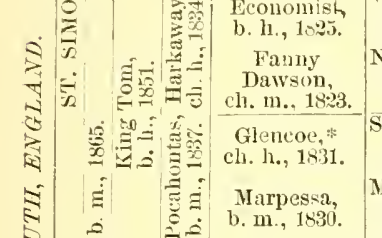

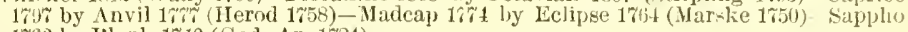
1763 by Blank 17 -10 (rod. Ar. 1\%24) Nabocklish 1811 (Rugantino 1808) - Miss Tooley 1808 by Teddy-the-Grinder 1igh (Aspar-

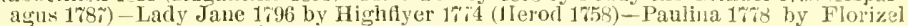
17 is (Hurod 1758)-Captive 17in by Matchem 17 18 (Cade 1794).

Sultan 1816 (Sclim 1802)-Trampoline 18.5 by Tranip) 1810 (Dick Andrews 17!6)-Web) 1808 by II axy 1790 (Pot-8-0-'s $17 \% 3$ )-Penclope 1798 by Trumpator 1782 (Conductor

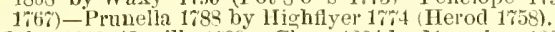

Mralcy 1810 (Orville 1799)-Clare 18:4 by Warmion 1806 (Whiskey 1789)-Harpalice 1814 by Gohanna 179) (Nercury 178)-Amazon
Fractious 1752 by Merciry 178 (Eclipse 1\% 1 .

Panlowitz 1813 (Sir Panl 18t2)-Dan. 1810 of Paynator 1791 (Trumpator 1782)-Dau. 1805 of Delpini 1781 (IIghflyel 1774)-Dau. 1795 of Y. Miarske 17i1 (Markke 1750)Genthe Kitty $17 \% 4$ by Silvio 1754 (Cade 1734)

Edmund 1821 (Orville 1799)-Medora 1811 by Selim 1802 (Buzzard* 178\%)-Dau. 1803 of Sir IIarry* 1795 (Sir Peter T. 1784)-Dau. 1793 of Volunleer 1780 (Eclipse 1764)-Dau. $17 \% 9$ of Herod 1708 ( Tartar 1743).

Velocipede 18:; (Blacklock 1814)-Dau. 18:0 of Cerberus 1802 (Gohanna 1i:0)-Miss Cranfield 1803 by Sir Peter T. 1781 (Highflyer 1rit)-Dau. 1796 of Pegasus 1784 (Eclipse 1764 ) - Dan. 1783 of Paymaster 1766 (Blank 1740

Zodiac 1801 (St. George 1783) -Jerboa 1803 by Gohanna 1790 (Mercury 178)_Camilla 1778 by Trentham 1766 (T. Sweepstakes 1743) - Coquette 1764 by the Compton BarbSist. 1743 to Regulus by God. Ar. $1 \% 24$.

halebone 1507 (Waxy 1790)-Dau. 1812 of Selim 1802 (Buzzard* 1787)-Maiden 1801 by Sir Peter T. 1784 (Highflyer 17\%4)-Dau. 1785 of Phenomenon 17t0 (Herod 1755)Mation 1782 by Florizel 1768 (Herod 1758) aster Henry 1815 (Orville 1\%99)-Boadicea 1807 by Alexander 1782 (Eclipse 1664)-Brunette by Amaranthus 1766 (Old England 1\%11) - Mayfly 17\%1 by Matchem 1\%48 (Cadé 1734)-Dau. 1755 of Anc. Starking 1 \%̈38 (Starling 1\%2\%).

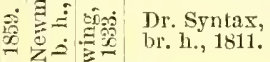

Payuator 1791 (Trumpator 1782) - Dau. of Beningbrough 1\%91 (King Fergus 16i5)-Jenny Mole 1787 by Carbuncle $17 \% 2$ (Babr. Blank 1758)-Dau, 1733 of Prince T'Q dassaw 1751 (Snip 1736)-Sultana 1759 by Regulns 1739 (God. Ar. 1724).

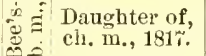
Arirossau 1809 (John Bull 1789)-Lady Eliza 1813 by Whitworth 1805 (Agonirtes 1797) X. Y.Z.'s dam 1793 by Spadille 1784 (Highflyer 1\% 1 ) Eylvia 1783 by Y. Marse 1\%1 (Marske 1750)-Felret 1765 by Broth. to Silvio (Cade 1734)

orville, Beningbrough 1791 (King Fergus 17\%5)-Evelina 1791 by Highflyer 1; 4 (Herod 1758)b. 1., 1799 .

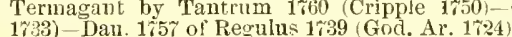

Emily Stamford 1704 (Sir Peter T 1784)-Dau. 1799 of Whiskey 1789 (Sallram 1 280 ) - Grey Stamford 1794 (Sir Peter T. 1784 )-Dau. 1799 of Whiskey 1769 (Saltram 1780) - Grey
Dorimant 1781 by Dorimaint $17 \% 2$ (Otho 1760)-Dizzy 1757 by Blank 1740 (God. Ar. 1724-Anc. Dizzy 1711 by Driver $172 \%$ (Wynn Ar.)

ch. m., 1810.

Walton 1749 (Sir Peter T. 1780 - Parasol 1800 by Pot-8-0."s 1773 (Eclipse 1764)-Yrunella 1788 by Highflyer 17\%4 (Herod 1758)-Promise 1768 by Snap 1750 (Snip 1\%36)-Julia 1756 by Blank 1710 (God. Ar. 1724).
Orville irga (Beningbrongh 1791)-Gं

b. h., 1811 .

ڤ̇ं Daughter of, pecker 17\% 至

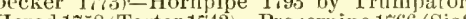
Herod 1758 (Tartar 1743)-Proserpine 1766 (Sist. to Eclipse) by Marske 1750 (Squirt 1732).

Partisan, Walton 1799 (Sir Peter T. 1781)-Parasol 1800 by Pot-8 - -1 i 17\%3 (Eclipse 1764)-Prunella b. 1., 1811 . 1783 by Highflyer $17 \% 4$ (Herod 1758)-Promise $1 \% 65$ by Snap 1\%50 (Snip 1736)-Julia 1756 by Blank 17.10 (God. Ar. 1\%24)

Fawn, Sulensko 1810 (Sorcerer 1796) -Jerboa 1803 bq Gohanna 1790 (Merculy 17\%)-Camilla 1778 by Trentham 176; (T. Sweepstakes 1743)-Coquetle $1 \% 64$ by Compton Barb-Sist. $1 \%+3$ to Regulus by God. Ar. 1724 .

br. m., 1823.

Royal Oak 1823 (Catton 180:)-Dau. 1819 of Orville 179.9 (Beningbroum 1 191 - $\overline{\mathrm{E} p} \mathrm{som}$

Slane,

Lass 1803 by Sir Peter T. 1\%84 (Hightyer 1\% (Eclipse 1764)-Lardella 1780 by Y. Marske $1 \%$ ( Marske $1 \% 50$ ).

Garcia Octavian 187\% (Stripling 1\%95)-Dau. 1806 of Sbuttle 1793 (Y. Marske 1\%1)-Katharine 1798 by Delpini 1781 (Hightlyer 1\%4)-Dau. 1786 of Paymaster 1766 (Blauk 1740)-Dau. 1 ritu of Le Sang 1759 (Changeling $174 \%$ ).

br. m., 182

Camel 1822 (Whalebone 1807)-Banter 1896 by Master Henry 1815 (Orville 1799)-Boa-

Tonchstone, dicea 1807 by Alexander 1782 (Eclipse 1764)-Brunette by Amarantbus $1 \% 66$ (Old England 1741)-Mayfly 1771 by Matchem 1748 (Cade 1\%34).

Priam* 182 (Emilius 1820)-Octaviana 1815 by Octavian $180 \%$ (Stripling $1 \% 5$ )-Dau. 180\% of Shuttle 1793 (Y. Mareke 17\%1)-Zara 1801 by Delpiui 1\%81 (Highflyer 1\%4)-Flora 1788 by King Ferous $1 \%$ (Eclipse 1rc4).

Selim 1802 (Buzzard*178\%)-Bacchante 1809 by $\pi^{\prime \prime s}$ Ditto 180 (Sir Peter T 1784) - Sist. 1791 to Calomel by Mercury 17\%8 (Eclipse 1764) -.Dau. 1766 of Herod 1758 (Tartar 1713)Folly $17 \% 1$ by Marske 1759 (Sqnirt 1\%32)

ह $\quad$ Sultan

Sister to

Phantom 1808 (Walton 1799-Filagree ch. m. 1815 by Sonthsayer 1808 (Sorcerer $1 \% 96$ ) Web b. m. 1808 by Waxy 1790 (Pot-8-o-s 1;73)-Penelope b. m. 1798 by Trumpator 1782 (Concluctor 1767)-Prunella b. m. 1788 by Higbflyer 17\% (Herod 1758)-Promise br. m. 1769 by Snap 1750 (Snip 1\%36) -Jnlia b. m. 1756 by Blank 1 140 (God. Ar. 1\%24)S jectator's dam b. m. 1735 by Parlner 1713 (Jirz)-Bonny Lass l). m. 1 i a by Bay Bolton 1705 (Grey Hautboy)-Dau. of Tregonwell's. 


\section{SIR DIXON.}

WINNER OF CAMDEN, SELECT AND FLATHLSH STAKES AT TWO YEARS OLD, 'THE WITHERS, BELIONT', LORILLARD, TRATERS, OMNIBUS AND OTHER STAKES AT THREE YEARS OLD.

\section{In the Runnymede Stud, property of Messrs. Clay \& Woodford, Paris, Ky. Tearling sales ammally.}

Sir Dixon, brother to Belvidere, bay horse, foaled 185.5, bred in the Rumnyede Stud, by imp. Billet, son of Voltigem by Voltaire, dam Jacouet, own sister to Iro quois, by imp. Leamington, grancim Maggie B. B. by imp. Australian, great granclam Madeline by old Boston, out of Magnolia, dam of Kentucky, Daniel Boone, Gilroy, ete., by imp. Glencoe.

Sir Dixon is by imp. Billet, a good race-horse, winner of the Zetland Stalies at York, Engham Strkes at Enghan, and other races. Billet's sire, Voltigenr, won both the Derby and St. Leger, and was by Toltaire, son of Blacklock. Toltigeur was also the sire of Vedette, sire of the noted Galopin, sire of the unbeaten sit. Simon. Sir Dixon's dam, Jaconet, is full sister to Iroquois, one of the best racehorses, judged by his performances, ever bred in America, and the only horse, except Donovan, that ever won the Derbr, Prince of Wales Stakes and the Doneaster St. Leger. Iroqnois was second to Peregrine in the 2,000 Guineas and beat him in the Derby. Iroquois also wou the Chestertield Stakes at Newmarket, Levant Stakes at Goodwood, the Burrell Stakes, Newmarket Derby and other important events. In these races he beat snch good ones as Peregrine, Ishuael, Scobel, Geologist, Tristan, Camilliarl, Bal Gal, Luey Glitters and others. Sir Dixon, therefore, is descended from one of the hest bred and most potent raciug families in America. His grandam, Nagrie B. 13., was the dam of Pera, Harold, Panique, Red and Blne (Sally IIcClelland's dam), ete. Harold had ouly one colt on the turf, Harefoot, an excellent race-horse, and Harold was own brother to Izoquois, a good index to the poteney of the blool. Madeline, his great graulam, was by the great Boston, sire of Lexington, Lecompte, Bostona, Nina and a host of good ones. Iagnolia was the dam of lientucky, the best son of Lexington, Daniel Boone, Magic, Charley Ball, Madonna, Skedadile, Gilnoy, Vietory, etc. Skedaddle is the dam of Sancebox, Scramble, Florence B., sly Boots, Joe S., 'The Slashes and squeez'em (the dam of Diy Star, winner of the Kentucky Derby, Blue Ribbon Stakes aud other fist races) and sylph (the dam of La Srlphide, $1 \frac{1}{3}$ miles, in $2.07 \frac{1}{2}$, and dam of Semper Fidele), Kaloolah, Kincsem, etc. Sly boots is the dam of Leveller, sly Dance, Sachem and Savanac. Iyrtle was by Mameluke (winner of the Derby). Bobarlilla won the Ascot Gold Cup and Drawing Room Stakes.

Sir Dixon was a superior race-horse. At two vears old won the Camden stakes. three-quarters of a mile, 109 1bs., in 1.16, defeating a field of nine; won the Select Stakes three-quarters of a mile, 111 lbs., in 117 , ant the Flatbush stalies, 7 furlongs, $115 \mathrm{lbs}$, in 1.29, beating snch good ones as Tea Tray, King Fish, Reclare, ete.; was placel third in the Jminior Champion stakes. At thee rears old won the Anilostan Stakes, 1 mile, 118 lbs., in 1.46 ; the Carlton Stakes, 1 mile, 119 lbs., beating Raceland, in 1.56 ; ran second to Emperor of Norfolk in Brooklyn Derloy, $1 \frac{1}{4}$ miles, in 2.08\%. beating Prince Royal and Raceland; ran second to The Barl in St. James Hotel

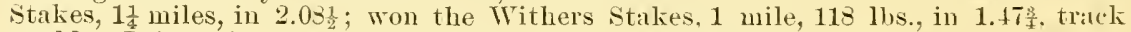
muddy, Prince Rosal second, Tea Tray third; won Belmont stakes, 1\% miles, 118 1bs., in 2.401, beating Prince Royal; won the Lorillard Stakes, $1 \frac{1}{2}$ miles, 118 bs., in $2.37 \frac{1}{2}$, beating Los Angeles, Prince Royal, ete.; won the Travers Stakes, 13 miles, 118 los., in 3.07 Omuibus Stakes, $1 \frac{1}{2}$ miles, in 2.41, giving lim 11 lbs.: ran second to Geo. Orster in Choice Stakes, $1 \frac{1}{2}$ miles, in 2.42, giving him $10 \mathrm{lbs}$. Taragon and two others behind him. Sir Dixon did not race at fonr Jears old. At five Jears old won the St. James Hotel stakes, $1 \frac{1}{4}$ miles, $126 \mathrm{lbs}$., defeatine Taragon, etc. He wis placed second twice and third five times. Sir Dixon was a good race-horse and is from a grand racing and producing fumily.

He is descended in direct female line from the Layton Barb nare, to which trace Young Greyhound. Cartonch, Matchem, Yomne Caile. Drone bs Heror, Andubon, Philammon, St. Honorat, Kentucky, Daniel Boone. Gilroy, Iroquois anel all the Mannolia famils, Powhattan, Wild Irishmam, Frankfort, Prince George, Virgilian, Feridia and all the imp. Cub mare's descendents. 


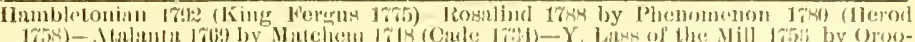

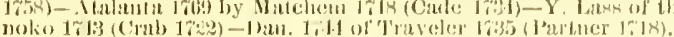

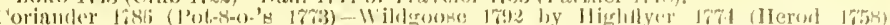

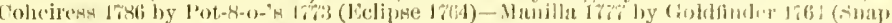

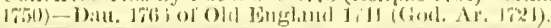

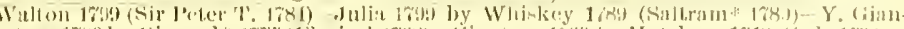

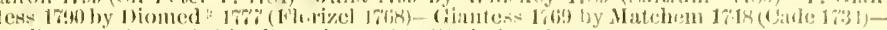

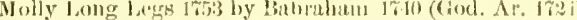

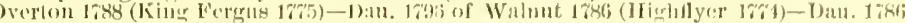

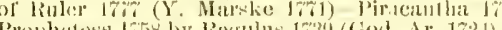

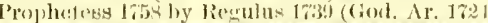

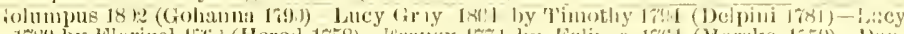

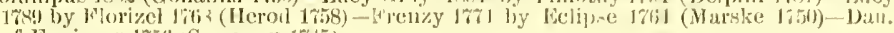

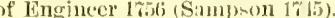

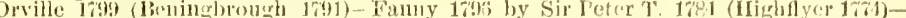

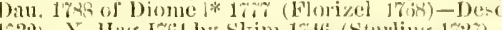

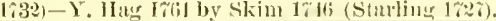

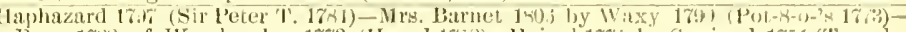

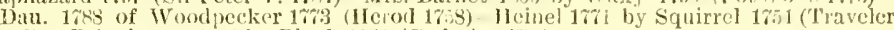

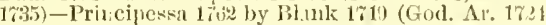

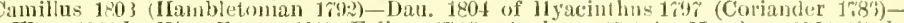

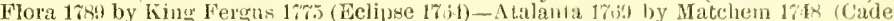
173i) - Y. Lass of the Nill 175; by Oroonokn 174) (Crab 1723).

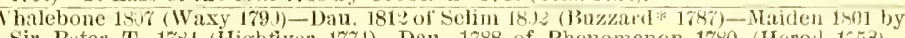
Sir Peter T. 17 i (IIightiyer 17\%t)-Dau. 1788 of Phenomenon 1780 (Herod 1r53)Mlatron 1732 by Florizel 1768 (Herod 1758)

Master Henry 1815 (Orville 1799)-Boadicen 1807 by Alexinder 1782 (Eclipse 17(54)Brunctie by Amarauthus 17,6 (Old England 17+1)-Mayfly 1761 by Matchem 1748 (Cade 1734)-Dau. 1755 of Anc. Starling 1738 (Starling 17\% ).

Haphazard 1797 (sir Peter 'T. 1784)-Mrs. Barnet 18); by Waxy 179) (Pot-4.0-'s 17m; Dau. 1788 of Woodpecker 1773 (Herod 1758)- Heinel $17 \% 1$ by Squiriel 1754 (Trayeler 1735)-Principessa 1762 by Blank 1710 (God. Ar. 1724).

Peruvian 1806 (Sir Peter T. 1784)-Violante 1892 by John Bull 1789 (Fortitude 17\%7)-

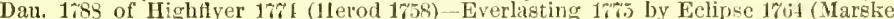
$1750)$ - Hyæna 1762 by Snap 1750 (Snip 1736).

Scud 180t (Beningbrongh 1791)-Diana $18: 8$ by stamford 1794 (Sir Peter T. 1781)-Dau. 1799 of Whiskey 17,9 (Saltram* 1783)-Grey Dorimant 1781 by Dorimant 17\%2 (Otho 1760)-Dizzy 175' by Blank 1\%10 (God. Ar. 1\%24).

Walton 1799 (Sir Peter T. 1781) - Comedy 181$\}$ by Comus 1-09 (Sorcerer 1796)-Dau. 180: of Star* 1785 (Hightlyer 1774)--Dan. 1794 of Y. Marske 17il (Marske 1750)-Emma 1 \%81 by Telemachus irio (Herod 1\%,8).

Titxy 1790 (Pot-5-o-'s 1773)-Penelope 1798 by Trumpator 1732 (Conductor 1767)-Prunella 1783 by Highflyel $17 \% 4$ (11erod 1753)-Promise 1768 by Snap 1750 (Snip 1736)Julia 175 by Blank 1740 (God. Al. 17\%

Sorceler 1796 (Trumpator 1782)-Dau. 1808 of Sir Solomon 1793 (Sir Peter T. 1784)-Dau. 179t of Y. Marske 17'1 (Marske 1750)-Dau. 1788 of Phenomenon 1780 (Herod 1758)Calliope 1763 by Slouch 1747 (Cade 1794)

Waxy 1790 (Pot-8-0-'s 1773) - Penelope 1798 by Trunipator 1782 (Condactor 1767)-Prunella 1788 by Hightlyer 1774 (Herod 1753)-Promise 1768 by Snap 1750 (Snip 1796)Julia 1756 by Blank 1740 (God. Ar. 17\%4).

Wanderer 1811 (Gohanna 1790)-Thalestiv 1809 by Alexander 1782 (Eclipse 1;64)Rival 1800 by Sir Peter T. 1784 (Highfiyer 17\%4)-Hornet 1790 by Drone 17\% (Herod 1758)-Manilla $177 \%$ by Goldfinder 1764 (Snap 1750).

Chanticleer 1ra7 (Woodpecker 1773)-lerne 1790 by Bagot 1780 (Herod 1758)-Dau. of Gamahoe (Bustard 17:1)-Patty by Tim 175: (Squirt 1732)-Miss Paich 1797 by Justice 1725 (H. C. Litton Ar.)

I1. Escape 1802 (Commodore 1793)-Y. Heroine by Bagot 1\%80 (Herod 1\%58)-Heroine 175 by Hero 1753 (Cade 1731)-Dau. 1766 of Suap 1750 (Snip 1736) -Sist. 1743 to Regulus by God. Ar. 1721 .

Buzzard* $178 \%$ (Woodpecker 17\%3)-Dau of Alexander 17e2 (Eclinse 1764)-Dau. of Highflyer 1774 (Ferod 1758)-Dau, of Alfred 17\%0 (Natchem 1748)-Dau. $17 \% 0$ of Engineer 1756 (Sampson 1745 ).

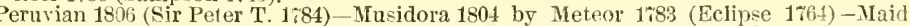
of all Work 1783 by Highflyer $17 \%$ (Herod 1753)-Sist. 17rit to Tandem by Syphon 1750 (Squirt 1732)-Dau. of Regulus 1739 (God. Ar. 1721)

Blacklock 1814 (Whitelock 1803) - Wagtail 1818 by Prime Minister 1810 (S.nclo 1801 ) Tranby*'s Dam 1812 by Orville 1793 (Beningbrongh 1791)-Nliss Grimstone 1\%98 by Weazle $1 \% 6$ (Herod 1758)-Dan. of Ancaster 1768 (Biank 1740)

Champiou 1812 (Selim 1802)-Etiquette 18:0 by Orville 1799 (Beningbrough 179†)Boadicea $180 \%$ by Alexander 178? (Eclipse 1\%64)-Brumette by Amaranthus 1\%65 (Old England 1717)-Mayfly $17 \% 1$ by Matchem 1748 (Cade 1\%24).

Humprey Clinker 1322 (Comns 1809)-Dau. 1825 of Cervantes 1808 (Don Quixote 1781)Dau. 1818 of Golumpus 1802 (Gohanna 1790)-Dau. 1810 of Payuator 17\%l (Trumpator 1732) —Circle 1802 by St. Georwe 17:9 (Highflyer 17.4)

Tonchstone 1831 (Camel 1822)-Emma 1821 by Whisker 1812 (Wary 1790)-Gib-ide Fairy 1811 by Hermes 1790 (Mercury 176R)-Vicissitude 180 ) by Pipator 1786 (Impera. tor 17,6$)$ - Beatrice 1791 by Sir Peter T. 1784 (Hichflyer 1\%

Emilins 1820 (Orville 1799) - Shoveler 1816 by Scud 1804 (Beningbrough 1791)_Goosander 1805 by Hambletonian 179: (King Fergus 17\%) - Rally 1790 by Trumpato

(Thetor 1

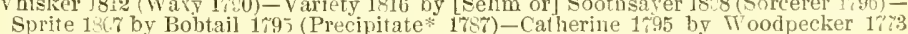
(Herod 178)-Camilla 1 - 78 by Trentham 1766 ( $T$. Sweepstakes $1 \%$ s

Sir Archy 1805 (Diomed 1\%i)-D m. of Saltram 1780 (Eclipse 1;61)-Dau. of Symme's Wildair 1767 (*Fearnought 1755)-Dau. of 'Tyler's Diver 1760 (*Othello)-Dau, of Fallower 1761 (Blank 1649 )

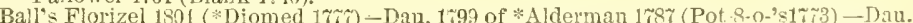
of clockfast $17 \%$ (Gimcrack 17t0)-Dau. of Symme's Willair 1767 (*Fearnought $1755)$ - Y. Kilty Fisher 1767 by *Fearnought 1755 (Regulus 17

Sultan 1816 (Selin 1802)-Trampoline 18*5 by Tramp 1810 (Dick Andrews sme-.Teb 1808 by haxy 1793 (Pot-8-0-'s 1773)-Penelope 1798 by Trumpator 1782 (Conductor 176\%)-Prumella 1788 by Highflyer $17 \% 4$ (Helod 1\%58)

Hamelulie 1824 (Partisan 1811) - Bobadilla br. m. 1825 by Bobadil 1813 (Rubeus 18in5)-P ness blk. m. 1813 by Sorcerer 1796 (Trumpator 1782)-Princess blk. m. 1796 oy Sir Peter ' $\mathrm{T}$. 1784 (Highfliver 177 )-Dan. br. m. 1789 of Dungannon 1780 (Eclipse 1764)-Dau. ch. 11. 1783 of Turf 1760 (Matehem 1748)-Dan. b. m. 1779 of Herod 1758 (Tartar 17t3)-Golden Grove

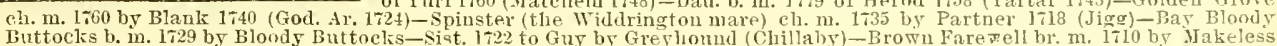

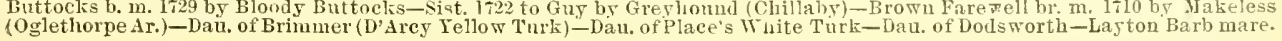




\section{IMPORTED SIR MODRED.}

WINNER OF CANTERBURY DERBY, DUNEDIN AND CANTERBERY CLP, NEW ZEALAND.

\section{Is private stallion in Rancho-del-Paso Stud, J. B. Haggin, proprietor, Sacra- mento, Cal. Yearlings sold annually.}

Sir Modred, bay horse, foaled 1877, bred by the Middle Park Stuil Co., New Zealand, by Tradueer, son of The Libel by Pantaloon, dam Idalia by Cambuscan, son of Nerminster hy Touchstone, grandam Duleibella by Voltigeur, son of Toltaire. His sire, Traducer was bred in England, by The Libel (son of Pantaloon) and Arethusa. Traducer was the most popular and suecessful stallion that has ever stood in New Zealand. From 1867 to 1881 he got nine winners of the Canterbury Derby, the great event in that contry, riz: 1867, Scandal ; 1870, Enry; 1871, Defamation: 1872, Calumny; 1877, Trump Card; 1373, Natator; 1880, Sir Modred: 1881. The Danphin ; 18×2, Cheviot. In three of these years his get ran first, second and third. and in two others first and second. He got Tanguard (winner of the Ner Zealand Cup), Welcome Jack (winner of the Canterbury Cup), and Lurline, a great mare, out of imp. Mermaid. Lurline is the dan of imp. Darebin, winner of the Victoria Derby of 1881, and the best horse of his day in Australia. Idalia, his dam, is full sister to Onslow (winner of the Prinee of Wales Stakes at York, defeating Cremorue). She is half sister to Mabelle, dam of Bean Brummell (winner of the Woodcote and Hopeful Stakes), and The Child of the Mist (Mr. M. Daly's), winner of the Chesterfield and Aseot Biennial Stakes and the Aseot Derby. Cambusean, her sire, is the sire of Camballo, wimer of the 2,000 Guineas. Duleibella, his grandam, won the Cesarewiteh Handicap, beating Optimist, in 1860, and Brighton Cup. Her sire, Toltigenr, mou both the Derly and St. Leger and was the sire of Vedette, sire of the noted Galopin. Priestess, his great grandam, was a superior race-mare, wimner of the Northhampshire Cup, Caledonia St. Leger, Caledonia Cup, Gold Cup at Warwick, and several Queen's Plates, and by The Doctor, one of the gamest horses of his day. Priestess is half sister to The Gem, dam of Regalia (wimner of the Oaks), and dam of Vernenit (winner of the Ascot Gold Cup) and Zut (winner of the French Derby, ete.). Idalia was a grand brood mare. She produced, in 1876, Betrayer; in 1877, sir MIodrerl: 1878, Idalium; 1879, Cheriot; 1880, July, all by Traducer; in 18s1, Licerpool by King of Glubs; 1883, ehestnut filly by Apremont, son of our imported Hortemer; 188t, a bay filly by Apremont. Betrayer won the Canterbury Champagne Stakes, Canterbury Cup, Wauganal Cnp and Timaru Cup. Sir Modred won the Dunedin Champagne Stakes, Canterbury Champagne Stakes, Dunedin Cup, Canterbury Derbs, Timaru Cup, Dunedin Birthday Handieap, Canterbury Cup, Christehureh Plate, and the Sydney Great Metropolitan. July ran second for the Dunedin Cup. Lirerpool won the Weleome Stakes. Cheviot won the Canterbury Derbs, Midsummer Handieap, and Craven Stakes, and only Sir Modred, his brother, eould beat him for the Canterbury Cup.

Sir Modred is a sueeess in the stnd, sire of the winners Ballarat, Sir John. Marie Lovell, Fannie J., Tournament (winner of the Realization Stakes), Dr. Hasbronck, Dr. Helmuth, Masterlode, Mary Stone, Gloaming Bererwyek, Discomut, Enid. Sykeston, Gold Dollar, Grand Prix, Sir Matthew, Lizetta, Motto, Dr. Wileox. Prinec Charming, Sir Lanneelot, Comanehe, Sir Roy, Wheeler, Uncle Jess, Fairplay. Courtship, Gladlator, Shellbark, Reginali, Integrity and many others.

He is deseended in direet female line throngh the Warlock Gallowar from the Byerly Turk mare, to whieh traces Cub, Sancho, Young Blacklock, Pantaloon. Prime Warden, Yattendon (Australian), Cymbal, Beau Brummell, Child of the Mist, imp. Sovereign, imp. Citizen and other noted horses. 


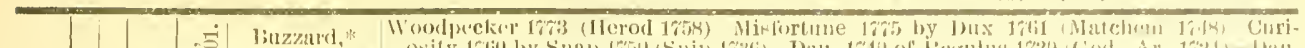
cli,

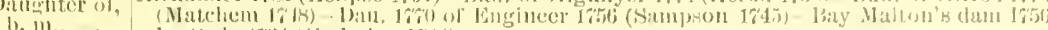

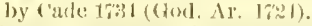

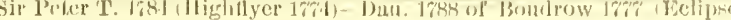

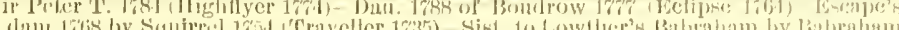

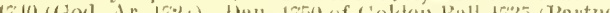
leteor los ledipo

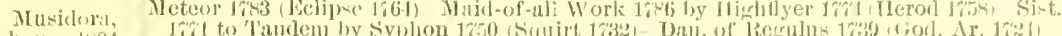
1. 11, , $1>01$

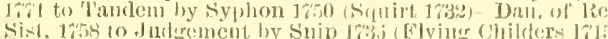

Whatebone,

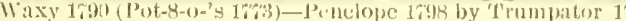

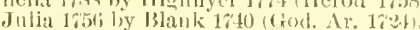

1) amglner of,
1), 111., 1:1:?

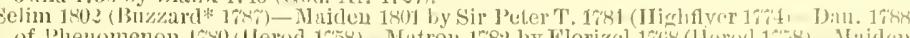

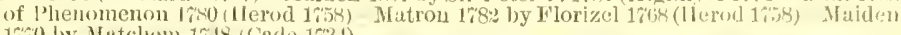

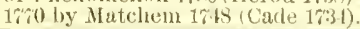

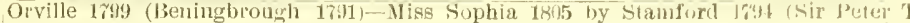

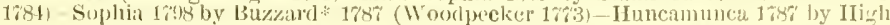

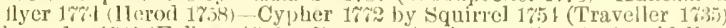

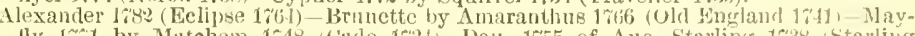

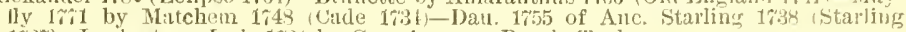

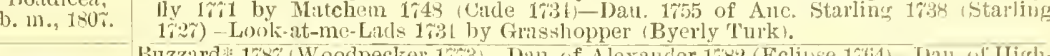

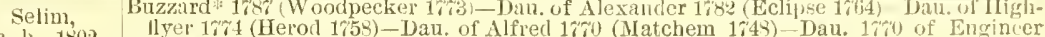
1 Tis (Sampson 1745).

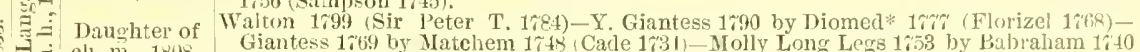
(God. Ar. 17:4t)-Dan. of Cole" Foxhunter 1\%2\% (Brisk 1\%11).

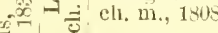

Sir Oliver

Sir Peter T. 1784 (IVighflyer 1\%4)-Fanny 1790 by Diomed $\% 1$;

焉 sia 1783 by woodpec Sist. 1751 to South by Regulus 1\%39 (God. Ar. 1\%21).

Scotilla, Anvil 17ry (Herod 1758)-Scota 1;83 by Eclipse 1764 (Marske 1750)-Harmony 17\%5 by Herod 1758 ('Tartar 1743) - Rutilia 1769 by Blank 1710 (God. Ar. 1724) Sist. 1651 to South by Regulıs 1739 (God. Al. 1724).

b. m., 179.5 .

i Paulowi:z,

.00 br, li., 1813.

Sir Paul 1803 (Sir Peter T. 1784)-Evelina 1791 by Highflyer 174 (Herod 1758)-Termagant by Tantrum 1760 (Cripple 1750)-Cantatrice by Sampson 1745 (Blaze 1733)-Dau. $175 \%$ of Regulus 1739 (God. Ar. 1724).

Paynator 1791 (Trumpator 1782)-Dau. 1805 of Delpini 1781 (Highflyer 17\%4)-Dau. 1795 of Y. Marske 1771 (Marske 1750)-Dau. ol Dorimond 1758 (Dormonse 1738)-Portia 1758 by Regnlus 1739 (God. Ar. 1724).

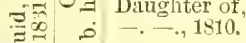

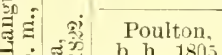

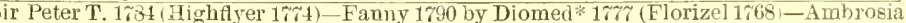
1783 by Woodpeeker $17 \% 3$ (Herod 1,5s) - Ruth 1761 by Blank 1 \%40 (God. Ar. 1721)-

Sist. 1751 to South by Regulns 1739 (God. Ar. 1724).
Hyacinthus 1\%97 (Coriader 1786)-Sist. 1790 to Swordsman by Weazle 1\%6 (Herod 175\%)-Dau. of Turk $1 \% 63$ (Pegulus 1 139 )-Dau. of Locust $1 \% 14$ (Crab 1\%2:)-Dan. of 1758 Changeling 174 $\hat{\imath}$ (Cade 1\%3t). Thalebone 1897 (Waxy 1790)-Dau. 1812 of Selim 1802 (Buzzard * 178\%)-Mlaiden 1801 by

Camel,

br. h., $18 \% 2$. Sir Peter T. 1784 (Highflyer 17\%4-Dau. 1788 of Phenomenon 1\%80 (Herod 1\%58)Matron 1782 by Florizel 1768 (Herod 1758 ).

Banter.

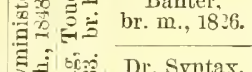

(Oster Henry 1815 (Olville 1799)-Boadicea 1807 by Alexander 1782 (Eelipse 1764)-Brunette by Amaranthus 1766 (Old England 1\%11)-Mayfly 1\%r1 by Matchem $1 \% 48$ (Cade 1734)-Dan. 1755 of Anc. Starling 1738 (Old Starling 172\%). Paynatol 1\%91 (Trumpator 1782)-Dau. of Beningbrough 1\%91 (Kiug Fergins 1\%5) - Jenny Hole 1737 by Carbuncle $17 \% 2$ (Babr. Blauk 1758)-Datr. 17\%3 of Prince T'Quassaw 1751 (Snip 1736)-Sultaua 175) by Regulus 1799 (God. Ar. 1724).

Ardrossan 1803 (John Bull 1789)-Lady Eliza 1813 by Whitworth 1805 (Agonistes 1797)-

Daughter of X.Y.Z's dam 1\%93 by Spadille 1784 (IIighfler irr4)-Sylvia 1783 by Y. Narske 1ri (Marske 1750)-Ferret 1765 by Broth. to Silvio (Cade 1;34).

ch. $\mathrm{m} ., 181 \%$. (Moton 1209 (Golum 130) - Dat 1818 of Srolenslo 181.

Roval Oak, Catton 1309 (Golumpus 1302)-Dau. 1818 of Smolenslio 1 S10 (Sorcerer 1r96)- Lady br. h., 1823 . 1758 ) - Sist. to Miss Bell by Marske 1750 ) (Squirt 1732).

Orville 1799 (Beningbrongh 1791)-Epsom Lass 1803 by Sir Peter T. 1784 (Highflyer 1774) - Alexiua 1788 by King Fergus 175 (Eclipse 1764)-Lardella 1780 by Y. Marske $17 \% 1$ (Marske 1750)-Dau, of Y. Carle 1\%47 (Cade 1731).

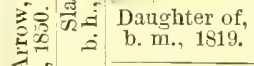

\section{@コ் Defence,}

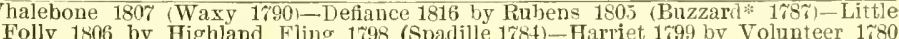
(Eelipse 1764)-Dau. 1785 of Alfred $17 \% 0$ (Matchem 1748)

E. Feltona,

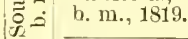

X. Y. Z. 1808 (Haphazard 1\%9\%)-Janetta 1803 by Beningbrough 1791 (King Fergus 17\%)-Dau. 1797 of Drone 17\% (Herod 1758)-Contessina 1\%8 by Y. Marske 17\%1 (Marske 1750)-Tuberose 17\% by Herod 1759 (Tartar 1743).

Blacklock

Whitelock 1803 (Hambletonian 1792)-Dau. 1799 of Coliander 1786 (Pot-8-0-'s 1,*3) Wildgoose 1792 by Highflyer 1774 (Herod 1758)-Coheiress 1786 by Pot-8-0-'s 1773 (Eelipse 1761)-Mauilla 17\% i by Goldfinder 1764 (Snap 1750)

= Daughter of, hantom 1808 (Walton 1799)-Dau. 1802 of Overton 1788 (King Fergus 17\%5)-Gratitude"s dam 1793 by Walnut 1786 (Highflyer 1774)-Dan, 1786 of Ruler 17\% (Y. Marske 17\%1)Piracantha $17 \% 2$ by Matchem 174 s (Cade 1734).

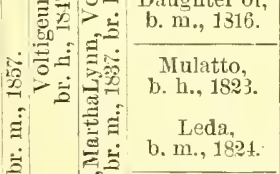
atton 1809 (Golumpus 1802)-Desdemona 1811 by Orville 1799 (Beninobrongh 1791) Fanny 1796 by Sir Peter T. 1784 (Hightlyer 174)-Dat. 1788 of Diomed $17 \%$ ' Florizel 1768)-Desdemona 1770 by Marske 17.50 (Squirt 1732).

Filho-da-Puta 1812 (Haphazard 1797)-Treasure 1809 by Camillus 1803 (Hambletonian 1792)-Dan. 1804 of Hyacinthus $179 \%$ (Coriander 1786)-Flora 1789 by King Fergus 17\% (Eclipse 1764)-Atalanta 1769 by Matchem 1748 (Cade 1734).

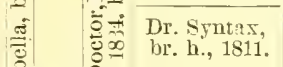
Paynator 1791 (Trumpator 1782) - Dau. of Beniugbrough 1791 (King Fergus 175)-Jenny Alole 1\% $x^{2}$ by Carbunele 1\%\%2 (Babr. Blank 1755)-Dau. 17\%3 of Prince T'Quassaw 1651

.

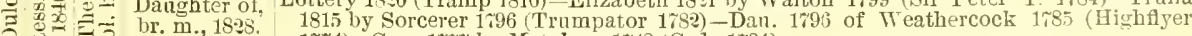
1774)-Cora 17\% by Matchem 174s (Cade 1\%34). E

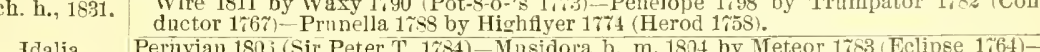

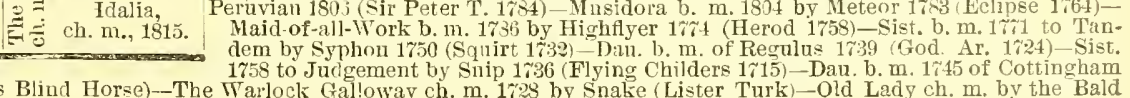

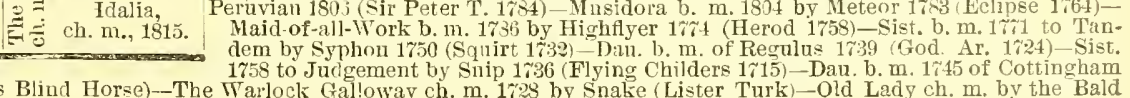

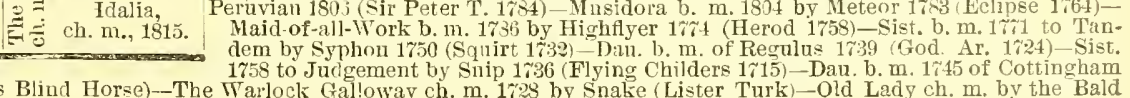
1735 (Hartley's Blind Horse)-The Warlock Gal!oway ch. m. $1 \% 28$ by Snake (Lister Turk)-
Galloway (St. Victor Barb) - The Wharton mare by the Carlisle Turk-Dan. of Byerly Turk. 


\section{SPENDTHRIFT.}

WINNER OF THE SANFORD STAKES FOR TWO-YEAR OLDS AT LOLISVILLE, YOUNG AMERICA STAKES No. 1 AT NASHVILLE, BELMONT AND LORILLARD STAKES AT JEROME PARK, CHAMPION STAKES AND JERSEY DERBY AT MONMOUTH PARK.

\section{Located in Hartland Stud, Versailles, $K y$. Yearlings sold annually.}

SPExdthrift by imp. Australian, son of West Anstralian, bred in the Woodburu Stud, Ky., foaled 1876, dam Aerolite, dam of Mozart, Rutherford, Felluweraft, Miser, ete., by Lexington, out of Florine, dam of Idlewild by imp. Glencoe. Aerolite, Spendthrift's dam. was the great brood mare of the Woodburn Stnd. Her full sister, Irllewild, was the best mare of her clas, ran four miles when five years old, 117 1lis., in $7.26 \frac{1}{4}$, and is the dam of Wildidle, that ran four miles in $7.25 \frac{1}{2}$. Spendthrift was the phenomenal two-year old of 1878; won all his races, five in number. At Lexington, Ky., won Sweepstakes for two-year olds, 1 mile, in $1.58 \frac{1}{2}$, beating Montreal, Senlly and three other's. At Lonsville, Ky., won the Sanford Stakes for two-year olds, 1 mile, in $1.46_{4}^{\frac{1}{4}}$, beating Montreal, Trinidad and five others, among which was Goorngeht and Strathmore; same place, won a Sweepstakes for two-yearolds, 1 mile, in 1.45. At Nashville, Tennessee, won the Young America Stakes No. 1 for two-rear olls, three-quarters of a mile, in $1.16 \frac{1}{4}$, veating Lord Murphy, Charlemagne and Cal.

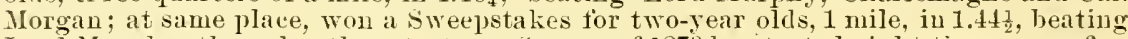
Lord Murphy, the only other starter. Season of 1879 he started eight times, won five races, and was second in three. Spendthrift made his first appearance at Jerome Park, Iay 31. He ran second in the Withers Stakes, 1 mile, won br his stable companion, Dan sparling, by snfferance, Report was third, Harold, Plerna and Mnlrooney nnplaced, time, 1.48; Jnne 5, won the Belmont Stakes, $1 \frac{1}{2}$ miles, defenting Monitor, Jericho, Pawnee, Rochester and Harold, time, 2.423: June 10, won the rich Lorillard stakes, $1 \frac{3}{x}$ miles, defeatiug Harold, Magnetism, Report, Dan Sparling, Monitor, Roches. ter, Jericho, Boardman, Plevua and Ennice. This race was the grandest achievenent ever accomplished by a thee-rear old in America. Spendthift carried 5 1bs. penalty for wimmng the Belmont stakes. making his weight 123 lbs., and was almost left at the post. Harold delayed the start by his ngly temper, and gave Spendthift a vicious kick just as the signal for the start was given. Harold bolted ofi in the lead, and Spendthrift was the last to leave the starting point, fully fifty yards in his rear. Harold tnined into the home-stretch with finly thirty yards lead on Spendthrift. Spendthritt gradnally gained on Harold, and the game son of Australian came on and

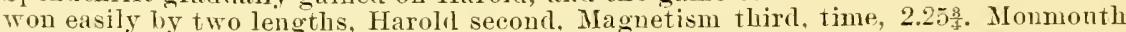
Park. July 8, won the Jersey Derloy, $1 \frac{1}{3}$ miles, (lefeating Wilful with eace, time, 2.53. Saratoga. N. Y., Jnly 9, Spendthrift met the son of Enquirer, Falsetto, for the first time. The race was for the Travers Stakes, 18 miles. Falsetto won, Spendthrift was

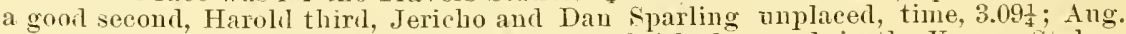
12. Falsetto arain defeated Spendthrift, who finished second, in the Kenner stalies.

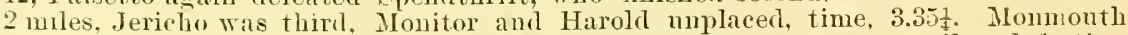
Park, Ang. 23. Spendthrift wou the Champiou Stakes for all ages. $1 \frac{1}{2}$ miles, refeating

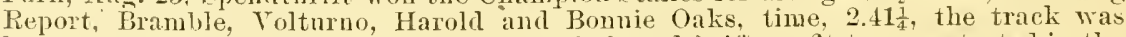
heary and slow. Jerome Park. N. S.. Oct. 2, Spendthrift. unfit to run, started in the Jerome Stakes, 1롤 miles, Nonitor won, Spendthrift second, Report third, Jericho fonrth, time, 3.12. Spendthrift, at four rears old, was sent to England. but when amiss ran mplaced for the Cambridgeshire. Ran two rares at Jerome Park when unfit at five years old : was second to barrett, 1 mile, in $1.44 \frac{1}{2}$, and was nuplaced in the other race.

Spendthrift is the sire of a nnmber of good wimners, including the famous sprinter Kingston, Bankrupt. Carre G., Stockton, Thriftless, Tonch Pas, Shasta, Golden Reel, Defunlter. Alarm Bell. America. Extravagance, Speedwell, Yictor sass, Prodigal, Speedwest, Bill Bames, Kingshridge, Kingstock, Marts B., Pall Mall, Pickpocket,

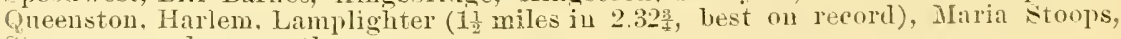
Stowaway and mans others.

Spendthift lias the T'onchstone. Wrinsker and Whalehome hlood on the sire's side. the Glencoe on the dam siste. and is much nubed to sir Archy aud Diomed, with the Gimerack blood through imp. Medley. 
Trumpator 1682 Conduetor Irir Malchem 1748-Cale 1731-Corblphin Arabian 1721.

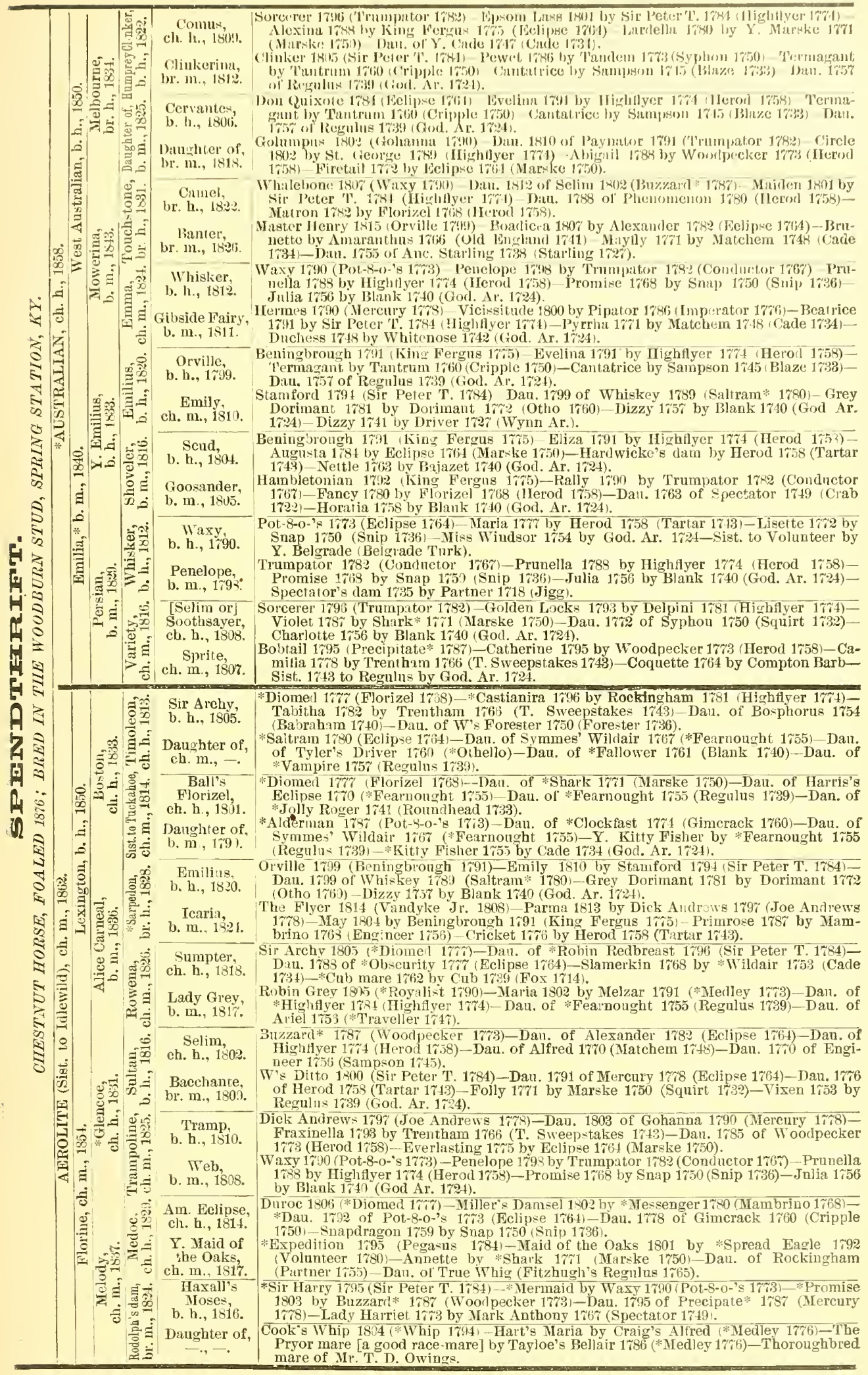




\section{SPRINGBOK.}

TINNER GE THE BELHONT STAKES AT JEROME PARK, SARATOGA CLP AT SARATOGA, AND MANY OTHER RACES.

\section{In the Megibben-Edgewater Stud. Application to F. S. Ashbrook, secretary, Cynthiana, Ky.}

SprixgBok by imp. Australian, son of West Anstralian, bred in the Woodhurn Stud, Ky., foaled 1870, dam Hester by Lexington, second dam Heads I say, dam of Maggie Hunter, Hazard, etc., by imp. Glencoe, ont of imp. Heads or Tails by Lottery. springbok eame out as a two-year old; started in two races. Jerome Park, won a dash of 5 furlongs for two-year olds in $1.05 \frac{1}{2}$, beating Mimnie Mae, liaty Pease and others, and was unplaced in the Saratoga Stakes, at Saratoga, three-cuarters of a mile, won by Cateshy in 1.17 $\frac{1}{2}$. As a three-rear old started in seven races, of which he won three. At Jerome Park, won the Belmont Stakes for three-year olds, 1 mile 5 furlongs, beating Connt D'Orsay, imp. Strachino, Waverly and six other's, among which were Felloweraft and imp. Ill-Used; same place, won a race of mile heats iu 1.45, 1.441, beating imp. Buckelen and two others; won mile heats in $1.46 \frac{1}{2}, 1.48$, $1.48 \frac{1}{2}$, Minnie Mae won the first heat. At Monmonth Park, was second in the Jersey Derby for three-rear olds, $1_{2}^{1}$ miles, won by Tom Bowling in 2.45. At Jerome Park, was second in the Jerome stakes for three-year olds, 2 miles, won by Tom Bowling, no official time given. At Saratoga, was unplaced in the Travers Stakes for threerear olds, 18 miles, won by Tom Bowling in 3.09: and was third in the Kenner stakes for three-year olds, 2 miles, won by imp. Ill-Used in 3.39. As a four-year old started in nine races, of which he won eight. Jerome Park, won a selling race, $1^{3}$ miles, in

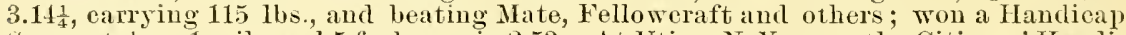
sweepstalies, 1 mile and 5 furlongs, in 2.53. At Utica, N. Y., wou the Citizens' Handivap Stakes for all ages, 2 miles, in $3.36 \frac{3}{4}$, beating Artist and Katy Pease; same place, wou the Hotel Purse, mile lieats, in $1.45,1.428$. At Saratoga, won a dash of $1 \frac{1}{4}$ miles, in 2.093, beating Mate, Snrvivor and Dublin; won the Saratoga Cup, $2 \frac{1}{4}$ miles, in 1.11 $\frac{3}{4}$, beating Preakness, Katy Pease and Wanderer; won a dash of 2 miles and a furlong, in 3.56; won a dash of 3 miles, in 5.421, beating Preakness and Felloweraft. Jerome Park, was second in the Jockey Clnb Handicap, 2 miles, won by Preakness in 3.42. As a tive year old he started in six races, winning four and running dead heat in one. At Jerome Park, wou a dash of $1_{\frac{1}{2}}$ miles, in 2.43, beating Mate, the only other starter; won a race ot mile heats in $1.41 \frac{1}{4}, 1.46 \frac{1}{4}$, beatiug Spindritt. Big Fellow and Bill Bruce; won a dash of 1 mile and a furlong in $158 \frac{1}{2}$, beating Bob Woolles, Mate

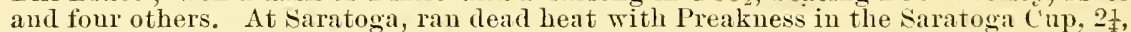
miles, in $3.56 \frac{1}{4}$, the fastest race ever ran at the distance. At Jerome Park, won a dash of 1 miles, in 3.12, beating Milner, Big Fellow and two others. At Saratoga, was second in a Sweepstakes, $1 \frac{1}{4}$ miles, won by Grinstead in 2.083. As a six-year old started once in a race of mile heats and was distanced in the first heat. In this race Freebooter was the winner, with 101 lbs., while Springbok carried 124 lbs. Spring. bok was a first-class race-horse, and is descended from a racing family on both sides. He is nuch inbred to Waxy through Whisker, Whalebone and Web, and traces on his dam's side to Eleanor by Whiskey, the first mare to win both the Derby and Oaks. In addition to his Diomed blood through Lexington, his dam traces to Diomed's best danghter in England, Yonng Giantess, the dam of Soreerer, and a sister to Roxana, who first brought the great Godolphin Arabian into notice to a danghter of Spanker.

Springbok is the sire of the winners Almeda, Huntress, Lamra Garrison, Winous, Lila May, Lute Amold, Elgin, Markiand, Amreliau, Ascoli, Kasson, Miss Charmer, Loreland, Ninola, Easterbok, Eberlee, The Elk, WT. G. Morris, Tallera, Mary Kinhl, Blue Jeans, Birdella M., Rook Laidly, Ben March, Spectator, Flower Dellis, Maj. Thornton, Neva C., Julia May, W. L. Munson, Springaway amd many others.

Splingbok descends in direct female line through old Balel Peg from the Barb mare, to which traces Lath, Cade, Flying Childers, Diomed, Sorcerer. Priam, Phantom, Langar, Mules, Plenipotentiary, Turnus, See Saw, Zinganee, Troubadour, Harry of the West and all the imp. sylva family.

springbok is a bright chesunt, 16 hands high, with star and smp over his left nostril, and white spot between the nostrils, and black spot orer his right eve. left fore leg white over the ankle, both hind feet white nearly to the hocks. He is a horse of great sulustance and power, highly finished all over, without a particle of lumber, and has made his mark in the stud. 


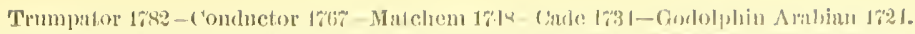

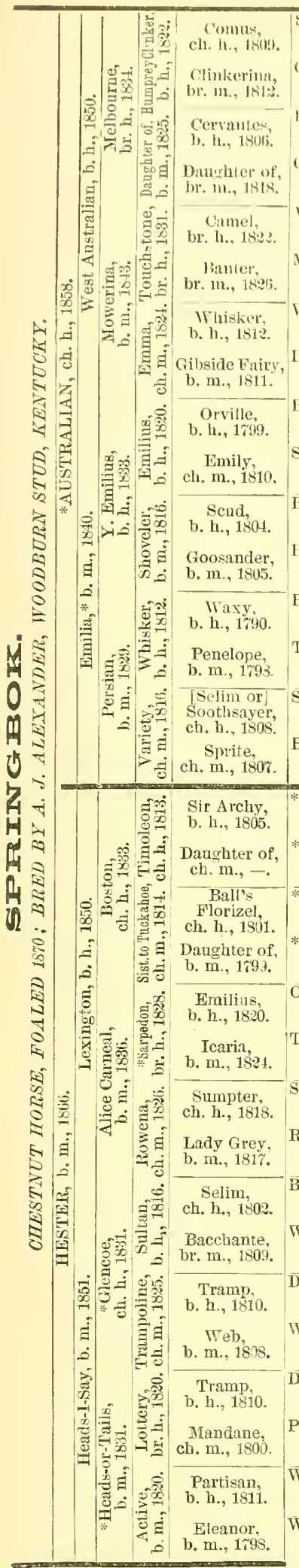

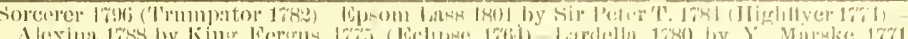

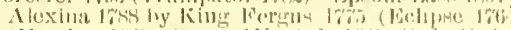

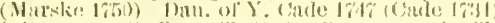

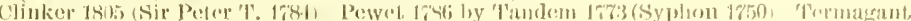

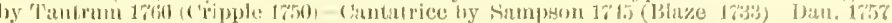

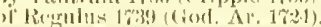

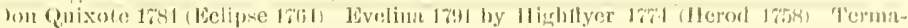

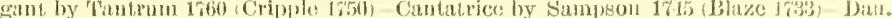

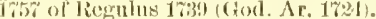

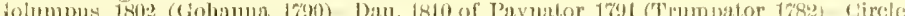

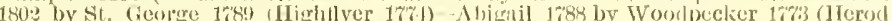

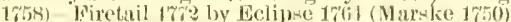

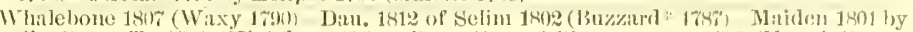

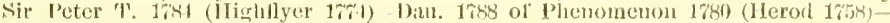

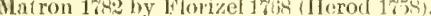

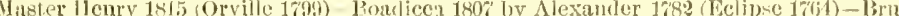

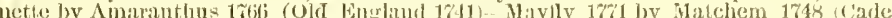
1734-Dau, 1755 ol Anc. Starling 1738 (Stalling 17\%6).

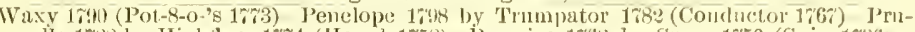

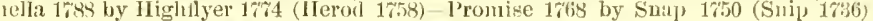
Julia 1756 liy Blank 17-10 (God. Ar. 1\%21).

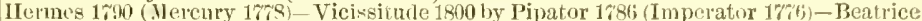

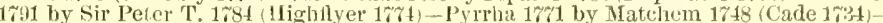
Duchess 17.18 by Whitenose 1712 (God. Ar, 17:4).

Beningbrough 1791 King Fergus 17,5) Evelina 17al by Higlullyer 1781 (Helod 1758) 'I'rmasant by Tantrum 1600(Cripple 1750)-Cantatrice by Sampson 1745 (Blaze 1733)Dau. $175 \%$ of Regulus 1739 (God. Ar. 17\%-1)

Stamford 1794 (Sir Peter T. 1784) Dau. 1799 of Whiskey 1789 (Saltram* 1780) Grey Dorimant $1 \% 81$ by Dorimant $1 \% \sigma^{2}$ (Otho $1 \% 60$ )-Dizzy $1 \% 5 \%$ by Blank 1740 (God. Ar. 1724)-Dizzy $17 \pm 1$ by Driver $172 \%$ (Wymm Ar.).

Beniugbrough 1791 (King Fergus 1775) Eliza 1791 by Hightlyer 1774 (Herod 1754) Augusta 1781 by Eclipse 1764 (Markke 1750)-IIardwicke's dam by Herod 1758 (Tartar 1743) - Nettle 1763 by Bajazet $1 \% 40$ (God. Ar. 1724).

Hambletonian 1792 (King Fergus 17\%5)-Rally 1790 by Trumpator 1782 (Conductor 1767) Fancy 1780 by Florizel $1 \% 68$ (Herod 1758)-Dan. 1763 of Spectator 1749 ( Crab 1722)-Horatia 1758 by Blank 1740 (God. Ar. 1\%24).

Pot-8-0-'s 1773 (Eclipse 1764)-Maria 17\%' by Herod 1758 (Tartar 1713)-Lisette 17\%2 by Snap 1750 (Snip 1736) - Miss Windsol 1754 by God, Ar. 1724-Sist. to Volunteer by Y. Belgrade (Belgrade Turk).

Trumpator 1783 (Conductor 1767)-Prunella 1789 by Hichflyer 17\%4 (Herod 1758) Promise 1708 by Snap 1750 (Snip 1736) -Julia 1756 by Blank 1740 (God. Ar. 1721)Spectator's dam 1735 by Partner 1718 (Jigg).

Solcerer 1796 (Trumpator 178*) Golden Lacks 1693 by Delpini 1781 (Highfyer 17\%4) Violet $178 \tilde{i}$ by Shark*1; 1 (Marske 1750)-Da11. $17 \% 2$ of Syphon 1750 (Squirt 1\%32) Challotte 1750 by Blank 1740 (God. Ar. 1\%

Bobtail 1795 (Precipitate* 178\%) -Catherine 1795 by Woodpecker $1 \% 33$ (Herod 1758 - Camilla 1\%'s by Trentham $1 \% 66$ ( $\mathrm{T}$. Sweepstakes 1743 ) -Coquette $1 \% 64$ by Compton BarbSist. 1743 to ReguIus by God. Ar. 1724.

*Diomed $17 \%$ (Florizel $1 \% 68$ ) — * Castianira 1796 by Rockinoham 1781 (Highflyer 17\%4) Tabitha 1782 by Trentham 1766 (T. Sweepstakes 1743)-Dau. of Bosphorus 1754 (Babraham 1740)-Dau. of W's Forester 1750 (Forester 1736).

* Saitram 1780 (Eclipse 1664)-Dan. of Symmes' Wildair 1'667 (*Fearnought 1755)_Dan. of 'Tyler's Driver $1 \% 60$ (*Othello)-Dau. of *Fallower 1\%61 (Blank 1\%40)-Dau. of *Vaupire 175; (Regulus 1\%39).

Diomed 1\% (Florizel 1\%68)-Dau of *Shark 17n1 (Marske 1750)-Dan of Harris's Eclipse 1760 ("Fearnought 1755)-Dau. of *Fearnought 1755 (Regulus 1739)-Dau. of * Jolly Roger 1741 (Roundhead 1733).

*Alderman 178\% (Pot-8-o-'s 17\%3)-Dau. of *Clockfast 1\%r4 (Gimerack 1760)-Dau. of Symmes" Wildair 1767 (*Fearnonght 1755) - Y. Kitty Fisher by *Fearnought $1 \% 5$ (Regulus 1739) — Kitty Fisher 175.5 by Cade 1\%34 (God. Ar. 1721).

Orville 1799 (Beningbrough 1791) -Emily 1810 by Stamford 1794 (Sir Peter T, 1784)Dau. $1 \% 99$ of Whiskey 1789 (Saltram* 1780)-Grey Dorimant 1781 by Dorimant $17 \%$ Otho 1760) Dizzy $175 \%$ by Blank 1740 (God. Ar. 1\%24).

The Flyer 1814 (Vandyke Jr. 1808)-Parma 1813 by Dick Andrews 1797 (Joe Andrews 17/8)-May 1804 by Beningbrough 1791 (King Fergus 17r5)-Primrose 17s brino 1763 (Engineer 1756)-Cricket 1766 by Herod 1758 (Tartar 1743).

Sir Archy 1805 (*Diomed 1\% $7 \%$ )Dak of *Robin Redbreast 1796 (Sir Peter T, 1784) Dau. 1788 of :Obscurity 1777 (Eclipse 1\%64)-Slamerkin 1768 by *Ildair 1753 (Cade 1734) - *ub mare 1762 by Cub 1739 (Fox 1714).

Robin Grey 1805 (*Royalist 1790)-Maria 1802 by Melzar $1 \% 91$ (* Medley 17\%3)-Dalt. of Highflyer 1784 (Highflyer 17\%4)-Dan. of "Fearnought 1755 (Regulus 1739)-Dau. of Ariel 1756 ( $\%$ Traveller $1 \% 47$ ).

Buzzard* $178 \%$ (Woodpecker $1 \%(3)$-Dan, of Alexander 178* (Eclinse 1764)-Dau, of Highflyer 17\%4 (Heror 1758)-Dau. of Alfred $17 \% 0$ (Matchem 1713)-Dau. 17\%0 of Engineer 1756 (Sampson 1745).

V's Ditto 1800 (Sir Peter T. 1784)-Dau. 1\%91 of Mercury 1\%8 (Eclipse 1764)-Dau. 1\%6 of Herod 1759 (Tartar 1713)-Folly $1 \% 71$ by Marske 1750 (Squirt 1732) - Vixen 1753 by Regulus 1\%39 (God. Ar. 1\%24).

Dick Andrews $179 \%$ (Joe Andrews 1\% Dan 1803 of Gohanna 1\%90 (Mercury 17s)Fraxinella 1793 by Trentham 1766 (T. Sweepstakes 1743)-Dau. 1785 of Woodpecker $17 \% 3$ (Herod 1\%58)-Everlasting 1\%'5 by Eclipse 1764 (Marske 1\%0)

Vaxy 1790 (Pot-8-0-'s 17\%3) - Penelope 1798 by Trumpator 1782 (Conductor $176 \%$ ) - Prunella 1788 by Highflyer 1774 (Herod 1758)-Promise 1768 by Snap 1750 (Snip 1736)-Julia 1756 by Blank 1740 (God Ar. 1\%2)

Dick Andrevs 179\% (Joe Andrens 1778)-Dau, 1803 of Gohanna 1790 (Mercury 17\%) Fraxinella 1793 by Trentham 1766 (T. Sweepstakes 1713)-Dan. 1785 of Toodpecker 1773 (Herod 1758)-Evarlasting 1775 by Eclipse 1764 (Marke 1750).

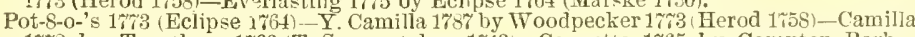
$1 \% 78$ by Trentham 1766 (T. Sweepstakes 1743 )-Coquette 1765 by Compton BarbSist. 1 \% 43 to Regulus by God. Ar. 1724.

Walton 1r99 (Sir Peter T 1\%84)-Parasol 1800 by Pot-S-0-'s 17mi3 (Eclinse 1761) - Prunella 1788 by Highflyer $17 \% 4$ (Herod 1758)-Promise 1768 by Snap 1750 (Snip 1736)-Julia 175 i) by Blank 1740 (God. Ar. 1\%21).

Whiskey 1789 (Saltram* 1780)-Y. Giantess b. M. 1790 by Diomed 17\%\% (Florizel 1768) Giantess b. m. 17'69 by Matchem 1718 (Cade 1734)-Molly Long Legs b. m. 1758 by Babraham 17t0 (God. Ar. 1721)-Dau. of Cole's Foxhnnter 1727 (Brisk 1711)-Sist. to Cato by Partner 1718 (Jigra) Sist. ch. m. 1619 to Roxana by Bald Galloway (St. Victor Barb) Sist. to Chaunter by Akaster Turk-Cream Cheeks by Leedes Ar.-Dau. 16.0 by Spanker (D'Arcy Yellow Turk) Old Irorocco mare by Fairtax's Morocco Barb-Old Bald Peg by an Arabian - A Barb mare. 


\title{
IMPORTED STALWART.
}

\author{
Imported and owned by the Estate of the late D. D. Withers, Holmdel, N. J. \\ Sales umually.
}

Stalwart, bay horse, foaled 1883 , bred by the Yardley Stud, by Sterling, son of Oxford by Birleatcher, dam Sea Mark by Adventurer, son of Newminster, ont of Sea Gull by Lileboat, son of sir Herenles. Stalwart received an injury crossing the ocean and wats never trained.

Sterling, the sire of Stalwart, one of the most popular stallions in England, starterl only a few times. He won the Liverpool Autumn Cup, beating Louise Vietoria and twelve others, and was third to Montargis and Walnut in the Cambridgeshire, with 133 lbs. He won the Ascot Biemial Stakes, the Summer Stakes at Newmarket, the Derby Free Handicap and Craven Stakes. He was second to Boswell in the 2,000 Guineas, a defeat which was one of the most glaring flukes in the annals of the turf, for it was admitted by everyone that he eonld concede quite $42 \mathrm{lbs}$. to the wimner. He was not in the Derby. His valne is best shown in the stud, having sired such good ones as Isonomy, who himself is the sire of Riviera, one of the farorites for her year's Derby, Formidable, another good two-year old, Antibes. Common, winner of 2,000 Guineas, Derby and St. Leger, ete, etc., and one of the best raee-horses of his time. His get this year won over $\$ 100,000$, and he was standing at $\$ 1,000$, with his season full. Harrester, who ran a dead heat with St. Gatien, and divided the stakes for the Derby, and was third in the 2,000 Guineas. Paradox, Enterprise and Enthusiast, all three wimners of the 2,000 Guineas, the former only beaten a head in the Derby and the latter defeating the famons Donoran. Energy, winner of sixteen races ont of thirty seven and one of the speediest horses of his day. Beaudesert, the winner of the Middle Park Plate and sire of many winners last year. Caxtonian, Discount, Post Orbit, Geologist, El Dorado (another conqueror of Donovan) and Cherr'y all come from Sterling's loins. Stalwart's dam, Sea Mark, is the dam of Astronomy, Beaeon and the fine young stallion Top Gallant. His grandam, Sea Gull, was the dam of Beandesert, winner of the Middle Park Plate. Qneenstown, The Admiral, Discordant, etc. Wild Cherry was the dam of Grace Darling, Cherry Ripe, Sugar Plum, Heliotrope, Reciproeity, ete. Bridget was the dam of The Baronet, Wild Strawberry, Pomona, Mrss Fanuy, ete. Stalwart traces through Ringlet, a daughter of Whisker, Clinkerina, the dam of Humphrey Clinker, sire of the notel Melbonrne by Clinker, Pewet, a winner of the St. Leger, by tandem, to the noted Blacklegs mare, dam of Marske, the sire of Eelipse. He combines in his pedigree a double eross of Sir Hercules, upon a large infusion of Tonchstone blood, throngh sueh excellent sources as Adventurer, Flateatcher and Surplice, and traces on his sirẹs and dam's sicle to the noted danghters of Prian, Crucifix and Miss Letty. Many of the best raee-horses and stallions in England are deseended from the family. He must be a valuable aequisition to the blood stoek of the eountry. He is descencled in direct fenale line from the Bustler mare, to which traces Merlin (by Castrel), Marske, sire of Eclipse, Orville, Cerrantes. Cain. Buzzard (by Blacklock), Humphrey Clinker, Newminster, Stratìord, Mariner, Melton, etc. 


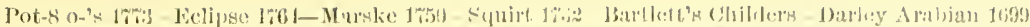

-

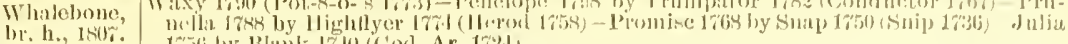

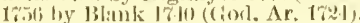

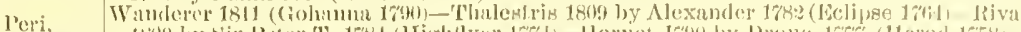

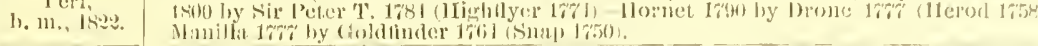

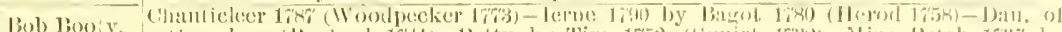
clı, h., Isili.

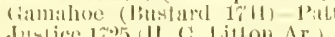

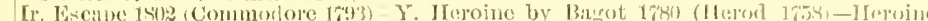

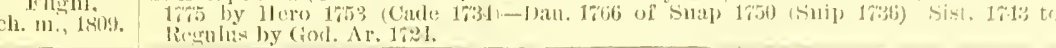

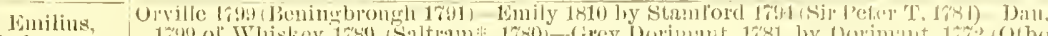
b. $11,16: 1$ ) 1

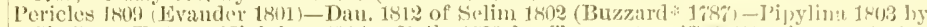

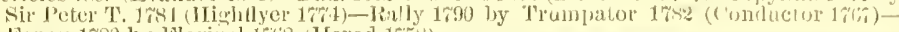
Finey 1780 by lilorizal fitis (Iferod 175x).

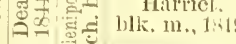

Bity

Mirdetom,

b. 11., 18:3:3.

(S)

1792 by Trumpation $178^{\circ}$ (Conductor Ir(ji)

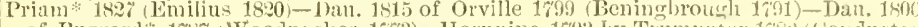

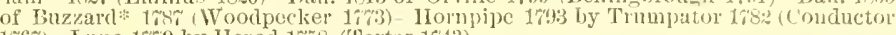
$1 \% 6 \%$ - Lma $17 \% 9$ by Ilerod $17 \% 8$ ('Tartur $1 \% 43$ )

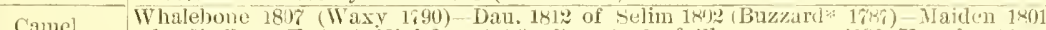
br. $11 ., 1822$.

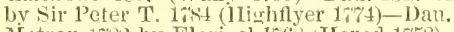

Bunter Master Henry 1815 (Orville 1\%(6))-Boudicea $180 \%$ by Alexander 1782 (Ecliuse 17(j4)-

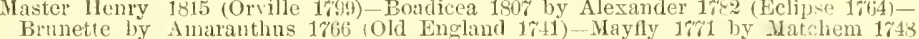

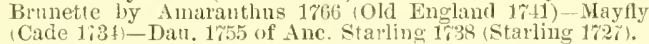

ठี่

br. h., 1812.

(Pot-8-0-'s 10i3)

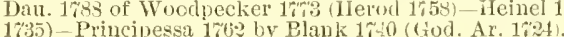

Finesse, Peruvian 1803 (Sir Peter T. 1684) Violante 1802 by John Bull 1r89 (Fortitude 1;r6)

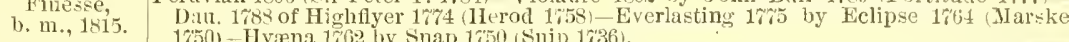
1750) - Hyæna $170 \cdot 3$ by Snap 1750 (snip 1736).

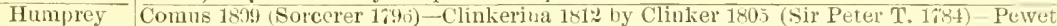

('linker

b. 1,182 ?

Daughter of

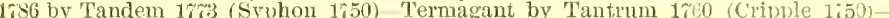
Cantairice by Sampson irt5 (13laze 1733 i.

b. m., 18.25 . Cervantes 1806 (Don Quixote 1784)-Dau. 1818 of Golumpus 1802 (Gohanna 1790)_Dall. 1810 of Paynator 1791 (Trumpator 172 ) Circle 1872 by St. George 1789 Hightlyet 1774 - Aligail 1789 by Woodpecker $17 \% 3$ (Herod 1758).

Velocipede 1525 (Blacklock 1814)-Dau, 182) or Cerberus 1×0 (Gohanna 17k) - Ilis

ch. b., 1832 .

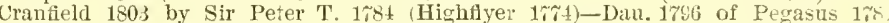

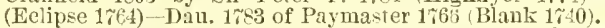

Solace, Longwaist 1821 (Whatebone 1807)-Dulcamara 1818 by Waxy 1790 (Pot-8-0-'s 17r73)-

b. m., 1830. Witehery 1814 hy Sorcerer 1796 (Trumpator 1782)-Cobbëa 1802 by Sliyscraper 1 (Highflyer 17\%t) Dau. 1788 of Woodpecker 17r3 (1lerod 1758).

Camel, TWbalebone 1807 (Waxy 1790)-Dau. 1812 of Selim 1802 (Buzzard* 1787)-Maiden 1801 by

br. $\mathrm{h}, 1809$ Sir Peter T. 1784 (Highflyer 17\%1)-Dan. 1788 of Phenomenon 1:80 (Herod 1758)Matron 1782 by Florizel $1 \% 68$ (Herod 1758).

Banter, Master Henry 1815 (Orville 1\%99)-Boadicea $180 \%$ by Alexander 1\%82 (Eclipse 1764)-Brunette by Amaranthus $1 \% 66$ (Old England 1\%11) - Mayfly 1\%1 by Mateliem 1\%48 (Cade 1731)-Dau. 1755 of Ane. Starling 1738 (Old Starling 172\%).

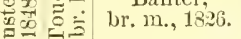

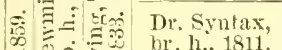
Paynator 1791 (Trumpator 1782)-Dau. of Beningbrough 1791 (King Fergus 1\%5) saw 1751 (Snip 1736) -Sultana 1759 by Regulus 1739 (Gool. Ar. 17.24).

Daughter of, Ardrossan 1603 (John Bnll 1789)-Lady Eliza 1813 by Whitworth 1205) (Agonjstes 1797)ch. $11 ., 181 \%$. X. Y. Z's dam 1793 by Spadille 1781 ( Highflyer 174 ) Sylvia

Orvile, Beningbrough $17 \% 1$ (King Fergus 17\%5)-Evelina 17.1 by llighflyer 1\%1 (Herod 1758)

b. Termagant by Tautrum 1\%60 (Cripple 1759)-Cantatrice by Sampson 1\%45 (Blaze 1\%33) -Dau. $175 \%$ of Regulns 1737 (God. Ar. 1721).

Emily, Stamford 1791 (Sic Peter T. 1781)-Dau. 1799 of Whiskey 1789 (Saltram* 1;8) - Grey cl. In., 1S10. Dorimant 1781 by Dorimant, 17i2 (Otho 17C0)-Dizzy 175\% by Blank 1710 God. Ar. 1721)-Anc. Dizzy 1\%t1 by Driver $1 \% 2 \%$ ( W vmn Ar)

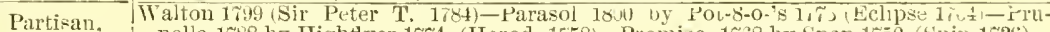

Partisan. nella 1788 by Hightlyer 17r4 (Herod 1758)-Promise 1608 by Snap $1 \% 50$ (Snip 1736)Julia 1756 by Blank 1740 (God, Ar. 1724).

Miss Fanny's Orville 1799 (Beningbrough 1791)-Dau. 1800 of Buzzard* $178 \%$ (Toodpecker 17\%)

dam, Hormpipe 1793 by Trumpator 1782 (Conductor 17t)-Luna 1779 by Herod 1758 (Tartar br. m.. 1815.

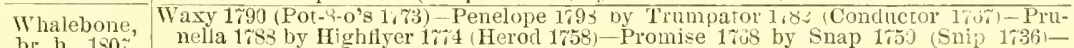
bl, b. 180\% Julia 1756 by Blink 1740 (God. Ar. 1724).

Peri lianderer 1811 (Gohanna 17:0)-Thalestris 1879 by Alexander 1782 (Eelipse 1764)-Riva 1800 by Sir Peter T. 1784 (Hightlyer 1\%4)-Holnet 1790 by Drone 1\% (Helod 1\%5s

S.

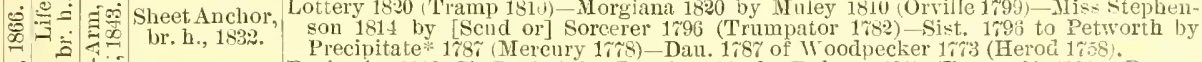

Paulowitz 1813 (Sir Paul 1872) Loyalty $181 \%$ by Rubens 1805 (Buzzard* $1 \%$ ' Pentyroyal 1805 by Coriander 1786 (Pot-So-'s 17\%)-Peppermint 178\% by Highflyer $17 \% 1$ (IIerod 1758)-Promise 1768 br Snap 1750 (Snip 1766)

Camel 1823 (Whalebone 1867)-Banter 1026 by Ma-ter Henry 1815 (Orville 17!s) - Boadicea 1807 by Alexander 1782 (Eclipse 1\%61)-Brunette by Amaranthus 1766 (Old Eng land $1 \% 11$ )-Mayfly $1 \% 1$ by Matchem $1 \% 48$ (Caile $1 \% 34$.

Touchis

Priam*1827 (Emilius 1820)-Octaviana 1815 by Oct 2 vian 1807 (Stripling 1795)_Dan. 1807

Crucifix,

of Shuttle 1793 (Y. Marske 17\%1)_Zara 1801 by Delpini 1781 (Hightyer 1 1 it)-Flora

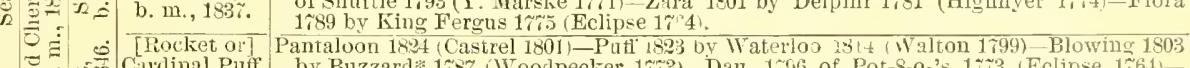

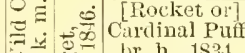

$= \pm$ :

by Buzzard\% 1787 (Woodpecker 17\%3) - Dau. 1796 of
Maid-of-all-Work 1 \% 66 by Hightlye* $17 \tau+$ (Herod 1758

B. Ringlet,

Whisker 1812 (Taxy 1790) Clinkerna br. 117.1812 by Clinker $180,($ Sir Peter T. 1781) Pewet b. m. 1\%86 by Tindem 1\%3 (Syphon 175))-Termagant by Tantrum 1\%60 (Cripple 1,50)-Cantatrice by Sampson 1745 (Blaze 1733)-Dan. "br. m. 175r by Regulns 1739 -Cantatrice by Sampson 1745 (Blaze 1733)-Dan. br. m. 175 by Blacklegs 1725 (Mulso Turk)-Dau, of Bay Bolton 1705 (Grey Hautboy) Dau. of Fox Cub 1714 (Clumsy)-Dan. of Coneyslins 17 (Lister Turk) -1) an, of Hution's frey Barb 1\%00-Dan. of Hutton's Royal Colt 170J (Helmsley Turk)-Dau. of Byerly Turk-Dau. of Bustler (Helmsley 'Turk). 


\section{IMPORTED STONEHENGE.}

WINNER OF THE COTTAGERS' CUP AT LONG BRANCH, 1873.

\section{In the Brookdale Stud, Estate of D. D. Withers, proprietor, near Holmdel, N. J. Private stallion. Sales ammally.}

Stonehenge by Blair Athol, best son of Stockwell, bred by Mr. W. Blenkiron, foaled 1870, dam Coimbra, dam Light of Wine, etc., by Kingston, son of Venison, ont of Calcavella, clam of Queen Bee, etc., by Irish Birdeatcher. His sire, Blair Athol, won the double events, Derby and St. Leger, and his sire, Stockwell, was the greatest and grandest of all the Euglish stallious. Kingston, the sire of his dam, traveled all orer Eugland, and was wimner in the best of company. Irish Birdcatcher by Sir Hercnles, son of Whalebone, was not only a good race-horse but he got The Baron, winner of the St. Leger, and he got Stockwell and Rataplan. Birdcatcher was also sire of Daniel O'Ronrke, a Derby winner, Songstress, wimer of the Oaks, Knight of St. George and Warlock, wimners of the St. Leger. Fangh-a-Ballagh, the sire of Leamington, was own brother to Birdcatcher. Stonehenge male his debut as a two-year old in the Nursery Stakes at Jerome Park, bnt was unplaced. This was his only start in his two-year old form. When three years old he started six times, won oue race,

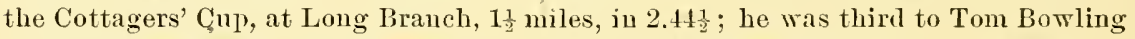
in the Robins Stake, with Lizzie Lncas and The Niustrel behiud him; was third to Survivor and Fellowcraft in a race of $1 \frac{1}{4}$ miles, with fonr others behind. He was unplaced in his other races. His son, Marsh Redon, showed himself a good two-year old.

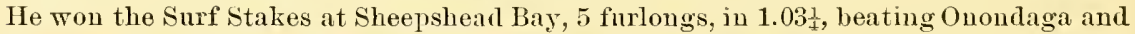
Memento; won Angust Stakes at Loug Brauch, three-quarters of a mile, in 1.16, with $115 \mathrm{lbs}$, beating Wyoming, Onondaga and Memento; was second in 1882 to Forester, in the Withers Stakes; second to Rnnnymede, in the Tidal Stakes at Sheepshead

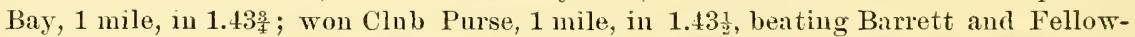
play. Bnckstone (2) won the Hoët and Chandon Stakes, three-quarters of a mile, in 1.21, track heavy, defeating a field of five; won the Homebred Produce Stakes, threeqnarters of a mile, in 1.18 $\frac{1}{2}$, both at Long Branch. He is a blood bay, with blaze face aud suip, near hind leg roan and white to the hock, is 15 hands 21 inches high, and weighs $1,140 \mathrm{lbs}$. With a Glencoe cross, through Stockwell, and a double cross of Whalebone, throngh Irish Burdcatcher, fortified by the bloor of Eclipse and Herod, he only needed a chance to distingush himself as a sire.

Stoneheuge is the sure of the winners Hopeless, Juclge Griffith, Frolic, Jack, Salısbury, Gold Star, Alice, Druldess, Elmstone, Richard K. Fox, Overstone, Adamant, Rosa, Rose, Stonemason, Genevieve, Soho, Necktie, Stonenell, etc.

Stonehenge descends in durect female lme from the Sister to Striping, to which traces Bnrgundy, Ambrose, Dnirlee, Brown Brear, Van Ambmrgh, Tibthorpe. St. Gatien, Ornonde, Kendal, Nuncaster, imp. Stylites, imp. Rossington, and all the Agnes famly in Euglanu. 


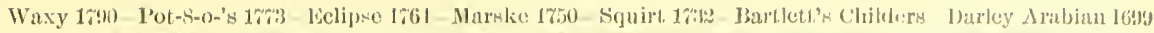

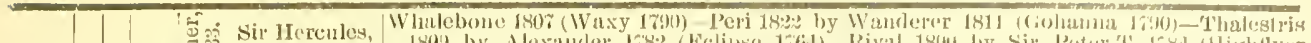

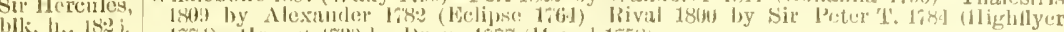

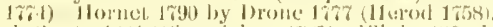

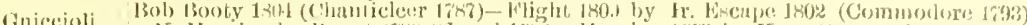

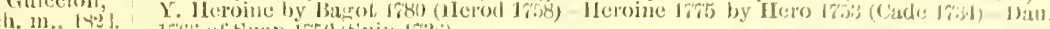

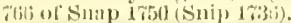

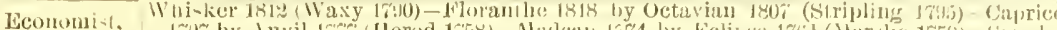

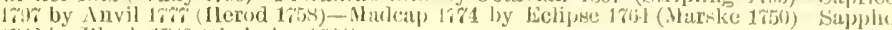

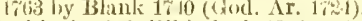

Miss Prall.

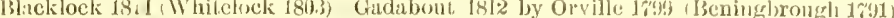

Sultiul 列 (Herod 1758) - Maiden 17\%0 loy Matelem 17.18 (Carle 17:3

b. li., 1816

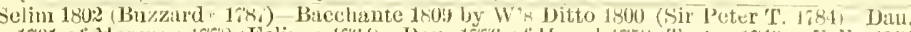

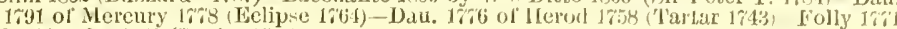
by Marske 1,50 (Squirt 17\%2).

Trampoline,

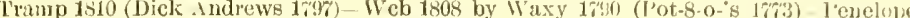
ch. $11 ., 1825$. Tos by Trumpator 1782 (Conductor 1,66)

Muley,

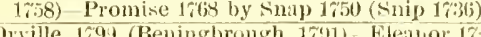

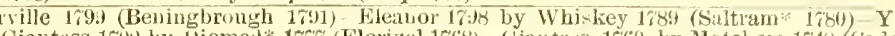
Giantess 1790 by liomed* 17r\% (Florizel 1768) Giantess 1660) by Matchem 1748 (Cade 1731) Molly loug Legs 1753 by Babraham 1740 (God. Ar. 17\%4).

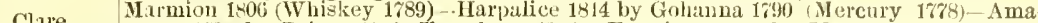

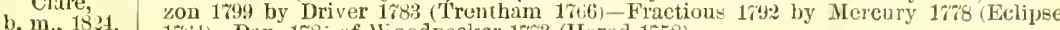

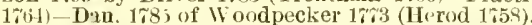
Sorcerer 1696 (Trumpator 1782) Houghton Lars 18

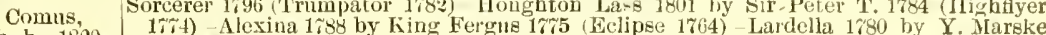
1771 (Narske 1750)-Dan. of Y. Cade 1747 (Cade 1784).

Clinker 1 (tos (Sip Peter T 1781 - Pewet

(Syphon 1750) - Termagant br. 11., 1812. of Regulus 1739 (God. Ar. 1724).

b. h., 1806 .

Don Quixote 1784 (Eelipse 1764)-Evelina 1791 by Highflyer 17\%4 (Hlerod 1758)-Termagant by Tantrum 1760 (Cripple 1750)-Cantatrice by Sampson 1745 (Blaze 1738)—Dau. 1757 of Regulus 173!) (God. Ar. 1724)

Danghter of,

Golumpus 1802 (Gohanna 1790)-Dan. 1810 of Paynator 1791 (Trumpator 1782)-Circle 1802 by st. George 1789 (Ilightlyer 17\%4)-Abigail 1788 by Woodpecker 1\%73 (Herod 1758)-Firetail $17 \% 2$ by Eelipse 1 \%64 (Marske 1750).

Partisan - $\bar{W}$ alton 1799 (Sir Peter 1784)-Parasol 1800 by Pot-\$-o's 1773 (Eelipse 1764) Prunella

Partisan 1788 by Highflyer $17 \% 4$ (Herod 1758)-Promise 1768 by Snap 1750 (Snip 1736)-Juli 1756 by Blank 1740 (God. Ar. 1724).

Moses 1819 ([Whalebone or] Seymour 1807)-Quadrille 1815 by Selim 1802 (Buzzard:

Pauline, 178\%)-Canary Bird 1803 by [Whiskey or] Sorcerer 1796 (Trumpator 1782)-Canary $179 \%$ by Coriander 1786 (Pot-8-0-' $17 \% 3$ ) - Mise Green 178\% l,y Highflyer 17\%4 (Hernd 1753).

Plempotent1- Emiljus 1830 (Urville 1799)-Harriet 1819 by Pericles 1809 (Evander 1801)-Dau. 1812 of ary, Selim 1802(Buzzard" 178\%)-Pipylina 1803 by Sir Peter T. 178 (Highflyer 17\%4)-Rally ch. h, 1831. 1790\%by Trumpator 1782 (Conductor 1767).

Whalebone 1807 (Waxy 1790)-Gift 1818 by Y Gohanna 1810 (Gohsnna 1790।-Dau, 1802 b. m., 1830 .

of Sir Peter T. 1784 (Hightyer 176) - Dau. 1788 of Trumpator 1782 (Conductor 176\%)Sist. 1744 to Postmaster by Herod 1758 (Tartar 1742)

Walton, Sir Peter T. 1784 (Highflyer 17\%4)—Arethusa 1792 by Dingannon 1780 (Eclipse 1764)-

b. h., 1799 Dan. 1777 of Prophet 1760 (Regulus 1739) - Virago 1764 by Snap 1750 (Snip 1736)-Dau.
of Regulus 1739 (God. Ar. 17\%4).

Pot-8-0-'s 1773 (Eclipse 1764)-Prunella 1788 by Highflyer 1774 (Herod 1758)-Promise

Parasol, 1768 by Snap 1\%50 (Suip 1736)-Julia 1756 by Blank 1740 (God. Ar. 1ว21)-Spectator's dam 1735 by Partner 1718 (Jigg).

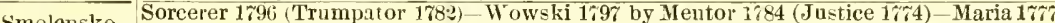

blk. h., 1810. by Herod 1758 (Tartar 1743)-Lisette 17\%2 by Snap 1750 (Suip 1736)-Miss Windsor 1754 by God. Ar. 1724.

Jerboa, Goh:mna 1790 (Mereury 17\%)-Camilla $17 \% 8$ by Trentham 1766 (T. Sweepstakes 1743)-

b. m., 1803. Coquette 1764 by Compton Barb-Sist. 1743 to

Royal Oak, Catton 1809 (Golumpus 1802)-Dau. 1818 of Smolensko 1810 (Sorcerer 1796)-Lady Mary

br. h., 1823. 1800 by Beningbrough 1791 (King Fergus 1775)-Dau. of Higbllyer 1774 (Herod 1758)Sist. to Miss Bell by Marske $1 \% 50$ (Squirt 1732).

Torville 1799 (Beningbrough 1791)-Epsom Lass 1803 by Sir Peter T. 1784 (Highfiyer

b. m. 1819, 1774)-Alexina 1788 by King Fergus 1775 (Eclipse 1764)--Lardella 1780 by Y. Harske 1771 (Marske 1750)-Dau. of Y. Cade 1747 (Cade 1734).

Octavian, Stripling 1795 (Phenomenon 1780)-Dan, 1797 of Oberon 1790 (Hightlyer 17\%4) - Sist. 1779

ch. h., $180 \%$ to Sharper by Ranthos 1\%63 (Matchem 1\%48)-Dan. of T. Sweepstakes 1\%43 (Bolt. Sweepstakes 1722) - Dan. 1\%48 of Hutton's Spot 1728 (Hartley's Blind Horse)

Daughter of Shnttle 1793 (Y. Marske 1771)-Katharine 1798 by Delpini 1781 (Highflyer 1774)-Dau.

b. m., 1806. 1786 of Paymaster 1766 (Blank 1740)-Dau. 17\%4 of Le Sang 1759 (Changeling 1747)Dau. 1751 of Rib 1736 (Crab 1\%22)

Whalebone Tha 1790 (Pot-8-0-'s 17\%3)-Penelope 1798 by Trumpator 178\% (Conductor 1767)-Prn-

br. h., $180 \%$.

axy 1790 (Pot-8-o-s 17\%3)-Penelope $1 \% 98$ by Trumpator 1782 (Conductor 1767)-Pra-
nella 1788 by Highflyer 17\% (Herod 1758)-Promise 1768 by Snap 1750 (Snip 1736)Julia 1756 by Blank 1740 (God. Ar. 1724).

Peri. Wanderer 1811 (Gohanna 1790)-Thalestris 1809 by Alexander 1782 (Eclipse 1764) -Rival

b. m., 182. 1800 by Sir Peter 'T' 1784 (Highflyer 1774)-Hornet 1790 by Drone 17\% (Herod 1758)Manilla $1 \%$ r by Goldfinder 1764 (Snap 1750).

Bob Booty, Chanticleer 1787 (Woodpecker 17\%3)-Ieme 1690 by Bagot 1780 (Herod 1758)-Dan. of Gamahoe (Bustard 1\%41)-Patty by Tim 1752 (Squirt 1732)-Miss Patch 173\% by

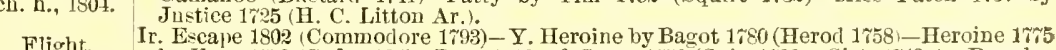

Fligh, Ilero 1753 (Cade 1,34)-Dau. 1766 of Snap 1750 (Snip 1736)--Sist. 1743 to Regulus by God. Ar. 1724.

Master Buffer 1798 (Prizefighter 1\%81) Spinster 1805 by Shut te 1793 (Y. Uarske 1\%71) -Dan.

Robert, 1797 of Sir Peter T. 1784 (Higtlyer 17\%4)-Bab 1787 by Bourdeaux 17\%4 (Herod 1758)-

gr. h., 1811. Speranza $17 \% \mathrm{~s}$ by Eclipse 1764 (Marske 1750)

- Daughter of Sir Walter Raleigh 1801 (Waxy 1790)-Miss Tooley 1808 by Teddy the Grinder 1798

br. m.. 181\%) (Asparagus 1\%87)-Lady Jane 1796 by Sir Peter T. 1784 (Hightlyer 1\%4)-Paulina 1\%8 by Florizel $1 \% 68$ (Herod 1\%58)-Captive 171 by Matehem $17+8$ (Cade 1734).

Orville 1799 (Beningbrongh 1791)-Peterea 1801 by Sir Peter T, 584 (Highflyer 1, i4) -

Don Juan,

b. h., 1814.

Mary Grey 1784 by Friar $1 \% 68$ (Hero $1 \% 53$ ) - Timante by Tim $1 \% 52$ (Squirt 1632 )-Nob-

lessa 1760 by Gamahoe (Bistard 1741)

Moll-in-the- Hanbletonian 1792 (King Fergus 1,i5)-Spitfire b. m. 1799 by Pipator 1786 (Imperator

Wad, 1768)-Farewell b. m. 1792 by Slope 1782 (Hightyer 17\%4-Dall. of Y. Marske $1 \% 1$ Marske 1\%00)-Dan. of Broth. to Silvio (Cade 1734)-Sist. to Stripling by Hutton's Spot 1 \% 28 (Hartley's Blind Horse) 


\section{STRATFORD.}

Will be used as private stallion in the Chesterbrook Stud, Berwyn, Pa., the property of A. J. Cassatt, Esq.

STRATFORD (Leamington 2d) by imp. Leamington, son of Faugh-a-Ballagh, bred by A. Welch, Erdenheim Stnd, Pa., foaled 1873, dam Susan Beane, dam of Sensation by Lexington, son of Boston, ont of Sally Lewis, dam of Hunter's Lexington, John Morgan, Acrobat, etc., by imp. Glencoe. Stratford was an exceedingly promisinghorse as a two-year old, but, having been taken with a severe attack of distemper, was totally unable to start, and the disease left him in such a poor plight, having injured his lungs, so that whilst he had speed he was mable to stay a distance. At three jears old he started in fifteen races, winning tro, rmming second in fire, third in one, and nuplaced in the others. Point Breeze Park, Pa., won purse, three-ruarters of a mile, in $1.17 \frac{1}{4}$, beating Durango, Paladin, and four others ; same place, won purse, heats of half a mile, in $0.49 \frac{3}{4}, 0.49 \frac{1}{2}, 0.49 \frac{y}{4}$, beating First Chance, who won first heat, Hobkirk and Grey Lag, the fastest three heats ever run to that date. Jerome Park, ran second to Ambush, 1 mile, in 1.48, beating Woodlands. Long Branch, ran second to Romney, three-qnarters of a mile, in 1.18, Faithless, Hattie F. and three others behind him. Point Breeze Park, ran second to First Chance, threequarters of a mile, in 1.15, beating Culpepper and two oflers; ran second to Wraco, 1 mile, in 1.44, beating Hobkirk, Emma G. and another. Washington, D. C., ran second to Burgoo, $1_{4}^{1}$ miles, in 2.14, beating First Chance, Faclladeen and one other. As a four-fear, ran unplaced in three races. Stratford is a highly bred horse, own brother to the great Sensation and Onondaga, is bred from one of the great racing families of America, a family which were almost uniformly large and profitable winners on the turf and very successful as stallions and brood mares, the family which produced Sensation, John Morgan, Acrobat, Hunter's Lexington, Motto, Nannie Lewis, Glenmore and a host of others, possessing speed, conformation, racing lineage and good blood.

Stratford is a brown, $15_{4}^{8}$ hands, with a Leamington blaze in his face and black legs; he has magnificent shoulders, good middle-piece, good back, hip and loin, and excellent legs and feet. He much resembles his sire in general conformation and appearance.

Stratford is the sire of the winners Columbine, Connemara, Lansdown, Now or Never, Tarragon, Bessie, Lady Areher, Leopold, Felicia II., Shamrock, Seymour, Emma J., Foxford, Francis S., Greylock, Josie W., Judge Mitchell, Nellie Blr, stratagem, Octagon, Tartar, Donohne, Baltimore II., Sir Richard, Sweet Alice, etc. A suceess, considering that he is a private stallion.

Stratford is descended in direct female line from the old Montagu mare and a Royal mare, to which trace Yonng Marske, Conductor, O'Kelly's Echipse, Toltane, Sterling, Oxford, Kingston, Marsyas, Scottish Chief, The Duke, Adrenturer, Prince Charlie, Lexington, Vandal, Lnke Blackburn, Leonatus, Salvator. Sensatıon, The Bard, Chesapeake, Potomac, Longstreet, John Morgan, Hunter's Lexington, and all the Levity and Lady Thompkins famnlies. 


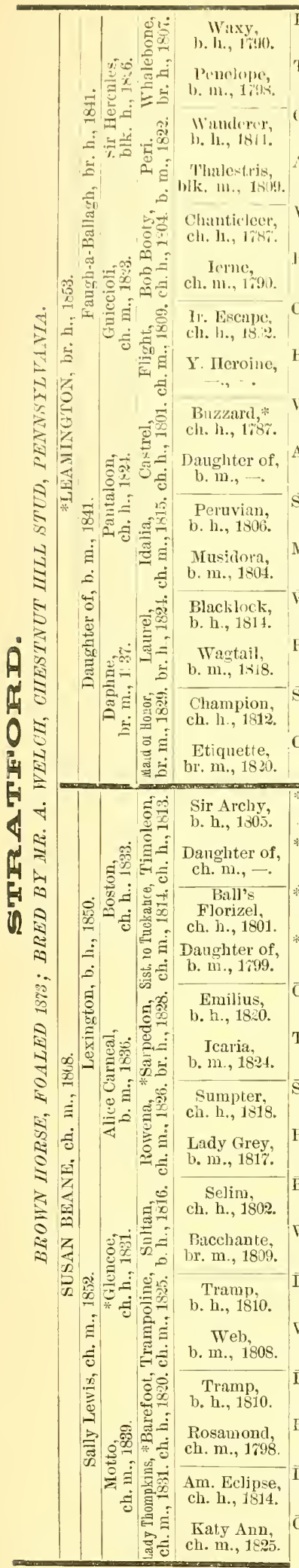

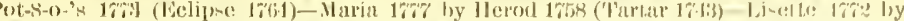

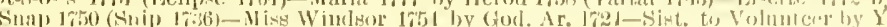

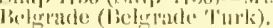

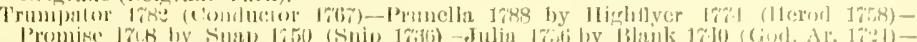

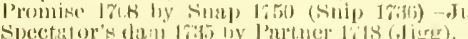

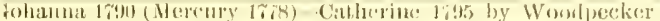

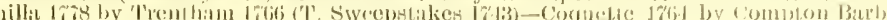

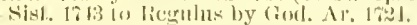

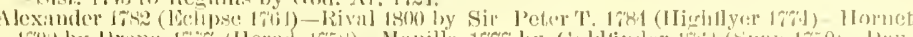

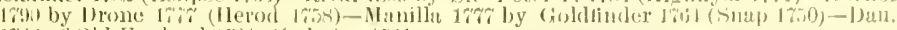
rititiol old Enerland fil] (

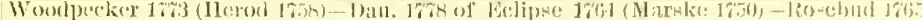

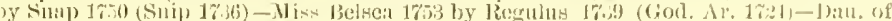

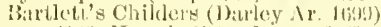

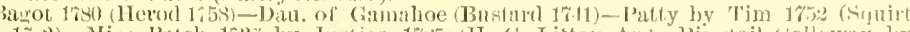

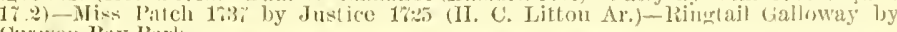
Curwen bily Birlo.

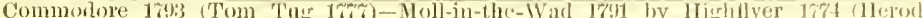

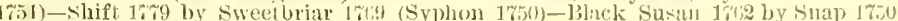
(Snip) 1;36)-Dant. of Carle 1731 ( ( i $(x)$. Ar. 17\%1).

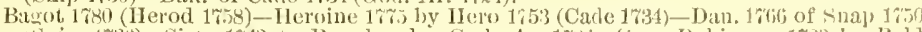

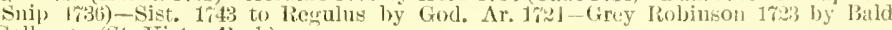
Galloway (St. Viclor Barb).

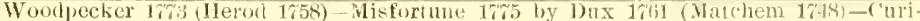
osity 1760 by Snap 1750 (Snip 173ii)-1)au. 1rit9 of Reculus 1739 (God. Al. 17\%-1)-Dau. of Barllett's Childers (Darley Ar. 16\%) ).

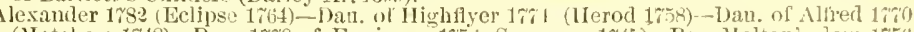
(Matchem 1748)-Dian. 1770 of Engincer 175i (Sampson 1\%t5)-Bay Malton's dan 175ij by Cade 1734 (God. Al. 1,24).

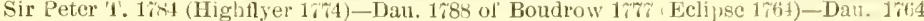

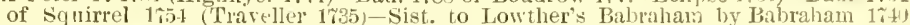
(God. Ar. 1721)-Din. 1750 ol Golden Ball 1735 (Partner 1\%18).

Meteor 1783 (Ecluse 176t)-Maid-of-all-Work 1786 by Highflyer 1\%t-t (Herod 1758)-Dan.

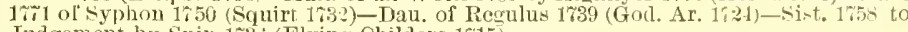
Judgement by Snip 1 ti3t (Flying Childers 175).

Whitelock 1803 (Hambletonian 1793) Dat. 1799 of Coriander 178; (Pol-R.o-"s 16i3) Wildcoose 1792 by IIighflyer $17 \% 4$ (Ilerod 1758)-Cohciress 1786 lyy Pot-8-0-'s 17.3 Eclipse 1\%6-1)-Manilla 17\% by Goldfinder 1\%64 (Snap 1\%0).

Prime Minister 1810 (Sancho 1801)-Tranby"s dam 1812 by Orville 16 s (Beningbrongh 1791)-Miss Grimstone 1796 by Weazle $17 \% 6$ (IIerod 1758)-Dan. of Ancaster 178 (Blank 1740)-Dan. of Damascus Ar. 1754.

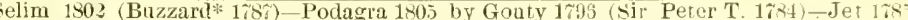
by Magnet $1 \% \% 0$ (IJerod 1758 ) - Jewel 1\%\% by Squiriel $1 \% 54$ (Traveller 1\%35) - Sojphia $1 \% 4$ by Blank $1 \approx+40$ (God. Ar. $17 \% 4)$.

Orville 1799 (Beningblough 1791) - Boadicea $180 \%$ by Alexander 1\%82 (Eclipse 1764)Brunette by Amarimthus 176 (Old England 1741)-Nayfly 1\%i1 by Hatchem 1\%t: (Cade 1734-1)an. 175j of Stariing 1738 (Star]ing 1727)

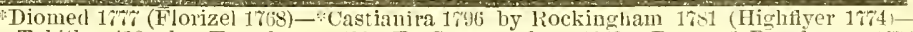
Tabitha 178s by Trentham 1766 (T. Sweepstakes 1743)-Dau. of Bo-phorus 17at (Babraham 1740)-Dan. ol Forester 1750 (Forester 1736).

*Saltram 1780 (Eclipse 1764)-Dau. of Symmes' Wildair 176\% (*Fearnought 1755)-Dau. of Tyler's Driver 1 \%60 (othello)-Dan. of *Fallower $1 \% 61$ (Blank 1\%4)-Dan. of * Vampire $175 \%$ (Regulu* 173.).

Diomed 17\% (Florizel 1768)-Dau. of "Shark 17\%1 (Marske 1759-Dan. of Harris" Eclipse 1\%0 (*Fearnought 1755)-Dau, of Fearnought 1755 (Regnlus 1\%39)-Dau. of *Jolly Roger $1 \% 11$ (Rouischead 1735).

Alderman 1\%87 (Pot-B-o-'s 1\%\%3)-Dau. of *Clockfast $17 \% 4$ (Gimcrack 1\%60)-Dau. of Symmes" Wildair 176\% "Fearnonght 1755) - X. Kitty Fisher 176\% by *Fearnought $1 \% 50$ (Regulus 1739) - Fitly Fisher 1755 by Cade 1734 (God. Ar. 1724).

Orville 1799 (Beningt)ongh 1791)-Emily 1810 by Stamford 1794 (Sir Peter T. 1781)-

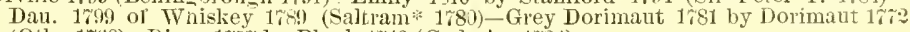
(Otho 1\%(60)-Dizzy 1\%5\% by Blank 1740 (God. Ar. 1724).

The Flyer 1814 (Vandyke Jr, 1808)-Parma 1813 by Dick Andrews $1 \% 97$ (Joe Andrews 173)-May 181$) 1$ by Beningbrongh $1 \% 91$ (King Fergus 17\%)-Primrose 178\% by Mambrino 1768 (Engineer 1\%5)-C Cricket 1766 by lferod 1758 (Tartar 1743).

Sir Ajchy 1805 ( Diomed 1\% Dau. 188 of Obscurity $1 \%$ (Eclipse 1764)-Slamerkin $1 \% 68$ by *Wildair $1 \% 53$ (Cade $1734)$ - Cub mare 1762 by Cub 1739 (Fox 1714).

Robin Grey 1805 (*Royalist 17\%0)-Maria 1802 by Melzar 1791 (*JIedley 1\%6)- Dau. of Highflyer 1784 (Himhflyer 1\%4)-Dau. of *Fearmought, 1\%55 (Regulus 1739)-Dau. of Ariel 1756 (

Buzzarl* $178 \%$ (Woodpecker 17\%3)-Dan. of Alexander 1782 (Erlipse 1\%61)-Dau. of

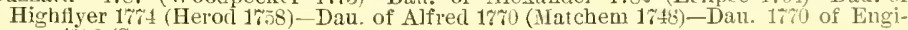
neer 1756 (Sampson 1745)

IT's Ditto 1800 (Sir Peter T. 1784)-Dan. 1791 of Mercury 1ir8 (Eclipse 1764)—Dall. 17i6

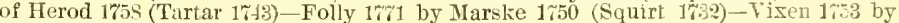
Regulus 1739 (God. Ar. 17:4).

Dick Andrews 1797 (Joe Andrews 17r8)-Dau. 1803 of Gohanna 1 r99 (Mercnry 178)Fraxinella 1793 by Trentham 1766 (T. Sweepstakes 1743)-Dau. 1785 of IT oodpecker 1773 (Herod 1758) - Everlasting $17 \%$ by Eclipse 1764 (Marske 1\%:0).

W axy 1790 (Pot-8-o-'s 17\%3-Penelope 1\%98 by Trumpator 178? (Condnctor 1\% - Prunella 17s by Highflyer 17it (Herod 1758)-Promise 1768 by Snap 1750 (Snip 1786) - Julia 1756 by Blank 1r4) (God Ar. 1\%24).

Dick Andrews 1797 (Joc Sndrews 1778)-Dan. 1803 of Gohama 1790 (Mercury 17is)Fraximella 1793 by Trentham 1760 (T. Sweepstakes 1743)-Dau. 1785 of Toodpecker $17: 3$ (Herod 1758)-Everlasling 17\%5 by Eelipse 1764 (Marske 1750).

Buzzard 1787 ( 1 oodnecker 1\% 13 )-Roseberry 1792 by Phenomenon 1780 (Herod 1758)Miss West $17 \%$ by Matchem 1448 (Cade 1734) Sist to Favourite by Reculns 1739 (God. Ar. 1724)-Y. Ebony 1742 by Crab 1722 (Alcock Ar.).

Duroe 1806 (*Diomed 1\% 7 )-Miller"s Damsel 1802 by *ilessenger 1780 Nambrino 1768 ) Mare $1 \% 92$ by Pot-8-0-'s 1773 (Eclipse 1764)-Dau. 17\% of Gimerack 1760 (Cripple 1750)-Suapdragon 1r59 by Snap 1759 (Snip 1736).

Ogles Oscar 1800 (*Gabrie] 1790)-Y. IIaid-of-the-Oaks ch. m. $181 \%$ by *Expedition 1795 (Pegasus 1\%84)-Haid-of-the-Oaks ch. m. 1801 by*Spread Eag]e 1792 (Volunteer 1780)Annette by Shark 161 (Marske 1750)-Dau. of Rockingham (Partner 1i55)-Dau. or True Whig (Fitzh agh's Regulus 1765)-Dau. of Gallant 17ro (*Fearnought 1755)-Dau.

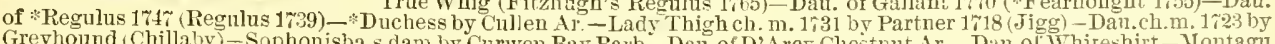
Greyhound (Chillaby) - Sophonisbas dam by Curwen Bay Barb-Dan.of D'Arcy Clestnut Ar, - D on ol ivhiteshirt-IIontagu mare by D'A rey's old Ionian-Dau.of IIautboy(D'Arcy I' hite Turk)-Dan.of Brinmer(D'Arey Iellow Turk)-Royal mare. 


\section{THE BARD.}

WINNER OF THE RED BANK, BOLQLET AND CAPITOL STAKES AT TWO YEARS OLD, THE PREAKNES, SPINDRIFT, BARXEGAT, FREEHOLD, OMNIBLS, CHOICE, SEPTEMBER, JEROME, DIXIE, BRECKENRIDGE AND POTOMAC STAKES AT THREE YEARS OLD, SPECIAL CONEY ISLAND CLP TWICE, MONMOUTH CLP, BROOKLYN CLP AND OTHER GOOD RACES.

\section{Is private stallion in the Chesterbrool Stud, Mr. A. J. Cassatt, proprietor, Berwyn, Chester Co., Pa. Fearlings sold ammally.}

TuE Bard, bay horse, hred by Messrs. Chas. Reed \& Sons, Fairview Stud, Tenu., by Longfellow, son of imp. Leamington, dain Bradenante hy War Datuce, son of Lexington, grandam Brema by imp. Kuight of St. George, son of Birdeatcher, ont of Lerity by imp. Trustee. The Bard was unquestionably one of the grandest racehorses ever bred in America, and the best son of his great sire Longfellow. Bralemante, his dam, was a superior race-mare, winner of two-mile heats in $3.32 \frac{1}{4}, 3.29$, dam also of Vivacity (dam of 'lenacity) aud the winners Fither John and Joseph. From the grandam, Bremna, eame Athalaric (dam of the good holse Tom Martin), Strathmore (a snecessfnl young sire), and the winners Kinkead. Sir Wilter, Long stop and Violante, the last named of which won five-eighths of a mile at Westcbester, in $0.59 \frac{1}{2}$. Great grandam Levity, whose descendants exreed in brilliancy those of any other mare in the worle. Amongst the prominent ones may be named, Rurje, Lightsome (dam of Salina, Sprightly, Crncifix, Nevada and Guluare), Mildred (dam. of Ringlet, Nora Worth, Minx, Monarchist, Stamps, Sultana and Frederick the Great), Lerer (sire of Leveller, Mahlstick, Apollo, Lon Lanier, etc.), I,egatee (a good race-horse) and Sister to Ruric (dam of Grinstead, Viceroy, Kelpie, Ermengarde and Gilly Flower). From the grandauginter's of Levity have come Salvator, Danicheff, Voltmmo, Elias Lawrence, Avalon, Aretino, Fairplay, Semper Felix (dam of Leonatus, Warder, Leopold, Felicia and Semper Vive, dam of Fordham, Folson, and grandam of Longstreet) Blanch J., Cripple, st. Angustine, Luke Blackburn, Greenland, Ecuador, Bradford, Bravo, Sierra Nevala (dim of Monntain Range, Monte Rosa's dam), Gulnare (dam of Costello and Satisfaction), Restless, Wandering, Force, Startle, Tramp, Finality, Monitor, Mirth, Minnock, Lonjsette, Preciosa, Bertha, Start, Loch Tamna, Katie Pearce (dam of Lizzie S., Ballard, Redstone and Katrina), Janet (dam of Sir Peter, Golden Reel, Ninaloa, Volnnteer's dam, and Spaldie, Lizzie D.'s dam), Miss Austine (dam of Tentou), Duke of Montrose, Annette, Kelp (dam of Onaway), Oration, Overtnre, Baltic, Brocade (dam of Bnrel, Jennie B. and Bertha B., the dam of Lizzie Baker and Jndge Murray), She, Padisha, Louisette (dam of Prince George), and any number of others.

As a two-year old started fourteen times, won three races, was second once and third in fonr races. Ran second to Portland in the Great Post Stakes, three-quarters of a mile, $115 \mathrm{llgs}$, in 1.17 mile, Electric tirst, Buftalo second; won Red bank Stakes, three-quarters of a mile, 108 lis., in 1.16 Buffalo second, Charity third; ran third in Flatbmsh stakes, $1: 0$ lbs., seven-eighths of a mile, in 1.31 Charity, 97 lus., won, Dew Drop, 107 lbs., second;

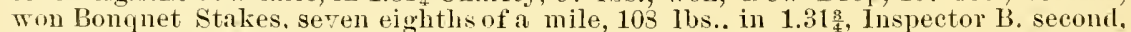

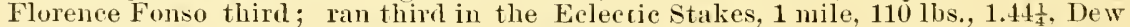
Drop, $107 \mathrm{lbs}$, won, Winfred, 100 lbs., second; ran third in the Arlington Stakes, three-quarters of a mile, 118 lbs., 1.17, Bess, 108 llos., won, Elkwood, 105 1lus., secoud. He wound mp his two-year olil carcer by winning the Capitul stakes, 1 mile 115 lbs., in 1.48, beating Bess, Biggonet, etc. At three rears old he started seventeen times, won eleven rices, was tive times secoud and once mplaced. He won Preakness Stakes, 11 miles, 118 los., 2.45, Enrus second, Elkwood third; ran second in the Belmont Stakes, $1 \frac{1}{2}$ miles, 11s liss., 2.41. Inspector B. won, Linden third; mnplaced in the Green Grass Stakes, $1 \frac{1}{8}$ miles, won by Dry Monopole; ran second to Inspector 13 . in the Stud Stakes, $1 \frac{3}{x}$ miles, 118 llos., in $2.23 \frac{8}{4}$, beating Ban Fox and Buftalo. Ran second by a short head to Winfred $108 \frac{1}{2}$ lbs., in the Emporimm, $1 \frac{1}{2}$ miles, 118 lbs., 2.43 ; ran dead heat with Dew Drop, 115 los.. in the sipendthritt stakes, $1 \frac{1}{4}$ miles. $11+1$ bs., in $2.09 \frac{1}{2}$, the Bard walked over for the Stakes; won Barnegat Stakes, $1 \frac{1}{2}$ miles, 113 los., in 2.451, in a canter from Qnito, Winfrel, etc. : ran seconel to Dew Drop, 118 lbs., in the

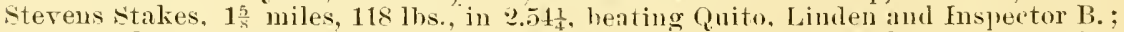
ran second to Charity, $106 \mathrm{lhs}$, in the Raritan Stakes, 1 miles, $11-1 \mathrm{bs}$., 2.14, beating Lindeu, Pontico and Wintred. After this race he scored eight conseentive winnings.

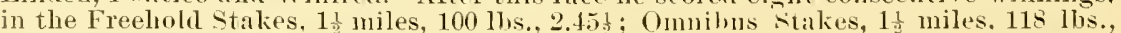
in 2.39, beating loy four lengths Itew Drop, Ben Ali, Charity, ete.; Choice Stakes, $1 \frac{1}{3}$ 


\section{THE BARD-Continued.}

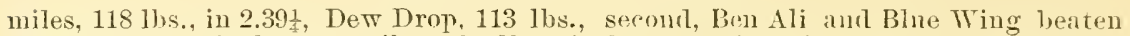

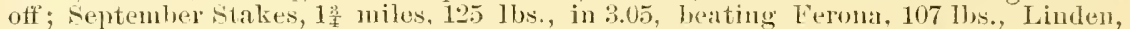
110 llos., etc ; Jerome Stakes, 1 liniles, 125 1lss., no time taken, beating Lilkwood, Mollie Mecurthy's last, ete. D Dixie Stakes, 2 miles, 1 s lhs., in 3.33 ; Brerkenrilge stalses, 2 miles, 123 llss, in 335 , and Potmmac strlses, 13 miles, 118 lbs., 2:27, wimning in a canter by eight lengths, Elkwoor secomb. At fomr rears old starterl eiglt times, wou six races, was second twice. Won Jume Special, $1 \frac{1}{\times}$ miles, 11311 s., in 1.55 ; St.

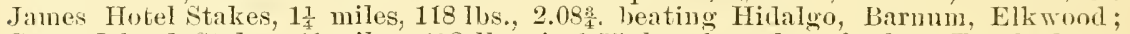
Coney Iskanrl Stakes, $1 \frac{1}{8}$ miles, 118 lbs., in 1.55, by three lengths from Tronbadour:

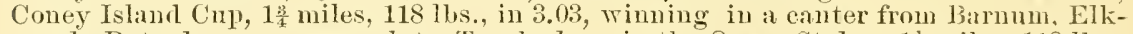
wood, Pataplan; ran second to Troubadonr in the Ocean Stakes, $1 \frac{1}{8}$ miles, 118 1hs.,

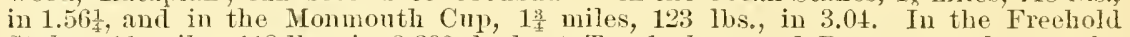
Stakes, $1 \frac{1}{2}$ miles, 118 lbs., in 2.39\%, he beat Tronbarlour and Barnum, and won the

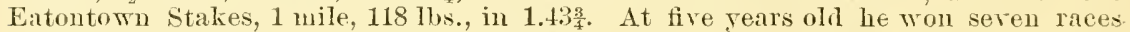
ont of eight starts, only beaten in his last race by Firenzi, when she ran in record

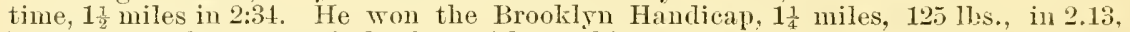
Hanover, 125 lbs., seconk, Exile, 114 1hs., third, eight others beaten off; St. James Hotel Stakes, $1 \frac{1}{4}$ miles 122 lbs., in 2.08

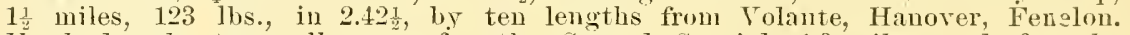
He hal only to walk over for the Second Special, 1, 3ites, and for the Coney Island Stakes, $1 \frac{1}{s}$ miles. Won the Coney Island Cup, 13 miles, 122 los., beating Hidalgo and Elkwood; the Ocean Stakes, $1 \frac{1}{8}$ miles, 120 1 $\mathrm{ss}$., in 1.55 , Kingston, 118 los., second, Firenzi, 113 lls., third. In the Freohold Stakes, $1 \frac{3}{2}$ miles, with 120 1bs., he ran second to Firenzi, 113 lbs., in 2.31 (recort time).

The Bard is mutried in the stud, yearlings being the oldest of his get, and they are grand ones. He is an extraorlinary fine horse, possessing speed, capacity to. carry weight, and conld stay over a distance of gromil.

He is descended in fomale line from the same Royal mare to which traces Eclipse, Voltaire, Sterling, Oxforl, Kingston, Scottish Chief, Lexington, Tandal, Leonatus. Sensation, Salvator. Strathmore, Monarchist, Grinstead, Longstreet, Potomac and all the Drichess family.

\section{IMPORTED THE JACOBITE.}

\section{The property of J. H. MIcGavock, ITrex MLeadows, Va. Terms of sevice adiertised anmally.}

Tine JAConite, chestmut horse, foaled 1876, hred by Her Majesty, by Prince Charlie, son of Blair Athol, dam sister to Little Lady by Orlando (wimner of the Derhy), son of 'Tonchstone, graudam sister to Voltigeur and Barnton by Toltaire, son of Bhacklock, out of Martha Lym by Mulatto, ete. Prince Charlie was tha wimner of the 2,000 Guineas and was regariled as one of the speediest horses of his day, sire of Princess Catherine, the dam of Clover and Clamirt, both winners of the Frencli Derlog, Prestompans (wimer of the Liverpool Autmun cup). In this country, Salvator, wimmer of the fistest suburan ever rm, in 2.06 and the finstest

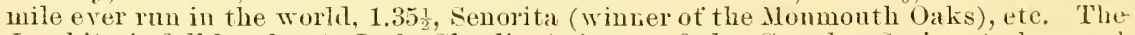
Jacobite is full brother to Larly Charlie (winner of the Croylon Spring stakes amil Juvenile Plate at Hampton, and dam of Matame d'Albany, wimer of the Liverpool Antumu Cup, 1891) and Lady Jacohite (winner of the British Dominion Two-year Uld Stakes. The Jacobite's dam is full sister to Little Lady, who won as a yearling Angleser Stakes, one-quarter of a mile, and won afterwards a gool mumber of stakes and plates, and was tam of Camballo (wimner of the 2,000 Guineas) by Orlankto, winner of the Derby. sire of Fitz Roland, Fazzoletto and Diophantus (winners of the 2.000 Guineas), Teddington (wimner of the Derbr), and Imperiense (wimner of the 1,000 Gnimeas and St. Leger), she being almost full sister in blood to Little Ladr, being ont of Eulogr, half sister to Tolley, which produced, to the cover of Orlanilo, Enyrlice, wimner of the Cambridgeshire Handicap. Volles, The Jacobite's grambam, was full sister to Barnton and the great Voltigen (wimer of the 1)erlyy, St. Leger and Doncaster Cup), and is the grandam of the good sire Lord Clifilen, winner of the st. Leger.

The Jacobite is a highly bred horse and from a graml racing family. He las hat hut little chance in the stmel, bnt is the sire of the wimers: Enh, Chiswell. ete.

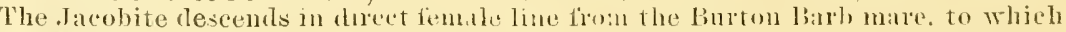
traces Whiskey, Selim. Castrel, linbens, Gattom, Blacklock, Nir lfercules. llarkaway,

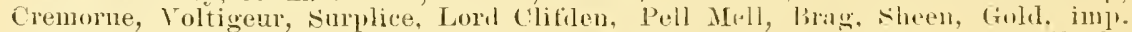
Ainderby, imp. Billet, imp. Inrah, imp. Margrave, imp. Lorlishire, and all the descenlants of imp. Mary Grey. 


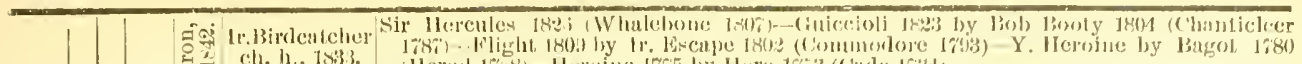

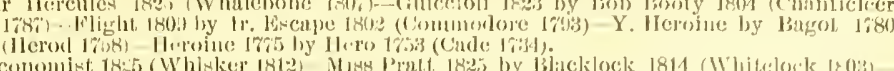

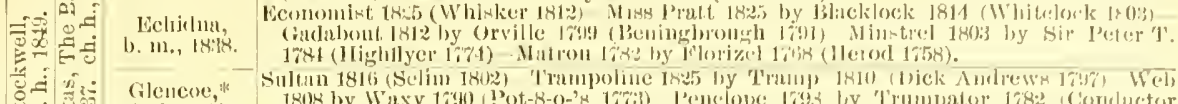

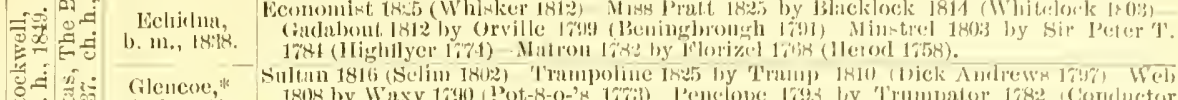

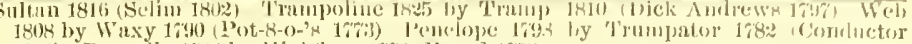

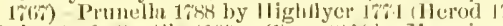

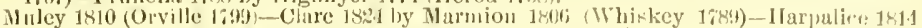

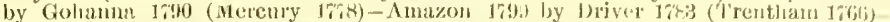

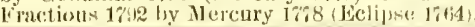

Marpessa,

IItmp)rey

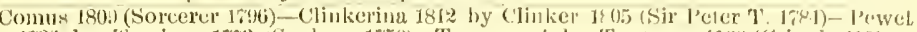

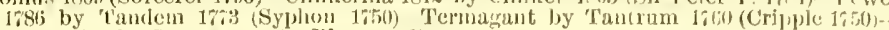
Cantatrice by Sump) $*$ on 174, (Blaze 17\%3).

Clinker,

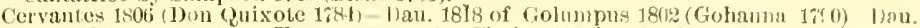
1810 of Paymator 179! (Trumpator 1:82)-Circle 1802 by st. Gicorere 1;89) llighllyer

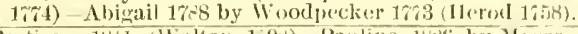

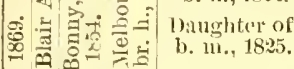

b. $111 ., 1825$.

Partisan 1811 (Walton 179.1)-Panline 18\%6 by Mobes 181!) ([Whalebone or] Seymour 1807)-Quadtille 1,15 by Selim 180:2 (Buzzard* 1787)-Canary Bird 180t; by [Wlikkey or horcere

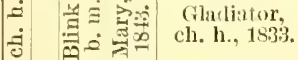
Gift 1 sis by Y Gohanna 1510 (Gohamia 1790)-Sist. 180, to Grazier by Sir peter. T.

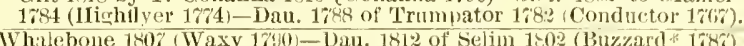

\&. Daumhter of, b. m., 1510 .

Camel,

bi. h., 18:2. Matron 1782 by Florizel 17 is (Herod 1758)

Master llenry 1815 (Orville 1799)- Bondicea $180 \%$ by Alexander 1;8: (Eclipse 1;f4)Brunette by Amaranthus 1766 (Old England 1\%4l) Nayfly $17 \% 1$ by Matchem 1748 (Cade 1734) Dau. 1755 of Ane. Starling $17 \% 8$ (Starling 17\%).

br, m., 1833.

Priam*

b. h., $18 \% \%$.

Emilius 1820 (Orville 1793 ) Cressida 1807 by Whiskey 1689 (Saltram*1780) Y. Giantess

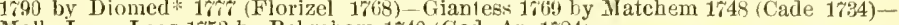
Molly Long Legs 1753 by Bal)raham 1740 (God. Ar, 1724).

Octaviang, Octavian 180\% (Stripling 1795)-Dau. 180\% of Shuttle 1793 (Y. Marske 1771) - Zara 1801 by

b. m., 1815 .

Delpini 1781 (Himhfiyer 17\%4)-Flora 1789 by King Fergus 1\%75 (Eclipse 1764)-Atalanta 1769 by Matchem 1749 (Cade 1231 ).

Slane,

Royal Oak 15:3 (Catton 1809)-Datt. 1819 of Orville 1799 (Beningbrough 1\%91)-Epsom Lass 1803 by Sir Peter T. 1784 (Ilighflyer 17/4)-Alexina 1788 by King Fergus 175 (Eclipse 1761) Laı'lella 1780 by Y. Marske 1\%1 (Marske 1\%00).

Palmyra, Sultan 1816 (Selim 1802)-Hester 18:2 by Camel 1822 (Whalehone 1807)-Monimia 1821 by Muley 1810 (Orville 1799) - Sist. 1796 to Petworth by Precipitale* 1787 (Mercury

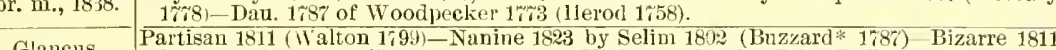
Glancus,
b. h., 1830 . by Peruvian 1806 (Sir Peter T. 1784)-Violante 1802 by John Bull 1789 (Fortitude $1 \%$ (\%)-Dau. 1788 of Highflyer $1 \%$ ' (Herod 1758).

Taurns 189? ([Phantom or] Moricco 1819)-Arethissa 1821 by Quiz 1408 (Burzard* 1787)-Persepolis 1803 by Alexander 1782 (Eclipse 1764) - Sist. 1;84 to *Tickle Toby by

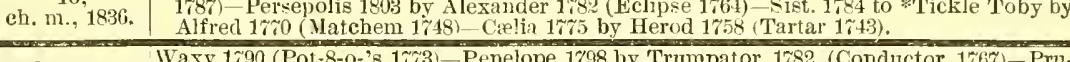

Whalebone, nella 1789 by Hightyer 17\% (Herod 1758)-Promise 1768 by Snap 1650) (Snip 1796)br. h., 1807. Julia 1ri5; by Blank 1740 (God. Ar. 172t)

Selim 1872 (Buzzard 1787)-Maiden 1801 by Sir Peter T. 1r84 (Highflyer 17\%4)-Dau. 1 - 188 Daughter of, of Phenomenon 1780 (Herod 1758)-Matron 1782 by Florizel 1768 (Herod 1758)Maideu $17 \% 0$ by Matchem 1748 (Cade 1734).

Orville 1;99 (Beningbrough 1;91)-Miss Sophix 1805 by Stamford 1794 (Sir Peter T

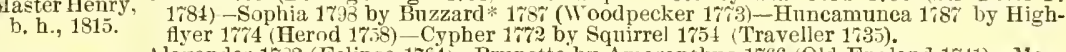

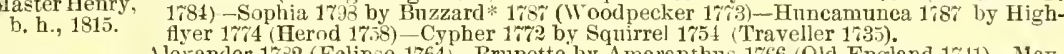

Boadicea, Alesander 1732 (Eclipse 1764)-Brunette by Amaranthns 1766 (Old England 1711) - Mlay$\begin{array}{ll}\text { Boadicea, } & \text { fly 1\%1 by Matchem 1\%48 (Cade 1\%34)-Dan. 175. of Ane. Starling 1738 (Starling 1727)- } \\ \text { b. m., 180\%. } & \text { Look-at-me-Lads } 1731 \text { by Bristol Grasshopper (Byerly Turk). }\end{array}$

Selim Buzzard*1787 (Woodpecker 1\%73)-Dau. of Alezander 1782 (Eclipse 1\%64)-Dan. ol High-

ch. h., 1802. flyer 17\%4 (Herod 1758)-Dan. of Alfred 17\%0 (3latchem 1718)-Dau. 17\%0 of Engineer 1756 (Sampson 1745).

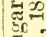

Daughter of

Walton $1 \% 99$ (Sir Peter T. 1784)-Y. Giantess 1\%90 by Diomed 1777 (Florizel 1768)Giantess 1669 by Matchem 1748 (Cade 1731)-Molly Long Legs 1753 by Babraham 1740 (God. Ar. 1\%24)-Dan. of Cole's Foxhunter 1\%2\% (Brisk 1711).

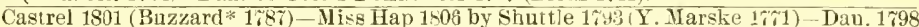
of Sir Peter 'T, 1784 (Highflyer 17\%4,-Miss Hervey $17 \% 5$ by Eclipse 176f (Marske 1750)Clio 1760 by Y. Cade 1747 (Cade 1734)

Bus=tard,

Sir Oliver 1800 (Sir Peter T. 1784)-Seotilla 1795 by Anvil 17\% (Herod 1758)-Scota 1783

Olympia, by Eclipse 1764 (Iarske 1750)-Harmony 17\%5 by Jerod 1758 (Tartar 1743)-Rutilia $1 \% 69$ by Blank 1740 (God. Ar. 1724).

Whitelock, Hambletonian 1792 (King Fergus 17r5)-Rosalind 1788 by Phenomenon 1780 Herod
1758)-Atalanta 1769 by Matchem 1748 (Cade 1734)-Y. Lass-of-the-1lill 1756 by Oroo-

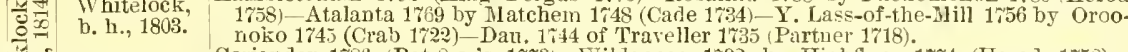

b. 11,18

Coriander' 1786 (Pot-8-o-'s 17\%3)-Wildgoose 1792 by Highflyer 1\% 174 (Herod 1758)-
Coheiress 1786 by Pot-8-o-'s 1\%3 (Eclipse 1764)-Manilla 17\% by Goldfinder 1764

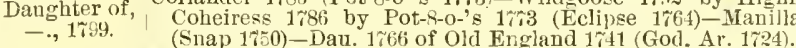

Walton 1799 (Sir Peter T. 1784)-Julia 1799 by Whiskey 1789 (Saltram* 1780 ) - Y. Giantess

Phantom, $\quad 1 \% 90$ by Diomed * 1\%r (Florizel 1\%68)-Giantess $1 \% 69$ by Matchem 1\%48 (Cade 1\%31) 1790 by Diomed $17 \%$ (Florizel 1768)-Giantess 1769 by $N a t$.
Molly Long Legs 1753 by Babraham 1\%40 (God. Ar. 1724).

Overton 1788 (King Fergus 1\%75)-Dau. 1796 of Walnut 1786 (Highflyer 17\%4)-Dan. 1786

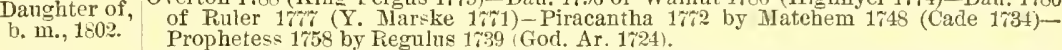

Danghter of,
b. m., 1802.
Prophetess 1758 by Regulus 1739 (God. Ar. 1724).

Golumpus 18) (Gohanna 1790)_Lucy Grey 1804 by Timothy 1\%94 (Delpini 1781)-Lucy
1789 by Florizel 1765 (Herod 1758)-Frenzy 1\%7 by Eclipse 1\%64 (Marske 1650)-Dan. of Engineer 1:56 (Sampson 1745). Orville 1799 (Beningbrough 1791) - Fanny $1 \% 96$ by Sir Peter T. 1\%84 (Highflyer 1ris)-

Desdemona, Dan. 1788 of Diomed* $17 \%$ (Florizel 1768)-Desdemona 1\%0 by Marske 1750 (Squirt
br. m., 1811.

Desdemona, Dan. 1788 of Diomed* 17\% (Florizel 1768)-Desdemona 1\%0 by Mlarshe 1750 (Squirt
br. m., 1811.

Haphazard 179\% (Sir Peter T. 1784)-Mrs. Barnet 1806 by Waxy 1790 (Pot-8-0-'s 17ra) 1735)-Prineipessa 1762 by Blank 1740 (God. Ar. 17\%4).

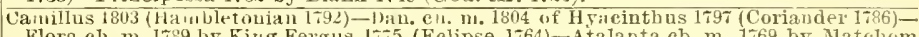
Flora ch. m. 1789 by King Fergus 1755 (Eclipse 1764) - Atalanta cb. m. 1769 by Mlatchem 1748 (Cade I734) - r. Litss-of-the-\$I ill b. M. 1756 by Oroonoko 1745 (Crab 1722)-Dall. 1744 of Traveller 1735 (Partner 1718)-Miss Nakeless b. m. 1737 by T. Greybound 1723 (G)

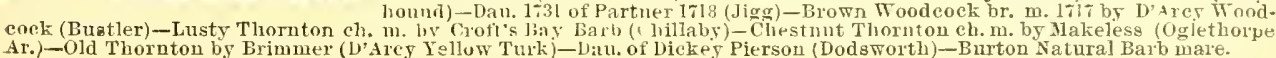




\section{IMPORTED THE SAILOR PRINCE.}

\section{WINNER OF THE CAIBRIDGESHIRE AND LEWES SPRING HANDICAPS AND PORTLAND STAKES.}

\section{Is private stullion in Rancocas Stud, IIr. P. Lorillard, proprietor, Jous- torn, N.J.}

The Satlor Prixce, bay horse, foaled 1880, bred by Mr. B. Norrington, by Albert Vietor, son of Marsyas by Orlando, dam Hermita by Hermit, son of Newminster, grandam Affection by Lifeboat, son of Sir Hercnles, ont of Rose d'Amonr by Will Dayrell, ete. The Sailor Prince is own brother to Trixie, winner of the Alexandra Plate, out of Hermita (winner of the Grand Stand, Kentish and Camden Park Handicaps and other races) by the great Hermit (wimner of the Derby), sire of imp. St. Blaise (winner of the Derby), Shotover (wimner of the 2,000 Guineas and Derby), Thebais (winner of the 1,000 Gnineas and Oaks), St. Marguerite (winuer of the 2,000 Guineas, dam of Seabreeze, winner of the Oaks and St. Leger), Tristan and imp. Mr. Pickwick. His grandam, Affeetion, is by Lifeboat, son of Sir Hereules and Yard Arm by Sheet Anchor (winner of the Great Metropolitan Stakes, Chester Cup and many other races). His great grandam, Rose d'Amour by Wrild Dayrell (winner of the Derby) and sire of Hnrricane (winner of the 1,000 Gnineas) and the dam of Atlantic (winner of the 2,000 guineas) and his full sister, Atlantis, dam of imp. King Ban, by Thormanby, and sire of Buccaneer, the sire of Kisber, winner of the Derby and Grand Prize of Paris.

The Sailor Prince was a good race-horse at two years old. He ran third to Rookery and Sigmophone in the Windsor Castle Stakes at Ascot; second to Britomarte in the Champagne Stakes at Bibnry, six others behind him; won the Fonr Oaks Twoyear Old Plate, with eight others behind him; was beaten a neck by Sarah Bernhardt in the Great Witley Stakes at Worcester, giving her 10 1bs.; won the Royal Two-rear old Plate at Kempton, with teu others behind him, and was second to Hornpipe in the Thames Plate. At three years old ran three times. Was third in Prince of Wales Handicap. At fonr years old won a Handicap siweepstakes, 5 furlongs, at Bibury. At five years old won Royal Plate Handieap, 1 mile, at Sandown; ran third in the Good wood Corinthian Plate, 1 mile, won by Reine Blanche, Wild Thyme second; ran second in the Daviss Park Free Trelter Haudicap, 138 los., Cintra, 108 lbs., won; ran second to Castor, 110 lbs., in the Autumn Plate at Manchester, he carrying $146 \mathrm{lbs}$; ran second to Cohort in the Great Shropshire Handicap at Shrewsbury; ran a deal heat and divided the stakes in the Great Lancashire Handieap, with Rimbolton at Liverpool ; ran second to Alb, 102 lbs., in the Holmby Handieap Plate at Northanpton, earrying 131 lbs, ran second to Verano, 140 lbs., he carrying 166 Ibs., iu the Coventry Welter Plate at Warwick. At six years old, won the Lewes Spring Handicap, 1 mile, 121 lbs., Mohawk second, Cavalier third; was third to Middlethorpe and Perdita II. in the Liverpool Cup, with eleven others behind him; won the Cambridgeshire Handicap, 1 mile 240 yards, 105 llos., with St. Mirin, Carlton, Melton and twelve others behind him. At seren years old, won the Portland stakes. 1 mile, with 131 lbs., with three behind him. He retired somnd.

The Sailor Prince is a handsomely bred horse, and from a racing family that not only races but prodnces race-horses.

He is descended in direct female line from the old Woodcock mare, to which trace Skim, Reveller (by Comus) Heron, Alarm, Vindex, Monarque, Veclette (sire of Galupin), Cambnscan, Vespasian, Isononiy, Fernandez, King Lud, in England; Lisbon. imp. Clockfast, Exile (by Mortemer), etc., ete. 


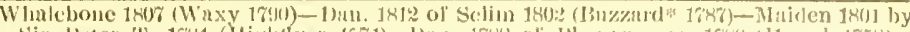

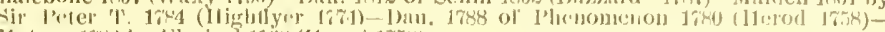

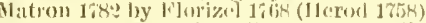

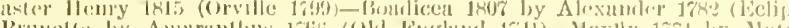

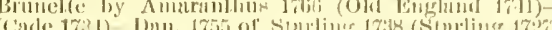

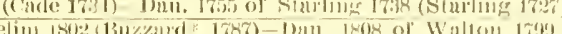

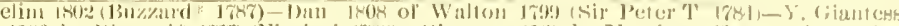

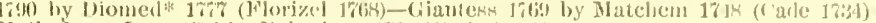

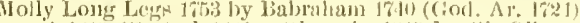

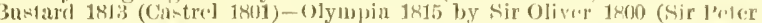

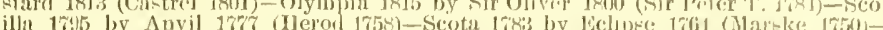

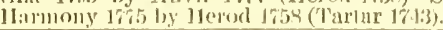

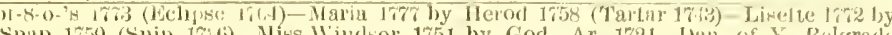
(litip) 1700 (sip)

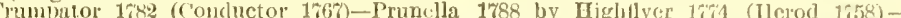

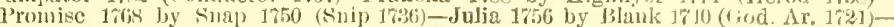

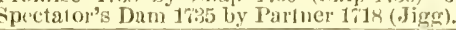

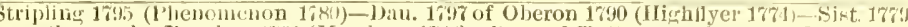
to Sharpel by Ranthos 1763 (Matchem 1748)-J)un. of 'T. Sweepsakes 1743 (P. Sweep-

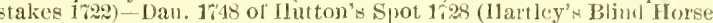

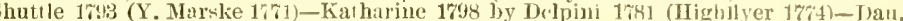

1788 of Paymaster 1766 (Blank 1740-Dau. 177.j of Le Sang 175!) (Chanceling 17f6)Dau. 1751 of lib 1736 (Crab 1722).

r Hercules 1826 (Whalebone 1807)-Guiccioli 1823 by Bob Booty 1814 (clianticleer 1786) - Flight 1809 by $\mathrm{Ir}$. Escape 1802 (Commodore 1793)-Y. Heroine by Bagot 1780 Ilerod 1758)-Hlerojue 175 by Hero 1753 (Cade 1734).

onomist 1525 (Whisker 1812) - Miss Pratt 1825 by Blacklock 1814 (Whitelock 1 ros)(Ilighlyer 17\% - - latron 1782 by Florizel 1768 (Herod 1758).

Glencoe; sultan 1616 (Selim 18u2)-Trampoline 1825 by Tramp 1810 (Dick Andrews 17s7)-Web cb. b., 1831 .

1808 by Waxy 1790 (Pot-8-0-'s 17/33)-Penelope 1798 by Trumpator 178\% (Couductor 1766)-Prunella 1788 by High flyer $17 \% 4$ (Herod 1758).

Muley 1810 (Orville 1699)-Clare 1821 by Marmion 1806 (Whiskey 1789)-Harpalice 1814 by Gohanna 1790 (Mercury 17\%8)-Amazon 1799 by Driver 1783 Trentham 1760)-

Humprey Comus 1809 (Sorcerer 1246 )-Clinkerina 1812 by Clinker 1805 (Sir Peter T. 1784)-Pewet

Clinker,

b. h., 182:

1786 by Tandem 17\%3 (Syphon 1:50)-Termagant by Tantrum 1760 (C'ipple 1753)Cantatrice by Sampson 1745 (Blaze 1733).

Danghter of Cervantes 1806 (Don Quixote 1:84)-Dan. 1818 of Golumpus 1802 (Gohanna 1790) - D)au.

b. m. 182, 1810 of Paynator 1791 (Trumpator 1782)-Circle 1802 by St. George 1789 (Highflyer 1764) - Abigail 1788 by Woodpecker 1773 (Herod 1758)

递宓 b. m.,

Velocipede, ch. h., $18: 5$.

$\rightarrow \Xi$ Lady Moor

Carew,

Blacklock 1814 (WVhitelock 180:s)-Dau. 181 of Juniper 1805 (Whiskey 17k9)-Dau. 1810 of Solcerer 1796 (Trumpator 1782)-Virgin 1801 by Sir Peter T. 1784 (Jighfiyer 1774)Dau. 1794 of Pot-8-o-'s 1773 (Eclipse 1764).

Tramp 1810 (Dick Andrews 179\%)-Kite 1821 by Bustard 1813 (Castrel 1<01)-Olympia 1815 by Sir Oliver 1800 (Sir Peter T. 1784)-Scotilla 1795 by Anvil 17r (Herod 1758)Scota 1783 by Eclipse 1764 (Mar-ke 1750)

\section{Camel,}

Whalebone 1807 (Waxy 179j)-Dan. 1812 of Selim 1802 (Buzzard*178\%)-Maiden 1801 by Sir Peter T. 1784 (Highflyer 1\%4)-Dau. 1788 of Phenomenon 1780 (Herod 1\%58)Matron 1782 by Florizel 1688 (Herod 1758).

br. h., 1822.

Master Henry 1815 (Orville 1\%99)-Boadicea 1807 by Alexander 1782 (Eclipse 1764)-Brubr. m., 1826. 1734)-Dau. 1 T55 of A nc. Starling 1738 (Old Starling 172\%).

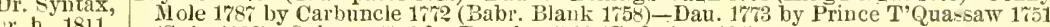
(Snip 1736) - Sultana 1759 by Regulus 1739 (God. Ar. 1724).

Daugbter of Ardrossan 1809 (John Bull 1789) - Lady Eliza 1813 by Whitworth 1805 (Agonistes 179\%)Daugbter of, A X. Y.Z.'s dam 1793 by Spadille 1784 (Highflyer 17\%4) - Sylvia 1783 1, Y Y. Mar-ke 1.: (Narske 1750 )-Ferret 1 - 65 by Bro. to Silvio (Cade 1734).

Ion,

Cain 1822 (Paulowitz 1813)-Margaret 1831 by Edmund 1824 (Orville 11 c9)_-Nedora 1811

by Selim 180: (Buzzard*178\%)-Dau. 1803 of Sir Harry*1795 (Sir Peter T. 1r84)-Dau. 1790 of Volunteer 1780 (Eclipse 1;64)

br. h., 1835 .

Sultan 1816 (Selim 1802)--Hester $183^{\circ}$ by Camel 1822 (Whalebone 180 ')-Monimia 1821

Palmyra, Sulta Muley 1810 (Orville 1799)-Sist. 1796 to Petworth by Precipitate 1787 (Mercury br. m., 1838. 17\%8)-Dau. 1787 of Woodpecker 1733 (Herod 1758).

Bay Middleton 1833 (Sultan 1816)-Crucifix 1837 by Priam*182\% (Emillus 1820)-Octavi-

Cowl,

b. b., $18+2$.

ana 1815 by Octavjan $180 \%$ (Stripling 1795)-Dau. $180 \%$ of Shuttle $1 \% 93$ (Y. Marske 1 ri 1 ) Zara 1801 by Delpini 1781 (Highflyer $17 \% 4$ )

Belle Dame,

ch. m., 1839 .

Belshazzar* $18: 30$ (Blacklock 1814)-Ellen 1831 by Starch 1819 (Waxy Pope 1806)-Cuirass 1823 by Oisean 1809 (Camillus 1803) - Castanea 1806 by Gohanua 1790 (Mereur'y 17 irs) Grey Skim 1793 by Woodpecker $17 \% 3$ (Heroł 1758).

Traxy 1790 (Pot-8-1)-'s 1773)-Penelope 1798 by Trumpator 1780 (Conductor 17(fi) - Prubr. h., 18u\%. nella 1:85 by Highflyer 1\%7 (Herod 1758)-Promise 1768 by Snap 1750 (Suip 1736)Julia 1756 by Blank 1740 (God. Ar. 1\%24)

Peri,

Wanderer 1811 (Gohanna 1793) - Thalestris 1809 by Alexander 1782 (Eclipse 1;64)-Rival ISC0 by Sir Peter T. 1:81 (Highflyer 1\%4) - Hornet 1790 by Drone $1 \%$ (Herod 1758)Ianilla $17 \% 7$ by Gold finder 1 Ti:4 (Snap 1750 ).

So

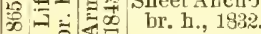

Fanny

Kemble,

Lottery 7820 (Tramp 1810) - Morgiana 1-20) by Muley 1810 (Orille 1799)-Miss Steplı $n$ soll 1814 by [Seud or] Sorcerer 1794 (Trumpator 1782)--Sist. 1793 to Petworth by Precipitate* 1;87 (Mercury 17\%8) - Dau. 1787 of Woodpecker 1773 (Herod 17\%8)

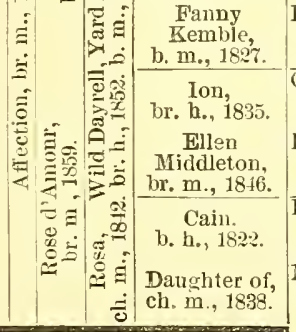

Paulowitz 1813 (Sir Paul 1802) - Loyalty 1817 by Rubens 1805 (Buzzard 178\%)-Penny. royal 1805 by Coriander 1786 (Pot-8-0-'s 17\%)-Peppermint $1 \% 8 \%$ by Highfiser $17 \%$ (Herod 17:8)-Promise 1768 by Snap 1750 (Snip 1736)

Cain 182: (Paulowitz 1-15) - Maraaret IA31 by Edmund 1824 (Orville 1799)-Medora 1811 by Selim 1802 (Buzzard* 178\%)-Dan. 1803 ol Sir Harry* $1 \% 95$ (Sir Peter T, 1784)-Dau. 1790 of Volunteer 1780 (Eclipse 1764).

Bay Middleton 1833 (Sultan 1S16) - Myrrba 1831 by Malek 1824 (Blacklock 1814)-Bessy 1815 by Y. Gouty 1805 (Gouty 1796)-Grandiflora 1810 by Sir Harry Dimsdale 1860 (Sir Peter T. 1784)-Dau. 1799 of Pjpator 1786 (Imperator 17\%6)

Paulowitz 1813 (Sir Paul 1 02)-Dau. 1k1) of Paynator 1791 (Trumpatol 1782)-Dau, 1803 of Delpini 1781 (Highflyer 1\%t) - Sist. 175 to Mary by Y. Marske 17r1 (Narske 1750)-Gentle Kitty 1\%̃ by Silvio 1754 (Cade 1294)

Muley 1810 (Orville 17:9) - Rosalia br m. 1825 by Walton 1799 (Sir Peter T. 1781)-Rosanne b. m. 1811 by Dick Andrews $179 \%$ (Joe Andrews 17\%8) - Rosette br. m. 1803 by Beningbrough 1\%91 (King Fergus 17i5)-Rosamond b. m, 1 is by Tandem 17\% 1745 by Bolton Starling 1727 (Bay Bolton 1705)-Coughing Poîly b. m. 1736 by Bartlett's Childers (Darley Ar) - Counsellor M. by Wood's Counsellor 1694 (D'Arcy Counsellor)-Dau. of Snake (Lister Turk) - Dau. of Luggs (D'Arcy White Turk)Dals. of Davill's Old Woodcock. 


\section{TOM OCHILTREE.}

\section{In. the Boulingbrook Stud, IId. Application to R. W. Walden, Middleburg,} IILC.

Tom Ochumpex br Lexington, son of Boston, bred by A. J. Alexander, Woorburn stnd, near spring Station. Ky., toaled 1872, dam Katona, the dam of Metarie and Sandtord, by Voncher, son of Wayner, out of Countess by inp. Margrave, winner of the st. Leger in 18:32. Wagner, the sire of Voncher, lie the sire of Katona, was closely inbred to sir Archy. He defeated the great Grey Eagle in the two memorahle contests, fonr mile heats, at Lonisville, Kentucky, in 1839. Voucher was a fine race-horse and was held in high esteem in his day. Margiave, the sire of his grandam, was a large, fine horse aud a rery suceessful sire; sired Brown Dick, whose three uniles in 5.35, 5.28 , hils not often been excelled; he was also sire of Blue Dick, a famous horse, and of Mollie Jackson, whose famous third heat of three miles in 5.28: has never been equalled. 'Iom Ochiltree did not run in his two-sear old form, but scored his first victors at Baltimore, and won four out of the nine races in which he started at three years old. Baltimore, won chash of three-qnarters of a mile in 1.24 , beating Andubon and seven others; won the Preakness Stakes, a sweepstakes for three-year olds, $1 \frac{1}{2}$ miles, in $2.43 \frac{1}{2}$, beating Viator and seren others. Jerome Park, won the Anumal Sreepstakes for three-rear olds, 2 miles and a furlong, in $4.09 \frac{1}{2}$, beating Chesapeake and Ascension. Baltimore, Md., won the Dixie Stakes for threevear olds, 2 miles, in 3.42! beating Viator, Aristides, Rhadamanthus and other good horses; was third in the Breckenridge Stakes for three-year olds, 2 miles, won by Aristides, Viator second, in $3.36 \frac{1}{\frac{1}{2}}$, he carrying a penalty of five pounds, and was unplaced in his other rices. Fonr years old, started in ten races and won eight. Baltimore, Md., won the Baltinore Cup, $2 \frac{1}{\ddagger}$ miles, in 4.09. beating Stampede, Viator and four others. Jerome Park, won the Juckes Club Handicap, 2 miles, in 3.41条, beating Kildare, Chesapeake and five others; won the Centemial stakes for all ages, $2 \frac{8}{4}$ miles, in 5.091, beating Aerobat and Olitipa. Mommonth Park, won the Mommouth Cup, 23 miles, in $4.48 \frac{1}{2}$, Stampede the only other starter; won the Capital Stakes for fourrear olds, 3 miles, in 5.35\%, beating Chesapeake and Ascension. At Saratoga, won the Saratoga Cup, $2 \frac{1}{1}$ miles, in 4.06 $\frac{1}{2}$. beating Parole, Big Samdy and Madge. Jerome Park, won the Maturity Stakes for tonr-cear olds, 3 miles, in $5.43 \frac{1}{2}$, beating Chesilveake, Matty A. and Grey Nnn; won the Centennial Cup, 4 miles, in 7.36, beating Acrobat, Big sindy and D'Artagnan. At Saratoga, was second in the All-aged Sweepstakes, $1 \frac{1}{4}$ miles, won by Parole in 2.128 ; was mplaced in race of two-mile heats, won by Add in $3.47 \frac{1}{1}, 3.48 \frac{3}{4}$, Ochiltree won first heat, but was distanced in the second. At five vears old, started fourteen times and was first in nine races. Baltimore, Mll, won the Baltimore Cup, 24 miles, in 4.14; won race of two-mile heats in 3.43 , distanced the field first heat. Jerome Park, won the Westchester Cup, $2 \frac{1}{4}$ miles, in

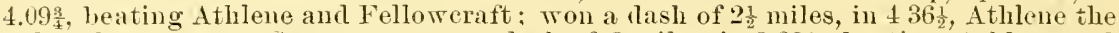
only other starter. Saratoga, won a dash of 2 miles, in $3.39 \frac{1}{3}$, beating Athlene and Annt Betsy; won a Handicap dash of 2 miles, in 3.421, beating Cloverbrook, Oriole and two others, Ochiltree carried 120 los. Jerome Park, won the Grand National Handicap, $2 \frac{1}{4}$ miles, in 4.181, carryiug 124 llss., beating Parole, Inspiration and Gal. way: wou dash of $1 \frac{8}{4}$ miles, in 3.14 , beating Virginius and Warlock, traek heary. Saratoga, was secont in the All-aged stakes, $1 \frac{1}{4}$ miles, won by Vera Cruz (3), Ochiltree carried 12tliss.; Was seeond in the Saratoga Cup, 2t miles, won by Parole in $4.04_{4}^{\frac{1}{4}}$; was second in a dash of $2 \frac{1}{2}$ miles, won by Whisper in 4.02 ; was second in a dash of 1 miles, wou by Tera Cruz in 3.17. At Baltimore, was third in a dash ot 21 miles, won by Parole in $4.37 \frac{3}{1}$. track rery heary. Tom Ochiltree is one of Lexing. ton's best sons; he could mu tist and stay under hears weights. His great size, coupled with symmetry of torm, should commend him to breeders. He is deeply inbred to Diomed through his many Archy erosses, and the Eclipse cross is an allition through a staying fimily, fortified with a triple cross of Orville throngh his sous, Inley and Emilius. Ochiltree is a bar, 16 hamds $2 \frac{1}{8}$ inches high, no white except a small star. He is one of the trnest ani best shaped big horses in the world. all bone and musele, withont a particle of lumber.

Tom Ochiltree is the sire of the wimners Major Domo (wimner of the Brokdale Haudicap, $1 \frac{1}{x}$ miles, in 1.5t; Parkway Hamienn, $1 \frac{1}{1}$ miles, in 1.17, I mile, in 1.39:3

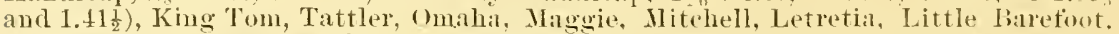
Constellation, Crusure, Orator, Slngard. Tom Boy. Waterloo, Crutelos. J. O. C.. Sandstone, Morrisinia, Jester, Disappointment, Exotic, Citizen, ete, He has covered only a few gool mares. 


\title{
IMPORTED TOP GALLANT.
}

\author{
Property of J. B. Ewing, Willamette Stud, Nashville, Tenn. Terms and yearling \\ sales anmually.
}

STERLING, the sire of Top Gallant, one of the most popular stallions in England, started only a few times. He won the Liverpool Autumn Cnp, beating Louise Victoria and twelve others, and was third to Montargis and Walnut in the Cambridgeshire, with 133 lbs. He won the Ascot Biennial Stakes, the Summer Stakes at "Newmarket, the Derby Free Handicap and Craven Stakes. He was second to Boswell in the 2,000 Guineas, a defeat whieh was one of the most glaring flukes in the annals of the turf, for it was admitted by every one that he could concede quite $42 \mathrm{lbs}$. to the winner; he was not in the Derby. His value is best shown in the stud, having sired such good ones as Isonomy, who himself is the sire of Riviera, one of the farorites for the Derby in 1890, Formidable, another good two-year old in 1890, Antibes, Common, winner of the 2,000 Gnineas, the Derby and St. Leger in 1891, etc., and one of the best race-horses of his time. His get last year won over $\$ 100,000$, and he stood at $\$ 1,000$, with his season full in advance. Harvester, who ran a dead heat with St. Gatien and diviled the stakes for the Derby, and was third in the 2,000 Gnineas. Paradox, Enterprise and Enthusiast, all three winners of the 2.000 Guineas, the former only beaten a head in the Derby, and the latter defeating the famons Donovan. Energy, winner of sixteen races ont of thirty-seven, and one of the speediest horses of his day. Beaudesert, the winner of the Middle Park Plate and sire of many winners. Caxtonian, Diseount, Post Orbit, Geologist, El Dorado (another conquerer of Donovan) and Cherry all come from Sterling's loins. Top Gallant's lam, Sea Mark, is the dam of Astronomy, Beacon, and Mr. D. D. Withers' fine young stallion Stalwart, who, from an injury received in crossing the ocean, was never trained. His grandam, Sea Gull, was the dam of Beandesert, winner of the Middle Park Plate, Queenstown, 'The Admiral, Discordant, ete. Wild Cherry was the dam of Grace Darling, Cherry Ripe, Sugar Plum, Heliotrope, Reciprocity, ete. Bridget was the dam of The Baronet, Wild Strawberry, Pomona, Miss Fanny, etc. Top Gallant traees through Ringlet, a daughter of Whisker, Clinkerina, the dam of Humphrey Clinker, sire of the noted Melbonrne by Clinker, Pewet, a winner of the St. Leger, by Tandem, to the noted Blacklegs mare, dam of Marske, the sire of Eelipse. He combines in his pedigree a double cross of Sir Herenles npon a large infusion of Touchstone blood through such excellent somrees as Arrenturer. Flateatcher and Surplice, and traces on his sire's side and dam's side to the noted danghters of Priam, Crucifix and Miss Letty. From the Coneyskin's mare, the fourteenth dam of Top Gallant, descend in direct female line the following noted race-horses and suecessful stallions: Marske, sire of Eclipse, Orrille, St. Leger wimner, Cervantes, Cain, Humphrey Clinker, Tomboy, Oetarian, St. Leger winner, The Colonel, St. Leger winner, Sultan, sire of Glencoe and Bay Middleton, Sir Tatton Șckes, St. Leger winner, Newminster, St. Leger winner, and sire of the famons Hermit, Andorer, Derby winner, Rifleman, Strafford, Cathedral, Mariner, Melton, winner of both Derby and St. Leger, and many other of the best race-horses and stallions in England. He is one of the few sons of the great Sterling in America accessible to breelers, and he must be a valuable acquisition to the blood stock of the country.

Top Gallant is a horse of rare individnal merit. He carried off the first prize at

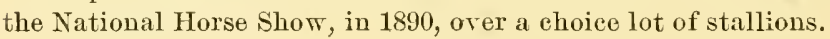




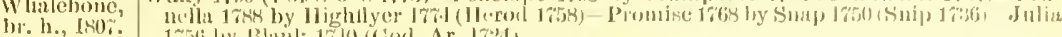

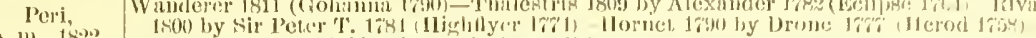

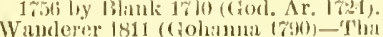

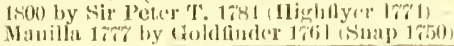

مُ

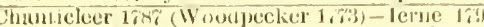

Flight,

(inmuhoe (Bustarl liti) Pal

Justice 1225 (11. C. Lition Ar.

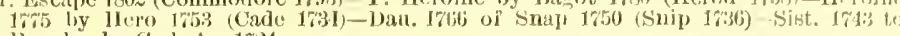
hiogulus by God. Ar. 17\%1.

b. h., 182).

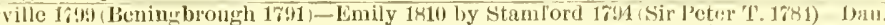

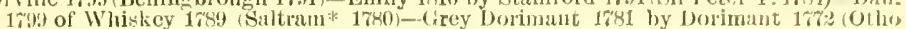

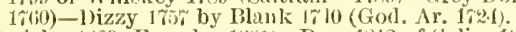

Pericles 1809 (Evandel 1801)-Dau. 1812 of Selim 1802 (Buzzard" 1687)-I'ipylina 1803 by

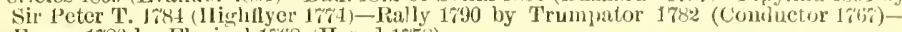
Fincy 1780 by Florizel 16 (He (Herod $175 \%$ ).

Bay

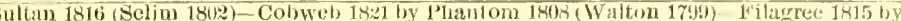
sootheayer 1808 (Sorcerer 1796)-Web 1808 loy Waxy 1790 (1'ot-8-0-'s 1673)-Penelope

$179 \times$ by Trumpator 1782 (Conductor 1767).
Prian* 1827 (Emilins 1820)-Dan. 1815 of Orrille 1799 (Beninglorough 1791) -Dan. 1800

b. H., 1s:3?

Miss Letty, of Buzzard 1787 (Woodpecker 17ri3)-Hornpipe 1793 by Trumpator 178: (Couductor $16(6)$-Luna $1 \% 99$ by Herod 1758 (Tartar $1 \% 4 ;)$

Camel,

Whalebone $189 \%$ (Waxy 1790) Dau. 1812 of Kelim 1802 (Buz\%ard 178\%) Yaiden 1801 br. h., $18 \% 2$.

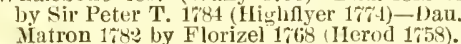

Matron 1782 by Florizel 1768 (Ilerod 1758). 1807 by Alexander 1782 (Eclipse 17t4)Brmette by Amaranthus 1766 (Old England 1741) - Maylly 17\%1 by Matehem 1748 (Cade 1731)-Dau, 1755 of Ane. Starling 1738 (Starling 1\%2\%).

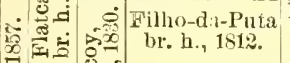

Haphazard 1797 (Sir Peter T. 1'84)-Mis. Barnet 1806 by Waxy 1790 (Pot-8-0-'s 17is) Dau. 1788 of Woodpecker 1773 (IIerod 1758)-11einel 1771 by Squirrel 1751 (Traveller 17:35) - Principessa 1\%6: by Blank 1\%40 (God. Ar. 1\%24)

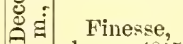

Peruvian 1806 (Sir Peler T. 1784)-Violante 1802 by John Bull 1789 (Fortitude 1777)-

b. m., 1815 .

Dau. 1788 of Highflyer 17\%t (Herod 1i58)-Everlasting $17 \% 5$ by Eclipse 17tit Marske 1750) - Hyæena 1762 by Snap 1750 (Snip 1736)

: 2 in Humprey

Comus 1809 (Soreerur $1200^{\circ}$ - Clinkeriua 1810 by

b. li., 18:2.

实 Daughter of 1786 by Tandem 1773 (Syphon 1750)-Termagant by Tantrum 1760 (Cripple 150) Cantatrice by Sampson 1745 (Blaze 1733).

Daughter of,
b. $\mathrm{m} ., 1835$.

1810 (Don Quixote 17s4)-Dau. 1818 of Golumpus 1802 (Gohanna 1;90)-Dau. 1810 of Paynator 1791 (Trumpator 1782)-Circle 1802 by St. George 1789 Hightiyer 1744)-Abigail 1789 by Woodpecker $17 \% 3$ (Herod 1758).

Hornsea,

Velocipede 1325 (B)acklock 1814 ) Dau 1820 of Cerberus 1802 (Gohanna 1790) - Mirs Cranfield 1803 by Sir Peter T. 1784 (Highflyer 1774)-Dau. 1796 of Pegasus 1784 (Eclipse 1764)-Dau. 1783 of Paymaster 1766 (Blank 1740)

Solace, Longwaist 1821 (Whalebone 1807)-Dulcamara 1818 by Waxy 1790 (Pot-R-0-'s 17ris)-

b. (Highflyer 1774)-Dau. 1788 of Woodpecker $17 \% 3$ (Herod 1758).

Camel,

Thalebone 1807 (Waxy 1790)-Dau. 1812 of Selim 1802 (Buzzard* 178\%)-Maiden 1801 by Sir Peter T. 1784 (Highflyer 177)-Dau. 1788 of Phenomenon 1780 (Herod 1758)Matron 1782 by Florizel 1768 (Herod 1758).

br. h., 1822

Master Henry 1815 (Orville 1799)-Boadicea 1807 by Alexander 1782 (Eclipse 1764)-Brunette by Amaranthus 1766 (Old Encland 1741) - Mayfly $17 \% 1$ by IIatchem 1748 (Cade

\section{1) - Dau. 1755 of Anc. Starling 1738 (Old Starling 172\%).}

Jenny 1791 (Trumpator 1782)-Dau, of Beningbrough 1791 (King Fergus 17\%5) saw 1751 (Snip 1736) - Sultana 1759 by Regulus 1 \%39 (God. Ar. 1724).

Daughter of Ardrossan 1809 (John Bull 1789)-Lady Eliza 1813 by Whitworth 1805 (Agonistes 1797 )

$\begin{array}{ll}\text { ch. M., 181\%. } & \text { X. Y. Z.'s dam } 1793 \text { by Spadille } 1781 \text { (Highflyer 1774)_Sylvia } \\ \text { (Marske 1750)-Ferret } 1765 \text { by Broth. to Silvio (Cade 1734). }\end{array}$

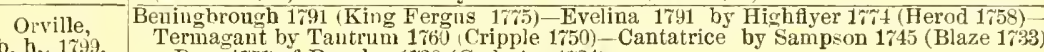
b. h. -Dau. 1757 of Regulus 1739 (God. Ar. 1724).

Emily Stamford 1794 (Sir Peter T. 1784)-Dau 1799 of Whiskey 1789 (Saltram* 1780)-Grey Dorimant 1781 by Dorimant $17 \%$ (Otho 1760)-Dizzy 175\% by Blank 1710 (God. Ar. 1724) - Ane. Dizzy $1 \%+1$ by Driver $172 \%$ (IVynn Ar.)

ch. in., 1810 .

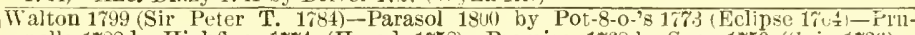

Partisan, nella 1788 by Highfiyer 177t (Herod 1758)-Promise 1768 by Snap 1750 (Snip 1736)Julia 1756 by Blank 1740 (God. Ar. 1724).

(Woodpecker 17/3)br. $111 ., 1815$. 1743)-Proserpine 1766 (Eclipse's sist.) by Narske 1750 (Squirt 1\%32)

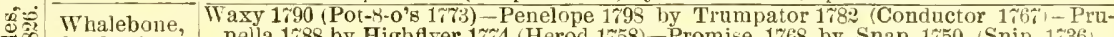
br. b., $150 \%$. nella 1788 by Highflyer $17 \% 4$ (Herod 1758)-Promise 1768 by Snap 1750 (Snip 1736)Julia 1756 by Blink 1740 (God. Ar. 1724)

Peli,

Wanderer 1811 (Gohanma 1790-Thalestris 1899 by Alexander 1782 (Eclipse 1\%64)-Rival 1800 by Sir Peter T. 1784 (Highflyer $17 \% 4$ ) - Hornet 1790 by Drone $17 \% 7$ (Herod 1758)Manilla 1rif by Goldfinder 1764 (Snap 1750).

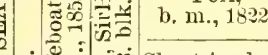

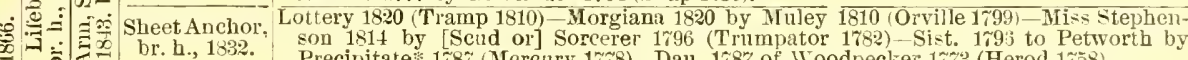
Precipitate* 1787 (Mercury 17\%8)-Dau. 1787 of Woodpecker 17\% (Herod 1758)

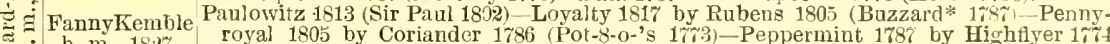
(Herod 1758)-Promise 1768 by Suap 1750 (Snip 1736).

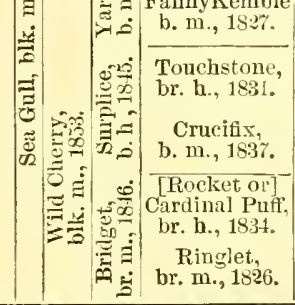

Camel 1822 (Whalebone 1807)-Banter 1826 oy Master Henry 1815 (Orville 1r99)-Boadicea 1807 by Alexander 1782 (Eclipse 1764)-Brunette by Amaranthus 1766 (Old England 1741)--Mayfly $17 \% 1$ by Matcliem 1748 (Cade 1734).

Priam* 1827 (Emilius 1820)-Oetaviana 1815 by Octavian 187\% (Stripling 1795)-Dau. 180\%

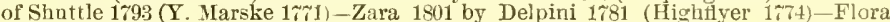
1789 by King Fergus $17 \% 5$ (Eclipse 1764).

Pautaloon 1824 (Castrel 1801)-Puff 1823 by Waterloo 1814 (Walton 1799)-Blowing 1803 by Buzzard 1787 (Woodpecker 1773) -Dau. 1796 of Pot-8-o-'s 1773 (Eclipse 1704)Miaid-of-all-Work 1786 by Highflyer $17 \% 4$ (Herod 1758)

Whisker 1812 (Waxy 1890)-Clinkerina br. m. 1812 by Clinker 1805 (Sir Peter T. 1784Pewet b. m. 1786 by Tandem 1773 (Syphon 1750)-Termagant by Tantrum 1\%60 (Cripple 1750)-Cantatrice by Sampson 1745 (Blaze 1733)-Dau. br. $\mathrm{m}$. $175 \%$ by Regulus 1739 (God. Ar. 1721)-The Ruby mare (Marske's dam) by Hutton's Blacklegs 1725 (Mnlso Turk)-Dau. of Bay Bolton 1705 (Grey Hautboy)-Dau. of Fox Cub 1714 (Clumsy)-Dau. of Coney-
skins 1712 (Lister Turk)-1) 1 . ố Hut on's Grev Barb 1700-Dau. of Hutton's Royal Colt 1\%00 (Helmsley Turk)-Dau. of Byerly Turk-Dau. of Bustler (Helmsley 'Turk). 


\section{TREMONT.}

WINNER OF THE JUVENILE, FOAI, SURF, JUNE, GREAT POST, ATLAN. TIC, TYRO, JUNIOR CHAMPION AND OTHER STAKES AT TWO YEARS OLD.

The property of Gen. W. H. Jackson, Belle Meade Stud, Nashville, Tenn. Terms anmully. Tearling sales in June each year.

Tremoxt, black horse, foaled 1884, bred in the Elmendorf Stud, Kr., by Virçil, son of Vandal by imp. Gleneoe, dam Aun Fief by Alarm, son of imp. Eclipse l,y Orlando, grandam Kate Walker by Eubry's Lexington, son of Lexington aud Bellamira by imp. Monarch, son of imported Priam, ete. Tremout was a phenomenally fast horse and never met defeat during his racing career, which ended at two vears old. Virgil, sire of Tremout, was by Vandal, the best son of imp. Glencoe, whose dam was the Tranby mare, that also prodnced Levity, Volga and Vistula. Tirgil's dam was Hymeuia by imp. Yorkshire. She produeed Daisy by Cracker, Alaric, Ansel, Lady Petry and Mollie IVood. Virgil was the sire of not only the unbeaten Tremont, bnt of the great Hindoo (sire of Hanover), Portland, Vigil. Vagrant, Vera Cruz, Virginius, Vauguard, Virgilian, Fairplay, Katrina, Menento, Isade Murpher, Carley B., Ben Ali, Kichmond, Kingfish. Hinalaya, ete., ete. Tremout inheritéd much of his speed from Ann Fief, the damghter of Alarm by imp. Eclipse. Ann Fief was ont of Kate Walker by Embry's Lexiugton, son of the great Lexington and graudson of the stont Boston. Kate Walker, the dan of Ann Fief, was the dam of Bend'or, one of the best race-horses this conntry has ever prodnced for speed, stam. ina and weight-carrying capacity. As a fonr-year old Bend'or started in twelve races, of which he won nine. He won at heats of a mile and a sixteenth, capturing the second and third beats; won at $1 \frac{1}{3}$ miles, over a heary track, at Chicago, earryiug a $10 \mathrm{lb}$. penalty; he wou the Board of Trade Handicap at the same distauce; witl $149 \mathrm{lbs}$, he ran a mile at Saratoga in 1.45; won at 1 $1 \frac{1}{2}$ miles, in $2.35 \frac{1}{2}$, defeating such a grand mare as Thora, aud agin in $2.36 \frac{3}{2}$, with 123 lis., conceding Geveral Monroe 22 lbs.; while in the Grand Prize at Saratoga, I3 miles, he carried $12216 \mathrm{~s}$. and ran second to Glidelia, $116 \mathrm{lbs}$. . in 3.01, the fastest and best race at the distavee up to that date. Besides Beud'or, Kate Walker prodneed the winuers Maggie H. and Hattie D. H. Ann Fief is the dam of Spanish King, Anrania (winuer of the New and Spring Stakes as a two-year ohl and other races), Auna B. (winuer of the Debntante Stakes) and Westehester (winner of the Seabright Stakes). Tremont won the Juvenile Stakes, Jerome Park, half a mile, 115 lls.. in $0.48 \frac{8}{4}$, fourteen starters: won the Seqnence Stakes, Jerome Park, 5 furlongs, 115 lbs, in 1.02 , seven starters; wou the Foam Stakes, Sheepshead Bar, 5 furlougs, 115 los., in 1.041, ten starters: won the Snrf Stakes, Sheepshead Bay, 5 fulongs, 12 . los., in 1.02, nine starters; wou the Zephyr Stakes, Sheepshead Bar; three-quarters of a mile, $1121 \mathrm{los}$, in $1.17 \frac{1}{4}$, fom starters; won the Paddock Stakes. Sheepshead Bay, three-quarters of a mile, 112 lbs., in $1.17 \frac{1}{2}$, two starters; won the Spring Stakes, sheepshead Bay, three-quarters of a

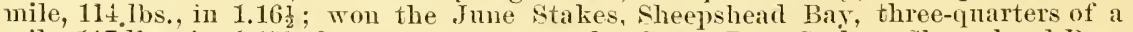
mile, $117 \mathrm{lbs}$, in 1.181, fonr starters; won the Great Post Stakes, Sheepshead Bar, three-quarters of a mile, $115 \mathrm{ll}$ s., in 1.19: fonr starters; won the Good-Bye Stalies, Sheepshead Bay, three-quarters of a mile, $115 \mathrm{lbs}$. , in 1.15, six starters: wou the Atlautic Stakes, Monmonth Park, three-rnarters of a mile, $115 \mathrm{ll}$ s., in 1.168, six starters; won the Tyro Stakes, Monmouth Park, three-quarter's of a mile. 115 lbs.. in 1.191, five starters; won the Junior Champion Stakes. Monmonth Park, threequarters of a mile, $115 \mathrm{lbs}$., in 1.17\%. In this last race he defeated Kingston aud Fitzros. He met and defeated all the best two-year olds of his year.

Tremont must be regarded as a snceess in the stud. The following winners are most all the get of his first season in the stud: Dagonet, Fremont, Fillide. Fleurette, Jessica, Lavish, Temple, Tringle, Marmont, Chicago, Seabright, Lorelace, etc., creditable performers. 


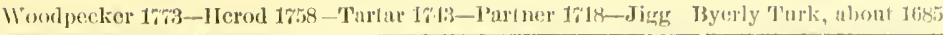

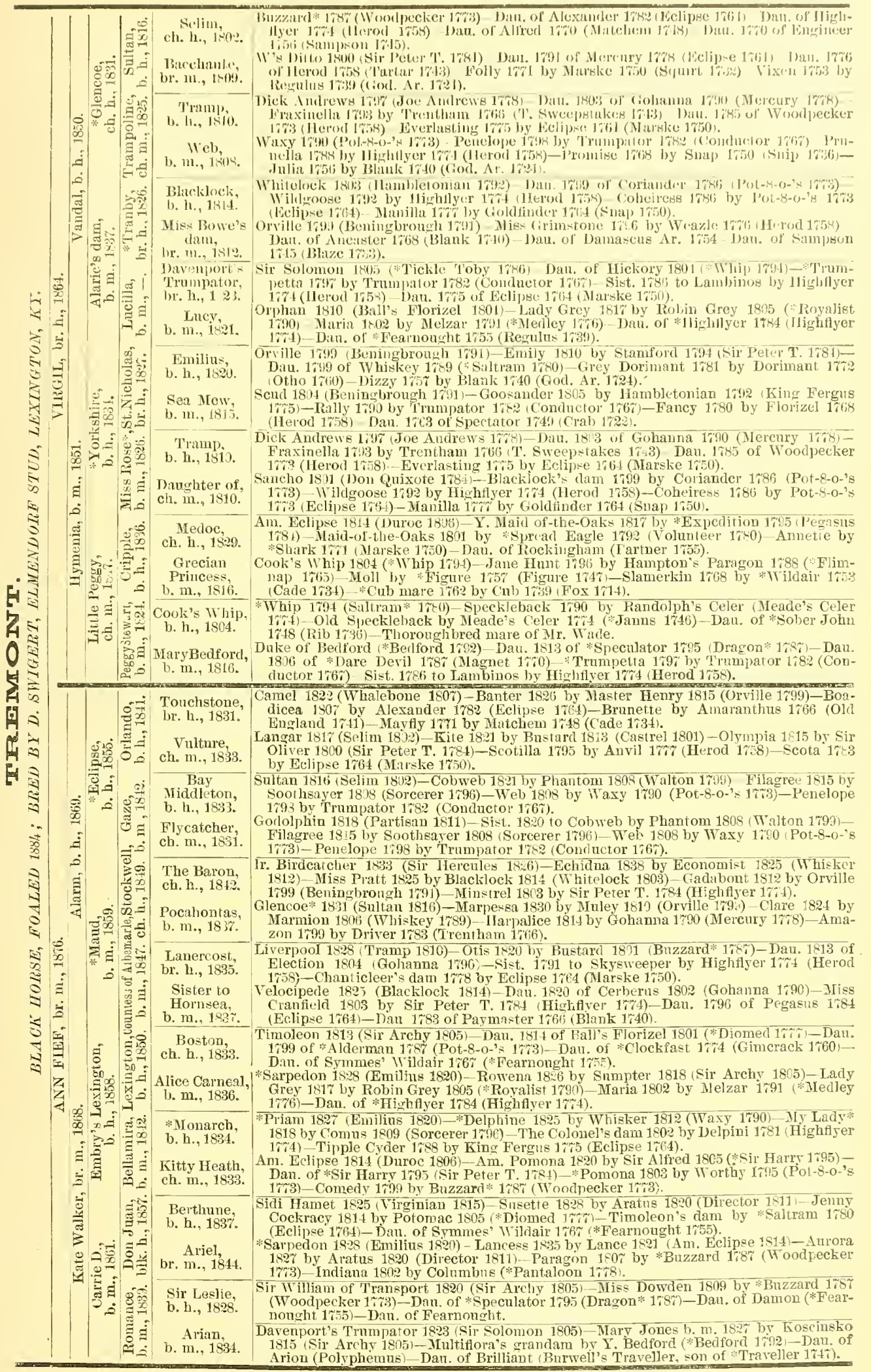




\section{TROUBADOUR.}

WINNER OF THE SENSATION, CRITERION, KIMBALL AND OTHER STAKES AT 'TWO YEARS OLD, THE CHARLES GREET. PALNER HOUSE ANI) ST. LEGER STAKES AT THREE YEARS OLD, SUBURBAN HANUICAP, OCEAN STAKES AND HONMOUTH C'UP, ETC.

\section{The property of Capt. S. S. Brown, Wildwood Stud, Pa.}

Troudadour, bay horse, foaled 1882 bred in the Woorlburu Stud, Ky., by Lisbon son of imp. Phaeton by King Tom, dam Glenluine, dam of Windrush by imp. Glenelg, son of Caterer by stockwell, grandau Lute, dam of Virginins by Lexington, out of kulu Horton by imp. Albion. Troubadour was a grand race-horse and is from a great racing and producing fimily. Glenlnine was a grand prodneer. She is the dam of sehool Girl and her sister, Patrimony, the dam of Lisimony (a first-class racehorse), and Patron (wimmer of the Great American stakes), Windinsh (winner of the Illinois Derby, etc.), and Lizzie Krepps, a good two-year old winner. Lute, the grandam, produced that good horse Virginins, and Lute Eilgar (the dam of Shiloh), Torrent (a two-year old winner), and Teuerine (dam of Leo and Louise, a two-year. winner in 1891). The great grandam, Luln Horton, prodneed Kildare and Amy Farley (dani of Mattie Amelia, dam of Hemlock, Borealis and Sallie Taylor, Terese. Fonsie's dam, Pathfinder and Blue Grass). Blue Grass won in England the Burwell Stakes, Newmarket, the Aseot Biemnial Stakes, and the Raeing Stakes. Goodwood, beating Ossian, winner of the St. Leger, ete. Other good ones from Lulu Horton were spartan, Pequot and Patula, dam of Ceawood (winner of the Clay stakes, ete.). The Stoekholder mare, the fifth dam, produeed Compromise, Invineible, Laura (dam of Lily IVard, Harry of the West, Fannie C'heathan, Jndge Durrell and Lerna) and Iodine. From these eame the good ones Laura Faris, Ascension, Buckette, Hattie Hugar, Fanny Brown, Ada Hayes and Memento. Tronbadour at two years old ran fonrteen times, won seren raees, was second in three and third in one. Ran second to Favor in McGrath Stakes five-eighth of a mile, $110 \mathrm{lbs}$., in $1.0 \mathrm{~s} \frac{1}{\text { : }}$ ran second to $O . B$.

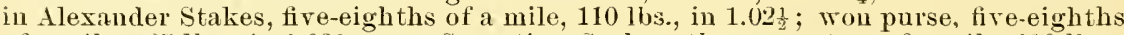
of a mile, 105 lbs.. in 1.028; won Sensation Stakes, three-quarters of a mile, 110 lbs., in $1.22 \frac{1}{4}$, beating 'Ten Stone, Freeman, ete.; wou Criterion Stakes, three-quarters of a mile, 110 lbs., in 1.21委; ran third in Kenwool Stakes, five-eighths of a mile, 112

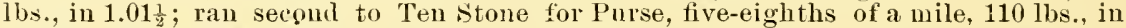
1.031 ; won purse, three-quarters of a mile, 110 lbs., in 1.18 ; won purse, $1 \mathrm{mile}, 109 \mathrm{lbs}$, in I.508; won Kimball Stakes, three-quarters of a mile, 115 lbs., in 1.17 ; won Barrett Stakes, 1 mile, 118 lbs., in 1.45. At three rears old ran twentytwo races, won five, was seeond in three and third in nine. Ran third in Distiller's'

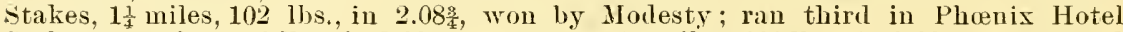
stakes, $1 \frac{1}{4}$ miles, 110 lbs., in $2.033^{2} ;$ wou purse, $1 \frac{1}{4}$ miles, $10^{2} 1 \mathrm{bs}$.. in $2.08 \frac{3}{4}$; ran second to Bersau in Clark Stakes, $1 \frac{1}{4}$ miles, 110 lbs., in 2.091 ; ran secoul to Aretino for purse, 15 miles. 105 lbs., in $2.5 \frac{1}{3}$; won Charles Green Stakes. $1 \frac{1}{1}$ miles, 118 lbs.. in $2.13 \frac{1}{4}$, beating Thistle, Favor, ete.; ran third in American Derby, $1 \frac{1}{2}$ miles, 123 lbs., in 2.49. Volante won, Favor second; ran third in Bonlevird Stakes $1 \frac{1}{4}$ miles, 112 lbs., in 2.09; ran third in Sheridan Stakes, $1 \frac{1}{4}$ miles, $1231 \mathrm{bs}$., in $2.09 \frac{1}{4}$; ran third in Drexel stakes, 1 mile, 123 lbs., in 1.50 ; won Palmer House Stakes, $1 \frac{1}{4}$ miles, 106 lbs., in 2.10: won St. Lonis St. Leger Stakes, 2 miles, $123 \mathrm{lbs}$, in 3.48; ran third in Kaskaskia stakes, $1 \frac{1}{2}$ miles, $11 \frac{1}{2}$ lbs.. in 2.44; ran third in Hotel Stakes, $1 \frac{1}{2}$ miles, 125 lbs., in 2.45; ran third in Brewer's' stakes, $1 \frac{3}{3}$ miles, $113 \mathrm{lbs}$., in 3.24; ran second to Editor in Falsetto Stakes, 2 miles, 125 los., in 3.43 , beating Volo. Ten Booker, ete. At four rears old ran three tinnes and won ali his raees. Won Handieap purse, $1 \frac{1}{\times}$ miles, 110 ibs., in 1.57; wou Suburban, $1 \frac{1}{4}$ miles, 115 lbs., in 2.12!. beating Richmoul, Barnum, Lizzie Dwyer, Ban Fox, Charity, Favor, ete.; won speeial race against Miss Woodford, $1 \frac{1}{4}$ miles, 118 lbs., in $2.08 \frac{3}{2}$. At five years old ran six races, won fonr, was second in one and third in the other. Won purse, 1 mile, 122 1hs., in 1.421; ran second to The Bard in Coney Island stakes, $1^{\text {l }}$ miles, 122 1bs, in 1.55; won sweepstakes. 1 mile, 1 I5 lbs., in 1.41; won Ocean Stakes. $1 \frac{1}{9}$ miles, 120 lbs., 1.564 . beating The Bard; won Monmonth Cup, 18 miles. 12l lbs, in 301 , beating The Bard ; ran

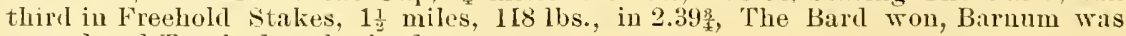
second and Troubadour broke down.

Tronbadon is young in the stud. Is sire of the winners Arnold, Lookont, Too Quick, La Cigale, about all that lave been triined.

Troubatonr is descendel in direct female line through imp. Silver (Sylva) from the Barb mare, to which trace Lath, Carle. Flying Childers, inp. Diomed, Sorcerer, imp. Priam, Phantom, Langar, Muley, The Cure, Plenipotentiary, Turnus, See-Siw, imp. Zinganee, in England; Windrish, 'Tyrant, Virginiıs, Blue Grass, Epsilou, Hidalgo, Voltigenr, ete., etc., in Antericia. 


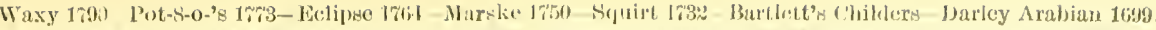

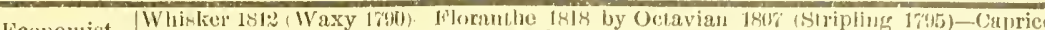

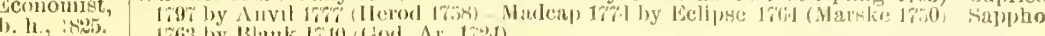

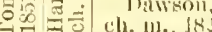

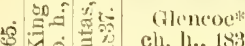

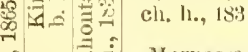

Marpeswa

(o)

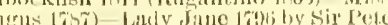

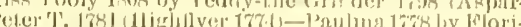

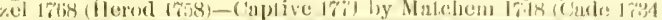

sulın 1ki(j (Selim lsos) Trampoline J

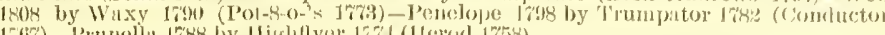

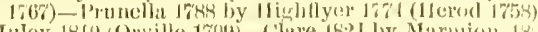

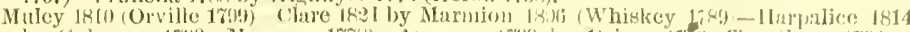

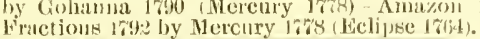

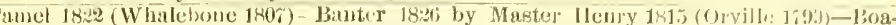

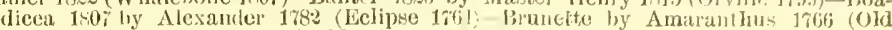

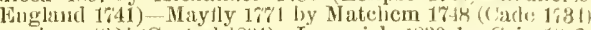

br. h., 1831

Pantuloon 18:1 (Castrel 1801) - Langiish 1830 by Cain 14:2 (Panlowit\% 181:3) Lyrlia 18?9 by loulion 1805 (sin Peter T. 178.J) Variety 1808 by 11 yacinthus $17 \%$ (Coriancter list)

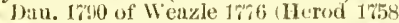

Touchstone 1831 (Camel 18:2)-Decoy 1830 by Filho-lla-Puta 1812 (IIaphazard 1797)Finesse 1815 by Peruvian 1806 (Sir Peter T' 1781) Violante 1802 by Joln Buli 1789 (Fortitude 1\% $1 \%$-Sist. 1788 to Skyscraper by llighllyer $17 \%$ I (Herod $175 \%$

Emilius 18:0 (Orville 1799) - Variation 182\% by Pustard 1813 (Custrel 1801) - Jolianna Southeote 1811 by Beningbrougl 1791 (King Fergus 1775)-Lavinia 1802 by Pipalor 1786 (Imperator 1776)-Dick Andrew's dam 1790 by IIiulafyer 17\%4 (IIerod 175x).

Ir. Birdcatcher $1 \times 33$ (Sir Hercules 1826)-Echidna 1838 by Economikt 1825 (Whiker 181.)_Miss Pratt 1825 by Blacklock 1814 (Whitelock 1803) (Gadabout 181: by Orville 1799 (Beningbrough 1791) Minstrel 1803 by Sir Peter T. 1784 (Highflyer 17\%4).

Glencoe* 1831 (Sultan 1816)-Marpessa 1830 by Muley 1819 (Orville 179:4) Clare 1824 by Marmion 1800 (Whiskey 1789) - Harpalice 1814 by Gohanna $17 \% 0$ (Mercury 1778) - Amazon 1799 by Driver 1783 (Trentham 1766 ).

Touchstone 1831 (Camel 182:) - Vulture 1833 by Langar 1817 (Selim 1802)-Kite 1821 by Bustard 1813 (Castrel 1801)-Olympia 1815 by Sir Oliver 1800 (Sir Peter T, 1784)Scotilia 1795 by Anvil 17\% (Herod 1758)

:

Velocipede 1825 (Blacklock 1814)-Emma 1824 by Whisker 1812 (Waxy 1\%90)Gibside Fairy 1811 by Hermes 1790 (Mercury 1788) - Vicissitude 1800 by Pipator 1786 (Imperator 1776)-Beatrice 1791 by Sir Peter T. 1784 (Highflyer 1774)

:

ch. m. 18:39.

in

Partisan 1811 (Walton 1799)-Pauline 1826 by Moses 1819 ([Whalebone or] Seymour 180\%)-Quadrille 1815 by Selim 1802 (Buzzard* 1787)-Canary Bird 1806 by [Whiskey or] Sorcerer 1796 (Trumpator 1782)-Canary 1797 by Coriander 1786 (Pot-8-0-' 1773).

ch, h., 1833.

Starch orj Voltaire 1826 (Blacklock 1814)-Belinda 1825 by Blacklock 1814 (Whitelock 1803) - Wagtail 1818 by Prime Minister 1810 (Sancho 1801)-Tranby*'s dam 1812 by Orville 1799 (Beningbrough 1791)-Miss Grimstone 1796 by Weazle $17 \% 6$ (Herod 1758).

Camel 1822 (Whalebone 1807)-Banter 1826 by Master Henry 1815 (Orville 1799)-Boadicea $180 \%$ by Alexander 1782 (Eclipse 1\%64)-Brunette by Amaranthus 1\%66 (Old England 1741)-Maytly 1771 by Matchem 1748 (Cade 1734).

Tomboy 18:9 (Jerry 1821) - Lapwing 1837 by Bustard 1813 (Castrel 1801)-Dan. 1830 of Iuley 1810 (Orville 1799) - Rosanne 1811 by Dick Andrews 1797 (Joe Andrews 17\%8)-

br. m., 1843. Rosette 1803 by Beningbrough 1791 (King Fergus 1775).

Ir. Birdcatcher 1833 (Sir Hercules 1826)-Echidna 1838 by Economist 1825 (Whisker 1812) - Miss Pratt 1825 by Blacklock 1814 (Whitelock 1803)-Gadabout 1812 by Orville 1799 (Beningbrough 1791) - Minstrel 1803 by Sir Peter T. 1781 (II Ghflyer 1764).

Glencoe* 1831 (Sultan 1816) - Marpessa 1830 by Muley 1810 (Orville 1\%99)-Clare 1824 by Marmion 1806 (Whiskey 1789)-Harpalice 1814 by Gohanna 1790 (Mercury 17\%8)Amazon 1 \%99 by Driver 1783 (Trentham 1766).

Humprey Clinker 1822 (Comus 1809)-Dau. 1825 of Cervantes 1806 (Don Qnixote 1784)Dau. 1818 of Golumpus 1802 (Gohanna 1790)-Dat1. 1810 of Paynator 1791 (Trumpator 1782) - Circle 1802 hy St. George 1789 (Highflyer 1774).

Tonchstone 1831 (Camel 1822) - Ghuznee 18.38 by Pantaloon 1824(Castrel 1801)-Languish 1330 by Cain 1822 (Paulowitz 1813)-Lydia 1822 by Poulton 1805 (Sir Peter T. 1784)Variety 1803 by 1 yacinthus 1797 (Coriander 1786)

1846.

Partisan 1811 (Walion 1799) - Fawn 1823 by Smolensko 1810 (Sorcerer 1796)-Jerboa 1803 by Gohanna 1790 (Mercury 17\%8)-Camilla $1 \% 78$ by Trentham 1766 (T. Sweepstakes 1743)-Coquette 1764 by Compton Barb.

Slane 1833 (Royal Oak 1823)-Garcia 1823 by Octavian 180\% (Stripling 1795)-Dau. 1806 of Shuttle 1793 (Y. Marske 17\%1)-Katharine 1798 by Delpini 1781 (Highflyer 17.4)Dau. $1786^{\circ}$ of Paymaster 1766 (Blank 1740)

$\bar{W}$ halebone 1807 (Waxy 1790 )-Defiance 1816 by Rubens 1805 (Buzzar $*$ 178\%)-Little Folly 1806 by Highland Flilg 1798 (Spadille 1; 1 -1)-Harriet 1799 by Volunteer 1780 (Echipse 1764)-Dau. 1785 of Alfred $17 \% 0$ (Matehem 1748 .

b. h., 1824 .

Gainsborough 1813 (Rubens 1805)-Dan. 1818 of Topsy Turvey 1805 (St. George 1789)-

Pet, Agnes 1805 by Shutte 1793 (Y. Marske 1\%71)-Dau. 1788 of Highflyer 174 (Herod

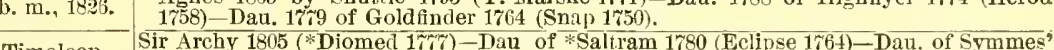

Timoleon, Wildair $176 \%$ ("Fearnought 1755)-Dau. of Tyler's Driver 1\%60 (*Othello)-Dau. of Fallower 1761 (Blank 1740 )

Ball's Florizel 1801 (*Diomed 17\% )-Dan of *Clockfast 17\%4 (Gimcrack 1760)-Dan. of

Sister to
Tuckahoe, ch. m., 1814. (Regulns 1739)—*Kitty Fisher 1755 by Cade 1734 (God. Ar. 1724).

Emilius 18:0 (Orville 1799)-Icaria 1824 by The Flyer 1814 (Vandyke Jr. 1808)-Parma 1813 by Dick Andrews 179\% (Joe Andrews 17\%8)-May 1804 by Beningbrough 1791 (King Fergus 17\%5)-Primrose $1 \% 87$ by Mambrino 1768 (Engineer 1756).

Sumpter 1818 (Sir Archy 1805) - Lady Grey 1817 by Robin Grey 1805 (\%Rovalist 1790)Maria 1802 by Melzar 1791 (*Medley 1771) - Dau. of *Highflyer 1784 (Highflyer 17t4) Dan. of *Fearnought 1755 (Regulus 1739)

Roweria,

Scud 1804 (Beningbrongh 1791) - Diana 1808 by Stamford 1794 (Sir Peter T. 1784)-Dar, 1799 of Whiskey 1789 (Saltram* 1780)-Grey Dorimant 1781 by Dorimant 17t2 (Otho 1760)-Dizzy $175 \%$ by Blank 1\%40 (God. Ar. 1724)

[Cain or

ch. h., 1822

Comus or] Blacklock 1814 (Whitelock 1803)-Manuella 1809 by Dick Andrews 1797 (Joe Andrews 17\%8)-Mandane 1800 by Pot-8-0-'s 1773 (Eclipse 1764)-Y. Camilla 1787
by Woodpecker 17\%3(Herod 1758)-Camilla 1778 by Trentham 1766 (T.Sweepstakes 1743).

Emilius 1820 (Orville 1799)-Fleur de Lis 1822 by Bourbon 1811 (Sorcerer 1796)-Lady Rachel 1805 by Stamford 1794 (Sir Peter T, 1;84)-Y. Rachel 1799 by Volunteer 1780 (Eclipse 1764)-Rachel 1790 by Highflyer 1\% (Herod 1758) (5tockolder 1806

tockholder (sir Archy 1805)-Dau. ch. m. 1822 of Pacolet 1806 (5itizen 7 785)-Nell Saunders ch. m. 1815 by Wilkes' Wouder 1800 (*Dioured 177)_Julietta bs * Dare Deril 1787 (Magnet 1770)-Rosetta ch. m. 1785 by *Centiuel 1758 (Blank 1740)-Diana ch. m. by by Bellsize Ar. 1756-Sist. to Cato by Partner 1718 (Jigg)-Sist. cl. m. I719 to Roxana by Bald Galloway (St. Victor Barb)-Sist. to Channter by Akaster Turk-Cream Clieeks by Leedes Ar.-Dau. 1690 of Spanker (D'Arey Yellow Turk)-Old Morocco mare by Lord Fairfax's Morocco mare-Old Bald Peg by an Arabian-A Barb mare. 


\section{TURCO.}

WINNER OF THE RARITAN STAKES AND OTHER RACES.

\section{The property of IIr. L. O. Appleby, near Eatontown, N. J. Yearlings sold annually.}

Turco, chestunt horse, foaled 1879, bred in the Nursery Stnd, by Kingfisher, son of Lexington by Boston, dam imp. Toncques, dam of La Tosea by Monarque, son of The Emperor by Defence, grandam La Toneques by The Baron, sire of Stockwell and Rataplan, great grandan Tapestry by Melbomrne, son of Humphres Clinker by Comms, out of Stitch by Hornsea, sow of Velociperle by Blacklock, etc. Tureo was a good bnt unfortunate race-horse. At two years old ran four races. Won purse, three-quarters of a mile, 100 lbs., in 1.15\%, beating Vampire, Bayadere, etc.; ran second to Hiamasse, three-quarters of a mile, in 1.16, with six others behind him ; ran third to Wyoming aud Olivia, 5 furlongs, in $1.03 \frac{1}{4}$, with five others behind him. At three years old, won two races ont of three starts; 1 mile, 118 liss, in 1.463, beating Free Gold, Hilarity and three others; won Raritan Stakes, $1 \frac{3}{8}$ miles, 118 1bs., in 2.29, beating Macbeth, Duplex and three others. His sire, Kingfisher, was a first-class race-horse, winner of the Belmont, Champion, Jerome and Travers stakes. Imp. Eltham Lass was half sister to Yiridis, dam of Springfield (winner of the Stockbridge Cnp) by Kingstou, son of Venison and winner of the Goodwood Cnp. Kingfisher is the sire of Lady Rosebery (winner of the Champagne Stakes), Rica, Prince Royal (winner of eighteen races, inclnding the Midsummer Handicap, 1 mile, at Monmouth, in which he conceded Eurus and Badge 9 lbs. each and won in 1.40; Rancho-del-Paso Handicap, $1 \frac{1}{16}$ miles, 115 lbs., in 1.46 $\frac{1}{2}$, which was the best on record to that date; the Harvest Handicap, $1 \frac{1}{4}$ miles, $1251 \mathrm{los}$., in 2.07 , an excellent race). Imp. Toucques, his dam, won the Filly Sapling Stakes, and was by Monarque (wimner of the French Derby and sire of Glartiateur, wimner of the 2,000 Gnineas, Derbs, St. Leger, Grand Prize of Paris and Ascot Gold Cup, the only horse that ever won all these events'. Toucques is the dam also of the Tarbonche, Turk and the great filly La Tosea. His grandam, La Toneqnes (winner of the Freuch Oaks, French Derby aud Prix Royal Oak, 1 mile 7 furlongs) by The Baron, sou of Birdeatcher and sire of the great Stockwell. Great grandam, Tapestry, own sister to Volante, dam of the good horse Thunder (winner of the Epsom Cnp, Craven Stakes, Good woor and Alexaadra Plate) by Melbourne, sire of West Australian (wimner of the 2,000 Gnineas, Derby and St. Leger), Blink Bonny (wimer of the Oaks aud Derby) and dam of Blair Athol (wimuer of the Derby and St. Leger), ont of Stitch, half sister to Lady Evelyn (winner of the Oaks) by Hornsea, she ont of Indnstry (winner of the Oaks) by imp. Priam. Threo is handsomely atul fushionalıly bred from a grand racing and prodncing family on both paternal and materual sides.

Turce traces through the best racing blood to the linrton Barb mare, from which descend in direct female line Whiskey, Selin, Rubens, Castrel, Catton, Whitelock. Blacklock, Sir Herenles, imp. Margrave, Harkaway, Voltigeur, Surplice, St. Albans, Lord Clifden, Mask, Pell Nell, Brag, Sheen, Gold, inp. Hurral, imp. Ainderbr, imp. Billet, imp. Eagle and spreat Eagle, Waverly (by iup. Australian), ete. 


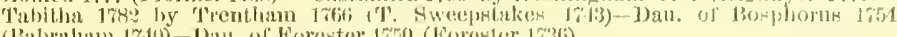

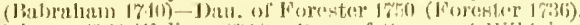

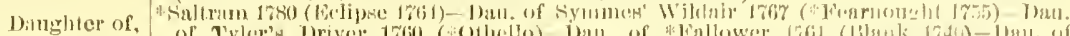

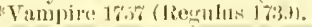

\section{li:1l's}

Norizel,

ch. I., Isit.

1) multerer of

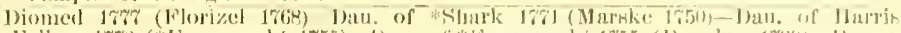

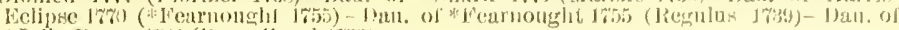
"Jolly lioger 17.11 (Romitllhead rigis).

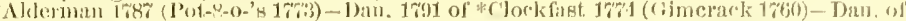

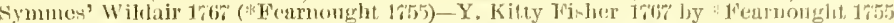

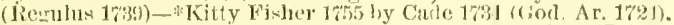

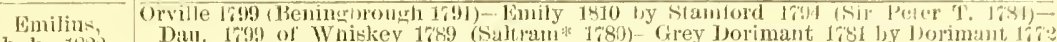

Gmilins,

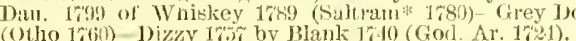

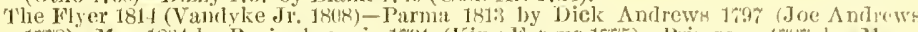
Tca! ia,

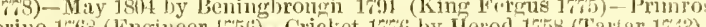

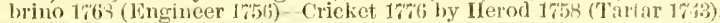

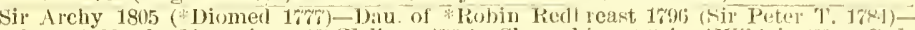

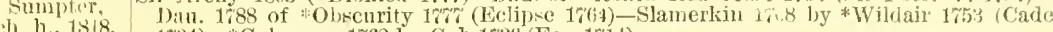
ch. h, 1818. 1\%34)- Cub mare 1762 by Cub 1\%39) (Fox 1714)

Lady Groy Robin Grey 1805 (* Royalist 1790)-Maria 1802 by Melzar 1791 (*Mecley 17\%(6)- 1)an. of b. $13,181 \%$

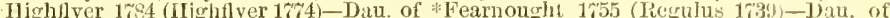
Ariel 1753 (*Traveller $1 \% 4 \%$ ).

Partisan Walton 1794 (Sir Peter T. 1784)-Parasol 1800 by Pot-8-0-'s 1773(Eclipse 17(j4) Prunella b. h, 1811.

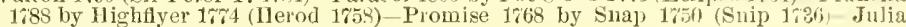
1756 by Blank 1740 (God. Ar. 1724

Smolensko 1810 (Sorcerer 1796)-Jerboa 1803 by Gohanna 1790 (Mercury 1\%'8)-Camilla Frwn, br. m., 1823. 1768 by Trentham 1666 (T. Sweep

\section{Slane,}

b. h., $10,3$.

\section{Royal Oak 18:3 (Catton 1809)-Dau.} (Eclipse 1764) - Lardella $\mathbf{1 7 8 0}$ by Y. Marslie $17 \% 1$ (Mar-ke 1750 )

Octavian 1807 (Stripling 1795)-Dan. 1866 of Shuttle 1\%98 (Y. Marke 17\%1) Katharine br. m., $18 \div 3$. 1774 of Le Sang 1759 (Changeling 1747 )

Enirus, Lancar 181\% (Selim 1802)-Olympia 1815 by Sir Oliver 1800 (Sir Peter T. 1784)-Scotilla Enirus,

1795 by Anvil 1777 (IIcrod 1758)-Scota 1783 by Eclipse 1\%64 (Marske 1750 )-Harmony $17 \% 5$ by Herod 1758 (Tartar 1743)

Foltress,

Defence $182 t$ (Whalebone 180\%)-Jewess 1827 by Moses 1819 ([Whalebone or] Sermonr 1807)-Calendulæ 1815 by Camerton 1808 (Hambletonian 1792)-Snowdrop is06 by Highland Fling 1798 (Spadille 1784)-Daisy 1793 by Buzzard* 178\% (Woodpecker 1773).

Suitan, Selim 180 (Buzzard 1787)-Bacchante 1809 by W's Ditto 1800 (Sir Peter T. 1784) Dau.

b. 1791 of Mercury $17 \% 8$ (Eclipse 1764)-Dau. 17\%6 of Herod 1758 (Tartar 1743)--Folly 17,1 by Marske 1700 (Squirt 1732).

Hester,

(Whalebone 1807) - Innimia 1821 by Muley 1810 (Orville 1799)-Sist. 1796 to Petworth by Precipitate* $178 \%$ (Mercnry 1778)-Dau. $178 \%$ of Woodpecker $1 \%$ 'r3 (Herod 1758)-Dau. $1 \%$ of Snap 1750 (Snip 1736).

[Waxy 1790 (Pot-8-0-'s 17\%3)-Penelope 1798 by Trumpator 1782 (Conductor 1767) - PruThaalebone, nella 1788 by Highfiyer 1764 (Herod 1758)-Promise 1768 by Snap 1750 (Snip 1736)br. h., $180 \%$.

Defiance, Julia 1756 by Blank 1740 (God. Ar. 1\% 24 ).

Rubens 1805 (Buzzard* 178\%) - Little Folly 1806 by Highland Fìing 1\%98 (Kpadille 1781)ch. m., 1816. Harriet 1792 by Voluntoer 1780 (Eclipse 1764)-Dau. 1\%85 of Alfred 1\%0 (Natchem 1\%48)-Magnolia $17 \% 1$ hw Marske $1 \% 50$ (Squirt 1732).

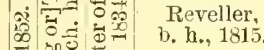

Comus 1809 (Sorcerer 1796) - Rosette 1803 by Beningbrongh 1591 (King Fergus 17 Rosamond 1788 by Tandem $1 \%$ (Syphon 1750)-Tuberose $17 \% 2$ by Herod 1758 (Tartar 1743) - Grey Starling 1745 by Starlicig 1727 (Bay Bolton 1705).

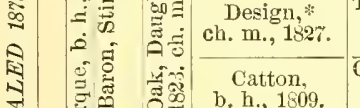

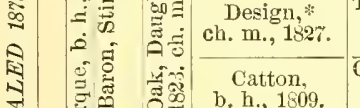

Tramp 1810 (Dick Andrew's 1797)-Defince 1816 by Rubens 1805 (Buzzard\% 178\%)-Little Folly 1806 by Highland Fling 1708 (Spadilie 1\%84)-Harriet 1799 by Volunteer 1780 (Eclipse 1764)-Dan. 1785 of Alfred 1760 (Matchem 1748). Golumpus 18.2 (Gohanna 17.0)-Lucy Gray 1801 by Timothy 1794 (Deipini 1781)-Lucy 1789 by Florigel 1768 (Herod 1758)-Frenzy 17\%4 by Eclipse 1764 (Marske 1750)-Dau. of Engineer 1756 (Sampson 1745) molensko 1810 (Sorcerer 1796)-Lady Mary 1800 by Beningbrough 1791 (King Fergus b. m., 1818 .

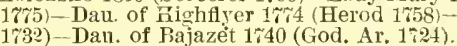

Waxy 1790 (Pot-8-o-'s 1773)-Penelope 1798 by

b. h., 1812 . nella 1788 by Highflyer 1774 (Herod 1758)
Julia 1756 by Blank 1740 (God. Ar. 1724).

Anna Bella, Shuttle 1703 (Y. Marske 1\%1)-Dau. 1797 of Drone 1\%7\% (Herod 1\%58)-Contessina 1\%57 b. m., $180 \%$. by X. Marske 1771 (Marske 1750)-Twherose 17\%2 by Herod 1758 (Tartar 1743)-Grey Starling 1745 by Staring 1727 (Bay Bolton 1705)

Sir Hercnles, blk, h., $18 \% 6$.

Whalebone 1807 (Waxy 1790)-Peri 182: by Wanderer 1811 (Gohanna 1790)-Thalestris 1809 by Alexander 1782 (Eclipse Tot)-Rival 1800 by Sir Peter T. 1781 (Hjgbflyer 1\%74)-Hormet 1790 by Drone $1 \%$ (Herod 175s)

Guiccioli, Bob Booty 1804 (Chanticleer 1787) - light 1809 by Ir. Escape 1802 (Commodcre 1793)-

ch. m. 1823. Y. Heroine by Bagot, 1780 (Herod 1758)-Heroine 17\%5 by Hero 1753 (Cade 1734)-Dau. Y. Heroine by Bagot, 1780 (He
1766 of Snap $17 \mathrm{H}^{\circ}$ (Snip 1736 ).

Whisker 1812 (Wary 1790)-Floran the 1813 by Octavian $180 \%$ (Stripling 1695)-Caprice Economist,
b. h. 1825, 1797 by Anvil 17\% (Herod 1758)-Macicap 1774 by Eclipse 1764 (MalgLe 1\%50)-Sanpho 1763 by Blank 174) (God. Ar. 1721).

Miss Pratt, Blacklock 181+(Whitelock 18C3)-Gadahout 1812 by Orville 1799 (Beninglorongh 1791)

b. M., 1825, Minstrel 1803 by Sir Peter T' 1784 (Highflyer 1764)-Matron 1782 by Florizel 1768 (Herod 1758)-Miaiden 1760 by Matchem 1748 (Cade 1724).

Humprey Comms 1809 (Sorcerer 17C6) - Clinkerina 1812 by Clinker 1S05 (Sir Peter T. 1784 ) - Perret Clinker,

b. h., 182:

1786 by Tandem 1773 (Syphon 1750)-Termagant by Tantrum 1760 (Cripple 1750)Cantatrice by Sampson 174 (Blaze 1733 ). Daughter of, Cervantes 1806 (Don Quixote 1781 )-Dau. 1818 of Golumpus 1802 (Gohanna 1790)-Dan.
b. 1810 of Paynator 1791 (Trumpator 1782)-Circle 1802 by St. George 1789 (Highflyer 1774) - A bigail 1788 by Highflyer 1; 14 (Herod 1753).

Velocipede 1825 (Blacklock 1814)-Dau. 1820 of Cerberus 1802 (Gohanna 1790).-Mis: Cranfield 1803 by Sir Peter T. 1784 (Highfivel 17\%4)-Dau. 1796 of Pegasus 1784

(Eclipse 1764)-Dau. 1783 of Paymaster 1766 (Blank 1740).

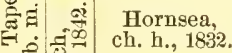

Industry

br. m., 1835 .

Priam*1827 (Ewilius 1820)-Arach ve br. m. 1822 by Filho-da-Puta 1812 (Haphazard 1797)-

Treasure ch. m. 1809 by Camillus 1803 (Hambletouian 1792)-Dan. $\mathrm{ch}$. $\mathrm{m}$, 1804 of Hyacin-

thus 1797 (Coriander 1786)-Flora $\mathrm{ch}$. m. 1789 by King Fergus 175 (Eclipse 1761)-Atalanta ch. m. 1769 by Matehem 1748 (Cade 1734)-Y. Lass-of-the-1Iill b. m. 1756 by Oroonoko
1745 (Crab 1722)-Dau, 1744 of Traveller 1735 (Partner 1718)-1liss Makeless b. m. 1737 by

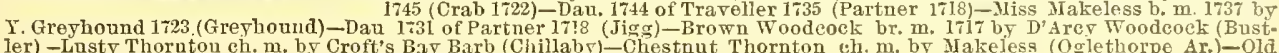

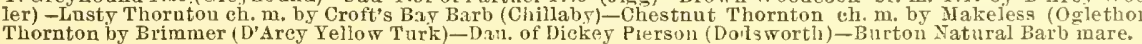




\section{IMPORTED UHLAN.}

WINNER OF TAE ASCOT AND GOODWOOD STAKES, PRIGHTON AND DON. CASTER CUPS AND FOUR QUEEN'S PLATES.

\section{Is prizate stallion in Chesterbrook Stul, Mr. A. J. Cassatt, proprietor, Berwyn, Chester Co., Pa. Tearlings sold annually.}

Uinldx, brown horse, foaled 1869, bred by Mr. Savile, by The Ranger, son of Voltigeu. by Voltaire, dam La Méchante by Turnus, son of Taurus by Phantom, grandam Traviata by The Libel, son of Pantaloon, ont of Fernande by slane, son of Royal Oak. Uhlan's sire, The Ranger, won the Grand Prize of Paris in 1-63. He was a full brother to Skirmisher (wiuner of the Aseot Gold Cup) and by Voltigeur (winner of the Derby and St. Leger), the sire of imp. Billet and grandsire of Galopin. Hence the male line is the most popnlar one at present, both here and in England. The Ranger's dam was the grandam of Cremorne (winner of the Derloy, Grand Prize of Paris and Ascot Gold Cup). La Méchante, his dam, won the Grand Stand Plate at Nottiugham and Handicap Plate, beating Dalesman, Blne Mantle, ete., and Town Plate at Lewes, and was by Turnus, sire of the Oaks winner Buttertly; his grandam Trariata by The Libel, the sire of Tradncer; who got the popular sire and race-horse, imp. Sir Modred, and his brother, imp. Cheviot. Zinc, his fifth dam, won the 1,000 Guineas and Oaks.

Uhlan was a great race-horse. He won the Ascot Stakes, the Goodwood Stakes, Brighton and Doncaster Cups, four Qneen's Plates and many other races. Uhlan stood sixth on the list of winning sires in France for the year 1885, with a credit of sixty-fonr races wou, and $\$ 46,654.90$, a remarkable showing, consideriug he had not been in that country since 1881, and consequently the soungest of his get in France were that season three-year olds. Amongst his principal wimers in France that season were Blond II., a three-year old fill $g$, who won the Prix de Lilas, $1 \frac{1}{2}$ miles, at Paris, also the Prix de la Societe d'Encouragement (handicap), $1 \frac{7}{8}$ miles, when she carried 133 lbs., beating Conlon, three years, 121 lbs., Bourges, three years old, 121 lbs., and three others. She also won the Prix National, 21 miles, with I22 lus. La Nouaille by Uhlan won the Prix de Petit Cercle, $2 \frac{1}{4}$ miles. Sceptique won the Prix de la Ferme, at Montanlan, also the Prix de Biarritz, 18 miles, with 120 lbs., conceding $11 \mathrm{lbs}$. to Bernay, the second horse, and $19 \mathrm{lbs}$. to third. Sceptique also won the Prix de la Ville, at Bordeanx. Sourire by Uhlan won the Prix de Compiegne, at Paris, and wou the Grand Prix de la Ville, 15 miles, at Lyons, beating the famous Relusiant, who had just won the Freuch Derby and the Prix de Chemin de Fer at Deanville. Anatole by Uhlan won the Prix ile Parc, at Vineennes, Prix de Garches, at Paris, and Prix de Bievre, at Vincennes. Don Gigadas by Uhlan won the Prix de Fervacques, $1 \frac{7}{8}$ miles, at Deanville.

Uhlan has had little chance in America, but is the sire of Grateful, Sir Abner, Mount Vernon, Rita, Expense and Tragedieune filly, etc.

He is descended in direct female line from the old scarthoro' mare, to which trace Comus, Slane, Young Melbourne, North Lincoln, Sefton, in England; Planet, Excheequer, and all the Nina fanily. 


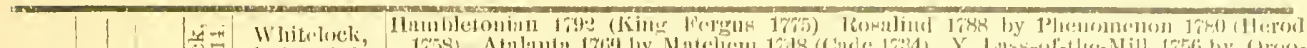

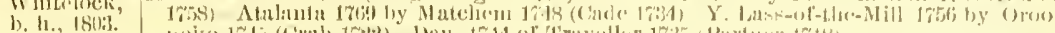

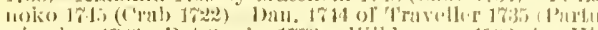

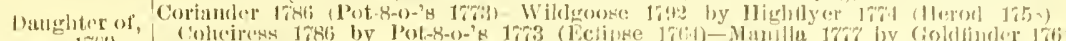

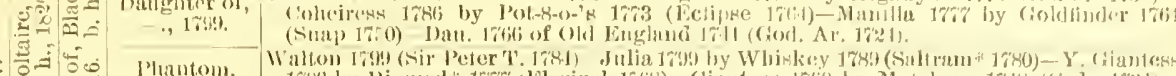

1

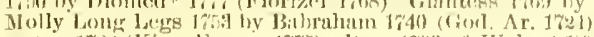

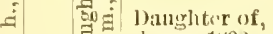

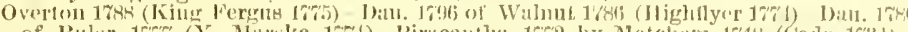

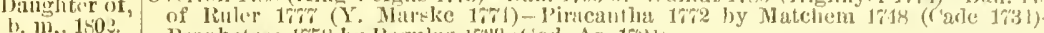

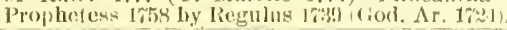

(atitom,

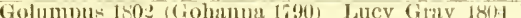

b. h., 1809 .

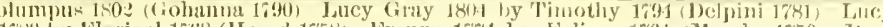

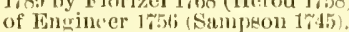

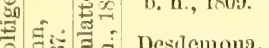

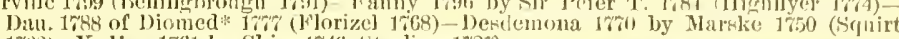

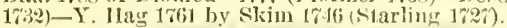

lor. m., 1861 .

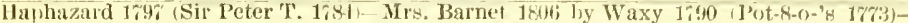

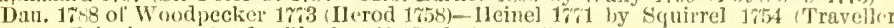
1735)-Principessa $1 \%(62$ by Blank 1740 (God. Ar. 17\%4).

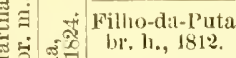

宊 Treasure

Camillus 1803 (Haubletonian 1692) -Dau. 1804 of 11 yacinthus 1797 (Coriander 1786)

cli. m., 1809. Flora 1789 by King Fergus 17\%5 (Eclipse 1764)-Atalanta 126!) l,y Matchem 1748 (Carle 1731)-Y. Lass-of-1he-Nill 175 ti by Oroonoko $1 \% 45$ (Crab 1\%2).

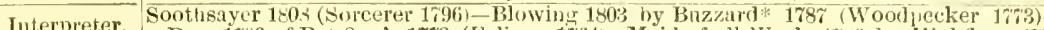

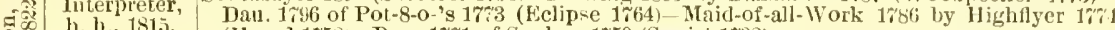

(llerod 1758 )-Dan. $17 \% 1$ of Syplon 1750 (Squijt 1732).

b. h., 1815.

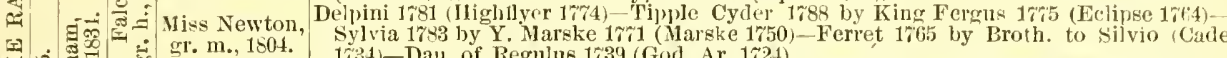

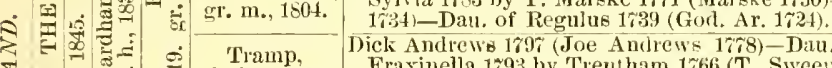

茛

ick Andiews 1797 (Joe Andrews 178)-Diu, 1803 of Gohama 1790 (Nerenry 17\%8)Fraxinella 1793 by 'Trent ham 1766 (T. Sweepstakes 1743)-Dau. 1785 of Woodpecker 17ris (Herod 1758)-Everlasting 17\%5 by Eclipse 1764 (Mar-ke 1750).

Mandane, Pot-8-0-'s 17\%3 (Eclipse 1764)-Y Camilia 17 67 by Woodpecker 17r3 (Herod 1758)-Canilla $17 \% 8$ by Trentham 1766 (T. Sweepstakes 1743 )-Coquette $1 \% 65$ by Compton Barb-

1. m., 1800. Sist. 1743 to Regulus by God. Ar. 1724.

a.

Selim Buzzard* 178 (Woodpecker 17\%3)-Dau of Alexander 1782 (Eclipse 1764)-Dau- of

ch. h., 1802. Highfiyer 1744 (Herod 1,58)-Dau. of Allired 1770 (Matehem 1748)-Dau. $17 \% 0$ of Engi-

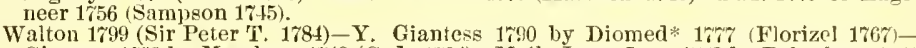

Danghter of, Giantess 1769 by Natchem 1748 (Cade 1734)-Molly Long Legs 1 \%53 by Babraham 1740 (God. Ar. 1\%24)-Dau. of Foxhunter 1\% $2 \%$ (Brisk 1\%11).

clinker

Sir Peter T. 1784 (Higntlyer 1774)-Hyale 1797 by Phenomenon 178( (Herod 1758) Rally 1790 by Trumpator 1782 (Conductor $176 \%$ )-Fancy 1780 (Sist. to Diomed $*$ ) by Florizel

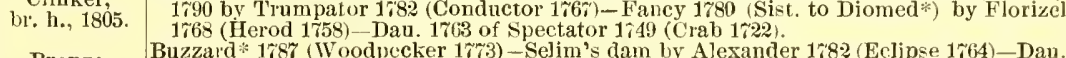

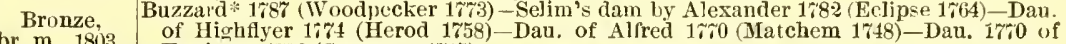
Engineer 1756 (Sampson 1745).

Iuley,

Orville 1799 (Beningbrough 1791) Eleanor 1798 by Whiskey 1789 (Saltram* 1780) - Y Giantess 1790 by Diomed $17 \%$ (Florizel 1768)-Giantess $1 \% 69$ by Matchem 1748 (Cade

b. h., 1810 . 1734)-Molly Long Legs 1753 by Babraham 1740 (God. Ar. 1794).

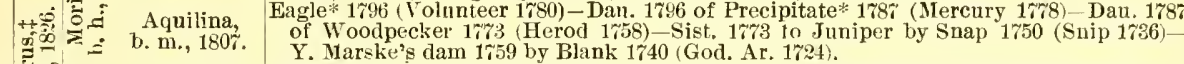

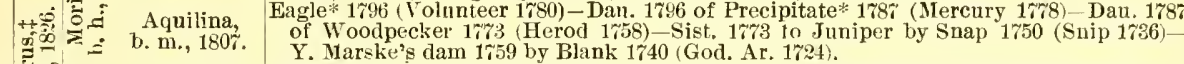
- $\quad 20=$ 点 过

orcerer 1793 (Trumpator 1782)-Golden Locks 1793 by Delpini 1781 (Highflyer 17\%4)Violet 178\% by Shark $17 \% 1$ (Marske 1750)-Dall. 17\% of Syphon 1750 (Squirt 1732)Charlotte 1756 by Blank 1740 (God. Ar. 1724).

Quadrille, Selim 1802 (Buzzard* 1787)-Canary Bird 1806 by [Whiskey or] Sorcerer 17\%6 (Trum-

b. m., 1815 .

pator 1789) Canury 1797 by Coriander 1786 (Pot-8-o-'s 1\%73)-Miss Green 178\% by Highflyer $177_{4}$ (IIerod 1758)-Harriet 1769 by Matchem 1748 (Cade 1734).

Whalebone, Waxy 1790 (Pot-s-o-'s 1773)-Penelope 1798 by Trumpator 1782 (Condnctor 1767)-Pru-

br. h. 180\% nella 1788 by Highflyer 17\%4 (Herod 1i58)-Promise 1768 by Snap 1750 (Snip 1736)Julia 1756 by Blank 1740 (God. Ar. 1724).

Rubens 1805 (Buzzard* 1787)-Little Folly 1806 by Highland Fling 1798 (Spadille 1784)-

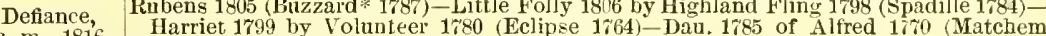
1748)-Magnolia 1 \% 1 by Marske 1750 (Squirt 1732).

Haphazard 1797 (Sir Peter T. 1784)-Mrs. Barnet 1806 by Waxy 1790 (Pot-8-o-'s 1773)-

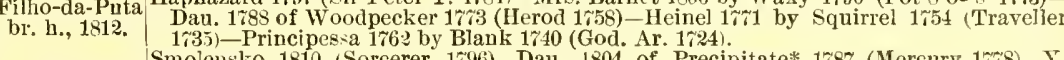

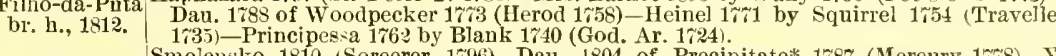

Clari, Smolensko 1810 (Sorcerer 174 (Herod 1758)-Juno 1764 by Spectator 1749 (Crab 1722)Horatia 1758 by Blank $1 \% 40$ (God. Ar. 1\%21).

Castrel, Buzzard* 1787 (Woodpeeker 17\%3)-Dau. of Alexander 1782 (Eclipse 1764)-Dau. of

Ch. h., 1801. Highflyer 1774 (Herod 1758)-Dan. of Alfred 1770 (Matchem 1748)-Dau. 17\%0 of Engineer 1756 (Sampson 1745)

$\S \underset{-1}{2}$ ch. h., 1801

Pernvian 1806 (Sir Peter T. 1784)_Musidora 1804 by Meteor 1783 (Eclipse 1764)-Maid-

Idalia, $\quad$ of-all-Work 1786 by Hightlyer 1774 (Herod 1758)-Dan. 17it of Syphon 1750 (Squirt 1732)-Dau. Ol' Regulus 1739 (God. Ar. 1724).

Whalebone 1807 (IIaxy 1790)-Dau. 1812 of Selim 1802 (Buzzard* 178\%)-Maiden 1801

Camel,
br, h. 1822. by Sir Peter T. 1781 (Highflyer 1\%'4)-Dan. 1788 of Phenomenon 1780 (Herod 1758)Matron 1782 by Florizel 1768 (Herod 1758 ).

Banter Master Henry 1815 (Orville 1799)-Boadice:1 $180 \%$ by Alexander 1782 (Eclipse 1764)-

Biunette by Amaranthus 1765 (Old England 1741)-Mayfly 17\%1 by Matchem 1748 (Cade 1734)-Dat. 1755 of Slarling 1738 (Starling 1727).

Royal Oak, Catton 1809 (Golumpns 1802)-Dan. 1818 of Smolensko 1810 (Sorcerer 1796)-Lady Mary 1800 by Bist to Miss Bell by Marske 1750 (Squirt 1732)

br. h., 1823

Orville 1799 (Beningbrongh 1791)-Epsom Lass 1803 by Sir Peter T. 1784 (Highflye

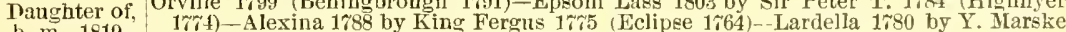
1771 (Marske 1750)-Dau. of Y. Cade $174 \%$ (Cade 1734).

Smolensko 1810 (Sorcerer 1\%96 - Charming Molly 1813 by Rubens 1805 (Buzzard*178\%)-

Shakespeare, Comedy 1804 by Beningbrough 1\%91 (King Fergus 175) - Hrs. Jordan 1784 by Highflyer 1774 (Herod 1759)-Halriet 1769 by Matchem 1748 (Cade 1734).

Zink, Woful 1809 (Waxy 1790)-Zaida blk, m. 1806 by Sir Peter T. 1784 (Hightlyer 17శ4)-

br. m., 1820. Alexina ch. m. 1788 by King Fergus 17\% (Eclipse 1764)-La!della b. m. 1780 by $Y$. Marske $1 \% 1$ ( Marske $1 \% 50$ )-Dan. of $Y$. Cade $1 \% 47$ (Cade 1\%34)-Beaufremont's dam gr. m. by Broth. to Fearnought (Bay Bo!ton 1705) - Niss Wyndham by Wyndbam 1719 (Hautboy) - Dau. of Belgrade Turk-Old Scarboro mare 1715 by Makeless Oglethorpe Ar.)-Dau. of Brimmer (D'Arcy Yellow Turk).

‡ Taurus is by Phantom or Morisco. Norisco's pedigree is aceepted. 


\section{UNCAS.}

WINNER OF THE KENTUCKY STAKES AT SARATOGA AND WESTCHESTER CUP AT JEROHE PARK, N. Y.

\section{A private stallion in the Brookdale Stud, Monmouth County, near Holmdel, X.J.} Estate of D. D. Withers, proprietors.

UxCAs by Lexington, son of Boston, bred in Woodburn Stud, Kentucky, foaled 1876, dam Coral, dam of Wanderer by Vandal, son of Glencoe, ont of Cairn Gorme lyy Cotherstone, winner of the 2,000 Guineas and Derby, son of Touchstone, winner of the St. Leger, Doncaster Cnps in 1835 and 1836, and Ascot Gold Cnps $111 \times 36$ and 1837. Uncas only started three times at two years old; won the Kentucky Stakes at

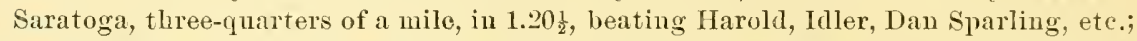
he ran second for the Saratoga Stakes to Harold, and second in the Nursery at Jerome Park to the King Ernest gelding. Uncas was then shipped to England, and in 1079 ran unplaced in the 2,000 Guineas, won by Charibert, he behaved very badly at the post and delayed the start. He was returned to America, and at fon rears old started fifteen times, won five races, was second in six, third in three and un-

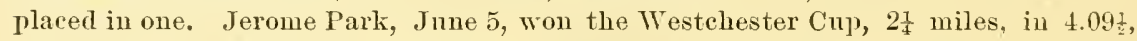
beating Ferida, Monitor and Frauklin, a capital race. Gravesend, June 23, ran secoud

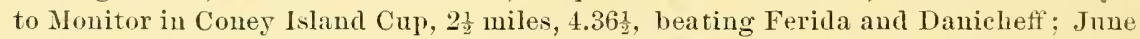
26, ran second to Glenmore in Stirrup Cup, 2 miles and a furlong, in 3.481, beating Jim Beck, an excellent race. Long Brauch, July 5 , ran second to Report (4), 108 lbs., Uncas (4), 11t lbs., in Shrewsbury Handicap, 18 miles, in 3 121, beating Ferida (4), 105 llss., and Danicheff' (5), $100 \mathrm{lbs}$; was third to Report, $115 \mathrm{lbs}$, and Monitor, $120 \mathrm{lhs.}$, Uncas, 121 llos., in Monmouth Cup, $2 \frac{1}{4}$ miles, in 2.34, the fastest race ever rum

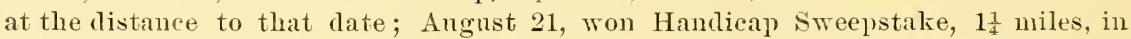

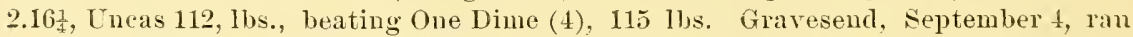

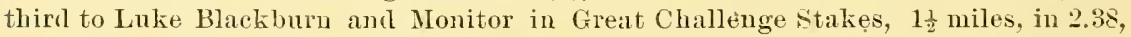
heating One Dime; September 7, ran sec sud to Glenmore (5), 107 llos., Uncas, 107 hhs., $1 \frac{1}{2}$ miles, in 3.07, beating Nonitor, 109 llss., etc.; September 14, was beaten by Lulie

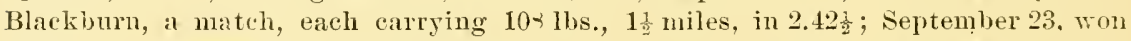

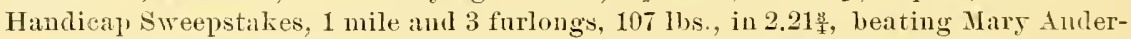
son (3), $781 \mathrm{hs} .$, and Checkmate (5), $114 \mathrm{lhs}$. This is the fastest and best race ever rum at the ristance to that date. Jerome Park, October 7, won Grand National Handicap, $2 \frac{1}{ \pm}$ miles, earrying 113 lbs., in $4.05 \frac{1}{2}$, beating Monitor, 116 lbs., Ferida, 114 lbs., and Franklin (5), 102 lbs. Baltimore, Oetoler 20, was beaten by Monitor in Pimlico Stakes, 2 miles and a furlong, in $3.4 \frac{1}{2}$, the fastest race ever rum at the distance. Jerome Park, Noveluber 2, won Handicap Śweepstakes, $1 \frac{3}{x}$ miles, in $3.16 \frac{1}{2}$, $119 \mathrm{lbs}$, beating Harlequin (4), 89 llss, and Krmpp Gun (5), $100 \mathrm{lbs}$. At five years old. started five times, won no race. Uncas, for his chances, is a snceess in the stud, is the sire of the wimners Dunboyne, Laggard (a first-class race-horse), Nat Goorlwiu, Caseade, Matawan, Chieftain, Sureerer, Snrplns, Bel Demonio, McCarthy, St. Michiel, Copyright, Pactolus and others. Uncas is a bloor bas, stands $15 \frac{1}{2}$ hands high, with his right fore-foot white, and a small star in his forehead. He is quite a compact, well aud evenly-formed lorse all orer, having a neat head and neck, with good shonlders and depth of girth, with extra good body, hips, stifles, and excellent legs and feet. The perligree is one of the hest in the Stud book, and from a distinguished racing family. His dam is by Glencoe's best son, and he traces back through an own sister to Glencoe to a natural Barl, mare. If the blood of Lexington and Glencoe is to be preserved to the conntry, it is through just such pure channels as Uncas presents.

Uneas traces in lirect fonale line to the nittinal Bar's mare of Mr. Tregonwell, to. which trares Woodpecker (by Herod), Waxy Pope, Whalehone, Whisker, Partisan. imp. Glencoe, Bay Midlleton, Melbourne, Benl'or, Bobert the Deril, imp. Mortemer, Nutbourne, speenlum and all the Pmuella family. 


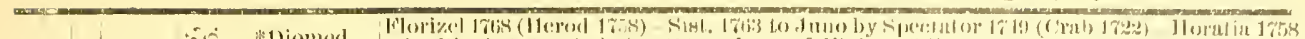

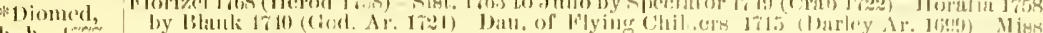

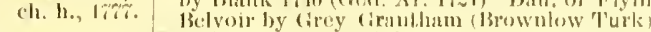

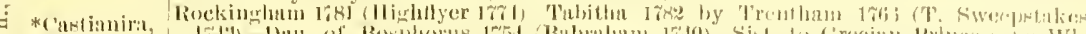

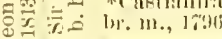

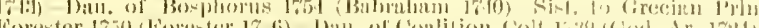

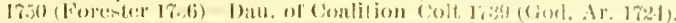

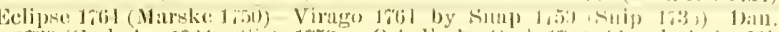

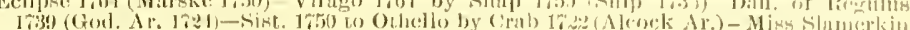

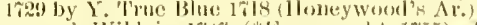

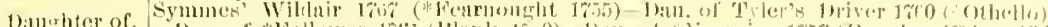

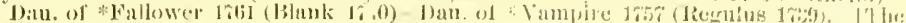
Saltram mare wats dan ol Jenny Cockincy].

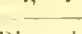

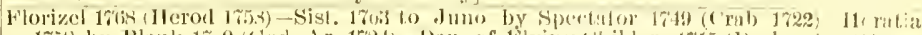

Diomed,

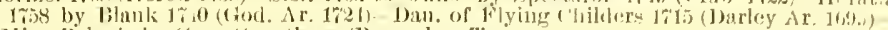
Mlis. Belvoir by Gey Grantham (Brownlow' 'l'urk),

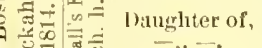

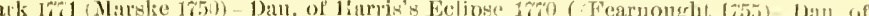

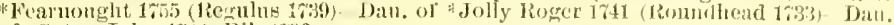
of "Sober John 17its (Rib 1736.

Alderman,

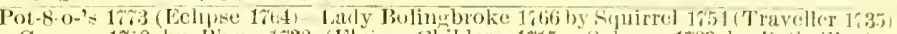

b. $178 \%$

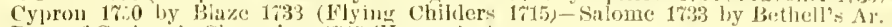

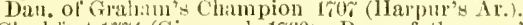

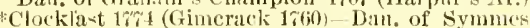

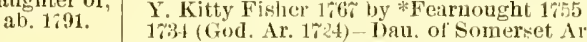

Orville,

b. h., $17: 19$

Beningbrouch 1.91 (King Ferous 1775)-Evel

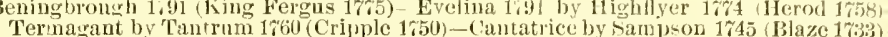
Dan. $175 \%$ of Reoulus 173) (God. Al. 1\%or).

Emily, ch. m., 1810.

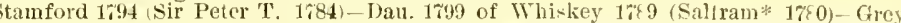

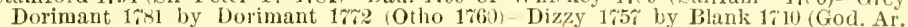
1724) - Anc. Dizzy 1641 by Driver 1727 (Wynn $\mathrm{Ar}$.

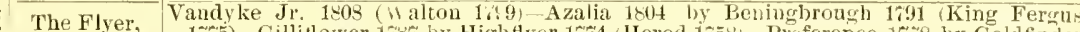
The Fyer, 1\%5) Gillillower $176 \%$ by Hightlyer $17 \% 4$ (Herod 1558 -Preference 1\%:8 by Goldfinder

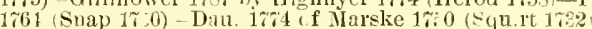

Dick Andrews $16 \%$ (Joe Andrews 17\%8) - May 180+1 y Foningbrongh 1791 (King Ferous

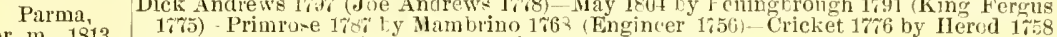
(Tartar 1743 ) Sophia lift by Blank 1740 (God. Ar. 1724).

br. m., 1813.

Sir Archy

Diomed 1\% (Ftorizel 1.68) - Castianira 1766 by Rockingham 1781 (Highflyel 1764)'Tubitha 178: by Trentham 1766 (T. Sweepstaker 17t3)-Dau. of Bosphoru-1754 (Babraham 17-0)-Dau. of Forester 175) (Forester 1726).

Robin mare,

Robin Redbrea-t 1796 (Sir Pet r T. 1081) Dan 1788 of * Obscurity 1rir (Eclipse 1r64) Slamerlin 1763 by *IVildair 1753 (Cade 1731)- Cub mare 176: by Cub 1739 (Fox 1711)-Dau. 1755 of Second 1732 (Flying Childers 1715).

\#政 Robin Grey.

Royalist 1790 (Saltram*1780)-Belle Maria by Grey Diomed 1786 (*) Merlley 1766) gr. h., 1805 .

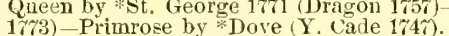

突苟 Ma:ia, nonght 175.5 (Regulus 1739) - Dan. of Ariel 1753 (*Travelled 1745)-Dau. of *Jack of Diamonds (Cullen Ar.)

Selim,

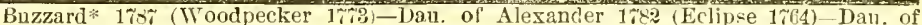

ch. h., 1802 .

Highflyer $1 \% 74$ (Herod 1758)

:

neer 1756 (Sampson 1745).

br. b., $180 \%$

1784)-Dau. 1791 of Mercury $17 \% 8$ (Eclipse 17(4)-Dan. 176 6 of Herod 1758 (T'artar 1743)-Folly $17 \% 1$ by Marske 1750 (Squirt 1732)-Tixen 1753 by Regulns 173) (God. Ar. 1724)

Tramp,

Dick Andrews 1797 (Joe Andrews 17\%8 -Dau. 1803 of Gohanna 1790 (Mercury 168) Fraxinelka 1793 by Trentham 1766 (T. Sweepstakes 1\%43)-Dall. 1785 of Woodpecker 1773 (Herod 1755) - Everlasting 1725 by Eclipse 1764 (Marske 1750).

b. h., 1810

Web,

b. m., 1808 .

\section{Blacklock,} nella 1783 by Hightlyer $17 \% 4$ (Herod 1758)-Promise $1 \% 68$ by Snap 1750 (Snip) 1736)Julia 1756 by Blank 1740 (God. Ar. 1724).

., 1814

Miss Bowe'

Whitelock 1803 (Hambletonian 1792) -Dau. 1799 of Coriander 1786 (Pot-8-o-'s 17\%3) Wildgoose 1792 by Hightlyer $17 \% 4$ (Herod 1758)-Coheiress 1786 by Pot-8-0-'s 1773 (Eclipse 1\%64)-Manilla 1\%7 by Goldfinder 17t4 (Snap 1750)

dam,

Dau 1745 (Blize 1733).

Trumpator,

Sir Solomon 1805 (*Tickle Toby 1\%86) -Dau. of Hickory 1804 (*Whip 1794)—Trumpetta $179 \%$ by Trumpator 1782 (Conductor $176 \%$ ) - Sist. to Lambinos 1786 by Highflyer 17\%4 (Hero 1755)-Dau. 17\%5 of Eclipse 1764 (Marske 1;50\%.

Orphan 1210 (Ball's Florizel 1801)-Lady Grey $181 \%$ by Rooin Grey 1805 (*Royalist 1790 -Maria 1802 by Melzar 1791 (*) Nediey 176)-Dan. of *Highflyer 1781 (Highflyer 1\%it) -Dan. of Fearnought $1 \% 55$ (Regulus $1 \% 39$.

b. Li., 1321 .

Camel,

Whalebone 1s0i (Waxy 1790)-Dan. 1812 of Selim 1802 (Buzzard $\$ 1 \% 8$ ) - Maiden 1801 by

br. b., 182.2. Sir Peter T. 1781 Highfyer 17\%4)-Dan. 1788 of Pbenomenon 1780 (Herod 1758)-Matron 1782 by Florizel 1768 (Flerod 1758!.

Banier,

Master Heury 1815 (Orville 1799) - Boadicea 180\% by Alexander 1789 (Eclipse 1764)-Brunette by Amaranthus 1765 (Old England 1741)-Nayfly 1\%r1 by Matchem 1\%4S (Cade 1734)-Dan. 1755 of Anc. Starling 1738 (Starling 172\%).

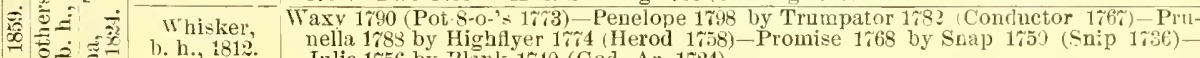
Julia 1756 by Rlank 1740 (God. Ar. 1\%24).

Hermes 1790 (Mercury 1\%8) - Vicissitude 1800 by Pipator 1786 (Imperator 17\%6)-Bea1. h., 1812

至 b. m., 1811 . trice 1791 by Sir Peter $T$. 178: (Highflyer 17\%1)-Pyrrha 1\%71 by Matchem 1\%48 iCade 1734) - Duchess 1748 by Whitenose 1742 (God. Ar. 1724)

Royal Ouk,

Catton 1869 (Golumpus 1802)-Dau. 1818 of Smolensko 1810 (Sorcerer 1796)-Lady Mary 1800 by Beningbrongh 1791 (King Fergns 17\%5)-Dan. of Highflyer 17it (Helod 1758)Sist. to Miss Bell by Marske 1i5u (Squirt 1732).

(3)

Orville 1799 (Beningbrough 1701)-Epsom Lass 1803 by Sir Peter T. 1781 Hightlyer 17\%4)-Alexina 1788 by King Fergus 1775 (Eclipse 1764)-Lardelia 1780 by Y. Markk $17 \% 1$ (Marske 1750)-Dau. of Y. Cade 1\%47 (Cade 1\%34.

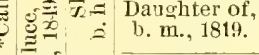

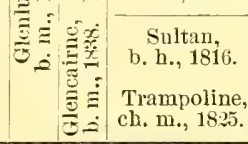

Selim 1802 (Buzzard* 1787) Bacchante 1809 by $1 W^{\prime}$ 's Ditto 180 J (Sir Peter T. 16St)-Dau. 1791 of Mercury $17 \% 8$ (Eclipse 1764)-Dan. 17\%6 of Herod 1758 (Tartar 1\%13)-Folly 1\%1 by Marske 1750 (Squirt 1732).

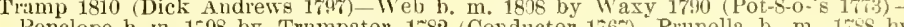

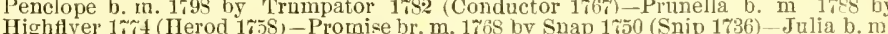
Hightyer 1,4 (Herod 165) - Promise br. m. 1608 by Suap 160 (Snip 1736)-Julia b. n. 1756 by Blank 1740 (God. Ar. 1724)-Spectator's dam. b. m. 1735 by Partner 1718
Bay Bolton 1705 (Grey Hautboy)-Dan. of Darley Ar. 1699-Dau. of Byerly Turk-Dau. (Jigg)-Bonny Lass b. m. 1723 by Bay Bolton 1705 (Grey Hautboy)-Dan. of Darley Ar. I6
of Taffolet Barb-Dall. of Place's White Turk - Natural Barb mare of Mr. Tregonwell's. 


\section{VENTILATOR.}

Is a private stallion in the Broodidale Stud, near Holmdel, N. J., Estate of D. D. Withers, proprietors. Yearling sales annually.

Vextilator by Vandal, best son of Imp. Glencoe. bred by Gen. W. G. Harding, Belle Meade Stud, near Nashrille, Tenn., foaled 1872, dam Carolin, the dam of Bounce, By-the-IVay, Ella, etc., by imp. Seythian, son of Orlando by Touchstone. grandam Rosette, dam of Quartermaster by imp. Yorkshire, out of Picayune, the dam of Doubloon, Florin, Lonis d'Or, etc., by Medoc, son of Ameriean Eelipse. Ventilator made his first appearanee as a two-year old in the Young Ameriea Stakes No. 1, 1 mile, at Nashville, Teun., running second to Katie Pearce in $1.45 \frac{1}{3}$, with Elemi Leona, Bob Woolley and six others behind him. Ran dead heat with Elemi for the Young America Stakes No. 2, 1 mile, in 1.46: Elemi beat him the deciding heat in 1.49: behind him in this were Katie Pearce, Bob Woolley and five others. At three years old was unplaeed in the Clark Stakes at Lonisville, won by his stable companion, Voltigeur. In 1876 and 1877 he was in retirement. In 1878 he came ont in poor hands, ran seeond in one race and unplaced in seven. In 1879 started in twenty-one races, all over timber, won four, was second in three, third in five and unplaeed in the others. He ran $2 \frac{1}{4}$ miles over the Steeplechase Course, 'at Sheepshead Bay, in $4.27 \frac{1}{4}$, and won the second heat in a hurdle race of heats, $1 \frac{1}{4}$ miles, in 2.23. In 1880 started in fourteen races, won seven, was seeond in five, and nnplaced in two. His races were all over timber, and some of them fast ones, beating such horses as Judith, Bertha, Pomeroy, Chimneysweep, etc. During his retirement he eovered three mares, and got Mary Auderson, Bagdad and Ventriloquist, all of them winners in good company. The family is a famons racing one on both sides. On the sire's side belong Lexington, Vandal, Monarehist, Volturno, Rurie, Alaric, Luke Blaekburn, Hindoo, Monitor, The Bard and others of the best horses of the American tnrf. On the sirle of his dam the family is perhaps eqnally famons, such horses as Doubloon, Florin, Louis d'Or, the best horses of their day, as also Quartermaster, Vagrant, Bonnce, Raceland, Madge, Brown Dnke, Red Dick, Bay Dick, Plenipo, Sherrod, ete.

Ventilator, in aldition to those mentioned above, is the sire of the winners Airskaft, Airtight, Airplant, Pnnka, Bass Viol, Mirth, Wizard, Wind Sail, John Fimn, Futurity, Drizzle, Single Stone, Oragense, etc., ete.

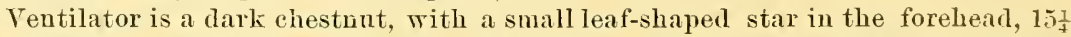
hands high, but very stont, well shaped and muscular. He weighs 1,055 lbs. He has gotten and will get raee-liorses with a fair chanee. 


\section{VOCALIC.}

In the Iroquois Stud, Tumes B. Clay, proprietor, Lexington, Ky. Terms advertised and yearling sales anmully.

Vocalic, black horse, foaled 1881, bred in the Elmendorf Stnd, by Virgil, son of Vandal by imp. Glencoe, dam Acoustic by imp. Australian, son of West Anstralian by Melbourue, grandam Nemesis, dam of Rhadamauthus by imp. Eclipse, ont of Echo by Lexington, ete. Virgil, sire of Vocalic, was a good race-horse and wiuner of many races. He was by the great race-horse Vandal, the best son of imported Glencoe, and whose dam was the Tranbs mare, that also produced Levity, Volga and Vistula. Virgil's dam was Hymeuia by imp. Yorkshire, and she also produced Daisy by Cracker, Alaric, Ansel, Lady Petry and Mollie Wood. Virgil is the sire of the unbeaten Tremont, the great Hindoo (sire of Hanover), Portland, Vigil, Vagrant, Vera Cruz, Virginius, Vanguard, Virgilian, Fairplay, Katrina, Memento, Carley B., Ben Ali, Richmond, Kingfish, Himalaya, etc, etc. His get were potent factors on the turf for many years, and nothing commends Vocalic more highly than that he is a son of Virgil. His dam, Aconstic, is by imp. Australian, son of West Australian and Emilia by Young Emilins, sire of Waverly, Spendthrift, Felloweraft, Maggie B. B., the dam of Iroquois, Farfalletta, dam of Falsetto, Ivy Leaf, Bramble's dam, Madge, Lizzie Lucas, dam of Cerise, Horello's dam, Perhaps, dam of Chance and Reckon, etc. His graudam, Nemesis, is the dam of Rladamanthus, the horse that laid the foundation of the turf fame and fortune of the Dwyer Brothers, by imp. Eelipse, sou of Orlando by Touchstone. Naphtha, the full sister to Nemesis, produced Golden Gate (dam of Oro and Lanra Winstou) and Explosion, the dam of Dew Drop, the best filly of her day, that sold at anction for $\$ 29,000$ and wou upwards of $\$ 40,000$ before her nutimely death at three years of age. Maria Innis was the dam of Bulletin, Meteor and Kathleen, the dim of the great racer George Kinney, Kennesaw, John Happy, Kern and other winners. Ann Innis was the dam of Hebron, Jim Barton and La Grande Dnehesse, dam of Aniella, Metella, Talisman, Uberto and Christine, dam of Bomnie Australian, Montana Regent, Julia L. and High Tariff. Yocalic won at Sheepshead Bay, 1 mile, in $1.45 \frac{8}{4}$, at two years old, defeating Dutch Roller, Blast, Rataplan, Ecomomy and other good ones, and a Handicap, $1_{4}^{1}$ miles, at Jerome Park, in 2.17; he was placed second and thirl in several good races.

Although young in the stud, nearly everything by him thus far trained has proved a winner, including Bellevue, Jay Q. L., the Alice Ward colt, Vortex, Vocalite, Vocalettạ, Blanche's Last, Vocal, etc.

He comes from the same family as Maiden, the best mare of her day, wimmer of the Travers aud other great stakes, dam of James A., Parole, Paw Paw, Pappoose, Perfection, Pawnee and the promising sire Powhattan, Kitty Clark, the dam of Charlotte Buforl (dan of Florence I., the dau of Powhattan III., Florence, Fonso and Florio), Kate Clark, Rosa Clark anı La Henelerson (dam of Ferida, Aella and Ferona). Miss Obstiuate was the dam of Mary Morris and Ann Inuis, from whom Falsetto, Lizzie Lneas, Geo. Kinnes, Rhadamanthns, Eachus, Dew Drop, Morello and many great ones have desceuded. The family is one of the grandest racing and producing ones In the world. 


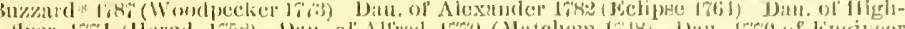
llyer $17,-1$ (lierod 175

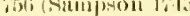

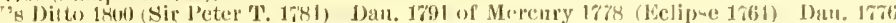

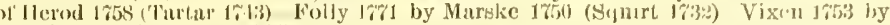
Regulus 173:) ((iod. Ar. 172.1).

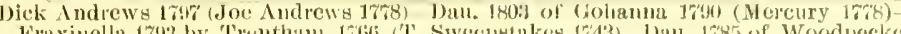

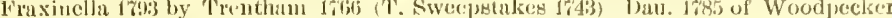

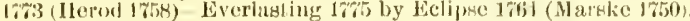

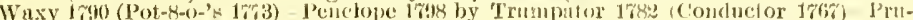

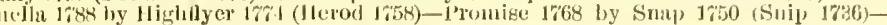
Julia 1750 by $13 l_{\text {ank }} 1640$ ( iod. $\left.\Lambda \mathrm{r}, 1 \% 21\right)$

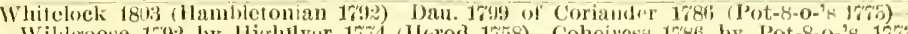

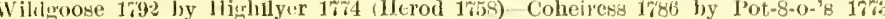

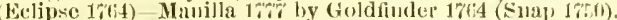

Orville 179.) (Beningbrourh 17\%)1) Miss (irimstom: 17!f by Weazle 1raf; (Herod 1758)

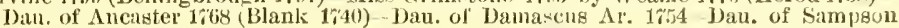

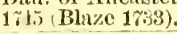

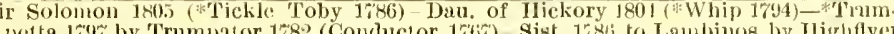
1.1 (Herod 154) pist. 1786

Orjhan 1810 (Ball's F'lorizel 1801)-Lady Grey $181 \%$ by Robin Grey 1805 (*Royalist

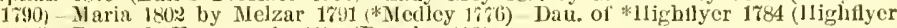
17\%4)-Dan. of Fearnought 1755 (Regulus 1739).

Orville 1799 (Beningbrough 1791)-Emily 1810 by Stanford 179. (Sir Peter T. 178f)Dau. 1799 of Whiskey 1789 ("Saltram 1780) Grey Dorimant 1781 by Dorimant $17 \%$ Otho 1760)-Dizzy 1757 by Blank 1740 (God. Ar. 1724).

Scud 1804 (Beninobrongh 1\%91)-Goosander 1805 by Hambletonian 1792 (King Fergus

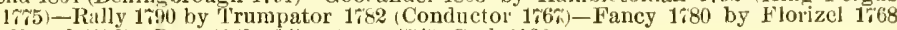
(IIerod 1758)-Dau. 17t3 of Spectator 174!) (Crab 1722).

Dick Andrews 1697 (Joe Andrews 17\%8)-Dau. 1803 of Gohanna 1790 (Mercury 1\%r8)Fraxinella 1793 by Trentham 1766 (T. Sweepstakes 17,3) - Dan. 1785 of Woorlpecker $17 \mathrm{r}^{3}$ (11erod 1758)-Everlasting $17 \% 5$ by Eclipe 1764 (Marske 1750).

Sancho 1801 (Don Quixote 1784) - Blacklock's dam 1299 by Coriander 1786 (Pot-8-0-'s 17i3) Wildgoose 1792 by Highflyer $17 \% 4$ (Herod 1758)-Coheiress 1786 by Pot-8-o-'s $17 \% 3$ (Eclipse 1754) - Manilla 17\%7 by Goldfinder 1764 (Suap 1750 ).

Am. Eclipse 1814 (Dnroc 1806)-Y. Maid of-the-Oaks 1817 by *Expedition 1795 (Pegasus 1784)-Maid-of-the-Oaks 1801 by *Spread Eagle 1792 (Volunteer 1780)-Annetie by * Shark 1;'1 (Marske 1750)-Dau. of Rockiugham (Fartner 1755).

Cook's Whip 1804 (*Whip 1\%94)-Jane Hunt 1796 by Hampton's Paragon 1788 (*Flimnap 1765)-Moll by *Figure 1757 (Figure 174\%)-Slamerkin 1768 by *Wildair 1753 (Cade 1\%34) - "Cub mare 1\%62 by Cub 1739 (Fox 1714).

Whip 1794 (Saltram* 1780)-Speckleback 1290 by Randotph's Celer (Meade's Celer 1744)-Old Speckleback by Meade's Celer 17\%4 (*Janus 1746)-Dau. of *Sober John 1748 (Rib 1736) - Thoronghbred mare of Mr. Wade.

Duke of Bedford (*Berlford 1792) -Dan. 1813 of *Speculator 1795 (Dragon* 1787)-Dau. 1806 of Dare Devil $178 \%$ (Magnet $17 \% 0$ ) - * Trumpetta $179 \%$ by Trumpator 1782 (Conductor 176\%) - Sist. 1786 to Lambinos by Higliflyer $17 \% 4$ (Herod 1758).

Comus 180 2 (Sorcerer 1796)-Clinkerina 1812 by Clinker 1805 (Sir Peter T. 1784)-Pewet 1786 by 'ianlem $17 \% 3$ (Syphon 1750) Termagant by Tantrum 1660 (Cripple 1750)Centatice by Sampson 1\%45 (Blaze 1\%:33).

Cervantes 1806 (Don Quixote 1784)-Dau. 1818 of Golımpns 1802 (Gohanna 1790)-Dau. 1810 of Paynator 1791 (Trumpator 1782)-Circle 1802 by St. George 1789 (Highflyer 17\%4) - Abigail 1788 by Woodpecker $17 \% 3$ (Herod 1758).

Camel 1822 (Whalebone 1807) - Banter 1826 by Master Henry 1815 (Orville 1799)-Boadicea 1807 by Alexander 1782 (Eclinse 1764)-Brunette by Amaranthus 1766 (Old England 1741)-Mayfly 17 - M1 by Matchem 1718 (Cade 1731).

Whisker 1812 (Waxy 1790)-Gibside Fairy 1811 by Hermes $1 \% 90$ (Mercnry 1778)-Vicissitude 1800 by Pipator 1786 (Imperator 17\%6)-Beatrice 1791 by Sir Peter T. 1784 (Highflyer 1;4)-Pyriha 17\%1 by Matchem 1748 (Cade 1734).

Orville 1799 (Beningbrough 1791)-Emily 1810 by Stamford 1794 (Sir Peter T. 1784)Dau. 1799 of Whiskey 1789 (SeItram* 1780)-Grey Dorimant 1781 by Dorimant $17 \%$ (Otho 1760)-Dizzy 1757 by Blauk 1740 (God. Ar. 1\%24).

Scud 1804 (Beningbrongh 1791) -Goosander 1805 by Hambletonian 1\%92 (King Fergus 17\%5) - Rally 1790 by Trumpator 1782 (Conductor $176 \%$ ) - Fancy $1 \% 80$ by Florizel 1768 (Herod 1758) - Sist. 1763 to Juno by Spectator 1749 (Crab 1722)

Waxy 1790 (Pot-8-o-'s 1773)-Penelope 1798 by Trumpator 1782 (Conductor 176\%) - Prunella 1788 by Highflyer 1744 (Herod 1758)-Promise 1768 by Snap 1750 (Snip 1\%36)Julia 1756 by Blank 1740 (God. Ar. 17\%4)

[Selim or] Soothsayer 1808 (Sorcerer 1\%96)-Sprite 180\% by Bobtail 1\%95 (Precipitate 1787 ) - Catherine 1795 by 1 oodpecker $17 \% 3$ (Herod 1r58)-Camilla 17 is by Trentham 1766 (T. Sweepstakes 17 13 )-Coquette 1765 by Compton Barb.

Camel 1822 (Whalebone 1807) - Banter 1826 by Master Henry 1815 (Orville 1799)-Boadicea 1807 by Alexander 1\%82 (Eclipse 1764)-Brunette by Âmaranthus 1\%66 (Old England 1741)-Mayfly 1\%71 by Matchem 1\%48 (Cade 1724)

Langar 1817 (Selim 1802) - Kite 1821 by Bustard 1813 (Castrel 1801)-Olympia 1815 by Sir Oliver 1800 (Sir Peter T. 1784) - Scotilla 1795 by Anvil 1767 (Herod 1758)-Scota 1783 by Eelipse 1764 (Marske 1750)

Sultan 1816 (Selim 1802) - Cobweb 1821 by Phantom 1808 (Walton 1799) Filagree 1815 by Sootlisayer 1808 (Solcerer 1796) - Web 1808 by Waxy 1790 (Pot-8-o-'s 17\%3) - Pene lope 1798 by Trumpator 1782 (Conductor $176^{\circ}$ ).

Godolphin 1318 (Partisan 1811) - Sist. 1820 to Cobweb by Phantom 1808 (Walton 1799)Filagree 1815 by Soothsaver 1808 (Sorcerer 1796) - Web 1808 by Waxy 1790 (Pot-8-0-'s 1773) - Penelope 1798 by Trumpator 1782 (Conductor $176 \%$.

Timoleon 1813 (Sir Archy 1815)-Sist. 1814 to Tuckahoe by Ball's Florizel 1801 (*Diomed 17\%)-Dau. 1799 of *Alderman 1\%87 (Pot-8-o-'s 1\% $1 \%$ )-Dau. of *Clockfast 1\%74 (Gimcrack 1760) - Dau. of Symmes" Wildair 1767 ("Fearnought 17:5

Sarpedon 1828 (Emilins 1820) _ Rowen 1826 by Sumpter 1818 (Sir Archy 1805)_T ady Grey 1817 by Rohin Grey 1805 (*Royalist 1790 )- Maria 1802 by Melzar 1791 (*Medley $1 \%(6)-D a u$. of $*$ Highflyer 1784 (Highflyer $17 \% 4$ ).

St. Nicholas $182 \%$ (Emilius 1820)-Mis Ro Re* 1826 by Tramp 1810 (Dick Andrews 1797)Dan. 1810 of Sancho 1801 (Don Quixote 1744)-Blacklock's dam 1799 by Coriander 1786 (Pot-8-o-'s 1773)-Wildgoose 1792 by Hightlyer 17\%4 (Herod 1758).

Am. Eelipse 1814 (Duroc 1806)-Niss Obstinate br, m. 1829 lo Sumpter 1818 (Sir Arcliy 1805)Jenny slamerkin b. m. 1823 by Tirer 1812 (Cook's Whip 1804)-Paragon b. m. 1807 bv - Buz-
zard 1787 (Woodpecker 173)-Indiana b. m. 1802 by Pintler's Columbus (*Pantaloon 17t8)Jane Hunt b. m. 1796 by Hampton's Paragon 1788 (*Flimnap 1765 )- 15 oll b. m. by * Figure 1757 (Figure 1747)-Slamerkin b. m. 1768 by $*$ W lliair 1753 (Cade 1734)-Cub mare b. m. 1762 hr Cub 1739 (Fox 1714)-Dau. of b. m. 1755 hy Second 1732 (Flying Childers 1715)-Sist. 1746 to Leedes by Starling 1727 (Bay Boltor

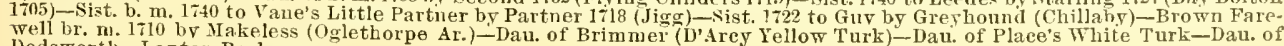
Jodsworth-Lastou Barb mare. 


\title{
VOLANTE.
}

\author{
WINAER OF THE FLASH, AMERICAN DERBY, SEQUEL, WOODLAWY, CO- \\ LUMBIA, EXCELSIOR AND CHAMPION STAKES, AND BROOKLYN \\ CUP, ETC.
}

\section{The property of Nieholas Finzer, Louisville, $K y$. Serviees anmally.}

Volante, bay horse, foaled 1882, bred by E. J. Baldwin, by Grinstead, son of Gilroy by Lexington, dan Sister Anue by imp. Glenelg, son of Citadel by stockwell, out of The Nun, sister to Norfolk by Lexington, son of Boston. Grinstead, the sire of Volante, is from the grand racing family known as the Lerity family. from which have come so many fimons race-horses, potent brood mares and successful stallions. Grinstead was a good race-horse; won the Mansion Honse All-aged Sweepstakes and the Summer Handicap at Saratoga. Volante was a superior race-horse; won two out of four races at two years old, including Flash Stakes at Saratoga, halt a mile, in $0.49 \frac{1}{2}$, with $110 \mathrm{lbs}$., was second in one and third in one. At three years old started eighteen times, won six races, was second in eight and thirc in three. Won the Street Railway Stakes, 13 miles, 118 lbs., in 2.25; won Bankers and Brokers Stakes, $1 \frac{1}{4}$ miles, 132 ibs., in 2.12; won the American Derby, $1 \frac{1}{2}$ miles, 128 Ibs., in

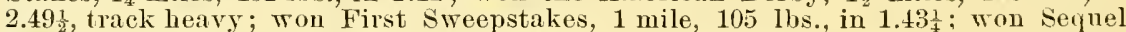
Stakes, $1 \frac{5}{8}$ miles, 123 lbs., in 3.00 ; won Woodlawn Stakes, $1 \frac{1}{2}$ miles, 124 lbs., in 2.41. At fomr years old started twenty times, won ten races, was second in six and third in

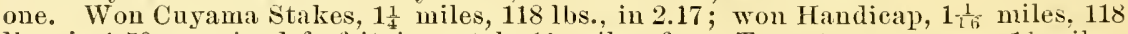
1bs., in 1.50; receiver forfeit in match, $1 \frac{1}{2}$ miles, from Tyrant; won purse, $1 \frac{1}{2}$ miles,

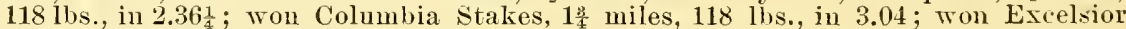

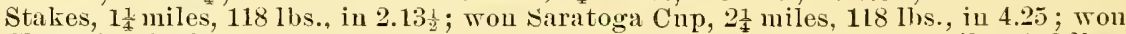
Champion Stakes, $1 \frac{1}{2}$ miles, 118 los., in 2.45; won Free Handicap, $1 \frac{1}{4}$ uniles, 119 lbs.,

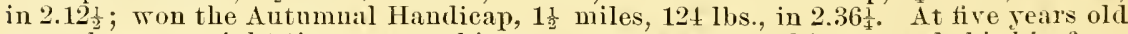
started twenty-eight times, won thirteen races, was second in ten and third in fonr. Won purse, $1 \frac{1}{8}$ miles, $114 \mathrm{lbs}$., in $1.56 \frac{1}{2}$; won Merchants' Stakes at Latonia, $1 \frac{1}{8}$ miles, 122 lbs., in 1.58 wou Ellis Wainwright Stakes, $1 \frac{1}{4}$ miles, 122 lbs., in 2.18; won Colnmbia Stakes, 1 miles, $116 \mathrm{lbs}$., in $3.06 \frac{1}{2}$; won purse, $1 \frac{1}{16}$ miles, $116 \mathrm{lls}$., in $1.51 \frac{1}{2}$; won Beverwyck stakes, 1 mile 500 rards, 120 lbs., in 2.15 ; won Handicap, $1 \frac{5}{\mathrm{~s}}$ miles, 1.201bs.. in 2.50; won First special Stakes, $1 \frac{1}{4}$ miles, $118 \mathrm{lbs}$, in 2.12; won Handicap, 1 mile, 121 lbs.,

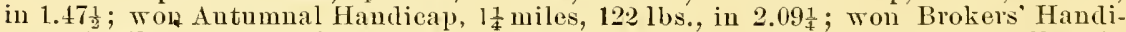
cap, $1 \frac{1}{4}$ miles, 123 lbs., in 2.11; won Brewers' Cup, St. Lonis, 18 miles, 114 lbs., in 3.073. At six years old started eleven times, won two races, was second in four and third in two. Won Handicap, 1 mile, 119 Ibs., in 1.44 miles, 120 lbs., in $2.08 \frac{1}{4}$; his last season. Volante won with high weights, wet the best horses and defeated the best of them. Volante is from a giand racing and producing family. His dam, Sister Anne, is full sister to Clara D. (the dam of Winona, Santa Anna, Santiago) by the great Glenelg. His grandam, The Num, was own sister to the unbeaten Norfolk, winuer of 3 -mile heats in $5.27 \frac{1}{2}, 5.29 \frac{1}{2}$, the best ever ruu, and he one of the most successful stallions. Chloe, Anderson, the thiri dam, was grand in the stud. She produced Nora (the dam of Bombar, Persia, Sorereign Pat and Grimaldi) and Kate Anderson that gave us Adelgiza (dam of Sarah B.), the grand mare Novice (dam of Norfolk, sire of El Rio Res, Emperor of Norfolk, The Czar, etc., and one of Lexington's best sons, The Nun, Notice and Notre Dame) and Sally Anderson (dam of Amanda, Bnford, Carrie Anderson and Florence Anderson). From the above-mentioned grandanghters of Chloe Anderson came the following winners and prodncers, viz.: Avomlale (dam of Ben Edwards, A. O. H. and Go Lncky), Fangh-a-Ballagh, Sister Anne (dam of Estrella, another good one, and Marie stuart, Caliente and San Pueblo's dam), Nota Bene (dam of Vindex, Geo. C. Buruett and Take Notice), Engenia Pickens (dam of Major), Bahama, Gambetta, Susie Linwood (dam of Volta, Red Light's dam), Sangaree (dam of Valne), Roderick Random, Fnll Sail, etc. Belle Anderson, the fonrth dam, produced the famoms Zenith, the best racer of his day. Volante, on his grand qualities as a race-horse, should get racehorses. 


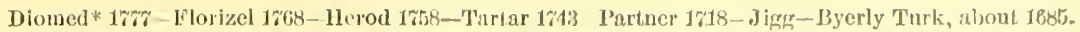

- 1 | |

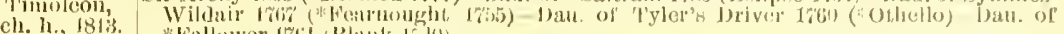

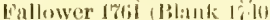

Dillurlitic of ,

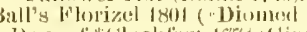

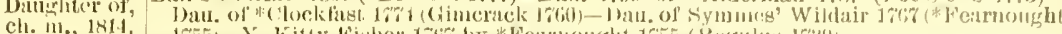

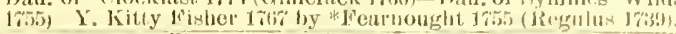

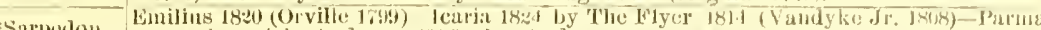

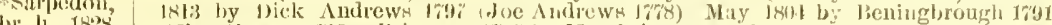
bi. li., 1823 .

Rowema, cli. I11., 182:

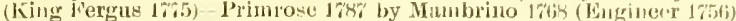

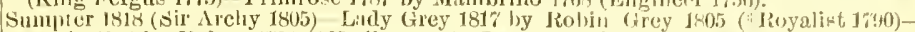

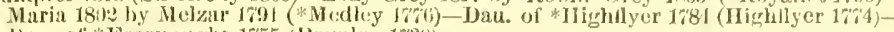
1)au. of "Fearnoughe 1755) (Regulus 173!)

Sultan, b. 11., 1816

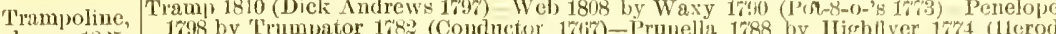

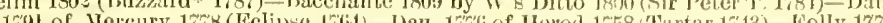
by Murse

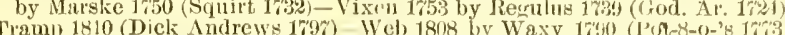
1798 by 'Trumpator 168: (Conductor 16t7)-Prunella 1788 by Jightlyer 1774 (11orod 1758) Promiso 1768 by Suap 1750 (snip 1736j).

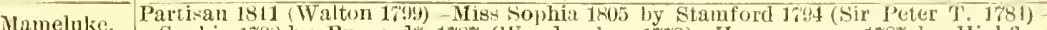
b. 11., 1821 .

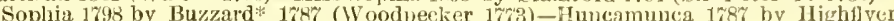
$17 \%$ (Horod 1758) - Cypher 17\%2 by Squirel 1754 (Traveller 1735 )

Bobadilla, Bobadil 1813 (kubens 18(5) - Pythoness 1813 by Sorcerer 1766 ('Trumpator 1782)-Prin br, m., 1825. eess 1795 by sir Peter T. 1781 (Highflyer 1774)-Dau. 1789 by Duugannon 1780 (Eclipse 17t4) Dau. 1783 of Turf $17^{\prime} 60$ (Mutchem 1748).

Beningbrougli 1791 (King Fergus 17\%5) Evelina 1791 by Hirhllyer 1\% 4 (t) crod 1758) b. h., 1799 Termagant by Tautrum 1660 (Cripple 1750) Cantatrice by Sampson 1745 (Blaze 1733) -Dan. 1757 of Regulus 1739 (God. Ar. 1721).

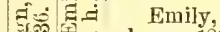

Stamford 1794 (Sir Peter T. 1784)-Dau. 1799 of Whiskey 1789 (Saltram* 1;81)-Grey Dorimant 1781 by Dorimant $17 \%$ (Otho 1\%t0) Dizzy 175\% by Blank 1710 (God. Ar. 1721) - Dizzy 1rit by Driver $172 \%$ (Wynn Ar.)

क्ष

b. h., 1811 .

1796 (Trumpator 1782)-Dau, 15:7 of Precipitate 178\% (Vlereury 17\%s)-Y. Tiffany $178 \%$ by Highflyer $17 \% 4$ (Herod 1758)-Tiffany 17\%5 by Eclipse 1\%64 (Marske 1750)-Y. Hag 1761 by Skim 1746 (Starling 1\%27).

Lady Rachel, Stamford 1794 (Sir Peter T. 1784) Y. Rachel 1699 by Volunteer $1 \% 80$ (Eclipse 1761$)-$

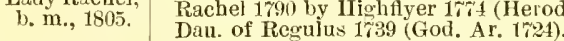

Gaton Golumpus 1802 (Gohanna 1790) - Luey Gray 1804 by Timothy 1794 (Delpini 1781) Ific

b. h., 1809. 1789 by Florizel 1768 (Herod 1758)-Frenzy 17\%4 by Echipse 1764 (Marske 1750)-Dau. of Engineer 1756 (Sampson 1745).

Emma, Whisker 181\% (Wasy 1790)-Gitside Fairy 1811 by IIermes 1799 (Mereury 17\%8)-Vicis situde 1800 by Pipator 1786 (Imperator 1776)-Beatrice 1791 by Sir Peter T. 178

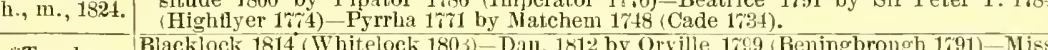

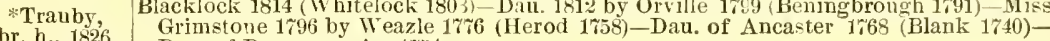
br. h., 1826. Dau. of Damascus Ar. 1\%54.

Lucilla, Trumpator 1823 (Sir Solomon 1805) - Luey 1821 by Orphau 1810 (Ball's Florize] 1801)Lady Grey 1817 by Robin Grey 1805 (*Royalist 1790)
(*Medley $17 \% 6$ - Dau. of *Highflyer 1781 (Highflyer 1774).

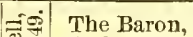

Ir. Birdcatcher 1833 (Sir Hercules 1826)-Echidna 1838 by Economist 1825 (Whisker

The Baron, 1812)-Miss Pratt 18\%5 by Blacklock 1814 (Whitelock 1803) -Gadabout 1812 by Orville 1799 (Beningbrough 1791) - Hinstrel 1803 by Sir Peter T. 1784 (Highflyer 17t).

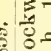

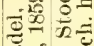

Pocahontas,

Glencoe* 1831 (Sultan 1816)-Marpessa 1830 by Muley 1810 (Orville 1799)-Clare 1824 by

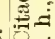

b. m., $183 \%$. Amazon 1 \%99 by Diver 1\%83 (Trentham 1\%66).

Helbourne, Humprey Clinker 18:2 (Comus 1809)-Dau. 18\%5 of cervantes 18 6 (Don Quixote 1781) Dau. 1818 of Golumpus 1802 (Gohanna 1790)-Dau. 1810 of Paynator 1791 (Trumpator 1782)-Circle 1802 by St. George 1789 (Highllyer 1774).

Touchstone 1831 (Camel 18:2)-Ghuznee 1838 by Pantaloon 1824 (Castrel 1801) - Languish 1830 by Cain 1822 (Paulowitz 1813) - Lydia 1822 by Poulton 1805 (Sir Peter T. 1784)Variety 1808 by Hyacinthus 1797 (Coriander 1786).

Escalade

b. m., $18+6$.

Venison.

Partisan 1811 (Walton 1799 )-Fawn 18:3 by Smolensko 1810 (Sorcerer 1796)-Jerboa 1803 by Gohanna 1790 (Mercury 1778) Camilla 1778 by Trentham 1766 (T. Sweepstakes 1743) - Coquette 1765 by Compton Barb.

Slane 1833 (Royal Oak 1823) - Garcia 1823 by Octavian 1807 (Stripling 1795)-Dan. 1806

Queen Anne,
b. m., 184 ?. of Shuttle 1793 (Y. Marske 1\%1)-Kathar

Defence,

Thatebe 180 (

b. b., 1821. Folly 1806 by Highland Fling 1798 (Spadille 1784)-Harr'et 1799 by Volunteer 1780 (Eclipse 1764)-Dau. 1785 of Alfred $17 \% 0$ (Matchem 1748).

Pet,

b. m., 1826 .

Gainsborough 1813 (Rubens 1805)-Dall 1818 of Topsy Turvey 1805 (St. Georo 1 189 ) Agnes 1805 by Shuttle 1793 (Y. Marske 1\%1)-Dau. 1788 of Highflyer 1\%4 (Ferod 1758) - Dau. $17 \% 9$ of Goldfinder 1764 (Snap 1\%50).

Timoleon, Sir Archy 1805 (Di med 17\%\%)-Dau. of *Saltram 1780 (Eclipse 1761) -Dau. of Symmes

ch. h., 1813 WVildair 1767 ("Fearnought 1755)-Dan. of Tyler's Driver 1760 (*Othello)-Dau. of *Fallower $1 \% 61$ (Blank 1\%40).

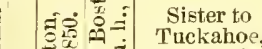

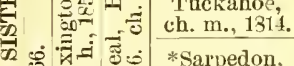

Ball's Florizel 1801 (*Diomed 1 r *Clockfast $1 \% 4$ (Gimerack 17C0)-Dall of Srmmes' Vildair 1"6\% (*Fearnough 1755) - Y. Kitty Fisher 1767 by *Fearnought 1755 (Regulus 1739).

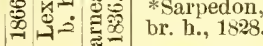
(1) King Ferwus 1\%75) - Primrose 1787 by Mambrino 1768 (Engineer 1,56)

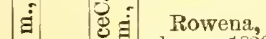

Sumpter 1818 (Sir A rchy 1805)- Lady Grey 1817 by Robin Grey 1805 (royalist 17@0) MIaria 1802 by Melzar 1791 (*Medley $1 \% 76)$-Dau. of *Highfiyer 1\%84 (Highflyer 1\%i4) Dall. of * Fearnought 1755 (Regulus 1739).

Sultan,

b. h., 1816 .

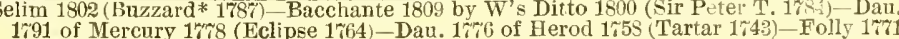
by Marske 1750 (Squirt 1732).

Z Tramp 1810 (Dick Andrews 1707 ) (Conductor $1 \% 6 \%$ )-Prunella $1 \% 88$ by Highflyer $1 \%$ (Herod 1758)-Promise 1768 by Snap 1750 (Snip 1736)

Rodolph, Sir Archv Montorio 1823 (Sir Archy 1805)-Nlelody's dam 1824 by Haxall's MIoses 1816

b. (*Sir Harry 1795)-Dau, of Cook's Whip 1804 ("Thip 1794)-Hart's Maria by Craig' Alfred (*Vedley 1776)-Pryor mare by Tayloe's Bellair 1786 (*1Ledley 1\%66).

Belle

Anderson,

Sir William of Transport 18:0 (Sir Arehy 1805)-Butterfly ch. m. 1825 by Sumpte 1818 (Sir Archy 1805)-Dau. of *Buzzard 1rsi (Wondpecter 1\%73)-Dau. of Dandridge's Fearnonght (*Fearnotight 1755)-Dau. of *Janns 1746 (Janus 1739). [The Dandridge's Fearwonght mare was a good race-mare in Kentucky about 1\%90.] 


\title{
IMPORTED WAGNER.
}

\author{
The property of Messrs. L. B. Field \& Bro., Lexington, Ky. Terms advertised \\ ammally.
}

WAGXER, hay borse, foaled 1\&82, bred by Mr. T. Stevens, by Prince Charlie, son of Blair Athol by Stockwell, dam Duchess of Malfi by Ellaud, son of Rataplan by The Baron, grandaim The Dnchess by St. Albans, son of Stockwell by The Baron, ont of Bay Celia by Orlando, son of Touchstone. Prince Charlie, the sire of Wagner, was one of the speediest horses ever in England, and was called the "Prince of the Twoyear old Conrse." He won the 2,000 Guineas, Midllle Park Plate, Criterion, Fernhill, Drawing Room, Don, Chereley and other good stakes; sire of Prestonpans (winner of the Liverpool Autumn Cnp), Eos, Pride of the Highlands, Reconeiliation, etc., in England; Salvator (winner of the fastest Snbnrban ever run, 2.065 , beat Tenny in the match, $1 \frac{1}{4}$ miles, in 2.05, and ran the fastest mile ever run in the world, $\left.1.35 \frac{1}{2}\right)$, Senorita (winner of the Monmonth Oaks) and other good ones in America. Wagner's dam, Duchess of Malfi, a winner, by Elland (winner of the Beanfort and Liverpool Autumn Cups, Gold Vase at Ascot, Claret Stakes and Queen's Plate). He beat snch good ones as Breadalbane, The Duke, John Davis, Broomielaw, etc. Elland was almost full brother to imp. Ill Used, sire of His Highness, Ill Used being by Breadalbane, sou of Stockwell, and Elland by Rataplan, the owi brother to Stockwell, both ont of Ellermire by Chanticleer, son of Birdcatcher, Ellermire being half sister to the Derby winner Ellington. Grandam The Duchess by St. Albans, winner of the St. Leger aud sire of Springfield (winner of the July Cup and Champion Stakes), ont of Bay Celia, dam of the Duke, winner of the Good wood Cnp and grandsire of Robert the Devil (winner of the St. Leger) and of The Earl (winner of the Grand Prize of Paris), she by Orlando (winner of the Derby), whose daughters are noted in the stnd as the dams of Gang Forward, Camballo and General Peel, winners of the 2.000 Guineas, and of Petrarch (winner of the 2,000 Gnineas and St. Leger). Wagner is thus by a very excellent race-horse and potent sire, and from a racing and prodncing family on the side of his dam. Wagner ran only once in England, won the Wilton Park Stakes, 5 furlongs, 121 lbs., in a field of four others. He is young in the stnd but is the sire of the speedy Mimnehaha, May T., ete.

Wagner is descended in direct female line throngh the old Montagn mare, from the Royal mare, to which traces Conductor, Eclipse (O'Kelly's), Voltaire, Sterling, Weatherbit, Springtield, Scottish Chief, Adrenturer, Prince Charlie, in England ; Lexiugton, Vandal, The Bard, Leonatus, Salvator, Longstreet, Sensation, Onondaga, Stratford, Tenny, Luke Blackburn, and all the Duchess family in America. 


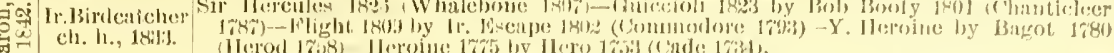

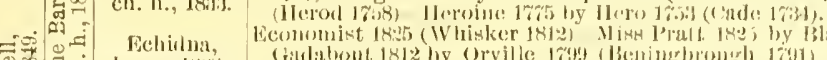

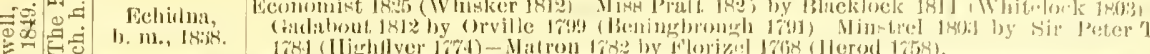

-

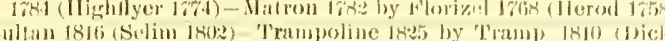

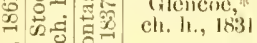

gु Marpessa,

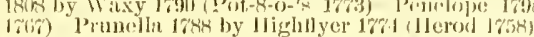

b. II., $18: 30$.

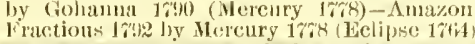

Clinker,

b. 11., 1822.

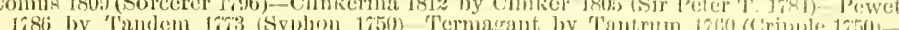

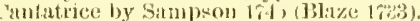
Corviutes 1 of

b. $111 ., 18 * 5$.

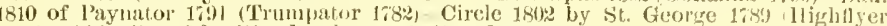

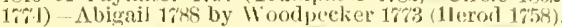

- 콜

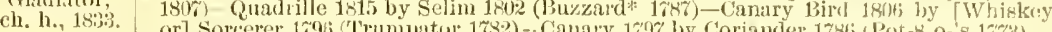

Dangliter of Pleuinoter

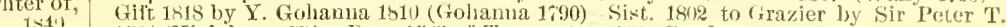

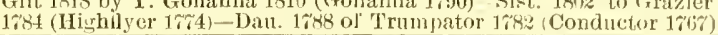

Camel, bl. li., 1822

Whalebone $180 \%$ (Waxy 17.01-Dau. 181\% of Selim 1802 (Buzzard 178\%) Mation $1 \% 8 \%$ by Florizel $1 \%$ (t8 (llerod $1 \% 58$ )

Master 1lenry 1815 (Owille 1799)-Pondicea 180\% by Alczander 168.2 (Eclipse 14f4)Brunette by Amaranthus 1766 (Old England 1\%t1)-Mayfly 17r1 by Matchem 1748 (Cade 1734) Dau. 1755 of Ane. Starling 1738 (Starling 17\%7).

Priam.* Emilins 1820 (Orville 179:3) C Cressida 1807 by Whiskey 1789 (Saltram*1780)-Y. Giantess

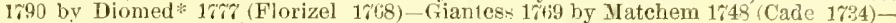
Molly Long Legs 1753 by Babraham 1740.(God. Ar. 1724).

b. h., $183 \%$ oravian $180 \%$ (Stripin $180 \%$ of Shit

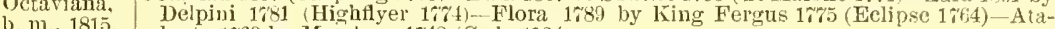
lanta 1769 by Matchem 1748 (Cade 1731).

\section{Slane,}

Royal Oak 18.3 (Catton 1809)-Dau 1819 of Otville 1799 (Beningbrough 1791)-Epsom

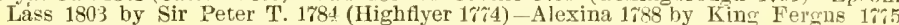
(Eclipse 1764) - Lardella 1780 by Y. Markke 17 il (Marske 1750).

Sultan 1816 (Selim 1802)-Hester 18:2 by Camel 1892 (IVhalehone 180\%)-Jonimia 1891

Palmyra, by Muley 1810 (Orvilie 17y9) - Sist. 1796 to Petworth by Precipitate: 1786 (11ercury 17 ) -Dan. 1787 of Woodpecker 1773 (IIerod 1758).

Glancus, Partisan 1811 (Walton 1799)-Nanine 1823 by Selim 1802 (Buzzard* 1787)-Bizarre 1811 by Peruvian 1806 (Sir Peter T. 1784)-Violante 1802 by John Bull 1789 (Fortitude 17\%( ) Dall, 1783 of Ilighflyer $1 \%$ (Herod 1758).

b. b., 1830 .

Io,

Taurus 18:5 ([Phantom or] Morisco 1819)-Alethissa 1824 by Quiz 1798 (Buzzard: 178\%)-Persepolis 1803 by Alexander 1\%82 (Eclipse 1761) Sist. 1\%84 to \%rickle Toby by

\begin{tabular}{ll} 
ch. m., 1836. & Alfied 1780 (Matchem 1748)-Cælia 1775 by Herod 1758 (Tarlar 1743). \\
\hline
\end{tabular}

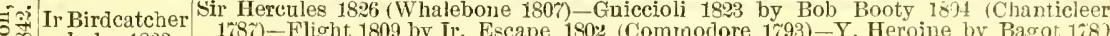

ch. h., 1833. (Herod 1,5s)-Heroine $17 \% 5$ by Hero 1763 (Cade 1731).

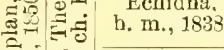
1781 (Highflyer $17 \% 4$ )_Matron 1782 by Florizel 1768 (Herod 1i53)

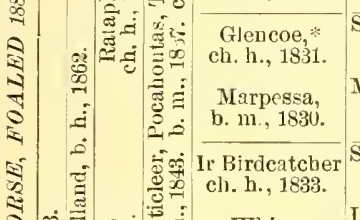
ultau 1816 (Selim 1802) - Trampoline 1825 by Tramp 1810 (Dick Andrews 159\%) - Wel) 1808 by Waxy 1790 (Pot-8-0-'s 17\%3)-Penelope 1798 by Trumpator 1782 (Conductor $176 \%^{\circ}$ )-Prunella 1788 by Highflyer 1 r $^{\prime} 4$ (Herod 1753).

Muley 1810 (Orville 1799)-Clare 1824 by Marmion 1896 (Whiskey 1789)-Harpalice 1814 by Gohanna $1 \% 90$ (Mercury 17\%8)-Amazon $1 \% 99$ by Driver 1783 (Trentham 1766)Fractious 1792 by Mercury $17 \% 8$ (Eclipse 1761).

Sir Hercules 1826 ( 1787)-Flight 1809 by Ir. Escape 1802 (Commodore 1793)-Y. Heroine by Pagot 1780 (Herod 1758)-Heroine 17,5 by Hero 1753 (Cade 1731).

亏 1810 of Champion 1797 (Pot-8-o-'s 1\%'r3)-Brown Fanny 1799 by Maximin 1785 (Evergreen 1769)-Dan. 1782 of Highflyer 17\%t (Helod 1758).

Lanercost,
br. h., 1835.

Liverpool 1828 (Tramp 1810) - Otis by 1820 Bustard 1801 (Buzzard " 178\%) -Gayhurst's dam 1813 by Election 1804 (Gohanna 1790) Sist. 1791 to Skysweeper by Highflyer 17 (Herod 1758)-Dan. 17\%8 of Eclipse 176t (Marske 1750)

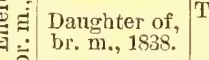
omboy 1829 (Jerry 1821) - Tesane 1830 by Whisker 1812 (Waxy 1790)-Lady of the Tees $18 \% 2$ by Octavian 1807 (Stripling 1795) - Dau. 1810 of Sancho 1801 (Don Qnixote 1784)Miss Furey 1798 by Trumpator 1782 (Conductor $176 \%$ ).

$\equiv$ The Baron,

Ir. Birdcateher 1833 (Sir Hercules 1826 ). Echidna 1838 by Economist $182 j$ (1) hisker 1812)-Miss Pratt 1825 by Blacklock 1814 (Whitelock 1803) -Gadabout 1812 by Orville 1799 (Beningbrough 1791) - Minstrel 1803 by Sir Peter T. 1781 (Highflyer 17\%t).

\section{ch. h., 1842}

Glencoe* 1831 (Sultan 1816) - Marpessa 1830 by Muley : 810 (Orville 1\%99) Clare 1824 by

Pocahontas, Marmion 1806 (Whiskey 1789)-Harpalice 1814 by Gohanna 1790 (Mercury 1\% Amazon 1799 by Driver 1789 (Trentham 1766).

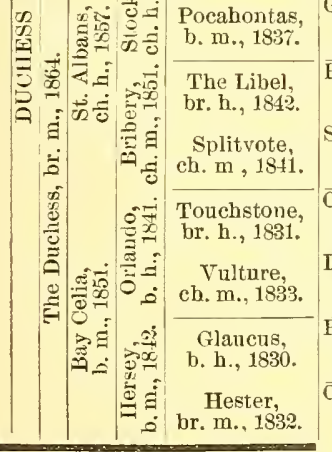

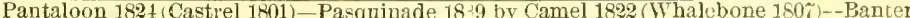
1826 by Master Henry 1815 (Orville 1793)-Boadicea $180 \%$ by Alexander 1782 (Eclipse 1764)-Brunette by Amaranthus 1766 (Old England 1741

St. Luke 1833 (Bedlamite 1823)-Electress 1819 by Election 1804 (Gohanna 1799)-Dau 1805 of Stamford 1794 (Sir Peter T. 1784) - Miss Judy 1781 by Alfred $17 \% 0$ (NIatchem $1 \% 18$ ) - Manilla $17 \%$ by Goldfinder $1 \% 64$ (Snap 1\%50).

Camel 1822 (Whalebone 180\%) - Banter 1806 by Yaster Henry 1815̃ (Orville 1899)—Boadicea 1807 by Alexander 1782 (Eclipse 1764)-Brunette by Amaranthus 1766 (O)

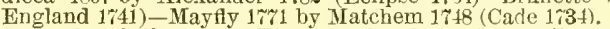

Langar 181 ${ }^{\prime}$ (Selim 1802)-Kite 1821 by Bustard 1813 (Castrel 1801)-Olympia 1815 by Sil Oliver 1800 (Sir Peter T. 1784)-Scotilla 1795 by Anvil 17\% (Herod 1758)-Scota $1 \% 83$ by Eclipse $1 \% 64$ (Marske 1750).

Partisan 1811 (IValton 1799)-Nanine 1823 by Selim 1802 (Buzzard\% 178i)-Bizarre 1811 by Peruvian 1806 (Sir Peter T. 1784/-Violante 1802 by John Bull 1789 (Foltitude 17\%i)Sist. 1788 to Skyscraper by Highflyer $1 \% 74$ (Herod 1\%58).

Came1 1822 (Whalebone 1807)-Monimia b. m. 1821 by Mule, 1810 (Orville 1799)-Sist. ch. m. 1796 to Petworth by Precipitate* 1787 (Mereury 1778)-Dan. b. m. 1787 nf Wondpecker 1773 (Herod 1758)-Sist. h. m. 1773 to Jumiper by Snap 1750 (Snip 1736)-Y. Narske's dam. ch.
m. 1759 by Blank 1740 (God. Ar. 1724) - Bav Starling b. m. ab. 1749 by Bolton Starling 1727 (Bar Bolton ! 705)-Meynell ch. m. 1736 by Partner 1718 (Jigg)-Sist. ch. m. 1723 to Sampson by Grevhonnd (Chillaby) - Sophonisba's dam by Curven Bay Barb-Dau. of D'Arcy Chestnut Arab-Dau. of Thiteshirt - Lord D'Arer's In tagu mare by his Old Hontagu-Dalu. of Hantboy (D'Arcy White Turk)-Dan. of Brimmer (D'Arey Yellow Turk)-A Royal mare. 


\section{WANDERER.}

WINNER OF THE RAILROAD STAKES AT NASHVILLE, 1872, THE MONMOUTH
CUP AT LONG BRANCH, AND WESTCHESTER CUP AT JEROME PARK, 1873.

The property of Dr. J. R. MeKee. Application to Dr.J. R. MeKee, Spring Station, $K y$.

Waxderer by Lexington, son of Boston, bred in the Woodburn Stud, Ky., foaled 1868, dam Coral, dam of I neas and Rambler by Tandal, son of Glencoe, out of imp. Cairngorme by Cotherstone, wimmer of the 2,000 Guineas and 1)erby, son of Touchstone, wiuner of the St. Leger.

Wanderer is descended from one of the most noted racing families of England, tracing back through an own sister to imp. Glencoe to the famous Web by Waxy. The family has furnished some of the most noted race-horses and successful sires of the English turf. From it came Whalebone, winner of the Derby in 1810 , Whisker, winner of the same event in 1815 , Cobweb, winner of the Oaks and 1,000 Guineas in 1824, Riddlesworth, winner of the 2,000 Guineas and Derby in 1836. 'Glencoe, winner of the 2,000 Guineas in 1831, Bay Middleton, winner of the 2,000 Grineas and Goodwood Cup in 1834, Blue Gown. winner of the Derbs in 1868, Silvio, winner of both Derby and st. Leger in 1877, and a host of others.

Wanderer made his first appearance as a three-sear old, and was unplaced in the Belmont Stakes at Jeronie Park and the Jersey Derby at Long Branch, both erents having been won by his half brother, Harry Bassett. At Long Branch he won a Clul,

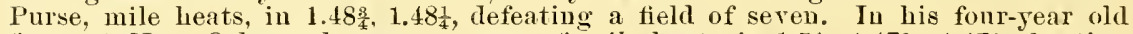
form, at New Orlesns, he won a race of mile heats in $1.51,1.47 \frac{1}{4}, 1.47 \frac{1}{2}$, beating Frank Ross, winner of the first heat, Niagara and Glenrose. IVon the Railroad Stakes at Nishville, Tenn., 2 mile heats, in $3.41 \frac{1}{4}, 3.38 \frac{1}{2}$, beating Hollywood, Frogtown, ete., and walked over for Club Purse, 2 mile heats. As a five-year old he won

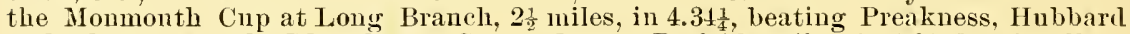
and others; won the Westchester Cup at Jerome Park, $2 \frac{1}{4}$ miles, in 4.04 . beating True Blue, Eolus and others. At Saratoga ran second to Hubbard, 3 miles, in 5.34, beating Harry Bassett and King Henry; same meeting, ran second to Arizona, 11, iniles, in 2.38, beating Boss Tweed and Eolus. As a six-year old won Club Purse at Savannah, Ga., 2 miles, in $3.43 \frac{1}{2}$, beating Granger and four others; and also, same meeting, a Club Purse, $1 \frac{1}{4}$ miles, in 2.18 $\frac{8}{4}$, beating Ortolan and 'Tabitha. Nashville, Tenn., won the Johnson Stakes, $2 \frac{1}{4}$ miles, in 4.06 ? benting Planchette, St. George and two others. At Jerome Park ran second to Shylock, son of Lexington, in the Westchester Cup, $2 \frac{1}{4}$ miles, in 4.13, beating Lizzie Lucas, Abd-el-Koree and two others, track heary. Saratoga, won Club Purse, $2 \frac{1}{4}$ miles, in $4.00 \frac{1}{2}$, beating Felloweraft, Jack Frost, Galway and Katie Pease; same place, ran second to Fellowcratt, 4 miles, in $7.19 \frac{1}{2}$, the fistest race at the distance ever run in a contested race. In this race Wanderer beat Katio Pease and was timed the distance in 7.20 .

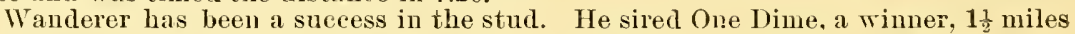

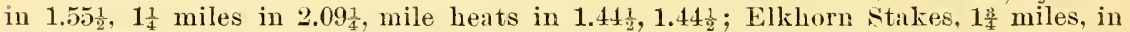
3.05․ Minnie C. (Mrs. Chubls), wimner of the Filly Stakes at Lexington. Juanita, $1 \frac{3}{4}$ miles in 2.10. Lizzy S., Filly Stakes at Lexington, half-mile, in 0.49 ; Coquette Stakes at St. Louis, three-qnarters of a mile, in $1.18 \frac{1}{2}$; 5 tiurlongs in 1.02 ; threequarters of a mile in 1.16. 1 mile in 1.43. Mary Lamphier. Farragit, Nomad, Wake. tield, Cash Clay, Waterford, Prophet, Rambler, Wandering, wimner 1 mile in $1.45 \frac{3}{4}$. and Capital Stakes. 1 mile, in 1.443. Cruiser, J. J. Healey, May Queen, Danville, Lottie Wall, Pearl L., Red Stone, Wanderment. Wanderoo, Warder, Loup, Tourist, Annie Queen and others, all wimners. His colts are the best the dams have produced. He is a rich golden chestnut, with the marks of his sire, is handsomely shaped and of very blood-like appearance, musenlar and highiy finished. His sire was the best race-horse and stallion this country has prodnced; his dam is by the best son of imp. Glencoe, and traces through an own sister to Glencoe and Web by Waxy to a natural Barb mare. This is one of the pure somees through which the blood of Lexington and Glencoe should be preserved. (See Uncas, his brother.) 


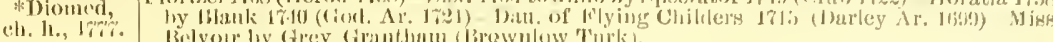

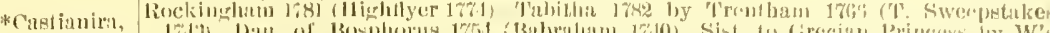

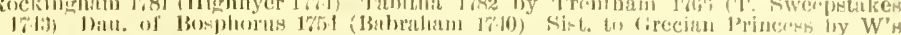

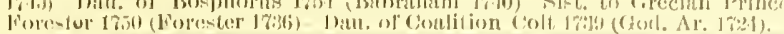

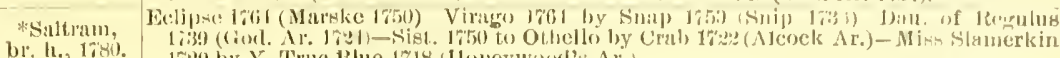
Dilnwhter of

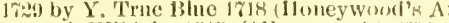

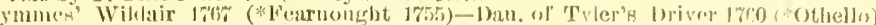

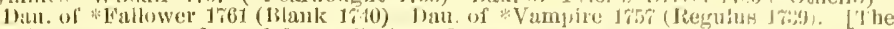
Saltram male was dim of Jenny Cockracy|

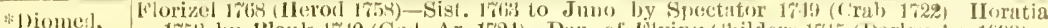

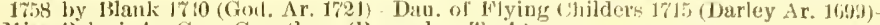
Miss Belvoir hy Grey Grantham (Brownlow 'T'nrk).

ch. h., $1 \%$.

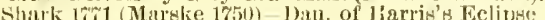

biaugliter" of

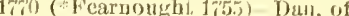

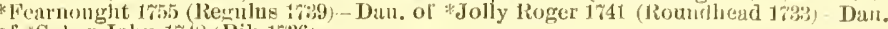
of "Sober John 1\%t8 (Rib 1736 ).

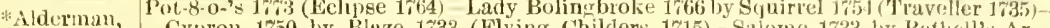
Cypron 1750 by Blaze 1733 (Flying Childers 1715)-Silome 1733 by Bethell's Ar. Datr, of Grah!n's Champion 1607 (11arpmr's Ar.).

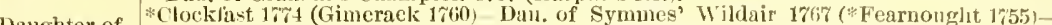

Y. Kitty Fisher 1766 by Fearnought 1755 (Regulus 1739) - * Kitty Fisher 1755) by Cade 1731 (God. Ar. 1724)-1 ball, ol Somerset Ar.

Orvilte Beniugbrongh 1791 (King Fergus 17\%5) - Evelina 1791 by Highflyer 17/1 (Herorl 1758)-

Termagant by Tantrum 1760 (Crip)le 1750)-Cantatrice by Sampson 1745 (Blaze 1733) Diu. $175 ;$ of Regulus 173: (God. Ar. 1724).

Stawford $1 \% 94$ (Sir Peter T. 1784)-Dau. 1799 of Whiskey 1789 (Saltram* 1700) Grey ch. m. $1810 . \quad$ Dorimant 1\%81 by Dorimant $177 \%$ (Otho 1760)-Dizzy 1757 by Blauk 174) (God. Ar 1724) - Ane. Dizzy 1741 by Driver 1727 (Wynn Ar.)

The Flyer, Vandyke Jr. 1808 (Walton 17,9)-Azalia 1804 by Beningbrough 1791 (King Ferons The Flyer, 175) Gilliflower 1787 by Highflyer 17\%4 (Herod 1758)-Preference $17 \% 8$ by Goldfincler $1 \% 64$ (Suap 1750)-Dau. 17r4 of Marske 1750 (Squirt 1732 ).

Dick Andrews 1797 (Joe Andrews 1778) - May 1804 by Peningbrough 1791 (King Ferous br. 11., 1813. 1775)-Primrose $178 \%$ by Mambrino 1768 (Engineer 1756$)$-Cricket $17 \% 6$ by Herod 1758 (Tartar 1 $\tau_{13}$ )-Sophie, 1764 by Blank 1740 (God. Ar. 1725).

$\rightarrow \quad$ Sir Archy, b. h., 1805

Diomed fir (Florizel 1768) - *Castianira 1796 by Rockingham 1781 (Ilighflyer 1774)Tabitha 178 by Trentham 1766 (T. Sweepstakes 1743)-Dau. of Bosphoru 1754 (Babratham 1740)-Dau. of Forester 1750 (Forester 1736).

Robin mare, *Robin Redbreast 1796 (Sir Peter T. 1781) - Dau. 1788 of *Obscurity 177\% (Eclipse 1764) Slamerkin 1768 by *Wildair 1753 (Cade 1734)-*Cub mare 1762 by Cub 1739 (Fox 1711)-Dau. 1755 of Second 1732 (Flying Childers 1715).

ch. m.,

Royali:t 1730 (Saltram*1780)-Belle Maria by Grey Diomed 1786 (*Medley 1776)

Robiu Grey, Queen by *St. George 1771 (Dragon 1757)-Dau. of Cassius 17\%8 (Black-and-all-Black

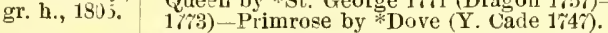

Maria, Melzar 1791 (*) Medley 17\%6)-Dau. of *Highflyer 1784 (Highflyer 1\%4)-Dau. of *Fearnought 1755 (Regulus 1739)-Dau. of Ariel 1756 (*Traveller 174\%)-Dau. of *Jack of Diamonds (Cullen Ar.).

Selim, Buzzard* 1787 (Woodpecker 17\%3)-Dau. of Alexander 1782 (Eelipse 1764)-Dau. of

ch. h., 1802. Hightlyer 1774 (Herod 1758)-Dan. of Alfred 1770 (Matchem 1748)-Dau. 1rro of Engi-

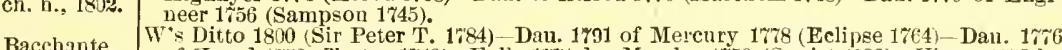
Bacchante,
br. h., 130\}. Regulus 1739 (God. Ar. 1724).

Tramp Dick Andrews 1797 (Joe Andrews 17\%8) Dau. 1803 of Gohanna 1790 (Mejcury 1\%78) Fraxinella 1793 by Trentham 1766 (T. Sweepstakes 1743)-Dau. 1785 of Woodpecker 1773 (Herod 1755)-Everlasting 1775 by Eclipse 1764 (Marske 1750).

b. h., 1810

Web,

b. m., 153s.

Blacklock,

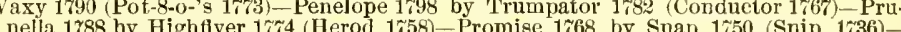
Julia 1756 by Blank 1740 (God. Ar. 1724).

b. b., 1814 .

Whitelock 1803 (Hambletonian 1792)-Dau. 1799 of Coriander 1786 (Pot-8-o-'s 1773) Wildgoose 1792 by Highflyer 1774 (Herod 1758)-Coheiress 1786 by Pot-8-o-'s 1773 (Eelipse 1764)-Manilla Irro by Goldfinder 1764 (Snap 1750).

IIiss Bowe's Orville 1\%99 (Beningbrough 1791) - Miss Grimstone 1796 by Weazle 17t6 (Herod 1758)-

dam, Dau. of Aneaster 1768 (Blank 1740)-Dau. of Damascus Ar. 1751-Dan. of Sampson 1 145 (Blaze 1733).

सी

Solomon 1805 (*Tickle Toby 1786)-Dau. of Hickory 1804 (*Thip 1794- $\div$ Trum-

petta $179 \%$ by Tiumpator 1782 (Conductor 1\%6\%)-Sist. to Lambinos 1786 by Hightlyer petta $179 \%$ by Trumpator 1782 (Conduetor $176 \%$ )-Sist. to I

Lucy Orphan 1810 (Ball's Florizel 1801)-Lady Grey 181' by Robin Grey 1805 (*Royalist 1790)-Maria 1802 by Melzar 1791 (*Medley 17\%6)-Dau. of *Highflyer 1784 (Highflyer 17/4) -Dalu. of *Fearnought 1755 (Regulus 1\%39)

b. m., 1321 .

Camel.

$\begin{array}{ll}\text { br. h., 1822. } & \text { Sir Peter T. } 1784 \text { (Highflyer 17\%4)-Dau. } \\ \text { tron 1782 by Florizel 1768 (Herod 1758). }\end{array}$

Whaleboue 1807 (Waxy 1790)-Dau. 1812 of Selim 1802 (Buzzard $\$ 178 \%$ ) Naiden 1801 by

Banter,

Master Henry 1815 (Orville 1;99)-Boadicea 180\% by Alexander 1\%82 (Eclipse 1\%64)-Brunette by Amaranthus 1\%66 (Old England 1741)--Mayfly 1\%t1 by Matehem 1\%48 (Cade

Whisker, Waxv 1790 (Pot-8-0-'s 1763)-Penelope 1798 by Trumpator 178\% (Condnetor 176\%)-Pru-

b. h. 1810 nella 1789 by Highflyer $17 \% 4$ (Ilerod 1758)-Promise 1768 by Suap 1759 (Snip 1736)Julia 1756 by Blank 1740 (God. Ar. 1724).

ヨ̊ Gibside Fairy, Hermes 1790 (Mercury 1778) - Vicissitude 1800 by Pipator 1786 (1mperator 17\%6)-Beatrice 1791 by Sir Peter 'T, 1781 (Hightlyer 1774)-Pyrrha 1\%71 by Matchem 1748 (Cade 1734) - Duchess 1748 by Whitenose 1742 (God. Ar. 1724)

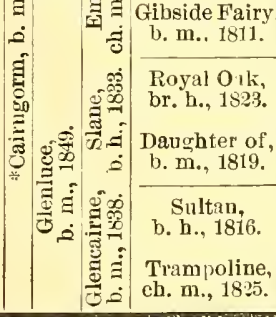
1734 1800 by Beringbrough 1791 (King Fergns 1775)-Dau. of Highflyer $17 \% 4$ (Herod 1\%58)Sist. to Miss Bell by Marske 1750 (Squirt 1732)

Orville 1\%99 (Beningbrough 1\%91)-Epsom Lass 1803 by Sir Peter T. 1\%84 (Highflyer 1774)-Alexina 1788 by King Fergus $17 \% 5$ (Eelipse 1764)-Lardella 1780 by Y. Marske $1 \% 71$ (Markke 1750)-Dau. of Y. Cade 1\%4\% (Cade 1734).

Selim 1802 (Buzzard* 178\%) Bacchante 1809 by W's Ditto 1800 (Sir Peter T. 1781)-Dau. 1791 of Mercury 1778 (Ecipse 1761)-Dau. 1\%76 of Herod 1758 (Tartar 1743)-Folly 17\%1 by Marske 1750 (Squirt 1732)

Trimp 1810 (Dick Andrews 17\%7)-Web b. m. 1808 by Waxy 1790 (Pot-8-o-"8 1773)Penelope b. m. 1798 by Trumpator 1782 (Conductor 1767)-Prnnella b. m 1788 by Highfler 1 14 (Herod 1758 )-Promise br. m. 17 - 8 b Snap 1750 (Snip 1736) - Julia b. m. 1756 by Blank 1740 (God. Ar, 1\%:4)_Spectator's dam, b. m. 1735 by Partner 1718 (Jigg)_Bonny Lass b. m. 1723 by Bay Bolton 1705 (Grey Hautboy)-Dau. of Darley Ar. 1699-Dau. of Byerly Turk-Dau. of Taffolet Barb-Dau. of Place's White Turk-Natnral Barb mare of Mr. Tregonwell's. 


\section{WHISPER.}

WINNER OF NASHVILLE CUP, LOUISVILLE CUP AT LOUISVILLE, KY., AND OTHER GOOD RACES.

In the Fleetwood Stud. Applicution to L. P. Tarlton, proprietor, Flcetwood Stud, Frankfort, $K y$.

Whisper by Planet, son of Rerenne, lired in the Woodburn Stnd, Ky., foaled 1870, dam Mattie Gross, dam of Miate, Grenala, ete., by Lexington, out of Dick Doty's dam by American Eelipse. Whisper did not rum as a two-year old. At three rears old

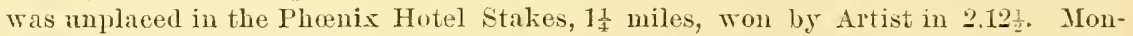

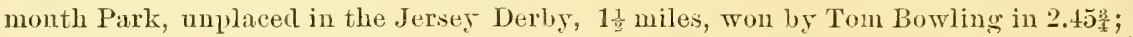
was second in the Jersey Jockey Chnb Purse, mile heats, best three in five, won by Arizona in 1.46, 1.48 $, 1.47 \frac{3}{4}, 1.53 \frac{1}{2}, 1.55$, Whisper won the first two heats ; was third in the Cottagers' Cup, $1 \frac{1}{2}$ miles, won by imp. Stonehenge $1 n 2.41 \frac{1}{2}$; unplaced in a Con-

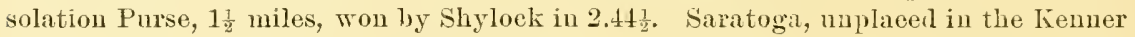
Stakes, 2 miles, won by imp. Ill Used in 2.39. At (4) Jerome Park, walkerl orer for purse of $\$ 700,1 \frac{3}{4}$ miles. Monmouth Park, was second in the Honmonth Cup, $2 \frac{1}{2}$

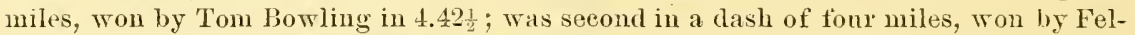
loweraft in 7.43. Jerome Park, was miplaeed in a dash of $1_{\frac{1}{3}}$ miles, won by Grinstead in $2.40 \frac{3}{4}$; was third in a dash of $2 \frac{1}{2}$ miles, won by Aerobat in $4.33 \frac{3}{4}$. Baltimore, dis. tanced first heat of the Bowie Stakes, 4 mile heats, won by Jack Frost in 7.33, 7.41, 8.11, Bessie Lee won the first heat. At (5) Lonisville Ky., unplaced in a dash of 1

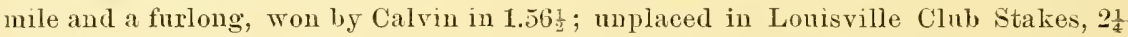
miles, won by Ballnkeel, in $4.01_{\frac{1}{2}}$; won a Handicap mile heats, in $1.52 \frac{3}{4}, 1.53 \frac{3}{4}$. At (6) Lonisville, Ky., was third in a dash of $1 \frac{1}{4}$ miles, won by Brakesman in 2.11; was third in a dash of 2 miles and a furlong, won by Elemi in $3.49 \frac{1}{2}$; was seeond in a race of mile heats, won by Kilburn in $1.45 \frac{1}{2}, 1.44_{\frac{1}{3}}, 1.43_{\frac{1}{4}}$, "Whisper won the first heat. Lexington, Ky., Fall Meeting, was third in a dash of $1 \frac{1}{2}$ miles, won by Phillis in 2.37 $\frac{1}{4}$; won a Selling Race, 1 mile and a furlong, in 1.58. Lonisville, Ky., won a Handicap Sweepstakes, $1 \frac{3}{4}$ miles, in 3.09. Nashville, Tennessee, won dash of $1 \frac{1}{2}$ miles for

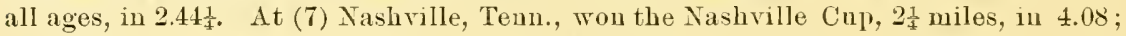
was second in a dash of $1 \frac{1}{2}$ mules, won by MeWhirter in 2.381. Louisville, Ky., won

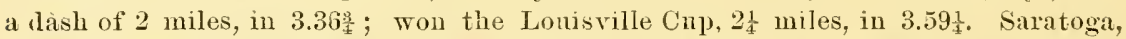
won Handieap for all ages, 1 miles, in 3.12 ; ; was thmd in a dash of 1 mile and a fnrlong, won by Vera Cruz, in 1.57 $\frac{1}{2}$; won a dash of $2 \frac{1}{4}$ miles in 4.02 . Louisrille Fall Heeting, nuplaced in a Handicap, $1 \frac{3}{\text { x miles, won by Longbow in 3.07 }}$; Whisper was third in a dlash of 2 mules, won by Ten Broeck in 3.36. At (8) Lonisville, Kr., was second in the Lonisville Cup, $2 \frac{1}{4}$ miles, won by Mahlstick in $4.07 \frac{1}{3}$; won a Haulicap dash of 4 miles 11 7.36. St. Louis, Mo., won the Blow Stakes, 3 mile heats, 1 5.33, $5.33^{\frac{1}{2}}$. IVhisper is by the best son of Rerenue, Planet, a winner at all clistances over the best horses of his day. Whisper's dam, Mattie Gross, is the dam of Mate and Grenada, and his grandan was the dam of Dick Doty, the fimons four mler, whilst his great grandam was the dam of Elıza Jenkins and the Big Arehy mare, wheh produced the great race-horse Creath, who beat Alice Carneal and won a second heat of 3 miles in 5.43, in 1811. Whisper is a bay, full 16 hands high, with a star and right hind leg white abore the hoof. He is one of the tinest and best shaper horses in Ameriea, and could not only run fast but stay a distanee. In addition to beng a grandson of imp. Trustee, he is much inbred to Sir Archy and Diomed, liaring ten crosses of that most desirable blood. He has also a double cross of Whisker.

Whisper is the sire of the wmmers Clarion, Canto, Clamor and others. 


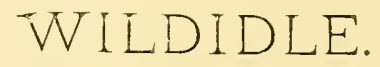

WINAER OF THE NURSERY STAKES, FORDHAM AXD JOCKEY CLUB HANDICAPS AT JEROME PARK.

In the Wildidle Stud, J. C. Sudson, proprietor, Santa Clara, Cal. Terms ammually.

Wibdide by imp. Australian, son of West Australian, bred in the Woodburn Stud, Ky., foaled 1870, dan Idlewild by Lexington, out of Florme by ww. Glencoe. Wildidle made his bow to the public by wmning the Nursery Stakes, 1 wile, at Jerome Park, un 1.48喿, defeating Long Branch, Cateshy and eleven others. He was out of condition and ran unplaced in one race as a three-year old. At four years old was second to Catesly in Matnrity Stakes, 3 miles, 1 5.36, beating Carver and Ransom; was nuplaced in purse, 13: miles, won by Grinstead in 3.10; was second to Acrobat in purse, $2 \frac{1}{2}$ miles, in $4.33 \frac{3}{4}$, beating Whisper, all run at Jerome Park. At fire years old, $10 t$ llus., Jerome Park, won the Fordham Handicap, $1 \frac{1}{4}$ miles, in 2.12, beating Spmdrift, aged, 118 lus., Preakness, aged, 131 lbs., and nine others; won the Jockey Club Handicap, 111 lbs., 2 miles, in 3.38 $\frac{1}{2}$, beating Preakness, 130 lbs., Griustead (4), 110 lbs., and Tubman (aged), 115 lbs. Monmouth Park, was beaten by

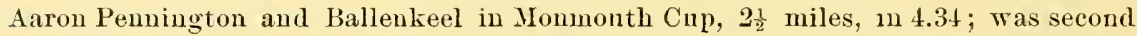
to Rutherford un 4 mile dash, rnn in 7.34 won Clnb Purse, 2 mile heats, $3.40 \frac{8}{4}, 3.47 \frac{1}{4}$, beating Dublin. Saratoga, was nnplaced in Saratoga Cup, $2 \frac{1}{4}$ miles, in $3.56 \frac{1}{4}$, dead heat, and stakes divided between Preakness and springlok: this is the fastest race erer run at thedistance; was second to Rutherford in Club Purse, 3 miles, in 5.38, beating Madge; was second to Grinstead (4), 110 lbs., in the Summer Handicap, 2 miles, in 3.37 $\frac{1}{2}$, Wildidle (5), 114 los., beating Mattie W. (3), 93 lbs.; won the Club Purse, 4 miles, in 7.39, beating Rutherford. San Francisco, Cal., won the Wise Plate, 4 miles, in $7.25 \frac{1}{2}$, beating Grinstead, Sherman and Revenue, Jr. Wildidle comes honestly by his racing qualities. His dam was second to no mare ever raised in America. She ran four miles orer the Centreville Course, L. I., 1863, when tive rears old, with 117 lbs., in $7.26 \frac{1}{4}$, and this was the lest time ever made by a mare nntıl beaten by Ferida, in 1880 , when she ran a first heat in $7.23 \frac{1}{2}$.

Wildidle, for his chances, has been a very snceessful sire. The best of his get are Tille C., May D., Record, Jack Douglass, Ellen Douglass, Belshaw, Jim Dougjas (wimner of ten ont of fourteen races in 1-81), Wildidler, Lottie J., Jack Brady, Carmen, Not Idle, Patti, Laly R., Nellson, Brown Idle, King Idle, Alfaretta, Ella Hill, Fanny S., Flambeau, Gambo, Mnta ,Phılander, Raindrop, Rosemead, Telephone, Wild Oats. Garcia, Rosebud, Rover, Sinfax, Tearless, Folly, Gorget, Nomad, Wild Rose, Edith, Lord of the Harem, Jessie Carr, Nero, Fanny F., Oscar, etc., etc.

Wildidle is inbred to Waxy on the sire's side, and has mnch of the blood of Sir Archy and Diomed, in addition to a cross of Eclipse, throngh his fanous son Medoc, and three crosses of imp. Medles, son of Gumcrack by Crupple, son of the Godolphin Arabian. His family has always been a grand racing and prodncing one. He is brother in blool to Spendthrift, sire of lingston, Lamplighter, etc.. and to Miser, sire of Yorkville Belle, and to Feliowcratit (4 mules in $7.19 \frac{1}{2}$ ). 


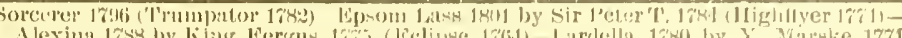
cli. 1., $18(9)$.

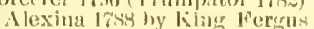

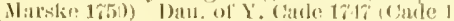

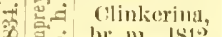

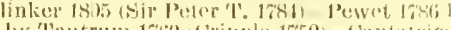

br. m., Is1:. by 'l'autrum 1700 ('ripple 1750)

Cervintex

b. 1., 18:4i,

Damgliter of,

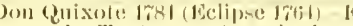

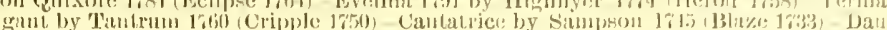

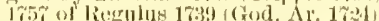

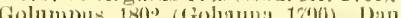

1)1. in., $181 \%$.

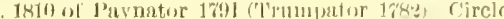

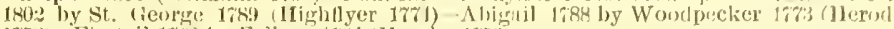

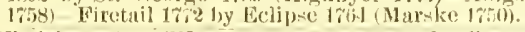

Camel,
br. h., 1823.

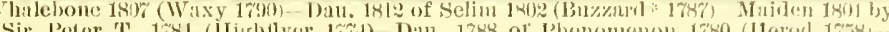

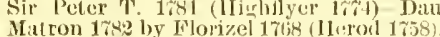

banter.

br. $\mathrm{m} ., 1829$.

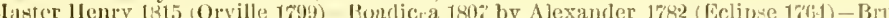
nette by Amaranthus 1766 (Uld England 1711, M:2ylly $17 \% 1$ by Matelem 17 s (Cade 1731-Diu. 1755 of Anc. Starling 1738 (Starling 172\%).

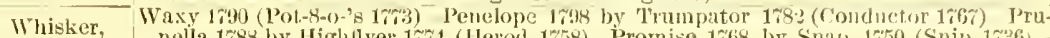
b. I1., 1812 . nella 1783 by llighllyer 17at (Herod 1758)-Promise 1768 by Snap 1750) (Snip) 1736)Julia 1756 by Blank 1740 (God. Ar. 1721)

音 Cibside Fairy,

b. m., 1811 .

Hermes 1790 (.Mercury 17'8)-Vicissitude 1800 by Pipator 1786 (Imperator 17\%6)-Beatrice 1791 by Sir Peter 'T. 1784 (IIghllyer 1774)-Py rrlu 17\%1 by Matchem 1718 (Cade 1734)Duchess 17 t8 by Whitenose 1742 (fod. Ar. 17\%)

Orville,

Beningbrough 179r (King Fergus $17 \% 5)$ Evelina 1791 by II ightlyer 1774 (Heror 175,

b. b., $\left.1 \boldsymbol{r}^{\top}\right) 9$.

Emily,

Dam. 175 of Regulus 1739 (Gol. Ar. $17^{2} 1$.

Datl. 16 of Regults

ch. m., 1810 .

Scud,

b. h., 1804 .

Goosander

b. m., 1805 .

Dorimant 1781 by Dorimant $17 \%$ (Otho 1760 )-Dizzy 1757 by Blank 1740 (God Ar. 1\%24)-Dizzy $1 \% 41$ by Driver $172 \%$ (Wym Ar.).

Beningbrough 1791 (King Fergus 1775) - Eliza 1791 by Highflyer 1774 (IJerod 175s) Augusta 1784 by Eclipse 1764 (Marske 1750)-Hardwicke's dam by Herod 1758 (Tartar 1743) - Nettle 1763 by Bajazet $1 \% 40$ (God. Ar. 1\%24).

Hambletonian 1792 (King Fergus 17\%)-Rally 1799 by Trumpator 1782 (Conductor $1767^{7}$ )-Fancy 1780 by Florizel 1768 (Herod 1758 )-Dau. 1763 of Spectator 1749 (Crab 1722)-IIolatia 1758 by Blank 1710 (God. Ar. 1\%21).

Waxy Pot-8-o-'s 1773 (Eclipse 1764)-Maria 17\%7 by Herod 1758 (Tartar 1713)-Lisette 17\%2 by Snap 1750 (Snip 1736)-Miss Windsor 1754 by God. Ar. 1\%21-Sist. to Volunteer by Y. Belgrade (Belgrade Turk).

b. h., 1790 .

Penelope,

b. m., 1793.

Trumpator 1782 (Condnctor 1767 )-Prunella 1789 by Highflyer $17 \% 4$ (IIerod 17581Promise 1768 by Snap 1750 (Snip 1736)-Julia 1753 by Blank 1740 (God. Ar. 1724)Spectator's dam 1735 by Partuer 1718 (Jigg)

[Selim or] Sotcerer 1793 (Trumpator 1782) - Folden Locks 1793 by Delpini 1781 (Higbflyer 1774)Soothsayer, ch. h., 1808 .

Sprite,

ch. m., 1807 Volet 1787 by Shark $17 \% 1$ (Marske 1750$)-D$

Bolail 1 ot ( milla 1798 by Trentham 1766 ( $\mathrm{T}$. Sweepstakes 1743 )-Coquette 1764 by Compton BarbSist. 1743 to Regulus by God. Ar. 1721

Sir Archy,

Diomed 1777 (Florizel 1768) — Castianira 1796 by Rockingham 1781 (Highflyer 1774)b. h., 1805 .

Danghter of, (Babrabam 1740)-Dau. of W's Forester 1750 (Forester 1736).

Saitram 1780 (Eclipse 1764)-Dan. of Symmes' Wildair 176\%

of Tyler's Driver 1760 (*Othello)-Dau. of *Fallower 1\%61 (Blanonght 1755 ) -Dau. *Vampire 175i (Regulus 1739).

Florizel,
ch. h., 1801

Daughter of,

Diomed $177 \%$ (Florizel 1768)-Dau. of *Shark 17\%1 (Marske 1750)-Dau. of IIarris's Eclipse 1770 (*Fearnought 1755)-Dall. of *Fearnought 1755 (Regulus 1739)-Dau, of *Jolly Roger 1741 (Roundhead 1\%33).

*Alderman 1787 (Pot-8-0-'s 17\%3)-Dau, of *Clockfast 17\%t (Gimcrack 1760)-Dau. of Symmes' Wildair 1767 (*Fearnought 1755)-Y. Kitty Fisher by * Fearnought 1755 (Regulus 1739) - * Kitty Fisher 1755 by Cade 1734 (God. Ar. 1721).

Emiling,

Orville 1799 (Beningbrough 1791)-Emily 1810 by Stanford 1794 (Sir Peter T. 1784)-

b. h., 1830 ,

Icaria,
b. m., 1821. Dau. 1799 of Whiskey 1789 (Saltram* 1780)-Grey Do

The Flyer 1814 (Vandyke Jr. 1808)-Parma 1813 by Dick Andrews $179 \%$ (Joe Andrews 1778)-May 1804 by Beningbrough 1791 (King Fergus 175) - Primrose 1787 by Mambrino 1763 (Eng:neer 1755) - Cricket 176 by Herod 1758 (Tartar 1743).

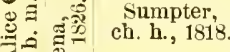

ir Archy 1805 (*Diomed 177\%)-Dau. of *Robin Redbreast 1796 (Sir Peter T. 1784)Dau. 1788 of *Obscurity 17\% (Eclipse 1\%64)-Slamerkin 1768 by *Wildair 1753 (Cade 1731) - $*$ Cub mare 1762 by Cub 1739 (Fox 1714).

ఏ. Lady Grey

b. m., $181 \%$.

*Hightlyer $178+$ (Hoyalist: 790)-Maria 1802 by Melzar 1791 (*Medley 17\%3)-Dan. of Ariel 1756 (*Traveller 1747 )

Selim,

$\stackrel{3}{=}$ ch. h., 1802

Buzzard* 1787 (Woodpecker 1\%73)-Dan. of Alexander 1\%83 (Eclipse 1764)-Dau. of Hightlyer $1 \% 4$ (Herod 1758)-Dau. of Alfred $17 \% 0$ (Malchem 1718)-Dau. 17\% of Engineer 1756 (Sampson 1745),

Bacchante,

$V^{4}$ s Ditto 1800 (Sir Peter T. 1784)-Dau. 1791 of Mercury 17\% (Eclipse 1\%64)-Dan. 1\%6 of Herod 1758 (Tartar 1713) - Folly 17i1 by Marske 1750 (Squirt 1732)-Vixen 1753 by Regulus 1739 (God. Ar. 1724)

Tramp,

Dick Andrews 1797 (Joe Andrews 17\%8)-Dan. 1803 of Gohanna 1790 (Mercury 17\%8)Fraxinella 1793 by Trentham 1766 (T. Sweepstakes 1743)-Dan. 1785 of Woodpecker 17 ; $($ Herod 1758)-Everlasting $17 \% 5$ by Eclipse 1764 Marske 1\%0).

b. h., 1810 .

Web,

b. m., 1808 .

axy 1790 (Pot-8-o-'s 1773) - Penelope 1793 by Trumpator 1782 (Conductor 1766) -Prunella 1738 by Highflyer $17 \% 4$ (Herod 1758) - Promise 1768 by Snap 1750 (Snip 1736)-Julia 1756 by Blank 1749 (God Ar. 1724)

Am. Eclipse

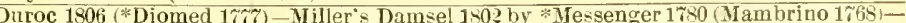
*Dau. 1792 of Pot-8-o-'s 1\%'3 (Eclipse 1\%64)-Dau, 17\%8 of Gimcrack 1\%60 (Cripple 1750) Snapdragon 1759 by Snap 1750 (Snip 1736)

Y. Maid of

Expedition 1795 (Pegasus 1781)-Maid of the Oaks 1801 by *Spread Eagle 179: (Volunteer 1780)-Annette by *Shark $17 \% 1$ (Marske 1750)-Dau, of Rockingham (Partner 175.5) -Dan, of True Whig (Fitzhugh's Regulus 1765).

the Oaks,

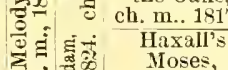

b. b., 1816 .

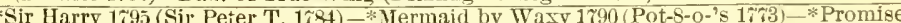
1803 by Buzzard* 1787 (Woodpecker 1773)-Dau. 1795 of Precipate* 1\%87 (Mercury 17\%8)-Lady Harriet 1773 by Mark Anthony 1767 (Spectator 1749).

릉ํㄹ Daughter of

Cook's Whip 1894 (*Whip 1794)-Hart's Maria by Craig's Alfred (*Medley 1\%76)-The Pryor mare [a good race-mare] by Tayloe's Bellair 1786 (*Medley 1776)-Thoroughbred mare of Mr. T. D. Owings. 


\section{WILFUL.}

WINYER OF THE JOCKEY CLUB HANDICAP AT JEROME PARK, SEASIDE HANDICAP AT PROSPECT PARK, AND HANDICAP SWEEPSTAKES AT MONMOUTH PARK, IN 1879.

\section{Is private stallion in Foxhill Stud, Mr. R. Ellis, Philadelphia, Pu., proprietor. Jearlings sold ammally.}

Truful, foaled 1876, bred by John Hunter, N. Y., by imp. Australian, son of West Australian, dam imp. Pussy, dam of Bangweola aud Lelaps by Diophantus, out of Agapenone by Bay Middletou, son of Snltan. Wilful ran unplaced in Champagne, Stakes at Jerome Park when two years old. As a three-year old started eleven times, won three races, was second in fomr, third in one and unplaced in three. Jerome Park, June 7, made his maiden effort in the Jockey Cln 5 Handicap, 2 miles, defeating his stable companion, Lou Lanier, who finished secoud, Gen Philips,-Bonnie Wood, Warfield and Bertha, time 3.428. Prospect Park, L. I., Inauguration Meeting, Coney Island Jockey Club, June 24, won the Seaside Handicap, 2 miles, defeating Gen. Philips, Gor. Hampton and Bramble, time 3.318, this was one of the best concested races of the year; same meeting, June 26, ran second to Keuney in the Brightou

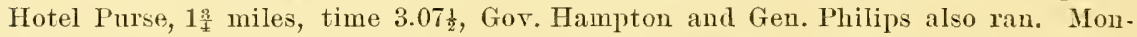

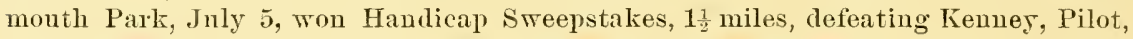
Lou Lanier and Belle, time 2.41; same place, Jnly 8, ran second to Spendthrift in the

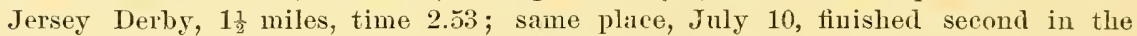
Shrewsbury Handicap, 18 miles, won by his stable companion, Lon Lanier, time 3.11: Wakefield, Terror and Zoo-Zoo also ran. Saratoga, July 24, ran second to Bramble in the Saratoga Cup, 21 miles, Lou Lanier third, Belle and Danicheff unplaced, time 4.11量. This closed his racing career. Imp. Australian, his sire, is the sire of spencthrift (sire of Kingston, Lamplighter, etc.), Felloweraft, the first horse to beat Lex-

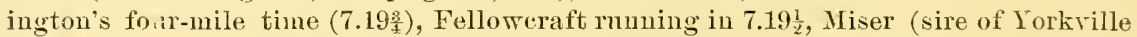
Belle), Rutherford, Wildille (4 miles in $\left.7.25 \frac{1}{2}\right)$ and of Ivy Leaf, dam of Bramble, Lizzie Lucas, dam of Cerise (Morrello's dam), Maggie B. 13., dam of the grand race. horse and snecessful stallion Iroquois, Farfaletta, dam of Falsetto and ethers.

Wilful is a very finely bred horse, having a double eross of Touchstone, and is much inbred to Waxy through his best sons Whisker and Whalebone, and to Godo!phin Arabian throngh Regnlus and Matehem. Lelaps, his half brother, has done well in the stud, and Wilful is sire of the wimners Wiltred, Dick Turpin, Meale, Parthian, Wild Cherry, Wayward, Westmoreiand, Wickham, Maiden Hair, ete. He is a dark chestnut, without white, except a small star in his forehead, is 16 hands high, and highly finished all over. His colts, from what we hear, are very promising and fine.

He is descended in direct female line throngh Flora by Regulns from the Belgrade Turk mare, to which trace Tamrus, Gludiator, Sting, Belladrum, imp. St. Blaise, Mainstay, New Holland, Boulevard, in Eugland; and the good colt Victory, ete. 


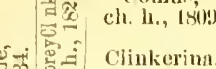

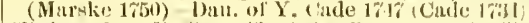

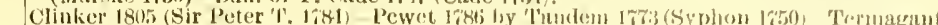

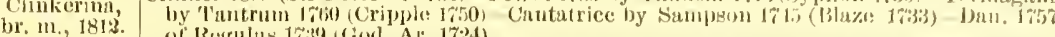
of Regulus 17 is ( iod. Ar. 1724)

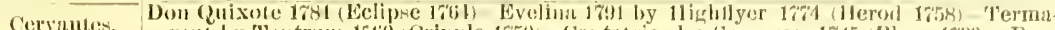
b. I., 1806. gant by 'Thutrum 1itio (Cripple 1750)

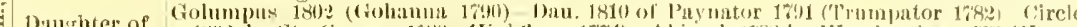

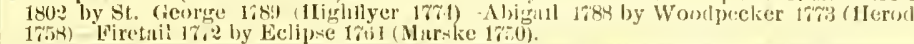

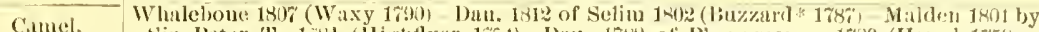
br. l.. $18: 2$

Banter, br. m., $18 \% 6$.

Whisker,

b. h., 1812 .

Fairy

b. M., 1811 .

Orville,

b. h., 1799

Emily, ch. m., 1810.

Scud b. h., 1804

Goosander, b. m., 1805 .

Waxy b. h., 1790

Penelope, b. m., 1793 .

[Selim or] Soothsayer,

Sprite,

h. m, 187 .

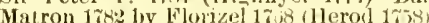

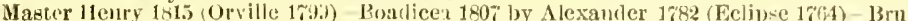

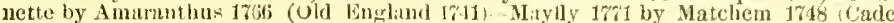
1734-Dau. 175.5 of Anc. Sturling 1738 (Starling 1\%2\%).

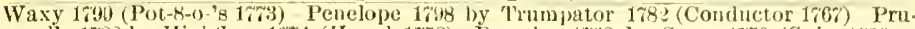
nella 1783 by llighllyer 1744 (Iferod 1758)-Promise 1768 by Snap) 1750 (Snip) 1736)

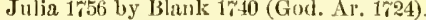

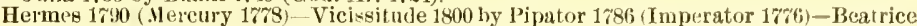

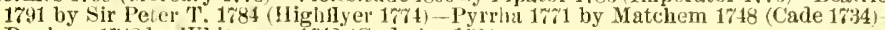
Duchess 1718 by Whitenose $1 \% 42$ (God. Ar. 17\%4)

Beningbrough 17:1 (Kine Fergus 175) Evelina 1791 by Highflyer 1714 (Herod 1758)T'ermagant by Tantrum 1760 (Cripple 1750)-Cantatrice by Sampson 1745 (Blaze 1733)Dau. $15 \%$ of Regulus 1 tri39 (God. Ar. 1724).

Stamford 1791 (Sir Peter T. 1784)-Dau. 1799 of Whiskey 1789 (Saltram* 1780)-Grey Dorimant 1781 by Dorimaut 1772 (Otho 1760)-Dizzy 1657 by Blank 1710 (God. Ar. 1724)-Dizzy 1741 by Driver $172 \%$ (Wyun Ar.).

Beningbrongh 1791 (King Fergus 1775) - Eliza 1791 by Highflyer 1771 (Herod 1758)Augusta 1781 by Eclipse 1764 (Marske 1750)-Ilardwicke's dam by Herod 1'58 (Tartar 1743) - Nettle 1763 by Bajazet 1740 (God. Ar. 1724)

Hambletonian 1792 (King Fergus 1775) - Rally 1790 by Trumpator 1782 (Conductor 1767)-Fancy 1780 by Florizel 1768 (Herod 1758)-Dau. $1 \% 63$ of Spectator 1749 (Crab 172:2)-Horatia 1758 by Blank 1740 (God. Ar. 1724)

Pot-8-0-'s $17 \% 3$ (Eclipse 1\%64)-Maria 17\%7 by Herod 1758 (Tartar 1743)-Lisette $1 \% 22$ by suap 1750 (Snip 1736) - Miss Windsor 1754 by God. Ar. 1724-Sist. to Volunteer by Y. Belgrade (Belgrade Turk).

Trumpator 1783 (Conductor 1767)-Prunella 1789 by Highflyer $17 \% 4$ (Herod 1758) Promise 1768 by Snap 1750 (Snip 1736) Julia 1755 by Blank 1740 (God. Ar. 1\%24) Spectator's dam 1735 by Partner 1718 (Jigg).

Sorcerer 1793 ('Trump:ator 1782)-Golden Locks 1793 by Delpini 1781 (Highflyer 1774)Violet 1787 by Shark* 17r1 (Marske 1750)-Dan. $17 \% 2$ of Syphon 1750 (Squirt 1732)Charlotte 1756 by Blank 1\%40 (God. Ar. 1\%24).

Bobtail 1795 (Precipitate* 1787)-Catherine 1795 by Woodpecker 1773 (Herod 1758)-Camilla 1778 by Trentham 1766 (T. Sweepstakes 1743 ) - Coquette 1765 by Compton BarbSist. 1743 to Regulus by God. Ar. 17\%4.

\section{Camel,}

Whalebone $180 \tau$ (Waxy 1790)-Dan. 1812 of Selim 1802 (Buzzard* 1787)-Maiden 180

br. h., 1822 . by Sir Peter T. 1781 (Highflyer 1774)-Dan.

Banter, Matrou 1782 by Florizel 1768 (Herod 1758 ).

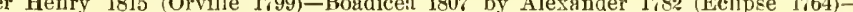
Brunette by Amaranthus 1766 (Old England 17.11) - Mayfly 1; 7 1 by Matchem 17.8 Cade 1734)-Dall. 1755 of Anc. Starling 1738 (Starling 1727).

Langar, Selim 1802 (Bnzzard* 1787)-Dau. 1808 of Walton 1799 (Sir Peter T. 1781)-Y. Giantess

ch. h., 1817. 1790 by Diomed* 1777 (Florizel 1768)-Giantess 1769 toy 1 -
Molly Long Legs 1753 by Babraham 1740 (God. Ar. 1724).

Kite Bustard 1813 (Castrel 1801) - Olympia 1815 by Sir Oliver 1800 (Sir Peler T. 1781)-Scotilla

b. 1795 by Anvil 177\% (Herod 1758)-Scota 1783 by Eclipse 1764 (Marske 1750)-Harmon $17 \% 5$ by Herod 1758 (Turtar 1743).

Orville, Beningbrough 1791 (King Fergus 1\%5)-Evelina 1791 by Highflyer 1\%:4 (Herod 1\%58)

b. h. 1799 Termagant by Tantrum 1760 (Cripple 1750) - Cantatrice by Sampson $1 \% 45$ (Blaze 1733)-Dau. 1\%57 of Regulus 1739 (God. Ar. 1724)

Emily Stamford 1794 (Sir Peter T. 1784)-Dau. 1799 of Whiskey 1789 (Saltram* 1780)-Grey

ch. 11., 1810. Dorimant 1781 by Dorimant $17 \tau^{2}$ (Otho 1 $17(0)$-Dizzy 1757 by Blank 1740 (God. Ar. 1724)-Anc. Dizzy $1 \% 11$ by Driver $172 \%$ (W ynn Ar.)

Whisker, Waxy 1790 (Pot-8-o-'s 17\%8)-Penelope 1798 by Trumpator 1782 (Conductor 1767)-Pru-

b. h., 1812 nella 1785 by Highflyer 1764 (Herod 1758)-Promise 1768 by Snap 1750 (Snip 1736)Julia 1756 by Rilink 1740 (God. Ar. 1724).

Gibside Hermes 1790 (Mercury 1778) - Vicissitude 1800 by Pipator 1786 (Imperator 17.6)-Bea-

Fairy,

b. m., 1811. 1734)-Duchess 17 t8 by Whitenose 1742 (God. Ar. 1724).

\section{$\therefore \quad=\frac{\text { Selim. }}{2}$.}

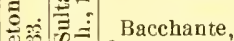

Buzzard * 175\% (Woodpecker 17\%3)-Dan. of Alexander 1782 (Eclipse 1\%64)-Dan. of

Bacchante,
br. m., 1899 . neer 1756 (Sampson 1745 ).

W's Di

84)-Dau. 1791 of Mercury 17 (Eclipse 1\%64)-Dan. 1 \% of Herod 1758 ('Tartar 1743) - Folly $17 \% 1$ by Marske 1750 (Squirt 1732)-Vixen 1753 by Regulus 1733 (God, Ar. 1724

Phantom,

b. h., 1808.

Walton 1799 (Sir Peter T. 1784)-Julia 1799 by Whiskey 1789 (Saltram* 1780)-Y. Giantess 1790 by Diomed* $1 \% 7 \%$ (Florizel 1\%68)-Giantess 1769 by liatchem 1748 (Cade 1734)-Molly Long Legs 1753 by Babraham 1740 (God. Ar, 1724)

Filagree, ch. m., 1815 . 1798 by Trumpator 1782 (Conductor $176 \%$ )-Prunella 1788 by Highflyer $1 \% \% 4$ (Herod 1758)-Promise 1708 by Snap 1750 (Svip 1736)

Whalebone Waxy 1790 (Pot-భo's 1 1773) - Penelope 1793 by Trumpator 1782 (Conductor 176\%)-Prunella 1788 by Highflyer 1774 (Herod 1758)-Promise $1 \% 08$ by Snap 1750 (Snip 1736)Julia 1756 by Blink 1740 (God. Ar. 1\%24)

Peri, Wanderer 1811 (Gohanna 17:0 - Thalestris 1809 by Alexander 1282 (Eclipse 1764)-Rival 1800 by Sir Peter T. $1 \% 84$ (Highflyer 1\%74)-Hornet 1790 by Drone $1 \% 77$ (Herod 1\%58) Manilla $17 \%$ by Goldfinder 1 î64 (Snap 1\%50).

rvilte 1799 (Beningbrough 1791)-Emily 1810 by Stamford 1794 (Sir Peter T. 1784)-Dau. 1799 of Whiskey 1789 isaltram* 1780 -Grey Dorimant 1781 by Dorimant $17 \% 2$ (Otho 1760)-Dizzy $17 \% 7$ by Blank 1740 (God. Ar. 1724)

\begin{tabular}{l|l} 
Danghter of \\
$\therefore$
\end{tabular} b. m., 1820 .

[Scud or] Pioneer 1804 (Whiskey 1789-Canary Bird br. m. 1806 by [Whiskey or] Sorcerer 1796 (Trumpator 1782) - Canary b. m. 1797 by Coriander 1786 (Pot-8-0-'s 17\% Miss Green b. m. 1787 by Hightlyer $17 \tau^{4}$ (Herod 1758)-Harriet b. m. 1769 by Matchem 1748 (Cade 1\%34)-Flora b.m. 1749 by Regulus 1739 (God. Ar. 1724)-Dau. of Bartlett's Childers (Darley Ar. 1699)-Dau. of Bay Bolton 1705 (Grey Hautboy)-Dau, of Beigrade Turk. 


\title{
IMPORTED WOOD MOSS.
}

\author{
Bred and ouned by Dr. A. W. McAlester, Columbia, IIo. Terms of Scrice \\ and sales ammually.
}

Wood Moss bay horse, foaled 1887, by Creancier, son of Le Sarrazin by Monarqne, dam imp. Lady Nar by Macaroni, grandam Queen of Scots by Blair Athol, ont of Last Sheen by Kingston, son of Venison by Partisan. Creancier won the Trial Stakes at Epsom and other races. Le Sarrazin, the sire of Creancier, was full brother to La Farorite, the dam of Flageolet (winner of the Goodwood Cup and sire of imp. Rayond'Or) by Monarque, the sire of Gladiateur (winner of the 2.000 Guineas, Derly, St. Leger, Grand Prize of Paris and Prix de Royal Oak), Creancier's dam by Vermouth (wimner of the Grand Prize of Paris and a successful stallion). Lady Nar, Wood Moss's dam, was a good race-mare, won the Winchester Biennial Stakes for threerear olds, 1 mile; was second in Welter Handicap, $1 \frac{1}{4}$ miles, beaten by a head. As an individual she is unsurpassed. She is by the great horse Macaroni (winwer of the Derby and the 2,000 Guineas). The Macaroni mares are more sought after in England than any others. The dams of the great horses Ormonde, Galliard, Bonavista, BusyBody, etc., are Macaroni mares. Macaroni was hy Sweetmeat, a grand race-liorse, started twenty-four times, won twenty-two and a half, among them the Queen's Vase at Ascot. Queen o' Scots, dam of Lady Nar, was by Blair Athol (Derby and St. Leger winner), he the sire of Prince Charlie (wimner of the 2,000 Gnineas), of Silvio (winner of both Derby and St. Leger), and Craig Millar (winner of the St. Leger). East Sheen, third dam of Wood Moss, was by Kingston, a winmer at all distances, from two to fice years old, carrying the heaviest weights, against the best horses of his dar, from one to four miles, and the sire of Caractacns (wimner of the Derby), Queen Bertha (winner of the Oaks and dan of Spinaway and Wheel of Fortune, wimers of the 1.000 Guineas and Oaks), imp. Eltham Lass, dam of Kingfisher, and Majestic, dam of the good race-horse Eurus.

Wood Moss's breeding is gilt-edged. The most successful cross of modern times is the donble cross of Whalebone, which is secured by intermixing the descendants of Whalebone through Sir Hercules, Birlcatcher, The Baron, Stockwell, Rataplan, Camel, Tonchstone, Newminster and Adventurer. Isonomy by Sterling, son of Oxford by Birlcatcher, one of the best race and best bred horses of the century, had no less than four strains of Whalebone and seyen of Waxy in his pedigree, besides one of Shuttle, the rarest of all. Measured by this standard, Wood Moss should make a successful stock getter. He has nine strains of Whalebone, two of Whisker, full brother to Whaiebone, thirteen of Waxy and two of Shuttle.

He is a rich, dark bay with black points, no marks, 16 hands high, highty finished and symmetrical. He is of the Leamington type, with more bone than the Leamingtous usnally show.

Wood Moss descends in direct line from the same Royal mare to which traces Woodpecker, Waxy Pope, Whalebone, Whisker, Partisan, Bay Middleton, imp. Flencoe, Melbourne, Robert the Devil, Bend'or, imp. Eclipse (Morris), Uncas, Wanderer and all the Prunella family. 


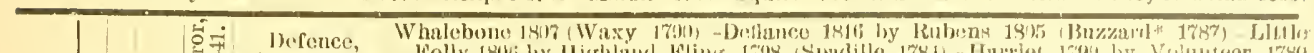

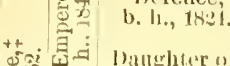

를

1อ

Royal Oak

1., b., 18.23.

Idik,

b. $111 ., 1821$

Parti×m,

b. 11., 1811

P'auline,

b. m., 1826

Hercule,

ch. h., 1830 .

Elvira,

b. m., 1 , 2 ?

The Nob,

b. b., 1838

Hester,

br. $11,, 183$

The Baron,
cl. h., 184?.

Fair Helen

b. m., $183{ }^{\circ}$.

Touchstone,

Latitude,

b. m., 133.5 .

Slane,

Hester,

r. m., 1832

lo

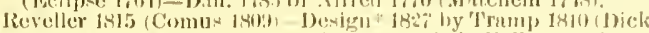

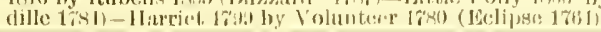

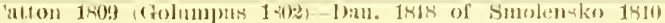

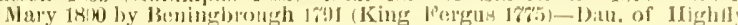

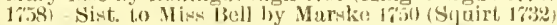

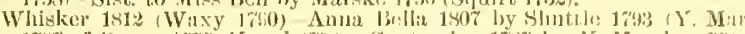

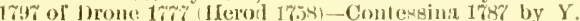

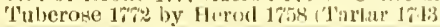

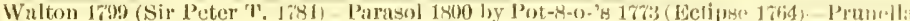

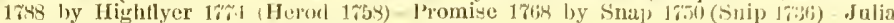
1756 by 13lank 174) (God. Ar. 1\%24).

Moses 181: ([Whialebone ol"] Seymour 180\%) Qualrille 1815 by Selim 1k0\% (Bu\%ard*

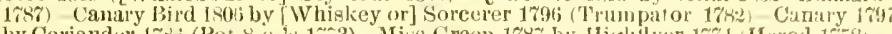

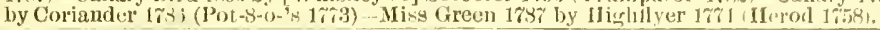

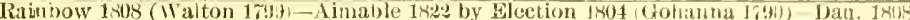

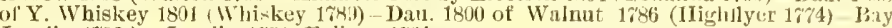
Javelin 1793 by Javelin $1 \%: 2$ (Eclipse $1 \%$ (t). $)$.

Eryx 1816 (Milo 180?)-Coral 1816 by Orvilie 1793 (Penincbrongh 1791, Fairing 1807 by Waxy 179) (Pot-8-o's 17\%3) - Rattle 1793 by Trumpator 1782 (Conductor 1767) Fancy 1730 (Sist. to *Diomed) by Florizel 1768 (I Lerod 1758).

Glacus 1830 (Partisan 1811 )-Octave 1830 by Emilius 1820 (Orville 179!)-Whizgig 141s by Rubens 1805 (Buzzard* 178\%)-Penelope 1798 by Trumpator 1782 (Conductor 1767) l'unella 1738 by Hightlyer $17 \% 4$ (Herod 1758)

Camel 1822 (IVhalebone 1807) Monimia 18:1 by Muley 1810 (Orville 1799)—Sist. 1796 to Petworth by Precipitate* 1\%8\% (Mercury 1778)-Dan. 1787 of Woodpecker 177; (Herod 1758) - Sist. 1773 to Juniper by Snap 1750 (-nip 1736).

I1. Birdcatcher 1833 (Sil Herenles 18:3i) Echidna 1838 by Economist 1825 (Whiske 1812)-Miss Pratt 1825 by Blacklock 1814 (Whitelock 1803)-Gadabout 1812 by Orville 1793 (Beningbrough 1791) - Ninstrel 1803 by sir Peter T. 1781 (Highflyel' 1774).

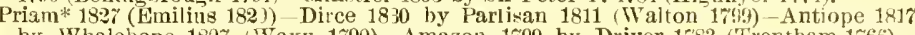
by Whalebone 1807 (Waxy 1790)-Amazon 1799 by Driver 17's3 (T'rentham 1766)Fractious 17 ; 2 by Mercury 1778 (Eclipse 1764).

Camel 1892 (Whalebone $180 \%$ )-Banter 1826 by Master Henry 1815 (Orville 1799-Bogclicea $180 \%$ by Alexander 1782 (Eclipse 1;64)-Brunette by Amaranthus 1\%66 (Old Englaud 1741)-Mayfly $1 \gamma^{*} 1$ by Natchem 1718 (Cade 1r34).

Langar 1817 (Selim 1802)-Olympia 1815 by Sir Oliver 1800 (Sir Peter T. 1\%84)-Scotilla 1795 by Auvil 1777 (Herod 1758)-Scota 1783 by Eclipse 1764 (Marske 1750)-Harmony $17 \%$ by Herod 1753 (Tartar $1 \% 43$ ).

Royal Oak 1833 (Catton 1899)-Dat1. 1819 of Orville 1799 (Beningbrough 1791)-Ep:om Lass 1803 by Sir Peter 'T. 1784 (Highflyer 17\%4)-Alexina 178s by King Fergus $17^{\prime \prime} / 5$ (Eclipse 176i) -Latdella 1780 by Y. Marske 1 \% 71 (Marske 1750).

Camel 182? (Whalebone 1807)-Monimia 1821 by Muley 1810 (Orville 1799,-Sist. 1796 to Petworth by Precipitate* 1787 (Mercury 1778)-Dan. 1787 of Woodpecker 1773 (Herod 1758) - Sist. 1773 to Juniper by Snap 1750 (Snip 1736).

Partisan, Walton 1799 (Sir Peter T. 1784)-Parasol 1800 by Pot-8-o-'s 17í3 (Eclipse 1764)-Pru-

Partisan, nella 1783 by Hiwhflyer $17 \% 4$ (Herod 1758) - Promise 1\%68 by Snap 1750 (Snip 1736)Julia 1756 by Blank 1710 (God. Al. 1\%24)

Pauline, Moses 1819 ([Whalebone or] Seymour 180\%)-Quadril]e 1815 by Sclim 1S02 (Buzzard*

b. 1787)-Canary Bird 1906 by [Whiskey or] Sorcerer 1796 (Trumpator 1782)-Canary 1797 by Coliander 178 ; (Pot-X-o-'s 1\%73)-Miss Green 178\% by Ilighflyer 1\% 4 (Herod 1758).

[Starch or] Blacklock 1314 (Whitelock 1803) -Dau. 1816 of Phantom 1808 (Walton 1799)-Dan 1802 Voltaire, of Overton 1783 (King Fergus 1775)-Dan. 1796 of Walnut 1786 (Eighflyer 17\%4)-Dau. br. h., 1823. 1783 of Ruler $17 \% 1$ (Y. Marske 17\%1).

Belinda. Blacklock 1814 (Whitolock 1803)-Wagtail 1818 by Prime Miuister 1810 (Sancho 1801) Tranby*'s dam 1812 by Orville $1 \% 99$ (Beningbrough 1\%91)-Niss Grimstone 1\%96 by Weazle 17 in (Herod 17.58)-Dau. of Ancasier 1768 (Blank 1740).

Castrel Buzzard* 1787 (Woodpecker 17\%3)-Dan. of Alexander 1782 (Eclipse 1764)-Dan. of ch. h., 1801. Highflyer 17\%4 (Herod 1758)-Dau. of Alfed 17\%0 (Matchem 1745)-Dau. 17\%0 of Engi-

Pernvian 1803 (Sir Peter T. 1784)-Musidora 1804 by Meteor 1783 (Eclipse 1\%f4)-Maid of-all-Work 1783 by Highfyer $1 \% 7+($ Herod 1758$)$-Dan. $1 \%$ i of Syphon 1750 (Squirt 1732)-Dau. of Regulus 1733 (God, Ar. 1724)

Orville 1799 (Beningbrough 1791)-Miss Sophia 1805 by Stamford 1794 (Sir Peter T. 1781)-Sophia 1798 by Buzzard 178\% (Woodpecker 1779)-Huncamunca 1787 by Highflyer $17 \% 4$ (Herod 1758)-Cypher $17 \% 2$ by Squirrel 1754 (Traveller 1735).

Alexander 1782 (Eclipse 1764) - Brunette by Amaranthus 1\%66 (Old England 1r11)-Mavfly $17 i 1$ by Matchem 1748 (Cade 173t)-Dall. 1755 of Anc. Starling 1738 (Starling 1727 )-Look-at-me-Lads 1\%31 by Grasshopper (Byerly Turk)

Ir. Birdcatcher 1\$33 (Sir Hereules 18:6)-Echidna 1835 by Economist 18.5 (Whisker 1812) - Miss Pratt 1825 by Blacklock 1814 (Whitelock 1803)-Gadabont 1812 by Orville 1799 (Beningbrough 1791) - Minstrel 1893 by Sir Peter T. 1784 (Highflyer 17\%4)

Glencoe* 1831 (Sultan 1916) Marpessa 1830 by Muley 1810 (Orville 1709) - Clare 18:4 by Marmion 1893 (IV hiskey 1789)-Harpalice 1814 by Gohanna 1790 (Mercury 1\% 18 -Amazon 1799 by Driver 1783 (Trentham 1\%66)

Humpley Clinker 18:2 (Comus 1809) - Dau. 1825 of Cervantes 1806 (Don Quisote 1781) Dau. 1818 of Golumpus 1802 (Gohanna 1690)-Dan. 1810 of Paynator $17 y 1$ (Trumpator $1 \% 8 \%$ ) - Circle 1902 by St. George 1789 (Highflyer 1\% 44 ).

Gladiator 1833 (Partisan 1811) -Dau. 1840 of Plenipotentiary 1831 (Emilins 1820)-Mrrrha 1830 by Whalebone 1807 ( $\mathrm{T}$ axy 1790 ) - Gift 1818 by Y. Gohanna 1810 (Gohanna 1790)Dan. 1802 of Sir Peter T. 1781 (Highflyer 17\%1).

Partisan 1811 (Wa]ton 1799 )-Fawn 1833 by Smolensko 1810 (Sorcerer 1796)-Jerboa 180.3 by Gohanua 1790 Mercury 1\%8)-Camilla $17 \% 8$ by Trentham $1 \% 66$ T. Sweepstakes 1743) - Coquette 1764 by Compton Barb.

Slane 1833 (Royal Oak 1823)-Garcia 1833 by Octavian 1807 (Stripling 1795)-Dan. 1806 of Shuttle 1793 (Y. Marske 1;i1)-Katharine 1798 by Delpini 1781 (Highflyer 17i1) Dau. 1786 of Pavmaster 1766 (Blank 1740)

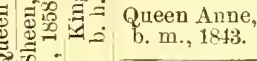

Muley

Moloch.

Muley 1810 (Orville 1799)-Nancy 1813 by Dick Andrews 1797 (Joe Andrews 17is)-

Suitfire 1800 by Beningbrough 1791 (King Fergus 17\%5)-Dau. of Y. Sir Peter 17is (Doge 176\%) - Dau. of Engineer 1756 (Sampson 17\%).

n Daughter of, Thisker 1812(Waxy 179J)-Dall. ch. m. 1326 of Sam 1815 (Send 1804)-Morel ch. m. 1805 by Sorcerer 1796 (Trumpator 1782)-Hornby Lass b. m. 1796 by Buzzard $* 178 \%$ (Woodpecker 1\%73-Puzzle b. m. 1\% 1 by Matchem 1745 (Cade 1\%31) Princess b. m. 1769 by pecked 1758 (Tartar 1743)-Julia b. $1 \% 56$ by Blank 17 to (God. Ar. 1724-Spectator's

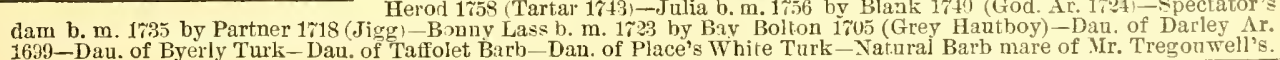
\$ Monarque is by The Baron, Sting or The Emperor. Emperor's pedigree is accepted. 



\section{MA'TCHEM,}

\section{HEROD,}

\section{ECLIPSE,}

THE FOUNDERS OF THE THREE GREAT LINES OF BLOOD. 



\section{MATCHEM.}

WINNER OF TIE JOCKEY CLIT PLATE AT NEWMARKLT, 17\%, LTC.

Matemen, a bay horse, by Cade, was foaled in 17t8, wod by Mr. John Holme, of Carlisle, and was the third prolnee of sister to Miss l'artuer (likewise daun of al iss Romulhead by liomulhoat, Changelinghy (arde, ete.) hy Crofts' lanrtner, who was beel in 17 Is by Mr. Cefofts, of Barforth, lorkshire. Matehen, who was jurehased by Mr. William fenwick, of Bywell, Northumberland, ran bis lirst race at York in 17.53, for the great subseription l'urse of 160 guineas, for fiva-year shls, which he won, beating Mr. Shafto's Barfortl billy by Forester and Mr. Watson's Bold by Cade, and the same year he won a Plate of $£ 50$ at Morpeth, beating Mr. Shafto's Blaneless. In 1754 Matchem won the Ladies' Plate of 126 guineas, four mile heats, at York, beatiug Sodbury in two smartly eontested heats, and he also won the Ladies' Plate of 80 guineas, at Lineoln, in two heats, from the Duke of Aneaster's Martin and Mr. Snith's Skim, while at Morpeth he walked over for a $£ 50$ Plate. In 1755 Matchem wou the $£ 50$ Plate for six-year olds, 8 st. 7 llos., aged, 9 stones, at Nowmarket, over the Beaeon Course, beating Mr. Bowle's Trajan by Regulus. 'The race was run iu 7.20, earrying 8 st. 7 lbs. each, and two others were distanced. Trajan showed the better speed but was mable to maintain it, owing, it was thought, to his indifferent condition; eonsecuently, on Mr. Fenwick offering to run shatchem for the Whip in the following April against any horse in the world, Mr. Bowles accepted the ehallenge with Trajan. In Angust Matchem walked over at York for \&20, no lorse entering. The pair met aceordingly on April 11th, 1756, for a sweepstakes of 200 guineas each and the Whip, 10 stone each, over the Beacon Conrse. Matchem, who was rirlen by John Singleton, permitted Trajan, who was a fretful, pulliug horse, to make the running, and he held suel a long lead over the Flat that 5 to 1 was betted on him; but at the Turn of the Lauds 100 to 1 was betted on Matehen, who there had managed to elose with his autagouist, and finally won easily. But, notwithstanding his defeat, Sir Richard Grosvenor gave $250 \mathrm{guineas}$ for 'Trajan immediately after the race. Matehem was subsequently beaten that year by Speetator for the Jockey Club Plate, but won the Plate of 60 guineas at Neweastle, beating Draweansir and Full Moon. In 1758 Matehen again ran for the Jockey Club Plate, which was decided in one heat, the Stewards having so ordered it, owing to the diftienlty of plaeing the horses in the previous year, an arrangement, however, that failed to prevent the usual heary wagering on their placing. The raee was won with great diffieulty by Mirza by the Godolphin Arabian, Matehem seeond, Jason third, Feather fourth aud Forester last. Feather was the farorite at evens, 6 to 4 against Jason, 6 to 1 against Mirza, and 10 to 1 against Matchem. Immense sums were won on Mirza, and also on Matehem being placen seeond, respeeting which it was observed "that the friends of Matchem not only combed the Golden Fleece, but dressed the Feathers rery handsomely." Matehem only started onee subseqneutly, viz., at Scarborough, where he won the £50 Plate, 9 stone each, beating Foxhunter and Sweetlips. In 1763 Matchem was put to the stud and beenme the leading sire 10 the North of England. He at first covererl at the low fee of 5 gnineas, whieh was raised in 1765 to 10 gnineas, and in 1770 to 20 guineas. In 1775 his fee was further inereased to 50 guineas for twenty-five wares, including those belonging to his owuer, Mr. Fenwick, who is believed to have realized $\notin 17,000$ by Matehem's services as a sire. The progeny of Matchem won on the turf, during the twenty-three years they were rumning, $£ 151,097$.

Matehem got Conduetor (the sire of Imperator and Trumpator). Imperator got Pipator and Remembrancer, and Trumpator got Soreerer. Sorcerer got Comus, he Humphrey Clinker, he Melbourne, the founder of the stout Melbourne line, whieh is so well represented in this conntry through Melbonrne's grandson, imp. Australian, one of the best and lnekiest importations ever made. Matehem got Alfred, who got imp. Tiekle Toby, who got sir solomon, sire of Trumpator (Dareuport's). 
Matchem got Teetotum (winner of the Oaks in 1780), Hollandaise (winner of the St. Leger in 1778), the dam of Eager (wimner of the Derby in 1791), Rarity (dam of Maid of the Oaks, winner of the Oaks in 1783), Miss West (dam of Quiz, winner of the St. Leger in 1801). He got also Giantess, that prodnced a mare by Highflyer (the dam of Cielia, winner of the Oaks, and the Fidget colt, winner of the Derby); and Young Giantess by Diomed, that produced Sorcerer; Eleanor, the first mare to win the Derby and the Oaks, aud dam of Muley; Julia, dam of the Derby winner, Pluantom; Cressida, dam of imp. Priam, winner of Derbs, 2,000 Guineas and Goodwood Cnp, and Antar, wimuer of the 2,000 Guineas; a Walton mare, dam of Nicolo, winner of the 2,000 Guineas, and Langar.-Atalanta, that produced Faith, the dam of Camillus, and Rosalind, the dam of Whitelock and Hyacinthus.-Captive, that produced Paulina, dam of the Oaks wiuner, Hermione, which was in turn dam of the Oaks winner, Briseïs, and she produced Corinne, wimner of the 1,000 Guiueas anct Oaks.-Teresa, that produced Calash, the dam of Whiskes and the St. Leger winner, Paragon.-Monimia, that produced a Highfyer mare, the dam of Hambletonian, winner of the St. Leger.-Puzzle, that produced Woodbine, the dam of the two Oaks winners, Musie and Minuet, and Hornby Lass, the dam of the Oaks winner, Morel, which was the founder of a great family.-Maiden, that produced a mare by Herod, the dam of Gohamna and Preeipitate; Walnnt and Matron, the dan of Sir Solomon.-Pyrrha, that prodneed a mare by Herod, dam of the St. Leger winner, Beningbrough, and Beatrice, the dam of V'cissitude.-Mayfly, that produced Brunette by Amarantlus, the grandam of Banter, Touehstone's dam.-Marotte, the dam of Bagot.-Purity, the dam of Rockingham, the sire of imp. Castianira. 


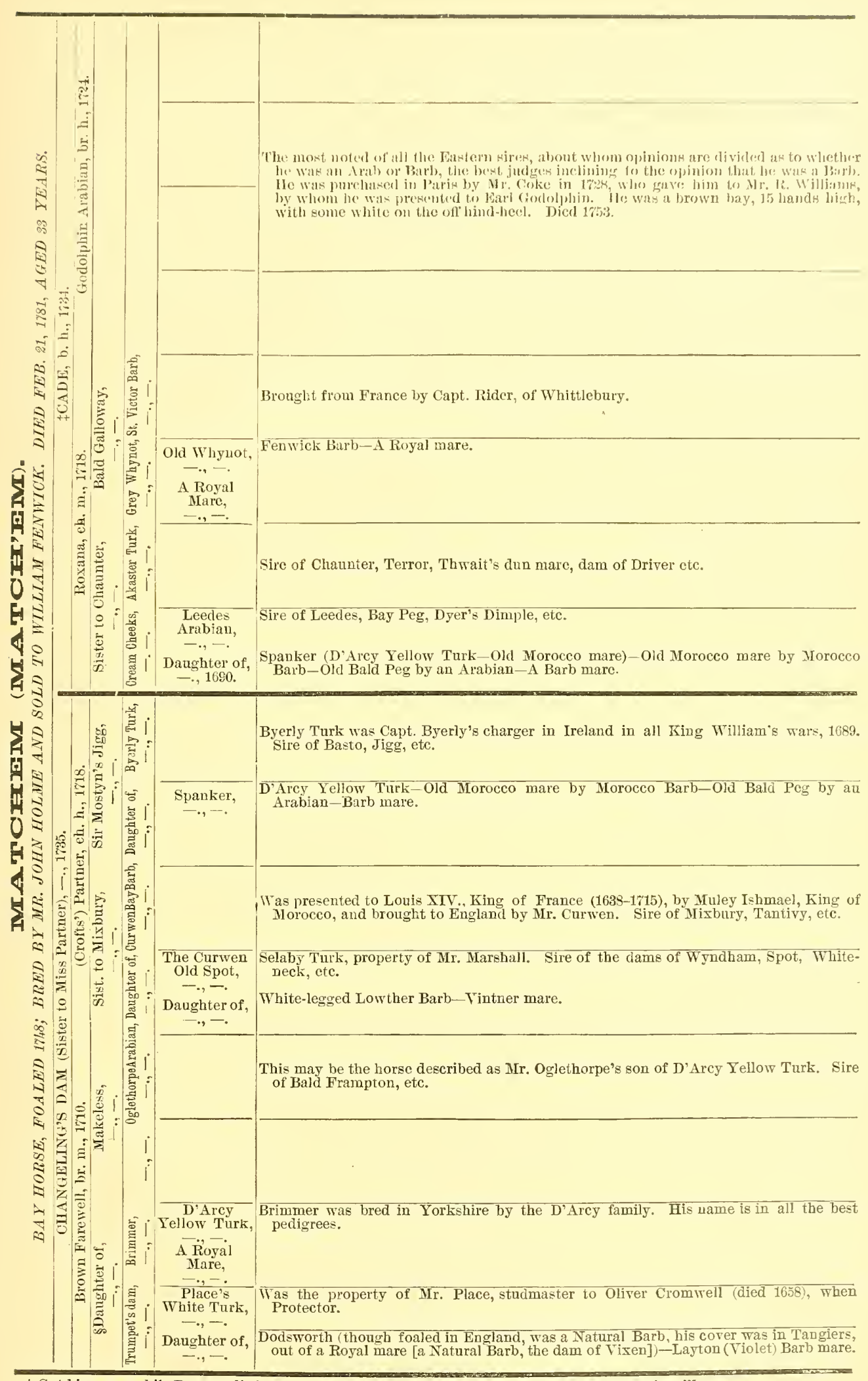

$\ddagger$ Got his name while Roxana died, leaving him about 10 days old, and he was fed with cow's milk.

Mare given to Mr. Crofts by Queen Anne. Trumpet's dam was called the D'Arcy Yellow mare. 



\section{HEROD (KING HEROD).}

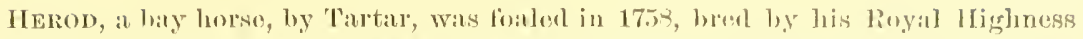

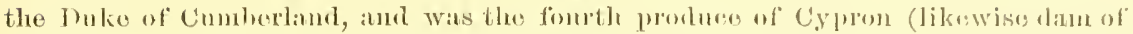

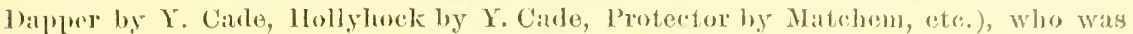

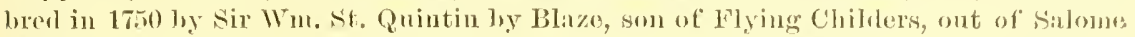
(Solima) by bethell's Arabian. Herod (first ealled King feroel) ran his first races in Oetober, 1763, when five years old, at Newmarket, where he beat the buke of Ancaster's Roman by blank, five yoars, 8 st. 71 hs, each, over the beacon Course, for an mateh of 500 gnineas a side; and in the following $\Lambda$ pril, 1764, he won a Sweepstakes of 300 sorereigns each (10 stone, nine subscriptions), Beacon C'ourse, beating sir John Mlore's (Mr. Willman's) Tartar by Tartar, out of Miss Meredith. At Ascot he won his match for 1,000 guineas a side, griving 6 lbs. to Lord Rockingham's Tom 'Yinker, four miles; and at Newmarket, in the Oetolser Meeting, he next gave 3 1lus. to the Duke of Grafton's Antinous, 8 st. 8 lbs. over the Beacon Course, for 500 guineas a side, 6 to 4 being betted on the loser. Not content with this defeat of Antinous, the Dnke of Grafton matched him to rnn in the following May, 1765, for 1,000 guineas a side, Herod to give him 9 1bs., but the result was the same, although Antimous was the favourite at 7 to 5 on. In Oetober, 1765, Herod, carrying 9 stone, suffered his first defeat, for a match of 1,000 guineas a side, against Sir Jas. Lowther's Ascham, six year's, 8 stone, over the Beacon Course. As much as 3 to 1 was betted on Herod, who was beaten easily. On the death of His Royal Highness the Duke of Cumberland, which happened that year, Herod was purchased by Sir John Moore, whomatched him at the following Newmarket April Meeting, 1766, to give Lord Bolingbroke's Turf (five years) 61 bs., over Beacon Course, for 1, 000 guineas a side. The lsetting was 7 to 4 on Herod, but again he suffered an easy defeat. At York he started for the Great Subseription Purse against Bay Malton, Beanfremont and several others, but, a blood vessel breaking in his head, he was beaten off. In $1767 \mathrm{King}$ Herod ran seeoud to Bay Malton for a Sweepstakes of 500 guineas a side, 8 st. 7 lbs. each, over the Beacon Conrse, iu which Lord Bolingbroke's Turf and Mr. Shafto's Ascham were likwise defeated. This race, says a chronicler of the time, brought together a greater number of noblemen, gentlemen, sportsmen and people of all ranks, from all parts of the kingdom, than were ever seen before at Newmarket, and those from Yorkshire backed Bay Malton freely and won thousands. The betting was 6 to 4 against Turf, 7 to 4 against Bay Malton, 4 to 1 against Ascham, and 5 to 1 against Herod, and immense sums changed hands on the result. Among other bets, Lord Rockingham took 500 to 20 that he placed the whole party and won. In the following May, 1767, Herod received 7 lbs. from Aschain, and beat him over the Beacon Course for 1,000 guineas a sicle, which was his last race. Herod was put to the stud in 1770 , and during the nineteen

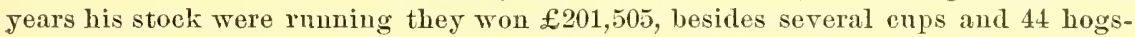
heads of elaret. The most distinguished of Herod's progeny on the turf and at the stud include the three Oaks winners, Bridget, Faith and Maid-of-the-Oaks, and the St. Leger winner Phenomenon (which died after landing in America in 1803), Anvil, Bagot, Bourdeaux, Drone, Evergreen, Florizel (sire of imp. Diomed), Fortitude (sire of John Bull), Highflyer (sire of Delpini, Rockingham, Sir Peter, Walnut, ete.), Justice, Rosalba, Rover (afterwards Tug in Ireland), Telemaehus, Tuberose, Weazle, Woodpecker (sile of imp. Buzzard, the sire of Selim, Castrel, Rubens, etc.). Herod got also the numamed danghter, dam of the Derby wimner Aimwell-another, the dam of the St. Leger winner Beningbrough (he the sire of Orville)-another, the dam of the Oaks winner Platina-another, the dam of the Oaks winner Portia-Hip, the dam of the Oaks winner Hippolyta-Cycherëa, the dam of Oaks winner Nightshade-Maria, the dam of the Derby winuer Waxy (one of the grandest sires) and Wowski, the dam of Smolensko (winuer of the 2,000 Gnineas and Derbs), and Thunderbolt, and Jemima, the grandam of imp. Miss Shipton-Calash, tne dam of the St. Leger winner Paragon, of Whiskey and Lady Charlotte, the dam of the 2,000 Guineas 
winner Cwrw-Aspasia, dam of the Derby winner Sergeant-Perdita, dam of the Oaks winner, the Yellow mare, and her sister, Deceit (the dam of the Oaks winner Parisot)Expectation, the dam of Anticipation, the founder of the great Hawthorne and. Manganese families-Princess, the dam of Puzzle-Tuberose, the dam of Contessina and Rosamond-Crelia, the dam of imp. Tickle Toby, Highland Fling and a maro by King Fergus (the dam of the Oaks winner Scotia)-Harmony, the dam of ScotaPeggy (sister to Postmaster), the dam of imp. Peggy. 


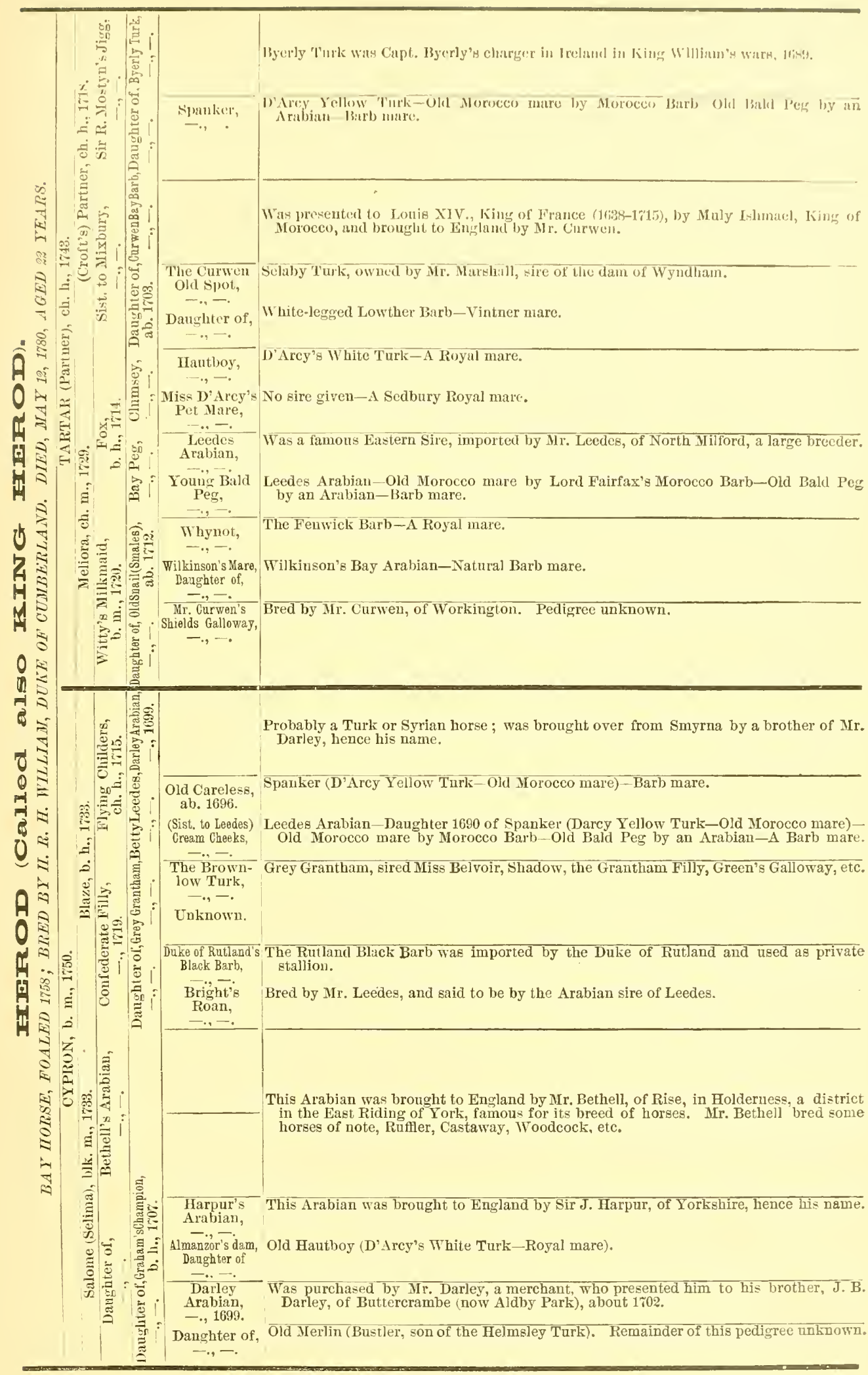





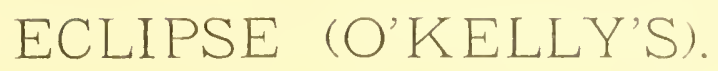

WINNER OF GLEVEN KING'S JLATES ANH NEVHR JEATEN.

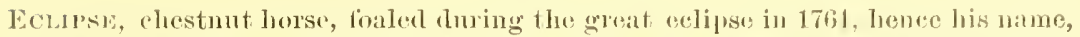

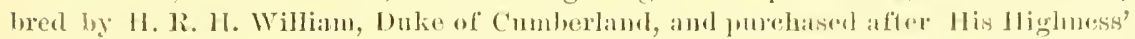
death hy Mr. Willman, who sold him to Captain Dennis o'kelly, hy Marske, son of Synirt lig bartlett's Childers; dam spiletta, the dam of Proserpine, (iarrick and Briseïs hy liegulus, son of the Godolphin Arabian; grandan Mother Western by smith's Son of Suake, son of Lister's Suake, ete. Eelipse made his debut at Ejsom, May :3, 1769. Won $\mathrm{E} 50$ for horses that never won $\mathcal{L} 30$, five-yenr olds 8 stone, six-year olrls 9 st. 3 lbs., four mile heats, beating Gower, Chance, 'Trial and Plume. 'The horses in this race were all bunched at the end of three miles, when Echipse drew away and distanced them all under the hardest pull. Mr. O'Felly lad laid large bets that he placed the horses. When called upon to do so, he replied, "Eelipse first, the others no place." Won $£ 50$ at Ascot Heath for five-year olds, 9 st. 3 lbs., two mile heats, beating Cream-de-Barbade. Won King's Plate for six-year olds (he only five years old), 12 stone, beating' Slonch (winner of the King's Plate at Guilford), Chigger, ete.; walked orer for $£ 50$; walked over for the King's Plate at Salislıry ; won City Silver bowl, with $£ 30$ added, 10 stone, beating Sulphur and distancing Forester; walked over for the King's Plate at Canterbury for six-year olds, 12 stone; won the King's Plate for six-year olds, 12 stone, at Lewes, beating Kingston; Won King's Plate at Lichfield, 8 st. 7 lbs., three mile heats; at Newmarket, 1770, beat Bucephalus, same age, 8 st. 7 lbs. each, Beacon Course, purchased after this race by Mr. O'Kelly: won King's Plate, 12 stone, Round Conrse, four mile heats, beating Pensioner, Diana and Chigger, latter drawn after first heat, balance distaneed; walked over for the King's Plates at Guilford, Nottingham and York, 12 stone; won E319:10s., 8 st. 7 lbs, beating Tortoise, aged, 9 stone, and Bellario, aged, four miles; walked over for the King's Plit te at Lincoln; at Newmarket won 150 guineas and upward (paying 100 gnineas entrance) for six-year olds, 8 st. 7 Ilus., Beacon Comse, four miles, beatiug Corsican, 70 to 1 on Eclipse; next day walked over for the King's Plate, Round Conrse, 12 stone. This ended his turf career. Won eleren King's Plates, in ten of which the weight was 12 stone (168 llos). Previous to rmnning for the King's Plate at Winchester in 1769, Mr. O'Kelly paid Mr. Wildman 650 guineas for half of the horse, and in April, 1770, paid 1,100 guineas for the other half.

Eclipse covered, at Clay Hill, near Epsom, Surrej, in 1771 at 50 guineas, in 1772, 1773 and 1774 at 25 gnineas; afterwards, hy subscription, 40 mares at 30 guineas, in 1779 at 30 guineas, in 1780 at 20 guineas. In $1781,1782,1783,1784$ he was stinted to 50 mares at 20 guineas; in 1785 and 1786 to 40 mares at 30 guineas; in 1787 and 1788 to 25 mares at 30 guineas, after which Eclipse was advertised to cover at the same price at Camons, Middlesex, to which he was removed from Epsom in his carriage, drawn by two horses, with his groom as inside passenger. When, like other travelers, he chose to take a glass of gin or anniseed for himself, he was ordered to furuish Eclipse with a lock of hay and a drop out of the pail.

His progeny continned to distinguish themselves on the turf for twenty-three years, and, besides various Cups, won fil58,0 7. Eclipse's most distinguished progeny on the race-conrse and at the stud include three Derby winners, I. Eelipse, Saltram (imp.) and Sergeant, and Annette, winner of the Oalis, also Alexander, Boudrow, Don Quixote, Dungannon. Harmonia, Hermes, Horatia, Javelin, Joe Andrews (sire of Jack Andrews), Dick Andrews, Jupiter, King Fergns (sire of Beninglorongh, Overton, Hambletonian, ete.), Lamra, Lnna, Madeap, Maria, Mercury (sire of Calomel, Precipitate, Gohanna, etc.), Meteor, Miss Hervey, imp. Obscurity, Pegasus, Satellite. Pot-8-o-'s (sire of Waxy and Corianter), Soldier, Sister to Soldier, spitfire, Ticklepitcher, Volunteer (sire of imp. Eagle and Spread Eagle), Zara and Zodiac, ete. 
Eclipse got also Augusta, the dam of imp. Anvelina and Eliza, the dam of ScndFrenzy, the dam of the St. Leger winner, Phenomenon, and Lney, the grandaun of Catton-Ererlasting, the dam of the Derby winner, Skyscraper, and his full sister, the dam of Violante, also a mare by Woodpecker, which was the dam of Fractions and Fraxinella-an mumamed daughter, that produced Chanticleer, the sire of Bol, Booty-Speranza, the grandam of imp. Psyche-scota, the dam of scotilla, that produced Olive, winner of the 2,000 Guineas, and the great Olsmpia, the dam of the St. Leger winner, Elis, Epirns and Kite-Qneen Mab (sister to Mercury and Volunteer), the dam of the St. Leger wimer, Remembrancer-Venus (full sister to Queen Mab), dam of the Oaks winner, Tag-Xantipje (full sister to Alexander), the dam of the Derby winner, John Bnll-Miss Herves, the dam of Haphazard-Nadeap, the dam of Caprice, grandam of Economist-Tiftany, the dam of Y. Tiffany, the grandam of Bourhon and imp.Popinjay mare-Horatia, the dam of the Derby winners, imp. Archrtnke and Paris-Anna, the clam of the Oaks winner, Bellina-Bohtail, the dam of the Oaks winner, Ephemera-Fanny, the dam of the Oaks winner, TolanteRuth, the dam of the st. Leger winner Tartar.

Eclipse was high in his hips and short in his forehand. His heart weigherl. when taken ont, $13 \mathrm{lbs}$. To such an extraordinary weight he was supposed to ome his natural comrage. At his interment ale and cake were given, as at that of the Godolphin Arabian.

\section{Epitaph ox Echipse.}

Praise to departed worth! Illustrions steed! Not the fam'd Phernicns of Pindar's ode

O'er thee, ECLIPSE, possess'd transcendent speed, When by a keen Nermarket jockey rode.

Tho' from the hoof of Pegasns arose, Inspiring Hippocrene, a fount divine,

A richer stream superior merit shows :

Thy matchless foot producil O'kelly wine.

True, o'er the tomb in which this far'rite lies, No vaunting boast appears of lineage good ;

Yet the Turf Register's bright page defies

The race of Herod to show better blood. 


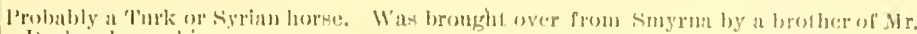
barlery, henceo his nature.

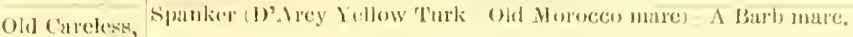

ats. 16ith.

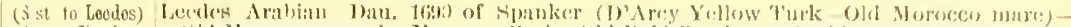

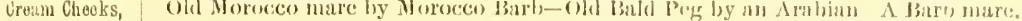

Lister trurk, Was lirough into knghnd by the make of Berwick from the sicgeof Budu, in the reign

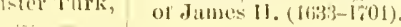

Danghter of, lautboy (1)'Arey White 'Turk-A loyal mare).

liantboy, W'Arcy White l'urk A Royalmare.

Miss B. D'Aroy's Daughter of a Sedbury Royal mare.

Pet Mare,

An Eastem lorse, imported abont 1 \%20 by Mr. IIutton, of Marské, York. Sire also of Black Clanec, the best horse of his day with high weights.

Coneykirs, Lister Turk-Danghter of Jigg (Byerly Turk-Daughter of Spanker).

gr. h., 1612

Old Club Hautboy (D'Arcy White Turk-A Royal mare).

Foot,

Greyilautboy, Old Hautboy (W'Arcy White Turk-A Royal mare).

要:

Ar. Pierson's IIakeless (Oglethorpe Arabian)-Danghter of Brimmer (D'Arcy Yellow Turk-A Royal Danchter of mare)-Danghter of D'Arcy's Diamond (The Helmsley Turk - A full sister to Old blk. M., - Merin by Bustler:

Fox Cub Clutusey (Hautboy-D'Arcy's Pet mare)-Charming Jenny by Leedes Arabian-Dau. Fox Cub, 1693 of Spanker (D'Arcy Yellow Turk-old Morocco mare-Old Moroceo mare by Moroceo Barb-Old Bald Peg by an Arabian-A Barb mare

Danghter of, Coneyskins gr. h 1,i2 (Lister Turk-Dan. of' Jigg) --Dau. of Hutton's Grey BarbDanghter of, Dau, of Hutton's Roval Colt ab. 1\%00 (The llelmsley Turk-Sedbury Royal mare)Dau. of Byerly Turk-Dau. of Bustler (The Helmsley T'urk).

-., -

\section{St. Victor} Barb,

Grey Whynot, gr. n., -.

Hautboy (D'Arcy White Turk-A Royal mare)-Miss B. D'Arcy's Pet mare-A daughter of a Sedbury Royal mare.

The most noted of all the Eastern sires, abont whom opinions are divided whether he was an Arab or Barb. The best judges inclined to the opinion that he was a Barb. He wass purchased in Paris by Mr. Coke in 1722, who gave him to MIr. R. Williams, by whom he was presented to Earl Godolphin. He was a brown bay, 15 hands high, with some whte on off hind-heel. He died in 1753.

Was brought into England by the Duke of Berwick from the siege of Buda, in the ., -

Tे Danghter of,

-., - .

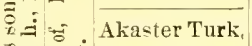

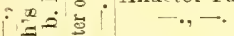

Daughter of, Cade. reign of James II. (1633-1701).

Hauiboy (D'Arcy White Turk-A Rcyal mare).

Sire of Chaunter, Thwaite's Dun mare and the dam of Roxana, the dam of Lath and

Son of Pulleine's Chestnut Arabian-Dau. of Brimmer (D'Arcy Yellow Turk-A Royal mare).

Was in Lord D'Arcy's sturl. Said to have been bred by Lord Montagu, a nobleman in Charles II.'s reign noted for his fine breed of horses.

Hautboy, D'Arcy Thite Turk-A Royal mare.

Daughter of, Brimmer (D'Arcy Yellow Turk-A Royal mare)-A Royal mare. 


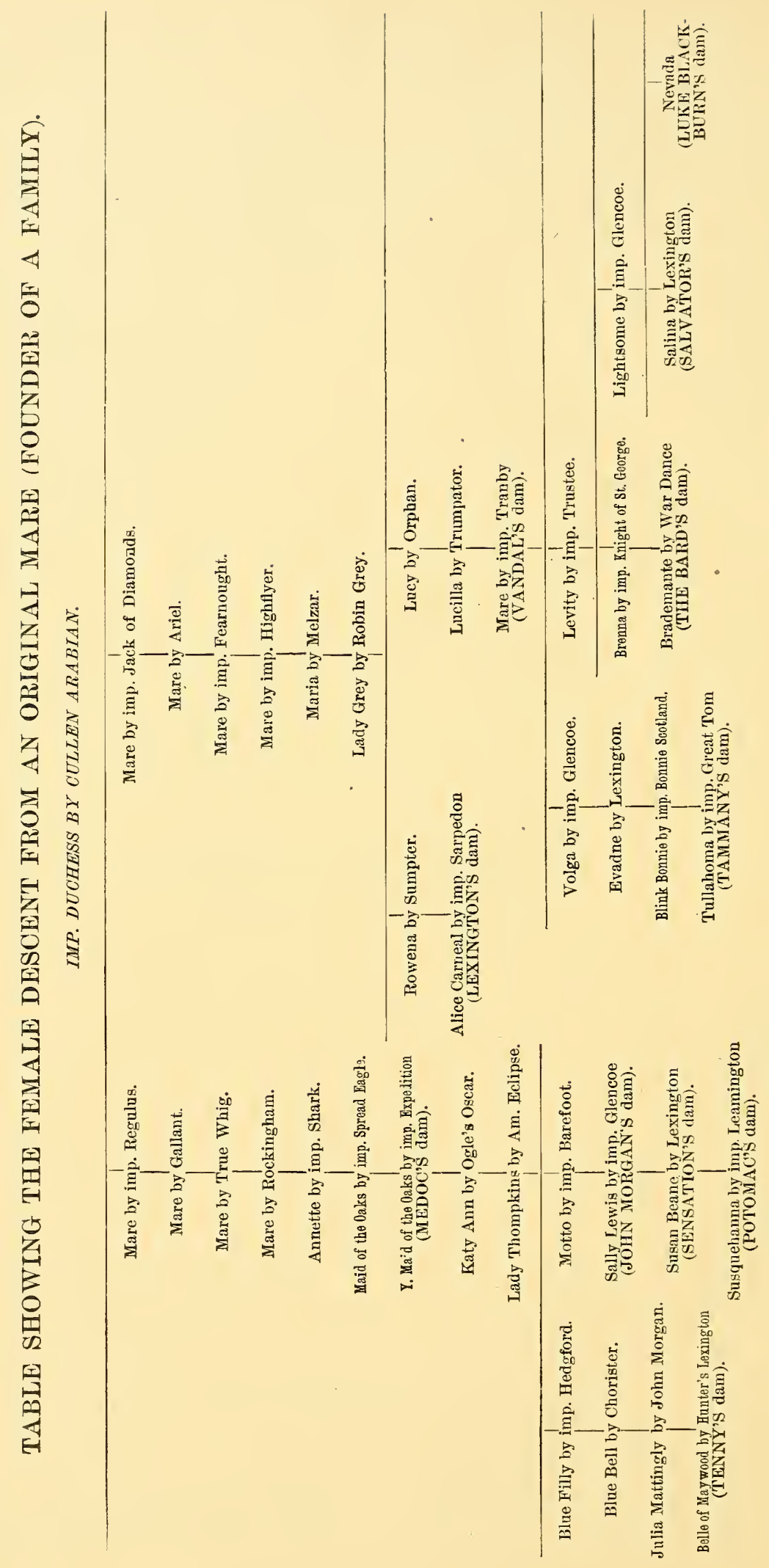





1) 


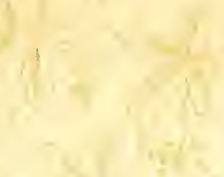

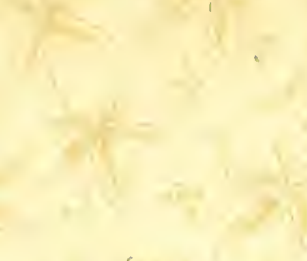

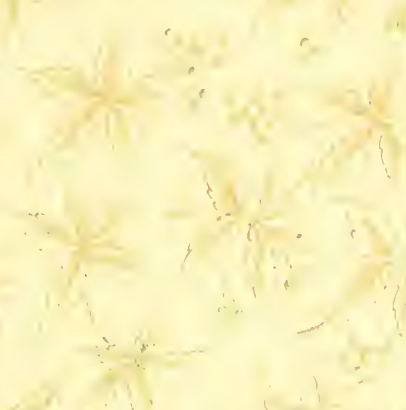

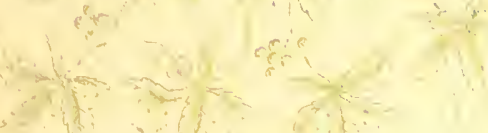

$\therefore$ (<smiles>[C+]=CCCCCC</smiles>

$\frac{4}{5}+4$

is

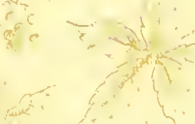

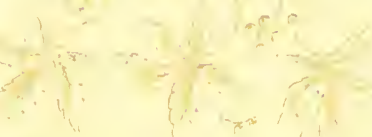

Tix

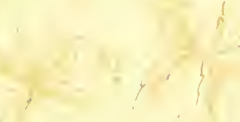
(a)

की कर

se

in

की<smiles></smiles>

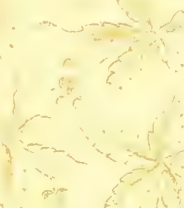

(

a

$\frac{-3}{20}$

बै का , यो

a

8

and

(2)

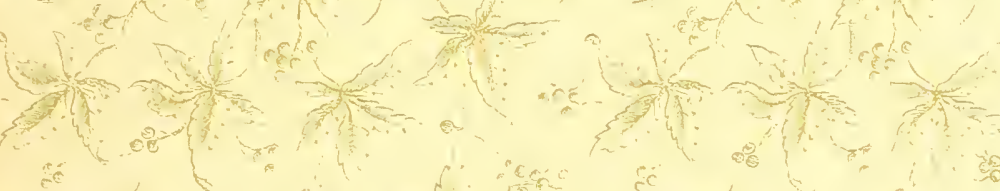

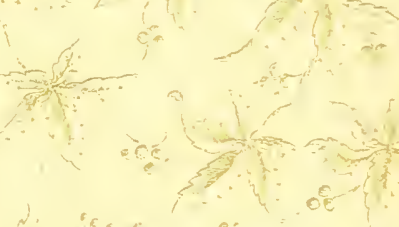

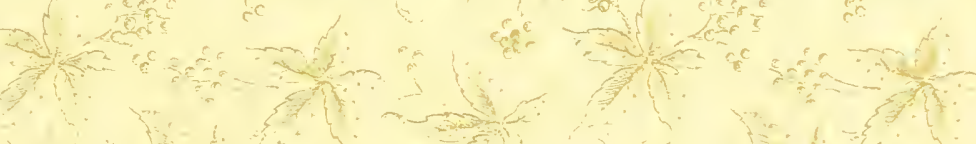
2.t:

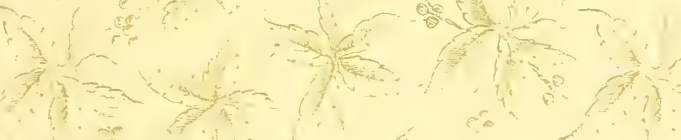

$2 \sqrt{2}$

ma

1) 


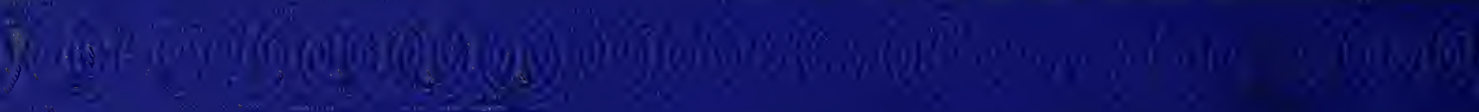

